


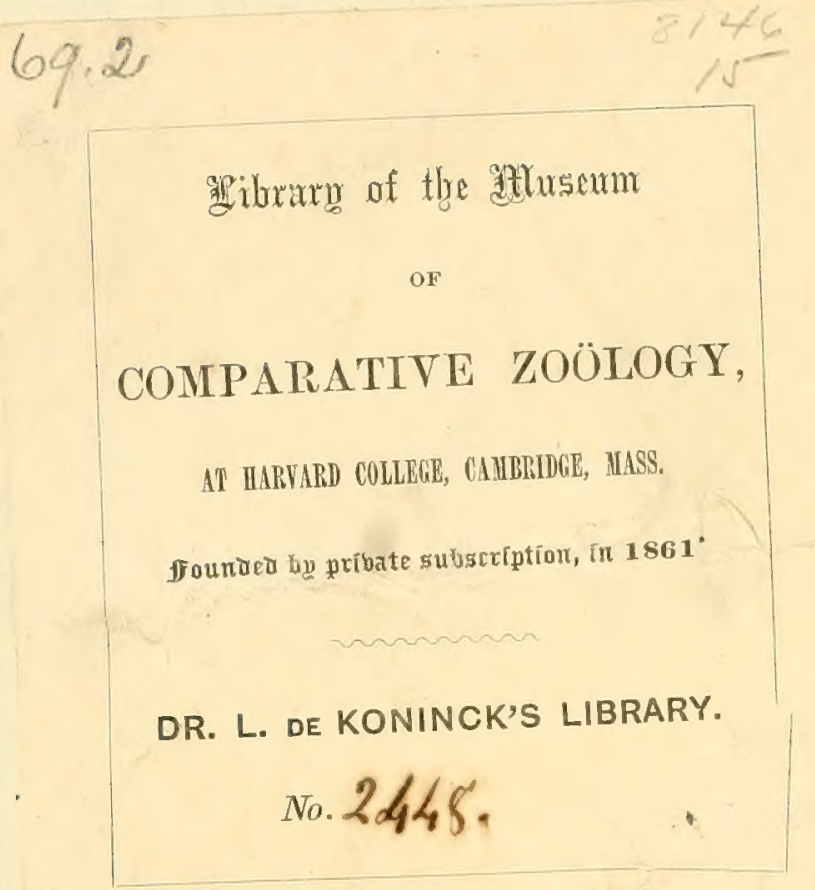




paiky Meffer segricte 


\section{SYNOPSIS OF THE CLASSIFICATION}

\section{OF THE \\ BRITISH PALAEOZOIC ROCKS,}

BY

THE REV. ADAM SEDGWICK, M.A. F.R.S.

WOODWARDIAN PROFESSOR, AND FELLOW OF TRINITY COLLEGE, CAMBRIDGE.

WITH A

\section{SYSTEMATIC DESCRIPTION}

OF THE

\section{BRITISH PALEOZOIC FOSSILS}

IN THE

GEOLOGICAL MUSEUM OF THE UNIVERSITY OF CAMBRIDGE.

\section{BY}

FREDERICK $M^{\mathrm{C} C O Y,}$ F.G.S. HON. F.C.P.S.

PROFESSOR OF THE NATURAL SCIENCES IN THE UNIVERSITY OF MELBOURNE;

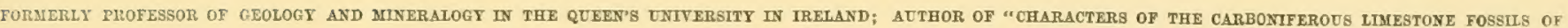
IRELAND"" "SYNOPSIS OF THE SLURIAN FOSSILS OF IRELAND"" "CONTRIBUTIONS TO BRITISH PALEONTOLOGY" \&C.

ขelith Ffigures of the \$ew and Emperfectly known species.

LONDON: JOHN W. PARKER AND SON, WEST STRAND.

CAMBRIDGE : DEIGHTON, BELL \& CO.; AND MACMILLAN \& CO.

M.DCCC.LV. 


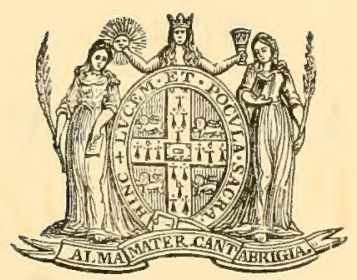

Cambríđge:

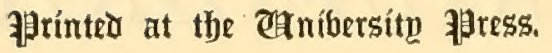




\section{SYNOPSIS OF THE CLASSIFICATION}

OF THE

\section{BRITISH PALEOZOIC ROCKS,}

BY

THE REV. ADAM SEDGWICK, M.A. F.R.S.

WOONWARDIAN PROFESSOR, AND FELLOW OF TRINITY COLLEGE, CAMBRIDGE. 


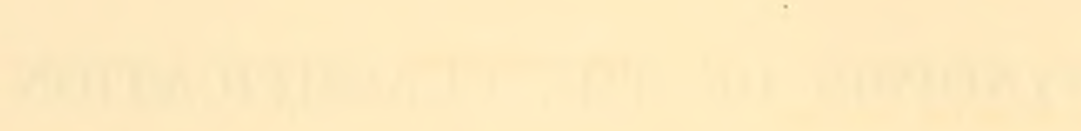

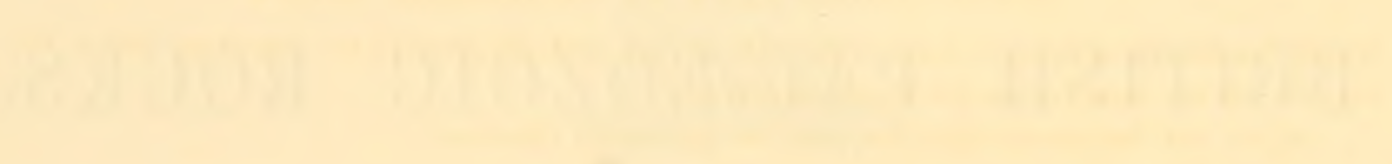




\section{ADDITIONS AND CORRECTIONS.}

\section{INTRODUCTION}

Page sri, line 27, for less, read more.

". $x \times x i$, 4th line, for beds below the May Hill Sandstone, read the May Hill Sandstone and the beds above it. "xxxvi, line one, transpose the words strike-joints and dip.joints.

\section{CORRECTIONS LEFT BY PROFESSOR $M^{\mathrm{C}} \mathrm{COY}$.}

Several localities in addition to those in the body of this work are given in the lists at pp. 332 to 374 .

Page 10, 9th line from bottom for Tregil, read Tregib.

" 24, for 2nd Sub-family Choetetince, read 3rd Sub-family Chotetino.

"27, last line add Calophyllum to the list of Genera.

" 86, 22nd line, and Explanation of Pl. 3. C. for paracida, read parricida.

"483, Streblopteria pulchclla add, Not uncommon in the carboniferous limestone of Berwick-on-Tweed.

\section{Directions to Binder.}

CAxCEL the half-title and 'list of Genera' prefixed to the 1st Fasciculus, and the list of Genera prefixed to the 2nd Fasciculus. Place the Adrertisement to Ist and '2nd F'asciculus' after the proface, and before the second half-title. After the Text place the Appendix, then all the plates marked 1 in alphabetical order, follored by all those marked 2, also alphabetically and finally those marked 3 ; each Plate to be faced by its corresponding lenf of 'Explanation.' 



\section{CONTENTS OF THE INTRODUCTION.}

Sryopsis promised, p. v.

Contents of the Third Fasciculus, and Benefactors to the Museum, p. vi.

Progress of Professor $\mathrm{M}^{\mathrm{C}} \mathrm{Coy}$ 's Work, and causes of delay. Consequent injustice done to him. Index, by Mr Carter, pp. vii.-ix.

Error in the localities of the Graptolites from the Moffat group, p. $x$.

Anatomical structure of Brachiopoda. A passage respecting $\mathrm{Mr}$. Woodward, in the Advertisement to the Second Fasciculus, explained, pp. xi. and xii.

Mr Salter's share in the work, p. xiii.

Gradual elimination of the May Hill group, pp. xiv, and $x v$.

Great labour of Professor $\mathrm{M}^{\mathrm{c}} \mathrm{Coy}$, pp. xvi. xvii.

True Geological nomenclature based on good physical groups, and their subordinate fossils. Examples, \&e. pp. xvii.-xix.

Corrected Tabular View of the Primary or Palreozoic System of England.-Their Divisions, pp. xx.xxvi.

Pomfret Series, for European comparison, better than the Permian, p. xxvi.

Difficulties in establishing the demarcations of the collective groups, pp. xxvii.-xxxi.

1. A good demarcation now established between the groups of the Cambrian and Silurian Series.

2. The demarcation between the Upper Silurian and the Lower Devonian groups not unequivocal. Partly arising from the Lower Devonian groups of Scotland. Hypothetical explanation.

3. A similar difficulty in separating the Devonian Series, of Devon and Cornwall, from the Carboniferous.

4. A like difficulty in separating the Carboniferous Series of the Northern Counties from the Pomfret (or Permian) Series, p. xxviii.

5. Difficulty in defining the separation between the Pomfret (or Permian) Series and the Triassic.
6. These difficulties do not materially affect our geographical nomenclature: but much caution is required in the application of the per-centage theory of Sir Charles Lyell.

7. Examples of this application in determining the per centage of fossils common to Cambrian and Silurian Rocks, p. xxxi.

Further remarlis on the Cambrian Series and on the nomenclature of its groups. Difficulty in correctly analyzing the Cambrian Series, from the following four causes :

1. From the vast thickness and complexity of the Series; and the almost entire absence of fossils from its lower groups, p. xxxii.

2. From the prevalence of cleavage-planes. Series of facts and conclusions, p. xxxiii. Cleavage-planes the result of crystalline action. Sometimes accompany a spherical structure. Theory of cleavage-planes confirmed by certain phenomena in the structure of the Cornish granite, p.xxxiv. A second cleavage-plane, p. xxxv. Dip-joints and strike-joints explained on a mechanical theory of Mr Hopkins. Cleavage-planes and joints in the conglomerates of Trebennau, p. xxxvi. Mechanical theory of cleavage-planes rejected.

3. From the prevalence of eruptive and stratified igneous rocks, $\mathrm{pp}, \mathrm{xxxy}$. - $\mathrm{xxxviii}$.

4. From the extraordinary dislocations and contortions. M. Elie de Beaumont's theory of parallelism, p. xxxix. Of great value when applied under proper limitations. Examples, p. xl.

May Hill Sandstone, its place and office in the general series, p. xli. Historical sketch of the gradual elaboration of the Cambrian series. Mistake by the author of "Siluria" as to the supposed place of the Snowdon fossils, p. xli. Early difficulties in uniting the Upper Cambrian groups to the Lower Silurian, p. xliii. Attempts to overcome those difficulties, pp. xliv.-xlix. All such attempts failed so long as the "Lower Silurian" sections were upheld and considered 
typical. The progress of discovery proved that the "Lower Silurian" Sections were put by the Author of the "System" in a false relation to the Upper Cambrian groups, p. xlvii., and note to p. xlviii. The Corndon Sections no exceptions to this remark, note to p. xlvii. To cover this mistake he destroyed his own base line and included Cambria in Siluria. Cambrian nomenclature never abandoned. Tampered with by Mr Warburton, pp. 1. li. Incongruity and injustice of the whole proceeding, note to p. lii.

The extended Silurian nomenclature an abandonment of the sections which formed the basis of the Silurian evidence, and also an abandonment of the principles affirmed in the "Silurian System." The nomenclature of the Tabular View is, on the contrary, derived from a true analysis of the physical groups -is sectionally and palæontologically true-is geographically consistent, and has the undoubted right of priority, pp. li.-liii.

Other schemes of classification and nomenclature applied to the Cambrian Series. All schemes fail without a true determination of the physical groups.-In what respects the "Silurian System" succeeded as a good scheme of nomenclaturein what respect it failed, pp. liv.-lvi.-True nomenclature not to be derixed from erroneous sections, p. Iviii.--The Caradoc group erroneons_-The Llandeilo group entirely out of place; the Russian nomenclature consequently erroneous-First principles not to be deserted-least of all among the older Palaozoic Rocks, pp. Ix. Ixi.

First principles deserted in the incorporation of Cambria into Siluria. Principles of true induction deserted, note to p. lxi. True principles of classification maintained by the author of the "Silurian System" till it was proved that the lower Silurian Sections were wrong. True principles then deserted, pp. Ixi. lxii. Cambrian nomenclature unfairly tampered with, p. lxiv. Mistaken classification of the Government Surrey. How it originated, p. lxv. Silurian nomenclature first accepted in the belief that the Lower Silurian Sections were true, in ignorance of the real structure of Wales, and of the true Silurian base (the May Hill Sandstone), pp. Ixvi. Ixvii. No longer any rational ground of controversy. Moral arguments. British Association, pp. Ixviii. lxix.

Passage in the President's Anniversary Address (1843), pp. Ixx. Ixxi. Erroneous statement of Mr. Sharp not corrected, lxxii. Virtually repeated in "Siluria," 1854, p. Ixxiii. Mistakes in the Silurian Sections not imputed to their real author, p. lxxiv. Answer required to a plain question of fact, p. lxxv. No fatal mistake in the Cambrian Sections of the Tabular View. The author of the Silurian System (while continuing a nomenelature originally based on erroneous sections) has twice changed his ground. Now appeals to a new interpretation of an old section. Argument a mere sophism, p. lxxvi. Unfair advocacy, p. Ixxvii. Silurian prototype, pp. Ixxviii.lxxix. No Silurian Section a prototype of Cambria. True geographical names changed, in order to preserve erroneous names derived from erroneous Sections. Note to p. Ixxix. Scheme geographically and palæontologically untrue, p. lxxx, Conclusions.

An important correction overlooked, and consequent errors in the ivth Chapter of "Siluria," p. Ixxxi. Lower Silurian Sections not a key to the classification of the older Palrozoic rocks of the North of England, p. Ixxxii. Skiddaw Slate, p. Ixxxiii.

Supplemental note, with quotations from the "Silurian System," p. Ixxxv.

Supplement, p. lxxxviii. Recapitulation, pp. lxxxix. and $x c$.

Discussions before the Geological Society, pp. xei. and xeii.

Mr. Greenough and Sir H. De la Beche. Condition of the Woodwardian Museum, pp. xcii, xciii.

Postscript, p.xciv. Classifications in the Manual of Professor Phillips examined, pp. xev. and xcvi. Cambrian strike.

Succession of the older Palcozoic roclis of North America, p. xevii.

Statement of Professol H. Rogers. France, p. xeviii. 


\section{INTRODUCTION.}

Professor M[Coy's Palicontological work is now complete; and I have, at present, nothing more to add on the Palaxozoic Fauna of England, so far as it is illustrated by the Collcetion in the Woodwardian Museum. Ilad he not been called away to his new duties in Australia sooner than he had anticipated, he would, I believe, have added a few pages, in the form of an Appendix, with woodents and descriptions of some new species which have found a place in the Nuseum since the Second Fasciculus was published. The new species would, however, have been few in number, and would not in any way have affected the general conclusions which may be drawn from the species described in the following work.

When we parted in September last, I promised my friend to draw up a Synopsis of the British Palcozoic System, so far as it appeared to have been made out on good physical evidence; and to put his work in such co-ordination with my own, that each specimen might (with some very limited exceptions) be referred to its right place in the British Palscozoic series, to be laid down by myself on the positive evidence of sections. This done, the whole work was to be published without further delay.

Since my last return to Cambridge, I have been so much interrupted by a lingering chronic malady that my promised task has made but little progress; and instead of a Synopsis based on numerous sections, derived chiefly from the Cambrian, Silurian, and Cumbrian mountains, I at length hasten to the press (constrained to this step by a duty I owe to Professor $\mathrm{II}^{\mathrm{C}} \mathrm{Coy}$ ) with little more, by way of introduction, than a corrected and enlarged Tabular View-resembling that which was prefixed to the Second Fasciculus of the C'anbridge Palreozoic Fossils.

I trust, however, so soon as my health is re-established, and the more pressing duties of the Academic Term are over, to commence a Synopsis in such a form that it may serve its proper purpose of an introduction to my friend's great work; and in some measure justify the title-page le has left behind hin, which was struck off before my return. I accept this title-page; regarding it as a pledge, on my part, given in good hope, to complete my task without any unnecessary delay: and the Synopsis may be hereafter either bound up with Professor MICCoy's "British Palicozoic Fossils," or used as an independent geological Essay*.

* Should any one object to the appearance of my name in the title-page of a work so essentially palicontological, I may reply, that $I$ have not been a perfectly free agent in the matter. In the formation of the Museum, during a period of thirty-six years, in the arrangement of the Palpontological pertion of it by Professor $\mathrm{M}^{\mathrm{c} C o y}$, and in the artistical 
The Third Fasciculus contains the Carboniferous and Permian Mollusca in the Cambridge Collection; several of which are so well preserved (especially in the series of Carboniferous fossils from Lowick) that the internal characters of the genera could be described more accurately than was possible before, on less perfect evidence.

Among the Palrozoic Fishes, here described, several new Devonian species have been added to the long lists published by Professor Agassiz. So far as regards the Carboniferous Fishes, great pains have been taken to ascertain the genera and species which were intended by the names given in the Manuscript lists published in the third volume of the "Poissons Fossiles:" and the typical specimens have been in all cases consulted in the collections of their several owners, so as to enable Professor $\mathrm{M}^{\mathrm{c}} \mathrm{Coy}$ to adopt the manuscript names of M. Agassiz, and thereby to give him as much credit for the specific determinations as if the several species had been fully described or figured. The figures and descriptions of such species in the present work (so far as they are contained in the University Collection) will therefore be of some interest; and they are the only parts of the Irish Collection, in the Cambridge Museum, which are introduced into this Fasciculus. Among the points of interest comnected with the Palieozoic Fishes may be mentioned the unexpected discovery that the tecth of Cochliodus succeded each other vertically upwards, as in the Pycnodonits; and, consequently, that the near relation which such Fishes were supposed to have to the Cestracions could no longer be maintained (infra pp. 621 and 623).

Before concluding this notice of the contents of the Third Fasciculus, I wish to put on record the great obligation the University owes to W. Hopkins, Esq. of St Peter's College, for a very fine series of Carboniferous Fossils which were collected by him in Derbyshire; and to the Rev. E. Jenkinson, of Lowick, Northumberland, for his noble local collection of Carboniferous species, formed by himself during many years of labour. Both the ahove-mentioned collections have now a permanent place in the Woodwardian Museum. A like obligation our Museum owes to the generosity of the Rev. W. Stolies, of Caius College, and the Rev. J. II. Pollexfen, of Queens' College. The former gentleman has contributed nearly all our best specimens of Fishes, from the Carboniferous limestone of Ireland, which are described in the subsequent pages of this Fasciculus: and to the latter we owe the best specimens we possess of the Devonian Fishes of the Orkneys and the North of Scotland. The Museum is also enriched by a fine series of Palrozoic fossils from various parts of Ireland, presented by Richard Griffith, Esq. of Dublin. Many of the species in the Irish Collection had been described by Professor $\mathbf{M}^{\mathrm{C}} \mathrm{Coy}$ in a previous work; and none of them (excepting certain Palxozoic Fishes) are therefore enumerated or specially referred to in the following work*.

illustrations of the following work, I have incurred a great cost. This was well known to the Syndics of the University Press, who hare generously assisted me by undertaking the cost of the letter-press; but on the positive condition (arising out of existing regulations) that my name should appear on the title-page of the work.

* It is not my duty to enumerate, in this place, any benefactors except those who have contributed to the Palieozoic Fossils of the Cambridge Museum. The chief benefactors to the other portions of the Museum are, however, enumerated in the "Blue Book" of the "Cambridge University Commission," published in 1852 (Evidcnce appended to the Report, p. 118). 
Some explanation is called for, to account for the long delay in the progress and final publication of this work. For, although commenced in 1849, the First Fasciculus was not published before the spring of 1851: and in the Advertisement to the Second Fasciculus (dated July 16, 1852,) I stated that the Third Fasciculus was in the Fress, and would, as I at that time hoped, be published before the end of the year. The following statement of facts will be my best explanation and apology.

In the latter part of $1846 \mathrm{I}$ had the good fortune to secure the assistance of Professol $\mathrm{MC}^{\mathrm{C}} \mathrm{Coy}$ in the arrangement of the whole series of British and Foreign Fossils in the Woodwardian Museum; and before long he fixed his residence in Cambridge, and immediately commenced his task, which was carried on uninterruptedly and with unflinching zeal for several years ${ }^{*}$.

In the evidence laid before the Cambridge University Commission is the following passage:- "Some notion may be formed of the greatness of his task when it is stated, that Count Mïnster's duplicates amount to more in number than 20,000 , and that they form but a minute fraction of the great Palicontological series Professor $\mathbf{I}^{\circ}$ Coy las now arranged stratigraphically in the Muscumf." This quotation is in itself a good apology for some delay in the publication of the present work, which was subordinate to the general arrangement of the Collection: and I may here remark, that "a detailed systematic description of the British Palcozoic Fossils in the Cambridge Nuseum," was not so much as thought of at the time of my friend's engagement to the University in $181_{+}^{+}$. The work now published arose out of an arrangement in which the University was no party; and was undertaken, at my own request, in 1849. Before the end of that year, the plates of the Radiata, described in the First Fasciculus, were, I believe, all struck off; and we both of us expected that the whole work would be completed and published within two years from the date of its commencement.

Some time afterwards Mr M[CCoy was elected to a Professorship in the Queen's College of Belfast; and it then became impossible for him to give us more than a divided service, during the spring and summer months of each year, after his collegiate labours in Belfast were, over. This involved a necessary delay. With the exception of one Plate, all the lithographic drawings for the First Fasciculus had been made by our Artist in a room contiguous to the Museum, and under the constant check and superintendence of Professor $\mathrm{MI}^{\mathrm{c}} \mathrm{Coy}$; and we were unwilling to commit the original outline sketches, and the typical specimens to be figured in the remaining portions of the work, to

* This laborious task was first undertaken by my friend Mr Salter; but not long after its commencement he was, to my great sorrow, called away from it by a permanent engagement under the Government Survey.

† "Blue Book" of the Commission, 1852, Report, p. 122, and Evidence, p. 118.

$\mp$ By a Grace of the Senate (Feb. 10th, 18t7, ) the University contributed one hundred pounds to assist me in the cost of the arrangements made in the Museum during the first year of Professor $\mathrm{M}^{\mathbf{c}} \mathrm{Coy}$ 's residence in Cambridge. The Grace did not, however, pass without opposition, though the sum roted was, I believe, taken from the Woodwardian surplus; and I made no attempt, during the seren subsequent years, to draw any help from the University funds in support of the work done in the Museum. 
any Artist who was absent from Cambridge, and had not the same assistance to ensure the scientific accuracy of his lithographic drawings. Nor was this the only cause of delay; for a dangerous attack of fever so greatly interrupted my friend's work, during one summer, that his First Fasciculus did not appear before the spring of 1851.

At that time, both the letter-press and drawings for the Second Fasciculus were in good progress; but by no effort could they be made ready for publication before my friend was again called away from Cambridge by his duties at Belfast. The Second Fasciculus could not, therefore, be published before his return to Cambridge in the following year.

The statement in the Advertisement to the Second Fasciculus, to which I have alluded in the first paragraph of the preceding page, was made in perfectly good faith. At the time of its publication, I did expect that the 'Third Fasciculus would be ready for the press, and perhaps published, before the end of the year 1852. The task was, however, far more laborious than we had anticipated; and when my friend was again compelled to leave Cambridge, many specimens still remained unfigured, and many descriptions were still to be written before the work could pass out of his hands. But to prevent delay, all the remaining specimens which required figures in the lithographic plates, were, at my request, conveyed by him to Belfast, in the hope of his being able to secure the help of an Irish lithographer; so that the Third Fasciculus might appear, if possible, during the approaching winter, or at latest in the early part of the spring of 1853. In these hopes we were disappointed, and the work again stood still for more than half a year.

After my friend's next return to Cambridge in 1853, his work was unfortunately retarded by the absence of Mr West, our artist, who for several weeks was prevented by engagements in London from meeting us at the time appointed, and proceeding with his drawings of the Cambridge Fossils. Much, however, of the remaining letter-press was struck off; and immediately on Mr West's return, the whole work was urged on with such well-directed labour, that it would, I believe, have been finished before the expiration of the summer, but for a very vexations accident, by which about a hundred drawings were so damaged in their conveyance to London, that the stones containing them were returned as unfit for the lithographic press. The damage admitted, indeed, of repair; but the summer months passed away, my friend was called back to Ireland, and the Third Fasciculus remained unfinished*.

On his final return to Cambridge, in the summer of 18.54 , little remained to be done by him; and in a few weeks he set his last hand to his long-continued and well-laboured

* An Assistant had been engaged by myself for several successive years, whoso chief task was to write labels and lay down the specimens in the arranged cabinets, during eight hours of each day. But in the summer of 18531 had to pay him an additional sum for extra labour, as he was frequently employed in the Museum moro than twelve hours a day: and during the same summer I had frequent bills to pay to the Artist for long-continued work done at extra hours. Meanwhile l'rofessor $31^{\mathrm{c}}$ Coy was employed upon the Collection, not only during long hours of the day, but frequently during late hours of the night. 
work; and if there be any blame for a further delay, he is not a sharer in it, and it must rest entirely with myself.

After a joint tour of fourteen days through a part of South Wales, we parted, never I fear to meet again. My health, which had been wretched all the preceding spring, still continued in a state which made sedentary labour almost insufferable; and I did not come back to my academical residence till near the end of October last. At that time my friend J. Carter, Esq. (the Cambridge Secretary of the Palacontographical Society,) was employed in drawing up an Index of the fossils described in this work. This Index had a frequent revision, and required much time for its completion; but it was finished before the end of the Academic Term, and is now printed. For this kind assistance, which confers a great additional value upon the "Detailed Systematic Description of the Cambridge Palæozoic Fossils," I am happy to record my warmest thanks.

The previous historical sketch is my best and only apology for a long delay in the publication of this work, against which some of my geological friends, not without apparent reason, have more than once complained. But I have another reason for making these statements. Since 1849, Palreontology has made a rapid progress; and many excellent works have appeared on the Palcozoic Fauna both of Europe and America. A mere comparison of the dates of publication, without the explanation here given, might lead (and in one instance lias led) to conclusions most unjust to myself, and injurious to my friend*.

No other English writer has shown such a wide and accurate linowledge of Palrontological litcrature, or so largely quoted from the works of those who preceded him; and this has been done by my friend, not from ostentation, but from an earnest wish to do full justice to those who had written on any of the difficult subjects which are treated of in this work. In the multitudinous details of the following pages, there is not, I most confidently affirm, one genus or species claimed by Professor $\mathrm{I}^{\circ} \mathrm{Coy}$ as his own to which he did not believe himself entitled when the pages were struck off. At the same time it is possible that, spite of an honest desire to do full justice to every one who had written upon the Palæozoic fossils, he may, in some rare instances, have failed from want of knowledge, and given his own name to a species that had been published before by another. This must be the almost inevitable fortune of one who writes, at great length, upon a rapidly progressive science; and conflicting claims of this kind, when fairly advanced, are very easily adjusted.

I am certain that my friend has many times, during the progress of this Volume, made a sacrifice to it of the credit he might have gained by an immediate publication of his

* I here allude to a charge insinuated against myself, as Curator of the Cambridge Museum, of want of liberality; and a more severe charge against Professor $\mathbf{M}^{\mathrm{C}} \mathrm{Coy}$ of disingenuous suppression. To both charges (published by the Palceontographical Society, British Fossil Corals, Part IIr. 1852, pp. 150, 151) I have replied, in two papers, published in the Annals and Magazine of Natural History, for April and September, 1854. No satisfactory answer has been, or can be given to my plain statements. The original charges, if advanced as statements of fact, are put in such a form as to be untrue: if they are insinuated as matters of opinion, they are uncourteous and unjust. 
new species, and new views of classification, in one of the quarterly journals of science; and he has shown this forbearance, again and again, contrary to my express wishes. Of this forbearance I will mention one instance; especially as it is connected with the greatest mistake, in the enumeration of fossil localities, that has bcen made in the following work.

Graptolites had been found in various parts of the frontier chain of Scotland:by J. Carrick Moore, Esq. in the western extremity of the chain-by the same gentleman and myself (1841) in some new localities farther inland-by Sir William Jardine in one or two localities in Dumfriesshire, which he pointed out to us in 1841-and afterwards by Professor Nicol in some fine quarries in the upper part of the Tweed. But in 1848, I found, to my great surprise, that within a circle of ten or twelve miles in diameterdescribed from a centre near Moffat-was enclosed a country abounding in great beds of carbonaceous and pyritous alum-slate alternating with sandstone; and that the alumslates, in places without number, contained Graptolites in vast abundance.

Many specimens were collected by my friend John Ruthven and myself, (in 1848), from the valleys descending from the south side of IIarter Fell; from the valleys and ravines on both sides of Moffat Water, and especially from some ravines above the branch of the river which falls over the "Grey Mare's Tail;" from valleys north of Beatock Bridge which branch from the line of the rail-road; from numerous quarries, and (fruitless) openings in search of coal, in the country round Moffat; from various water-courses on both sides of the road from Moffat towards Locherby; from the water-course above Breconside, \&c. \&c. With a change of mineral type in the rock, the Graptolites gradually disappear; but one specimen was found in the cutting of the rail-road about two liundred yards above the Locherby Station.

In conformity with the general plan of this work, all these localities would have appeared, each in its proper place, in the systematic description of the Graptolites, had not the specimens been so much damaged and mixed together in their passage to Cambridge, that their accurate separation became impossible. By myself they were therefore all packed together as the Graptolites of the "Moffat group;" and under that general name the species were cnumerated in a paper read before the British Association at Edinburgh in 1850*.

By the greatest geographical mistake committed in the First Fasciculus the name Locherly has been affixed to tho several species derived from the Moffut yroup. How the mistake originated is more than I can tell. None of the proof-sheets of the following work were revised by myself. Some of them were printed while Professor Mccoy was in Ireland, and others during the vacations when I was absent; and he had not visited any of the localities. It only remains for me to express my regret for this mistake, and to request the reader of those early pages of this work (p. 3 to p. 9) which contain MICoy's Groplulitida', to expunge the word Locherby wherever it occurs, and in its place to substitute the words Moffat group.

* Report of the Brilish Association for 1850, Transactions of the Sections, p. 107. 
When Professor M Coy had made out sixteen species of Graptolites, and arranged them (early in 1849) in the order in which they still remain in our Museum, they became open to the public. Several of those from the Moffat group were new; and I urged him more than once to describe and figure them for the Annals and Nagavine of Natural IIistory. But he refused to do so; stating that they rould appear in their right place in the First Fasciculus, and little thinking at that time of the long delay in its publication, or of the great labour that awaited him before he could complete his description of the Radiata. Ile gave me, however, a revised list of the species, which was read before the British Association in 1850, aloug with my deseriptive sketch of the Moffat group, and of some other portions of the southern chain of Scotland*.

After that Meeting, a good series of Graptolites was collected from the Moffat group, and was publisherl in the Journal of the Geological Society of London. I mention this in no wish to throw blame on any one. The long delay in the publication of the Cambridge work was no reason for arresting the progress of Geology. I have however given these facts to secure my friend from the risk of blame; and at the same time to prove, that in this branch of Palæontology he had not been treading in the track of any previous observer; but rather had taken the lead and pointed out to others the road of discovery. IIad he not published one or two new species, long after the time when I had urged him to publish the entire series of the Graptolites in our MInseum, he might have lost his whole credit for the classification and arrangement which he had made, as before stated, in 1849.

In the Advertisement to the Second Fasciculus (p. vii.) I have alluded to a remarkable muscular apparatus in Brachioporla, the use of which in enabling the animal to open its shell was first discovered by Professor McCoy; although published, in the preceding year, by Mr Woodward. While making this statement I did not mean to throw any blame on my friend Mr Woodward. Ile had described in the Introduction to his "Manual of Recent and Fossil Shells" (p. S) the function of this peculiar apparatus; and he had done so without note or comment; ncither claiming the discovery as his own, nor linowing, at the time, who had the first claim to it. In an elementary work he was not called upon to discuss such a point as this: and I may add, that $\mathbf{M r}$ Woodward had not been in correspondence with Professor MrCoy, or scen the recent arrangements of the Cambridge Nuseum, or knew the progress of the Second Fasciculus.

That the parenthetical sentence in the Adrertisement, where Mr Woodward's name is mentioned, had not been more clearly expressed I much regret. My object in writing it was not to throw blame on any one; but to sare Professor $1 f^{\circ} \mathrm{Coy}$ from the imputation of blame, for haring published as his own what had been published before by another. It would indeed have been great injustice, on my part, to have imputed any blame to Mr Woodward for not knowing, when he printed his "Manual," the contents of another work which had not heen mblished, and with the author of which he had not been in correspondence. This explanation is certainly due to my friend Mr Woodward, and I now give it at his request.

* Transactions of the Sections, p. 103 to p. 107. 
I may avail myself, however, of this occasion to state $x h y$ I believe that Professor $\mathrm{M}^{\mathrm{c}} \mathrm{Coy}$ was the original discoverer of the peculiar muscular action on a leverage supplied by what he calls the "entering valve," which, in the absence of the cartilage, enabled the Brachiopoda to open their shells "in a manner unexampled in Lamellibranch Bivalves" (infra, p. 191).

Sometime after the return of Mr Jukes to England, he presented several excellent specimens of an Australian Terebratula to our Museum. I cannot fix the date of their arrival; but it cannot have been later than 1848, or the early part of 1849. Very soon afterwards Professor $\mathrm{M}^{\mathrm{c}} \mathrm{Coy}$ carefully examined these specimens, and found in some of them the animal structure so entire, and so well connected with the shell, as to demonstrate the true function of the peculiar muscular apparatus alluded to above. He pointed this out to myself, and afterwards to others (among whom I may mention Mr. Hopkins); and at the same time dwelt upon its importance as throwing a new light on the internal and hitherto almost inexplicable structure of the shells of many Brachiopoda. I urged him to publish this discovery; but he refused to do so, and stated that it should appear in his description of the Palæozoic Brachiopoda of the Cambridge Museum. Ife never made any secret of it; and, among others, exhilited it to Mr Morris (the author of the Catalogue of British Fossils), than whom there is not a Palæontologist in England more likely to have known of the discovery, had it been already made by any of his friends before his visit to Cambridge. That visit was made long before the publication of Mr Woodward's "Manual." I cannot fix its date; but I believe that it took place some time during the year 1849. Mr Morris had not, then, seen any explanation of this peculiar mechanism within the shells of Brachiopoda, or heard of it; and he requested and obtained a drawing of it from Professor $\mathrm{MI}^{\mathrm{C}} \mathrm{Coy}$, which he took back with him to London. Along with this drawing was, if I mistake not, a description of some new species of Oolitic Brachiopoda in our Museum, which the Professor had figured and prepared for the press, and was on the point of publishing; but he willingly gave them up to Mr Morris, who was at that time contemplating a general description of the British Oolitic Mollusca.

The anatomy of Brachiopoda had long been well known from the descriptions of our greatest Comparative Anatomist. But Professor M'Coy was, I believe, the first to show the full physiological meaning of the muscles; which are not entirely homologous in function to the "adductor" museles of other bivalves: but, on the contrary, constitute, in one portion of the animal, an apparatus for opening the shell. The discovery of this function (however minute it may appear) has a bearing upon a very large and difficult section of Palicontology.

I may here remind the reader, that no specimens are figured in this volume but such as illustrate species that are new; or, at least, exhibit some new character, not well brought out in any published work with which the Author was acquainted. But every Palicozoic species in the Cambridge Museum, whether known or new, is carefully described: and every locality in which each species has been found (so far as can be made out from the specimens in the I[useum) is distinctly enumerated. I may add, that the duplicates are preserved, and are arranged, so far as possible, in their proper subordination to the typical collection. This has been done for the express purpose of shewing the geographical distribution of the several species, and of assisting 
the student in drawing a right conclusion from them, so far as they have a bearing on any doubtful question of geological classification and nomenclature.

Minute details, like those just noticed, involved a great amount of labour in the arrangement of the collection, as well as in the determination of the species. Such labour would be ill bestowed, were the details inaccurate: and some one may porhaps think that the geographical mistakes (above mentioned), committed within the first nine pages of this work, are but a bad omen for its general fidelity. I am alone responsible for the localities; and, on such points, I have done my best to secure the work from error. During my friend's labours in the Museum, hundreds of good single specimens have been rejected, because the labels were lost, or so damaged as to be of doubtful authority: and, for a like reason, the contents of several ponderous packing cases of fossils have been cast away as worthless, when it was found that the labels had perished, or the exact place from which the species were gathered had partly faded from my memory. In this way I have made many a stern, and I might almost say painful, sacrifice to the integrity of the Museum: and on this score I dare claim for it a credit fully equal to that of any other great collection which has been formed in England.

Mistakes, however, there must he in a work like this, the materials of which were collected during a period of more than thirty years. For more than twenty years of that time there was no Museum for the reception and arrangement of the great additions made, every succeeding summer, to the University collection : and when it was at length unpacked, some parts of it had suffered great injury from the decomposition of pyrites*, as well as from other causes; though fortunately the Palaeozoic portion had suftered least. A few of the cases of fossils collected by myself in Cumberland and Wales were sent to London for examination; and nearly all that were jointly collected by $\mathrm{Mr}$ Salter and myself in 1842 and 1813 were first unpacked in London and afterwards sent to Cambridge. Under such circumstances, loose labels may have become attached to wrong specimens, and two distinct parcels of fossils may have become mixed together. Causes such as these may have produced some errors in the geological grouping of the characteristic species, and in the localities given to them: and one inevitable consequence of such mistakes, should they in any instance have been made, would be an cxaggeration of the number of species common to two distinct but contiguous formations. I can only say, once for all, that during the progress of this work I have done my best (in the way already pointed out) to secure the Museum against the consequences of such mistakes; and I confidently trust that they are rery few in number.

With the exception of the Appendix to the Second Fasciculus (which is from the pen of my friend and former fellow-labourer $M r$ Salter + ) all the descriptions of the following

* It may perhaps deserve remark, as a caution to collectors, that large boxes containing tertiary shells mixed with masses of fossiliferous clay were sent by me from Hampshire to the Museum in 1821 and 1825 . It was intended that the masses of clay should be washed so that the minute fossils they contained might be collected on a filter. When the boxes were unpacked, after the crection of the Museum, the specimens they contained had become utterly worthless from the cause alluded to in the text. Not one of the larger shells was left entire.

+ There is a mistake of dates in the introductory words of Mr Salter's Appendix. It was in the summer months of $18+2$ and $18+3$ (and not in the summer months of $18+3$ and 1844) that I made a joint tour with him in North Wales. In 
work are due, exclusively, to Professor $\mathrm{N}^{\circ} \mathrm{Coy}$; and during the first two years of his systematic work on the older Palcozoic fossils, he had, from myself, no clue toward an exact determination of the geological groups of strata to which the several species were subordinate. Each species was determined on its own evidence, without any warp or prejudice; and I had learnt by past experience that this was a matter of some moment*. But when the Second Fasciculus was well advanced, I gave my friend that more exact and detailed classification of the older Palarozoic rocks which was afterwards prefixed to it as a "Tabular View." (Adtertisement to the Secont Fusciculus, p. iii.) He then procected to group the species geologically in agrecment with this scheme; and, in conclusion, he drew up (checked and assisterl by myself on points that were local or geographical) the three lists which commence at p. 326 and end at p. 374 of this volume: riz. Alphabetic and Systematic Lists of all the Lower Palrozoic Fossils, and an Alphabetical List of all the Localities.

When this work was done there was no difficulty in confronting physical and fossil evidence, so far as the sulject could be illustrated by the Cambridge collection; and in secing how far the development of organic species accorded with the succession of those natural groups of rocks, which were indieated by my sections, and enumerated in the Tabular View. With one exception, the accordance was as good as we had any right to anticipate.

This exception was found in the so-called Caradoc group; which in the sections and lists of the "Silurian System," and in the Government Survey, was regarded and described as a group wherein the most characteristic Cambrian and Silurian types were so blended as to be inseparable, either on zoological or physical evidence. This I had admitted on such high authority, though the conclusion bore against myself; and it had never been my task to examine, critically and in detail, any one of the most typical of the so-called Lower Silurian sectionst. While under this belief, I had for several years supposed that there was an overlap between the Upper Cambrian and the Lower Silurian groups; and I had once proposed, for a part of my Upper Cambrian group, the name Cambro-Silurian, as an intermediate term which would include all doubtful cases, give every labourer his due, and secure a congruous and correct geographical nomenclature.

1844 he made, at my request, a short tour with a view of ascertaining the relations of the undulating groups of the Radnorshire mountains to tho Llandeilo group of Builth, but did not arrive at a satisfactory result. At that time I was secking health at a German bath and not able to take the field with him.

* I here especially refer to the fact, that in 1936 a set of Barnstaple fossils (collected by Sir R. I. Murchison and myself from beds which at first sight wo supposed to bo Caradoc sandstone) were sent to London for examination; and the species were, after examination, returned as "Caradoc." Taking this as a point established, I endeavoured, in vain, during portions of the two following summers, to torturo the Cornish and Devonian sections and fossils into an agreement with it. But when the truth of the Devonian sections became, at length, firmly settled, the Barnstaple fossils were re-examined, and proved to be all either of Devonian or Carboniferous species. How entirely Professor $\mathrm{M}^{\circ} \mathrm{Coy}$ was unacquainted with the fossil localitics of North Wales, during the progress of his work in Cambridge, is obrious from the mistakes he has made, in reference to the place of cortain fossil groups, in some of his early papers in the "Annals and Magazine of Natural History." Thus, under the name Wenlock shale, he has united the shales of Builth Bridge with the Llandeilo shales which are north of Builth. The same errors are, I find, repeated in a reprint (by Macmillan and Co. of Campridge) of these very valuable papers, under the title of "Contributions to British Palæeontology ;" but they will be corrected in a list of errata.

if Sec the Advertisement to the First Fasciculus, and compare it with the Advertisement to tho Second. 
Fortunately, this proposition was rejected. I say fortunately, because when we had, in the way above mentioned, arranged the whole series of the older Palcozoic fossils in the Cambridge Museum geologically-putting to the best of our power every species (as well as every duplicate) in its proper physical group-lrofessor M I'Coy saw in the successive groups of fossils no proof of that blending of the older and newer types which had been very confidently affirmed, and was virtually assumed in the Silurian nomenclature*. On the contrary, resting on the whole evidence of the Cambridge fossils, and before he had seen any part of the Silurian country, he asserted his conviction that there must have been some false grouping, or physical mistake, in the interpretation of the "Lower Silurian" sections, which could only be settled in the field. "If the present interpretation of the field sections in Siluria be right, I will," he said, "abandon Palwontology."

We have since then, by short excursions made in three successive summers, put the previous opinion to the test; and have found that the supposed blending of the most characteristic Cambrian and Silurian types was a mistake arising out of a positive misinterpretation of the sections; and that under the name Caradoc group, two unconnected and often unconformable groups had been improperly confounded. On the contrary, by making a break in the Palocozoic series, where nature herself had made it, and by cutting off the May IIill sandstone from the Caradoc group, and by placing it at the base of the "Silurian Systemt," we could bring the physical and fossil evidence of the whole Lower Palæozoic series into a good harmony and accordance.

Having, in these prefatory remarks, told nearly all that I am called upon to tell, of the personal labours of Professor McCoy during the progress of this work; I might go on at once to the corrected Tabular View of the whole British Palsozoic Series, and the short comment I have to make upon it. But I cannot do so without a few parting words of truth and good-will, which would not perhaps have been written had my friend been still amongst us; but which I may give with less reserve, now that he is so far removed from us, that I am deprived of his ever-ready help, and that we are never, I fear, to meet again.

From his childhood he was a lover of natural history; and being destined for the medical profession, he was, in carly life, initiated in the studies of human and comparative anatomy, which he united to that literary training, which marks the education of an English gentleman. Hence his knowledge, as he advanced in life, was never exclusively concentrated on minute and unconnected facts; but was at once cxtensive and solid, well-grounded

* When M. Barrande first communicated his account of the Bohemian fossils to the Geological Socicty of London, it appeared that the whole scries might naturally be separated into two divisions in conformity with the order of superposition; and that between the upper and lower division there was but a very small percentage of common species. In commenting upon this statement, I heard it affirmed, by one of the most distinguished members of the Society, that taking the Silurian rocks of England collectively, there were more than sixty per cent. of species common to tho upper and lower divisions! The statement was not contradicted; and at the time was, no doubt, beliered by many who were present.

t The results alluded to above are described in the Journal of the Geological Society of London for 1852; and in the "Philosophical Magazine" for October, Norember, and December, 1854. Taylor and Francis, London. 
and philosophical. What first led him to devote so large a portion of his time to the fossil world I am not called upon to notice: but years before I linew his name, he had entered (with an ardour which has never since abated) on that great field of Palrontology which spreads itself into every department of organic nature; and when I first saw him (in 1841) he had nearly completed his volume on the Carboniferous Fossils of Ireland. IIis Irish works put him in the front rank of British palrontologists. In one respect however they fell short of his wishes; for, in the systematic description of each species, he was anxious that every known Irish locality should have been enumerated, (on the model afterwards happily adopted in the Cambridge work); but his suggestions on this point were not acted on.

When my friend formed his first engagement with this University, he came amongst us young indeed in look; but, even then, a reteran in Palcontology. IIe was well trained and ready for the task he had undertaken; and far better stored with a linowledge of the foreign standard works on Paleontology than any man with whom I had before conversed. This great advantage he partly owed to his previous residence in Dublin, which gave him access to its public libraries; and it was an advantage which he never afterwards let slip during the years that he laboured in our Museum under the public library of the University.

Great knowledge does not, however, necessarily imply great skill in the use of it; and of my friend's skill in the systematic classifications and specific descriptions of the following work the scientific world is the only judge; and to that judge I resign it, with sentiments, I might almost say, of paternal interest.

On some points I do, however, profess myself a good judge of my friend's labours; because I have means of information respecting them which can hardly be possessed, to a like extent, by any other person. He is gifted with very acute senses, which have been sharpened by long-continued scientific use; and these physical qualities are combined with great knowledge, and so happy a memory that the species submitted to his examination seemed hardly less present to his eye than the kindred species about which he had only read. IIence his knowledge seemed to be ever at hand for immediate use when the occasion called for it. With this ready and productive power, he had, by a long and hard training, acquired a clear perception of the bearing of one part of organic nature upon another, and a grasp of the highest philosophical requirements of natural history.

Nor is it wide of my present purpose, or unconnected with the credit of the following work to declare, after an intercourse the most fran and confidential, and continued, without a moment's abatement of mutual good-will, for nearly eight years, that in the list of those whom I have rejoiced to call my friends there has not been one more single-minded, more truth-loviug and honourable, than Professor McCoy. To say that he was indifferent to his scientific reputation would not be true, and if true would be very little to his credit; but upon this I would dare to stalie my credit and happiness among my friends, that he has never sought for honour by taking to himself one atom of credit which was due to another son of science. 
With all my friend's other good qualities he might have been a comparatively unproductive labourer, had he not been gifted with a constitutional power of enduring longcontinued application which has seldom had its match. Whatever may be the merits of the following work, it is one of enormous labour. Every part of it has been well considered, and none of its pages have been struek off without patient thought and study. IIence the specific descriptions (apart from yuestions of classification about which our best naturalists may differ, and upon which I do not presume to offer an opinion), are at once condensed and full, and have a clearness which is almost unrivalled. They are put before the lalixontologist with a precision like that of a geonetrical demonstration; and while he reads them (whatever may he his own views), he camnot doubt about the author's meaning, the real character of his species, or the grounds on which his scheme of arrangement rests.

Willingly then, for such reasons as have now been very plainly stated, I repeat some of the words of the Cambridge University Commission in their Report on the Woodwardian Museum; and conclude-"that the self-derotion and untired zeal with which Professor $2 I^{\circ} \mathrm{Coy}$ gare himself to his great task in the ILuseum, and the skill with which he has carried out its details, are far above all common praise, and entitle him to the enduring gratitude of the University*."

Grounds of Gicolofical Nomencluture-Tabulur Tien of the Primary or Palcenoic System of England and Wales-Three principal Divisions,-Loner, Middle, and UpperGeneral conclusions.

TuE following remarks, chiefly copied from a paper published in the Philosophical Magfasime for Oetober and Norember 1854t, may serve as an Introduction to the subjoined Tabular View of the British Palicozoic rocks. No metamorphic groups are enumerated; as they are essentially azvic, and often of very doubtful age. The triple division of our whole series of fossil-bouring rocks into Primary, Serondary, and Tertiary, may still he conveniently retained; and, when these three divisions are deseribed with reference to their organic types, they have heen respectively defined by the terms Puluozoic, Mesozoic, and Canozoic. To each of the three great divisions I would, on palsentological grounds, give the name of System. Thus, in the following corrected Tabular View, all the Palixozoic rocks, from the oldest Cambrian to the Permian inclusive, are described as forming parts of one systenthe Palaozoic. This extended application of the word system is an innovation on a nomenclature now in common use; but it was suggested ly myself fourteen years since, for the express purpose of avoiding what I thought an unphilosophical use of the word systcm,

* Report of the Cambridge Commission, pago 122: and Evidence subjoined to it, p. 118.

t Messrs Taylor and Francis, London. 
as applied to the subdivisions of the Palieozoic rocks-such as Carboniferous, Devonian, Silurian, \&c.; and since then I have repeatedly used the word system in this extended sense, and recommended its adoption*. Strictly spealing, all organic types, of whatever date, belong to one great Systema Vuture. Ifad this not been true, palieontology could never have risen into a science. Still there is such a great organic interval between the Flora and Fuunce of the Primary and Secondary groups, that we may conveniently, and without any risk of error, describe each of them as belonging to a separate organic system. $\Lambda$ single glance convinces us that the Funne of the Secondary period greatly differs from that of the Primary or Palæozoic. But the case is widely different in comparing the organic types of the subdivisions of the Palaozoic rocks. Both physically and palacontologically, we find a great difficulty in drawing fixed lines between these subdivisions; nor at this moment are geologists in all cases agreed as to the true places where such lines should be drawn.

Not only have the Palæozoic rocks a peculiar organic type, but there are several species which run through nearly all the subordinate groups; and seem, therefore, to unite them into one Palrozoic System. For example, Farosites alreuluris, and F. Gothlantica, Stcnopora fibrosa, Spivigerina reticularis, and Leptagonia depresea are all found in the Bala group; yet three of them rise into the Devonian series, and the remaining two rise into the Carhoniferous. And this list of common species might, I doubt not, be considerably increased. There is, then, no incongruity, and certainly no risk of error, in applying the term System to all the Palicozoic rocks; while there is some incongruity, and (as we know from experience) a great risk of error, in applying the definite term Sy/stem to the great subdivisions of the Palarozic rocks, such as the Carboniforous, Devonian, and Silurian. The use of the word Series, in describing the subdivisions of the Palrozoic System, is by no means an innovation; but is, on the contrary, a return to the language formerly in very common use among the members of the Geological Society; as any one may see on turning over the pages of their early Volumes.

Among the most exact continental writers, the word Terrain is used for collective, and sometimcs imperfectly-defined, groups of rocks; while the word Systeme is applied to the subortinate and well-defined groups, whether natural or artificial. This sense of the word system is consistent and philosophical, and can seldom lead to mistakes of interpretation. In England we have no technical word corresponding to Terrain, though the word Country might perhaps be used to supply the want; and the word System has frequently been used by us in a luose and ill-defined sense; sometimes being applied to certain well-defined groups, on evilence partly physical and partly palsontological; sometimes to utterly undefined groups, on evidence purely palaeontological. And hence has been introduced an incongruous nomenclature, which is sometimes geographical, sometimes palcontological, and sometimes neither geographical nor palacontological. By adopting a definite nomenclature, before we are well acquainted with the physical and paleontological phænomena on which it must ultimately

* For example, Procedings of the Geological Society, Vol. IV. Junc, 1843, p. 221. 
rest, we incritably retard the progress of geology, and damage its scientific language. For no one who has prematurely adopted a definite nomenclature is ever very willing to change it; and it is notorious, that men are far more ready to distort new facts so as to fit them to an accepted nomenclature, than to modify and improve their nomenclature so that it may meet the demands of advancing knowledge.

The rocks of England are now so well known, that a pretty good classification of them (from the oldest Cambrian to the newest Tertiary) might, with a few exceptions, be made on physical evidence alone. In like manner (so soon as the long succession of physical groups is known and the palaontological evidence has been put in co-ordination with it), an approximate classification of the whole English series might be made on purely palreontological evidence. One would represent a rast succession of physical conditions-the other a similar succession of organic types; and each might have its appropriate nomenclature. Nature has been so true to her workmanship, that the two would, with a few exceptions, run harmoniously together. But in the actual state of our information, we have done well constantly to use both kinds of evidence (physical and palacontological); and on both tugether has our best, and our only consistent and secure nomenclature been founded. If it be true that experienced geologists have sometimes, from the neglect of paleontology, blunlered in the arrangenent of the physical groups; it is equally true, that very expert palacontologists, from some mistake of arrangement among the physical groups, have sometimes blundered in their palacontology. The double kind of evidence, above described, has seldom been lost sight of with impunity.

We have, within a few years, had an excellent illustration of the combined value of physical and fossil evidenec, in the definition of our oldest Tertiary groups, and in the determination of their nomenclature by $\mathrm{Mr}$ Prestwich; and principles precisely similar have ler to a good geographical nomenclature of the great subdivisions of our whole P'alreozoic System. So far as our Palirozoic nomenclature is good, and fitted to endure, it has been grounded both on physical and palweontological evidence. So far as it is inadequate or erroneous, it has either been derived from sections which were misinterpreted, or from a positive desertion of those principles of combined evidence from which the good and enduring parts of our l'alaozoic nomenclature are derived.

From the same combined principles of evidence, I have given (in the following corrected Tabular Vicw) what I believe a true geographical nomenclature of the oldest British Palacozoic groups. It may not be the most scientific, and it may hereafter be superseded by something better: but it is a nomenclature well suited to the present condition of our linowledge; and it exactly falls in with, and gives us the true physical base of, all those groups which have, on the very same principles, been well established in the "Silurian System." In every case where this kind of nomenclature has led to a geographical incongruity, we may rest assured that such incongruity is not the fault of nature's workmanship, but has sprumg from some misapplication of our principles of classification, or some great mistake in our assumed succession of the physical groups. 


\section{Lower Patconoic Dirision, representing the Cambrian and Silurian Series in ascending groups.}

a. Longmynd slates, \&c.

b. Llanberris slates; alternations of roofing-slates and grits.

c. Harlech grits; sometimes approaching a conglomerate form.

a. Lingula flags.

b. Tremadoe slates.

c. Arenig slates and porphyries; Festiniog slates; slates, flags, and grits; indefinite alternations of porphyry and trap-shale: one irregular band of limestone near the top of the group. Thickness great.

a. Lower Bala rocks. (1) A great zone of dark and sometimes earthy slate. (2) A great series of slates, flags, and grits, ascending to the Bala limestone.

b. Upper Bala rocks. Under this term are included-(1) the Bala and Hirnant limestone and the Llandeilo calcareous flag-(2) Flagstones, slates, calcareous beds, and shelly sandstones of Caer Caradoc. The whole series ending, in North Wales, with slate and flagstone; and, in South Wales, with slates, grits, and coarse conglomerates. The group of very great thickness.

Immediately above these three groups there is a great change of physical conditions. The most characteristic and abundant of the older organic types disappear, and new types take their place. The sections are usually broken and discontinuous; and the upper (or Silurian) groups sometimes overlap the lower (or Cambrian) groups unconformably. IIere, therefore, (to adopt a language in common use), we have the commencement of a new System. Without counting the vast thickness of the Longmynd slates, the thickness of the Cambrian Series, where well developed, is, I think, more than 25,000 feet.

\section{Lower Palceozoic Division continued.}

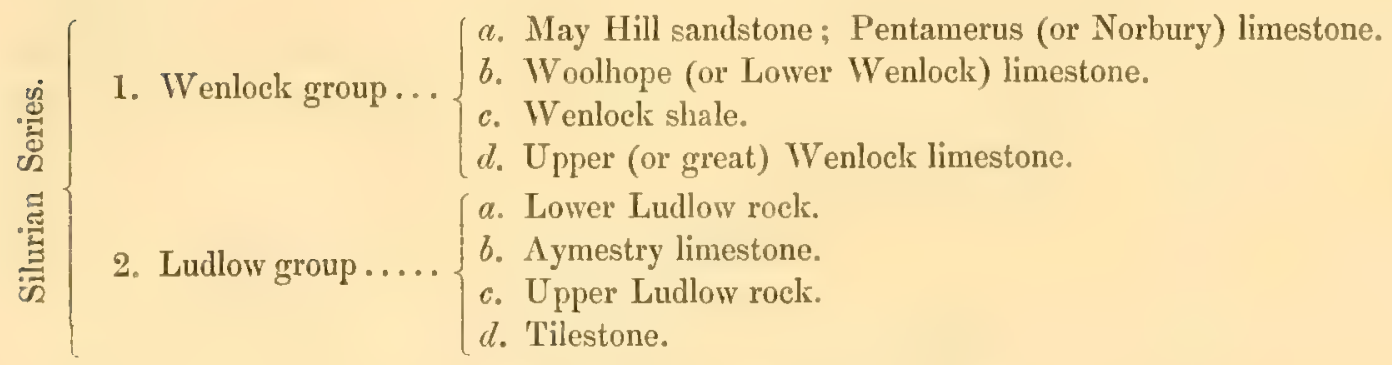

The aggregate thickness of the series about $5000 *$ feet?

* I obtain this number from an estimate of the thickness of the "Upper Silurian" rocks, by Dr Fitton, added to the thickness of the May Hill sandstone, as given by Professor Phillips. Aggregates of this kind are frequently too great. For, as a general rule, where one of a set of connected groups rises above the average thickness, another group will probably descend below it. For example. The Woolhope limestone of Presteign is a noble rock, but the Wenlock limestone is there quite degenerate. At Wenlock the limestone forms a grand terrace, but the $\Lambda$ ymestry limestone has almost vanished. At Leintwardine the Aymestry limestone is a grand rock, but the Wenlock limestono is degenerate. IIany other cxamples might be quoted. 
The introduction of the May Hill sandstone as a part of the Wenlock group is the only important change I have made in the corresponding portion of the "Tabular View" which is prefixed to the "Second Fasciculus of the Cambridge Palrozoic Fossils." It gives a true physical and palicontological base to the Silurian Series: and assuredly there is not (under this arrangement) any such thing in nature as a "Niddle Silurian Group," which inseparably links together the Cambrian and Silurian Series, and makes them into one Systen. The May Hill subgroup is not unfrequently discordant to the older groups, on which it rests; and its fossils unite it unequivocally to the $W^{T}$ enlock group. It must therefore, both on physical and palientological evidence, be cut off from the shelly sandstone of Caer Caradoc and Horderly; to which it is discordant in position, and with which its palcontological relations are not comparably so near as to the Wenlock Group. It is in fact, as now given in the Table, an integral portion of the Wenlock group.

\section{Lover Palceozoic Division as developed in the Cumbrian mountains of the North of England.}

\footnotetext{
$\left\{\begin{array}{c}\text { 1. Skiddaw slate } \\ \text { (Lower Cumbrian).. }\end{array}\left\{\begin{array}{l}\text { A group of vast thickness, and probably admitting of several subdivisions. } \\ \text { In some of its upper beds a few graptolites and fucoids have been found. } \\ \text { Generally it is without a trace of fossils. Near the Granite of Skiddaw } \\ \text { Forest entirely metamorphic. It is the supposed equivalent of the Long- }\end{array}\right.\right.$ mynd slate $(1 \alpha)$ of the Cambrian series.

A group of enormous thickness, composed of alternating masses of slate, sandstone, porphyry, porphyritic conglomerate, trap-shale, \&c. \&c. It forms no passage into the Sliddaw slate, and is sometimes separated from it by trappean conglomerates. The conglomerates become attenuated, and pass into trap-shales (schaalstein); and the shales pass into roofing-slate. The alternations are innumerable. The great deposits of slate are good mineral equivalents of the Llanberris and Festiniog slates. The group seems to pass, at one extremity, into the calcareous slates of the Coniston group; and (when taken collectively) may be considered as the equivalent of all that part of the Cambrian series which extends from the Llanberris and Bangor slates to the Lower Bala rocks inclusive.

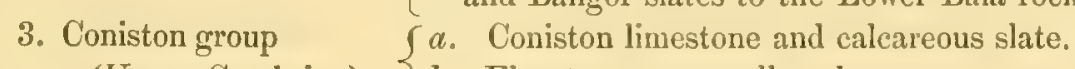

(Upper Cumbrian) . \{ b. Flagstone; generally calcareous*.
}

* While the May Hill sandstone was confouncled with the Caradoc group, and the Coniston limestone and flagstono were confounded with the Caradoc sandstone and Wenlock shale, the Coniston grits appeared to be quite anomalous among the true Silurian groups: but now that these grits have found their right place, the anomaly ceases altogether. They produce a remarkable impress on the physical features of the Silurian country of the North of England; and spite of their general sterility, they make a noble exhibition of the May Hill sandstone, and thus form the natural base of the Silurian series of the Cumbrian mountains.

There never was any real difficulty in the natural succession of the plysical groups of Cumberland and Westmoreland; and I could have described this succession, in 1824, as well as, perliaps better than, it is given in this Tabular View. The only subsequent difficulty was in attempting to put the successive groups into co-ordination with those of Wales and Siluria; and so long as the sections, the fossil lists, and the nomenclature of the "Lower Silurian" rocks wero 
The Coniston limestone appears to be the exact equivalent of the Bala limestone both in its mineral type and in its group of fossils; and the Coniston flagstone seems to represent (in a very degenerate form) the slate, flags, grits, shelly sandstones, and coarse conglomerates which in North and South Wales overlie the Bala limestone and the Llandeilo calcareous flagstone.

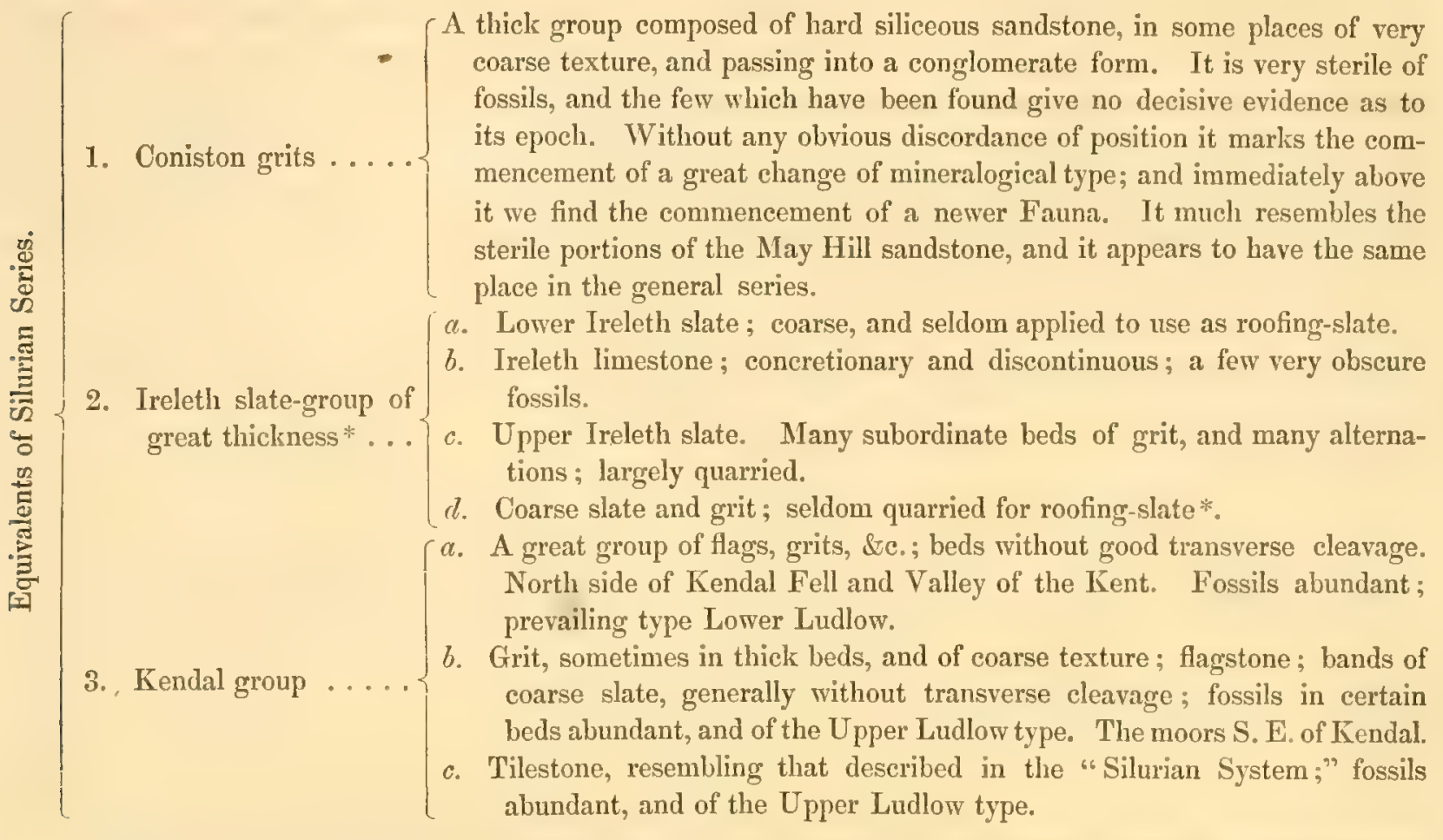

Collectively, the above scries (from the Coniston grits to the Kendal group inclusive) is of very great thickness; yet, being almost without any subordinate beds of limestone, it is not so prolific of fossils as the corresponding groups in Siluria.

There are in the Woodwardian Nuseum, I believe, 166 ascertained species collocted from the groups between the Skiddaw slate and the Tilestone inclusive; and when these species are divided into two groups-the upper representing all the known fossil species down to the base of the Coniston grits, and the lorer, all the known species below the Coniston grits-the two groups are found to liave but five species in common. In other words, between the Cambrian and Silurian series in the North of England, there are not more than about three per cent.

taken as a key, the confusion among the groups was inexplicable; simply because the key was false to nature. But the moment the so-called "Silurian key" was thrown aside, the Coniston limestone naturally fell into the place I had first given to it. It became the equivalent of the Bala limestone; and the whole succession became, once more, perfectly natural, both on physical and palxontological grounds.

* The Ireleth slate-group is spread over a wide extent of country, and is of great thickness, and its fossils, though generally rare, are of the Wenlock type. In the sub-group (d) some of the fossils seem to belong rather to the Ludlow rocks; among which the Hemithyris novicula is in great abundance. This sub-group seems to pass into, and to be blended with, the sub-group $(a)$ of the higher, or Iiendal, group. 
of common species, and some of those belong to types which are not confined to the Lower Palreozoic Division.

The whole Silurian Series of Westmoreland is overlaid by unconformable and discontinuous masses of red conglomerate; generally of very coarse structure, but sometimes passing into red sandstone. These masses are the degenerate representatives of the Old Red sandstone. Among the imbedded pebbles we find both Cambrian and Silurian fossils; and on the upper surface of the older rocks (whether Cambrian or Silurian) on which the conglomerates rest, are remarkable examples of mechanical abrasion.

\section{Middle Palcoo oic Division.}

Devonian Series or Old Red Sandstone.

(1) In Herefordshive and South Wales.

1. Cornstone group ........... Cephalaspis, \&c.

2. Red sandstone and conglomerate... Holoptychius, \&c.

The aggregate thickness eight or nine thousand feet.

\section{(2) In Devonshive and Commall.}

1. Liskeard or Ashburton group.

2. Plymouth group $\cdots .\left\{\begin{array}{l}a . \text { Great Devon limestone. } \\ \text { b. Calcareous slates. } \\ c . \text { Coarse red sandstone and flagstone. }\end{array}\right.$

3. Dartmouth slate group. \{ Coarse roofing slates and quartzites; ending in North Devon, with beds of red,

4. Petherwin (or Barnsta- $\{a$. Marwood sandstone. ple) group ...... $b$. Petherwin slate and Clymenia limestone; Calcareous slates of Barnstaple.

The aggregate thickness of this series is very great, but is not computed.

In Devon and Cormwall the above series has no base; and we are without any evidence as to the beds which are below the lowest Devonian group. Hence there is much uncertainty in the co-ordination of the series of Herefordshire with that of Deron and Cornwall: for the Herefordshire cornstone has characteristic Fishes withont characteristic Shells and Corals; while the Devoushire and Cornish series has characteristic shells and corals, but is without fishes.

In a former scheme* the Liskeard and Plymouth groups were united; but they may, I think, be conveniently separated. The Herefordshire fish-beds (Cornstone) I had formerly placed over the Plymouth group, on the understanding that certain supposed Fish-beds of Cornwall were probably of the age of the Dartmouth group. But the Cornish Fish-beds

\footnotetext{
* Advertisement to the Sccond Fasciculus of the Cambridge Palæozoic Fossils.
} 
having now disappeared from the sections, I think it much the safest plan to place the Cornstone group below all the groups of Devonshire; especially as it seems in some places to pass downwards into the Tilestone of the Ludlow group, and therefore appears to gire us (what we do not find in Devon and Cornwall) a base to the Devonian series. On this hypothesis we might arrange the Deronian series of Iterefordshire and the sub-groups of the Silurian series in a regularly ascending and unbroken numerical order; but the numerical scries would be defective in its last term. The phienomena in Scotland seem however to be adverse to this hypothesis.

The Petherwin (or Barnstaple) group is moxisionally arranged in the Devonian series. Physically, it is best connected with the older groups of Devonshire and Cornwall; but palcentologically, it is perhaps better connected with the rocks of the Upper Palacozoic division*. Ilere, therefore, there secms to be a continuous ascending order of deposits, and a passage from the Devonian series to the Carboniferous.

\section{(3) Deronian Series of Scotland.}

Grand as is the development of the Old Red sandstone of Herefordshire, it dwindles into insignificance when compared with the rocks which pass under the same name in Scotland. They are divided by Miller as follows :-

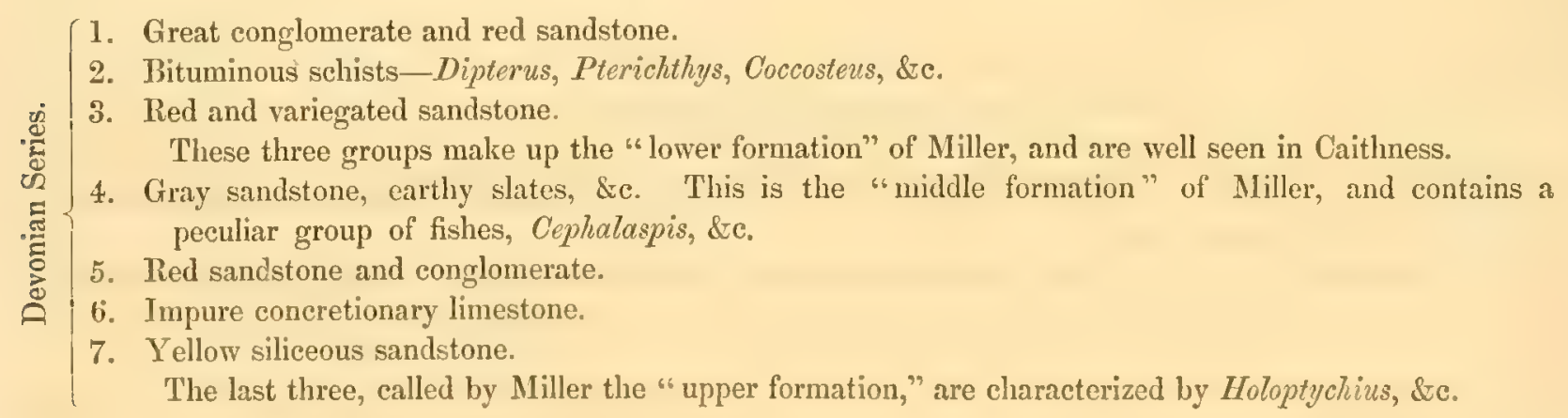

This vast North-British series has no true palæontological base; but its "upper formation" seems to graduate into the Carboniferous series.

Its lower groups have no linown representatives in the Old Red sandstone of IIerefordshire, and cannot (with our present information) be drawn into a close and unequirocal comparison with the "Tilestone" and Fish-beds of the Ludlow rock. But its "middle and upper formation" seem to be represented, though imperfectly, by the "cornstone" and overlying conglomerates, \&c. of IIerefordshire. From this also it scems to follow, that the upper part of the Old Red sandstone of IIerefordshire is defective in its development; and the conglomerate form of

* This question is discussed in a paper on the Slate Rocks of Devon and Coruwall, Quarterly Journal of Geol. Soc. Vol. vir. 1852 . 
its upper beds appears to sanction the conclusion. If this conclusion be received, it will follow that the Devonian series of Herefordshire is defective at its upper extremity, while the same series in Devon and Cornwall is defective at its base.

But if we take the Devonian series of Scotland as our type, a still more remarkable conclusion seems to follow: viz. that the Devonian series of Herefordshire (spite of its apparent passage into the Tilestone) is also defective at its base. For we have little or nothing in Herefordshire to match the first three great groups, or "lower formation," of Miller. May we not, however, suppose that this "lower formation" actually descends below the Old Red Sandstone of England, and is on the parallel of the Tilestone and Fish-beds of the "Silurian System"?

\section{Upper Paleozoic Dixision including the Carboniferous and Permian rocks.}

1. Great scar-limestone: coal-field of the basin of the Tweed, and lower coal-field of Scotland. Under this group may, perhaps, be finally arranged the "Carboniferous slates" of Ireland, and also the Marwood and Petherwin groups above mentioned. The coal-field of the Tweed appears to include the "great scar-limestone" of Derbyshire and Yorkshire, and even to descend below it.

2. "Limestone shale" of Derbyshire, "Yordale series" of Phillips.

3. Mill-stone grit. A deposit variable in structure and thickness; seldom entirely wanting; in Yorkshire, a complicated group of great thickness, and containing beds of coal.

4. Great upper coal-field of England, to be divided into two or three sub-groups.

\section{Upper Division continued.}

1. Coarse red sandstone and conglomerate, generally unconformable to the Carboniferous strata. It contains (though rarely) true Carboniferous fossils (Lepidodentra, Stigmaria, \&c.), which may, perhaps, have been drifted mechanically out of the contiguous coal-fields into this coarse, overlying Permian sandstone.

2. Marl-slate, and thin bedded compact limestone; a few impressions of Plants ; shells of Palæozoic genera-Producta, Spirifer; some Lamellibranchiata ; many impressions of Fishes-Palaconiscus, Platysomus, Pygopterus, Acrolepis, \&c.

3. Magnesian limestone, in some parts of the north of England of great thickness, and most complicated structure: e.g. rarely a crystalline dolomite, compact, cellular, earthy, brecciated, globular, oolitic, \&c., occasionally with organic remains-Producta, Spirifer; several Lamellibranchiata; Synocladia Fienestella, \&c.

4. Red gypseous marls, very slightly saliferous.

5. Thin-bedded gray limestone, sometimes cellular and dolomitic. A few traces of bivalves, \&rc.

6. Red gypseous marls. The above series is overlaid by the great red and variegated sandstone which forms the base of the Trias.

The preceding six groups are derived from the sections of Yorkshire and Durham, where the series is best developed. It is evident from the description of these groups, as well as from their general want of conformity to the Carboniferous groups, that the Permian series of England is physically more nearly connected with the Triassic than with the Palæozoic rocks. But its fossils (even without including the undoubted Carboniferous 
plants which have been found in the first group) are of a decided Palæozoic type-a fact which greatly astonished me when I examined the Magnesian limestone groups more than thirty years since. If we adopt the term Permian, as a general designation of the series, it must be done with proper limitations derived from the English types. For to class under the Palrozoic name, Permian, the red sandstone of St Bees' Head, or the great Red Sandstone of central England, would, I think, be perfectly erroneous. It would be the sacrifice of a natural and well-establisher sequence of the British deposits to the consistency of a newly adopted foreign name. On this account we have, $I$ think, been premature in using the term Permian to define a British series, which appears not to be quite co-ordinate with the Permian series of Russia. The English type is in fact better, for the purpose of European comparison, than the Russian; and where we have a good and unambiguous linglish type it is an injurious anomaly, in the present condition of our nomenclature, to introduce a foreign name into the English series*.

In the south of England the whole series is sometimes represented by a mass of conglomerate. In central England, Warwickshire, \&c. it is represented by a coarse red sandstone, some beds of which become calcareous; and the whole group is conformable to, and appears to pass into, the coal-measures. About the commencement of the Triassic period, these Permian sandstones underwent contortions along with the coal-strata; in consequence of which we sec, in Warwickshire, the upper Triassic groups resting discordantly upon the inclined berls of these sandstones.

In conclusion we may remark, -

1. That it is not in all cases an easy matter to draw a clear line between this series and the carboniferous. Thus Mr W. Smith, in his old geological map of Yorkshire, considers the lowest group (No. 5) as one of the coal-measures. The series most frequently commences with a discordancy of position and a co-ordinate change of organic types. With limited exceptions, the flor a and fanna of the Permian groups differ from those of the Carboniferous period.

2. The several groups of the series admit of a very close comparison with the Rothetodte-liegende, the Kupfer Schiefer, and the Zechstein, \&c. of Germany.

* The present nomenclature of the British groups, from the oldest Palaozoic to the newest Tertiary, is essentially geographic and local. The Pomfret Series would be a far better, and a far less ambiguous name for the English dolomitic series than the name Permian. The name Pomfret series (or system) would moreover connect the nomenclature with that of Mr W. Smith, as recorded in his old map of Yorkshire 1821. We have, however, done right in adopting one foreign designation, Trias; because in that part of the general series the English type is singularly defective.

\footnotetext{
** The provious part of the Introduction was commenced before the expiration of the past year, and some of it has been standing several months in type. What follows may be regarded as a Postscript to the Introduction. $A$ long continued indisposition has prevented the Author from resuming what remained of his task before the time indicated below. Had he been in better health, he could easily have completed the Introduction in the course of a few days.
}

Trinity College, March 2, 1855 . 


\section{General Conclusions.}

On casting an eye over the above short Synopsis, or Tabular View, of the whole Palaozoic series, several conclusions seem to force themselres on any well-informed reader: and I will enumerate them here, though they involve a partial repetition of what has been stated above. A more detailed discussion of them will, I hope, before long form the subject of another Essay.

Fivet. There is a frequent difficulty in separating the collective groups, such as the Cambrian, Silurian, Devonian, \&c., by well-defined lines of demarcation: and this difficulty is very little affected by our nomenclature; for it obviously remains the same, by whatever names we describe these collective groups. But the Cambrian Series is now, physically and palieontologically, well separated from the Silurian by the intervention of the May IIIl Sandstone. Commencing with the May Iill group there is a sudken change of mineral type, and an obvious physical break, sometimes marked by a change of strike and clear discordancy of position; and along with these changes there is also a sudden (and almost complete) suppression of the most abumdant and churecteristic of the older organic types. So far as regards the evidence supplied by Wales, and the bordering English counties, and by the north of England, the question respecting this line of demarcation is, I think, perfectly set at rest: nor does there appear to be anything in the development of the older Palæozoic series of the continents of Europe or America which is opposed to this conclusion.

Sccondly. The Silurian groups, from the May IIill (or Wenlock) sandstone to the upper Ludlow rocks inclusive, are by no means so well separated from the Old Red sandstone (or Deronian rocks) of IIerefordshire and South Wales. The Old Red sandstone was subdivided by Buckland and Conybeare into the Tilestone group, the Cornstone group, and the Red Sandstone and conglomerate group; and this triple division, with many new and important additional details, was adopted in the "Silurian System." Chiefly on the combined physical and fossil evidence supplied by the corresponding groups of Westmoreland, this triple division of the Old Red sandstone was afterwards abandoned. The Tilestone was struck off from the Devonian series, and placed at the top of the Silurian. There is, therefore, in the typical Silurian country such a graduation or passage between the Silurian and Devonian groups as to place a physical difficulty in our way when we attempt to draw a line between them. This line, as it is drawn at present, might, however, be considered as very well fixed and determined, were it not for the enormous development of the Old Red sandstone of Scotland, which (as before hinted) seems to descend below the base line of the Devonian series of Siluria. And when we bear in mind that Fishes begin first to appear in the Upper Silurian groups, and become eminently characteristic of the Devonian, we seem (through this Vertebrate Class of the Animal Kingdom) to make out a nearer connexion between the Silurian and Devonian groups that was at one time imagined.

I am here discussing no evidence but what is supplied by British rocks; and assuredly the classification of British rocks should, in the first instance, be based on British evidence. But I may remark, by the way, that the lower Devonian groups of the continent (e. g. those 
of the Rhenish provinces) seem to run into an intimate union with the Silurian. Hence it appears to me by no means improbable that we may be hereafter induced (provided we continue to separate the whole Palrozoic System, as in the Tabular View, into three primary Divisions) to place the Silurian Series not in the Loner, but along with the Devonian Series in the Middle Division of Palæozoic rocks. I only throw this out as a mere hypothesis; and if it be hereafter adopted, it must be on a wider base of evidence than is at present supplied by the Palæozoic System of England.

Thirdly. Though the Devonian Series, of the Herefordshire type, seems to pass downwards into the Upper Silurian groups, it does not appear to pass upwards into the Carboniferous. There is generally a palæontological and physical gap between them, which is in many places obscurely indicated by the Upper Conglomerates of the Old Red sandstone. Now this gap is, if I mistake not, filled up by by the higher Devonian groups in Cornwall and Devonshire. In those counties, when we draw a line between the Devonian and Carboniferous rocks, we find the physical and palæontological evidence in positive conflict. For if we go on the single principle of counting species, the Petherwin and Barnstaple groups (as was, I believe, first pointed out by $\mathrm{Mr}$ Griffith on the specific determinations of Professor $\mathrm{M}^{\mathrm{c}} \mathrm{Coy}$ ) must be packed with the Carboniferous Series. But in so doing we deprive of all importance a grand group of dark slates and flags, which seem to have been laid down by nature's hand as the true and continuous base of the great Culm-trough of Devonshire and Cornwall. Nor is this all. The Petherwin and Barnstaple groups, along with many true Carboniferous types, contain several genera and species which have not hitherto been considered as Carboniferous. In such a case as this we may strike a balance in the conflicting weight of evidence offered by the groups, by giving them an undefined margin, and by adopting a provisional nomenclature*.

Fourthly. There is in like manner, in some localities, a great difficulty in drawing the demarcation between the Carboniferous and Permian Series. This difficulty was acknowledged by Smith in his old Geological Map of Yorkshiret, in which he classed the "Lover Red Sandstone" (or Permian Sandstone of a more modern nomenclature) as one of the coalmeasures. The difficulty was also fairly stated by myself in a paper (founded on independent observations made in 1821, 1822, and 1823) published in the "Transactions of the Geological

* The case of the Old Red sandetone of the North of England has not been prominently noticed. It generally appears (as above stated) in the form of a very coarse conglomerate, which, if I mistake not, represents only the upper part of the Devonian series. In following the base of the Carboniferous rocks (as they wind round the Cumbrian mountains) we in several places find them underlaid by a coarse red conglomerate, and in a few places both by red conglomerate and red sandstone. In the latter case (e. $\mathrm{g}$. in the neighbourhood of Shap Wells) the beds of red sandstone are perfectly parallel to the overlying beds of the Great Scar-limestone. Nor is this all. Beds of red sandstone, of an identical mineral type, alternate, in thick masses, with the beds of the Great Scar-limestone; as may be scen in sereral places in the fine sections between Ravenstone Dale and Shap, and thence into Cumberland. In all such cases there is obviously an intimate union between the Old Red and the Carboniferous series-a fact which seems to sanction the opinion that the Old Red conglomerates of the North of England represent only the upper part of the Devonian series.

+ A work not without some errors, but of very great merit considering the early date of its publication (1821). 
Society*;" in which, on physical grounds, I classed the Magnesian limestone (now called Permian Series) with the New Red sandstone (now Triassic) Series; while on palcontological grounds it was far more nearly connected with the Carboniferous.

Nor did the progress of discovery remove this difficulty: for near Whitehaven many true Carboniferous fossil plants have been found in the Permian sandstone which underlies the Magnesian limestone; and similar fossils have also, I believe, been found in the Permian Sandstone of Yorkshire.

Again, as a prevailing rule, both in the northern and south-western English counties, the Permian groups (as before stated) are unconformable to the Carboniferous. But in central England this rule fails. Thus, in the coal-fields north of Coventry there is a fine Permian sandstone which is perfectly conformable to the coal-strata, partakes of their accidents, and appears to pass into themt. On the contrary, it is overlaid discordantly by the gypseous marls, sandstones, \&c. of the Triassic group.

Fifthly. There is a similar difficulty in drawing a fixed line of demarcation between the Permian and Triassic groups. In Yorkshire, where the Permian Series is most perfectly developed, its upper beds are parallel to, and (through some red gypseous beds) seem to form a good mineral passage into the Triassic Series. And on the coast of Cumberland, geologists are not agreed where to draw the line between the two great groups-Permian and Triassic. Sir R. I. Murchison has drawn the line above the Red Sandstone of St Bees' Head. I think this is a mistake, and that the line ought to be drawn below that Red Sandstone; which is, I believe, the equivalent of the Bunter sandstein, or Grès rouge of the Trias.

After the remarks above made (under the five preceding heads) let no one suppose that I have any wish materially to change the nomenclature of the Palreozoic Series as sketched in the Tabular View. Whatever may become of the three Divisions of the Palaozoic Serieswhether they be retained as they are, or admit of a new adjustment-very little affects any important question of classification and nomenclature: but I see no ground for anticipating that the subdivisions into Cambrian, Silurian, Devonian, Carboniferous, and Permian, will ever require any material change or adjustment: at least so long as we continue to adopt a geographical nomenclature, which is based on the actual succession of physical groups and is

* Second Series, Vol. III. pp. 121 and 122. The following words occur in these pages: "Notwithstanding the entire break which, in many parts of England, exists between the coal-measures and the superior deposits, in certain parts of Yorkshire there is no such want of continuity; and the Lower Red sandstone (Permian) seems to form a connecting link between the carboniferous order and the group of the New Red sandstone (Trias). Moreover the fossils of the Magnesian limestone have little resemblance to the fossils of the Lias and the Oolites; but have several genera and species in common with the mountain limestene." If the word species be struck out (or given as doubtful) this quotation will very nearly represent the truth: and I well remember my surprise when I first saw the Palæozoic type (to adopt the present nomenclature) of the Magnesian limestone fossils, and the reluctance there was, on the part of some others, in first admitting the fact. For at that time most English geologists regarded the Carboniferous rocks as Transition; while all of them were agreed in regarding the New Ked sandstone and its dolomites as Secundary.

$\dagger$ The words "to pass" may, perhaps, be considered inaccurate, when it is added, that (in the coal-fields alluded to) the Carboniferous Series is separated from the Permian sandstone by one, and sometimes two, thin hands of limestone (exactly like the thin bands described in the Silurian System, in the same geological position) which are supposed to be of freshwater origin. Whatever be their origin, they are (in the country alluded to above) associated with true Carboniferous plants. 
fortified and defined by a co-ordinate weight of fossil evidence. Nor does it much matter by what names we call these several subdivisions. Whether each is to be called a System or a Series, seems, at first sight, rather a question of taste than of science. I think, however, that the facts just stated do prove that the word Series is a more correct description of the Palæozoic subdivisions than the word System-among other reasons because it is a less definite term, and admits of a broader margin : and to this reason we may now add, with perfect certainty, that the abuse of the word System has been a drag-chain on British Palæozoic Geology, and has led to many and great mistakes, both in classification and nomenclature.

Sixthly. To the previous remarks I may add, that if the succession of our geological deposits were physically complete, we might, with proper caution, apply the percentage theory of Sir Charles Lyell to their limitation and nomenclature, by counting the well-ascertained species in each successive group. But in the actual condition of our palæontological series we cannot follow this rule, universally, without introducing the elements of confusion. Thus on the percentage theory, we should unquestionably be led to give a false date to the Red Crag of Suffolk; for this simple reason, that a great number of its fossils have been mechanically drifted out of an older deposit, the Coraline Crag-a fact first clearly pointed out by Mr Charlesworth.

There may not be a similar example in the whole British Palæozoic Series: but assuredly it is not improbable that among the coarser and more mechanical Palæozoic deposits (such as the Red Sandstone which overlaps the Carboniferous rocks and forms the base of the Permian Series; or such as the coarse mechanical beds of the May Hill sandstone, which, in like manner, overlap the Cambrian rocks, and form the base of the Silurian Series) there may be some examples of species which have drifted out of the rocks of an earlier date. On this ground, while we are making a comparative estimate of the Cambrian and Silurian Faunas, we can only count at a very low value such species as abound in the lower, and appear very rarely in the upper division; and appear there only within a very little distance of the line of demarcation between the two. To count such species of the same numerical value in the two Faunas, would be as gross an instance of miscalculation as could well be imagined.

Seventhly. Without dwelling on cases of immediate ambignity, we may affirm generallythat when we profess to give a comparative estimate of the Fauna of any two Palæozoic groups, we have no right to overlook the question, whether certain species belong to a prevailing type in one of the groups; or, on the contrary, are rare (and perhaps doubtful) exceptions. I will take, for example, six species which are given by the author of "Siluria" as common to the Llandeilo, Wenlock, or Ludlow formations; viz. Tentaculites ammulatus, Petraia elongata, Trinucleus concentricus, Leptena sericea, Orthis Actonia, Orthis respertitio*. This list might be largely increased; but I select these six species for a reason

* If the reader turn to the following pages of this Volume where these species are described, he will seo how largely some of them have been collected. But the published lists, ample as they are, give a very inadequate notion of the mass of materials that was submitted to Professor $\mathbf{M}^{\circ} \mathrm{Coy}$ during the years that he laboured in our Museum. Hundreds (or I might say thousands) of specimens were broken up by him with a view of determining the nature of the hinge, or some character (occasionally microscopic) which was important to the determination of the several species. 
given below. In many parts of the Cambrian Series they are found in millions: and they produce a very characteristic impress on its Fauna. But not so much as a single unequivocal fragment of any one of them is to be found in those parts of the Cambridge collection which are derived from heds below the May Hill sandstone. Negative facts cannot stand a moment against positive. This we all allow: but if negative facts be honestly and laboriously stated, they may, at least, prove that certain positive facts (such as the six examples above quoted of species common to Cambrian and Silurian rocks) are very rare and exceptional cases. Such cases are not to be received but on evidence that is unequivocal; viz. the production of the very species upon which the exceptional lists have been formed. Now I was informed by Professor MCCoy (in a note which is now before me) that he had applied, at the Museum of Economical Geology, for a sight of five, out of six, of the very species above enumerated, and that not one of them was shewn to him, or found in the Museum, under conditions which confirmed the assertion that they were common to Llandeilo, Wenlock, or Ludlow rocks. $\Lambda$ s to one of the six species (Orthis Actonia) I myself applied to Professor Forbes for his authority. He replied that he could not give his sanction for this species as a type common to the (so-called) Upper and Lower Silurian rocks-that he had nothing but a field memorandum respecting it, and that he might very easily have mistaken the species, or mistaken the rock from which it was obtained.

Taking Sir R. I. Murchison's list, as published in the Appendix to his "Siluria," and without any deduction whatsoever, it does not give us much more than ten per cent. of species common to true Cambrian and true Silurian British rocks. But when we have struck out from this common list, (1) all those species which range beyond the limits of the Lower Palrozoic Division, into the Devonian and Carboniferous groups; (2) all species of doubtful authority; (3) all species of which the geological place is not established on good physical evidence; (4) all species which however abundant in the lon $r$ series disappear in the uppereither altogether, or ascend into it through so very limited a space above the line of demarcation as to produce no general impress on the upper Fauna;-when all this has been done, I have no doubt that the number of common specics will fall considerably betow ten per cent.: perhaps as low as the percentage shewn by the Paleozoic series of North America or Bohemia; but not so low as the per centage shewn by the Cambrian and Silurian rocks of the North of England.

\section{Further Remarlis on the Cambrian Series, and on the Nomenclature of its subordinate Groups.}

On returning to the Cambrian series, I know well how impossible it is to describe it in any adequate terms within the limits of this Postscript: but I may give a short summary of some of the leading facts connected with its history which could not be noticed in the Tabular View. Firstly. In extent, in complexity of structure, and in grandeur of development, it rises far above all other collective Palrozoic groups; and in 
thickness it is equal to all of them put together-counting them from the May IIIll sandstone to the highest beds of the dolomitic (or Pomfret) group (or Permian, if the word be limited as above) inclusive. Secondly. It is difficult of interpretation, especially from four causes.

1. The first diffculty arises from the rarity of organic remains in the lower groups of the series, and from their apparent absence from the lowest. Should this negative result be confirmed, the lowest groups are then properly defined by Professor Phillips's term, hypozoic. They are not merely a zoic, or without any traces of former organic life; but they are hypozoic, or below the oldest rocks which have been found with such traces*. Hence arises a peculiar difficulty. We find traces of organic beings in some of our oldest rocks; but when did they begin? The answer to such a question is involved in inextricable obscurity; like that we meet with in tracing the origin of races and languages and institutions during the darkest periods in the history of man. But we have no comparable difficulty in tracing the history of the other subdivisions of the great Palæontological Series, such as the Silurian, Devonian, \&c., up to the Tertiary. For each subdivision has some defined physical boundary; and a more or less defined Fauna, which has a relation to two other Fannas-one above it, and the other below it.

Nor is this all. As a great fact in the natural history of the earth, in comparison of which the exceptions to it sink into insignificance, great groups of species have disappeared, and new types of organic life have begun; not as a consequence of a vast lapse of time incompatible with the longer continuance of certain species, but in consequence of a change of physical conditions; and, as a general rule, these changes of conditions are marked by a defined succession of physical monuments, which are among the most instructive and fundamental phenomena in geology $\dagger$. The study of such successive monuments is, and has been, the first great work of geology in which Palæontology has been but her handmaid. Without such successive monuments, Palæontology is only a supplement to zoology; and, in that point of view, it gives us no indication whatsoever of epoch, or date, or physical revolution in the past history of the earth.

2. The next difficulty in the analysis of the older Palæozoic rocks arises (at least in England) out of the general prevalence of cleavage-planes. Till these planes are understood and distinctly separated from the beds (and also from the divisional joints,

* In some of the grand sections of North America (exhibited to the Geological Society by Mr Logan) the Potsdam sandstone and other groups which are here called Cambrian rest unconformably upon a vast series of contorted metamorphic rocks containing phosphate of lime in great abundance. If this fact wero assumed as a proof of the original existence of organic beings in these old rocks, before they hecame metamorphic, it would, I think, prove that there were in America the traces of a Palseozoic group that was probably older than theoldest of those enumerated in the above Tabular View. But I am not in this Introduction discussing metamorphic rocks, or leaning on any evidence that does not properly belong to the British series.

t The opinion stated in the text has always been held by myself; not as a consequence of any theory, but as a fair induction from intelligible facts. It was vindicated many years since by M. Élie de Beaumont. In more recent times it has (with certain modifications) been upheld by Professor E. Forbes: but his cheering and powerful holp, on this and all kindred subjects, is now alas taken from us, to the deep sorrow of every British lover of natural science! But his name is chorished among the good treasures of our memory; and his works will be honoured, long after all the men of this generation have passed away, and long after many of them have been forgotten. 
which in many places are not only numerous, but in almost perfect parallelism to one another), it is impossible to take a single safe step in determining the successive groups of the Cambrian series.

Several facts connected with this subject were established by myself in 1822, after much hard labour, and a multitude of careful sections made among the Cumbrian mountains: viz. (1) That the strike of the cleavage-planes, when they were well-developed, and passed through well-defined mountain-ridges, was nearly coincident with the strike of the beds. (2) That the dip of these planes (whether in quantity or direction) was not regulated by the dip of the heds; inasmuch as the clearage-planes would often remain unchanged while they passed through beds that changed their prevailing dip, or were contorted. (3) That where the features of the country, and the strike of the beds, were ill defined, the strike of the cleavage-planes becane also ill defined, so as sometimes to be inclined to the strike of the beds at a considerable angle. (4) Lastly, that in all cases where the cleavage-planes were well developed, among the finer slate-rocks, they had produced a new arrangement of the minutest particles of the beds through which they passed.

As a general conclusion from these facts, it seemed to follow, that the cleavage-planes were the result of a crystalline, and not of a merely mechanical action. This latter conclusion scemed to he sunctioned by a series of facts, of a kind hoth positive and negative. Thus I found examples of old strata, where the cleavage-planes occasionally disappeared, and again within a short distance reappeared, on a sulden modification of the mineral constituents.-Such, for example, as a change in the proportion of carbonate of lime, which seems in many cases to have facilitated the formation of cleavage-planes.

I will take a more definite. example, from the calcareous slates and the limestone of Coniston. Generally, the calcareous slates and the limestone range together; the former shewing transverse cleavage-planes in great perfection; the latter very little affected by them: lut at the south-western extremity of their range (not far from the coast of Cumberland) the calcareous matter of the slates becomes superabundant, the fissile structure partly disappears, and the whole mass puts on a globular structure-being to a considerable extent made up of spherical calcareous concretions, some of which are two or three inches in diametel. But how are these concretions arranged? Not parallel to the true beds, as might have been expected; but parallel to the cleavage-planes of the ordinary calcareous slates. The case admits of no doubt; for the globular and fissile structures pass, almost insensibly, one into the other along the line of strike; as may be clearly seen in a succession of open quarries. That the several spheres have been formed by a crystalline action round a fixed center no one will perhaps doubt. But this action has been accompanied by another, and a more general action, which has modified the position of the spheres, and has coincided in direction with that power which, under other mineral conditions, produced the cleavage-planes. It may not be easy to explain such complicated phrnomena; but it is, I think, obvious that they are utterly out of the reach of any merely mechanical agency, in whatever way applied. 
After the summer of 1822, the exposition of cleavage-planes (as given above) formed a part of my public teaching, and was a matter of frequent discussion. And so far from overlooking the fact that, under proper limitations, the strike of the cleavage-planes coincided nearly with the strike of the beds, I absolutely assumed, in my traverses among the higher Cumbrian mountains in 1823 and 1824, that the two strikes were so nearly coincident that the strike of cleavage (which was in numberless instances visible when the true bedding was concealed) might be assumed as a good approximation to the strike of the beds. But several years afterwards, though the above rule might still be considered approximately true, I found so many limitations to it, that I was compelled to notice them whenever I described the conditions of the cleavage-planes of slate-rocks, especially in Devonshire, Cornwall, and a portion of South Wales*.

When my paper on the cleavage-planes of slate-rocks and of large mineral masses was first read, it was attacked by one of the most distinguished members of the Geological Society in terms of extreme vituperation, and its statements were for some time controverted by the Director of the Government Survey. And after the paper was published, it was attacked, by a third gentleman, in one of the Philosophical Journals, in terms I might almost say of contemptuous bitterness. But, all theory apart, it was a true statement of very important facts of structure, and it gradually was accepted as true; and though not perfectly original, it has been the means of helping subsequent observers in making their way among some of the most perplexing phænomena of geology.

That the cleavage-planes, in a mountain-chain of slate-rocks, have been produced by the compounded effect of all the crystalline forces acting on the mass, receives a remarkable confirmation from certain phænomena exhibited by the protruding bosses of granite in the south-western parts of Cornwall. The granite is a mineral aggregate of a very common kind; and its crystals were formed by the mutual action of its molecules at the time it was passing into a solid state. It gives no appearance of a slaty structure; yet it cleaves (sometimes through large spaces) in one constant direction, and in nearly parallel planes, much more readily than in any other. And this direction is known to the quarrymen by the approximate arrangement of some of the larger crystals of felspar, upon the same planest. The phenomena prove, I think, to demonstration, that while the crystalline

* For example: I made many additional observations on the modifications of cleavage-planes in Cornwall in 1828 ; in Wales in 1831 and 1832 ; and in Deronshire and Cornwall in 1836, 1837, and 1838. The statement of the text may perhaps seem out of place in this Introduction. I make it however here, because my viows have been misrepresented. Thus, in an Anniversary Address ex cathedra, the President of the Geological Society of London asserted that I had orerlooked one leading fact, viz. that the strike of the cleavage-planes was nearly coincident with the strike of the beds: and the same assertion was virtually repeated in a printed memoir by the only member of the Society who has written, at any length, on the theory of cleavage-planes. Neither of these gentlemen (at the time their statements wero made public) would appear to hare so much as looked at my Paper on cleavage-planes. (Geol. Trans. 2nd Series, Vol. III. pp. 473 and 483. )

t This structure is perfectly understood by the quarrymen. It was well described in a paper (to which $I$ am not able to refor) by Mr R. Fox and Mr Eneys-two Cornish gentlemen who have made valuable contributions to physical geology. It was also alluded to by myself in the paper referred to in the provious note, Geol. Trans. 2nd Series, Vol. uI. p. 483 . 
action of the molecules produced the mineral aggregate we call granite, a more general crystalline action produced a peculiar and parallel arrangement of the whole mass. In a case like this, a merely mechanical foree (like that of compression) is entirely out of question: and we have a full right to make use of such facts in illustration of the more obscure phænomena of cleavage-planes through slate-rocks and deposits which are mechanical. All I contend for is, that the phænomena of clearage-planes are due to a crystalline rather than a mechanical action.

While my first observations on cleavage-planes were made-during long by-gone yearsin Cumberland, I had hardly noticed the phenomenon of a second cleavage-plane: but on many occasions I have subsequently collected, from various parts of England, a considerable and unpublished mass of materials, in illustration of this second plane. I should not have noticed it here, but from its connexion with a mechanical theory which I do not think even approximately true. The second cleavage-plane is generally inclined at a great angle to the first plane. Most beautiful examples of this double structure were seen (in 1839) by Sir R. I. Murchison and myself in the quarries of the Ardennes, where the fine, glossy surfaces of the slates are frequently marked by the parallel stria of second cleavage; and the economical value of the slates is sometimes much deteriorated by the second plane. By a powerful reflected sun-light I have frequently been able to trace these strix of a second cleavage on the surface of the Bangor slates which have been brought to Cambridge. Instructive, though coarse, examples of this double structure are seen, here and there, in Devon and Cornwall; and also in North Wales, especially among the Upper Bala rocks, as well as among the slaty varieties of the Wenlock group.

It has been proved by Mr Hopkins, that when a great mass of strata is pushed out of its place by a vertical movement of elevation, it will be acted on by two sets of divellent forces that are nearly at right angles to one another. Have these forces been the mechanical cause of double cleavage-planes? I reply, no: because mere mechanical forces cannot account for the phrnomena, which imply a positive re-arrangement of the molecules of the mass. Moreover we find in many slaty rocks (in addition to the cleavage-planes) two sets of nearly vertical joints (one set, running parallel to the strike of the beds, I have called strike-joints; and the other set, which are nearly at right angles to them, dip-joints) which do accord with the mechanical conditions stated by Mr Ilopkins, and probably represent them. The two names, dip-joints and strike-joints, I have frequently made use of, because of the very common occurrence of such joints*.

In illustration of these views I will quote one example derived from the very coarse Cambrian conglomerates in the pass of Trebennau, on the old road between Llandovery and Pumsant. These conglomerates are highly inclined, and regularly alternate with great beds of coarse slates which have a distinct transverse cleavage. The conglomerates are cut by

* Other less uniform breaks of continuity I have called diagonal-joints. They are of great irregularity; and I doubt not that multitudes of such joints have been formed by mechanical tension during the gradual desiccation and contraction of aqueous rocks, as well as by the gradual cooling and solidification of those which were partly of igneous origin. 
regular and nearly vertical strike-joints, and partly also by lip-joints. They also flake off, here and there, into masses, more or less tabular, which are parallel to the cleavage-planes of the slates. It appears, therefore, that the forces which produced the clcavage-planes acted also, sensibly, on the very coarse conglomerates. Noreover, the conglomerates are separated into beds; which, however obscure, were proved to be the true beds by the organic remains I collected from their planes of junction both in 1846 and in 1854 . The case admits of no ambiguity. Now when we examine the open mechanical joints, we find that they have actually cut through the pebbles of quartzite and other hard masses which enter into the composition of the conglomerates. But when we examine the divisional planes, that are parallel to the cleavage-planes of the slates, the appearince is entirely different. In this second system of divisional planes the pebbles have not been at all affected or moved from their place; and they stand out in high relief on the surface of the exfoliating masses. What then has produced this tendency to a regular exfoliation? A new arrangement of the earthy, gritty, and micaceous particles which form the cement of the conglomerates. This cement has been re-arranged by the same crystalline action (I know no other name by which it can be described) which has produced the cleavage of the neighbouring slates. Here then we have the clearest proof of a mechanical action like that brought to bear in the theory of $\mathrm{Mr}$ Hopkins; and in the same rock we have an equally clear proof of another kind of action which cannot have been produced either by a divellent force, or any conceivable mechanical force like that of pressure*. I conclude, therefore (while putting out of account all opinions which are theoretical), that I have, during the progress of Palcozoic Geology, given such a real account of the phrnomena of cleavage-planes as has enabled other observers to make their way, with comparatively small difficulty, through some of the complicated sections of Wales and Cumberland.

3. The third difficulty arises from the extraordinary development of eruptive and stratified igneous rocks in the central parts of the Cambrian series. When I began, in the

* I do not accent Mr D. Sharpo's mechanical theory of cleavage-planes, for the following reasons. (1) It is not based on a sufficiently wide induction of facts: it is, at best, but an ingenious hypothesis. (2) It is directly opposed to a multitude of positive facts, of which it gives no explanation. (3) Its author has made some great mistakes in what may be called the solid geometry of the subject, which in limine throw doubts upon the accuracy of his observations. (4) It gires no adequate explanation of the rearrangement of the molecules in cases of most perfect cleavage planes. (5) It offers no explanation of the disappearance and reappearance of cleavage-planes in mineral masses which have been under the sane conditions of mechanical pressure. (6) It gives us no account of the entire absence of transverse cleavage-planes in large regions of old contorted Cambrian rocks; such (for example) as those in the frontier chain of Scotland. (7) Lastly (though this is an argument I do not wish to press against it), it seems to be out of harmony with Mr. Sharpo's theoretical explanation of the complicated structures exhibited by the old metamorphic rocks of the northern Highlands of Scotland.

The frontier chain of Scotland (from St Abb's Head to the Mull of Galloway) requires a few additional words of notice. It is generally made up of beds which are highly inclined and much contorted. It exhibits all the conditions of an elevation implying an enormous lateral pressure. It comprehends many subordinate tracts of country, whore the rocks scem of a structure well fitted to receive the impress of a transverse slaty cleavage. It contains some good quarries of roofing slates, which, howerer, are not derived from oblique cleavage-planes; but, in every instance whure I havo seen them, are exfoliations parallel to the bedding. The theory of mechanical pressure fails to give us any good account of these negative facts. The crystalline theory has a ready reply to explain them: viz. the almost entire absence of calcareous matter, and a prevalent coarse mechanical structure unfarourable to the development of true eleavage-planes through the great mineral mass. 
year 1822, to examine the district of the northern lakes, and the structure of the Cumbrian mountains, "I believed in the igneous origin of basaltic and porphyritic rocks: but I was staggered in my creed, and filled with astonishment, almost at every step, when I saw the alternating masses of slate and porphyry, and the way in which they were blended together. The Wernerian hypothesis has now passed away, and has been extinguished by the more mature discoveries of an advancing science; but it lent itself readily to the explanation of many perplexing facts; it had the merit, at first sight, of great simplicity; and I may venture to affirm, that no one is prepared to understand it, or to do any justice to its author, who has not studied, in the ficld, such phrnomena as are continually offered by the Cumbrian slates."

"The central division of the Cumbrian slate-rocks forms a vast group, that rises into the highest and most rugged mountains of the whole region. It contains two distinct classes of rock-aqueous and igneous: but they are piled one upon another in tabular masses of such regularity, and are so interlaced and blended, that we are compelled to regard them as the effects of two distinct causes, acting simultancously during a long geological period. The igneous portions present almost every variety of felstone and felstone porphyry*; sometimes passing into greenstone, and rarely into masses with a structure like that of basalt. All the aqueous rocks have more or less a slaty structure, and pass in their most perfect form into the finest roofing slates.

"But why are rocks, so different both in appearance and origin, to be confounded in one formation?-Because nature has made them inseparable. The tabular masses of true erupted 'plutonic rock' alternate with, and pass by insensible gradations into, great beds of breccia and 'plutonic silt.' The breccias are often as hard as the parent rocks; being cemented by a felspathic paste, occasionally studded with garnets and crystals of felspar; and they sometimes put on a columnar form: and the plutonic silt passes into a hard, flaky, shining rock, which often has a transverse cleavage with an uneven, shining; wavy surface (exactly like that of some varieties of the German schaalstein). We have only to follow such changes a little farther, and we are conducted, without seeing where we pass their boundaries, into great deposits of the most perfect roofing slates. Of these slates, quartz in the finest state of comminution, and earthy chlorite partly derived from the plutonic silt, are the chief constituents.

"The plutonic roclis were poured out under a deep sea; and the breccias were formed mechanically (like volcanic breccias found among streams of modern lava), and were cemented under great pressure. The plutonic silts have an intermediate structure; but their beds must have been spread out by the waters of the sea. The roofing slates are but the extreme case of fine aqueous sediment, chiefly derived from the erupted matter, and sinking into successive

* I adopted the word felstone from the German miners of Nassau; who by the word feldstein, sometimes describe those minerals which we have commonly, but inaccurately, called compact felspar. The words, compact spar, surely involve a verbal contradiction. What is described, in the above quotation, as plutonic silt, I now generally call trap-shalea recomposed plutonic rock not supposed to have been ever sub-aerial, and therefore not a true volcanic ash. 
beds during intervals of repose: and so far they are analogous to the fine beds of voleanic silt as often formed by the waters of a lake out of the ashes of a modern crater.

"In the Cumbrian mountains no organic remains are found among these rocks. The aqueous deposits seem to have been too often interrupted by igneous action to permit the growth of shell-beds and coral-banks. Shells and corals are however found (though rarely) among the slate-rocks of Snowdonia: but there the igneous beds are less abundant, and were probably poured out at longer intervals of time."

These quotations are from a letter to my late honoured friend Wordsworth, the great poet of the lakes. They were written in the Spring of 1842, before I had revisited North Wales after my first survey of it in 1831 and 1832. I do not wish to change one word of them, and I have little to add to them*.

It might, perhaps, be said that views of a like kind had been published before 1842 , by Sir II. de la Bêche and Sir R. I. Murchison, and that I had eked out these deseriptions by borrowing from the property of others: and after some words which were let fall at the last meeting of the British Association (in 1854) I looked back with some anxiety, among the early published Proceedings of the Geological Socicty of London, to see whether there were any printed records of my views respecting the Cumbrian plutonic rocks; and I rejoiced to find in the first Volume (p. 400) an abstract of a paper by myself (of the date of May 16, 1832) containing the following abridged description of the great central group of the "Cumbrian Mountains."

"This great group, which occupies all the highest and most rugged mountains of the region described in the memoir, is essentially composed of great tabular masses, composed of different modifications of porphyritic and felspathic rocks, and of quartzose and chloritic slate, all the finer portions being derived from a cleavage transverse to the stratification of the beds. The modifications of the slate are first described, and it is shown that they pass, on one hand, into compact felspathic slate sometimes porphyritic; on the other, into coarse granular and concretionary slaty masses, and through them into breccias, or pseudo-breccias; all these changes being effected without any change of strike or dip. In like manner it is shewn that the amorphous, and even semicolumnar, prismatic, porphyries are not only arranged in directions parallel to the tabular masses of grcen roofing slate; but pass themselves into a slaty texture with a strike and dip parallel to those of the true roofing slates. They also pass into brecciated masses similar to those which form a part of the slate-groups. From these facts, - as well as from the negative facts, that the porphyries never penetrate the roofing slate in the form of dykes, and produce no mineral change in the limestone beds resting on them,-it is inferred that the whole group is of one formation, which has originated in the simultaneous action of aqueous and igneous causes long continued."

After the year 1824 I regularly taught the conclusions implied in these quotations; and I maintained that many rocks, which now have a perfect porphyritic structure, were so far

* Appendis to a Guide to the Lakes. John Hudson, Kendal. 
aqueous deposits that they had been spread out into beds by the action of the sea, and that their actual structure (though certainly metamorphic) was not the effect of torrefaction, or of heat enanating from any eruptive or igneous center. On the contrary, that the natural temperature at great depths, combined with great pressure long continued, was a cause quite sufficient to explain the phænomena of the old stratified plutonic rocks*.

Many are the discussions I have held on points like these which are now forgotten; and I allude to them only in self-defence.

I do not deny great merit, as well as originality, to the observations of Sir R. I. Murchison, and Sir II. de la Bêche, on the stratification of plutonic rocks; nor have I the shadow of any complaint against cither of them on this score. What I contend for is-that views, such as are here given, were only completed by myself after great and long-continued labour; that they are essential to a right interpretation of the successive groups of our older Palieozoic rocks; that they belong, (so far as regards this Island) to the very alphabet in which nature's old records have been written, and without which her records cannot be read and comprehended; and that in this field of correct interpretation I preceded, by a good many years, all my fellow-labourers of the Geological Societyt.

4. The fourth difficulty, in making out the order of the physical groups in the Cambrian series, arises out of their extraordinary dislocations and contortions.. With these difficulties I grappled, single-handed, in 1831 and 1832; and I so far overeame them in North Wales, that with one doubtful exception I was enabled to make out the general grouping and superposition in the very order in which it now stands in the above Tabular View

While carrying on this task-the hardest that ever fell to my lot-I freely made use of M. Élie de Beaumont's theory of parallelism, and turned it to good account: and whatever may now be thought of the great, and controverted, extension which he has given to

* A discussion on this subject took place before the British Association (I think) in 1832. It arose out of a statement that the bulb of a thermometer could not be maintained in the boiler of a steam-engine when the temperature was much elevated. The glass bulb was dissolved by the chemical action of water heated under pressure. Hence I contended, during the discussion, that at the depth of ten or twelre thousand feet below the sea-bottom there would not only be a natural heat that was considerable, but probably a set of reagents at work capable of producing among the deposits great changes of structure and many metamorphic phænomena. No one, of course, contended that the actual protrusion of a mass of granite, or other igneous rock, was not also a true, and more powerful, agent in producing metamorphic structure. But this kind of direct metamorphic agency did not fall under discussion at the meeting.

† One, and so far as I know the only one, of the members of the Geological Society who has written on the general classification of the older Palæozoic rocks of.England has fallen into complete error as to the epoch and origin of the stratified porphyries of the Cambrian age. This one great mistake inevitably damaged the wholo of his Memoir on the Older Rocks of Wales; which is, consequently, in its beginning, in its middle, and its end, erroneous in nearly all its general riews respecting the epoch and the order of the great Cambrian groups.

‡ This remark, so far as regards the contortions of the Middle Cambrian Group, does not apply to the "mountains of the Lake district" in the north of England. In that country, however, the dislocations are enormous.

\& The exception alluded to was the doubtful position assigned to the dark, earthy slates which range near the Menai Straits. I had no doubt, in 1831, after I had examined them, that they belonged to an old group; but I could only gire them a provisional, and not a positive place in my first sections. In 1846, when I again had an opportunity of examining them, I determined their right place, as they now stand in the Tabular view, under the name of Tremadoc slates. On still more direct and perfect evidence, Professor Ramsay has referred them to the same part of the general series. 
it, I can only express myself towards him (as I have done before, many years since, when I was President of the Geological Society of London), in terms of gratitude for the great help which his works, on the theory of parallelism, have lent to me. Viewed in connexion with that theory, the Cambrian series becomes a vast and complicated system; which, as a general rule (however modified by local dislocations and subsequent contortions), has a north-castern and a south-western strike; and with that prevailing strike is thrown into great parallel undulations, which, in many parts of the British Isles, were completed before the existence of a single Silurian deposit. So great has becn the physical influence of these old north-eastern and south-western movements of elevation, that (within the limits of the British Isles) we can often decide upon the date of the older constituent deposits of a given region, by a glance of the eye over the physical map in which they are delineated, and where their north-eastern strike has produced its characteristic impress on the geographical surface. Thus, for example, in the Isle of Man (in which I have never set my foot) I should conclude, from the outline of the map, that the slate-rocks had a north-eastern and south-western strike; and hence, that they were probably Cambrian, and not Silurian*.

* The best English illustration of the parallelism of contemporaneous axes of elevation, with which I am acquainted, is to be found in Charnwood Forest, in the Warwickshire (or Nuneaton) coal.field, and in the beautiful Silurian groups near Dudley. In these three countries the principal axes of elevation are parallel (having the same approximately north-western strike); and they are, I believe, due to elevations of an epoch inmediately preceding the Trias. These parallel axes affect, alike, large groups which are of the Cambrian, Silurian, and Carboniferous periods.

A single axis of elevation (which I made out in 1833) brings up the old rocks of Charnwood Forest, all of which are Cambrian. This fact, considered by itself, proves nothing respecting tho epoch of elevation; for any great elevation may be expected occasionally to affect any rock of an anterior age. But we can prove that this elevation affects the coal-field on the south-west skirt of the Forest, and that it does not affect the Trias. Again, if we follow the axis of elevation towards the north-west, beyond the limits of the Forest, we find that it has brought up at a high angle, and dolomitized, great broken masses of carboniferous limestone; but it has not affected the position of the Trias, which is horizontal. As we trace the-line of elevation towards the north-west, its effects gradually disappcar. The limestone sweeps round, skirting, and forming the geological base of, the Leicestershire coal-field; and as it recovers its natural position it ceases to be dolomitized. In one or two places, however, where the beds have been interrupted by minute vertical fissures, a mineralizing influence has ascended through the fissures, dolomitized the beds on both sides irregularly, introduced minute crystals of galena, and produced miniature representations of the well-known pipe-veins of Derbyshirc.

The Nuneaton coal-field may be described as a very excentric elliptical basin, the major-axis of which is parallel to the axis of Charnwood Forest. It is underlaid on the east side (and in one single spot also on the west side) by old (Cambrian?) slate-rocks, which strike and dip exactly with the carboniferous overlying groups. Tho carboniferous series is orerlaid by a Permian sandstone, which partakes of the strike and other accidents of the basin on which it rests, and of which it forms a part. But all the rocks, whether Cambrian, Carboniferous, ol Permian, are skirted and overlaid by horizontal deposits of the Triassic marls and sandstones. Here we have a proof that the elevation of tho Cambrian rocks did not take place till after the Carboniferous and Permian period, and that the elevation was completed immediately before the period of the Trias. The facts, so far as they admit of comparison, exactly harmonize with those of Charnwood Forest.

Respecting the Dudley elevation I have no observations of my own worth recording in this note. The axes of elevation (as appears from the memoirs of Sir R. I. Murchison and others who have written on the district) are in a direction that is almost mathematically parallel to the axes of Charnwood Forest and the coal-ficld above described. I believe also, from the published descriptions, that the Dudley period of elevation was the same with the periods above noticed: viz. after the date of the Permian sandstone, and before the date of the Trias.

I conclude with this practical remark. While we contend against what we may suppose to be the unphilosophical extension of a theory, Iet us not fall into an opposite error and reject it altogether, even when it helps us to comparo and marshal facts together. The parallelism of contemporaneons elevations is not a universal truth derived from any known law of natuve. But, taken with proper caution and proper limitations, it is, I believe, a fact of geology which admits of a very extensive practical application, and greatly assists us in grouping together our unconnected phænomena. I beliero 
In conformity with the same general views, we might describe (and certainly with approximate truth) the conglomerate and sandstone beds (now called May IIill Sandstone) which form the true Silurian base, as an ancient shore. or shallow-sea deposit, mantling round the deposits of a more ancient elevation, and marking the commencement of a perfectly new epoch. $\Lambda$ nd, spite of the great movements and dislocations which have moditied and broken up the continuity of this ancient shore, the peculiar place it once held among our palrezoic rocks is not yet obliterated from the Geological map. I wish not, however, to rest on speculation, but on facts; and to them I return.

My work in 1831 was almost confined to Caernarvonshire, the whole of which I endenroured to map, laying down all the larger bosses of protruded porphyry; and, as far as possible, all the anticlinal and synclinal lines. This map, with its system of parallel undulations, along with a transverse section, was exhibited and described in a lecture before the British Association in June, 1832. On that occasion I dwelt especially on the position of the fossiliferous trough of Snowdon, and on its strike along the Caernarvon chain; and I shewed, on the unequivocal evidence of sections, that the fossil-beds were many thousand fect above the great slate-quarries of Nant Francon and Llanberris*.

Before the expiration of 1832 I had traced two parallel sections from the Menai Straits to the east side of the Berwyn chain as far as the groups of the Carboniferous series; and I had completed one section which appeared to include every group, above the great Mcrioneth anticlinal, up to the limit of the Cambrian series near Corwen; not far from which place (but amidst enormous and complicated dislocations) this series seemed to pass under

also that it is often suggestive of the right points towards which new obserrations ought to bo directed; and, on that account, an efficient belp towards new generalizations and discoveries. What has been the cause of this parallelism (in the cases where it does occur) is a question of physics rather than of geology.

* I never considered (as is erroneously stated by the author of "Siluria," p. 9,) the fossiliferous trough of Snowdon "to lie near the bottom of the so-called Cambrian rocks!" I proved the contrary by the direct evidence of sections: viz. that commencing with the (Harlech) grits over the great Nant Francon or Llanberris quarries there was an ascending series through more than two miles of highly inclined beds before we came to the fossiliferous trough of Cwm Idwal or of Snowdon. This was one of the main points of my lecturo in June 1832, and my friend Murchison was, if I mistake not, present when I gave it. I had no means, at that time, even of guessing what were the beds which overlaid the Snowdonian fossil-beds in Merionethsire, and I gave no conjectural opinion on the subject. I did however then identify the beds at the top of Snowdon with the fossiliferous beds farther south near Bodean.

When I afterwards (during the same summer) made out the relations of the Bala group, I had great doubts about the relative position of the fossiliferous slates of Snowdon. The Bodean fossiliferous beds ceemed to be identical with those of Bala. Were then the Snowdonian fossil-beds on the parallel of the Bala limestone? There were three objections against a positive reply to this question. (1) Counting from the Harlech grits to the Snowdonian trough, there was a far less thickness of beds than there was from the same grits near the Merioneth anticlinal up to the Balu limestone. (2) Orer the Snowdon fossils there appeared (as I constructed the sections) a far greater thickness of beds than I could make out from any section over the Bala limestone. (3) The Snowdonian fossils were both embedder amongst, and overlaid by, contemporaneous plutonic rocks; but the Bala limestone seemed to be above all the plutonic rocks; in which respect it presented a good analogy to the Coniston limestone. These three facts of ohservation did not, however, amount to a proof either positive or negative. Hence I continued in doubt about the exact age of the fossil-beds of Suowdon. And (so far as I remember) I never afterwards made use of them in any single section in which $I$ endeavoured to eliminate the successive Cambrian groups. In not one paper did I ever make use of them as a point of departure which assisted in the definition of the Cambrian groups. The "erroneous idea" attributed to mysclf ("Siluria," p. 9,) is but the erroncous idea of the author. 
a group of sandstone and conglomerate which forms the base of the slates and flagstones of Denbighshire (afterwards called "Upper Silurian.")

During the same summer I also completed a series of detailed sections among the dislocated and contorted groups on the east side of the Berwyns; where (in consequence of enormous, but local, dislocations) the north-eastern strike of the true Cambrian groups entirely disappears. But I made no attempt to map, in any detail, that part of the country. The task was reserved for the work of another year.

It was during the same summer that I first saw the great importance of the Bala group, and its discordant relations to the overlying series (Denbigh flag, \&c.) which is now called Silurian. The Bala limestone seemed, both in its sectional place and in its fossils, to represent the Coniston limestone of the lake mountains of the north of England: and these two calcareous bands seemed to derive a new importance from the fact, that each of them very nearly defined the epoch when there was an entire cessation of those contemporaneous plutonic eruptions which had such a marked effect upon the older Cambrian deposits both of Wales and Cumberland.

Lastly, at the end of a summer of very great labour, I made two or three long and rapid traverses through the older rocks of South Wales; in the hopes of finding by the prolongation of the prevailing strike, and especially by the prolongation of the Bala limestone, a base line for the operations of another summer. In these hopes I was disap. pointed; for the Bala limestone loses its distinctive type, and the strike among the older rocks of South Wales is broken and disjointed: the region having been crushed between two great forces of elevation-one represented by the north-eastern strike-the other (of a much later period) represented by the east and west strike which produces such a vast impress upon the physical features of South Wales, affecting not only the Cambrian and Silurian, but also the whole Carboniferous series.

After the summer of 1532 my health broke down, and I was incapable of taking up my task, at the time I intended, in 1833; but spite of this great disappointment I had done enough in 1832 to establish a conclusion from which I have never flinched, and which I believe indisputably true: viz. that the South Welsh equivalents of the Bala limestone and its calcareous slates have their true geological place near the base of those great groups which roll, in countless and unsymmetrical undulations, from the shores of Cardigan Bay, towards Mynydd Epynt, and other ranges of the comparatively low Silurian hills. I affirm, therefore, with the confidence of perfect truth, and as a conclusion to the previous remarks, that at the end of the summer of 1832 I had so far overcome the four difficulties above-mentioned, as to have put the Cambrian groups in their true co-ordination.

The detailed sections I exhibited to the Geological Society in 1838, in illustration of a Paper, of which an abstract is given in their Proceedings (Vol. II. p. 679 , \&c.), were all copied from my field sketches of 1831 and 1832: and so far as regards the country to the west of the Berwyns, nearly all the sections published by Mr. Warburton*, in illustration

* Quarterly Journal of the Geological Society, Vol. I. pp. 5-22. 
of my joint work with Mr Salter, in 1842 and 1843 , were also copied from my old notebook. Not, I believe, so much as a single important line, in any of my old sections in Caernarvonshire and Merionethshire, was touched during the two summers I spent in North Wales with MIr Salter*: and the Cambrian groups of the ahove Tabular View are (with the exception of two new names-Lingula flag and Tremadoc slate-given to two previously acknowledged subgroups) literally copied from my field-notes of 1831 and 1832. I had no wish (after 18:1) to publish any Cambrian details before the promised "Silurian System" had made its appearance; and I had no fear of intrusion into a field of such extent and rreat difficulty as the one in which I had been toiling both in Cumberland and Wales. Moreover, the upper and discordant groups (the Denbigh flagstone, \&c.) of North Wales were obviously far less perfect than the corresponding groups in Siluria which, year by year, were brought under notice hy my friend and fellow-labourer. At the time to which I allude (between 1834 and 1842) I did not care a straw ahout the priority of nomenclature among any of my upper groups (whether in Wales or the North of England); and I adopted, at once and without any reserve, all the Silurian names of the subgroups so far as they admitted of a plausible application; and had my friend ever proved that one of his lower Silurian groups fairly incluted any one of my upper Cambrian groups, I should have given that group up to him without a minute's hesitation, and called it Silurian $\uparrow$.

There were, however, early difficulties, both physical and palwontological, in distinguishing the lower Silurian from the upper Cambrian groups, and in fixing their true geographical limits: and it was partly in the hopes of settling such points of doubt, that in 1834 I went during six weeks, under my friend's personal guidance, to examine the order of succession, as established by himself in the typical Silurian country. Beginning, therefore, at Llandeilo, and ending the first part of our joint-work at Welsh Pool, we examined many of his best sections. Occasionally, while he was working out miute details, I spent some days in

* Among several other sections exhibited by me in 1838 was one (copied from my note-book by Mr Lonsdale) from the Menai Straits to the Berwyn chain inclusive: (1) showing the position of the fossil trough (the equivalent of the Snowdonian trough) at the top of Moel Hebog; (2) all the anticlinal lines, and the fundamental position of Merioneth anticlinal; (3) the great ascending section from that anticlinal to the Bala limestone, and the groups superior to it, with its reappearance (with a reversed dip) beyond the Berwyn water-shed; (4) the contemporaneous slates and porphyries which emerge from below the Bala limestone; after which the continuity of the section is arrested by enormous faults, and by an entire change of strike on the east side of the Berwyn chain. This section was afterwards exhibited on every occasion on which I described the Cambrian rocks. Another section took up the details of the preceding, and carried them forward to the northern end of the Berwyn chain near Corwen, where the series appeared to terminate. This section was perfectly true in its essential details. But how was it to be reconciled to the Lower Silurian Sections of Murchison? Here was an arowed difficulty; and the reconciliation was afterwards found to be impossible, not from any error in my sections exhibited in 1S38, but simply because the "Lower Silurian" Sections of Murchison were upon a mistaken base.

Let no one think, from the expressions in the text, that I undervalue the help I reccived from Mr Salter. His help was invaluable. Besides collecting fossils, we worked out many points of minute detail; and we mapped some large tracts of North. Wales with an accuracy equal to that of the Government Survey. We worked out the sections east of the Berwyns and north of the Holyhead road far better than I had time to do in 1832 ; and he enabled me to put unequirocally in its right place, and to map as "Upper Silurian" the sandstone (now May Hill sandstone) at the base of the Denbigh fag.

$\dagger$ To aroid unnecessary periphrasis I have here and in other places used terms such as Cambrian and Silurian, even where I am alluding to periods when these terms had not been introduced. This anticipation can lead to no mistake. 
collecting fossils, many of which are now described in this volume. I believed his sections, so far as I saw them, to be true to nature; and I never suspected (nor had he then suspected) any discordancy, or break of continuity, amongst his typical rocks, from the Upper Ludlow down to the Llandeilo group. I adopted all his groups I might say with implicit faith; never dreaming of a chance (during a rapid visit) of correcting those elaborate sections on which he had bestowed so much successful labour. In one respect our examination of the sections was (as I now think strangely and almost unaccountably) defective. We never examined, or discussed together, the Silurian base-line, in the country south of Welsh Pool; and whatever be the merit or demerit of the base-line afterwards published in the Map of the "Silurian System," belongs exclusively to my friend. As to this base-line, I neither gave, nor had I an opportunity of giving, any opinion either good or had. One thing however was certain, that my friend placed all the groups of South Wales, which I have called Upper Cambrian, below all his Silurian groups; and if this were a mistake, I assuredly had no participation in it; nor had I the means, by any suggestion of my own, of leading him into it. That it was a great mistake is now certain; and it arose, beyond question, from a want of knowledge of the May IIill group, and the generally discordant relations of the Cambrian to the Silurian groups-a fact at that time unobserved in South Wales, and not even suspected by the author of the "Silurian System."

When we afterwards extended our joint examination of the natural sections to the district North of Welsh Pool, we had then reached a country (east of the Berwyns) with which I was previously acquainted; and of which I had commenced a geological map, and made some detailed field sections in 1832. My friend now made use of, and interpreted, some of my field sections of 1832. On his interpretation of them, the shelly sandstones of Meifod, (and consequently the calcareous slates of Glyn Ceiriog) became the equivalents of the Caradoc sandstone; and another calcareous band became the equivalent of the Llandeilo flag*.

On the principles in which the "Silurian System" was worked out, this interpretation, so far as it regarded the Caraloc sandstone, was unquestionably correct; for the Meifod beds, as well as the calcareous slates of Glyn Cciriog, are immediately under the Wenlock shale, without any apparent discordancy of position; and in Glyn Ceiriog the lower group actually seems to pass into the overlying Wenlock beds. Yet this appearance is deceptive: unless, indeed, we start the hypothesis, that the lower Wenlock beds, to the north of Glyn Ceiriog, are the actual equivalents of the May Ilill sandstone on the western side of the Berwyn chain. In point of fact these sections, apparently so clear, are very deceptive; and they present those very difficulties which long misled geologists, and threw the lower groups of the "Silurian System" entirely out of their true geological place.

IIere, then, was the commencement of a difficulty, which, after 1842, led to a divergency of opinion and a controversy affecting both classification and nomenclature. Could the groups of Meifod, or Glyn Ceiriog, be so far separated from the group of calcareous

* See the Sections of the "Silurian System," Pl. 32, fig. 9. 
slates associated with the Bala limestone*, that the former groups might remain Silurian while the latter group was to be packed in the Upper Cambrian Series of South Wales? A single traverse, from Glyn Ceiriog to the northern end of the Berwyn chain, immediately south of Corwen, would have settled this question on evidence not short of a physical demonstration, and proved that any such separation was impossible. But we did not make this traverse: nor did I know, from my previous labours of 1832 , that, in point of evidence, it was of such vital importance. I did not however blink the difficulty; and I guided my friend (as he in his Silurian country had guided me) over the Berwyn chain to the Bala limestone, along the high road from Rbaiadr to Bala. We made no mistake in the interpretation of the section. We first saw the limestone (near the water-shed) dipping west-then forming the base of a great trough containing strata several thousand feet in thickness-and lastly emerging at the western outskirt of the chain with its true eastern dip. We examined this limestone and collected its fossils; and my friend then declared that the Bala limestone was no part of his Silurian System. Was this conclusion derived from any peculiarity in the fossil evidence of the Bala rocks? Certainly not: for the Bala fossils belunged to a palrontological group that was apparently identical with that of Meifod or Glyn Ceiriog. Of this there never was started any doubt. The conclusion was derived from the sections which showed several thousand feet of strata abore the Bala limestone; while no such strata were developed over the Caradoc or Llandeilo groups of the Silurian country we had been previously examining. Perliaps, also, I may have iuflucnced my friend's judgment on the point, by cxplaining to him that the Bala limestone (though mineralogically lost in the range of the groups through South Wales) was not far from the base of the great undulating groups which extended, on the north-west side of his Silurian hills, as far as the shores of Cardigan Bay, and collectively formed the great group I have called Upper Cambrian. Be this as it may, the explanation I gave was correct, and the conclusion my friend arrived at was not based, or professed to be based, on palæontological evidence. It was absolutely and simply based on the evidence of the sections.

\footnotetext{
* Under the name Bala limestone I would now include, as a subgroup, both the Bala and Hirnant limestone; and all, or nearly all, the calcareous slates of Glyn Ceiriog, commencing with the lower of the two calcareous bands. Under the same name might bo included all, or nearly all, the contorted beds near Meifod. One of the present desiderata in geology is a good subdivision of the great Bala group of the Tabular View. In North Wales it admits of four good subdivisions. The first and lowest, distinguished by its dark pyritous slates, ought to have a distinet name; and from one of its localities it might be called Sub-Arenig. It contains in some places many graptolites, and is perhaps the equivalent of the "Moffat-group" of Scotland.

The second is not so well defined in mineral structure. Among many other Cambrian species it contains the (solitary) Ophiura Salteri, and an abundant species of Asterias. (Moel y Garnedd.)

The third is the Bala limestone subgroup.

The fourth includes all the higher beds, till they are overlaid, or cut off unconformably, by the May IIill sandstone of the Berwyus. But in South Wales (though the lower subgroups are perhaps less perfect) the upper subgroups above the parallel of the Bala limestone are more perfect, and far more extensively developed than in North Wales, before they reach the representatives of the May Hill beds at the true Silurian base. It is perfectly ruinous to any distinct conception of the Upper Cambrian Series to merge all these subgroups under one defined name, such as "Llandeilo flag."
} 
The following day we parted, and we never afterwards, before the publication of the "Silurian System" in 1839, had any interchange of opinion respecting Cambria or Siluria. I went to re-examine the relations of the Denbigh flagstone, and the underlying sandstone, to the beds of the Bala group; and then, as before in 1832, I saw good evidence to prove that the upper and lower groups were discordant in position. But I was called away before I could return to any of the most critical scetions at the contact of Cambrian and Silurian rocks, or attempt to settle any remaining doubt, whether the Meifod and Ceiriog beds were, or were not, to be separated from the Bala Group.

In 1835 I was prevented, to my great sorrow, from revisiting the critical sections alluded to above; and after that year I was anxious that my friend should gather in his rich Silurian harvest before I again put my sickle into that of Cambria. Certainly he had fair play in bringing his work to maturity; for not many days after we parted in 183t, I left the Principality, and never again set my foot either in North Wales or Siluria before the summer of 1842 .

The question between us had been reduced (in 1834) to a very narrow compass. If the Silurian sections rere right (and they were exhibited year by year and discussed again and again without a single opposing voice*) -then the Bala limestone (on my interpretation of the Upper Cambrian sections) must be at the very leust five or six thousand feet below the Llandeilo flag. If, on the other hand, the Glyn Ceiriog or Me'iful buds were exactly, or nearly, on the parallel of the Bala limestone group, it then seemed inevitably to follow, that a great error must have been committed in the "Lower Silurian" sections, and that the relations of the Caradoc and Llandeilo and Cambrian groups had been utterly mistaken by the author of the "Silurian System;"-that, in short, the Llandeilo group (and the Caradoc group also, if the Meifod beds were to be called Caradoc) instead of being at the top, was near the bottom, of my Upper Cambrian group.

I did not, in 1834, venture to draw a conclusion so fatal to all the typical "lower Silurian" sections, and to the integrity of the "System;" and I theu thought it possible, that by help of enormous faults, and the obscurity of a discordant junction, we might in the end find in North Wales some representative of the Llandeilo flag above the Bala limestone group. This hypothesis (it was a mere hypothesis, not at all suggested by my own sections; but it was provisionally thrown out, on the supposed integrity of the Lower Silurian sections) was dissipated at once when I returned to North Wales in 1842, accompanied by my friend Mr Salter. I knew the critical sections we had to examine on the line of junction between the Cambrian and Silurian rocks. They all told one story, and proved

* See an article by Dr Fitton in the Edinburgh Review (Vol. Lxxim. p. 1, 1841) for an excellent synopsis of the "Silurian System." There, and in every other published section, the descending order was Ludlow, Wenlock, Caradoc, Llandeilo, Cambrian. With tho old slates of the Longmynd there was an obviously discordant junction; but in no other case was any obvious discordancy acknowledged or described. Thus the Author of the Silurian System, in a paper of 1836, described the slates of Caermarthenshire as the upper part of the "Cambrian System," and added-that among them were beds of passage from the Cambrian to the Silurian System. Proccedings of the Geol. Soc. Vol. II. p. 229. This view was not contradicted, but was reaffirmed, on further evidence, when the "Silurian System" appeared in 1839. 
that my sections, made in 1831 and 1832, and exhibited in 1838, were perfectly right in principle, and generally right in detail. What then became of the Loner Silurian groups? They became absolutely baseless; and so far as they were concerned, the Silurian nomenclature had not the evidence of one true and well understood geological section to rest upon*.

During the eight summers which elapsed after 1834, I was employed in exploring the palrozoic rocks of England, so far as my engagements and health permitted. Four years I spent chiefly upon the Devonian series, and in accumulating evidence for its establishment. This long, and not unprofitable task, was first undertaken as a joint labour by Murchison and myself in 1836. In the two following summers I was a solitary labourer in the great Devonian ficld, with the exception of very raluable help I occasionally had from the present secretary of the Geological Society ( $\mathrm{Mr}$ Austin). It is not true (as I have been told) that I ever deserted the great Palseozoic field. As soon as my engagements would permit I went over (in 1841, 1842, and 1843) what appeared to be the best Devonian, Silurian, and Cambrian ground in Treland, in Scotland, in a part of Cumberland, and in North Wales. While crippled in 1844, my friend Salter became my representative; and he endeavoured to carry our joint work onwards into a part of Suuth Wales, so as to ascertain the relations of my higher Upper Cambrian groups to the Llandeilo group of Birilth. At that time I suspected (as it was then almost certain that the two "Lower Silurian" groups had been put in a mistaken relation to the Upjer Bala rocks) that many of the great undulating groups of South Wales would prove to be "Upper Silurian." But no satisfaction was gained as to this point.

In 1845 and 1846 I was again toiling among the Cambrian and Silurian rocks of the North of England and of Wales-not to maintain any hypothesis, but in the search of truthseeking to establish a real succession of groups, and a co-ordinate succession of fossils, such as might be the foundation of a true and consistent classification and nomenclature. The traverses I made, with my friend John Ruthven, in 1846, proved that I was mistaken in my expectation, that a considerable portion of the old undulating groups of South Wales would prove to be "Upper Silurian." The gentlemen of the "Government Survey were at that time working out the details of the South Welsh sections, near the junction of the Llandeilo and the true Silurian groups. I therefore spent little time upon the sections, thinking that they were in better hands than mine; and after collecting a series of fossils along the valley of the Towy, I left that part of Wales, never expecting again to return to it.

The reader may well ask why I have given this short chronological narrative in my Introduction to the Cambridge Palaozoic Fossils. I have done so for the sole purpose of repelling an assertion that I had at one time deserted the Palrozoic field and abandoned

* The sections of Builth and Corndon are well and elaborately described in the "Silurian System:" but they are put in an crroneous relation to the "Upper Cambrian" group; as is proved by the name, Llandeilo, which is given to their fossiliferous beds. If the typical Llandeilo flag of the valley of the Towy be in a falso relation to the Upper Cambrian rocks, the Llandeilo rocks of Builth and Corndon must inevitably partake of the same error. Rocks with a common name must have common geological relations. 
my proposed Palxozoic nomenclature. The task I had on hand was incomparably the hardest in British Geology, and I never thought of abandoning it; and as for nomenclature, I had no cares about it; and I was ready, at every turn, to modify or change it, in any way compatible with truth and reason. What I have done, since 1846-in Scotland, Yorkshire, and Westmoreland; in Cornwall and Devonshire; in making out minute points of detail on the junction line of Cambria and Siluria; and in establishing the May Hill sandstone as a distinct group-is work too recent to require a notice here*. But all of it was destined to the same important end-the right classification of the British Palacozoic rocks. I am not able now to labour as I did in former years; but I never abandoned my task; and it is at length as complete as I can make it. Its condensed results are given, so far as regards classification, in the Tabular View.

Should any one ask whether I ever doubted, between 1834 and 1842, about the integrity of the "Lower Silurian" sections, I should reply, that I doubted about the geographical propriety of certain parts of their base line, that I could not reconcile them with the upper groups of my own sections; that I always objected to the name system being given to the Silurian rocks from the Upper Ludlow to the Llandeilo group; and that I did so partly on physical and partly on palæontological grounds.

Sometime after 1834 (I believe in 1836) I submitted a small collection of about twenty very characteristic and abundant Bala species to $\mathrm{Mr}$ J. Sowerby. He could not find among them one single specimen that he had not before among his Lower Silurian fossils. Ilere mas matter for some misgiving: for if the "Lower Silurian" sections (which had been discussed over and over again at the Geological Society) were right, the Llandeilo group was at the least five or six thousand feet above the Bala limestone. This fact respecting the Bala fossils was published by myself at the beginning of 1837 .

* The term May IFill Rock was used by Murchison (Jan. 1834) instead of Caradoc, a term introduced afterwards by himself. In using the terms May Hill Sandstone, I have not innovated in nomenclature, but, on the contrary, have restored an old Silurian name to its right place and office. The scheme of classification then given by my friend (Proceedings of the Geological Society, Vol. II. pp. 13, 14) would bo nearly correct were the May Hill beds struck off from the Horderly group and packed at the base of the Wenlock group; and were it stated, also, that the Llandeilo Rocks were, on one side, unconformable to those of the Longmynd. But in the same paper the Longmynd Rocks are placed on the same horizon with the undulating series in the hills west of Llandovery. This mistake he afterwards corrected : but the error in placiog the undulating rocks of South Wales to the west of Llandovery (my Upper Cambrian group) below the Llandeilo group was not corrected; nor was it apparently suspected. Thus two year's afterwards (Jan. 1836), he stated "that in a portion of the preceding summer he had been employed in tracing these rocks (the 'Cambrian System') from Caermarthenshire into Pembroke; and in doing this he was led to attempt a general survey of the country, examining the strata from the youngest to the oldest; dwelling, however, especially on the deposits of the "Silurian System."”

Again, in the abstract of the same paper (Procecdings, Vol. 1I. p 229) he separates the Cambrian system into three subdivisions, in the lowest of which he places the Longmynd rocks: and while describing the rocks composing the highest of the three subdivisions (my Upper Cambrian Group) he uses these words; viz. "They occupy a great breadth; and, as in Cardiganshire, they form the beds of passage between the Silurian and Cambrian systems-sometimes without a break." How was it possible for me, or for any one else (after such statements, and after the repeated exhibition of the detriled Silurian Sections to the Geological Society), not to believe that the Lower Silurian Groups were superior to the rocks I called Upper Cambrian? If this belief was founded in a great geologieal mistake, let me not be blamed for it; and let its consequences rest with its author. It was not corrected, but was reaflirmed when the "Silurian System" was published in 1832 . 
In a paper, above mentioned, read before the Geological Society (May, 1838) I exhibited many of my best Cambrian sections, described them in detail, and followed them into the conclusions to which they led. The paper was not printed; because the upper groups of the sections could not be reconciled to the lower groups of the "Silurian System *." A part of one paragraph of the abstract published in the Procedings (Vol. II. p. 679) is as follows: "Many of the fossils of the Ulper Cambrian System (i.e. the Upper Bala rocks of the above Tabular View) are identical in species with those of the lower division of the Silurian System; nor have the true distinctive characters of the groups been well ascertained." Again, in the next paragraph, are these words:- "At the north end of the Berwyn chain the Upper Cambrian System appears to pass by insensible gradations into the lower division of the upper System (the Curadoc sandstone)." The section here alluded to provoked some discussion. Professor Phillips believed it true, and that it gave the full sequence of the Cambrian series. But if it were true, and a complete section, it was (for reasons above stated) in direct antagonism with the sections of the Lower Silurian groups (Caradoe and Llandeilo). Nor was this the only difficulty. The beds of sandstone and conglomerate, at the base of the Denbigh flag, were at that time considered by me as Caradoc; yet were they represented in the sections as unconformable to all the beds of the Bala group. Had my paper of 1838 been published, it would have anticipated by four years what was proved (certainly on fuller and clearer evidence) by Mr Salter and myself, in 1842 and 1843.

When it appeared (after 1842) not that my Cambrian sections were wrong in principlc. but that the Caradoc and Llandeilo groups had been erroneously packed in the "Silurian System," and were by a positive blunder in the published Silurian sections, "th th' ver"! leust, five or six thousand feet out of their true place in the general section of North Wales; I was perfectly ready to admit them into the Upper Bala group; and, by way of an equitable, and (as I thought) generous, compromise, to withdraw the name Upper Cumbrian. and to define the group by the name Cambro-Siturian. My friend, however, with what I think very bad judgment and very bad taste, and without a syllable of communication to myself. had previously brushed out the whole of his silurian base line, and incorporated all Cambria in Siluria!

Strange as I thought this step, when I first became acquainted with it, a year or two after it had been taken, it was far distanced by the President of the Geological Society; who undertook to abridge, for the Proceedings of the Geological Society, and also for the first Volume of its Journal, the two long papers which recorded the best part of the work done by Mr Salter and myself in North Wales, during the Summers 1842, 1843†. I was very grateful to $\mathrm{Mr}$ Warburton for undertaking this task, while I was engaged in duties which kept me away from Cambridge and London; but while the abridgment was

* The reconciliation was impossible (as the event proved), simply because the "Lower Silurian" sections were misinterpreted by the author of the "Silurian System."

+ See the Proceedings of the Geological Society, Vol. IV. p. 251; and Quarterly Journal of the Geological Society, Vol. 1. p. 5. 
passing through the press he refused (on my repeated application) to let me see a single moof-shect! I believe that he did his very best with my sections; though in their illustration he alopted a complicated symbolical system of notation which is painful to follow, and of which I never have made myself master. In the reduction of my map he made mistakes both of omission and commission*: but in naming the groups delineated upon it, without any warrant from myself he campered with my nomenclature, so as to bring it into agreement with that scheme which, unknown to myself, was newly adopted by Murchison, and to which I have before alluded. It was a scheme which utterly excluded me from any share in the nomenclature of the older rocks of Wales. It was a scheme in which my friend claimed Wales as his own, though he had only touched its outskirts, and though he had absolutely mistaken the geological relations of every part, he had touched, that was below the Wenlock group.

To aroid all possible wrangling about the words Cambrian and sfiturian, I had proposed to designate all the groups below the Wenlock, by the name Protozoic (a name nriginally proposed, nearly in the same sense, by Murchison himself). Where the division could be made upon the map of Wales, the Protozoic series was to be separated into two divisions-upper and lower-by a line on the parallel of the Bala limestone sub-group. All above the Bala limestone was to be Cambro-Siturian-all below was to be Cambrian. Tet in Mr Warburton's reduction of my map, Protozoic is made the equivalent of Loner Silurian! I cannot believe that this was done by orersight. It was an unwarrantable

* Many critical parts of North Wales were mapped by Mr Salter and myself in as much detail as is given in the map of the Government Survey. We traced, laid down, and followed on their whole line of strike towards the North, the two bands of limestone below Llanwddyn (distinctly shewing the Bala limestone repeated by a fault). The second band is left out in Mr. Warburton's reduced map and sections. Our maps were, for several weeks together, suspended in the Geological Society's meeting-room; and they were some months in Mr Warburton's possession. So also were my seetions of Carnarvonshire and Cader Idris, \&c. which had been exhibited in 1838. His reduced map was not at all taken from the maps above-mentioned; but exclusively from a bold cnlarged sketch of North Wales made (for illustration of the papers while read) by my friend Mr S. Woodward; and upon which I had roughly drawn the principal demarcations, the lines of strike, and the other conditions of structure that seemed essential.

In 1832 I had followed the Glyn Diffws limestone (deseribed in the first section of Mr Warburton's abridgment) towards Bala, and identified it with the Bala limestone; and so it is represented, by the help of dotted lines, on my fieldmap. But in $18+3$ I followed this broken calcareous hand along with Mr Salter, much more completely than I had dorie in 1832 ; and it appeared to me, that on physical evidence (and so it was stated in my paper, though the passage is rery obscurely indicated in the abridgment) the Rhewlas limestone must be identical with that of Glyn Diffws or Bala. Nor on this supposition should I have made any difficulty in the enormous shift of the Bala limestone, from the old Rhewlas limeworks to Rlewedog, which is considerably to the east of the Bala lake. For the intersecting valley of the Tryweryn was a feature which, on the analogy of the Coniston limestone, naturally suggested the expectation of a great fault, and consequent shift of the Bula limestone. (Transactions of the Geol. Soc. 2nd Series, Vol. IV. pp. 50-53) Why then did I not act on this opinion? Because, in the year preceding, Mr Sharpe had discorered a limestone (undoubtedly connected with the Rhewlas beds) which he appeared to have traced considerably to the west of the Bala lake; and which he represented (with no hint that the representation was hypothetical) in a section from great Arenig to the Berwyns. Wo sought this limestone more than once; and, of course, could not find what did not exist. I hare no doubt that Mr. Salter's judgment respecting tho Rhewlas fossils was somewhat influenced by a belief (derived from the section above mentioned) that they were obtained from a bed that was far below the Bala limestone: but I take shame to myself for haring surrendered my faith, in what I thought good physical ovidence, to a belief in a section which I could not rerify. (See Proceedings of the Geol. Soc. Vol, Iv. p. 253) 
liherty (very nearly resembling a pious fraud), which no man living has a right to take, under whatever views of expediency he may conceive himself to be acting*.

I must not load this portion of the Introduction with any further references to personal labours, which my present limits do not permit me to fortify by sections, or illustrate by details. My statements have not been made in a spirit of self-praise, but of self-rlefence. Since I began the study of the British Palæozoic rocks, I have (to the best of my knowledge) sought for truth and nothing else:-being ready, at every turn, to embrace it heartily; whether it marle for my previous notions, or against them. After 1834, when I learnt, in the field, whit were the "Lower Silurian" groups, and found that there was an unsolved difficulty in uniting them to my Upper Cambrian groups in an intelligible order of superposition, I did not give up my belief in the integrity and truthfulness of the lower section: of Siluria; but, on the contrary, I was ready to sacrifice my own sections to them; believing" them (in spite of my own evidence, and almost with superstitious faith) to be right, on the authority of their author. I did this, be it remembered, while the evidence for his adopter order of superposition and nomenclature was exhibited, year by year, in every form of illustration, and without any hesitation or doubt, on his part, as to its physical truth.

After I had again visited North Wales (in 1842), and found, on evidence no longer to be resisted, that ny sections in North Wales were right in principle, and consequently that the Lower Silurian sections (from some great error of observation) were wrong in principle; I did not, even then, stickle for any exclusive system of nomenclature to magnify my own work at the cost of my fellow-labourer; but I was ready (under the name Cambro-Siluriau) to admit into my true Upper Cambrian group his two misinterpreted "Lower Silurian" groups. Nor did I ever make a stand, as I had a full right to do, on the integrity of my own work, and on the nomenclature that was legitimately derived from it; till (without any word of warning; he had sponged out all my work in Wales, and claimed it as his own. And this was done, not by the establishment, but by the abandonment, of those sections which had formed the very basis of all his Silurian evidence; and on which, and on which alone, his published system of nomenclature had either truth or meaning. To have accepted this monstrous innovation would have been an abandonment of the canse both of historical and geological truth; and would have been, at the same time, a flagrant

* In the early years of the Geological Society of London Mr Warburton was of invaluable assistance in condensing, correcting, and arranging the communications. At the time be became President, geology had made great advances, while he had been employed, many years, in the duties of a Senator. He appears, however, rapidly to have made himself master of the "Silurian System." Important as that work is, it gives but a very narrow, one-sided, and imperfeet view of that rast succession of phrenomena which illustrate the physical and Palrontological history of our oldest rocks; and its lower groups are, as we now know, in a position which is incorrigibly erroneous. Mr Warburton might have ascertained all this, by an excursion, of no great toil, to one or two of the critical sections. But he seems to have thought that geology had found the level on which he stood, and from which it ought never to be moved: and hu probably imagined (while remembering his early and successful labours in the Geological Society) that he was conferring upon me a great benefit, while he was quietly tampering with a nomenclature (proposed by myself in the spirit of a generous compromise), and blotting out all the indications of my bard labour in a field with which he was not at all acquainted from any personal labour of his own. 
abandonment, on my part, of the very principles on which the "Silurian System" put in its claim for our acceptance. For, it professed, from first to last, to be grounded on the evidence of superposition, fortified by corresponding groups of fossils: and if, in its lower groups, it failed in that kind of double evidence; then the ground on which it rested was struck from under it, and it ceased to have any meaning as a real system.

It would ill become me to torture, beyond its meaning, the opinion expressed by my friend respecting the age of the Bala limestone, when we were, for the last time, together in North Wales (1834). But I may remark, that it was an opinion fairly derived from a true and unambiguous section, that it was delivered on a vital point of evidence, and that it throws a clear light upon the original meaning of the words Cambrian and Silurian when they were first made use of. This, at least, I do affirm without reserve, that if any loubt as to the soundness of that opinion ever afterward rose within the mind of my friend, it ought in fairuess to have been communicated to myself before he had procceded to incorporate Cambria in Siluria*.

The only legitimate questions which can arise in this concluding part of the Introduction are such as the following: viz. Is the analysis of the Cambrian Series right in principle? Are the successive groups of the Tabular View in a true order of superposition? I have no doubt of the general truth of the analysis, not only because it is the result of observations of my own, long continued and made with no common toil; but, also, because it was most critically and severely sifted, during the last two meetings of the British Association, without being invalidated on any one essential point. During the meeting of $185+$ my scheme of classification and nomenclature was met by some distinguished geologists, and especially by the gentlemen of the Government Survey, in a spirit of direct antagonism; but not one of my antagonists convicted me of error in a single group of my Tabular View. It was acknowledged that the analysis of the Cambrian Series, in the Tabular View, was substantially right; and that I was the first person who had worked out the analysis. Lastly, it was admitted by the President of the Geological Section (once my opponent on the very point) that the May Hill sandstone was a true physical and palrontological group, occupying the place I had given it in the general section.

I therefore conclude:-First, that the analysis given in the Tabular View is right and true. Secondly, that the nomenclature proposed is on an accepted and right principlebeing based on true sections, and also (so far as the case admits of it) on the co-ordinate evidence of fossils. Thirdly, that-so far as regards the lower groups of the Lower Palicozoic

* Had my friend discovered for himself the mistaken relations of his lower groups ; then corrected his mistakes; and afterwards (by traverses through North and South Wales) shown that the Llandeilo flag was nearly on the parallel of the Bala limestone - he would by so doing have vindicated his claim (not as a matter of courtesy, but of right) to a share in the Upper Bala Group. But he did none of these things. He found that his own Lower Silurian work was wrong, by the gradual progress of geology; and to save all further difficulty he proceeded, without any notice, to merge all Cambria in Silurial This might be a ready way of saving a nomenclature which he had extended to foreign lands. But it neither recognised the mistakes of the Silurian sections, nor gave us a true and congruous English nomenclature, nor was it just toward myself. 
division (Cambrian Series) - the classification and nomenclature lave the undoubted right of priority. Fourthly, that the nomenclature is geographically consistent and true-the best (and the only good) types of the Cambrian Series being derived from the sections of Cambria. Lastly, that no other classification and nomenclature which have yet been proposed satisfy all (or so much as one) of the above four essential conditions.

On a review of all the facts above described, and adopting the words made use of by myself in the Philosophical Magasine*, I can now affirm with unhesitating confidence, "that the scheme of classification, and consequently of nomenclature, given in the above Tabular View, is true for the whole Cambrian series,- that it is the only approach to a good analysis of this series which has yet been given-that it was worked out correctly by my own labours among the older rocks of Wales, and has the claim of priority-that it is geographically appropriate- that it is physically true, because it makes a break between the Cambrian and the overlying Silurian serics where nature herself had made it-and lastly, that it is palicontologically true, inasmuch as that break is followed by an immediate and great change of the fossil species. It is true, exactly for the same reason that Smith's original classification and nomenclature (however uncouth and harsh sounding) of the Oolitic series was true-because founded on true sections backed by lists of fossils. It is true, for the same reason that Mr Prestivich's analysis of the deposits above our chalk is true. Lastly, it is true, for the same reason that the classification and nomenclature of the "Upper Silurian" racks is true. Nor is there, in the past history of British geology, any example of a single group, or series of groups, which has stood its ground and been established, except on principles like those which I have, I believe, correctly followed, and by the test of which I am willing that the scheme of classification and nomenclature, above given in the Tabular View, should stand or fall. That it will stand, I have not the shadow of a doubt, so long as we adhere to our geographical nomenclature."

That it may be superseded, hereafter, by some more general and scientific classification which may embrace the old and new world, and in which all merely geographical and local names will disappear, is quite possible, and I trust probable: but such a speculation does not come within the limited views of this Introduction.

\section{Other Schemes of Classification and Nomenclature applied to the Cambrian Series.}

Before I had, for the first time (1822), entered on an examination of the older Palrozoic rocks of England, their characteristic Fauna was by no means entirely unknown, or without any illustrations in the old Woodwardian Museum. Many good collections had been made from the Dudley Rocks, and some of the species had been named. One of the most characteristic fossils of the calcareous flags of Builth and Llandeilo (the Asaphus Buchii) was well known to collectors; and (along with one or

\footnotetext{
* Paper on the May Hill Sandstone and the Palæozoic System of England, Philosoplical MIa gazine, Dec. 1854.
} 
two other species) had been placed in our old Museum, as Builth and Llandeilo fossils. More than forty years since, two or three species from Meifod had been placed in our old Museum (by my predecessor in the Woodwardian chair), side by side with one or two species from Snowdon, and identified (I believe correctly) though not named. A very fine collection had been made by Mr Hennah from the Plymouth fossils. Some of the species were named (when I first saw them in 1819), and not long afterwards several Plymouth species were figured * Many Scandinavian fossils had been well described and figured. Some characteristic specimens from Scandinavia, and some good specimens of the longwinged Spirifers, and other fossils from the Rhenish provinces, had been placed in the old Woodwardian Cabinets by the founder of our Museum.

We knew in 1822 as certainly as we know now, that Trilobites, Orthoceratites, and multitudinous species of Brachiopoda, formed a very characteristic portion of the oldest Palrozoic fauna. But no information of this kind could lend us the least help in the classification and nomenclature of the lower division of the Palæozoic Series, till the fossils had not only been more perfectly collected and described, but also referred to their right place, in some natural succession of physical groups established on good sectional evidence.

I had, indeed, ascertained before 1824, that there were two distinct groups of fossils in the Cumbrian mountains: viz. the Coniston group with its numerous Brachiopods, Trilobites, and Orthoceratites; and the much higher group of Kendal and Kirkby Moor with its numerous unsymmetrical bivalves, (Lamellibranchiata) and other fossils. Very few of the species had been at that time correctly named: but when the fossils were put side by side, the two groups did not appear to contain so much as one species in common. I had done well (if my own reputation had been my only object) had I collected more largely (ccrtainly no hard task) the fossils of the Coniston and the Kendal group, had I submitted them to $\mathrm{Mr}$ Sowerby for their specific determination, and then left the event to fortune. But I could not bear to deal in that manner with a great question in Palæozoic Geology; while, for three reasons, its difficulties were unsolved.-(1) Because no fossils had been found in the vast group of slates and porphyries below the Coniston limestone. (2) Because there was a great, and unknown, chasm between the Kendal group and all the overlying rocks, whether Devonian or Carboniferous. (3) Because the Plymouth fossils (and that was after all the great difficulty), spite of their approach to a known Carboniferous type, were in a group which nearly all English Geologists, of that day, considered of a much older date than the coarse greywacke of Kirkby Moor. I consequently left the Cumbrian mountains in 15:4-after laying down the demareation of the physical groups, step by step, from actual survey, and determining their order in the natural sections-not without a feeling of bitter disappointment. In a subsequent year I sought in Scotland, but in vain, for some

* In 1819 I traced the Plymouth group into Cornwall, and found it overlaid by old-looking chloritie slates. I therefore concluded that (spite of the newer Palocozoic type of its fossils) the Plymouth limestone must belong to a very old Palioozoic group! To have denied this conclusion would (at that period of our knowledge) have been regarded as an absurdity not less than denying the truth of the first book of Fuclid. Mr Hennah and Mr Greenough were at that time, if I mistake not, disposed to identify the Plymouth with the Carbonifurous limestone. 
of the missing chapters in nature's older Palseozoic records. There was in the frontier chain of Scotland even a greater chasm than I had found abore the Kendal group.

In $1831 \mathrm{I}$, for the first time, entered Wales, not without a hope of solving the old Palrozoic riddle; but I was again met, in Denbighshire. by a broken succession of depositsalmost identical with that which interrupted the section (of Westmoreland) between the Kendal group and the old red conglomerates. I therefore abandoned the descending. order; and for two summers (as above stated) worked upwards from a base line near the Menai Straits, and established the Cambrian Series of the Tabular View; and I have now, I believe, put it in its true relation to the overlying Silurian Series.

During the same summer (1831) my friend and fellow-labourer was led to that beautiful Silurian country which his works have made classical in the history of British Palæozoic Geology. Ife found at length-what I had sought for in vain during by-gone years -an apparently complete succession, which linked without a break the highest fossiliferous greywacké to the Old Red sandstone, and the Carboniferous limestone. I have dwelt on these facts only to do honour to the "Silurian System." It not merely gave us a beautiful descending succession of physical groups, along with a corresponding series of characteristic fossils; but it rescued Palacozoic Geology (which is its far higher praise) from a very great difficulty which no previous observer had been able to overcome*.

How were the successive Silurian groups determined? By elaborate field-work, by natural sections, and by ample lists of fossils. All the author's groups, from the Upper Ludlow Rock down to the base of the Llandeilo Flag, were defined, or professed to be defined, on the same unexceptionable principles: and we are all ready to sanction the affirmation, "that so long as British geologists establish a classification founded on the sequence of strata and the imbedded contents, so long will their insular names be honoured with a preference by foreign geologistst." And I may venture to add, that these principles never have been, or will be, deserted with impunity. Down to the base of the Wenlock shale the Silurian groups are demonstrably established on the joint evidence of sections and fossils; and they are universally admitted to their right place in our great Palxozoic system. But below the Wenlock shale the evidence breaks down, or is misinterpreted. The typical Cararloc sandstone is not a continuous, but a broken group. It is made up, in fact, of two groups which are sometimes discordant in position; and which, if we use the Silurian language, belong to two different systems. It will not do to mask this mistake by the names $L p p r y$ and Lower Caradoc. One group is a true Wenlock sandstone, the other is an integral part of that great collective group which I have correctly called Upper Cambrian.

'The typical Ilandeilo flag is a good physical group; but in the Silurian System its geological relations, both to the beds above it and below it, are entirely mistaken. It is

* One result was different from what I had at one time expected. There is (as above stated) an unknown chasm between the Kendal (or Lullow) group, and the orerlying rocks of Westmoreland and North Wales. This chasm does not arise so much from the removal of the highest Silurian groups, as from the absence of the lower groups of the Old Red Sandstone.

† Anniversary Address to the Geological Society of London, by R. I Murchison, Vol. m. p. 619, 1S42. 
not above, but below, the Upper Cambrian rocks of the neighbourhood. It is not a Silurian group, to be packed (as is done in all the typical Silurian sections) near the base of the Wenlock shale-to which it has no relations except those of an accidental and discordant contiguity. A greater and more injurious mistake, in the collocation of contiguous groups, has not been committed during the progress of British Palicozoic Geology. The fact is, that the author missed the true relations of the May Hill sandstone to his upper groups; and, consequently, missed both the physical and palæontological base of his own "System." When he passed below the May IIill sandstone, he orerstepped the true and comected sequence of the Silurian deposits; and he descended at once, and without being conscious of it, among the vast and complicated groups of Cambria, through which he had never made his way, and with which he was then very imperfectly acquainted: and, however laboriously and well he did the work of the naturalist and collector, he inevitably failed, so far as regarded his two lower groups, in the real task-work of the geologist. He neither truly interpreted the Caradoc group; nor did he define (even with approximate truth) the place of the Llandeilo group in the great Cambrian Series. Without a good definition of such groups, their nomenclature, as parts of a system, is untenable, and absolutely without meaning.

But if the author of the "Silurian System" orerstepped its base, mistook the relations of his lower groups, and was led, thereby, to a nomenclature which was untrue to nature; he has since then done far greater injury to the cause of physical truth and scientific progress, by a desertion of the principles he once vindicated, and on the happy application of which rests the best part of his scientific fame. For what is the system of classification and nomenclature that he has for some years been endeavouring to enforce? A classification and nomenclature on the well-combined evidence both of sections and fossils, whereby group is linked to group in a natural order? No! But a classification derived from fossils only, and of almost boundless application. The "Lower Silurian" groups, in the very sections which were assumed as typical, were misinterpreted in the "Silurian System," and were out of their true place in the general sections of North and South Wales. Yet while this is virtually admitted, all the rocks of the Principality which contain the fossils of these mistaken lower Silurian groups, and also rocks which descend many thousand feet below them, are now to be called Silurian: and the Llandeilo formation is to pass as the name for all the vast groups which are here described, as the Cambrian series, in the Tabular View!

After the history of the Llandeilo Flag, I should have thought it far better taste to have suppressed the name Llandeilo from any prominent place in Palxozoic classification and nomenclature. But without discussing a point of taste, this I dare to affirm, that the title-page and the map, of the new work called "Siluria," are in themselves as severe a satire as the pen could write against the work, if it is to be considered as a scheme which is to settle the grouping and geographical nomenclature of the older Paleozoic rocks of Fngland. The Llandeilo flag was the lowest group of the "Silurian System;" but all old rocks below the upper Ludlow must be Silurian; therefore the oldest rocks of Wales are Llandeilo flag! I know no better logic whereby the author of the System can maintain his 
monstrous proposition. I am certain that it is not derived from natural and connected groups-honestly worked out in the field, and backed by corresponding lists of fossils. On the contrary, it is gained by a positive abandonment of the very principles which give truth and meaning to the homely inductive logic of geology-the very logic whereby every real group of Siluria was lawfully established. "Est Jupiter quodcunque vides," was once said by Dean Conybeare in mockery of the old despotic rule of the name Greywacké. A golden age of truth and reason, and slow, but secure, inductive logic, seemed to follow: but the jovial days of a new dynasty are to spring up, it seems, under a new name, not less despotic than the one which had ruled before it! If all the fossil-bearing rocks below the old Red sandstone are to pass under one name, let us cling to the venerable name Greywaclié. It can do no mischief while it describes things indefinite, simply because it is without meaning. But the name "Silurian System," if used in the same extended sense, is preynant with mischief. It savours of a history that is fabulous; it leads us back to a false type; it unites together as one, two Systems that nature has put asunder; and it is geographically untrue.

Two great mistakes were committed during the elaboration of the "Silurian System." In the first place the nomenclature of the author was too ambitious. For even on the supposition that all his groups were correctly linked together and put in a true relation to the groups below them (which assuredly they were not), they never did make anything like "System-certainly not in the sense in which he afterwards endeavoured to enforce the meaning of that word. When his great work appeared in 1839, he believed-on no teaching of mine, but on evidence which he had examined for himself-that the Cambrian System of South Wales admitted of three principal subdivisions; and that the highest of the three subdivisions was not only inferior to, but actually, in several places, formed $\mathrm{ar}$ ascenting passage into, the Llundeilo Flag. At the same time he believed (and he believed correctly), on the evidence of the sections to which I had conducted him in 1884, that the Bala limestone was deep-seated in those groups which both he and I had called Upper. Cambrian; and which, on his own interpretation, were below the Llandeilo Flag.

We collected some of the most common, and therefore most characteristic, Bala fussils. They were carried off by my friend, and he did not find anong them one species which was not also abundant in his "Lower Silurian" groups. An exactly similar result was published by myself full two years before the appearance of the great classical work on Siluria (1839): and in every instance in which I had occasion to allude to the fossils of my upper Cambrian groups, I described them (in the printed Syllabus of my Lectures and in two papers read before the Geological Society,) as exhibiting many specics identical with those of the "Lower Silurian" groups. My lists of fossils were meagre (for before 1843 the best part of my collection was inaccessible); but they were amply sufficient for a good general inference; and, as a matter of fact, they did not give me su much as one species which was an exception to the rule of identity with those of the Lower Silurian groups. 
Hence the author had no right whatsoever, on Palacontological grounds, to call his Silurian rocks a "System." He had no right to throw out the word at random; with a reservation that he might afterwards make it good by a new and arbitrary act of incorporation of Cambria into Siluria. When he did this he virtually deserted those principles of classification and nomenclature which he had (above any other member of the Geological Society) helped to establish. I opposed his use of the word System whenever the nomenclature of his groups was discussed between us either in private or before the Geological Society. A System, however, they were called; and if he made his first mistake in adopting his name "Silurian System" before he had found its geological base, he must abide the consequence of the mistake, without making me a sharer in it. The facts I exhibited to him in 1831 might well have made him doubt about the truth of his own sections. His belief in the geological truth of his lower sections, does not, however, appear to have been shaken in 18:39. Hence I contend (even on the admission that the lower groups of his Silurian scetions were rightly placed) that he was not a good and true instructor of nomenclature: on the contrary, that he overstepped the evidence given by the older British Palacozoic rocks, and positively misled the Russian geologists, when he taught them to describe as "Lower Silurian" crery rock in which they found the "Lower Silurian" fossils.

The second great mistake was perhaps a natural consequence of the former. For if the author of the "Silurian System" had a right to call all foreign rocks-below the old Rcd Sandstone-Silurian, unquestionably all Cambrian rocks must become Silurian. But liere the fundamental sophism, involved in the Silurian syllogism, became perfectly transparent; for the author's next step (when he sponged out the whole of his own base line, and coloured all Cambria as if it were but a part of Siluria) brought him into direct collision with another workman in the same field, who knew the Cambrian rocks far better than himself; and also into direct collision with his own lower sections, and the very evidence on which the scheme of his classification and nomenclature had any claim upon the acceptance of geologists.

It was perfectly certain, before the Silurian map was changed (1843) and its colours spread over the older rocks of Wales, that some great mistake had been committed in the construction of the "Lower Silurian Sections." $\Lambda$ great mistake there was; but its extent was, perhaps, not then known. The progress of discovery shewed that the Llandulo group had (by the greatest and most mischievous mistake committed in the history of English Palreozoic Geology-a mistake which actually arrested for full seven years all progress in the analysis of the older portions of the great Palrozoic System) been placed in a false relation to the Upper Cambrian (or Upper Bala) group. At a later period (1552) I proved that the Caradoc group had also been misinterpreted; and I at length (as stated above) discovered, with Professor $\mathrm{I}^{\circ} \mathrm{Coy}$, the true Silurian base.

But apart from any discussion on this latter point, was the Silurian scheme of nomenclature to stand good when the sectional groups on which it rested were struck from under it? Were geologists (British or Foreign) who had adopted the nomenclature on 
the assumed integrity of the sections, to persevere in it (when the sections were proved untrue), out of deference to the author of the System, and out of regard to his great services? Any one who can give a positive reply to such questions is out of the reach of argument; and has but a low conception of the true dignity of physical science, and the sanctity of philosophic truth.

When the author (in 1842) examined-I believe for the first time-the Cambrian Series of Torth Wales along with his Russian fellow-labourer Count Keyserling, he fouml. among the Cambrian groups, the fossils he had called Lower Silurian; and the very rocks he had taught his Russian friends to designate by that wame. But, so far as regarded the fossils, was this a new discovery? It was no such thing. It was but the lesson I had put before him, and which he hat read correctly, when we visited the Bala rocks together in 183t. There was no shade of difference in the fossil cridence. But in $183 \pm$ the Bala group was to be called Cambrian; because it was deep-seated in a group which he (by mistake) had placed below his Llandeilo flag:- while in 184:2 the same Bala group and other Cambrian rocks were to be called Silurian; because he had called the Russian rocks of the same age Silurian! This proves, I think, to demonstration, that the author had no right whatever to the nomenclature he gave to the rocks of Russia; and that a deep injury may be inflicted on the cause of scientific truth by a precocious classification and nomenclature.

That the author (in 1839) doubted about his base line, is evident from a single paragraph near the end of his great work-"The Silurian System." But if there were any palxontological, or other grounds of doubt, the nomenclature and the classification wcre, so far, in abeyance; and as there were two labourers in the field, the natural question (if any (loubts arose) seemed to be, who was in the right, or who was in the wrong? Yet this rery natural question never seems to have crossed the mind of the author of Siluria, except in an crroneous and one-sided form. His only doubt was whether he might not enclose, at some future day, a part of Cambria within his boundary. But surely there was another doubt, whether (if his Lower Silurian sections proved wrong) he might not have to contract his Silurian base to some position that was more compatible with physical and fossil evidence. While these doubts remained, it seemed but reasonable to establish a middle group, with a name that should recognize the joint labours of the author of "Siluria" and of myself. Had this concession been made the author would have gained by it more than was his due; for his true Silurian base is the May Hill sandstone, and nature has given him no other.

But concession was far from his thoughts. IIc had given (without any true claim based on his own sections or on his knowledge of the older rocks of Eugland) the name "Lower" Silurian" to the oldest Palaeozoic rocks of Russia. When he afterwards examined the Cambrian rocks of England he must have known, or at least suspected, that his typical Lowel' Silurian sections were wrong. Did he then attempt to qualify his Russian nomenclature? No such thing. Dazzled, it seems, by the well-earned honours he had gained in Russia, he could not see the false position in which he stood among the older rocks of Fingland: nor had he ever the magnanimity to ackmowledge limself wrong on one single point. 
And to scttle all dispute, he swept all Cambria into Siluria-claiming as his own twenty or thirty thousand feet of good physical groups which he had never well studied, and of which he had absolutely mistaken the geological relations in his published works. Such a desertion of first principles cannot easily find its match in the history of British Natural Science. It discards geographical, physical, and scetional evidence. It practically sets at nought the nomenclature on the double evidence of sections and fossils. Its upper groups are defined on one principle, and its lower on another. It makes two "Systems" into nne. It virtually masks the author's own mistakes and attributes them to a fellow-labourer; and it thereby involves a great historical injustice.

Let me once again (for it involves the whole question in debate) go back to first principles, and ask how has the classification, and consequently the nomenclature, of British rocks been established? The answer is-by a severe examination of physical groups and their order of succession, and by a corresponding examination and collocation of the fossils. Then from physical groups and fossils combined (one kind of evidence sometimes modifying, but never in long conflict with, the other) formations have been named and grouped into systems and collective groups. But when formations, and systems of formations (such e.g. as the Oolitic or Mesozoic) have once been well established-each formation, with a defined name, having its place also defined by its true relations, both to the formations abore it and below it-we can then reason inductively from our first type, extend our conclusions to distant lands, and identify a foreign succession with our own. And, such is the general uniformity in nature's laws, that we can often make this identification with great confidence by help of fossil evidence only, in cases where we are deprived of all other evidence. But in every instance (and there is no exception to the rule) where we apply the fossil test, and pretend to give an English name to a distant formation by help of it, it is assumed that we have a good base to work upon-a good English type worked out on the double principle, and actually established and acknowledged. Thus if, on the continent of Europe, or in the more distant continents, I found a rock with the fossils of the Lias (though nature had quite changed her features, and though the distant sections were without further evidence) I should call the rock Lias; and that name would define its epoch in the palicontological history of the earth. It would be a rock newer than the Triassic and older than the Jurassic groups. Geologists have found, as a matter of very wide experience, that this kind of reasoning, when cautiously and logically applied, has never led them far astray.

But when we are in a terra incognita, and among formations which are, as yet, unclassified and unnamed, and not yet referred to any acknowledged type, we have no right whatever to apply the fossil test alone, and pretend to generalize at once from it. For the fossil evidence, in that case, would want the sanction of some acknowledged type, worked out on the more perfect evidence both of sections and fossils.

If Geology is to stand as an inductive natural science, its classification must be based on a true induction from observed facts: and the fundamental facts of Geology are physical groups and their fossils. But physical groups are the facts first in order; and without the 
observed succession of such groups we never could have dreamt of a natural succession of palieontological types; or used such types in proof of a long succession of epochs recorded in the ancient chronicles of the earth. These principles have heen happily applied in eliminating and classifying the geolonical deposits of all ages; and they have never (I repeat) been abandoned with impunity and without loss. And if it has been found needful to adhere to these principles among the acknowledged British groups, from the upper Palrozoic to the newest Tertiary, - and if it has been found, from past experience, that the exact determination of physical groups has, in every age of Geology, been the first step in advance: still more are we bound to these first principles while we are dealing with the lowest division of the whole Palrozoic System; because, within the limits of that division, fossil evidence gradually disappears, and physical evidence becomes, at length, not only our first, but our only guide.

When I entered Torth Wales in 1831, it was, geologically, little more than a terra incognitn. IIonestly, and with no small labour, I worked my way through this unknown land. I was guided by the physical groups which marked a true physical succession; and in classifying and naming the successive groups I never once deserted the great first principle of double evidence, so far as it admitted of application. The final result appears in the above Tabular View.

The "Silurian System" was admirably worked ont, on the same acknowledged principle, as far as its base-the May Hill Sandstone; and (without, for the present, making any count of the May Hill Sandstone) every downward step in the "Silurian System" professed to be made on the same double evidence of sections and fossils, till the whole series ended in the Llandeilo Flag, which had its supposed base resting upon the highest of the great collective Cambrian groups of the Tabular View. In the nomenclature of the "System" the true principle of classification was acknowledged and proclaimed ex cathedri by the author; and it was incontestably at the same time assumed, that the physical groups, from the Upper Ludlow rock down to the Llandeilo Flag and Upper Cambrian rocks, were arranged in the very order of nature*.

* This was assumed as the true order in the typical section engraved on the original map of the Silurian System, and in all the other sections of tho work that had any bearing on the point; and it was assumed as the true order (virtually the groundwork of the whole scheme of Silurian Classification and Nomenclature) in [Dr] Fitton's Article in the Edinburgh Review (April, 1841) above referred to. At the time that Article was in preparation for the press the Author of the System seems still to have upheld the geological truth of his own sections.

It would be a pitiful criticism upon a work of such great extent and importance (the publication of which (1839) formed an epoch in the history of Palæozoic geology) to say that its boundary lines were here and there a little divergent from a true geographical delineation. But it is not a small or pitiful criticism to prove that its base line was wrong in principle, and that the colours of tho Silurian Map were erroneous in principle. For in the arrangement of the colours it was assumed (and for that assumption the author of the "Silurian System" was alone responsible) that the collective Upper Cambrian groups of South Wales (including all the undulating rocks between Cardigan Bay and the true Silurian terrace) were inferior to the base line of the Llandeilo Flag. The change made in the Silurian Map in 1843 was not an adjustment of a base line: it was a complete change of principle, which properly and naturally included a change of nomenclature. But the old nomenclature, which was erroneous because derired from erroneous sections, was kept entire; and the change was made in a wrong direction, by throwing the whole mistake upon the true geographical nomenclature, by sinking the name of Cambria, and by involving all Cambria in Siluria. A more direct offence against sound inductive logic and geographical propriety has nerer, perhaps, been committed in the history of geology. 
In the progress of British Geology it was however found that the Lower Silurian sections were wrong in principle. The so-called Caradoc sandstone transgressed the true physical and palæontological base of the "Silurian System ;" and, by a mistake of classification, united together, under one name, two contiguous (but sometimes discordant) groups of two distinct Systems. And so far as regarded the typical Llandeilo Flag, the mistakes were still more fatal. It was put in an erroneous relation to the upper Bala group, by a positive inversion of the sections: and it was put in an erroneous relation to the Wenlock group by a misconception of the sections; which did not shew a consecutive and complete succession, but one which was broken and discordant.

If these fundamental mistakes implied (as they unquestionably did) some change of classification and nomenclature, who was to suffer from this cliange? The author of the Cambrian series, or the author of the Silurian? Let common reason and common sense give the reply. I had adhered to, and followed out, an acknowledged principle; and I had at length derived from it-without any violation of physical evidence, or any want of completeness in it-a good classification and a good geographical nomenclature. My friend deserted his principles when he found his sections wrong. IIe no longer pretended to estahish his nomenclature on true physical groups borne out by lists of fossils. But because he had described the Llandeilo fossils (which had by the great undulations of South Wales been hrought from beneath the upper Cambrian group into a discordant contact with his true Silurian terrace) and called them by mistake Silurian; therefore all the older rocks, both of North and South Wales, were to become Silurian!

Thus, in violation of all geographical propricty, he proceeded to incorporate all Camlrria within the limits of his Silurian kingdom. In doing this he claimed as his own a country over which he had no right of conquest. And while doing this he turned the whole logic of Geology upside down:- by making the true nomenclature to precede, and not to follom, the true classification of the physical groups:-and by establishing his scheme on fossil evidence alone, in those very parts of the descending series where, above all others, the sections were most difficult, and true physical evidence was most needed. I do not believe that I am at all distorting the facts by overstating then: and I must not dwell any longer on first principles, to which I consistently held fast; and which my friend, unfortunately, leserted-to the great retardation of English Geology, and the great subsecquent danage of its classification and nomenclature.

No great step (he its direction right or wrong) is ever taken in physical science without : :ome show of reason. In the illogical (and finally the unjust) expansion of the Silurian nomenclature, the steps are easily uncovered. The Silurian groups were established on what was (at the time) supposed to be good and perfect evidence. The groups, from the Ludlow to the Llandeilo base, were then called "a System." From the first, I objected to this "lpplication of the word "System" for several reasons; but chiefly because the Bala fossils, $\therefore$ far as I knew them, were identical with species of the "Lower Silurian" groups. This fact was known to the author of "the System," though he still placed his Llandeilo Flag 
above the Bala group. But a system his groups were called. Here was the first mistake. A verbal mistake may, and often does, become the foundation of an unconscious sophism.

Following in this train, the oldest fossil-bearing rocks of Russia were called Silurian. They were identified with the "Silurian System*" But the author afterwards found among the Cambrian mountains (of the Bala group) the rocks he had called Silurian in Russia. Therefore the Cambrian mountains (all the groups, in short, of the Cambrian series in the Tahular View) were to be Silurian! And as such he mapped them (in 18t3) without a syllable of communication to myself. If we admit the Silurian syllogism advanced in the concluding words of a preceding page (supra, p.56), we must accept the consequence of this new syllogism. It is irresistible. Yet from the very starting-point of the author's reasoning there lurks both a mistake on a point of fact, and a virtual sophism. The Silurian sections were not true; and had the groups (down to the Llandeilo Flag) been truly placed, they did not form a System, as he interpreted their relations when he illogically grouped them into "a System."

I think it evident that the author of "the Silurian System" suspected that his lomer sections were erroneous hefore he altered the colours of his map in 1843. He may also have suspected that my upper Cambrian sections were in principle erroneous; and if so, he was mistaken. But on no conceivable supposition could he have a right to mask his own mistake by a spoliation on the scientific property of his fellow-labourer. Had he been playing a solitary game he might have shifted the cards as he pleased: but the game was not solitary. I had done the hard work in Cambria. Of Cambria he had only touched the outskirts, which he certainly had misinterpreted at the time he published his System and defined its base. Small reason, therefore, had he (except the despot's plea) to rearljust his boundary at my cost, to extrude me from the country over which I had the right of conquest, and to claim it as his own. Had his lower groups been right they would have sanctioned no claim beyond a share in the Bala (or Upper Cambrian) group: but that claim is now at an end by the establishment of the true Silurian base-the May Hill Sandstone. Iad the extended Silurian nomenclature been more symmetrical, and geographically more true than mine, it might have had some claim in point of taste: but geographically it is incongruous to the last degree. The rocks of Cambria are no longer to be called Cambrian, but they are to be called Silurian, to give a stability to the so-called "Silurian System," which without their help is baseless!

But it may well be asked, if such were the facts of the case, how came geologists so generally to accept the Silurian nomenclature in its widest and most illogical extension?

* Let no one say that my objections to the extended use of the words "Silurian System" were an afterthought. When the magnificent work done by my friend and his fellow-labourers in Russia was first expounded to the Geological Society, I took an objection to the name "Silurian System" as applied, without qualification, to the oller rocks of Russia. My objection was ill-receired by those who knew nothing of its true meaning. The author of the Silurian Systcm saw, I cannot doubt, the direction in which his scheme of nomenclature was drifting. I at least saw very plainly that it involred, as its logical consequence, the incorporation of nearly all North Wales into the Silurian System. My objection was not therefore captious and frivolous, as was supposed and asserted by some who knew little of the true development of the older Palæozoic rocks of Britain. It was only a vindication of first principles which ought nerer to have been abandoned. 
I reply-Because the facts were little known to geologists: and, perhaps, because they little cared about them; for palæontologists who know little of field labour may regard nomenclature as of very secondary moment-Because they had not cousidered the sophism by which the Silurian nomenclature had been expanded, or the positive injustice and geological untruth which it virtually involved-Lastly, and I believe chiefly, because they supposed that I had made some egregious, but unacknowledged blunder; and that I had, in consequence, quietly abandoned my whole scheme of classification and nomenclature. And well might they believe so, after the audacious liberty taken by $\mathrm{Mr}$ Warburton with the nomenclature of a paper published in my name in $1843 \%$.

It was under this impression (I write advisedly) that the Director of the Government Survey began, and went on with, his great Survey of Wales. "He believed that I had abandoned a very good nomenclature," for reasons known to myself; and that the Silurian nomenclature was, therefore, to be regarded as, in fact, acknowledged and established: and hence that the primary object of the Survey was to give meaning to the Lower Silurian groups. Be this as it may, the Surveyors did not (as they were logically bound to do) keep their nomenclature in abeyance till they had worked out all the physical and paleontological subdivisions of the great Cambrian Series. On the contrary, assuming the Silurian nomenclature and the new Silurian map as their guide, though by their early observations in South Wales they proved that the Llandeilo Flag had been put in a false relation to the Upper Cambrian groups, they first reduced it to its right place in the general series; then they expanded it upwards through five or six thousand feet of strata, and downwards through more than twice as many thousands; and thus they elaborated their second division (in conformity with the new Silurian map of 1843), by a process which had no reference to the natural succession of physical groups, and with a nomenclature which was geographically incongruous and untrue. They did this while a truer and more philosophical nomenclature was before them; which, however, they believed that I had abandoned.

* Strange as it may appear, yet is it literally true, that for a period of about seven years I remained in absolute ignorance of the fact that Mr Warburton-in the opening paper of the Quarterly Journal of the Geological Society, which was published in my name, though never revised by myself during its passage through the press, and studiously kept from my revision-had quietly tampered with my nomenclature, and made me perpetrate (quite unconsciously and against plain trutl and reason) an act of scientific suicide. I have had a long, and perhaps unreasonable, dislike of premature nomenclature. But it can do no harm, and it may sometimes do good as a means of marshalling our supposed facts together, so long as it is used provisionally. But when our provisional nomenclature is assumed as dogmatically fixed and permanent, while the critical and fundamental facts assume a new type through the progress of discovery - when our provisional names are not so modified as to suit our new facts, but our new facts are so distorted as to suit our first nomenclature; it then becomes not merely unsymmetrical and in bad taste, but it becomes a very mischievous hindrance to the cause of truth and reason; for it literally compels us to march in fetters. I cared littlo about nomenclature, and I was ready to modify my own in any way compatible with scientific truth. It was not till I found myself excluded from the classification and nomenclature of North Wales (though I had, with a near approach to truth of detail, analysed the whole Cambrian Series, which assuredly had not been done by any other English geologist) that I began to maintain my own position; and I then found that while vindicating myself I was only contending against palpable error, and vindicating those very principles which have been the guide of Geologists in every step of real progress; and form the basis of the logic by which geology has gradually risen into a symmetrical and secure system of classification and nomenclature. 
Nor were the consequences of this scheme only an inconsistent and unphilosophical nomenclature. All Cambria and Siluria must form one System. Therefore, on the schene of the Survey, the oldest fossil-bearing rocks of Wales (under the name "Lower Silurian") were linked to the true and undoubted groups of Siluria by a "Middle Silurian" group made up of the Caradoc Sandstone and the May Hill Sandstone. This link (the only support of the scheme which packed the rocks of Cambria and Siluria in one System) has now been broken; for it was not of nature's workmanship: and the attempt at its fabrication showed the importance of a cautious adherence to fundamental principles; and also proved that excellent palrentologists and excellent ficld observers, even while combined together, may be greatly misled by a premature classification and nomenclature*.

After his well-deserved triumphs, and the high honours gained in Russia, my friend seemed to aim at nothing short of a Palæozoic Empire, over which the supreme authority was to center in himself. The highest collective group of the whole Palrozoic System must have a new name-Permian; and the symmetry of our English geographical nomenclature became disfigured by the interpolation of a foreign name, which put out of sight our own more perfect European typet. In pursuance of this commanding aim, the Silurian System was no longer a philosophic scheme worked out on principle and defined by admitted facts: but Siluria became a region undefined and expansible-capable of absorbing within itself, right or wrong, all neighbouring countries which had with it any community of character or language.

* While the May Hill Sandstone and the Caradoc Sandstone were regarded as one group, and called Midule Silurian, there was no motive for a nice separation of the fossil localities. At any rate, it is quite obvious that, in the collection of the Government Survey, the May Hill and Caradoc fossils must have been injuriously blended together. The collection made by myself had been formed without any hypothesis as to nomenclature, and with great care as to the localities, Hence (as has been above stated) Professor $\mathrm{M}^{\mathrm{c}} \mathrm{Coy}$ was enabled from my collection (though far inferior to that of the Government Survey) to make the critical separation of the May Hill and Caradoc Sandstone, before be ever visited any part of Siluria. This separation was the very turning-point in the right interpretation of the physical as well as of the palaontological groups which enter into the structure of North and South Wales.

As the classification and nomenclature of the Survey is hardly more or less than a following out of that which was adranced by Murchison in his map of 1843 ; the same objections apply to both. As I have succinctly stated the objections which I believe fatal to the scheme of the Government Survey, in one paragraph of a paper published by myself in the Philosophical Magazine of December last, I will subjoin them word for word to this note: though they are virtually but a repetition of the reasons above given against the unphilosophical and illogical extension of the published Silurian nomenclature. They are as follows: "Once for all, then, I confidently affirm, that the great Cambrian series is a natural and true series, and that its subdivisions bave been rightly named in the above Tabular View. On the other hand, I contend that the classification and nomenclature of the same series in the scheme of the Government Survey are erroneous and untenable. 1st. Because it overlooked the true physical and palreontological base of the Silurian series. 2nd. Because its nomenclature is but an expansion of Silurian names derived from sections which were not true to nature. 3rd. Because no section, within the limits of Siluria, gives us a good older Palsozoic type. 4th. Because the nomenclature of the Cambrian series (as given in the Survey) was not deduced from the natural groups; but, on the contrary, the natural groups were so packed as to fall in with a previous (Silurian) nomenclature, which was based on erroneous sections. 5th. Because it introduces two different and incongruous schemes of nomenclature into one System, and consequently involres the nomenclature in most needless geographical contradictions and incongruities. There ought never to have been any controversy on the questions $I$ have been discussing; and since the establishment of the May Hill Sandstone, there is now at least no shadow of reason for its continuance."

f For the purpose of comparison with the corresponding rocks of France and Germany, our own highest Britisl Palxozoic type is more perfect than the Permian of Russia. (Supra, note to p. sxri.) 
This over-ambitious aim was followed with all the energy of a bold hunter who, while he pursues his game to the death, little thinks of his neighbours' fences, or that he is trampling their crops under his horse's hoofs. One who adopts a daring scheme of philosophy often has, for a while, a great advantage over another who is pursuing truth by the secure and sober steps of inductive logie. For men hate to be dangling in doubt; and one who offers to the enquiring mind an apparent resting-place, is sure of immediate favour. $\Lambda$ bold generalization, ratified by a technical name, nay have the promise of some endurance. For when a man has accepted a technical name, he never readily submits to the humiliation of parting with it: and he will often cling to names with more tenacity than he clings to principles; which he never perhaps examined for himself, or, it may be, never thoroughly comprehended. Ialf the wrangling in the world of science has arisen from premature generalizations, embodied in a premature nomenclature.

The Silurian nomenclature was first accepted because all English and Foreign Geologists believed (and, so far as regarded the two lower groups, believed erroneously) that the Silurian sections were true to nature; and consequently, that the subordinate fossils were arranged also in a true descending order. Now, although the sections were wrong, the palecontological sequence $w a s$ true to nature: and for this simple reason, that the greater part of the so-called "Lower Silurian" species were (by a great mistake in the "Lower Silurian Sections") taken from their true place, which was in some cases thousands of feet below the May IIill Sandstone, and catalogued as the fossils of two groups which were placed (by a great physical error') immediately under the Wenlock group. To a foreign palæontologist, or to any one unacquainted with the true physical structure of England, the sequence indicated by the fossil evidence seemed therefore to give a very high sanction to the supposed truth of the "Lower Silurian Sections," and the nomenclature that was derived from them.

The descending palcontological sequence in America, and on the continent of Europe, was proved to be the same, or nearly the same, with that given in the so-called "Silurian System." Therefore it was naturally concluded that the Silurian groups must be in a true physical arrangement, and that the Silurian nomenclature was justified by its evidence.

But how was the Silurian kingdom to be upheld when its foundations were not only shaken, but overturned, and when the first principles of its constitution were found to be devoid of a true geological sanction? After a manifesto which acknowledged a great mistake, but blinked the truth by very unfairly throwing the blame of the mistake on myself, it was upheld by a despotic act of usurpation, carried into effect without my knowledge or participation, without any respect to historical justice, and without any regard to geographical propriety. All rocks below the Old Red Sandstone were to be one System, and that System was to be Silurian!

When this scheme was accepted, in great ignorance of the true bearing of the facts on which alone it could be entitled to acceptance (and let me remark, by the way, that apart from all other evidence, no one could have any just conception of the true bearing 
of the facts before the establishment of the May IIill group as the true Silurian base) -when it was adopted, almost to the letter, by the Goverument Survey-and when it was affirmed that the only workman, who had any claim against it, had abandoned his own work and thereby acknowledged himself wrong-the act of usurpation secmed for a time to be complete and triumphant. Any opposition to it was a philosophic heresy, and any word raised against it was received by the Geological Society of London with absolute mockery and misplaced scorn.

A conquest made in war, whether just or unjust, may be long upheld by the same brute force which gained it. But it is far otherwise in the more honest and peaceful conflicts of natural science. Science is a republic which admits of no dictation but from truth and reason; and from them there is no appeal.

If in the progress of a rapidly advancing scicnce a great and good workman make a great mistake; and if that mistake be larcely adopted under the sanction of his name; so much the worse for himself. Physical truth is not a thing mutable and dependent on popular voice. The truths of nature are eternal. Physical mistakes (whether of classification and nomenclature, or of a false induction from facts imperfectly observed,j may last their day: but that day cannot be long, while the spirit of enquiry is alive anong mankind, and they are awake to the power and sanctity of philosophic truth. Mugna est reritas et pro'ealubit, is a trite old saying; but it will be true so long as there is constancy in nature.

There never ought to have been any controversy between the author of the "Silurian System" and myself. Our work was sufficiently distinct to allow each of us his own province, even while a large border country remained in doubt, and was open to a double claim. But he contrived from the first (casting the consequences of his own mistakes upon myself) to malie it a very ungenerous controversy; by excluding my hard and long-continued work, which was substantially right, fron all name and notice: and claining by despotic title a country over which he had gained no rightful conquest, many parts of which he had nerer touched; with which, when his scheme of absorption was first published, he was very imperfectly acquainted; and which, even now, he only knows well at sccond hand. Since the establishment of the May Hill Sandstone as the physical and palreontological base of the Silurian rocks, we have, at length, a well-defined separation betrecn Cambria and Siluria; and there is no longer any equitable or reasonable ground of controversy on the score of classification and nomenclature. If it be continued now, it is nothing more or less than a useless struggle for the perpetuation of a positive wrong.

It might seem incredible that a scheme of classification which involved the gross geographical absurdity of absorbing Cambria into Siluria, and the palpable geological absurdity of making the Cambrian Series of the Tabular View the equivalent of the Llandeilo Flag, could set up its claims for our permanent acceptance. But moral arguments have been advanced I think unfairly, which if true would put me greatly in the wrong: and I believe that such arguments have had more weight with some English geologists than those which were physical. 
1. Thus at the Mecting of the British Association (in 1854) it was contended by a gentleman of the Government Survey, that the nomenclature was settled, and that I was only disturbing a settled point*. One who has put himself in the wrong may well contend for this: but I reply, that there can be no settlement which is on a false basis-that no authority can vindicate a wrong-that it will not do to perpetuate an error because many may in ignorance have embraced it.

2. By others, the controversy between the author of the "Silurian System" and mysolf was called a mere dispute about words and names. I deny the justice of such an assertion. A name, like Cambrian or Silurian, implies a true classification, or the name is good for nothing. $\Lambda$ true classification implies the application of true principles and the right use of them. A name may become the mere watchword of a party, and do infinite mischief to scientific truth. Geology is an expanding science; and if its nomenclature remain fixed and be not adapted to the advance of facts, it either does not move at all, or it moves in fetters. Whenever a great step is taken in physical science and is defined by a general name, such as "Silurian System," that name will assuredly be abused by those who have a prurient and incautious appetency for generalizations; nor is it an easy matter even for cautious men to escape this kind of mischief. I may quote one or two examples that are in point.

An erroneous identification of a single group in North Devon with the Caradoc Sandstone, imposed on me a task which detained me in Devonshire and Cornwall for the greater part of two summers. An erroneous identification of certain Belgian with certain Silurian groups, had been made before the Belgian and Rhenish provinces were visited by Murchison and myself in 1839. By prematurely accepting some of these identifications we lost the labours of nearly half the summer; and though we did make some true steps in advance, our joint Memoir was afterwards damaged by our attempt to Silurianize the lower Devonian groups on the borders of the Rhine. A premature extension of the Silurian groups and names over Cambria led the Government Survey into their error in the determination of a "Middle Silurian" group. And lastly, the name "Silurian," which professed to be geographical, and based on an accepted physical principle, is to remain fixed at the cost of geography, and by the abandonment of the very principles which gave truth and meaning to the name. I contend, therefore, that a dispute about names, involves, in the present case, nothing more or less than a dispute about the first principles of Science, which we cannot violate without damage to the cause of truth.

3. Thirdly, it was hinted that the classification of the Tabular View virtually embodied all new discoveries. If the remark meant anything, it must, at the time it was made, have meant that my work was not original, and that I was claiming what was not my own. Whatever may have been the value of my work among the older Palæozoic rocks-how-

* The same fallacy appears more than once in the pages of Siluria. "The point in dispute is settled :" but the following questions cannot be suppressed. If the point be settled; by whom? and by what arguments? 
ever small-it was, at least, original. I worked first, and single-handed. The only material changes I have made in the grouping of the Cambrian Series since 1832 have been the shifting of the base line of the great collective Bala group to a lower level; the adoption of the name Lingula flag; and the separation of the May Hill from the Caradoc Sandstone. In none of these changes have I owed anything to the Government Survey; and to whom else could I owe them*?

4. It was hinted (and it was the only point which grieved me) that the Silurian System was a great work, the appearance of which made an epoch in British Palaozoic Geology; and that I did not treat the author with the honour and consideration he deserved. I emphatically deny the charge. I have done all honour to the Silurian System, and accepted its groups, and the names given to them, without reserve, wherever they were right and admissible. I might have attempted to unpack my old collection; or I might, with the utmost ease, have made a good new collection from the fossils of Coniston and Kirkby Moor, and submitted them to $\mathrm{Mr}^{\circ}$ Sowerby for determination; and thereby have endeavoured to go shares in my friend's Silurian discoveries. But I made no such attempt. I was certain that his physical types and fossil lists were excellent, and that he had a full right to make them typical. I only abandoned the Silurian classification when I believed that the author had deserted his own principles. If I differ from a fellow-labourer, the greatest respect I can pay him is to tell him plainly and honestly why and where I differ from him; and it is no mark of respect to merge plain truth in words of stupid and unmeaning courtesy. He had made a noble conquest, and received from it honour enough to satisfy a reasonable ambition: but "too much honour," the poet tells us, is a burden too heavy for a man to bear. My friend became ambitious of a more extended conquest. With much gravity he expunged his own base line of about 200 miles in length, and then consummated what I thought an act of spoliation. If I resisted this, did I thereby cease to do leserved honour to the author of the Silurian System? Let facts speak for themselves. He tells us, with just pride, (Siluria, p. 9) "that his

* In three instances (and three only) I wrote for informution to my friends employed on the Government Surrey. (1) When in 1846, I had traced the Lingula flag from Tremadoe to Cader Idris, I wrote either to Mr Jukes or Mr Salter, and stated that if the views I had formed in 1832, of the structure of Carnarvonshiro were correct, the Lingula flags ought to be found above the Harlech grits which overlie the great Nant Francon slate quarries. In that position I had sought for these flags for a few hours (during my hasty passage through the country in 1846) but had not found them. The reply was, that the Surveyors had found them in the position indicated. (2) I wrote some time afterwards to Mr Jukes, and inquired where the Llandeilo flag, of the Towy, emerged-on a line drawn from that valley to the shores of Cardigan Bay, or to the south-east flank of Cader Idris. The reply was, that tho Surveyors considered all the rocks on those tivo lines as Llandeilo flag. When I read the reply, I must honestly state that I thought it indicated a very strange and unnatural nomenclature; and that it gave a very bad promise of a successful analysis of the great and difficult groups of South Wales. (3) I afterwards (but I have no means of fixing the date of the letter) stated to Mr Jukesthat if the Silurian rocks were, as a whole, unconformable to the older groups I called Cambrian, there were no physical difficulties in the way of a right interpretation of the whole Series-Cambrian and Silurian. He wrote in reply, that the hypothesis of a general discordancy had once been adopted by the Surveyors, but was abandoned. I think the abandonment was a great mistake. Before Mr Salter revisited the Wenlock and Horderley sections in 1853, I requested him to look carefully for a discordant overlap mado by the true Silurian rocks. He found a discordant overlap which included the Norbury limestone - an important fact afterwards verified, during the same summer, by Professor $M^{c} \mathrm{Coy}$. By this discovery the Norbury limestone at length obtained its true place; as a part of the unconformable and orerlying May Lill Sandstone at the physical and palieontological base of a true Silurian System. 
System was honoured with the highest distinction the Royal Society bestows." I was then on the "Committee of Recommendations," and I urged his claims with every argument I could adduce: and had my voice been followed, he would have received the Gold Medal a year sooner than it was awarded to him. I stated in the Committce that a great and difficult step had been taken by him, which, during many by-gone years, I had tried in vain to take. That it was the greatest movement in advance that had been effected since I had a right to call myself a geologist; and that it was entitled to the immediate and highest distinction that the Royal Society could award. On this score, then. let no one hereafter utter a petulant and unmerited sneer against my conduct in the present controversy.

5. The author of "Siluria" pointed out to the Association, that if my Tabular View were accepted, he must lose his honour by seeing a new name given to large tracts of Europe which had been coloured and describer as Silurian. What had that to do with the question in debate? Absolutely nothing, while we were discussing the proper classification of British rocks on British evidence. Ilis views were so one-sided that he seemed incapable of seeing that, while on my scheme I actually gave his Silurian colours as large a surface as they occupied on his original map, he was obliterating every memorial of my work in a great and intricate country which I had analysed correctly, and he had not; and of which he had absolutely mistaken the physical relations after he had, quite unconsciously to himself, overstepped his own physical and palwontological base-the May Mill Sandstone.

Leaving the British Association, and the two days' discussion that took place before it, I will address myself to one or two statements which my friend made the groundwork of his first aggression, and which I can only meet by a direct and unequivocal denial.

1. In his Anniversary Address to the Geological Society in 1843 (at the very time he was, quite unknown to myself, meditating no less a change in his Silurian map than the incorporation of Cambria into Siluria) he wrote as follows: "We were both aware, and the point i; fully commented upon in my own work (Sil. Syst. p. 308), that the Bala limestone fossils agreed with the Lower Silurian; but, depending upon Professor Sedgwick's conviction that there were other and inferior masses also fossiliferous, we both clung to the hope that such strata when thoroughly explored would offer a sufficiency of new forms to characterize a new System."

I think it best to quote my own reply to this passage, as it appears in a fifth letter on the Lake District, lated June, 1853. It is as follows:- "In omission and commission, the passage above quoted is a virtual misstatement of the facts. The author does not inform the reader that he lad himself consented in 1834 to put the Bala limestone in my Upper Cambrian group.-Bccause it had a sufficiency of new forms to mark a new system? By no means; but bccause it was the base of a great physical group which he himself lad excluded from his own system in South Wales, and over which he had (erroneously, as was afteruarls made out by other observers) placed his Llandeilo group. Nor does he tell the reader that I had, from the first, strenuously opposed the word System when applied to the (collective) Silurian groups; because they had no well-defined base, either physical 
or palieontological. The sentence quoted proves to demonstration that my objection (and I may add the repeated objections of Professor Phillips) to the word System (as applied to the Silurian groups) had been right, that the Silurian nomenclature was in abeyance, and that it must be considerably modified in order to bring it into any conformity with a true geographical nomenclature, and with the palaontological evidence of more complete sections.

"When the author states 'that we both clung to the hope that the Cambrian groups would offer a sufficiency of new forms to characterize an inferior system,' I can only reply, that the hope to which he clung was not derived from anything I had ever said or written; and that I had not, in 1842 and 1843, the shadow of a hope that any new system of animal life, any group of new forms marking' 'an inferior system,' would be found among the Lower Cambrian groups: I had constantly expressed, and repeatedly published, a directly contrary opinion*".

Had I acted in a controversial spirit, I should have then answered (as I am now doing') the above quotation from the President's Anniversary Address. I contented myself, in at Paper read before the Geological Society, four months afterwards, with an indirect and amicable refutation of the passage, so far as it misrepresented my well-grounded hopes and anticipations. It is the policy of my opponent to represent me as if in error about the Cambrian fossils. Now in the above quotation the error is exclusively his onn; and how he could have fallen into it appears to me almost incredible, after what took place between us in $\mathbf{1 8 3 4}$.

The subsequent discoveries respecting the Cambrian sections and fossils, by no means sanctioned the audacious incorporation of Cambria into Siluria; but they did prove that the Lower Silurian groups had been greatly misplaced, and that the "Silurian System" (even though its groups had not been misplaced in the sections) was without any palaontological base.

In short, my opponent, after the publication of a Paper on the Bala limestone, by Mr Sharpe, (Procedings, Vol. IV. p. 10,) must I think have suspected that there was some great error in his own sections, and perhaps also in mine. To profit by the errors, whoever might have made them, he shifted his ground; and the shift would lave been fair harl he been the only workman in the field. But without acknowledging the possibility of great mistakes on his own part, he was quite ready to throw the whole blame of them upon me. and to deal with me as if I had been the blunderer; and while meditating his aggression on Cambria, le imputed to me opinions respecting the Cambrian fossils which I lad neither published nor ever entertained.

2. The reader may perhaps think the preceding comment both harsh and unjust towards my friend; and I should think so too, but for another fact which self-defence and the plain truth of history compel me next to notice. In his Paper on the Bala

* See the Fifth Letter on the Lake District, J. Hudson, Kendal, 1853, and Philosophical Mragazine, December, 1854. 
limestone, Mr D. Sharpe stated:- "that Professor Sedgwick placed the Bala and Coniston limestones in the Upper Cambrian System, which he states to lie below the Silurian System of Mr Murchison and above the Lower Cambrian System-a view adopted by Mr Murchison in his work on the 'Silurian System,' upon the authority of Professor Sedgwick."

The assertion implied in the concluding words of this short extract-that Mr Murchison borrowed from me, or adopted on my authority, his views respecting the relation of his Lower Silurian groups to the Upper Cambrian System (the Upper Bala group of the Tabular View) - is so directly contrary to fact, that I can only oppose it by a direct denial. There is no other way of dealing with it. I do not by any means accuse Mr Sharpe of wilfully misrepresenting me. He made a mistake, which, at the time he wrote, might, perhaps, be natural; and it only shewed how little acquainted he was with the true history of the Silurian System, and with the physical evidence on which it was primarily made to rest by its author.

But what shall I say of the author of the System? He cannot have overlooked this passage, because the Paper containing it was the subject of a special comment in his Anniversary Address of 1843. He knew that Mr Sharpe's statement was historically erroneousso palpably erroneous that a mistake as to that point of error was absolutely inpossible. Why then did not my friend manfully and instantly rectify this error? The severity of historical truth and common candour to myself required this correction. But he never made it; and by proceeding to profit by it, he virtually threw the blame of his own mistakes upon myself. Never since the controversy began has he in one instance put himself in the right by acknowledging himself in the wrong, even when his mistakes were palpable; and in thus masking a part, and by no means an unessential part, of the historical facts, he has shewn both a want of candour towards myself, and a want of true wisdom as a controversialist. The establishment and extension of his own System was the one object he had in view: and the object might be very laudable; and any means of gaining it might be right, provided there had been no other labourer in the field. After the lapse of twelve years it may be thought unreasonable, on my part, to moot this point of controversy; but I am now (for reasons given under the next head) compelled to do so, or to abandon my own cause altogether; even while I believe it to be the cause, geologically and historically, of common sense and common truth. I have not been the aggressor. From first to last I have only acted on the defensive: and, so far from showing a prurient love of controversy, I have rather shewn, in years past, a lazy and apathetic indifference to my own interests as a hard and honest workman at the severe task of an English palreozoic geologist.

3. In the new work called "Siluria," * are the following words: "At that time (1833) it was supposed that the slate region of North Wales, then under the examination of Professor Sedgwick, consisted of rocks, in part fossiliferous, and of an cnormous thickness,

\footnotetext{
* John Murray, London, 1854 (pp. 7 and 8).
} 
Which rose up, according to my friend and fellom-lahourer, from beneath my Silurium Types. Hence, another term, that of Cambrian, was afterwards, in 1836, applied to masses that were supposed to be inferior, hefore the true relations to the Silurian strata of Shropshire had been ascertained. This assumed inferiority of position, in the slate-rocks of North Wales, being considered a fixed point, it was naturally thought that in such lower. formations, the fossils of which were then undeseritied, would be found to contain a set of organic remains differing as a whole from my classified and published 'Silurian System." With other geologists, therefore, I waited for the production of the fossils which might typify such supposed older sediments."....." It was, however, in vain that we looked for a peculiar type of life from the "Cambrian' rocks. Silurian fossils alone were found in them; and the reason has since become manifest. The labours of many competent obscrvers, in the last fifteen years, have proved that these rocks we not inferior in position, as the" mere supposed to be, to the lowest stratified rocks of my Silurian region of Shropshire and the adjacent parts of Nontgomeryshire, but are merely extensions of the sume strata..... and that the fossil-bearing rocks of North Wales are both in their order and contents th., absolute equivalents of the chief mass of strata which had been described and named by me 'Lower Silurian' in Shropshire and Montgomeryshire..... Although in 1839 I held $i$ " rommon with Professor Sedguick the erroneous idea of the infra-Silurian position of the rocks of North Wales, I soon saw reason to abandon that view, and to adopt (in the year 1841) the opinion I have subsequently maintained."

I do not mean to misrepresent the author by garbled extracts. It is both my interest and my duty not to misrepresent him. Are these extracts a true philosophical history of facts and inferences? They are not history, but sheer advocacy: and rery bad advocacy, because they blink some essential facts, draw the reader away from the first Silurian types on which the whole nomenclature rested, and inevitably lead him (if he be not bettr.l. informed) into conclusions respecting myself which are positively untrue.

In the first place, in alluding to the old slate-rocks of North-Wales, he tells us, that according to my friend and fellon-labourer they rose up from beneath my Silurian tupes. What is this but virtually to repeat, and turn to profit, the very erroneous statement of Mr Sharpe, which I have already discussed? Sir R. I. Murchison (when President in 1843) ought to have corrected the misstatement; and in failing to do so, he failed, I think, in a duty he owed to plain historic truth. And if he failed somewhat in 1843, much more does he fail in 18.54, if in the words I have quoted, he means most remotely to insinuate that I misled him in his mistaken riews as to the relation of his Lower Silurian croups to my Upper Bala group, or generally to the slate-rocks of North Wales. If thi: lie lis meamin!l he is either under some strange delusion arising out of his one-sided earnestness to establich his own System; or, having claimed a despotic title to all older Palrozoic rocks, he may think that he has a right to claim a royal privilege, and that "he can d" no wrong;" while he is dealing with his own subjects. Science is a republic that admits un such plea. I declare, with the earnestness and sincerity of plain straightforwird truth. 
that I did not mislead him-that he adopted no part of his order of superposition on my authority. He gave me no opportunity in 1834 of correcting his Silurian base, or of removing the Llandeilo group into its right place in the Cambrian Series. Had we made the attempt, we might, perhaps have failed, while together, as he had done while toiling by himself: and we might have failed mainly for this reason-that it is far easier to advance in the way of truth from a state of ignorance, than it is to correct an error which has been put forward on authority and received as an established fact. Be this as it may, it has nothing to do with the present question in debate. For full twelve years I never touched the Llandeilo country after 1834. The author of the "Silurian System" had the game in his own hands; and he continued so to deal with it, as to put his two lowest groups in an absolutely false relation to the Upper Bala groups both of North and South Wales.

Again, on the East side of the Berwyns I accepted, provisionally, his erroneous interpretation of the fossiliferous groups, and thereby damaged the integrity of my own sections, which were perfectly right in principle. And lastly, (in 1834) I did not blink a single difficulty; but I shewed him the Bala limestone, and explained to him its true relations, which he accepted, and which he interpreted correctly. He did not tell me that I must pause till I had produced a set of organic remains from the Bala group, "differing as a whole from those which afterwards appeared in his classified and published Silurian System." He did not tell me "to wait for the production of a set of new typical fossils:" but on the contrary, guided, and very properly guided, by the physical evidence, he called (so soon as the nomenclature was agreed upon) the Bala group, as woll as its equivalents in South Wales, Upper Cambrian. And if the Upper Cambrian groups of South Wales were, as he had placed them, below his Llandeilo Flag, the Bala limestone must be at the rery least five or six thousand feet below it.

Here, no doubt, was a great difficulty; which arose, as the event proved, from a great mistake. But who had made the mistake? The author of the "Silurian System," and no one else. My Bala sections were perfectly correct. And, I repeat, that if during the eight years which elapsed after our joint examination of the Berryn scctions in 1834, my friend had a single doubt about the correctness of the nomenclature agreed upon, he had no right in courtesy to introduce a change of names without some communication with myself. Still less had he any ground in scientific truth to change his principles of classification; by putting out of account his oxn very great mistake (to the fatal damage of a consistent geographical nomenclature), and by throwing the sole responsibility of it on myself.

To have written with common historical fairness, my opponent should not have used such words as I have quoted from his "Siluria," p. 7. He ought to have stated that he had mistaken the relations of the lower groups which he had classified and published in the "Silurian System." That by accepting this classification "his friend and fellow-labourer" had unfortunately been misled. That the Upper Cambrian rocks were not below (as they appeared in his published Silurian sections) but above the base line of his Llandeilo group. That he had described the fossils corrcetly, though he had mistaken the sections; and, 
therefore, that on fossil grounds the whole Bala group was Silurian. Lastly, that he had done enough to entitle him to shift his base; to change all his principles of classification: and to absorb all Cambria into Siluria. Such a statement might have scemed compatible with literal truth; yet I can hardly think that any English geologist would have accepter it as a good ground of classification and nomenclature.

Geologists, however, did accept the Silurian classification; but on mistaken grounds of evidence. A very great and fatal mistake was committed. Who made the mistake? In the answer to this question $I$ am at issue with my opponent on a very plain question of fact. On this point he has long done me great injustice; which I endured, only because I thought it so plain and palpable that it must work its own cure. But I was mistaken; for it is greatly aggravated by its mode of insinuation in the words on which I now comment. I call upon him to do now what he ought to have done long since,-to retract a misstatement, on an unequivocal point of fact, which is injurious to myself. I believe that he will do so; and so far set himself right. If he refuse to do so, amply and without reserve, then I have done with this work of a pitiful controversy: and I have done with "Siluria" now and for ever.

Again, he plainly insinuates that I made a mistake in supposing that the old slaterocks of North Wales "were beneath his Lower Silurian types." I made no such mistake. The Llandeilo Flag was his lowest group; and the lowest horizon he can claim for it is exactly, or very nearly, that of the Bala limestone. He mistook its relations by placing it far above the Bala limestone; and that mistale was exclusively his onn. When the mistake was corrected, I was ready to admit (under the name Cambro-Silurian) the Caradoc and Llandeilo rocks into their true place in the great series of Cambrian rocks. But I will, for sake of argument, give up this point, and Silurianize all the Welsh rocks down to the Bala limestone. Can my friend then insinuate that I made a blunder in my descending sections, as now given in the Tabular View? Below the Bala limestone I had several thousand feet of strata making a very characteristic Lower Bala group; and then, in il true descending order, the Arenig porphyries and Festiniog slates; next in order the Lingula Ilag; then the Harlech grits, and the grand old group of Bangor slates. These collective groups were partly fossiliferous, were of enormous thickness, were magnificent as true physical groups; and they were all below the Llandeilo group -as that group was understood when my opponent (in 1843) took the rash and unwarrantable step of extending his Silurian colours over all the old rocks of North and South Wales.

But in the passage above quoted, my friend has again changed his ground, and appealed to a comparatively new interpretation of the Lower silurian types, and thereby greatly mystified his argument. He has deposed the rocks of Llandeilo from their typical honours (and indeed it was high time to do so), and now makes the Montgomery sections his "prototype." Technical names may be right or wrong; but they may, if they fail in all things else, help us in exposing a fallacy. The flag of Llandeilo was the original type, and hy the typical relations of that rock were the relations of all other groups of Llandeilu, 
Flag determined. There is no escape from this conclusion; for if we reject it, our nomenclature is nothing better than a verbal cheat. But by a great geological mistake the flag of Llandeilo was put in a false relation to my Upper Cambrian group. Therefore when the "Silurian System" was published, the author must have so misinterpreted the Montgomeryshire sections as to put the Llandeilo Flag of that county also in a false relation to the Upper Cambrian group. That he did so, there can be no doubt. And it is, I think, plain that he continued in this error in 1841, when Dr Fitton's Review of the "Siluyian System" was published. He may, during that year, have had some glimmering of his own great mistake; and he may afterwards have made a second mistake in supposing that my Welsh sections were erroneous in principle*. He knew after 1834 that the fossils of the Bala group, so far as they were known, were identical in species with those of his Lower Silurian groups. I had myself published the fact two years, or more, before the appearance of the "Silurian System," and I published a corresponding fact respecting the Snowdonian fossils before I revisited North Wales in 1842. At that time my friend believed (by a positive mistake of his own) that I placed the fossils of the Snowdonian trough near the base of the whole Cambrian Seriest. Hence he believed that the fossils of the whole Cambrian Series were nothing more or less than fossils of his two lower Silurian groups. His whole logic (if that may be called logic which was an abandonment of his own principles of classification) was perfectly transparent. His own fundanental and typical sections were wrong; but what of that? the fossil lists were right: and by developing the Llandeilo Flag upwards through five or six thousand feet of strata, and downwards through more than twenty thousand feet of strata-in short, by absorbing Cambria into Siluria-his scheme of nomenclature would stand good upon palæontological grounds alone. That this was the scheme, and the logic by which it was worked out when the Silurian map was changed in 1843, I have not the shadow of a doubt. It was publicly avowed and vindicated.

What right, then, has my opponent to bring forward the Montgomery sections with a view of insinuating a fundamental mistake on my part, when I had, in fact, made no mistake whatsoever? Up to 1843, and a later period, he misunderstood the Montgomery sections; as is indeed certain from his own nomenclature. And when the controversy began about ten years since, if he had discerned the least glimmering of light, from a now interpretation of the Montgomery sections, he would not have failed to turn it to his own account. I contend, therefore, that in the above quotation my friend has historically mystified the whole subject, by keeping out of sight his original types, and his original grounds of evidence;

* I believe that my friend was led into some error by Mr Sharpe's sections, who first wished to make the Bala group into the equivalent of the Caradoc sandstone. Afterwards Mr Sharpe gave a still newer date to the Arenig polphyries; and by the interpolation of supposed faults, made the rocks near the Menai Upper Silurian! If the author of the Silurian System accepted any part of these very crroneous views, he must have suspected that my Cambrian sections were all construeted on a mistaken principle. That he was misled is certain; and after 1834 he had no communication with myself respecting any of the Welsh sections,

† See Siluria, end of first paragraph, p. 9. 
and by arguing for his classification, on perfectly new grounds of eridence (never so much as seen by myself), and thereby trying to convict me of an erroneous interpretation of the meaning of his Lower Silurian types. If this is to be called fair reasoning, and the languarge of an impartial historian, there is an end of the rules of philosophic evidence. It is, as I stated before, sheer adrocacy; and if my views of right and wrong be not utterly confounded, it is very transparent, and therefore very bad, adrocacy. This may be called a harsh comment; but an unjust comment it is not, if plain words and plain facts are to retain their meaning.

Anxious as I now am to bring this Introduction to an end, I must request the reader's attention to another extract (Siluria, p. 25): "The term 'Cambrian' is not used in this work because when introduced by Professor Sedgwick it was employed both by him and myself, as applying to a vast succession of fossiliferous strata containing undescribed fossils, the whole of which were supposed to rise up from beneath the well-known Lower Silurian rocks. The Government geologists have shewn that this supposed order of infraposition was erroneous, and that all the fossiliferous rocks of North Wales, which had been called Cambrian, before their included fossils were described, are physically the same strata as those which had been laid down as Lower Silurian on the immediate west flank of the fundamental rocks of the Longmynd."

If this be not sheer advocacy I know not where I am to seek for it. It is true that a vast succession of fossiliferous strata (all the great collective groups of the Cambrian Series as given in the Tabular View) was supposed to rise from beneath the "Lower Silurian" rocks. But if this were a mistake, to whom do we owe it? To the author of the "Silurian System," and to no one else. The mistake rested on his sole authority. And even allowing that the lowest Silurian group, by a monstrous process of development, might become the equivalent of the Upper Cambrian group (of all the Cambrian rocks above the Bala limestone); by no process of physical development could it be stated, compatibly with common truth, that the Festiniog slate, the Lingula Flag, the Harlech grits, and the magnificent lowel slate-zone of Wales (Llanberris and Nant Francon slates, \&c.) were the plysical equivalents of the Caradoc and Llandeilo groups. It is not true that the fossils of the Bala group were unknown. Several species were known, and every known species was desuribed as identical with species in the Lower Silurian lists. In the progress of discovery a peculiar group of fossils was found in the Lingula Flag; and it is, I believe, true that all the vast Cambrian Series (with the doubtful exception of its lowest group) is fossiliferous-though the number of species gradually diminishes as we descend. This is no new doctrine. And if we have a right so far to relinquish our first principles, as to classify the true Silurian Series by physical and fossil evidence combined, and then to classify and uame the Cambrian Series on fossil evidence alone, we may give something like plausible evidence for the expanded Silurian nomenclature. This is incontestably the very ground on which the question was first argued both by the author of the System and the geologists of the Government Survey: and it was done while the broad fact was plainly standing up before them that a 
great mistake, directly bearing on nomenclature, had been committed by the author of the "System" (the greatest mistake in the history of British Palrozoic geology); while in the interpretation of my own sections, and in the true and consistent geographical nomenclature I derived from them, I was not convicted hy the Government Surveyors of one single mistake of principle affecting the natural classification of the groups.

Let us now examine the second sentence of the previous extract. The author described the rocks on the western flank of the Longmynd with many excellent details. About the Longmynd rocks there was no dispute. They were certainly very ancient rocks, and when asked (in 1834) my opinion of their age, I told my friend that I should provisionally identify them with a portion of the Skiddaw slate of Cumberland. Above the Longmynd rocks were other very difficult and obscure rocks, some of which were also very well deseribed in the "Silurian System." Then came the Llandeilo Flag; after which the ascending section was broken and defective. Part of this series was called Silurian; but the section was not typical, nor was it appealed to as the basis of the nomenclature. Its groups were named from other sections that were then regarded as typical, and were the basis of the nomenclature: and it is as certain as any fact can be in the history of geology, that the so-called Silurian rocks of the above section were supposed (at the time of the publication of the System and for some years afterwards) to be superior to the Upper Cambrian group. If then, in the progress of discovery, it turned out that some of the rocks of this section, which the author had named Silurian, were rocks of a much greater antiquity than he had first supposed, this did not make them typical; nor did it (as he wishes to prove) convict me of error. But it did prove, out of all question, that he had misinterpreted, and therefore had misnamed, some of the rocks of his section on the western flank of the Longmynd. To desert his original Silurian types, while he retains their names-then to give a new meaning to such names, by shifting his ground and appealing to a new type where these names had been applied by a positive blunder of interpretation-then on such grounds to contend that he has now both physical and fossil evidence to offer in vindication of his System-and lastly, to contend that in placing my Lower Cambrian groups many thousand feet below his "well-known Lower Silurian rocks," I had made a blunder, while he had all the while been interpreting the sections correctly ;all this is, I affirm, neither true history, nor good advocacy. It appears to me nothing but a mystification of the whole question, by a plain shifting of the meaning of plain words, while we are working our way to a foregone conclusion-a lind of sophism by which men unconsciously impose upon themselves as well as upon others.

One more quotation, and I have done with my remarks on the second chapter of "Siluria." "Miniature as it is in comparison of North Wales, this tract of the Stiperstones and Shelve, which with a description of its fossils was formerly described and mapped as Lower Silurian, and which extends from Shropshire into Montgomeryshire, is, I repeat, now determined to be the geological prototype of the grander undulations of the same rocks which spread over so large a portion of the Principality of Wales." (p. 39). If the author had entertained eren the remotest suspicion that the tract here describal contained the representatives of the whole 
Cambrian Series, he ought to have made it typical, and based his nomenclature upon it. Even had he but published this suspicion, without the support of proof, he might perhaps have had the shadow of a claim to the publication of a prototype. But he did no such thing: and if his present views be conveyed by the above extract, they only prove how entirely at fault he was in his original interpretation of his own section. For he surely will not contend that he had a right to mean one thing by such words as Llandeilo Flay and Lover Silurian while he was in Caermarthenshire, and quite another thing when he was applying the same words to his rocks in the miniature tracts of the Shelve and the Stiperstones. To do this would only be to introduce (as I have said before) a palpable sophism. To call his miniature section a prototype is, therefore, a strange fallacy of language. It was neither a prototype, nor was it taken as a type at all when he included (in 1843) all Cambria in Siluria. Nor was it taken as a type by the Government Surveyors while they were endeavouring (though they had utterly destroyed the typical meaning of the Lower Silurian Sections) to sanction the extended Silurian nomenclature, by a monstrous and unnatural process of development of its groups, through the older regions of North Wales. The Cambrian Series of North Wales is the true mototype, both historically and geologically. I first made known this prototype; and no one has any right to tamper with it; unless where he can prove it wrong. If Professor Ramsay and Mr Salter can shew that certain obscure and difficult groups between the Llandeilo Flag and the Longmynd are the probable equivalents of some of the older subdivisions of the Cambrian Series, so much the better; they do not thereby destroy, but confirm, the truth of the Cambrian prototype: and but for the evidence supplied by the typical Cambrian groups, the groups to the west of the Longmynd might have remained, to this day, in the same erroneous relations in which they were left in the "Silurian System."

In leaving this chapter of "Siluria" I cannot but express my astonishment at its want of complete and fair historical statement, and consequently of conclusive argument. It is, in fact, a one-sided adrocacy of that which is indefensible: plainly shewing, that however well informed, and armed at all points in his own Silurian country, my friend lost his strength when he wandered, unconsciously, beyond his true Silurian base. The Montgomeryshire sections, west of the Longmynd, are well deserving of study; and, classification apart, they are excellently described in the Silurian System. But when the author offers them as the mrototype of the Cambrian Series he misdates their chronological place in the geological history of our Palæozoic rocks. And if he represent them as conveying, by themselves, the most distant conception of nature's clear and grand development of the Cambrian series, he, thereby, either proves that he writes as an advocate, or that he writes on a subject he has not worked out for himself, and with which he is even now but imperfectly acquainted*.

* Two very grave errors affect my friend's reasoning in every part of the controversy. Ist, He assumes that he has a right to change his principles of nomenclature when he is dealing with his lower groups. 2ndly, That having committed a 
In the previous discussion I have been arguing at a great disadvantage; for the question, between the Cambrian and Silurian nomenclature, ultimately turns upon the establishment of the May Hill group. In missing the elimination of that group, my friend missed that which was essential to his own System; and everything he did below the May IIill group was affected by this one fundamental error, which vitiated his sections and put the whole scheme of his nomenclature (so far as regarded his lower groups) in direct antagonism with the development of nature. For his scheme, when followed out, became not only geographically monstrous, and sectionally untrue; but after the May Iill and Horderley beds had been placed (as nature had placed them) in two different Systems, the scheme became also palicontologically untrue. Enough has been stated on this subject in the previous pages of the Introduction.

It does. however, appear strange, that while writing the fourth chapter of "Siluria," published in 185t, the author should have overlooked a correction of vital consequence, made nearly two years before by Professor $1\left[^{c} \mathrm{Coy}\right.$ and myself (1852). The author of "Siluria" was present when this correction was made in a paper read before the Geological Society. He probably did not believe in our elimination of the May IIill from the Caradoe group: for it was opposed, strenuously though courteously, by the gentlemen of the Government Survey who were present. But it was adopted by four of them (including their two best palacontologists), within a period of about five months * after my paper on the May Ifill sandstone was first read.

Whatever may be the cause, the fourth chapter of "Siluria" has errors of no small magnitude (sectional or palicontological) in almost every page; and it is pretty clear, from his Appendix B, (p. 490) that the author is now aware of them; though not of their whole extent and real importance.

Formally to catalogue and discuss these mistakes would be both an invidious and a useless task; for they all arise, by direct implication, from the fact, that the author, while writing the fourth chapter of his new work, overlooked the determining facts of the whole controversy - the physical meaning of the Upper Cambrian (or Caradoc) conglomerates,

grave geological error in deternining the place of his lower groups, he is not on that account called upon to chinge his geographical nomenclature. On the contrary, that the geographical names of the Principality are to be changed, in order to bear out a nomenclature, which was, from the first, erroneous, because based upon erroneous sections. I know of nothing more anomalous in reasoning, and more gengraphically monstrous, in the history of science. This appears to me only i plain uurarnished statement of the question; in which any argument, on the grounds of priority, is left out of sight, however greatly it adds to the real truth and equity of the question.

* 'The reader of the Proccedings of the Geological Society of London is requested to attend to the dates of the papers on the May Hill Sandstone. The printing of my first paper on that subject was postponed by the Council without any satisfactory reason given to myself; and, if I am not misinformed, against the advice of the frst Referee. Meanwhile two papers on the same subject, by two gentlemen of the Government Survey, wero very properly printed without delay. The consequence was, that their papers appeared before mine, though they were read several months after it. Mine was a very short and simple statement, and ought not to have been postponed; especially as it relaterl to a new and controverted question, upon which, as the event proved, I was perfectly in the right. 
and the place and office of the May Hill Sandstone. In short, not only here, but in every part of the controversy, since it first began, he has argued on grounds which prove, that, however admirably he had worked out the physical and palicontological history of his own true Silurian groups, he had missed their true physical and palrontological base; simply because he was unacquainted with the true physical history of the older rocks of Wales. and their general discordancy of position, when brought into contact with the orerlying Silurian rocks*.

Let me. however, in drawing this Introduction to a close, distinctly express my dissent from such assertions as the following: "That the Upper Silurian rocks are brought hy conformalle folds into proximity with the Llaudeilo formation of South Wales" (p. 79);"that the typical formation of the Caradoc Sandstone gradually passes into the Wenlock and Ludlow rocks" (p. \&\%);- "that the typical sandstone of Caer Caradoc dips erev"yntere conformably under the Wenlock shale" (p. 83);- "that the operations which, in some places, have produced a break between Llandeilo and Caradoc formations, had no influence nhatever in destroying the races of animals" which belonged to the old period (p. 88); " "that the black Malvernian schists (with Olenus, \&c.) may be as old even as the Lingula beds of North Wales" (p. 92); - " that in some tracts we must expect to meet with links, lithologieal and zoological, which bind together the inferior and superior divisions of the System," or in other words, the two Systems Cambrian and Silurian (p. 97). I might casily double the list of passages to which I could take an objection: but they all, or nearly all, merge under the one fundamental error which virtually appears to be admitted in Appendix B (p. 490). Now I had, as above stated, corrected this fundamental error of the "System" nearly two years before the publication of "Siluria." Not to notice this correction in Chapter IV, or not to cancel the errors, if Chapter IV. was, in fact, written before 1852 , was not to deal well with the public. It was virtually teaching the student to projulye " question, in long debate, before the most important facts of evidence had been

* In illustration of what is abore stated, I give in this note an example of that strarge spirit of adrocacy which runs through so many pages of "Siluria." At p. 72 the author, while describing the section of Noedd-Grüg, writes as follows, "It is gratifying to me to obserre that this diagram (from the Government Surrey) is quite in accordance with my old, published, coloured section across the same tract." (Sil. Syst. p. 352, and Pl. XXXIV. fig. 3.) Would not any plain, unprejudiced reader conclude, from these words, that the interpretation of this section, by the Government Survey, was quite in accordance with the previous interpretation of the same section in the Silurian System? Yet the two interpretitions are very widely apart. In the Silurian section the descending order is as follows: (1) Old Red Sandstone, (2) Upper Silurian Rocks, (3) Caradoc Sandstone of Noedd-Grüg, ( $₫$ ) Llandeilo flags, passing into Cambrian rocks, (5) Cambrian rocks. The first three subdivisions of the section, thus interpreted, may be in a right order; though I believe there is no true Caradoc Sandstone at Noedd-Grüg. It is probably May Hill Sandstone. There is no Llandeilo flag whatsnever (in the sense in which the words were used in 1839) answering to group (4); consequently there is no passage (like that described) into Cambrian rocks. If the typical Llandeilo flag of the Towy exist at all in the line of the section, it must be sought for, about five thousand feet further down, anong beds not brought out in the section. Had the author succeeded in interpreting this section correctly, he would in so doing hare destroyed his own order of superposition in the valley of the Towy-he would have destroyed the order of the fundamental and typical groups from which the Lower Silurian nomenclature derired its existence. The Government Surreyors saw this consequence, and got rid of it by a novel process of development-by designating the great Upper Cambrian series of South Wales under the name of cne mistaken Silurian group-(Llandeilo flag). And this is to pass as an improrement upon, or a correction of, my Cambrian nomeuclature! 
submitted to him. In like manner, I think I could demonstrate that some of the pictorial sections, adduced by the author as critical evidence in confirmation of his general views of classification, are erroncously interpreted; and that, when rightly interpreted, they make directly against himself. But while I forbear any further discussion on this point, I confidently affirm - that I have not yet seen so much as one single unambiguous section in which we rise from the true Cambrian to the true Silurian rocks (using the words Cambrian and Silurian in the sense given to them in the Tabular View) without a discordant junction, or a discordant succession of the contiguous groups.

Two extracts more and I will close this Introduction. (1) "The region of Siluria, as geologists now admit, afforded the key by which the fossiliferous strata of the North-western tracts of England (i.e. the whole cluster of the Lake Mountains) were brought into order, and had their right places assigned to them*" On this point I have a right to speak with some confidence. The statement is unintentionally, but not less directly, contrary to fact. There is no great difficulty in the sections of the Lake district so far as regards superposition: and I first correctly identified the Coniston limestone with that of Bala, and therefore (when the nomenclature had been agreed upon) called it Cambrian. About the highest groups there was neither sectional nor paleontological difficulty-they were obviously on the parallel of the Upper Silurian rocks. But how were the upper and lower groups to be united in a continuous section? The Silurian key was first applied to this purpose in 1842 and it led me wrong; by leading me to regard the Coniston limestone as Caradoc sandstone: and it led me wrong for this one reason:- viz. because I then believed that the so-called Lower Silurian groups had been placed correctly on the general scale, by the author of the "Silurian Systemt." The Silurian key led me wrong; as Mr Sharpe, and Mr Bowman, and the author of the "Silurian System" himself, had been led wrong by it, in their interpretation of some of the Berwyn Sections. We were all inevitably led wrong while ignorant of the true place of the May IIill Sandstone; while believing in the truth of the Lower Silurian groups; and while we were deceived, in certain sections, by a seemingly concordant succession between the highest Cambrian and the lowest Silurian rocks. But the error of interpretation, so far as regarded the Cumbrian Mountains, had been corrected by myself, in a paper read before the Geological Society, (and afterwards printed in their Quarterly Journal) full two years before the publication of "Siluria." When the Silurian key was rejected, the Coniston limestone again found its right place as a Cambrian rock: and after the establishment of the May IIill Sandstone, the "Coniston grits" (which had long been regarded by myself as a puzzling and anomalous group) found their natural place as the equivalents of the May Hill Sandstone. These facts were laid before the Geological Society in 1852, and were published by myself, in detail, in a separate work ${ }_{+}$. Is it possible that

* Siluria, Chap. vit. p. 146.

+ Letters on the Lake District (J. Hudson, Kendal). They were written in the spring of 1S42, before I bad rerisited North Wales, after my prerious visit of 1834 .

F Third Edition of the Letters on the Lake District, 1853. 
they could be altogether unknown to the author of "Siluria" in 1854? If they were known, he had unquestionably no right to publish such a sentence as the one last quoted. The Silurian key did not help us to unlock a single geological mystery in the north of England: and when he concludes (p. 148) that my recent observations prove that the Coniston grits are the equivalents of the Caradoc sandstone, he misrepresents me; and states, unconsciously, what is contrary to fact. What I do now state is, that the Coniston grits are probahly the equivalents of May Ilill Sandstone; because they are the mechanical deposits which mark a great physical, as well as a great palrontological, change*.

(2) The next and concluding extract ("Siluria," p. 147,) is as follows. "All we can safely say is, that, reasoning from the Graptolites, the whole (Sliddaw Slate) is a Lower. Silurian Series, which is metamorphosed and obscured by igneous irruptions in its lower parts, and exhibits beneath it no clear representative whatever of the Longmynd or bottom rocks."

I protest argainst this kind of writing, and this kind of reasoning from a single fossil genus. The great group to which I have given (after my friend Mr Jonathan Otley) the name of Skiddaw Slate, is of vast thickness and great complexity of structure; and it certainly admits of thrce or four good physical subdivisions. It rises into some of the highest Cumbrian mountains; and is, I believe, the most ancient, certainly is one of the most remarkable of the physical groups of our ohler Paleozoic Series. If we succumb to the Silurian syllogism (supra, p. lvi.) there is an end of all debate. Est Jupiter quodcunque vides, is a dogma which shews us a royal road to a grand conclusion of nomenclature. The Skidelaw Slate contains Graptolites; therefore the Skiddaw Slate is "a Lower Silurian Series!"

To describe the Skiddaw Slate in full detail would require a paper as long as this Introduction: but I may suljoin, in this place, a few facts in addition to those given in the Tabular View (supra, p. xxi.)

(1) Immediately over the central Granite of Skiddaw Forest we have a very complicated metamorphic group, superior perhaps in importance to any other metamorphic group in South Britain. It has mineral veins which, though apparently of a much older epoch, present very interesting analogies to the mineral veins of Cornwall. This subgroup passes, almost insensibly, into the ordinary lower Skiddaw Slate, through the intervention of a chiastolite rock, and a porphyritic chiastolite Slate. In this respect, also, it presents good analogies to certain rare metamorphic rocks of Cornwall: but in that county, schorl, rather than chiastolite, is the mineral which more frequently seems to mark the passage from the Granite to the Slate.

(2) Next, in ascending order, is the Lower Skiddaw Slate. It is of various colours;

* Thus it is stated above (p. xxii), that if all the Cumbrian fossils below the Coniston grits, and all the fossils in and above the same grits (to the Upper Ludlow rocks inclusive) be formed into two groups, the two groups thus formed do not contain much more than three per cent. of common species. 
generally dark grey; more rarely of a reddish tinge; sometimes much penetrated by quartz veins; does not effervesce with acids; alternates with coarser gritty bands, which are, however, quite subordinate; is of very great thickness, forming the larger mass of Skiddaw and Saddleback, \&c.; so far as is yet known, does not contain a trace of fossils, either vegetable or animal; presents the closest analogies with the rocks of the Longmynd; but as a type is perhaps more perfect than those rocks; inasmuch as it has a mineral, though not a palæontological, base.

(3) Next in ascending order is a great group, occupying the high mountains between Keswick and Buttermere, in many parts of which the gritty bands begin to predominate. Its more slaty bands are, in structure, analogous to the slates of the preceding group. So far as it is yet known it is without a trace of fossils. Some parts of it, if exposed to metamorphic action, would pass into quartz rock.

(4) Lastly, comes a higher group, also of great thickness; obscurely separated from the preceding (No. 3); and overlaid, in some places I believe discordantly, by the trappean conglomerates, chloritic slates, \&c., which form the great central division of the older Cumbrian Series. In this fourth group are found, occasionally, more earthy dark-coloured slates, which contain some rare examples of Fucoids and Graptolites. It also contains traces of carbonaceous matter; which seems to have been partly sublimated into certain veins of the green slate and porphyry, and to have contributed to the formation of the blacklead mines of Borrowdale.

I have never examined the Skiddaw Slates since 1824; but my opponent in nomenclature has not examined them at all. And when he pronounces the whole collective group to be Silurian, from the existence of some rare Graptolites in the highest subgroup, he not only deserts the principles of sound nomenclature, but he mistalies, I think, his own position as an original observer among the older rocks of England. Here, as he had done before in Wales, he strives to clench the nomenclature before he has learnt, by a study in the field, to comprehend the characters of the physical groups. Till this is done, it is idle to discuss points of nomenclature while we are dealing with rocks of such antiquity as the Skiddaw Slate.

Who can fix the date of the bottom rocks of the Longmynd? They have neither a mineral, nor a palæontological base to rest upon. Under these circumstances it is ubviously impossible to decide whether the oldest Slates of the Longmynd be older or newer than the oldest Skiddaw Slates. The former have no base that I have ever seen or heard of. The latter are arrested by the Granite. Under these conditions it is a very safe asscrtion to make- "that the Skiddaw Slate does not exhibit beneath it any clear representative whatever of the Longmynd or bottom rocks." Such a statement is a truism which tells us nothing.

Should any one, after the above description of the facts, (and before they are met by some better interpretation of the older groups of Cumberland than I have given in the Tabular View), choose to call all the subgroups of the Skiddaw Slate, Silurian; I am 
incapable of arguing with him. For in that case we must differ in those first principles of inductive reasoning, without an agreement in which all rational argument is impossible.

To conclude the whole discussion:-the author of "Siluria" has not improved, but greatly weakened, his own position by his new Volume. While he argued from fossils only, he might keep out of sight the positive mistalies of his carly sections; and he might contend, with some show of reason, that the fossiliferous Cambrian strata must be called Silurian because they contained the fossils he had described and called Silurian. But he was well aware that the argument thus stated implied a desertion of his first principles of nomenclature : and he has at length attempted to vindicate his scheme of nomenclature and classification by the help of sections-by physical as well as by fossil evidence. With something which appears to me like a blinking of the facts, and like a deception of the realer by a palpable sophism, he has put forth a section as a Cambrian mototype, though entitled to that name neither geolorically nor historically. And because he had (by a palpable inconsistency of nomenclature) called some of its older groups Silurian; therefore-discarding his original Silurian types-the older Cambrian equivalents of such groups must also become Silurian! Thus, whether he argues on palieontological or physical grounds, he proceeds, at once and despotically, to turn his own mistakes to positive profit. But this can never last, while we have a true geographical nomenclature, honestly worked out by the help of true sections, and a reel prototype, which deserves its name physically as well as chronologically. My classification and nomenclature are true, if there be truth and consistency in the principles of Geolugy. They have the right of historical priority, and ought never to have been tampered with; and when the controversy began they were tampered with in great ignorance of the real structure of the older Palæozoic rocks of ITales, and consequently of the real merits of the question in debate. There is, now, I repeat, no legitimate ground of contest between Cambria and Siluria; they are separated from one another by Natures own boundary line: and the attempt to confound them is only the vindication of a preposterous nrong by a pretended right of usurpation. The republic of Science refuses, and to write without a figure-which is far better-common sense and reason refuse, to sanction this usurpation.

I subjoin the following note to introduce some references which ought to have been made in the preceding pages of the Introduction*.

\footnotetext{
* The reader is requested to bear in mird that the original Silurian descending order was as follows: Ludlow, Wenlock, Caradoc, and Llandeilo; below which came the Cambrian rocks. On this scheme, all the typical Silurian Scetions, the Silurian nomenclature, and the Silurian map, were constructed: and all my collective upper Cambrian groups (whether in Merionethshire, or, spread out in multitudinous undulations, in Radnorshire and Cacmarthenshire) were placed by the author of the "Silurian System" below the Llandeilo group. Thero was no douht ever expressed by him as to the reality of this order. Nor was it supposed that there was any very great break of continuity in the descending sections: for he affirmed that in several places there was an ascending passage from the highest upper Cambrian strata into the beds at the base of the Llandeilo group ("Silurian System," p. $35 \%$ to p. 363). Such was the scheme-adopted by its author, before I saw the typical Silurian sections in 1834 , formally repeated in 1836 , and more formally published and vindicated in 1839.

In confirmation of what has been just stated, I will now appeal to some passages in the "Silurian Srstem" which I had not the means of quoting when the latter pages of the Introduction were sent to the press. At p. 356 are the following words. "The Grüg quarries (about three-quarters of a mile north-west of Llandeilo) exbibit the oldest calca-
} 
reous beds of this formation (the 'Llandeilo flags') as they lio to the west and north-west of the flags; and the same nodular limestones occur at Llangathen and Grongar Hills in similar positions, rising from beneath the younger strata, and graduating on their western flanks into the rotten slates and greywacke grits of the Inferior or Cambrian System, in which (in this district) all traces of fossils are lost."

In the next page (357) the Author describes a range of beds near the hamlet of Rhew-yl-adar, "as the best examples in Caermarthenshire where this formation (Llandeilo flag) passes into strata of the Inferior System." In the same paragraph, after describing certain sandy beds, which he supposes to be at the base of the Llandeilo flags; he adds, that there is "an imperceptible nassage from these sandy beds into still more ancient strata void of fossils: viz. the black schists, which, in common with Professor Sedgwick; I consider the link connecting the Cambrian and Silurian Systems. Similar successions are observablo near Llan-rhaidr in Denbighshire (p. 307), and in Pembrokeshire." Again (p. 35s), he considers that the fossiliferous beds, to the west of Noedd-Grüg, "occupy the base of the Llandeilo formation:" and in a previous page (352) he had stated that these strata of Noedd-Grïg "constituted the most interesting tract of Caermarthenshire; since they exhibit a passage on the one side into the Upper Siturian Rocks, and on the other into the Upper Cambrian." $\Lambda$ gain, he describes the "Cambrian rocks" between Llandovery and Llampeter, and between St Clears and Newcastle Emlyn, without expressing any doubt as to the general order of superposition-any misgiring as to the fact that his Llandeilo group was superior to the rocks which he very properly had called Cambrian (p. 361).

As a plain matter of fact (first, I believe, brought to light by the Gorernment Survey), every section, above alluded to, was misinterpreted; the great groups were turned upside down; the Cambrian groups were not below, but above, the Llandeilo flags. I had no share, whatsoever, in the origination of this fatal mistake; and (with the exception of Noedd-Grüg) I never so much as saw (in 1834) any one of the critical sections alluded to above. I never gave any opinion about the black schists and beds of passage (between the Cambrian and Silurian rocks of South Wales), or knew of their existence from any observations of my own. Nay, as a general rule, I did not believe in such beds of passage; but rather thought (on the analogy of North Wales) that the passage from Cambrian to Silurian rocks must be through the intervention of great dislocations and unconformable junctions. As for the errors of the Noedd-Grüg sections, the supposed downward passage of tho beds into the Upper Cambrian rocks, and the supposition that the fossiliferous beds at the west side of the ridge "occupy the base of the Llandeilo formation," I had no share in these original mistakes of interpretation. I did (in 1834) visit the summit of Noedd-Grüg; but I saw no beds of passage, nor did I, on the day of that risit, accompany my friend to those western fossiliferous beds which he (erroneously) regaried as "the base of the Llandeilo formation."

For the succession of the groups near Llan-rhaidr, alluded to abore, described in the Silurian System, p. 307 , and delineated Plate XXXII. fig. 9, I $\mathrm{mm}$ in part responsible. The S.S.E. end of the section is cxclusively by $\mathbf{M}$.urchison; the central part, from the vale of Meifod to the Tanat, was copied by him from my note-book of 1832 . For the general position of the beds up to Craig-y-rlyn, I am in part responsible; as we traversed that portion of the section together. For the general position and dip of the beds which rise into the eastera flank of the Berwyn mountains he is alone responsible. There is, in fact, an enormous down-cast fault (not represented in his section), a little beyond Craig-y-glyn; and the prevailing dip of the higher Berwyns (as I knew well from my own sections of 1832) is the very reverse of that which is given in the Plate. The beds in this part of the higher Berwyns have a westerly dip; which carries them, on the west side of the chain, under the May Hill Sandstone and the Bala limestone. Such is the section (Pl. XXXII. fig. 9).

There is one calcareous band which is repeated in the undulations north of Meifod; and there is one calcareous band (not I think four, as represented in the Plate) at Craig-y-glyn. The question proposed by myself was this. Do the calcareous bands belong to two, or to ono group? My friend decided (erroneously, as is now, I believe, admitted) that between Meifod and Craig-y-glyn there were two groups-Caradoe and Llandeilo. But if this were true, and if the typical Liandeilo sections were also true, the Meifod and Craig-y-glyn beds must be, geologically, several thousand feet above tho Bali limestone. This seemed an unnatural conclusion, both physically and palsontologically. For the natural conelusion was that the Bala, Meifod, and Craig-y-glyn beds must be very nearly on the samo horizon. And had the Berwyn beds been in the position erroneously represented in the Silurian Section (Plate XXXII. fig. 9), (and without the intervention of the great down-cast fault on their north-restern side), the conclusion would not merely hare been probable and natural, but absolutely inevitable. I did not conceal this difficulty; but plainly laid it before my friend whon we made our traverse over the Berwyn chain to the Bala limestone: and so far from misleading him (in 1834) as to his typical Lower Silurian sections, and inducing him to believe in their truth "on my authority," I shewed him very good reasons for suspecting that they might be fundamentally erroneous. But during the five suceeding years he failed to follow out the conclusions to which the Berwyn sections seemod very naturally to poirt; only because he believed in the truth of his Llandeilo sections. For if the calcareous and fossiliferous groups on the east side of the Berwyns were the equivalents of the Llandeilo rocks, and were also the equivalents of the Bala limestone, it then followed, on evidence not short of demonstration, that the Llandeilo rocks had been put in a false relation to the Cambrian groups of Caermarthenshire and Radnorshire. This is the most remarkable instance, in the history of British. Palxozoic Geology, of the manner in which the progress of truth may be arrested by an erroneous classification, and a premature nomenclature. 
When Dr Fitton's Review of the Silurian System appeared in 1841, the author of the System had not, I think, any perecption of the fact that his lower groups were in a false relation to the Upper Cambrian rocks: and one or two years after the publication of the Rericw, when a controversy first arose between the author of the Silurian System and myself, he appealed to his original typical section-apparently at that time believing that his original order of superposition was true. His order was, Wenlock, Caradoc, Llandeilo, Cambrian; and as no general discordancy of position was known or acknowledged, the word Cambrian meant Upper Cambrian. The caso of the Longmynd formed the only exception to this rule: for on the south-east side of that mountain-ridge there was an obriously discordant junction; and there the (exceptional) order was Wenlock, Caradoc, Longmynd rock.

The order given in the Review is, at any rate, only a repetition of the order giren in the typical sections and map of the Silurian System. Hence it is, I think, absolutely certain that when the anthor of the Silurian System described certain groups, thrown off from the older rocks of Pembrokeshire and from the north-western flank of the Longmynd, as Silurian, he believed them to be superior to the Upper Cambrian groups of Caernarvonshire, Radnorshire, and Merionethshire. There is no escape from this conclusion; unless we concede to him the liberty of using such words as Llandeilo flag and Caradoc Sandstone, in one sense in the valley of the Towy, and in another in Pembrokeshire; in one sense in South Wales, in another in Shropshire - of using, in short, a palpable sophism. And if it appeared, in the progress of discovery, that some of the groups he had called Silurian were of a greater age than he had supposed, and that some others were the representatives of very old Cambrian strata; such a discovery would not prove that my Cambrian types were wrong; but would assuredly prove, that the author of the Silurian System had misunderstood some of his own sections, and given names to their groups which wero inconsistent with the fundamental scheme of his own nomenclature.

His first afterthought was to secure his nomenclature, and cover the mistakes of his typical sections, by absorbing Cambria into Siluria. This afterthought had howerer nothing to do with any mistake or inconsistency in the interpretation of the sections thrown off' from the north-western flank of the Longmynd-such, for example, as the Shelre, Stiperstone, and Corndon Sections. To make them the prototype of Cambria was a much more recent afterthought: and to apply the term prototype to such sections was surely a very strange and imprudent abuse of language.

When I began this note, I intended to examine critically the sections to which I hare last alluded. But I have abandoned this intention, in the fear that the note might become too long; and still more in the fear that I might, on some points of detail, misrepresent the author of the sections; for they are complicated and difficult, and I only know them at second-hand. Hence I have concluded in a general statement, which I think unquestionably true, and therefore unassailable.

I may, however, just appeal to the sections of the Silurian System at Plate XXXI, fig. 4, and Plate XXXII. fig. I. (1) About the Longmynd rocks there never was any doubt. (2) As to the rocks between the Longmynd and the Stiperstones, they are also rocks of great antiquity; but they are no type of Cambria; nor were they given as such, or understood as such, by the author. (3) The application of the term Caradoc to the Stiperstones, and some beds above it, was probably a mistake. (4) The ascending sections are cut off unconformably by the overlying and discordant Silurian rocks. To call these sections types of Cambria is a strange imprudence; when it is virtually admitted that they become intelligible by help of other and truer Cambrian types; and to call them prototypes is a grave historical misstatement. The sections have however (especially when studied along with the map of "Siluria") another use:-they shew the absolute necessity of a truo physical knowledge before any good classification can be attempted; for in no part of Wales is the great physical factthat the true Silurian rocks are generally in a position discordant to the true Cambrian-more apparent than it is in the Longmynd sections. 


\section{SUPPLEMENT TO THE INTRODUCTION.}

Trinity College, July, 1855.

AFter a very long delay the Introduction has passed through the press, and the whole of it is now before me. It was commenced late in the October Term of 1854, and was continued without delay to the end of the Tabular View (p. xxvi), when I became incapable, from a long illness, of making any further progress with it. At the beginning of March (supra, note to p. xxvi) I resumed my task, which was painfully carried forward through about thirty additional printed pages, when I was again reluctantly compelled to suspend it. The last four or five sheets have, in consequence, been printed from MSS. sent, from time to time, from Norwich (during my Cathedral residence of May and June), when I was without any works of reference except a copy of "Siluria." I fear, therefore, that some portions of the Introduction are less perfect than they ought to be, and that some useful, and perhaps needful, references may have been omitted $\%$ Thus, e.g., after glancing the eye over the Introduction, I found that I had quoted (p. Ixxii) an assertion, made by Mr D. Sharpe in 1842, without giving, at the same time, a proper reference to his paper. The sentence quoted is found in the "Proceedings of the Geological Society of London" Vol. IV. p. 10.

An Essay, written and printed during the lassitude of a long-continued illness, many times interupted, and at length finished under a pressure of engagements quite foreign to geology, is inevitably wanting in a true unity of plan, and I have to ask the reader's indulgence for some clumsy verbal repetitions which ought to have been avoided; and in some of the more lengthened arguments I have so far repeated myself, that I appear while writing at Norwich to have partly forgotten what had been, some months before, written at Cambridge. I have also to request the reader's indulgence for some verbal mistakes, which will be corrected in the list of erota, when the mistakes materially affect the meaning of the text.

So far as the Introduction is historical it is, I trust, literally true. So far as it is argumentative it is, no doubt, the plea of one who is his own adrocate; but it is, at the same time, the plea of one who is acting on the defensive, and who firmly believes that he is vindicating the cause of common justice and common sense, as well as of scientific trutl.

I never abandoned my Cambrian nomenclature after I had adopted it; but I never refused to modify it so that it might meet the requirements of an advancing science. That it has been misunderstood, misrepresented, and very ignorantly tampered with, is as certain as any fict in the past history of Geology. From first to last, the classification and nomenclature, given in this Introduction, have been followed out on the same principles on which English geologists have established the classification and nomenclature of all great collective groups,-whether Primary, Secondary, or Tertiary. On the contrary, the extension of the

\footnotetext{
* Some of the references, here alluded to, have now been supplied in tho note appended to the Introduction (p. lxxצv).
} 
Silurian nomenclature, beyond its true base, was commenced, and has been followed out, by the abandonment of the very principles on which every true Silurian group was first established and became accepted by geologists. Itence I confidently affirm, that so far as there is any contest between my opponent and myself, it is by no means a ruestion of mere expediency about the retention of certain names; but it is a question of principle - a contest for a Cambrian nomenclature which is geographically, historically, and palæontologi(ally right, against another nomenclature which, on all these grounds, is positively wrong.

I think that I have succeeded, in the previous pages, in pointing out the origin of the erroneous nomenclature adopted in 1843 by Sir R. I. Murchison; and from him, unfortunately, by the gentlemen of the Government Survey. I say unfortunately, because their adopted nomenclature led them into the mistake (the greatest they could have committed in the actual state of our knowledge of the Palrozoic groups) of confounding the May Ilill Sandstone with the Cambrian beds of Horderley, and of uniting them together as a (so-called) "Middle Silurian group." Be this as it may, it is at least true that the original groups and sections, from which the Lower Silurian nomenclature was derived. turned out to be erroneous. The first mistake of nomenclature was in degrading the "May Ilill rock" from its true place at the base of the Silurian System, and substituting for it the Caradoc (or IIorderley) sandstone. The "Nay IIill rock" of Murchison I have restored to its right place and office. The Caradoc sandstone is made up of two discordant groups, belonging (if we use the Silurian language) to two distinct systems. The grand mistake, however, was in placing the Llandeilo Flag above my Upper Cambrian group, which was based on the Bala limestone. If the Lower Silurian groups were physically and sectionally wrong, the nomenclature derived from them could not be right. How, then, was it to be amended, or to be so amplified as to fall in with the true physical development of the Cambrian series? Mr Sharpe led the way in the attempted solution of the difficulty; and in 1842 he instructed the Geological Society that this grand error of the Lower Silurian sections " had been adopted by Mr Murchison on the authority of Professor sedgwick"-that all the older fossil-bearing rocks of Wales were Caradoc santstone-and that, collectively, they were not thicker than Caradoc and Llandeilo formations of the published Silurian Sections!

Had all this been true, I should have no true ground for complaint of injurious treatment on the part of the Geological Society, or of injustice on the part of Sir R. I. Murchison. I have little doubt but from that year, and for some years afterwards, a majority of those who formed the Council of the Geological Society believed that a great blunder had been committed, and that I had been the blunderer. The statement of MIr D. Sharpe was not however historically true. It was unintentionally, but not on that account the less lirectly, contrary to fact; and only proved how imperfectly he had become acquainted with the physical structure of Wales, and with the previous history of the Society.

The unintentional historical misstatement was not by any means set right, as it ought to have been, hy the author of the "Silurian System." On the contrary, he silently turned it to his own advantage; and after some other statements on his own part, upon which I have 
been compelled to make an unfavourable comment, he cleared away all futurc difficulties by incorporating Cambria in Siluria! Nor is this all. The original (unintentional) misstatement of Mr D. Sharpe is reaffirmed, or, to say the least, is insinuated in the new work called "Siluria."

This is the one point I wish to reopen in this Supplement; and before I leave the controversy, I trust for ever, I again call on Sir R. I. Murchison formally to repudiate the misstatement; and at length to acknowledge, however tardily, that I never led him wrong, as to his Lower Silurian groups, or had the means of doing so. The real mistake I made (along with many other English geologists) was, in believing, for several years, that the "Lower Silurian" sections were true, on the authority of their author. To make me, on that account, a sharer in his original mistakes, would be to the last degree ungenerous. To affirm that any one of them originated in suggestions of mine would be positively untrue.

The controversial and egotistical style of the Introduction may, perhaps, offend the taste of some of my readers; but its defensive character is, I trust, at once an explanation and apology for its apparent egotism. I certainly never sat down to boast of my long-continued labours among the Palæozoic rocks of Eugland. But I have a right to state what I believe the truth, and to affirm that I have pursued it honestly; that I have shumned premature generalizations, as the very clogs of science, and sometimes the mere masks of positive error; that I believe the tabular analysis of the whole Cambrian Series to be true, and on that account the groundwork of a good and consistent nomenclature.

Some readers may perhaps think that I must needs be in the wrong because I have been opposed by the Council of the Geological Society. But in the controversies of an advancing science, is it not true that the majority is rery often in the wrong? It would be a sorry thing if physical judgments, like political, were to be settled by counting heads. There is not one member of the Council who, so far as English evidence is concerned, has sifted the question to the bottom, and examined it in all its bearings. Some of them have dogmatized very broadly on very narrow and erroncous knowledge. Some of them have now an admirable, but at the same time a one-sided knonledge, respecting our older Palrozoic rocks: but they began their nomenclature before they knew the fundamental facts on which it ought to rest. Others have adopted their nomenclature as a means of classifying their fossils; without knowing, or perhaps much caring about, its evidence; and to such persons names are everything. There are some again who profess to be no judges in the matter, and therefore have followed the lead of their associates.

Far be it from me to speak disrespectfully of the Geological Society; but plain truth ought never to be offensive to the ears of truth-loving men. It was, in its carly days, composed of robust, joyous, and independent spirits, who toiled well in the field, and who did battle and cuffed opinions with much spirit and great good will. For they had one great ohject before them-the promotion of true knowledge - and not one of them was deeply committed to any system of opinions. But the progress of geological knowledge, along with 
much good, brought some inevitable evils in its train. Men became committed to opinions: and at length hardly any broad question could be discussed without coming into collision with some published book-English or Foreign; or without running counter (it might be to the supposed interests of some scientific body. Hence, by inevitable necessity, the discussions of the Geological Society, while they improved in variety and accuracy of knowledge. became less joyous, less liberal, and less truth-loving in their spirit. To prevent the risk of mischief, the Council seem now resolved to wage war upon all discussions and canrassing of opinions, on points which they themselves wish to regurd as settled. Such a resolution, if carried out, might abate one evil: but it would introduce another far more deadly. For true physical progress is hardly ever made without previous discussion: and often is but the gradual and legitimate triumph of one, over many conflicting opinions.

I cannot be accused of a very precocious spirit of controversy. Perhaps I deserve blame for a fault of a directly opposite spirit. When at length, in 1852, I vindicated. in a Paper read before the Geological Society, my classification and nomenclature of the older Palæozoic rocks, more formally than I had ever done before, my statements were received with downright mockery; and, in the discussion that followed, offensive doggerel took the place of solid argument. In due time, however, the Paper, after going through every previous formality, was printed and mublished in the Quarterly Journal of the Geological Society. What then followed? The Council, at its next meeting, resolved (I believe unanimously) that the number of the Journal should be withdrawn from circulation, till the offending Paper had been struck out of it! This was a useless as well as an ignorant and bitter insult. Too many eopies of the Paper had been sold to admit of its suppression by any decree of the Council. They had a full right to put their previous reto against the printing of the Paper, but they had not done so. And what was the Paper that provoked this unprecedented insult? If I called it "a clear and temperate vindication of my own labours and the justness of my nomenclature;" and were I to add "that so long as the Geologists of Furope employ a geographical nomenclature I have the right of a real priority in thought and research and the claims of a sound philosophy in my inductions, and am entitled to erect the Cambrian rocks (as I have done in the offending Paper) into an independent series equal in value to the Silurian;"-I might, in using such words, be accused of egregious self-praise; but they are not my own words-they are the very words which express the unprejudiced opinion of one of the greatest of living Geologists: but he was not a member of the Council, nor is he a native of this country.

When again, in the autumn of 1852, I brought before the Society, along with my friend $\mathrm{NI}^{\circ} \mathrm{Coy}$, a short and plain statement of facts respecting a group to which we applied the old name of May Hill Sandstone-shewing its distinction from the lower group (Caradoc with which it had been confounded-the Paper was opposed by all who took part in the discussion; but they all allowed the importance of the Paper if our statements were correct. We only were responsible for the facts; and the Paper (from the critical nature of its subject ought to have been printed without any unnecessary delay. But it came in collision with 
opinions which the Council wished to regard as settled. It was referred, and (after a single correction, adopted without any delay whatever) it received the sanction of the Referee. But this was not enough. It was again referred; and was at length published anong the postponed matter of the volume: but not till other persons, working in the same field, had made a correction identical with that of our Paper. But for the previous insult, I should have considered this delay as accidental, and counted it as nothing. There was, however, no accident in the case.

For a refusal of the Council (during 1853) to publish my next Paper, continuing the same subject, I make no complaint. Part of it was in a controversial form; part of it was only a statement of plain facts; and they had a perfect right to refuse its publication. It is now printed in the Philosophical Magazine; and, be it good or bad, it is a part of the common stock of Geology. After these statements let the reader judge for himself whether I am called upon to bow before the opinion of the Council of the Geological Society on any point of Palæozoic Geology, which they may have dogmatically pronounced as settled.

During many years I was a frequent, I might almost say a constant. attendant on the joyous mectings of the Geological Society, and a member of the Council. Among the members were some of my most honoured and cherished friends; and while boasting of these meetings and of the generous, unsclfish, and truth-loving spirit that glowed throughout the whole body, I little dreamt that I should ever have to complain of an "ignorant and bitter insult" from the Council. But, strange though it be to tell, the words are literally true.

Time has produced its inevitable and melancholy changes; and for the two last years I have not been present at a single meeting of the Geological Society. Not because I wished to be away, or ever feared to do battle for what I thought the truth, against whatever seeming odds; but simply because I was unable to attend the meetings. In a preceding page I have alluded to the painful news of the death of Professor Forbes: and during the passage of the latter shects of this Introduction through the press, I learnt, with deep sorrow, that my old and much valued friends, Mr Greenough and Sir Henry De la Beche, were no longer to be counted among the living members of the Geological Society. The former was its founder and munificent patron: and that he was a very hard and very early labourer in the field, his Geological Map of England bears ample testimony. IIis knowledge was wide and accurate, and the scientific materials he had collected, in illustration of Physical Geography and Geology, were absolutely unrivalled. Although his severe field-work had for some vears been interrupted by decaying strength, his friends had good hopes that he might go on with a task congenial to the lahours of his previous life, and become the scientific historian of Geological discovery. So far as regards the future, all such hopes, alas! are gone.

Sir IIenry De la Beche was a friend of thirty-five years' standing. That he was an unflinching and successful workman so long as his strength lasted - that he wrote many original memoirs of great value-that he published several works of great practical usethat he had an honoured name amoug those who belong to the early and rising history of Einglish Geology:-these are facts so notorious that it would be impertinent to dwell 
upon them. But in one respect he stood without a rival. To his good hopes, untiring zeal, and prospective wisdom, we owe the first establishment of the Museum of Practical Geology; and to his administrative skill, we owe its admirable organization. To him we owe the Govermment Geological Survey; and every new work done, in our days or in times to come, by that great staff of scientific labourers, will be a fresh tribute to the memory of Sir Henry De la Beche, and will add a fresh decoration to his monument.

So far I have been addressing the general reader. The few remaining sentences of this Supplement are addressed to the Members of the University of Cambridge, In addition to the old cabinets of Dr Woodward we have a noble collection in our Museum, formed partly by purchase from the University funds,-partly by the gifts of our academical friends, and partly by the labours of my own hands, continued year after year so long as my health and strength endured. The valuable collection of recent shells, and all the Palaontological collections,-English and Foreign, Secondary and Tertiary, - have been put in a good, approximate arrangement by Professor $\mathrm{M}^{\mathrm{c}} \mathrm{Coy} \%$. His largest and finished labour has been bestowed on the Palxozoic series described in this volume, which is at length completed by the publication of a Third Fasciculus. Of the extent and value of this series the reader may now form his own judgment.

The publication of this volume I regard with feelings of great and natural interest, as a goodly addition to the stores of English Palsozoic Geology; and as conferring, through the labours of my friend $\mathrm{IC}^{\mathrm{C}} \mathrm{Cy}$, a vast additional value on a public Collection brought together during the years I have filled the Woodwardian chair.

For a quarter of a century, after my appointment to the geological chair, we had no room adequate to the reception of the additions made year by year to our Collection. Hence, all but very limited arrangements were necessarily suspended; and when our new Museum was built, the accumulation of unarranged materials was enormous. And even now, after all the labours of $\mathrm{M}^{\mathrm{c}} \mathrm{Coy}$, great and I think valuable collections (some purely mineralogical, some volcanic, some metamorphic, many of a mixed nature, and none purely palicontological) remain unarranged, or in a state of such imperfect arrangement as makes them of comparatively small value to the geological student.-The infirmities of advancing years, an increasing imperfection of sight, and the frequent interruptions of bad health, make me despair of personally finishing the work that still remains to be done in our Museum. I therefore invite such younger members of the University as take an interest in natural science to assist me in this task. Though, at first, it might seem dry and perhaps repulsive, it would increase in interest as it advanced, and would not be without its share of intellectual profit; and assuredly, if carried out, would greatly contribute to the value of our Collection and to the honour of the University.

* I am happy, in this place, to express my own thanks, and those of the University of Cambridge, to Professor H. Rogers, of the United States, and to the Rev. W. B. Clarke, of Sidney, New South Wales, for very valuable Palæontological collections presented by them to our Museum. The collection of recent shells was a great addition to our Museum, presented by H. J. Bronke, Esq., F.R.S. - a distinguished labourer in kindred fields of science. 


\section{P. S. July $19,1855$.}

ON returning to Cambridge before the expiration of the first week in July I rearl orer the printed Introduction; and as soon afterwards as my engagements permitted I affixed an explanatory note to p. lxxxy, containing some references I had previously omitted; and then drew up the Table of Contents, and added the Supplement-all of which were sent to the Press without delay. Before the proof-sheets of these additions were returned, I received a copy of Professor Phillips' "Manual of Geology" (London and Glasgow, 1855), and naturally turned to his scheme of classification and nomenclature as applied to the older Palrozoic rocks. His scheme is given in the early part of his volume (Pp. 101, 103, 105): and so far as regards the Cumbrian mountains and the adjacent parts of Yorkshire, the successive physical groups, from the Skiddaw Slate to the Tilestone inclusive, are copied, I believe rerbatim (with the exception of a parenthetical interpolation of the words- "Transition group" - written after the Coniston grits) from a scheme which was published by myself in 1852, and laid before the British Association, in a more expanded form, at their Annual Meeting of 1853.

At the same meeting (18.33) Professor Phillips exhibited a published geological map of Yorkshire (illustrative of his excellent physical and geological description of that county), in which he adopted, without reserve, my classification and nomenclature of the older Paleozoic rocks. In one district (Howgill Fells) he made a slight mistake, by extending the Cambrian colour of his map a little too far; so as to include within it some beds above the Coniston grits, which ought to have had a Silurian colour, and which I have considered as Silurian in everything I have of late years written on the subject.

It appears, from the published Manual, that he has changed his views of classification since 1853; so that all those parts of the Yorkshire map which he first coloured as Cambrian must now have another name, and be coloured as Silurian. I see no reason for such a change; involving, as it does, not merely a change of names, but of the principles of classification: and so far as I understand the sections of Wales and Cumberland, it is a change in a wrong direction. For the new sections I have examined, along with Professor $\mathrm{M}^{\mathrm{c}} \mathrm{Coy}$, since 1853, have tended to confirm my belief that there is no such thing in Englisl geology as a great "Middle Silurian" or "Transition group" which blends together the most characteristic Cambrian and Silurian types. On the contrary, that there is a good palæontological, as well as a good physical, separation between Cambria and Siluria. Enough, and perhaps more than enough, has been written on this question in the previous Introduction: as well as in the paper's submitted to the British Association at their last two meetings, and printed in the Philosophical Magazine for October, November, and December, 1854.

To the arrangement of the physical groups, given in the Manual (pp. 103 and 10j) I can take no material objection. The successive groups, up to the Caradoc sandstone, and 
their arrangement, are substantially my own. They were made out with no small labour; and nearly all of them were first named as distinct physical groups by myself. Let then the lowest six groups-(1, the Longmynd strata; 2, the Llanberis slates; 3, the Harlech grits; 4, the Lingula flags; 5, the Tremadoc beds; 6, the Arenig porphyry and Festiniog slates;)-stand as they are arranged in Professor Phillips' vertical section, and be called Cambrian.

Afterwards (in the Manual) follow in regular ascending order:-7, Lower Bala, slates, flags, \&c.; 8, Bala limestone; 9, Upper Bala, slates, flags, \&c.; 10, Caradoc sandstone These four groups are called Lower Silurian. Here there is a divergence in our nomenclature. I call them Cambrian, in the Tabular view.

Continuing the ascending section, and commencing with the May Hill Sandstone, we have seven ascending groups, (No. 11-No. 18,) about which (excepting No. 11) there never has been a dispute. They are the rightful conquest of Murchison-the Silurian Series of the Tabular view-the Upper Silurian rocks in the Manual of Phillips.

To justify this scheme of classification and nomenclature, (Mamual, p. 105), there surely ought to be some great change (physical or palæontological, or both together) before we alter the names of the collective groups from Cambrian to Silurian. But there is no such change or break of continuity. There is nothing to indicate such a break in the sections north of Tremadoc, in the grand sections on the Holyhead road, or in the sections near Festiniog. If the Tremadoc slates and the Festiniog slates be Cambrian, the Bala group is also Cambrian. Hence, spite of its historical injustice, its geographical incongruity, and its abandonment of first principles, I think that the scheme adopted by Murchison in 1843, and still vindicated in 1854, is more logically consistent than the scheme proposed by Professor Phillips in 1855. The scheme of Murchison, below the May Hill Sandstone, is consistently wrong. The scheme of Phillips is partly right and partly wrong.

Let no one suppose that I am in this remark flinching from my own scheme of nomenclature. I am doing no such thing. I am only pointing out what I think the inconsistency of calling the collective Bala group Silurian, while the lower groups are called Cambrian. What we at present most want is a better analysis of the great Bala group, and especially of its upper sub-groups in South Wales; and I believe that the unfortunate and illogical adoption of the Llandeilo Flag as the guiding type of this great collective group, and the erroneous incorporation of it into the system of Siluria, by the Government Surveyors, have stood in the way of its more perfect analysis. They seem to have been cramped by a confined and utterly inadequate nomenclature. Their true work was to make out the older physical groups of South Wales, and separately to name them: and then to give them some good collective name: and I do not think they could have found a better collective geographical name for them than Upper Cambrian, which I had used long before they made their first essay upon the older Palæozoic rocks of Britain.

Again, if the scheme given in the Manual (p. 105) were logically consistent, there surely ought to be a far more decided break between the Festiniog slates and the Lower Bala slates, than there is between the Caradoc and the May Hill Sandstone. But such 
is not the fact: for the real break, and the only great break, in the older Palrozoic series is at the base of the May Hill Sandstone.

Professor Phillips seems still inclined to retain the name Upper Caradoc-first proposed by himself-and to regard it as a "Transition group" between his Upper and Lower Silurian rocks (Manual, p. 103). Ile was the first to point out a distinction between the (so-called) Upper and Lower Caradoc; but he did not follow it into all its consequences; nor do I think that the sections of the Malverns and the neighbouring country gave him the ready means of doing so in 1842, while he was working with the clog of an erroneous "Lower Silurian" nomenclature. Be this as it may, the full and true distinction was first pointed out by Professor $M \Gamma^{\circ} \mathrm{Coy}$ and myself; and though it was at first opposed by the gentlemen of the Government Survey, it was, not long afterwards, adopted by them.

So long as the collective Caradoc group was placed at the top of, and was classed with the (so-called) "Lower Silurian" rocks, no one could object to such a name as Upper" Curadoc. But after it had been separated into two distinct physical and palæontological groups (as is now done in the Manual, p. 105), the name "Upper Caradoc" ceased to be an appropriate term. I am certain that this was the opinion of the late Professor Forbes*: and I did not propose a new name for the higher group, as Professor Phillips supposes (Manual, 1. 115, note): but, to make the least possible innovation, I replaced an old name, May Hill Sandstone (first adopted by the anthor of the Silurian System), as the appropriate designation of that arenaceous group which is the physical base of the true Silurian rocks.

Before I leave this comment on what some may think a minute question-one, however, of no small importance-I would suggest the expediency of repudiating altogether the name "Caradoc" as the designation of the great and very ill-defined groups of strata at the top of the Cambrian series of South Wales; and of using in its place the name "Horderley sandstone"-as a better general term to define, approximately, any of the shelly sandstones and conglomerates which appear near the top of the Upper Bala group-as a term also which involves us in no ambiguity arising out of previous mistakes in the definition of the (so-called) Upper and Lower Caradoc sandstone.

In following out the previous remarks, I request the reader to turn back to pp. $x$ l and xli of the Introduction; and afterwards by help of the great map of the Government Survey, or of the reduced map prefixed to "Siluria" - to test the truth of what I have stated, as to the Cambrian strike, and the peculiar place and office of the May Hill Sandstone, which is the true Silurian base. There have been enormous dislocations in North America (below the Potsdam sandstone), of which we have, perhaps, no trace in England; but of which there may be a trace in Ireland; and we need not doubt that

* I have alluded to the opinion of Professor Forbes on this question of nomenclature (supra, p. lii); and he had freviously expressed himself much more distinctly on this point in the last conrersation he held with Professor M Coy and myself, some time before the meeting of the British Association in 1854. 
there have been local dislocations during all geological periods. I accept, without reserve, many of the statements given, on this subject, by Professor Phillips (p. 119). But the grund disturbance of the older Palcozoic rocks of England marks the separation between the Cambrian and Silurian groups, as defined in the Tabular View. The N.E. and S. W. strike of the British Isles is the characteristic Cambrian, and is by no means the characteristic Silurian strike: although the May Hill and Wenlock beds, from having been deposited on Cambrian rocks, which have a N.E. and S. W. strike, are partially affected (spite of all subsequent disturhances) by the strike of the old rocks on which they rest.

Professor Phillips very properly notices (Manual, p. 120) the prevailing north-eastern strike of many of the greater mountain-ranges of the British Isles. But when he adds, "that all these chains were thrown up, though not exactly to their present height and aspect, after the termination of the Silurian ages and before the deposition of the Old Red Sandstone," his statement, if not erroncous, is at least incomplete, and might therefore mislead the student of geology. That there is a great break in many parts of the Palreozoic series at the base of the Old Red Sandstone is certainly true: but in many parts of England the true Silurian rocks below the Old Red Sandstone have not, even approximately, a N.E. and S. Wr. strike. There is, however, another great break at the base of the May Iill Sandstone; below which, as a good general rule, the English rocks have the old north-eastern, or Cambrian strike. That these older dislocations extended into South Wales there can be no doubt: and they help us to explain the perplexing and discordant junctions of certain Cambrian and Silurian rocks in Radnorshire and Caermarthenshire. Among other causes, it was a want of knowledge of this fundamental fact which led to the first mistakes of classification among the lower groups of Siluria. I fought my way, single-handed, to a knowledge of the Cambrian Series which is sketched in this Introduction; and I have defended my classification single-handed, and without any fear of consequences; only because I have had to contend with opponents who had adopted a premature nomenclature before they were adequately acquainted with those great physical facts which are the basis of every good original classification, and without which a good geological nomenclature is impossible.

At pp. 10 and 106 Professor Phillips copies from the works of IIall (the great American palæontologist), that magnificent series of deposits which extend, in North America, from our Devonian series down to the Lingula beds, or Potsdam Sandstone; and gives the English equivalents on the combined authority of Lyell, Sharpe, De Verneuil, and Murchison. But all these authors examined the question of the English equivalents while they were under the influence of a classification and nomenclature which (so far as England is concerned) is unquestionably erroneous. I should endeavour to compare the Oneida conglomerate (No. 8 of Hall's Series) with the conglomerates of South Wales which are high in the Upper Cambrian series; and the Medina Sundstome (No.9) with the May IItll. Sandstone, or the English Silurian base. I should not, perhaps, have ventured to throw out such a speculation as this, against the authorities above quoted; had I not learned, from Professor II. Rogers, that there was, in many large tracts of North America, a break in the older Palnozoic series exactly. 
or very nearly, where I had placed it-at the top of the Cambrian groups of England, and at the base of the May Hill Sandstone-and that my scheme of classification would, he believed, be more acceptable to American geologists than any other which had been published in this country. I may add, that the Professors Rogers both declared, during their successive visits to the Woodwardian Museum, that they saw in it an arrangement of the older Palieozoic rocks of England which harmonized well with the grand natural series in North America. I know of no higher authorities: for the two Professors are excellent palrontologists; and have carried on their field-labours with very great and most happy skill, and with an amount of personal labour that is almost incredible. Such an accordance, on the other side of the Atlantic, as that above mentioned, was almost beyond hope: but in the development of the older Palacozoic series of France we have a right to look for a near accordance with that of the corresponding rocks of England. On this subject I have no help, either from my own observations in the field, or from the collections of our Museum. I conclude, therefore, not with an affirmation but a question: Is not the older Palæozoic series of France in a good approximate accordance, both physically and palæontologically, with the older Palæozoic series of England, as given in this Introduction? 


\title{
ADVERTISEMENT.
}

\begin{abstract}
THE following sheets make up the First Fasciculus of Professor $\mathbf{I}^{c}$ Coy's Descriptive Catalogue of the British Palæozoic Fossils that have been placed by myself in the Woodwardian Museum. It is devoted to the Radiata and Articulata; and a second Part (to be published, I trust, before the expiration of this year) will complete the series, and give a corresponding list of the Palrozoic Mollusca and Vertetrata. The entire Catalogue will extend to about five hundred pages, and will be followed by about twenty-three plates, eleven of which appear with the present Fasciculus.
\end{abstract}

Those species only are figured which are either new, or exhibit some character that has not been brought out in the figures published in previous works. All the drawings have been made in the Museum, with great care and labour, by $\mathbf{M r}$ G. West, under Professor II'Coy's immediate direction (with the exception of Pl. 1. G.) and will, I trust, be of value to palieontologists, and especially to those academic students who have a daily opportunity of examining the collection in the Cambridge Museum.*

I can claim no merit from the Part now published, except that of having brought the collection together, and given it a permanent academic place, and of having for nearly four years secured the very valuable assistance of Professor $\mathrm{I}^{\mathrm{C} C o y}$. But the work, when complete, will contain a Preface, in which I shall endeavour to give a short history of the manner in which the collection has been formed; partly by my own labours-continued, with some interruptions, for more than thirty years-and partly by the assistance of my friends and fellow-students.

The Preface will end with a synopsis of the different natural groups into which the whole British Palreozoic series may be separated-both on the evidence of actual sections. and on the Palieontological evidence supplied by the Catalogue. I may so far anticipate the result as to state, that the natural groups will be described in the following order:-

* Mr J. W. Salter's descriptions of several fossils in this work lave been already printed; and will appear with the second Fasciculus in the form of an Appendix, as they contain references to a Plate not yet prepared for the engraver. 
1. Hypozoic rocks.

2. Cambrian rocks. $\begin{cases}(1) & \text { Older Cambrian groups inferior to the Bala limestone. } \\ (2) & \text { Upper Cambrian groups based on the Bala limestone. }\end{cases}$

3. Caradoc group. It has perhaps no distinct representative in Scotland and the North of England. In Wales and Shropshire, it often overlies the Cambrian rocks unconformably, and there forms the physical basis of all the upper Silurian groups, while Palæontologically it connects itself with the Cambrian rocks.

4. Upper Silurian rocks-including all the groups from the upper part of the Wenlock Shale to the Tilestone.

5. Old Red Sandstone, or Devonian, groups.

6. Carboniferous groups.

7. Permian groups, which end the Palæozoic series, and are immediately followed by the Trias, or New Red Sandstone.

In concluding this Notice, I have to return my grateful thanks to the Syndies of the University Press for generously taking on themselves the expense of the letter-press of this Part; which, after all the assistance thus given to me, has not been brought before the public without much anxiety, and a great personal cost.

CAMbridge, MIay, 1851.

ADAM SEDGIVICK, Woodwardian Professor. 


\section{ADVERTISEMENT TO SECOND FASCICULUS.}

THE former Fasciculus (published May 1851) contains all the palrozoic Radiata and Articulata:-the present contains all the loner and middle palwozoic Mollusca:-and the third Fasciculus (now in the press) will contain the upper palæozoic Mollusca, and also the palreozoic Fishes-thus completing the palrontology of the British palreozoic rocks, so far as the subject is illustrated by the collections I have placed in the Woodwardian Museum.

When the former Fasciculus was printed Professor $\mathbf{M}^{\mathrm{c}} \mathrm{Coy}$ was absent in Ireland, and I had no opportunity of examining the proof-sheets: neither had I, at that time, supplied him with any detailed geological information respecting the localities from which the several fossils were derived. This want has been since supplied; and in an Alphabetical List (commencing p. 326, and ending p. 331) of all the lower palreozoic localities alluded to in this as well as the preceding Fasciculus, each locality is referred to its supposed geological place in the general series, agreeably .. a scheme of nomenclature given in the following Tabular View. In the same list, and for the express purpose of easy reference, each locality is defined by the number which precedes it.

\section{Tabular View of the British Palwozoic System.}

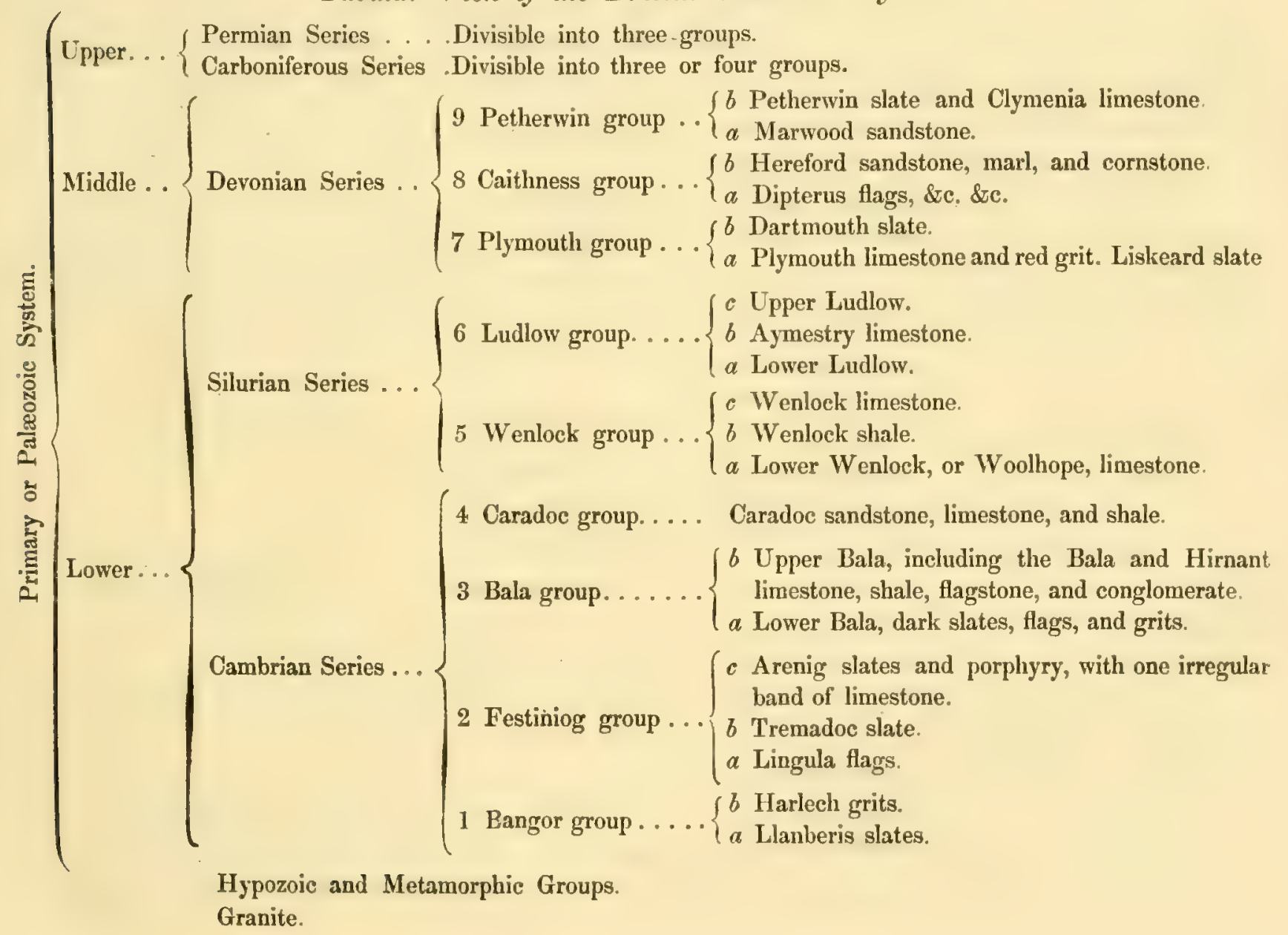


The series of old slate-rocks, found in the Longmynd, and the neighbouring parts of Shropshire, are not included in this Tabular View; because no fossils have been discovered in them, and because their exact place in the general series is doubtful. They are, probally, in part co-ordinate with, and in part inferior to, the Llanberis slates. I believe them also to be physically co-ordinate with the Skiddaw slate-the lowest Cumberland group.

In the Advertisement prefixed to the first Fasciculus (May 1851), I have stated "that the Caradoc group has, perhaps, no distinct representative in Scotland and the North of England." Since the Advertisement was written, I have revisited some parts of the North of England, and now think (for reasons published in the Joumal of the Geological Society, Vol. virr. Part 2) that the Coniston grits are the true representatives of the Caradoc group.

In the same Advertisement I divided the Cambrian series into two groups-Upper and Lower :- the upper commencing with the Bala limestone. In the previous Tabular View I have not made any use of the terms Upper and Lower Cambrian; but I have divided the whole series into what I think good natural groups derived from actual sections. Were I now to make use of the term Upper Cambrian, it would include all the strata under Nos. 3 and 4 of the Tabular View: and in this arrangement the upper Cambrian groups would commence (several thousand feet below the Bala limestone) with the black slates at the East of Great Arenig, and at the South-East side of Cader Idris. In my present scheme of nomenclature the Bala group is the equivalent of all the undulating rocks of South Wales which are inferior to the true over-lying Silurian groups, and are superior to some older groups (Festiniog groups) which emerge in a part of Pembrokeshire.

The old subdivision of the Cambrian series into upper and lower-(the upper commencing with the Bala limestone)_though I now think inconvenient for Wales, would not be inconvenient for the groups of Cumberland and Westmoreland. The Palæozoic system, in the North of England, may be arranged naturally in the following sub-divisions :-

Carboniferous.

Old red sandstone.

Silurian $=$ All the Lower Palæozoic rocks above the Coniston grits.

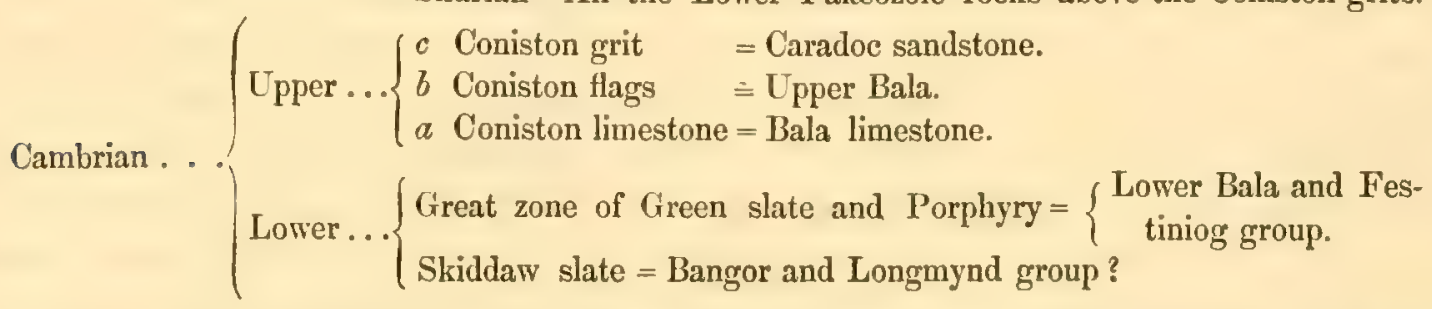

I do not, however, give this scheme in opposition to the preceding Tabular View, as I think that the nomenclature of the older British palæozoic rocks can only be fixed by a reference to the more perfect Silurian and Welsh sections.

At p. 332, and ending p. 350, is given a List of all the Lower Palæozoic Fossils described in the work, with a reference, in each case, to the page where any species is described. The genera are given systematically, and in the order in which they appear in the body of the work. 
Under each genus, the several species are referred to their proper geological groups, agreeably to the scheme given in the above Tabular View. To save space the localities are, in cach case, given by the help of numbers: but these numbers may be immediately translated into proper names by consulting the preceding List (commencing p. 326). For example: Vioc misca-the first fossil of the Systematic List, is referred to Lower Ludlow or Wenlock shale. The number, 169, attached to it, gives (by help of the previous List) Malvern, Worcestershire, for the locality. Here the locality is of no value, because many different formations are found near the Malverns : but in very many cases the locality may confirm, or, it may be, invalidate, the assertion of the text. Again, if we turn to the 24 th genus, Stenopora, we see,

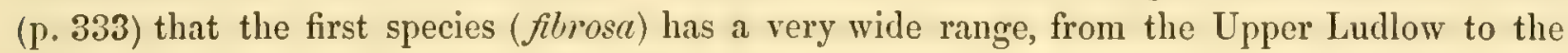
Bala group inclusive: not less than twenty-nine localities are given to this species from the Upper Bala, or $3 b$. of the Tabular View. The last number (122) indicates the last locality from which I have obtained the species: viz. the flagstone of Horton in Ribblesdale.

This Systematic List shews that no small labour has been bestowed upon the formation of the collection; and also shews the enormous amount of labour bestowed upon it by Professor $\mathrm{MI}^{\mathrm{c}}$ Coy. A bare list of species might mislead us while we are, on fossil evidence, endeavouring to determine our successive geological groups. A fossil may be highly characteristic of one group, and may be found in it in thousands; yet an individual of the same species may, perhaps, straggle into an upper group of which it cannot be called characteristic. Several cases of this kind occur in the present Systematic List; and in all such cases, if the geological place of the localities has not been well determined, the exceptions to what seems to be a general rule almost entirely lose their value.

When by this kind of sifting the species are, as far as possible, referred to their true groups and localities, there still remains this question: What is the fossil evidence offered by each locality? Now this evidence is put before us in a third List, which gives all the fossil localities alphabetically, with an enumeration of all the fossil species found under each head.

By help of the three Lists above described (which have been very carefully reduced by Professor $\mathbf{M}^{\mathrm{I}} \mathrm{Coy}$ ) all the geological information to be at present derived from the Lower Palæozoic fossils of the Cambridge collection is at once given to the reader.

That the nomenclature adopted in the Tabular View is geologically and geographically true, I have shewn, in a memoir before alluded to (Journal of Geol. Soc. Vol. xiIr. p. 136); and that my nomenclature of the Cambrian series has the claim of priority is certain. What is the scheme proposed? That the great Longmynd group, which, if seen at all, is very faintly represented in Wales, is to be called exclusively Cambrian; and that the grand Cambrian Series-not less than 25,000 or 30,000 feet in thickness-is to be called Silurian; although the whole map of Siluria contains only one group of that great series-the Caradoc sandstone-which is referred to its right place in the general section of Wales. It is true that the Llandeilo flagstone is described, and its fossils enumerated, in the "Silurian System." But the group was not put in its right place in the general section of Wales. Its position was 
mistaken; for it is the equivalent of the Bala limestone which is in the centre of a true Cambrian group; and to this Cambrian group it was made superior, and described as united in one group with the Caradoc sandstone.

Let the Cambrian rocks be called Cambrian, and the Silurian rocks be called Silurian, as first agreed upon; still there will remain a considerable difficulty presented by the Caradoc sandstone. In the former Advertisement I stated that this group formed the physical base of the true over-lying Silurian series, while palæontologically it was more connected with the Cambrian groups. Hence, on palæontological grounds I have ranged the Caradoc sandstone with the Cambrian series, as scen in the above Tabular View. But if all the rocks now called Caradoc sandstone be of the same age, then the evidence is in conflict; for the fossils of Horderly are in very near agreement with those of Bala, while the fossils of May Iill are in near agreement with those of the Wenlock group. Perhaps these discrepancies may be soon removed by a new adjustment of the Caradoc group. Meanwhile, that interpretation of the facts which is most in conflict with the conclusions I am advocating, would merely prove, that during a period of movement and change of conditions which introduced the true and well-defined Silurian deposits, species very characteristic of the Silurian groups were flourishing in one part of the sea, contemporaneously with species in other parts of the sea which were equally characteristic of the upper Cambrian groups.

Leaving the discussion of such questions as unfit for these introductory remarks, I call the reader's attention to the wide difference exhibited between the fossils of the Cambrian and Silurian series.

On counting over the lists, including a few supposed varieties, I find 304 species given to the Cambrian Series, and 262 to the Silurian, while 85 are common to both. This gives about 15 per cent. of the whole series common to the Cambrian and Silurian rocks. But this per centage is too large; for many doubtful cases of common species were recorded in counting up the lists. Are the true Silurian rocks palæontologically more separated from the Devonian, and the Devonian from the Carboniferous rocks? I greatly doubt it. It is obvious that the greatest interchange of species nust be near the plane which marks the separation of one group from another. In the fine list of fossils from the Upper Ludlow group of Westmoreland there are scarcely more than three or four species found in the lists of the Coniston fossils; unless it be species that ranges through nearly the wholc palæozoic system.

I conclude this Introduction by noticing one or two of the more striking additions made by Professor $\mathbf{M}^{c} \mathrm{Coy}$ to our palæontological knowledge.

The discovery of the peculiar diaphragm at the base of the cells in the Graptolites (as in the recent Sertularia) and other points in their structure, fixes their place among the IIydroid polyps with certainty-completely refuting the generally-received notion of their being allied to the Sea-pens (Virgularia), as well as the opinion recently revived by Geinitz of their being Cephalopods, and that given in the preface to the "Geology of Russia," of their being sea-weeds.

The fossil identified by former observers as an Ichthyodorulite, from the Bala limestone, 
was proved by microscopic and other characters, to be the silicious axis of a Gorgonian zoophyte, allied to the recent Hyalonema of the Chinese seas. (See p. 10).

On the corals, generally, great labour has been bestowed; the characters of most of them being now first noted in detail, and their internal structures ascertained by vertical and horizontal sections. Many new genera and species have been made known and figured; and species, supposed to be common to the Cambrian, Silurian, and Devonian rocks, have been discriminated by tangible characters.

Those curious fossils from the Devonian slates of Polperro, supposed by all previous olsservers to be scales, teeth, bones, and fin-rays of fishes, partly Devonian and partly Upper Silurian species, have been proved, from examination of the Cambridge specimens, to belong to the Amorphosoa, or Sponge-group, forming a new genus (Steganodictyum), fragments of which are figured on Pl. 2. A.

To avoid the confusion and error arising from the constant misapplication of the undefined terms 'pelvis,' 'costals,' 'scapulæ,' \&c., proposed by Miller, and used by most subsequent authors with various meanings to designate the plates of Crinoids, a new and simple system of nomenclature has been proposed (p. 52), applicable alike to the most complex or most simple forms.

At page 124 a new Order is established for the Echinites of the Palæozoic rocks, and it is pointed out that they will not accord with MI. Agassiz' view of the quinquepartite composition of the crust of the sea-urchins, applicable, without exception, to all those of the newer rocks and recent seas.

At page 139 the homologies of the Cephalic shield and eye-line of Trilobites have been investigated for the first time, with reference to the variations made known by anatomists in the rings forming parts of the head and mouth, in the whole group of recent Crustacen of higher organisation. Attention is also drawn to an indication of antenne, the supposed want of which in those creatures has hitherto obscured their affinities.

All the great groups have been taken in zoological order, and each is introduced by such condensed remarks, as the space allowed of, on the zoological and anatomical characters of the living analogues, as will enable the academic student using this Catalogue in the Museum, to form just notions of the place in the organic scale of the various fossil types, and dispel certain false popular notions of "progressive development."-At the foot of page 191 is a notice of a discovery, first made by Professor $\mathrm{M}^{\mathrm{c}} \mathrm{Coy}$ some years ago, from some recent specimens in the Museum, (recently published by Mr Woodward since those sheets were printed off,) that the valves of Terebratula are opened by the action of a pair of muscles-a contrivance without parallel in Conchology. Naturalists formerly supposed that Tevebratula, having no cartilage like Lamellibranch bivalves, to force the valves open, opened them by inflating the arms, or by the pressure of the elastic loop; neither of which explanations could be structurally correct. The present explanation obviously applies to all Brachiopods.

In matters of nomenclature, priority in specific names has been carefully observed; and the exact relation of synonyms to each other is rendered more obvious and exact than in 
English or French books, by the use of algebraic symbols, according to a practice partially introduced by some recent writers in Germany. The proportions of the shells have been expressed in fractions of the greatest absolute measurement, and the angles given in degrees by the goniometer, in accordance with the modern French practice, as more brief and precise than the ordinary use of indefinite expressions.

Of the number of new species described in this work a general notion may be formed by a glance of the eye over the plates; as no species is here figured of which a good and sufficient figure has been before published. The description of the species and genera is full and luminous, and will, I trust, be found of great value to the palæontologist. The third and concluding Fasciculus will, I trust, be published before the end of this year, and to this I hope to prefix a short account of the English Palrozoic System, with comparative and illustrative sections indicating the true relations of the successive groups in each system or series.

ADAM SEDGWICK.

Trinity College,

July 16, 1852. 


\section{DESCRIPTION}

OF THE:

\section{BRITISH PALAEOZOIC FOSSILS}

IN THF:

GEOI.GICAL MUSEUM OF THE UNIVERSITY OF CAMBRIDGE,

BY

FREDERICK M ${ }^{\mathrm{C}} \mathrm{COY}$, F.G.S.

PROPESSOR OF NATURAL SCIENCE IN THE UNIVERSITY OF MELBUURNE,

HONORARY FFLLOW OF THE CAMBRIDGE PHILOSOPHICAL SOCIETY, \&C. 
- 


\section{E S C R I P T I O N S,}

\&c.

\section{Kingdom ANIMALIA.}

THE Animal Kingdom consists of all the organized beings possessed of a mouth and internal digestive cavity. By these characters they are exeluded from the Vegetable Kingdom, which contains all the rest of the organic creation.

The Animal Kingdom is divided into four Sub-kingdoms: 1st, Radiata; 2nd, Articulata; 3rd, MLotlusca; and 4th, Vertebrata. Examples of all occur in the Palacozoic Rocks.

\section{1st Sub-kingdom RADIATA.}

This sub-kingdom comprises a vast number of the lowest organised forms of animal life. One great section, named Acritu by Prof. Owen, shewing no trace of a nervous system, being capable of increase by spontaneous fission, and by buds, as well as by ova, and having only one opening to the digestive cavity. The higher section, named Nematoneura by the same author, from having a rudimentary nervous system of threads, without ganglions or distinct nervous centres, is generally speaking increased by ova alone, and has two openings to a distinctly-walled digestive cavity. This 2 nd group comprehends the Rotifera, Echinodermate, Polyzoa, and Entozoa-some of the last being the most highly organized, and approaching the true worms in many points. The most universal character of the group Radiata is that which suggested its name, namely, the more or less perfect radiated arrangement of all the parts round the mouth as a centre: this appearance is often deceptive, but is on the whole scarcely to be met with in any other division of the animal kingdom. The existence of distinct nervous threads in the Actinice, and the progress of discovery shewing every year the existence of nervous filaments in others of the Acrita, induce me to leave the Radiata as one group.

This sub-kingdom is divided into the following Classes: 1st Infusoria ; 2nd, Entozod or intestinal worms; 3rd, Zoopliyta; 4th, Polyzoa; 5th, Acalephle or sea-jellies; and 6th, Echinodermata. The first are not known in the Palreozoic rocks, and the second and fifth, from the softness of their tissues, cannot be expected in the fossil state, though it is probable they may have existed from very early geological periods.

SEct. I.-RADIATA OF THE LOWER PALAOZOIC ROCKS. (Cambrian and Silurian).

\section{3rd Class, Z0OPHY'TA. (Lin.)}

= Anthozoa, Ehrenberg.

In the lower types of this Class the body is soft, and capable of expansion by water received through the mouth; all the parts, internal and external, perform equally the same functions; respiration is performed by the whole surface; no circulation has been discovered, nor organs of sense, nor distinction of sex; the individuals are essentially composed of a closed tubular stomach terminating in a wouth and circle of tentacles. 
In the lamelliferous corals the number of the lamelle mostly corresponds with that of the tentacles, and as they are generally believed to be nearly constant in number in adult individuals, they afford very valuable characters for the discrimination of species. Lamelle only exist in the two higher orders, and extend from the stomach to the outer wall; they are connected with the generative system, the broad lamell e having usually a great convoluted spermatic vessel attached to its edge, and the sides of the others are loaded with clusters of ova; in some Aleyonaria (in which the lamellex are membranous and eight in number) the same lamella is oviferous above and spermatic below, or two are spermatic and the other six are oviferous. These spermatic cords were considered biliary ducts, till the American naturalists recently found spermatozoa in them. The ova either escape through a small opening in the bottom of the stomach into the sea by the mouth, or some of them are developed inside, and bud out through the side of the parent; the buds either fall ofl' and heconte separate individuals, or are retaincd forming lmanched compound animals, always aceording to a definite mude of growth, and the angle of branching being often so constant as to assist in defining the species.

The modes of budding, as defined by Mr Dana, are lateral or terminal. The terminal or disk-budding hegins by the animal forming two or more new mouths to the one stomach, being the true fissiparous generation. The lateral disk-budding should be carefully distinguished, for in it, it is only une of the ova which grow out through the side of the disk, and the second mouth has a separate stomach of its own hanging into the ovarian cavities of the old one. Acrogenous growth is the upward extension of the tip of the branches; prolate grouth is the production of lateral huds firom the lower part, so that great flat expansions are proluced (as in some Curyoply,gllider), or by extension of the upper part from disk-budding (as in the latpudr-). The spiral-budding, or crmulutu-remente growth, is seen in the Madrepores, where each branch is composed of a great central parent polyp (forming the perforated apex), surrounded by a whorl of spiral buds. In all the coralbearing polypes there is a constant death below, leaving only the tips of the cells alive; and in certain cases those die periodically, leaving a germ to grow from the old centre, forming cup-shaped rings of growth, as seen in our figure of Strephodes multilamellatum. An intermittent retraction of the base of the stonach gives rise to the transverse partitions of Cyathophyllum and Favosites.

This Class contains three Orders-1st, Hydroida*; 2nd, Zoophytaria; 3rd, Zoantharia.

\section{1st Ord. HYdRoIDA (Joluston.)}

= Sertulariens $($ II. Edw. $)=$ Hydrozoa $($ Owen $)=$ Nudibrachiata $\left(\right.$ Farre. $\left._{0}\right)>$ Polypiaria (Blainville) .

The Polypes of this Order are rarely single, locumotive, and naked (as the IIylrut); more usually ('ompunul and inclosed in a horny, tubul:ur sclerenchyma or sheath, which is generally branched, jointed by interruptims of growth, and fixed at the base to submarine bodies; always destitute of internal vertical -trie or lamelie'; muth surrounded by a serics of rough, rigid, filiform tentacles, without cilia; digestive cavity hollowed in the granular parenchyma of the body. without membranous walls, having but the one openingt, and no intestine. 'The young sprout from the side of the parent by lateral budding, or are developed in external vesicles connected with it; the former occurs in the naked Hydra, in which at intervals cellular male and female organs are developed, sometimes in different individuals, more commonly both in the one creature; the impregnated ova mostly escaping through the mouth, but some being retained, grow out like buds from the parent. In the compound speeies, with the horny, tuhular integument, the young buds adhere permanently to the parent. forming branched polypidoms of a peculiar pattern for each species; but, in addition to these, peculiar ovigerous vesicles are developed at particular seasons on some definite parts of the stem containing the true

* Although I think the recent admirable rescarches of Prof. Agassiz, on the living Naked-oyed Meduso of the shores of Massachusetts, nearly settle the question of the Hydroid Polypes being only the larral state, or alternate generations of such free Medusce as Sarsia and Tiaropsis, yet I prefer, in a work like the present, learing them in their old systematic place till we have the whole question before us, by the publication of his observations on the first stages of the metamorphosis.

+ Corda imagined a small pore near the torminal sucker to bo an anus, but the food is seen to bo rejected by the mouth. 
ova, which increase in size from an organic connexion kept up with the living, circulating, nutrient fluids common to all the polype-mouths, and filling the stems and branches: the ova, on attaining maturity and a coat of cilix, escape and swim to a convenient site, where they become fixed, lose their cilix, and sprout into the form of the parent stem. The ovarian vesicles fall off when the ova are all gone. The first and all subsequent cells are formed by a cessation of growth in the convex, soft, growing tip of the branches, both the horny and inner membranous layers of which become inverted and cup-shaped by the shrinking of the pulp within; and when the cup is of the proper depth the two layers tum inwards to form the strong septum or bottom of the cup, in the centre of which the outer horny layer is deficient, leaving a f.crforation through which the inner membranous layer furotrudes, gradually expanding into a stomach-like cavity, in and out of which the nutrient granules of the stem ebb and flow, and at the distal end of which a perforation or mouth and the circle of prehensile tentacles are ultimately developed. I have no hesitation in placing the Graptolites in this order, from the perfection in which the above characters are preserved in a great collection of them made last year by Professor. Sedgwick in Scotland. I believe they should form a particular family, closely allied to the Sertulariada, which have similar sessile polype-cells, in one or two rows according to the genus, intermediate between them and Corymorpha, which has the polypidom free, unattached, and living buried in the sand.

\section{Fam. GRAPTOLITIDA $\left(M^{c} \mathrm{Coy}\right)$.}

Stem simple or branched; thin, usually linear, horny, unrooted; polype-cells sessile, in one or two rows; each with an internal transverse diaphragm at base.

In the form of the thin horny polypidom and polype-cells the Graptolitides agree with the Sertulariada, but differ in not being rooted. I have never found any trace of ovarian vesicles; others may find them, however, by examining great numbers of specimens, or by some fortunate accident; or the ova, as in the closely allied Corymorph (which agrees with the Graptolites in having a free polypidom), may have been developed in naked sacks attached to the base of the tentacles of the polyps, and would not in that case leave any trace in the fossil state.

On the same grounds that the allied recent genera Plumularia and Sertularia are separated, I propose to restrict the term Graptolites to those which, like the original typical species, have the cell-denticles only on one side; and for those having them on both sides, I propose the generic name Diplograpsus. Professor Nilsson and Colonel Portlock have published nearly similar views, the latter with great clearness.

In connexion with the spirally inrolled species, I may call attention to a curious fact observed by my friend Mr Patterson of Belfast, that a broken stem of another Hydroid Zoophyte, the Tubularia larynx, when thrown into a jar of water lept "coiling itself up, uncoiling, stretching, twisting, knotting itself," giving him the notion "that the stem is not only flexible, but under certain circumstances is truly and entirely under the control of the zoophyte." (Johnston's Brit. Zooph. p. 51).

\section{Graptolites convolutus (His. Sp.)}

Ref. and Syn.,-Prionotus convolutus, Hisinger, Leth. Suec. t. 35. f. 7.=Graptolites spiralis, Geinitz, in Leonhard and Bronn's Jahrbuch für Mineral. for 1842. t. 10. fig. 24, 28, 29.

Sp. Ch. - Length unknown, occurs in short fragments, spirally convoluted in a few turns; cell-denticles on the outer side, radiating nearly at right angles to the capillary axis, slightly curved or straight, nearly one line long, very slender and apparently cleft to the bases; the space of axis between the denticles rather less than half their length.

The figure of Hisinger seems considerably too large and coarse in its details, but there can be little doubt as to the species; Geinitz's figures quoted are rather better, but the ones not quoted which he gives are doubtful.

Position and Locality.-Not uncommon in black earthy slate near Lockerby, Dumfriesshire. 


\section{Graptolites latus $\left(M^{c}\right.$ Coy). Pl. 1. B. fig. 7.}

Ref.-McCoy. Quart. Jour. Geol. Soc. Vol. IV. p. 223.

Sp. Ch.-Several inches long, straight, undivided portion of the stem between the axis and the base of the cell-denticles one line (or slightly more) in width; cell-denticles very small, triangular, slightly curved, their bases touching, and their length not exceeding the width of their base; five occupy a space of only two lines.

The very small triangular denticles and width of the undivided portion of the stem easily separate this remarkable species from its congeners. In some states of preservation fine straight lines are seen dividing the cells from each other and descending from their mouths obliquely to the axis, at an angle of about $45^{\prime \prime}$; in other states, stronger horizontal diaphragms may be seen extending across the middle portion of the stem at right angles to its length.

Position and Locality.-Common in the black shale of Builth Bridge; in the greenish Skiddaw slates of Scawgill; in the black Skiddaw slates of Whiteless; and in those of Knockmurton, near Lamplugl Cross, Cumberland.

Explanation of Figures.-Plate 1. B. fig. 7. Portion natural size, shewing the great width of the undivided portion of the polypidom and small denticles from the shale of Builth Bridge. Fig. $7 a$. Do. Magnified six diameters, denuded of its outer coat and shewing the tubular stem, the oblique divisional walls between the cells with the form of their mouths, and the transverse diaphragms near the bottom of each to sustain the polyp. Fig. 76 . Do Shewing a portion of the outer envelope, preserved in addition to the above. Fig. $7 c$. Do. A common appearance resembling $7 a$ but with the transverse diaphragms invisible.

\section{Graptolites lobiferus $\left(M^{c} \mathrm{Coy}\right)$. Pl. 1. B. fig. 3.}

Ref.-McCoy. Annals of Nat. Hist. 2nd S. Vol. VI. p. 270.

Sp. Ch.-Several inches long, straight, axis capillary, undivided portion of the stem about one-third of a line wide; cells forming large, obtusely rounded lobes, uniformly convex on the upper and outer margin; a notch on the under edge separates the rounded extremity from the oblique descending margin; four cell-lobes in three lines; width from axis to end of cell-lobe slightly less than one line.

The rounded lobe-like form of the cells and their size render this one of the most distinctly-marked species of the genus. Fragments are often beautifully iridescent.

Position and Locality.-Common in the black shale of Lockerby, Dumfriesshire.

Explanation of Figures.-Plate 1. B. fig. 3. Portion natural size, from Lockerby. Fig. $3 a$. Do. Magnified six diameters,

\section{Graptolites ludensis (Murch.)}

$$
\text { Ref.-Sil. Syst. t. 26. f. 1, \& } 1^{\text {a }} \text {. (Not. 2.) }
$$

$S p . C h$ - Polypidom scveral inches long, thick, coriaceous, averaging one line wide, rather rapidly tapering towards the base; cell-denticles having their upper margin thickened and abruptly recurved into a rounded hook, the membranous inner margin of which when finely preserved shews a pendulous, subtubular, bell-shaped cell, with a round mouth, the oblique lines between the cells meeting the marginal axis at an angle of about $35^{\circ}$; four denticles in a space of two lines (or five in the same space close to the attenuated base).

After the careful study of an extensive suite of most exquisitely preserved specimens, I feel unable to distinguish the species of the Lower Ludlow rock from the similar one in the inferior beds by any constant character.

Position and Locality.-Common in the olive slates of Greiston, on the Tweed (one fragment upwards of nine inches long without tapering); in the slate-quarry of Ludlow rock N. of Nantyre; in the schists 
of Cwm W. of Cefn Grugos; Lower Ludlow rock of Garden quarry, Aymestry, Herefordshire; in the nodules at Brathray, Westmoreland; in the olive schists of Peniarth uchaf; N.W. of Pen y Glog; the limestone of Balmae Shore, near Kirkcudbright ; in olive-schists of Pen y Craig, Llangynyw, Montgomeryshire; in oliveschists of Gwyddelwern, Derwen; black shale bed of the Wye, Builth, Radnorshire; Cwm Bach, Builth; in the flags of Nant Moifydd, near Derwen.

\section{Var. Minor $\left(\boldsymbol{I}^{c} \mathrm{Coy}\right)$.}

Under this provisional reference I give a species resembling the above, but of only half the width, yet having from four to five denticles in a space of two lines. It is common in some parts of the Green Ludlow rocks or mudstone at Llangynyw Rectory, Montgomeryshire.

\section{Graptolites millipena $\left(M^{c} \mathrm{Coy}\right)$. Pl. 1. B. fig. 6. Ref.-MCCoy. An. Nat. Hist. 2nd S. Vol. VI. p. 271.}

Sp). Ch.-Length unknown, occurs in short curved or spirally inrolled fragments; cell-denticles on the outer side, each broad at the base and abruptly contracted to a small mucro, deflected or strongly curved backwards, both the upper and lower margins being sigmoidally curved; the denticles touch each other (when fully preserved) at their bases. Five to six denticles in the space of two lines; width from axis to ends of cell-denticles slightly more than half a line.

The much closer, shorter and wider cell-denticles, with their abruptly recurved points, easily separate this species from the $G$. concolutus (His.), the inrolled form of which agrees with it. I only provisionally characterise the species, as there is a possibility that if the G. concolutus be only the tip of G. Sedguickii, this might ultimately prove the corresponding portion of the G. lobiferus; a supposition which at present, however, is not supported by any evidence, there not being the same amount of resemblance between the two latter as between the two former species, the difference in size and structure of the cells being much greater.

Position and Locality.-Not uncommon in the black shale of Lockerby, Dumfriesshire.

Explanation of Figures.-Plate 1. B. fig. 6. Natural size from Lockerby. Fig. 6 a. Do. Magnified six diameters.

\section{Graptolites murchisoni (Beck.)}

$$
\text { Ref.-Murch. Sil. Syst. t. 26. f. } 4 .
$$

$S p$. Ch. U Upwards of two inches long, stems united in pairs at a small mucronate simple base, each branch nearly straight, about one line wide, having a simple, rather strong, capillary axis along the outer margin, from which the lines dividing the cells set off at an angle of about $35^{\circ}$; there are five to six cells in the space of two lines, having simple concave terminations, the lower angle acute, slightly projecting, but little or not at all recurved.

I have not actually traced the twin junction of the stems, so distinetly figured by Sir R. Murchison, but disjointed fragments are easily distinguished from the other single-sided Graptolites by the great number of cells in a given space, their obliquity to the axis, and the simple character of their serratures; much resembling in these points the Diplograpsus folizm and $D$. foliaceus, from which, of course, they are fully distinguished by having their cells on only one side of the axis.

Position and Locality.-Common in the flags at Ffyrnwy, Llanfair, Welshpool; in the schists South of the Dee.

\section{Graptolites sagittarius (His.)}

Syn. and Ref.-Prionotus Sagittarius, id. Leth. Suec. t. 35. f. 6.

$S p$. Ch. - Several inches long, two-thirds of a line wide, straight; a very fine capillary axis at the smooth edge, and rather large, angular, cell-denticles on the other, the distance between each of which is equal to the diameter of the stem; upper margin of each denticle nearly straight and horizontal; lower 
margin about one-third longer than the upper, nearly straight, and inclined to the axis at an angle of about $40^{\circ}$, to which some specimens indicate the prolongation of the cells by fine lines; four to five denticles in a space of two lines.

Fragmentary specinens, imperfect at each end, occur eight or nine inches in length, without perceptible difference in the above diameter, which with the size and shape of the denticles separate it from its congeners.

Position and Locality.-Common in the black flags of Horton in Ribblesdale; in the flags under Mocl Seisiog; in the black schists of Balmae Shore, Kirkeudluright; at Lockerby, Dumfriesshire; in the Skicklaw slate of Haykin Gill, and of Knocknurton, near Lamplugh Cross, Cumberland; in the slate of Scawgill; schists of Cautley Crangs, above Scdburgh; Graig dhu Allt, Llangollen. A varicty apparently of this species, a little larger in all its parts, but possibly from great compression, occurs abundantly in the black slates over the Tron IVorks at Tremadoc, Merionethshire.

\section{Graptolites sedgickil (Portl.) Pl. 1. B. fig. 2.}

$$
\text { Ref-Geol. Rep.t. 19. f. 1, 2, 3, and } 6 \text {. }
$$

$S p . C h$._Several inches long, (extremities unknown); lateral axis capillary; flattened space between the axis and the denticles rather less than half a line wide, from the axis to the tips of the denticles nearly one line and a half; cell-denticles very long and slender, nearly straight, and almost at right angles to the axis; flat space between their bases equal to the width between their bases and the axis; four denticles in a space of two lines,

This species is distinguished at a glance from all but the $G$. convolutus (His. Sp.) by the very long, slender, and nearly horizontal denticles.

Col. Portlock mentions (Geol. Rep. p. 391) straight fragments eleven inches long, which I think I remember his shewing me. Straight fragments now figured are upwards of three inches long, lnt with them occur some more or less curved, making an approach to the $G$. convolutus, with which it is nearly identical in the size, shape, and peculiar proportion of the denticles, seeming strongly to countenance the suggestion of that author himself, that the latter species may be only the inrolled tip of the former. The figures given in the above-quoted work do not exactly represent the character of the Irish species: I have therefore re-figured it from Scotch examples, satisfying myself of the identity lyy direct comparison with 'Tyrone specimens.

Position and Locality.- Not very uncommon in the black slates of Lockerby, Dumfriesshire.

One specimen in the olive-slates of Greiston on the Tweed, which had apparently been dead before petrifaction, is abont seven inches long, slightly flexuous, and has a peculiar aspect from the long attenuated tips of the cell-denticles being absent almost entirely; the size and peculiar proportions of the remaining portion is however identical with normal examples, and in one or two places the remains of the filiform ends may be traced.

Explanation of Figures.-Plate 1. B. fig. 2. Portion natural size from Lockerby (to shew the true form of the denticles.) Fig. $2 a$. Do. Portion magnified six diameters.

\section{Graptolites tenuis (Portl.) PI. 1. B. fig. 4 and 5.}

$$
\text { Ref.-Geol. Rep.t. 19. f. } 7 .
$$

Sp. Ch.-Several inches long, extremities unknown, slightly more than the third of a line wide; serratures formed by the ends of the cells comparatively remote and large, their lower margins long, straight. very oblique, (forming an angle of about $20^{\circ}$ to $30^{\circ}$ with the axis), the upper margin about half the length of the lower, slightly concave, nearly horizontal; four cell-denticles in the space of two lines.

This species is very distinct, by its comparatively remote denticles, and very small width. Professor Hall has figured fragments, imperfect at both ends, nearly eight inches long, retaining the above diameter. As none of the published figures are quite exact, I have given a figure of a Scotch example. 
Position and Locality.--Common in the black shale at Lockerby, Dumfriesshire; some curled up doubtful specimens in the slate at Greiston on the Tweed.

Explanation of Figures.-Plate 1. B. fig. 4. Portion natural size, from Lockerby. Fig. 4a. Do. Magnified six diameters, shewing the tubular stem with the denticular cells, coming off at an acute angle each with its transverse diaphragm on which the body of the polyp rested. Fig. 5. Do. Curved specimen.

\section{Genus. DIPLOGRAPSUS (McCoy).}

For Gen. Char, see p. 3.

\section{Diplogratsus Foliaceus (Murch. Sp.)}

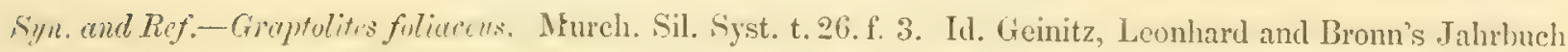
for 1812. t. 10. f. 15.

Sp. Ch.-Straight, simple, about two inches long (Geinitz), gradually tapering to the base, average width one and a half lines; cells narrow, straight, coming off from the axis at an angle of about $60^{\circ}$, forming a small sharp scrration at the margin; seven cell-denticles in the space of two lines.

If the figure above quoted of Geinitz be strictly after nature, it shews the form and size to be nearly that of the $D$. pristis, but rather wider, differing principally in the more numerous, narrower, and closer eells, producing also a smaller serration of the margin; in those latter characters it approaches the D. folinim; but when fragments of the two are compared, this is distinguished by the mueh more ofture angle at which the cells come off from the axis.

Position and Loculity. - Tare in the shale and nodules of Pentre W. of Llangynyw, Montgomeryshire (Ludlow Rock).

\section{Diplograpsus folium (His. Sp.)}

Syn. and Ref--Prionotus folium. Hisinger, Leth. Suec. t. 35. f. 8. Portlock, Geol. Rep. t. 20. f. 5.

$S p$. Ch. - Simple ovate, broadly rounded at the end, gradually tapering to the base, about five lines long, and nearly two lines wide; axis fine capillary; cells narrow, lincar, coming off at a very acute angle (about forty degrees) from the axis, and either straight or with a slight downward curvature, the distal extremity of each truneated at right angles to its length, producing small rectangular denticles with sides of equal length at the margin; seven in the space of two lines.

From the discrepancies between the two figures of Hisinger with each other, and with his description, it is clear they are not of authority; I therefore quote Portlock's figure, which, though not good, is more like all the specimens $\Upsilon$ have examined. I have little doubt of Hisinger's species being the same.

Position and Locality.-Common in the black shale of Lockerby, Dumfriesshire.

\section{Diplograpsus mucronatus ( Hall. Sp.)}

Syn. and Ref.-Graptolites mucronatus. Hall. Pal. N. Y.t. 73. f. 1.

Sp. Ch.-Polypidom simple; about one and a half inches long, and one line wide (in slate), tapering rather abruptly towards the base; denticular cells, five in the space of two lines, outer and lower margin oblique, upper margin horizontal, the angle produced into a long, slender, flexible filament; axis excessively fine hair-like.

A beatiful and distinct species, easily recognized by the little mueronate film terminating each dentiele. and which films, from their flexibility, extend in every direction, upwards and downwards, or horizontally, Professor Hall describes the species from the partially altered slates of the Hudson River group, nea" the upper limit of the New York Cambrian system (probably not far from the parallel of our ('aradoe shale).

Position and Locality.-Abundant in the partially altered slates of Cairn Ryan, Ayrshire; rare in the black shale of Pen Cerrig, Builth, Radnorshire. 


\title{
Diplograpsus rRistis (His. Sp.)
}

\author{
Syn. and Ref--Prionotus pristis. His. Leth. Suec. t. 35. f. 5 .
}

Sp. Ch.-Straight, simple, about two inches long, and one line wide, gradually tapering to the base; central axis capillary, the dissepiments diverging from it at an acute angle, their upper and lower margins parallel, forming narrow cylindrical tubes, when uncompressed, with the opening simply truncate at the outer end; when compressed, the walls of the cells form parallel lines very oblique to the axis, producing denticles at the edge, with a long straight lower, and a very short concave upper, margin; five in the space of two lines.

$$
\text { Var. } \beta \text {. Hall, Pal. N. Y. t. 72. f. 1. r. s. }
$$

This probably distinct species accompanies the above in the Utica slate of New York, and also rarely at Lockerby; it seems distinct from the true pristis by its broader, triangular teeth, slightly mucronate at the tip, and cells much less oblique to the axis; it is more strongly and broadly toothed than the $D$. mucronatus.

Position and Locality.-Common in the shale, three miles North of Builth; at Pen Cerrig; Lockerby, Dumfriesshire; Llansantfraid Slate-quarries, Denbighshire; a small doubtful fragment in the fine Caradoc sand-stone of the Hollies, Church Stretton, Shropshire.

\section{Diplograpsus ramosus (Hall. Sp.)}

Syn. and Ref.-Graptolites ramosus. Hall. (Pal. N. Y. t. 73. f. 3.)

$S p . C h$.-Polypidom several inches long, slender, two-thirds of a line wide, bifurcating at an angle of $45^{\circ}$; main stem with cell-denticles on both margins, branches with them only on the outer margin, the inner margin straight, smooth, and thickened; denticles scarcely five in the space of two lines, narrow, only slightly inclined to the axis, obtuse at the extremity, upper and lower margins sub-parallel, the wide space between each denticle with a straight edge parallel with the axis.

The small size, remoteness, and peruliar form of the denticles, distinguish to the careful observer the main stem from the $D$. pristis, and the branch from the G. Sagittarius.

Position and Locality.-Only one specimen of this very distinct species has occurred to us, in a decomposing bit of shale from an old slate-quarry between Ulverstone and Ireleth. Hall's specimens were from the "Utica slate," near Albany; and this specimen, therefore, seems to connect the bed in which it occurs with the glazed slates of Cairn Ryan, in Scotland, where most of the other Utica slate Graptolites are found.

\section{Diplograpsus rectangularts $\left(M^{c}\right.$ Coy $)$. Pl. 1. B. fig. 8. Ref.-M다. Annals Nat. Hist. 2nd S. Vol. VI. p. 271.}

$S p$. Ch.-Straight, simple, usually from one to one and a half inches long, one line wide, gradually tapering to the base, which is a fine simple point; axis fine, capillary; cells perfectly at right angles to the axis, forming square denticles to the margin, distinctly separated by rather wide parallel-sided notches, reaching two-thirds of the way to the axis; five in the space of two lines.

This species is more distinct and constant in its characters than most of the allied forms; in general appearance it approaches the D. pristis (His. Sp.), but is easily distinguished by the short square cells, set at right angles to the axis, instead of the narrow very oblique ones of that species. The only Graptolite making any approach in the form and direction of the denticles is the bicornis of Hall, which, however, is distinguished by the strong, lunate process to the base from which it derives its name-the base of the present species being a simple point, as in the $D$. pristis. There is also in most of Mrs Hall's figures a perceptible obliquity in the denticles, which so admirable an artist could not have designed for this species: the bicornute base (so commonly preserved in the D. licornis) certainly does not appear in ours. Both this and the $D$. pristis being of considerable thickness are occasionally liable to be compressed in a plane at right 
angles to that usually seen, the two rows of cells being pressed flat against each other, and so producing a form like that figured and described by Hisinger, Portlock, Hall, Sce. under the name of Crraptolites sculuris; as the numerous specimens under my examination shew every stage of the accident, I do not hesitate to recommend the suppression of that species.

Position and Locality.-Abounding in the black shale of Lockerby, Dumfriesshire.

Explanation of Figures.-Plate 1. B. fig. 8. Natural size from Lockerby, of an average sized perfect specimen, with its filiform apex preserved.-Fig. $8 \alpha$. Do. Portion magnified six diameters, shewing the rectangular form of the two rows of denticles.-Fig. 9. Do. Portion of specimen compressed at right angles to the direction of the above.-Fig. 10. Do. Shewing an intermediate state of the above accidental distortion.

\section{Diplograpsus? sextans (Hall. Sp.)}

Syn. and Ref.-Graptolites sextans. Hall. (Pal. N. Y.t. 74. f. 3.)

Sp. Ch.-Polypidom about five lines long, formed of two branches diverging from the base at an angle of $60^{\circ}$, rather less than half a line wide, inner margin of each smooth, outer margin with rather large acute denticles, having the upper margin straight, slightly inelined upwards, the lower margin slightly sigmoid, very oblique, and nearly twice the length of the upper, the projecting angle slightly mucronate; five denticles in the space of tivo lines.

From the strong affinity between this species and the D. furcatus (Hall. Sp.), I provisionally leave it in the present genus, though it differs much from the normally formed species. Those species bifid from the hase as this, the scrvatulus (Hall), Murchisuni (Beck), Sc. form a peculiar little group, having one row of cells on each branch, sometimes on the inner, sometimes on the outer edge: if necessary, they might be called Didymograpsus-the twin-graptolites.

Position and Locality.-Not uncommon in the glazed slates of Cairn Ryan, Ayrshire; Hall's locality is the Utica slates, near Albany.

\section{2nd Ord. Zoophytaria (Blainv.) \\ = Zoocorallia-octactinia $($ Ehrenb. $)=$ Alcyoniens $($ MI. Edwards. $)=$ Alcyonaria $\left(D_{\text {ana. }}\right)$}

Animal with eight equal tentacles (never more nor less), each fringed with perforated papille; individuals always united into compound masses by a common tissue, either fleshy alone, or with calcareous or siliceous grains, spicula or threads developed in the substance. When a regular calcareous corallum exists, it is invariably destitute of radiating lamellie, or internal vertical strix, and is formed by the aggregation of the earthy grains in the outer coat. When an internal axis is formed, it is fibrous, horny, spicular, or of a cork-like texture, and being secreted by the in-turned bases of all the polypes, it exhibits concentric rings of growth, and is without cells; the polypes being lodged in the outer fleshy or granular crust.

The order is divided into three families:-1st, Alcyonidce (not known in Palæozoic strata), having a fleshy or coriaceous polypiary, strengthened by irregularly arranged calcareous spicula, cells superficial; 2nd, Gorgoniade, with a distinct branching basal, corneous, calcareous, or siliceous axis, coated by a fleshy crust, strengthened by calcareous granules, in which the polypes are placed, either in impressed or in pedunculated cells; 3rd, Tubiporide, having a distinct, unradiated, tubular calcareous corallum.

\section{2nd Fam. GORGONIADE (see supra.)}

To this family I provisionally refer the two following genera, from the relation of their nearest living analogues. 


\title{
Genus. PROTOVIRGULARIA (McCoy).
}

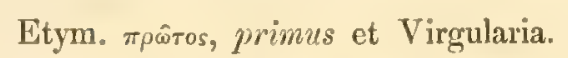 \\ Ref.-McCoy, Annals of Nat. Hist. 2nd Series, Vol. VI. p. 272.
}

Gen. Char.-Stem capillary, dichotomously branching, closely set on each side with short, alternately placed pinnules, either contracted close up to the axis in a doubly oblique alternating series, or extended with a gentle upward and outward curve, each pinnule transversely ridged, with about five parallel cylindrical cells placed at right angles to its length.

This is a most interesting type, as it perfectly resembles the recent Virgularia mirabilis in the form of its axis and the structure of the transversely ridged celluliferous pinnæ, both in the curved extended, and in the straight contracted states; while by its branching it approximates to the Hydroida; thus completing the passage between that great group and the eight-rayed corals, by the present genus on the one hand, and the free Hydroid Graptolites on the other. I know but one species which resembles at first sight the Graptolites ramosus of Hall; but that species has only simple denticles on one side of the branches, while this differs from it and all other Graptolites by its two alternating rows of moveable pinnules, transversely furrowed, apparently to contain each a number of polypes, as in the recent group to which I have approximated it. I have little doubt the so-called Graptolites amplexicaule, figured by Hall (Pal. N. York, t. 26. f. 11), may ultimately be referred to the same group, though the characteristic cellfurrows at right angles to the upper edge of the pinnules have not yet been noticed in it.

\section{Protovingularia dichotoma ( $M^{\circ}$ Coy). Pl. 1. B. figs. 11 and 12.}

\section{Ref.-Mc $\mathrm{M}^{\mathrm{C}} \mathrm{Cy}$, Annals of Nat. Hist. 2nd Series, Vol. VI. p. 272.}

One specimen, about two and a half inches long, branches twice at an angle of about $30^{\circ}$, and shews all the pinnules extended at right angles to the capillary axis with a gentle upward curvature, like the living Virgularia in the same state; another simple fragment about the same length has them half-expanded, being nearly straight and oblique to the axis; a third fragment has them quite contracted, resembling a bit of narrow braid, exactly like the contracted state of the recent Virgularia mircbilis. This one shews very plainly the transverse cell-ridging. Width rather less than one line; four pinne in the space of two lines.

Position and Locality.-In the slate at Lockerby, Dumfriesshire.

Explanation of Figures.-Plate 1. B. fig. 11. Branched specimen, natural size, from Lockerby, shewing the pinnules extended.-Fig. $11 \alpha$. Portion of ditto, magnified six diameters, shewing each of the pinnules divided by tubular sulci for the polyps.-Fig. 12. Do. Fragment with the pinnules contracted up against the stem,-Fig. 12 $\alpha$. Do. Magnified six diameters, shewing the tubular cellules on the margin of each pinnule in its contracted state.

\section{Pyritonema fasciculus $\left(M^{c} C o y\right)$. Pl. 1. B. fig. 13. \\ Ref.-M $\mathbf{M}^{\mathrm{C}} \mathrm{Coy}$, Annals of Nat. Hist. 2nd Series, Vol. VI. p. 273.}

I have proposed the above name for a singular fragment of a fossil from the dark limestone of Tre Gil, S. of Llandeilo. It is nearly straight, about two and a half inches long, four lines wide, and one and a half lines thick, and marked longitudinally with coarse thread-like ridges, about the third of a line in diameter, oceasionally cut by small sharp transverse wrinkles; the whole having some resemblance to an Ichthyodomlite (Onchus or Ctenacenthus). On first seeing the specimen I doubted this reference, from observing that the ridges, instead of being merely superficial, thicker, and more numerous at one end as they should be on this view, seemed equally thick at each end, and clearly not in one plane, but those at the surface of one part plunging into the mass and giving place to others emerging from it. Owing to the skill and kindness of Mr. Anthony, of Cains College, two sections for the microseope were prepared, which proved that the whole mass was really 
a bundle of thread-like rods of silica, corresponding exactly in diameter with the external ridges, the sections of which exactly correspond with the others in the interior; the siliceous fibres are solid, cylindrical, with slight occasional transverse rugosities; they are less than their own diameter apart, and the interstices shew no organization under a magnifying power of 330 diameters, the limestone being of a finer texture and lighter colour than that of the matrix, as if there had been originally a soft animal matter in the spaces between, which kept out the coarse calcareous mud, but the space occupied by which became filled with fine material by percolation on its decomposition. I am therefore inclined rather to compare the fossil in question with the Hyalonema of Gray, of which a short notice was published in the Zoologicul Procectinfs 183.5, being, according to that naturalist, a recent marine zoophyte allied to Gorgonia, called glass-plant by the English at Canton. It has a long, thick, rope-like axis, formed of a bundle of very long, slightly-twisted threads of pure silica, held together by a little animal matter, the whole having an external animal pulpy layer in which the polyps were lodged, and which falls away at their death, leaving the siliceous axis of glass-like fibres exposed. The analogy between these seems to me very strong, and I know of nothing else in nature like the fossil. I have named the genus from IIvpisns, silex, and $\nu \bar{\eta} \mu a$, filum. Lest the specimen might be supposed to resemble a bundle of certain Serpulae, I may mention that the rods of silica are not tubes, and have no walls.

Explanation of Figures.-Plate 1. B. fig. 13. Natural size from the Limestone of Tre Gil_-Fig. $13 \alpha$. Portion of ditto magnified three diameters, shewing the external surface of the bundle of tubes with irregular transverse plice, and sherving in the horizontal section at top the termination of the various filaments in the interior of the mass.-Fig. $13 \mathrm{~b}$. Do. Smaller portion more highly magnified, shewing the absence of intermediate structure or walls to the tubes.

\section{3rd Fam. TUBIPORIDE (see p. 9).}

\section{Genus. FISTULIPORA $\left(\boldsymbol{M}^{e} \mathrm{Coy}\right)$.}

\section{Ref.-McCoy, Annals of Nat. Hist. 2nd S. Vol. III. p. 130.}

Gen. Char.-Corallum incrusting, or forming large masses, composed of long, simple, cylindrical, thickwalled tubes, the mouths of which open as simple, equal, circular, smooth-edged cells on the surface, and having numerous transverse diaphragms at variable distances; intervals between the tuljes occupied by a cellular network of small vesicular plates, or capillary tubules traversed by diaphragms.

This genus was proposed to include the ILanon cribrosun (Gold.) of the Eifel, \&c., and some new species. They have no affinity with the fossil sponges of the genus Manon, with which the only previously known species was classed by Goldfuss and others, but are more allied to the so-called Porites of the palæozoic rocks (Palcopora, $\left.\mathbf{I}^{\mathrm{C}} \mathrm{Coy}\right)$, from which they differ in the absence of the rudimentary radiating or vertical lamella to the cell-tubes. The sides of the tubes do not seem to be perforated by connecting pores. The absence of vertical lamella induces me to place this genus among the Zoopluytariu, in the family Tubiporiclec. from the type of which (Tubipora) it will be found not to differ materially. In Tubipora we find exactly similar main tubes, but with rather less regular diaphragms: that is however merely a question of degree; the only positive difference between these genera is, that in Tubipurw the connecting vesicular tissue is developed only in distant horizontal layers with clear interspaces, while in Fistulipora it fills all the space between the main pipes.

\section{Fistulipora decipiens ( $\mathrm{I}^{c} \mathrm{Coy}$ ).}

Ref.-M대, Annals and Mag. Nat. Hist. 2nd Series, Vol. VI. p. 285.

Sp. Ch.CCorallum forming hemispherical or subcylindrical masses three or four inches in diameter, concentrically wrinkled at base; cell-tubes straight, subparallel, with moderately thick walls, leaving clearly definite, circular, smooth-edged cells in the transverse section, very regular in size and disposition, usually slightly less than half a line in diameter, and averaging rather less than their diameter in the shortest line between adjacent cells, in which line there are usually two, or more rarely three, of the intermediate vesicular cellules; about eighteen of the intermediate or polygonal cellules in the space of two lines: 
diaphragms in the small tubes slightly more or less than their diameter apart, two inter-diaphragmal spaces in the large tubes slightly exceeding the diameter.

So exactly does this resemble the Palaopore interstincta (Wahl. Sp.) (Porites pyriformis of Lonsdale, Silur. Syst.), that I have little doubt it has often been confounded with it, although an attentive examination will shew that the distinctly walled tubes are smooth within and perfectly destitute of lamell $u$. I have seen this coral also in large masses in the Upper Silurian limestone of Grothland. It may be distinguished from the very nearly allied Manon (Fistulipora) cribrosa (Gold. Sp.) by the smaller size of the cell-tubes and their greater number in a given space, their proportionate distance being pretty nearly the same. In both the British and foreign specimens the cells are so beautifully distinct that it would be impossible to overlook the notches or rudimentary lamellæ if they existed.

Position and Locality.-Forming large masses, not uncommonly in the Wenlock limestone, near Aymestry, Herefordshire.

Explanation of Figures.-Plate 1. C. fig. 1. Portion of large mass natural size, from near Aymestry, exhibiting the surface above, and rough weathered section below, shewing the main tubes distinct from the capillary cœnenchyme-Fig. $1 \alpha$. Horizontal section magnified six diameters, shewing the thick-walled non-lamelliferous circular main tubes, and the small polygonal intervening ones. - Fig. $1 \mathrm{~b}$. Side view of weathered portion, shewing the diaphragms in both sorts of vertical tubes.

\section{Genus. STROMATOPORA (Gold.)}

\section{Ref.--Gold. Fet. Germ. p. 21.}

Gen. Char.-Corallum calcareous, forming large amorphous masses, composed of very thin, superposed layers of minute vesicular tissue, of the thickness of one cell each, occasionally marked on the upper surface with extremely obscure distant quincuncially arranged small pits.

The general inpression that the Stromatopore are sponges, is, I think, manifestly incorrect, inasmuch as the vesicular tissue of the whole mass is composed of minute curved calcareous plates, forming an immovable corallum incapable of those systolic and diastolic motions, essential to the life of a sponge; on the other hand, there is an approximation to the structure between the cell-tubes of Palcopora, Fistulipora, \&c.; and it seems to me that as the Goniopora differ from the deep-celled Astrace in having their polyps exserted, and consequently forming little or no cell-cup on the surface of the corallum, so the Strometopore may be placed beside Fistulipora or Palcopora, the cell-tubes being supposed to be absent for the same reason as in the Goniopora; and this I think is rendered more likely by the existence of the small regularly-disposed obscure pits which I have noticed, and which are distant about as far from each other as the tubes of the above genera usually are; so faintly marked are they, however, that it is only by a favourable incidence of oblique light and using a lens of low power that they can in general be detected; as the specimens decompose by weathering, the depressions often become more marked, extending into the mass like holes, and perforating down through many layers, in the manner of the more strongly marked vermicular perforations of the Caunopora placenta. As neither Stromatopora, nor the subgenus Caunopora, have any radiating lamellie, they should be most probably placed among the Zoophytaria in the family Tubiporide near Fistulipora. I have noted in the Devonian species of the subgenus Caunopora, that the tubes increase (in some instances at least) by lateral budding; the young, when still imperfectly separated, not indenting the circular wall of the parent, and being much smaller; thus agreeing with the Madreporacea rather than with the Tubiporide, strengthening the impression which I entertained of the transition between these groups by Palcepora on the one hand, and Fistulipora on the other.

\section{Stromatopora striatella $(d O r b$. $)$}

Ref. and Syn--D'Orb. Prod. Pal. p. 51. Stromatopara concentrica (Lonsd. Sil. Syst. t. 15. f. 31., not of Gold.)

$S p . C h$. - Corallum forming hemispherical or flattened expansions from three to eighteen inclies in diameter, composed of extremely thin regular concentric layers of suall rounded cells; eleven or twelve layers in the 
space of one line; upper and under surface of slightly weathered specimens sherving vertical, vermicular perforations about one-fourth of a line in diameter, passing nearly at right angles through the numerous layers composing the mass, at distances varying from one to two lines apart.

This exclusively Silurian species has been confounded with the exclusively Devonian Stromatoporch concentried of Goldfuss by Mr Lonsdale (Silurian System, \&e.), and by Prof. Phillips (Palieozoic Fossils, Memoirs of the Geological Survey, Vol. II. Sc.) but has been briefly distinguished by d'Orbigny, in his recent "Prodrome," on account of the greatly fewer number of the layers in a given space, and more delicate nature of the reticulation; a conclusion to which I had independently come before receiving his volume, using the same character as an easy mode of distinguishing the Stromatopora of Newton Bushell (Devonian) limestone from that of the Silurian limestone of Wenlock. It may be well to state that I derive my notion of the true S. concentrica of Goldfuss fron authentic specimens from the Eifel. One specimen, partially weathered, from the Wenlock limestone of Wenlock edge, shews most clearly on its upper and under surfaces and crossing the vertical edges of the mass, the long tube-like perforations which have escaped general observation, and which in the more compact and better preserved specimens can searcely be seen.

Position and Locality.-Abundant in the Wenlock limestone of Wenlock, Shropshire; also in the Aymestry limestone near Aymestry, Herefordshire.

\section{3rd Ord. Zoantharia (Blainv.) \\ = Zoophyta helianthoidea (Johnston) = Actinaria (Dana).}

Animal with simple tentacles, perforated at the tip, and either six (Antipethecect), twelve (Madreporacect), or a larger number (Madrephyllacea). The individuals are either simple or compound, and either fleshy and naked, or with a strong internal, supporting calcareous corallum. The body is in all cases distinctly radiated by vertical, double, membranous lamellæ extending from the short central stomach to the outer wall; which lamellæ becoming calcified at the base in those possessing a corallum, form the stellate cells therein; each cell of the corallum is continued in the living state into a perfect individual. In the extreme young state, most coral-cells have six lamelle, and this number remains through life in the 1st Tribe, Autipathacea: subsequently a second cycle of six shorter lamella is developed, one between each pair of larger, and this number remains permanent in all the genera of the Ind Tribe, Itudreporceere. In the other grouns additional lamellæe are intercalated between these. Mr Dana notices that in those groups which are more than twelve-rayed, there are usually three smaller between each pair of larger lamella, and the number is a multiple of four, if over twenty-four; below this, if more than six, the lamellre are usually alternate, and the number a multiple of six. The Zooplyytreric having eight equal tentacles, and rays to the cells, belong to a different system.

The Order is divided into the following Tribes: 1st, Antipathacea, having six tentacles and a horny axis, of which we have no fossil examples; 2nd, DLadreporacea; 3rd, Madrephyllacea.

\section{2nd Tribe. MADREPORACEA.}

Corallum composite; composed entirely of cellular, or porous, calcareous sclerenchyme; cells small ; each cell with six primary cellulose, lamellie in the young state, usually receiving six alternating or secondary lamellie when adult, total number never exceeding twelve; interlamellar structure composed of small, irregular, often rudimentary vesicular plates, never forming diaphragms; cells remaining unfilled at base by age; no epitheca. This Tribe contains the families, 1 Madreporide ; 2 Poritides ; 3 Palacoporidos.

To this tribe I provisionally refer the genus Palcepora on account of the twelve radiating lamella to the cells; a number so characteristic of the Hadreporreca generally, with which it also agrees in the cellular texture intervening between the individual stars. The main difference between the P'alcoprobe and the true Madrepores 
is the existence in the former of transwerse diaphragms, as well as oceasionally of distinct tubular walls to the cells; thus forming a passage from the Madreproracen to the Matrephyllaced by the present corals on the one hand, and the sixteen- or eighteen-rayed Ilelioporce and Pocilloporce on the other.

\section{Genus. PALEOPORA ( $\left.M^{\circ} \mathrm{Coy}\right)$.}

Ref. and Syn.-MICoy, Annals Nat. Hist. 2nd S. Vol. III. p. 129.> Geoporites (d'Orb.) Prod. p. 49, (1850.) > Plasmopora (Edw. and Haime.) 1819.> Propora, id.

Gen. Char.-Corallum polymorphous, generally subhemispherical and concentrically ridged beneath, rarely branched; formed of cylindrical, distinctly walled, tubular cells, having internally twelve vertical sulci, or rudimentary lamell:t, and divided at irregular intervals by transverse diaphragms; the tubes surrounded and connected by a uniform minute net-work of small vesicular plates.

I have proposed this genus for most of the so-called Porites of the Palzeozoic rocks. First described by Goldfuss as Astraca, they were removed by Ehrenberg (Ueber Corallenthiere des rothen MIeeres, \&c.) and Lonsdale (Silurian System) to the recent genus Purites, in which they were followed-probahly without examination-by many writers; Profs. Bronn (Lethea, Sc.), Phillips (Palæozoic Fossils), and others, have, however, much more happily pointed out their resemblance to Hetioprere. The distinctly walled tubular cells visible in both sections, connected by cellular tissuc, with their twelve rudimentary lamellec, distinguish the present ancient corals from the modern genera just named; for Porits has a minutely reticulated or lacunose corallum impressed by shallow, polygonal, undefined cells on the upper surface, and presenting in the horizontal and vertical sections an uninterupted, irregular, uniformly vesicular structure. Hetioporc agrees perfectly in external appearance, and in the two sections exhibits the same characters of vesicular structure, connecting tubular cells with transverse diaphragms, but in it the tubes have eighteen or more rudimentary lamella, while they are constantly twelve in the present genus, which I only know as yet in the older and middle Palwozoic rocks. The species are extremely difficult to define and discriminate, owing to the diameter and distance between the main tubes varying in one mass. Since the above remarks were written, this genus has been divided into three others by MM. Edwards and Haime; but as I am unable to appreciate the distinctive characters of two of them, and the third is of very obscure structure, I refer, at present, for the genus Plasmopora, to the description of Palcopora petalliformis; for Propora, to P. tubulata; for Thecia, to $P$. expatiata.

\section{Palmopora? (Thiecia) expatiata (Lonsd. Sp.)}

Ref. and Syn.-Porites expatiate. Lonsd. Sil. Syst. t. 15. f. 3.

$S_{y}$. Ch. - Corallum forming thin flattened, irregularly mammillated expansions; upper surface with slightly impressed olsscurely polygonal, close, small cells (three to four in the space of two lines), the twelve radiating thick, rugged lamelle of which irregularly cross the rounded intervals between the cells; no distinct intermediate tubular structure.

This remarkable species is doubtfully placed in the present genus, from the apparent absence of intermediate tubular structure between the main tubes, although in some cases $I$ think $I$ have noted traces of them in the corners or widest space between four adjacent cells. I have been unable to see more of the vertical section than that the main tubes were strongly walled, and had horizontal diaphragms, two spaces between which rather more than equalled the diameter of the tube; in both the horizontal and vertical sections (only obscurely seen) the space between the cell-tubes seemed nearly solid, forming polygonal walls with a slight vermicular porosity. MM. Edwards and Haime have proposed for this species their family Thecide, and its single genus Thecia, characterized by the radiating lamelle being very much developed and united to form an abundant compact cœnenchyme and superficial stars. I cannot make out the internal structure of the coral with certainty, in any of the specimens at my disposal, but I adopt Thecia provisionally as a subgenus.

Pusition and Locality.-Not common in the Wenlock limestone of Dudley, Staffordshire, forming large flattened masses; Wenlock limestone at Wenlock, Shropshire. 


\author{
Palmopora favosa $\left(M^{\circ} \mathrm{Coy}\right)$. Pl. 1. C. fig. 3. \\ Ref.-MICoy, Annals and Mag. Nat. Hist. 2nd Series, Vol. VI. p. 285.
}

$S p$. Ch.-Corallum forming irregular rounded masses formed of prismatic tubes, opening as polygonal shallow cells on the surface, (averaging one and half lines in diameter in limestone, and about one line in sandstone), the dense narrow interspace, or thick boundary walls of the cells formed of one, or in places two, rows of small cells; concave bottoms of the stars very obscurely radiated with twelve irregular, rugged, nearly obsolete lamellar projections, scarcely distinguishable from a few intermediate granules; a small papillary axis in the centre; vertical section, clear open space of the tubes, one to one and half lines in diameter, separated by thick vertical walls (or very narrow dense interspaces of one or two rows of cells), traversed by strong distant horizontal, or slightly coneave diaphagms, varying from the diameter to little more than lialf the diameter of the tubes apart.

It is very probable that this coral should form the type of a particular genus, the polygonal cells, very narrow, dense interspaces, apparent absence of the circular tube of the cells, and the small central axis, distinguish it from the other species of Puleogron. The large masses preserved in limestone are singularly like Fucosites Cothlamelice, the surface shewing apparently the same size and shaped polygonal hollow cells, with strong divisional walls, and the rough vertical section shewing apparently prismatic tubes with distant diaphragms; a sharp eye or a lens will however detect the cellular structure of the divisional walls, and careful search will shew the radiation, \&c. of the cells; this is most distinct in a polished horizontal section. Specimens preserved in the fine sandstones present a very different appearance, forming small fig-shaped masses, covered with hexagonal, nearly smooth, or very minutely granular, convex or concave casts of the cells, with a distinct axal puncture in the centre of each: I have, however, connected them satisfactorily, though with difficulty, with the more perfectly preserved limestone examples.

Position and Locality.-Extremely abundant in the calcareous schists and limestones of Craig Head, Ayrshire; Girvan; and in the fine Caradoc sandstone of Mulock Quarry, Dalquorhan, Ayrshire.

Explanation of Figures.-Plate 1. C. fig. 3. A portion of large mass natural size, from the limestone of Craig IIead, shewing the upper surface and rough vertical fracture, exhibiting the diaphragms in the main tubes.-Fig. $3 \mu$. Vertical section magnified five diameters, shewing the narrow interstices or apparent walls of the lamelliferous tubes and diaphragms to be composed of rows of cells; with the internal lamellar sulci.-Fig. 37. Horizontal section magnified five diameters, shewing the twelve short lamelle in the main tubes, and intervening polygonal tubuli.-Fig. $3 c$. Small mass (east) from the sandstone of Dalquorlan, natural size.-Fig. $3 d$. One of the stars of ditto magnified five diameters, shewing the impressions left by the central axis and component cells.

\title{
Palmopora interstincta ( $W a h l . S p$.)
}

Syn. and Ref.-Madreporites interstinctus (Wahlenberg, Upsal. Vol. VIII.); Porites pyriformis (Lonsd. not Blainv.), Sil. Syst. t. 16. f. 2. Geoporites Lonsdalei and G. intermedia (D'Orb.) Prod. Pal. p. 49.

$S p$. Ch. C Corallum forming large sphreroidal masses composed of vertical very thin-walled tubes, usually rather less than one line in diameter (or two-thirds of a line), and about half their diameter apart, the edges with twelve very small granulations, the corresponding radiating lamelle nearly or quite obsolete in the polished section and weathered surface; intervening eapillary tubes numerous, polygonal, very fine (averaging six in one line); diaphragms, in the large tubes very numerous, irregular, about five in the space equal to the diameter of the tube; diaphragms of the capillary tubes rather more distant than their diameter.

Owing to the extreme thinness of the walls of the stellular tubes in the typical variety, they are seldom or never exhibited as separate columns by weathering as in the $P$. tubulata or $P$. megastoma, nor has it the well-developed radiating lamelle of thuse species. 'The tubes vary slightly in diameter and in their distance apart, which determines the number of minute interstitial tubes between them; these latter however are very obviously smaller and more numerous than in the other lower Palacozoic species (seldom 
less than three and often five between cach of the cell-tubes). Mr Lonsdale's reference (Sil. Syst.) of this coral to the Devonian P. pyriformis (Blainv.) is universally admitted to be injudicious. The two specific names above quoted from M. d'Orbigny, are merely given as names to the separate figures of this species in the Silurian System, without definitions; and I believe there is no specific distinetion to be drawn between them.

Pusition and Lacality.-Abundant in the Wenlock limestone near Aymestry, Herefordshire; calcareous shales, Wenlock, Shropshire; Malverns; Coniston limestone of Long Sleddale, IVestmoreland. A doubtful varicty rare in Coniston limestone at Coniston Water-Head, Lancashire, and in the impure calcareous schists of Applethwaite Common, Westmoreland.

\section{Var. $a$. subtubulata $\left(M^{c} C o y\right)$. Pl. 1. C. fig. 2.}

Sp. Ch. - Corallum composed of radiating thick-walled persistent cylindrical tubes (often exhibited separately in the weathered vertical section), with the usual diameter of half a line, generally more than their diameter apart, crenulations and radiating lamellae very small and indistinetly marked; horizontal diaphragms strong, flat, two interdiaphragmate equal to the diameter of the tube; interstitial spaces filled with very numerous, minute, capillary, polygonal tubes, the spaces between the diaphragms of which are slightly less than their diameters.

In the frequency with which the cylindrical tubes are exhibited in weathered specimens distinctly separated from the mass, as well as the distance of the diaphragms apart, this species resembles the $P$. tubulata (Lonsd. Sp.), from which it is distinguished by the distance of the tubes apart, the nearly obsolete crenulations or radiation of their interior, and by the intervening space being filled with very numerous capillary prismatic tubes; in the last two characters it approximates to the $P$. interstincta, from which it is distinguished by the greater strength of the walls of the tubes, their small diameter and greater distance from each other, and more distant diaphragms; but as I have noted a small-tubed variety of the $P$. interstincta from Malvern, apparently in some degree intermediate, I only propose this at present as a strongly-marked variety of that species.

Position and Locality.-Occurs oceasionally in the Coniston limestone of Coniston Water-Head, Lancaşhire, and Llansantfrail, Denbighshire; Wenlock limestone, near Aymestry, Herefordshire.

Explanation of Figures,-Plate 1. C. fig. 2. Portion of weathered mass, natural size, from Coniston Water, shewing the main tubes projecting in one part. $-F i g .2 \ell$. Portion of ditto magnified six diameters, shewing the weathered appearance of the base of the lamelliferous tubes and the interstitial tubules.Fig. 2b. Portion of weathered mass magnified six diameters, shewing the projecting lamelliferous tubes, and intervening polygonal tubuli.

Paleopora megastoma $\left(M^{c} C o y\right)$. Pl. 1. C. fig. 4.

Ref. and Syn.-Porites megastoma (M ${ }^{\circ} \mathrm{Coy}$ ). Syn. Sil. Fos. of Ireland, t. 4. f. 14.

$S p$. Ch.-Corallum forming large hemispherical or irregular masses; base concentrically rugose; stellular tubes averaging a line and half in diameter, with strong radiating lamelle about one-fourth the diameter of the tube in length; diaphragms strong, apparently pitted on their upper surface; interstices of small polygonal vertical tubes, (averaging five in one line); nsually about three interstitial tubes in a line between the lamelliferous tubes, which are in most cases rather less than half their diameter apart.

This species seems to replace in abundance, in the lower Silurian beds, the so-called P. pyriformis ( $P$. interstincta) of the Wenlock Rocks. It is distinguished from that species by the great size of the stellular tubes, which vary in the adult from one and half to nearly two lines in diameter, and the great proportional strength of the walls, which frequently causes them, like $P$. tubulata, to stand up as separate suleated columns in the wenthered examples; the radiating lamelle are also nuch more strongly marked in the $P$. megestome, which serves to distinguish the dwarf examples in which the tubes may occasionally sink to near the same diameter; the transverse diaphragms seem irregularly pitted on their upper surface and to be smooth below. 
Position and Locality.-Very abundant in the Coniston limestone and calcareous schists of Coniston, Lancashire; also at Mathyrafal, S. of Meifod, Montgomeryshire; and High Haume, Dalton in Furness, Lancashire; in the englomerates (at junction) of Blain y C'wm, W. of Nantyre, Glyn Ceiriog, and a variety in the Bala limestone of Maes Meillion, S. of Bala, Merionethshire.

Explanation of Figures.-Plate 1. C. fig. 4. Portion of large mass, slewing weathered impressions of the surface, natural size from Coniston.-Fig. $4 \alpha$. Stars of ditto, magnified two diameters, shewing the lamellex, cellular structure of the diaphragms, and few intervening tubuli.-Fig. $4 b$. Side view of weathered lamelliferous tubes; part of large mass natural size.

\title{
Palmopora Petalliforais $(\text { Lonsd. Sp. })^{*}$
}

\author{
Ref. and Syn._Porites petalliformis. Lonsd. Sil. Syst. t. 16. f. 4.
}

Sp. Ch.-Corallum forming irregular hemispherical masses, with coneave, nearly smooth, concentrically wrinkled epitheca on base; upper surface covered with very shallow, circular, floriform cells, about one line in diameter; diaphragms distant about two spaces equal to one diameter of the tube, with a flat circular centre, and the circumference (one fourth of the diameter) broadly undulated between the twelve petal-like radiating lamella; stars nearly in contact, the interstices occupied by small capillary prismatic tubules (about five in the space of one line).

In this beautiful species the central flattened part of the diaphragms in the shallow cells seems to have been taken by Mr Lonsdale for the tube, and the petal-like undulation between the vertical lamella, for the first row of interstitial tubules. This species is separated from the others, by MM. Edwards and Haime, to form the genus Plasmopore, on the supposition that the cell-tubes are united by large vertical radiating lamellax, but a very careful examination of several large masses has convinced me that this ground of distinction cannot be depended on.

Position and Locality.-In the Coniston limestone of Sunny Brow near Coniston, Lancashire; and the impure limestone of Golugoed, Mandinam, Caermarthenshire.

\section{Paleopora subtilis ( $1 /$ C COy $^{2}$ ).}

\section{Ref.-MCoy. Annals Nat. Hist. 2nd Series, Vol. VI.}

Sp. Ch.CCorallum forming cylindrical branches, usually one and a half to two lines in diameter; large stellular tubes about one sixth of a line in diameter, and a little more or less than their diameter apart; polygonal intervening tubuli invisible to the naked eye, usually five between adjacent cell-tubes, or about thirty in the space of one line; three cell-tubes with their intervening tubuli in a space of one line; main tubes often weathering as separate sulcated columns.

In the middle of the branches the cell-tubes seem to be parallel and vertical, but diverge rapidly at the circumference, to reach the surface; they are very often weathered as separate tubuli, as in the $P$. subtululctu and $P$. tibuluta, and on the other hand they often break away from casts of the surface, leaving so little trace among the intervening tubuli, that the surface seems merely shagreened under the lens, and bearing some resemblance to the Ptilodictya (S'tictopora) fucoides ( $\mathrm{M}^{\mathrm{C}} \mathrm{Coy}$ ), but the casts of the cells are polygonal instead of oval, and far more minute in the present coral. The extreme minuteness of the parts of this species distinguish it easily from the $P$. subtubulata, to which alone it has any affinity.

Position and Locality.-Very common in the fine Caradoc Sandstone of Mulock, Dalquorhan, Ayrshire.

* As these pages were passing through the press, I received MI. Edwards and Haime's great English Memoir on Corals, but at too late a period to profit materially from the new portions not previously published in the Comptes Rendus. 


\section{Palzopora tubulata (Lonsd. Sp.)}

Ref. and Syn.-Porites tubulata, (Lonsd. Sil. Syst. t. 16. f. 3). Astrcopora Lonsdalei, and A. grandis, (D’orb. Prod. Pal. p. 50, nom.)

Sp. Ch. C Corallum forming large hemispherical masses of equal, regular, very thick-walled tubes, slightly more than half a line in diameter, and about half their diameter apart; on the surface the edges project and are strongly crenate, the radiating lamelle being about one third the diameter; intervening cellular space, very open, loose, and irregular, being most frequently a single plate from one cell to the other, and very rarely more than two irregularly united, appearing in the vertical section as horizontal or oblique irregular vesicular plates; weathered vertical fractures shew the stellular tubes separated as long distinct suleated columus; diaphragms in the large tubes about two in a space equalling their diameter; in the interstitial structure, the diaphragms are rather less than the diameter of the tubes apart, their upper surface granulated.

From the strength of the walls of the lamelliferous tubes and the small number of the intervening cellular tubules the former often remain as slender persistant columns, often four inches in length; the small diameter of the tubes, and the absence of the numerous small cellular openings of intermediate tubes between them, easily distinguish this abundant species from the $P$. megastoma $\left(\mathbf{M}^{c} \mathrm{Cny}\right)$. The two new names above quoted from M. D'Orbigny, are mere nominal references to the two typical figures of Lonsdale's species in the "Silurian System." The size and relative distance of the large tubes, and other characters are much more constant than in most of the genus. The upper surface of the diaphragms seems to be pitted or cellular. This species forms the type of the genus Propora of MM. Edwards and Haime, from the margin of the cells being prominent, and the radiating lamellse strongly developed, but I am unable to appreciate the grounds of generic distinction from the other species.

Position and Locality.-Abundant, forming large masses in the Wenlock limestone at Aymestry, Herefordshire, and Wenlock, Shropshire; a variety ( $(\ell)$ with a row of one or two small polygonal tubules between the cells, rare in the Coniston limestone of Coniston Water Head, Lancashire, and the same doubtful variety in the conglomerate of AIt Goch, Llanfyllin, Montgomeryshire; good specimen in the limestone of the same locality, and calcarcous schists of Golugoed. Well-marked specimens in the schists of Alt Goch; Caradoc Sandstone of Mulock, Dalquorhan, Ayrshire.

\section{3rd Tribe. MADREPHYLLACEA.}

= (Zoantharia aporosa, Edw. and Haime. + Eupsammide, Edw. and Haime.) + Zoantharia tabulata, E. and $\mathrm{H}_{\text {. }}+$ Zoantharia rugosa, E. and $\mathrm{H}$.

Corallum calcareous, simple or compound; radiating lamella rarely obsolete, usually well developed, each of two strong plates, and very numerous, always (when present) exceeding twelve in number; usually connected by transverse vesicular plates; usually an external wall or epitheca.

With a strong predisposition to view the Cyythophylleced and Coryophylleced as separate tribes equalling the Madreporacea in value, I carefully studied a considerable series of recent and fossil corals with the growing conviction that the grounds of separation hitherto stated were insufficient, viz. the absence of fission, the greater strength of the interstitial plates in proportion to the lamelle, and some obscure numerical properties of the lamelli, in the former group. The last point of difference (if it exists) has never been definitely stated, and I believe is incapable of definition, and fission of the centre is well known to occur in the Cyathophyllum (Strephodes) Helianthoides of Goldfuss, as well as in all the species of Diphyphyllim, which latter, in other respects, are highly typical Cyathoplyglle: I therefore prefer, for the present, falling back on Blainville's larger group Madrephyllacea as the third tribe of the Zoantharia, and considering the groups just mentioned, as well as the other main groups of many-rayed corals, to form distinct families only therein.

On this view the tribe would contain the following families: 1, Milleporide; 2, Cyathophyllides; 3, Astraidas 4, Oculinido; 5, Fungida ; 6, Turbinolida. 
1st Family. MILLEPORIDE.

Corallum polymorphous; cell-tubes small, numerous, distinetly walled; lamella redneed to rudimentary stria, exceeding twelve in number; transverse diaphragms numerous, strong, distinctly separated.

Contains the Subfamilies:-1, Milleporino (not found in the Lower Palæozoic rocks); 2, Favositine; 3, Chatetine: 4, Halysitine.

\section{2nd Subfamily. FAVOSITINE.}

Corallum massive; cell-tuhes of moderate size, in contact: no coenenchyme: walls perforated by connecting pores; lamellæ nearly obsolete, usually forming numerous vertical internal strix.

MII. Edwards and Haime place the Pocilloporce in their family Favositide, but as these have an abundant conenchyme, I think they would be better placed with the Seriatopores, with which they seem to agree in structural details, and might be referred to the family Oculinida.

This sub-family contains the following Genera: 1, Favosites; 2, Alveolites; 3, Conites; 4, Nebulipora ; 5, Michelinea.

\section{Genus. FAVOSITES (Lam. restricted.) \\ = Calamopora (Gold.)}

Gen. Char.-Corallum composed of very numerous tubes, rounded, or prismatic and polygonal (from mutual pressure), traversed by numerous horizontal diaphragnins; destitute of vertical radiating lamellie, or internal sulci; sides or angles with distinct communicating pores; young tubes formed by lateral budding or interpolation, mouths of the tubes opening at right angles to their length.

Distinguished from Chatetes by the lateral communicating fores; by the young being added by interpolation and not by fission or splitting of the old tubes, and, as a consequenee of this mode of development, the exterior walls of the tubes being exposed by rough vertical fracture.

\section{Favosites alveolaris (Gold.)}

Ref. and Syn.-Gold. Pet. Germ. t. 26. f. 1. Id. Lonsd. Sil. Syst. t. 15. bis. f. 2.+ Var. a. Farosites multipora. Lonsd. Sil. Syst. t. 15. bis. f. 5 .

Sp. Ch.-Corallum forming large irregular masses, or small hemispherical expansions, with concentrically wrinkled flattened base, impressed by the rhomboidal slightly oblique bases of the tubes; tubes from four to six angled, the latter being adult with the average diameter of one line, the former being the young tubes, which are fer, and smaller; diaphragms flat irregularly indented, or undulated at the margins, placed at slightly unequal distances, averaging two or three intervals to the width of a tube; exterior wall of the tubes with four to six vertical, slightly irregular, rows of impressed foramina on each face, the angles of the columns, when not perfectly in contact, connected by small transverse papiliate processes about as distant as the diaphragms, varying greatly in prominence, and oceasionally absent.

The forms of the tubes of this species are not so regular as Mr Lonsdale's description indicates, but follow the same variations as the $F$. Gothlandica, the young tubes being, however, less numerous. The great variation in size of the connecting processes on the angles of the tubes in the $F$. alveolaris has been noticed by Lonsdale, but they have escaped him in what I have no hesitation in considering a variety-his $F$.multipore, they are distinet on most specimens, and shew the perfect transition of that species, or variety, to the true $F$. alveolaris of Goldfuss (which has also several rows of pores on each face of the tube in Goldfuss's, and part of Lonsdale's figure). I see no reason for believing the processes on the angles to be perforated.

Position and Locality.-Abundant in the impure limestone of Mathyrafal, S. of Meifod, Montgomeryshire, and in the conglomerate under the limestone of same place; Llansantfrail, Glyn Ceiriog, Denbighshire; Pen y Craig, above Glyn, Llangynyw, Montgomeryshire; Llangynyw Rectory; schists of Grolugoed, Mandinam, Cacrmarthenshire; sandy schists, Alt Goch, Llanfyllin, Montgomeryshire; and Middleton Park, Llandeilo; heds on the lower limestone of Mynydd Fron Frys, five miles IV. of Chirk, Glyn Ceiriog, Denbighshire; Cefn y coed Quarry, Glyn Ceiriog, Denbighshire. 


\section{Favosites aspera $(d \%$ r $b$.)}

Ref. and Syn.-(Nom.) D'Orb. Prod. Pal. p. $49 ;-F$. alveolaris. Sil. Syst. t. 15. f. 1. (not f. 2, nor of Goldfuss.)

Sp. Ch.-Corallum forming large, irregular, masses of small polygonal subequal tubes, averaging half a line in diameter; external walls with the faces nearly smooth, (? unpunctured), faintly wrinkled transversely, the angles very rough with large mammilate connecting (?tubuli); diaphrarms flattened with a slight central boss, about one-third of a line apart, but varying a little in this respect.

This species is easily distinguished from the $F$. alveolaris (Gold.) by the comparatively very small size of the tubes (averaging one-third the diameter of that species), by their external wall being apparently unpunctured, by the diaphragms not being indented at the margins, but having a central boss, as in the F. favosa. An English specimen of this species, in Count Münster's collection, received from him the manuscript name, Calanopora crinclis, but as I can find no published record of this name, I adopt that suggested in M. d'Orbigny's "Prodrome," in referring to Lonsdale's figure as above.

Position and Locality.-Abundant, forming great masses in the Wenlock limestone, near Aymestry, Herefordshire; in the Wenlock limestone of Dudley, Staffordshire; Malverns, Worcestershire; Ledbury, Herefordshire; near Wenlock, Shropshire.

\section{Favosites crassa $\left(M^{c} C O y\right)$. Pl. 1. C. fig. 9.}

\section{Ref.-(M $\left.{ }^{\mathrm{c}} \mathrm{Coy}\right)$. Ann. Nat. Hist. 2nd Series, Vol. VI. p. 284.}

$\left.s^{\prime}\right)$. Ch _Corallum forming large, subcylindrical, curved branches, composed of long, slightly diverging. remarkably regular and equal prismatic tubes, opening as thin-walled polygonal cells on the surface, with a nearly uniform diameter of half a line; two rows of pores on each face of the prismatic tubes, diaphragms either slightly more or less than the diameter of the tubes apart; interpolated young tubes few.

In the general characters of the tubes and connecting foramina this species nearly agrees with $F$. Gothlandica, from which it is distinguished by the elongate, branch-like form of the general mass, by the tubes averaging rather less than half the diameter, and being far more uniform in size than in that species, owing to the small number of interpolated young tubes, connected probably with the shape of the corallum being elongated, instead of forming low wide masses, as in F. Gothlandica. I suspect this to be the coral occasionally quoted as the Devonian $F$. polymorpha in Silurian rocks, a species which is very distinct from the present, and which I have never myself seen in Silurian strata, nor have I seen any recognisable figure of a Silurian specimen: as, however, the essential characters are neither described nor figured, I do not like to refer to the figure (t. 15. f. 2) of the so-called $F$. polymorpha, given by Mr Lonsdale in the Sil. Syst, although the size of the tubes coincides. This latter figure is placed in the genus Alveolites by M. d'Orbigny, under the name (without definition) of A. Lonsdalei.

Position and Locality.-Masses two inches in diameter, and six inches long, in the Coniston limestone, Coniston Water-Head, Lancashire.

Explanation of Figures.-Plate 1. C. fig. 9. Portion of large branching lobed mass, natural size, from Coniston Water.-Fig. 9 a. Portion of ditto, magnified eight diameters, shewing the projections of the diaphragms, and rows of connecting pores.

\section{Favosites Gotulandica (Linn. Sp.)}

Syn. and Ref.-Corallium Gothlandicum. (Lin.) Amæn. Acad.t. 4. f. 27. Calamopora Gothlandica. (Gold.) Pet. Germ.t. 26. f. 3.

Sp. Ch. - Corallum forming irregularly pyriform or very large circular, slightly convex masses, with concentrically wrinkled base; composed of polygonal tubes, averaging one line in diameter when adult (but with occasional large irregular spaces in which the diameter is only half a line), with very numerous, young, smaller, irregularly interpolated columns of smaller diameter, and fewer angles; transverse dia- 
phragms flat, about three in the space of one diameter; external walls as exposed in rough vertical fracture, slightly roughened by small transverse wrinkles, which obscurely crenulate the edges, sides with one or two rows of large round communicating pores.

I agree with Mr Lonsdale in thinking that the Farosites basaltica (Gold. sp.) characterized by having but one row of pores on each face of the tubes, should be viewed as only a variety of this species, as I think I have seen from one to three rows in portions of a single mass.

Specimens from Gerolstein, in the Eifel, seemed to agree (on the most careful comparison of good specimens) perfectly with the Silurian ones from Wenlock, and the carboniferous ones from Derbyshire. The great number of the young tules gives a peculiar irregularity of aspect to the surface of this species.

Position and Locality.-Common in the Wenlock limestone of Dudley, Staffordshire; and near Wenlock, Shropshire; Golu Goed, Mandinam, Caermarthenshire; Ledbury, Herefordshire; limestone near Old Radnor, Presteigne, Radnorshire.

\section{Favosites? oculata (Gold. Sp.)}

\section{Ref. and Syn.-Ceriopora oculata. Gold. Pet. Germ. t.65. f. 14. Millepora repens. Lonsd. Sil. Syst.} t. 15. f. 30, (not of Hisinger.)

sp. Ch._-Corallum forming dense, eylindrical branches about a line in diameter, and bifurcating at lengths of three or four lines; openings of the cell-tubes very large, circular (about four or five in half the circumference) arranged in longitudinally spiral lines, their lower margins very prominent, inner and upper margins undefined; walls very thick; cells about their diameter apart, measured in vertical lines (three to four in one line) or half their diameter apart, measured transversely (five in one line); tubes penetrating the branches very obliquely; transverse diaphragms far apart, connecting foramina few, distant, very large.

The abundance and compactness of the apparent cenenchyme, as well as the regular linear arrangement of the large round cell-tubes, when worn smooth, gives this coral almost exactly the appearance of Serictopor", but there is no trace of radiating lamelice, nor central style, and I have also noticed the large few connecting pores as in the $F$. spongites: both these species agree in the great thickness of the walls of the tubes resembling conenchyme, and the obliquity of the opening of the tubes on the surface, their lower margins only being prominent; differing in these respects from the true Farosites; and if the circular form of the mouth was only a specific character, I should prefer including it with that fossil in the genus $C u^{\prime} n i t e s$ of Eichwald, in the typical species of which I notice much of the same general character, compactness of structure, and oblique openings prominent only in the lower half. I think, as Eichwald suggests in his Urwelt Russlands, that the Millepora repens of Lonsdale, in the "Silurian System," is not the coral soealled by Hisinger, to which he refers it, but that the latter is truly a Cocnites, probably identical with the so-called Limaria clathrate; the present coral being, however, obviously the Baltic species figured by Fougt in the Amenitates Academica of Linné.

Position and Locality.-Abundant in the Wenlock limestone, near Aymestry, Herefordshire.

\section{Gemus. COENITES (Eichw.) 1829.}

\section{Ref. and Syn.-Eichwald, Zoologia specialis. p. $179=$ Limaria (Stein.)}

Cren. Char._Corallum simple or branched, cell-tubes vertical, or divaricating, oblique to the surface, openings irregular, prominent, triangular, quincuncially arranged, lower margin (or angle) most prominent, giving a file-like or squamose aspect to the surface, interstices very thick, compact, increasing by age and reducing the cavity of the cell-tubes; no trace of radiating lamella, transverse diaphragms distinct; communicating pores large, few.

That the genus Canites of Eichwald is perfectly identical with Limaric of Steininger there can be no doubt; neither of these writers detected the internal structure, which I lave found horvever to resemble Furcositis in the transverse diaphragms to the tubes; both writers found the genus on the triangular form of the oblique openings of the cells, Steininger stating, that that is the only difference between it and his genus Tlumnoporu, 
formed for those Farosites with branches composed of oblique divaricating tubes. I find that the tubes are hexagonal in the interior, but distinguished remarkably from the true Favosites by the great thickness of the walls, especially at the surface, where they resemble an abundant compact coenenchyme, widely separating and often almost closing the apertures. I have only indistinctly seen the connecting pores.

\section{Conites intertextus (Eichw.)}

Ref. and Syn._Eichwald, Zool. Specialis, t. 2. f. 16, and remarks, p. 42, of Truelt Russlands; = Limaria clathrata. Lonsd. Sil. Syst. t. 16. bis. f. 7.

$S_{p . C h}$-Corallum forming irregular, cylindrical or compressed branches, two or three lines in diameter, dichotomising irregularly, and oceasionally anastomosing; apparent conenchyme very abundant and compact; cells three to four in an oblique line in the space of one line; when most developed, quineuncially arranged, rather less than their diameter apart, triangular, usually broader than long, anterior margin, broadly rounded, posterior or inferior prominent angle separated from the lateral angles by a large prominent tooth, projecting inwards from each of the straight sides; in other states the posterior angle shortens, and the arched cells nearly close by the increased thickness of the compact intervening tissue, leaving slender transverse doublyarched impressed lines, for the cell-apertures; in other states (probally worn) the compact pseudo-coenenchyme is of very variable extent, and the cell-openings are of very irregular size and shape, for the most part triangular, rhombic, or irregularly rounded; surface under the lens between the cells very minutely granular, and marked with conentric lines round each opening; transverse diaphragms rather more than the diameter of the tubes apart.

The changes of form in the apertures of the cell-tulhes in this cornl are extremely remarkable and difficult to account for, but do not in practice cause much diffienlty, as almost every specimen shews in some part the characteristic transversely-arehed triangular forms of the perfect cells; the triangular or irregular form of the apertures, and their being scparated by such a distance of compact interstitial matter, or thicked walls, prevents this coral being confounded witl any of the polygonal-celled Favosites, or round-celled Stenopores.

Position and Locality.-Common in the Wenlock limestone near Aymestry, Herefordshire, in company with the Favosites? oculata (Gold.) sp. also in the Wenlock limestone at Dudley, Staffordshire; one very irregular doubtful specimen from the Wenlock limestone near Sedgely.

\section{Coenites strigatus $\left(M{ }^{\circ} C o y\right)$. Pl. 1 . C. fig. 8.}

Ref.-M Moy, Annals Nat. Hist. 2nd Series, Vol. VI.

Sp. Ch.-Corallum forming cylindrical, dichotomous branches, two to three lines in diameter; surface with small, narrow, triangular cells, the base of the triangle below, and the apex usually more or less prolonged upwards into a vermiform channel, often upwards of half a line long; four to five rows of cells in the space of one line, measured transversely, about two in the same space measured longitudinally; compact interstitial space between the rows of cell-openings usually rather exceeding their width.

The usual compact appearance of the Conites combined in this species with the interrupted scratch-like channels of the cell-mouths, completely distinguishes it from any species of Favosites or Stenopora.

Position and Locality.-Not uncommon in the Wenlock limestone of Dudley, Staffordshire.

Explanation of Figures.-Plate 1. C. fig. 8. Branch natural size, from Dudley.-Fig. 8 a. Portion of do. magnified four diameters.

\section{Genus. NEBULIPORA $\left(M^{\circ}\right.$ Coy).}

\section{Ref.-MCoy, Ann. Nat. Hist. 2nd Series, Vol. VI. p. 282.}

Gen. Char.-Corallum incrusting or forming lenticular masses, with a concentrically wrinkled epitheca below; composed of small prismatic tubes perpendicular, or nearly so, to the upper surface on which they open; among the small tubes, are regularly arranged clusters of similar tubes of rather larger size; all the tuhes in contact, traversed by horizontal diaphragms at regular distances, (walls apparently perforated hy rows of small foramina). 
The Farosites? favulosa (Phill.) Mem. Geol. Surv. Vol. II. is the only published species I know of this genus, which differs from Fucosites in the clusters of enlarged tube-cells at subregular intervals, and from Stromatopora by the tubules being regularly prismatic, with diaphragms and connecting pores.

\section{Nebulipora explanata $\left(M^{c} C o y\right)$. Pl. 1. C. fig. 6.}

\section{Ref.-N'Coy, Ann. Nat. Hist. 2nd Series, Vol. VI. p. 283.}

Sp. Ch.-Corallum forming very thin, irregularly expanded, lamini, upward of two inches long, covered above with nearly regular, quincuncially arranged, flat or slightly depressed, nebular clusters of larger tubes, about one and half lines in diameter, and rather less than twice their diameter apart (about twelve or fourteen cells between one centre and the next); smaller intermediate tubes about six in one line.

To the naked eye the whole of the tubular structure of this coral is manifestly coarser than in the $N$. lens, from which it differs in its large, irregular, foliaceous expansions of growth; it seems that the proportion (one lundred and fifty to an inch) of small cells in a given space was also greater in the $F$. (Nebulipora) favulosa (Phill. sp.), to which I should have otherwise referred it.

Position and Locality._Coniston limestone, Coniston, Lancashire; limestone of Applethwaite Common, IVestmoreland.

Explanation of Figures.-Plate 1. C. fig. 6. Portion of irregular foliaceous expansion, natural size, from Coniston.-Fig. $6 a$. Portion of surface magnified four diameters, shewing the eluster of larger tubes, including a few small ones, and surrounded by the numerous, uniform, smaller tubuli.

\section{Nebulipora lens $\left(\boldsymbol{I}^{\mathrm{C}} \mathrm{Coy}\right)$. Pl. 1. C. fig. 7.}

\section{Ref.-McCoy, Ann. Nat. Hist. 2nd Series, Vol. V1. p. 283.}

$S p . C h$. C Corallum forming lenticular masses, averaging ten lines in diameter, and one and half lines thick in the middle, gradually thinning to the edge; base slightly concave, with small concentric wrinkles; upper surface evenly convex; clusters of large cells rounded, flat or slightly concave, about one line in diameter, and usually a little more than their diameter apart (averaging from sixteen to twenty cells between one centre and another): smaller tubes averaging eight in one line, larger tubes of the clusters averaging four or five in one line; two inter-diaphragmal spaces equal the diameter of the tubes; apparently two irregular, close rows of connecting pores on each face of each tube.

When imperfectly developed or rubbed, it is difficult to recognise the imperfect star-like clusters of large tubes. The structure not being composed of concentric layers round a central nucleus, and the appearance of the mouths of the tubes on the upper surface easily distinguish this fossil from the stromatopora nummulitisimitis (Lonsd.). Owing to the minuteness and imperfect mode of preservation, it is difficult to be satisfied about the connecting pores, but from the appearance under a high power of several specimens, I have little doubt they are, as in the above notice.

Position and Locality.-In great abundance, clustered like Nummulites in some parts of the fine Caradoc sandstone of Horderly West; more rare in the schists of Moel Uchlas? Pont $y$ Glyn, Diffiws, near Corwen. Cwm of the Cymmerig, Bala.

Explanation of Figures.-Plate 1. C. fig. 7. Portion of mass, containing numerous lenticular specimens, natural size, from Caradoe sandstone of Horderly; the right-hand figure shewing upper surface with the imperfect star-like clusters of large tubes, at regular distances, surrounded by numerous uniform smaller tubes; the left-hand figure shews the central nucleus of base; the edge of the mass shews the form of the section, of two individuals.-Fig. $7 \alpha$. Portion, of surface magnified four diameters, shewing the nebular clusters of larger tubes amongst the smaller,-Fig. $7 \mathrm{~b}$. View of portion of vertical weathered section, magnified ten diameters, shewing the diaphragms of the tubes. 


\section{Nebulipora papillata $\left(M{ }^{\circ}\right.$ Coy). Pl. 1. C. fig. 5. \\ Ref.-McCoy, Ann. Nat. Hist. 2nd Series, Vol. VI. p. 284.}

$S p$. Ch.-Corallum forming very thin layers (usully coating Orthoceratites); clusters of large cells elevated into conical papillæ, about ten in each cluster; the papillæe a little wider than high, usually about twice their diameter apart, quincuncially arranged; thickness of corallum usually less than half a line, diameter of papillo about half a line, distance apart about one line; about nine or ten of the smaller cells occupy one line.

Position and Locality.-Not very uncommon coating Orthoceratites in the upper Ludlow rock of Brigsteer, Kendal, Westmoreland; and Coniston flags of Coniston, Laneashire; also at Firbank, Sedbergh, Kendal.

Explanation of Figures.-Plate 1. C. fig. 5. Natural size coating an Orthoceratite from Coniston.Fig. $5 a$. Portion of surface magnified six diameters.

\section{2nd Subfamily. CHETETIN E.}

Corallum resembling that of the Facositine in general structure, but the walls imperforate; lamellit obsolete. This subfamily contains the Genera.-1, Chatetes; 2, Stenopora.

\section{Genus. STENOPORA (Lonsd.)}

Ref. and Syn.-Lonsd. Appendix to Darwin on Volcanic Islands and Strezelecki's New S. Wales = Tubuliclida. Lonsd.

Gen. Char.-.-Polypidom polymorphous, composed of round or polygonal tubes radiating from an imaginary axis to the surface, where the bounding ridges are tubereulated; young tubes interpolated by lateral budding between the old; tubes constricted at irregular distances in planes parallel with the surface, and partially closed at the orifice by a concave diaphagm perforated in the centre; no connecting tubuli, nor foramina.

In some species the tubes are polygonal throughout, in others they are polygonal in the middle where closely packed, and round near the surface where further apart. The interior of the tubes exhibits only imperfect diaphragms perforated in the middle. This genus differs from Chatetes by the constrictions of the tubes and the young ones being interpolated between the old (by lateral budding), so that a fracture exposes the outer walls. (In Chetetes the old tubes divide by fissiparous gemmation, and a rough fracture exposes the interior of the tubes.)

\section{Stenopora fibrosa (Gold. Sp.)}

Ref. and Syn.-Favosites fibrosa Gold. Pet. Germ. t. 28. f. 3. and 4. id. Sil. Syst. t. 15. bis f. 6. =F. Lycopodites Say and Hall. Pal. N. Y.t. 23. f. 1, 2, 3, and t. 24. f. 1 .

Sp. Ch. - Corallum polymorphous, usually forming cylindrical branches composed of polygonal tubes (usually six in the space of one line), slightly and irregularly flexuous, nearly straight in the middle, abruptly bending outwards to the surface near the sides, edges and sides smooth or marked in parts with strong, close, inequalities of growth forming tubercles on the angular edges, and wrinkles across the sides; young interpolated tubes rapidly reaching their full diameter; substance of the tubes thick, the interior cylindrical, traversed by numerous diaphragms, at irregular distances, usually the width of the tubes apart, sometimes in places irregularly crowded: surface having a net-work of polygonal ridges with an inner concave space in which is the small round aperture (six in one line usually).

\section{Var. a. Lycopodites (Say.)}

Corallum hemispherical, growing from a flat, oval, concentrically wrinkled, membraneous base; cells and characters of the tubes as in the above. 


\section{Var. $\beta$. Regularis ( I $^{\circ}$ Coy). = Alvealites fibrosa (Lonsd.) Sil. Syst. t. 15. f. 1.}

Corallum investing univalve shells; tubes one or two lines high; diaphragms at the same height in adjacent tubes.

The best glasses at my disposal fail to shew connecting pores on the tubes in a great variety of specimens, and I have no doubt of their absence; the rugged tubercles sometimes developed with much regularity on the angular edges of the tubes have, I suspect, been taken for pores in some cases, but even where they exist, parts of the same mass will be found with the more ordinary character of smooth edges. The var. $\beta$, seems to me properly referrible to this genus and species; the peculiar character of the uniformity of height of the diaphragms being probably produced by the uniform height and age of the tubes. With regard to the hemispherical peculiar variety named Facosites Lycoporlites (Say.), I have not quite traced the intermediate links between it and the polymorphous or branched varieties, with which however it is identical in the size and all points of structure of the tubes. The original American specimens figured by Goldfuss, represent the characters of the coarser varieties, as seen by the naked eye, so faithfully, that I am surprised the American writers have not adopted his name. The slender cylindrical, separated tubules, exposed in some weathered sandstone or shale specimens, are casts of the interior of the tubes, the coral being gone. With regard to the Chatetes Petropolitana of Fischer, which seems so identical with the $F$. Ly/copoclite's, as Mr Lonsdale (Geol. Russ.) distinctly states that the fracture and other characters of the tubes were those of Chatetes, as distinguished by him from Favosites and Stenopora, it must be generically distinct from the American and our British coral, in which the fracture exposes the exterior only of the tubes, and the growth of which is clearly by interpolation.

The Dudley specimens I have examined of the Ceriopora punctata and C.affinis of Goldfuss, seem to differ from the Eifel specimens bearing the same name, the latter being apparently the true types, the former being, I have no doubt, young branches of Stenopora fibrosa, only differing from the ordinary examples in having about eight pores in the space of a line, and the young cells proportionally more numerous.

Position and Locality.-Var. Lycopodites.-Abundant in the Coniston limestone, Coniston Water-Head, Lancashire; limestone of Carler Dinmael, near Corwen, Denbighshire; schists of Llansantfraid, Glyn Ceiriog. Denbighshire: Bryn Melyn; Blain y Cwm, W. of Nantyre, Glyn Ceiring; Mnel Tehlas; Caradoc sandstone of Alt yr Anker, Montgomeryshire; schists, hills N. of Conway Falls; schist, (ielli Grin, Bala; schists, Selothyn lioad; schists, Tan y Bwlch y Groes, S. of Bala. Var. regularis, schists, Blaen y Cwm, IV. of Nantyre, Glyn Ceiriog; Upper Ludlow Rock, Kendal. Branched and polymorphous vars., Wenlock limestone of Sedgley; Wenlock limestone of Dudley; ('oniston limestone, Hortons, in Ribblesdale, Yorkshire; limestone of Pont y Glyn Diffwrs, W. of C'orwen; Coniston limestone of Coniston Water-Head, Lancashire; calcareous schists of Bryn Melyn ; limestone, St Helen's, Westmoreland; schists of Cim y Brain, W. of Wrexham, Denbighshire; limestone of Llansantfraid, Glyn Ceiriog, Denbighshire; schists of Gelli Grin, Bala; limestone, Mathyrafal, S. of Meifod, Montgomeryshire; slates of Blain y Cwm, W. of Nantyre, Glyn Ceiriog; limestone and sandstone of Alt yr Anker, Meifod, Montgomeryshire; schists, Pentrys, near Meifod; limestone of Girvan, Ayrshire; schists of Corwen, Merionethshire; limestone of Llandeilo, Caermarthenshire: limestone, Golugoed, Mandinam, Caermarthenshire; schists, Conway Falls; sandstone, Tre Giil, S. of Llandeilo; Upper Ludlow Rock of Helms Knot, Dent, Yorkshire; and Rother Heath, Kendal, Westmoreland; schists of Bryn Eithin, S. of Mathyrafal, Montgomeryshire; limestone, Old Radnor, Presteign, Radnorshire; schists of Tyn y Cabled; limestone of Applethwaite Common, Westmoreland; schists of Tyn y Bwlch y Groes, S. of Bala; slates, S. of Llanfyllin, Montgomeryshire; Caradoc sandstone, Acton Scot, Church Stretton, Shropshire; slates of Tottlebank Heights, Coniston Water-Head, Lancashire; sandy schists of Goldengrove, Llandeilo; schists, Alt Goch, Llanfyllin. Montgomeryshire; sandy schists of Cader Dinmael, near Corwen, Denbighshire. A small variety with curved, frequently forked, branches, about half a line in diameter, occurs not uncommonly in the schists of Alt Goch, Montgomeryshire, and near Llanfyllin. 


\section{Stenopora? granulosa (Gold. Sp.)}

Syn. and Ref.-Ceriopora granulosa, Gold. Pet. Germ. t. 64. f. 13.

Sp. Ch.-Corallum forming varicose, or irregularly swollen, eylindrical, dichotomous branches, about two lines in diameter, covered with irregularly polygonal small cell-openings, about five in the space of one line measured transversely, or four in the same space measured longitudinally; cells separated by obtuse spaces about their own diameter in width, each surrounded (when well preserved) with a row of about twelve large obtuse granules.

From the irregularity of the shape of the cell-openings and the obtuseness of the thick interspaces, I have some doubts of this coral belonging to the genus Stenopord, these points rendering it possible the species may be an aberrant Conites.

Position and Locality.-Wenlock limestone, Dudley, Staffordshire.

\section{4th Subfamily. HALYSITIN E.}

Cell-tubes more or less separate, either connected by the lateral union of two sides, in linear series, or by transverse tubules; lamella forming rudimentary internal strix; diaphragms strong, usually imperfect in the middle; walls strong imperforate.

Genera:-1, Halysites; 2, Syringopora; 3, Thecostegites; 4, Aulopora; 5, Cladochonus.

$$
\begin{gathered}
\text { Genus. HALYSITES (Fisch.) } \\
\text { Sym. }=\text { Catenipora. (Gold.) }
\end{gathered}
$$

Gen. Char.-Corallum of numerous rarely dichotomous tubes laterally united in numerous elliptical or irregularly labyrinthine cylindrical groups, their mouths opening nearly at one level in an open chain pattern; each tube with about fourteen or sixteen internal vertical sulci (rudimentary lamella), and transversed by numerous internal funnel-shaped diaphragms.

This genus is closely related to syringuporc (Goldfuss), differing mainly in the lateral union of the branches into contorted cylindrical groups. The increase is by lateral budding.

\section{Halysites catenulatus ( $\operatorname{Linn} . \mathrm{Sp}^{\mathrm{s}}$.)}

Ref. and Syn.-Tubipora id. Lin. (Gm. ed.) = Catenipora escharoides (Lam.) + Catenipora labyrinthien (Giold.)

Pet. Germ. t. 25. f. 5 \& 4. $=$ C. approximato + C. distans $+C$. reticulata, Eichwald. Zool. Spec. t. 2. f. 9 to 11 .

+ C. exilis, id. f. 13 .

sp. Ch.-Corallum of vertical plates formed by the lateral union of the tubes, either anastomosing irregularly into sub-pentagonal groups, three or four lines in diameter, or anastomosing less frequently, forming elongate winding loops on the surface an inch or more in length; openings of the separate tubes oval, more or less compressed, and varying from half a line to one line in length, the space between two of the internal diaphragms about equals the diameter of the tube, the small opening of the young tubes most frequently seen at the points of anastomosing; external surface of plates, longitudinally undulated by the convexity of the separate tubes and crossed by fine transverse striæ of growth.

From the careful examination of the changes manifest in different parts of one large specimen, I think with $\mathrm{Mr}$ Lonsdale, it is not possible to separate the two extreme varieties, figured as above by Goldfuss, under the names Catenipora escharoides, and C. labyrinthica, and I consequently unite them under the oldest name of Linnæus.

Position aud Loculity. - Common in the dark limestone of Llansantfraid, Glyn Ceiriog, Denbiglshire; limestone at $\Lambda$ pplethwaite Common, Westmoreland ; forming large masses in the Coniston limestone of Coniston Water-Head, Lancashire; and Sunny Banks, near Coniston, Lancashire; in the calcareous schists of High Haume, Dalton in Furness, Lancashire; in similar calcareous schists of Pen y Craig, above Glyn, Llangynyw, Montgomeryshire; Mathyrafal, S. of Meifod, Montgomeryshire; east foot near Tyn y Fron; Wenlock limestone, Wenlock, Shropshire; Golugoed, Mandinam, Caermarthenshire. 


\section{Gems. SYRINGOPORA (Gold.) = Harmodites (Fisch.)}

Gen. Char.-Corallum of thick, minutely porous, rarely dichotomising tubes, with numerous internal funnelshaped diaphragms, often leaving a vacant tubular centre, and forming a thick vesicular lining to the walls: internal vertical sulei (rudimentary lamellie) exceeding twelve in number; tubes connected by numerous short tubular cross branches.

The radiating vertical strix are very rarely to be seen, and then chiefly on the edges of pèrfect terminations of the cell-tubes.

\section{Syringopora BIFURCata (Lonsd.)$$
\text { Ref.-(Lonsd.) Sil. Syst.t. 15, bis f. } 11 .
$$

Sy. Ch.CCorallum forming a loosely connected group of smooth tuhes, averaging one line in diameter. dilating a little, and branching dichotomously at intervals of about three lines, the branches equal and of the former diameter, occasionally anastomosing or uniting laterally with the adjoining tubes; lorizontal section, outer wall thick, within which is a loose cellular zone of curved vesicular plates, leaving a clear circular central space, usually about half the diameter of the tube : vertical siction shews the thick external wall, an irregular, narrow, vacant space down the centre, and the intermediate space on each side made up of irregular cells, formed of curved vesicular plates directed upwards and outwards.

The funnel-shaped diaphragms usual in this genus are in this species so irregular as rather to form a thick lining of irregular cells to the walls. fordshire.

Position and Locality.-Rare in the Wenlock limestone of Wenlock, Shropshire; and Dudley, Staf-

\section{2nd Family. CYATHOPHYLLIDE.}

Corallum simple or compound; lamellie very numerous, strongly developed, usually with smooth sides and entire edges, connected by very numerous, strong, transverse vesicular plates; cells often surrounded with a cellular perithecal area, which is always bounded both in the simple and compound species by a thick solid epitheca, exterior to which there is no conenchyme in the compound species. Increase by lateral diskbudding.

This family is easily distinguished from the Turbinolide and Astride by the strongly developed transverse vesicular plates, and the strong solid epitheca round each individual, both in the simple and compound forms, though often separated from the interior cell-tule by a perithecal area.

Subfamilies:-1, Cyathophylline; 2, Cystiphylline; 3, Nematophyllince.

\section{1st Subfamily. CYATHOPHYLLIN E.}

Corallum simple or compound; lamellæ strong, numerous, usually not reaching the centre; no axis; vertical section usually bi-areal; the narrow outer area, when present, composed of small vesicular plates between the radiating lamellic; broad central area always traversed by broad, transverse, nearly simple diaphragms, with deflected edges.

The strongly developed transverse diaphragms, forming the smooth, central bottom to the cells, form the great characteristic of these corals.

Genera:-1, Cyathophyllum; 2, Diphyphyllum; 3, Caninia; 4, Cyathopsis; 5, Amplexus ; 6, Columnaria. 


\section{Genus. CANINIA (Mich.)}

Ref. and Syn.-Michelin Dict. des Se. Nat. Sup. Vol. I. p. 485. = Siphonopleyllia (Sc. in McCoy), Synop).

Carb. Foss. of Ireland, p. 187.

Gen. Char.-Elongate conic, simple; an outer variable area of loose vesicular structure ; an inner area of broad transverse diaphragms, supporting at their circumference a series of short vertical radiating lamella which do not reach the centre, one or two are deficient at one point of the circumference, and there the transverse diaphragms are each prolonged downwards into a sort of siphon; edges of the diaphragms at the circumference bent downwards, forming a narrow intermediate area.

I suspect all the simple Cyathophyllo may belong to this genus. In some species the outer vesicular area is only added when near its adult diameter, and in all increases proportionately with age. The inner edges of the lamellie often exhibit the tubular papillæ, supposed by Mr Lonsdale to characterise his genus Tryplasma.

Caninia lata $\left(M^{c} \mathrm{Coy}\right)$. Pl. $1 . \mathrm{C}$. fig. 12.

Ref.-Michoy, Ann. Nat. Hist. 2nd Series, Vol. VI. p. 277.

$S p . C h$ - Young corallum very widely conic, attaining the adult diameter of three inches at a height of about two inches, after which it remains eylindrical for a height of several inches, marked with irregular concentric obtuse undulations and small fimbriated edges of growth; in the young the radiating lamellie are alternately longer and shorter, but before reaching the adult diameter they are all thin and nearly equal, four or five in a space of three lines at a diameter of two inches nine lines (or a hundred and ten to a hundred and sixteen all round) connected by numerous transverse curved vesicular plates; inner area formed of broad horizontal simple diaphragms, which at a diameter of an inch, extend almost across the corallum to the exclusion of the outer vesicular and radiated layer, at a diameter of two and half to three inches, they maintain a diameter of about an inch, the outer lamellated and resicular zone having proportionately increased: each of the diaphragms is strongly bent downwards at one point of the circumference forming a distinct siphon; outer wall extremely thin, forming a few root-like tubereles on the conical young; terminal cup with a depressed flattened centre, and very convex outer area.

Position and Locality.-In the Wenlock limestone of Wenlock, Shropshire.

Explanation of Figures.-Pl. 1. C. fig. 12. Part of old terminal cup, natural size, from near Wenlock, shewing a portion of the very thin epitheca on one side-Fig. 13. Do. Natural size, sherwing the form of the young cup, with one of the diaphragms exposed at base, with the deep siphonal intlection, and a few radiciform tubercles from the surface.

\section{Caninia turbinata (Limn. Sp.)}

Syn. and Ref.-Madrepora turbinata Linn. Fougt. Var. B. Amon. Acad. t. at p. 312. f. 2. Turbinolia turbinate His. Var. ß. Leth. Suec. t. 28. f. 7. Cyathophyllum turbinatum Lonsd. (not Gold.) Sil. Syst. t. 16. f. 11 a. Cyathophyllum subturbinatum d'Orb. Prod. p. 47.

$S p$. Ch.-Corallum simple, conic, slightly curved, averaging three and half inclees long, and varying at that length from one inch ten lines, to two inches three lines in width at large end; adult cup deep with highly inclined walls, sulcated by the radiating lamellx, which are about ninety-six, alteruately longer and shorter, nearly equal at the edges, and a broad flat, circular, smooth diaphragm forming the bottom; rertical section, inner area about one-third of the diameter at top, of nearly equal width from base to top, composed of very close, irregular transverse diaphragms, about nine in three lines throughout, bending down at one point of the circumference to form a thick siphonal inflection; outer area of large curved vesicular plates, forming very lighly inclined rows of elongate cells, averaging one-third the diameter on each side in adults, but gradually narrowing towards the apex, where it almost disappears; outer surface with a very thin outer wall, longitudinally marked by equal lamellar sulci, five or six in three lines at the large end; irregularly wrinkled concentrically and with occasional irregular papillate protuberances towards the smaller end.

Although agreeing with M. dOrbigny, that this is not the Devonian Cyathophyllem turbinatum of 
Goldfuss, I do not think we should change the specifie name of the Silurian species, as it is elearly to this formation that the original coral of Linné and Fougt belonged, and the particular var. and figure which I have quoted above, from the Amonitates Academica describe our present species very well (the figure faintly shews the root-like tubercles). The lateral siphon is perfectly distinct when the section is in the right direction. The inner edges of the lamell seem obscurely tubuloso-papillate as in Tryplasma. The $C$. turbinatum (Gold.) has fewer, and thicker lamellæ, and no external root-like tubercles. In the specimens varying in the rate of increase, I can find no other difference.

Position and Locality.-Common in the Wenlock limestone of Dudley, Staffordshire, and Ledbury, Herefordshire; schists of Mathyrafal, S. of Meifod, Montgomeryshire; limestone of Craig Head, Ayrshire.

\section{2nd Subfamily. CYSTIPHYLLINE. $>$ Cystiphyllidoe (Edw. and Haime).}

Corallum simple or compound; individuals always defined by a distinet epitheeal wall in both simple and compound species; increasing by lateral buds or rarely by fission; uni-areal, without distinct axis ; radiating lamelie very delicate, usually meeting in the middle, connected by a nearly uniform vesicular tissue, not forming transverse diaphragms.

Genera:-1, Strephodes; 2, Cystiphyllum; 3, Clisiophyllum.

\section{Genus. STREPHODES $\left(\mathrm{M} \boldsymbol{I}^{\circ} \mathrm{Coy}\right)$.}

Etym.- бтpé $\phi \omega$, torqueo (from the twisting of the lamellac about the centre).

Ref.-M M Coy, Ann. Nat. Hist. Series 2, Vol. III. p. 4. (= Strombodes pars of Lonsdale, not of Schweigger).

Gen. Char.-Corallum simple and conic, or compound and forming rounded masses of inseparably united polygonal cells; in either case the terminal cup is deep, with numerous, equal, radiating lamell:e, converging from the walls to the centre, where they meet and are complicated, usually twisted in bundles about an imaginary axis; vertical section, small vesicular structure, the rows of cells arranged in a semielliptical curve, convexity downwards, descending from the sides at a steep angle and rounding under the centre, where the cells are a little larger than at the sides; horizontal section, radiating lamellæe meeting and complicated in the centre, connected by very thin transverse vesicular plates, and the stars of the compound species separated by thick divisional walls; budding in the compound species marginal, stars rarely splitting in the middle; growth in the simple species often exhibiting periodical death and continuance of growth from the centre, giving an imbricating "ringed," appearance to the exterior.

This genus is most allied to Cyythophyllem and Clisiophyllum, all three having simple and conic, and also compound, polygonal-celled species. Strephodes differs from C'yuthephyllum by the equality of the radiating lamellæ, and their meeting in the centre, both in the terminal cup and horizontal section, and in wanting the transverse diaphragms; from Clisiophyllum, which it resembles in the meeting of the lamellæe in the centre, and the absence of horizontal diaphragms, it differs in the centre (though often slightly projecting) not being elevated into the large tent-like cone, characteristic of that genus, and in the rows of vesicular cells in the vertical section not having the reversed upward curvature which is connected with that peculiar form of cell. The simple species have been placed-I cannot imagine why-in the genus Strombodes of Schweigger by Mr Lonsdale, and some others. (See the observations below on this latter genus). The compound species differ from 1 streed, with which many palicontologists confound them, ly the solid epithecal boundary-walls to the cells, and from Acervulavia (Schweig. not Lonsd.) by the marginal budding and want of the central tube of that genus.

The genus Streptoplasma of Hall, in his recent volume on the Paleontology of New York, although defined nearly in the same manner, and the name having the same meaning, applies obviously, according to his specific descriptions and figures of all the species, not to the present corals, but to those known in Europe under the names Pctraia and Turbinclopsis, in which the lamellie extend directly and simply almost to the centre, only a portion of the centre exhibiting in some species a trace of twisting, and there being none of the resicular plates between the lamellex which are so strungly developed in the present group. 


\title{
Strephones craigensis $\left(M^{c}\right.$ Coy). Pl. 1. C. fig. 10.
}

\author{
Ref.- $\mathbf{M}^{\mathrm{c} C o y, ~ A n n . ~ N a t . ~ H i s t . ~ 2 n d ~ S e r i e s, ~ V o l . ~ V I . ~ p . ~} 275$.
}

Sp. Cle.CCorallum forming irregular, slightly flexuous, slowly tapering, olsscurely nodulous, subcylindrical stems averaging seven or eight lines in diameter when old, but both at that size and at three to four lines in diameter, tapering at the rate of one line in one inch; outer wall thick, marked with longitudinal fine lamellar sulci (ten in three lines); terminal cup shallow, lined by the radiating lamella, which are strongest a little within the circumference, and are obscurely complicated at the centre; connected at the sides by distinct transverse vesicular plates: horizontal section, outer solid wall thick, sixty-five to sixtyeight, slightly flexuous, radiating lamelle, one half of which extend about half way to the centre, the other half slightly thickening, uniting in groups of two or three, and complicated at the centre; transverse vesicular plates few, most numerous towards the circumference; vertical section shews a thick external wall on each side from which rows of depressed elongated irregular cells curve gradually under the centre, being thickest and nearly horizontal in the middle half of the diameter.

In the greater thickness, size, and approximately horizontal disposition of the vesicular plates in the middle of the corallum, there is an approach to Cyathophyllum, which might deceive at first sight; but these pseudo-diaphragms are not bent down at the edge of the inner area as in Cyathophyllum, and in the cup and horizontal sections the radiating lamelle are clearly seen to unite in bundles and reach the centre; characters totally at variance with those of Cyathophyllum. On some of the slender stems obscure signs apparently of lateral buds appear, but I cannot be certain of their true nature. It tapers more slowly than any other species I know.

Position and Locality._Common in the limestone of Craig Head, near Girvan, Ayrshire.

Explanation of Figures.-Plate 1. C. fig. 10. Fragment of large branch natural size, from Craig Head.-Fig. $10 \%$. Vertical and horizontal section of ditto magnified two diameters, shewing the very thick, nearly solid, lining to the walls, the characters of the radiating lamellae, and the loose, nearly horizontal vesicular plates, forming the transverse cells in the vertical section,-Fig. $10 b$. Young twisted branch natural size.

\section{Strephodes pseudo-ceratites $\left(M^{c}\right.$ Coy). Pl. 1. B. fig. 20.} Ref.-M다, Ann. Nat. Hist. 2nd Series, Vol. VI.

$S p . C h$-C Corallum small, simple, curved, conical, obscurely wrinkled concentrically; ordinary specimens about one inch three lines long, and nine lines in diameter at that distance from the apex; rarely exceeding that diameter, though occasionally longer; outer wall with faint vertical lamellar sulci, nine in three lines, at nine lines in diameter or about sixty-five all round; horizontal section shews a dense, nearly solid, outer area less than one-third the diameter of the tube, in which the radiating lamellae and the excessively close fine vesicular connecting plates are obscure; an inner circular area about half the diameter, into which only thirty-two to thirty-four (or each alternate one) of the radiating lamella penetrate, uniting irregularly and slightly twisted about the centre, connected by very few, thin, vesicular plates: vertical section, shewing the nearly.solid outer area as above (about half an inch of the apex often also filled with solid matter), inner arca traversed by numerous depressed small irregular cells, arranged almost horizontally, or with a slight upward curvature.

This species almost exactly resembles the small variety of the Devonian Cyathophyllum ceratites of Goldfuss (which I also find to be a Strephodes, thus differing from his larger variety to which I restrict his name), but is readily separated by its closer and more numerous lamellae (that having only thirtyseven lamellie at the above diameter). The Streptoplasma corniculum (Hall), from the Trenton limestone, is still more closely allied, but as it is impossible to be certain of the species of those turbinated corals without knowing their internal structure, I cannot venture to unite our British species, which I have worked out, with the American one in which that has yet to be done, and of which I have no specimen to do it. 
Pasition and Locality.-Common in the limestone of Old Radnor, Presteign, Radnorshire; Wenlock limestone of Dudley, Staffordshire, and Sedgley.

Explanation of Figures.-Plate 1. B. fig. 20. Natural size from the limestone of Old Radnor, Presteign.-Fig. 20 $\alpha$. Ditto rertical and horizontal sections, shewing the filling up of the base, and thick lining of the outer area, with nearly solid sclerenchyme.

\section{Strephodes trochiforyis $\left(M^{c}\right.$ Coy). Pl. 1. B. fig. 21.} Ref.-McCoy, Ann. Nat. Hist. 2nd Series, Vol. VI.

$S p . C h$-Corallum simple, slightly curved, widely turbinate, average length one inch three lines, and width at mouth one inch one line, with irregular swellings of growth; outer wall very thin, marked with equal lamellar sulci (six in three lines at one and quarter inch in diameter, or eighty-three all round); terminal cup very deep, conical, margin rounded, sides gradually sloping, lined by the thin alternately longer and shorter uneven edged lamell.", the longest of which unite and are irregularly blended at the centre, connected throughout by numerous curved transverse vesicular plates: horizontal section shews the same characters as the terminal cup, the alternate lamella extending about half way to the centre: vertical section, apex filled with solid matter, centre with irregular vermicular lines (the sections of the complicated edges of the radiating lamellee), from thence to the walls made up of small thick rounded resicular plates. the obscure rows having a slight downward curve.

One worn specimen from Dudley, in the collection of Count Münster, was considered by him and Dr Goldfuss to be a variety of the Cyathophyllum dianthus (Gold.) of the Devonian rocks, from which I find it differs generically.

Position and Locality. - Not uncommon in the Wenlock limestone of Dudley, Staffordshire.

Explanation of Figures.-Plate 1. B. fig. 21. Natural size from Dudley.

\section{Strephodes vermiculoides $\left(M^{c} \mathrm{Coy}\right)$. Pl. 1 . B. fig. 22. Ref.-MI'Coy, Ann. Nat. Hist. 2nd Series, Vol. VI. p. 275.}

$S p . C h$.-Corallum of closely grouped, round columns, of exceedingly irregular diameter, from frequent intermittance of growth producing very unequal annular swellings and funnel-shaped rings; external wall thin, marked by lamellar sulci (six in three lines at a diameter of one inch, or about seventy all round, indistinct at the more usual diameter of eight or nine lines); cup deep, lined with alternating larger and smaller vertical lameil.r irregularly uniting about the centre, their edges and sides papillose and perforated, the union of which papillæe forms a dense broad granular margin to the cup obscuring the lamellæ: horizontal section about seventy slightly and irregularly curved flexuous radiating lamellix, extremely thin, indistinct and equal in the dense, nearly solid, or granular outer area, where they are connected by rery close, minute, curved, vesicular plates; one half of the lamellæ scarcely extend beyond the outer zone, the other half suddenly increase in thickness and proceed towards the centre, where they are irregularly united, connected by few, large, curved, vesicular plates, forming nearly transverse rows of irregular cells: vertical section, outer third on each side very dense, of extremely small rounded vesicular plates nearly united, inner half of diameter composed of much larger, thin, irregular vesicular plates.

This coral may be distinguished from the Cystiphyllum rylintrimin (Lonsd.) by the distinct radiating lamelle towards the centre, and the small size of the vesicular structure torards the circumference, forming an almost solid, white granular structure. The Devonian Cyathophyllum vermiculare of Goldfuss (also a Strephodes) is almost identical in external appearance, but has the radiating lamellet thickest in the outel. area, straighter and alternately of rery unecual thickness, and wants the remarlialsle dense, alnost umadiated. outer zone. The lamellæ, as usual, are less numerous in young tubes of smaller diameter.

As far as I can judge from the figure alone, I should think the coral figured by Lonsdale, as the Cyathophyllem cespitusum of Goldfuss (Sil. Syst. t. 16. f. 10), from the Wenlock rocks, might be probably referred to this species, which in general size, form, and mode of grouping of the branches it resembles- 
it is quite certain that it has no relation to the true Eifel species of Goldfuss, which is common in the Devonian limestone of Newtown, Bushel, Torquay, Plymoutl, dc. (which sce below) which has slender, even, dichotomous branches and broad transverse diaphragms, \&c.

Position and Locality.-Wenlock limestone of Wenlock, Shropshire, and near Aymestry, Herefordshire.

Explanation of Figures.-Plate 1. B. fig. 22. Portion of large group, natural size, from near Aymestry, shewing the form of the deep cups lined with strong lamellæ, and the latter becoming obscure on the thick obtuse margin.-Fig. $22 \alpha$. Ditto, portion natural size, vertical and horizontal sections, the former shewing the very loose vesicular tissue of the central area and wide lining of the walls with nearly solid sclerenchyme, the latter shewing the primary radiating lamellie extending to the centre, and the secondary ones barely projecting within the wide sclerenchyme lining, through which the lamellac may be obscurely discerned.

\section{Genus. CYSTIPHYLLUM (Lonsd.)}

Gen. Char.-Corallum turbinate, or subcylindrical, outer wall thin, marked with longitudinal lamellar strix; radiating lamellæ quite obsolete, or only extending a short way from the walls; horizontal and vertical sections shewing a vesicular structure throughout, the obscure rows of cells, curving regularly from the walls under the centre, where they are rather larger than at the circumference, where some species shew short radiating lamellie.

The obsolete character of the lamellae, their frequent absence, and never approaching the centre, distinguish this genus from Strephodes, and the absence of a prominent boss in the centre of the cup, and corresponding upward curvature of the rows of cells in the middle of the vertical section, separates it from Clisiophyllum.

\section{Cystiphylum brevilamellatum (Mc Coy). Pl. 1. B. fig. 19.}

Ref.-Ann. Nat. Hist. 2nd Series, Vol. VI. p. 276.

$S p . C h$-Corallum elongate, subcylindrical, preserving for several inches a diameter of little more than an inch, slightly tortuous, and with obscure, irregular swellings of intermittent growth; outer wall extremely thin, strongly ribbed, with alternately larger and smaller vertical lamellar sulci, about four larger and three smaller in the space of three lines, at the diameter of one inch (or eighty-four all round), terminal cup with a circular depressed centre, equalling rather less than half the diameter, surrounded by an inclined outer area: horizontal section, outer area composed of forty-two radiating lamellæe (corresponding to the stronger external sulci) extending from the walls about one-fifth of the diameter, connected by close numerous transverse vesicular plates, having at the margin an equal number of extremely short lamellæe (corresponding with the smaller external ridges), internal area broad, formed of large vesicular plates irregularly arranged: certicul section composed of arehed irregular vesicular plates, curving gradually from the walls under the centre, small and numerous at the sides, considerably larger in the middle.

It is possible that Mr Lonsdale's second figure of Cystiphyllum Siluriense, t. 16. bis f. 2, may be a young group of this species; as this figure by its narrow form, radiated cups, \&c. seems totally distinet from his fig. 1, which is the true type of his species, a new specific name would be required for it in any case.

Position and Locality.-Wenlock limestone of Wenlock, Shropshire.

Explanation of Figures.-Plate 1. B. fig. 19. Natural size from Wenlock.-Fig. $19 a$. Ditto, vertical and horizontal sections, the former shewing the loose vesicular tissue in rows, gradually curving downwards, the cells being much larger in the middle than at the sides, where they correspond to the small lamelliferous area of the horizontal section. 


\section{Genus. Chisiophyluum (Dana).}

Etym.-K $\lambda i \sigma \iota v$, a tent (from the conical central boss).

Gen. Char.-Corallum simple, branched, or aggregate, with vertical radiating lamelle; a thin epitheca or outer wall: internal structure (vertical section), central area composed of small vesicular plates and cells converging or arching upwards to the centre, so as to form a conical boss in the cup; no distinct central axis; outer area of small cellular structure, inclining in the opposite direction or upwards and outwards, separation between these arex formed by an intermediate area of larger, nearly horizontal, cellular structure; (horizontal section) a large central area of small irregular cellular texture, from which the primary lamella radiate to the outer walls, intermediate zone with few vesicular plates between the lamellie; onter zone having the primary and secondary lamelle connected by very numerous vesicular plates.

The upward wave of the vesicular plates in the middle area of the vertical section, and consequent projecting boss in the middle of the cup, separate this genus from some of the radiated Cystiphylla.

\section{Clisiopitluum vortex $\left(\boldsymbol{M}^{c} \mathrm{Coy}\right)$. Pl. 1 . B. fig. 18.}

\section{Ref.-McCoy, Ann. Nat. Hist. 2nd Series, Vol. VI. p. 277.}

$S \%$. C C C Corallum simple, conic, slightly curved, enlarging at the rate of one inch eight lines in three inches from the apex; outer wall thin, faintly marked with subequal longitudinal lamellar striæe (five or six in the space of three lines at a diameter of one inch), and small concentric wrinkles; at a diameter of one inch the horizontal section sherws an outer area of about sixty thick, equal, radiating lamellæ, barely reaching one-fourth of the diameter towards the centre, connected by small irregular transverse vesicular plates; a few of the pairs have a very thin, short, marginal lamella between each of the larger pairs, and where this occurs the vesicular transverse plates become much more numerous; inner area rather more than half the diameter, forming a circular mass of confused vesicular tissue, crossed by a few arched radiating delicate lamellec: vertical section, having the narrow outer area on each side (corresponding to the lamelliferous zone) of arched vesicular plates, forming large unequal horizontal or slightly inclined cells, one or two cells extending across the width of the area; wide inner area composed of small oval cells arranged in much-curved transverse rows, the convexity of the curve upwards.

Position and Locality.-Wenlock limestone, Wenlock, Shropshire.

Explanation of Figures.-Plate 1. B. fig. 18. Natural size from Wenlock.-Fig. 18 a. Do. Vertical and horizontal sections near base, natural size, shewing the very large vesicular inner area of rows of upward-curved cells, the narrow outer area containing the primary radiating lamellæe in the horizontal section, and large vesicular tissue in the vertical section; and the extremely narrow layer of minute vesicular tissue lining the wall and corresponding to the short secondary lamellæ in the horizontal section.

\section{3rd Subfamily. NEMATOPHYLLIN E.}

Corallum rarely simple and turbinate, usually compound, of numerous polygonal tubes; in either case each cell defined, by a distinct, solid, outer wall or epitheca, within which is a vesicular outer or perithecal area, either radiated or not, by the costal extensions of the lamella; within this outer zone is an inner cylindrical area, forming the true cell-tube, defined by a thin wall and containing the radiating lamellic, of two sizes, connected by numerous transverse vesicular plates; usually a distinct central axis.

The corals of this subfamily are distinguished by the perithecal zone round the cell-tubes, defined for each individual by a solid boundary wall or epitheca, sometimes single, sometimes double in the massive species.

Genera:-1, Nematophyllum ; 2, Stylaxis ; 3, Stronbodes ; 4, Lonsdaleia; 5, Stylastrax; 6, Acervuluria ; 7, Siphonodendron. 


\section{Genus. STROMBODES (Schreigger) not of Lonsdale. $=$ Lithostrotion $($ Lonsd.) $=$ Actinocyathus (D’Orb.) Prod. p. 48.}

Gen. Char.-Corallum of numerous aggregated, inseparably united, prismatic, polygonal tubes; triareal; axis thick, prominent, of variously twisted plates; inner area of vertical radiating lamellæ, connected by vesicular transverse plates inclining slightly upwards and outwards; outer area of vesicular plates forming rows of cells extending very obliquely upwards and outwards; thick solid divisional walls between the cells; young forming circular buds within the parent star, in the outer area.

This genus is defined by Schweigger (Beobachtungen auf Naturhistorischen Reisen, Sc., tab. 6), as "Cellulco lamellosa, centro depresso, stirps e conis lamellosis in strata horizontalia conjunctis. Cellula terminalis cyathiformis." And he makes two divisions, first, "coni e centro proliferi," for which he refers to the Amonitates Academicce of Linné, Vol. I. t. at p. 312. f. 11. and 4. (the former figure, however, shews the origin of a marginal bud at one point). His second group, "coni e disco proliferi," and the reference to the same plate, fig. 10 and 3 , refers to a true Cyathophyllum (C.truncatum, Linn. Sp.); his first group, and the reference to the figures and description in the Amxitates Academico, must be taken as the types of the genus, and seem fully to justify the reference by Goldfuss of his American Strombodes pentagonum to this genus, the more when the reference in Fougt's description, above referred to, to fig. 18 of the above plate is taken into account. A coral perfectly similar to that of Goldfuss is also figured by Mr Dana, in Siliman's American Journal, as an example of Strombodes. As, therefore, the notion that those compound, polygonal-celled corals, are the true Strombotes of Schweigger, seems to prevail extensively, and I think justly, it only remains for me to add, that having carefully examined authentic specimens of the S. pentagonum, I find the cone-in-cone appearance of some of the figures, to be produced by a peculiarity of weathering, by which many of the vesicular plates towards the circumference of the stars have fallen out, and that the coral truly possesses all the characters so admirably elucidated by $\mathbf{M r}_{r}$ Lonsdale, in the "Geology of Russia," under the title of Lithostrotion-a name which it will be well now to replace by the old title Strombodes of Schweigger. In no case could either the words or reference of Schweigger justify the placing those Silurian and Devonian corals, called Strombodes by Mr Lonsdale, in this genus.

\section{Strombodes Wenlockensis ( $M^{\circ}$ Coy). Pl. 1. B. fig. 28.}

$$
\text { Ref.-MCoy, Ann. Nat. Hist. 2nd Series, Vol. VI. p. } 274 .
$$

Sp.Ch.-Corallum forming large irregular masses of polygonal stems, the mouths of which vary usually from eight to ten lines in dianeter; boundary walls strong, prominent, vertically sulcated on the inside; stars depressed round the margin of the walls, forming a large circular convexity nearer the centre, within which is a concavity from which rises the thick prominent compound axis; radiating lamellie twenty-four in small specimens, thirty in large ones, strongest and most prominent on the circular convexity of the star, where an equal number of small alternate ones disappear; vertical section shews the thick central axis composed of irregularly twisted plates; inner area a little narrower than the outer area, from which it is separated by a solid vertical wall, crossed by loose vesicular structure curving upwards and outwards, one or rarely two vesicular plates reaching across the area on each side; vesicular plates of the onter area more curved, slightly smaller, the rows inclining slightly upwards and outwards scarcely three cells in a row. A star nine lines in diameter, has the prominent circular portion seven lines in diameter, and the prominent axis rather more than one line in dianeter.

To judge from the figure in the Silurian System, that marked t. 16. f. $S^{d}$ (not the $S^{b}$ ) of Mr Lonsdale's Acervularia Battica (Schw.) seems to belong to this species; the species represented by the latter figure has neither axis nor divisional walls to the stars, and is generically distinet. The true $A$. Baltica of Schweigger, according to his reference to the Amonitates Academico, has no axis, and cannot belong to this genus, of which the present species is the only one I am acquainted with in Silurian strata. The 
fracture, as usual, passes through, and not between the columns, and the buds are developed in the corners of the old star.

Position and Locality.-Not uncommon in the Wenlock limestone near Wenlock, Shropshire.

Explanation of Figures.-Plate 1. B. fig. 28. Portion of large mass, natural size, from Wenlock.Fig. $28 \alpha$. Do. Vertical section shewing the strong divisional walls bounding the axis, the inner area, and the individual stars, as well as the peculiar tissues of each.

\section{Genus. ACERVULARIA (Schweigger).}

Cren. Char.-Corallum of aggregated prismatic columns; terminal cells polygonal, defined by strong solid walls, convex, each with a circular depressed centre, from which the young cones sprout, from two to six, or more in number; radiating vertical lamelle, of two sizes, the larger reaching from the walls to the centre, where they are simply united; no axis; vertical section, minutely and uniformly vesicular, the transverse rows of the outer area inclining upwards and outwards, those of the inner area curving under the centre, conforming to the surface of the star, a solid epithecal plate defining each star, and the tubular centre having also solid walls.

From the fissiparous mode of growth mentioned (that is, by the splitting of the centre) from two to seven or eight centres of radiation, or young cells, are frequently seen within the undisturbed circular boundary of the inner area of ene star. The genus differs from simeinule by the solid epithecal boundary walls between the cells.

\section{Acervularia ananas ( $\operatorname{Linn} . S p$.)}

Syn. and Ref.-Madrepora ananas (Linn.) Amœen. Acad.t. at p. 312. f. 9, 8, and 2.=Caryophyllia truncata (His.) Astrad ananas (Lonsd.) Sil. Syst. t. 16. f. 6. Lithostrotion Lonsdalei (D'Orb.) Prod. p. 48.

$S p . C h$. Corallum forming large tuberose masses, usually four or five inches in diameter, cells averaging four lines in diameter in the small variety, eight lines in var. major, varying between these in var. ramosa; sex- to oct-agonal boundary walls, crenulated, prominent; average diameter of circular inner area two lines, prominent edged, usually rather more than double the wiclth of the outer area; outer area nearly horizontal, slightly concave; imer area deeply concave, with a small prominence in the centre, produced by the meeting and slight twisting of the radiating lamell:r, which are thick, from forty-five to fifty in number, one half reaching the centre, the others barely entering the inner area; buds developed in the inner area from two to seven in number, separated by thick prominent ridges; vertical section shews a nearly uniform loose vesicular structure in both areas, the inner area and individual tubes being defined by solid walls.

It is evident from Fougt's reference to the small diagram, fig. 2 on his plate (representing excellently the cluster of buds arising solely from the inner area) that it is this present species alone which should bear

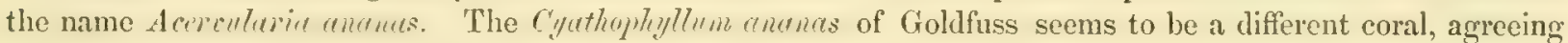
with the Devonian species figured under that name by Michelin. Fougt's fig. 9 is no doubt different in size from the other two figures, but it is obviously generically different from the coral with prominent centres referred to it by Lonsdale under the name Acervularia Baltica, in the "Silurian System," but it

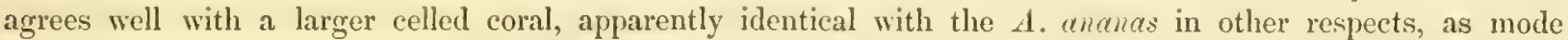
of gemmation, number of lamellæ, \&c. This might be referred to as a variety major. A more remarkable variety, and which has frequently been taken for a distinct species, is that in which the tubes form separate, rounded, rery irregularly-ringed branches (well figured by Hisinger, t. 28. f. 14, under the name Caryophyllia truncata but not of Linné); in this also, however, the gemmation and number of lamella is the same as in the two massive polygonal-celled varieties, and $I$ have repeatedly noticed the two forms oceurring together in one mass; - it might be called var. ramosa.

Position and Locality.-Common in the Wenlock limestone of Dudley, Staffordshire; also near Ledbury, Herefordshire. 


\section{3rd Family. ASTRAIDE.}

Corallum simple or compound, with an external imperforate epitheca to the general mass; usually increasing by disk budding or fission; cœnenchyme absent, or formed by the extension and union of the costre and their connecting vesicular plates, never compact; base of the cells becoming uniformly reticulated by the addition of small numerous transverse vesicular plates, no synapticula.

Subfamilies:-1, Eusmiline; 2, Astraince.

\section{1st Subfamily. EUSMILINE.}

Lamellæ with smooth, entire edges; costx plain; axis often solid.

This subfamily is divided into the following sections *

1 Sect. Simple, or composed of defined cells, arranged in lines, or in branching groups, and, when compound, usually increasing by fission. (Containing Cyathaxonia, \&ce.)

2 Sect. Compound, of gyrating lines of confluent, undefined cells; lamellæ smooth-sided; fissiparous. (Not occurring in Palreozoic rocks).

3 Sect. Compound, massive; cells defined, not arranged in lines, connected by their walls and costal cœenenchyme. (Containing Sarcinula, \&o.)

4 Sect. Compound, individuals tubular, distant, with distinct walls, united by an abundant spumous exotheca, the costae not prolonged; increase by lateral budding, not by fission. (This section scarcely differs from the third, but is not found in Palaozoic rocks).

Genus. CYATHAXONIA (Mich.) as here defined.

Gen. Char.-Corallum simple, conical, outer wall longitudinally sulcated, thin; axis thick, solid, styliform; radiating lamellæ strong, extending from the axis to the outer wall; very few or no connecting vesicular plates, no diaphragms.

This genus is not well defined by M. Michelin, and both he (Iconographie) and M. d'Orbigny (Prodrome) seem to include under it the present types and the Clisiophyllice of Dana. As these latter types have been properly defined by Mr Dana, I propose to restrict Michelin's name, to the corals presenting the above internal characters. They seem most allied in internal structure to some of the Eusmilince of MM. Edwards and Haime, such for example as Stylosmilia.

Cyathaxonia Siluriensis ( $\left.\boldsymbol{M}^{c} \mathrm{Coy}\right)$. Pl. 1. C. fig. 11.

Ref.-M다으, Ann. Nat. Hist. 2nd Series, Vol. VI. p. 281.

Sp. Ch.-Corallum elongate conic, about five lines long, and two lines in diameter at that height from the base; strong central axis nearly one-third of the diameter; sixteen or seventeen strong radiating lamelle, each extending from the axis to the outer wall, before reaching which it bifurcates, leaving a triangular interlamellar space about equal in width to the distance between the adjoining lamellae; surface coarsely ridged longitudinally, the sulci corresponding to the divided edges of the lamellix, leaving one of the equal intervening ridges to correspond with each of the spaces between the individual lamella, and between their divided edges.

This is the only species of the genus I am aware of in the Silurian rocks.

Position and Locality.-Rare in the Upper Ludlow Rock of Underbarrow, Kendal, IVestmoreland.

Explanation of Figures.-Plate 1. C. fig. 11. Natural size from Upper Ludlow Rock of Underbarrow, Kendal.-Fig. 11 a. Do. Magnified three diameters, shewing the strong costre, very large axis, and thick radiating lamellæ, most of them splitting as they reach the wall.

\section{Genus. SARCINULA (Lam.)*}

Gen.Char.-Corallum composed of vertical, cylindrical, strong-walled tubes, with internal tranverse scpta, bearing delicate, vertical, radiating lamelle mceting in the centre, where there is often a small styliform axis;

* MM. Milne Edwards and J. Haime (Am. des Sciences Nat. s. 3, v. 10, p. 211) make the following note on the 
tules generally rather distant from each other, forming circular cells on the surface, the interval being of a fine cellular texture, having an obscure horizontal arrangement, and sometimes shewing radiating lines, or costal prolongations of the lamellie on the surface, but having no polygonal epithecal boundaries between the exotheca of the individual cells; a thin epitheca at base of the entire compound mass.

The buds or young tubes seem to arise from the interstitial cellular substance (as in Anthophyllum, Ehrenb. not of Goldfuss, \&c.) wherever the distance becomes great between any two cells, but the young tubes do not seem traceable into the old. This genus is perhaps scarcely distinguishable from the more recent Fascicularia (Lam. 1812 = Stylina, Lam. 1816), except by the coenenchyme forming a uniform vesicular mass, instead of dense, separated, transverse lamellæ.

\section{Sarcinula organum (Limn. Sp.)}

Ref. and Syn.-MIadrepora organum Linn. Amœn. Acad. t. at p. 312, f. 6 and 1. Sarcinula organum (His. Leth. Suec. t. 27. f. 8. id. Gold. Pet. Germ. t. 24. f. 10).

$S p . C h$ - Corallum forming large irregular masses of subparallel, nearly vertical, cylindrical, thickwalled tubes; averaging slightly more than one and half lines in diameter, and varying slightly in distance, but usually a little more than their diameter apart; upper surface with the tubes forming deep cylindrical cells, each surrounded by a slightly concave outer area, inclining a little upwards and outwards, so as to form an angular ridge, forming polygonal boundaries between the cells, each centre surrounded by twentyfour to twenty-six thick, equal, radiating sulei; young columns interpolated: horizontal section shews the thick circular walls of the tubular centres, surrounded by an obscure radiation and vesicular structure, but no polygonal boundaries between the cells: revticul sertion shews the strong walls of the vertical tubes and the interior of the latter, divided by irregularly shaped, strong, transverse diaphragms, averaging four in a space equal to the diameter of the tube; intertubular spaces occupied by strong upward-arched transverse plates, rather more numerous than the diaphragms.

It is remarkable that this long described coral should not have been recognized before in Great Britain. It varies greatly according to the state of preservation, one of the most common weathered conditions shewing the tulhes projecting from the compact mass of the matrix, as long, separated, slightly fringed, cylindrical, quill-like columns.

Position and Locality.-Extremely common in the Coniston limestone of Coniston IVater-Head, Lancashire; Sunny Brow, near Coniston; High Haume, Dalton in Furness, Lancashire; and Coniston limestone, Long Sleddale, Westmoreland; Applethwaite Common, Westmoreland.

\section{2nd Subfamily. ASTREIN E.}

Lamellæ with lobed or denticulated edges, costre spinulose; axis usually reticulated, rarely lamellar, never styliform.

This subfamily contains sectional groups similar to those of the Eusmilince, the only Palacozoic genera probably entering the subfamily, are Arachnopluyllum and Palestreer, which should probably be placed near Acanthastroca and Synastroca.

\section{Gemes. ARACHNOPHYLLUM (Dana).}

Gen. Char.-Corallum forming large irregular incrusting ${ }^{+}$masses, having on the upper surface obtusely defined polygonal stars, each with a depressed flattened centre in which the radiating lamellie meet;

Sarcinula organum of Lamarck, "Cette espèce diffère beaucoup du Madrepora organum de Linné, qui est un fossile des terrains de transition, et auquel elle avait été rapportée par Lamarck. C'est ce dernier polypier qui forme le genre Sarcinula

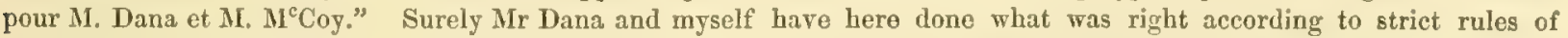
nomenclature; Lamarck made a blunder in identifying a recent coral with the Silurian one of the Swedish naturalists, and no one should follow him, now that the distinctions are known. That the Sarcinula organum (Linn.) is the true type of the genus Sarcinula, is further proved by the fact, that the other species of Sarcinula, as defined by Edwards and Haime, noted by Lamarck, were placed by bim in the genus Caryophyllia.

* A specimen which had incrusted a fragment of C'yuthophyllum misled me formerly as to the septate structure of the centres. 
radiating lamellæ fine, granulose, perforated, strongly marked about the depressed centre, their costal extensions becoming very fine towards the margin, where those of adjacent stars are often continuous; buds marginal; vertical section shewing a sub-uniform small vesicular structure, arranged in transverse undulations corresponding to the form of the cells, the curve directed downwards under the centres and upwards between them; no defining walls to the centre or between the stars; centre marked by a few vertical striae resulting from the twisted edges of the vertical lamellie.

This genus differs from Sarcimula in wanting the distinct-walled, septate, tubular centre; from the compound Strephodes it differs in the absence of solid boundary walls to the cells in both sections; and from Acervularia by its lateral buds, and want of solid boundaries to the centre and to the stars in the sections.

\section{Arachnophyllum typus $\left(M I^{c} C o y\right)$. Pl. 1. B. fig. 27.}

Syn. and Ref.-McCoy, Ann. Nat. Hist. 2nd Series, Vol. VI. p. 278.

Acervularia Baltica (Schw.) Lonsd. pars. Sil. Syst.t. 16. f. 8b. (not of Schweigger).

$S p . C h$.-Corallum forming thick irregular enveloping masses; upper surface undulated, covered with large shallow polygonal stars, defined by very obtusely angular ridges; the eentres averaging seven or eight lines apart, circular, depressed, rather more than one-third the diameter of the star, radiated with about thirty-three strong, granulose, sub-alternate, lamellæ, half of which reach the flattened centre where they are irregularly united and slightly twisted; on the outer inclined area of each star each of the lamellæ becomes much thinner and more faintly marked, branching di- or tri-chotomously once or twice, and often waving in a variable manner before reaching the boundary, over which they frequently pass into the adjoining stars; vertical section shewing a few delicate vertical stria under the centres of the stars (edges of the twisted vertical lamellay, and a nearly uniform small vesicular tissue, the cells of irregularly unequal size, passing from star to star, with a few irregular dense bands nearly coinciding in eurvature with the form of the cells: average of larger cells two to three in one line.

That this is one of the fossils figured by Mr Lonsdale in the "Silurian System," as the Acervularia Baltica, of Schweigger, I have little doubt, but neither the particular figure which I refer to above, nor the others which that writer has given under the same name in that work, have any specific relation to the true Acervularia Battica of Schweigger, who avows that name to be only a synonym of the A. ananas (Linn. Sp.) referring to the original figure, Sc. in the Amonitates Academica of Linné, representing a coral which has a distinct-walled tubular centre, from which the groups of young are developed, solid walls between the cells, \&ce. (See Acervularia ananas). The lateral disk buds are often seen in this curious coral.

Position and Locality.-Wenlock limestone, near Aymestry, Herefordshire.

Explanation of Figures.-Plate 1. B. fig. 27. Natural size from Aymestry, portion of large mass.Fig. $27 \alpha$. Portion of ditto magnified three diameters, shewing the form of the cup, with the strong lamellie lining the depressed centre, becoming abruptly thinner, more numerous by branching, and flexuous as they pass irregularly into those of the adjoining stars; the vertical section in lower part shewing the uniform vesicular tissue of the whole mass, without divisional walls to the cells; the few vertical lines under the centre are divided edges of some of the lamellæ.

\section{6th Family. TURBINOLIDE.}

Corallum usually simple, never fissiparous, sometimes increasing by lateral buds; radiating lamella strong, simple, usually granulated on the sides, no connecting vesicular plates or processes; epitheea thin, usually imperforate, surface usually marked with lamellar sulci; no cenenchyme in the compound forms.

Subfamilies:-1, Cyathino; 2, Turbinolino: 3, Eupsammina. 


\section{2nd Subfamily. TURBINOLIN E.}

Outer wall thin, imperforate; lamellæ meeting in the centre, or joining the axis, when present, without the intervention of pali.

I only know one Palæozoic genus probably referrible to this subfamily.

\section{Genus. PETRAIA (Münst.) as elucidated by Lonsdale. $=$ Streptolasma (Hall, 1847).}

Geri. Char.-Corallum simple, turbinate, radiating lamellae of one or two sizes, the larger extending from the walls to the centre where they are more or less twisted, (often thus forming a spirally rolled conical centre, the base upwards), without connecting vesicular plates, or transverse diaphragms.

I find that the flattened appearance often seen truncating the apex of the commonly-seen casts of this genus, and which has been taken for the impression of a diaphragm, is really produced by a nearly solid calcareous filling up of the old apex of the cone, and which, with the rest of the coral, often disappears in sandy matrices. The lamellæ are often perforated by long tubes opening as papillæ on their edges, as in the supposed genus Tryplasma (Lonsd.) An irregularity at one side, as in Caninia, is very common, marked by one strong plate extending directly to the centre, and several on each side uniting branch-wise to it; a corresponding peculiarity is seen on the external strix. The rounded ridges of the cast are moulded on the diverging halves of the split outer edges of the biplated lamellae which occupied the sulci. The grenus difiers from Strephortes ( $\left.\mathrm{I}^{\circ} \mathrm{C} \mathrm{Cy}\right)$ in wanting the vesicular structure letween the lamella, and from Calophyllum (Dana) in the supposed want of transverse diaphragms.

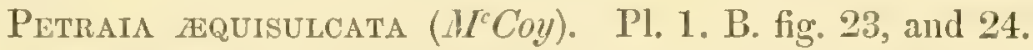 Ref.-M Mcoy, Ann. Nat. Hist. 2nd Series, Vol. VI. p. 279.}

Sp. Ch.-Conical, slightly curved, oblique, with a few broad, obtuse, undefined concentric swellings of growth, regularly increasing from the apex to a diameter of one and half inch, at tivo and half inches from the base; external wall very thin, it and the cast regularly marked with equal obtuse ribs, about eighty-five in the adult diameter of one and half inch (six in three lines), eighty at one inch (eight in three lines), seventy-five at nine lines and forty-six at four or five lines (ten in three lines) separated by thin equal equilistant slits representing lamellix, cach alternate one of which is merely marginal, the others occasionally and irregularly uniting before reaching the centre, round which they are twisted to form a spirally conical central area; no connecting vesicular plates.

The regularity and equality of size of the lamellar ribs, both on the exterior and on the cast, as well as their large number, gives a peculiar aspect to this species. In parts of some specimens the lamellar sulci are bent in a zigzag manner, but it is an unusual appearance, for which I cannot account. By carefully removing part of the outer wall each of the lamelle is seen to be split near the exterior (not visible on casts), and each to be perforated by tubuli as in $\mathrm{M}^{\circ}$ Lonsdale's supposed genus Tryplasma; these punctures leare no trace on the equal, obtuse, smooth, ridges of the casts. I have usually seen this coral ticketed in collections as Cyathophyllum turbinatum, to which it bears some superficial resemblance, but has no real specific or even generic relation.

Position and Locality.--Very abundant in the Coniston limestone of Coniston, Lancashire; in the calcareous flags of Applethwaite Common, Westmoreland; fine Cararloe sandstone of Mulock Quarry, Dalquorhan near Girvan, Ayrshire; flags of High Haume, Dalton in Furness, Lancashire; slates of Llansantfraid, Glyn Ceiriog, Denbighshire.

Explanation of Figures.-Plate 1. B. fig. 23. Average sized specimen from Coniston, shewing the equal lamellar sulci, and portion of the epitheca towards the base.-Fig. 24. Do. Shewing the form of terminal cup, with the lamella uniting in pairs without vesicular connecting plates; and vertical fracture, shewing the conical twisting of the lamelle in the centre. 


\section{Petraia bina (Lonsd. Sp.)}

Syn. and Ref.-Turbinolopsis bina (Lonsd.) Sil. Syst. t. 16. bis f. 5 , and $5 a$.

$S p . C h$.-Adult size of corallum, length nine lines, width six lines, slightly curved towards the apex, rapidly enlarging for the first three lines to a width of about the same; exterior marked with alternately larger and smaller lamellar strix; terminal cup (and east) about one-fourth wider than long, obtusely conical, radiated with thirty to forty vertical rows of strong conical papillie, forming the primary lamellie, extending but a very short way towards the centre, leaving a corresponding number of large pits on the cast, about seven rows at the margin in a space of three lines; between these an equal number of rows of much smaller and less prominent papillie form the secondary lamellie, and secondary row of small pits on the casts; the larger papillie about one-third their diameter apart, the smaller papillie (and pits) about their diameter (or rather more) apart.

Position and Locality._Caradoc sandstone of Horderly; Malverns, Worcestershire.

\section{Petrata elongata $(P h i l l . S p$.}

Syn. and Ref.-Turbinolopsis elongata (Phill.) Pal. Foss. t. 2. f. 6b. Sil. Syst. t. 16. bis f. 6.

Sp. Ch.-Corallum regularly elongate, conic; casts conical, subtruncate at the smaller end, little wider than long; average diameter nine lines, marked with thirty-two to thirty-six strong primary lamellæ extending nearly to the centre, where they are complicated in a cellulose mass; between each pair of primary sulci is a finer secondary one, pierced with tubular papillæe (forming a row of pits on the cast) extending but a short way towards the centre, and reaching about four-fifths the length of the cast from the base towards the apex.

The sixty-four or seventy lamellar sulci often seem nearly equal at the edge of the cup in strength, (six or seven in three lines at the above diameter) but only the secondary ones pitted. The pitting of the secondary lamellæ, the greater coarseness of the ribs between the lamellar sulci, greater size, and greater number of the lamellæ distinguish this from the $P$. subduplicata $\left(\mathbf{M}^{\mathrm{c}} \mathrm{Coy}\right)$.

Position and Locality.-Caleareous flags of Bala, Merionethshire.

$$
\begin{gathered}
\text { Petraia rugosa (Phill. Sp.) } \\
\text { Ref. and Syn.-Turbinolopsis rugosa. (Phill.) Pal. Foss. t. 2. f. 7. C. }
\end{gathered}
$$

$S p . C h$. Cast conical, marked with one or two large concentric undulations of growth; average diameter nine lines, height varying from one half to slightly more than the diameter, (the latter form being very young) radiated with about seventy sub-equal, strongly pitted lamellar sulci, nine or ten in three lines (at six lines in diameter); the primary extending but a short distance towards the centre, which is wide and obscurely cellulose, secondary rows and pits as broad as the primary, but merely marginal and reaching only about half way from the edge of the cup to the base.

The close, equal, rows of large pits, of both the primary and secondary lamellæ, give a uniformly porous or cellular appearance to the casts of this species, totally unlike any of the others with which I am acquainted; Prof. Phillips's figure very imperfectly represents these peculiarities, although taking his description into account, there cannot be a doubt of the identity of the species.

Position and Locality.-Occurring occasionally in the schists of Pen lar, Llandovery; Castel Craig, Gwyddon, Llandovery, Caermarthenshire; and Peniarth.

\section{Petraia subdulicata $\left(M^{c} \mathrm{Coy}\right)$. Pl. 1. B. fig. 26.}

\section{Ref.-MCoy, Ann. Nat. Hist. 2nd Series, Vol. VI. p. 279.}

Sp. Ch. - Regularly conic, slightly oblique and eurved at the tip, outer wall thick, marked with one or two small interruptions of growth, and with fine, longitudinal, distant impressed equal strix (seven in two lines at a 
diameter of five or six lines); average length nine lines, of which the three lines nearest the apex are filled with solid calcareous deposit; width seven lines; casts regularly conic, subtruncate at small end, length and width about equal, regularly sulcated by twenty-seven to twenty-eight strong, straight, primary lamellar sulci, extending to the centre, where they are irregularly complicated into a large cellular mass; between the larger slits are an equal number of finer ones, extending about three-fourths the length of the cast from the wide edge of the cup (representing the secondary lamella) which extend only a short way towards the centre.

\section{Var. $\alpha$. Crenulata (McCoy).}

This beautiful variety differs from the ordinary type in the primary and secondary lamellar sulci, particularly towards the edge of the eup, being bent into numerous small, angular, zigzag, flexures (perhaps from alternating projections on their sides).

I might have supposed this to have been a small form of the $P$. elongata (Phill. Sp.) if it was not for his reference to Lonsdale's figure, Sil. Syst. t. 16. bis f. 6, which represents a perfectly distinct species which I have seen; the lamellix of the present species are also fewer, the size smaller, the form more regular, and the lamellar ridges never pitted. On the cast the lamellar sulci are regularly alternate in size, except at the strong simple odd lamella, on each side of which are two or three short ones.

Position and Locality.-Very abundant in the fine greenish Caradoc sandstone of Mulock quarry, Dalquorhan, Ayrshire; in the schists of Cyrn y Brain W. of Wrexham, Denbighshire; greenish schists of Llansantfraid, Glyn Ceiriog, Denbighshire.

Explanation of Figures.--Plate 1. B. fig. 26. Natural size from the Caradoe sandstone of Dalquorhan, shewing the east of the cup above, and a rough vertical section of the dense deposit of sclerenchyme which fills the base and lines the wall. Fig. $26 \alpha$. Two of the interlamellar projections magnified two diameters, shewing the slits of the primary and secondary lamell.x. Fig. 26b. Do. Two of the interlamellar projections of the var. crenulate.

$$
\begin{aligned}
& \text { Petraia uniserialis }\left(M^{\circ} \mathrm{C} o y\right) \text {. Pl. 1. B. fig. } 25 . \\
& \text { Ref.-MI Coy, Ann. Nat. Hist. 2nd Series, Vol. VI. p. } 280 .
\end{aligned}
$$

Sp.Ch.CCorallum rapidly and regularly expanding, oblique, averaging five lines in height and width; radiated with about forty-five or fifty lamellar sulci; average internal casts nearly five lines wide and two lines high, radiated by the deep slits of twenty-five strong primary lamelle (six or seven in three lines at the margin) extending to the centre where they are united and irregularly complicated; between each pair of these slits is a row of numerous small close, irregular pits (representing papillae of the secondary lamella) about three in a space equalling the distance of the lamellar slits apart.

I frequently find this common species confounded with the $P$. bina (Lonsd.) which in form and size it resembles, but from which it differs completely in the primary lamelle, being simple plates, extending to the complicated centre, leaving deep slits in the cast, which therefore has but one set of rows of pits instead of two; while in $P$. bina these lamella are replaced by a row of large papilla, leaving a row of large pits in the cast, extending but a little way towards the centre. The secondary row of lamellar papille (and pits on the cast between the slits) is much smaller, closer, and less regular in the present species than in the $P$. lina. Some of the casts present a depression in the smaller end, into which a process of the solid part of the apex must have penetrated. Between the lamellar sulci in some damaged specimens, obseture traces of cells seem doubtfully visible under the lens; if these should prove to be vesicular plates, the species should be placed in the genus Strephodes, thus removing it still farther from $P$. bina in which there is nothing of the kind.

\section{Var. u. Gracilis $\left(M^{c}\right.$ Coy).}

Certain casts a little larger and of a much more elongated form than the above,-being about as high as wide, and having about thirty to thirty-six primary lamellar slits at a diameter of six or seven lines, and an equal number of rows of close small puncta, require separate mention, though $I$ do not sce that they differ in other respects. 
Position and Locality._Common in the schists of Pen Lar, Llandovery; Mathyrafal, S. of Meifod, Montgomeryshire; Llansantfraid, Glyn Ceiriog, Denbighshire; and Castel Craig, Giwyddon, Llandovery, Caermarthenshire; fine Caradoc sandstone of Alt yr Anker, Meifod, Montgomeryshire.

Explanation of Figneres.-Plate 1. B. fig. 25. Natural size of east from the slates of Llansantfraid. Fig. $25 \alpha$. Do. Two of the interlamellar projections of the cast, magnified three diameters, each with a small row of puncta corresponding to the secondary lamellie, and divided by the deep slit corresponding to one of the primary lamellie.

$$
\begin{gathered}
\text { [Systematic place uncertain.] } \\
\text { Genus. SPONGARIUM (M.Edw.) } 1839 . \\
=\text { Discophyllum }(\text { Hall, 1847) = Actinophyllum (Phill. 1848). }
\end{gathered}
$$

Cien. Char.-Corallum simple, thin, corneous, broad oval, depressed, sancer-shaped, attached by a small oral central space to foreign hodies; inner concave surface smooth, exterior surface with numerous simple, or once or twice branched, ridges radiating from the centre to the circumference; both surfaces strongly marked with irregular concentric wrinkles and strix.

The affinities of these fossils are very obscure, the first example being referred to the Sprongidec by $\mathbf{M}$. Edwards, the second to corals by Hall, and to plants (Culcipliytes) by Profs. P'hillips and Forbes, and Dr Hooker. (See Mem. Geol. Survey, Vol. II. p. 386). All observers agree that there is little or no calcareous matter in them, which makes the latter opinion doubtful; the first impression on my mind was that they might be a sort of corneous base of a polype allied to Actinia-but $I$ have observed that the inner, upjer, or concave side is unradiated, which is a fatal objection to that notion; as to its being allied to the cartilage of Velclla or the like, that is also impossible, as I have noticed a specimen firmly attached by the grasping of its base round a bit of Orthoceratite. From the examination I have made I do not think it possible to separate, generieally, the species with simple rays (Discophyllem and Actinophyllum) from those in which they are branched (spongarium) - the character affording scarcely a recognizable specific distinction in practice.

\section{Spongarium equistriatum ( $M^{c}$ Coy). PI. 1. B. fig. 15. \\ Ref.-M다, Ann. Nat. Hist. 2nd Series, Vol. VI. p. 281.}

S'p. Ch.-Elliptical, depressed, proportion of width to length varying from as 85 or 90 , to 100 ; marked with sharp, rugged concentric wrinkles, entire disk closely and equally radiated, by coarse rounded very approximate ridges, averaging five in one line; long diameter from eight lines to one inch.

This species is perfectly distinguished from its congeners by the coarse, close, equal, striation of the entire disk, giving it a peculiarly harsh aspect; the ridges are much less than their thickness apart.

Position and Locality.-Rather rare in the quartzose Upper Ludlow rock of Benson Knot, Kendal, Westmoreland.

Explanation of Figures.-PI. 1. B. fig. 15. Natural size from the Upper Ludlow rock of Kendal.Fig. 15 . Do. Portion of outer surface magnified two diameters, shewing the rugged, subequal, strix.

\section{Spongarium Edwardisi (Mrurch.)}

\section{Ref.-Murehison, Sil. Syst. t. 26. f. 12.}

$S p . C h$.-Nearly orbicular, very broad oval, proportion of breadth to length, as 90 to 100 ; radiating ridges comparatively few, slender, thread-like, some distinctly branching two or three times (when the diameter is one inch), a few others remaining simple, averaging one line to nearly two lines apart, intervening spaces flat marked with few irregular obtuse concentric wrinkles, without distinct intervening radiating strix ; average diameter one inch. 
The substance of this species seems excedingly thin; it is easily distinguished by the very slender ristinetly forkind, distant, radiating ridges, with the intervening spaces smooth or nearly so, the margin of one specimen shewing doubtful traces, at one point of the margin, of intermediate striv'; the distance between the ridges is about ten or fifteen times their thickness.

Position and Locality.-Not uncommon in the black schists of Dinas Bran, Llangollen.

\section{Spongarium interlinentuil (Mc Coy). Pl. 1. B. fig. 14.}

Ref.-Michoy, Ann. Nat. Hist. 2nd Series, Vol. VI. p. 281.

$S p . C h$. Broad oval, usual proportion of width to length as 85 to 100 ; marked with very strong concentric undulations; radiating ridges very numerous, straight, slender, simple, of unequal lengths, avuraging with considerable regularity half a line apart; intervening spaces finely striated radiatingly; long diameter varying from seven lines to one inch three lines.

This species is easily distinguished from the S. Edrarki (Mureh.) by having considerably more than doulle the number of radiating ridges; they have never been seen to dichotomise, but retain their comparatively near approximation by the interealation of similar, straight, shorter ridges towards the circumference; the sulstance also appears stronger and is more strongly wrinkled concentrically, the small radiating striae between the larger ridges are very characteristic.

One very obscure specimen, apparently of this species, mensures two inches in its long diameter, the distance between the main ridges is about four times their thickness.

Position and Locality.-Abundant in the green micaceous quartzite of the Upper Ludlow at Benson Knot, Kendal; Brigsteer and Scalthwaite Rigg, Kendal, Westmoreland.

Explanation of Figures.-Pl. 1. B. fig. 14. From the Upper Ludlow rock of Kendal, natural size.Fig. 1f $\alpha$. Do. Portion of exterior surface magnified two diameters, shewing the fine strix between the larger radii.

\section{Spongarium internuptum $\left(M{ }^{\circ}\right.$ Coy $)$. Pl. 1. B. fig. $16,17$.}

Ref.-MICoy, Ann. Nat. Hist. 2nd Series, Vol. VI. p. 282.

Sp.C Ch-Elliptical, proportion of width to length about 5.5 to 100 , convex below or externally, concave above or internally; interior smooth, or marked with faint concentric wrinkles; exterior rugged with coarse concentric undulations, and its entire surface marked with sharp, sub-alternate, thread-like strice, five or six in one line; some of which rise at regular intervals into short, very thick, sulb-angular, radiating ridges interrupted by the concentric wrinkles and not regularly resumed. Average length one inch.

The sharp alternately large and small strix, and the short irregular interrupted ridges or elongate tubereles produced by the irregular prominence of some of the ridges, distinguish this species readily from the others. Two of the specimens are of great interest, one shewing the attachment of the base half round a bit, apparently, of an Oithoremetite; the other shewing, for the first time, the thickness of the sulstance to be about one sixth of a line, and shewing the unradiated inner concave surface, and the impression of a part of the peculiarly radiated exterior.

Position and Locality.-Rare in the green micaceous quartzite (Upper Ludlow) of Spital, Kendal, Westmoreland.

Explanation of Figures.-Pl. 1. B. fig. 16. Natural size, from the Upper Ludlow rock of Kendal, shewing the attachment of the base, and peculiar interrupted marlings. - Fig. $16 \%$. 1). I'ortion of surface magnified two diameters._Fig. 17. Do. Portion of specimen shewing the upper concave, concentrically wrinkled, surface, and at the upper corner a portion broken away, leaving the impression of the radiated exterior on the supporting matrix. 


\section{4th Class, POLYZOA.}

The Polyzoa of Thompson of Cork form a peculiar class of Radiata, subsequently named Bryozoa, by Ehrenberg, from their moss-like growth, and Ciliobrachicta by Farre, from their tentacles (unlike those of other polyps) being covered with vibratile cilia; they are of far higher organization than the Zorpthytet, with which they were long confounded, although individually they are all very much more minute; by their aggregation, however, they form delicate but moderately large coralla. Each individual is contained in a long cylindrical, or short oblong or ovate cell, never divided by transverse, nor radiating, lamellix, composed of the more or less hardened outer integument of the animal; the upper portion, or that near the aperture, always remaining flexible and continuous with the neck of the inlabitant, and being inverted with it when it contracts within the cell. The mouth is at the anterior end, surrounded by about twelve long tubular stiff tentacula, covered with vibratile cilia, causing a perpetual current of water. The mouth selects the proper particles of food brought by the inner current, and passes them to a contractile pharynx, leading to a large oesophagus, ending in a muscular gizzard, in which the food is comminuted before passing into an elongate stomach studded with brown hepatic glands; a very straight intestine extends from the stomach to the anus, which is near the mouth at the base of the tentacles. This complexity of the digestive system induces many modern naturalists to remove the Polyzoc from the Radiata to the Mollusca, placing them next the Tunicata. Respiration is usually referred to the ciliated arms. No distinct circulation, nor nereous system, has yet been recognised, but the muscular system is fibrous and well developed; one set of muscles for retracting the creature within its cell arises from the inner wall, and is inserted into the base of the tentacles; another set arises from the bottom of the cell and is inserted into the stomach; other shorter fasciculi retract the soft edge of the cell by extending from it to the inner edge of the hard portion. The animal is protruded by the action of a few circular muscular fasciculi compressing the fluid parts. Reproduction is both by buds and ciliated free locomotive gemmules, neither of which originate from any special organ, but are developed from the parietes of the cell; the former from the outer, the latter from the inner surface. The gemmules becoming free are developed in the eavity between the cell and the body of the polyp, which they kill by their growth, finally escaping through the aperture.

This class is divided into the following families:-1, Escheride; 2, Tubutiporide; 3, Mryriaporide? 4, Asteradiscides; 5, Halcyonellida.

\section{1st Family. ESCHARIDE.}

Polypidom free or encrusting, never rooted by a calcareous mass; substance stony or crustaceous, seldom flexible; cells shallow, oblong, or ovate, often provided with an operculum, capable of being closed by special muscles.

Genera:-1, Eschara; 2, Escharina; 3, Berenicea; 4, Ptilodictya; 5, Escharites; 6, Escharoides; 7, Melicerita; 8, Tilesia; 9, Membranipora; 10, Flustra; 11, Discopora; 12, Ocellaria; 13, Cellepora; 14, Apsendesia; 15, Cellaria; 16, Vincularia; 17, Intricaria, \&c.

\section{Genus. BERENICEA (Lam.)}

Gen. Char,-Corallum encrusting foreign bodies, composed of a very thin, calcareous, foliaceous base, bearing numerous ovate, distinctly separated cells, not piled; aperture round near the broad anterior end; cells disposed in an obscurely radiated arrangement.

The cells resemble Cellepora, but are not piled; they also resemble, in some measure, the cells of S'tictopora (Ptilodictya) but are parasitic and confined to one side; they differ from Discopora by each cell being separated by a small space from its neighbour. 


\title{
Berenicea heterogya $\left(\boldsymbol{M}{ }^{\circ} \mathrm{Coy}\right)$. Pl. 1. C. fig. 17.
}

\author{
Ref.-M대, Ann. Nat. Hist. 2nd Series, Vol. VI. p. 286.
}

Sp. Ch.-Parasitic, often on Orthoceratites, covering spaces of upwards of two inches square; cells disposed in circular groups of irregularly radiating, or divaricating fan-shaped lines, ten or eleven occupying the space of one line (measured across their length), and about three in the same space in the direction of their length; each cell slightly more than the third of a line long, very narrow, fusiform, about four times longer than wide, and separated by a space, varying from their greatest width to less than one half their width, or nearly in contact; upper convex surface of each cell with four or five large tubercles when well preserved.

This remarkable species is almost invisible to the naked eye, but occurs forming patches of considerable size; the small size of the cells, and their very elongate slender form, distinguish it from the $B$. irrerntlaris of Lonsdale.

Position and Locality.-Coniston limestone of Coniston Water-Head, Lancashire.

Explanation of Figures.-Pl. 1. C. fig. 17. From the Coniston limestone of Coniston, natural size, parasitic on an Orthoceratite.-Fig. $17 \alpha$. Portion of Do. magnified six diameters.-Fig. $17 b$. A ferw of the cells of Do. magnified fourteen diameters, shewing the terminal aperture and the granulation on the outer wall.

\section{Genus. PTILODICTYA (Lonsd.) 1839 as here redefined.}

< Stictopora (Hall, 1847).

Gen. Char._Corallum thin, calcareous, foliaceous, or branching dichotomously, branches sometimes coalescing; a thin laminar, flattened, concentrically wrinkled central axis, set with oblique short subtubular or orate cells on both sides, with prominent oval mouths nearly as large as the cells within; branches often flattened, with the margin solid, sharp-edged, striated and without cells; the boundary ridges of the cells square or rhomboidal.

Mr Hall believes that the cells are only simply tubular, not utricular or contracted at base as in Cellepora, Ilembranipora, \&c. I have, however, clearly determined them in our British examples to be so; yet I think the genus is undoubtedly distinct from both those recent genera-from the first by the cells not being piled, and from the second by the cells being calcified in every part, instead of the anterior wall being mere membrane. I have ascertained that the flat surface of most specimens of Ptilodictyca is owing to a splitting of the coral parallel with the flat central axis, which I have traced in several specimens of Lonsdale's type species, presenting the exact appearance of that in the Stictopora of Hall. I also find a perfect generic identity in the form, structure, and disposition of the cells; the latter genus must therefore be united to the former under the old name, which, however, is very inappropriate to all but the first described species. Mr Hall's name might perhaps be used as a subgenus for the polymorphous species.

\section{Ptilodictya (Stictopora) acuta (Hall. Sp.)}

$$
\text { Syn. and Ref.-Stictopora? acuta (Hal. Pal. N. Y.t. 26. f. 3.) }
$$

Sp. Ch.-Corallum forming flat, thin, linear expansions, about one and half lines wide; dichotomously branching at an angle of about $50^{\circ}$, the branches almost as wide as the main stem; from seven to ten alternating longitudinal rows of small ovate cells, apparently arranged in lines extending from the centre very obliquely upwards and outwards, or abruptly curving outwards at the sides; lateral edges with a narrow, sharp, apparently solid margin, smooth or with oblique strix, corresponding to the direction of the lines of cells; mouths of the cells in each row four in one line. 
This coral seems to agree exactly with the American ones from the shaly beds of the Trenton limestone. I can find no trace of axis any more than $\mathrm{M}_{1}$ Hall.

Position and Locality.-Common in the shales of Llansantfraid, Glyn Ceiriog, Denbighshire; apparently a dwarf variety (five cells in one line), ? Var. minor, occurs in the schists, Llechwedd, Llwyd.

Ptilodictya (Stictopora) costellata $\left(M I^{c}\right.$ Coy). Pl. 1. C. fig. 15.

Ref.-McCoy, Ann. Nat. Hist. 2nd Series, Vol. VI. p. 287.

S.P. C $\%$-Corallum frequently dichotomising at an acute angle; average width about one and half lines; sides gently convex; section acutely elliptical; edges acute with a rather broad lateral margin, with a minutely granular non-celluliferous surface, each surface averaging from seven to ten rows of longitudinally oblong, or nearly oval cells, arranged in alternating longitudinal lines (six to eight rows in the sprace of one line, about four or five cells in the same space in each row); cells about a third longer than wide, and half their length between the rows, and about half their width between the cells of each row, giving the casts the appearance of being regularly marked with longitudinal sulci; intercellular spaces very minutely granulose.

The sulcated appearance of the cast and the linear arrangement of the cells easily distinguish this species from the Ptilodictya (Stictopora) acuta (Hall. Sp.) By grinding down a fragment I have ascertained with certainty, the presence of the flat internal axis, which is, however, of great delicacy, and not to be seen in the shale or sandstone specimens.

Position and Locality.-Not uncommon in the slates of Llansantfraid, Glyn Ceiriog, Denbighshire; calcareous schists of Mathyrafal, S. of Meifod, Montgomeryshire; and limestone of Girvan, Ayrshire.

Explanation of Figures.-Pl. 1. C. fig. 15. Branch natural size, from the slates of Llansantfraid.Fig. 1.j «. Section of ditto magnified eight diameters, shewing the thick flattened axis or plate on which the two rows of cells rest.-Fig. 15 b. Ditto. Portion of surface of cast magnified six diameters, shewing the granular non-celluliferous margin, and the linear disposition of the lengthened cells.

\section{Ptilodictya (Siclopora) explanata $\left(M^{c} \mathrm{Coy}\right)$. Pl. 1. C. fig. 16.}

$$
\text { Ref.-McCoy, Ann. Nat. Hist. 2nd Series, Vol. VI. p. } 286 .
$$

Sp. Ch.-Corallum forming large, funnel-shaped, foliaceous flexible expansions, upwards of three or four inches long, and upwards of two inches wide; axis semi-membranous, very thin, marked with small close concentric o: forward-curved undulating wrinkles; tube-cells pyriform, obliçue, three or four times longer than wide, narrowed posteriorly, anterior ends of the adjacent cells convex rhomboidal with a round perforation nearest the anterior edge; cells scparated by depressed lines which (when finely preserved) shew one or two alternating rows of small cellules; about seven or eight cells in a space of two lines.

The brond foliaceous expansions of this species readily distinguish it from any of those described by $\mathrm{Mr}$ Hall, as well as the very narrow depressed spaces between the cells on the surface and the broad rhomboidal, convex, portion of the cells surrounding the aperture. Finely preserved casts of the surface sherv the strong granules on the ridges, corresponding to the intercellular depressions of the true surface. Old specimens often shew a few thick irregular branching ridges on the surface as in Nempopore. One young specimen is flat and oval, like the base of Say's Favosites (Stenopora) Lycoperdon, with which it might be confounded if the posterior tapering of the cell-tubes was not noticel; others are more elongate, conical, and the greater number of specimens are irregularly undulated fims, parts of large expansions. The large expanded undulated and wrinkled axis, when the cells are rubbed off, resemble pieces of Stionutopora; a careful search will howeves usually shew some remaining cells, or by rubbing through the thin axis, some of the cells of the under side will be brought into view, when their comparatively great size, and oblique ovate form will identify them. 
Position and Locality.-Very common in the slates of Mynydd, Fron Frys; five miles W. of Chirk, Glyn Cciriog; Llansantfraid, Glyn Ceiriog, Denbighshire; Llanfyllin, Montgomeryshire; IBlain y Cwn, WV. of Nantyre, GIrn C'ciriog; Cyrn y Brain, IV. of Wrexham, Denlighshire ; Coniston limestone of Coniston, Laneashire; limestone of Mathyrafal, S. of Meifod, Montgomeryshire; schists, N. end of Pen y Craig, above Glyn Llangynyw, Montgomeryshire.

Explanation of Figures.-Pl. 1. C. fig. 16. Portion of one of the thin undulating foliaceous expansions, sherving the thin wrinkled central plate or axis, with the cells sticking on in some places; natural size, from the slates of Llansantfraid.-Fig. $16 \%$. Portion of ditto, magnified six diameters, shewing the cast of the cells, cach with its terminal aperture, and attached by its posterior narrow end to the thin undulated mesial plate - Fig. $16 \mathrm{~b}$. Cast of portion of surface magnified twelve diameters, shewing the round apertures of the cells, in the midlle of the rhomboidal outer wall, with the granular impressions of the interstitial pitting; from Coniston.

\section{Ptilodictya (Stictopora) fucoides ( $I^{\circ}$ Coy). Pl. 1. C. fig. 14. Ref.-MICoy, Ann. Nat. Hist. 2nd Series, Vol. VI. p. 288.}

Sp. Ch._Corallum forming very thin, flat, sub-membranous, folinceous, linear expansions, averaging one and half to two lines wide, frequently dichotomising at an acute angle; branches very rarely, but occasionally anastomosing; cells extremely small (cight in the space of one line) about eighteen rows in the width of the frond, rery close, quincuncially arranged, without perceptible lincar disposition; internal axis smooth, nearly membranous.

The extreme minuteness, number, and close disposition of the cells easily distinguish this species from the $P$. acuta, or costulata, and often give a resemblance to some fucoid.

Position and Locality.-Not uncommon in the schists of Llansantfraid, Glyn Ceiriog, Denbighshire; schists of Gelli Grin, Bala, Merionethshire; and schists of Corren, Merionethshire.

Explanation of Figures.-Pl. 1. C. fig. 14. From the schists of Llansantfraid.-Fig. 14a. Portion of ditto magnified twelve diameters.

\section{Ptilodictya lanceolata (Gold. Sp.)}

\section{Ref. and Syn.-Flustra lanceolata (Gold.) Pet. Germ.t. 37. f. 2. Sil. Syst. t. 15. f. 11. Ptilodictya sublanceolate (D'Orb.) Prod. p. 44.}

S.p. Ch.-Corallum forming a simple compressed, slightly eurved, nearly parallel-sided or linear cxpansion, from an inch long, with a width of one and half lines, to upwards of five inches long with a breadth of five lines; two broad faces slightly convex, but specimens often splitting parallel with the flat central axis; edges acute; both surfaces marked with longitudinal, parallel, very slender ridges (averaging nine in one line), cight or ten in the middle, closer, and more prominent than the rest, crossed ly transverse prominent strix (about six in one line) which are nearly horizontal for a narrow space in the middle, but incline upwards and outwards at the sides, at an angle of about $70^{\circ}$, the included oblong and rhomboidal spaces containing each an elongate ovate cell, placed longitudinally to form a few small longitudinal rows in the middle, and diagonally at the sides to form rows extending obliquely upwards and outwards; axis thin marked along the middle with strong arched undulations, the convexity towards the apex; the margins nearly smooth or marked with obscure longitudinal and oblique strix.

I have clearly ascertained the existence of a central axis as above described in this species, and most specimens are actually split parallel to this axis, thin irregular films of which usually adhere to the tat surface; by examining the matrix towards the edge, the two rows of cells, one above and one below this central plate, may usually be found.

Position and Lucality.-Not uneommon in the limestone of Clungunford, Shropshire; limestone of Pen y Craig, above Glyn, Llangynyw, Montgomeryshire; Aymestry limestone of Aymestry, Herefordshire. 


\section{3rd Family. MYRIAPORIDE.}

Corallum always strongly fixed at base by a root-like calcarcous expansion (distinguishing them from the Escharid(c); cells short, oval, never prolonged into tubes (separating them from the Tubuliporidec).

Genera:-1, Retepora; 2, Glauconome; 3, Fenestella; 4, Synocladia, \&c.

\section{Genus. RETEPORA (Tam. restricted by Blain.) \\ = Elasmopora (King).}

Gen. Char.-Corallum forming a fan-shaped, or irregularly cup-shaped, expanded net-work, composed of frequently anastomosing interstices, leaving subregular, ovate quincuncially arranged fenestrulcs; upper or inner surface closely set with several rows of small, close, uniformly-arranged, oval cell-mouths (on the dissepiments as well as on the interstices), the cells oblique to the surface; outer surface with dense, minutely granulose strix.

The absence of distinct nonporiferous dissepiments separates this from Polypora ( $\mathrm{NI}^{\mathrm{C}} \mathrm{Coy}$ ), the same character and the numerous rows of cells separate it from Fencestella, as well as (according to Lonsdale) the want of a layer of vertical tubuli to the nonporiferous face.

\section{Retepora Hisingeri ( $M^{c}$ Coy). Pl. 1. C. fig. 18.}

\section{Ref.-M당, Ann. Nat. Hist. 2nd Series, Vol. VI.}

$S p . C h$.-Corallum forming irregular fan-shaped expansions; interstices about one-third of a line wide; dissepiments narrower than the interstices; fenestrules ovate, slightly angulated about two-thirds of a line long and half a line wide (five interstices in the space of two lines), cells very small, from four to seven rows on the interstices, generally about three on the dissepiments, internally forming short ovate cells about a third longer than wide; obverse very minutely granular.

As it is scarcely possible ever to determine Hisinger's Retepora reticulate with certainty, (as he gives no information relative to the pores), there could be no objection to applying that name to the present species, which agrees with his figure as far as it goes, were it not that Mr Lonsdale has already applied it to a very similar coral, which he however places in the genus Fenestella, and figures with only the two rows of pores usual in that genus.

Position and Locality.-Very abundant in the slates of Cefn Coedog; Cyrn y Brain, IV. of Wrexham, Denbighshire; Blain y Cwm, IV. of Nantyre, Glyn Ceiriog, Denbighshire; slates of Mynydd, Fron Frys, five miles IV. of Chirk, Glyn Ceiriog; and in the Coniston limestone of Coniston Water-Head, Lancashire.

Explanation of Figures.-Pl. 1. C. fig. 18. Natural size from Coniston limestone, of Coniston WaterHead.-Fig. $18 \alpha$. Cast of portion of ditto, magnified seven diameters, shewing the casts of the numerous cells left by the decomposing corals.

\section{Genus. GLAUCONOME (Gold. as restricted by Lonsd.) \\ = Penniretepora (D'Orb.) Prod. = Acanthocladia (King).}

Gen. Char.-Corallum of a narrow central stem, with numerous pinnules or lateral branches unconnected with each other; both stems and branches have two rows of cells on one face which is usually carinated between them; in some species a row of small cells on the keel; opposite face striated.

In decomposing specimens the cells are seen to be short, ovate, or pyriform vesicles, arranged in rows obliquely under their external openings on the surface. As $M r^{\circ}$ Lonsdale has very properly restricted Goldfuss's generic name to the present corals, restoring Goldfuss's simple species to Vincularia (Defi.) I do not see the necessity for the new names more recently proposed. 


\title{
Glauconome nisticha (Gold.)
}

\author{
Ref. and Syn.-Gold. Pet. Germ. t. 65. f. 15. Lonsd. Sil. Syst. t. 15. f. 12. (branches too irregular)
}

= Penniretepora Lonsdalei D'Orb. Prod.p. 45 .

Sp. Ch.-Tripinnate, all the ramifications coming off at angles varying (in the same specimen) from $50^{\circ}$ to $60^{\circ}$, and varying (in short distances) from opposite to alternate; primary branches slightly more than half a line wide, giving off three lateral branches in the space of two lines; secondary branches half a line wide, upwards of an inch and half long, giving off three lateral branches in the space of two lines; ternary branches upwards of half an inch long, about one-third of a line wide, giving off nearly four lateral branches in the space of two lines; all the branches slightly convex and marked with minute granulose longitudinal stria on one face, obtusely keeled on the other, with a row of large oblong, thick-edged pores on each side, about one-third longer than wide, occupying the width of the face, and their ends in contact, three pores in the space between each pair of lateral branches; a row of very small cell-pores on the medial keel.

The figure of Goldfuss, above quoted, does not exactly agree in the distance of the ramuli with specimens I have seen labelled by himself, from Dulley, nor with any other I have seen; but as he quotes his species both from Dudley and the Eifel, I think, if even he has confounded two species, that it is to this wellknown one we ought to retain the name, first, because the authentic specimens I have examined were from the former locality, and identical with the fossil before us; second, the second Devonian species, if such really exists, has not been separately recognised.

Although the specimens in the schists seem more developed in size and number of the ramifications than the fragments usually seen in the Wenlock limestone, still the proportions, when taken by delicate instruments with every care, leave the impression on my mind that it is impossible to separate them specifically. The small third row of cells on the keel can in general only be detected with difficulty by a good lens, and their apparent absence in ordinary cases is not to be depended on.

Position and Locality.-Very abundant and of luxuriant growth in the slates of Llansantfraid, Glyn Ceiriog, Denbighshire; Blain y Cwm, W. of Nantyre, Glyn Ceiriog; Llanfyllin, Montgomeryshire; Wenlock limestone, Dudley, Staffordshire.

\section{Genus. FENESTELLA (Miller, MSS. as given by Lonsdale.) $>$ Fenestrellina d'Orb.; > Reteporina d'Orb.}

Gen. Cher.-Polypidom calcareous, cellular, forming a conical or fan-shaped expansion, of radiating branches (interstices) connected by transverse dissepiments; exterior surface of branches rounded, covered by a dense minutely porous layer; inner surface with a keel along the middle, separating two rows of mouths of short tubular cells, which extend a variable length obliquely downwards and inwards into the interior of the branch; dissepiments usually without cells; a small row of cells occasionally on the mesial keel; the non-celluliferous side formed internally of a layer of vertical capillary tubules.

Allied to Tubulipora rather than to Gorgonia, with which it is often confounded, though that genus has a solid axis and the cells scattered in an external gramular crust: Retepora differs by having the net-work of anastomosing branches with simple impressed cells, no dissepiments, and a solid interior. II. dOrbigny (Prod. p. 153) proposes the name Fenestrellina for those with a row of small distant pores on the keel, separating the two main rows of cell-mouths, and Reteporinc (Prod.p. 101) for those in which the two rows of cells are not separated by a keel.

\section{Fenestella Milleri (Lonsd.)}

Ref.-Lonsd. Sil. Syst. t. 15. f. 17.

$S p . C h$.-Corallum forming undulated fan-shaped expansions, two or three inches long; interstices slender, about five or six in the space of two lines, usually bifurcating at distances of about two to three 
lines; dissepiments thin, averaging two lines apart; fenestrules oblong, usually five or six times longer than wide; pores round, alternating or inosculating, prominent, deeply indenting the edges of the thin interstices, about twelve to the length of a fenestrule.

Position and Locality.-Not uncommon in the slates of Blain y Cwm, WV. of Nantyre, Glyn Ceiriog; Cefn Coedog; and Llansantfraid, Glyn Ceiriog, Denbighshire.

Fenestella patula $\left(M^{c}\right.$ Coy). Pl. 1. C. fig. 20.

Ref.-M $\mathbf{I}^{\mathrm{c}} \mathrm{Coy}$, Ann. Nat. Hist. 2nd Series, Vol. VI. p. 288.

$5 p . C h$. C Corallum forming small semicircular expansions, about half an inch in diameter; interstices broad, strongly carinate, slightly flexuous, and dichotomising very frequently (usually at rather less than every line in height) about seven in the space of two lines; fenestrules about one-third wider than the interstices, of very irregular shape, but nearly equal in length; dissepiments strong, about half a line apart; pores large, very prominent (about three or-four to the length of an interstice).

This species is more nearly allied to the Retepora (Fenestella) antiqua of Goldfuss than the Silurian species referred to it by Lonsdale ( $F$. subentique, D'Orlb.) From the latter species it is easily distinguished by its thick, widely divaricating, and frequently branched interstices, the irregular shape of the fenestrules, and the much fewer and more prominent pores.

Position and Locality.-Not uncommon in the Wenlock limestone of Dudley, Staffordshire.

Explanation of Figures.-PI. 1. C. fig. 20. Natural size, from Dudley.-Fig. 20 . Portion of ditto, magnified twelve diameters.

Fenestella rigidula $\left(M^{c}\right.$ Coy $)$. Pl. 1. C. fig. 19.

\section{Ref.-MI'Coy, Ann. Nat. Hist. 2nd Series, Vol. VI. p. 288.}

$s_{1}$. Ch.-Corallum formed of very slender, ridged, straight interstices, branching seldom (at distances of about every two lines), several interstices often branching at the same height, at a very acute angle, about ten interstices in the space of two lines; mesial keel very strong, with two close rows of small alternating pores; fenestrules very regular in size and shape, quadrangular, about one-third longer than wide, their width about equalling that of the interstice, usually three large thick-edged pores to the length of a fenestrule, and one larger at the end of each dissepiment.

In size, mode of branching, and rigid straightness of the interstices, this is not unlike the $F$. subantiqua, but is distinguished by its closer dissepiments, forming shorter fenestrules and its much fewer and larger pores. I suspect, from some specimens I have seen, that it is possible some of the figures given by Lonsdale in the Silurian System, as the Fenestella prisca (Gold. Sp.) may be coarse, inaccurate representations of this species. If this should even prove so, the name I propose should be retained, as it has no affinity with the large Devonian coral of Goldfuss.

Position and Locality.-Not uncommon in the Wenlock limestone of Dudley, Staffordshire.

Explanation of Figures.-Pl. 1. C. fig. 19. Natural size from Dudley.-Fig. 19 . Portion of ditto, magnified thirty diameters.

\section{Fenestella subantiqua $\left(d^{\prime} O r^{\circ} b\right.$. $)$}

Ref. and Syn-d'Orb. Prod. p. 44. = Fenestella antiqua Lonsd. Sil. Syst.t. 15. f. 16. (not of Groldfuss).

$S p . C h$-Corallum formed of very slender, straight interstices, seven or eight in two lines, seldom bifureating; dissepiments rather thick, very regularly placed at about half a line apart; fenestrules rectangular, oblong, about three times longer than wide, rather more than double the width of the interstices; pores small, with thickened prominent edges their own diameter apart, six or seven to the length of a fenestrule.

Mr Lonsdale has identified this species with Retepora antiqua of Goldfuss, which species does not probably oceur in Silurian strata, and the figure of the Eifel specimen in the Petrefacta Germanie, represents 
a coral greatly larger (or with more interstices in a given space) than the present species, and laving on the arerage much fewer cells to the length of a fenestrule; the present species has had the aloove new name applied to it by M. d'Orbigny. The magnified figure in the Silurian System has the interstices too thick in proportion to the size of the fenestrules.

Position and Locality.-Rare in the schists of Mathyrafal, S. of Meiford, Montgomeryshire, and Llansantfraid, Glyn Ceiriog, Denbighshire.

\section{6th Class, ECHINODERMATA.}

\section{= Nematoneura (Owen.)}

The Echinodermata is the first class in ascending order in which a nervous system has been detected. It exists in them in the form of distinct threads (whence the name Nematoneura) without. ganglia or centres of perception; the most distinct thread round the œsophagus. The Zoophyta have no bloodvessels, but a distinet arterial and renous system is present in all the Eckinodermetc. Respiration is performed apparently by the peritoneal surfaces of the interior as well as by the exterior membranes, which are covered with cilia to excite the necessary currents; in addition, the Asteriadk, Echinida, Holothurice, have pinnate rascular branchia round the mouth, and a peculiar aquiferous system which is apparently the most efficient, and is formed by two rows of large vesicles running along the ambulacra, covered with a dense vascular plexus of minute blood-vessels, which arate their contents by contact with the sea-rwater with which they are filled; these resicles give off each two little tubes, which perforate the integument by separate openings, and immediately unite to form a long tube, with a terminal disk, to which, from its office in locomotion, the term "sucker," has been applied; these suckers are provided with circular and longitudinal muscular fibres, by the contraction of the first of which on the fluid contents of the resicle the tube is extended, and by the action of the others it is retracted and the terminal disk caused to adhere. Some of the Echinodermata are soft and smooth, while others are covered with a hard calcareous crust, but as they never moult, like crustacea, it is necessarily composed of a number of polygonal pieces, which are secreted by the membranes which envelope them and jass between their edges, where the principal additions are made as the animal grows larger. Digestion is always performed in a distinctly-walled carity.

Previous to the researches of Agassiz, the Echinodermata were usually considered perfectly radiated animals, without a trace of that symmetrical disposition of the parts observable in higher animals; he noticed, however, that in Spatangus, there was a flattened ventral disk below, with the mouth near one end which was therefore the anterior, the anus at the opposite end defining the posterior extremity, and therefore the right and left sides, the general form being elongated in the direction of the length; the whole being perfectly bipartite and symmetrical; of the five ambulacra, one was observed to go directly to the mouth, therefore called the anterior, the other two pairs being lateral, leaving one interamlulacral space (opposite the anterior ambulacrum) at the posterior end, in which the anal opening was situated, and which was terminated superiorly by the peculiar large odd, or fifth, porous plate, connected with the sand canal, while the four lateral interambulacra were terminated by the ordinary small genital plates; by the coincidence between the position of this fifth plate and the anal opening, whenever the latter was excentric, a clue was obtained whereby to recognize the posterior interambulacral space, no matter how the position of the alimentary openings was varied-in Gaterites the mouth was observed to be in the middle of the ventral disk, but the anus was still at the posterior margin, and defined the symmetrical position of all the rest of the parts; finally, in Eclinus, \&ec., where the form was spheroidal, without perceptible elongation in the direction of the length, and the two alimentary openings were precisely central, one in the middle of the ventral aspect, the other vertically over it in the middle of the dorsal, the position of the odd porous ovarian plate, determined with certainty as before the posterion intertumbulacmet space, and consequently the symmetrical disposition of the remainder of the creature. In the same way the position 
of the madreporiform tubercle of the Starfishes defined their posterior interambulacral space, and the opposite ray, like the opposite ambulacrum of the Echinidan, becomes the anterior one.

Divided into the orders:-1, Crinoidea; 2, Blastoidea; 3, Ophiuros; 4, Asterios; 5, Perischoochinidoe; 6, Echinido; 7, Holothurice; 8, Sipunculide; 9, Cystidte. The 7th and Sth being naked and soft, are not known in the fossil state, the former in other respects resemble the Echinidce, the latter so far resemble worms externally as to be so classed by Agassiz.

\section{1st Ord. Crinoidea.}

Viscera enclosed in a cup of numerous polygonal, calcareous plates; mouth surrounded by five solid, prehensile, branching rays, set on the inner side with jointed fimbriated tentacles; attached to foreign bodies either permanently or in the young state, from the middle of the back by a long flexible jointed column, perforated by an alimentary canal, and often furnished on the sides with slender pointed "auxiliary sidearms" of numerous joints, to aid occasionally in securely anchoring the stem.

To avoid the discrepancies which exist between the opinions of Miller, Phillips, Austin, \&c., as to which plates of the cup should in all cases bear the distinctive terms, Pelcis, 1st and Ind costuls, \&c., proposed by Miller, and used even by himself in a different sense in different genera, I would propose the following system of nomenclature for the plates, which is applicable to the most complex as well as to the most simple cups, and will enable us to particularize any individual plate for description (which cannot be done according to the methods employed by MM. A gassiz and D'Orbigny, who define their genera simply by enumerating the number of rouss of plates forming the cup, and without giving any greater importance to the normal regular lines, than to the irregular intercalated ones). In reviewing the whole class Echinodermata, we must be struck with one of the most persistent characters of the group, namely, the disposition of the organs of prehension or locomotion in five rays round the mouth-this is without exception in the higher groups, as the Echinidle: in the lower Asterice they are occasionally more numerous; in the lower Ophiurce they again resume the typical number, and the prehensile arms of the Crinoids, are with very few exceptions, five in number at their origin. Taking this as a starting point, we may call the column and its appendages, and the first row of plates resting immediately on it, forming the pelvis, by the old names of Miller. The five plates usually found resting on the pelvis, I propose to call 1st primary radial plates, as they are the first of the vertical rows which form, or originate, the rays; on the upper edge of each of these rests the 2nd, and vertically over that, the 3rd, \&c., primary radial plates, as far as the first cuneiform or pointed joint, the number varying with the genus without, on this system, occasioning any ambiguities, each individual plate of the series being only distinguished by a numeral. The last or cuneiform joint, originates a double set of plates, or branches, and these I propose calling the secontary radials as far as their last or cuneiform joint, distinguishing each individual, as before, by a numeral, commencing from the base. The succeeding branches are unimportant, never forming part of the cup, and do not require particular names. When (as in Actinocrimus) six joints rest on the pelvis, only five of them originate vertical rows going to the rays, and I propose to call the intercalated plate 1st interradial; the two plates resting on its pointed summit I would call and interradials, as well as the plates at the same level in the other four spaces between the primury ratial rows; the plates resting on the 2nd interradials I would call 3rd interradials, and so on without limit. The rows of interradial plates alternate with those below and above them, and never form vertical continuous lines like the radials. To give an example of the superior precision and simplicity of this notation, we may take two well-known genera-Platycrinus and Actinocrinus: the first has a very simple cup of one row of plates, the other has a very complex cup of numerous rows. In Platycrinus the five plates resting on the pelvis are named scopula by Miller and most succeeding writers, and the five rows resting vertically on them as far as the first cuneiform joint, he terms arms; the two rows of plates going from each first cuneiform joint, he calls hands. In Actinocrinus, however, he calls the six plates, resting on the pelvis, lst costals, although one of them is abnormal, and the other five are precisely the same plates which in Platycrinus he called scapular; the next row he calls and costals, although identical with thuse called arm-juints; 
in Platycrinus and the next, or cuneiform plate, he here calls scapula, although having nothing in common with the plates so called in the former genus (agreeing rather with its last or cuneiform arm-joint), and so of the succeeding plates; the same confusion exists among succeeding writers to as great an extent, and in various genera. According to the plan here proposed, the scapule in the one case, and true 1st costal in the other, would equally be called 1st primary radial, and the irregular one of Actinocrinus, the 1st interradial, and the 1st cunciform arm-joint in one, and the scapula in the other, would be designated by its number, as the cuneiform or last of the primary radial plates in each case. The cup should, in the descriptions, be defined as composed of so many rows of each series (each series being supposed to terminate at a pointed, or cuneiform, joint) and so many rows of inter-radials, the proper numerals being prefixed to each.

\section{Genus, TAXOCRINUS (Phill.)}

= Isocrinus (Phill. not of V. Meyer) = Cladocrinus (Aust. not Agassiz).

Gen. Char.-Column and alimentary canal round or pentagonal, cup formed of pelvis, 1st and 2nd primary radials and five 1st interradials; pelvis of five pentagonal pieces, alternating above which, are five large pentagonal (or slightly heptagonal) 1st primary radials (or scapul $\alpha^{\prime}$ ); remainder of the primary radials, nearly equalling the first in width; five hexagonal interradial plates intervene between the second primary radials, resting on the upper lateral edges of the 1st ditto.

The interradial plates and the separation of the primary radial rows seem to separate this genus from Ichthyocrinus.

\section{Taxocrinus? Orbignil $\left(\boldsymbol{M}^{c} \mathrm{Coy}\right)$. Pl. 1. D. fig. 1. \\ Ref.-M McCoy, Ann. Nat. Hist. 2nd Series, Vol. VI. p. 289.}

Sp. Ch.-Column cylindrical, about two lines in diameter at an inch from the pelvis, and not varying materially in character within two inches from the pelvis; joints finely granulated, uniformly two in the space of one line; pentagonal pelcic plates one line high, alternating with which are the pentagonal or obscurely heptagonal 1st primary radial joints, (or scapulie) nearly one and one-third lines long; arms of two quadrangular and one cuneiform (래, $3 \mathrm{rd}$, and 4 th primary radial) joints, each one line long, and one and a third lines wide, the latter giving off two rows of secondary radials, (or hands) of five joints, the last being cuneiform, and giving origin to two fingers; from pelvis to end of fingers one inch three lines.

I have not distinctly made out the interradial plates, but as there seems a notch between the upper adjacent edges of the first primary radials or scapula, I have little doubt they existed; besides their presence, the species is easily distinguished from the Ichthyocrinus pyriformis (Phill. Sp.) by the greater number of joints in the arms and hands, and the much thicker column, and the nearly unvarying character of the joints, as they approach the pelvis.

Position and Locality.-In the "Asterias" bed of the Upper Ludlow rock at High Thorns, Underbarrow, Kendal, Westmoreland.

Explanation of Figures.-Pl. 1. D. fig. 1. Body, rays and part of column, natural size from High Thorns, Underbarrow.

\section{Taxocrinus tuberculatus ( Iill. Sp.)}

\section{Ref. and Syn.-Cyathocrinus tuberculatus (Mill.) Crin.}

$s p$. Ch.-Arms of two primary radial joints equalling the lst ditto (or scapulæ) in size; hands of three secondary radial joints, fingers of five or six joints to the first cuneiform joint, from which they dichotomise once; all the plates coarsely tuberculated; column round of thin joints near the pelvis, becoming thicker and alternately larger and smaller at a little distance; from pelvis to top of first cuneiform joint (at end of primary radials or arm) six lines, width of arm two lines, length of hand and fingers about one inch.

Position and Locality.-Common in the Wenlock limestone of Dudley, Staffordshire. 


\title{
Gemus. ICHTHYOCRINUS (Conrad.)
}

\author{
Ref.-Conrad. Journ. Acad. Phill. Vol. VIII. (Partly defined by D'Orb. Prod. Pal.)
}

Gen. Char._Column round; cup composed of pelvis and all the primary radials; pelvis small, of five pentagonal joints, the re-entering angles supporting five pentagonal first primary radials (scapulat), on which rest five equally wide quadrate 2nd ditto; 3rd ditto pentagonal or cuneiform, supporting two rows of secondary radials (or hands) of four joints each, from which proceed two fingers, each dichotomising, of one row of tertiary radial joints.

The absence of interradial plates separates this genus from Tacocrinus. Without the suggestion of M. d'Orbigy (see supra) the figure and description of $\mathrm{Mr}$. Conrad would not have been definite enough to establish this genus, I therefore take them in conjunction as authorities for it.

\section{ICHTHYOCRINUS PYRIFORMIS (Phill. Sp.).}

\section{Ref. and Syn.-Cyathocrinus pyriformis, Id. Silurian System t. 17. f. 6.}

$S p . C h .-$ Column round, joints of unequal thickness till near the pelvis, where the column slightly widens, and the upper twelve or thirteen joints become very thin and equal; pelvic pieces rather more than half a line high; 1st, 2nd, and 3rd primary radials (or scapulce and two arm joints), each about a line long; secondary radial rows (or hands) two lines long, the outer fiuter of each hand three lines long, with eight joints before bifurcation; the inner finger two lines long, with five joints before the furcation, which only occurs once in either finger; width of all the primary radial joints about one line and a third each; width of column about one line at an inch from the pelvis; length from pelvis to end of rays one inch.

Position and Locality. - In the Asterias bed of the Upper Ludlow rock at Light Beck, Underbarrow, Kendal, Westmoreland.

\section{Genus. MARSUPIOCRINUS (Plill.)}

Gen. Char.-Column round, of nearly equal joints; cup formed of the pelvis, one primary, one secondary, two or three tertiary radials, and five 1st interradials; fretris pentagonal, supporting five large hexagonal (or slightly octagonal) 1st primary radials (or scripli"), each of which bears two large flattened oblique, polygonal sccondary radials, having between them at hase, on the truncated apex of the primary radial, a small pentagonal interbrachial plate; over each secondary radial (or arm plate) is a double series of three or four wedge-shaped tertiary radial plates, representing two flattened liands, the last joint of each of which gives origin to a very long tentaculated finger, each of a double row of joints; one large hexagonal interradial plate between each pair of primary radials.

The tentacula, suggested by Prof. Phillips to be alosent, are, I find, very largely developed, and the column is certainly round.

\section{Marsupiocrinus ceelatus (Phill.)}

$$
\text { Ref.-Phill. Sil. Syst. t. 18. fig. } 3 .
$$

Sp. Ch. - Width of cup one inch four lines; length from base of fingers (last tertiary radial) to pelvis eight lines; length of fingers three inches; length of primary radials or scapule three and half lines; width seven lines; length of interradial plate four lines; plates of the cup marked with small irregularly radiating vermiform wrinkles.

Position and Locality.-Wenlock limestone, Dudley, Staffordshire.

\section{Genus. CROTALOCRINUS (Aust.)}

Ref.-Austin, Ann. Nat. Hist. 1843, p. 198.

Gen. Char.-Peleis pentagonal, of five pentagonal plates, supporting one heptagonal and four large hexagonal primary radials (first costals), which alternate with the pelvic plates; resting on the truneated 
apex of the heptagonal plate is a hexagonal interradial; above, and alternating with the prinary radirels, are five large pentagonal secondary radials (scapulie) completing the cup, on each of which rests a series of small pentagonal plates, supporting for the wilth of each plate a large number (? fifteen or sixteen), very slender long rays; cotumn round, joints radiatingly striated; alimentary canal pentapetalous.

Messrs. Austin omit to notice the sixth or interradial plate in the second perisomic row, in their description. The genus differs from Cyathocrinus in the vast number of its rays.

\section{Crotalocrinus rugosus (Mill. Sp.)}

\section{Ref. and Syn.-Cyathocrinus rugosus (Mill.) Crin.}

Sp. Ch.-Length of body from pelvis to base of free rays eleven lines, greatest width (one-third below base of free rays) one inch two lines, length of fingers three inches five lines, wilth of hands rather less than a line, width of fingers about half a line, joints of rays a little longer than wide; length of pelvie plates three lines; width of columnar articulation six lines, length and width of primary radials seven and half lines; plates marked with numerous radliating ridges about three in the space of a line, forming triangular patches; the centre of the plates sometimes obscurely tuberculated.

Position and Locality.-Not uncommon in the Wenlock limestone of Dudley, Staffordshire.

\section{Genus. ACTINOCRINUS (Mill.)}

Gen. Char.-Column round, of alternately thinner and thicker joints, radiatingly striated from a round alimentary canal; pelvis hexagonal, of three pentagonal plates, supporting five hexagonal 1st jumary radiuls (first costals), and one pentagonal interradial; on each 1st primary radial rests a hexagonal 2nd ditto (second costal), bearing the 3rd ditto (or scapulre), from which proceed two rows of secondary radials or arms, of one or two flattened plates, laterally united to form part of the cup, giving origin as free rays to two hands of about four joints each, from which proceed several tentaculated fingers, composed of two rows of joints each; over the pentagonal 1st interradial, rest two hexagonal 2nd ditto (intercostals); alternating above each pair of primary radials, is one Ind interradial; over the Ind interradials rest three or more 3rd ditto (interscapular plates) blending gradually with the capital plates, which are often spinose; mouth produced into a long tube; all the plates of the cup usually radiatingly ridged.

\section{Actinocrinus pulcien (Salt. MSS.)* Pl. 1. D. fig. 3.}

$S p$. Ch.--Length of cup from pelvis to 2nd secondary radial or arm-joint two lines, width at base of arms three lines, length of rays from 3rd primary radials (scapulæc) to the tip of the fingers six and half lines; plates of the body conforming in number and shape to the generic type, but so strongly radiated, that they seem surrounded by a number of pits, corresponding to the number of their angles; column near the pelvis one line in liameter, composed of circular, alternately thicker and thinner joints, every third or fifth larger than the others; at a foot from the pelvis the column is scarcely two lines in diameter, all the lower portion having the joints of nearly uniform thickness, each with an irregular circle of from eight to ten slender spine-like auxiliary side-arms three lines long; cuneiform secondary radials or arms supporting two rows of tertiary radials or hands about one and half lines long, each dividing into two fingers, the inner of which dichotomises again at about the same distance into two branches,

* Mr Salter (now of the Geological Survey) undertook, some jears ago, to engrave and write notices of Prof. Sedgwick's Welsh and Westmoreland Fossils, but only a small portion of the task was ever achieved; such of the figures as were of use have been now transferred to stone (PI. 1. G.), and I have noted in the Explanations some little points requiring correction. I read over the notes, but made no farther use of them than to quote, with his name, \&c., as above, such of his new species as seemed to me really new (giving, howerer, new descriptions), and I wished the MSS. to be printed entire to prevent misconceptions on this point; but, at the Author's request, they have been returned to him for corrections, and will appear in an Appendix. 
the outer of which continues simple, but the inner one branches again near its extremity; the outer finger of each hand continues simple for rather more than three lines, then branches once; all the fingers are densely tentaculated (of two rows of joints).

Position and Locality.-Numerous perfect specimens of this little species, with their rays and columns attached, are preserved on a thin slab of Upper Silurian flag from Nant-gwchwyd-uchaf, S. of Llangollen; fragments of the remarkable column with the spine-like auxiliary processes in the Upper Ludlow quartzite of Shepherd's Quarry, Kendal, Westmoreland.

Explanation of Figures.-Pl. 1. D. fig. 3. Part of large slab from near Llangollen, natural size, shewing three perfect cups with their rays, attached to their columns, and some portions of the older columns.

\section{Genus. PERIECHOCRINUS (Aust.)}

\section{Ref. and Syn-Austin, Ann. Nat. Hist. 1843, p. 203. = Geocrinus (D'Orb. 1847).}

Gen. Char.-Pelvis (? of three plates) 1st and 2nd primary radial plates (castals) hexagonal; 3rd ditto (or scapula) pentagonal, supporting two nearly similar hexagonal, 1st secondary radial (arm) plates, each supporting a pentagonal and ditto, from each of which proceed two rows of tertiary radials, that on the outer side ending in one very long simple finger, that on the inner side giving off two fingers, the outer one simple, the inner one soon dichotomising; all the fingers have two rows of joints, with long plumose tentacles; each of the five rows of primary, secondary, and tertiary radials (costals, scapulæ, and arm-plates) more prominent than the other plates of the cup (often keeled); none of the plates conspicuously radiated; above and between the two 1st secondary radials (arm-joints), is situated in each row one large hexagonal interbrachial plate, surmounted by two smaller, and so blending with the capital plates; the interradials are irregular, being apparently one hexagonal 1 st interradial between the 2 nd primary radials, surmounted by two or three 2nd interradials between the scapulæ, or 3rd primary radials, succeeded by more numerous polygonal plates, blending with those of the summit; column round, of alternately thicker and thinner joints.

The remarkable characters of the secondary and tertiary radials or arm- and hand-plates being flattened and forming part of the walls of the cup, leaving only the fingers free, distinguish this complex crinoid from Actinocrinus. The specimens I have examined are unfortunately crushed about the pelvis, so that I have doubts as to the propriety of separating Glyptocrinus of Hall from Pericchocrinus; the comparatively smooth plates in the latter, however, and the pelvic plates not being divided vertically under the middle of the 1st primary radial (or 1st costal), go to prove the correctness of the separation.

\section{Periechocrinus moniliformis (Mill. Sp.)}

Ref. and Syn.-Actinocrinus moniliformis Mill. Crin. Id. Phill. Sil. Syst. t. 18. f. 4. = P. costatus Aust. Ann. Nat. Hist. Vol. XI, p. 204.

Sp. Ch.-Cup from pelvis to base of fingers conoidal, little wider than long; a strong ridge extends from the pelvis up each of the primary radial rows, branching at an angle of $40^{\circ}$ on the scapular or 3rd primary radial plate, the two branches running up the secondary radials or arm-plates, and again dichotomising to the tertiary radials or hands; 1st, 2nd, and 3rd primary radials (or costal and scapular plates) as long as wide; joints of the column very tumid; fingers strong, nearly four times the length of the cup; average length of cup one inch ten lines.

Position and Locality.-Common in the Wenlock limestone, Dudley, Staffordshire.

\section{Genus. GLYPTOCRINUS (Hall.)}

Gen. Char.--Cup pyriform, pelois of five, hexagonal or pentagonal pieces, alternating above which are five pentagonal 1st primary radiuls (first costals), each supporting a hexagonal Ind ditto (sccund custal), on which rests a heptagonal 3rd ditto (scapula), bearing two rows of secondary radials or arms, of two 
hexagonal, and one pentagonal or heptagonal flattened plates, from which proceed two hands of three plates each (completing the cup) from whence the rays originate; one or two rows of large interbrachial plates between the secondary radial rows; a strong ridge runs up the middle of each of the primary radial rows, then dichotomising, one branch going to each of the secondary radial or arm rows; all the plates of the cup marked with thick radiating ridges, one usually passing through the middle of each side to the centre of the adjoining plates; one large octagonal or hexagonal 1st interradial (or intercostal ytate, supporting two or three end ditto (or intersecupular ylutes); column rounded or subpentagonal, the joints radiated or marked with five petalloid crenulated ridges.

Like Periechocrinus this genus has the plates of the arms and hands, or secondary and tertiary radial rows, flattened, to form part of the eup instead of the rays; the chief distinctions between these genera being the distinctly quinquepartite pelvis and strongly radiated plates of Glyptocrinus.

\section{Glyptocrinus basalis (McCoy.) Pl. 1. D. fig. 4.}

Ref.-McCoy, Ann. Nat. Hist. 2nd Series, Vol. VI. p. 289.

sp. Ch.-Cup semipyriform; pelvic plates hexagonal, slightly exceeding the primary radials in length and supporting the interradials on their upper truncated edge; all the plates marked with thick radiating ridges, one to each side, except in the pelvic plates, which have them only to the three upper sides, the lateral pair being the forked ends of the strong vertical ridge of the primary radial rows; average length of cup from pelvis to base of free rays, one inch six lines; width the same; length of pelvic plates three and half lines; pentagonal 1st primary radial three lines; hexagonal 2nd ditto two and half lines; heptagonal 3rd ditto (scapular) plate three lines; hexagonal 1st secondary radial or arm-plate two and half lines; 2nd ditto two lines.

This fine species differs from the Glyptocrinus decadactylus (Hall.) of the Hudson River group of New York, by the great size of the pelvic plates, and their being hexagonal instead of pentagonal, and their bearing the interradial plate directly on their truncated upper edge, the interradial in the American species being supported on the sides of the laterally united 1 st primary radials, which latter plates in this species are completely separated. The first of the secondary radial, or arm-plates, are laterally united without the intervention of an interbrachial plate, which exists, however, between the end secondary radials, and nearly equalling them in size. In one of the most distinctly preserved interradial spaces, three 2nd interradials (interseapular plates) are seen to rest on the upper half of the octagonal 1st interradial, the lateral ones being pentagonal, and the middle longer one hexagonal.

All the plates seem to have been thin and allow considerable variety in form of the cup from slight pressure.

Position and Locality.-Not uncommon in the calcareous schists of Alt yr Anker, Meifod, Montgomeryshire.

Explanation of Figures.-Pl. 1. D. fig. 4. Natural size from the schists of Alt yr Anker, Meifod.

\section{Genus. EUCALYPTROCRINUS (Gold.)}

= Hypanthocrinus (Phil.)

Gen. Char.-Column and alimentary canal round; body very large, oval, mouth central, projecting; capital plates large, convex; rays very short, only reaching to the base of the mouth; pelvis small, concave; 1st primary radials five, hexagonal, each supporting a quadrangular 2 nd primary radial, on which rests a pentagonal or slightly hexagonal 3rd primary radial (scapula), from the sides of which come off two rows of one or two secundary molials (arm-joints), often with one interbrachial plate between them ; each cuneiform secondary radial supports two free rays or hands, of two or more fingers, each finger of a double row of joints; five very large rounded polygonal 1st interradial pletrs, surrounded by the whole of the primary and secondary radials, supporting a pair of small ovate -nd interradial plates, generally extending in a thick club-shaped ridge as far as the tips of the fingers. 


\title{
Eucalyptrocrinus decorus (Phill. Sp.)
}

\author{
Ref. and Syn.-Hypanthocrinites decorus (Phill.) Sil. Syst. t. 17. f. 3.
}

Sp. Ch.-1st primary radials rather more than one-fourth wider than long, and primary radials onethird wider than long; 3rd primary radials (or scapuloe) hexagonal, each supporting on its truncated apex an ovate interbrachial plate, nearly twice as long as the scapula; from the two upper sides of the scapula, or cuneiform primary radial, proceed two rows of secondary radials (or arms) of two or three joints, the first of which is much the largest; from the last of which proceed two rows of tertiary radials (or hands) of three or four joints, each hand terminating in one thick finger, of two rows of cuneiform joints; on each large 1st interradial plate rest two semi-elliptical 2nd interradial plates, together about equalling the interbrachial plate in size; from each of these pairs and from each of the interbrachial plates, a thick smooth clubshaped ridge runs nearly to the ends of the fingers, followed towards the mouth by a large ovate tubercle; capital plates very gibbous. Length from pelvis to base of mouth, two inches four lines; width of cup, one inch one line; length of fingers, one inch two lines.

Position and Locality.- Wenlock limestone, Dudley, Staffordshire.

\section{Eucalyptrocrinus polydactylus $\left(M^{\circ}\right.$ Coy). Pl. 1. D. fig. 2.}

Ref.-McCoy, Ann. Nat. Hist. 2nd Series, Vol. II. p. 249.

Sp.Ch.-(The small concave pelvis not seen); 1st primary radials hexagonal, convex, one-third wider than long, each supporting a quadrangular 2nd primary radial nearly twice as wide as long, its width nearly one-third less than that of the 1 st primary radial; on each 2 nd primary radial rests a pentagonal $3 \mathrm{rd}$ primary radial (or scaprelar) joint, equalling the second ditto in width, but exceeding it in depth: on each cuneiform primary radial or scapula rests two hexagonal 1st secondary radials or armjoints, nearly equalling the scapule in width and depth, and joining by their inner margins (so that the interbrachial plates cannot rest on the scapula); on each of these rests a smaller hexagonal 2nd secondary radial, from each of which arise two rows of tertiary radials, or hands, bearing four or five fingers each; between the two 2 nd secondary radials or arm-joints of each arm is a small heptagonal interbrachial plate, its inferior pointed end resting on the two 1st ditto, and its truncated upper end supporting the usual small lozenge-shaped plate (second interbrackial) peculiar to this genus; circumscribed by all the primary radials and 1st secondary radials, are the five large, equal, convex, nine-sided interradial plates, each supporting on its upper edge a vertical row of three 2nd, 3rd, and th hexagonal interradial plutes. Diameter of cup about one and quarter inch.

Besides the minor differences of proportion in the various plates which may be gathered from the description, this differs from the IIypenthocrinus (Eucalyptoverinus) drcurus (Plill.) and E. rosuceus (Gold.) in the lateral union of the 1st arm-joints or secondary radials, and their supporting the interbrachial plates, instead of the cuneiform primary radial or scapula, the seapulac consequently being pointed above; also in the plates resting on the interradials, not being bifid, and most remarkably from all of the genus in the number of fingers, there being but one to each hand in the other species. I have only seen a cast, and am not certain whether the fingers have one or two rows of joints.

Position and Locality.-Rare in the Wenlock limestone of Dudley, Staffordshire.

Explanation of Figure.-PI. 1. D. fig. 2. Natural size from Dudley.

\section{4th Ord. Asteria.}

Body divided into five or more hollow, simple, ray-like, lobes, containing the viscera, and grooved on the under side for ambulacra, or rows of suckers, for locomotion. One of the rays (considered the anterior) has opposite to it, in the space between the bases of two rays at the dorsal aspect, a peculiar porous 
'marleporifurm tubercle' marking the posterior side and forming the external termination of a peculiar organ termed the "sand canal" extending from thence to the arterial circle round the mouth. The genital openings pierce the bony circle round the mouth. The mouth has no teeth; the resophagus is short, and two large creca extend into each ray, exposing the chyle to the veins, which latter communicate with a large circular venous trunk surrounding the mouth, and communicating by a vertical muscular tube, or heart, with a smaller arterial circle also surrounding the mouth and giving out branches to the mouth, to the intestine, others running between the ambulacra supplying the suckers, and perforating the integument at the tips of the ambulacra to supply the external membranes. The nervous system is distinct, one cord runs round the mouth, giving off three branches to each ray, one running between the ambulacra to the tip, where, according to Ehrenberg, it dilates to form a bulb or optic nerve, to supply a bright red point at the end of each ray, usually considered to be, in consequence, a true eye; the other two nervous branches supplying the viscera. The sexes of all the Starfishes are in distinct individuals, the ovaries in the one case, and testes in the other, forming bunches of slender caeca round the osophagus, two at the origin of each ray.

The following notice of the Palæozoic Starfishes has been contributed by Prof. E. Forbes. As the specimens belonging to the University Collection have been figured by the Geological Survey, it has not leen thought necessary to refigure them. Before I was aware Professor Forbes had described them it seemed to me that the $U$. Ruthveni and $U$. Hirudo, as well as the similar American species, might be easily separated from the great star-fishes forming the recent genus Uraster, by their small size and much more simple skeletons, and I had named the genus Urasterella in my MSS. The $U$. Primovnes I thought generically distinct from the other two, as the rays were not contracted at base \&c.; and I had named it Palasterina, from its resemblance to the recent genus $A$ sterina.

"True starfishes have rarely been met with in the older rocks. When they do occur, however, they are not likely to be overlooked, as their forms and structure cannot easily be confounded with those of the other radiata. At the same time, the fragility of the existing species and the difficulty attending their preservation entire, after death, reduce the chances of our finding them frequently in the fossil state. Such as do occur in Palrozoic rocks have a singular resemblance to existing forms, especially to those species which are characteristic of Northern seas. Hence it is convenient to retain them in known genera; for although parts may lave been lost, and textures disappeared, which might have warranted their generic separation, there is nothing remaining to us of their organization which would not be consistent with that of existing Asteriade of the generic groups to which they are here referred.

\section{Genus. URASTER (Agassiz).}

Uraster RUthVEni* (Forb.)

\section{Ref.-Forb. Mem. Geol. Surv. Dec. 1. t. 1. f. 1.}

"Sp.Ch.-Disk small; arms rounded, very long, linear-lanceolate, subearinate. Upper'surface reticulated; interspaces irregular; under surface marked with the impressions of the double series of linear ambulacral ossiculre, each of which is slightly curved.

"The back and upper surface of arms of this species were probably covered with close set fasciculi of small obtuse spines. Disk to ray as $1-5$. Breadth of ray $0_{\frac{25}{25}}^{3}$ Breadth of Disk $\frac{5}{25}$ inch. Length of ray $1_{10}^{\frac{4}{10}}$.

\section{URASTER? HIRUDO (Forb.)}

\section{Ref.-Forb. Mem. Geol. Surv. Dec. 1.t. 1. f. 4 .}

"Sp.Ch.-Disk very small; arms tapering, linear lanceolate, acuminate, contracted at their bases. Upper surface with radiating series of reticulated spinous bundles, placed very regularly, so that each ray appears

* Named in compliment to the zeal and intelligence of Mr. John Ruthren, of Kendal, who has collected the greater part of the Westmoreland fossils-and is well acquainted with the structure of his rative county. 
as if it were marked with three or four longitudinal furrows, crossed at regular intervals by transverse grooves. Under" surface with short ambulacral plates and broad avenues.

"This combination of characters gives a singular Ophiura-like aspect to this curious little star-fish; possibly it may not belong to the same genus with the following. It is a gregarious species. Disk to ray as 1 - 4 . Breadth of disk $0 \frac{1}{19}$ inch. Length of ray $0 \frac{4}{\sqrt{2}}$. Greatest breadth of ray $0 \frac{1}{12}$.

\section{Uraster prisizvUS ( Forb.)}

Ref. and Syn.-Asterias primava. Sedgwiek, Letters on the Lake Country, 2nd Ed. Appendix.

Mem. Geol. Surv. Dec. 1. t. 1. f. 2.

"Sp.Ch,-Disk broad; arms triangular, short, acuminate. Upper surface irregularly reticulated, having probably been studded with tufts of obtuse spines, which were largest on the centre of the arms, so as to form a sort of keel. Under surface shewing the double series of linear-oblong, curved ambulacral ossicula, which are shorter in proportion than those of the $U$. Ruthveni. Breadth of disk to length of rays, as $1-1 \frac{1}{2}$. Breadth of disk $\frac{3}{10}$ inch. Breadth of ray at base $\frac{2}{10}$ inch. Length of ray $\frac{5}{10}$ inch.

\section{Genus. PROTASTER (Forb.)}

"Gen. Char.-Body circular, covered with squamiform plates; genital openings in the angles of junction of the arms beneath; arms (simple) formed of alternating ossicula.

\section{Protaster Sedgwickil $(F o r b *$ )}

Ref.-Mem. Geol. Surv. Dec. 1. t. 4.

"The remarkable fossil, of which, through the co-operation of Professor Sedgrwick, we are enabled to give a figure, is unique of its kind, and has a peculiar interest in being the only representative of the tribe Euryales as yet discovered in the fossil state. I refer it to that tribe, and not to the Ophiurce, with which at first sight it might be confounded, on account of the alternation of the ossicula of the arms, a conformation of which the Astrophyton and other genera of the former group exhibit examples, whilst it is never seen in any genus, as yet discovered, of the latter division. Like many other Silurian fossils, this one affords but imperfect materials for an investigation, zoologically, of its characters; such, however, as are to be seen in the specimens hitherto procured, are sufficient to enable us to assert with certainty, that it is distinct both generically and specifically from any known starfish, whether recent or fossil.

"The specimen figured consists of tolerably preserved impressions of the upper and under side of the disk or body, and of portions of the arms. The disk is circular, and shaped liked that of an Ophiura. The arms are five in number, very narrow, equidistant, and similar.

"The upper and under surfaces of the disk were covered by small, similar, more or less regular, polygonal or crescentic plates, imbricated in scale-fashion, and having punctated surfaces. Those of the under side of the body are smaller and more regular than those of the upper. The mouth is central,

* A specimen, ticketed, 'Ophiura Salteri, Forbes,' from the upper Ludlow rock of Shepherd's Quarry, has been sent to the Cambridge Museum by Mr. Salter; on examination I find it to be a specimen of Protaster Sedgwicki, with the scaly circular disk very indistinctly visible, except in particular lights. On communicating this observation to my friend, Prof. Forbes, he wished his name Ophiura Salteri (which has appeared in some of Prof. Sedgwick's lists of fossils, and been copied into Prof. Bronn's Index Palrontologicus) to be cancelled. I might add from this specimen that the spinoso appendages are at least twice the length of the ossicles, and that the ossicles seem to increase in length at a distance from the disk; with a high magnifying power some of these spire-like processes seem jointed; if this observation be confirmed by exanination of more distinet specimens, it will be extremely interesting, as strongly supporting the above view of the general affinities of the fossil being with the Crinoids or Euryales rather than with the Ophiura, in which the apparently similar processes are rigid spines for locomotion.-F. $\mathbf{M}^{\mathrm{C}} \mathrm{C}$. 
and rather small in proportion to the disk. The buccal apparatus is composed of ten parts or processes, arranged in pairs; half of each springs from the origin of each arm in a diverging manner, and meets the corresponding half to form a lanceolate tooth-like projection, deeply indenting the cavity of the moutl. Of how many separate ossicles each of the buccal processes was composed, the specimen affords but very indistinct indication. They seem to affect a slightly falcate form at their extremities. The arms were composed of alternating somewhat quadrate ossicula, the sides of which were deeply indented superiorly, in order to form spiniferous crests. The spines were apparently short, and not equal in length to the length of an ossicle; obtuse, and few in a row. The under surfaces of the brachial ossicula were not indented laterally. The central portions of the upper surfaces of the hrachial ossicles were hollowed out slightly, and the sutures between them deeply impressed. About twelve of the brachial ossicles were imbedded in the disk, and the parts of the dorsal surface of the latter, corresponding to the arms and central skeleton, do not present traces of scales, a feature seen in existing Euryales.

"The dimensions of Professor Sedgwick's specimens are as follows:-Breadth of disk, $0 \frac{8 \mathrm{~s}}{19}$ inch. Average breadth between the arms, 0 ths inch. Breadth of an arm, at its junction with the body, $0_{10}^{!}$th inch.

"Locality and Geological Horizon.-Silurian, from Ludlow rocks at Docker Park, near Kendal, WVestmoreland; associated with Eucrinit's, and at Benson Knot, also near Kendal, in hard sandstones, full of characteristic Ludlow fossils. Collected by the Rev. Professor Sedgwick, and Mr Juhn Ruthven." $-(P$ rof. $E$. Forbes' note on Silurian Starfishes).

\section{9th Ord. Crstidea.}

Bndy enclosed in an ovate bag covered by numerous polygonal, calcareous, plates; attached by the base, or a small stem, to foreign bodies; mouth at the upper or distal end, opposite the point of attachment; ovarian opening pyramidal, usually pentagonal, and formed of five triangular plates, situated between the mouth and the base, nearer to the former; anal opening small, a little to the right side, midway between the mouth and ovarian pyramid; no free arms, nor ambulacra.

\section{Genus. CARYOCYSTITES ( $V$. Buch.)}

Gen. Char.-Spheroidal, pelvis small, hexagonal, of two large pentagonal, and two tetragonal, plates, half the size of the others, above which rests a row of six pentagonal plates with pointed summits, alternating with and above which are three more rows of large polygonal plates, forming a closed cup; mouth opposite the point of attachment; ovarian apparatus nearer to the mouth than the base, situated in the line drawn through the intersection of the two large pelvic plates to the mouth; anus close to the mouth, and a little to the right of the ovaries; surface with strong rhombic strice from centre to centre of the plates at right angles to their sides.

\section{Caryocystites Davisi ( $\boldsymbol{K}^{\circ}$ Coy). Pl. 1. D. fig. 5.}

\section{Ref.-McCoy, Mem. Geol. Surv. Vol. II. Pt. 2. p. 513. t. 21. f. 4 and 5.}

Sp. Ch.-Spheroidal, most gibbous on the left side (or that containing the ovary), slightly flattened on the opposite side; plates slightly convex, radiated by thick ridges passing from centre to centre through the middle of each of the straight sides of each plate; (in some states of preservation each ridge appears double or triple, but still forming a simple ridge-like bundle); columnar adherence strong, one line in diameter; height of body, eight lines; length (at right angles to middle of height) seven lines; width six lines; ovarian opening oval, one and half lines long, and less than its length from the mouth; anus large, very close to the mouth, nearly one line in diameter; from centre to centre of lateral plates about three lines.

As I have remarked (see supra) this Cystidean resembles the Echinospherites Balticus in the simplicity of the ridging of the plates and the smoothness of the intervening triangles, but $I$ pointed out 
that even the imperfect fragment then known to me could not belong to the genera Lichingiplecrites nor Heliocrinites, from the large size of the plates compared with the diameter of the body, and their consequent small number. I have since examined perfect specimens from Coniston, fully bearing out my original view of its being a species of Criryncystites, distinguished from the C. frenatum* of the Oeland limestone, by the smoothness of the triangles between the five or six radiating ridges of each plate, from the absence of the five or six sets of intervening converging ridges which fill those triangles in that species.

Position and Locality.-Common in the limestone of Coniston, Lancashire; rare in the impure limestone of Yspatty Evan.

Explanation of Figures.-Pl. 1. D. fig. 5. side view of specimen from Coniston, natural size.-Fig. 5 a front view of ditto.

\section{Caryocystites GRANATUM (}

\section{Syn. and Peef.-Sphoeronites testudinarius (His. Leth. Suec, t. 25. f. $9 a$ ).}

An imperfect fragment, probably of this species, is in the collection from the limestone of Rhiwlas. (See observations on preceding species).

\section{Genus. TETRAGONIS (Eich.)}

Eichwald, in his "Urwelt Russlands," p. 81, has provisionally given this name to a (probably) Silurian fossil, having some relation, he thinks, to lichadites (Murch.), but of an ovate form, apparently coriaceous texture, without distinct plates, and the surface covered with a rectangular lattice-work of thread-like, vertical and encircling lines. A small, but generically similar, fossil is common in the Upper Ludlow Rocks of Westmoreland, and has received from Mr Salter the manuscript name of Recepluculites Denbyi, having perhaps overlooked Eichwald's notice. Since the explanation of our plate was printed, he requests me to describe and name it on my own authority, as he does not propose drawing up any description himself; I therefore alter the genus, but adopt the name he suggested for the species, in honour of the Rev. F. B. Danby.

\section{Tetragonis Danbye. Pl. 1. D. fig. 7 and 8.}

$S p . C h$. A verage length one inch two lines; width near base eight lines, near opposite end five lines; subovate, most tumid, and abruptly rounded towards the slightly larger, or basal end, in the middle of which is a small scar-like impression (? of attachment); slightly tapering towards the opposite end which lad apparently a large opening; some of the vertical strix run from one end to the other, while others converge before reaching the base, so as to form three elliptical, obscurely defined facets; the vertical and horizontal lines are about equal, but of irregular sizes; the larger as thick as fine threads, defining squares about a line in diameter, (rather more towards the middle and less towards the ends, each divided by finer stria into four or six smaller squares or oblongs. Average length one inch two lines; width near base eight lines, near opposite end five lines.

Position and Locality.-In the green quartzites of the Upper Ludlow rock, Brigsteer, Kendal, Westmoreland.

Explanation of Figures.-Pl, 1. D. fig. 7. Small specimen, natural size, from Brigsteer.-Fig. 7 a portion of ditto, magnified four diameters.-Fig. 8. larger specimen of ditto, natural size.

* The specimen figured t. 21, f. 4 of Memoirs of the Geological Survey as C. granatum I do not think referrible to that species, but rather to represent a portion of C.Davisi; and I am at a loss to conceive how it conld be separated from the fig. 5 on the same plate representing avowedly the latter species. 


\section{Incenta Sedes (Probably Echinodermata or Ammlata).}

\section{Genus. CORNULITES (Schl.)}

Gen. Char.-Tube gradually tapering, conical, slightly flexuous, most so at the small end, which is usually eurved, and attached by its sides to foreign bodies; walls of the tube very thick, cellular, composed of numerous imbricating conoidal rings, their widest edge next the slender base, subregular in old specimens. more or less distorted or oblique in the young; external surface obscurely annulated, finely striated longitudinally; inner surface and casts scalariform, with two or three longitudinal impressed furrows.

This curious genus differs from Tentaculites in its greater size, being attached, and its irregularities of growth and curvature towards the smaller end. The only well-known species is that originally described by Schlotheim, the Cornulites serpularius.

\section{Cornulites serpularius (Schl.)}

\section{Refo--Schl. Petref, t. 29. f. 7. and Sil. Syst. t. 26. f. 5 to 8.}

Sp.Ch.-Adult tube about three inches long, and eight lines in diameter at the larger end, slightly flexuous, curved towards the small end; rings averaging, in decorticated specimens, one line apart in the last two inches, being closer and oblique at the narrow end.

Position and Locality.-Common in the Wenlock limestone of Dudley; dwarf specimens about an inch long, and two lines in diameter, the rings averaging half a line apart, not uncommon in the Upper Ludlow quartzite of Benson Knot and Brigsteer, Kendal, Westmoreland.

\section{Genus. TENTACULITES (Schl.)}

Gen. Char.-Shell small, free, straight, regular, slender, conical, tapering nearly to a point; girt with numerous thickened circular rings; one (or both ?) ends open, circular; walls moderately thick.

I can see no reason for believing these bodies to be portions of Crinoids, as suggested by many authors, much less spines of Lepteno, as suggested by others: their small size, general form, and the appearance which large clusters of them often present on the surface of the beds, gires one the idea of their belonging to the Pteropoda; it is not in my power at present, however, to offer any satisfactory opinion on their zoological affinities. Their being unattached, small size, and straight, regular form, separate them from the allied genus Comulites.

\section{Tentaculites annulatus (Schl.)}

Ref. and Syn.-Schlotheim, Petrefacten, t. 29. f. $8+$ T. scalaris, Id. Id. f. 9.

$S p . C h$. - Average length ten lines, diameter of the large end one and a third line; girt with numerous subequal rings separated by slightly wider concave spaces, four rings in the space of one line near the larger end; surface with extremely minute close longitudinal strie; internal cast, scalariform of a number of smooth step-like cylindrical articulations, the projections of which correspond in position to the external rings, but so much less prominent that the rings are much the thickest part of the shell.

The exterior of this species was figured and described by Schlotheim, Sowerby, \&c., as the T. annulatus, while the internal cast forms the $T$. scalaris of the same authors.

Position and Locality.-Very abundant in the fine Caradoc sandstone of Horderly, W.; Pwllheli, Caernarvonshire; the Hollies, Church Stretton, Shropshire; Coniston limestone, Coniston, Lancashire; Llansant. fraid, Glyn Ceiriog, Denbighshire; Ravenstone Dale, Westmoreland.

\section{Tentaculites onnatus (Sow.)}

$$
\text { Ref.-Sow. Sil. Syst. t. 12, f. } 25 .
$$

$S p$. Ch.-Average length seven lines, width at larger end one line; girt with narrow round rings at irregular distances, averaging three in one line at the larger end; intervening spaces broad, flat, and girt 
with from three to six sharp lines parallel to the large rings; easts scalariform, but the joints more equal in diameter than in the $T$. anmulatus, and girt with lines corresponding to those of the exterior.

This species is easily distinguished from the $T$. anmulatıs by the thinner, more distant, and irregularly placed rings, and the smaller intervening ones on the flat interspaces; the cast also differs from the cast of that species by the smaller steps, and the annular markings of the interspaces. Count Minster applied the manuscript name $T$. striatocostatus to a Dudley specimen of this species in his collection.

Position and Locality.-Very common in the Wenlock limestone of Dudley, Staffordshire; one very large fragment, one and half line in diameter, and with the rings two-thirds of a line apart, in the passage beds, Montgomeryshire.

\section{Tentaculites tenuis. (Som.)}

Ref.-Sow. Sil. Syst. t. 5. f. 33.

Sp. Ch.-Average length three and half lines, diameter at larger end rather less than half a line; girt with small narrow rings at irregular distances, intervening spaces slightly coneave and marked with occasional finer rings between the larger ones: average number of rings in the space of half a line near the large end, about three.

If this species was not confined apparently to the Upper Ludlow rocks, I should be inclined to suppose it might be the young of $T$. ornatus, which it resembles in the irregular distance of the rings and the flattened minutely ringed interspaces.

Position and Locality.-Common in the Upper Ludlow rock of Benson Knot, and Kirkby Lonsdale, Kendal, Westmoreland. 
SECT. II.-RADIATA OF MIDDLE PALEOZOIC (DEVONIAN) ROCKS.

\section{3rd Class, ZOOPHYTA. (Lin.) See page 1.}

\section{2nd Ord. Zoophrtaria (Blainv.) see page 9.}

3rd Family. TUBIPORIDE (See page 9).

Genus. STROMATOPORA (Gold.) (see page 12).

Stromatopora concentrica (Gold.)

Ref.-Goldfuss Pet. Germ. t. 8. f. 5. Phill. Pal. Foss. t. 10. f. 28.

Si. Ch.-. Corallum forming amorphous undulating masses, composed of undulating slightly irregular and unequal laminse, connected by vertical filaments, forming layers of sub-prismatic cells (three or four layers of cells in the space of one line) in the vertical section, and obscurely concentric or uniform clouds of short vermicular dots (sections of the filaments) in the transverse section.

The more irregular undulating forms of the mass and undulations of the component laminie, as well as the comparatively large size of the cells, and small number of layers in a given space, easily distinguish this species from the Silurian Stromatopora, with which it has been usually confounded. The long vermicular tubular perforations passing through the mass, are about one-fifth of a line in diameter, and being little larger than the ordinary openings, are in consequence rarely seen, except by the careful observer. I have identified the British Devonian species with authentic specimens from the Eifel.

Position and Locality.-Common in the Devonian limestone of Newton Bushel, and Teignmonth.

\section{Stromatopora POLYMorpia (Gold.)}

Ref.-Gold. Pet. Germ. t. 64. f. 8. Phill. Pal. Foss. t. 10. f. 27. Geol. Trans. Vol. V. t. 58. f. 2.

$S \%$. Ch.-Polymorphous, usually forming rounded masses about two inches in diameter, irregularly wammilated at the surface, summits of the mamilla irregularly perforated by radiating vermicular channels ; section shewing a minutely reticulated irregular tissue (as in Porites) of thick vermicular plates, traversed at irregular intervals (usually about a line) by long cylindrical tubuli, about a fifth of a line in diameter, and having irregularly stellate centres, formed of a few similar tubuli irregularly converging and anastomosing at distances of about four lines; concentric undulating distant bands of denser structure, very obscurely marked. I have carefully compared the British Devonian species with authentic specimens from the Eifel.

Position and Locality.-In the Devonian limestone of Newton Bushel. 


\title{
Subgenus. Caunopora (Phill.)
}

\author{
= Sparsispongia (d'Orb.)
}

Ger. Chatr-Corallum polymorphous, composed of minute irregular vermicular cellulose tissue, disposed in obscure concentric layers, traversed by few long, larger, variously disposed, vermiform, cylindrical channels.

From what I have stated of the small vertical channels in the typical species of Stromatopora, it is obvious that there is no struetural difference between these genera, beyond the irregular porosity of the tissues in Caunopora, and the more regular concentric lamination of Stromatopora. It is impossible on any account to separate generically the Stromatopora polymorplu, forming the type of d'Orbigny's genus s'parsispongia from the Caunopora placenta; the star-like convergence near the surface of certain sets of the vertical channels being merely a specific peculiarity, interspersed in the intermediate spaces with the ordinary straight tubuli.

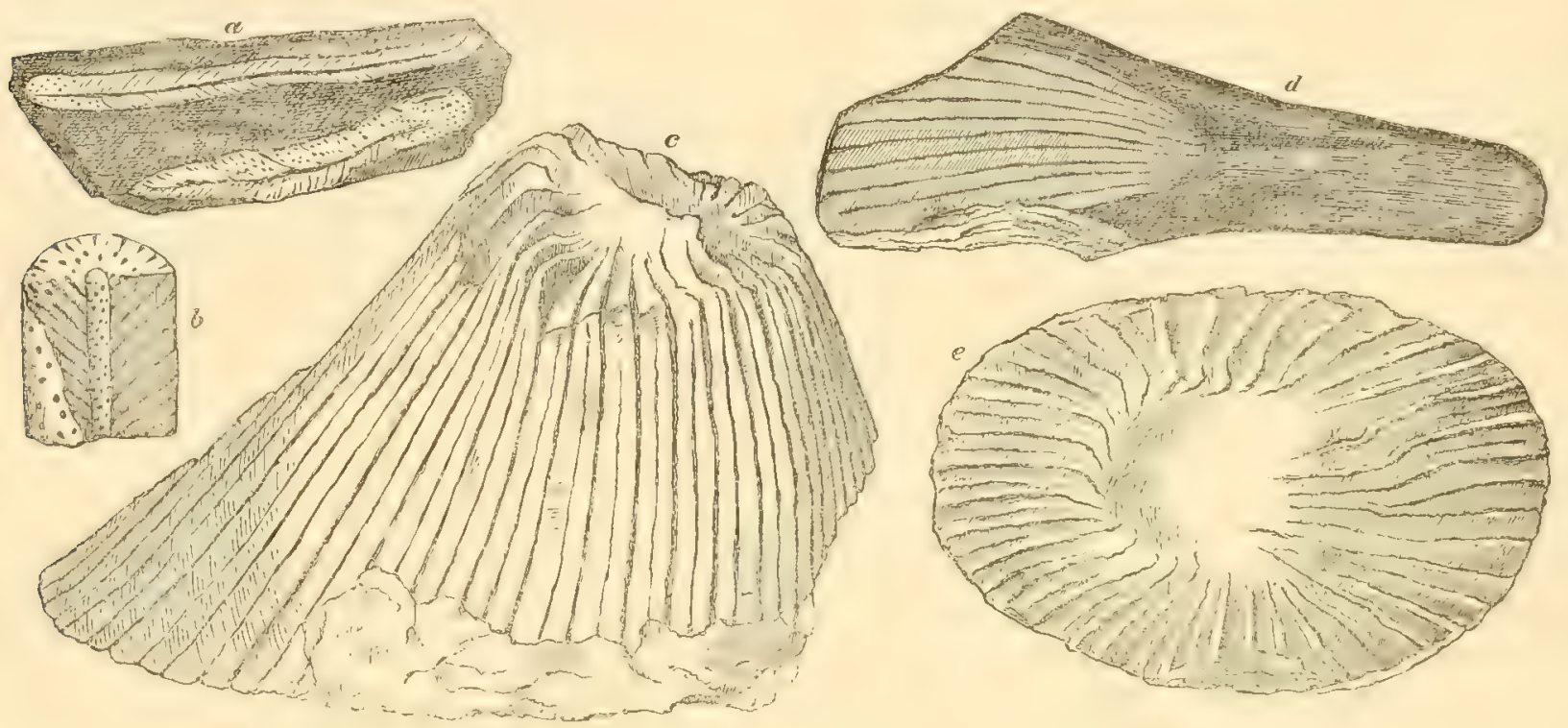

a Stromatopora (Caunopora) verticillata ( $\mathbf{I}^{*} \mathrm{Coy}$ ) two branches, natural size, each shewing the surface near one end, and a section in the rest of the lengtb shewing the central canal and whorls of verticillate tubuli. $b$ Portion of surface and horizontal and rertical sections of ditto, magnified. c Petraic Gigas (McCoy) natural size. $d$ Worn section of apex, natural size, shewing the solid filling up of the young cavity and cause of the obtuse apex to the cast. $e$ Natural section of ditto, natural size.

\section{Stromatopora (Cannopora) Placenta (Lonsd. Sp.)}

Ref. and Syn.-Coscinopora placenta Lonsd. Geol. Trans. Vol. V.t. 58. f. 5. (not of Gold.) Ceunopora placenta (Phill.) Pal. Foss. t. 10. f. 29.

Sp. Ch.-Corallum forming amorphous masses, composed of thin obscurely defined, concentric layers, traversed by long cylindrical nearly vertical, subparallel, vermiform, thick-walled tubes, one-fourth to onethird of a line in diameter, averaging a line apart; intervening tissue minutely reticular, composed of small thick vermicular vesicular plates.

The longitudinal persistent channels of this species have distinct calcareous walls, rendering them unusually conspicuous in the vertical section or fracture. The Cascinopora placenta of Goldfuss, to which the present species has been referred by Lonsdale and Phillips, has the tubes so very much larger, and fewer in a given space, that their specific identity is impossible, and it has been referred by d'Orbigny (from specimens in his cabinet) to his genus Geoporites (Palocopora), in which the tubes have transverse dia- 
phragms, and radiating lamellic. The concentric laminæe are close and distinct in some states of preservation, lut more usually obsolete; there are in many specimens the usual larger lroad concentric variously coloured hands seen commonly in this genus, which will not of course be confounded with the lamina above referred to. Position and Locality.-Common in the Devonian limestone of Newton Bushel.

\section{Stromatopora (Caunopora) Ramosa (Brass. Sp.)}

\section{Ref. and Syn.-Favosites ramosa (Brass.) Cannopora ramosa (Phill.) Pal. Foss. t. 8. f. 22.}

$S p$. Ch.-Corallum forming long, cylindrical, dichotomous branches, averaging three lines in diameter, each traversed by a distinct, open, central, tubular channel, one-third to one-half a line in diameter, surrounded by obseurely coneentric layers of small vesicular tissue, formed of very numerous, thick, vermicular plates (abruptly flexuous, at short distances), of a granulo-porous structure, radiating obliquely upwards and outwards, from the large central channel to the surface, where the openings are small, distant in pro. portion to their diameter, (about six or seven in the space of one line); sections in all directions, shewing a nearly similar close vermicular reticulation.

This remarkable species is easily distinguished by its large central channel running down each branch, but the external reticulate structure is precisely identical in size and other characters with that of the Stromatopora polymorpha, bearing out my view of these fossils being generically similar; in some of the branches I have noticed towards the edge a few irregular vermieular, or regular straight ehannels, slightly smaller than the central one, and indications in some of the decomposing slate specimens of the central channel becoming irregular, excentric, and obsolete after a distance, giving way to a new central one.

Position and Locality.-Not uncommon in the red and grey Devonian limestones of Teignmouth.

\section{Stromatopora (Camopor $a$ ) vertichlata ( $I^{c} C o y$ ). Fig. $a$ and $b$, page 66. \\ Ref.-McCoy, Ann. Nat. Hist. 2nd Series, Vol. VI. p. 377.}

Sp. Ch. - Corallum forming slender cylindrical, vermiform branches, one to two lines in diameter, each with a distinct central canal, one-fourth to one-third of a line in diameter; surrounding sclerenchyme, nearly solid, traversed by verticillate whorls of simple, nearly straight canals, averaging about one-third the diameter of the central channel in most of their length, extending obliquely upwards and outwards, from the inner channel, (whose walls they perforate with regular quincuncially arranged pores) to the surface, where they form slightly elongate quincuncially arranged pores, four in the space of one line, separated by solid interspaces thicker than their diameter.

This species, by its narrow eylindrical branches and distinet central channel, resembles the $C$. ranosa (Brass.sp.) but instead of having a minute vermicular, sub-equal, reticulated structure, the general tissue is nearly solid, and regularly traversed from the centre to the surface, by large oblique, nearly straight, verticillate canaliculi, giving a plumose appearance to the longitudinal section.

Position and Locality.-Not uncommon in some parts of the Devonian limestone of Teignmouth.

Explanation of figures-Page 66, a. Two branches, natural size, each shewing the surface near one end, and a section in the rest of the length shening the central canal and whorls of verticillate tubuli. $b$, portions of surface, and horizontal and vertical sections of ditto, magnified.

\section{Gemus. PALAOPORA (McCoy). See page 14. Palzopona PYRIFormis (Blainv. and Guett. Sp.)}

Syn. and Ref.-Astroca porosa (Grold.) Pet. Germ. t. 21. f. 7. Heliopora pyriformis (Blain.) Porites pyriformis (Lonsd.) in Geol. Trans. (not in Sil, Syst.)-id. Phill. Pal. Foss. (not in Mem. Geol. Surv.)

S\%.Ch.-Corallum amorphous, tuberose, composed of obscurely defined coneentric layers, average diameter of circular tubes rather more than two-thirds of a line, and rather more than their diameter (rarely once and a half) apart; walls thin, distinet, lamellar crenulations short; horizontal diaphragms irregular, IK 2 
averaging two inter-diaphragmal spaces to the width of the tube; usually about four polygonal tubules in the shortest line between adjacent tubes; diaphragms in the polygonal tubules, about half their diameter apart at the concentric bands of renewed growth, rather more than their diameter apart between these bands.

This species, so often confounded with the Silurian $P$. interstincte, is clearly confined to the Devonian system, both in this country and on the continent, and is easily distinguished therefrom by the much greater distance of the lamelliferous tubes and much larger number of the interstitial tubules, which latter more usually exceed the above average than fall below it. Care must be taken to examine specimens rubbed flat, as many specimens shewing a weathered surface have a deep depressed circular space round the mouth of each tube, increasing its apparent diameter, and giving a deceptive appearance of narrowness to the intervening spaces. I have seen one rare specimen in which the cell-tubes are only half a line in diameter, but the average distance from centre to centre was the same as in the other specimens; it agrees with Phillips's figure, and is named Phillipsii by d'Orbigny in his Prodrome.

Position and Locality.-Very abundant in the Devonian limestone of Newton Bushel and Teignmouth.

\section{Genus. FAVOSITES (Lam.) See page 19. \\ Favosites polymorpha (Gold.)}

Ref.-Gold. Pet. Germ.t. 27. f. 2, 3, 4 .

Sp. Ch.-Corallum forming thick, curved, cylindrical branches, averaging five to fifteen lines in diameter, composed of polygonal tubes, averaging two-thirds of a line in diameter, but with numerous smaller, irregularly interpolated ones; the tubes are nearly vertical in the middle of the branches, arching outwards to the surface, on which they open obliquely; the walls are thin, polygonal, and prismatic in the interior, and in old specimens greatly thickened to render the aperture small and round towards the surface; averaging three cell-openings in the space of two lines; internal diaphragms very thin, irregular, oblique or horizontal in position, averaging two inter-diaphragmal spaces to the diameter of one tube; connecting pores large, one row on each face, nearly the diameter of the tubes apart.

This extremely fine, well-marked species, is remarkable for the size of its branches, and the great thickness which the walls assume towards their oblique termination on the surface, rendering the interior of the tubes cylindrical, as well as the comparative shortness and great number of the interpolated young tubes, arising from their rapid divergence. I doubt its occurrence in Silurian rocks (see $F$. crassa, p. 20).

Position and Locality.-Extremely abundant in the Devonian limestone of Newton Bushel, and Teignmouth; and in the shales of Newquay and S. of Plymouth, and slates at Bedruthen Steps in St Eval.

\section{Genus. ALVEOLITES (Lam.) as redefined.}

Gen. Char.-Corallum polymorphous, composed of irregular, superposed concentric layers of short prismatic tubes, with very thick common inseparably united walls, traversed by numerous horizontal diaphragms, and pierced by distinct communicating pores; cell-openings very oblique to the surface, semicircular or rhomboidal, lower margins most prominent; tubes increasing occasionally by dichotomous fissure.

I have noticed the dichotomous fission of the transversely septate tubes, both in the true $F$. spongites of the Eifel (which, with MMI. Milne Edwards and Haime, I take as the type of the genus Alceolites) and in our British A. remicularis, shewing that in this respect and the consequent community of the walls, this genus is more nearly related to Chetetes than to Facosites, while by its communicating pores it is most allied to the latter, and differs from the former. 
Alveolites vermicularis $\left(M^{c} C o y\right)$. Fig. $a, b, c$.

Ref.-M I Coy, Ann. Nat. Hist. 2nd Series, Vol. VI. p.'377.

Sp.Ch.-Corallum forming polymorphous masses of obscurely defined concentric layers of short irregularly and obtusely polygonal, vermicular, flexuous tubuli, traversed by regular horizontal diaphragms, slightly more

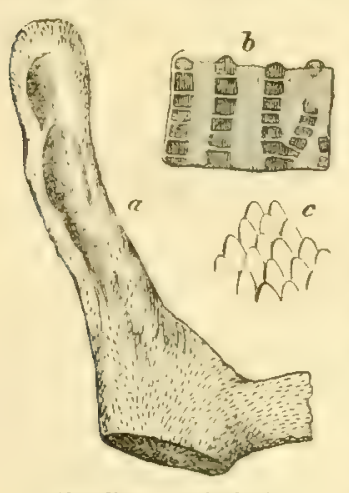

Alveolites vermicularis. a Part of branch, natural size, shetring at upper part traces of the internal cavity of old examples. $b$ magnified section shewing the
diaphragms in the tubes and thick solid interspaces. c outer surface solid interspaces. $c$ outer surface
magnified. or less than the diameter of the tubes apart; cavity of the tubes in vertical and horizontal sections separated by at least their diameter of sclerenchyme; about six tubes in the space of one line.

I believe this species has been confounded with the very distinct Favosites (Alveolites) spongites of the Eifel, in which, however, the tubes are half a line in diameter (only two openings in the space of one line), they are also straight, instead of vermicular or minutely flexuous, and have the sclerenchyme much thinner in proportion to the size of the tubes, presenting all the characters (as I find from examination of authentic specimens) represented with great fidelity in Goldfuss's figures t. 28. f. $1 a$ to $1 e$ of the Petrefacta Germanio. The branched varieties which become hollowed by age, are extremely liable to be confounded with large specimens of the Cannopora ramosa, but the structure is coarser, the tubules though flexuous, are far straighter and more tube-like, and finally, the transverse diaphragms can always be made out by a little rubbing down of the surface, while they certainly do not exist in the smaller and far more irregular sponge-like tissue of the Counopora. I have noticed in some slate specimens that the oblique cell-openings on the surface are rhomboidal, with the lower angle very prominent and spinose.

Position and Loculity.-In the Devonian limestone of Teignmouth; Devonian shale of Newquay, and slates of Bedruthen Steps, St Eval.

\section{Genus. CYATHOPIILLUM (Gold.) = Floscularia (Eich.) 1829.}

Gen. Char-Conical, simple, branched, or densely aggregate; cup concave: horizontal section with radiating straight lamellie from the walls towards the centre, which they either reach or not; lamellae connected by numerous small transverse plates: vertical section; centre crossed by horizontal, thick plates, between which and the walls is a cellular structure composed of small arched plates inclining upwards and outwards. The young cones sprout in the compound species from the margin of the old cell.

This genus, when closely aggregate, las been frequently confounded with Astrec, but the polypes have no community, and there is in every case a distinct solid thin wall between the contiguous stars, which is never the case in Astraca.

Those Cyathophylle which have no vesicular outer area, and approach Amplexus, are called Calophyllum by Dana, and fall better perhaps under that genus. The species in which the rows of vesicular structure of the outer area run downuards and outwards, are separated by Hall under the name Heliophyllum (American Journal of Science, 1846).

\section{Cyathopitylum caspitosum (Gold.)}

\section{Ref.-Gold. Pet. Germ. t. 19. f. 2.}

Sp. Ch.-Corallum forming slender, cylindrical branches, upwards of five or six inches long, with a nearly uniform diameter of four to five lines; epitheca thin, with small, irregular, transverse undulations; inner area rather more than half the diameter of the tube, occupied by inclined, slightly irregular, nearly horizontal, diaphragms, about two reaching across the base; outer area composed (in the vertical section) of about two rows of rounded vesicular plates: horizontal section, shewing forty-five to fifty radiating 
lamellex, strongest in the narrow outer area, where half of them cease, the alternate ones sending delicate prolongations at a variable distance towards the open centre; branches at intervals of seldom less than two inches, either perfectly dichotomous, or lateral; abraded surface, shewing six interlamellar spaces in two lines.

I have carefully compared this species with authentic specimens from the Eifel, and find them perfectly identical. Some specimens are so perfectly dichotomous that they might he placed (as M. d'Orbigny has done) in the genus Diphyphyllem (Lonsd.), if that group could be retained, while other specimens in the same mass shew the young projecting as a lateral bud, from the straight undisturbed side of the parent tube, as in the Cyathophylla generally.

Position and Locality.-Common in the Devonian limestone and red shales of Newton Bushel.

\section{Cyathophyllum ceratites (Gold.)}

\section{Ref.-Pet. Germ. t. 17. f. 2. $f$ and $h$.}

$S p . C h$-Corallum simple, conical, slightly curved; averaging two inches long, and one inch three lines in diameter at that length; rugged, with strong, irregular, concentrie wrinkles; epitheca thin, marked with obscure, obtuse, longitudinal strie, four to five in two lines; cup moderately deep, edge obtuse-angled; centre flattened, smooth, surrounded by about seventy-six nearly equal, subalternate, finely denticulated, radiating lamellæ, extending to the edge of the cup (four or five in two lines): vertical section shews the inner area to equal about half the diameter of the cone, composed of strong, slightly concave transverse diaphragms, about half a line apart.

The so-called Cyathophyllum turbinatum of Goldfuss grows to a larger size, has much thicker, and

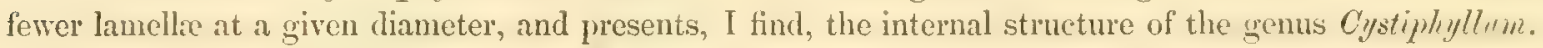

Position and Locality.-Rare in the Devonian limestone of Newton Bushel.

\section{Genus. AMPLEXUS (Son).}

Gen. Char.-Corallum simple, cylindrical when old, elongate-conic when young, flexuose; transversely septate, the plates reaching across the central area and deflected at their edges, where they are crenulated by very narrow, obsolete, radiating lamellæ, which mark the surface with vertical striæ.

The shortness of the radiating lamellx, and want of the outer zone of small connecting vesicular:

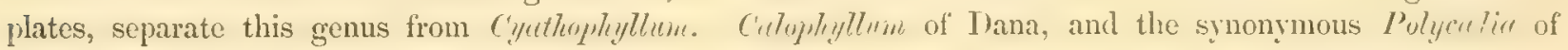
King, only differ in the greater extension of the lamelle, and can only be retaind as provisional subgenera.

\section{Amplexus tortuosus (Phill.)}

$$
\text { Ref.-Phil. Pal. Foss. t. 3. f. } 8 .
$$

Sp.Ch.-Corallum irregularly flexuous, subnodulose, or marked with irregular large obtuse, transverse wrinkles, most numerous in old specimens; young specimens three inches long and six lines in dianeter, have about twenty-seven equal, vertical, marginal lamellæ, three spaces between which occupy two lines; transverse diaphragms flat, or irregularly undulated, with a narrow deflected margin, on which rest twentyfour to twenty-eight vertical lamellix, which only extend towards the centre slightiy more than their distance apart; transverse septa slightly irregular in distanee, hut averaging three interseptal spaces in two lines, so that the intersections of the vertical lamelixe, and edges of the diaphragms on the abraded surface, form nearly square reticulations.

In the young narrow examples of this species, the narrow marginal area, of vertical lamella and deflected edges of the diaphragms, often splits off like a thick sheath from the inner horizontal scptate portion, as shewn in Prof. Phillips's figure, which however does not indieate the largely wrinkled surface, which, with the small number of lamelle, easily distinguish it from the Carboniferous il. corclluides of the same size. A specimen, nine lines in diameter, has only twenty-seven lamellic, and retains its lamellar sheath permanently. One enormous specimen, one inch nine lines in diauneter, scems undoubtedly to be 
the adult of this species; it has the lamellar sulci very little more distant than in the young (three in two lines), the number, howerer, being about fifty-one; the diaphragms are closer than in the $A$. coralloirdes, and the lamellated margin broader, being rather more than one-fourth of the diameter, and the surface also differs from the carboniferous species in being more wrinkled.

Position and Locality. - Not uncommon in the Devonian limestone of Newton Bushel.

\title{
Genus. CYSTIPHYLLUM (Lonsd.) See page 32. \\ Cystiphyllum Daminoniense (Lonsd.)
}

\author{
Ref.-Lonsd. Geol. Trans. Vol. V.t. 58. f. $11 b$. Phill. Pal. Foss. t. 4. f. $11 b, d$ and $c$.
}

$S p$. Ch.-Corallum very elongate, conic, slowly tapering, reaching a diameter of one and half inch at about three and half inches from the apex, continuing nearly cylindrical for several inches at a diameter of one inch eight lines; marked with concentric strong wrinkles of growth; epitheca thin, smooth, with or without obsolete longitudinal strie; lamelle thin, the primary ones reaching about one-third of the diameter tonards the centre; secondary lamelle very fine, rather more than half the length of the primary: about forty-four primary, and an equal number of secondary lamella, all of which reach the outer wall in the young (or at a diameter of one inch), but separated from it by a narrow dense vesicular layer in the adult; about four lamelle in the space of two lines in the adult: horizontal section, central area nearly lalf the diameter, composed of very irregular vesicular plates of moderate size; outer area containing the radiating lamellex, connected by very irregular cellular tissue of thin vesicular plates, which entirely obseure the lamella at the circumference of large examples: certicul section composed of rounded vesicular plates, forming rows gradually arching under the middle; cells largest in the centre.

Position and Locality. - Common in the Devonian limestone of Newton Bushel.

Cystipitylum vesiculosum (Gold. Sp.)

Syn. and Ref.-Cyathophyllum id. Gold. Pet. Germ. t. 17. f. 5; Phill. Pal. Foss. t. 4. f. 12.

$S p$. Ch. Corallum conic, varying considerably in the rate of increase in different specimens; cup decply excavated, when finely preserved markerl with narrow, close, minutely denticulated lamellie about four in two lines (eighty-eight all round), and in some states of preservation these are visible externally, while in others both the cup and exterior seem one mass of large vesicular rounded cells: horizontal and vertical sections presenting a nearly uniform large vesicular tissue, without trace of radiating lamella; the cells slightly depressed, rounded, averaning one line or slightly more in length, arranged in obscure rows, curving under the centre. Average diameter of adult cup, one inch eight lines; usual length of specimens, four or five inches.

The much greater size of the vesicular plates, and alsence of radiating lamelli in the transverse section, easily distinguish this species from the $C$. Damnoniense. I have compared our British species with authentic examples from Gerolstein of Goldfuss's species to be certain of their identity; some of the latter occasionally shew vertical lamellar strice on the outside of the same character and number in a given space, as the Devonshire specimens.

Position and Locality.-Common in the Devonian limestone of Newton Bushel.

Genus. ACERVUliRIA (Schw.). See page 35.

Acervularia pentagona (Gold. Sp.)

Syn. and Ref.-Cyathophyllum pentagonum (Gold.) Pet. Germ. t. 19. f. 3. Astraca pentagona (Lonsd.) Geol. Trans. Vol. V.t. 58. f. 1.

$S p . C h$.-Corallum forming rounded masses of hexagonal unequal-sided stars, averaging two to two and half lines in diameter (a few stars pentagonal, from the straight line indicating the original bipartite fission of an old hexagonal star); central area circular (tubular), thick-waller, about a line in diameter; boundary walls distinet, not thicker than the lamellie, often angularly bent to meet their alternating ends: 
Jamellie twenty to twenty-six, strong, equal from the wall to the circular boundary of the inner area, where one half cease, the other half abruptly diminished in thickness faintly continued towards the centre, and irregularly united; horizontal section, shewing all the above characters distinctly: vertical section, shewing the thin vertical walls, dividing one cell from another, and the thick solid walls defining the inner area; outer area with rows of very minute delicate vesicular plates; inner area, with nearly obsolete confused structure, resulting from the sections of the edges of the irregularly contorted vertical lamella.

There are in mary places on the polished specimens, evidences of the corallum increasing by an exact bipartite division of a parent star; and when this is advanced so as nearly to form two stars of the average size, the fact may be detected by the pentagonal form of these younger stars, resulting from the straight line dividing the hexagonal old star; this occurs so frequently as to have suggested the name and species to Goldfuss, who however did not notice the reason of this pentagonal form, or that the normal shape of the old stars was irregularly hexagonal as in ordinary cases.

Position and Locality.-Common in the Devonian limestone of Newton Bushel and East Ogwell.

\section{Genus. ARACHNOPHYLLUM (Dana). See page 37.}

Arachnophyludi Hennami (Lonsd. Sp.)

Syn. and Ref.-Astroca Hennahi (Lonsd.) Geol. Trans. Vol. V.t. 58. f. 3 ; id. Phill. Pal. Foss. t. 6. f. 16 a and $A$. intercellulosa id. id. t. 6. f. 17.

Sp. Ch.-Corallum forming masses of undefined irregular stars, averaging four or five lines from centre to centre; depressed centre of the stars usually a line and half in diameter; radiating lamelle twenty-nine to forty, alternately longer and shorter, all very thick round the prominent edge of the depressed centre, within the margin of which half the lamellie cease abruptly, the other half becoming suldenly very thin, and uniting irregularly at the centre; all the lamella become thinner as they pass the circular boundary of the centre, and either join the rays of the adjoining stars in a slightly irregular manner by a thin zigzag line, sometimes slightly cellulose, or continue without interruption from one cell to another, in which case the long rays of one star become the short rays of the other: all the lamellae densely granulated and spinulose on their sides, occasionally uniting to form very delicate filamentary irregular connecting plates: vertical section, shewing the edges of several of the vertical radiating lamellix, clothed with filamentary vesicular plates on their sides.

Prof. Phillips has given the name Astraca intercellulosa to those specimens in which the rays of adjoining stars did not exactly meet, but were united by zigzag irregular junctions, and occasional small cells; I have, however, observed both modifications in the same specimen, and I think there can be no doubt of the identity of these species, concerning the propriety of the separation of which Prof. Phillips has expressed his own great doubts. M. d'Orbigny, in his Prodrome, has separated this species into four genera: Actinocyathus Henuali for Phillips's f. $16 \alpha$; Phillipsastrece Hennati for the same author's f. $16 b$; Facastrca intercelluluar for his f. 17; and Lithostrotion Hennali for Lonsdale's figure in the Geological Transactions: there is, however, no structural difference between any of these, the slight difference of appearance being due to the amount of weathering, or the accident of whether the upper or lower ends of the coral were exposed-in the latter case the central pit of each star shewing as a prominent boss. The lateral diskbuds may very frequently be observed in this species.

Position aud Locality.-Not uncommon in the Devonian limestone of Barton; limestone of Teignmouth.

\section{Genus. STREPHODES $\left(M^{\circ}\right.$ Coy). See page 29.}

Strephodes gracilis $\left(M^{c} \mathrm{Co} y\right)$. Not figured.

Ref.-Mic Coy, Ann. Nat. Hist. 2nd Series, Vol. VI. p. 378.

$5 \%$. C $\%$-Corallum simple, very gradually tapering, irregularly twisted, averaging three inches long, and cight lines in adult diameter; horizontal section, outer wall very thick, solid; radiating lamellie at the above diameter, about fifty-six, very thin, extending in a slightly irregular manner towards a large central 
space, which the primary ones fill with their irregular complicated extremities; secondary lamelli as thick as the primary, of irregular lengtlis, but seldom extending one-fourth the distance to the centre; transverse vesicular plates extremely delicate, rather few, irregular; vertical section shewing in the middle a few irregularly flexuous delicate longitudinal lines (edges of the complicated ends of the vertical radiating lamellæ); sides occupied by very open vesicular tissue, composed of large, curved, delieate, oblique plates, forming about tiro rows of great cells on each side; outer wall very thick, forming a nearly smooth surface; when decorticated, the lamellar sulci average five in two lines; terminal cup deep, strongly radiated to the flattened centre.

This little species is extremely remarkable for the looscness of the vesicular tissue in the vertical section, or great size and consequent smaller number of the cells. Decorticated fragments bear some external resemblance to the Cyathophyllum cespritusum of the same beds, when in the same condition; but a vertical fracture with the hammer, wetted or polished, will easily distinguish them by shewing the broad transverse diaphragms of the latter.

Position and Locality.-Not uncommon in the Devonian limestone of Newton Bushel.

\section{Strephodes Helianthoides (Gold. $S p$.) \\ Ref. and Syn.-Cyathophyllum helianthoides Gold. Pet. Germ. t. 20. f. 2. Strombodes helianthoides Phill. Pal. Foss. t. 5. f. 13.}

s.p.Ch.-Corallum forming short, simple, conical, slightly curved individuals, averaging two inches high and three inches in diameter, or by lateral budding forming compound inasses of large polygonal stars; central portion of the cup narrow, circular, deeply impressed, and filled at the flattened bottom, with the complicated, twisted, very delicate extremities of the radiating lamella; an undefined large cireular portion round the depressed centre is convex, and gradually slojing or lecoming slightly enneave at the boundary walls which are usually at a lower level; upper surface radiated with from seventy to ninety, strong apparently equal lamellae, which seem very thick, from being lined nearly to their edges with minute resicular plates: hurizontul section shews the radiating lamelle to be extremely thin, almost equal in thickness, but each alternate one ceasing near the centre, into which the others extend, very abruptly diminishing in strength at the central circular area, where they are irregularly complicated and twisted, connected throughout by close, very delicate, irregular, curved vesicular plates (the vesicular structure sometimes becomes so dense round the circumference as to prevent the lamelle reaching the wall); vertical section, shewing a small vesicular structure of curved plates arranged in doully sigmoidal curves corresponding to the form of the cup, becoming extremely obscure in the cylindrical narrow central area, corresponding with the central depression and twisted portion of the lamellæ; in sections of the compound masses, a very thick solid divisional wall defines each individual. In specimens of the above diameter the vertical costæ on the outer wall, and the lamellie near the margin, are three in the space of three lines.

Position and Locality.-Rather rare in the Devonian limestone of 'Teignmouth.

\section{Strephodes veruicularis (Gold. Sp.)}

Syn. and Ref.-Cyathophyllum vermiculare Gold. Pet. Germ, t. 17. f. 4.

Sl, Ch._C'urallum simple, conic or subeylindrical, irregularly curved, gradually, but unequally tapering, strongly marked with large, obtuse, transverse irregular wrinkles of interrupted growth; suffoce obscurely marked with obtuse longitudinal ribs, corresponding to the primary lamellre, averaging four in two lines at the nearly adult diameter of one inch, which size it attains at a length varying from one and half to nearly three inches from the apex, and then scarcely enlarges for a length of several inches: lamello at the average diameter of one inch, varying from seventy-six to eighty-two, which in the deep terminal cup are denticulated on their edges, and alternately larger and smaller, the primary ones irregularly uniting in bundles and twisted at the centre into a small umbo: hurizontal section shews the radiating lamella, very irregularly uniting in bundles as they approach the centre, where they are much twisted spirally, and connected 
by close, delicate, irregular, vesicular plates; the most usual character of the lamella, both of the Eifel and Devonian specimens, is to be extremely thin and slightly flexuous near the outer wall, straight and much thickened in the middle half of their length, and again becoming thin and irregular, towards the spirally twisted inner ends; the secondary lamella being much thinner and about a third shorter than the primary; in other specimens (and parts of the same specimen) the primary and secondary lamellæ are more nearly equal in length and thickness, and the fusiform section or mesial thickening of the lamellix not so obvious.

A young specimen, eight lines in diameter, has sixty lamella. When weathered in a farourable manner the lamelle are seen to be perforated by central rows of tubes, parallel with their sides, extending from the outer wall to their inner edge, where they produce denticular perforated papillæ, as in Mr Lonsdale's supposed genus Tryplasma.

Position and Locality.-Common in the Devonian limestone of Newton Bushel.

\section{Genus. PETRAIA (Mïnst.) See p. 39. Petraia celtica (Lam. Spo)}

S'yn. and Ref.-Turbinotia celtica, id. Exp. Nethod. t. 78. f. 7 and 8. = Turbinolopsis, id. and T. panciracliulis (Phill.) Pal. Foss. t. 1. f. 1 and 4.

Sp.Ch.-Casts, obtusely conical, average length eight lines, and width (pressed flat) ten lines; sulci left by the primary lamellie usually sixteen to twenty-two very strong, reaching nearly to the centre, the broad intervening ridges divided by an obtusely angular shallow sulcus, reaching two-thirds of the way from the edge of the cup to the base, in specimens of the above size, confined to the margin of the cup in specimens of smaller size, rarely forming a narrower obscure slit, representing the secondary lamelle; the intervening obtuse ridges bear each a row of very small close elevated puncta, often obscurely marked, five or six in the space of one line.

The specimen figured by Mr Lonsdale in the Memoir of Prof. Sedgwick and Sir R. Murchison, on Devonshire, as $P$. celtica, I find agrees most exactly in the obtuse sulci of the intermediary lamella and other characters, with the T. pauciradialis of Phillips, and I find no difference between those species, which I accordingly place together under the oldest specific name. The apparent great difference of the number of the lamella in Prof. Phillips's descriptions of the two species may be seen to arise from his counting all the lamella in one case and only the alternate or primary ones in the other.

Position and Locality._Common in the carboniferous slate of Padstow*.

Petraia gigas $\left(M^{c} C o y\right)$. Fig. $c, d$, e, page 66.

Ref.-M ${ }^{c}$ Coy, Ann. and Mag. Nat. Hist. 2nd Series, Vol. III. p. 1.

Sp.Ch.-Corallum elongate, conic, gradually increasing (at an angle from the apex, of about $30^{\circ}$ externally) slightly oblique; section apparently elliptical, the axes in the proportion of 70 to 100 ; intermal cast obtusely conic, expanding at an angle of about $50^{\circ}$ in compressed specimens, its small end obtuse from the filling up of a considerable length of the base of the coral, by nearly solid sclerenchyme; external walls thick, dense; lamellie averaging seventy-four in the adult cups, with the diameter of two and half inches, the primary

* A few localities noticed in the memoir of Prof. Sedgwick and Sir R. Murchison on the "Deronian System" struck mo as so perfectly identical with the "Carboniferous slates" of Dr Griffith, which in Ireland are developed near the base of the carboniferous system, that I asked and obtained Prof. Sedgwick's sanction, on Palæontological grounds, to include them in the carboniferous period; but as most people would look for the particular species in the Devonian sections of the present work, I have given them there, but calling the matrix Carboniferous Slate, to aroid mistake. I noted many years ago that many of the fossils from Tintagel, Padstow, \&c. occurred in the Irish carboniferous slates, and yet these certainly belong to the carboniferous, and not to the Devonian system, because in many places they are underlaid by carboniferous limestone containing numerous fossils, all of which $I$ recognised as the ordinary furms of the great scar, or main Irish limestone. I have since recognised many of these Tintagel, \&c. fossils in great abundance in the undoubted carboniferous limestones of Derbyshire, \&c. - $\mathbf{H}^{\mathrm{V}}$. $\mathbf{M}^{\mathrm{C}} \mathrm{C}$. 
ones extending towards the centre, nearly straight for about one-third the diameter, then abruptly diminishing in strength, and gradually convoluted spirally towards the broad, central area; the secondary lamellie much finer than the primary, extending about a fifth of the diameter towards the centre; internal casts with thirty-three to thirty-seven broad, flattened, smooth ribs, separated by deep smooth-edged sulci, (representing the primary lamella); these sulci in some specimens, divided by connecting filaments of matrix, produced by perforations, in the original plate; each rib divided in the middle by a very fine slit, not reaching quite to the narrow base, (representing the secondary lamellæ,) becoming nearly as strong as the primary towards the broad edge of the cup; no transverse vesicular laminx. Length of imperfect casts, about two and half inches; width of same specimen pressed flat, nearly four and half inches; width of ribs between the primary sulci at edge of cup, varying from two to three lines.

The difference in the rate of increase between the cast and exterior, as well as the obtuse apex of the former, is produced, as I have shewn in some of the Silurian species, by the solidifying of the narrow basal portion of the cavity of the corallum, by a deposition of the sclerenchyme. Several of the specimens shew, as I have remarked also in some of the well-preserved Silurian specimens of this genus, that there is a total absence of connecting vesicular plates between the lamellæ. This large and strongly-marked species, from the number of its lamella, can only be confounded with the $P$. pleriradialis (Phill. sp.) and $P$. elongate (Phill. sp.) from both of which it differs in its form and great size, width of the ribs on the cast, absence of puncta, \&c.

Position and Locality.-Very common in the fine grey Devonian slates of New Quay.

Explanation of Figures.-c. Compressed cast, natural size. d. Worn section of apex, natural size, shewing the solid filling up of the young cavity and cause of the obtuse apex of the cast. $e$. Natural section of ditto, natural size.

\section{4th Class. POLYZOA. See p. 44.}

Genus. FENESTELLA. See p. 49.

Fenestella antiqua (Gold. Sp.)

Syn. and Ref.-Retepora antiqua Gold. Pet. Germ. t. 36. f. 3. (not Fenestella antiqua Lonsd. Sil. Syst.)

sp. Ch,-Corallum forming irregular funnel-shaped expansions, about one and half inch ligh ; interstices thick, very slightly flexuous, very obtusely carinate, usually two-thirds the width of the fenestrules, sometimes equalling them; dissepiments thick, short, at regular intervals; fenestrules oblong, or slightly oval, usually a third longer than wide, sometimes nearly twice as long as wide; pores small, with slightly prominent margins, nearly their diameter apart, usually three to the length of a fenestrule, and one rather larger at the origin of each dissepiment; three fenestrules in the space of two lines measured longitudinally, five in the same space measured transversely.

The inosculation of the rows of cells, noticed as a specific character by Mr Lonsdale and Prof. Phillips, is common to all Fenestella when in such a state of decomposition (usually in shales) that the internal casts of the cells are seen as packed in the interior of the branch.

The species as above defined, from the Plymouth limestone, agrees exactly with the Eifel coral of Goldfuss, but is quite distinct from that in the shales of S. Petherwin, \&uc., with which Mr Lonsdale and Prof. Phillips have confounded it; the latter coral has been described by me from the carboniferous limestone of Ireland (see $F$. plebcia), and is easily distinguished by its thinner interstices, more distant dissepiments, and larger and proportionally longer fenestrules, \&c.

Position and Locality.-Common in the Devonian limestone of Plymouth. 
Fenestella plebeia $\left(M^{c}\right.$ Coy $)$.

Ref.-McCoy, Carb. Foss. Irel. t. 29. f. 3.

$S p . C h .-F l a t$, expanded, fan-shaped; interstices thick, carinated; fenestrules equal, rectangular, from two to three times as long as wide; width equal to that of the interstices; dissepiments thin, regular; pores four or five to the length of a fenestrule, with slightly prominent margins, about their diameter apart; reverse, minutely granulated, and very coarsely sulcated longitudinally; nearly four fenestrules in the space of two lines measured longitudinally, six to seven in the same place measured transversely.

This is a very abundant species in the carboniferous limestone series, and one of the two species confounded under the name Fenestella antiqua, by Mr Lonsdale and Prof. Phillips, in the carboniferous slates of Petherwin, seems to be only a slightly more slender variety.

Position and Locality.-Of the last-mentioned variety, abundant in the Carboniferous Slate* of Petherwin. For the localities of the other varieties, see the section on the Zoophytes of the Upper Palrozoic Rocks.

\section{Fenestella prisca (Gold. Sp.)}

Syn. and Ref.-Retepora prisea Gold. Pet. Germ. t. 36. f. 19. (not Fenestelle prisea Lonsd. Sil. Syst.)

Sp. Ch.-Corallum forming broad, undulating, fan-shaped expansions, usually about two inches high; fenestrules broad, ovate, or very obscurely hexagonal, alternately placed on most parts of the coral, two in two lines measured vertically, three in the same space measured across; interstices about half the width of the fenestrules near the margins, about two-thirds the width near the base; dissepiments about as wide as the interstices; surface of reverse marked with close flexuous, longitudinal striæ.

I have noticed distinct traces of a wrinkled, membranaceous covering, filling up the fenestrules in several cases, giving strength to a suggestion T threw out in my volume on the "Limestone Fossils of Ireland," that all Fenestelle, when perfect, probably bad such a covering as we see strongly calcified in Hemitrype. The specimens I have examined do not shew the poriferous face, but there cannot, even from the above characters, be a doubt of its distinctness from the Silurian coral, which Mr Lonsdale has assigned to the same species. In Goldfuss's figure the interstices are carinated, flexuous, with about four pores to the length of an interstice, and two to the width of a dissepiment.

Position and Locality.-Devonian limestone of Plymouth.

\section{6th Class. ECHINODERMATA. See page 51. 1st Ord. Crinoidea. See page 52. \\ Genus. CYATHOCRINUS. (Mill.) restricted by Aust.}

Gen. Char.-Cotumn round or pentagonal, with auxiliary side-arms; alimentary canal round, or pentagonal; cup composed of pelvis, 1 st primary radials, 1st secondary radials, and one 1st interradial; pelvis pentagonal, of five equal pentagonal pieces, alternating above which are four pentagonal and one hexagonal 1st primery radials (1st costals), alternating above the re-entering angles of which are five pentagonal 1st secondery raclials (scapula), each with a small excavation in the middle of its upper edge for the 2nd secondary radial (1st arm-joint), which is much narrower than the preceding (or scapular) joint; the hexagonal 1st primary radial (or costal), supports on its upper truneated edge a large hexagonal 1st interradial (interscapular) plate.

\footnotetext{
* See note at page 74 .
} 


\section{Cyathocrinus geometricus (Gold.)}

Ref. and Syn.-Gold. Pet. Germ. t. 58. fig. 5. Phill. Pal, Foss. t. 60. f. 41.

$S p$. Ch.-Cup from pelvis to top of 1 st secondary radials (scapula), about eleven lines (large specimen), greatest width (at middle of Ist primary radials) one inch three lines, diameter of pelvis ten lines; height and width of the primary radials equalling seren lines, or the width slightly exceeding the length, if measured directly; secondary radials about six lines wide, and five high, with a deep narrow articular notch, for the second joint of the secondary radial series, forming the base of the free rays; interradial plate six lines wide, and the same in height; surface of the five primary radial plates, conically protuberant in the middle, the rest flattened; two or three coarse subequal parallel ridges extend from the centre of each plate, through the middle of one of its straight sides to the centre of each of the adjoining plates.

Position and Locality.-Not uncommon in the Devonian limestone of Newton Bushel.

\section{9th Ord. Crstidea. See page 61.}

\section{SPHÆROnites tesselatus. (Phill.)}

\section{Ref-Phill. Pal. Foss. t. 59.}

This name has been provisionally given by Prof. Phillips to an irregularly pyriform 'fossil, of which a figure is given by Sir Henry de la Béche, in the "Transactions of the Geological Society of London,"v. 3. t. 20. which has been copied by the former into his "Palcozoic Fossils." None of the characters of the genus Sphoronites have yet been recognised in it however; and the true genus of the fossil is very doubtful. All the specimens are more or less pear-shaped, inflated, and oltusely rounded at one end, tapering nearly to a point at the other; the length varies from three to six inches, and the greatest width (about onethird from the broad end) is rather less than two-thirds the length; the whole surface seems covered with subequal hexagonal, or oceasionally heptagonal, calcareous plates, usually one-half or two-thirds of a line thick, and about $2 \frac{1}{2}$ lines in length and width. I have never seen any plates so large as those represented in the above-mentioned figure, but they vary slightly in size and shape within short distances, sometimes the length, sometimes the width, being a little in excess. On the outer side each plate is raised into an obscurely defined rounded tubercle in the middle: the entire of the inner surface is latticed with strong vertical, prominent lamellar ridges, coinciding with a vertical line drawn through the centre of each row of plates, new ridges being added by intercalation as the width increases; the intervening spaces are crossed at regular intervals by less prominent lamellar ridges, at right angles to the strong vertical ones, and also coinciding with the centres of the plates-each plate bearing on its inner face a lamellar cruciform projection, the vertical branches strongest, and bisecting the upper and lower sides of each plate, and the lateral branches reaching the lateral angles; the union of these parts forming the regular reticulating ridges of the general interior.

From the obscure specimens I have seen of the Recepteculit's Teptuni, I should say the present fossil ought to be referred to that genus, rather than to splueronites, and it is possible they may be specifically identical. One of the smallest specimens in the Cambridge collection shews near the broad extremity what may be a rounderl valvular ovarian rosette, about three lines in diameter, apparently of five pieces, but the entire appearance may be deceptive, and requires to be confirmed by other specimens.

Position and Locality.-Common in the Devonian limestone of Plymouth. 

Sect. III.-RADIATA OF UPPER PALAEOZOIC ROCKS (Carboniferous and Permian). 3rd Class. ZOOPHYTA. (Lin.) See page 1. 2nd Ord. Zoophttaria. See page 9. 3rd Family. TUBIPORIDE. See page 11. Gienus. FISTULIPORA. See page 11.

Fistulipora minor $\left(\mathrm{M}^{\mathrm{c}} \mathrm{Coy}\right)$. Pl. 3. B. fig. 12. Ref.-MI ${ }^{\mathrm{C}} \mathrm{Coy}, \mathrm{Ann}$. Nat. Hist, 2nd Series, Vol. III. p. 130.

Sp. Ch.-Cell-tubes with slightly prominent margins at the surface, about four in the space of one line, rather less than their own diameter apart, the intervening space composed of from one to three rows of the minute vesicular cells.

The diaphragms in the main tubes slightly irregular, about half their diameter apart; the tubes are from half a line to nearly an inch in length, according to the age of the example, but not altering materially their diameter or relative distance. It most usually occurs incrusting crinoid stens or other foreign bodies, from which the tubes radiate to the surface, and I suspect the whole corallum. from the minuteness of its parts, may have been taken for a Farosites or Alveolites, from which the lens will casily distinguish it by shewing the reticulated interstices between the tubes.

Position and Locality.-Not uncommon in the carboniferous limestone of Derbyshire.

Explanation of Figures.-Pl. 3. B. fig. 12. Old specimen, natural size, from Derbyshire, enveloping a foreign body, shewing the appearance of the rough fracture and a portion of the exterior.-Fig. $12 \%$. Ditto, vertical, rough, and polished sections magnified four diameters, the former shewing the tubes entire with the intervening cellular structure, the latter shewing also the transverse septa of the tubes,-Fig. 12b. Ditto, horizontal section of another portion magnified twelve diameters.

\section{3rd Ord. Zonntharia. See page 13.}

2nd Tribe. MADREPORACEA. See page 13.

Dendropora megastoma $\left(M^{c} \mathrm{Coy}\right)$. Pl. 3. B. fig. 11.

Ref.-IICCoy, Ann. Nat. Hist. 2nd Series, Vol. III. p. 129.

$S \%$. C $\%$.-Stem slightly flexuous, subquadrate, branches few, distant, resembling the main stem in size and shape, and coming off from it nearly at right angles; each face has a row of large oval cells with prominent edges, the sides of which have twelve vertical sulci ending in tubercles; the cells of each row are rather less than twice their dianeter apart, the lateral rows opposite and alternating with the other two rows; the width of the cells slightly exceeds that of the face on which they rest, so as to indent the margin, interstices obscurely striated and poroso-punctate; width of stem about half a line. 
This beautiful coral is distinguished from the D. explicita (Mich.) from the Devonian beds of Boulognesur-Mer, by its smaller size and larger cells. Michelin, in his Iconographie Zooplyytolugique, founds this genus for the last-named coral, and approximates it to the genera Criserpia and Auloporce; the twelve sulci which I observe to the margin of the cells in this species, however, shew that this cannot be the true affinity of the group, which must now rather be placed in the Madreporacea, characterised by that number, although the general characters of the coral and budding resemble seriatopara. The minute porosity also agrees with this view. This species is erected into the genus Rhabdopora, by MII. Edwards and Haime, and distinguished from Dendropora by the granulation of the intercellular spaces; as this, however, is extremely minute, it may easily have escaped M. Michelin, in his species in which he overlooked the lamellar notches.

Position and Locality.-I have examined several specimens on a piece of carboniferous limestone of Derbyshire.

Explanation of Figures.-Pl. 3. B. Fig. 11. Several portions on a bit of limestone, natural size, from Derbyshire.-Fig. 11 . Ditto, a portion magnified six diameters, to shew the twelve tubercular sulci of the cells, and the obscure porosity and striation of the exterior.

3rd Tribe. MADREPHYLLACEA. See page 18.

1st Family. MILLEPORIDE. See page 18.

2nd Subfamily. FAVOSITINE. See page 19.

Genus. FAVOSITES. See page 19.

Favosites Gothlandica (Gold.) See page 20.

On the most careful examination I find it impossible to distinguish this species, as found in the carboniferous rocks, from Eifel or Silurian examples, on comparison of several well preserved specimens. I first published the species as carboniferous, several ycars ago, in my volume on the Fossils of the Carboniferous Series of lreland, from a single specimen, on the locality of which some doubt was thrown. I am now, however, able to confirm my original observations.

Position and Locality.-Abundant in some parts of the carboniferous limestone of Derbyshire. A doultful specimen in the carboniferous shale of the Isle of Man.

\section{Genus. MICHELINEA (Kon.) \\ Ref.-Anim. Foss. Bel. p. 30.}

Gen. Char.-Corallum compound, forming rounded, depressed, or conoidal masses, of inseparably united, . thick-walled polygonal tubes of large size, marked internally with numerous vertical lamellar strix, and communicating pores; base of the cells filled up by very irregular, numerous, highly inclined vesicular plates, not forming distinct horizontal diapluragms; external or basal epitheca of the general mass, strong, con. centrically wrinkled, and sometimes spinose.

This genus differs from Farosites, in its inseparably united cell-tubes, from Chatetes by its communicating pores, and from both genera by the numerous vesicular plates filling up the tubes instead of regular distinct transverse diaphragms, and in the great comparative size of the cell-tubes.

$$
\begin{aligned}
& \text { Michelinea Glomerata }\left(M^{c} \mathrm{C} O y\right) \text {. Pl. 3. B. fig. } 14 . \\
& \text { Ref.-McCoy, Ann. Nat. Hist. 2nd Series, Vol. III. p. } 122 .
\end{aligned}
$$

Sp.Ch.-Cells polygonal, irregularly aggregated, so as to open on every side of the large amorphous masses formed by its irregular mode of growth; cells averaging two lines in diameter, internal vesicular plates very irregular, much curved, and variously inclined. 
The small size of the eells and mode of growth seem somewhat analogons to the Russian $1 T$. concinne (Lonsd.) and separate them at a glanee from the three other published species; but the present species differs in its vesicular plates not being nearly flat and horizontal, but much curved and variously inclined.

Position and Loculity.-Common in the carboniferous limestone of Derbyshire, forming subeylindrical masses three or four inches long.

Explanation of Figure.-Plate 3. B. fig. 14. Portion of large mass natural size, from Derbyshire, with a rough section of one corner, and a polished section below.

Michelinea grandis $\left(\mathrm{I}^{\mathrm{C}} \mathrm{Coy}\right)$. Pl. 3. C. fig. 1.

Ref.-MI ${ }^{\mathrm{c}} \mathrm{Coy}$, Ann. Nat. Hist. 2nd Series, Vol. III. p. 123.

sp. Ch.-Corallum widely conic, the width considerably exceeding the height, externally marked with thick, rounded, radiating ridges, finely wrinkled across; polygonal cells, on the upper convex surface, averaging five to eight lines in diameter (most near the former at a height of half an inch, most near the latter size at a height of two inches), very deep, with thin walls not coated by vesicular plates, but having numerous distinct foramina, and many longitudinal strin within; internal vesicular plates small, very thin, much curved, forming nearly horizontal irregular rows of vesicles at the bottoms of the cells.

This fine species is most allied to the $M$. tenuisepta (Plill. sp.), but is distinguished by the much wider conical form of the mass, and by the cells having, on an average, a diameter three times greater at the same height than in that species, of which I have examined many specimens both 13ritish and foreign, and find the figures of Michelin and Koninck, as well as of Prof. Plillips, exact in this respect. Young specimens (one to two inches in diameter) slightly resemble the $M$. favos (Gold. sp.) in form, having the base much flatter than in the adult; but on comparison with authentic Belgian specimens, thay are found to be distinguished by the large, rounded, radiating ridges on the exterior, of which no traces exist in that species, as may be also seen from the figures of Goldfuss and Michelin; the cells also of the present coral are, even at that stage larger, and increased growth destroys all resemblance.

The $M$. megastoma (Phill. sp.), which has large cells (although much less than the present species), is distinguished by its mode of growth, it forming large flattened expansions; internally its vesicular plates are much larger, fewer, and highly inclined at the circumferenee, coating the walls of the cells to their very edge, giving them a peculiar thick tumid appearance, which may be imperfectly recognised in the worn specimens figured by Prof. Phillips, but which distinguishes eren fragments from the other four species. Average height of the conical masses two and a half inches, width, three and half inches.

Position and Locality.- Tery common in the carboniferous limestone of Arnside, Kendal; carboniferons shale, Isle of Man.

Explanation of Figures.-Plate 3. C. fig. 1. Natural size, from Arnside, some of the cells shewing the vertical internal stria and connecting pores; one of the external walls, slightly worn, shews the internal vesicular structure. $1 a$. Do. Vertical (and of some of the columns slightly oblique) sections, shering the internal vesicular plates, and the foraminated structure of the walls.

\section{Subfamily。 Chemtetine. See page 24.}

\section{Genus. CHETETES (Fischer as defined by Lonsd.)}

Gen. Char.-Corallum polymorphous, composed of closely aggregated, prismatic, capillary tuhes, inseparably united, crossed at variable distances by transverse diaphragms; no connecting tubuli or foramina in the sides; increase by splitting of the old tubes into two or three, the divisional walls arising from the middle of a side (not from the angles).

Erroneously supposed by Fischer to differ from Facosites by the want of transverse diaphragms, but the true characters of the well-preserved Russian type has been well developed by Mr Lonsdale (Geol. of Russia, Vol. I. p. 593$)$. 
Owing to the fissiparous generation, the adjacent tubes have only one common wall, and a rough vertical fracture always exposes the inner cavity of the tubes, instead of the external walls as in Stenopora or Facosites.

\section{Cuztetes capillaris (Plill. Sp.)}

Ref. and Syn.-Favosites capillaris Phill. Geol. York. V. 2. t. 2. f. 3, 4, and 5.

Sp. Ch._-Corallum forming rounded masses of three or four inches in diameter, composed of slightly diverging prismatic tubes, opening at right angles to the surface, averaging fourteen in the space of two lines; diaphragms at nearly equal heights in adjacent tubes, and usually a little more or less than the diameter of the tubes apart.

The very small size of the tubes separates this species from the C. septosus.

Position and Locality.-Carboniferous limestone of Kendal, Westmoreland.

\section{Chеtetes septosus (Flem. Sp.)}

Ref. and Syn.-Favosites septosus Flem. Phill. Geol. York. V. 2. t. 2. f. 6, 7, and 8.

$S p$. Ch.-Corallum forming very large tuberose masses, composed of radiating cell-tubes, averaging seven or eight in two lines; walls thin, diaphragms at very irregularly unequal heights, in the adjacent tubes, varying from one third to nearly twice the diameter of the tubes apart; fissiparous development of the young tubes very frequent and easily observed; boundaries of the cells coarsely granulated on the surface.

One very large specimen of irregular growth from Kendal has on some parts of the undulations the cellmouths oblique, as in the $F$. spongites, and only five or six in two lines, with the boundary ridges strongly tuberculated, other portions of the same mass shew the usual size and direction of the cells; the specimens of luxuriant growth seem to have the diaphragms at the most unequal distances, while the more stunted groups, which have grown in a regular manner, incrusting a level surface, seem to have the diaphragms at as equal a distance and as nearly at the same level in adjacent tubes, as in the Farosites capillaris of Phillips, which may thus prove to be an extreme variety of the present species.

Position and Locality.-Forms great masses in the carboniferous limestone of Derbyshire, and Kendal.

\section{Genus. S'IENOPORA. See page 24.}

\section{Stenopora inflata (Kon. Sp.)}

Ref. and Syn.-Calanopora inflata Koninck, Anim. Foss. t. A. f. 8.

$s p$. Ch.--Corallum usually forning irregularly tumid or hollow lobulated masses, one or two inches long, and usually under three quarters of an inch in diameter; composed of an outer layer, about one-third of a line thick, of subequal prismatic tubes, perpendicular to the surface, averaging from twenty-one to twentytwo in one line; interior of the tubes cylindrical.

Owing to the extreme minuteness of the structure of this very distinct coral, I am unable to see all the generic characters. It has no relation to the Calamopora dentifera, as $\mathbf{M}$. de Koninek seemed to think, being far more minute in structural details. The hemispherical granules of the surface he figures and describes are the casts of the cylindrical interiors of the tubes. I have identified the English specimens with authentic Belgian examples from the author.

Position and Locality.-Abundant in the carboniferous limestone of Kendal, Westmoreland.

\section{Stenopora tumidda (Phill. Sp.)}

Ref. and Syn.-Calamopora tumida Phill. Geol. York. Vol. II. t. 1. f. 25.

Sp. Ch.-Corallum forming cylindrical, irregularly tumid branches, dichotomising at an angle of about $40^{\circ}$ to $75^{\circ}$, composed of elose, nearly equal tubes, averaging seven to eight in the space of one line, apparently cylindrical within, prismatic without, nearly vertical in the central part of the branches, abruptly 
diverging to the surface which they meet at nearly right angles; each tube towards its extremity rendered irregularly moniliform, by numerous, strong, unequal contractions nearly at the same level in adjoining tubes; diaphragms about the diameter of the tubes apart, surface minutely granulose, marked with polygonal boundary walls of the tubes; each cell-mouth nearly closed by a concave diaphragm, perforated by a small, circular, central opening, about one-third the diameter of the tube; two circular openings sometimes seeming within the one polygonal boundary, owing to the unequal development of the boundary walls; young interpolated tubes, few.

Position and Locality.-Very common in the carboniferous limestone of Derbyshire. A small, more regular variety, with often hollow branches, common in the dark limestone of the Isle of Man.

\title{
Subfamily. HALYSITIN死, See page 26. \\ Genus. SYRINGOPORA. See page 27. \\ Syringopora catenata (Mart. Sp.)
}

Syn. and Ref.-Erismatholitus (Tubiporites) catenatus Martin, Pet. Derb. t. 42. f. 1. (not 2).

$S p . C h$.-Corallum forming large masses of nearly equal, subparallel, very slightly diverging tubes, averaging half a line in diameter, and about their diameter apart, connected by nearly equal, transverse tubuli, slightly more than the diameter of the tubes apart, the origin of each producing a slight angular flexuosity in the main tubes; tubular central opening rather large.

This delicately formed species, as here restricted, corresponds exactly to the first figure and first variety mentioned by Martin, but not to his second variety or figure, which belong to the S. reticulata (Gold.)

Position and Locality.-In the carboniferous limestone of Derbyshire.

\section{Syringopora geniculata (Phill.)}

\author{
Ref.-Syringopora geniculata Phill. Geol. York. Vol. II. t. 2. f. 1.
}

Sp. Ch.-Corallum forming large masses, composed of slightly radiating, or nearly vertical, round, tubes, averaging one line in diameter, about half theil diameter apart, slightly flexuous or geniculate at each of the connecting tubuli, which vary from one to one and half lines apart, and are less than one line in diameter; surface smooth.

The very numerous short connecting tubuli, and the slight angular flexuosity of the main tube at the origin of each, give a very characteristic rugosity to this species, which frequently forms masses of great extent.

Position and Locality.-Abundant in the carboniferous limestone of Derbyshire.

\section{Syringopora ramulosa (Gold.)}

$$
\text { Ref.-Gold. Pet. Germ. t. 25. f. } 7 .
$$

Sy. C'\%.-Corallum forming very large masses, of radiating, thick, gently flexuous, nearly smooth tubes, forking with nearly equal branches at long irregular distances; average diameter of main tubes one and half lines; connecting tubuli thick, varying usually from three to five or six lines apart; main tubes varying, from their flexuosity, from a little less than their diameter (the average) to two or nearly three times their diameter apart.

The great size and flexuosity of the tubes, and the irregular distribution of the thick transverse sibuli, easily distinguish this species from the other carboniferous ones; the internal vesicular lining to the walls, or very oblique funnel-sbaped imperfect diaphragms, occupy nearly the whole cavity of the tube, leaving but a very slender open median space; the mode of branching is remarkable from its resemblance to dichotomous fission, the parent and young being nearly of equal size, and nearly equally deflceted from the original direction.

Position and Locality.-Common in the impure carboniferous limestone of the Isle of Man. 


\section{Syringopora reticulata (Gold.)}

Ref. and Syn.Gold. Pet. Germ. t. 25. f. 8. Harmodytes parallelus (Fisch.) Oryct. Mosc. t. 37. f. 6. Tubiporites catenatus (pars.) Martin, Pet. Derb. t. 42. f. 2. (not f. 1).

$S p . C h$.-Corallum forming large masses of subparallel tubes, slightly flexuous, at the origin of the very deliente connecting tubuli; main tubes averaging two-thirds of a line in diameter, usually less than half their diameter apart; connecting tubuli very slender in irregular whorls, at nearly equal distances, usually rather more than the diameter of the tubes apart; oblique vesicular lining to the walls, or funnel-shaped diaphragms, very thick, reducing greatly the central cavity.

Branching by distinct lateral buds is frequently and easily observed in this species; the young branch being for some distance much smaller than the parent, which is not much deflected; the strong foraminated, vertical, internal lamellar strix are also seen, wherever the outer wall is decomposed. The characters of the species seem very constant, as might even be gathered from the coincidence between the figures of Goldfuss, Fischer, and Martin; the latter separating it as a distinct variety from his true catenata, in which I fully agree with him on examination of Derbyshire specimens of the latter species. The S'. reticulata is intermediate between the $S$. catenata and $S$. geniculata, in form and size, but perfectly distinct from both.

Professor Phillips figures under this name a straighter and more slender coral, which I have seen in the carboniferous shales near Dublin, but which, if not a distinct species, is a strongly marked variety, requiring particular specification.

Position and Locality.-Common in the carboniferous limestone of Kendal, Westmoreland.

\section{Genus. CLADOCHONUS (McCoy).}

$$
\text { Ref.-Ann. Nat. Hist. Vol. XX. p. } 14 .
$$

Cen. Char.-Corallum erect, attached by the basal portion, embracing some foreign body, of very thick straight, slender, calcareous tubes, suddenly dilating, at regular distances, into large, oblique, cup-shaped terminal chambers, marked within by more than twelve longitudinal sulei; from the point where the dilatation commences, a second slender tube similar to the first is given off at an angle varying with the species, and terminating at the same distance as the former in a similar cup, bent in nearly an opposite direction to the first, and giving rise at its base to a third slender tube, as before, \&c.

These singular and beautiful corals have some relation to Aulopora, but differ in their curious erect habit, regular, angular mode of branching, slender equal stem-like tubes, and abruptly dilated, terminal cups, bent in nearly opposite directions. The Aulopores are attached for the most part by one side; the tubes gratually expand to the months, which all open nearly in one direction; they have no regular distance for branching, and frequently anastomose. The present corals have also much thicker walls to the tubes, the central hollow being proportionally very small.

\section{Cladochonus bacillarius $\left(M^{c} \mathrm{Coy}\right)$.}

Ref. and Syn.-Jania bacillaria (McCoy), Carb. Foss. Irel. t. 26. f. 11.

sp. Ch. - Corallum upwards of two inches high, branches very slender, eylindrical, straight, five or six lines long, and two-thirds of a line in diameter, each rapidly dilated at the summit to a short conical cup, about double the diameter of the stem, slightly inclined to one side, and giving origin, from the opposite near its margin, to similar straight stems and oblique conical cups.

The very thick dense lining to the walls leaves a very small central perforation; the walls become gradually thin at the edge of the cup; and I have seen traces of the numerous vertical lamellar strix in one or two cones.

Position and Locality.-Abundant in some parts of the carboniferous limestone of Derbyshire. The original Irish locality was the carboniferous slate of Lisnapaste, Ballintra. 


\section{Cladochonus brevicolls $\left(M^{c}\right.$ Coy). Pl. 3. B. fig. 10. \\ Ref.-McCoy, Ann. Nat. Hist. 2nd Series, Vol. III.p. 128.}

Sp. Ch.-Slender stem-like neck of each cell about one line long and half a line in diameter, the upper end suddenly swelling to a cup-shaped cell about two lines long and one line in diameter, curving downwards at an angle of about $135^{\circ}$, the point of junction of the cup and the stem giving origin, at an angle of $45^{\circ}$, to the stem of a second cell similar to the first, but inclining in the opposite direction, and, in like manner, giving origin from its upper convexity to a third, and that to a fourth, Ste. perfectly similar cell, forming together an erect, regularly zigzag corallum.

From its regularly angular mode of growth or connexion of the large drooping bell-shaped cups, inclining in opposite directions from thin short slender stems, this is one of the prettiest species of the genus. It most resembles the C. tomionllis ( $\mathrm{II}^{\circ} \mathrm{Coy}$ ), figured in the "Annals" for October, $18 \pm 7$ (Pl. 11, fig. 8), from the carboniferous shales of New South Wales, but is distinguished by its smaller size and much shorter necks to the cells, while, as in that species, their small diameters compared with their cups distinguish it from the C. crassus ( $\left.\mathrm{M}^{\mathrm{C}} \mathrm{Coy}\right)$ of the carboniferous slate of Ireland.

Position and Locality.--Rare in the carboniferous limestone of Derbyshire.

Explanation of Figure.-PI. 3. B. fig. 10. Natural size, from Derbyshire.

\section{Cladochonus crassus $\left(M^{\circ} \mathrm{Coy}\right)$.}

Syn. and Ref.-Jania crassa (McCoy), Syn. Carb. Foss. Irel. t. 27. f. 4.

sp. Ch.-Irregularly di- or tri-chotomous; branches thick, conical,short, two to four lines long, nearly one and half lines thick at their origin, expanding gradually to form a very short conical cup, about one and two-thirds of a line in diameter, slightly inclined obliquely to one side, and giving off one, or sometimes three similar branches and terminal cells from the opposite side.

This is the largest species of this group I have seen; it most nearly resembles the C. bacillarius ( $\mathrm{II}^{\mathrm{C}} \mathrm{Coy}$ ), from which it differs in the great thickness and conical form of the branches. The mode of attachment of the young is most usually by the early branches growing in a circle round a crinoidal stem. Length of specimens in the shales is usually from one to two inches; length of branches about three lines, diameter of branches at base usually about one line, at extremity one line and half.

Position and Locality.-Abundant in some parts of the limestone of Derbyshire. The original Irish locality was the carboniferous slate of Lisnapaste, Ballintra.

Family. CYATHOPHYLLIDA. See page 27.

Subfamily. CYATHOPHYLLINE. See page 27.

Genus. CYATHOPHYLLUM. See page 69.

Cyathophyllum dianthoides $\left(\boldsymbol{M}^{c} \mathrm{Coy}\right)$. Pl. 3. C. fig. 7.

Ref-_McCoy, Ann. Nat. Hist. 2nd Series, Vol. III. p. 7.

Sy. Ch.-Corallum very proliferous, forming wide conical groups; individual cones rapidly expanding; averaging one third (or less) longer than wide, concentrically wrinkled, and with obsolete longitudinal strixe externally ; terminal cup very deep, with either a sharp or truncated edge, and containing from ninety-six to a hundred (as it approaches one inch in diameter) very thin, apparently crenulated, radiating lamella, alternately longer and shorter; vertical section shews less than one third the diameter on each side occupied by minute vesicular tissue, the rows of rounded cells extending obliquely upwards and outwards, about ten in each row, but 
varying with the age of the cup; the broad middle part is occupied by close, thick, transverse diaphragms, each reaching half or the entire way across, and bent down at the ends. From eight to sixteen young cones take their origin from the inner part of the margin of favourably situated parent cups, thus forming compound masses three inches or more in diameter; adult cones averaging one and half inches long; horizontal section, shews a circular space free of lamella in the middle, about one third of the diameter; the primary lamella extending from thence to the rather thick outer walls with a slight flexuosity, and the secondary lamella reaching from the wall half as far as the primary ones; an outer zone of minute irregular vesicular plates connects the lamellæ only as far as the short ones extend.

This is closely allied to the $C$. dianthus, (Gold. truncatus Linn.), and the compound examples of $C$. turbinatum (Linn. and Gold.), but is distinguished from the first by its wide, rapidly expanding cones, and from both by the lamellie being distinctly of two alternating sizes, much thinner, and greatly more numerous.

Position and Locality.-Common in the carboniferous limestone of Arnside, Kendal, W estmoreland.

Explanation of Figures.-Plate 3. C. fig. 7. Compound group of old stems, shewing the way in which clusters of young stems grow from within the edge of the parent. Natural size.-Fig. 7 a. Do. Horizontal section of part of star magnified tro diameters, shewing the outer vesicular zone with its short and long lamellie, the extension of these latter without vesicular plates towards the centre, and the central space destitute of lamellæ.-Fig. 7 b. Do. Cone of middle age, magnified two diameters, shewing at top the characters of the terminal cup, with its alternately large and small lanellæ, and the flat unradiated space at bottom, formed by the transverse diaphragms. The lower part is a vertical section shewing the transverse diaphragms, and outer highly inclined area of minute vesicular tissue (the vertical lines at bottom are radiating lamelle shewn by the curving of the centre out of the plane of section).

\section{Cyathophylum paracida $\left(M^{c}\right.$ Coy). Pl. 3. C. fig. 9. \\ Ref.-McCoy, Ann. Nat. Hist. 2nd Series, Vol. III. p. 7.}

Sp.Ch.-Corallum of slender cones averaging half an inch wide at mouth, and one and half inches long (gencrally somewhat smaller), straight or variously bent, and sometimes irregularly coalescing so as to form loose irregular masses; three or four young cones take their origin from within the margin of the parent cell, which they smother by their growth*; internal structure, centre occupied by broad slightly undulated transverse diaphragms, four-fifths the width of the tubes; narrow outer area occupied by thirty-two equal, narrow, radiating lamellæ, variously connected by small, curved, vesicular plates; outer surface faintly striated longitudinally.

Allied to the $C$.caspitosum and $C$. quadrigeminum of the older rocks, but the branches are not so iong anci cylindrical as in the first, nor so short or laterally united as in the latter; the number of the lamella and character of the narrow lamelliferous zone (only one-tenth of the diameter), and the very wide, distinct, transverse diaphragms will serve to discriminate even fragments of the species.

Position and Locality.-Not uncommon in the carboniferous limestone of Derbyshire.

Explanation of Figures.-Plate 3. C. fig. 9: Natural size of a single old stem, shewing the usual way in which four young ones spring from within the terminal cup of the parent, smothering the latter.

Cyathophyllum pseudo-vermiculare (McCoy). Pl. 3. C. fig. 8.

$$
\text { Ref.-McCoy, Ann. Nat. Hist. 2nd Series, Vol. III. p. } 8 .
$$

Sp. Ch.-Elongate, cylindrical, flexuous; surface very irregularly annulated or transversely nodular. coarsely striated longitudinally (about six stria in one-fouth of an inc.1); branches averaging from half to

* Tho spccific name refers to this appearance and may be allowed to remain, although it is quite possible the parent may have died first, leaving four ora to bo developed in its cup. 
three-fourth of an inch in diameter; small eylindrical branches project at distant irregular intervals from the sides: internal structure-central area, rather more than half the diameter of the tube, defined, composed of flat, slightly undulated transverse septa, bent downwards at the end, bearing at their circumference a series of from twenty-four to twenty-seven very short, equal, rather distant, radiating lamells, not reaching half way to the centre; interval between this inner area and the walls filled with loose cellular structure, formed of little more than a single row of large vesicular curved plates, highly inclined upwards and outwards.

This interesting coral perfectly resembles the Cyathophyllum cermiculare of Goldfuss in external characters, but by cutting and grinding down some specimens of the true Eifel coral of that species, I have ascertained beyond doubt (what was before suspected by Mr Lonsdale), that it is not a true Cyathophyllum, but belongs to that group which I have named Streplodes, having the radiating lamella extending from the walls to the centre, and there twisted together, without transverse diaphragms; it also has the curious characte: of the radiating lamella, having an elliptical section, being thicker in the middle than at either end, a per.liarity which I have also noticed in a British (Devonian) specimen of the same species, although not alluded to by Mr Lonsdale in his note on this species in the Memoir of Prof. Sedgwick and Sir R. Murchison, on the Devonian System. The present mountain-limestone coral I have shewn above to possess the true Cyathophyllum structure, and it is not therefore likely, after what I have stated with regard to the Devonian species, to be in future confounded with it. Externally it also bears a strong resemblance io the mountain-limestone fossil which I have called Lonsduleic duplicatu (Mart. sp.), but that coral I have ascertained to possess the very different internal structure of Strombodes (Lithostiotion of Lonsdale), and it is consequently, with a little care, incapable of being confounded with the present fossil.

Pusition and Loculity.-Not uncommon in the lower carboniferous limestone of Kendal, Westmoreland; (a variety also occurs in the lower carboniferous limestone of Kiltullagh, Roscommon, Ireland).

Explanation of Figures.-Pl. 3. C. fig. 8. Column natural size, from Kendal, shewing the vertical striae and transverse nodulation.-Fig. 8 \%. Do. Shering origin of young branch.-Fig. 86 . Do. Vertical and horizontal sections magnified one-third linear, the first shewing the simple transverse diaphragms, bent down at the circumference, and the open simple vesicular tissue of the outer area, the second shews the outer vesicular area, the central clear space, and the intervening zone of radiating lamellie, (the two concentric lines connecting the lanellæ in this section are only the deflected edges of two of the transverse diaphragms cut across).

\section{Subgenus. DIPHYPHYLLUM (Lonsd.)}

Ref._Lonsd. Geol. Russ. Vol. I. p. 624.

Gen. Char._Corallum forming elongate, cylindrical branches, dividing by dichotomous fissure of the main stem; no axis; biareal; the large central area occupied by strong simple transverse diaphragms, deflected at the circumference, surrounded by a narrow, outer vesicular area; outer wall thick, radiating lamellie numerous, not reaching the centre.

The dichotomous mode of division of the branches (so exceedingly rare among the Cyathoplyllidce) distinguishes this genus from Cyathophyllum. 


\section{Dipiyphyluum gracile $\left(M^{\circ} \mathrm{Coy}\right)$. Page 88 , figs. $d, e, f$. Ref.-McCoy, Ann. Nat. Hist. 2nd Series, Vol. VII.}

Sy. Ch.-Corallum forming large masses of eylindrical tubes two lines in diameter, dichotomously branching, and occasionally coalescing laterally; surface marked with sharp longitudinal lamellar strix, about four in one line; vertical section, shews transverse, very slightly convex, thick, smooth, regular diaphragms reaching nearly across the tube, two interdiaphragmal spaces in one line, bent downwards at the circumference; lateral vesicular area extremely narrow (less than one-fourth the diameter, of about one layer of cells; horizontal section, primary radiating lamellxe thick, equal, extending less than half-way to the centre, leaving the broad, smooth diaphragms, or clear space in the middle nearly two-thirds the diameter; between each pair of primary, in some specimens, is an extremely ninute marginal lamella.

The small diameter of the tubes distinguishes this species easily from any other Diphyplyyllum I know, and gives the whole much the appearance of Siphonodendron agrregatum $\left(\mathrm{M}^{\mathrm{c}} \mathrm{Coy}\right)$, but the lamella do not extend nearly to the centre; there is no axis, and the dichotomous fission of the star and tubes may be distinetly observed.

Position and Locality.-Not uncommon in the impure limestone of Lowick, Northumberland.
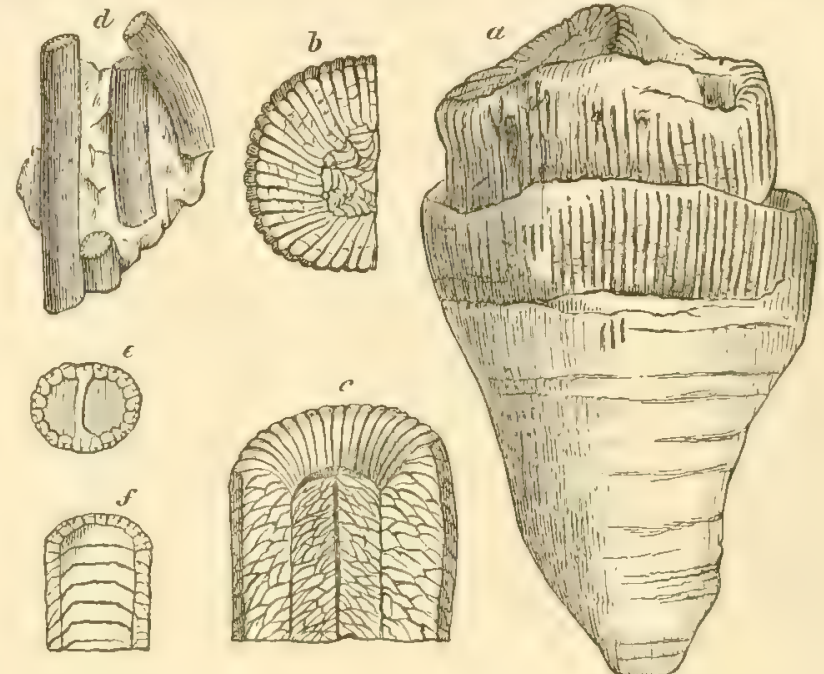

Clisiophyllum turbinatum, $-a$. Old specimen, natural size, shewing the imbricating interruptions of growth, and costal edges of lamellæ in the worn upper portion; b. horizontal section, natural size, shewing the lare, partially radiated vesicular tissue of the inner or axal area, the equal lamella min tlic middle area and the very narrow, unegually developed outer or jerithecal zone; $c$, vertical section and form of terminal cup, natural size of smal areas and the solid defining lines apart, as well as the section of the mesial crest of the axis.

Diphyphyllum gracile $-d$. Small portion of mass, shewing the natural size of the tules; $e$. horizontal section of a tube magnified slightly, shew ing the very small radiating lamella, and the thick, straight divisional zontal and with their narrow, complicated, deflected edges, bearing the short radiating latmellæ.

\section{Diphyphylum lateseptatum $\left(M^{\circ} C o y\right)$. Pl. 3. C. fig. 10.}

Ref.-M - Moy, Ann. Nat. Hist. 2nd Series, Vol. III. p. 8.

Sp. Ch.-Stem upwards of eight inches long, cylindrical, about three lines in diameter; nearly smooth, faintly striated longitudinally, and obsoletely wrinkled concentrically; vertical section, middle area occupied by slightly irregular transverse diaphragms, extending across two-thirds the diameter of the tubes, about four in the vertical space of one line, their edges abruptly bent downwards; lateral area very narrow, of nearly equal width, the inner composed of one set of small horizontal plates, the outer of two rows of minute, curved, vesicular plates inclining upwards and outwards.

This species differs from the $D$. concinnum (Lonsd.) of the carboniferous limestone East of the Ural chain, in the great proportional width of the transverse medial plates, which average two-thirds the diameter of the stem, or three times the width of the two outer areas of one side in the present species, but average one-third the diameter of the stem, or about equal to the two outer areas of one side in the other. The dichotomous mode of division of the stems (characteristic of this group among the septate corals), and also the conical upward projections of the centre of the transverse lamelle immediately under the point of fissure, were very well shewn in many of the specimens.

Position and Locality.-Abundant in the carboniferous limestone near Corwen.

Explanation of Figures.-Pl. 3. C. fig. 10. Small portion of mass, natural size.-Fig. 10 a. Do. I ertical section magnified three diameters, shewing the three areas, apparently dichotomous mode of division of the parent stem, and conical elevation of the transverse diaphragms below the point of fissure; the top 
of the left hand branch shews a portion of a terminal cup with the broad, smooth diaphragm forming its botton.-Fig. $10 \mathrm{~b}$. Do. Horizontal section, magnified three diameters, the outer vesicular area forming two rows of small connecting plates between the lamellae at their origin.

\section{Genus, CANINIA. See page 28. \\ Caninia gigantea (Micle.)}

Ref. and Sym._Michelin, Iconog. p. S1. = Siphonophyllia cylindrica, Sc. MIcCoy, Carb. Foss. Irel. t. 27. f. 5.

Sp. Ch.-Corallum simple, nearly cylindrical; a specimen five inches long, imperfect at each end, two inches three lines in diameter at the larger, being one inch ten lines in diameter at the smaller; girt with nearly regular obtuse rings of growth about four lines apart; the above greater diameter shews the lamelliferous cylindrical area, one inch six lines in diameter, radiated with about sixty-nine strong, subequal, biplated lamellie, with smooth sides, reaching rather more than half way to the centre, where they sink to the level of the smooth, nearly regular, horizontal diaphragms, the flattened part of which is about ten lines in diameter, surrounded by a margin, abruptly deflected at an obtuse angle to the boundary of the inner area; two or three of the lamelle nearly obsolete at the siphonal depression; lamelle connected by numerous close, curved, oblique, vesicular plates; outer or perithecal area, surrounding the inner or lamelliferous area, increasing in width by age, formed of nearly uniform strong cellular tissue, composed of very numerous curved, oblique, vesicular plates, faintly, or not at all, radiated by delicate costal prolongations of the radiating lamella.

Position and Locality. - Common in the impure carboniferous limestone of Castle-town Bay, and Scarlet, Isle of Man.

\section{Caninia subibicina ( $\left.\mathbf{K}^{c} \mathrm{Coy}\right)$. (Not figured).}

Ref.-M Mcoy, Ann. Nat. Hist. 2nd Series, Vol. VII.

Sp. Ch.-Corallum much curved, increasing, when young, at the rate of six lines in one inch to a diameter of one inch three lines; after which it remains nearly cylindrical for two or three inches more; surface with a thin, nearly smooth, epitheca, marked with obsolete transverse undulations of growth; when the epitheca is removed, the very fine, equal, costal strice are brought into view, five in two lines at a diameter of one inch two lines; the outer, small, vesicular area is rather more than a line wide, within which the sixty-five thick primary radiating lamella extend, about four lines towards the centre, leaving the broad, flat, smooth, slightly undulated central portion of the diaphragms about six lines in diameter in parts of the circumference; short secondary lamelice appear one between each of the primary; lateral siphonal depressions strongly marked; vertical section shews the outer vesicular area (at about the above dianeter) one and half line wide, composed of about four very oblique rows of small rounded cells, extending upwards and outwards, from the broad deflected edges of the diaphragms, which latter are thick, tolerably regular, nearly horizontal in the middle, about three interdiaphragmatal spaces in two lines.

This species is most nearly like Fischer de Waldheim's figure of his Turbinolia (Caninia) ibicina, from which it differs in the greater number of the lamellæ, \&c. It differs from the $C$. gigantea in its smaller size, slender form, more regular and smoother surface, much finer cells of the narrow outer area. I suspect this may be the coral quoted occasionally by authors from mountain-limestone, under the name of the Devonian Cyathophyllum flexusum, to the figures of which it bears some resemblance in external form, but from which it differs in its greater size, coarser lamellar strix, deflected edges to the diaphragms, siphonal depression, \&c.

Position and Locality.-Not uncommon in the carboniferous limestone of Kendal.

\section{Genus. CYATHOPSIS (D'Orb.)}

$$
\text { Ref.-Prodrome, p. } 105 .
$$

Gen. Char.-Corallum simple, elongate, conic, outer wall thin; radiating lamellie strong, reaching the walls, but not reaching the centre; no outer perithecal vesicular area between the ends of the lamella and the 
wall : no axis; vertical section shewing irregular transverse diaphragms or broad vesicular plates in the middle, extending downwards and outwards, and diminishing in size at the circumference; a strong lateral siphonal depression as in Caninia.

These corals differ from Caninia in wanting the outer perithecal small vesicular area, or lining to the walls; from Amplexus, in the more irregular vesicular nature of the transverse plates, particularly at the circumference, distinct siphon, and greater extension of the lamelle; from Calopleyllum (which I only know by name), by the vesicular edges of the transverse plates between the lamellie at the walls, and the distinct lateral siphonal depression.

\section{Cyathopsis CORnu-bovis (Mich. Sp.)}

Syn. and Ref.-Caninia cornu-bovis. Michelin, Icon. Zooph. t. 47. f. 8.

Sp. Ch.-Sub-cylindrical, slightly curved at the tip, abruptly tapering at the end, seven lines wide at eight lines from the base, generally about two inches long, diameter at that length only nine lines; vertical lamella thirty-three, large, very thick, equal, only three or four in one-fourth of an inch at the margin, one extremely small secondary lamella at the margin between each pair of primary, making about six of the obtuse vertical costal strix in a quarter of an inch; no cellular structure between them and the walls; marginal siphon large, occupying the space of two lamella; middle transversely septate, the circumference of the diaphragms deflected to the walls between the lamellæ; surface transversely rugose.

Known by its slender form and remarkably thick distant lamellæ.

Position and Locality.-Not uncommon in the carboniferous limestone, Derbyshire.

\section{Cyathopsis CORNu-COPI}

Syn. and Ref.-Caninia cornu-copice Michelin, Icon. Zooph. t. 59. f. 5.

$S p . C h$.-Corallum slender, conical, averaging one inch five lines long, and ten lines in diameter, at that distance from the apex; terminal cell very oblique; external surface without distinct lamellar strix, smooth or only marked with fine, transverse plice of growth; transverse diaphragms strong, with a very wide and deep conical, siphonal depression, near the convex side of the curve; radiating lamella thin, thirty-four or thirtyfive in number, uniting branch-wise in few large bundles as they reach the centre, one being obsolete at the siphon.

The smooth surface (without vertical lamellar strix), generally smaller size and more slender form, distinguish this from the young of Cyothopsis fungites; the transverse diaphragms, and conical siphonal depression, are very remarkably developed in this species, in which the absence of the vesicular plates of the true Caninia is very remarkable, care being taken in the horizontal sections not to confound the deflected edges of the lamelle with them. In sections towards the apex, we note that the diaphragms which are horizontal in the middle in old corals, converge upwards at a very acute angle in the young (as occurs also in others of the genus), and the irregular anastomosing, or branching of the lamellic, is also most strongly marked at that part.

Position and Localify.-Not uncommon in the carboniferous limestone of Kendal, Westmoreland ; carboniferous shale of Glasgow; carboniferous limestone of the Isle of Man.

\section{Cyatiopsis? ERUCa $\left(M^{c} \mathrm{Coy}\right)$ not figured.}

\section{Ref.-MCoy, Ann. Nat. Hist. 2nd Series, Vol. VII.}

Sp. Ch. - Corallum very small, subcylindrical, after a diameter of three lines, which it reaches at six lines from the apex, slightly curved; length of large example one inch two lines, diameter three and half lines; surface marked with coarse, longitudinal, obtuse lamellar strix, three in the space of one line ; radiating lamella strong, slightly irregular, comnected by several curved thick transverse vesicular plates in the hori- 
zontal section, one of the lamelle stronger than the rest, and extending through the centre, where it is either thickened or confounded with a slight mesial boss of one of the transverse septa: vertical section, middle third traversed by thick, subregular, transverse diaphragms, convex upwardly, three interdiaphragmatal spaces in one line; outer third on each side formed of one or two rows of irregular large cells, formed by the junction and occasional duplicature of the deflected edges of the diaphragms.

This so exactly resembles the Cyathaxonire comu in size, shape, and general external appearance, that it might be very easily confounded with it; even externally, however it might be distinguished by the smaller number in a given space of its much coarser lamellar vertical stria'; internally it is easily distinguished by wanting the solid styliform axis, by the distinct transverse vesicular plates between the lamellie in the horizontal section, and the transverse septation, \&c., of the vertical section.

Pusition and Locality.-Very common in the black carboniferous limestone and shale of Beith, Ayrshire.

\section{Cyathotsis fungites (Flem. Sp.)}

Ref. and Syn.-Turbinolie fungites Fleming, Brit. Anim. p. 510. Cyothopluyllum fungites Koninck, Foss. Bel. t. D. f. 2. Caninia patula Michelin, Icon. Zooph. t. 59. f. 4.

Sp.Ch.-Corallum conical, slender when young, more rapidly enlarging when old, slightly curved; terminal cup oblique; length of adult specimens about two and half inches, with a diameter at that length of one inch eight lines; diameter at an inch from the apex eight lines; surface with obsolete transverse wares of growth, and very strong, subequal, obtuse, Iongitudinal lamellar strie or ridges varying from four (at one inch six lines in diameter) to six in the space of two lines (the latter number at three lines in diameter). The external lamellar stria are double the number of the radiating lamella, the cleft outer edge of each of which form two external ridges; radiating lamelle about fifty at one inch in diameter, about thirty-six at six lines in diameter, uniting irregularly by various branch-like junctions into few bundles as they reach the centre, and also occasionally uniting obliquely from being inclined at different angles; siphonal irregularity occupying the place of one lamella; transverse plates depressed in the middle, and much deflected, and occasionally branched towards the outer wall; terminal cup very deep.

The strong longitudinal lamellar sulei easily distinguish even the dwarf varieties from the $C$. comm-copice.

The specimens in limestone seem to expand more rapilly than those in shale (excluding variation from pressure).

Position and Loculity.-Common in the carboniferous limestone of Kendal, WVestmoreland; in the dark (arlonniferous limestone and shale of Craige, near Kilmarnock; carboniferous shales near Glasgow; abundant in the black carboniferous limestone and shale of Ronald's Way, Isle of Man; not uncommon in the black carboniferous limestone and shale of Beith, Ayrshire.

\section{Genus. CALOPHYLLUM (Dana.) $=$ Polycatia (King).}

Gen. Char.-Corallum simple, conie; radiating lamella subequal, strong; no transverse vesicular tissue; transverse diaphragms strong, smooth in the middle, deflected at the edges; no siphonal depression.

This genus is intermediate between Aimplexus and Cyathopllyllum, and only differs from Cyathopsis ( $\mathrm{d}^{\prime} \mathrm{O} \mathrm{r} b$.) in wanting the siphonal depression at the side; the absence of the outer layer of vesicular tissue separates it from Cyathophyllum.

\section{Calophyllum spinosum (Kon. Sp.)}

Ref. and Syn.-Amplexus spinosus Koninck, Anim. Foss. Bel. t. C. f. 1.

$S p . C h$.-Corallum small, conical, with the base irregularly curved, averaging one inch long and about five lines in diameter, at that distance from the point of attachment; radiating lamelle strong, subequal; surface marked with concentric, irregular, obtuse lines of growth, and rather strong, narrow, vertical lamellar 
sulci, obscurely disposed in pairs, six in two lines, with numerous seattered, irregularly placed spinose tubercles.

I have not seen the internal structure of this species, but as it has clearly no distinct axis, I cannot, with M. Michelin, refer it to the genus Cyathaxonia, and have no hesitation in placing it in the present genus, from Koninck's figure.

Position and Locality.-Rare in the black carboniferous shale, Poolwash, Isle of Man.

\section{Genus. AMPLEXUS. See page 70. \\ Amplexus coralloides (Sow.)}

Ref. and Syn.-Min. Con. t. 72.=A. Sowerbyi. Phil. Geol. York. t. 2. f. 24 .

$S_{p} . C h$._Corallum cylindrical, or slightly compressed, long, tortuous, very slowly tapering; extreme young, slender, irregularly flexuous, and with small irregular distant transverse wrinkles, crossed by faint longitudinal stria, double the number of the marginal lamellie; adult surface nearly even, marked with fine close transverse wrinkles, or stria, and faintly marked longitudinally by the lamellar striae; marginal lamella forty-four to forty-six at the diameters of nine to fourteen lines, very short, strong, resting on the deflected edges of the diaphragms, across which faint strix proceed (? membranous continuation of the lamella) towards the centre; diaphragms strong, numerous, slightly undulated.

There is often a Caninic-like depression towards the margin of certain of the diaphragms, but it is not a true siphon, is never perforated, and does not correspond in position with a similar depression on the adjoining diaphragms. A young specimen, three lines in diameter, has got twenty-three marginal lamellx. The ordinary adult diameter is about one inch three lines, at which size the corallum is nearly straight, or slightly curved, cylindrical, and tolerably even; the lamellar sulci of the surface measuring two to three spaces in two lines.

Position and Locality.-Common in the carboniferous limestone of Derbyshire.

\section{Genus. COLUMNARIA (Gold.) redefined.}

Gen. Char.-Coraltem of aggregated subparallel branches, either round and concentrically wrinkled, or more usually, by mutual pressure becoming polygonal and longitudinally sulcated, but always easily separable; internal structure as in Amplexus, having many transverse simple diaphragms, and the walls longitudinally sulcated by marginal rudimentary lamella, which crenulate the edges of the transverse plates. Inerease by fissure of the parent tube, or cell, as in Stylastrace (Lonsd.) Type of the Genus Columnaria sulcate (Gold.)

This genus has been erroneously described by Goldfuss in the first instance, and has been misunderstood by nearly every subsequent author-all describing radiating lamelle from the walls to the centre, and stating that there are no transverse plates; I was rather surprised, therefore, to find the characters I have given above in anthentic specimens from the Eifel of the C. sulcata (Gold.); they also exist in the C. irregularis (Miunst.), C. senilis (Koninck), and the following. I deny the existence in those species of radiating lamellie near the centre, and find the transverse diaphragms conspicuous. The real affinities of the genus seem to be between Micheline and Amplexus, differing from the former in the tubes being individually distinct (as in Stylastreca), and easily scparable by fracture, and being without communicating pores; from the latter it only differs in its compound mode of growth. As thus restricted the genus is, no doubt, a good one: the other dissimilar species, placed in this genus by Dr Goldfuss and others, will easily fall into Cyathophyllum and other existing genera.

\section{Columinarta laxa $\left(M^{c} \mathrm{Coy}\right)$. Pl. 3. C. fig. 11.}

Ref:-McCoy, Ann. Nat. Hist. 2nd Series, Vol. III. p. 122.

Sip. Ch.-Corallum forming large masses of contiguous, slightly flexuous tubes, rarely in contact; generally round, and finely wrinkled transversely, occasionally the tubes in some part of their length touch the adjoining ones, and then become polygonal and longitudinally sulcated; transverse diaphragms undulated, and obliquely inclined in various directions; diameter of tubes from three to four lines. 
The tubes being rarely in contact, and often cylindrical and flexuous, distinguish this species from its congeners. The transverse diaphragms, and absence of radiating lamellit, will serve to separate prismatic portions from the other basaltiform corals found with it.

Position and Locality.-Not uncommon in the carboniferous limestone of Derbyshire.

Explanation of Figures.-Pl. 3. C. fig. 11. Portions of large mass, natural size, shewing the loose mode of growth, and the variation of the columns from round and nearly smooth, to prismatic and longitudinally sulcated; the tops, by rough fracture, exhibiting the transverse undulated diaphragms with their crenulated edges.

\section{Subfamily. CYSTIPHYLLIN E. See page 29. \\ Genus. STREPHODES. See page 29.}

\section{Strepiodes multhamellatum $\left(M I^{c} \mathrm{Coy}\right)$. Pl. 3. C. fig. 3. \\ Ref.-M Mc Coy, Ann. Nat. Hist. 2nd Series, Vol. III. p. 5.}

$S p . C h$.-Elongate conic, very gradually tapering (generally about five inches long, with a diameter of about one and half inch at the termination); terminal cell oblique, oval, the short axis about one-fifth less than the long; surface regularly girt at about every quarter of an inch with slightly oblique, strong, cup-shaped rims of growth, coneave above, and produced by the successive growths from the centre leaving the prominent edges of the previous cells; weathered surface finely striated by the edges of the vertical lamellie, of which there are about twelve in a quarter of an inch; the horizontal oral section shews the centre to be eccentrie, close to one of the broad sides, and formed by the slight twisting or complication of the radiating lamella about an imaginary axis; radiating lamellie very thin, of equal thickness, from one hundred to a hundred and thirty at the margin, some stopping and some uniting as they approach the centre, in parcels; all the lamellae connected throughout at regular intervals by minute transverse vesicular plates; internal structure exposed by horizontal and vertical sections uniformly and minutely cellular.

The great number and closeness of the lamellæ distinguish this species from those published forms allied to it.

Position and Locality.-Rare in the lower carboniferous limestone of Arnside, Kendal (and Lisardrea, Boyle, co. Roscommon, Ireland).

Explanation of Figures.-Pl. 3. C. fig. 3. Natural size, from Arnside (the top has been ground more nearly at right angles to the axis than the true opening of the cup, which latter is indicated by the direction of the rings of growth).-Fig. $3 \alpha$. Do. Horizontal section magnified one-third linear.

\section{Genus. CLISIOPHYLLUM. See page 33.}

\section{Clisiophylum bipartitum $\left(\boldsymbol{M}^{c} \mathrm{Coy}\right)$. Pl. 3. C. fig. 6. \\ Ref. $-\mathrm{M}^{\mathrm{c} C o y}$, Ann. Nat. Hist. 2nd Series, Vol. III. p. 2.}

Sp. Ch.-Very elongate conic, nearly cylindrical, with a diameter of one and a quarter inch for the greater part of its length; strongly and regularly striated externally (about five strix in one fourth of an inch); external stria corresponding in number to the radiating lamelle; in the transverse rough section the central area is rather more than one-third the whole diameter, composed of the edges of confusedly blended vesicular plates, crossed by a few faint extensions of the radiating lamelle, and divided into two symmetrical portions by a strong median fissure; the space between this inner area and the outer wall is narrow and regularly radiated with about fifty-eight equal, thin, rather distant lamellic, connected by numerous delicate, transverse vesicular plates; between each pair at the circunference, a shorter radiating lamella occurs, which only reaches half way to the axis, and where they occur, the connecting vesieular plates are smaller and more numerous than from thence to the axis, the intermediate open cellular space less than the outer one in width; rertical section indistinctly tri-areal; outer area defined, about one-sixth of the width on each 
side, composed of small, much-curved, vesicular plates, forming minute semicircular cells, arranged in very oblique rows upwards and outwards, about seven in a row; middle zone rather less than the outer one in width, passing gradually into the central structure, formed of few larger and less-curved vesicular plates than the outer zone, and having a nearly horizontal direction, one or one and half reaching across the space; central area composed of large, thin, close, little-curved, vesicular plates, forming a strongly arched series of narrow, elongate cells, the convexity of the arch upwards conforming to the shape of the central boss in the cup. If the vertical section be at right angles to the medial fissure or crest of the central boss, there is a line visible down the middle of the section: terminal cup deep, lined by the vertical lamellæ, and having a large oval prominent boss in the centre, traversed by a sharp mesial crest; about one-half or onethird of the radiating lamelle ascend the central boss, always in a direct line, those at the sides of the mesial crest being at right angles to it, the others joining at a more acute angle as they approach the extremity; and opposite one end of the crest we generally observe one or two of the radiating lamellæ shorter than the rest, producing a sort of siphon-like irregularity, such as we see in Caninia.

This coral nearly equals the Caninic giganted (Mich.) in size and cylindrical form, but is easily distinguished by the strong longitudinal strixe of the surface, the want of transverse septa in the central area, Sc. The young reach a diameter of nine lines at about ten lines from the apex, and at this diameter there are about six lamellæ in the space of three lines; dwarf specimens, not exceeding this size are common in the black carboniferous shale of Beith, Ayrshire, shewing the axis rather more than half the diameter, the narrow horizontal-celled zone, and the outer zone as in the larger examples.

Position and Locality.-Rather common in the carboniferous limestone of Derbyshire; shale of Beith, Ayrshire.

Explanation of Figures.-Pl. 3. C. fig. 6. Young stem natural size, retaining a few patches of the external epitheca, and shewing the shape of the terminal cup (the medial erest on the boss not distinctly seen in this view).-Fig. $6 a$. Do. Horizontal and vertical sections natural size.

\section{Chistophyllum Keyserlingi ( $\mathbf{M}^{c}$ Coy). Pl. 3. C. fig. 4.}

$$
\text { Ref.-M } \mathbf{M}^{\mathrm{c}} \mathrm{Coy}, \text { Ann. Nat. Hist. 2nd Series, Vol. III. p. } 2 .
$$

Sp. Ch.-Conical, slightly curved, terminal cell oblique, one inch two lines in diameter in a specimen three inches long; surface finely striated longitudinally (about eight strix in one-fourth of an inch); about fifty-one thin, equal lamellæ, descend straight into the deep part of the terminal star, and there abruptly twisted spirally about an imaginary axis, forming a prominent conical centre about one-third the diameter of the cup, and as high as its base is wide; between ench pair of long lamellie is a very short flexuous marginal one (about one line long); horizontal section shews a very narrow external zone of minute vesicular structure, extending as far as the short lamella, the central area seems a confused, close, crumpling of vesicular plates, occupying rather more than one-third the whole diameter, and from it to the circumference, the strong, equal, rather distant plates, radiate with a slight curve.

This highly typical species of Mr Dana's American genus Clisiophyllem is closely allied to the Cyathophylhm coniseptum of Count Keyserling's "W issenschaftliche Beolsachtungen auf einer Reise in das Petschora-Land," from which it is distinguished by the strong twisting of the plates about the central cone, and by having little more than half the number of lamelle at the same diameter. Viewing with Mr Dana the conical arrangement of the septa as a generic instead of specific character, it seens probable that the two varieties given by Count Keyserling, of his Cyathophylluin coniseptum, are really two species; and the present species, though presenting some intermediate characters, is, I think, distinet; if hereafter any one should think otherwise, they still could hardly object to the name I have proposed in honour of so enterprising a geologist; the more so as the term coniscptume would not be applicable as a specifie name in the genus Clisiophyllum, where all have the conical arrangement of septa alluded to. There can, however, I think, be little doubt of the distinctness of the species. 
Position and Locality.-Rare in the carboniferous limestone of Derbyshire.

Explanation of Figures.-Pl. 3. C. fig. 4. Natural size, shewing the thin external wall or epitheca in parts, absent in others.-Fig. $4 a$. Horizontal section, natural size.

\section{Chisiophyludi multiplex (Keyserl. Sp.)}

Syn. and Ref.-Cyathophyllum, id. Keyserling, Reise in das Petschora-Land, t. 2. f. 1.

$S p$. Ch.-Corallum forming slightly curved and compressed short, broad, conical individuals, rugged with deep, obtuse, concentric rings of growth; about one inch nine lines in diameter, at one inch three lines from the base; large examples three and half inches long, and two inches in the long diameter, and one inch five lines in the short diameter of the cup, one of the broad sides of which is slightly higher than the other; terminal cup shallow, with a wide slightly sloping outer margin, and a flattened base, from near the centre of which is an elongate, lateral, siphonal depression; radiating lamella of alternate length, very delicate, about one lundred and seventy, at one and half inch in diameter, meeting in the centre, their edges set, with perforated papillie; external lamellar strie about five in two lines; vertical section, shewing a nearly uniform, very minute, vesicular structure, the outer area rather more than one-fourth of the diameter, having the rows of small, very numerous, elongate, rounded cells, extending obliquely upwards and outwards, with a slight reversal or deflection of the curve close to the outer wall (corresponding with the form of the outer area of the cup); inner area nearly half the diameter of the coral, the rows of cells taking an M-shaped double upward curve; about eight or nine cells in the space of two lines, either in the inner or outer area, measured at right angles to the direction of the rows.

The British specimens increasing more rapidly in proportion to their height than the foreign species, to which I refer them, is the only difference I see, and as the coincidence is so exact in other external characters, and in those of the vertical section, I think it best to note it only as a distinct variety at present, with a name which can be considered specific at any time, if necessary. When the shorter diameter is compared with the length, the difference between the two varieties seems in this respect very trifling.

Position and Locality.-Not uncommon in the carboniferous limestone of Kendal, Westmoreland.

\section{Clistophyllum prolapsum ( $\boldsymbol{I}^{\mathrm{C}} \mathrm{Coy}$ ). Pl. 3. C. fig. 5.}

$$
\text { Ref.-M } \mathrm{I}^{\mathrm{c}} \mathrm{Coy}, \text { Ann. Nat. Hist. 2nd Series, Vol. III. p. } 3 .
$$

Sp. Cl._-Elongate conic, much curved and twisted on its axis; terminal cell oblique, deep, with stcep sides, a narrow flattened or concave space at bottom, from which protrudes the central boss, which is about one-third the diameter of the cup, nearly as high as wide, cylindrical, obtusely rounded alove, and with a deep umbilical cavity in the middle (in partially decomposed or weathered specimens, a rough vertical fracture frequently shews the central area or axis as a thick, smooth, persistent tube); diameter of the adult little more than an inch, and which it attains at two inches long, remaining nearly cylindrical after that length; surface closely striated longitudinally, about fourteen strie in one-fourth of an inch, when slightly rubbed so as to shew both sets of lamelle, or half that more usually, when the large ones only are seen: horizontal section, inner area rather more than one-third the diameter, of small, closely blended, vesicular plates, defined by a thick circular line; outer area with 160 radiating lamellic (in a large specimen one inch four lines in diameter), half of which reach from the wall to the edge of the inner area, and the intermediate ones only reach half way; transverse vesicular plates very delicate, about five rows of very small ones in the space occupied by the short lamelle, ferrer in the intervening space from thence to the axis: vertical section, inner area defined by rather thick walls; it consists of minute, compressed, elongate cells, arranged in very numerous, transverse, curved rows, the convexity of the curve upwards; outer area narrow, of minute cellular structure, inclining upwards and outwards, about five cells in a row; middle area of much larger, and less inclined, vesicular structure, three to four cells in a row.

This species forms the type of the genus Aulopleyllum of MM. Milne Edwards and Haime, from the definite tubular boundary to the inner area or axis; this however is merely a question of degree, scring 
to distinguish a well-marked species, but scarcely applicable as grounds of generic division, for this inner area or axis is more or less defined in all, and different parts or ages of the same specimen shew variation in this respect.

Position and Locality.-Rather common in the carboniferous limestone of Derbyshire. Var. a minor, a single dwarfed specimen from the impure carboniferous limestone of Lowick, Northumberland, shewing 110 lamellæ at nine lines in diameter, and about ten external strix in three lines. In this specimen the tubular perforation of the lamellie, parallel with their sides, is clearly seen, and also a branch-like union of the short, with the long lamella, in part. The same small variety is common in the black carboniferous limestone of Beith, Ayrshire, often shewing a strong wall between the middle and outer areas, and having about eighty-two lamellæ at a diameter of seven lines, and also a slight siphonal irregularity.

Explanation of Figures.-PI. 3. C. fig. 5. Natural size, shewing the form of the terminal cup, and projecting base of the inner area, and in the lower part an accidental fracture shews the inner area as a persistent tube.-Fig. 5 a. Do. Horizontal and vertical magnified two diameters, shewing the strong wall to the inner area.

\section{Clisiophyllum tulbinatum $(M c$ Coy $)$. Page 88 , figs. $a, b, c$. Ref.-M $\mathbf{M}^{\mathrm{c}} \mathrm{Coy}$, Ann. Nat. Hist. 2nd Series, Vol. VII.}

Sp. Ch._-Corallum simple, turbinate, very rapidly enlarging, attaining the adult diameter of about one and a half inches at two inches from the point of attachment; surface of the strong external wali, or epitheca, marked by coarse, numerous, imbricating, transverse strix, and a few larger inequalities of growth, (no distinct longitudinal strix, except where abraded); horizontal section, central area, or axis, nearly equalling one-laalf the diameter of the coral, composed of a close crumpling of fine vesicular plates, crossed by a few radiating irregular extensions of every th or 5th of the radiating lamellac, one of which, stronger than the rest, is usually seen to cross the middle (forming a thick mesial line in the vertical section, and a prominent crest in the cup); lamelliferous area rather less than one-third of the whole diameter, radiated by about fifty-four strong equal lamellie (at a diameter of one inch), connected by numerous delicate transverse vesicular plates; four lamella in the space of two lines, near the margin; onter or perithecal area less than one-fourth the width of the lamelliferous zone, from which it is separated by a thin definite boundary; it is composed of about two obscure rows of small, compressed, cells, more or less crossed by costal extensions of the lamella: vertical section shews a strong solid line down the middle of the axis, or inner area, a thinner solid line defining the axis on each side, and a similar one between the middle and external areas; external area very narrow, of about two rows of minute cells; middle area of about three rows of large rhomboidal cells, formed of thin, moderately-curved vesicular plates, converging upwards and inwards, at a low angle; inner area composed on each side of about three rows of cells, converging upwards to the mesial line, much smaller, and more compressed than those of the middle area; terminal cip' of moderate depth, lined by the thick, equal, radiating lamella, the axis forming a moderately pro. minent boss in the bottom, crossed by a small prominent crestiform plate.

This is easily distinguished from the other known species by fits short, rapidly expanding, turbinate form; it resembles the $C$. bipartitum in the crest-like median plate on the boss, or central area (axis), but differs in having the axis much smaller, the middle area much larger, the perithecal area smaller, and fewer lamellac, besides the difference in shape. The $C$. Keyserlingi, like the last species, has short secondary lamellac between the larger ones; it also differs in its very slender form, and wants the crest across the axial boss in the cup, but is otherwise nearly allied, although very distinct as a species.

Position and Locality. - Common in the carboniferous limestone of Beith, Ayrshire; rare in the carboniferous limestone of Derbyshire.

Explanation of Figurs.- - a. Old specimen, natural size, shewing the imbricating interruptions of growth, and costal edges of lamella in the worn upper portion; $b$. horizontal section, natural size, shewing the large, partially-radiated vesicular tissue of the inner or axal area, the equal lamella in the middle area, and the very narrow unequally developed outer, or perithecal zone; $c$. vertical section, and form of terminal cup, natural size of small specinen, shewing the proportions and directions of the cells of the three areas, and the solid defining lines of each, as well as the section of the mesial crest of the axis. 


\section{Subfamily. NEMATOPHYLLINE. See page 33. Genus. NEMATOPHYLLUM ( $\left.\mathrm{I}^{c} \mathrm{Coy}\right)$.

\author{
Ref.-M다, Ann. Nat. Hist. 2nd Series, Vol. III. p. 15.
}

Gen. Char:-Curallum composed of numerous, inseparably united, polygonal, prismatic tubes, each having a straight, thin, flat, fillet-like solid, or nearly solid, axis, from which, in the horizontul scrtion, the fine numerous radiating lamellic are seen extending directly to the walls; radiating lamelle connected by very fine transverse dissepiments, only visible externally in the outer area : vertical sction shews three distinct areas: first, the thin flat axis; second, a sharply defined cylinder of small vesicular arched plates, the rows directed from the axis obliquely downwards and outwards; outside this is the third area of similar small arehed plates, forming a minutely vesicular structure, slightly smaller than that of the inner zone, but the rows direeted obliquely upwards and outwards; reproduction by small circular buds, developed within the area of the parent star.

In mode of reproduction and tri-areal structure this genus approaches Strombod's (as above understood), from which it differs altogether in the nature of the axis, which in all the species of that genus is cylindrical, composed of numerous plates variously twisted together, and giving a cellulose section in every direction, but, on the contrary, forms a thin, flat, simply solid lamina in the present group, and is exhibited in a vertical fracture, either as a narrow oparque white line, or as a broad ribbon.like fillet, according to whether the section is in the direction of its width or across it. A further difierence is constantly observalble between these groups in the vertical section, which is, that the interstitial vesicular plates of the inner area in Strombodes have their rows either nearly horizontal, or inclining obliquely upwards from the axis towards the outer wall, while in Nematophyllmm, on the contrary, they converge towards the axis above and incline downwards and outwards below, so as usually to meet at a considerable angle those of the outer area which incline in the usual direction upwards and outwards towards the walls. This peculiarity in the inclination of the interstitial vesicular plates of the inner area produces a marked difference in the stars on the weathered surface in the two genera, causing the inner area to form a large prominent oval or conical boss in Nematophyllum, and a flat or deeply-hollowed cup in stromboles. A third difference between these generic groups is, that in the latter, the vertical radiating lamellix are principaily confined to the inner area, not existing in most of the species at all in the outer area, and do not reach the walls; while, on the contrary, all the radiating lamella in Nomatoplyyllum arise from the outer walls, are strongest in the outer area, and only half of them in general penetrate the inner area. In the latter corals also, the whole vesicular structure is much more minute and delicate in stems of the same size than in the others, and the cells of the inner area are larger than those of the outer, which is the reverse of what we find in Strombodes. As the young columns are produced from circular buds continuing their development within the walls of the parent, it results that the stems are inseparably united; the walls defining the stars being one simple plate, the joint production of the adjacent polypes, cannot be divided, and consequently, vertical fractures of the mass, instead of exposing the flat striated external surface of the stems, pass invariably through the substance of the coral itself, exposing only sections of the interior; the external walls being only seen in those rare cases shewing the extreme limits of a mass, or where in a section two masses may have coalesced. Some of the species resemble Clisioplyyllum, but are distinguished by the peculiar axis, and by the cells of the inner area being larger and fewer than those of the outer. The genus is, I believe, exclusively Palrozoic.

\section{Nematophyllum arachnoideum ( $\left.M \Gamma^{c} \mathrm{Coy}\right)$. Pl. 3. A. fig. 6.}

\section{Ref.-MIc Coy, Ann. Nat. Hist. 2nd Series, Vol. III. p. 16.}

Sp. Ch. - Stars with from four to seven angles, and averaging from six to nine lines in diameter; axis very thin, one line wide; vertical section, inner vesicular area wider than the outer, of little-arched plates inclining slightly downwards from the axis; it takes about two (rarely one) of those plates to reach from 
the axis to the extent of this area, or two irregularly elongate unequal cells in a slightly oblique line from the axis to the wall of the inner area; outer area separated from the inner by a sharp distinct line on each side, and composed of much smaller and more highly curved resicular plates, so that there are from five to seven small, nearly equal, rounded cells, extending in a line obliquely upwards and outwards from the inner area to the outer walls of the tube; horizontal section, boundary or divisional walls thin, stars radiated with from fifty to fifty-five very thin lamellæ, of equal thickness, but alternately long and short, the long reaching to the centre, the short barely entering the edge of the inner area; weathered surfece, stars flattened, separated by a depressed line; inner area forming a gentle convex, oval, or circular boss, with the axis forming a short impressed line in the middle; the radiating lamellie exhibit numerous delicate curved interstitial plates in the outer area, but none in the inner area.

This beautifully delicate species is the largest of the genus I am acquainted with, the usual width of the stars being seven lines, diameter of the inner area about two and half lines. It very frequently exhibits the young oval buds within the corners of the old stars, generally but one, very rarely two in a star.

Position and Locality.-Forms large masses in the carboniferous limestone of Derbyshire.

Explanation of Figures.-Pl, 3. A. fig. 6. Part of mass, natural size, from Derbyshire, shewing the weathered appearance of the stars (the impressed lines being the sites of the original coral which wore faster than the matrix); several of the stars shew young buds within their lengthened corners. - Fig. $6 \alpha$. Do. Horizontal section of one star magnified two diameters, shewing the central axis, and the circular germ of a young individual within the area of the parent.-Fig. $6 b$. Do. Vertical section magnified three diameters of one column and part of a second, to shew the thick solid divisional wall between them, the thick central axis, the broad transversely septate inner area, and broad vesicular outer one.

\section{Nematoriyllum Clisioides $\left(M^{\circ} \mathrm{Coy}\right)$. Pl. 3. B. fig. 2.}

\section{Ref.-McCoy, Ann. Nat. Hist. 2nd Series, Vol. III. p. 18.}

Sp. Ch.-Stars generally hexagonal, and averaging two lines in diameter : wcothered surfuce, stars defined by a rather thick, prominent, crenulated divisional wall; outer area inclined downwards and inwards to form a shallow eup, in the middle of which the inner area rises into a conical tent like boss, having the small flattened axis in the centre; horizontal section, divisional lines of the stars thin, straight; axis thin, half a line wide; radiating lamelle thirty-six, thin, one-half extending in a flexuous manner from the walls to the centre, the intervening ones also flexuous but of irregular lengths, most of them reaching half-way; tranverse vesicular plates about two rows only at the circumference, few and delicate, if visible at all; vcrticul section, axis as in the other species; inner area very wide, of large, little-curved vesicular plates, inclining obliquely downwards and outwards; one or two (or most commonly one and half) lengthened irregular cells reach from the axis to the outer area; outer area very narrow, of small, much-curved vesicular plates, inclining very obliquely upwards and outwards, forming minute rounded cells about two in a row.

This species unch resembles some of the massive Astræoid Clisiophyllioe of Dana, by the conical tent-like aspect of the immer area within the cups or weathered terminal cells; the distinct flattened axis, resembling that of the other Nematophylla, will however distinguish it. The flexuous character of the radiating lamellæ in the transverse polished section is remarkable. The Astrece imeguluris of Portlock's Report on Londondery, \&c. which I know to be a true Nematophyllum, resembles this species in the small size of the stars and flexuous lamelle, but is easily distinguished by the cells being simply cup-shaped, descending uninterruptedly from the walls to the small, flat, prominent axis in the bottom of the cup, instead of the large tent-like boss formed by the inner zone of the above species.

Position and Locality.-Forms irregular, tuberose masses in the carboniferous limestone of Derbyshire.

Explanation of Figures.-Pl. 3. B. fig. 2. Natural size, shewing the form of the terminal stars.Fig. 2a. Do. Vertical section magnified three diameters, shewing the solid axis and the characters of the outer and inner areas, and giving the profile of the terminal star at top, shewing the narrow, steep, outer area, the wide tent-shaped inner area and the projecting axis.-Fig. 2 $b$. Do. Horizontal section 
of one star magnified three diameters, shewing the flat axis, the flexuous radiating lamelli, and the few rows of vesicular plates of the outer area.

\title{
Nematophyllum decipiens $\left(M^{c}\right.$ Coy $)$. Not figured.
}

\author{
Ref.- $\mathrm{M}^{\mathrm{e}} \mathrm{Coy}, \mathrm{Ann}$. Nat. Hist. 2nd Series, Vol. III. p. 18.
}

Sp.Ch.-Weathered surface having the stars undefined, the lamelle of the outer area of adjoining cells appearing continuous, and forming a flat surface, in which the inner area of each star forms a decp cylindrical cell one and lialf lines in diameter, and about their own diameter apart; in the bottom of these cells the lamella rise to form a little cone, from the apex of which projects (when well preserved) the long thin flat axis, rising to the level of the outer area; on the polished transverse section the stars are perfectly defined by distinct walls, four to six-angled, two to three lines in diameter, with a flat central axis half a line wide, and shew the circular germs of young columns in the corners of some of the old stars; radiating lamelle thin, about thirty-four, of equal thickness, one-half reaching the centre, the other barely touching the inner area, which forms a circle about one and half lines in diameter; the radiating plates are connected by numerous curved resicular plates in the outer area, but few or none are visible in the inner area; wertical sertion, axis thin, solid; inner area of small, curved, resicular plates, extending obliquely downwards and outwards from the axis, about two or three cells in a row ; outer area separated from the inner by a thin vertical line, it is composed of small curved resicular plates, in rows inclining obliquely upwards and outwards, about four cells in a row.

The flat broad spaces between the cups, the seeming continuity of the radiating lamelle of adjoining stars, and the apparent want of divisional walls hetween these latter, give the weathered surface of this coral much the aspect of the so called Astroxa Hennati (Lonsd.) of the Devonian rocks; but it is clearly distinguished by the divisional walls appearing distinctly in the horizontal sections, and by the flat, nearly solid axis, which is very obvious both in the polished section and weathered stars.

Position and Locality.-Not uncommon in the carboniferous limestone of Derbyshire.

\section{Nematophyllum minus $\left(M^{c} \mathrm{Coy}\right)$. Pl. $3 . \mathrm{B}$. fig. 3. \\ Ref.-M[Coy, Ann. Nat. Hist. 2nd Series, Vol. III. p. 17.}

Sp. Ch.-Stars having from four to seven angles, and averaging from three to four lines in diameter; axis thin, about three-fourths of a line wide; vertical section, inner area slightly wider than the outer on each side, composed of but slightly-curved resicular plates extending obliquely downwards and outwards, each one nearly reaching from the axis to the external boundary of the inner area, forming thus but one or two elongate cells in each oblique row between these points; outer area of much smaller and more curved plates, forming smaller, more regular and rounded cells, disposed in indistinet rows obliquely upwards and outwards, about four in a row from the inner area to the outer wall; weathered surface, stars nearly flat, inner area forming a large convex oval or circular boss in the middle of the star, and having the axis in the centre; horizontal section, axis, and forty-five to fifty-three, thin, radiating lamellæ, of equal thickness, one lalf of them reaching the centre, the intermediate ones entering but a short way into the inner zone; numerous small, curved, interstitial plates between the lamelle in the outer zone, (four or five rows), not visible in the inner one.

In all our weathered specimens the solid axis and divisional walls appear sunk below the level of the rest of the star, giving the idea that the mineral matter of the matrix having at first penetrated the vesicular tissues of the more delicate parts of the star, tended to their ultimate preservation, while the originally thicker portions of solid coral, being now unprotected, decay more rapidly.

This species is allied to the $\mathrm{N}$. arachnoideum ( $\mathrm{II}^{\circ} \mathrm{Coy}$ ), but is constantly distinguished by the smaller size of the stars, lamellæ, and more open internal vesicular structure. 
Position and Locality.-Forms large depressed, convex masses, ten inches or more in diameter, in the carboniferous limestone of Kendal.

Explanation of Fiqures.-Pl. 3. B. fig. 3. Portion of large mass, natural size, shewing the weathered terminal stars (a peculiarity of weathering, shewing the solid walls and axis as impressed lines), the very slight convexity of the inner and outer areas, and the oceasional circular young buds developed in the corners of some of the stars.-Fig. $3 \alpha$. Do. Vertical section magnified three diameters, shewing the characters of the axis and the vesicular plates of both areas, together with the supposed original form of the star deduced from the direction of the vesicular plates of both areas.-Fig. 3b. Do. Horizontal section magnified three diameters.

\section{Genus. STYLAXIS $\left(M^{c} C o y\right)$.}

\section{Ref.-McCoy, Ann. Nat. Hist. 2nd Series, Vol. III. p. 119.}

Gen. Char:-Corallum composed of adjacent polygonal prismatic, easily separable tubes, internally divided into three areas: vertical section, first, a thin, flat, straight axis; second, a broad inner area, composed of numerous curved vesicular plates in irregular rows, converging upwards to the axis; third, an outer area on each side, composed of smaller and more curved vesicular plates, in rows inclining obliquely upwards and outwards: horizontal section, displaying the central flat axis, surrounded by radiating lamellie extending from the walls, and connected in the outer area by numerous transverse vesicular plates: additional columns, produced by a bipartite division of the parent stem, parallel to one of its faces: polyps distinctly separated above.

The corals of this genus bear precisely the same relation to Nematophyllum that Stylastrea (Lonsd.) does to Lithostrotion of the same writer (Strombodes), with regard to their mode of development, that is to say, in Nematophyllum, as in Strombodes, the increase is by circular buds developed within the walls of the parent stem, the polygonal walls being gradually perfected by the joint labour of adjacent polyps, which it is inferred from their mode of growth had a community of existence and organic union at the surface, and from the same cause the columns have no outer surface to exhibit in a rough fracture, but break through the middle rather than separate one from another. In the Stylaxis, however, as in the Stylastrea, the new columns are produced by a sudden splitting of one of the columns into two, the divisional lines commencing along the middle of one face and going directly across to the opposite face, distinctly separating the young foursided column at once by a double plated, rectilinear boundary-ivall, parallel with one of the faces; the external strix of the old column being traceable upwards into the young one which may probably be viewed as a compressed branch from a lateral bud. The columns are easily separable one from another in the rough fracture, and the polyps are inferred to have been distinct from each other, and each to have constructed independently its own boundary-wall.

Stylaxis Flemingit $\left(\boldsymbol{I}^{c} \mathrm{Coy}\right)$. Pl. 3. A. fig. 3.

Ref.-M당, Ann. Nat. Hist. 2nd Series, Vol. III. p. 121.

Sp.Ch.-Corallum of very long, prismatic, generally hexagonal, easily separable tubes, averaging three lines in diameter; outer surface strongly striated longitudinally, and marked with direct transverse rugosities of growth; bipartite division of the columns frequent; vertical section, exhibiting the thin flat axis, surrounded by an inner zone of small, slightly curved, interstitial plates, inclining downwards and outwards from the axis, forming on each side a row of nearly simple oblique cells; outer zone of small vesicular, much curved plates, inclined in an opposite direction, or upwards and outwards, four or five in a row: horizontal section, axis thin, half a line wide, surrounded by about forty-three thin, radiating lamelle from the walls, half of which only reach half way; numerous small, thin, transverse, connecting plates between the lamellie in the outer zone.

The bipartite mode of division of the column is frequently and easily observed in this species, which commonly forms large masses. It greatly resembles, externally, the Stylastrace basaltiformis, but is easily 
distinguished by the small, but distinct, central axis visible in the transverse fracture, and further by the different disposition of the lamella of the inner zone. The small size of the tubes, and less number of lamellix, distinguish it from the Stylaxis major.

This is probably the Lithostrotion striatum of Fleming (Brit. Anim.), as he particularly says, "the rays of the star unite with a small solid central axis;" I think, however, with Mr Lonsdale, that he is wrong in his references. I have, with great pleasure, dedicated the species to so admirable a naturalist, the extraordinary merit of whose writings on the British marine animals is well known to all who engage in the same laborious and difficult study.

Position and Locality.-Common in the carboniferous limestone of Derbyshire.

Explanation of Figures.-Pl. 3. A. fig. 3. Portion of mass, natural size, from Derbyshire-Fig. 3 a. Do. Horizontal section magnified three diameters, shewing the central axis and inner and outer area.Fig. 3 $b$. Do. Vertical section magnified three diameters, shewing the central axis, the nearly simple inner area, and resicular outer area; and the top giving a portion of horizontal section, sherving the relation of the two views.

\section{Stylaxis inregularis $\left(M^{\circ}\right.$ Coy $)$. Pl. 3. A. fig. 5.}

\section{Ref. and Syn._Stylastraca irregularis $\mathbf{M}^{\mathrm{C}} \mathrm{Coy}$, Ann. Nat. Hist. 2nd Series, Vol. III. p. 9.}

$S p . C h$-Corallum of polygonal five or six-angled tubes two lines in diameter, of such twisted and irregular upward growth that a vertical fracture frequently exposes a mixed appearance of outer walls and internal sections; outer surface longitudinally striated and transversely wrinkled by waves of growth; certical section, inner area broad, regularly septate by nearly straight, equal, thick, transwerse plates; outer area very narrow, composed of much-curved vesicular plates, forming rather open rounded cells, in rows obliquely upwards and outwards, two or three in a row; horizontal section, central area smooth, surrounded by about thirty slightly flexuous radiating lamella from the walls, fifteen of which are much shorter than the others; near the walls the radiating lamellæe are connected by few, thick, vesicular plates.

This species is remarkable for the peculiar, irregularly twisted, mode of growth of the columns, which, when the rock is compact, gives the mixed character to the fracture, seemingly between that of Lithostrotion (Strombutes) and Syylastred. It is also remarkable for the nearly perfect transverse chambering of the central area. The small diameter of the tubes and few lamellæe easily distinguish it from the other allied species.

Position and Locality.-Forms small masses in the carboniferous limestone of Derbyshire.

Explanation of Figures.-Pl. 3. A. fig. 5. Portion of mass natural size from Derbyshire, shewing the very irregular mode of growth.-Fig. $5 \alpha$. Horizontal section magnified six diameters, shewing the central axis and irregularly anastomosing lamellie.-Fig. 56 . Tertical section magnified four diameters, shewing the central axis on the right, and part of the left column, the broad, transversely septate inner area, and narrow outer vesicular area, upper part of the left-hand column shewing a partially weathered section.

\section{Stylaxis major $\left(M^{\circ}\right.$ Coy). Pl. 3. A. fig. 4.}

$$
\text { Ref.--MCoy, Ann. Nat. Hist. 2nd Series, Vol. III. p. } 120 .
$$

$S p . C h$. T Tubes averaging six lines in diameter, mostly hexagonal, external surface coarsely striated longitudinally, and transversely marked with strong curved irregularities of growth, the convexity of the curves upwards: howizontal section, sixty-three slender radiating lamellie converging from the walls towards the flat central style or axis, which is about one line in width; one half of the lamellæ reach the centre, the intervening ones reach rather more than half way; outer area exhibiting numerous transverse vesicular plates between the radiating lamellie. Tertical section, axis straight, ribbon like, inner area broad, of slightly-curred vesicular plates, forming rows of lengthened irregular cells, extending obliquely downwards and outwards from the axis, about three in a row; outer area of rows of small, hemispherically-curved 
plates, including small rounded cells extending very obliquely upwards and outwards, about five or six in each row.

This species is remarkable for the large size of its tubes and great number of the radiating lamelli.

Position and Lacality.-From the carboniferous limestone of Derbyshire.

Explanation of Figures.-Pl. 3. A. fig. 4. Natural size from Derbyshire, shewing near base the mode of division of certain faces of a column to form a young individual.-Fig. $4 a$. Do. Horizontal section magnified three diameters, shewing the axis and inner and outer areas.-Fig. 4b. Do. Vertical section, magnified three diameters, shewing the central axis, complex inner area, and vesicular outer area; at top a portion of horizontal section, shewing the relation of these appearances.

\title{
Genus. STROMBODES. See page 34.
}

\section{Strombodes conaxis $\left(M^{\circ} \mathrm{C}\right.$ oy $)$. Pl. 3. B. fig. 4.}

\author{
Ref.- Mc Coy, Ann. Nat. Hist. 2nd Series, Vol. III. p. 10.
}

S\%. Ch.-Columns irregularly aggregated, averaging half an inch in width, mostly hexagonal; axis elliptical, formed of a series of closely superposed conical plates, connected by a few fine vertical lamellic; vertical section, the outer area formed of broad, curved, slightly inclined plates, two rows between the wall and inner area; between this and the inner area there is a fine vertical defining line; inner area, very open cellular structure, of slightly curved, rather distant vesicular plates, which are nearly horizontal near the outer zone, but within seem gradually to bend up and become continuous with the close conical cuplike plates forming the axis; these latter seem connected by extremely delicate, irregular, radiating plates. Horizontul scction, axis oval, of close irregular concentric lines, connected by few delicate radiating ones; lamelliferous zone surrounding the axis, of about forty-two to forty-six alternately broad and rudimentary lamellix, supported by a double circle of interstitial plates at the circumference, with an outward curve; outer zone wide, formed of large arehed plates forming a loosely vesicular structure, the convexity of the curve inwards. Terminal star, axis very prominent, oval, vertically ribbed, but not twisted, seated in a deep oval or circular cup, lined by the strong radiating lamelle; outer zone nearly flat, oblique at the sides, faintly marked with rather distant, fine lines, representing probably a membranous extension of the strong radiating lamelle of the inner zone to the boundaries of the cells, which are strong, prominent, and slightly crenulated.

In a rough transverse section the axis appears as a deep conical hollow on the under side. It will thus be seen that in the remarkable cone-in-cone structure of the axis this resembles the Russian stiomliode: mamillare and S. astroides (Lithostrotion id. of Lonsdale), from both of which it differs in the axis not being twisted in the terminal star, in the outer zone not being traversed by strong radiating costal lamellx, from the former in the much less obliquity of the plates of the outer area, as well as the distinctness of all the three areas under every circumstance. In general appearance and imperfect radiation of the outer area it resembles the S. cmarciatum and S. floriforme (Lithostrotion id. of Lonsdale), but is distinguished from the first by the rudimentary radiating lamella between the primary ones, and from both by the conical structure of the axis, which is formed in them of irregularly twisted vertical plates.

Position and Locality.-Not uncommon in the carboniferous limestone near Bakewell, Derbyshire.

Explanation of Figures.-Pl. 3. B. fig. 4. Portion of large mass natural size, shewing the appearance of the weathered terminal cups, with the projecting conical axis-Fig. $4 \alpha$. Do. Vertical section, the upper half polished, shewing the two rows of large cells of the outer area, the large, nearly simple, and horizontal cells of the inner area, and the fine, close, upward-curved lines representing the scetions of the conical plates of the axis, with the few irregular connecting filaments; the upper end gives a profile of the terminal cup. The lower half is a rough section, shewing the separate cones of the axis entering into each other.-Fig. 4 $b$. Do. Horizontal section shewing the axis, the lamelliferous cylinder bounded by a double circle of small plates and the large vesicular structure of the outer area. 


\section{Strombodes emarciatum (Lonsd. Sp.)}

Syn. and Ref.-Lithostrotion id. Lonsd. Geol. Russ. p. 603.

Sip. Ch. - Corallum forming large masses of polygonal tubes, very unequal in size and shape, with an average diameter of about five lines, boundary walls strong, crenulated, vesicular perithecal zone of each star broad, not radiated by extensions of the lamella; circular inner lamelliferous area, or true cell-tule, usually three lines in diameter, radiated by about twenty-three, thick equal lamellæ, which reach the central axis; axis one line in diameter, composed of spirally complieated vesicular plates: horizontal section, boundary walls of the stars very thick, enclosing a broad, irregular, largely vesicular perithecal zone, not radiated by the lamellæ; lamellx thick, connected by very few transverse vesicular plates; axis of irregularly complicated sections of its component lamellie: wertical section, onter area composed of moderately inclined, arehed vesicular plates, extremely irregular in size and distribution, usually about three in a row; inner area composed of slightly curved vesicular plates, forming nearly horizontal irregular cells, one or two reaching from the onter area to the axis.

Easily distinguished from the S. floriforme by the unradiated outer area, \&c.

Position and Locality.-Rare in the carboniferous Limestone of Derbyshire.

\section{Strombodes Floniforme (Martin Sp.)}

Syn. and Ref.-E. Madreporites floriforme Martin, Pet. Derb. t. 43. fig. 3. and t. 44. f. 5. Lithostrotion floriforme Lonsd. Geol. Russ. p. 609.

$S_{1}$. Ch.-Corallum forming large, compound masses, of polygonal unequal cells, averaging five lines in diameter; boundary walls thick, prominent, crenulated, outer surface of the tules with obtuse costal stria, about five in two lines, rugged with large transverse inequalities of growth; terminal cups with the outer area slightly inclined, and strongly radiated by the costal extensions of about fifty radiating lamellie, half of which become slightly stronger in lining the very deep circular, central area, or cell-tube which is nearly three lines in diameter, from the centre of which projects the large cylindrical obtuse axis (about a line and half in diameter), rising nearly to the height of the boundary walls. Ferticul section shews the thick cylindrical axis, composed of spirally twisted lamine; inner area composed of slightly curved vesicular plates, forming small, nearly horizontal cells, one or two reaching from the axis to the boundary-wall of the area, which is very thick and strongly defined; outer area composed of highly inclined, slightly curved, vesicular plates, forming lengthened cells, extending obliquely upwards and outwards, one or two extending from the inner cell-tube to the strong epithecal wall of the individual: horizontal section, epithecal wall strong, boundary-wall of the circular lamelliferous tube strong; outer or perithecal area, irregularly vesicular, crossed by about fifty-two delicate costal prolongations of the radiating lamellie, twenty-six of which penetrate but a short way within the cell-tube, the other twenty-six increasing in thickness and reaching the axis, connected by few or no delicate vesicular plates; axis forming a confused circular mesh of the divided edges of its component laminæ.

Although the above diameter of the stars is the average one, I have yet seen occasional columns, nine lines in diameter. The radiation of the outer area and distinct secondary lamelle, easily distinguish this species from the Strombodes emarciatum.

Position and Locality.-Very common in the carboniferous limestone of Derbyshire; in the red carboniferous limestone of Bristol; and beautifully weathered in the pinkish carboniferous limestone of Chalk Quarry, near Rosley, Cumberland. 


\section{Genus. LONSDALEIA (McCoy).}

Iief.-Mc $\mathrm{I}^{\mathrm{C}} \mathrm{Cy}, \mathrm{Ann}$. Nat. Hist. 2nd Series, Vol. III. p. $11 \%$

Gen. Char.-Corallum composed of circular, tapering, proliferous stems, not laterally united, or polygonal from the mutual pressure of a crowded growth; internally composed of three areas; 1 st, a cylindrical, defined, complex axis composed of irregular blended plates; 2nd, a cylindrical defined area of strong, rertical, radiating lamellæ, connected by thin oblique transverse dissepiments; 3rd, largely cellular outer zone between the vertical lamellie and the external wall of the stem, composed of much curved vesicular plates extending obliquely upwards and outwards; outer walls of the tubes longitudinally striated and transversely rugose; reproduction by circular germs developed in the cellular outer zone, and springing at once obliquely without the area of the parent stem, which continues its growth uninterruptedly with the slender young stem projecting from one of the transverse rugosities of the external surface; the young stem seems at first only composed of the axis, and gradually acquires the inner lamelliferous and outer perithecal vesicular zones as it increases in size, the latter being widest in proportion in the adult individual.

The little known Erismatholites Madreporites duplicatus of Martin's 'Petrificata Derbiensia,' may be looked upon as the type of this genus, which I have dedicated to Mr Lonsdale. It will he seen from the above notice, to unite in itself the internal structure of Strombuels (Lithostrotion Lonsd.) with the external characters and mode of growth of Cyathophyllum (C. dianthus, \&c.)

\section{Lonsdaleia crassiconus $\left(\boldsymbol{M}^{c} \mathrm{Coy}\right)$. Pl. 3. B. fig. 5.}

\section{Ref.-MIC Coy, Ann. Nat. Hist. 2nd Series, Vol. III. p. 12.}

$S p . C h$. - Corallum forming groups of loosely connected masses of elongate-conical stems, averaging six to seven lines in diameter; surface with concentric wrinkles and coarse flexuous longitudinal strix; lateral branches rapidly expanding, conical, widening from their base at the rate of six lins in nine lines of length: horizontal section shews a central circular axis one and half lines in diameter of fine angulated concentric lines crossed by a few radiating ones; outside which is a circular area three lines in diameter, of about twenty-four vertical radiating lamellæ, with few or no connecting vesicular plates between them except one thick circle at the circumference; the outer area composed of irregular, curved vesicular plates, forming large irregular cellulose texture: certical section, the central axis of close delicate spirally and conically twisted laminx; the inner area of one row of distant, delicate, irregular, curved transverse plates forming very open cells; outer area defined from the inner by a line on each side representing the bounding circle of the inner area of the horizontal section, formed of loose irregular cellular tissue, of large, slightly eurved, vesicular plates, extending obliquely upwards and outwards, two in a row.

This species is much less irregularly wrinkled than the $L$. duplicato (Mart. sp.), forms shorter and more widely turbinated masses, and is distinguished externally at a glance by the lateral branches expanding rapidly from their point of attachment to a conical form, while in the $L$. duplicata the lateral branches retain their original small diameter for a great length (increasing at about the rate of four lines in three inches), and present a strange contrast to the parent stem, as is faithfully shewn in the rough figure of Martin.

* Since I published my paper above referred to, M. d'Orbigny has used the same name generically in his 'Prodiome, (p. 25), for the Porites inordinata of Lonsdale, without however defining the Genus, and only judging of the fossiLfrom the figure. Most of the discoveries in this work of $M$. d'Orbigny are dated 1847 for reasons given on p. xiil, but in accordance with the rules for nomenclature of the British Association for the Adrancement of Science, I have supposed their true date to be that of their publication, which seems to be 1850, for though the title-page bears 1849 the cover bears 1850 , and $\mathrm{my}$ bookseller could not obtain the work from the publisher till March, 1850. It must be delightful to M. d'Orbigny to see so many of his generie groups, determined in the privacy of his own study in $18+7$, coincide with those established by independent observers during the three years which succeded previous to making his own results known. 
Position and Locality...-In the red carboniferous limestone of Arnside, Kendal; also near Bakewell, Derbyshire, in the limestone of the same age.

Explanation of Figures.-Pl. 3. B. fig. 5.-Natural size, from Arnside, shewing the rapid increase of the young.-Fig. 5a. Do. Vertical section magnified three diameters, shewing the characters of the axis and the inner and outer areas, terminated by a horizontal section of half the tubes, shewing the relation of the characters exhibited in the two sections.-Fig. 5b. Do. Horizontal section magnified two diameters.

\title{
Lonsdaleia duplicata (Mart. Sp.)
}

\author{
Ref. and Sym.E. Madreporites duplicatus Martin, Pet. Derb. t. 30. f. 1, 2.
}

Sp. Ch.-C'orallum forming very large, lonsely aggregated masses of round, concentrically rugose branches, nearly in contact throughont, of very unequal diameter, and rate of increase, the young branches often less than two lines in diameter, at two inches long, others near the same part of the mass reaching nine lines in diameter, at three inches in length; average diameter of tubes eight lines; circular strong prominent boundary wall of the cell-tulse, four and half lines, containing about twenty-eight subequal radiating lamellx, reaching nearly, or quite, to the very large circular axis; axis nearly two lines in diameter; terminal cup, outer area convex, highly inclined, of large smooth vesicular plates, sometimes imperfectly radiated in parts by distant delicate costal prolongations of the radiating lamella; wall of the inner area, or cell-tube, very prominent, lined by the strong subequal radiating lamell ('; axis composed of irregularly complicated and spirally twisted vesicular plates : certical section composed of very large highly inclined curved vesicular plates in the outer area, two or three cells in a row ; axis of delieate irregularly complicated plates; intermediate narrow area of delicate, simple, distant, slightly curved transverse plates: horizontal section, outer area of very large vesicular tissue, with few or no radiating lines from the lamellæ; lamelliferous tube strongly defined, with its thick, equal lamellie, with fow or no connecting vesicular plates; axis defined, of fine irregularly blended tissue, usually with a strong central line; external surface of the strong epitheca with vertical obtuse costal ridges, five or six in two lines.

Position and Locality.-Common in the carboniferous limestone of Derbyshire.

\section{Lonsdaleia rugosa ( $M^{c}$ Coy $)$. Pl. 3. B. fig. 6. \\ Ref.-McCoy, Ann. Nat. Hist. 2nd Series, Vol. III. p. 13.}

Sp. Ch.-Branches six or seven lines in diameter, elongate-conic, exceedingly rugose, with large transverse irregular uncinlations and funnel-shaped irregularities of growth. crossed by eoarse, obtuse, longitudinal strix (four in the space of two lines), young lateral brauches small, continuing very slender for a considerable length; terminal cups deep, with a prominent compressed axis in the centre, middle portion with strong radiating lamellie, which, as they approach the margin, become fainter and united into a net-work by strong interstitial vesicular plates: horizontal section, central axis two lines wide, of close, fine, complicater laminx, crossed by one thick mesial plate; axis, surrounded by an area five lines wide, of about forty-two equal radiating lamelln, with very delicate transverse vesicular plates; outer area, partially radiated by delicate costal prolongations of the radiating lamellæ, with numerous strong, curved, vesicular plates, one circle defining the inner area much stronger than the rest; vertical section, shews a thick solid line, indicating the centre of the axis (and corresponding to the mesial line through the axis of the cross section), from which the delicate, thin, close, complicated laminu of the axis diverge downwards, bit puss fmenludly into the larger and more horizontal cellular tissue of the second area; this latter is separated by a definite line from the outer area, which is of smaller cellular tissue, composed of small, curved, vesicular jlates, extending obliquely upwards and outwards, four to five in a row.

In general appearance this resembles the $L$. duplicata (Mart. sp.), but is nuch more rugose, and the young branches expand more rapidly; in the rertical section it is distinguished by the central line and the undefined sides of the axis, as well as the very much smaller size of the cells of the vesicular structure, 
and the much greater number of the radiating lamelle, which do not exceed twenty-four or twenty-six in that

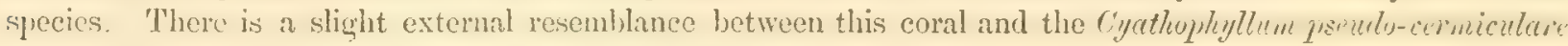
$\left(\mathrm{M}^{\mathrm{c}} \mathrm{Coy}\right)$, but the prominent axis easily distinguishes it.

Position and Locality.-Common in the carboniferous limestone of Corwen.

Explanation of Figures.-Pl. 3. B. Fig. 6. Old branch, natural size, shewing the concentric irregularities produced by the periodic death and continued growth of the main stem, and the mode of growth of the young slender stems.-Fig. 6 a. Do. Young, perfect, terminal cells, shewing the very prominent axis in the deep sharp-edged cup.-Fig. 6 b. Do. Vertical section, magnified three diameters, shewing the solid line down the middle of the conical axis, the very oblique close cellular structure of the axis graduating to the more open and less inclined cells of the inner area, the divisional line and small rounded cells of the outer area; the top shews a profile of the terminal cup and the extension of the lamella, with their connecting plates. -Fig. 6 c. Do. Horizontal section, magnified two diameters, shewing the nearly equal radiating lamellie delicately prolonged to the walls, supported by the strong eircle of vesicular plates surrounding the inner area.

\section{Lonsdaleia stylastr ziformis $\left(M^{\circ} \mathrm{Coy}\right)$. Pl. 3. B. fig. 7.}

\section{Ref.-McCoy, Ann. Nat. Hist. 2nd Series, Vol. III. p. 14.}

Sp.Ch.-Corallum of easily separable (four to six-sided) prismatic tubes, from three to five lines in diameter; outer walls, faintly striated longitudinally, and marked with arched, transverse, imbricating rugosities; wrtical action, axis large, defined, composed of irregular, spirally complicated lamellat; inu, urec, of littld-curved, vesicular plates, inclining oblicuely upwards and ontwards, each plate generally extending from the axis to the circunference of the inner zonc, so that there is but one, or occasionally two, lengthened cells in a row hetween these points; onter "w " narow, composed of slightly arched plates, inclining obliquely upwards and outwards, each plate usually reaching from the imner zone to the outer wall; more rarely a second areherl plate is required, so that generally there is but a single row of cells between the inner zone and onter wall, with occasionally a small irregular cell towards the margin; transverse polished section, shewing a large oval or cireular, irregularly reticulated or cellular axis, from which twenty-five lamellac, of ergual length and thichness. radiate almost to the outer walls; the cellular part of the walls, free of radiating lamellie, being very narrow, and forming apparently a single row of irregular cells, sometimes alsent in part of the cireunference, in which case the radiating lamellæ reach the walls; the spaces between the radiating lamellæe crossed by very thin arched plates: transverse rough fracture, generally cup-like above, the outer zone forming an oblique, nearly uniform margin, faintly undulated in a radiating direction, within which is the rough flat fracture of the inner zone and axis; on the under side the position of these parts is reversed, the inner area being prominent and surrounded by a narrow, radiated border, sloping to the walls.

This coral is very remarkable for uniting in itself the internal structure of Strombodes (Lithostrotion, Lonsd.) with the external form and easily separable columns of the Stylastrea of the same writer. I am unable to afford any information on what would, under the circumstance, be the most interesting point, namely, the mode of production of new columns: taking all circumstances into consideration, I suspect the mode of increase was similar to that I have described in Lonsdaleia generally, the external prismatic form (which is of itself of no value) being produced by the pressure of a closer mode of growth than in the $L$. duplicata. As it is impossible to conceive a Sirombodes (or Lithostrotion) splitting into easily-separable columns, I provisionally, therefore, place it in Lonsdcleia.

Position and Locality.-Rare in the carboniferous limestone of Kendal, Westmoreland.

Explanation of Figures.-Pl. 3. 13. Fig. 7. One detached column, natural size.-Fig. 7 a. Do. Vertical polished section magnified three diameters, shewing the characters of the axis and the two areas, the up per fart is a rough transerse fracture, shewing the oblipue undulated outer area and a horizontal fracture of the axis and lamelliferous area.-Fig. 7 b. Do. Horizontal section magnified two diameters, shewing the occasional unradiated portion of the outer area in lialf of the circumference. 


\title{
Genus. STYLASTRAA (Lonsd.)
}

\author{
Ref.-Geol. Russ. p. 619.
}

Gen. Char.-Corallum forming large masses, composed of prismatic, easily separable tubes, each having a thick, distinct, epithecal wall, marked with vertical costal strix, and transverse rugosities of growth; within the external epithecal boundary of each tube, is a narrow vesicular perithecal zone, usually radiated obscurely ly delicate costal prolongations of the radiating lamella: within the perithecal zone, is a cireular lamelliferous area, or true cell, traversed horizontally by distinet, strong diaphragms, without central axis; radiating lamellie numerous, strong, biplated, of two sizes, not reaching the centre; young, produced as four-sided columns, by a rectilinear boundary, parallel to one of the faces of the old prismatic tube.

\section{Stylastrza Basaltiformis (Phill. Sp.)}

\section{Ref. and Syn.-Cyathoplyyllum basaltiformis Phil. Geol. York. Vol. II. t. 2. f. 21.}

Sp. Ch.-Corallum forming large masses of easily separable prismatic tubes, often ten inches long, usually hexagonal, with an average diameter of four lines, or rather less; circular inner area usually three lines in diameter, radiated by about twenty-five thick primary lamellæe, leaving a clear unradiated central space, of rather more than a line in diameter; narrow outer vesicular area, of from two to four rows of cells, faintly radiated by delicate costal extensions of the thick primary lamella, and an equal number of intervening secondary lamellac, which barely enter the lamelliferous zone; surface marked with strong, irregular, transverse wrinkles of growth, and coarse vertical lamellar strix, averaging six or seven in two lines: criticul setion, inner area traversed hy broad, distinet, nearly flat, subregular, horizontal diaphliagnis, about five in two lines; outer area, of rery highly inclined, slightly curved vesicular plates, usually two in a row.

I have seen, in one or two cases, a slight axis-like projection of the middle of a diaphragm, but there was notling of the sort on the diaphragm above or below it. The peculiar mode of forming easily separable young square tubes is often observed in this species.

Position and Locality.-Abundant in the carboniferous limestone of Kendal, Westmoreland.

\section{Genus. SIPHONODENDRON ( $\left.1 \mathrm{I}^{\mathrm{C}} \mathrm{Coy}\right)$.}

\section{Ref.-MI Coy, Ann. Nat. Hist. 2nd Series, Vol. III. p. 127.}

Gen. Char.-Corallum of variously aggregated, branching, cylindrical or elongate-conic stems; young branches produced by lateral buds; outer wall thin, lined by two or three rows of small vesicular plates, forming a narrow outer vesicular, or perithecal area in both sections, defined by a thin tubular wall; terminal cups deep, lined by numerous vertical lamelle, alternately larger and smaller, and having in the bottom a small prominent, styliform, compressed axis: vertical section shews a slender, central axis, and a series of large conical or dome-shaped transverse diaphragms, occupying the greater part of the width of the tube, the convexity upwards forming in this section lines diverging downwards and outwards from the axis, till they reach the narrow external cellulose layer on each side: horizontal section shews the small axis, surrounded usually by a few thin concentric lines, which are the edges of the conoidal diaphragms cut through by the section; from these the vertical lamella radiated to the circumference, where they are connected by the small transverse vesicular plates, forming the narrow external cellular zone.

I have proposed this genus for a number of corals exceedingly abundant in the mountain limestone, but hitherto classed, by Prof. Phillips, Mr Lonsdale, and others, with Lithodendron. This latter genus was originally proposed by Schweigger (Benbachtungen, de. tab. (i) to inchude, first, the Oculium of Lamar's. including the type of Blainville's Dendroptyllia; and secondly, a division, which, allowing the previously' constituted geusus Oenline and the subseruently defined Dendropleyllia to stand for the first division, lecennes the real type of his genus, and the four references he gives to Esper's 'Pflanzenthiere' ( $L$. capitatum fastigiatum, angulosum, cristatum), as examples of this genus are typical examples of the group sulse- 
quently named Lobophyllia by Blainville; which latter name, therefore, becomes a synonym merely of Lithodendron: the two latter of these examples belong to the genus Lobophlyllia, as restricted by MM. Edwards and Haime, but they have formed the type of the two first into their new genus Eusmilia, which latter therefore should, according to the usual rules, be considered the true Lithodendra, and bear that name if it be used at all. In no case can the Siphonodendra of the mountain limestone be brought in any close relation with those recent and mesozoic types. The differences are briefly these: first, Siphonodendron increases by lateral buds, - Lithodendron by a lateral elongation and gradual division of the old cup and dichotomous fissure of the stem; second, Siphonodendron has a slender, distinct, simple axis, and wide conoidal transverse diaphragms, while Lithodendron has a large cellular axis, and no diaphragms.

\section{Siphonodendron agGregatum $\left(M^{\circ} \mathrm{Coy}\right)$.}

Ref. and Syn.-Lithodendron pauciradialis $\mathrm{M}^{\circ} \mathrm{Coy}$, Carb. Foss. Irel. t. 27. f. 7.

$s p$. Ch.-Corallum of numerous, slightly flexuous, nearly parallel tubes, two lines or slightly more in diameter, either round and smooth or marked with very fine transverse strix of growth, or very often prismatic, from mutual pressure, and then marked with vertical lamellar striæ five in one line; columns often coalescing laterally; branches few; radiating lamellse about twenty-two, reaching to the central, conical projection of the diaphragms, or to the central styliform axis, according to the height of the section, between each pair in some tubes are an equal number of short secondary ones, two of the lamella stronger than the rest seem to pass through the centre, and the two lateral next ones often unite branch-wise to it; external vesicular perithecal area very narrow, about two cells wide: vertical section shews at the sides, the outer epithecal wall, the very narrow perithecal area of one or two cells wide, and transverse diaphragms (three in one line) converging upwards to the persistent filiform axis.

This species is remarkable for its peculiar mode of branching, or crowded, nearly parallel mode of growth. I alter my first name, as I now believe that all the primary lamelle are of nearly equal length, so that the number is not particularly small, and I propose one alluding to the peculiar mode of growth.

Position and Locality.-Common in the carboniferous limestone of Corwen. The original Irish locality was the Arenaceous limestone of Magheramore, Tobercurry.

\section{Siphonodendron fasciculatum (Flem. Sp.)}

Ref. and Syn.-Lithodendron fasciculatum Phil. Geol. York. Vol. II. t. 2. f. 16 and 17.

$S p$. Ch.-Corallum forming very large masses of loosely aggregated, slightly flexuous tubes, averaging three lines in diameter, branching and occasionally coalescing laterally; external or epithecal wall strong, marked with distant, obtuse ridges, about five in two lines, but when slightly worn the vertical costal edges of the lamellix are seen five in one line: vertical section shews within the outer wall, a very narrow vesicular perithecal area, separated by a thin wall from the inner area, or true cell-tube, which latter is traversed by wide, conoidal diaphragms, converging upward into an axis, about two diaphragmatal spaces in one line: horizontal section shews the circular boundary wall of the cell-tube, surrounded by a very narrow perithecal vesicular area, enclosed by the epithecal or external wall, and radiated by costal extensions of about forty-four radiating lamellse, one half of which extend to the axis, the remaining twenty-two barely entering within the lamelliferous tube; axis very variable, usually presenting, a slightly radiated vesicular crumpling of the conical centres of the diaphragms, sometimes appearing as a smaller solid point; terminal cups very deep, lined by the radiating lamellie, and having the slender, styliform axis, very prominent in the bottom.

Position and Locality.--Abundant in the carboniferous limestone of Derbyshire; carboniferous limestone, Bristol. 


\section{Sipionodendron sexdecimale (Phill. Sp.)}

Ref. and Syn._Lithodendron id. Phil. Geol. York. t. 2. f. 11, 13.

Sp.Ch.-Corallum forming loosely branched masses; cell-tubes slightly flexuous, subparallel, areraging slightly more than one line in diameter, and usually rather less than their diameter apart, branching at an acute angle, the branches attaining their full diameter at about four lines long; outer wall very thick, smooth, with faint transverse lines of growth, without distinct costal strie; axis strong, solid, persistent; transverse diaphragms nearly horizontal, strong, three interdiaphragmatal spaces in one line; radiating lamellie of moderate thickness, sixteen long, reaching quite to the axis, or a few occasionally uniting branch-wise with their neighbours; an equal number of very short marginal ones, one between each pair of primary.

The very small size of the branches, and small number of the lamellæ, easily distinguish this rare species from its congeners.

Position and Loculity.-Not uncommon in the carboniferous limestone of Kendal, Wrestmoreland; impure carboniferous limestone of Lowick, Northumberland; also at Burdiehouse; and carboniferous limestone of Derbyshire.

\section{Family. ASTREIDE. See page 36.}

\section{Subfamily. EUSMILINE. See page 36.}

Genus. CYATHAXONIA. See page 36.

\section{Cyathaxonia cornu (Mich.)}

$$
\text { Ref.-Michelin, Icon. Zooph. t. 59. f. } 9 .
$$

SP. Ch, -Corallum very small, slightly curved when young, nearly straight when old, the adult diameter of about three and half lines, is reached at about six lines from the apex; sometimes an inch in length with the same diameter; axis prominent, thick, solid, eylindrical, about one fourth the diameter of the tube; radiating lamellø appearing in small terminal cups as thirty-five or thirty-six alternately larger and smaller lamellix, which unite in pairs near the axis: lurizonted soction of larger specimens shew twenty-four radiating lamellice, extending from the axis a short way, and then splitting into a pair of slender ones, extending to the walls; no connecting vesicular plates; external surface with distinct, obtuse, close vertical striæ (about five in one line) branching not unfrequently; no transverse vesicular plates.

I have compared the specimens described with one from the original locality of Tournay, and find the coincidence exact.

Pvition and Luculity.-Rare in the carboniferous limestone of Derbyshire; and Kendal, Westmoreland.

$$
\text { Cyathaxonia costata ( } I^{c} \text { Coy). Pl. 3. C. fig. } 2 .
$$

$$
\text { Ref.-M다, Ann. Nat. Hist. 2nd Series, Vol. III. p. } 6 .
$$

$5 \%$. Ch.-Elongate-conic, generally about one inch long and half an inch in diameter at the cup, which is circular and horizontal; surface irregularly wrinkled transwersely, and marked longitudinally with remarkably, thick, strong, sharply-defined strix, about seven in one-fourth of an inch; central solid axis very thick (often one line in diameter), and from it twenty-five thick, wedge-like, vertical lamella, radiate to the walls; transverse versicular plates connecting the lamellix exceedingly delicate; in the sections the vertical lamellie are seen to dichotomize upwards, and the large curved plates of the loose vesicular structure incline upwards and inwards towards the axis. 
This is more slender in form than the C.mitratum (Schl. sp.) or C.cornu-copice (Mich.), and from which, and all the other turbinate corals of the palitozoic rocks, it is distinguished, extcrnally, lyy the strong, distinct, distant, longitudinal ridges; the internal characters approximate it only to the Cyathaxonia cornu (Mich.), from which it is distinguished by its simple, few and thick lamelloe, and thick axis, as well as more turbinate form.

Position and Locality.-Rare in the carboniferous limestone of Derbyshire.

Exptanation of Figures.-Pl. 3. C. fig. 3. Natural size.-Fig. $2 \alpha$. Do. Vertical and horizontal section magnified two diameters; the former shewing the thick solid axis and very loose vesicular structure, of thin slightly curved plates, converging upwards to the axis; the latter shewing the thick radiating lamellie connecterl by the thin edges of the vesicular plates.

\section{Genus. SARCINULA. See page 36.}

\section{Sancinula Philupsir (MCom).}

\section{Ref.-MCoy, Ann. Nat. Hist. 2nd Series, Vol. III. p. 125.}

Phill. Pal. Foss. f. 15. D.

I have given the above name, provisionally, to a coral which I believe to be identical with the Flintshire one figured as above, by Prof. Phillips, but not named nor described. It is closely allied to the C. placenta, but is of a thicker growth, the tubes are one-third larger, usually less than their diameter apart, and surroundert by thirty-two to forty strong radliating lamelie extending to the adjoining tulses; there is an obvious tendency in the mildle of the transverse diaphrams to extend upwards, to form an irregularly compressed solid axis, often visible in the weathered cups.

Position and Locality.-Common in the carboniferous limestone of Corwen.

Sarcinula placenta $\left(M^{c} C o y\right)$. Pl. 3. B. fig. 9.

Ref.-M $\mathrm{M}^{\mathrm{C}} \mathrm{Coy}$, Ann. Nat. Hist. 2nd Series, Vol. III. p. 124.

Sp. Ch.-Corallum forming tabular masses, about one inch thick; under side with a thin epitheca, marked by suluall, concentric, imbricating undulations of growth, and rarliating scratch-like strie; the uper and lower surfaces parallel and flat; composed of vertical cylindrical tubes, forming circular cells at the surface, one line in diameter, and averaging about two lines apart; the intervening space being flat, cellular, and obscurely radiated on the weathered surface by about twenty-five curved radii; vertical section, tubes irregularly transversely septate by vesicular plates; spaces between the tubes composul of slightly-waved transverse rows of small, curved, vesicular plates, forming a nearly uniform minutely cellular structure; horizontal section, tubes either plain or shewing more or less of the transverse vesicular plates; intervening spaces irregularly cellular, but shewing a slight disposition to form curved star-like lines round the tubes.

This interesting coral bears a strong external resemblance to the Nematophyllum decipiens (Mㄷoy), but is distinguished by having no divisional lines between the stars in either section.

Position and Locality. - Rare in the carboniferous limestone of Derbyshire.

Explanation of Figures.-Pl. 3. B. fig. 9. Fragment natural size, shewing the lamellæ passing from centre to centre on the flat upper surface, and the edge of the mass shewing the mode of weathering in horizontal lamina, the centres remaining as persistent cylinders, vertically striated by the radiating lamella.Fig. $9 a$. Do. Vertical section.-Fig. $9 b$. Do. Horizontal section, shewing the near equality in strength of the radiating and vesicular plates, and the consequent indistinctness of the radiation.

Sarcinula tuberosa $\left(M{ }^{c}\right.$ Coy $)$. Pl. 3. B. fig. 8.

Ref.-McCoy, Ann. Nat. Hist. 2nd Series, Vol. III. p. 124.

Sp. Ch.-Corallum forming large shapeless masses, the upper surface covered with irregular tuberose projections, separated by flat or concave spaces, and each having a depressed tubular centre, one line in diameter, average distance between the centres five lines; from the margin of each centre about thirty slightly sigmoidal, 
very delicate lamine radiate $t o$ 'the arjoining ones, generally without interruption, the radii connected l,y numerous small transverse vesicular plates; vertical section, centres forming nearly vertical and subparallel cylindrical tubes, with close coneave transverse septa, the tuhes comnected by exceedingly fine, uniform, cellulose structure, which secms formed of small depressed colls, arranged nearly in horizontal layers, with a double curve conforming to the projections of the surface; horizontal section, shews the tubular centres connected by a minute uniform cellular structure with a scarcely appreciable radiation.

This strongly resembles the Wenlock limestone, so-called Acervularia Baltica of the 'Silurian System.'

Position and Locality.-Rare in the carboniferous limestone of Derbyshire.

Explanation of Figures.-PI. 3. B. fig. 8. Portion of large mass, natural size, exhibiting the terminal weathered stars, and rough vertical scetion shewing the thin layers of vesicular tissue, extending with a double curve from one centre to another, and the transverse cellular plates filling the central tubes; also, the not uncommon appearance of the axis weathering as a separate cylinder, vertically sulcated by the origins of the radiating lamelle. - Fig. $8 \alpha$. Do. Horizontal and vertical sections of portion of a small specimen magnified three diameters, the former shewing the plain centres and the uninterrupted passage of the radiating lamellæ from one centre to another, connected by the vesicular plates.

\section{Subfamily. ASTREIN玉. See page 37.}

\section{Astr fa (Palastraca) carbonaria ( $I^{c}$ Coy). Pl. 3. A. fig. 7. and 3. B. fig. 1.} Ref.-MCoy, Ann. Nat. Hist. 2nd Series, Vol. III. p. 125.

Sp. Ch.-Corallum forming very large masses; terminal stars from nine lines to an inch and a half in diameter, obseurely pentagonal, hounded hy narrow, rounded, or obscurely angular cellular spaces (no simple divisional walls), having from one hundred and seven to one hundred and thirty thin, jagged, radiating lamellæ, which descend to form an oval or circular cup, and one half of which rise again to form an oval central boss, by the edge being produced into an abrupt paliform lobe (not distinguishable from the lamella); in the centre the lamella become indistinctly blended: vertical section shews the uninterrupted passage of the loose vesicular tissue, conforming to the shape of the terminal cup, in gentle curves from star to star; a very small space directly under the centre of each star, having the vesicular structure almost transverse; horizontal section shews the alternately long and short radiating lamellæe, connected (except in a small space near the centre) by fine transverse vesicular plates, and the former obscurely blended at the centre (no axis), and the irregular cellular structure intervening between the adjacent stars.

This magnificent species is the only apparently true Astroca I have yet seen from the Palreozoic moclis; the numerous Paleozoic corals described under this generic title by British and foreign authors. belong, for the most part, to Strombodes, Nematophyllum, Acervularia, Sc.; often transversely septate in the midule and having solid polygonal divisional walls to the stars-characters completely at variance with those of the recent and mesozoic Astrrea, and indicating important differences in the animals and mode of increase. I propose the subgeneric title Palastrac for this species, as it seems to differ from the newer types in the vast number and tenuity of the lamellæ, and the great cylindrical boss in the cup from the unthickened pali-form lobes of the larger lamelle.

Position and Locality.-Abundant in some parts of the carboniferous limestone near Bakewell, Derbyshire; more rare in the same formation at Corwen.

Explanation of Figures.-Pl. 3. A. fig. 7. Part of mass, natural size from Derbyshire, shewing weathered terminal cells of small stars at the right-hand corner. Ditto, worn at the left-hand.-Fig. $7 a$. Do. Part of same mass shewing at top horizontal sections of one large star, magnified two diameters, and portions of two others shewing the vesicular character of the spaces between them, the irregular centres, numerous radiating lamellie and connecting vesicular plates; the lower portions of the figure shew a vertical section, the vertical lines in the left half being the ends of the radiating lamellac, the vesicular structure in the right half shewing the uninterrupted passage of this texture from the interspace to the centre.-PI. 3. B.f. 1. Do. Terminal stars, natural size, from Derbyshire. 


\section{(Systematic place uncertain.)}

\section{Genus. HETEROPHYLLIA $\left(\boldsymbol{M}^{c} \mathrm{Coy}\right)$.}

Ref.-McCoy, Ann. Nat. Hist. 2nd Series, Vol. III. p. 126.

Gen. Char.-Stem elongate, subeylindrical, irregularly fluted "longitudinally; horizontal section, few distant lamellie, destitute of any order of arrangement, but irregularly branching and coaleseing in their passage from the solid external walls towards some indefinite point near the centre, where the few main lamelle irregularly anastomose; vertical section shewing about the middle an irregularly flexuous line (the edge of one or two of the radiating vertical lamellæ), from which on each side a row of thin, distant, sigmoidally curved plates extends obliquely upwards and outwards, forming a row of large rhomboidal cells on each side.

The paradoxical characters of the lamelle, their perfect want of symmetry of disposition, and their irregular branch-like union among themselves, together with the remarkable openness of the cellular structure, render these corals totally unlike any other recent or fossil group. From Cludocora and Caryopleyllix, to which they are most allied, they are distinguished by the want of the cellular axis, and by their few, unsymmetrical and anastomosing lamellie. I suspect the Cladocora? sulcata of Lonsdale may belong to this group, but I have not seen examples of it myself.

\section{Heterophyllia grandis $\left(M^{\circ} \mathrm{Coy}\right)$. Pl. 3. A. fig. 1.}

Ref.-Mㄷoy, Ann. Nat. Hist. 2nd Series, Vol. III. p. 126.

sp. Ch. - Stem slightly flexuous, about five lines in diameter, scarcely tapering in three inches, longitudinally marked with deep unequal grooves, and few, large, polygonal, unequal ridges, giving a very irregularly angulose section to the stem; surface smooth, internal structure as given in the generic character.

Position and Locality.-Rare in the earboniferous limestone of Derbyshire.

Explanation of Figures.-PI. 3. A. fig. 1. Natural size from Derbyshire, shewing the irregular longitudinal coste.-Fig. $1 \%$. Do. Horizontal section magnified three dianeters, shewing the irregular anastomosing of the lamella.

\section{Heterophyllia onnata $\left(M I^{c} \mathrm{Coy}\right)$. Pl. 3. A. fig. 2.}

Ref.-McCoy, Ann. Nat. Hist. 2nd Series, Vol. III. p. 127.

Sp. Ch.-Stems subcylindrical, long, flexuous, averaging one and half lines in diameter, with about sixteen narrow, subequal, longitudinal ridges sharply defined, and separated by flat spaces rather wider than the ridges they separate; the ridges are set with small round tubercles more than their own diameter apart; surfoce very minutely granulose: internal structure as in generic character; horizontal section, lamella about fourteen at the margin (one usually coinciding with each external ridge).

Position and Locality.-Rather rare in the carboniferous limestone of Derbyshire.

Explanation of Figures.-Pl. 3. A. fig. 2. Natural size from Derbyshire-Fig. 2a. Do. Magnified four diameters, shewing at top the horizontal section and irregular anastomosing of the lamelle, below this the external surface with the tubereulated costre; and at bottom the vertical section sherving the distant, oblique, interstitial plates, the mesial line being formed by some of their edges. 


\title{
4th Class. POLYZOA. See p. 44.
}

\author{
Genus. FENESTELLA. See page 49. \\ Fenestella carinata $\left(M^{\circ} \mathrm{Coy}\right)$. \\ Ref.-Mc Coy, Syn. Carb. Foss. Irel. t. 28. f. 2.
}

$S p . C h$. - Interstices externally close together, irregularly bifureate; dissepiments and interstices flattened, of equal breadth, and on the same level; fenestrules circular; poriferous face of interstices angular, with a strong, longitudinal keel in the middle; dissepiments very thin, small, rounded; fenestrules elongate, oval, two in one line measured longitudinally or transversely. Two irregular rows of pores with projecting margins, and one irregular row of small ones on the central keel.

This coral, to the naked eye, has the appearance of a perfectly flat surface, with regular, round dots, resembling pin-holes.

Position and Locality.-Carboniferous limestone, Derbyshire, and Isle of Man. The original Irish localities were the lower limestone of College Hall, Tynan (abundant), and in the calp of Malahide, Dublin.

Fenestella formosa ( I $\left.^{c} \mathrm{Coy}\right)$.

$$
\text { Ref.-McCoy, Syn. Carb. Foss. Irel. t. 29. f. } 2 .
$$

$5 \%$. Ch.-Corallum forming flat leaf-like expansions, ahout one inch long and half inch wide; interstices thin, irregularly branching, about three in the space of one line; fenestrules large, irregular in size and shape; dissepiments very thin; pores of the sides of the interstices large, numerous, their thickened edges indenting the margin, four or five to the length of a fenestrule; at each bifurcation, and at each setting off of a dissepiment is one pore, nearly twice the size of the others; in the middle of each dissepiment is placed one oval pore, and on the strong keel of the interstices is a very regular row of small pores, all having raised margins.

To the naked eye it has much of the habit of the common Fencstelle undulate (Phill.), but the disposition of the pores separates them at once; it is very constant in its characters, several specimens from different localities presenting precisely the same structure.

Position and Locality.-Rare in the carboniferous limestone of Derbyshire. The original Irish localities were in the carboniferons slate of Hook Head, Wexford (common); in the carboniferous slate at Currens, Tralee; in the black upper limestone of Killymeal, Dungannon (the figured specimen).

\section{Fenestella memibranacea (Phill. Sp.)}

Syn. and Ref.-Retepora membranacea Phill. Geol. York. Vol. II.t. 1. f. 1 to 6.

Sp. Ch.-Elongate conical; interstices straight, equidistant, with a sharp, central keel; dissepiments nearly equal in thickness to the interstices; fenestrules five in the space of one line, measured transversely, four in one line measured longitudinally, elongate, rather wider than the interstices, nearly three times as long as wide; pores small, about three to the length of a fenestrule; non-poriferous face granulated.

This species is remarkable for its elongate conical shape, and very recular elongate oblong fenestrules. I noticed (Syn. Carb. Foss. Ireland, p. 202) that it was "fixed at the base by long, solid, non-poriferous roots of considerable thickness," these root-shaped processes much resemble serpule when found detached, they arise irregularly from various points near the small end, and are usually under a line in diameter, and from one to two or three inches in length, and irregularly flexuous; they occasionally occur in other species. This species often attains nine or ten inches in length. I have occasionally seen specimens with traces of the external sheath supposed to characterise the genus Hemitrypa.

Position and Locality.-Common in the carboniferous limestone of Derbyshire. 


\section{Fenestella plebeia $\left(\boldsymbol{M}^{c} \mathrm{Coy}\right)$. See page 76 .}

Position and Locality.-Common in the carboniferous limestone of Derbyshire. The original Irish localities were the arenaceous limestone of Killybrone, Killala; carboniferous slate of Poulseadden, Howth: and Malahide, Dublin; lower limestone of Howth, Dublin, and Little Island, Cork; calp of Malahide; Bundoran, and Ballintrillick; upper limestone of Killymeal, Dungannon; carboniferous shales of Ringstown, Mlount Rath, and Rahan's Bay.

\section{Fenestella polyporata (Phill.Sp.)}

\section{Ref.-Retepora polyporata Phill. Geol. York. Vol. II. t. 1. f. 19, 20.}

$S p . C h$.-Interstices thick, rounded, carinated, irregularly branched; dissepiments short, thin, placed at irregular distances; fenestrules large, very irregular in size and shape, averaging three in two lines, measured longitudinally, five in the same space measured transversely; pores very small, impressed, from five to seven to the length of a fenestrule.

Position and Locality.-Carboniferous limestone, Derbyshire.

\section{Fenestella retiforais (Schloth.Sp.)}

Ref. and Syn.-Keratophytes retiformis Schlotheim Akad. Munch. Vol. VI. t. 1. f. 1, 2. = Retepora flustracea (Phill.) Geol. Trans. 2nd Series, Vol. III.t. 12. f. 8. = Gorgonia infundibuliformis and antiqua Gold. Pet. Germ. t. 36, f. 2 and 3. King, Perm. Foss. t. 2. f. 8. to 11.

Sp. Ch.-Corallum forming very irregularly folded, short, wide, funnel-shaped expansions; interstices thin, keel strong, with vesicular tubercles less than their diameter apart, and alternating with the cell-pores which are very prominent, strongly indenting the margin, varying from two to three to the length of a fenestrule; dissepiments strong, at regular intervals; fenestrules regular, oblong or oval, usually about twothirds the width of the interstices, and nearly twice as long as wide (five or six in two lines, transversely or longitudinally measured); reverse with a few minute pores and irregular longitudinal strix.

Position and Locality.-Very abundant (usually three or four inches or more in diameter) in the magnesian limestone of Humbleton Hill.

\section{Fenestella undulata ( $P /$ i ill. $S p$. $)$}

Syn. and Ref.-Retepora undulata Phill. Geol. York. Vol. II. t. 1. f. 16, 17, 18.

$S p . C h$.-Interstices and dissepiments very thin; fenestrules large, irregular; pores very large; rather' distant, prominent, indenting the margin, about four to the length of a fenestrule; reverse with undulating, longitudinal striae.

This is a loosely branched, but very delicate species, the substance of the coral itself being very slender; the fenestrules are four or five times the width of the interstices; the pores are only sulb-alternate, and so large as to give a nodular aspect to the interstices. It grows to upwards of two inches in length; there are about two interstices in the space of one line.

Position and Locality.-Rare in the carboniferous limestone of Derbyshire.

\section{Genus. SYNOCLADIA (King).}

\section{Ref.-King, Ann. Nat. Hist. 2nd Series, Vol. IIl.}

Gen. Char.-Corallum cup-shaped, with a small central root-like base, reticulated, composed of rounded, narrow, often-branched interstices, bearing on the inner face from three to five alternating longitudinal rows of prominent-edged pores, separated by narrow kecls, studded with sniall, irregular vesicles alternating with the cell-pores; dissepiments thin, rarely direct, usually forming short spur-shaped pinna 
extending upwards from the sides and meeting those from the adjoining interstice at an angle directed upwards, bearing two alternating rows of cell-pores.

Differs from Fencetclla in the large number of rows of pores on each interstice, and in having pores on the dissepiments, and from Polypora it differs in the keels and linear arrangement of the pores on the interstices and also in the poriferous character of the dissepiments; the angulated form of these latter is not peculiar to the genus but occurs in some otherwise very different cretaceous forms. As I have pointed out in Fencstclla, long, solid, root-like fibres occasionally extend from various parts near the base of the polypidom.

\section{Synocladia virgulacea (Phill. Sp.)}

Syn. and Ref.-Retepora, id. Phil. Trans. Geol. Soc. 2nd Series, Vol. III. t. 12. f. 6. Synocladia id. King. Perm. Fos. t. 4. f. 1 to 8.

Sp. (K.-Corallum irregularly funnel-shaped, much wider than high; interstices slightly unequal, averaging one third of a line wide, branching at short intervals and occasionally anastomosing, rounded and smooth exteriorly, bearing on the inner side from three to five rows of cell-pores their own diameter apart, separated by longitudinal keels bearing small vesicles alternating with the eell-pores; dissepiments usually oblique, often disconnected $01^{\circ}$ angulated upwards in the middle, thin, and bearing on the inner side two rows of approximate alternating cell-pores, resembling those of the interstices; fenestrules subequal, irregularly quadrate, rarying from three to four in the space of two lines measured transversely, or longitudinally.

Position and Locality.-Tery alumdant, forming cup-shaped masses three or four inches in diameter in the magnesian limestone of Humbleton Hill.

Genus. POLYPORA (MC Coy).

Ref.-M $\mathbf{I}^{\mathrm{C}} \mathrm{Coy}$, Synopsis Carb. Foss. Irel. p. 206.

Cín. C'hu'-Corallum forming a delicate, reticulated, calcareous expansion, usually fan-shaped; interstices round, laving on one side from three to five rows of cell-openings, the margins usually not projecting; interstices connected by thin, transverse, non-poriferous dissepiments; reverse rounded, striated or granulated.

I have not seen any infundilulifurm species of this genus, which is easily distinguished from Fenestelln by the numerous rows of pores on the uncarinated interstices, and from Retepora by the nonporiferous dissepiments. The genus is very common in the carboniferous series.

\section{Polypora dendroides $\left(M^{\circ} \mathrm{Coy}\right)$.}

Ref.-McCoy, Syn. Carb. Foss. Irel. t. 29. f. 9.

Sp. Ch.CCorallum flat, fan-shaped, usually about one inch long and one and a half inch wide; interstices divaricating, loranching at short irregular intervals, about half a line wide; obverse with five rows of small, close, impressed quincuncially arranged pores; revarse longitudinally striated; dissepiments rery thin, often oblique, giving a rhomboirlal outline to the fenestrules which are about two-thirds of a line wide and usually a little more or less than a line long.

This species has a peculiar aspect from the arched divarications or divergence of the interstices.

Position and Locality.-Not uncommon in the carboniferous limestone of Derbyshire. The original Irish localities were the arenaceous limestone of Townparks, Killeshandra; lower limestone of Kildare; and upper limestone of Black Lion, Enniskillen. 


\title{
Polypora verrucosa $\left(M^{c}\right.$ Coy).
}

\author{
Ref.-McCoy, Syn. Carb. Foss. Irel, t. 29. f. 6.
}

$S p$. Ch.-Interstices straight, round, nearly half a line wide, equal, bifurcating rarely at less than three or four lines, (often upwards of an inch without branching); obverse with four alternating rows of prominent wart-like pores, about eight or ten in each row to the length of a fenestrule, intervals between the pores marked with waving longitudinal strix; reverse nearly smootlı; dissepiments thin, distant; fenestrules regular, rectangular, oblong, sub-equal, about five times longer than wide, slightly wider than the interstices (three in two lines measured transversely) and about two and a half lines long.

This is the only species of the genus in which I have seen prominent-edged pores.

Rare in the carboniferous limestone of Derbyshire; the original Irish locality was the lower limestone of Kildare.

\section{6th Class. ECHINODERMATA. See page 51.}

\section{1st Order Crinotidea. See page 52.}

\section{Genus. POTERIOCRINUS (Mill.) restricted by Aust.}

Gen. Char.-Colnmn and alimentary canal round, with round axillary side arms; cup conical, formed of pelvis, one row of primary and one row of secondary radials, and an irregular group of three interradials on one side; pelvis of five large pentagonal plates, their bases resting on the upper columnar joint; alternating above these are two obscurely heptagonal and three hexagonal primary radials, alternating over which, are five pentagonal 1st secondary radials (scapulix), hetween two of which, are two or three small, interradial plates; free rays composed of a few of the secondary radials (arm-joints) as wide, or nearly so, as the 1st (or scapulic).

Prof. Phillips and some other authors notice in their descriptions of this genus the existence of a very minute, pentagonal, tripartite pelvis, entirely concealed within the columnar articulation marking the bases of the five plates above considered 'pelvic': I have never seen any trace of this supposed, very abnormal, pelvis, and I can state that it does not exist in the Poteriocrimus impressus (Phil.), in which I have seen the base clearly exhibited with the five divisional lines extending to the minute alimentary opening.

\section{Poteriocrinus granulosus (Phill.)}

$$
\text { Ref.-Phill. Geol. York. Vol. II. t. 4. f. 2. 4, 8, 9, } 10 .
$$

Sp.Ch.-Cup obtusely conical, one-third wider than long to the edge of 1st secondary radials (scapulit); pelvis small, pentagonal of five pentagonal plates, twice as wide as long, excavated and radiated at their base to form part of the columnar attachment; between and above these are inserted five pentagonal (or obscurely hexagonal) 1st primary radials, one-third wider than long; alternating over these are five pentagonal 1st secondary radials (scapula) twice as wide as long; all the plates nearly flat and closely covered with fine granules. Length of cup about half an inch.

One of the primary radials is hexagonal and has one of its upper sides so long and nearly horizontal that it seems to support one of the scapulre or secondary radials, and on its shorter side it has the long irregular hexagonal 1st interradial plate, supporting two small lengthened 2nd interradials.

Position and Locality.-Common in the carboniferous limestone of Derbyshire. 


\section{Poteriocrinus nuciformis $\left(M I^{c} C o y\right)$. Pl. 3. D. fig. 4. \\ Ref.-Mc Coy. Ann. Nat. Hist. 2nd Series, Vol. II. p. 245.}

$S p$. Ch. - Bodly subovate, pointed below, contracted above from the upper margins of the 1st secondary radials (scapulæc) being narrower than their lower portion; pelvic plates long, pentagonal, very narrow below, giving a pointed appearance to the lower portion of the cup ; primary radials large, tumid, subhexagonal, nearly twice the length of the pelvic plates, a little less wide than long; 1st secondary radials or scopulce pentagonal, about one-third wider below than above, giving a very perceptibly constricted appearance to the upper part of the cup; articulations for the free rays or 2 nd secondary radials extending the whole width of the 1st secondary radials or scapula; irregular 1st interradial large, subhexagonal, supporting two small pentagonal 2nd interradials; surface smooth. Length of cup eight lines, greatest diameter (at middle of primary radials) seven lines.

This closely resembles the P. Bockschii figured by Geinitz in his 'Grundriss der Versteinerungskunde,' t. 23. f. 13, but of which no description or definition have been published.

Position and Locality.-Not uncommon in the carboniferous limestone of Derbyshire.

Explanation of Figures.-Plate 3. D. figs. 4 , and $4 a$ different profile views of one specimen, natural size.

\section{Genus. CUPRESSOCRINUS (Gold.)}

Gen. Char.-Column round or four sided, with a crucial alimentary canal; cup broad, shallow; pelvis pentagonal of five pentagonal joints, supporting five large pentagonal primary radials; alternating above which are five very wide and thick secondary radials or scapulx completing the cup; the arm articulation and articular ridge extend the entire width of the scapule or 1st sccondary radials; arms five, as wide as the scapule, rapidly tapering to an obtuse point, (not divided into hands or fingers) formed solely of plates of the secondary radial series.

We might add to the above description, that between one pair of the 1st secondary radials or scapula are three small interradial plates, not noticed by Goldfuss, but which I have observed in an authentic specimen from the Eifel of one of his species, and which tend to approximate the genus to Puteriocrinus, from which it differs in the very wide shallow form of the cup, and broad undivided rays.

\section{Cupressocrinus calyx $\left(M^{c} C o y\right)$. PI. 3. D. fig. 1.}

\section{Ref.- $\mathrm{II}^{\mathrm{c}} \mathrm{Coy}$, Ann. Nat. Hist. 2nd Series, Vol. II. p. 244.}

$S p . C h .-C^{\prime \prime} p$ very wide, cvenly convex, sancer-shaped, three times wider than long; pelois small, slightly coneave, pentagonal, of five pentagonal pieces; alternating with and above which are five large primary radials, their length and width equal to the diameter of the pelvis, four pentagonal, and one with a very short sixth lateral side; alternating with and above these, are five pentagonal 1st secondary radials (scrpulece), as long as the primary radials, but the width double the length; to the short side of the hexagonal 1st primary radial is obliquely attached a long pentagonal interradial supporting two very small 2nd interradial plates; scapulce or 1st secondary radials very thick, articular surface flat with an articular ridge running its whole width; all the plates slightly convex and smooth. Width of cup nine lines.

Position and Locality.-Rare in the carboniferous limestone of Derbyshire.

Explanation of Figures._Pl. 3. D. fig. 1, basal view of specimen natural size-Fig. $1 a$ profile of ditto.

\section{Cupressocrinus impressus $\left(M{ }^{c}\right.$ Coy $), \quad$ Pl. 3. D. fig. 2.}

\section{Ref.-M $\mathbf{I}^{\mathrm{C}} \mathrm{Coy}, \mathrm{Ann}$. Nat. Hist. 2nd Series, Vol. II. p. 244.}

$S p . C h$-Cup four times wider than deep; pelcis concealed in a deep cireular pit, out of which spring the broad ends of five ovate-lanceolate primary radials, the apex of one of which is truncated to support a small elongate interradial plate, and on its side rests a somewhat larger 1st interradial plate; 1st secondary radials (or scapul(c) about one-third wider than long, pentagonal, the two lower sides concave, and the lower angles very much prolonged to fit between the lanceolate primary radials; substance of the joints very thick, projecting far 
into the visceral cavity; a strong perforated articular ridge runs across the top of the scapulæ (1st secondary radials); all the plates slightly convex and smooth.

Distinguished from the $C$. caly $x$ by its deeply impressed pelvis and long lanceolate primary radials.

Position and Locality.-Not very uncommon in the carboniferous limestone of Derbyshire.

Explanation of Figures.-Plate 3. D. fig. 2. End view of specimen, natural size.-Fig. 2 a profile of Do.

\section{Genus. SYNBATHOCRINUS (Phill.)}

Gen. Char.-Cup conical; pelvis pentagonal, of one (?) undivided piece, supporting five very thick pentagonal scapulze, (1st primary radials) greatly diminishing the internal cavity; the articulations for the arms or succeeding secondary radials extending across their entire width; joints of rays (secondary and tertiary radials) simple.

\section{Synbathocrinus conicus (Phill.)}

\section{Ref.-Phill. Geol. York. Vol. II. t. 4. f. 12, 13.}

Sw. Ch. - Cup rapidly expanding, conical, depth to upper margin of 1st primary radials (scapula) about two-thirds the width; columnar articulation deep, circular, crenulated at the edge, perforation very minute (I think I see three divisional lines in the pelvis): scapula (or 1st primary radials) broad, quadrate, of great thickness extending nearly into the middle of the eavity (as in Apiverinus), and having as in that genus a strong transverse perforated articular ridge. Length of cup about five lines; surface smooth, (according to Austin there is one thick cuneiform arm-joint (2nd primary radial) having two long fingers of one row of joints (secondary radials).

Position and Locality.-Carboniferous limestone, Derbyshire.

\section{Genus. PLATYCRINUS. (Mill.) \\ $=($ Centrocrinus + Pleurocrinus $)$ Aust.}

Gin. Char:-Column-joints round and radiatingly striated near the pelvis, elliptical and with a thick transverse articular ridge lower down; pelvis pentagonal of three pieces, often anchylosed into one, supporting five Jroad, equal, subquadrate lst primary radials or scapulie, each with an excavation for the much narrower 2nd primary radial (arm), which gives off from its upper pointed edge two rows of secondary radials of about two joints each (hands) which are tentaculated on their inner face; fingers of donble rows of joints, tentaculated, and variable in number.

There are two subgeneric types named by $\mathrm{Mr}$ Austin of this genus, one Centrocrinus (or to which the name Platycrinus might be restrieted if necessary, having a long tubular central mouth; the other group Pleurocrinus, in which the mouth forms a simple lateral opening.

\section{Platycrinus cononatus (Gold.)}

Syn. and Ref.-Goldfuss, Nova. Acta. Akad. Cæs. Leop. Carol. Nat. Cur. Vol. XIX. Pl. 31. f. 8. = Platycrinus mucronatus (Aust.)

SH.Ch._Body small, short, semicylindrical, little wider above than below, visceral portion equalling the cup in deptlı; pelvis thick, flat as if truncated, the margin forming an obtuse tubercle opposite each line of division between the 1 st primary radials or scapulce, which are thick, nearly square, length and width equal, exeavation for 2nd primary radials or arm-plate half the depth of the scapula (? mouth between one pair of arms); eapital plates large, few, with an obtuse conical protuberance in the centre of each; surface smooth.

Pusition and Locality.-Rare in the carboniferous limestone of Bolland. (Bristol is the original locality of Goldfuss.)

\section{Platycrinus elitipticus (Phill.)}

Ref.-Phill. Geol. York. Vol. II. t. 3. f. 19 and 21.

$S p . C h$.-Cup obtusely oval, subcylindrical in the middle, pelvie and pectoral ends equal; 1st primary radials (scapula) nearly square, scapular articulation narrow, about one-third the depth of the plate; capital 
plates large, polygonal more or less prominent in the centre; mouth small, excentric; plates of the cup generally marked with radiating rows of small tubercles, and two or three rows parallel with the margin; interradial (or inter-scapular) plate large, hexagonal.

This much resembles the $P$. mugosus, but the form is more cylindric, the plates thinner, with smaller and more regular tubercles, the interradial plate larger, and the excavation in the scapuln or 1st primary radials for the arms or 2nd primary radials much narrower.

Position and Locality.-Abundant in the carboniferous limestone near Bakewell, Derbyshire.

\section{Platycrinus alegastylus $\left(\boldsymbol{M}^{c} \mathrm{Coy}\right)$.}

\section{Ref.-M ${ }^{\circ} \mathrm{Coy}$, Ann. Nat. Hist. 2nd Series, Vol. II. p. 247. = P. lowis Phil. Geol. York.} Vol. II. t. 3. f. 14, 15, (not of Miller).

Sp. Ch.-Borly broad, ovate, visceral portion convex, not much elevated ; chp rapidly expanding, conical : metcis pentagonal, very small, resembling a prominent rim to the very large circular columnar attachment, the diameter of which is three times greater than from its circumference to the elge of the pelvie plate; lst primary radials (scapule) slightly convex, even, nearly twice as wide above as below, little wider than long; excavations for the 2nd primary radials (arm-plates) large, nearly half the depth of the 1st or scapulie: capital plates variable in size and number, but large, few, unequal, polygonal, and most of them presenting a large conical protuberance in the centre; entire surface smooth. Length of body ten lines, width between the arms nine lines.

This species is excellently figured by Prof. Phillips (Geol. Yorksh.) with a doubtful reference to the $P$. lavis of Miller. The latter speeies is, I lelieve, generally admitted now to be distinct; but having exanined specimens agreeing with the above figure, I find the species to which it belongs differs both from that to which Goldfuss and that to which Mr Austin have referred it by the comparatively enormous size of the columnar attachment, and the narrow prominent rim to which the rest of the pelvis seems reduced.

Position and Locality. - The specimens above deseribed are from the carboniferous limestone of Bolland, where it occurs in company with numbers of the $P$.pileatus, Gold. ( $P$. anthetiontes, Aust.), which it much resembles, but from which it is easily distinguished by the above characters.

\section{Platycrinus pileatus (Gold.)}

Ref. and Syn.-Goldfuss. Nova. Acta. Akad. Nat. Cur. \&c. Vol. XIX. t. 31. f. 7. $=P$. antheliontes Aust. Crin. t. 2. f. 3 .

Sp. Ch.-Cup expanding rapidly, conic; capital portion depressed; pelvis conical, rounded, columnar adherence small, its diameter searcely equalling the shortest line from its circumference to the edge of the pelvis; 1 st primary radials (scapula) wider above than below, length and breadth nearly equal, arm-exeavation large, depth rather more than one-third the length of the plate; surface smooth ; capital plates large, few, polygonal, with a large more or less prominent conical umbo in the centre of most of them : mouth marginal.

I do not think with Mre Austin that this is the crinoid figured by Plillips as the I'. lectis of Miller: I have seen specimens from Bolland agreeing with Phillips's figure in the great size of the columnar adherence, dre, and which are certainly distinct. (See $P$.megastylus.)

Pusition and Locality. - Very common in the arboniferous limestone of Bolland. (Bristol is the original locality given by Goldfuss.)

\section{Platychinus vesiculosus ( $M$ Coy). P1. 3. D. fig. 3. \\ Ref.-Ann. Nat. Hist. 2nd Series, Vol. II. p. 216.}

Sh. Ch.-Borly spheroidal, depressed : visceral portion hemispherical, deeper than the cup: pucis pentagonal, small, flattened; 1st primary radials or sccepule: small, rotundato-quadrate, one-third wider than long, very thick, gilbhons, slightly coneare in the centre, lower edge hanging below the pelvis, excavation for the first arm-joint (or 2nd primary radial) very small, round, marginal, less than one-third the depth of the lst primary 
radial or scapula; visceral plates very large, irregular, polygonal, some of them nearly equalling the 1st primary radials (scapula) in size, they are moderately convex, and each rendered rugged by several small tubercular projections; mouth lateral, surrounded by small plates. Length of small specimens from pelvis to vertex six lines, width eight lines.

The very large, bubble-like tuberculation of the visceral plates and the small, gibbous scapulic give a most peculiar aspect to this species, quite unlike any other I am acquainted with. I find the characters very constant.

Position and Locality.-Not uncommon in the carboniferous limestone near Bakewell, Derbyshire.

Explanation of Figure-Plate 3. D. fig. 3. Profile of specimen natural size.

\title{
Genus. ACTINOCRINUS. See page 55.
}

\author{
Actinocrinus (Amphoracrinus) atlas (McCoy). Pl.3. D. fig. 5. \\ Ref.-Ann. Nat. Hist. 2nd Series, Vol. IX. p. 248.
}

Sp. Ch.-Bodly elongate-oval, diameter betwcen the arms little more than half the height of the body ; pelvis pentagonal, of three thick flattened joints; Ist interradial small, pentagonal; five 1st primary radials hexagonal, nearly twice as wide as long; 2nd primary radials as long as the first, but only one-third wider than long, hexagonal or sometimes quadrate (according as the upper lateral angles are entire or slightly truncated); 3rd primary radials (scapula' ) short, pentagonal, as wide as the 2 nd primary radials; interradials hexagonal, excecding the 1 st primary radials in length; arm-bases prominent, and over each is an elongate conical tubercle; pectoral plutes rather large, convex and irregularly polygonal; vertex covered by a very large hemispherical plate, surrounded by six slightly smaller polygonal ones, each having a large conical protuberance in the middle ; moutle longitudinally oval, rather nearer the vertex than the arm-base over the pentagonal 1st interradial, to which it inclines; all the plates except the large ones of the vertex nuarked with minute vermicular wrinkles. Length from pelvis to plate on vertex one and a half inch, diameter between the arms ten lines.

The enormous size of the visceral portion above the arms (nearly three times the height of the cup) has suggested the specific name for this crinoid, which resembles the A. (Amphorccrinus) Gilbertsoni and A. (Amphoracrimus) ranplow in its markings, prominent tubercles over the arm bases, and great plates on the vertex; but it differs from those, besides the great size of the visceral portion, very obviously in the greater proportional length and less width of the radials, most remarkably of the second series.

Position and Locality.-Rare in the carboniferous limestone of Bolland.

Explanation of Figure.-Plate 3. D. fig. 5. Profile of specimen, natural size.

\section{ACTinocrinus Gilbertsoni (Mill.)}

\section{Ref. and Syn-Actinocrinus Gilbertsoni Mill. Phillips, Geol. York. Vol. II. t. 4. f. 19.}

$S p$. Ch.-Cup very short, coneave, conic; arms large, the diameter at their base equal to the depth of the cup; prominent, abdominal portion of cup above arms very large, tumid, three times as high as the depth of the cup; near the vertex is a large convex plate, surrounded, except near the mouth, by a circle of smaller large convex plates; month small, longitudinally oval, half-way between the central plate and the bases of the two arms over the pentagonal 1st interradial; rest of abdominal plates small, convex, except one sharp conical one near the base of each arm; plates of the cup formed and sculptured as in the A. amploro, but the primary radials much wider and shorter, the length of the 1st and 2nd primary radials together, only two-thirds the width of the Ist primary radial, and the sculpturing more minute.

The height considerably execeds the width, which with the smaller and more lateral mouth, small spiniform arm-tubercles, smaller size, and the above-mentioned characters of the plates of the cup distinguish this from the A. amphora.

Position and Locality.-Carboniferous limestone, Bolland. 


\section{Actinocrinus (Amphoracrinus?) olla (MICoy). Pl. 3. D. fig. 6. Ref.-MIC Coy, Ann. Nat. Hist. 2nd Series, Vol. III. p. 247.}

$S p . C h .-B o d y$ inversely pyriform, very gibbous; arm-bases small, not very prominent; cup below the arms hemispherical, visceral portion above very wide, elevated, eylindrical; all the plates above and below flattened; pelcis small, flattened, hexagonal, supporting on five of its sides five large hexagonal lst primary radial plates, about one-third wider than long, and on the sixth side one pentagonal 1st interradial plate; the five 2nd primary radials are scarcely one-third wider than long, smaller than the first ones, and hexagonal with the two upper lateral sides so short as sometimes to make the plates seem quadrangular; 2nd interindiul. hexagonal, longer than the 1st primary radials; pectorul plates rather large, flat, polygonal; 3rd primary radials (scapule) pentagonal (or occasionally with the upper lateral angles truncated so as to be slightly hexagonal or heptagonal), one-third shorter than the 1st primary radials; 3rd interradials (intersecputer:s) heptagonal or octagonal, as long as the 2 nd interradials; the surface of all the ylates marked with minute vermicular wrinkles. Diameter of cup one inch nine lines.

The sculpturing resembles that of the A. (Ampluracium:) anphora, from which the species is distinguished by its round inflated pot-like figure, small arm-lases, proportionate length of the primary radials, ste.

Position and Locality. - Very common in the Derbyshire carboniferous limestone in company with the Poteriocrimus granulosus.

Explanation of Figure.-Pl. 3. D. fig. 6. Profile of specimen, natural size.

\section{Actinocrinus polydactylus (Mill.)}

Ref. and Syn.-Actinocrinites polydactylus Mill. Crin. Actinocrimus polydactylus Phill. Geol. York. Vol. II. t. 4. f. 17.

Sp. Ch.-Plates nearly as in A. triuconte-ductylus, but the radiation much stronger and more simple, only one ridge going from the centre of one to the centre of each surrounding plate; five arms, each having two hands, of one lateral simple finger, and the inner portion divided into six.

This is a smaller species than the A.triaconta-dactylus, but closely resembles it in many of the details; the ridges are much more distinct, however, and it is at once distinguished lyy the greater number of its fingers: the pectoral plates generally shew the remarkable character of being palmated, and divided into several points or branches.

Position and Locality.-Carboniferous limestone, Bolland.

\section{Actinocrinus tessellatus (Plitl.)}

Ref and Syn._Actinocrinus tessellatus (Phill.) Geol. York. Vol. II. t. 4. f. 21.

Sp.Ch.-Cup, shape and size of the A.triaconta-dactylus; 1st primary radials large, hexagonal, longer than wide; three upper sides nearly equal and shortest: Ind primary radials hexagonal, all the sides nearly equal ; 3rd primary radials (scapnle heptagonal: surfuce of the plates nearly smooth, crenulated at the edges with short, museular ridges; visceral portion convex, mouth tubular excentric: visceral plates of moderate size. very irregularly polygonal, convex.

This species is very rare; the peculiar form of the 3rd primary radials or scapula distinguish it from the allied species. Is it not the A. lavis (Mill.)?

Position and Locality.-Carboniferous limestone, Bolland.

\section{ACtinocrinus triaconta-DaCtylus (Mill.)}

$$
\text { Ref.-Actinocrinus triaconta-dactylus Mill. Crin. }
$$

Sp. Ch.-Cup obtusely conical; 3rd primary radials (scapulie) hexagonal, supporting five arms, having each two hands, provided with three fingers each; arm-bases prominent; visceral portion flattened; mouth a little excentric, tubular, visceral plates very small, forming rugged short points: each side of the plates of the 
cup crossed by two to four ridges running towards the centre of each adjoining plate, and the interval at the corners sometimes filled with angularly bent ridges. Length of body, from the scapula or 3rd primary radials to base of pelvis, one inch; width one inch three lines.

The column of this abundant species is round, formed, near the pelvis, of thin joints, alternately a little longer and thicker, every third or fourth joint larger; nearer the base the joints become of an uniform thickness and size; when young they are contracted at the sutures, so as to be slightly moniliform; the articulating surface is regularly striated from the centre; round auxiliary side-arms come off irregularly from the columns; the plates of the body generally exhibit very distinctly the marks of muscular contraction, in the form of strong, variable, radiating ridges. The fingers are formed, as usual, of two series of joints.

Position and Locality.-Carboniferous limestone, Bolland.

\section{2nd Ord. Brastotdea.}

Body enclosed in a cup of few, thin, calcareous plates; fixed by a small jointed stem to foreign bodies: five rows of pseudambulacra, extending from the mouth in the middle of the upper aspect towards the base, set with small jointed tentacles in place of suckers or arms.

\section{Genus. CODASTER ( $M T^{c}$ Coy).}

\section{Ref.-McCoy, Ann. Nat. Hist. 2nd Series, Vol. III. p. 250.}

Gen. Char.-Cup conical, with the upper part broad, flat, truncate; pelvis deep, conical, of three pieces, one tetragonal and two pentagonal, each having its imer apex notehed to form part of the round columnar canal; on the upper edges of these rest five large equal first supra-basal plates which reach to the truncated summit, to which, from their mesial gibhosity, they give a pentagonal outline; in the centre of this superior disk the mouth seems situated, and from it five prominent, minutely porous pseudambulacra diverge, one to each angle, each being placed on a thick tapering ridge divided by a mesial sulcus; from the re-entering angles of these ridges four other thick, rapidly tapering ridges proceed, one to the middle of each of four of the straight sides, each ridge at its thick, oral end, shews an obscure impression; the fifth space is without a ridge, being occupied by a large, ovate or lozenge-shaped (? anal) opening; the depressed, triangular intervening spaces are marked with coarse, rough parallel strice nearly coinciding in direction with the pseudambulacral ridges, and converging to the second set of ridges; the impressed lines between these strix seem punctured; the fifth (? posterior) space is without sulcation.

These strange and beautiful forms, the "bell-stars," as they may be called, are obviously allied to Pentremites (taking P. Derbiensis, florealis, oblongus, ellipticus, and such like, as the types of the genus), from which they differ in having the small basal plates enormously developed into a conical pelvis, and having the pseudambulacra entirely confined to the capital plates (which here form a truncated disk), instead of being continued through a slit in the supra-basal plates nearly to their base. The peculiar sulcation, represented in our figures in four of the interambulacral spaces, resembles that of some Cystiden, but is unlike anything in Pentremites. I cannot find any trace of the four small ovarian pores, although the large opening above mentioned holds the place of the fifth or great posterior ovarian pore of the I'entremites and the Echinicla; it will also be observed that it holds the place of the month of certain Platycrini. In Prof. Forbes's paper on the British Cystidea in the second volume of the "Memoirs of the Geol. Survey," p. 529, there is a figure representing "the projection of the arm-bearing surface of the Pentremites pentagonalis," which resembles the disk of our genus except in having the posterior interambulacral space sulcated, and with a thick mesial ridge like the rest; I do not suppose that that figure is meant to represent the Platycrinus pentagonalis of Miller, forming the Pentremites id. of G. Sowerby and Phillips, which presents no resemblance of the kind. I only know the following two species, from the carboniferous limestone. 
Codaster acutus $\left(M^{c} C o y\right)$. Pl. 3. D. fig. 7.

Ref.-M $\mathrm{M}^{\mathrm{C}} \mathrm{Coy}, \mathrm{Ann}$. Nat. Hist. 2nd Series, Vol. III. p. 251.

Sp. Ch.-Pelvic and supra-basal plates of equal length; pelvis acutely conical, obtusely subtrigonal in section; columnar adherence small, round, prominent; surface smooth. Length six lines, width of disk five lines.

Position and Locality. - Not very uncommon in the carboniferous limestone of Bolland.

Explanation of Figure.-Pl. 3. D. fig. 7. Profile of speeimen, natural size.

Codaster trilobatus $\left(M^{c}\right.$ Coy $)$. Pl. 3. D. fig. 8 .

Ref.-McCoy, Ann. Nat. Hist. 2nd Series, Vol. III. p. 251.

Sp. Ch. - Supra-basal one-third longer than the basal or pelvie plates; pelvis divided into three tumid lobes which hang below the columnar adherence; surface smooth. Length seven lines, width of disk five lines.

Position and Locality.-Not uncommon in the carboniferous limestone of Derbyshire.

Explanation of Figures.-Plate 3. D. fig. 8. Profile of specimen, natural size.-Fig. Sa. End view of truncated summit of ditto, magnified.

\section{Genus. PENTREMITES (Say).}

Gen. Char.-Pelvis small, pentagonal, of five pentagonal pieces, supporting five large pentagonal suprabasal pieces or scapulie, each of which has a long narrow fissure from the apex nearly to the base, to receive the ends of the pseudambulacra ; in the upper re-entering angles of the plates are five large ovarian pentagonal plates, the apices of which converging towards the vertex close the eup, leaving at their junction a small central mouth; a narrow space intervenes, between each pair of these plates, for the pseudambulacra, and each is pierced at its apex by an ovarian foramen, one of which is much larger than the rest; pseudambulacra of two rows of very minute pentagonal plates, one oblique pair of pores (sections of alimentary canals) in each row.

I think I observe ocular pores at the oral ends of the pseudambulacra, in which ease they would be in an abnormal position, though as usual beside the ovarian pores; these latter, it will be remarked, resemble those of the Echinida in structure, but those of the star-fishes in position. Before M. Yondell's discovery of the rows of fingers on the pseudambulacra of the American Pentremites it lad struck me that these latter could not really be ambulacra as was supposed, because instead of being lodged in the sutures between the so-called scapulæ, they were each received in a deep notch down the middle of those plates, - a position which is obviously identical rather with that of the arms of true Crinoids.

\section{Pentremites campanulatus $\left(\boldsymbol{I}^{c}\right.$ Coy $)$. Pl. 3. D. f. 9.}

$$
\text { Ref-M Mc Coy, Ann. Nat. Hist. 2nd Series, Vol. IlI. p. } 249 .
$$

Sp.Ch.-Bell-shaped, base as wide as the body; psendambulacra wide above, tapering to the angles at the base; transverse sutures between the first and second series of supra-basal plates nearly medial; base flattened; surface minutely granulated. Length three lines, width three lines.

If we suppose the lower third abruptly cut off a $P$. ellipticus we should have a good idea of the shape of this little species, which, agreeing with the above in most characters, is distinguished by its small size more tapering ambulacra, greater proportional width, and wider base.

* I have used the word pseudambulacra to designate those poriferous rows in Pentremites, \&c., which resemble ambulacra, but the pores of which are found by MM. Röemer and Yondell (Bulletin de la Soc. Géol. de France, for April 17,1848$)$ to be really the alimentary canals of a double row of little jointed tentacles resembling, I imagine, those of Pseudocrinites. 
Position and Locality.-Rare in the carboniferous limestone of Derbyshire.

Explanation of Finure.-Plate 3. D. fig. 9. Tiew of specimen from Derbyshire, magnified four diameters; the line shews the natural size.

\title{
Pentremites Derbiensis (Som.).
}

\author{
Ref.-Sow. Zool. J. Vol. II. t. 11, f. 3. Phil. Geol. York. t. 3. f. 10.
}

Sp.Ch._Spheroidal or slightly pyriform, greatest width above the middle, upper part oltusely rounded, lower portion slightly tapering to the coneave, pentagonal base, the angles of which are prominent; section olseurely pentagonal, each of the sides slightly flattened in the middle, and slightly convex at the margins; re-entering angles of transterse suture slightly less than one-third of the length from the base; surface shagreened with obscure rows of close minute obtuse granules; average length six lines, width the same (or a little more in many specimens).

This species varies a little in shape, the lower half of some specimens being more tapering, and the upper part more inflated than in others; in some the base is unusually narrow, and the width varies considerably. The transverse suture being considerably below the middle separates it from the $P$. orbicularis, although certain lines ocensionally visible in old inflated specimens, on the second series of supra-basal plates, parallel with the transverse sutures, might casily he mistaken for them if eare be not taken to observe that the certical suture is not continued above the basal third of the length.

\section{Pentremites elifipticus (Sow.).}

\section{Ref.-Sow. Zool. J. Vol. II. t. 11, f. 4. Phil. Geol. York. t. 3, f. 6, 7, 8.}

$S p . C h$.-Elliptical, greatest width about the middle, gradually narrowing to the obtusely-rounded apex, and narrow, pentagonal, coneave base; section obscurely pentagonal, the sides slightly convex in the middle, and very slightly concave towards each end; reentering angle of transverse suture midway between the apex and base; surface closely covered with olsseure lines of minute granules: average length six lines, in proportion thereto the greatest diameter is $\frac{85}{100}$, width of base $\frac{17}{100}$.

In size and shape this resembles the $P$.oblongus (Gilb.), from which, however, the mesial transverse suture easily distinguishes it.

Position and Locality.-Not uncommon in the carboniferous limestone of Derbyshire.

\section{5th Ord. Perischoechinidz.}

Body encased in a spheroidal crust, of more than twenty rows of strong calcareous plates ; five ambulacra, composed of two rows of pentagonal plates each, extend from the month in the middle of the ventral aspect to the anus on the middle of the superior or dorsal aspect, piereed by two double rows of ambulacral pores, and terminated above by a pentagonal ocular plate; interambulacra terminated dorsally by five large pentagonal ovarian plates, the posterior one of which is larger than the rest and porous; rows of interambulacral plates three, five, or more, the outer or lateral rows pentagonal, the inner ones hexagonal.

I have established this Order (Ann. Nat. Hist. 2nd Series, Vol. III. p. 251) for the reception of those Echinodermata of the Palrozoic Rocks hitherto confounded with the Echinider; all of the latter Order however agree in having the case made up of twenty vertical rows of plates, five pair of ambulacral, and five pair of interambulacral ones; this is not only the most persistent character of the entire group, but the number becomes of great interest when, with $A$ gassiz, we view the globose test of the sea-urchin as a mere modification of the parts of a five-rayed star-fish,, -an ideal division of the medial suture connecting the two rows of plates in each interambulacrum of the former, giving at once the ambulacra, lateral ossicles, and other eharacters of the latter. The Echinites of the Palreozoic rocks however are constructed on an entirely different plan, having three or some greater odd number of rows of interambulacral plates, instead of teco as in those of the newer 
rocks or existing seas. In these latter it would of course be impossible to divide the test at the suture into five equal parts, and the name I have proposed refers to the comparative complexity of their structure.

On the same grounds that the Order Echinide is divided into the families Echinide and Cidarida, this might he divided into the families Palechinitu and Archacociduride-the first of both families laving imperforate spiniferous tubereles of one lind, the ?nd family of each order having numerous small secondary tubercles and few large primary ones, perforated for the ligamentum teres of the spine.

\section{Genus. ARCHEOCIDARIS ( $\left.\boldsymbol{I}^{\circ} \mathrm{Coy}\right)$.}

Ref.-McCoy, Synopsis Carb. Foss. Irel. p. 173, and Ann. Nat. Hist. 2nd Series, Vol. III. p. 252.

Gen. Char.-Interambulacra of three or more rows of plates bearing each one large, mammillated, perforated, primary tuberele surrounded by an elevated ring, round which the small secondary tubercles are seattered; primary spines very large, resembling those of Cidaris in form.

\section{ArCilæocidaris vetusta (Phill. sp.)}

Syn. and Ref.-Cidaris vetusta Phil. Geol. York. Vol. II. p. 208.

Prof. Phillips gives no detailed description, nor figure of his $C$. vetusta, and I have little doubt it is identical with the previously described $C$. Crii (Flem.), and the subsequently deseribed C. Benturbensis (Portk.); I have hovever used his specific name here to designate a fragment of a primary spine, and its supporting plate in the collection from the Derbyshire limestone, which may perhaps be distinguished from the $A$. $I$ rii by the generally smaller size, and the more delicate, thorn-like denticles of the spine. 


$$
\text { - }
$$




\title{
Sub-kingdom ARTICULATA Cw.
}

\author{
$=$ Annulos $\alpha$ Mac Leay, =Diploneur $\alpha$ Grant, = Homogangliata Owen .
}

The most striking external characteristic of the multitudinous forms included in this sub-kingdom, is the division of the more or less indurated integument into a succession of transverse ring-like segments. All animals with jointed bodies belong to it, but a few members of the group (e.g. the Cirripedia) scarcely shew this character, and they have accordingly been scparated from what we now know certainly to be their true allies, even by such observers as Cuvier and Lamarck. One unvarying characteristic of the entire group is, however, to be found in the disposition of the nervous system, which distinguishes them completely from the preceding group of so-called radiated animals, and from the next higher group, or mollusea. From this consideration it is that Grant and Owen have named the division. One pair of principal ganglia (representing the brain of vertebrate animals in function and position) is dorsally placed occ the asophagus at the anterior end, supplying nerves to all the higher senses-taste, smell, hearing, sight, the antenna, frc.; from these, two cords surround the osophagus, and form two parallel lines along the ventral aspect of the body, and on these are symmetrically placed numerous, nearly equal, ganglia, usually one pair for each segment of the body; generally speaking, the lower the type the greater the number of segments in the body and of ganglionic centres, while the higher the type (whether we speak of adult conformation, or the progress of metamorphosis) the greater becomes the nervous centralisation, the ganglia coalescing as it were from behind, as the joints of the body diminish in number; as the ganglia decrease in number they increase in size, and the intelligence and physical perfection of the creature increase in a corresponding ratio.

The sub-kingdom Articulata includes the five following classes:-1, Annellida (or Annulutu); 2, $V_{y}$ riapoda; 3; Insecta; 4, Arachnida; 5, Crustacen.

\section{1 st Class, ANNULATA.}

The animals of this class have long vermiform bodies, composed of a great number of only moderately indurated annular segments, only differing from each other in size, except the first, which contains the jarrs, and generally eyes, and often antennie for touch, and the last, which is perforated by the anus; each of the other rings usually is furnished with setæ for locomotion, but never provided with articulated legs; the blood is red, not (as some writers suppose) from red globules, as in the Tertebrata, but uniformly tinged. They have a mouth at the anterior end, followed by a short o'sophagus, leading to a stomach, and often a gizzard, from which a straight intestine extends directly to the anus, which is dorsally placed in the last segment; numerous creca (or biliary duets!) enter the stomach on each side. A tortuous pulsating dorsal vessel sends the blood from the tail to the head, where it enters a large ventral vessel, which returns the blood again to the dorsal one by numerous anastomosing branches at the posterior end. Over the great ventral vessel, and chain of ganglia, is another longitudinal vessel, the "supra-ganglionic," into which the blood 
is driven from the anterior part of the dorsal vessel by a series of vertical, moniliform, muscular hearts, the current rushing towards the tail, where it enters the great dorsal vessel by anastomosing branches, and helps to propel its contents towards the head. Most of them are hermaphrodites. The eyes, when present, are formed of a simple expansion of the optic nerve, eovered by a transparent cornea, without any of the usual lenses or humours.

The class Annulata is divisible into three orders: 1st, Abranchia; 2nd, Dorsibranchiata; 3rd, Tubicola.

\section{1st Oid. ABRANCHia.}

This group is distinguished by the absence of external branchix, respiration being effected partly by the surface of the skin, and partly by internal vascular sacenli opening by external spiracles. It contains, as tribes, first, the Annulata Suctoria or leeches; second, the Annulata Terricola or earth-worms; and third, the little-known $N$ emertina, a marine group of very long, slender, smonth worms, without antenna, feet, or other appendages to the skin, and very indistinetly annulated. To this group has been provisionally referred the Silurian genus, Nemertites.

\section{Genus. NEMERTITES (Mac Leay).}

Gen. Char.-Body very long, linear, slender, of nearly uniform thickness throughout, without distinct articulations.

Only one species of this supposed genus of Nemertina has occurred, and it is very doubtful whether it and the so-called Gordice of the American Taconic slates may not belong more properly to the vegetable kingdom. (See the genus Palceochorda, $\mathrm{M}^{\mathrm{C}} \mathrm{Coy}, \mathrm{Pl}$. 1. A.)

\section{Nemertites Olivantii (Murch.) \\ Ref.-Murchison Sil. Syst. t. 27. f. 4 .}

This body occurs usually in long loop-like folds, about half an inch apart, and three or four inches long. The diameter of the smooth subcompressed body is rather more than half a line; the length many inches, but unknown.

Position and Locality.-Not uncommon in the fine olive slates of Llampeter, Pembrokeshire.

\section{2nd Ord. Dorsibranchiata $(C w$.}

This group is almost equivalent to the Annellida Errantia of authors; it is composed of centipedelike worms, having the body entirely naked, and possessed of great powers of locomotion; the head is distinct and provided with eyes, jaws, antennæ, \&c. The group is characterized by the almost uniform distribution of the gills in tufts over the remainder of the segments, which are very numerous and equal among themselves; one pair of gills on the outer edge of most of the rings; at the base of each branchial tuft is a retractile bunch of stiff bristles for locomotion, enclosed at the base in a thick, fleshy, lobe-like foot, and often a short, slender, fleshy, articulated process above and another below, called "cirri."

The two Cambrian genera, Nereites and Myrianites, apparently the first ereated beings of their class, belong to this, the most highly organized, group of all the Annulata.

\section{Genus. NEREITES (MIac Leay).}

Gen. Char.-Body very long, of nearly equal width throughont, of upwards of one hundred nearly equal and similar segments; each segment with a thick, short, ovate, lobe-like foot, surmounted by a slender cirrus exceeding the foot and the segment in length (or the distance between one cirrus and the next). 


\title{
Nereites Cambrensis (Murch.)
}

\author{
Ref.-Murchison, Sil. Syst. t. 27. f. 1.
}

$S p . C h$.-Length unknown (upwards of two feet), usually seen in irregular obtusely angular contortions; width three lines (or rather more, as the cirri have a gentle backward curve); width of the body half a line; cirri thick, gradually tapering, two lines long; feet forming thick, ovate, fleshy lobes, one and half lines long; distance between the cirri (equal to length of segments) one and half lines.

The thick fleshy feet are not sufficiently distinet beneath the cirri in the above quoted figure, and these latter do not taper quite enough. A single indistinct specimen, a little wider than the above and having the feet slightly longer and more pointed, has occurred in the Scotch slates in the valley of the Tweed, in company with a multitude of the Crossopodia Scotica ( $\left.\mathbf{M}^{\mathrm{C}} \mathrm{Coy}\right)$, and it may perhaps ultimately prove distinct; but as there are exactly the same number of feet and cirri in a given space, I have little hesitation in considering it as only a variety-if even so much, of the Llampeter species.

Position and Locality.-Not uncommon in the slates of Llampeter, and Var, $a$. very rare in the olive slate of Thorney Lee Quarry, on the Tweed (opposite Ashestiel).

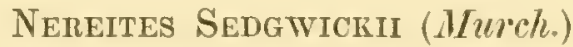

Ref.-Murchison, Sil. Syst. t. 27. f. 2.

$S_{p} . C h$.U Usually disposed in long straggling trails, and short irregular rounded loops; length unknown (upwards of a foot); width of specimen slightly more than two lines (but the ends of the cirri curved, which diminishes the apparent width); width of body slightly more than half a line; length of the segments (equal to the distance between the cirri) one line; length of cirri (supposing them straightened) one and half lines; feet narrow, slightly more than half the length of the cirri.

I have been so fortunate as to detect the feet of this species in one part of the specimen in the Cambridge Collection; they are much smaller and more delicate than in the $N$. Cambrensis. A semielliptical hollow space, rather difficult to account for, is frequently seen on each side between each pair of cirri; it strikes me it may be the trace of the sweeping action of the little bush-like, retractile packet of bristles, forming the locomotive organs of the allied recent worms.

Position and Locality.-Not uncommon in the olive slates of Llampeter.

\section{Genus. MYRIANITES (Mac Leay).}

Gen. Char.-Body longer and more slender than in Nereites; cirri of the feet short (scarcely as long as a segment of the body, or the distance between one cirrus and the next); feet indistinct.

\section{Myrianites Macleayi (Murch.) \\ Ref.-Murchison, Sil. Syst. t. 27. f. 3.}

Sp. Ch.-Upwards of a foot long, usually coiled in long curved transverse folds, about one-fourth of an inch between the parts, which are very frequently approximately parallel; width of the animal throughout slightly more than one line, of which the body occupies nearly one half (being half a line wide), the cirri of the feet forming the remainder; the space between the cirri on one side slightly exceeds their length, being equal to the width of the body (indicating segments as broad as long).

The above quoted figure represents the worm slightly too wide where the cirri are marked.

Position and Locality.-Not uncommon in the olive slates of Llampeter. 
Mrriantes tenuis $\left(M^{\circ} C^{\prime} o y\right)$. Pl. 1. D. fig. 13.

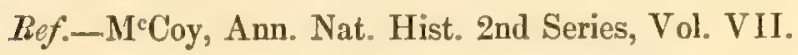

$S p . C h .-U$ sually coiled in numerous, small, very irregular, undulations; diameter of body about onethird of a line.

This little worm is easily distinguished from the $M$. Macleayi (Murch.) by its very slender proportions, agreeing more nearly in this respect with the MI. Murchisoni of Prof. Emmon's "Taconic Slate." I think it was about a foot long, from following, as well as I could, the convolutions of three individuals. I have only in one part seen traces of the cirri, which have the same general proportions as in the DI. Macleayi (Murch.)

Position and Locality.-Not uncommon in a particular layer of the fine olive slate of Greiston, on the Tweed, near Inverleithen.

Explanation of Figure-Pl. 1. D. fig. 13. From the slate of Greiston, on the Tweed, natural size.

\section{Genus. CROSSOPODIA ( $M^{c}$ Coy).}

Ref.-McCoy, Ann. Nat. Hist. 2nd Series, Vol. VII.

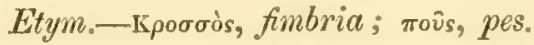

Gen. Char.-Body long, moderately slender, of excessively short, numerous, wide segments, from which arise very long, delicate, crowded cirri, forming a broad dense fringe on each side, completely concealing the feet (at least five or six times longer than a segment of the body, or interval between one cirrus and another).

These beautiful worms are easily distinguished from their Protozoic companions, the Nereites and $M I y-$ rianites, by the excessive shortness of the joints of the body, as indicated by the very crowded cirri (only one of which comes from the dorsal aspect on each side of any given segment) and by the broad, close, fringe-like, development of these latter, concealing the lobes of the feet, so conspicuous in the two genera named.

\section{Crossopodia lata (Mcoy). Pl. 1. D. fig. 14.}

Ref.-M당, Ann. Nat. Hist. 2nd Series, Vol. VII.

$S p$. Ch.-Length unknown (upwards of one yard); width nine lines, width of body three lines, length of cirri three lines; articulation of body and number of cirri indistinct, but apparently three in a space of one line.

Prof. Sedgwick informs me, that the portion of this remarkable worm which he saw in the rock, and of which the specimen described is a part, measured upwards of a yard in length, without signs of tapering or alteration of character, thus agreeing in proportion with its living allies. Its great width easily distinguishes it from the older C. Scotica ( $\mathrm{I}^{\mathrm{C}} \mathrm{Coy}$ ), and it has no resemblance to any other fossil I know of. The piece described is about four inches long, and is gently flexuous.

Position and Locality.-Tilestone (Upper Ludlow) of Storm Hill, Llandeilo.

Explanation of Figure.-PI. 1. D. fig. 14. Fragment, natural size, from the Tilestone Storm Hill, Llandeilo.

$$
\begin{gathered}
\text { Crossopodia scotica }\left(M^{c} C o y\right) \text {. Pl. 1. D. fig. } 15 . \\
\text { Ref.-McCoy, Ann. Nat. Hist. 2nd Series, Vol. VII. }
\end{gathered}
$$

Sp. Ch.-Length unknown (upwards of two feet), width nearly two lines, width of body (and trail on the surface of the beds) one-third of a line; cirri very fine, close, delicate, about five in the space of one line.

This interesting worm is closely allied to the so-called Nereites Loomisii of Prof. Emmon's "Memoir on the Taconic System," t. 3. f. 3, from the taconic slates of Waterville, Maine. The American species 
certainly belongs to our new genus Crossopodia, but, if correctly drawn, has much thicker and fewer feet. The narrow deep trail of the middle part of the body on the upper surface of the planes of deposition of the slate, and the narrow cord-like ridge formed by the casts in them on the under surface of the lamina, might possibly be mistaken for a different worm resembling a Gordius, without due caution or the absolute demonstration of their nature, afforded by many of the specimens.

Position and Loculity.-Absolutely swarms in some parts of the greenish slates of Thorney Lee Quarry, on the Tweed, opposite Ashestiel, near Inverleithen.

Explanation of Figures.-Pl. 1. D. fig. 15. From the slates of Thorney Lee Quarry, on the Tweed; natural size; the narrow markings being the trails left by the worms, the broader portions containing the body and fringe-like cirri perfect.

\section{3rd Ord. Tubicola.}

As their name implies, all of this order inhabit tubes, and are more or less sedentary, though not absolutely fixed organically to their dwelling. Their tube is either simply membraneous, formed of dried exudations from the surface of the body, or formed of agglutinated grains of sand, \&c., or still more commonly composed entirely of calcareous matter; it is usually long, open at one end and closed at the other. The inhabiting worms are without eyes or antennæ, and have the gills attached to the sides of the head (whence their name Cephalobranchiata), forming two large feather-like pulsating tufts, having a contractile power sufficiently strong to drive back the blood received from the heart when it becomes aerated. The organs of locomotion are reduced on most of the segments to small processes, to assist in protruding or retracting the creature in its tube; and the cirri immediately about the head are altered into long tentacles, one on each side of the mouth, one of which in Serpula is much larger than the other, and bears on its extremity a circular, or conical, calcareous operculum for closing the mouth of the tube (which has sometimes been mistaken for Patella).

The tube affords characters for recognizing in the fossil state the two tribes, Serpulince and Amphitritce, into which the order has been divided in the recent state.

\section{1st Tribe. SERPULIN E.} Marine.

Tube strong, calcareous, dull (not polished), contorted irregularly, and attached to foreign bodies.

\section{Genus. SPIRORBIS (Lam.)}

Gen. Char.- - Tube discoidally coiled, of few whorls, and attached by one side of its whole lengtl.

\section{SPIRORBIS TENUIS (Sow.)}

\section{Ref.-Sow. Sil. Syst. t. 8. f. 1. and t. 11.f. 8. (S. Levoisi on plate).}

Sp. Ch.-Discoid, dextral, of one and half or nearly two whorls, partially exposed in a wide, deep, umbilicus; whorls with a broad or high back, sides sloping to the umbilicus, slightly concave, bounded by an obtusely rounded angle on both the umbilical and outer edges; diameter rather less than one line, width of last whorl rather less than one-third the diameter; surface with strong transverse, and obscure spiral lines.

Not uncommon, adhering to the inside of the last chamber of cephalopod shells, so that specimens often seem sinistral. I have only seen the surface very imperfectly preserved.

Position and Locality.-Lower Ludlow rock of Green Quarry, Leintwardine. 


\section{2nd Tribe. AMPHITRITE.}

Tube fragile, straight or gently curved, unattached, formed either of naked membrane alone, membrane with grains of sand, \&c. agglutinated, or solidified by a small proportion of calcareous matter, forming a dense thin, smooth, glossy tube. Marine.

\section{Genus. SERPULITES (Hurch.)}

Gen. Char.-Tube smooth, arched, slightly calcareous, glossy; having two small longitudinal tubes at opposite points of the circumference (the convex and concave faces of the curve), stronger than the rest of the shell, and prolonged at the posterior end.

\section{Serpultes Dispar (Salt. in App.) Pl. 1. D. fig. 11, 12.}

$S p$. Ch._Upwards of four inches long and two lines wide in the greater part of its length, slightly curved, rather rapidly tapering towards the small end; extremities unknown; two lateral tubules very strong, calcareous, one-third of a line in diameter, intervening portion of tube very delicate, nearly membrancous.

The small diameter, and the exceeding delicacy of the sides of the tube compared with the strength and hardness of the two lateral tubules, easily distinguish this species from the S. longissimus (Murch.) Not unfrequently the delicate membraneous portion disappears, leaving a very puzzling appearance in the two disconnected wire-like lateral tubules.

Position and Locality.-Abundant in the Upper Ludlow rock of Sealthwaite Rigg, N. end of Benson Knot, Kendal, Westmoreland; in the calcareous flags of Dinas Bran, Llangollen; N. end of Tenter Fell, Kendal. Single lateral tubules apparently of this fossil occur in the black shale at three miles N. of Builth, Radnorshire; in the fine greyish sandstone of Tan y Craig, Builth; in the sandstone of the Hollies, Church Stretton, Shropshire.

Explanation of Figures.-Pl. 1. D. fig. 11. Natural size from Benson Knot,-Fig. 12. Ditto.

\section{Serpulites Longissiaus (Murch.)}

$$
\text { Ref.-Murch. Sil. Syst. t. 5. f. } 1 .
$$

Sp. Ch. - Subcompressed tube upwards of a foot long, gradually tapering at the rate of only two lines in five inches, forming part of a curve about one foot in diameter at the large end, but curving more rapidly towards the apex; surface with obtuse transverse undulations; shell thin, glossy, opaline; average diameter four lines, of thickened convex and concave margins nearly one line.

Position and Locality.-Common in the Upper Ludlow rock of Aymestry, Herefordshire.

\section{Genus. TRACHYDERMA (Phill.)}

Gen. Char.-Tube submembraneous, tough, flexible; surface with short irregular transverse wrinkles or plaits.

This genus has been proposed (Mem. Geol. Surv.) by Prof. Phillips for some large, cylindrical, variouslycurved coriaceous tubes of the Upper Silurian rocks, with an irregular, sharp, transverse plication of the surface; this latter character is so variable, and obviously unimportant, that by extending the genus so as to include all the simple submembraneous naked tubes of the Silurian rocks it would be more useful and intelligible, being distinguished from Serpulites by the latter having two strong lateral tubules, which I have shewn (Synopsis of the Carboniferous Fossils of Ireland, p. 170) to be highly characteristic of that genus, although it seems not to have occurred to the Survey observers as a distinctive character. 


\section{Trachyderila squamosa (Phill.)}

Ref.-Phill. Mem. Geol. Surv. Vol. II. t. 4. f. 3.

A very obscure fragment, apparently of this species, has occurred in the Upper Ludlow rock of Benson Knot, Kendal, IVestmoreland.

\section{Trachyderia ? Levis $\left(M^{c} C o y\right)$. Pl. 1. D. fig. 10. \\ Ref.-McCoy, Ann. Nat. Hist. 2nd Series, Vol. VII.}

$S p . C h$.-Tube slightly curved, thin, coriaceous, slightly tapering, subcompressed, slightly more than one line in diameter at the broad end, and slightly less than one line at the imperfect smaller end of a specimen one inch seven lines long; surface nearly smooth.

The specimen is a brown, tough, flexible tube, irregularly and gently compressed (parallel to the plane of stratification of the rock) assuming an oval section; and being filled with the bright-coloured matrix shews clearly the thinness of the tube, which, from the same cause, has a few irregular indentations of the surface, which otherwise seems smooth.

Position and Locality.-In the rery fine beds of Caradoc sandstone of Acton Scott, Church Stretton, Shropshire.

Explanation of Figures.-Pl. 1. D. fig. 10. Specimen from the fine Caradoc sandstone of Acton Scott, natural size and section.

\section{2nd Class. CRUSTACEA.}

The animals of this class have a hard-jointed integument, composed of a thick, internal, spongy chorium or vascular cutis, a coloured pigmental layer, and a cuticular secreted external layer; these three layers are at first all equally flexible and continuous; subsequently transverse wrinkles appear, which gradually become segments by the cuticle acquiring calcareous matter, principally carbonate of lime, with a little phosphate of lime and magnesia, (and, according to some, a little 'chitine,' as in insects); these solidified bands become segments by separating posteriorly from the lower layer or chorium, which remains flexible, and permits the various motions. Each segment is believed (for they can seldom be all demonstrated) to consist of six pieces, two tergal pieces above (separated by a median longitudinal suture), two similar sternal pieces bclow, an epimerian piece on the upper half of each side, and an episternal piece forming the lower half of each side. In the lower crustacea the segments are very numerous, distinct, and nearly alike, but they gradually coalesce in the higher types, coinciding with the condensation of the nervous centres. No segment ever bears more than one pair of appendages, a fact which is used to demonstrate the true number of the segments which may be anchylosed into the apparently undivided head or thorax of many groups. In the majority of crustacea the first seven joints belong to the head, and bear the organs of sense and parts of the mouth, the next seven to the thorax (according to M. Edwards), bearing the organs of locomotion, the last thoracic joint being always defined by the male sexual openings, and the last seven to the abdomen, containing the principal viscera, and having the anus in the last joint. The first ring bears the eyes when they are present, the second and third rings bear the two pair of antenne, which are absent only in the lowest types, the fourth bears the mandibles, the fifth and sirth the jaws, the appendages of the succeeding rings varying in shape and use according to the group.-Digestion: the complex mouth is always on the under side of the head, composed of the labmen or upper lip, a labiens or under lip, jaw-feet, mandibles, maxille, palpi, \&c., which it is unnecessary to describe, followed by a short vertical cesophagus leading to a large globular stomach directly over the mouth (often containing sharp tubercles for triturating the 
food), from which, as in all the Annulata, a straight intestine leads to the anus; there is a well-developed liver. Circulation, by a well-developed heart placed behind the stomach, of mixed blood, which imbibes the chyle from the intestine. Respiration, in the higher groups by gills, which are modifications of the flabelliform appendage of certain legs; in the lowest, apparently by the whole surface of the body, without special organs. Nervous system, on the plan mentioned when first speaking of the subkingdom Articulata (p. 127). Hoaring: the higher groups hear well, the ear being situated in the base of the second pair of antenn:e. Sight: a few parasitic groups are blind in their perfect state, but nearly all the rest have perfect eyes either simple, or what I have termed semicompound. The simple eyes are small, two or three in number, of a single set of lenses, each eye covered by a round, smooth cornea; the semicompound eyes are an agglomeration of simple eyes, each with its set of lenses and separate twig of optic nerve, the group of eyes covered by one simple, smooth, external cornea (true compound eyes, having a separate facet of the outer cornea for each eye beneath). Reproduction: sexes always distinct and in different individuals.

The class Crustacea is naturally divisible into the five following orders, commencing with the lowest in organization: 1st, Cirripedia, or Barnacles; 2nd, Suctoria, or the little parasitic Crustacea with tubular mouths; 3rd, Entomostraca; 4th, Edriophthalna; 5th, Podophthalma, or most highly organized, and having pedunculated eyes (Crabs, Lobsters, \&c.)

\section{3rd Ord. Entomostraca.}

= Aspidostraca, Burm.

The little crustacea which compose this order are very variable in their characters; they include a vast number of the most minute crustacea known; all those enclosed in a bivalve shell-like carapace (an extension of one of the cephalic rings) belong to it. They have no gills, but breathe by flat, membraneous, vascular vesicles attached to the thoracic extremities, and representing the flabelliform appendage and palpi thereof, modified for the purpose, or by the surface of the body only. The eyes, whether simple or compound, are covered by a smooth cornea. This order, which is of more importance to the geologist than all the rest of the class, is divisible into three tribes, named according to the structure of the feet: 1st, Phyllopoda; 2nd, Pocilopoda; 3rd, Lophyropoda.

\section{1st Tribe. PHYLLOPODA. \\ = Branchiopoda, Edw.}

These have the feet extremely numerous, and, as their name implies, all leaf-shaped; they form extremely numerous, thin membraneous lobes, subservient to respiration.

The tribe is divisible into the five following families:-

1st, Lymnadiada.-In which the carapace covers the entire body in the form of a vertical bivalve shell, opening along the ventral margin; head adhering to the carapace; twenty to thirty pairs of feet, two eyes, either separated or united in one median mass (Lymnadia, \&c.)

2nd, A podiade. - Carapace horizontally semioval, not covering the abdominal segments, which are distinct; sixty pairs of feet (Apus).

srd, Tribobitade.-Head and abdomen covered by separate dorsal shields; thorax of naked segments generally trilobed by two longitudinal depressions. Eyes two, large, semicompound, or absent.

4th, Branchipodiado.-No carapace, all the body rings distinct, naked (Branchipus, \&c.)

5th, Daphniade (or Cladocera).-Body enclosed in a vertical oval shell, the anterior portion forming a beak-shaped hood for the head, which bears the single semicompound eye in front, and is separated below from the rest of the carapace, which is bivalve; only four pair of foliaceous feet ; first pair of antennse small, second pair very large, branched and bristled for swimming. 


\section{Family, LYMNADIADE $\left(M^{c} C o y\right)$.}

Body entirely enclosed in a vertical, bivalve, calcareo-corneous, oblong carapace, opening along the ventral margin; head adhering to the carapace; twenty to thirty pair of membraneous respiratory feet; two eyes, either united in one central mass or separate, one soldered to each valve.

The type of this family is the recent genus Lymnadia; and I think it may include all the so-called Cytherece of the Palzozoic rocks, which, as Burmeister suggests, are much more probably Phyllopodous, and for which I have proposed the name Cytheropsis, also the two following genera.

\section{Genus. BEYRICHIA (Mc Coy).}

Gen. Char.-Bivalve, rotundato-quadrate or longitudinally oblong, ends unequal; anterior, posterior, and dorsal margins convex, and surrounded by a sharply-defined, narrow, tumid border or rim; ventral margin simple, straight, or concave; sides tumid, strongly divided into lobes by very deep, nearly vertical furrows, extending from the ventral more or less towards the dorsal margin.

Several species of this genus have been figured and described by Klüden, as varieties of his "Battus tuberculatus." I long ago perceived that the tubercles and furrows being unsymmetrical, the creature could not be a Trilobite, and soon recognized its bivalve structure; shortly before I published this genus (Synopsis Silurian Fossils, \&c.) Dr Beyrich announced a similar observation incidentally in his memoir "Ueber Einige böhmish Trilobiten," but without naming or defining the genus, which I dedicated to him. The thickened margin separates it from those carboniferous so-called Cypridince of Koninck, some of which shew vertical furruws from the ventral margin, which latter character separates them, however, from the other crustacean bivalves which resemble them in form. An interruption may usually be detected in the sulcus which separates the thickened margin from the rest of the shell, at about one-third the length from the anterior end; this probably indicates the position of the connecting ligament of the hinge. (See our figures of $B$. complicata, Pl. 1. E. fig. 3, and $3 a$ ). I only know the genus in the Silurian rocks.

\section{Beyrichia Ktödeni $\left(M^{c} C o y\right)$. Pl. 1. E. fig. 2.}

Ref. and Syn.-Beyrichia Klïdeni ( $\left.\mathrm{I}^{\mathrm{C}} \mathrm{Coy}\right)$, Synop. Sil. Fos. Irel. p. 58. B. tuberculata and B. gibba. Mem. Geol. Surv. Vol. II. PI. 8. fig. 14, 15.-(not B. tuberculatus of Klöden).

$S p . C h .-$ Valves truncato-orbicular, ventral margin slightly concave; thickened margin very large and strong; surface tumid, having a lengthened oval, nearly vertical, tubercle reaching from the ventral twothirds of the way to the dorsal margin, and nearest to the narrow end, surrounded by a very deep and wide sulcus confluent with the ventral margin, and helping to define the unequal ended, deeply sinuate, uniform contour of each valve. Length about one line and half.

This species does not exactly accord with any of those figured by Klöden, as varieties of his Battus tuberculatus (nearly all of which I have identified myself in the Gothland limestone). I therefore think that Mr Salter, in the Surrey Reports, and the editors of the Ray edition of Burmeister's work on Trilobites, are not justified in replacing my name as above, by that of "tuberculata (Klöd. Sp.)" Any one attentively reading the elaborate description, or looking at.the figures given by that author in his rare work, the Tersteinemungen der Mirk Brandenburg, will readily perceive, as I have above mentioned, that his Battus tuberculatus includes many species-the peculiarities of which he recognized as varieties; and I may further state, that of all his figures (none of which agree exactly with the present species) continental geologists generally apply his specific name to his fig. 22 only, which best deserves the name, and is the most common in the Gothland beds, though not yet recognized in Britain.

I have not seen the granulation of the surface figured in the Mem. of the Geol. Survey. The $B$. gibba figured by Mr Salter in that work is a very trifling variety of this species. His B. plicata of the Ray edition of Burmeister seems to be the same differently observed, and is, I think, only an elevated rariety (? the female). 
Position and Locality.-Gaer Fawr (in the fine sandy beds), Montgomeryshire; Cowan Head, and Underbarrow, Kendal, Westmoreland; in the Ludlow schists of Llanfair, Welchpool.

A remarkable variety of the above, or perhaps a new species, much elevated, and the middle lobe forming a very long vertical ridge extending nearly to the dorsal sulcus, and not defined by a sulcus at the upper end, occurs in the schist at Dermydd Fawr, near Craig Bronbanog, N.WV. of Corwen.

Explanation of Figures.-Pl. 1. E. fig. 2. Left valve magnified eight diameters, and natural size.

\section{Beyrichia complicata (Salt.) Pl. 1. E. fig. 3.}

$$
\text { Ref.-Mem. Geol. Surv. t. 8. f. } 16 .
$$

Sp. Ch.-Rotundato-quadrate, ends unequal, about one-third longer than deep, thickened border strongly defined; sides flattened, divided by three very deep and wide sulci, extending obliquely from the ventral towards the dorsal margin, two of these almost reaching the dorsal margin and dividing the surface into three unequal lobes; that near the middle of the shell narrowest, that of the small end pyriform and larger, that at the large end largest, the latter again divided by the third sulcus (which is much shorter than the others) into a small branch-like lobe from its inner side; the ventral ends of all these lobes occasionally swell into tubercles. Length about one line.

The figure of the Survey is incorrect in regard to the proportion of size between the lobe of the larger end and the branch which originates from it.

Position and Locality.-Very abundant in the calcareous flags of Pont y Meibion, two miles S. of Llansantfraid on the Ceiriog; Milltit Cerrig, Llangynnog; Cwm of the Cymerig, Bala, Merionethshire ; Hill N. of Moel Uchlas; Pen y Park, Llanfyllin; Mathyrafal, S. of Meifod, Montgomeryshire; Tre Gil, S. of Llandeilo.

Explanation of Figures.-PI. 1. E. fig. 3. Left valve magnified eight diameters, and natural size, from the schists of Pont y Meibion.-Fig. 3 a. Right valve magnified eight diameters, and natural size.

\section{Beyrichia strangulata (Salt. in App.) Pl. 1. E. fig. 1.}

Sp. Ch.-Oblong, ends nearly equal, depth varying from half to two-thirds the length; dorsal margin slightly flattened, ventral margin straight, ends rounded; thickened margin tumid and separated from the sides by a very deep sulcus; sides moderately convex, with a small, oval, nearly vertical depression, a little nearer the narrow end than the other, and having a small tuberele on its margin nearest the narrow end. Length about one line.

The sulcus which defines the thickened margin is so very deep in this species, that in many specimens portions break easily off from the sides, and appear at first sight to have been deficient: this has obviously misled $\mathrm{Mr}$ Salter in his view of the species, which, however, as above defined, is a very good one; he informs me that his Cytherina lavigata (Quart. Geol. Journ. Vol. I. p. 445), is the same species. Sometimes the depression is less elongated than usual, being elliptical, and not reaching the margin.

Position and Locality.-In great abundance in the calcareous schists at Coniston Water-Head, Lancashire.

Explanation of Figures.-PI. 1. E. fig. 1. Left valve of deep variety, magnified eight diameters, and natural size from Coniston.-Fig. $1 a$. Right valve of long variety, magnified eight diameters, Coniston.-Fig. 1 b. Left valve of intermediate variety, and natural size: the thickened margin imperfect in parts, the dotted line indicating its completion. From Coniston.

\section{Genus. CERATIOCARIS $\left(M^{\circ} \mathrm{Coy}\right)$.}

Ref.-M $\mathbf{M}^{\mathrm{c}} \mathrm{Coy}$, Ann. Nat. Hist. 2nd Series, Vol. IV. p. 412.

Etym.-Kєрárcov, a pea-pad, and Kapis, a shrimp.

Gerb. Char.-Carapace bivalve, the dorsal line simply angulated (? undivided), with a slight furrow beneath it on each side; sides semielliptical, much elongated from before backwards, evenly convex; ventral margin 
gently convex, posterior end abruptly truneated obliquely; on each side near the anterior end, considerably below the hinge-line, is an ocular (?) spot, sometimes raised and distinct, in some species flat; surface marked with fine, obliquely longitudinal, imbricated strix.

In the pod-like form some of the species resemble such shells as Solenocurtus and Solenimya, except in the truncation of the posterior end; others resemble the Crustacean genus Dithyrocaris, with which I think their affinity lies, though they differ in form, and want the peculiar ridges of that group. I conceive they were phyllopodous crustaceans allied to Lymuctiu: the peculiar texture and kind of lineation of the surface resembles what we find in crustacea allied to Apus, \&c. rather than in Mollusea; the general pod-like form, large size, and posterior truncation, separate the typical forms from any of the large species of Cypridina, and the two ocular spots separate them from all others. I suspect, from some of the specimens, that the two sides met along the dorsal line at an angle of about $45^{\circ}$, with probably little power of motion. The ocular spots even when flat may generally be recognized with care from the difference in their mineralization; they are often dark-coloured, as if retaining some of their pigment, and have a slightly grannlar aspect, corresponding in fact very closely, both in position on the shell and in apparent structure, with the double-eyed Cypridino of the Indian Ocean. In one species there is a short sulcus, extending on each side from the medial line behind the eye obliquely backwards and ontwards, reminding us of the, perhaps, somewhat similar nuchal furrow of Apus. I only know the genus in the upper Silurian rocks.

\section{Ceratiocaris ellipticus ( $\boldsymbol{M}^{c} \mathrm{Coy}$ ). Pl. 1. E. fig. 8.}

$$
\text { Ref.-MI'Coy, Ann. Nat. Hist. 2nd Series, Vol. IV.p. } 413 .
$$

Sp. Ch.-Each side longitudinally elliptical, evenly convex, about twice and a half longer than wide; greatest width of the side and curvature of the margin about one-third from the anterior end, which is elliptically pointed; posterior end obtusely rounded, the oblique truncation nearly effaced; ventral margin convex: ocular spot elevated like a small tubercle, twice its diameter from the dorsal line, and about one-fourth the length from the anterior end. I believe the strie of the surface have the direction usual in the genus, but they are very delicate. Length, one inch three lines, greatest width of the side six lines.

The elliptical form, prominence of the eye-spot, and its distance from the anterior end, mark the species well.

Position and Locality.-Rare in the Upper Ludlow rock of Benson Knot, Kendal, Westmoreland.

Explanation of Figures,-Pl. 1. E. fig. 8. Natural size, from Benson Knot.

\section{Ceratiocaris inornatus. Pl. 1. E. fig. 4.}

Sp.Ch.-Valves twice and half as long as wide, moderately convex along the middle, abruptly contracted to a small mucronate point in front; dorsal line straight till near the anterior point, to which it slightly inclines; ventral margin most convex about the anterior third, which is the decpest part of each valve, from thence nearly straight to the posterior end, which is slightly narrowed, and truncated obliquely from the dorsal margin, the lateral angle being nearly of $90^{\circ}$; surface with short irregular impressed 'crustacean' strix, imperfectly parallel with the ventral margin; ocular spot large; flattened, its own diameter from the dorsal line, and about three diameters from the anterior end. Length, one inch eleven lines, greatest depth eight lines.

In a note of Mr Salter's this was named Dithyrocaris inornatus, and I have accordingly used his specific name on the explanation of the plate; on revision, however, he has eancelled this, and requested me to describe it as of the genus to which I referred it. What Mr Salter took for a longitudinal lateral ridge, as in Dithyrocaris, may be seen from other specimens to be an accidental crmpling. The ocular spot escaped his notice, but is very distinct.

Position and Locality.-Not very uncommon in Upper Ludlow rock, at Benson Knot, Kendal, Westmoreland.

Explanation of Figure.-Pl. 1. E. fig. 4. Natural size of one side, from Benson Knot. 


\title{
Ceratiocaris solenoides $\left(M^{c}\right.$ Coy $)$. Pl. 1. E. fig. 5.
}

\author{
Ref.-McCoy, Ann. Nat. Hist. 2nd Series, Vol. IV. p. 413.
}

Sp. Ch. - Sides meeting along the back at an acute angle, each being nearly four times longer than wide, the ventral margin nearly straight and parallel with the dorsal line; anterior end narrowed and truncated obliquely forwards and outwards from the dorsal line; posterior end searcely narrowed, truncated obliquely backwards and outwards; evenly convex, the edge slightly thickened; ocular spot a little depressed, close to about the middle of the truncated anterior margin; from the internal (dorsal) anterior angle a small furrow extends a little way obliquely backwards and outwards; oblique, longitudinal stria very close and fine; eye two-thirds of a line in diameter. Width of each side from dorsal to opposite margin five and half lines; length one inch eight lines.

The ocular spot is generally dark-coloured. This much resembles a little Solen in form. It is the Cultellus rectus of Mr Salter's list in Prof. Sedgwick's printed papers, but has, however, clearly no relation to that Molluscan genus, as the above characters shew.

Position and Locality.-Common in the Upper Ludlow rock of Benson Knot, Kendal, Westmoreland.

Explanation of Figures.--PI. 1. E. fig. 5. Natural size, shewing the ocular spot and oblique nuchal furrow, from Upper Ludlow, Benson Knot.-Fig. 5a. Shorter specimen, shewing the two valves in contact; same locality.

\section{Ceratiocaris? unbonatus (Salt. $S p$.) Pl. 1. E. fig. 6. Syn.-Cythere? umbonata (Salt. in App.)}

Mr. Salter has applied this latter name to a bivalve fossil, the generic position of which secms to me very doubtful. The valves are obliquely oval, with a slightly-defined margin; anterior and posterior ends elliptically rounded; dorsal margin slightly more convex than the ventral; sides diagonally gibbous, forming an obtuse 'umbo at about the anterior third, near the hinge line, a little in front of which a small, depressed, eye-like spot is visible with a lens; texture very minutely granulose under a high power; average length two lines, width one and a half line (one specimen four lines long).

In some specimens the umbo, or most prominent part of each valve, is nearer the centre. The size and eye-spots separate it from Cythere, and although the form is very different from the typical species of the present genus, still the C.ellipticus seems to form a transition in this respect.

Position and Locality.-Common in the schists of Gelli Grin, Bala; Dermydd farwr, Craig Bronbanog, N.W. of Corwen; Conway Falls; Llanfurog.

Explanation of Figure.-Pl. 1. E. fig. 6. Natural size, and magnified six diameters, from the schists of Dermydd fawr.

\section{3rd Family. TRILOBITADE. \\ = Palccadce Dalman.}

Body covered (with a few exceptions) by a longitudinally trilobed crust, the head and abdominal segment anchylosed into distinct cephalic and caudal shields, the thoracic segments alone remaining distinct and moveable.

The cephalic shield is approximately semicircular; when most fully developed it presents the following parts: an external thickened "limb" or "margin," often prolonged backwards at the lateral angles into "vings;" the shield is usually divided into two pieces by a suture peculiar to trilobites termed the "eye line" or "facial suture," being continuous from one side to the other near the front margin, descending with a slight outward curve to the eye over which it makes an abrupt outward curve to define a small semicircular lobe, improperly called the "eye-lid," its direction from the lower end of the eye varies according to the Genus and forms a very valuable character; in some cases the eye-lines do not join in front of the glabella, but cut the anterior margin separately, thus dividing the shield into three pieces, and in Calymene, to this latter disposition 
is added a peculiar marginal transverse "rostral suture," dividing the head into four pieces. These sutures exist in no recent Crusteceu, being only now known in true insects. By some recent continental Palrontologists all outside and anterior to the eye-line is called the "checks," and all within or posterior to it is called the "glabella;" by a greater number of writers however (and in the following descriptions) the latter term is used only for the elevated middle portion of the head, and the triangular depressed space on each side form the cheeks, through the middle of which the "eye-line" runs; the glabella is divided by not more than three lateral sulci into never" more than four lohes; at the base of the glabella a strong furrow going across is called the "neck furrow", behind which is the "neck segment," or spira; these sulci indicate the attachment of the buccal muscles. The cyes are reniform, prominent, situated in a gap in the eye-line, beneath and external to the eye-lid; they have all the "semi-componud yes," the outer thin layer of the cornea being entire and smooth, the inner thick layer facetted and perforated; Burmeister notes that the larger the eye of living crustacea, the thinner the cornea, hence why the large-eyed Phacops having a thin easily-lost outer cornea, seems to have a facetted eye. I have drawn attention to a deep puncture on each side of the antennary lobe, in the furrow separating the glabella from the cheeks near the front margin, which I have ealled the "antennary puncta," and which I conceive gave passage to small antennie like those of Branchipus, of which organs they hold the normal position. Attached to the under side of the anterior edge of the head is an ovate crustaceous piece varying in shape according to the genus, its anterior part is dilated into two horn-like processes following the curve of the anterior margin of the shield, the surface of this organ is marked with fine irregular impressed strike like the rest of the under surface of the erust of Trilobites; it is believed to be immovable, and corresponds to the enlargement in front of the mouth in some of the recent Plyyllopoda, and is, as in them, named the "Hypostoma." The Thorax is formed of a variable number of segments (constant for each genus), forming the morable portion of the crust between the cephalic and caudal shields; it is in general strongly trilobed longitudinally, the middle and most convex portion termed the "axis," and the lateral, lobes or pleure; each segment has the axis divided in many genera into a raised, posterior exposed portion, and a depressed anterior articular portion, which is concealed under the preceding segment when the animal is extended, becoming visible as it rolls, up, or on the fracture of the edge of the preceding ring; the pleurce are straight, or bent down at the end; in the latter case the end often 'sharpened at its anterior edge for contraction,' or provided with a triangular 'facet;' one of its sides parallel with the anterior edge, its base at the distal extremity, and its apex reaching about one-third towards the axis, its thickened posterior margin joining the anterior margin of the segment at an obtuse angle, at the point where the end of the pleura begins to bend down, has, from its form, been called the "knee" by Pander, Portlock, \&c.; the same point has by others been termed the "fulcrum." In most cases a deep groove extends transversely from the axis along the middle of each pleura as far as the "knee, and then its extremity is often bent backwards at an obtuse angle, I propose to term this the "pleural groove", and Dr Burmeister suggests, with great probability, that the membraneous gill-feet were attached to the corresponding ridge on the under side; caudal shield or "pygidium" semi-elliptical of one solid piece, axis and side lobes generally with transrerso false segmental furrows, rarely corresponding in number on the axis and sides, and not admitting of independent motion.

Dr Burmeister comparing trilobites with Branchipus, suggests that the narrow body was lodged exclusively in the narrow prominent middle lobe or axis extending from the front of the glabella to the end of the pygidium, and that the lateral lobes were merely to protect the delicate respiratory feet hanging heneath them; these being mere lateral extensions of the true or axal rings renders it impossible they could have acted as oars, as has been suggested. In such cases, as Paradoxides, where the thoracic segments are very numerous, and the abdominal shield disproportionally small, a doubt occurs as to whether some of the abdominal segments may not be erroneously counted as thoracic; but as this could only be determined by observing the position of the female genital openings, which mark the last thoracic ring, Palrontologists are content to call all the free movable segments thoracic, and refer to the abdomen only those which are anchylosed into a caudal shield or pygidium. The lateral portions of the body are covered with a thin, tough, membrane on the under side, marked with oblique dichotomous impressed strix.

The homologies of the cephalic shield of Trilobites have been less attended to than almost any part 
of their structure. The apparently anomalous nature of the facial suture has been spoken of by Burmeister, who saw no clue to its nature; the nature of the parts outside the eye-line, or 'wings," as they were called, has also been alluded to by authors as inexplicable; while those who, comparing the 'Trilobites witl Branchipus, supposed the body of the animal to occupy the axal lobe only, have expressed their astonishment at the eyes being placed on the lateral lobes, or "cheeks." When we bear in mind that the carapace of a crab, for instance, is a great backward prolongation of one of the rings of the head, and is quite distinct from the posterior cephalic and the thoracic segments which it covers, and which exist in a membraneous state beneath it, we are prepared to admit, that though the segmental furrows on the glabella of many Trilobites indicate cephalic rings, they by no means prove the cephalic shield to be formed of the anchylosis of such rings, which may only exist below, impressing the shield like the various regions on the back of a crab. To determine of what rings the shield is composed, I started with the main characteristic of the first ring of all crustacea, which is, to bear the eyes when they are present; the second and third rings bear the antemix; and the remainder of the cephalic rings bear the parts of the mouth. The eyes of Trilobites, when they exist, are always connected with the piece anterior and external to the eye-line; this piece is usually continuous from side to side at the front margin, and I think is probably the first or ophthalmic ring; its lateral portions produced backwards, and bearing its peculiar appendages, the eyes, with it: every ring being theoretically divisible into six pieces, affords an explanation of the suture which sometimes separates the two parts in front, and even of the rostral shield of Calymene (if it belongs to this ring). On this view the facial suture becomes at once intelligible as the line of separation between the first and second cephalic rings, analogous to the divisional line between one thoracic ring and another. The piece within and behind the eye-line should on this supposition be the second or antennary ring; and as remarkably supporting this, I must refer to p. 42 of my "Synopsis of the Silurian Fossils of Ireland," where I announced the discovery of the remains of antennx, as a deep pore on each side of the front of the glabella, in the furrow which surrounds it, and in which, when clear of matrix, I have observed them in Trinucleus, Acidaspis, Calymene, Ampyx, Griffithides, Sc. We would thus have the cephalic shield of Trilobites composed of an extension of the first two cephalic rings. The protuberance ealled the glabella probably contains the stomach, which is always in erustacea large and placed over the mouth; the segmental furrows on the sides, indicating the rings beneath, which bear the parts of the mouth.

The arrangements hitherto proposed of this group fall far short of what could be desired for a satisfactory or natural classification. I have satisfied myself that the number of the segments, so far from being of family importance, as hitherto supposed by some authorities, cannot indicate more than subgeneric differences among Trilobites, being an instance of a law well known to every experienced zoologist, that those claracters of most vital importance in any class or order are often found suddenly to lose their importance in some subordinate section of the group. Thus in the whole class Crustacea the number of segments is of great importance, and scarcely varies in the largest groups, while in the Eutomostrace alone (to which the Trilobites belong) we have every variety, from the smallest to greatly the largest number of segments known in the class. The consideration therefore of the characters of all the recent and fossil Crustacea, taken as a whole, warns us against laying the stress, which has hitherto been done, on the number of segments as a general character for the formation of the great groups. Such a use of this character separates the most nearly allied forms into distinct families, and allies those agreeing in no other points. The two chief systematic arrangements which have been proposed are those of Dr Burmeister, taking as the principle of division the presence or absence of such contractile power as enables the animal to roll itself into a ball ; and that of Hawle and Corda, who rest their great divisions on the margin of the pygidium being toothed or entire. The latter character seems to me of no more than specific importance, and the former, though of imperfect application and not ascertainable in many cases, is included in the following mode of arrangement, which, after a careful study of the British and Foreign types, I venture to propose, founded on a consideration, in the first instance, of the structure of the pleuro, or lateral portions of the thoracic segments, which I find to afford definite characters easily ascertainable in all moderately wellpreserved specimens. I propose to divide the Trilobites into the five following subfamilies;-1st, Agnostince; 2nd, IIarpedine; 3rd, Ogygina; 4th, Paradoxince; 5th, Asaplince. 


\section{1st Subfamily. AGNOSTINE.}

Minute, blind, head and tail covered by nearly equal and similar rotundato-quadrate shields; only two thoracic segments.

This sulfamily includes both the families Phalucrumiles and Battoides of Hawle and Corda which only differ in the margin of the tail of the latter being denticulated, and that of the former being smooth, - points in my mind scarcely of generic importance.

From the absence of eyes and the very slight powers of locomotion argued by so small a number of feet bearing rings, I strongly suspect that the genera of the present family were parasitic, and may hold the same position among the Trilobites that the Suctoric do among the crustacea generally, that group being distinguished from its allies by the want of eyes, few body rings, little or no powers of locomotion, abnornally and variously shaped bodies, and being parasitic (generally) on fish. Bophyyrus, the analogous group among the Isopoda is usually parasitic on the gills of Crustacea under their carapace, and such I strongly suspect were the habits and mode of life of the Agnostince, living in all probability attached to the gill feet on the under side of Trilobites, the largest known species of which accompany the little Agnosti.

\section{Genus. TRINODUS $\left(\mathrm{I}^{\circ} \mathrm{Coy}\right)$.}

Syn.- = Arthrorachis Hawle and Corda.

Gen. Char.-Cephalic and pygidial shields nearly equal, semielliptical (or from the projection of the middle of the articular margin, obscurely pentagonal); qlebelle semicylindrical, strongly defined, having a very minute lobe at each side of the base; cheeks convex, horse-shoe shaped, entirely surrounding the glabella; cutemul murgin narrow, defined, convex, not extended at the angles; fyridlum having an elongate tubercle down the middle of the axal lobe, which is strongly defined, semicylindrical, and divided on each side of the mesial tubercle by two fine transverse sulci; lateral lobes horse-shoe shaped, convex, entirely surrounding the axal lobe, surrounded by a distinct external margin: surface smooth.

I originally defined this genus in $18+6$ in my "Synopsis of the Silurian Fossils of Ireland," and pointed out its distinctions from Agnostrs (absence of the characteristic transverse divisional sulcus of the glabella, Sce.) Subsequently (1st7) Hawle and Corda figured and described the group under the title cirthrorachis, and likewise distinguished it from Agnostus, or Battus, without knowledge of what I had done. By some curious mistake however, Mr Salter has stated in the "Mem. of the Geol. Survey," (Vol. II. Pt. 1. p. 351) that I have only described the tail in my generic eharacter, and also overlooking the independent establishment of the same genus by the Bohemian Palæontologists, has reunited it to Agnostus.

\section{Trinodus agnostiformis $\left(M^{\circ} \mathrm{Coy}\right)$. Pl. 1. E. fig. 10.}

Trinodus agnostiformis ( $\left.\mathrm{M}^{\mathrm{c}} \mathrm{Coy}\right)$, Syn. Sil. Foss. Irel. t. 4. f. 3. Agnostus trinodus $\beta$ convexus (Salt.) Mem. Geol. Surv. Vol. II. p. 350.

Sp. Ch.-Cephalic shield semioval, about one-fifth longer than wide; glabella sharply defined, very convex, narrow, semicylindrical, front rounded; cheek-piece horse-shoe shaped, convex, width equal at the sides and round the front, slightly exceeding that of the glabella (? the front divided by a faint longitudinal mesial furrow); outer margin about half the width of the cheeks, convex. Length of head two lines, length of glabella one and half lines, width of glabella rather more than half a line.

I have some doubt whether the longitudinal furrow in the middle of the front of the cheek-piece be correctly observed, as I have only one specimen of the species at hand for examination, and if constant it must have escaped me at first. The tail has been figured in the above volume of the "Memoirs of the Geol. Survey," but the segmental furrows seem to have been overlooked.

Position and Locality.-One specimen, Limestone of Rhiwlas, Bala, Merionethshire.

Erplanation of Figure--Pl. 1. E. fig. 10. Head natural size, and magnified six diameters; the dotted line indicates the portion of the margin which is wanting. From Rhiwlas. 


\section{Trinodus tardus? (Bar. Sp.) Pl. 1. E. fig. 9.}

Syn.-Battus tardus Barrande. Arthrorachis tarda Hawle and Corda. Agnostus trinodus Salt.

Mem. Geol. Surv. Vol. II. t. 8. fig. 11. (omit the ref. to $M^{\mathrm{c} C o y}$ ).

Sp.Ch.-Cephalic shield truncato-orbicular, about one-fifth wider than long; glabella not quite two thirds the length of the head, very broad, ovate, nearly as wide as long, convex, defined by a very deep furrow; cheek-piece of equal width all round, about one-third less wide than the glabella, convex, a wide hollow separates the cheek from the narrow external margin, the hollow and margin taken together about equalling the cheeks in width. Length of head two lines.

We have only the head of this species which seems to agree exactly with the Bohemian form noticed; the tail apparently of the same species is figured from a Wexford specimen by Mr Salter in the "Memoirs of the Geol. Survey" as the original variety of my $T$. agnostiformis; this reference however (as any one may see by referring to my original description and figure,) belongs rather to his A.trinodus $\beta$ concexus. The segmental furrows of the pygidium are not indicated in Mr Salter's notice.

Position and Locality.-One specimen in the Limestone of Rhiwlas, N. of Bala Lake, Merionethshire.

Explanation of Figures.-Pl. 1. E. fig. 9. Head, natural size, and magnified six diameters: the dotted line indicates the completion of the broken margin.

\section{Genus. DIPLORHINA (Hanle and Corda).}

Gen. Char.-Cephalic shield rotundato-quadrate; glabella subcylindrical, rounded in front, divided near the middle by a strong transverse sulcus, and having a small rotundato-trigonal lobe on each side of the base; cherels horse-shoe shaped, entirely surrounding the glabella; outer margin narrow; thorax of two rings, axis about four times wider than the pleure, which are obtuse, and divided by a diagonal pleural furrow; pygidizm very obscurely rotundato-pentagonal, longer than wide, axis convex, mitre-shaped, middle of the sides concave, pointed posteriorly, bordered behind and at the sides by uniformly continuous side lobes; outer margin rather wide, smooth.

\section{Diplorhina triplicata (Hanle and Corda)? Pl. 1. E. fig. 11.}

Syn. and Ref.-Agnostus pisiformis Murch. Sil. Syst. t. 25. f. 6 a (not of Brong.)

Sp. Ch.-Head rotundato-quadrate, length and width almost equal; cheek-piece slightly narrower than the glabella, and a little wider near the middle of the glabella than in front, moderately convex, divided in front by three radiating sulci, one medial and one on each side about half way between that and the medial transverse sulci of the glabella; glabella subcylindrical, rounded in front, slightly concave at the middle of the sides, divided slightly in front of the middle by a strong transverse sulcus, the anterior portion evenly convex, posterior portion more prominent, obtusely carinate along the middle; a small obtusely trigonal segmental lobe on each side of the base of the glabella. Surface minutely shagreened. Length and width each about one and a half lines.

As Hawle and Corda have not figured their species, I subjoin, in a note*, that part of their description applying to the head.

Position and Locality.-Rare in the black shale of Pen Cerrig, three miles N. of Builth.

Explanation of Figure.-Pl. 1. E. fig. 11. Head, natural size, and magnified six diameters.

* "Kopf flach gewölbt, vorne gerundet, fast parallelopipedisch; breit gerandet, Rand flach, Randfurche seicht. Vangenstück hufeisenförmig und überall gleich breit, Vor den Vorderlappen der Glabella mit drei kurzen, nach vorne gerichteten Falten geziert. Dorsalfurchen tief. Vorderlappen trapezoidisch, mit der breiten Basis an den etwas nach Vorn ausgoschweiften Mittellappen der Glabella stossend; letzterer ist nahe am Vordern Ausschnitt mit einem kurzen scharfkieligen Buckel geziert, zur Seite und nach hinten ausgeschweift ausgeschnitten. Basilarlappen klein, dreieckig." Prod. Monog. der böhm. Tril. p. 47. 


\title{
2nd Subfamily. HARPEDINE.
}

Ovate, head large; eyes small; glabella with segmental furrows; body very long and rapidly tapering, of numerous rings; pygidium very small; pleurse wide, straight and flat till near the end which is obtuse and abruptly bent downwards, each having a straight mesial furrow not reaching the margin; no facets.

The principal genera of this subfamily are:-1st, Amplion; 2nd, Harpes (subg.? Harpidella;) 3rd, Conocephalus.

\section{Genus. HARPIDELLA (MCOy).}

\author{
Ref.-M둥, Ann. Nat. Hist. 2nd Series, Vol. IV.
}

Gen. Char.-Cephalic shield subtrigonal, surrounded by a thick narrow flattened border, sides nearly vertical, compressed; checks entirely surrounding the glabella in front, forming there a narrow tumid border, widening backwards as they descend into tumid, broad, triangular, nearly vertical wings, having large prominent eyes near the middle of their posterior margin, from which on each side an obscure impressed line extends upwards and inwards to about the first third of the glabella, (perhaps indicating the eye-line); glabelle very convex, semielliptical, obtusely rounded and wide in front, surrounded by a strong defining sulcus; two segmental furrows on each side, the first very strong, curving, from about the middle of the side of the glabella, inwards and backwards into the neck furrow, so as to include a large tumid ovate lobe on each side; a little above this the very short and faintly marked anterior segmental furrow curved in the same direction; surface granulated.

The head alone of this genus is known; it differs from Harpes (Gold.) in its small size, narrow, unpunctured rim, absence of the ocular tubercles on the anterior part of the cheeks, great size and basal position of the eyes, and furrow from them to the glabella, \&c. The true place of the genus cannot be determined till the thorax and pygidium are known.

\section{Harpidella megalops $\left(M I^{\circ}\right.$ Coy $)$.}

Ref. and Syn.-Harpes? megalops (McCoy) Syn. Foss. Irel. t. 4. f. 5.

As this is the only species of the genus known, I can only add to the above description the measurements, and remark that from the abrupt bending down of the cheeks, from the nearly horizontal front and glabella to the nearly vertical wings, the eyes are rarely seen, except when most carefully cleared, and that when in the rock the whole animal generally seems, in consequence, much narrower than it ought, as shewn in the figures above quoted. The granulation in the English specimen is coarse and very irregular in size.

Length of head three and half lines, width of glabella one and half lines.

Position and Locality.-Not uncommon in the Wenlock limestone of Dudley.

\section{3rd Subfamily. OGYGINE.}

Body flat, broad, oval; thorax as long as the head, four to eight thoracic segments; pleurre flat, sickleshaped, horizontal, having a pleural furrow not reaching the margin, ends not produced into spines; no facets; pygidium nearly as large as the head; eyes small or absent.

The Ogygine include (so far as I know) all the flat-sided Trilobites not entering into the group of Paradoxine; ; unlike them, however, the body is very short and wide, and the pygidium instead of being diminutive is nearly as large as the head, giving a broad oval form to the body; the thoracic segments are only from four to eight in number, never facetted, and their extremities are never prolonged into spines.

The British genera are:-]st, Trinucleus (subgen. Tretaspis); 2nd, Ampyx; 3rd, Orygia (subgen. Barrandia); 4th, Bronteus; 5th, Lichas, (subgen. Acanthopyge, Trochurus). 


\title{
Genus. TRINUCLEUS (Murch.)
}

\author{
= Cryptolithus Green.
}

Gen. Char.-Cephalic shield semicircular, the limb broad and flat, with several rows of impressed cup-like puncta on both surfaces; spines of the external angles very long; glaleflo pyriform, witlıout lateral furrows; cheeks spherical triangles without eyes or eye-lines; generally a small spine on the neck furrow; thorax of six joints, lateral lobes twice the width of the axis, flat, straight, with parallel sides, slightly deflected at their free ends, pleural groove broad, shallow, not reaching the margin; pygidium triangular with a deflected margin, axis with about seven segmental furrows, sides flat with about six segmental divisions each subdivided by a faint line towards the end.

I have (Synopsis of Sil. Foss. of Ireland) drawn attention to a particular (? antennary) pore in this and other genera of Trilobites near the front margin on each side of the glabella, in the furrow which separates the latter from the cheeks; in the same furrow $I$ often observe in certain states of preservation two or three punctures on each side of the base, one of them in the neck furrow, indicating apparently the insertion of the oral muscles, and holding the place of the segmental furrows of other Trilobites.

The facial suture of this genus as figured by Burmeister, on the authority of Lovèn, was supposed to go round the edge of the punctated border, to turn in at the angles, and cut the posterior.margin near the angles of the cheeks; this would be so singularly unusual a course, that I have taken every pains to investigate the point, and feel satisfied there is no suture in the position indicated; on the other hand, I think I have ascertained their true course, in several species, to be in a more normal position; as I have observed them, they run from the re-entering angles between the front of the glabella, and the cheeks close outside the furrow which separates the glabella from the cheeks nearly to the posterior margin where it turns outwards, (and may generally be well seen at this point) and runs parallel with, and a little above the posterior margin which it finally cuts near the outer angles of the cheeks. I have discovered a facial suture in precisely the same position in Ampyx, the proximity to the furrow of the side of the glabella having probably caused them to be overlooked in both genera.

\section{'Trinucleus Caractaci (Murch.)}

Ref.-Murch. Sil. Syst. Pl. 23. f. 1. and Port. Geol. Rep. PI. 1. B. fig. 3 and 5.

Sp.Ch.-Cephalic shield nearly semicircular, its width exceeding twice its length; margin wide, regularly rounded, three concentric rows of punctures in front of the glabella, five rows in front of the cheeks, more numerous and scattered towards the angles, which have a triangular extension backwards and outwards, nearly half as far as the pygidium before giving off the slender spines which extend oblicuely outwards and backwards; glabella smooth, broad, ovate, moderately gibbous; neck furrow strong with a small spine on the middle; cheeks gibbous, smooth, triangular, their length and width about equal; pygidium nearly as long as the abdomen, three times wider than long, slightly and obtusely mucronate, lateral lobes with five to eight furrows, the three first most distinct, axis with about fourteen minute segments.

I agree with Col. Portlock in thinking this species has never more than three rows of pores in front of the glabella, I therefore believe it distinct from the Bohemian $T$. ornatus which has always five; but besides the greater width of the punctured border in the T. ormetus it is fully distinguished from our species by the few furrows on, and the extremely small size of, the pygidium, which in the $T$. Caractaci nearly equals the abdomen in length, but is only half that in the $T$. ornatus. (See the figure of Beyrich, Untersuchungen uiber Trilobiten, Pl.4. fig. 1, and the description of the same under the name T. Goldfussi in Barrande's "Notice Préliminaire," \&c. p. 31).

Position and Locality.-Alt yr Anker, Meifod, Montgomeryshire; Llechwedd, Llwyd, W. of Llanfechan, Montgomeryshire; Pwllheli, Caemarvonshire; Craig y beri, Llanarmonfach, Montgomeryshire; Tan y Bwlch y Groes, S. of Bala, Merionethshre; Hordely S.; Gelli Grin, Bala, Merionethshire; Llanwddyn in the Berwyn Mountains; Rhiwargor, near Llanwddyn; Chiney Longville, Shropshire. 
T. elongatus (Port.) t. 1. B. fig. 7 only differs in the entire animal being longer and narrower, the length of the cephalic shield being considerably more than half the width._One specimen of this variety has occurred in the schists of Pwllheli.

\title{
Trinucleus gibbifrons $\left(M^{c} C o y\right)$. Pl. 1. E. fig. 14.
}

\author{
Ref.-MIcCoy, Ann. Nat. Hist. 2nd Series, Vol. IV
}

Sp. Ch.-Cephatic shield nearly semicircular, length rather more than one-third of the width; glabella pyriform, rounded in front, gradually narrowing towards the base, compressed, exceedingly gibbous, its height above the cheeks nearly equalling its width; on each side of the neck-furrow (in casts) there is a deep puncture, and another similar a little in front of it; a small spine on the neck-furrow; cheeks spherical triangles, height and width about equal, moderately convex; border of moderate width, three rows of punctures in front of the glabella and four rows in front of the cheeks, more numerous at the sides, generally connected in front by radiating furrows, forming an imperfect fimbriation. Usual length of cephalic shield three lines. Surface very minutely granulated.

This very common species is figured without a name by Portlock (Geol. Rep. Pl. 1. B. fig. 13 and 14). The fine granulation of the lobes of the head, and the extreme prominence of the gradually narrowing, pyriform, compressed glabella separate this at once from either the $T$. Caractaci or $T$. latus, with which it seems to have been confounded; it is wider than the former, less so than the latter. From the two little punctures on each side of the base of the glabella this strongly approximates to the $T$. scyllarus (His ), as distinguished from $T$. seticornis, but, although with abundance of specimens, I cannot find any trace of ocular tubercles or eye-lines in the midst of the cheeks, as in Tretaspis, to which those species belong; these punctures indicate, no doubt, the insertion of the muscles of the jaws, but are not extended into transverse segmental furrows as in those last-named species; in the radiation of the border and number of rows of pores in front, it approaches slightly to the $T$. racliutus (Murch.), but is distinguished by the head being rounded, the cheeks wider, and the border not being more than half the depth as well as being by no means so distinctly radiated.

Position and Locality.-Common in the limestone of Goldengrove, Llandeilo; the schists of Tre Gil, S. of Llandeilo; and Alt yr Anker, Meifod, Montgomeryshire; also at P'en y Craig, above Llangynyw, Montgomeryshire; a variety with a shorter shield, the lobes of which are more spherical, perhaps from pressure, occurs in the black shale three miles N. of Builth, Radnorshire.

Explanation of Figures.-Plate 1. E. fig. 14. Natural size, Caradoe sandstone, Goldengrove.-Fig. $14 \alpha$. Ditto, magnified three diameters.

\section{Trinucleus latus (Portk). Pl. 1. E. fig. 15.}

Ref.-Portk. Geol. Rep. Pl. 1. B. fig. 11 and 12.

Sp. Ch.-Cephatic shield smooth, transversely elongate, from three to four times wider than long; anterior and posterior margins subparallel, the angles produced laterally (not deflected backwards); glabella convex, with nearly parallel sides, anterior and posterior ends almost equal, obtusely rounded; cheeks transversely semielliptical, about one-third wider than high, gently convex. Average length of cephalic shield four lines.

Confounded with the T. fimbriatus by Portlock, from which it differs in the margin, being punctured, not radiated, the posterior half of the glabella not being contracted nor furrowed at the sides, and the lobes of the shield being smooth and the cheeks destitute of the ocular tubercles, or eye-line.

Position and Locality.-Rare in the schists at Selottyn Road; Gelli Grin, Bala, Merionethshire; Maes Meillion, S. of Bala, Merionethshire; Llwyn y Ci, N.W. of Bala; Bryn Evan Yspatty; Rhiwlas, N. of Bala; Pen Cerrig Serth.

Explanation of Figure-Plate 1. E. fig. 15. Specimen natural size from Tyrone, shewing antennary pores, and general transverse form. 


\title{
TrinuCleus? Radiatus (Murch.)
}

\author{
Ref.-Murch. Sil. Syst. Pl. 23. fig. 5.
}

Sp. Ch.-Cephalic shield rotundato-quadrate, little more than twice as wide as long; margin very wide, at least as deep as the cheeks at the sides of the front; anterior margin wide, concave; anterior lateral angles obtusely rounded, sides nearly straight, generally inclining slightly inwards towards the posterior lateral angles, from each of which a short slender spine extends outwards and backwards at an obtuse angle with the sides; about four rows of punctures in front, more numerous at the sides, connected in lines by strong radiating furrows; glabella ovate, gibbous, cheeks little wider than high, convex. Usual length of cephalic shield seven lines.

This species is easily recognised by the great width and square form of the radiated border to the head, but though I have seen many specimens none have shewn me the glabella or cheeks in perfect preservation; I am consequently uncertain whether they have the characters of a true Trinuclens or of a Tretaspis.

Position and Locality.-Common in the slates of Dinas Mowddy, Merionethshire; N. of Tremadoc, Merionethshire.

\section{Gemus. TRETASPIS ( $\left.\boldsymbol{I}^{C} \mathrm{Coy}\right)$.}

Ref.-McCoy, Ann. Nat. Hist. 2nd Series, Vol. IV.

Gen. Char.-General characters of Trinucleus, but having but five body-rings, the base of the glabella having two short segmental furrows on each side, and the cheeks being traversed diagonally by a nearly straight eye-line, extending on each side from the junction of the cheeks and glabella in front towards the lateral angles, cutting the posterior margin a little within the angles, and usually exhibiting a small ocular (?) tubercle in the middle. Type of the genus T. seticomis (His. Sp.), T. Bucklandi (Bar.)

In my Synopsis of the Silurian Fossils of Ireland, I pointed ont the course of the eye-line in this genus, which separates it at once from Trimucleus, and renders it probable that the small tuberele in the middle of the cheeks in the $T$. seticomis, $T$. fimbriatus, \&c. are true eyes.

The furrows at the base of the glabella also are distinctive from that genus. Mr Salter, (Mem. of the Geol. Survey, Vol. II. Pt. I. p. 335), speaking of Hawle and Corda's work, says, "Tetrapsellium is distinguished from Trinucleus solely by a swelling in the axal furrow of the head; it is almost identical else with $T$. seticornis:" this might mislead the English reader with the idea that the present genus then was identical with Tetrapsellium; the fact is, however, in his strictures on the Bohemian authors $\mathrm{Mr}$ Salter overloolss the grand character of their genus, namely, its having but four body-rings ("Vier Leibringe," H. and C. Monog. p. 42. Sth line).

\section{T'retaspis fimbriatus (Muv ch. Sp.) Pl. 1. E. fig. 16. Syn. and Ref.-Trimeleus fimbriatus (Murch.) Sil. Syst. t. 20. f. 2.}

Sp. Ch.-Cephatic shield very minutely granulated, more than twice as wide as long; glabella pyriform, moderately convex, one-third longer than wide, two short segmental furrows at each side of the base; cheeks moderately convex, with the straight diagonal eye-line and central ocular tubercle almost imperceptible; margin very narrow, radiatingly furrowed, except the lateral angles, which are directed outwards and downwards, and bear irregular punctures, as in the other species; thorax shorter than the glabella; axis two-thirds the width of the pleuripedes; pygidium three times as wide as long, with seven axal and six lateral segments. Most usual length of shield about two lines, of which the fimbriated margin is about half a line; width, exclusive of the spines, five lines.

Position and Locality._Llandeilo flag, Pen Cerrig, three miles N. of Builth, Radnorshire; Bryn Melyn, near Bala, Merionethshire.

Explanation of Figures.-Pl. 1. E. fig. 16. Entire specimen, natural size, from Pen Cerrig.-Fig $16 a$. Ditto, magnified three diameters. 


\section{Tretaspis seticornis (His. Sp.)}

Syn. and Ref.-Asaphus seticomis. Hisinger Leth. Suec. Pl. 37. fig. 2.

Sp. Ch.-Cephalic shield closely granulated, nearly semicircular, about twice as wide as long; angles prolonged into slender spines directly backwards; margin broad, four rows of punctures in front, more numerous at the sides, usually a smooth furrow separates the outer two rows of punctures from the rest; glebcllu having the anterior lalf nearly spherical, posterior half abruptly contracted to a narrow neck, with a distinet neck-furrow and two short segmental furrows at each side, the ends forming three deep punctures in casts; cleeks spherical triangles, convex, as high as wide, traversed diagonally by the eye-line and having a small ocular tubercle in the middle; pygidium obtusely rounded, more than twice as wide as long, seven segments in the axal lobe, six on the lateral lobes. Length of head about five lines.

Position and Locality.-In the slates of Moel y Gunnedd uchaf, IV. of Bala Lake, Merionethshire; Alt yr Anker, Meifod, Montgomeryshire; Cwm of the Cymmerig, Bala.

\section{Genus. AMPYX (Dal.)}

Gen. Char-Buckler trigonal; glabella very large and prominent, narrow behind, and having a long slender process projecting upwards and forwards from its anterior end; cheels flattened, posterior lateral angles prolonged backwards into long slender spines; (? no cyes nor eye-lines); thorax of five or six flattened segments, the sides straight, divided by a large diagonal pleural groove, which is narrow and close to the upper edge near the axis, gradually widening towards the obtuse ends; pygidium nearly as large as the hucliler, subtrigonal, one strong anterior segmental furrow; axis faintly marked with numerous transverse furrows, sides smooth or ribbed, flat, with a narrow vertical margin.

From the examination of a vast number of specimens in various states of preservation, I think I have ascertained the course of the facial sutures in the A. nasutus (Dal.) and A. nudus (Murch. Sp.); they run almost parallel with the furrows which separate the glabella from the cheeks on each side, from the front nearly to the posterior margin, near which they turn outward and finally cut it at a short distance from the base of the glabella; there is a tumid spot about the middle of the eye-line which may be an eye, the proximity to the sides of the glabella rendering it difficult to detect

\section{Ampyx latus $\left(M^{c}\right.$ Coy $)$. Pl. 1. E. fig. 13.}

\section{Ref.-M $\mathrm{M}^{\mathrm{C}} \mathrm{Coy}, \mathrm{Ann}$. Nat. Hist. 2nd Series, Vol. IV.}

Sp.Ch.-Entire animal transversely oval, length one-fifth less than the width; cephalic shield smooth, front margin regularly curved, width three-fifths the length; glabellu moderately tunid, pyriform, laving a narrow vertically elongate (? ocular) swelling close to the middle third of each side, and two short, minute, segmental furrows at each side of the narrow base; thoracic segments five, pleuripedes of each side twice the width of the axal lobe; pygidium very obtusely and regularly rounded, four times wider than long, axis with about seventeen minute segmental furrows, sides with about eight. Length of entire animal three and a half lines.

This rare species is most allied to the $A$. parvulus (Forb.) and the $A$. nasutus (Dal.), from both which the perfect animal is easily known by its transversely oval form; the regular curvature, and great width of the cephalic shield, and of the pygidium, easily distinguish these parts when found separate; the lattel agreeing nearly in form with that of the $A$. parvulus, from which it differs equally with the other in all the other characters of cephalic shield, \&c.

Position and Locality.-Rare in the Black shale, three miles N. of Builtl, Radnorshire.

Explanation of Figures.-Pl. 1. E. fig. 13. Natural size, black shale, three miles N. of Builth.-Fig. $13 \alpha$. Ditto, magnified three diameters. 


\section{AMPYx nudus (Murch. Sp.)}

Ref. and Syn.-Mem. Geol. Surv. Dec. 2. t. 10. Trinucleus nudus Murch. Sil. Syst. p. 660. t. 23. f. 5.

$S p$. Ch.-Entire animal longitudinally ovate, length about one-fourth more than the width; cephalic shield smooth, about two-fifths the length of the animal, about twice as wide as long; glabella very tumid, pyriform, with a short spine projecting from the convex front, narrowed posteriorly and with two short segmental furrows at each side of the base; antennary pores large, in the furrow between the cheeks and the glabella near the front margin; cheeks longer than wide; thoracic segments six, pleuripedes one-third wider than the axal lobe; pygidium triangular, slightly mucronate, twice as wide as long, the axis with sixteen segmental furrows, the sides with nine. Average length of cephalic shield, five lines.

At about half the length of the eye-line there is an elongate swelling which may indicate the position of an eye.

Position and Locality.-Very common in the shale at three miles $\mathbf{N}$ of Builth, Radnorshire: Wellfield, Builth; Tre Gil, S. of Llandeilo.

\section{Genus. OGYGIA (Brong.)}

Gen. Char.-Body ovate, flattened, not contractile; buckler semicircular, flattened, with the angles produced backwards into flat spines; cheeks large, continuous beneath the front margin; glabella indistinetly clavate, with three very indistinet lateral segmental furrows on each side; eyes semicircular, moderate, corresponding in height to the two anterior lobes of the glabella, reniform; eyc-line coinciding with the margin in the front, then abruptly bending towards the eye, over which each forms the eye-lobe, and thence diverges to cut the posterior margin about the outer third of each side; thorax of eight segments, axis narrow ; pleuripedes straight, flat, at least twice as wide as the axis, pointed and falciformly bent backwards at the extremities; no facets, a fine mesial pleural furrow not reaching the end; pygidinm semielliptical, with a narrow distinct articulated axis, the lateral lobes also with segmental furrows not reaching the margin, and each having a shorter slightly oblique duplicating furrow.

\section{Ogygia Buchi (Brong. $S p$.)}

Syn. and Ref.-Asaphus id. Brongniart. Crust. Foss. and Murch. Sil. Syst. t. 25. f. 2.

Sp. Ch.-(Female?) Broad ovate, one-fourth longer than wide; cephalic shield widely arched, about twice and one-fifth wider than long, as long as the thorax; pleuripedes about twice and one-fifth wider than the axis; pygidium obtusely rounded, the width of the axis and one side lobe taken together at the anterior margin, slightly exceeding its length; axis of about fifteen segments, the sides with thirteen.

(Males?) Narrow ovate, one-third longer than wide; cephalic shield semielliptical, length half the width, as long as the thoracic and one pygidial segments; pleuripedes rather more than twice the width of the axis; pygidium semielliptical, length slightly excecding the width of one side and the axis, abont twelve double segmental furrows to the sides, and fifteen to the axis.

The figures of Brongniart, Murchison, and Bumeister, represent what 1 here suppose to be the female; the more lengthened elliptical form, with longer head and more pointed pygidium, which I suspect (from the general analogy of recent crustacea) to be the male of the same species, does not seem to have been previously observed, though nearly as common in all localities as the other*; with the exception of the more slender contour and difference of proportion indicated above, I see no grounds for thinking there is more than a sexual distinction-if others should consider it a distinct species, the name $O$. elliptica might be given to it.

Position and Locality.-Very abundant in the limestone, shales, and Llandeilo flag, three miles N. of Builth, Pen Cerrig and Wellfield, Builth, Radnorshire; Llandeilo, Caermarthenshire.

* Since the above was written, Mr Salter has noticed the difference in proportion of different specimens, but without drawing any conclusion therefrom. (See the second Decale of the Geol. Survey.) 


\title{
Ogygia radians ( $\boldsymbol{M}^{\circ}$ Coy). Pl. 1. F. fig. 2.
}

\author{
Ref.- $\mathbf{M}^{\circ} \mathrm{Coy}$, Ann. Nat. Hist. 2nd Series, Vol. IV.
}

$S p$. Ch.-Pygidium nearly semicircular, slightly convex; axis conical, undefined at the end, having three narrow segmental furrows at the anterior end, lateral lobes with three broad radiating ribs faintly divided at their axal ends by a small pleural furrow; margin tumid, entire length four lines, width seven lines.

I provisionally give this name to a small pygidium not unlike that of the Barrandia Cordai, but which from the duplicate lateral furrows belongs more probably to Oyggia, and probably confirmatory of this view, I observe in the 2nd Decade of the "Geol. Surv." t. 7. f. 5 , a small eight-jointed true Ogygia from Builth, having the pygidium almost identical with the present species, if, as I suspect, the duplicating furrows have been accidently onitted in the plate (the figure alluded to is given as the probable young of the Ogygia dilatata (Phill.) which abounds in the schists at Waterford).

Position and Locality.-Not uncommon in the black shale of Pen Cerrig, Builth, Radnorshire.

Explanation of Figures. -PI. 1. F. fig. 2. Pygidium natural size, from the black shales of Pen Cerrig, Builth -Fig. $2 a$. The same magnified to shew the fine duplicating furrows, as in Ogyain generally.

\section{Genus. BARRANDIA $\left(\boldsymbol{I}^{\circ} \mathrm{Coy}\right)$.}

\section{Ref.-McCoy, Ann. Nat. Hist. 2nd Series, Vol. IV.}

Gen. Char.-Body ovate, depressed; cephalic shield semicircular, with the lateral angles produced backwards into short spines; glabella widely clavate, the axal furrow strong and nearly parallel at the base, becoming obsolete towards the front; eyes large, narrow, reniform; eye-line behind the eye cutting the posterior margin about the middle, in front of the eyes, arching forwards, first outwards and then inwards; thorax of seven segments; axis convex, nearly as wide as the pleure, tapering towards the pygidium; pleuræ flat, their ends slightly falcate and bent backwards, no facets, a slightly oblique submesial pleural furrow not quite reaching the end; mygidium semicircular, entire, having very few simple segmental furrows placed near the anterior margin (one to three in number); axis short, having one to three small segmental furrows.

This I conceive to be a subgenus of Ogygin, from which it differs in its fewer thoracic segments, and laving but very few and simple ribs to the tail. The genus agrees witl the description given by Hawle and Corda of their genus Alceste, with the exception of this having seven thoracic rings, and that having but four-it is remarkable that Alceste is figured by those authors with three segmental furrows to the pygidium, while this has only one, making the total number of segments visible the same in both; the number of the pygidial segments, is, however, of course, liable to vary with the species, while the thoracic ones are allowed to be constant. I know but one species, the following. Since the above was written, Mr Salter has given a figure (2nd Decad. Geol. Surv. Pl. 7. f. 4) of a species of this genus, with three segments to the pygidium, which he gives without any apparent reason, as the young of an Irish species of Onygia (O. dilatata Phill. $=$ O. Portlocki, Salt.) My reasons for dissenting from this view, are, 1 st, it is contrary to analogy of other Trilubites to suppose that the young and adult differ in the number of their thoracic segments; 2nd, in the Cambridge Collection, specimens of the $O$. Buchi, half an inch wide, have exactly the same number and character of segments as adults, six inches long; 3rd, his supposed young has only been found at Builth, where the Irish species (his supposed adult thereof) has never been found, being only known in the schists of Waterford, where it abounds, but where the supposed young has not occurred.

\section{Barrandia cordai ( $M^{c}$ Coy $)$. Pl. 1. F. fig. 1.}

$s p$. Ch.-Length one-fourth more than the width; length of head, thorax and pygidium almost equal; cephatic shield slightly more than twice as wide as long, lateral angles very short; eyes half their length from the axal furrows; pygidium depressed, length rather more than half the width, axis two-thirds the length, conical, segmental furrows obtuse. Length eleven lines. 
Position and Locality.-Black shale of Builth, Radnorshire.

Explanation of Figures.-Pl.1. F. fig. 1. Natural size from the black shale of Builth.-Fig. 1 a. Two thoracic segments of ditto, magnified to shew the coincidence of their form and pleural furrow with Omygia.

\section{Genus, LICHAS (Dal.)}

Gen. Char.-Body ovate, very flat; surface granulated, head semicircular; glabella large, semioval, with one long segmental furrow curving inwards and downwards from the upper third of the glabella on each side, nearly to the neck-furrow, partially enclosing two large oval spaces, and close to the ends of the neck-furrow a posterior pair of furrows enclose a very small trigonal lobe on each side; neck-segment bruader than the base of the glabella; checks small; oyes moderately large, reniform; eye-line cutting the outer margin in front of the angles; thoirdx of ten segments, pleurce flat, falcate, each with a fine slightly sigmoid pleural furrow, not reaching the margin; pygidlum semi-oval, axis undefined, the lateral furrows instead of encircling the end, converge about the middle, and diverge again towards the posterior margin, which they do not reach, two short segments at the anterior convex part; side-lobe, flat, of two broad falcate ribs on each side projecting beyond the margin, each with a fine mesial duplicating groove; mildle lobe semielliptical, pointed, a small divisional line coming off from the middle of the dorsal furrow on each side, curving downwards and outwards towards its extremity, so as partially to include an oval space on each side.

\section{Lichas PROpinqua? ( Bar.)}

\section{Ref.-Barrande. Notice Prélimin. p. 54.}

Sp. Ch.-Pygidium semielliptical, obtusely pointed; axis semicylindrical, about one-third the entire length, of two narrow ring-shaped joints and a conical slightly longer portion, which becoming abruptly narrow and depressed is continued as an obscure ridge to the end; the three flat side-lobes each duplicate by a strong sulcus reaching almost the whole length, and slightly nearer the posterior than the anterior margin; the posterior pair of lobes anchylosed with the centre in one lozenge-shaped piece, the ends of the two upper pairs slightly project separately at the margin; surfuce covered with very unequal, sharp, conical granules, their own diameter apart. Length one inch two lines, width the same.

The only doubt I have in referring this fossil to Barrande's species, with which it agrees in form and peculiar granulation, is that he compares the form with the $L$. scabra (Bey.), without saying whether the extremity is notched, as in that species, or not.

Position and Locality.-Coniston limestone, Coniston Water-Head, Lancashire.

\section{Subgenus. ACANTHOPYGE (Hanle and Corda).}

Cien. Chur.-Cephalic shield semicircular, with the lateral angles produced backwards into small spines: glabella large, moderately gibbous, narrow at the base, from whence nearly to the anterior margin the middle portion is nearly parallel-sided, defined by the retroflexion of the anterior pair of segmental furrows, which enclose on each side a large oval, very gibbous, space by their confluence behind with the lateral bounding furrow of the glabella; a little below this a posterior segmental furrow forms a simple transverse line, parallel with the neck-furrow and a little anterior to it, the enclosed space about equalling the necksegment in size, often with a tubercle at each end; cheek's triangular, gibbous, having a small rounded eyelobe near their upper and outer part, from which the eye-line runs directly upwards and inwards towards the glabella, and backwards and outwards to cut the external margin a little in front of the lateral angles: surface granulated; pygidizm semielliptical, the apex terminating in two long spines, axis suddenly attenuated posteriorly, of one joint, sides flat, each with two narrow prominent ribs, running out at the margin to long spines. 
The simplicity of the head, there being but one enclosed space on each side of the glabella, and the transverse segmental furrow in front of the neck-furrow (which is not indicated clearly by Hawle and Corda), separate the genus from the other groups of Lichas, \&c.

\section{Acanthopyge Anglica $(B e y . S p)$.}

\section{Ref. and Syn.-Arges Anglicus (Bey. Untersuch. über Trilobiten).}

Sp. Ch.-Cephatic shicld about four lines long; middle part of the glabella two lines wide, the gibbous oval space on each side about one and half lines wide; granulation seattered, of numerous unequal mammi. lated tubercles, the spaces between which are minutely granulated.

This species has been placed by Beyrich in the genus Arges from which the presence of the eye-lid alone would separate it; as it seems to agree correctly with Acanthopyge of Hawle and Corda, I have placed it in that genus. By the imperfect deseription I should have supposed the Liches parca of Barrande allied to this, hut as Hawle and Corda in redescribing that species, make no mention of Beyrich's figure, I suppose they are distinct.

Position and Locality. - Wenlock Limestone, Dudley.

\section{Genus. TROCHURUS (Barr.)}

$$
\text { Syn. = Corydocephalus (Hawle and Corda.) }
$$

Gen. Char.-Ceplealathwax semicireular, lateral angles a little prolonged; glabella large, gibbous, middle portion narrow, subclavate; three segmental lobes on each side large, the anterior pair obliquely pyriform, the middle pair oblique, oval, the posterior pair much smaller, transversly oval; neck-furrou strong, not wider than the base of the glabella; clecks triangular; eyes small; yeline cutting the lateral margin in front of the angles; body of eleven segments, pleura flat, slightly faleate, and rather wider than the axis, each with a fine slightly sigmoid pleural furrow, not reaching the edge; no facets; pygidium senicircular, axis narrow, three-jointed, two first joints narrow, ring-shaped, third contracted, extending to the margin which is thickened, sides flat, each with two narrow straight segmental ridges, extending from the axis beyond the thicliened margin into thick narrow spines, the middle of the margin at the end of the axis produced into two small spines, extending backwards like the rest.

The number of the body-rings, and form of the pygidium and glabella, separate this genus from Lirlue: See description of Staurocephalus below.

\section{Trochurus nodulosus (Salt. Sp.) Pl. 1. F. fig. 16.}

$$
\text { Syn.-Lichas noelulosus (Salt. in Ap.) }
$$

$S_{p}$. $\left(Y_{t},-\right.$ P!ridium senielliptical, axis semicylindrical, reaching little more than half-way to the margin, rather less than its anterior half occupied by three narrow ring-like segments, the terminal mass very gibbous, and connected with the thickened margin by an abruptly smaller slender prolongation; lateral lobes, with twn broad segments on each side, gibbous, most so near the margin, each divided by a wide mesial sulcus, and extending beyond the margin in a long slender flattened spine directed backwards; the middle lobe has a broad thickened margin; on each side of the small mesial ridge two tumid spaces, separated by a longitudinal sulcus, not crnssing the margin; two thick spines extending backrards, one on each side of the middle: surfare with fine close granules and small seattered obtuse tubercles. Length, three and half lines, width five and half lines.

Position and Locality.-Rare in the schists of Pont y Glyn, Diffivys, near Corwen.

Explanation of Figure.-Pl. 1. F. fig. 16.--Pygidium natural size.

* As this sheet was going to press I received the Journal of the Geological Society for August 1850, in whicl Mr. Fletcher gives figures of this species under the name Lichas Bucklandi (Milne Edw. sp.) - but as M. Edwards' name was merely given to an unintelligible figure, without description of any of the essential parts, there can bo little doubt that Beyrich's name is the proper one to use. 


\section{4th Subfamily. PARADOXIN E.}

Pleure flat, horizontal, without facets, with a straight pleural groove, and terminating in spines inclining backwards.

This subfamily is composed of a group of long-bodied Trilobites, having for the most part large cephalic shields, with the angles prolonged into spines, and very small flat eaudal shields of few segments; none of them, I believe, can roll into a ball; their pleure are very wide and horizontal, not bent downwards at the ends, so that the body is flat; they are destitute of facets, and have a long straight pleural groove extending their whole length, dividing each into two tumid portions, one or both of which are extended into long sharp spines, inclining obliquely backwards. This latter character, of all the pleure terminating in separated spines, gives a peculiar physiognomy to the Trilobites of this group. The thoracic segments vary from eight to twenty-three in number;

The principal British Genera are, 1st, Paradoxides (Olenus being regarded as a subgenus); 2nd, Acidaspis ; 3rd, Staurocephalus; 4th, Ceraurus; 5th, Eccoptochile; 6th, Spharexochus; 7 th, Zethus.

\section{Genus. ACIDASPIS (Murch.) \\ Syn.-Odontopleura (Emmerich.)}

Cren. Char.-Cephalic shield wider than long, subquadrate or semicircular, margin tumid, often spinous, lateral angles forming long slender spines; glabella convex, narrow in front, not reaching the front margin, with two or three lateral lobes on each side, base prolonged backwards into one or two long thick spines; antennary pores usually distinct, close to the front of the glabella; eye-line tumid, cutting the margin on each side in front of the glabella, and extending from the eyes, which are very small, to the posterior margin rather nearer the angles than the glabella on each side; thorax of eight joints, axis convex, narrow; pleure wide, perfectly flat, each with a nearly mesial pleural furrow parallel with the margin, the upper portion thickest, prolonged beyond the posterior, and terminating in a long spine deflected at a considerable angle backwards; pygidinm small, semicircular, axis very short, of two joints, sides flat with but one segmental furrow, ending in a long spine at the margin of each side, the rest of the margin with many smaller spines.

\section{Acidastis Brightil (Murch.)}

Ref.-Murch. Sil. Syst. t. 14. f. 15 .

Sp. Ch.-Cephaiic shield convex, subsemicircular, front flattened, limb thick, rounded, denticulate at the sides, produced at the angles into long, slightly flexuous, obtusely rounded spines; glabella convex, strongly defined, narrow and rounderl in front, widening towards the base, each side with a pair of large spheroidal segmental tubercles, the posterior ones largest; cheeks small, very tumid; eyes situated near the base of the glabella; a narrow ridge extends from the eye on each side to the antennary punctures, which are large, on each side of the front of the glabella; neck-segment prolonged horizontally backwards into an appendage, wide and triangular at its origin, rapidly tapering to a rounded extremity, equalling that of the lateral angles in size and shape; surface covered with a small, very unequal scattered granulation. Length of head excluding the neck-segment two and half lines, length of produced neek segment three and half lines, width at base of cheeks six lines.

Position and Locality.-Not uncommon in the Wenlock limestone of Dudley; of small size in the oliveschists Blain y Cwm, W. of Nantyre, Glyn Ceiriog, Denbighshire.

\section{Genus. STAUROCEPHALUS (Barr.)}

$$
\text { Syn-_- Staurocephalus + Trochurus. }
$$

Gen. Char.-Cephalic shield granulose, front half of the glabella spherical, posterior half abruptly contracted to a small cylindrical neck, marked on each side with two minute segmental furrows, exclusive of the neck-furrow, which is very broad and deep; neck-segment large, with a short spine on its middle; cheeks trian- 
gular, gibbous, the angles prolonged backwards into sharp spines; eyes large, prominent, near the outer margin; eye-line coming from the front to the eye with an outward curve, and extending thence with an outward curve to a little in front of the angle; thorax with nine segments; pleure broad, flat, straight, and longitudinally furrowed, one half only reaching the margin, the other thicker and produced beyond into a slender spine, bent abruptly backwards; pygidium small, quadrate, axis of four segments, the first three narrow, the last large, semicireular; side lobes flat, with three small segmental furrows, and the margin produced backwards into six slender spines.

The genus Trochurus of Beyrich was originally founded on the head of this genus and a tail belonging to the group of Lichas, and he only figured the latter part; subsequently Barrande proposed the generic term Staurocephalus for the head alone, which was adopted by Beyrich in his subsequent memoir, "Untersuchungen über Trilobiten," for the head; and the tail, formerly called by him Trochurus, for which he had now found the true head, was placed in the genus Arges; lastly, Hawle and Corda figured and described the entire animal, and restored to it Beyrich's old name Trochurus; and to the originally figured tail of Trochurus and its subsequently found true head they gave the name Corydocephalus. As this would be productive of much confusion, I have used Barrande's name (sanctioned by Beyrich) for the animal to which the head described belongs, and to the tail originally figured by Beyrich as the T. speciosus, the type of this genus Trochurus, (subsequently named by him, with its appropriate head, Arges speciosus, and perfect specimens of which have been figured by Hawle and Corda in their "Monog. böhm. Tril." under the new name Corydocephalus flabellatus) I have retained the original name Trochurus.

\section{Staurocephalus Murchisoni (Bar.) Pl. 1. F. fig. 15. \\ Ref.-Barrande, Notice, p. 53.}

Sp. Ch.-Anterior half of glabella an oblate spheroid, slightly wider than long, posterior half abruptly narrowed to a small stem-like, cylindrical neek, about one-third the diameter of the front half; cheeks hemispherical; surface with a strong granulation, the granules sharp, subequal, and nearly their diameter apart. Length two and half lines, width four lines.

I have only seen the head of this interesting addition to our list of British Trilobites, which I detected in a small parcel of duplicate Trinuclei labelled Trinucleus seticornis by Mr Salter, to whom they had been lent to illustrate ( $I$ believe) his paper on Trinucleus; but the resemblance to that species and genus seem to me deceptive, the large eyes alone separating the heads easily, in my opinion.

Position and Locality.-Very rare in the limestone of Rhiwlas, W. of Bala Lake, Merionethshire.

Explanation of Figures.-Pl. 1. F. fig. 15. Glabella and part of cheeks, natural size.-Fig. 15 a. Ditto magnified.

\section{Genus. CERAURUS (Green.) (as here redefined.)$$
\text { = Chirurus (Beyrich). }
$$

Gen. Char.-Cephalic shield granulated, semicircular, lateral angles prolonged into spines; glabella clavate, reaching the front margin, gibbous, with three subequal segmental furrows on each side, the basal one retroflexed; eyes small in the midst of the cheeks; eye-line going from their base directly to the outer margin, which they cut considerably in front of the angles; thorax of eleven segments; pleurce wider than the axis, each having its origin thickened into a large oblong tubercle cleft by a deep diagonal pleural sulcus: a little beyond this a small rounded tubercle, beyond which the extremity is flat and falcately pointed; pygidiun with a short four-jointed axis, and the margin produced into three strong spines on each side, the anterior largest.

A careful examination of the details of the original specimen of Green's Ceraurus, recently published by Hall in his Palæontology of New York, satisfies me there is no difference between that genus and the Chirurus of Beyrich, as restricted by Hawle and Corda; which latter I therefore propose to suppress as a synonym, Green's type being specifically distinguished by the unusual length of the anterior marginal spine of the pygidium on each side. 


\section{Ceraurus clavifrons (Dal. Sp.) Pl. 1. F. fig. 11, 12; and Pl. 1. G. fig. 9.}

Ref. and Syn._Calymene clavifrons (Dal.) = Chimerus globosus (Bar.) = Sphcerexochus juvenis (Salt.) Mem.

Geol. Surv. (Pt. 1. t. 7. f. 1, 3.-Corrected to S. clavifrons Dalm, in list of plates in same work.)

$S p$. Ch.-Ceplalic shield semielliptical, width twice the length, lateral angles prolonged into short spines; glabella large, ovate, very gibbous, about one-fifth longer than wide, and half as high as wide, minutely granulose; basal pair of segmental furrows wide and deep, curved backwards nearly to the neckfurrow, but not confluent with it, partially enclosing a subovate space on each side about as wide* as the intervening portion of the glabella; middle and anterior pair of side furrows also curved downwards, and nearly as strong as the basal pair, the anterior pair about half the length of the basal, the middle pair rather more; neck-segment strong; cheeks tumid, triangular, much more closely pitted than the glabella; eyes small, on a line with the middle segmental furrow; eye-line going horizontally from thence to the outer margin. Length of head from five to nine lines.

This agrees exactly with the head Beyrich (Ueber, bohm. Tril. p. 22) supposes to be the C. clavifrons of Dalmann, and also with the head aseribed by Lovén to the same species, with the single exception of their not noticing the more coarse pitting of the cheeks, which however might be easily overlooked-if there were any doubt on the point Barrande's name might be used, as his description under the name Chirums globosus applies exactly. The discrepancy pointed out by Mr Salter in the Mem. of the Geol. Survey does not really exist; our specimen (figure three) shewing the commencement of the prolonged lateral angles beyond what he imagined to be the tumid rounded margin. The reference of the species to Sphcerexochus is negatived by the presence of all the characters which distinguish the head of that genus from Chirums (Ceraurus), namely, the direction of the eye-line, form of the lateral angles, and size of the two anterior pair of segmental furrows.

Position and Locality.-Applethwaite Common, Westmoreland; S. W. of Cefn Grugos, Llanfyllin, Montgomeryshire (passage beds); Cader Dinmael, Denbighshire; Llwyn y Ci, N. W. of Bala, Merionethshire.

Explanation of Figures.-Pl. 1.F. fig. 11. Small specimen of glabella, shewing the extent of the segmental furrows, from the limestone of Llwyn $\mathrm{y} \mathrm{Ci}$ - Fig. $11 a$. Profile of ditto, magnified.-Fig. $11 b$. Granulation of ditto, magnified.-Fig. 12. Glabella and part of cheeks of large crushed specimen from Applethwaite Common.-Pl. 1. G. fig. 9. Profile of part of head, natural size, from Cefn Grugos.-Fig. $9 a$. Front view of another specimen from schists of Cader Dinmael (spaces enclosed by posterior furrows too swall in this figure of Mr Salter's.)

\section{Ceraurus octo-lobatus $\left(M{ }^{c}\right.$ Coy). Pl. 1. G. fig. 10. \\ Ref.-M $\mathrm{M}^{\mathrm{C}} \mathrm{Coy}, \mathrm{Ann}$. Nat. Hist. 2nd Series, Vol. IV.}

Sp. Ch.-Pygidium transversely elliptical, twice as wide as long, two first rings of the axis narrow, distinct, third or terminal one large, terminating in four flattened elliptically pointed lobes; two rather larger similar lobes on each side. Length two and half lines.

This curious little species differs from all of this and the allied genera in having the terminal segment of the pygidium quadrilobate, so that the margin of the pygidium exhibits eight marginal pointed lobes in all. It is figured in the Memoirs of the Geol. Survey, from Shole's Hook, under the same reference as the cephalic shields there called Sphorexochus juvenis (Salter)t, but not alluded to in the text.

Position and Locality.-In the limestone of Rhiwlas, N. of Bala Lake, Merionethshire.

Explanation of Figures.-Pl. 1. G. fig. 10. Pygidium, natural size from Rhiwlas.-Fig. 10 . Ditto, magnified.

* Mr Salter's figure in this work, and those of this species in the Mem. of the Geol. Survey, are deceptire in this particular.

p Corrected subsequently to S. clavifrons (Dal.) in the list of plates prefixed to the same work. 


\title{
Ceraurus Williaisi ( $M$ Coy). Pl. 1. F. fig. 13.
}

\author{
Ref.-McCoy, Ann. Nat. Hist. 2nd Series, Vol. IV.
}

Sp.Ch.-Cephatic shield semielliptical, length rather more than half the width; glabella semicylindrical, gibbous, rounded in front, with nearly parallel sides, three nearly equidistant, curved, segmental furrows on each side, the basal pair nearly confluent at their ends with the neck-furrow, enclosing a tumid ovate space on each side, separated by an undivided space about one-fourth of the width of the glabella; thora $x$ twice the length of the glabella, axal segments large, two-thirds the width of the pleuræe, each of which has a very large, oblong tubercle at its margin, diagonally cleft by the pleural sulcus, and followed at one-third from axis by a hemispherical tubercle, about half its diameter distant from the first, beyond which the distal two-thirds of each pleura is falciformly dilated into a thin, flat, fin-like appendage, the anterior margin of which is very convex, posterior margin slightly concave, extremity pointed; pygidium small, the six marginal spines small, all extending about the same distance backwards, the anterior pair therefore longest; they are thick, triangular, and three or four times wider than the others. Length of entire animal one inch four lines, of glabella five lines, width about nine lines.

The disconnected, broadly falcate, paddle-shaped pleurie help to distinguish this beautiful little species, which by its narrow elongate form resembles a Remopleurides.

Position and Locality.-One entire specimen, collected from the schists of Golu Goed, Myddfai, by Mr Williams, of Llandovery, and presented to Professor Sedgwick by him.

Explanation of Figures.-Pl. 1. F. fig. 13. Entire animal, natural size-Fig. $13 \alpha$. Profile of ditto.Fig. 13 6. Two pleurx and portion of axis magnified.

\section{Genus. ECCOPTOCHILE (Havle and Corda).}

Syn. < Chirurus (Beyrich) and? Cryphocus pars Green.

Gen. Char.-Cephatic shield rounded, glabella semicylindrical, convex, extending as far as the front margin, with three short segmental furrows on each side, the lower pair curving inwards and downwards; checks moderately convex, rugose, lateral angles extended into short spines; eye-line cutting the lateral margins, considerably in front of the angles; (eyes small, facetted fid. Corda); thorax of twelve joints, axis convex, smooth, pleuræ much wider than the axis, ending in thick deflected contracted points; pleural groove straight, nearly mesial, and parallel with the margins, pitted, ceasing at the thickened base of the terminal spine; pygidium of four joints, those of the axis simple, the terminal one subtrigonal; lateral ribs three on each side, two first pair with a pleural pitted groove, all six ending each in a broad ovate terminal expansion.

\section{Eсcoptochile Sedgwicki (M*Coy). Pl. 1. F. fig. 14.}

Ref, and Syn.-Crypheeus Sedgwicki, MCoy, Ann. Nat. Hist. 2nd Series, Vol. IV. p. 406.

Sp.Ch._Cephatic shield subsemicircular; glabella slightly clavate, smooth, three segmental furrows on each side, the posterior pair longest, turning backwards and inwards nearly to the neck-furrow, enclosing a triangular space on each side longer than wide, the width rather less than that of the undivided portion of the glabella between their bases, the two anterior pair of furrows shorter; cheeks broad, gently convex, closely and coarsely pitted; neck-segment thick, smooth; eye-line extending with a slight curve to the margin in front of the angles; axal lobe very convex, narrow, slightly tapering, nearly parallel-sided, smooth, of twelve segments, three similar belong to the pygidium, a fourth terminal one being obtusely trigonal; the side lobes are flattened, and more than double the width of the axal lobe; pleurce nearly straight, narrow, and for the greater part of their length flattened, and having a broad, nearly mesial, pleural suleus, deeply punctured like the cheeks, dividing each into two parts, the posterior largest and forming a thick, smooth, rounded ridge, in the distal third of its length bent down and a little backwards, swelling to a thick narrow ridge in the middle, the sides and the extremity expanding into a broad, thin, foliaccous 
appendage; the pygidium terminates in six broad, ovate, leaf-like, semimembranous flaps. Length of thorax and pygidium two inches two lines, width two inches three lines, width of axal lobe six lines.

This magnificent trilobite can only be confounded with the Eccoptochile clavigera (Bey. Sp.), from which it is distinguished by the much greater width of the lateral lobes of the thorax, and the thin, flat, leaf-like appendages of the pygidium, which in that species resemble thick pear-shaped clubs. A comparison with the old description and casts, published by Green, induces me to place this trilobite in his little-known genus Cryphous, and to doubt very much the propriety of separating the genus Eccoptochile of Hawle and Corda from it; but as there are two forms confounded under this name by Green, and the nne now best known in America by his name being the type allied to Phacops arachnoides (Asteropyge H. and C.), I use the Bohemian genus for the present fossil, in accordance with the suggestion of $\mathbf{M}$. de Verneuil.

Position and Locality.-The nearly entire specimen described was collected by Prof. Sedgwick from the black shale, two miles N. of Builth, Radnorshire.

Explanation of Figure.-Pl. 1. F. fig. 14. Entire specimen, natural size.

\section{Genus. ZETHUS (Pand.) (as defined by Volborth). \\ Syn. = Cybele Lovén. + Atractopyge Hawle and Corda.}

Gen. Ch.-Ovate, rapidly tapering from the cephalic shield which is nearly semicircular, with the lateral angles forming short spines; glabella clavate, narrowing towards the axis, coarsely tuberculated, three small straight more or less distinct segmental furrows on each side of the base; neck-segment strong and smooth; cheeks triangular, flattened, coarsely tuberculated, posterior margin thick and smooth; eyes forming small tubercles near the middle of the anterior margin, with an apparently smooth cornea; facial suture terminating at the angles of the head behind; thoracic segments eleven*; pleura divided by a small angulated furrow, their extremities often produced; pygidium triangular, axis rounded with many joints, much curved downwards: side lobes nearly vertical, the ribs few (four to seven) deflected nearly from their origin.

This genus is intermediate between Phacops and Calymene in the form of its head and glabella, and agrees with the former in the number of body-segments, and with the latter in the course of the eye-line; the pygidium approaches in some measure to Encrinurus, which differs by its elevated eye-pedicles, and the Phacops-like course of the eye-line.

I follow Dr Volborth (see his paper Ueber einige russischen Trilobiten in the Verhandlungen der 'ussisch-kaiserlichen Min. Gesellschaft zu St Petersburg for 1847) in referring Cybele of Lovén to Zethus of Pander; and after a most careful consideration of the different species, I find so imperceptible a gradation in structure of pygidium from Atractopyge, in which the four upper axal segments are prolonged into the side lobes, and deflected close along the axis (believing with Lovén that those are really pygidial segments), to those in which two or three more lateral ribs are added, that I also feel satisfied that Atractopyge of Hawle and Corda should be added to Zethus.

\section{Zethus atractopyge $\left(\right.$ / $\left.{ }^{c} \mathrm{Coy}\right)$. Pl. 1. G. fig. 1 to 5.}

Syn._Cybele verrucosa Lovén, (not Zethus verrucosus Pander) = Atractopyge vermecosa (Hawle and Corda).

sp. Ch.-Cephatic shield coarsely tuberculated, rounded, about three times wider than long; glabella clavate, convex, front obtusely rounded, not reaching the margin, basal two-thirds narrowed, nearly parallelsided, with three strong nearly equal segmental furrows on each side, eyes small, about one-third nearer the glabella than the lateral angles; neck-segment narrow; thorax having the segments narrow, those of the axis terminating in a tubercle at each end (not well shewn in the figure); pleure having a horizontal

* The difficulty, without great care, of distinguishing betweer the thoracic and pygidial segments may account for the different numbers occasionally assigned to the former. 
portion about as wide as the axis, divided by a straight pleural groove into a large, very convex, anterior, tuberculated portion, and a narrow smooth posterior portion; beyond this the extremities are free and gently arched backwards and a little downwards for nearly as great a length; pygidium subrhomboidal, length about two-thirds the width, anterior margin very much arched, longer than the posterior; axis narrow, conical, of about twenty narrow segments, of which only the first four reach entirely across; the others being confined to the sides, leave a smooth space down the middle, which is bordered by an obscure double row of tubercles (in the sandstone casts the axal segments all seem to go across); broad lateral lobes of only four ribs, which are continuous at their origin with the four anterior axal segments; each bears an irregular row of tubercles, and terminates in a slightly projecting blunt extrenity. Length of head about seven lines, of pygidium nine lines.

In placing this species (which is the Cybele rerrucosa of Lovén) in the genus Zethus, I have been obliged to propose a new specific name for it, as it is not the $Z$. verrucosus of Pander, and as I cannot agree with Volborth in referring it to the $C$. bellatula of Dalmann. Having in the article on the genus stated the reasons for uniting the genera Zethus of Pander and Atractopyge of Hawle and Corda, of which latter genus the present species formed the type, I have used the generic name of those authors to designate the species.

Position and Locality.-Not uncommon in the schists of Ravenstone Dale and Coniston, also in the sandstone of Alt yr Anker, Meifod, Montgomeryshire.

Explanation of Figures.-Pl. 1. G. fig. 1. Part of head and part of thorax, natural size, from the schist of Ravenstone Dale.-Fig. 2 and 3. Pygidium, natural size, from the slate of Coniston.-Fig. 4. Do. Magnified.-Fig. 5. Part of head a little larger than natural.-Fig. $5 \alpha$. Portion of fig. 5 magnified.

\section{Zetmus Sexcostatus (Salt. Sp.) Pl. 1. G. fig. 6 and 7.}

Ref. and Syn.Cybele sexcostata. Salt. Mem. Geol. Surv. Vol. II. Pt. 1. t. 8. f. 9, 10.

Sp. Ch.-Pygidium twice as wide as long, subtriangular, or slightly rhomboidal from the backward curve of the front margin; axis narrow, cylindrical or very gradually tapering, of about twenty minute segments and an abruptly deflected tripartite smooth termination, and two obscure rows of minute tubercles, one pair on each segment; side lobes with six or seven strong obtuse ribs without tubercles, the first two pair nearly horizontal for the first third or halt of their length, then abruptly curved almost vertically downwards, the others bent down nearly from their origin, the ends projecting beyond the margin in the casts. Average length six lines.

Position and Locality.-Abundant in the limestone of Rhiwlas N. of Bala Lake, Merionethshire, Llwyn y Ci, N.IV. of Bala, Merionethshire.

Explanation of Figures.-PI. 1. G. fig. 6. Pygidium, natural size, from the schists of Rhiwlas.-Fig. 7. Larger individual, same locality.

\section{Zethus variolaris (Brong. Sp.)}

Ref. and Syn.-Calymene variolaris? Brong. pars (t. 1, f. 3 B.) id Murch. Sil. Syst. t. 14. f. 1.

Sp. Ch.-Cephalic shield rather more than twice as wide as long, obscurely trilobed in front by the projection of the broad front of the glabella, which is broadly clavate; height and width of the cheeks about equal, lateral angles slightly produced; eyes nearly marginal, rather nearer to the glabella than to the lateral angles; tubercles of the surface coarse, irregular, obtuse, each with a little pit on its summit, three on each side of the base of the glabella larger than the rest (? segmental); posterior margin of the hear, and neck-segment smooth, and resembling one of the thoracic segments in character; thorax one-third longer than the glabella, axis nearly as wide as the pleuræe above, narrowing posteriorly, the few last segments having obtuse tubercular ends; pleurce with their posterior portion very small, anterior portion thickened and produced beyond the margin, anterior segments slightly bent down, and either horizontal or directed a little forwards at their extremities, posterior ones abruptly curved down about the middle or nearer the axis, nearly to right angles with their origin, and directed backwards, nearly smooth, with a 
few small irregular tubercles: pygidium much curved downwards, obtusely pointed, sides straight, nearly vertical; axis with about nine to eleven distinct segments, each of those near the end, and every alternate one above, with a strong tubercle at the middle, and all having one at each end; sides with seven or eight rounded ribs, having a tubercle at their origin, their ends blunt and prominent, and a few tubereles between. Length one inch three lines, width ten lines.

I have not ascertained whether the ends of the posterior pleurre are prolonged in this species; they are all marked with obscure tubercles.-The distinction in character between the thoracic and pygidial segments is not marked in the figure in the Sil. System, giving the appearance of too many body-segments. (They are only eleven). Brongniart's figure, t. 1.f. 3. A. though agreeing closely in many respects with the other specimen, seems to differ in the great number of lateral segments to the axis of the pygidium, (so also Mr Curtis' original figure, apparently of the same specimen in Buckland Bridg. Treatise, t. 46. f. 6, under the name Asaphus tuberculatus); and finally Mr Fletcher has just published figures of exactly similar specimens in the Quarterly Geol. Journal of London, Vol. VI. t. 32. (under the name Cybele punctata), which clearly prove the species to be a good one of the genus Encrimurus by its eye-line and cephalic angles, and easily distinguishable from the true $E$. punctatus by the narrow, tuberculated body segments, \&c.

Position and Locality.-Not uncommon in the Wenlock limestone of Dudley.

\section{Genus. ENCRINURUS. (Emmerich).}

Gen. Char.-Elongate ovate; cephalic shield semielliptical, tuberculated, the lateral angles produced backwards into spines; glabella pear-shaped, with three slightly-indicated segmental furrows at each side of the contracted base; cheeks flattened, triangular; eyes in the middle of the cheeks, elevated on tall footstalks; eyc-line extending from behind the eye direct to the outer margin, which it cuts in front of the angles; eleven body-rings shaped as in Zethus; pygidium triangular, lateral lobes with about eight segments, very much deflected, sometimes ending in short points; axis narrow, convex, with very numerous, fine segmental lines, often only indicated at the sides, leaving a smooth space down the middle.

This genus has been confounded with Cybele of Lovén (Zethus Pand.), from which it differs in the course of the eye-line.

\section{Encrinurus punctatus (Brïnn. Sp.)}

Ref. and Syn.-Entomostracites punctatus Wahlenberg, Nov. Acta Upsal. E. Stokesii $\mathrm{M}^{\circ}$ Coy, Syn.

Sil. Fos. Irel. t. 4. f. 15 (not Cybele punctata Fletcher, Geol. Jour. Vol. VI. t. 32. fig. 1 to 5).

Sp.Ch.-Entire animal elongate, ovate, more than twice as long as wide; cephalic shield semielliptical, length more than half the width, coarsely tuberculated, except the posterior margin, which is broad and smooth; body-rings broad, smooth, lateral lobes scarcely wider than the axis; pygidium triangular, pointed, a little longer than wide, having about eight narrow, nearly smooth ribs on each side, bent backwards and much downwards at their ends, the intervening spaces nearly as wide as the ribs, concave, smooth, coming off from the axis at an angle of about $45^{\circ}$ (the upper ones rather more, those towards the apex less), the last few embracing the end of the tail; axis with a narrow smooth space down the middle, on which are six or seven small tubercles, each side marked with about twenty-eight segmental furrows, one pair corresponding to each tuberele, and usually three or four pair between one tubercle and the next. Length of entire animal two inches two lines, of pygidium, seven and half lines.

I have figured the perfect animal for the first time in my "Synopsis of the Silurian Fossils of Ireland," under the name $E$. Stokesii, a name which I gave from the difficulty of fixing what was the true species of Brünnich and Vahlenberg, as I was acquainted with many unpublished forms, all sufficiently like to have been confounded with that species. I have since, however, examined so many specimens identical with this, from his original locality, Gothland, that I believe I may safely recur to the old specific name, though the accordance is not at all perfect between the species and the account or figure either of Wahlenberg, in the "Nova Acta Reg. Soc." \&c., Upsaliensis, or of Dalmann; the latter, however, agrees with the former, and shews the smooth body-rings, which separate the species so widely from that figured in 
Brongniart, Pl. 1. fig. 3. A., which has been referred to it by several authors (Mem. Geol. Surv., Burmeister, Fletcher, in Geol. Jour. Vol. VI., \&c.), but to which Dr Buckland has applied the specific name tuberculatus, which should be retained therefor.

Position and Locality.-Common in the Wenlock limestone, Dudley; sandstone of Pwllheli, Caernarvonshire; Middleton Park, near Sedburgh.

\section{5th Subfamily. ASAPHIN F ( $\left.M^{c} C O y\right)$.}

Pleure bent down at the end, and having distinct trigonal facets; thoracic segments eight to thirteen.

This subfamily may be looked on as the type of the entire group, and contains the most perfectly organised trilobites. They all, I believe, have the power of rolling themselves into a ball, and they are the only trilobites having the triangular facets at the anterior part of the extremities of the pleurx. They have a compact ovate form, and from the deflection of the margin are all of considerable depth.

The subfamily contains the following British groups, to which the rarik of families has been assigned by some writers, who, perhaps, magnified their importance from not studying them in connexion with the rest of the class Crustacea. I feel satisfied they are of only generic value, and each contains other groups hitherto called genera, but which seem to me only subgenera, and which I have grouped accordingly. 1st, Phacops; 2nd, Calymone; 3rd, Trimerocephalus; 4th, Asaplus; 5th, Illoomus; 6th, Forbesia; 7th, Phillipsia.

\section{Genus. PHACOPS (in a wider sense than Emmerich.)}

Gen. Char.-Head large, with the angles prolonged backwards into large spines; glabella clavate, wider in front than at the base, and marked with three strong segmental furrows; eyes very large, reniform, with a coarsely granular, largely facetted inner cornea; thoracic segments eleven; facial sutures cutting the lateral margin of the head in front of the angles.

This genus contains the following British sub-genera:-1st, Phacops; 2nd, Odontochile; 3rd, Portlockia; th, Chasmops.

\section{Sub-genus. Phacops (Em.)}

Gen. Char--Ovate, contractile; cephatic shicld semicircular, with a strongly-developed margin, terminating in spinous lateral angles; glabella clavate, broadly rounded in front, narrowed posteriorly, sides divided into three lobes, the anterior one on each side much the largest; eye-line curving round the glabella in front, bordering the small eyelid over each eye, and then passing from the posterior end of each eye direct to the lateral margin, which it cuts considerably in front of the lateral angle; eyes large, reniform, prominent, of many large lenses; thorax of eleven segments; pleuripedes subtruncate at their ends, facets large, triangular, strongly marked; pleural groove strong, slightly bent downwards at an angle on a level with the apex of the facet; pygidium semicircular or pointed, with eight to twelve joints in the axis, sides with about five strong duplex ribs, margin thickened, entire.

\section{Phacors altfrons (Salt. in Ap.) Pl. 1. G. fig. 12 to 14.}

$S p . C h$. Cephalic shield about twice as wide as long, very gibbous; glabella narrow, clavate, elevated, sides nearly straight; front obtusely rounded, projecting beyond the margin, with which, at the sides, it is confluent by a thick wing or horn-shaped extension on each side; (? lateral angles obtusely rounded). surface of the glabella coarsely tuberculated, lateral segmental furrows rather small, not very unequal in size; first lobe largest, first furrow directed obliquely backwards, the rest nearly transverse, with a slight inclination forwards, neck-segment about as thick as the last glabellar segment; cheeks steeply inclined from the glabella towards the lateral angle; surface with smaller granules than the glabella; eyes small, reniform, close to the glabella. Length of head nine lines.

The horn-like running out of the sides of the front of the glabella into the thickened margin of the cheeks gives a very peculiar character to the species. The pygidium supposed to belong to it is tumid, 
very obtusely rounded, width rather more than twice the length, of three tumid lobes, the axis most convex and rather more than half the width of the side lobes, with eight strong rounded segments, lateral lobes with a narrow entire margin and seven strong rounded ridges, the first one or two of which shew a very fine mesial dividing line; length five lines.

Position and Locality.-Caradoc sandstone, Alt yr Anker, Meifod, Montgomeryshire; impure limestone of Capel Garmon, on the Cowney River, Denbighshire; Wilfa, near Penmachno; Pont y Glyn, Diffwys, near Corwen; Cwm of the Cymmerig, Bala, Merionethshire.

Explanation of Figures.-Pl. 1. G. fig. 12. Cephalic shield, natural size, (angles not perfect in specimen), from Capel Garmon.-Fig. 13 and 14. Pygidium natural size, from Pont y Glyn, Diffwys.

\section{Pinacops Downingize (Murch. Sp.)}

Syn. and Ref.-Calymene Id. Murch. Sil. Syst. t. 14, f, 3.

$S p$. Ch.-Ovate, depressed, head and pygidium of equal length; cephalic shield rotundato-trigonal, flattened, slightly more than twice as wide as long, margin obtusely angulated in front, (?lateral angles rounded); glabella very minutely and obscurely granulated, clavate depressed, anterior segmental furrows slightly sigmoid, oblique, second and third pair nearly transverse, all the furrows narrow and nearly reaching to the middle, the spaces behind the first pair are triangular, and broader than long, the second pair are transversely oblong, the space behind the third pair forms a nearly perfect transverse segment, only half as thick as the second space, or two-thirds that of the neck-furrow, which is very strong and prominent; first seven rings of the thorax equal to the length of the head; pygidium semi-oval, length more than half the width, axis prominent, of seven thick segments, sides with five flattened duplex segments. Length one inch two lines.

Neither the figures in the "Silurian System," nor the "Memoirs of the Geol. Survey," exhibit the intermediary or duplicating furrows on the lateral ribs of the pygidium, they however may be seen to exist.

Position and Locality.-Wenlock limestone of Dudley; Upper Ludlow of Benson Knot, Kendal; Moel Sessiog, Llanrwst.

\section{Sub-genus. Odontochile (Hawle and Corda.)}

$S_{y n}=$ Dalmannia Emmerich, (not of Robineau-Desvoidy).

Gen. Char.-General form, buckler, glabella, eyes and eye-lines, as in Phacops, but the lateral lobes of the glabella more equal; not contractile; thorax of eleven segments; pleuripedes curved backwards and generally pointed at their extremities, facets very long, narrow rhomboidal, slightly defined; pleural groove strong, slightly sigmoid and oblique (not angulated); pygidium elongate, generally pointed, axis with from twelve to twenty-two segmental furrows, sides with fewer (about half the number) strong ribs, usually duplex, confluent at their ends with the thickened entire margin; hypostoma with a dentate edge.

This genus was first noticed by Emmerich under the name Dalmannia, which was used fifteen years before for a genus of insects by Robineau-Desvoidy, I therefore use the name of Hawle and Corda, who do not allude to Emmerich's having previously characterised the genus.

\section{Odontocinle caudata (Brong. Sp.)}

Ref. and Syn.-Asaphus caudatus Brong. Crus. Foss. t. 2. f. 4, and Murch. Sil. Syst. t. 7. f. 8.

Sp. Ch.-Ovate, cephalic shield depressed, semi-ovate, twice as wide as long, exclusive of the lateral spines, which extend backwards and a little outwards as far as the sixth or seventh segment, confluent at base with the thick strongly defined borders of the circumference and posterior margin; glabella broadly clavate, slightly angulated in front, coarsely and irregularly granulated, the anterior pair of segmental furrows broad, and inclining obliquely backwards and inwards, the two posterior pair much narrower and nearly transverse; cyes very large conico-reniform; axal segments of the thorax four-fifths the width of 
the pleurx, each side with a small tubercle; pleurce gently arched backwards towards their falciform extremity, each with a strong submesial furrow reaching noarly to the end; pygidium as long as the head but much narrower, semielliptical, abruptly narrowed towards the apex to form a short flattened solid mucronate point, an extension of the lateral margin; axis narrow, of twelve segments, with a faint tubercle at each end, lateral ribs eight, separated by deep furrows, and each divided by a fine medial sulcus. Average length of pygidium one inch, width thirteen lines.

At Underbarrow, and Benson Knot, Kendal, occurs a trilobite about one-third the ordinary size of this, and of which I have not seen the tail, but which seems. identical in the charaeters of the head and body so far as I have seen, except, perhaps, the Iateral cephalic spines may be smaller; it was figured in a (ancelled plate of this work by Mr Salter as the P. Downingice, from which however it differs in its more elongate glabella, more equal side-lobes, and coarsely granulated surface (the latter claracter being overlooked, apparently, by Mr Salter, and not represented in the figure he made of the species). It may for the present be called Odontochile caudata, var. minor.

Position and Locality.-Very common in the Wenlock limestone of Dudley; Llandeilo, Caermarthen. shire; Leintwardine; Llanfair Road, W. of Velshpool; above grits Park Lane.

\section{Odontochile LONGicaudata (Murch. Sp.)}

Ref. and Syn.-Asaphus longicaudatus Murch. Sil. Syst. t. 14. f. 11-13.

$S p . C h$. Cephalic shield semioval, external defined margin very large, abruptly extended in front into a small, obtuse, tongue-shaped process, extending backwards into very long spines at the lateral angles; glaluelle clavate, moderately gibbous; pygidium triangular, sides slightly convex, apex running out into a slender spine as long as the rest of the pygidium, axis narrow, of fourteen or fifteen segments, eight or nine oblique, strongly defined, lateral rilos. each divided by a fine mesial sulcus. Averarge length of head nine lines, width one inch nine lines.

Position and Locality.-W Wenlock shale, Chiney Longville, Shropshire; Middleton Park, Llandeilo.

\section{Odontochlle obtusi-Caudata (Salt. Sp.) Pl. 1. G. fig. 15, 16.}

Ref. and Syn.-Dalmannia obtusi-caudata (Salt. in Ap.)

Sh. Ch.-Cephalic shield more than twice as wide as long, slightly angulated in front; glabella convex, clavate, front portion transversely oval, segmental furrows very strong, reaching neariy across, first pair inclining obliquely inwards and backwards, second pair slightly forwards, third pair horizontal; first lobe equal in size to the second and third together: neck-furrow and segment strong and large: clecks depressed, lateral angles with a very small spine. pyes small, close to the glabella, little exceeding the first lobe in size, deeply lunate: pygidium semielliptical, about twice as wide as long (varies from mechanical causes affecting the matrix), margin narrow, angulated at the apex, but not extended into a point; axis very convex, gradually tapering, about two-thirds the wirth of the lateral lobes, having twelve rounded segments, lateral lobes flattened, with twelve Hattened ribs, each divided by a very fine impressed line. Average length of head ten lines, of pygidium six lines.

In Mr. Salter's engraving of this species the neck-furrow is represented as interrupted in the middle, like the lateral segmental furrows of the glabella, but in the specimens it is seen to go right across, as in the other Trilobites.

This species is allied to the $P$. $(O$.$) caudata, but the margin does not become widened into a flat,$ triangular point, as in that species; the specimens are much distorted.

Position and Locality.-Very abundant in the calcareous flags over the Coniston limestone of Coldwell, Westmoreland.

Explanation of Figures.-Pl. 1. G. fig. 15. Cephalic shield natural size.-Fig. 16. Pygidium natural size. 
Odontochile truncato-caudata (Portk. Sp.) Pl. 1. G. fig. $20,21$.

Ref. and Syn.-Phacops truncato-caudatus Port. Geol. Rep.t. 2. f. 1. 4. Dalmannia affinis (Salt.) Mem.

Geol. Surv. Vol. II. Pt. 1. t. 5. f. 5.

Sp.Ch.-Pygidium semielliptical or subtriangular, with the posterior end obtusely truncated and emarginate in the middle; axis gradually tapering, rather more than four-fifths the length of the pygidium, and about two-thirds the width of the lateral lobes in front (sometimes a little more or less), of sixteen or eighteen segments; lateral lobes with a very narrow entire margin, and fifteen or sixteen broad, flattened ribs, each divided by a very fine impressed line. Average length of pygidium one inch three lines, width the same.

The proportion of the width of the axis to that of the lateral lobes varies considerably from pressure hoth in the $D$. affinis and in English and Irish specimens of the $P$. truncato-caudatus. The figure given by Mr Salter of his $D$. affinis, in the Mem. Geol. Surv., shews the same proportion of axis to the lateral lobes as Portlock's figure t. 2. f. t. of his species. Mr. Salter in the same work mentions that his species has fifteen or sixteen lateral ribs, which is more than the $P$. truncato-caudatus, but Tyrone specimens of the latter now before me shew the same number; the length of the ribs is certainly the same in both. I at first thought $D$. affinis might be distinguished from the Irish species by the more acute angles at which the lateral ribs set off from the axis; I find this, however, to differ on two sides of the same specimen, and is as marked occasionally in one species as in the other. It is only the pygidium that has occurred to collectors as yet in England, and in the absence of distinctive characters I have reunited the species.

Position and Locality.-Shales of Blain y Cwm, W. of Nantyre, Glyn Ceiriog; the Hollies, Church Stretton, Shropshire.

Erplanation of Figures.-Pl. 1. G. fig. 20. Pygidium natural size (type specimen of the Placops affinis, Salt.)-Fig. 21. Small specimen.

\section{Subgenus. Pontlockia $\left(M^{c} C o y\right)$.}

Gen. Char.-Cephalic shield truneato-orbicular, lateral angles not produced into spines; glabella very large, broad in front, sides converging to a narrow base behind and having (on the outer crust) but one small, segmental furrow at base; cheeks small, triangular; eyes large, reniform; eye-lines extending from the base of the eye to the outer margin, a little in front of the angles; abdomen of eleven seguents, resembling those of Phacops; pygidium small, semielliptically rounded, with a simple, entire margin, of about five to eight segments to the axis and about five to the lateral lobes, each with a very fine mesial divisional line in the distal portion.

I originally proposed this genus in my Sil. Fos. of Ireland in $\$ \$ \$ 6$, for those species of Pliacops in which the two anterior pairs of great segmental lobes of the sides of the glabella were deficient, and the lateral angles of the cephalic shield were not prolonged. The Calymene Bufo of Green, C. macrophthatma of Murchison, duc. being the types of the genus, which has been recognised as a natural group by Goldfuss, Burmeister, \&c., as well as by my friend Col. Portlock, to whom I dedicated the group.

\section{Pontlockia? apiculata (Salt. Sp.) Pl. 1. G. fig. 17 to 19. \\ Syn.-Phacops apiculatus (Salt. in Ap.)}

sp. Ch.CCphatic shield moderately convex, semioval, length slightly exceeding half the width. glubellu senicylindrical, front obtusely rounded, not very much wider than the base, sides nearly straight, converging from the front to the wide neck-furrow; segmental furrows three, nearly equidistant, on each side, the two upper (or anterior) pairs very fine and almost obsolete, basal pair very strong and gently arehed backwards; eyes long, narrow, semilunar; checks triangular, longer than wide, sloping from the eye to the rounded lateral angles, furrow at the posterior margin much stronger than the one at the external margin; surface smooth; Mygidium (supposed of the same species) depressed, semielliptical, length about two-thirds the width, slightly pointed, margin narrow, entire, axis narrow, tapering, strongly projecting at the end, 
with seven or eight narrow segments, sides slightly convex, with five Hattened ribs, each divided by a fine mesial sulcus. Arerage length of head four lines, of rygidium three lines

This interesting species blends in some measure the characters of the subgenus Portlockin with those of Phacops proper. I have noticed that all the Portlockin, though when perfect shewing but the basal pair of segmental furrows to the glabella, yet when decorticated shew faint and delicate traces of the other two pairs, never comparable in strength, however, to the basal pair. All the specimens of the present species are internal casts, therefore shewing the three sets of furrows, but the basal pair being so much stronger than the others farours the idea of its being a Portlockia, as no such difference exists in Phacops proper. The head and pygidium, here noted, have not been absolutely found in contact.

Position and Locality.-Very common at Maes Meillion, Bala, Merionethshire; Glyn Ceiriog; Bryn Melyn, Bala, Merionethshire; S. W. of Pwllheli, Ciernarvonshire; Rhiwargor, near Llanwddyn; Cowney River, Montgomeryshire; Cefn Goch, Llansantfraid; schists of Hengurt Uchaf.

Explanation of Figures.-Pl. 1. G. fig. 17 and 18. Cephalic shields, natural size.-Fig. 19. Pygidium natural size.

\section{Portlockia Stokesit (M.Edw. Sp.)}

Ref. and Syn.-Asaphus macrophthalmus (Brong. pars. t. 1. fig. 5). Calymene id. Sil. Syst.t. 14. f. 2.

Sp. Ch.-Cephalic shield semicircular, twice as wide as long; glabollit subrhomboidal, clavate, the broad front slightly pointed in the midlle, granulated; neck segment thick and strong, one strong segmental furrow on each side of the narrow base immediately above the neck-furrow, reaching nearly across (on casts of the inner surface I have seen traces of the other two segments as delicate impressed lines not visible on the external crust); cheeks tumid, small; eyes very large, reniform, coarsely reticulated; lateral and posterior margins strongly defined, thickened, lateral angles obtusely rounded; pingitium nearly semicircular, slightly more than twice as wide as long, axis of five segments, side lobes with about four fine segmental furrows; length of head about three lines.

P'sition aud Loculity._Wenlock Limestone of Dudley, Staffordshire; Llangynyw Rectory, Montgomeryshire; Garden Quarry, Aymestry, Herefordshire.

\section{Genus. CHASHOPS (MCCOy).}

\section{Ref.- $\mathbf{M}^{\mathrm{C}} \mathrm{Coy}, \mathrm{Ann}$. Nat. Hist. 2nd Series, Vol. IV.}

Gen. Char.-Cephalic shield sub-semicircular, lateral angles produced backwards into triangular spines; ald, lobes, the anterior pair very large, triangular, posterior pair small, middle pair entirely obsolete or reduced to minute tubercles; neck segment strong; cheeks small, triangular; eyes small, prominent, rounded, corresponding in length to the middle portion of the first lateral lobes of the glabella; eye-line encircles the front of the glabella close to the margin, descends with an inward inclination to the eye, extending from behind the eye directly outwards to the lateral margin, which it cuts considerably in advance of the angle (thorax of eleven joints, fid. Eichwald); pygidium obtusely rounded, posterior margin deflected, anterior margin wider than the posterior, axis of about ten ribs, lateral ribs about two less, duplex.

The Calymene Odini of Eichwald may be looked upon as the type of this genus. It differs from Calymene in the glabella being so much wider in front than at base, in the anterior lateral lobes being largest, in having but eleven (!) body segments, and in its eye-line cutting the external margin in front of the produced angles; these differences become agreements when compared with Phacops, from which it differs in the size and shape of the eyes. Of these organs in the present genus, and in Calymene, nothing is known beyond that they were of so tender and delicate a nature as readily to fall out after death so as seldom or never to be found in the fossil state, their position being merely indicated by a hole, roughly filled by the matrix, forming the "hiant" eyes of systematists; in Phacops, on the contrary, the cornea is of extraordinary strength and so firmly united to the rest of the cephalic shield, that no matter how much crushed the specimens may be the eye always remains, and from its constant 
presence, coarse reticulation, and large lenses, gives an appropriate name to the genus, and one which is in antagonism with that I have adopted for the present group*. Chasmops differs, besides, from both these genera in the almost complete suppression of the middle pair of segmental lobes of the glabella.

Chiasmons Odini? (Eich. Sp.) Pl. 1. G. fig. 22, 23.

Ref. and Syn.-Calymene Odini Eich. Sil. Syst. in Esthl. Phacops felinus Salt. in Ray ed. of Burmeister, p. 125. Asaphus Powisii (head only) Murch. Sil. Syst. t. 23. f. 9.

Sp. Ch.-Cephalic shield semicirculs, lateral angles extending backwards into triangular flat spines; glabella gently convex, nearly one-fourth wider than long, broadly clavate, first segmental furrow of each side arched obliquely backwards and inwards, having about one-fourth the width of the glabella between them, second pair of furrows inclining forwards and inwards so as nearly to meet the ends of the first pair; space behind the anterior segmental furrow very large, triangular, extending nearly to the neckfurrow, middle lobe entirely obsolete or reduced to a minute granule; third lobe much larger but less than the neck-furrow; neck-segment thick, strongly defined; cheeks triangular, slightly convex, a little wider than high; cyes rounded, their diameter less than half the length of the first lateral lobe of the glabella, close to the axal furrows; surface granulated; pygidium elevated, marginal third deflected almost vertically, axis of ten segments, convex, two-thirds the width of the side-lobes in front, abruptly narrowed after the fifth segment, lateral segments thick, about eight, each divided by a fine mesial line; entire part of margin narrow. Average length of head nine lines, width one inch nine lines; length of pygittium nine lines, width one inch four lines.

On examining the specimen figured on the plate by Mr Salter, I find that the angles are broken, but shew evident traces of the large spines on both sides, and another specimen from Applethwaite Common shews one of them distinctly, and of great size.

Position and Locality.-Common in the limestone at Llandeilo, Caermarthenshire; in the beds under the limestone Glyn Ceiriog, Denbighshire; Llansantfraid; Alt yr Anker, Meifod, Montgomeryshire; Applethwaite Common, Westmoreland; Coniston Water-Head, Lancashire; Tre Gil, S. of Llandeilo; Selottyn Road.

Explanation of Figures.-P1. 1. G. fig. 22. Cephalic shield, natural size (Mr Salter's figure on this plate erroneously represents the angles as rounded-they are produced into long, flattened spines, partially broken off in the specimens); schists of Llansantfraid.-Fig. 23. Pygidium, natural size, same locality.

\section{Genus. CALYMENE (in a wider sense than heretofore).}

Gen. Char.-Lateral angles of the head obtusely rounded, exactly bisected by the facial sutures; eyes small, "hiant;" glabella narrower in front than at the base; thoracic segments thirteen.

These trilobites differ remarkably from Phacops in the structure of their small eyes, which are seldom or never preserved, seeming to have been of so delicate a nature as to fall out on the animals death, leaving a hole in the cephalic shield where they were set, whence Dalman's term "hiant." The head differs from Phacops in its blunt lateral angles, and the glabella being wider at base than in front, and in the course of the eye-line; the body differs in having thirteen instead of eleven segments.

The two following are British subgenern; 1, Calymene, 2, Homalonotus.

\section{Subgenus. CALYMENE (Brong.)}

Gen. Char.-Buckler semicircular, with a reflected anterior margin and obtusely rounded lateral angles; glabelle narrower in front than at base, sides marked with three maxillary furrows and tubercles on each side, the anterior smallest; eyes about the middle of the cheeks, reniform, prominent, strongly facetted; eye-line advancing to the anterior margin, where being confluent with the marginal suture it joins that of the opiosite side; over the eye it makes a small curve outward, defining a semicircular eyelobe, from whence

* I need scarcely say, that of course, both this genus and Calymene hal originally eyes, like other Trilobites in gencral structure, but differing remarkably from their allies in form, or strength of cornea. 
it extends to the lateral angles, which it bisects on each side: thorax of thirteen rings, axis very convex, lateral lobes wider than the axis, bent down at their ends with large facets, each with a strong pleural groove angularly bent down and confluent at its end with the posterior margin; pygidium narrower than the buckler, semioval, with distinct seven, nine, or eleven joints, prominent axis, and broad. convex, lateral lobes, the segments of which are flat, about equal to the axal in number, and divided by a sulcus at their ends.

\section{Calyanene Baylei (Barr.) Pl. 1. F. fig. 8.}

\section{Ref.-Barrande, Notice Prélim. p. 51.}

Sp. Ch.-Glabelle alout one-fifth longer than wide, not very prominent, front subtruncate, about half the width of the base, anterior lateral tubercle scarcely perceptible, two posterior pairs large, rounded; neck-seginent and furrow small; margin in front of the glabella flat, truneated in front, parallel with the posterior margin, less than half the length of the glabella; eyes small, on a level with the anterior and middle tulercle of the glabella; cheek convex, nearly as prominent as the glabella near it, gradually becoming depressed and produced lackwards into short spines at the lateral angles; surface covered with a minute unequal granulation. Length of head about six lines.

This differs from the $C$. Irevirapitata in the length of the glabella and the flat truncated margin in front of the glabella, while the shortness of this margin separates it from the $C$. Tristani and C.parvifrons, as well as the backward position of the eyes.

Pusition and Locality.-Common in the limestone of Golden Grove, Llandeilo; Sandly beds of Tre Gil, S. of Llandeilo.

Eirplanation of Fignues.-Pl. 1. F. fig. 8. Cephalic shield, natural size, from Tre Gil (antennary punctures on each side near the front of the glabella) -Fig. $8 \alpha$. Profile of ditto.-Fig. $8 b$. Granulation magnified from flat plate in front of head of a specimen from the limestone of Golden Grove.

\section{Calymene Blumenbacmi (Brong.)}

\section{Ref.-Murch. Sil. Syst. Pl. 7. f. 6. and 7.}

Sp. Ch.-Body deep, compressed posteriorly, the pygidium and outer two-thirds of the pleure steeply inclined; cephatic shield minutely granulated, and with irregular small tubercles, semicircular, twice as wide as long. with the lateral angles olbtusely rounded; alcbelle touching the narrow thickened anterior margin with its obtusely rounded front; three flattened. spheroidal tubercles on each side, anterior one small : cyles small, on a level with the second tubercle; cheeks triangular, a little longer than wide, slightly convex; pleurce about one-fifth wider than the axis, the portions each side of the pleural furrow of nearly equal prominence; Intenral grooves angularly bent down alout their middle, towards the posterior margin; the ends of the axal sergments very slightly thickened: pygidium having the lateral and posterior edges nearly horizontal (in one plane). anterior margin one-third larger than the posterior, length more than half the width of the posterior margin, and less than half the width of the anterior margin; axis convex of seven segments, lateral lohe flattened, oi five flattened ribs separated by strong furrows, each divided by a mesial sulcus, extending almost hatf-way from the margin; stufice of tail minutely and closely granulated, of head and body with small irregular tubercles among the granules.

Position and Locality.-Tery common in the Wenlock limestone of Dudley, Staffordshire: Llanwddyn, in the Berwyn Mountains; schists of Drummuck.

\section{Calmaene brevicapitata (Portk.) Pl. 1. F. fig. 4, 5, 6.}

Ref. and Syn.-C. Blumenbachii (Port. not of Brong.) and C. brevicapitata id. Geol. Rep. t. 3. f. 1. 3.

$S_{p}$. Ch. - In size and form resembling $C$. Blumenbachii, but the body narrower and flatter; the glabella triangular, the narrow rounded front little more than half the width of the base, and having a concave space between it and the thickened anterior margin equal to the width of this latter, the two together being nearly equal to half the length of the glabella, excluding the neck-segment; checks triangular, ahout one-fifth longer 
than wide, the part anterior to the eyes elevated into a gibbous, oblique, ridge running inwards and forwards towards the margin, the posterior half gently convex; antennary pores large; cyes small, in the middle of the width of the cheeks, extending from the top of the basal to the top of the middle tubercle of the glabella; axis of the body exceeding the width of the pleurre by nearly one-fifth, and having tubercles at each end nearly one-third of the width of the axis in length; the line of angulation of the pleural furrows, and at which the pleure bend down, is about one-third the width of the pleure from the axis near the head, but mradually. approaching the axis towards the tail ; tail minutely granulose, flattened, about seven or eight segmental furrows in the axis, and seven flat lateral ribs, separated by narrow sulci, and each divided by a fine mesial line.

The triangular narrow-fronted glabella, with the space between it and the nargin, and the strongly ridged cheeks in front of the eyes, distinguish the head from $C$. Blumenbarhii; the great proportional width of the axis, with the very large tubercles at the ends of the segments, distinguish the body, and the flatness of the lateral ribs, their duplicating furrows extending to the axis, and narrow divisional sulei, distinguish the tail from the same. The great width of the axal, and narrowness of the lateral lobes, separate the body from that of the C.tuberculosa (see the latter), while the less wide and flat anterior margin, and the width of the base of the glabella equalling, or a little exceeding the cheek, separate the head. I cannot think, with Mr Salter (Mem. Geol. Surv.) this species referrible to the $C$. parvula of Barrande and Beyrich, in which the position of the eyes is much further back (on a level with the middle of the basal lobe), the segmental furrow very small, and the shield as remarkably long and angulated as this is wide and obtusely rounded. It is possible some of the so-called varieties of the C. senaria of the American geologists may be identical with this species.

Position and Locality.-Abundant in the schists of Nant yr Cwm; Acton Scott, Church Stretton, Shropshire; Llandeilo, Caermarthenshire; Applethwaite Common, Westmoreland; Alt yr Anker, Meifod, Montgomeryshire; Mathyrafal, S. of Meifod, Montgomeryshire; Bryn Melyn, Bala, Merionethshire; Llangynyw Rectory, Montgomeryshire.

Explanation of Figures.-PI. 1. F. fig. 4. Cephalic shield from the schists of Nant yr Arian (antennary punctures distinct at each side of the front of the glabella). - Fig. 5. Pygidium of ditto, from the same mass.-Fig. 6. Profile of head from Applethwaite Common.

\section{Calymene sub-diademata* (Mc Coy). Pl. 1. F. fig. 9, 10.}

Ref.-C. diademata Barrande, Beyrich Untersuchungen, \&c. t. 2. fig. 4.

sp. Ch.-Cephulic shicld nearly twice and half wider than long; glabella broad, tumid, subcylindrical, front two-thirds the width of the base, very obtusely rounded, two posterior pair of lateral tubercles large, rounded, anterior first pair very minute; a prominent reflexed rounded margin about as thick as the necksegment and rising nearly to the height of the glabella, is separated from it in front by a deep sulcus, equal to the thickened margin in width, the two together equal to about one-third the length of the glabella (ex. clusive of the neck-segment); checks wider than high, gibbous, particularly in front of the eyes, which are small, and on a level with the anterior and middle lateral tubercles; neck-segment thick. Usual length of cephalic shield ten or eleven lines.

This species differs from the Calymene brevicupitata in the greater width and obtuseness of the front of the glabella, the wider side-lobes of head and body, and the shorter front margin, while from C. Blumenbachii it differs in the greater width of the shield, and the broad furrow and high reflexed margin in front of the glabella, as well as wider pleure; imperfect casts of the middle part of the head of the latter species are in some cases, however, I think, undistinguishable.

* This fossil scemed to me perfectly identical with Beyrich's figure of what he considered Barrande's undoubted C. diademata, and I think so still, but M. Barrande assures me that these specimens aro not of his species, and as his suggestion that they belong to C. Lrevicapitata, is elearly negatived by the great proportional width of the side-lobes both of the body and head, as well as the wider front of the glabella, I am obliged, as these sheets pass through the press, to propose a separate name. It is a representative of the American C. senaria of the New York Llandeilo Hag, or Trenton limestone-differing by its greater width and the tubercular ends of the axal segments of the thorax. 
Position and Locality.-Caradoc sandstone of Mulock, Dalquorhan; schists of Pwllheli ; schists of High Haume; limestone of Acton Scott; limestone of Leintwardine; a small variety at Coed Sion, and Coniston Water, seems only to differ in size, giving the follorving additions:-axis narrow, the segments tubercular at their ends; pleure more than twice as wide as the axis, abruptly bent downwards at about one-third their length from the axal lobe in front, but almost directly from their origin nearer the pygidium; pygidium nearly vertical, as in the C. Blumenbachi, the middle lobe with about five segments, five lateral ribs separated by large furrows, each divided by a small medial sulcus.

Explanation of Figures.-Pl. 1. F. fig 9. Imperfect head, natural size, from the limestone of Leintwardine-_Fig. $9 a$. Profile of ditto-_Fig. 10. Perfect specimen of small variety from Coniston.-Fig. $10 a$. Profile of ditto magnified, shewing the great width of the side portions both of the head and body.

\section{Calymene Parvifrons (Salt. in Ap.) Pl. 1. F. fig. 7.}

Sp. Ch.-Width of the checks equal to the length of the ceplalic shield; front three-fourths the length of the glabella, margin subtruneate, not reflected, tumid in the middle: alabella slightly wider than long, but little convex, lateral lobes prolonged very obliquely forwards and outwards, the anterior pair obsolete; neckfurrow small; checks large, tumid; antennary punctures large; eyes very small, their upper edges on a line with the upper edge of the glabella. Length of cephalic shield six lines, width one inch four lines.

The general depression and great size of the margin in front of the glabella, and very forward position of the eyes, seem to distinguish this species.

Is this the Calymene incerta of Barrande? It is possibly a Pharostoma of Hawle and Corda, but as we have only the middle piece of the head, it is not certain.

Position and Locality.-Only one specimen has occurred in the Porphyry Slates of Tahirion, near Arennig Fawr, Merionethshire.

Explanation of Figures.-Pl. 1. F. fig. 7. Cephalic shield, natural size.-Fig. 7 a. Profile of ditto.

\section{Calymene tuberculosa (Salt.)}

Ref.-Mem. Geol. Surv. Vol. II.t. 12.

Sp. Char,-Cephalic shich minutely granulose, nearly semicircular, depressed, front rounded, a slightly reflexed margin-plate, nearly one-half the length of the glabella, in front of its anterior end; glabella as in the r. Urevicupituta, but only two-thirds the width of the cheeks at base; eyes rather before the second glabellar tubercle, near the upper angle of the cheeks, which are moderately convex; body depressed ; axis convex, narrow, the segments with a small rounded tubercle at each end; pleurce at least one-third wider than the axis, flattened at their axal half, and rapidly curved downwards from thence to the extremities; knee at about half their length from the axis in the anterior portion, approaching the axis towards the tail portion behind; the pleural sulcus most prominent at the angle; pygidium granulose with more convex lobes, and more rounded posterior margin than the C. Blumenbachii; axis flattened with seven rounded segments ending in obscure tubercles; five lateral ribs with strong dividing furrows becoming gradually obsolete at the margin.

The broad margin in front of the short conical glabella, the great width and flatness of the pleuripedes in froportion to the axis, and the convexity of the rounded pygidium, separate all the parts of this from the C. Blumeruchii. The head closely resembles that of the C. brevicapitata, but is easily distinguished by the narrowness of the base of the glabella when compared with the posterior margin of the cheeks.

Position and Locality.-Common in the Lower Ludlow shale of Garden Quarry, Aymestry, Herefordshire; Wenlock, S. Cheney Longville, Shropshire; upper Ludlow rock of High Thorns, Underbarrow.

\section{Subgenus. HOMALONOTUS (König). \\ Syn. = Trimerus + Dipleura. (Green).}

Gen. Char.-Buckler semielliptical, convex in the middle, obtusely pointed in front, lateral angles not produced; glabclla indistinct, simple, subquadrate, with concave sides, narrower in front than behind, not reaching 
to the front margin; eyes small, hiant, reniform, in the midst of the cheeks, opposite about the middle of the glabella; eye-line continuous from one side to the other, all anterior to the eyes being nearly parallel with the margin of the buckler, pointed in front, forming the usual small outward lobes over each eye, and from thence to the lateral angles or a little in front of them; thora $x$ slightly arched, imperfectly trilobed, of thirteen segments ; axis wider than the lateral lobes, which have subtruncate ends with large distinct facets; pleural sulcus as in Calymene, arising from the posterior margin near the undefined axis, and at half its length abruptly bent down again to it; pygidium subtrigonal, pointed, with a very narrow axis or none, the lateral ribs undivided.

\section{Iomalonotus bisulcatus (Salt. in Ap.) Pl. 1. G. fig. 24 to 31.}

Sip. Ch.-Pygidium semielliptical, edge compressed, convex anterior margin widely arched, sides nearly: straight, converging to an obtusely rounded termination; axis gradually tapering, nearly as wide as the side lobes, flat, indistinctly marked, not quite reaching the margin, eleven or twelve segmental furrows, the two anterior stronger than the rest; sules with about seven broad flat ribs, separated by narrow sulci, the two anterior of which are disproportionably deep furrows, the rest very shallow; surface smooth; pygidiun from half to one and quarter inches in length.

The disproportionate strength of the two anterior segmental furrows of the pygidium, and the obtusely rounded extremities, characterize this species well. There is a small variety in whicli only eight or nine segments can be counted in the axis, and the first two furrows not so strongly marked. The head supposed to belong to this species has the glabella oblong, one-third longer than wide, distinctly bounded by a strong furrow at the sides, more obscurely in front.

Position and Locality.-Caradoc sandstone of Acton Scott, Church Stretton, Shropshire; Alt yr Anker, Meifod, Montgomeryshire; Maes Meillion, S. of Bala, Merionethshire; Ravenstone Dale, WVestmoreland; Capel Garmon, Denbighshire.

Explanation of Figurs.-Pl. 1. G. figs. 24 and 25. Portions of cephalic shield, natural size, from near Pwllheli.-Fig. 26. Pygidium and part of thorax (this specimen is not in the collection).-Figs. 27 and 28. Pygidia natural size, from near Acton Scott.-Fig. 29. Part of small cephalic shield.-Figs. 30 and 31. Pygidia of supposed varieties from Ravenstone Dale.

\section{Homalonotus KNightil (König).}

Ref. and Syn.-H. Knightii König, Icon. Fos. Sec. H. Ludensis and H. Knigltii Murch. Sil. Syst.

$$
\text { t. } 7 . \text { f. } 1,2 \text {. }
$$

Sp. Ch.-Axis of the abdomen very wide and obscurely defined; pygidium ovate, convex, anterior margin nearly senicircular, sides converging rapidly to a smooth, simple, undivided, subtrigonal pointed truncation; about nine gently curved distinct, narrow segments, separated by strong sulci, the axal and lateral portions appearing continuous, a slight oblique depression on each side marking the axis. Average length of the pygidium nine lines, width one inch.

Position and Locality.-Upper Ludlow rock of Tenter Fell, Kendal, Westmoreland; schists of Middleton Park, near Sedburgh.

\section{Homalonotus rudis (Salt. in Ap.) Pl. 1. E. fig. 20.}

Sp. Ch.-Pygidium semielliptical, elevated, axis defined by strong furrows, gradually tapering, convex, of about seven or eight strong nodulous segments; sides slightly convex, sloping downwards and outwards from the axis, of six strongly defined, broad, nodulous ribs. Length of pygidium about one and a quarter inches.

One of the specimens seems to shew but three great ribs on the anterior half of the axis, and may possibly be distinct.

Position and Locality.-In the coarse grey schists of Capel Garmon, Denbighshire.

Explaration of Figueres.-Pl. 1. E. fig. 20. Pygidium, natural size-Fig. $20 a$. Portion of much larger ditto. 


\section{Genus. ASAPHUS (in a wider sense than Brong.)}

Gen. Char.--Head and tail nearly equal; eyes with a firmly fixed, thick cornea, with a smooth external surface; facial suture cutting the posterior margin of the cephalie shield within the lateral angles; thorax with eight to ten segments, having large facets and distinct, wide, nearly straight pleural grooves, not reaching the margin; alubella indistinctly defined in front; pygidlun with the segments usually indistinetly marked, the axis generally distinct and annulated, when traceable, always elongate conic (of the ordinary type).

Contains among others the following subgenera, 1st, Asuphus (not British, taking the A. coinigemes as the type); 2nd, Isotelus.

\section{Sulgenus. ISOTELUS (Dekay).}

Gen. Char.-Large, elliptical; buckler semielliptical, with the angles rounded, or produced backwards into spines; alcublla indistinctly defined; eye-lines meeting at an acute angle at the front margin, thence diverging backwards, slightly approximating again about the middle of their length, where the "liant" eyes are situated, and again diverging to cut the posterior margin near the angles; thurer of eight segments, axis as wide or wider than the lateral lobe, the ends of the pleure rounded, with a strongly marked triangular facet and pleural groove; pygidium resembling the buckler in size and shape, trilobed, and generally with a broad smooth margin; axis and lateral lobes with fine segmental furrows, or smooth.

There seem to be two types, 1st, the Isoreuus (gigas, \&ce.), having the angles at the head rounded, and no distinct segmental divisions of the pygidium; 2nd, (Asuphus tymonus, dc.) having the lateral cephalic angles produced into spines, and both the axis and lateral lobes of the pygidium distinctly defined and divided into simple segments. After a careful review of all the species I do not, however, feel competent to separate them; if it should be found convenient to distinguish them as sulgenera, the name Isotelus should be retained for the former, and the latter might be called Busilicus, as suggested by $\mathbf{M r}$ Salter, in the 2nd Decade of the Creol. Survey. Busilicus differs from Ontygit, which it closely resembles in shape, in the facets of the pleure, as well as the simple (not duplex) furrows of the pygidium; the glabella is more prominent than in Isotelus proper.

\section{Isotelus affinis $\left(M^{c} C o y\right)$. Pl. 1. F. fig. 3.}

Syn. and Ref.-Isot. nigas, I. planus and I. Powisii of Portk. Geol. Rep. (not of the writers he refers to) PI. 6. f. 1. and t. 7. f. 2 and 3.

Sp. Ch.-Axis of the body only slightly exceeding the pleure in width; pleurce gently arched downwards at a very obtuse angle; from about half way between the axis and the extremity, a large pleural furrow reaches from the axis to about one-third of the truncated extremity of each; pygrelinm flattened, semielliptical, or slightly trigonal, from the straightness of the sides; axis narrow, sharply defined, gently convex, reaching as far as the concave space round the margin.

In general proportion this resembles the Isotelus gigas (Dekay), from all the varieties of which it is distinguished when specimens of the same size are compared, by the much greater flatness or depression of all its parts, the long, narrow, sharply defined axal lobe of the pygidium, and the much greater length of the pleural groove of the pleure (nearly double that of the $I$. nigus), and distance of knee from the axis, as well as their slight degree of deflection (being bent at nearly right angles at one-third from the axis in $I$. gigas). The pygidium differs from that of the $I$. Powisii (Murch. Sp.) by the absence of all segmental furrows on the lateral lobes, except the first, and by the more pointed outline and narrow margin.

Position and Locality. - Not uncommon in a schist over the iron-works at Tremadoc, Merionethshire; very similar in appearance to that at Pomeroy, county Tyrone, which afforded the species to Col. Portlock.

Explanation of Figures.-Pl. 1. F. fig. 3.' Pygidium and thorax natural size, from the fine slates over the iron-works of Tremadoc. 


\title{
Isotelus (Basilicus)? Laticostatus (Green Sp.) Pl.1.E. fig. 18.
}

\author{
Ref. and Syn._Lsaphus laticostatus Green, Monog. cast 13.= Ogygia? radiata Salt. Ap. Ray ed. of
} Burmeister, p. 125.

Sp.Ch.-Obtusely oval; cephatic shicld obtusely rounded about three times wider than long; thorax (indistinctly seen) shorter than the head, of eight very slender segments; axis rather less than two-thirds the width of the pleure, which are nearly straight, slightly bent downwards and backwards at the tip; pygidium nearly semicircular, length rather more than half the width, and abont one-third longer than the thorax; axis flattened, undefined at the end, the axal furrows converging most at about the ninth furrow, and then slightly diverging, of ten distinct and about four very faint terminal segments, sides grently convex, of nine broad, convex, simple ridges, ending in a wile, flattened, simple margin. Length of pygidium from nine lines to two inches.

The pygidium of this species strongly resembles (as Green remarks) the A. Hausmanni of Brongniart, but has much fewer segments: our large specimen from Maen Goran exactly agrees in size and all characters with Green's cast; the small perfect specimen has much the habit of Bronteus. Mr. Salter probably overlooked Green's species when he proposed it as new, and his reference of it to Ogygia is negatived by the simple (not duplex) lateral ribs of the pygidium.

"This is the species referred to in Prof. Sedgwick's papers as O. Buchi, from the Bala limestone."- Salter in letter referring to our fig. 18.

Position and Locality.-Limestone of Rhiwlas, Bala Lake, Merionethshire; schists of Maen Goran, Llangollen; Black shale, near Builth, Radnorshire (in a newly-opened trial-pit for coal.)

Explanation of Figures.-Pl. 1. E. fig. 18. Small nearly perfect specimen, natural size, from Rhiwlas.-Fig. 18 a. A very large pygidium, natural size, from Maen Goran.

\section{Isotelus (Basilicus) PowisII (Murch.)}

Ref. and Syn.-Asaphus Powisi Murchison, Sil. Syst. t. 23. f. 9. = A. elevatus Salter in Ray ed. of Bưmeister, p. 125.

Sp. Ch.-Axis of the pygidium as long as the thorax, width slightly less than twice the length, nearly senicircular, with the sides slightly straightened; axis rapidly tapering two-thirds the width of the side at the anterior margin, less than half that width at the middle, segmental furrows almost obsolete, except the first one; lateral lobes with about eight broad, simple radiating furrows, the radiated portion gently convex, surrounded by a flattened, less steeply inclined margin of equal width all round (about one-third the anterior margin); this is only crossed by the first or strong articular furrow; axis of the thoracie segments nearly one-third wider than the pleura, gently convex in the middle, abruptly flattened towards the two ends (so as to form, when connected, a narrow flattened band on each side of the middle portion), middle portion corresponding in width to the anterior end of the pygidial axis; plewre each with a very strong facet, and wide diagonal pleural furrow, truncated at the end. Average length of pygidium one inch nine lines.

The head supposed to belong to this species has the portion within the cye-line flattened, truncate in front, sides nearly straight, diverging slightly to the eyes, from whence on each side it turns abruptly outwards, parallel with the posterior margin, then gently arching nearly to the lateral angles; a sharp segmental furrow a little in advance of the straight posterior margin; two slightly converging, shallow axal furrows extend from the posterior margin towards the front, obscurely defining an oblong glabella.

The specimens I have examined of the body and pygidium of the Asaphers elecatus (Salter) only differ in a slight lateral compression (I should think mechanical); but, as far as I can sec, there is no real difference of proportion, or any other character, if a slight allowance of this kind be made.

Position and Locality._Llanwddyn in the Rerwyns (in limestone) Bryn Eithin, Penmachno, S. of Mathyrafal, Montgomeryshire; Ravenstone Dale, Westmoreland; Pen Cerrig, two miles N. of Builth, Radnorshire; Alt yr Anker, Meifod, Montgomeryshire. 


\title{
Isotelus (Basilicus) tyrannus (Murch. Sp.)
}

\author{
Ref. and Syn.-Asaphus tyrannus Murch. Sil. Syst. t. 25. f. 1.
}

5 r. Cho_Cephatic shield semicircular, about twice as wide as long, length equalling the thoracie and three first pygidial segments; glabella obscurely pyriform, convex, not reaching the front margin, with an obseure tubercle on the neck and an oval swelling on each side between the neck and the eye-lobe; eyes with very minute lenses, narrow, crescent-shaped; thorax, axal as wide as the lateral lobes; mygidimm elevated, onethird longer than the head, obtusely triangular, one-fifth wider than long, axis less than half the width of the lateral lobes, moderately convex, of about fifteen distinct and many minute segments, sides with about thirteen strong, equal, rounded ribs reaching about two-thirds to the margin, the upper ones reaching nearest to the margin, and nearly at right-angles to the axis, becoming gradually more oblique, and reaching a shorter way as they approach the extremity, leaving a steep, concave, smooth margin, one-third the width of the pleuric all round. Average length of pygidium two to three inches.

Position and Loculity.-Llandeilo, Caermarthenshire; Craig y Glyn, near Llanarmon Fach, E. of the Berwyns; Rhiwlas, N. of Bala Lake, Merionethshire; Goldengrove, Llandeilo; Nant yr Arian; Tre Gil, S. of Llandeilo.

\section{Genus. ILLENUS (Dal.)}

Gen. Char.-Cephatic and caulal shields forming two nearly equal and similar portions of hemispheroids, the articular margin of each being truncated, the base of the glabella and caudal axis only indicated in the respective shields by two short axal sulci; nine or ten body-segments, destitute of pleural grooves, and with long, very narrow, nearly obsolete facets. Eyes and eye-line nearly as in Asaphus.

There are three British subgenera:-1st Illowus, having ten body-rings and the lateral cephalic angles rounded. Ind Bumastus (Murch.), differing only in having no trilobation of the body. 3rd Dysiplanus (Burm.), having the lateral cephalic angles produced backwards into spines, and only nine body-rings, otherwise like Illomus.

\section{Subgenus. IlLzNus (Dal.) restricted.}

Gen. Char.-Body subeylindrical, with equal rounded ends; ceplealic shield subhemispherical; glabella only defined by two short, parallel, unconnected longitudinal furrows at the posterior margin; eyes smootl, small, semicircular, placed very far apart on the sides of the head; eye-lines subparallel, longitudinal, cutting the posterior margin near the midale of the cheeks, forming the small eye-lobe over the eye and extending thence to two widely-distant points of the anterior margin, where they are connected by a transverse suture; thorax three-lobed, of ten equal segments; pygidiun resembling the buckler in size and shape; axis only indicated at the anterior margin by two short parallel unconnected furrows.

\section{Illenus Davisii (Salt.) Pl. 1. G. fig. 36.}

$$
\text { Ref.-Mem. Geol. Surv. Dec. 2.t. } 2 .
$$

Sp. Ch.-Head, thorax, and Pyaidium, of nearly equal length, gibbous; cephatic shield semioval, length rather more than two-thirds the width, very gibbous, the front nearly vertical; axal furrows sigmoid, half the length of the head, slightly nearer in front than at base; the included space about one-fourth wider than the cheeks; eyes rather more than their own length in advance of the posterior margin, and halfway between the axal furrows and the margin; thoracic segments with the axal and lateral portions of about equal width, deflexion from the knee close to the axis in the anterior segments, gradually removing to one third of the width in the posterior ones; pygidium semioval, length two-thirds the width, moderately convex, the outer third of the circumference rather abruptly sloping to the margin, axal furrows barely indenting the margin. Surface smooth. Average length of head nine lines. 
On comparison with Swedish specimens of the $I$. crassicauda of Dalman, I find the present species differs in the greater length of the head in proportion to its width; the cheeks also of $I$. crassicauda are wider than the glabella, while they are much less wide in the present species; the caudal shield is also considerably wider in proportion to the length in the Gothland trilobite, and the axal lobe of the thorax is one-fourth wider than the pleuræe.

Position and Locality.-Abundant in the calcareous schists of Rhiwlas, N. of Bala Lake, Merionethshire; Llwyn y Ci, N. W. of Bala Lake, Merionethshire; Llanwddyn, E. of the Berwyn Mountains; Pont y Glyn, Diffwys, W. of Corwen.

Explanation of Figures.-Pl. 1. G. fig. 36. Perfect specimen, natural size, from Rhiwlas (the example figured belongs to the cabinet of Mr Davis.)

\section{Illendus latus $\left(\boldsymbol{M}^{c} \mathrm{Coy}\right)$. Pl. 1. E. fig. 17. \\ Ref.-MCoy, Ann. Nat. Hist. 2nd Series, Vol. IV.}

Sp. Ch.-Cephalic shield more than twice as wide as Iong, moderately gibbous towards the base, but about half of the front arched over to a vertical position (or at right angles to the basal portion or plane of the body); axal furrows considerably less than half the length of the head, width of the included space or glabella equal to two-thirds the length of the head; yes small, near the lateral angles, their own length in front of the posterior margin, two-thirds the width of the glabella distant from the axal furrows. Length of head ten lines, width one inch nine lines.

This is only likely to be confounded with the $I$. crassicauda ( $\mathrm{Dal}$.), from Gothland specimens of which it differs by the greater width of the head and less depth of the deflected front, and most remarkably, by the very small size of the cheeks, resulting from the eyes being removed almost to the lateral angles-in the 1 . cressicanda they are only half the width of the glabella distant from the axal furrow, and the portions of the cheeks from the eyes to the lateral angles is nearly one-third more than from the eye to the axalfurrows, while in the present species the cheek beyond the eye is little more than half the width of from them to the side of the glabella. Heads of the Dysplanus centrotus (Dal. $S_{p} .=I$. Bowmani Salt.) differ in their much greater proportionate length.

Position and Locality. - In the limestone of Wrae Quarry, Upper Tweed, near Broughton, S. W. of Peebles. A young specimen of the head, possibly of this species, little more than one line long, and with a front not quite so much deflected, and the glabella slightly longer and narrower, has occurred in the schistose "Chazy limestone" of Knockdollian, three miles from Ballintrae.

Explanation of Figures.-Pl. 1. E. fig. 17. Head, natural size, from the limestone of Wrae Quarry. -Fig. $17 \alpha$. Profile of ditto.

\section{Ildannus Rosenbergi (Eich.) Pl. 1. G. fig. 83 to 35.}

Ref. and Syn.-Cryptonymus id. Eichwald per Ingriam, \&c. t. 3. f. 3.=Illonus Durchisoni Salter, Mem. Geol. Surv.

Sp.Ch.-Cephatic shield semielliptical, front narrow, much inflated, and curved inwards towards the margin; axal furrows slightly sigmoidal, about half the length of the unbent part of the head, rather nearer to each other in front than at base, width of the enclosed space equal to the length of the furrows; eyes scarcely their own length from the posterior margin, and about half the width of the glabella from the axal furrows: thorax about as long as the unbent portion of the head, of ten very broad flat segments; axis twice the width of the pleurse, which are square at their extremities, abruptly deflected at right angles from the knee, which is tumid, close to the axis in front, and about one-fourth the width of the pleurr from it towards the tail; the anterior pleure are directed backwards, the posterior ones a little forwards, and the middle ones are slightly narrowed at the ends and extend at right angles to the axis; pygidlum larger than the head, semielliptical, its length slightly exceeding the width, moderately convex, most so in the middle, axal furrows short, obtuse, parallel: entire surface, in some states of preservation, marked with minute flexuous strix 
and puncta, and the extremities of the pleurx with elevated strix parallel to their anterior margin. Average length of head one and a half inches.

The width (about one and a half lines) and flatness of the segments, and the narrow, inflated and muchinflected front, distinguish this species.

Pusition and Lucality. - Abundant in the Coniston limestone at Coniston Water-Head, Lancashire; Coniston limestone of Sunny Brow, near Coniston; Blain y Cwm, W. of Nantyre, Glyn Ceiriog.

Explenution of Finures.-Pl. T. G. fig. 33. Part of cephalic shield, natural size, from Coniston. Fig. 34 thorax, and fig. 35 pygidium, same locality.

\section{Dysplanus centrotus (Dal. Sp.) Pl. 1. E. fig. 19.}

Ref. and Syn.-Illomus centrotus Dal, and Portlock. Geol. Rep. Pl. x.f. 3 to 6.

= Illcenus Bowmani (Salt.) Mem. Geol. Surv, Vol. II. t. 8. fig. J, 2.

Sp. Ch. - Thorax little more than half the length of the head, of nine short weak segments, axal portion about equal to the pleure, which are abruptly bent downwards and backivards at rather less than half their width from the axis; cphalic shield slightly longer than the pygidium, about one-third wider than long, moderately convex, axal furrows one-third the length of the head, slightly arched, the enclosed space one-third wider than the eheeks; eyes small, their own length in advance of the posterior margin of the head, and nearer to the external margin than to the glabella; pygidium one-sixth wider than long, gently convex at the anterior portion, becoming more depressed towards the margin, axal furrows barely forming a short rounded sinus on each side; average length of head one inch three lines.

I sce no grounds for Mr Salter's opinion (Mem. Geol. Surv.), that the present fossil had not the lateral angles of the cephalic shield prolonged, and consequently differed from the I. centrotus (Dal.) All the English and Trish specimens recorded, or which $I$ have seen, have this part broken; and when we consider that in all other respects the species are identical, I think Col Portlock is correct in uniting them; the more so, as in the foreign perfect examples rounded angles to the buckler are only found in those species having ten joints to the thorax, while the $I$. centrotus forms the type of the genus Dysplemus from having but nine segments, like the example before us, and the cephalic angles prolonged. The very circumstance of the angles being broken ofi' seems rather to indicate their having been prolonged, the projecting portion acting as a lever, while if they were nuturally rounded they would probably present the rounded angle entire, like that of the pygidium. The greater length of the pygidium in proportion to its width distinguishes it from that of the $I$. crassicaude.

Position and Locality.-Very common in the limestone of Llanwddyn in the Berwyn mountains; rare, of large size in the Coniston limestone of Llandeilo, Caermarthenshire.

Explanation of Figneres.-Pl. 1. E. fig. 19. Entire specimen, natural size-Fig. 19 a. Head, natural size. of a rolled-up specimen.

\section{Genus. FORBESIA (Mc Coy). \\ Ref.-MIcCoy, Synop. Sil. Foss. Trel.}

Gen. Cher.--Head semielliptical, with distinetly defined glabella; eyes finely reticulated; eye-lins nearly parallel, cutting the middle of the posterior margin; budy-rings ten, facets large, pleural furrow slightly oblique, not reaching the margin; pygidium smaller than the head, with duplicate lateral furrows, and a distinet conical articulate axis.

Two Subgenera: 1st, Forbesia; 2nd, Proetus.

\section{Subgenus. FORBESIA ( $\left.\boldsymbol{I}^{\circ} \mathrm{Coy}\right)$.}

Ref. and Syn.-Lonia (Burmeister). Ray 2nd Ed. Organ. of Trilobites.

Gen. Char.-Cephalic shield semielliptical, the lateral angles produced backwards into long spines; glebelle oblong, contracted in the middle, with three small transverse segmental furrows on each side, the basal 
one largest and curved downwards; neck-furrow terminating in a large oblique tubercle at each end; eyeline nearly vertical, cutting the anterior and posterior margins in a line with the eyes, which are lunate and smooth; thorax of ten joints, pleurx with distinct facets and obtuse ends, pleural furrow slightly oblique; pygidium semielliptical, with a smooth margin, both the axis and side lobes with distinct segmental furrows, the latter duplicate at their ends.

This genus differs from Proetus in the lateral angles of the buckler being produced into long spines, in the lateral segmental furrows to the glabella, the large oblique tubercles terminating the neck-furrow, and the distinct segmental furrows of the lateral lobes of the pygidium.

Subsequently to the publication of this genus under the above name, in my Synopsis of the Silurian Fossils of Ireland, Burmeister, in the second edition of his work on Trilobites, p. 100, characterised it similarly, and pointed out particularly its distinctions from Proetus.

\title{
Forbesia latifrons $\left(M^{\circ} \mathrm{Coy}\right)$.
}

\author{
Ref.-McCoy, Sil. Foss. Irel, t. 4. f. 11. Mem. Geol. Surv. Vol. II. Pt. 1. t. 6. fig. 1.
}

Sp. Ch.-Ovate; head and thorax of equal length; pygidium as long as six segments of the thorax; cephalic shield nearly semicircular; spinose angles reaching to the sixth thoracie segment; glabella wider at base than in front, not reaching the anterior margin; limb thick, tumid; articular margin and necksegment also thickened, the extremities of the latter forming very large tubercles; eye-lines cutting the anterior and posterior margins nearly in a line with the outer edge of the eye, inclining outwards and forwards from the eye-lobe in front, running parallel to the axis behind, till it reaches the articular margin, which it cuts obliquely outwards nearly in the middle; eyes large, very close to the glabella; axis of body about as wide as the pleure, the segments strongly tubercular at the ends; pygidium semicircular, nearly twice as wide as long, with a broad smooth margin; axis conical, not reaching the margin of seven narrow ridges; side lobes with fine broad, obscurely-defined ribs, each with a faint duplicating furrow. Length ten lines; length of head four lines, width of head seven lines.

Position and Locality.-Very abundant in the Upper Ludlow rock of Underbarrow, Kendal.

\section{Forbesia Stokesii (Murch. Sp.)}

\section{Ref. and Syn-Asaphus Stokesii Murch. Sil. Syst. t. 14. f, 6.}

Sp. Ch.-Ovate; head semielliptical, the angles reaching as far as the pygidium, length of the middle portion equal to half the width; thorax as long as the head, axis only as wide as the pleure in front, and considerably less wide behind, knee at about one-third the width from the axis (a little more in front, a little less behind), ends of the axal segments not distinctly tubercular; pygidium semielliptical, with a broad tumid margin and six wider flattened ribs on each side, each divided by a fine mesial impressed line. Length five and half lines, width of head three and half lines.

This species differs from the $F$. latifrons $\left(\mathrm{M}^{\mathrm{c}} \mathrm{Coy}\right)$, by the much greater size of the lateral cephalic angles, by the longer and narrower head, the narrower axis, and want of the distinct tubercles to the ends of the axal segments.

Position and Locality.-Wenlock limestone of Ledbury, Herefordshire.

\section{2nd Tribe. PCECILOPODA.}

In this tribe the feet are constructed on two different types, the thoracic ones (six pairs) being strong, crustaceous, didactyle, and ambulatory; but the abdominal ones forming transverse, membraneous leaflets subservient to respiration. In the recent type, the mouth is without jaws, but the bases of the feet which 
surround it are toothed and shaped so as to serve for mastication. The head and thorax are confounded under one semicircular shield-like carapace.

There seem to be only two families: 1st, Limutida, having the abdominal segments anchylosed into a shield (Limulus, $\delta c_{0}$ ) 2nd, Eurypteride, with the abdominal segments distinct, simple (Eurypterus, Pterygotus, Bellinurus, \&s.)

\section{Genus. EURYPTERUS (Marlan.)}

Gen. Char.-Body crustaccous, elongate, ovate, very convex, attenuated posteriorly; cephalo-thorax covered by a small, semiorbicular or rotundato-quadrate shield, truncate behind, margin obscurely depressed, often with a faint $\mathrm{V}$-shaped, re-entering angle in front; two large reniform eyes, one on each side of the middle of the cephalic shield; at least three pairs of large, unequal, crustacean, didactyle, thoracic legs; at,domen semicylindrical, of thirteen distinct, transversely arched segments, gradually narrowing towards the terminal one, which forms a short spine, serrated on the sides as in Limulus.

I have little doubt, from the figure, and description of Conrad and Römer (see the paper on the American species in Dunker and Von Meyer, "Beitrige zur Naturgeschicte der Vorwelt," \&c.), that the present genus is closely allied to Limulus; we might therefore expect that the thorax would bear crustacean prehensile feet, but each joint of the abdomen a pair of membraneous gill-feet.

\section{Eurypterus cephalaspis (Salt. $S p . *$ ) Pl. 1. E. fig. 21.}

Ref. and Syn.-Homalonotus cephalaspis Salt, in Appendix to Ray ed. of Burmeister, p. 125.

Sp. Ch.-Cephalic shield semielliptical, length one inch, width one inch three lines, strongly and evenly convex, the anterior and lateral arched margins with a narrow, flattened, horizontal rim, all in one plane, with the edge deflected; posterior margin simple, truncate, elevated by the general convexity; cyes hiant, obscurely reniform, about three lines long, four lines apart, and their own length within the front margin; a very obscure indication of a mesial ridge branching at an acute angle from between the eyes towards the front; surface obscure.

This is about double the linear measurement of the head of the E. tetragonoplthatmus of Fisher (Bull. de la Soc. Imper. des Natur. de Moscou. Vol. for 1839).

Position and Locality.-Rare in the liard green micaceous quartzite of Kirkby Moor, Kendal, West. moreland.

Explanation of Figure.-Pl. 1. E. fig. 21. Head, natural size.

\section{Pterygotus lepto-dactylus ( $M^{c}$ Coy $)$. Pl. 1. E. fig. 7.}

\section{Ref.-McCoy, Ann. Nat. Hist. 2nd Series, Vol. IV.}

$S_{p}$. Ch.-Scale-like sculpturing of the surface very irregular, but of two principal very unequal sizes, the larger about six times the size of the smaller and more numerous size, averaging rather less than one line in diameter; large pincers having the hand about five lines wide, the penultimate or immoveable finger compressed, about two inches ten lines long, and two lines wide at base, gradually tapering to less than a line towards its obtuse point, nearly straight, with a searcely perceptible inward curvature; sides divided into ridges by three or four longitudinal furrows, thicker towards the back, inner edges of both fingers destitute of teeth or tubercles; moveable finger similar to the immoveable one, but rather smaller.

* Mr Salter, on becoming aware of my referring his species to Eurypterus, instead of to the trilobites, now adopts the same view. 
The semicircular scale-like ridges of the carapace are rather irregular in size, but the larger entirely covered by the smaller, otherwise resembling the fragment in Sir R. Murchison's Sil. Syst. from the Upper Ludlow, and named Pterygotus problematicus by Agassiz. The pincers are very remarkable; instead of being excessively thick and strong and armed on the inner edges with powerful teeth, as in the Pterygotus Anglicus, they are perfectly unarmed, and so long and slender as possibly to indicate a separate genus, which might be named Leptocheles ( $\lambda \epsilon \pi r \dot{s}$ s, tenuis, and $\chi \eta \lambda \dot{\eta}$, forceps). It strikes me forcibly (judging from the figures) that the Onchus Murclisoni (Ag.), figured in the same work and from the same bed as the P. problematicus, is not an Ichtlyyodomlite, but the long fingers of the chele of this crustacean, the size, form, and sculpturing, agreeing very nearly. In the same bed as the long chele and fragments of carapace here described, were found one moveable finger, and one perfect claw with both fingers in situ of a much shorter form, the hand about three lines wide, the penultimate immoveable finger about one inch long and rapidly tapering from two and half lines wide at the base to the tip; it is longitudinally sulcated like the one above described: the last joint or moveable finger is very different, being perfectly flat, triangular, scven lines long, one and half lines wide at base, and tapering rapidly to a point, the inner edge being straight and simple, the outer edge slightly convex. The hands of both linds of chelæ are similarly sculptured with fine sharp, short, irregular, longitudinal, curved plics. It seems probable therefore that more than one pair of feet were didactyle.

Position and Locality.-In the fine olive-schists, Leintwardine.

Explanation of Figures.-Pl. 1. E. fig. 7. The long penultimate or immoveable Onchus-like finger of one of the didactyle pincers, with a portion of the peculiarly sculptured crustaceous hand connected with its base, natural size; from Leintwardine.-Fig. $7 \alpha$. The terminal or moveable finger of probably the same pincer, seen from the opposite side, also shewing trace of the peculiar sculpturing of the hand near its expanded articular base; same locality.-Fig. 76 . Portion of the sculpturing of the hand of fig. 7 magnified three diameters.-Fig. $7 c$. A shorter didactyle claw, or pincer, with both fingers in situ belonging to a different pair from fig. 7 , having a portion of the crustaceous hand and carpus attached, with traces of sculpturing resembling that of fig. 7 in character; same locality.-Fig. $7 d$. A detached terminal joint (or the moveable finger) of a pincer identical with that of $7 c$; same locality. 


\section{Sub-kingdom. ARTICULATA. See page 127. \\ Class. CRUSTACEA. See page 133.}

Tribe. PHYLLOPODA. See page 134.

Family. TRILOBITIDA. See page 138.

Genus. PORTLOCKIA (Mc Coy). See page 162.

Portlockia granulata (Mïnst. sp.)

Syn. and Ref._Calymene id. Münster, Beiträge, t. 5. f. 3. Phill. Pal. Foss, f, 248.

Sp. Ch.-Cephatic shiclel semicireular, the sides much bent downwards; glabella large, tumid, widely pyriform or subdeltoid, slightly pointed in front, greatest width usually exceeding its length including the neck-segment, sides rapidly converging to the base, which is scarcely half the width of the front; two deep punctures at each end of the deep neck-furrow, (but no trace on inner or outer surfaces of anterior segmental furrows); chetis of moderate size, with a strong border overhung by the glabella in front; eyes very large, reniform, of about thirty-seven coarse lenses (five in one line); surface of cheeks and glabella covered with small, irregular granules, smaller than the lenses of the eyes but not so close (four in one line); length three lines, width in a direct line six lines; pygidium semicircular, averaging two lines long and four lines wide, with a flattened margin half a line wide; mesial lobe narrow, prominent, of nine or ten obscurely tuberculated rings, lateral lobes with about eight strong ribs each divided by a fine pleural furrow.

The smaller size of the granulation easily separates this from the $P$. latifrons; and the absence on the casts of the fine anterior segmental furrows separates it from the Silurian $P$. Stokesi, as well as the more pointed front of the glabella, and fewer lenses to the eye from the encroachment of the larger eye-lobe. In the Silurian species the eye-lenses are about fifty, and seven occupy the space of one line.

Position and Loculity.-Very abundant in the soft decomposing schists of Petherwin, Cornwall.

\section{Portlockia latifrons (Bronn $s p$.)}

Ref. and Syiz. - Calymene latifrons (Bronn) Leth. Geog. t. 9. f. 4.=Calymene Latreillii (Stein.) Phill. Pal. Foss. t. 56. f. 249, and C. accipitrina Phill. (name only) Pal. Foss. bottom of p. 128.

Sp. Ch.-Cephalic shield semicircular, sides much deflected, lateral angles obtusely rounded; glabella tunid, depressed, pyriform, or obscurely angulated in front, width equal to its length including the strong 
neck-furrow, covered with close, coarse, obtuse tubercles (about two in the space of one line); cheeks small without tubercles, with a broad thickened border, which is not seen in front of the glabella; eyes very large, close to the glabella, of aljout fifty lenses (three in one line). Length of head (small specimen) six lines, width from centre of neck-segment to one lateral angle seven lines, width measured in a line from one lateral angle to the other ten lines.

This is one of the largest species of Portlockia, and is easily recognised by the large size of the tuberculation of the glabella as compared with the size of the lenses of the eyes; the lateral lobes seem nearly smooth.

Position and Locality.-In the Devonian sandy schists of Croyde.

\section{Genus. Trmaerocephalus ( $I^{c}$ Coy).}

Ref.-M $\mathrm{M}^{\mathrm{c}} \mathrm{Coy}$, Ann. Nat. Hist. 2nd Series, Vol. IV.

Gen. Char.-Elongate ovate; cephalic shield semicircular, with the lateral angles obtusely rounded; glevelle very broad, gently convex, widely rounded and touching the margin in front; sides straight, converging to the narrow base; neck-furrow strong, one fine directly transverse segmental furrow a little above it across the base of the glabella; cleck smaller than the glabella, triangular; evenly convex, without cyes or facial sutures; limb almost wanting in front of the glabella, forming a narrow margin to the cheeks, and being rounded at the lateral angles forms the thick posterior nargin of the shield and neck-segment; thorax of eleven joints, lateral loles wider than the axis, bent down at the margin; each of the axal segments with a strong tuberele at each end; pleuree of equal wilth throughout, blunt at their ends, which are bent downwards and a little backwards, each marked along the middle by a pleural groove, angularly bent backwards alout the middle, but not reaching the margin; trigonal facets small, narrow; mygidium small, obtusely rounded, entire, axal lobe distinctly rounded with about four or five segmental furrows; lateral lobes with about five flattened segments each divided by a furrow.

This genus has been confounded by Count Münster, in his 'Beiträge zur Petrefactenkunde', for 1812 (only knowing the head), with Trinuclens, from which the structure of the body and tail, as well as the absence of the punctured border of the head, remove it very far; and it has been referred by Prof. Phillips (Palæozoic Fossils) to Calymene, from which the form of its cephalic shield and glabella, want of eyes and facial suture, and the different number of the hody segments, will, I think, sufficiently distinguish it.

I only know the genus in the Devonian rocks, the type being the Trinucleus lovvis of Münster (Calymene lavis, Münst. of Phill. Pal. Foss. but not of Münster, whose Calymene levis is a true Portlockia, $\mathbf{M}^{\circ}$ Coy), It is perhaps most allied to Ellipsocephahes of Zenker, which has however twelve body-rings, eyes at the sides of the cheeks, a glabella pointed in front, and a little pygidium without segmental furrows.

\section{TrimeroceptraluS LAVIS (Mïnst. sp.)}

Ref. and Syn.-Trinucleus lavis Münster, Beiträge zur Pet. Heft. 5. t. 10. fig. 6. = Calymene id. Phill. Pal. Foss. t. 55. f. 250. (not Münst.)

Sp. Ch,-Head smooth, areraging six lines long, and nearly one inch wide; glabella subrhomboidal, slightly convex, smooth, seven lines wide in front, three lines wide at base; cheeks small, spherical triangles slightly convex, their length and width about equal; limb about one line wide, at the rounded cephalic angles, becoming very narrow in front of the glabella; neck-segment broad, a very narrow segmental ridge in front of it; width of axal lobe of thorax three lines; pygidium, length three lines, width eight lines, rounded, lateral segments, divided by a fine pleural groove nearly from their origin.

Position and Locality.-Very common in the purple Devonian slate, near Nerwton Bushel. 


\section{Genus. BRONTEUS (Gold.)}

Gen. Char.-Oval, flat; Cephatic shield, outline unknown; glabella depressed ovate, widest in front, three segmental furrows the most anterior farthest apart; eye-line as in Aspulues, proceeding upwards from the middle of each side of the posterior margin, with a short sigmoidal curve to the eye-lobe, and thence curving inwards and forwards to the front: thorax of ten segments, the axal lobe equalling the lateral lobes in width; lateral lobes flat without facets, bent backwards at the tip, no pleural groove; pygidium semiorbicular, with a flattened entire margin, axal lobe very short of one joint, but the axal sulci prolonged towards the margin, but not joined at their extremities, lateral folds broad, not reaching the margin.

This genus by the number of body-rings \&e. forms the passage to the Asaphide; still in its flat pleurie, and want of facets and contractile power, it clearly belongs to the present group though aberrant in its characters towards the Asaphine.

\section{Bronteus alutaceus (Gold.)}

Syn. and Ref.-Leonhard and Bronn's Jahrb, 1843, t. 6. f. 1. (Bronteus flabellifer Gold. Phill. Pal. Foss. t. 57. f. 254, not of Gold.)

Sp. Clo.-Pygidium semi-elliptical, anterior margin on each side convex; length (of small specimen) ten lines, width one inch two lines; axal lobe tumid, triangular, of two joints, the anterior very narrow, ring-shaped, length of both together two lines, width three and half lines; margin radiated with fifteen broad, depressed ribs, separated by narrow sulci, which vanish before reaching the edge; surface with obtuse granules, about their diameter apart, about three in the space of one line; general surface gently convex in the middle portion, becoming gradually concave towards the margin, which is flattened or slightly elevated.

I have only seen the tail, which is often one and half inch long. The granulation is sometimes very obscure, at others very distinct.

Position and Locality.-Common in the Devonian limestone of Newton Bushel. 
SeCt. VI.-ARTICULATA OF UPPER PAL EOZOIC ROCKS (Carboniferous and Permian).

\section{Sub-kingdom. ARTICULATA. See page 127.}

\section{Class. ANNULATA. See page 127.}

\section{Order. Tubicola. See page 131.}

Tribe. AMPHITRIT无。 See page 132.

Genus. SERPULITES. See page 132.

Serpulites Carbonarius $\left(\mathrm{I}^{c} \mathrm{Coy}\right)$.

Ref.-M $\mathbf{I}^{\mathrm{C}} \mathrm{Coy}$, Synop. Carb. Foss. Ireland, t. 23. f. 32.

Sp. Ch.-Tubes small, averaging one and half to three lines in width, thin, shelly, rery glossy, lateral thickened ridges strong; length unknown (upwards of five inches).

This species is intermediate between the S. longissimus (Sow.), and the s.. membranaceus ( $M I^{c} \mathrm{Coy}$ ), in the texture of its tube, being more delicate than the former and more shelly than the latter; it is, however, greatly inferior to either of them in size.

Position and Loculity.-Not uncommon in the black limestone beds of Derbyshire; the original Irish locality was the Calp of Manor Hamilton.

\section{Class. CRUSTACEA. See page 133.}

Order. Entomostraca. See page 134.

Tribe. PHYLLOPODA. See page 134.

Family, APODIADÆ. See page 134.

Gemus. Ditmyrocaris (Scoul. MSSS.)

Gen. Chur.-Carapace semioval, the two sides meeting along the middle at a very obtuse angle; anterior end rounded, often with an obscure notch in front; posterior end subtruncate, with the lateral angles produced backwards into short, flat, angular spines; surface fitintly marked with irregular imbricating strie, the margins being usually thickened and corrugated, and with three well-marked longitudinal ridges, one in 
the middle extending the entire length, and one on each side not reaching the front margin; within, and anterior to the ends of these latter, are two small, obliquely longitudinal sigmoid ridges, extending inwards and forwards towards the mesial ridge; posterior part of body naked, tail terminating in three large, strong, equal triangular spines, the middle one bayonet-shaped, with a triangular section, the lateral ones flattened.

I have not as yet detected any trace of eyes in this genus, which seems closely allied to Apus.

I have exanined four species from the carboniferous rocks of Ireland, but the only British example I have seen is a specimen in the collection from the black carboniferous limestone of Derbyshire, indistinctly preserved, but most probally the tripartite tail of a new species, allied to D. Colei (Port.) "Geol. Rep." t. 12, and to the D. Scouleri (MCOy), figured in my "Synopsis of the Carb. Foss. of Ireland," t. 23. f. 2, from the black shales of Aughnaclough, Clogher. In this species the central, angularly-ridged spine is about ten lines long; the two lateral spines about one inch five lines long, coarsely sulcated longitudinally by only three or four strong ridges:the species very well, and I would provisionally call it Dithyrocaris lateralis ( $\left.\mathrm{I}^{c} \mathrm{Coy}\right)$; when imperfect, the coarseness of the few large sulci of the lateral spines easily distinguishes those parts from the two figured species alluded to.

\section{Family. TRILOBITADE. See page 138.}

\section{Subfamily. ASAPHIN}

\section{2nd Subgenus. GRIFFITHIDES (Portk.)}

Gen. Char.-Elongate, oval, buckler semielliptical with produced lateral angles; glabella without segmental furrows, gibbous, pyriform, contracted to a narrow neck posteriorly, from whence a small gibbosity extends on each side obliquely upwards and outwards, forming a nucleus to the eyes, which are small reniform, covered by a thick smooth cornea; thorax of nine segments with distinct facets; pygidium semioval, both the axis and lateral lobes with distinct segmental furrows (duplicate in the latter) and entire margin.

Distinguished from the Silurian genus Asaplus by having one more segment to the thorax, and distinet, duplex, segmental furrows to the lateral lobes of the tail.

The strongly contracted base of the pyriform glabella, absence of glabellar segmental furrows, and the thickness of the outer cornea of the eye obscuring the reticulation, separate this genus from the other carboniferous group Phillipsia.

\section{Griffithides, meso-tuberculatus $\left(M{ }^{c} C o y\right)$. Pl. 3. D. figs. 10, 11.}

\section{Ref.-McCoy, Ann. Nat. Hist. 2nd Series, Vol. IV.}

Sp. Ch. - Cephalathorax ten lines wide; glabella widely pyriform, broadly rounded in front, gently convex and narrowing posteriorly with concave sides, very minutely granular; length five lines, width four lines; cheeks triangular, flat, smooth; eyes large, reniform, very minutely reticulated, witl a large convex eye-lid, connected with the base of glabella by a small, oblique, oval nucleus; limb broad, convex, with nine or ten imbricating strix,' two-thirds concealed in front of the glabella, ending posteriorly in acute spines as long as the glabella; neck-segment broad; pygidium six lines long, and seven and a half lines wide; axal lobe two lines wide, cylindrical, slightly tapering, of sixteen rings, each ornamented with about ten lengthened oval tubereles; lateral lobes depressed, of ten broad, flat divisions, each having a fine impressed line running close to its posterior margin; smooth to the naked eye, but with a strong glass, one or two rows of minute crowded granules are seen; margin wide.

The axal lobe of the pygidium being strongly tubereulated and the lateral lobes nearly smooth, separate it from all other carboniferous trilobites I know of. It is allied to the G. calcaratus (M ${ }^{\circ} \mathrm{Coy}$ ), and G. longispinus (Port.) 
Position and Locality.-Common in the shales of the Derbyshire limestone.

Explanation of Figures.-Pl. 3. 1). fig. 10. Part of cephalic shield, natural size-Fig. 11. Pygidium of ditto, natural size.-Fig. $11 \alpha$. Two segments of pygidium magnified.

\section{Subgenus. PHILLIPSIA (Port.)}

Gin. Char.-Elongate oval; buckler semielliptical, with produced lateral angles; glabella subcylindrical not contracted at base, marked on each side by three curved segmental furrows; cyes large, reniform, distinctly reticulated; thorqu of nine segments, having pleural grooves and distinet facets; pygielium semioval, axis and lateral lobes with distinct segmental furrows, those of the latter duplicate at their ends, and with an entire smooth margin.

The great comparative width of the base of the glabella, the distinctly marked three pairs of segmental furrows, and delicate outer cornea of the eye exposing the reticulation, ensily distinguish this genus from Griffithides.

\section{Phillipsia gemiulifera (Phill. $s p$.)}

Syn. and Ref.-Asaphus gemmuliferus Phill. Geol. York. Vol. II. t. 22. f, 11.

Sp.Ch.-Pygidiun semielliptical, average length five lines, width six and half; axal and lateral lobes equal, very tumid; margin flat, smooth, half a line wide; axal segments fifteen, with six regular, longitudinal rows of tubereles, the two middle rows strongest; lateral lobes with twelve segments, the anterior ones with six indistinct, irregularly unequal rows of granules, that along the middle of the lobe strongest and continued to the apex, the other rows shorter and smaller.

The head and thorax of this species are not yet known.

The prgidium resembles that of the $P$. truncatula, but is distinguished by its constant smaller size, being more convex, and the inequality of the rows of tubercles, particularly on the lateral lobes.

Brongniart's figure, t. 4. f. 12, supposed by Phillips referrible to this species, really represents a prgidium neatly distinguished by its four regular rows of large granules on each lobe.

Position and Locality.-Rare in the carboniferous limestone of Derbyshire.

\section{Pimllitisia Jonesil (Porti.)}

$$
\text { Ref.-Portlock. Geol. Rep.t. 11. f. } 3 .
$$

Sp. Ch. - Entire animal twice as long as wide; glabella oblong, rather more than one-third the entire length, very broad, depressed, obtusely rounded in front, contracted in the middle, width at base three fourths of its length, exchding the neck-segment; eyes large, reniform, more than laalf the length of the glalsella; cheeks small, narrow, slightly convex; surface covered with rather distant impressed puncta: thorax and pygidium smootl. Average length of cephalic shield three and half lines, width four and half lines.

This species is extremely common in the red fish-beds of the lower carboniferous limestone of Armagh, but is very rare elsewhere, and the only British example I have seen is the head in the collection. It is casily distinguished by the very broad, depressed glabella, which is slightly hour-glass shaped, being remarkably contracted in the middle.

Position and Locality.-Rare in the red carboniferous limestone of Arnside, Kendal.

\section{Phillipsia seminifera (Plill. sp.)}

Ref. and Syn.-Asaphus seminiferus Phill. Geol. Y. Vol. II. t. 22. f. 8, 9, and 10.

$S \%$. C $/$. - Head, thorax, and abdomen, of nearly cqual lengths; head semiciscular; glabella semicylindrical, very convex, rounded in front, which is slightly narrower than the base; neck-segment very large ; anterior pair of segmental furrows rery short, slightly oblique, posterior pair very large, strongly impressed, semicircularly curved inwards and backwards nearly to the neck-furrow, enclosing a large longitudinally oval 
convex space on each side, separated at base by a portion of the glabella as wide as their length; surface of glabella and cheeks covered with sharp subequal granules (two to three in one line) about their diameter apart, the intervening spaces finely granulose; thorax, axal lobe one-third wider than the lateral lobes, each axal segment of the thorax and pygidium with about nine granules nearly as large as those of the head, mixed with several irregular smaller ones: side lobes of thorax and anterior part of pygidium with about seven or eight rows of large, and several irregular smaller granules, about the size of those of the axal lobe; pygidium semielliptical, one-fourth wider than long, axal lobe rather abruptly narrowed from the axis of the thorax, about as wide as the lateral lobes, composed of about twelve segments, lateral lobes with ten segments. Average length one and half inches, width of glabella four lines, of axal lobe of thorax nearly four lines, middle of axal lobe of pygidium three lines.

Position and Locality.-Extremely abundant (with head, thorax, and abdomen in contact) in the rottenstone of the carboniferous limestone of Derbyshire. 


\title{
3rd Sub-kingdom. MOLLUSCA.
}

\author{
= Heterogangliata (Owen.)
}

TuEse are all soft, unarticulated animals, often unsymmetrical, and characterised by an unsymmetrical disposition of the nervous centres; one principal nervous mass forms a ring round the osophagus, from which various nerves radiate; a pair of ganglia above and at the sides of this collar represent the brain, and are variously connected with other ganglia unsymmetrically placed through the body, mostly below the alimentary cavity. The sexes are in distinct individuals or hermaphrodite and requiring a reciprocal coitus; oviparous or viviparous. They are either terrestrial and breathing air by pulmonary cavities (as the snails, $\& c_{.}$), or inhabit fresh or salt water, and breathe by gills (as all bivalves, and most of the other groups). They either swim by fins (as the cuttlefishes), crawl on a ventral disk (as most univalves), float on the surface of the sea (as the Janthino), or are permanently fixed to foreign bodies (as the oysters, \&c.).

This sub-lingdom is divided into six classes:-1, Tunicata; 2, Palliobrancliuta; 3, Lamellibranchiata; 4, Pteropoda; 5, Gasteropoda; 6, Cephalopoda.

\section{1st Class. TUNICATA.}

This class has not been distinctly recognised in the fossil state. It is composed of the lowest organised Mollusea having the body enelosed in a tough coriaceous bag, generally fixed to foreign bodies, sometimes grouped in elusters; each individual having two small projecting external openings; an inner muscular coat adheres to the outer one only at the openings, one of which leads to a large pharynx, covered with cilire for respiration, and transversely and vertically plicated, at the bottom of which is a small stomach and a sigmoidal intestine, ending near the lateral opening: a constant current of water flows in at the oral and out at the lateral aperture. They have a heart and blood-vessels, some of the latter forming part of the stem of the compound species; the blood is supposed to ebb and flow; a dendritic ovary occupies the concavity of the intestine, and sends a simple duct to terminate near the anus. The young swim by a long tail, and resemble some polypes (Bryozoa) in budding and general structure.

\section{2nd Class. PALLIOBRANCHIATA.}

Respiration (as the name suggests) by the surface of the mantle, which is of two open lobes, fringed and covered with vibratile cilie; enclosed in a bivalve shell, usually inequivalve and equilateral, one valve on the anterior and the other on the posterior aspect of the animal (being, therefore, at right angles to the position of the valves of lamellibranchs). There is no head, eyes, tongue, organs of sense, nor mastication. 
The mantle also deposits the shell, which is either, 1st, horny and fibrous, as in Lingula and Orbicula, in which the mantle is not attached, the mouth has two, free, spiral extensile appendages, and the margin of the mantle is provided with very long corneous fringes; 2nd, testaceous and fibrous (as in the recent IIemithyris Psittacea), having also apparently the mantle with thin undeveloped edges, and unconnected with the shell, and fleshy, free, spiral arms, supported on simple apophyses (all the fossils with similar disconnected apophyses as Rhynchonella, Strigocephalus, Pentamerus, \&c., have dense fibrous shells and are supposed to have had similar soft parts, also some without apophyses, as Orthis, \&c., and in those with spiral apophyses, except Spiriferina); 3rd, testaceous punctured shells (recent Terebratula, Megathyris, Sce.), having the mantle closely adherent to the shell, and giving off processes which project through all the minute perforations, so that the shell is an integrant part of the animal as in the Biyozod. This latter structure is found in all genera with loop-shaped connected apophyses, in one with spiral apophyses (Spiriferina), and in the thick-shelled, armless Rudistes, under the form of branching tubular canals. This punctured shell, therefore, co-exists with no arms (Rudistes), or with arms having little or no power of motion, and D'Orbigny suggests that the connexion kept up between the respiratory mantle and the exterior through these pores is a compensation, enabling the animal to breathe even with the shell closed. The spines of Sipleonotreta and Producta are of similar nature, the site of each moveable fimbria of the mantle interrupting the deposition of earthy matter, leaves a puncture or channel in the shell.

The class contains two Orders. Ist Rudistes; and Brachiopodd.

\section{1st Ord. Rudistes (Lam.)}

Animal without arms; borders of the mantle greatly developed, lobed, and ciliated, representing the arms of the Brachiopoda in function; shell very thick, rarely symmetrical.

The order contains three families :- Ist, Thecides; 2nd, Caprinide; 3rd, Radiolides; not found in the Palreozoic rocks.

\section{2nd Ord. Brachiopoda.}

This order contains a large group of symmetrical, usually thin, sharp-edged shells. The border of the mantle is little developed, and the group derives its name from two long arms, one on each side of the mouth, which may be regarded as an enormous development of the labial palpi of Lamellibranchiata, among which Anomic alone shews anything approaching the same development. These arms are hollow tubes, coiled or doubled up, and capable of a greater or less protrusion by the contraction of a doubly oblique set of muscular fibres, with which they are coated, acting on the fluid contained within them; they unite in front of the mouth, and have their outer margin fringed with filaments, the motion of which, whether protruded beyond the shell or not, is supposed to produce a strong current of water, conveying nutrient particles, towards the mouth; the absence in them of large blood-vessels shews they are not respiratory. The edge of the mantle is also fringed with long fleshy, or semicorneus filaments, covered like the surface with microscopic cilix, and exciting currents of pure water over the surface for respiration, the blood being exposed to it in four thick branching pallial vessels in the lower, and two similar in the small or upper valve; these great vessels communicate with a vascular sinus, ventricle, or heart, on each side of the body, and from the opposite ends of those hearts come the ressels supplying the viscera. Digestion: the mouth is in the middle close to the base of the arms, leading (in Terebratula) by a short oesophagus into a wide stomach, surrounded by a liver or group of hepatic follicles; the stomach bending a little, ends in a short straight intestine (convoluted in Lingula), terminating on the right side. Nervous system: a nervous collar, with small ganglionic swellings, surrounds the ossophagus, and gives off twigs to the mantle and the adducturs.

The order has been divided into the following families:-1st, Craniadce; 2nd, Orbiculider; 3rd, Terebratulida; 4th, Magaside; 5th, Spiriferides; 6th, Uncitida; 7th, Rhynchonellidce; 8th, Orthisidce; 9th, Productide; 10th, Calceolidee; 11th, Lingulide. 


\section{1st Family. CRANIADE ( $(0 r b$.}

Shell thick, pyramidal, calcareous, without muscle of attachment; free or fixed by the substance of the lower valve; arms spirally fixed among themselves, not extensile, nor supported by apophyses; thickened margin of the valves with ramified impressions of the fimbriated edge of the mantle.

The family contain two genera:-1st, Crania; 2nd, Pseudocrania.

\section{Genus. PSEUdOCRANIA $\left(\mathrm{I}^{\mathrm{C}} \mathrm{Coy}\right)$.}

Ref.-McCoy, Ann. Nat. Hist. 2nd Series, Vol. VIII. p. 387.

Gen. Char.-Shell slightly inequivalve, free; both valves regular, depressed, subconical, unattached; dorsal valve with or without a small cardinal area; internally, margin broad, flat, smooth, or minutely striated concentrically; anterior pair of muscular impressions much larger and more strongly marked than the posterior pair; pallial impressions numerous, linear, not interrupted along the middle.

This Palreozoic genus differs from the true Cranio in the following points: Ist, Crania is attached by the substance of the dorsal valve, and exhibits thereon an irregular scar, - both valves are free and regular in Psendocrania; 2nd, in Crania the posterior or marginal pair of adductor muscles are always larger and deeper than the medial or anterior pair; the reverse is remarkably the case in the present genus, which also has a smooth or minutely striated margin, destitute of the strong granulation and punctures of most Cranio. The Crania antiquissima, as given by Verneuil, may be taken as the type of the genus, as also the following species.

\section{Pseudocrania divanicata $(\boldsymbol{M} C$ Coy). Pl. 1. H. figs. 1 and 2 Ref.-M M Coy, Ann. Nat. Hist. 2nd Series, Vol. VIII. p. 388.}

$S p$. Ch.-Longitudinally oblong, length and wilth almost equal, slightly narrowed posteriorly; hingeline straight, a little shorter than the width of the shell; dorsal valve (analogue of the lower or attached valve) with a very low triangular carlinal area; external surface ornamented with sharp, prominent, narrow, rugged lines divaricating from the beaks, those of the sides arched backwards towards the cardinal angles, about equally distant throughout, from the intercalation of shorter strix, as the longer approach the margin; intervening spaces flat, about four ridges in the space of one line: internal casts shew a broad, flat, defined rim, with minute irregular concentrie strice, and the following parts in relief (depressions in the shell): 1st, a small oral mesial space originating near the hinge, and reaching to one-fourth of the length; 2nd, on each side of this, close to the hinge-margin, are two diverging oval muscular impressions; 3rd at a little behind the middle of the shell are two ovate, subtrigonal, anterior, muscular impressions; considerably larger and deeper than the posterior pair; 4th, close in front of these, a narrow semicircular impression (visceral aponeurosis?), with its extremities arching backwards round the muscular impressions; 5th, between this and the front and lateral margins a series of from fifteen to twenty-two uninterrupted, equidistant, longitudinal, narrow, pitted, pallial impressions, each dividing at its anterior half, separated by rather wider, smoother spaces. Length ten lines, greatest width (a little in front of the middle) ten and onethird lines, height of cardinal area three-fourths of a line.

In size and general character this agrees with the Pseudocrania antiquissima (Eichw. Sp.), as given by M. de Verneuil (Geol. Russia, t. 1. fig. 12), but is easily distinguished externally by the beak being close to the posterior margin, and by the remarkably divaricating sculpture of the valves, and internally by several minor points of detail, obvious on comparing the figures.

Position and Locality.-Common in the schists on the Bala limestone at Bryn-Melyn quarry near Bala, Merionethshire; schists of Pont y Glyn, Diffwys, West of Corwen, Merionethshire; and in the fine grits of 'Tan y Craig, Builth.

Explanation of Figures.-Pl. 1. H. fig. 1. From the Upper Bala rocks of Bryn Melyn, Bala. Natural в в 2 
size of exterior.-Fig. 1 a. Portion of superficial markings magnified.-Fig. 2. Ditto cast of interior shewing the two pairs of muscular impressions projecting.-Fig. $2 \alpha$. Portion of ditto shewing the impressions of the pallial vessels magnified.

\section{2nd Family. ORBICULID F.}

Arms fleshy, spirally coiled one on each side, the parts united and fixed to one valve, leaving only the tips free, incapable of protrusion, provided with very long, close, sub-corneous ciliated fimbria, without supporting apophyses; shell conical, without hinge or deltidium, fixed by a muscle of attachment going out through an opening in the lower valve, which, though perforated, is proved to be the analogue of the imperforate valve of Terebratule, by having but two branchial vessels, and by the position of the alimentary canal. Eight adductor muscles, part of the anterior pair of which go out through the fissure and dilate into a disk for attachment; the large anterior and posterior pairs pass obliquely from one valve to the other without crossing; within these are two slender pairs which decussate and slide the valves on each other.

The muscles and viscera form a mass in the posterior half of the shell; the mouth is near the middle, and from each side of it the anterior crescentic pair of muscles diverge obliquely backwards; behind the mouth is the trigonal green liver, and behind it the large grey ovary, and nearly at the posterior margin are the impressions of the small posterior pair of muscles; the stomach is large, pearshaped, and from its posterior end a short curved intestine bends to the right side, and there opens between the lobes of the mantle; within the anterior crescent-shaped pair of muscles are two hearts, giving off two thick branching pallial veins to the perforated, and four to the imperforate valve, each with a small (?) artery attached to it. There is no trace in the shell, or fossils, of the existence of the arms.

The family includes the following genera:-1st, Siphonotreta; 2nd, Orbicella; 3rd, Orbiculoidea; 4 th, Discina.

\section{Genus. SIPHONOTRETA (Vern.)}

Gen. Char.-Shell elongate ovate, inequivalve, calcareo-corneous ; one valve slightly convex with no beak, the other with a produced beak, filled internally by a solid pad enclosing a tubular sheath for the pedicle, one end opening at the end of the beak of the great valve; substance obliquely punctured; surface with scattered tubular spines.

\section{Siphonotreta Anglica (Morris).}

\section{Ref.-Morris, Ann. Nat. Hist. 2nd Series, Vol. IV. t. 7. f. 1.}

Sp.Ch.-Longitudinally broad ovate. imperforate valve sulhorbicular, depressed; perforate valve ovate, very convex in the middle, most so about one-third from the beak; beak produced with a distinct perforation; surface of both valves with minute close, imbricating, concentric strix, about fifteen in the space of one line, reticulated by minute close punctures, less than their diameter apart, their diameter equalling the width of the imbricating lines from each other. Length of perforated valve four lines, proportional width (greatest about the middle) $\frac{85}{1001}$, length of small valve $\frac{85}{100}$, depth $\frac{40}{100^{\circ}}$.

Mr Morris figures and describes long annulated setaceous spines, projecting from some of the lamina of growth, which the mode of preservation of ou: specimens renders invisible, although the marks of their large bases are seen scattered here and there; on the other hand, impressions taken from the cavities left by some of our specimens, shew the perforated tubular beak which he had not seen, and confirm his reference of the fossil to Siphonotreta.

Position and Locality.-Abundant in the shale nodules of Sunny Banks, Coniston.

\section{Sipitonotreta micula $\left(M^{c}\right.$ Coy.) Pl. 1. H. fig. 3.}

Ref. id-McCoy, Ann. Nat. Hist. 2nd Series, Vol. VIII. p. 389.

Sp. Ch. -Longitudinally ovate, length and width about equal; sides and front broadly rounded with a uniform curve, posterior extremity slightly acuminated: gently convex, perforated valve most so, greatest depth at about one-fourth the length from the beak, which is near the posterior margin, and perforated by a round tubular opening; surface marked with a few concentric waves of growth, and sharp flat regular con- 
centric laminar strix, about seventeen in the space of one millemetre; several short slender conical spines are rather irregularly seattered over the surface, the substance of shell exhibiting under a high power an extremely minute reticular punetation. Average length (of rather large specimen) two lines, width usually rather less.

This small species vaties from nearly orbicular to ovato-pentagonal in outline; in some specimens, particularly those from Wellfield, the depressions left by the spines of the surface are very obvious and rather crowded, producing a puckered irregularity of the surface, which is not to be seen in most of the specimens from Pen Cerrig; the concentrie lineation is also more distinct in the former, between which the reticular punctation is so excessively minute that it can only be traced with very fine and powerful glasses, in favourable lights, on the best preserved portions of the shell, differing therefore very much from the most nearly-allied fossil, the so-called Tereluctule hemifire of Barrande. In nearly all the specimens, the distinct and rather large circular opening at the apex of the beak is easily seen, and in many specimens an irregular fissure, apparently produced by crushing, extends a variable distance towards the front margin, either in the medial line, or more or less to one side or the other. The few rather large coneentric waves, or interruptions of growth, are only seen in some specimens.

This species seems to agree in every thing with the little Terebratuld hamifera (Bar.) (Haidingers Naturwissenschaftliche Abhandlungen, Vol. I. p. 418 , t. 20 . f. 9), but has the reticular punctation infinitely more minute than he describes that of his species to be (half a millimetre long, or four in a square millimetre). M. Barrande gives the geological place of his species in Bohemia as "Gehört der Quartzitetage (D) an, $d . h$. dem am höchsten gelegenen Theile des untern silurisehen systems von Böhmen," and the schists in which it oceurs in such profusion in Britain seem to hold precisely the same place. Its gregarious habits are curiously shewn by the circumstance of a framment of shale four or five inches long and wide, from Pen Cerrig, having afforded upwards of a hundred specimens now in the collection; and another mass, not much larger, from WVellfield, having yielded upwards of seventy.

Position and Loculity.-Very common in certain spots in the black shale of Pen Cerrig, Builth, Radnorshire, and not uncommon in the olive schists of Wellfield, Builth, Radnorshire; very rare in the olive schists of Pentre, Llangynyw, near Welchpool, Montgomeryshire.

Explanation of Figures.-Pl. 1. H. fig. 3. Several specimens, natural size, on portion of shale, from three miles North of Builth. $-3 a$ perforated valve, magnified four diameters.

\section{Genus. ORBICULOIDEA (D'Orb.) 1847.}

Syn. = Schi otreta Kutorga, 1847-8.

Gen. Char.-Both valves conical; shell corneous, not punctured; muscle of attachment pedunculated, passing through a hole near the beak of the smaller valve, in the distal end of a closed, fissure-like, longitudinal depression.

Dr Kutorga's descriptions were probably read in 1817 , but not published till 1848 . (See the Proceedings of the Royal Mineralogical Society of St Petersburg for those years).

\section{Orbiculoidea implicata (Som. Sp.?)}

Ref. and Syn。? = Patella implicata Sow. Sil. Syst. t. 12. f. 1ta. = Schizoticta elliptica Kutorga. Verhandl. der Russ. Kaiser. Min. Gesellschaft. zu St Petersburg. for 1846, t. 7. f. 7, and 1847, t. 7. f. 6.

Sp. Ch.-Longitudinally oval, about one-fifth longer than wide, apex of the perforated valve at about two-fifths the length from the anterior edge, and the same length from the lateral edges; surface with slightly unequal and irregular sharp elevated concentric lines, about nine in the space of one line. Length about six lines, or rather more; width slightly less than five lines.

In the Orbicula (Orbiculoidea) Forbesii (Davidson), both as figured in the Bulletin of the Geol. Society of France (Oct. 1848), and in the Memoirs of the British Geological Survey, the outline is a broader oval than in our specimens, and the distance from the beak to the anterior margin is less than from the same point to the lateral margin at right angles to the length; I do not therefore unite the species, 
but provisionally refer it to the so-called Patella implicata (Sow.), with the proportions of which it agrees very well. If the reference to Sowerby be rejected the species should bear Dr Kutorga's specific name.

Position and Locality. - In the olive Ludlow-heds above the second grits, Keeper's Lodge, Croldengrove, Llandeilo, Caermarthenshire; a crushed example possibly of this species in the fine Ludlow Rock above Parklane, Llandeilo.

\section{Genus. DISCINA (Lam.) \\ = Orbicula (Auct. not of Cuvier).}

Gen. Char.-Shell corneous, not punctured, muscle of attachment not pedunculated, passing through a slit in the flat dorsal valve, the opposite valve obliquely conical.

Prof. Fleming and Mr J. E. Gray have satisfactorily shewn that the shells commonly called Orbicula, properly belong to the genus Discina of Lamark-Orbicula of Cuvier being a synonym of Crania.

\section{Discina Monrisi (Davidson Sp.)}

Ref. and Syn. = Orbicula id. id. Bull. de la Soc. Géol. de France. 2nd Series, Vol. V.t. 3. f. 47.

$S p . C h$. - Nearly orbicular, length slightly exceeding the width; imperforate valve gently convex, surfuce remarkably even and smooth; beak obtuse, at about one-third the length from the posterior end, with a short, narrow, internal longitudinal ridge, extending a short way from it towards the anterior margin; entering-valve slightly coneave at the margins and at the anterior half, tumid towards the opening, which is very broad oval, half its length from the posterior margin, the intervening space being about one-sixth the entire length. Length about seven lines, proportional width about $\frac{95}{1009}$ depth $\frac{30}{100^{\circ}}$

This species is easily distinguished from the Discina mugete by its nearly smooth surface, having its beak rather farther from the margin, and wider fissure, and from the Orbiculoidec implicata by its less elongate form, and wanting the sharp concentric ridging.

Position and Locality.-Not uncommon in the Lower Ludlow rock of Leintwardine, Shropshire.

\section{Discina Rugata (Som. Sp.)}

\section{Ref. $=$ Orbicula id. Sow. Sil. Syst. t. 5. f. 11.}

Sp.Ch.-Rotundato-subtrigonal, or nearly orbicular, usually a little wider than long, but sometimes the length slightly greater than the width, depressed; apex about one-fifth the length from the margin, height varying from one-third, to rather less than one-fifth the length; surface very glossy, marked with sharp interrupted, irregular, concentric wrinkles, (sometimes, in soft rocks more regular) separated by comparatively wide spaces, six or seven in the space of one line, crossed in some specimens by faint coarse radiating strix; interior of attached valve flat, slightly tumid towarls the apex, which is nearly central, and from which a broad oval perforation extends rather more than halfway to the margin; the concentric lines rather more regular than in the large valve. Average length four lines.

The substance of this species is distinctly corneous when preserved in sandstone (though apparently calcareous in limestone) and unpunctured, and I camot see why M. d'Orbigny places it in his shelly punctured genus Orbicella. I have not seen any specimens quite so coarsely wrinkled as Mr Sowerby's. In one group the specimens within a few inches of each other varied from having the length and width equal, to having the width one-fifth greater than the length. Few of the specimens shew the radiating strix in parts.

Position and Locality._Common in the hard Upper Ludlow rock of Benson Knot, Kendal, IVestmoreland; in same rock, north end of Potter's Fell, Kendal, Westmoreland; Upper Ludlow rock of WVolhope; Upper Ludlow rock of Burton and Brockton; Upper Ludlow rock near Ludlow, Shropshire. 


\title{
Discina? striata (Son.)
}

\author{
Ref. and Syn.= Orbicula id. Sow. Sil. Syst. t. 5. f. 12.
}

Sp. Ch.-Rotundato-subtrigonal, tumid; beak obtuse, marginal; surface slightly glossy, corneous, radiated with minute, close, subequal, prominent, rugged strix, about fifteen in one line at the margin. Width six lines, proportional length $\frac{80}{100}$, depth $\frac{22}{100}$.

The genus of this fossil seems very doubtful; the two specimens I have examined (if Discina) had undergone an oblique distortion, and from having the beaks nearly in contact resembled the two valves of a lamellibranch. There are a few irregular concentric wrinkles.

Position and Locality.-Upper Ludlow rock of Benson Knot, Kendal, Westmoreland.

\section{õth Family. SPIRIFERIDE.}

Arms probably with long fimbrix, incapable of extension, and fixed to internal testaceous spirally-rolled apophyses; shell calcareous, fibrous, or punctured.

The family contains the following genera:-1, Spirifera; 2, Spiriferina; 3, Athyris; 4, Spirigerina.

$$
\begin{gathered}
\text { Genus. SPIRIFERA (Sow.) } \\
=\text { Delthyris }(\text { Dal. })=\text { Choristites }(\text { Fisch). }
\end{gathered}
$$

Gen. Cher.--Transversely oval, gibbous, radiatingly-ridged; hinge-line as long as the shell is wide; area nearly parallel-sided, of moderate width in the receiving* valve, very narrow in the opposite one; shell fibrous, foramen notching the area of both valves, that of the entering valve open, that of the receiving valve with an internal pseudo-deltidium bordered by two strong diverging, dental lamella in the receiving valve, and by the flattened bases of the spiral apophyses in the other, which also usually shews a small mesial septum: casts of receiving valve are trilobed towards the beak, the small middle lobe being defined by the ends of the diverging dental lamella on each side, its rounded end (analogous to a pseudo-deltidium) as well as those of the lateral lobes being formed by an inner layer of shell, between which and the external one is a wide hollow space. The muscular impressions of the great valve are shallow, radiated just within the ends of the dental lamelle: those of the entering valve (in the Permian S. alatus, and the Silurian S. Lynx) resemble those of Orthis, the four impressions being rounded and grouped together on the rostral half of the middle, their boundaries forming a more or less distinct crucial mark, depressed in casts. There are three sub-genera besides Spirifera proper.

1. Sub-genus Cyrtia $\left(D_{a l}\right)$-General characters of Spirifera, but the cardinal area very wide, triangular, and confined to the receiving valve, nearly closed by an external pseudo-deltidium.

* The shells of the Brachiopoda, not only differ from those of the Lamellibranchiata in having one applied to the dorsal aspect and the other to the rentral aspect of the animal, but all are destitute of the "ligament' which connects the valves of Lamellibranchs to each other, and of the 'cartilage' which forces them open. 'The valves of the Brachiopoda are either entirely unconnected, or adhere by the interlocking of the hinge teeth, and in the latter case we have the curious peculiarity of the beak of that valve called 'dorsal' by anatomists, and 'ventral' by nearly all describers of shells, cntering within the cavity of the large or perforated valve. This obvious peculiarity furnishes me with the terms 'entering and receiving valves,' which I hope may be generally adopted in future, instead of the terms 'dorsal and ventral valves,' which lave been so invariably used in the wrong sense by conchologists, that reversing them in accordance with anatomy would be productive of constant confusion. It has been suggested that the use of the internal loops and other apophyses of the Brachiopoda was by their elasticity to force open the ralves, in the absence of cartilage; but it will be found that they do not even touch the ralves when closed, and I found about three years ago on examining some uncleaned Terebratulae, sent by Mr Jukes to the Woodwardian Museum, that this was really effected in a way unexampled in Lamellibranch bivalves, namely by the action of a pair of muscles, which arise from the middle of the perforated or receiving valve, and the tendons of which aro inserted into the internally prolonged entering beak of the entering valve, which thus forms a lever moving on the hinge teeth as a fulcrum. 
2. Sub-genus Braснутичris ( $I$ C Coy).-General characters of Sipirifera, but the hinge-line shorter than the width of the shell, and the cardinal angles obtusely rounded.

3. Sub-genus M artivia (IFCOy). -General characters of Brachythyris, but the surface smooth, without radiating ribs; spiral appendages very small.

\section{Spirifera Biforata (Schlot. Sp.) \\ Ref. and Syn。=Terebratulites biforatus Schlot. Petrefacten, p. 265.}

This species has been made the type of a new genus of Orthisidce, by Professor King, but both he and M. de Verneuil in forming for it his group, "bifores," of Syivifer, seem to have overlooked the double area and foramen pointed out in the true carboniferous Spirifers by d'Orbigny, and which certainly exist.

There are several varieties of this species which I describe separately.

\section{Var. $\boldsymbol{\alpha}$. Spirtfera LYNX (Eichw. Sp.)}

Ref.-M. V. K. Geol. Russ. t. 3. f. 3 and 4. Hall. Pal. N. Y. t. 32. D.

Sp. Ch. - Subquadrate, lateral margins subparallel; apical angle about $145^{\circ}$; valves very gibbous, entering valve most so; hinge-line as wide as the shell; cardinal area rather narrow, of nearly equal width in both valves, and each area with a nearly equal triangular opening; mesial ridge quadrate, very prominent, sharply defined to the beak, forming a deep oblong sinus in the front margin, mesial ridge with four simple, obtusely angular plaits, sides with from five to eleven simple, angular plaits, about the same size as those on the sinus; substance of shell thick, fibrous, the ends of the fibres giving a slightly granulose aspect to the surface in some conditions, under a high power: casts of receiving valve shew the usual small ovate rostral prominence bordered by the short strong dental lamelle, and the shoulder-like lateral lobes usual in the genus; the entering valve shews a small ovate prominence of the beak, with a deep oval diverging pit on each side for the apophyses; from these on each side extends a rotundato-quadrate, sulcus enclosing a space as long as wide, the width about a third greater than that of the mesial ridge, this space divided by a crucial sulcus into four subequal rotundato-trigonal muscular impressions. Average width one inch two lines, proportional length of receiving valve $\frac{87}{100}$, of entering valve $\frac{85}{100}$, depth $\frac{70}{100}$.

Position and Locality.-Extremely common in the Upper Bala sandstone of Alt yr Anker, Meifod, Montgomeryshire; schists of Pen y Craig, Llangynyw, Montgomeryshire; schists upon Bala limestone at Bryn Melyn quarry near Bala, Merionethshire; schists of High Haume, Dalton in Furness, Lancashire; schists of Bwlch y Ciban; schists upon Bala limestone of Maes Meillion, S. of Bala, Merionethshire; Pont y Glyn, Diffwys, W. of Corwen, Merionethshire; concretionary limestone of Maes y fallen, Bala (small specimen with trace of branching on some of the lateral ribs indicating a passage to the Var. S. terebratuliformis, $\mathbf{M}^{c}$ Coy).

\section{Var. $\beta$. SpIrifera dentata (Pand. Sp.)}

Ref. and Syn。=Porambonites dentatus Pander Beitr. z. Geol. Russ. t. 11. f. 4. Spirifer id.

M. V. K. Geol. Russ. t. 3. f. 5 .

$s p . C h$. - General characters of the $S^{\prime}$ lynx, but the width rarely reaching nine lines, the simple lateral plaits six to eight in number, mesial plaits constantly two in the sinus and three on the meisal ridge; substance of the shell coarsely punctured.

Position and Locality.-Not common in the Bala schists of Coniston Water Head, Lancashire; schists of Cyrn y Brain, Wrexham, Denbighshire; and schists of Rhiwargor, near Llanwddyn, Montgomeryshire.

\section{Var. $\gamma$. Spirifera biforata (Schlot. Sp.) (Vera.)}

$$
\text { Ref.-M. V. K. Geol. Russ. p. } 135 .
$$

$S p$. Ch. -General characters of the preceding varieties, but the shell usually wider in proportion to the length, the ribs narrower and more numerous, mesial fold wider and less elevated, bearing usually from six to 
nine rilss on the sinus, at six lines or less from the beak, and five to seven in the sinus, the lateral ribs narrow, simple, from nine to twelve on each side at five or six lines from the beak.

This variety is much rarer than the others, but seems to pas: gradually into them, though very distinct at first sight.

Position and Locality.-Rare in the Bala limestone of Llandeilo, and Bala sandstone of Alt yr Anker, Meifod, Montgomeryshire: a narrow globose variety with only seven or eight large lateral ribs on each side, and the six ribs on the mesial fold very narrow, occurs in the limestone of Mathyrafal, S. of Meifod, Montgomeryshire.

\section{Var. S. Spinifera fissicostata ( $\mathrm{F}$ Coy).}

Sp. Ch.-General characters of preceding varieties, four ribs on the rostral part of the mesial furrow, the two outer of which usually branch at four or five lines from the beak, the others branch irregularly lower down once or twice; lateral ribs varying from six to fifteen within three or four lines from the beak, branching irregularly, some into two, others intn four, with age; surface crossed towards the margin with sharp stri:e of growth.

This variety does not seem to have been noticed either in Russia or America, yet it is extremely common in our old rocks; many of the specimens shew a difference in the muscular impressions in the entering valve frem the variety lynd, in having the posterior pair much smaller than the anterior and obliquely elongated, so that the division between them and the anterior pair is no longer a horizontal line forming a cross-shaped mark; other specimens, however, more distinctly preserved, seem to have the usual internal characters along with the divided ribs. So very variable are the ribs in size and number, that extreme specimens which I have noted, might be referred on the one side apparently to the $S$. terebratuliformis, ( $M^{c} \mathrm{Coy}$ ), and on the other to the S. ovata, $\left(\mathrm{I}^{\mathrm{C}} \mathrm{Coy}\right)$.

Position and Locality.-Very common in the Bala schists of Bryn Melyn, Bala, Merionethshire; schists of Peniarth. Meifod, Montgomeryshire; Bala sandstone of Alt yr Anker, Meifod, Montgomeryshire; Bala schists of Gelli Grin, Bala, Mcrioneth-hire; impure Bala limestone of Ravenstone Dale, Westmoreland; Coniston or Bala limestone of Coniston Wrater Head, N. Lancashire; calcareous (Lpper Bala) flags of Ash Gill, Westmorcland; schists of Blain y C'wm, W. of Nantyp, Glyn Ceiring, S. of Llangollen, Denbighshire; schists of Maes Lir, N. E. of Aber Himant, N. Wales; impure Bala limestone of Iathyrafal, S. of Meifod, Montgomeryshive; impure limestone of Tyn y Cabled; schists at Bala, Merionethshire; schists, Aber Hirnant, E. of Bala, N. Wales.

\section{Spirifera crispa (Linn. Sp.)}

Ref. and Syn.=Anomia crispa Linn. Syst. Nat.; Spirifer id. Sil. Syst.t.12. f. 8; Bull. Géol. Soc. de France, 2nd Series, Vol. V.t. 3. f. 42 .

Sp. Ch.-Transversely oval, gibbous, cardinal angles broadly rounded, hinge-line rather shorter than the width of the shell; cardinal area triangular, varying from one-fourth to nearly one-third the length of the hinge-line in height; entering valve with a rounded mesial ridge, not exceeding in size or prominence the adjoining lateral ridges, which are broally romded, and either two or oceasionally three on each side; mesial sulcus of receiving valve corresponding to the opposite ridge, and not intenting the lateral margin more than the lateral sulci; surface crossed by sharp, concentric, regular lamina of growth. Average width four lines, proportional length of entering valve ${ }_{100}^{65}$, proportional length of receiving valve $\frac{75}{100}$, depth of both valves $\frac{55}{100}$.

Pusition and Loculity. - C'mminon in the limestone of Clungunford, Shropshire; schists near Llangollen, Denbighshire; schists of Keeper's Lodge, Goldengrove, Llandeilo.

\section{SPIRIFERA CYRTANA (Dal. Sp.)}

Ref. and Syn. = Delthyris cyrtena Dal. Acad. Holm. 1827. t. 3. f. 4 .

Hisinger, Pet. Suec. p. 73. t. 21. f. 4.=? Spirifer interlineatus Sil. Syst. t. 6. f. 6.

$S_{p}$. Ch.-Rhomboidal, very gibbous, particularly the receiving valve which is strongly arched, towards the large, gently incurve beak; hinge-line rather less than the width of the shell; cardinal angles obtuse ; cardinal

[FASC. 1I.] 
area broad, curved, triangular, height one-third of its width, foramen narrow, with prominent edges; receiving valve with a very deep, wide, rounded, mesial sulcus; and four or five strong, rounded coste on each side; receiving valve moderately convex, with a corresponding prominent, rounded mesial ridge and set of costre; entire surface covered with close, fine, subequal costx (seven in one line), at three lines from the beak. Average width one inch one line, proportional length of receiving valve about $\frac{80}{100}$.

This species seems to me totally distinct (when typical forms are considered) from the Spirifer radiutus of Sowerby, by its very strongly costated valves, and for the same reason it agrees perfectly with Dalman's Delthyris cyrtona, which has usually been referred to the S. radiatus of Sowerby, although it is his S. interlineatus which presents the mixed costated and lineated character of Dalman's species; the $S$. interlineatus of the Silurian System has more obtuse lateral angles than Dalman's specimens; but this character seems to vary.

Position and Locality.-Not uncommon in the Wenlock limestone of Ledbury, Herefordshire; rare in the Wenlock limestone of Woolhope.

\section{Spirifera insularis (Eichw. Sp.)}

Ref. = Terebratula insularis Eichw. Urwelt. Russl. Part II. t. 2. f. 6. Syrivifer id. M. V. K. Geol. Russ.t. 8. f. 7.

Sp.Ch.-Suborbicular, very gibbous; entering valve sometimes very slightly longer than the receiving one from its larger, much arched, tumid beak, very gibbous, nearly three times the depth of the receiving valve, with a broad, elevated, flattened mesial ridge, with narrow, nearly vertical sides, extending from the very deep oblong sinus in the front margin, to within a short variable distance of the beak; sides tumid; lateral margins rounded, advancing with a deep wave towards the receiving valve, before turning angularly upwards to form the marginal sinus; receiving valve tumid for a short distance near the small short beak, which is not incurved; sides flattened or slightly concave towards the margin, middle portion abruptly depressed into a wide, flattened, angular depression, corresponding with the sinus in the front margin; hinge-line considerably less than the width of the shell, cardinal angles obtuse; cardinal area of receiving valve flat and triangular, about five times wider than high, inclined backwards at an angle of $105^{\circ}$; cardinal area of entering valve very narrow, invisible externally, from being inflected parallel with the plane of the lateral margins, with its small triangular open foramen. Internally the entering valve shews a slender mesial septum, extending one half the length of the shell, but scarcely raised above the surface of the valve; and on each side of the little triangular opening beneath the beak is a large divergent cardinal tooth (broken at the apex); the receiving valve shews a similar mesial septum, and two moderately long dental lamellie, diverging at an angle of about $80^{\circ}$; surface smooth. Length one inch one line, proportional width $\frac{87}{100}$, depth of entering valve at middle, and height of sinus, $\frac{86}{100}$, depth of receiving valve $\frac{18}{100^{\circ}}$.

The discovery, on a small fragment, of the concealed cardinal area of the entering valve with its small triangular foramen, proves the correctness of M. de Verneuil's reference of this fossil to the genus Spivifera, and the great divergent cardinal teeth, though broken at the apex in the only specimen shewing these parts, present the usual appearance of the bases of the spiral appendages of Spirifera.

Position and Locality.-Common in the Coniston or Bala limestone of Coniston, Lancashire; rare in the impure schistuse limestone of Llangynyw, Montgomeryshire.

\section{Spirifera per-crassa $\left(M^{\circ} \mathrm{Coy}\right)$.}

\section{Ref. and Syn.= Atrypa crassa Sow. Sil. Syst. t. 21. f. 1.}

$S p . C h$.-Transversely oval, or subrhomboidal, gibbous; large valve with a mesial concavity, narrow and ill defined towards the beak, very wide and bounded by two obtuse ridges towards the front; sides sloping rapidly; beak prominent, apical angle about $115^{\circ}$ (less when young, rather more when old), sides rounded, front slightly produced in an obtusely rounded deflected lobe: lateral margins nearly level; small valve tumid, with an obtuse, tongue-shaped lobe in the front; slightly elevated corresponding flattened ridge not extending half way to the beak: casts of receiving valve shew two very strong slits of the dental lamellie, converging 
so as to meet in the rostral part, enelosing the large triangular formen, and again diverging in their anterior part, reaching to within one fourth the length of the anterior margin; each side with about six thick radiating ridges (ovarian?), and two or four on the middle lobe, all obseurely forking at the margin; casts of entering valve shew two thick diverging dental pits at the beak, a wide shallow mesial depression, with an obscure crucial arrangement of four angular ridges defining the muscular impressions; there are three or four short, thick, radiating ridges on the smiall elevated part of the front, and a few very short marginal lateral ones; surface smooth. Width of receiving valve nine lines, proportional length varying from ${ }_{100}^{85}$ to $\frac{100}{1(x)}$, depth of receiving valve $\frac{30}{100}$.

This fossil seems to belong to the same section of Spirifer as the S. Mosquensis of Fischer, as figured by de Verneuil in the Geology of Russia, and in which the dental lamellre present the same unusual size and curvatures. The less apical angle, shorter mesial fold, and near equality of length and width, as well as the generie difference in the intemal plates, separate this from the Atyple (Pentamerns) undute of Sowerby. In placing this species in the genus Spirifer, I have been obliged to use a new specific name, as it is not, of course, the carboniferous Spirifer crassus of de Koninck.

Position and Locality. - Upper Bala schists and limestones of Mathyrafal, S. of Meifod, Montgomeryshire; very common in the Upper Bala schists of Cefn Rhyddan. Llandovery, S. Wales; Coniston or Bala linestone of Coniston, Lancashire; ? sehists, Cyrn y Brain, W. of Wrexham, Denbighshire; fine green conglomerate (Caradoc sandstone) of Moel Seisiog, Llanrwst, Denbighshire; sandy Cpper Bala schists of Mathyrafal, Meifod, Montgomeryshire.

\title{
Spirifera radiata (Som.)
}

\author{
Ref.-Min. Con. t. 493. f. 1, 2. and Sil. Syst. t. 12. f. 6.
}

Sip Ch.-Transversely subrhomboidal. gibhous; hinge-line slightly less than the width of the shell; cardinal area moderately wide, triangular, curved; cardinal angles obtusely rounded; receiving valve with a large incurved beak, and a wide, deep, rounded mesial hollow, extending from the apex to the front margin, which is abruptly raised into a deep quadrate simus; sides gibhous; entering valve with a very prominent rotundatoquadrate mesial ridge, strongly defined from the beak to the sinus in the front margin; sides tumid; surface radiated with very fine, close, nearly equal, thread-like strix. bifureating oecasionally ( 23 in 3 lines at 6 lines from the beak); casts of receiving valve shew the slightly diverging slits of two extremely thick dental lamella. Average width 1 inch 6 lines, proportional length $\frac{75}{100}$ length of entering valve $\frac{63}{100}$, depth $\frac{70}{100^{*}}$

Position and Locality.-Common in the Ludlow rock, Keeper's Lodge, Goldengrove, Llandeilo, Caermarthenshire.

\section{SPIRIFERA SUB-SPURIA $(d O r b$.}

Ref. and Syn-d'Orb. Prod. Pal. p. 42. Spirifer octoplicatus Sow. Sil. Syst. t. 12. f. 7. (not of Min. Con.) = S. plicatus Sharp. Quart. Geol. Journ. Vol. IV. (not of Hön.).

Sp. Ch.-Rhomboidal, hinge-line nearly as long as the shell is wide, cardinal angles obtusely rounded; cardinal area rather broad, slightly curved, triangular; entering valve convex, with a strongly-defined mesial ridge, divided except near the beak by a deep rounded sulcus, each half being about the size of the adjacent lateral ridges, the separating sulcus at margin being about as wide as the ribs, each side with four or five strongly defined rounded ridges; receiving valve very tumid, much arched towards the incurved beak, mesial sulcus as large as the opposite ridge, very deep, rounded, without ribs, bounded by a very strong rounded ridge on each side, much more prominent than the three or four lateral ribs; surface slightly marked with delicate concentric lines of growth; average width five lines, froportional length ${ }_{1: u}$, length of entering valve ${ }^{80}$, depth about $\frac{70}{100}$.

The casts shew the two dental lamelli in the receiving valve very thick but short, and a faint trace of the mesial septum on the ridge of the entering valve. I do not think, with Mr Davidson or M. d'Orbigny, that 
the Spirifer spurius of Barrande (Naturwissenschaftliche Abhandlungen Vol. II. t. 18. f. 17) is the same as the Spirifer octoplicatus of Sowerby in the Silurian System, although I agree with them that that species is quite distinct from the true carboniferons $S$. octoplicatus of the Mineral Conchology. The species figured in the Silurian System is distinguished from the S. spurius (Bar. not Braun) by the much narrower mesial sulcus, and the want of ribs therein, unless they only appear in extreme age; in any case, M. d'Orbigny's name is the proper one to retain for this species.

Position and Locality.-Extremely abundant in the hard, siliceous Upper Ludlow rock of Lamb-rigg Fell, Benson Knot, and N. end of Potter"s Fell, Kendal, IVestmoreland.

\section{Spirifera (Cyrtia) trapezoldalis (Dalm.)}

Ref. and Syn.=Cyrtia trapezoidalis Dal. Act. Holm. 1827. t. 3. f. 2.

Spirifer id. Davidson, Bull. Géol. Soc. de France, 2nd Series, Vol. V. t. 3. f. 43.

Sp. Ch. Entering valve nearly semicircular, twice as wide as long; cardinal angles rectangular, or obtusely rounded; mesial ridge large, strongly defined throughout, prominent, flattened above, forming a deep subquadrate lobe in the margin; sides gently convex; receiving valve pyramidal, with a very deep mesial suleus from the beak; hinge-line as wide as the shell; cardinal area triangular, or slightly incurved; height varying from one-half to little more than one-third the width: surface uniformly radiated with very fine, close, thread-like strix, about eleven in one line at three lines from the beak, increasing in number towards the margin by intercalation. Average width (of small specimen) eight lines; proportional length of entering valve $\frac{81}{100}$; height of cardinal area ${ }_{100}^{43}$ to $\frac{56}{100}$.

In casts the slits left by the dental lamella are very strongly marked in the entering valve, and the centre of the ridge of the receiving valve shews traces of a fine mesial septum.

Position and Locality.-Common in the schists of Goldengrove, Llandeilo; schists of Coed Sion, Llangadoc, S. Wales; Upper Ludlow rock of Woolhope.

$$
\begin{gathered}
\text { Genus. ATHYRIS ( } \left.M^{\circ} \mathrm{Coy}\right) .1844 . \\
\text { Syn. }=\text { Spirigera (d'Orb.) } 1848 .
\end{gathered}
$$

Gen. Char.-Nearly orbicular or ovate, both valves convex; no cardinal area, foramen, or hinge-line; spiral appendages to beak of entering valve very large, nearly filling the shell; a strong mesial septum in rostral part of entering valve; dental lamelle moderate; tissue of shell apparently fibrous.

One specimen (of $A$. tumida) shews the pallial and ovarian impressions to be thick, numerous, and dichotomising frequently from the beak to the margin.

\section{Athyris tumida (Dal. Sp.)}

Ref. and Syn.=Atrypa tumida Dal. Acad. Holm. t. 5. f. 3. =A. tenuistriata Sow. Sil. Syst. t. 12. f. 3.

Sp. Ch. Rotundato-quadrate; valves almost equally tumid; margins level in young specimens, raised in adults into a small obtuse square sinus, forming an obtuse ridge (sometimes divided by a faint mesial sulcus) extending a small way from the margin on the small valve, but usually no corresponding depression in the receiving one; lateral margins nearly straight, front margin forming a rotundato-quadrate lobe towards the small valve; beaks very small, incurved, touching each other; apical angle about $115^{\circ}$; surface smooth, or rarely with a fine obtuse longitudinal lineation on the sides. Average width one inch eight lines; proportional length $\frac{98}{100}$; length of entering valve $\frac{85}{100}$; depth of both valves $\frac{70}{100}$.

When in good condition the surface is smooth, but when partially decorticated fine radiating strix appear, as I have noticed in nearly all the smooth species of Athyris and Martinia. On comparing the English and Gothland specimens I have no doubt that Mr Sowerby's name should be considered a synonym of Dalman's.

Position and Locality.-Abundant in the Wenlock limestone and shale of Dudley, Stafiordshire; not uncommon in the Wenlock limestone of IVoolhope. 


\section{Gonus. SPIRIGERINA $(d O r b$.}

Gen. Char.-Shell oblong, marked with radiating dichotomous ridges; bealss closer, or sherving a small round opening close under the beak, separated from the hinge-line by a distinct deltidium of two pieces; internally the receiving valve has two short diverging cardinal teeth (one each side of the deltidial space); the entering valve has a very short mesial septum, and two long apophyses coiled in large flattened spires, each nearly parallel with the horizontal plane of the margins of the valves, or a little oblique, so that part of the right spire is over the other; in receiving valve the two adductor impressions are very large, occupying nearly half the space of the interior; the pallial trunks are rery simple, with few slender branches.

Most usually, I think, the foramen and deltidium are concealed, but I have myself distinctly seen them, and this, as well as the curious nearly horizontal direction of the spires, separates it from the others of the family: (for muscular, and other impressions, see S. reticularis).

\section{Spirigerina? cuneata (Dal. Sp.)}

Ref. and Syn.=Terebratula cuneata Dal. Vet. Acad. Verhandl.t. 6. f. 3. Sow. Sil. Syst. t. 12. f. 13.

$S p . C h$. - Longitudinally trigonal, apical angle $75^{\circ}$, sides long, straight, greatest width at one-third the length from the front margin; receiving valve with a nearly straight prominent beak, deeply depressed, to form a wide and deep sinus in the front nargin; from about two lines from the beak, sides searcely convex; entering valve with the sides very slightly convex, the two mesial ridges very muel elevated from about two lines from the beak, forming a prominent mesial ridge towards the front; each valve coarsely radiated with from twelve to fourteen strong, angular, decply-divided simple ridges, deeply indenting the margin, four of which are elevated with the front, but the two middle ones usually more elevated than the lateral pair; an elongate, ovate, concave, smooth space, formed by the partial inflection of the posterior lateral margins of the valves, the edge of the receiving one forming a very marked rounded lobe, the convexity towards the entering valve, which it thus overlaps considerably; surface sharply striated transversely by lines of growth. Length six lines, proportional width $\frac{80}{100,}$, depth of both valves (greatest near front margin) $\frac{60}{100}$.

The curious embracing lobe of the sides of the receiving valve has been noticed by Dalman; the long straight sides meeting at so small an angle easily distinguish this species from the $I I$. diadonta, to which those varieties, in which the two mesial plaits are remarkably prominent, make some approach. I have not been able to see the aperture distinctly, nor whether the tissue is certainly fibrous or punctured, so that the generie position of the fossil would remain doubtful, as far as my own observation went, but M. d'Orbigny scems to have ascertained the existence of the characters of his genus Spirigerina, in which I accordingly follow him.

Position and Locality.-Not very uncommon in the Wenlock limestone of Wenlock, Shropshire.

\section{Spirigerina marginalis ( $\mathrm{Dal}$. Sp.) \\ Ref. and Syn. = Terebratula marginalis Dal. Vet. Acad.t. 6. f. 6.= Terebratula imbricata Sow. Sil. Syst. t. 12. f. 12.}

$S p$. Ch.-- Rotundato-quadrate, both valves gently convex, receiving valve least so, mesial hollow deep and wide at the margin, continuing with sharp angularly defined sides quite to the beak, which is small, prominent, and scarcely incurved; foramen round, separated by a distinctly marked hipartite deltidium from the hinge; apical angle $140^{\circ}$; entering valve with the mesial ridge prominent, convex, or slightly flattened, very shaiply defined up to the beak; lateral margins nearly level, front marghin abruptly raised into a deep rotundato-fuadrate sinus; radiating ridges close, angular, branching two or three times from the beak to the margin, where, in a specimen eight lines long, there are about seven on the mesial ridge, and eleven on each side; at three lines from the beak there are eight on each side, and five on the sinus, all the ridges crossed by strong, prominent, scaly lines of growth; shell-tissue fibrous. Width nine lines, proportional

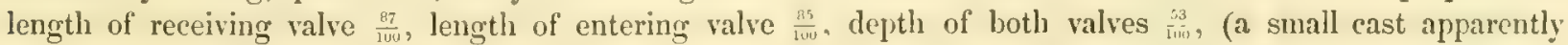
of this species shews the usual oval pit on each side of the beak for the apophyses in the small valve, 
and a trace of a small mesial septum, and the slits of the wide, slightly diverging, dental lamellec, bordering the beak of the receiving valve); tissue of the shell fibrous.

This species varies considerably, but is easily distinguished by its strong branching sealy ribs and sharply defined mesial fold; from the dichotomising of the lateral ribs they often seem to arch outwards; the figure in the Silurian System is considerably Ionger, and Dalman's figure rather wider, and with more prominent beak, than the usual forms.

Position and Locality.-In the Wenlock limestone of Wenlock, Shropshire; in the calcareous Upper Bala beds of Pont y Glyn, Diffwys, W. of Corwen, Merionethshire; Upper Bala sandstone of Alt Goch, Llanfyllin, Montomeryshire; Upper Bala schists of Rhosfawr, N. of Glog, Llanfyllin, N. Wales; fine sandy Bala schists of Tre Gib, S. of Llandeilo. Variety with much branched ribs in the schists of Pen y Craig, Llangynyw, Montgomeryshire; Bala limestone of Mathyrafal, S. of Meifod, Montgomeryshire; in the olive schists W. of Llanfyllin, Montgomeryshire; in the fine Bala sandstone of Alt yr Anker, Meifod, Montgomershlire; sandy schists of Goleugoed, Llandovery, Mandinam, Caemarthenshire (very wide variety); Lpper Bala schists of Blaen y Cwm, W. of Nantyr, Glyn Ceiriog, Denbighshire; schists of Gelli Grin, Bala, Merionethshire.

\section{Spirigerina reticularis (Limn. Sp.)}

Ref. and $S y n .=$ Anomia reticularis Linn. Syst. Nat. $=$ Terebratula prisca Schlot. $=T$. explanatus Schlot. $=$ Terebratula affinis Sow. Min. Con. and Sil. Syst. t. 6. f. $5 .=A$. aspera Sow. Sil. Syst. t. 12. f. 5. (not of Dal. nor Schlot.) $=$ A. orbicularis Sow. Sil. Syst. t. 19. f. 3, 4 .

$S p$. Ch.-Elongate, ovate, or sub-triangular from the hinge-line extending into compressed ears as wide as the shell (small varieties often nearly orbicular); in ordinary adult specimens the receiving valve is nearly flat, convex at the beak, which is small and prominent, becoming gradually concave towards the margins, which are more or less reflected; the opposite valve very gibbous along the middle, gradually sloping towards the margin, surface covered with strong rounded or subangular strix, irregularly branching and increasing in thickness towards the margin, separated by deep sulci rather less than the ridges in width, both crossed by irregular, strong, sealy lines of growth, averaging five or six in two lines, at six lines from the beak (varying from four to seven). Length one inch two lines, width the same, proportional depth of both valves $\frac{60}{100}$ to $\frac{20}{100}:$ in specimens four lines long the valves are evenly convex and nearly orbicular; the entering valve little more tumid than the receiving one; cast of the beaked valve shewing a deep oblique pit, on each side of the beak for the hinge-tooth; a large, broad oval muscular impression, faintly divided down the middle and obscurely radiated, occupies the middle of the rostral half, round this is a space closely set with small irregular papillice (much smaller than in Barrande's figure, Tatumisenschaftliche Ablendlungen, Vol. I. t. 19. f. 9), probably indicating thick fleshy cirri of the mantle, traversed by one thick trunk on each side giving branches obliquely up and down, probably indicating the place of the ovaries; external margin smooth.

This is a very variable shell, but the above description indicates the most common and characteristic variety. It varies, 1 st, in the convexity of the valves, both as to degree, distance from the beak at which it is greatest, and equality, some small varieties, and the young at all times, having the valves almost equally and evenly convex; and, in form, some, particularly the young and the small varieties, being nearly orlicular, others being elongate and nearly triangular from the width of the hinge-line and narrowness of the front; 3rd, in the number, thickness, and closeness of the ridges, and the scales which cross them, both of which are often smaller, and closer than the the above-described typical variety. I could not trace any connexion between these varieties and their geological position; there being not the slightest difference between the series of varieties in the different parts of the Cambrian, Silurian, and Eifel rocks.

Position and Locality. - In the Lower Ludlow rock of Leintwardine, Shropshire; common in the Wenlock limestone of Sedgley, near 1)udley, Staffordshire, and Wenlock, Shropshire, and Dudley, Staffordshire; Upper Ludlow rock of Collin field, Kendal, Westmoreland; olive schists of Parklane, Llandeilo, above the white grits; flags of Middleton Park, Caermarthenshire; schists of Coed Sion, near Llangadoc, S. Wales; olive Ludlow rock of Mynydd-y-Gaer S. side, Llanefydd, near Ruthin, Denbighshire; alumdant in the schists 
of Kieeper's Lodge, Goldengrove, Llandeilo, above second grits; common in the Wenlock limestone of Woolhope; Upper Ludlow of Brockton and Burton, near Wenlock; Woolhope limestone of Littlehope; fine sandstone of May Hill.

\section{7th Family. RYNCHONELLADE.}

A rims free in their entire length, rolled laterally, and sustained by two separate, internal, arched, shelly apophyses, and capable of extension beyond the shell, provided with short fringes; texture of the shell fibrous, not punctured,--an opening under the beak of the large valve, which is pointed.

Genera: 1, Hemithyris (d'Orb.); 2, Rhynchonella (Fisch.); 3, Strigocephalus (Def.); 4, Pentamemus (has an opening, and ought to come here); 5, Camerophoria. (The genus Porambonites, placed in this family by d'Orbigny, seems from its double area to be better placed in the family Orthiside, where I have arranged it).

\section{Genus. HEMITHYRIS $\left(d^{\prime} O \cdot r^{\circ}\right)$}

Gen. Char.-Foramen triangular, not separated from the hinge; beak acute, pointed, entire; no cardinal area; entering valve with a small mesial septum; apophyses short, arched, triangular, with small dental lamellie; two strong, diverging, cardinal teeth hordering the opening in the large valve, supported by dental lamella, extending to the surface of the valve, (type, Terebratula psittacea).

The fossil species even of the Palrozoic Rocks seem to agree exactly with the recent type in fibrous tissue of the shell, form of the beak and foramen, internal dental lamellie in beak of receiving valve (leaving two diverging slits in the east), de. They shew great variety in the size of the opening, depending on the degree of curvature of the beak, which sometimes seems to close it entirely; casts usually shew two elongate muscular impressions close to the mesial line on the rostral half of the entering valve, and these being bounded by slight ridges, we have one or three slight longitudinal sulci on the cast; something similar may be observed on old specimens of the recent $H$. psittacea.

Mr Davidson refers this genus to Hypothyris of Phillips, but a reference to the "Palieozoic Fossils" shews that that genus has the opening separated from the hinge, and is therefore equal, as d'Orbigny shews, to Rhynchoulla (Fisch.) It is Cliothyris of Phillips (proposed as a substitute for Atrypu) that includes the fossil species with foramen touching the hinge, along with the closed Atrype; and I should have considered this latter name the proper one for this group, but for Prof. Phillips, to my great surprise, placing the Silurian species in his genus Itypothyris, in the ?nd Vol. of the Memoirs of the British Geological Survey. Under these circumstances then, there seems no alternative but to adopt M. d'Orbigny's clearly defined and extensively applied genus.

\section{Hemithyris angustifrons $\left(M^{\circ}\right.$ Coy). Pl. 1. H. fig. 6 to 8.}

Ref.-Id. Quart. Geol. Journ. v. 7. t. 9. f. 10; McCoy, Annals Nat. Hist. 2nd Series, Vol. VIII. p. 391.

$s p . C h$. - Elongate ovate; both valves very gibbous in the middle, gradually sloping to the margins, which are nearly level, or with a very slight elevation of the front torards the entering valve; greatest width in most specimens rather behind the middle, from whence the width diminishes to the narrow, obtuselyrounded front; beak of the receiving valve large, pointed, with a long triangular opening beneath it; substance of the shell coarsely fibrous; surface nearly smooth, or with irregular transverse squamæ of growth: casts shew in the entering valve two sub-parallel, approximate, longitudinal sulci, marking the inner edges of the muscular impressions, and with a fainter suleus between them, left by the slight mesial septum; two pits near the beak left by the apophyses strong; receiving valve with two strong dental lamella, one each side of the beak, and a slight indication of a mesial septum; few straight, once- or twice-branched impressions of the pallial vessels on each side. Length nine lines, proportional length of entering valve ${ }_{\text {ivo }}^{85}$, width $\frac{75}{100}$, depth of both valves $\frac{50}{100}$; shell fibrous.

The general ovate form of this species with its narrow front, without mesial ridge or sinus, and its pointed beak with large foramen, easily distinguish it from any of the other Lower Palicozoic forms. It 
varies considerably in depth, being sometimes rather less than the above dimensions, and having in one specimen the proportion of $\frac{\text { in }}{1 w i}$ : compared with the length, the width is sometimes a little more, and sometimes a little less than the measurement given above. Some specimens seem to shew projecting irregular transverse squamæ of growth.

Position and Locality.-Occurs in great numbers in the greenish sandstone of Mulock quarry, Dalquorhan, near Girvan, Ayrshire; Craig Head, near Girvan, Ayrshire.

Explanation of Figures.-Pl. 1. H. fig. 6. Natural size, from the sandstone of Dalquorhan, shewing the entering valve and the foramen beneath the beak; $6 a$, Ditto, profile; 7 , internal cast of receiving valve; 8 , internal cast of entering valve.

Hemitiyris crispata (Som. Sp.)

Ref. and $S y n .=$ Terebratula id. Sil. Syst. t. 12. f. 11 .

$S p . C h$-Longitudinally ovate, or subtrigonal, depressed; apical angle $100^{\circ}$; beals of receiving valve moderate, without distinct concavities at the sides; entering valve slightly convex, with an obscurely defined, rounded elevation, in the marginal third of the length; receiving valve very slightly convex near beals, and on the sides, with wide, shallow, rounded mesial concavity, extending from the margin to within one-third of the beak; lateral margins with a broad, slightly-curved wave towards the entering valve; middle of front margin elevated into a rounded sinus, twice as wide as high; six mesial, and six lateral plates on each side, all nearly equal, obtusely angular, and continued separately to the beak; a considerable space at the sides smooth; shell fibrous; a moderate foramen beneath the beak. Length eleven lines, width the same, proportional length of entering valve $\frac{95}{100}$, greatest depth of both valves $\frac{53}{100}$.

This species seems to me constantly distinguished from the $H$. lacunosa, with which several writers unite it, by the greater length and depression of the valves, small rounded front sinus, and larger smooth space on each side, as well as continuity of the lateral mesial ribs to the beak.

Position and Locality.-Aymestry limestone, Leintwardine, Shropshire. Apparently a wide variety of this species, (width one inch,) and proportionate length only $\frac{85}{100}$, but agreeing in number and character of ribs, general depression, \&c. with the above, occurs in the limestone, Old Radnor to Presteign, Radnorshire.

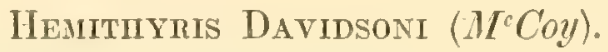

Ref. and Syn.-id. McCoy, Annals Nat. Hist. 2nd Series, Vol. VIII. p. 392."= Terebratula sphcerica Sow. Davidson, Bull, de la Soc. Géol. de France, 2nd Series, Vol. V. t. 3. f. 36. (not of Sow. Sil. Syst. nor Sow. Geol. Trans.)

Sp. Ch.-Globose, or subcuboidal; entering valve deeper than the receiving one, moderately convex on the rostral half, abruptly and obtusely bent over towards the margin, nearly at right angles; beak of the receiving valve small, with a minute triangular opening beneath the apex, moderately convex, depressed towards the margin, to form a broad, slightly-defined sinus, the corresponding ridge to which in the entering valve is scarcely elevated; lateral margins nearly straight, front margin elevated into a quadrate sinus twice as wide as high; valves radiated with from eighteen to twenty very obtusely angular, simple ridges, reaching distinctly to the beak, and deeply notching the margin, the four middle ones perceptibly larger than the rest. Length and width equal, and about five lines; proportional depth of deflected front $\frac{55}{100}$, depth of both valves $\frac{88}{100}$.

This species differs from the Terebratula spharica (Sow.) Sil. Syst., by having the elevation of the front towards the entering valve, as in ordinary cases, instead of towards the receiving one as in that species, which, in consequence of this, Mr Davidson suggests to be a variety of $H$. deflexa. The Devonian Atrypa spherica (Sow.), to which the present fossil is referred by Mr Davidson, differs completely by having all the rostral portion smooth, while the ridges extend clearly to the beak in this 
Silurian type. The general form slightly recalls that of the II. Wilsoni, but there are much fewer ribs, and they are not divided by a medial sulcus on the deflected front.

Position and Locality.-Very rare in the Upper Ludlow rock of Burton and Brockton, near WVenlock.

\title{
HeMithyris depressa (Sow. Sp.)
}

\author{
Ref. and Syn.=Atrypa depressa Sow. Sil. Syst, t. 13. f. 6.
}

$S p . C h$.-Transversely broad-oval; receiving valve with a small, pruminent, pointed beak, beneath which is a distinet, narrow, triangular, opening; rostral portion gently convex, sides flattened, middle deeply depressed towards the margin by a wide triangular sinus, disappearing considerably in front of the beak; entering valve deeper than the receiving one, profile strongly arched, greatest depth at rather more than one-third from the beak, obtusely subearinate along the middle, rising to a wide, low, convex mesial ridge towards the front margin, sides sloping rapidly to the margin, with a slight convexity; lateral margins sharp, slightly sigmoid, front margin raised into a deep, wide, rotundato-quadrate sinus; surface smooth, with regular, obtuse,

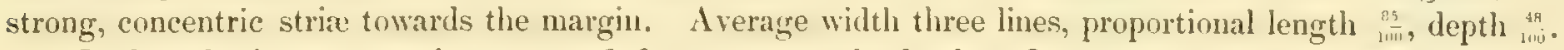

It is only in one specimen out of fourteen examined, that I see the slightest trace of the three obscure furrows along the middle mentioned by Mr Sowerby. The depth varies considerably, being commonly greater than represented by Sowerby's figure.

Position and Locality.-Abundant in the Bala limestone of Brynbedwog Quarry, near Bala, Merionethshire.

\section{Hemitiyis Didyma (Dal. Sp.)}

\section{Ref. and $S_{y n}=$ Terebratula didyma Dal. Vet. Acad. Handl. t. 6. f. 7 .}

$S p . C h$.-Pentagonal; apical angle $87^{\circ}$; valves very gibbous, smooth, each with a narrow mesial sulcus, reaching two-thirds to the beak, and notching the front margin, which is slightly cornute from the concavity of the antero-lateral margins; length six lines, proportional width $\frac{\varepsilon_{7}}{1 v 0}$, depth of receiving valve alone $\frac{50}{110}$, length of entering valve ${ }_{i 00}^{85}$; shell fibrous.

This species is distinguished by its much greater gibbosity from the $H$. Upsiton of the lower strata, and by its width from the $H$. canalis.

Position and Locality.-Wenlock limestone, Ledbury, Herefordshire.

\section{Hemithyris diodonta (Dal. Sp.)}

Ref. and Syn. $=$ Terebratula $i d+T$. bidentato. Dal. t. 6. f. $4 .=$ Ter. bidentata Sow. Sil. Syst. t. 12. f. $13 \alpha$. $=$ Ter. decemplicata Sow. Sil. Syst. t. 21. f. 17 .

Sp. Ch. - Subrhomboidal, apical angle $115^{0}$; sides of both valves slightly convex, moderately deep; mesial ridge and hollow very large, and sharply defined, forming an abruptly defined angular sinus in the front margin, nearly as high as wide, bidentate by two strong angular ridges on the entering valve, and one in the middle of the sinus of the receiving valve; lateral ribs rather smaller than the mesial ones, five or six in number, all continued simply to the beak; surface crossed by fine transverse lines of growth. Average width (of small specimen) five and half lines, proportional length

Position and Locality.-Not common in the sandstone of Pwllheli, Caernarvonshire, and sandy schists of Yspatty Evan, N. Wales; limestone of Balmae Shore, Kirkcudbright.

\section{HeMithYRIS HEMISPHerica (Sov. Sp.)}

Ref. and Syn. = Atrypa hemispharica Sow. Sil. Syst. t. 20. f. 7.

Sp. Ch.-Suborbicular, small valve flat, with a slightly deflected margin and inconspicuous beak: large valve evenly gibbous, subhemisphrrical, with minute prominent beak; apical angle about $140^{\circ}$; hinge-line nearly as long as the shell is wide, cardinal angles obtuse; both valves radiated with about seventeen subequal, rounded, or obtusely angular ridges, separated by concave spaces resembling them in size and

[FASC, II.] $\mathrm{D}$ D 
curvature, crossed at nearly regular intervals by sharp scaly lines of growth. Custs shew, in the flattened entering valve, a small pit each side of the beak for the cardinal teeth, and a shallow mesial sulcus extending half way to the margin, produced by a mesial septum; in the large receiving valve, two short, oblique, diverging slits of the dental lamellae bordering the beak. Width four lines, proportional length of receiving valve $\frac{90}{104}$, length of entering valve slightly less, depth $\frac{32}{100}$; tissue of shell fibrous.

As some modem writers have referred this shell to the genus Ortlis, I have taken great pains to ascertain the characters of the hinge, as the obvious absence of the puncturing in the tissue of the shell rendered the reference to Orthis very doubtful in my mind; and I have convinced myself that there is no cardinal area whatever, but that the beak of the entering valve is simply pointed, scarcely incurved, while that of the receiving valve is pointed, hollow, and so much incurved only as to leave a wide triangular foramen beneath it; the hinge-characters therefore warrant the placing this singular shell in Hemithyris, with which also its tissue is identical.

Position and Lacality.-Abundant in the fine Bala sandstone of Pwllheli, Caernarvonshire; abundant in the coarse sandstone and conglomorate near Presteign, Radnorshire; common in the fine sandstone of the Braes, one and half miles E. of Girvan, Ayrshire (common southern variety).

$$
\text { Var. Scotica (Mc Coy). PI. 1. H. fig. } 10 .
$$

Ref.-Quart. Geol. Journ. August, 1851, t. 9. f. 12.

This may ultimately prove a distinct species, in which case the varietal name may become specific. It is distinguished from the type species by the ribs being more numerous (usually about twenty to twentyfour), considerably narrower, less prominent, and less regular in size and directness, and often imomlurly forked-a character seldom or never seen except at the inner edge of the flat valve in the typical specimens. The receiving valve is also slightly more carinate, and the entering valve not so perfectly flattened, and with a faint trace of a wide, undefined, mesial hollow.

This Scotch variety closely approaches MI. de Verneuil's figure of the Pruductu eminens of Pander, which he considers a variety of $P$. obtusa, Pand, and places in the genus Orthis. This Orthis obtusa has been shewn by de Verneuil to want the cardinal area of Orthis, and is clearly congeneric with our present species, which seems to differ from the var. eminens by having ferver ribs, being less tumid, particularly in the entering valve, having no distinct muscular internal impressions; and from all the varieties, by having the front narrower or more convex, and the hinge-line shorter. A comparison with abundance of Russian specimens might obliterate some of these differences.

Position and Locality.-This variety is extremely common in the greenish sandstone of Mullock, Dalquorhan, near Girvan, Aryshire.

Explanation of Figures.-Pl. 1. H. fig. 10. Natural size, entering valve; $10 a$, Ditto, receiving valve; $10 \mathrm{~b}$, Ditto, view of front margin.

\section{Hemithyris lacunosa (Limn. Sp.)}

Ref. and $S y n_{0}=$ Terebratula lacunosa Schlot. Nachträge, t. 10. f. 6. $=$ T. borealis id. Kat. 65; Sil. Syst.

$$
\text { t. 12. f. } 10 \text {. }
$$

$S_{p}$. Ch.-Transversely oval, or subtrigonal, very gibbous, entering valve most so; sinus in front margin quadrate, very deep, aloruptly defined, but the mesial ridge scarcely elevated, except at the margin, and the corresponding wide, flat, mesial hollow extending two-thirds to the beak; six or seven strong, angular, simple ridges on each side, those nearest the angle short, leaving an obscurely defined smooth space on each side of the beak; mesial ridge with four angular ridges, equal to the lateral ones in size for about five lines from the beak, where the outer pair dichotomise, forming six large equal ridges at the margin of large spceimens, and five ribs in the mesial hollow; surface nearly smooth, or crossed by minute, regular, transverse stria. Width of large specimen one inch one line, proportional length $\frac{R 5}{1.10}$, length of entering valve $\frac{\frac{76}{100}}{100}$, depth of both valves $\frac{57}{i m .}$; tissue of shell fibrous. 
This shell by its greater width in proportion to the length, greater gibbosity, and depth of front-sinus, distinct branching of outer pair of mesial ridges, Sce. seems to be constantly distinguished from the $I I$. crispata of Sowerby. As this is the only one of the several supposed varieties from different formations figured by Schlotheim, it is, I think, most correct to retain for it the present name, particularly when, as Mr Sowerby suggests, the supposed oolite examp'es may be the T. intermedia Sow of the Min. Conchology, and this Silurian species may be the Anomia lacunosa of Linné.

Position and Locality.-Not uncommon in the Wenlock limestone of Wenlock, Shropshire.

\section{Hemithyris Lewisi (Daridson Sp.)}

Ref. and Syn。= Terelratula Lewisi David. Bull. de la Soc. Géol. de France, 2nd Series, Vol. V. t. 3. f. 30 .

$S p . C h$.-Subrhomboidal or transversely oval; entering valve most gibbous, evenly tumid nenr the beaks, sides gradually curving towards the margin; mesial ridge prominent, oltusely rounded in the anterior half of the length, forming a very deep oblong sinus in the front margin; receiving valve convex near the beak, flattened at the sides, and with a deep wide depression in the anterior two-thirds of the middle; about nine strong angular ridges on each side, and two or four on the mesial ridge, and one or three in the corresponding ridges in the mesial sinus; ridges crossed by sharp, scale-like transverse strie, most strongly narked near the margin; beak of entering valve small, much curved with a perforation beneath it; width of rather small specimen six and half lines, proportional length of receiving valve ${ }_{i i,}$, length of entering valve $i$, depth of both valves $\frac{5 s}{100}$; substance of shell fibrous.

The greater width and more numerous lateral plaits separate it from the depressed varieties of the A. increbescens (Hall). Casts shew in the receiving valve two short, slightly diverging slits of dental lamellie, between which are three or four short diverging ridges, in the rostral portion; the entering valve shews a wide mesial slit of the thick septa, and impressions of two short cardinal teeth, just within the ends of the dental lamella of the opposite valve.

Position and Locality.-Not uncommon in the Wenlock limestone of Dudley, Staffordshire; in the black calcareous flags of Matliyrafal, S. of Meifod, Montgomeryshire.

\section{Hemithyis nasuta $\left(\mathrm{M}^{\mathrm{C}} \mathrm{Coy}\right)$. Pl. 1. L. fig. 5.}

Ref.-id. $\mathbf{I I}^{\mathrm{C}} \mathrm{Coy}, \mathrm{Ann}$. Nat. Hist. 2d Series, Tol. VIII. p. 393.

$S p . C h$.-Longitudinally ovate, longer than wide, gibbous, entering valve much deeper than the receiving one; receiving valve with a small obtuse beak, incurved nearly to touch the beak of the entering valve, with a small triangular perforation beneath; rostral portion tumid for about five lines from the beak, beyond which a wide, Hattened, mesial depression is developed, gradually deepening towards the front, which in old specimens is rery much produced into a flat tongue-shaped lobe, nearly as long as wide, gently sloping to the level of the most convex part of the entering valve; sides obtusely defined from the mesial furrow, gently convex; lateral margins slightly sigmoid, and bent upwards at the front at a rounded angle of about $100^{\prime \prime}$; cntering valve with a slightly prominent beak: rostral portion and sides gently convex; after about five lines from the leak, the middle is prolonged nearly in a straight line to the produced front margin, forming a large obtusely rounder mesial ridge; surface radiated with simple, close, obtusely rounded ribs, ahout four of which, rather larger than the rest, are raised with the mesial furrow, the broad sides of which are smooth, each side with about twelve, slightly smaller ribs (seven in two lines at six lines from the beak near the side of the mesial furrow), leaving a rather broad smooth space at the rostral lateral margin on each side; (a fine longitudinal striation is seen in some parts). Length one inch two lines, proportional length of entering valve s..., greatest width about the middle of the length $\frac{88}{10}$, greatest depth of both valves (one-third from the beak) $\frac{57}{100}$.

In form this species much resembles the Tertibatula promontorium of Kutorga from the lower Silurian limestones of Pulkowa, (see Verhandlungen der Russ. Kais. Min. Gesellschaft zu St. Petersburg, for 1815. t. 6. f. 3), but is distinguished by its ribbed surface. 
Position and Locality. - Not uncommon in the schistose limestone of Craig Head, near Girvan, Ayrshire.

E.cplanation of Figures.-Pl. 1. L. fig. 5. Profile, natural size, from the limestone of Craig Head; $5 \alpha$, Ditto, receiving valve.

\section{Hemithyris navicula (Sow. Sp.)}

$$
\text { Ref. and Syn. }=\text { Terebratula navicula Sow. Sil. Syst. t. 5. f. } 17 \text {. }
$$

S.p. Ch.-Ovate, widest at one-third from the beak, front gradually narrowing, obtuse; receiving valve with a semicircular profile, middle obtusely subcarinate, sides steeply inclined to the margin ; front margin forming a flattened arch towards the large valve; lateral margins broadly arched towards the small valve; beak small, incurved; apical angle $85^{\circ}$; entering valve slightly convex at the sides about the middle of its length, with a medial depression widening from the beak to the front; surface smooth, or with traces of faint radiating stria. Cast shewing a very deep $\mathrm{V}$-shaped depression on the most convex part of the receiving valve below the beak towards which it points, and defining the muscular impressions; nearer the beak are the usual pair of diverging dental lamelli; a thick mesial septum extends from the beak nearly half the length of the entering valve. Length five lines, proportional width $\frac{86}{1.1+1}$, length of entering valve $\frac{90}{104}$, depth of both valves $\frac{68}{100}$.

The peculiar chevron mark on the cast of the great valve is very remarkable, and makes the cast very easily recognisable; it forms the anterior boundary apparently of two great, prominent, muscular impressions, which are marked by radiating sulci from the beak.

Position and Locality.-This well-marked fossil, so abundant at the base of the Upper Ludlow rock, abounds in the strata following; sandstone of May Hill, Gloucestershire; Welchpool, Montgomeryshire; grey micaceuns grits at Dinas Bran, Llangollen; schists of Mynydd y Gaer near Ruthin, (S. side); schists of Crwm (raig Ddu, Builth, Radnorshire; olive schists of Erew Gill Fach, Builth; Cowan Head, Kendal, Westmoreland; Potter's Fell, Kendal, Westmoreland.

\section{HeMithYris nucula (Som. Sp.)}

Ref. and Syn. = Terebratula nucula Sow. Sil. Syst.t. 5. f. $20=$ Terebratula pulchra Sow. Sil. Syst. t. 5. f. 21. = Atrypa semisulcata (Dal.) Salt. Quart. Geol. Journ. Vol. I. and Geol. Surv. Vol. II.

Sp. Ch.-Broad-ovate, subpentagonal; beak moderate, pointed, apical angle $105^{\circ}$; receiving valve less tumid than the opposite one, gently convex at the sides and near the beak; becoming depressed from half its length into a gradually widening mesial hollow towards the margin, which is raised thereby into a deep rotundato-quadrate sinus, a third wider than high : entering valve evenly tumid, with a shallow medial depression near the beak, margin deflected, mesial ridge only marked near the margin; surface radiated with about sixteen to twenty strong, smooth, angular, simple ridges, all continuing to the beak, about four (three in the sinus) in the midule somewhat larger than the rest towards the front, and forming strong prominent teeth to the sinus; the six to eight lateral ridges abruptly curved with the margin in front (most usually seven). Width six and half lines, proportional length $\frac{87}{i n 0}$, length of entering valve $\frac{m 7}{10,}$, depth of both valves $\frac{7 z}{i v u}$. Casts shew two very short subparallel dental lamellæe, one each side of the beak in the receiving valve: the opposite valve las a strong medial septum, extending nearly half way from the beak to the margin, and a small ovate impression close to the beak on each side for the origin of the apophyses; tissue fibrous; foramen moderate; surface smooth, with a few longitudinal lines at the edge.

Varies slightly in depth, and in the prominence of the mesial ridges at the margin. The limestone specimens are larger than those in the grits, and more ohtuse. As there seems to be no such species as semisulcata described by Dalman, I have used Sowerby's old name.

Having carefully examined a large number of specimens, I think with Professor Bronn, that the T. pulchra and $T$. mucula of Sowerby should be united, the very trifling difference in form, and number of lateral plaits 
not co-existing, sometimes the one, and sometimes both being observable in the contiguous specimens, which are clustered in great numbers in the Upper Ludlow rock; and the obtuse looking examples (nucula) often prove, on counting, to have the same number of ridges, and to have the same proportions as the sharplymarked ones (pulchra).

Position and Locality.-Very abundant in the Upper Ludlow rock of Burton and Brockton, near Wenlock; abundant in the green quartzose Upper Ludlow rock of Collinfield, and Benson Knot, Kendal, Westmoreland; in the fine Ludlow rock alone Parklane, Llandeilo, (above the white grits); Upper Ludlow of Downton Castle, Aymestry, Herefordshire; Lower Ludlow of Leintwardine, Shropshire; Upper Ludlow of Dinas Bran, Llangollen, Denbighshire; in ditto, Lambrigg Fell, Kendal, Westmoreland; in laard gritty ditto, near Llan. gollen, Denbighshire; in the olive schists of Mynydd y Gaer, Llanefydd near Ruthin, Denbighshire; schists of Cwm Craig Ddu, Builth, Radnorshire; Aymestry limestone of Mortimer's Cross, Aymestry, Herefordshire; Wenlock limestone of Sedgley, near Dudley, Staffordshire; limestone of Balnae Shore, Kirkcudbright; Braes, one and half mile E. of Girvan, Ayrshire; abundant in Upper Ludlow rock of Woolhope.

\section{Hemithyris pentagona (Som. Sp.)}

\section{Ref. and Syn. = Terebratula pentagona Sow. Sil. Syst. t. 5. f. 22.}

$S p$. Ch. - Obscurely pentagonal, very much depressed, margins sharp; apical angle $115^{\circ}$; beak of entering valve pointed, slightly curved; lateral margins nearly level, anterior margin slightly raised into a very wide and shallow sinus, from which the mesial ridge and hollow are very slightly indicated for a short distance from the margin; surface radiated with about thirty obtuse, narrow, unequal, occasionally branched ridges, about eight of which correspond with the mesial sinus in a specimen four and half lines long, and all of which become indistinct at two or three lines from the beak. Width of rather small specimen five lines, proportional length of receiving valve $\frac{9.1}{1+1}$, of entering valve $\frac{25}{1100}$, depth of both valves $\frac{45}{100}$; substance fibrous.

Pusition and Locality.-Rare in the limestone of the Hollies, Church Stretton, Shropshire. Rare in the limestone of Clungunford, Shropshire.

\section{? Hemithy Ris pisum (Sow. $S p$. ) \\ Ref. and Syn. = Spirifer ? pisum Sow. Sil. Syst. t. 13. f. 9.}

Sp.Ch.-Suborbicular, beaks very small, searcely projecting; front slightly narrowed, and with a minute obsolete sinus, not raising the edge; valves nearly equal, both gibbous a little behind the middle, gradually becoming depressed towards the sharp edge; a faint linear mesial sulcus extends from the beak of each valve to the sinus in the middle, coinciding posteriorly with a Iong internal mesial septum in each valve; beak of the receiving valve very slightly prominent, with a wide triangular opening beneath the apex. Width three lines, proportional length about $\frac{25}{100}$, depth of both valves about $\frac{63}{100}$.

I have ascertained by carefully breaking a specimen, that there are no internal spiral appendages, and therefore the species does not belong to Spirifer, and I have olsserved a large triangular opening beneath the beak, so that it does not belong to Atrypa, where M. d'Orbigny has placed it.

Position and Locality.-Not uncommon in the Wenlock limestone of Wenlock, Shropshire.

\section{Hemithyris Rotunda (Sow. Sp.)}

$$
\text { Ref. and Syn.=Atrypa rotunda Sow. Sil. Syst. t.13. f. } 7 .
$$

$S_{p}$. Ch._Ovate, very gibbous, valves nearly equally convex, beak moderate, apical angle $115^{\circ}$, lateral margins nearly straight, front margin raised into a wide trilobed wave, from which three short, broad, obscure ridges extend half way towards the beak. Width about five lines, proportional length $\frac{95}{10}$, deptli of both valves $\frac{70}{100}$. 
Differs from the Permian Terebratula superstes (Vern.) in the greater width of the shell and wider and shallower wave in the front margin.

I have not ever seen a moderately good specimen of this species, and am consequently uncertain of the genus.

Position and Locality.-Sandstone of Alt Goch, Llanfyllin, Montgomeryshire, (one very imperfect cast).

Hemituris spheroidalis $(M C$ Coy). Pl. 1. L. fig. 4.

Ref.-id. MCoy, Ann. Nat. Hist. 2nd Series, Vol. VIII. p. 393.

$S p . C h$. - Suborbicular, gibbous, nearly equivalve, margins very obtuse from the inflection of the edges; lateral margins nearly level, front margin abruptly raised into a quadrate sinus, alont twice as wide as long; receiving valve with a very small, pointed, slightly incurved beak, with a minute triangular perforation beneath it, evenly gilbous, except close to the sinus in the front margin, where there is a very slightly-marked depression; entering valve evenly gibbous, with a very slightly-marked broad square ridge, extending a short way from the margin of the sinus; both valves radiated with from twenty to twenty-four very obtuse, rounded ribs, becoming gradually obsolete near the beaks, leaving the rostral portion nearly smooth; four of the ribs rather larger than the rest, slightly elevated with the mesial sinus; a short mesial septum in the entering valve; sulstance of the shell densely fibrous. Length five lines, proportional width $1 . .$, , pronortional depth of both valves $\frac{70}{100}$.

The depressed spharoidal form, and very obtusely rounded ribs becoming obsolete towards the beak, distinguish this species from the $H$. mucule; and the elevation of the mesial sinus being towards the entering instead of the receiving valve, as well as more depressed form, distinguish it from the Terebratula splucrica, and Terebratus deflexa of the Wenlock rocks, to which it is otherwise very similar. 'This seems to be the upper Silurian species referred to by Mr. Davidson as identical with the Devonian Atrypa spluericu of Sowerby, to which it is very strongly allied, but is more depressed, has only four mesial ribs, and the beak is not adpressed. The obtuseness of the plaits and smooth rostral portion separate it from the Terebratula pusilla (Sow.) of the Lower Silurian rocks. The very obtuse margin and smaller number of mesial plaits, and obtuse inflated form, separate it from the Terebratule famula of Barrande (sce Haidinger Naturwissensehaftliche Abhandlungen, Band 1.t. 17. f. 6.)

Position and Locality.-Not uncommon in the Wenlock limestone of Dudley, Staffordshire; Wenlock limestone of Ledbury, Herefordshire; and the limestone of the Hollies, Church Stretton, Shropshire.

Explanation of Figures.-Pl 1. L. fig. 4. Profile, natural size, from the limestone of the Hollies; $4 a$, front view; $4 b$, entering valve.

\section{Hemitimyris Strtcklandi (Son. Sp.)}

\section{Ref. and Syn. = Terebratula Stricklandi Sow. Sil. Syst. t. 13. f. 19.}

$S p . C h$. - Ovato-subtrigonal, beak of the receiving valve very small, flattened, and closely pressed over the beak of the opposite one, which is obscurely bilobed by a longitudinal mesial depression; apical angle $130^{\circ}$; receiving valve much smaller than the other, flattened or gently convex at the sides, and in the third of the length near the beak, sinking abruptly into a deep, wide, mesial hollow towards the margin, which is lifted therely into a deep, oblong, slightly rounded sinus, the corresponding flattened ridge to which in the opposite valve extends only half-way to the beak; ridges close, narrow, angular, simple, all extending nearly to the beak, but leaving a narrow, elliptical, smooth space at each side, usually eight raised with the sinus, the outer pair often becoming obsolete at the margin, eight or ten similar ridges on each side; plicated part of the lateral margin nearly straight; the sides of some specimens shew a few coarse longitudinal stria towards the margin.

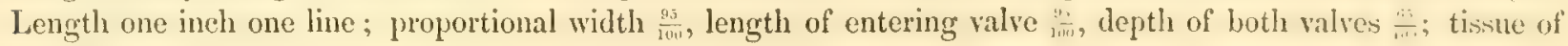
shell fibrous.

It is very seldom that any perforation can be seen under the singularly small, depressed, beak of the receiving valve.

Position and Locality.-Not uncommon in the Wenlock limestone of Scdgley, near Dulley, Staffordshire. 


\title{
Hemtimris subundata $\left(M^{c} C o y\right)$. Pl. 1. H. fig. 9.
}

\author{
Ref.-id. II Coy, Ann. Nat. Hist. 2nd Series, Vol. VIII. p. 394.
}

Sp. Ch.-Transversely broad-oval; valves gently and almost equally convex; beaks very smail, apical angle $140^{\circ}$ near the apex, lateral margins straight, front raised into a rounded wave, from which in the large valve a wide shallow mesial depression extends half way to the beak, with a corresponding elevation in the small ralve, in some specimens faintly extended to the beak; surface smooth. Arerage width one inch, proportional length $\frac{86}{500}$, length of entering valve $\frac{85}{1100}$, depth of both valves $\frac{43}{100}$ to $\frac{50}{100}$.

This species is flatter and less wide than the Atrypa (Pentanems) undatu (Sow.), but less long than the Atrypa (Pentemerus) lems, being internediate in form between the two; the casts shew however in the small valve a rather strong slit in the beak for the short medial septum, and a transverse pit on each side for the origin of the apophyses or hinge-teeth. The receiving valve has two short diverging dental lamella bordering its beak, as in Hemithyris, with one or two small ridges between them; the sides of both ralves shew about three straight once or twice-branched ridges of the pallial and ovarian vessels. The very small beak separates it from the Terebratula Herculea (Bar.)

Position and Locality.-Very common in the schists and limestone of Mathyrafal, S. of Meifod, Montgomeryshire, and in the schists of Pen y Craig, Llangynyw, Montgomeryshire; slate of Alt fair ffynnon, Llanfyllin, N. Wales.

Explanation of Figures.-Pl. 1. H. fig. 9. Natural size from the limestone of Mathyrafal, shewing the smooth shell partially removed, exposing the dichotomous impressions of the pallial vessels; 9 a, profile of rostral portion; $9 b$, end view of internal cast; $9 c$, front view, shewing the elevation of the margin.

\section{Hemitiyris Uisilon (Bar. Sp.)}

\section{Ref. and Syn.=Terebratula id. (Barrande, Naturwissenschaft Abhaudl. Vol. I. t. 15. f. 9).}

Sp. Ch. - Subpentagonal, depressed; apical angle $90^{\circ}$; valves almost equally convex, greatest width about the middle of the length, front narrow, with a rounded notch in the middle, from whence a deep narrow depression extends two-thirds to the beak in the receiving valve; entering valve evenly convex, or slightly depressed in the middle of the front margin; surface smooth. Length seven lines, proportional width $\frac{89}{100}$, length of receiving valve $\frac{88}{100}$, depth of receiving valve alone $\frac{30}{100}$.

I have only seen the large valve of the British specimen, but in the Bohemian the small valve has only a marginal depression instead of the long sulcus of the opposite one. It is considerably mider than the $T$. canalis (Sow.), and longer and more depressed than the T. didyma (Dal.)

Position and Locality.-In the sandy schists of Pwllheli, Caernarronshire.

\section{Hemithyris Witsoni (Son. Sp.)}

\section{Ref. and Syn.=Terebratula id. Min. Con. t. 118. f. 3; Sil. Syst. t. 6. f. 7.}

$S p$. Ch.-Subpentagonal when young, apical angle $110^{\circ}$; with valves evenly tumid, becoming semicylindrical with age, by the abruptly deflected vertical extension of the front, with nearly parallel sides; a space about three to four lines long round the beak nearly smooth in both valves, but after this length (when the abrupt deflexion of the margin commences) about forty-eight equal, obtuse, longitudinal ridges, suddenly appear (about six in two lines) in middle of front, each of which becomes flattened, and divided by a fine mesial sulcus; commissure of the ralves nearly straight at the sides, abruptly raised into a very deep oblong sinus in front, which gives rery slight or no trace of mesial ridge or hollow in most specimens. Length of small specimen five lines, width the same, depth of both valves $\frac{95}{100}$. In older specimens the depth of both valves exceeds the length by one-third. The muscular impressions in the casts of receiving valve forming a very prominent subpentagonal boss.

Position and Locality.- Tery common in the Aymestry limestone of Sedgley, Dudley, Staffordshire; in Upper Ludlow rock, right bank of Dee, near Llangollen; Aymestry limestone of Leintwardine, Shrop- 
shire; Lower Ludlow mudstone of Green Quarry, Leintwardine, Shropshire; Wenlock limestone of Wenlock; in the Upper Ludlow rock of Presteign, Radnorshire; Upper Ludlow limestone of Burton and Brockton, Wenlock.

\title{
Genus. PENTAMERUS (Som.)
}

Gen. Char.-Shell globose, ovate, receiving valve largest; generally destitute of mesial fold, but the sinus when it exists is usually in the entering valve, and the ridge in the receiving; no hinge-line, area large, undefined, and having a deep triangular pit in the centre, under the beak of the dorsal valve, and into which the beak of the entering valve is strongly incurved; internally the receiving valve has one large bipartite central septum, the walls of which suddenly divaricate as they approach the entering valve, forming the walls of the external triangular opening, and enclosing between them a triangular chamber much smaller than the two lateral ones; in the entering valve the two corresponding plates are subparallel, and separate from their origin, being so curved that internal casts shew one of their edges, like the diverging cardinal teeth of Orthis, and the inner edges form the long subparallel slits (casts shew a narrow cardinal area in this valve), the middle one of the three resulting chambers being much the narrowest.

The forms of the lines of growth on the internal plates, their relative distance, and the proportion of the central to the lateral chambers in depth of the receiving valve, afford specific characters of great value.

\section{Pentamerus galeatus (Dal. Sp.)}

\author{
Ref. and Syn $=$ Atrypa galeata (Dal.) Vet. Acad. Handl. t. 5. f. 4. Sil. Syst. t. 12. f. 4.
}

$S p . C h$-Longitudinally ovate, very gibbous, receiving valve much arched, beak blunt, incurved, nearly in contact with that of the opposite valve, apical angle about $75^{\circ}$; in old specimens the margin is raised into a wide square ridge, reaching only a short way from the margin; lateral margin nearly level, except a small rounded wave toward the receiving valves at the cardinal angles; entering valve depressed, convex near the beaks, sides flattened, anterior half depressed at the margin into a sinus; surface with minute close concentric undulations, and very variable longitudinal ridges, seldom reaching the beak. Length one inch, width the same, proportional length of entering valve $\frac{82}{100}$, proportional depth of both valves $\frac{75}{100}$; the mesial line of the septa in the receiving valve scarcely one-third the length of the valve, diverging parts very small scarcely one-third the depth of the septum; two septa in the entering valve not half its length, thin, diverging at an angle of about $7^{\circ}$.

There are sometimes two or four subequal obtuse plaits in the sinus, extending half way to the beak, three or four undulations of each lateral margin, and the rest of the shell free of them, or, in other cases, they amount to twelve or fifteen distinct lateral and medial ridges reaching more than half way to the beak, and either subequal and simple, or very unequal and branched, in all cases being however most distinct on the middle of the shell.

Position and Locality.-Common in the Wenlock limestone and shale of Dudley, Staffordshire, and in the Lower Ludlow rock of Garden Quarry, Aymestry, Herefordshire. A-smaller variety, about oneseventh wider than long (var. globosus), more rounded, and with very unequal plaits, occurs in the Aymestry limestone of Leintwardine, Shropshire; Ludlow rock above Parklane, Llandeilo; in greenish mudstone, and in Wenlock limestone of Wenlock, Shropshire; not uncommon in the Wenlock limestone of Woolhope.

\section{Pentamerus ? globosus (Som. Sp.)}

\section{Ref. and Syn.=Atrypa id. Sow. Sil. Syst. t. 22. f. $2 b$.}

Sp. Ch.-Rounded, subrhomboidal, globose, or when old subcuboid from the deflexion of the front; a very shallow undefined mesial depression in the large valve, forming a shallow wave in the margin towards the opposite valve, which is evenly convex without a corresponding mesial ridge; lateral margins nearly even; apical angle $115^{\circ}$ : casts of the receiving valve coarsely punctured about the rostral portion; beak 
with a short strong slit (of the medial plate), rapidly divaricating inwards to enclose the beak of the entering valve; sides marked with four or five obscure longitudinal ridges (probably of the ovaries). Average width of small specimen seven lines, proportional length of receiving valve $\frac{86}{1 \cdots+1}$; depth of receiving valve $\frac{45}{100}$, increasing greatly with age.

Position and Locality.- In the schists above the second grits, Keeper's Lodge, Goldengrove, Llandeilo; fine Bala sandstone of Beaver's Grove, Bettws-y-coed, N. Wales.

\section{Pentanerus Knighti (Som.)}

\section{Ref. and Syn. =P. Knighti + P. Aylesfordi Sow. Min. Con. t. 28, and Sil. Syst. t. 6. f. 8.}

Sp. Ch. - Small valve rotundato-trigonal, evenly and moderately convex; large valve only little more convex than the opposite one when one inch long, but with age becoming rapidly more prominent, into a large conical incurved beak; average apical angle about $85^{\circ}$; cardinal area smooth, very variable in size, with an obtuse edge; septa of the small valve diverging at an angle of $12^{\circ}$, about half the length of the mesial septum in the receiving valve; septum of the large valve extending from the beak nearly to the margin, medial flat portion with a coneave terminal edge (and having concave lines of growth), about a fifth wider than the divaricating portions which form the hood-shaped chamber connected with the triangular opening under the beak; front and lateral margins level; surface radiated with about forty subequal, obtusely angular ridges in a specimen two inches long (increasing to about sixty, and becoming irregularly alternate in size at the margin of a specimen fuur inches long). Length of rather small specimen two inches four lines, proportional length of entering valve $\frac{82}{100}$, width $\frac{92}{100}$.

The beak of the large valve is often slightly oblique, and five or six of the ridges in the middle of the valves are often less than the others.

Position and Locality.- Very abundant in the Aymestry limestone near Aymestry, Herefordshire, and in same rock at Leintwardine, Shropshire; ditto, Sedgley; in the green mudstone (Lower Ludlow rock) of Garden Quarry, Aymestry, Herefordshire; very common in the Aymestry limestone near Woolhope, with an extremely elongate, narrow variety, with slightly thicker and fewer ribs (var. elongatus,) length three and half inches, proportional width $\frac{60}{100}$.

\section{Pentamerus lievis (Sow.)}

\section{Ref.-Sow. Min. Con. t. 28. Sil. Syst. t. 19. f. 9.}

$S p . C h$. - Transversely oval, both valves evenly convex, smooth, or with few faint, broad, radiations near the edge; front and lateral margins level; apical angle about $115^{\circ}$ : casts shew in the receiving valve the wide slit left by a rery thick medial septum extending nearly to the front edge (the divaricating rostral portion much larger than in the $P$. oblongus); entering valve with two long thin septa diverging at about $10^{\circ}$, reaching more than lalf way to the front margin, the nearly horizontal curved outer edge, forming the large slits parallel with the hinge-margin, having a faint mesial septum between them reaching within one-half or one-third of the beak. Width one inch eleven lines, proportional length $\frac{7 i}{140}$, length of entering valve $\frac{70}{100}$, depth of receiving valve $\frac{36}{1000}$.

Position and Loculity.-Abundant in the sandstone of Pwllheli, Caernarvonshire; Upper Bala sandstone of Penlan, Llandovery; C pper Bala flag of Cyrn y Brain, Wrexham, Denbighshire; ditto 3 miles N. of Builth, Radnorshire; Caradoc sandstone and limestone of Soudley, Shropshire. Not uncommon in the Caradoc sandstone of Horderly.

\section{Pentamerus lens (Som. Sp.) \\ Ref. and Syn.=Atrypa lens Sow. Sil. Syst. t. 21. f. 3.}

Sp. Ch-Longitudinally ovate, moderately convex, greatest width slightly nearer the beak than the front; a large, oltusely rounded mesial ridge from the beak of the small valve, widening greatly towards the front margin, which is prolonged into an obtuse tongue-shaped lobe, margins nearly level; surface crossed by sharp small lines of growth, with occasional obscure indications of fine longitudinal lines (? internal); casts [FASC. II.] $\mathrm{E} \mathrm{E}$ 
shew the usual hood-shaped piece within the beak of the great valve, from the ridge of which a thick but short mesial plate extends to the surface (forming a short slit in the cast); in the small valve are two short lamella diverging at an angle of $33^{\circ}$, and between them, but not reaching the beak, is a very delicate mesial septum (as in the $P$. oblongus); small valve shews two impressions on each side of the beak nearly parallel with the hinge-line, but connected with the diverging plates by an inward curve, the muscular impressions are within the diverging plates. Length of small specimen (of small valve) eleven lines, width about the sane, depth about three and half lines.

This species has exactly the same internal structure as the $P$. oblongus, but having all the internal plates much shorter, the cast of the receiving valve sometimes shews the mesial septum, and sometimes the two diverging plates; the latter I suspect searcely reach the inner surface of the large valve, and the former probably scarcely projected from it, so that a slight difference of level in the cast brings one or the other into view: it is externally distinguished from that species by the widest part being nearer the beak, and the more prominent rounded, prolonged mesial ridge in front.

Position and Locality.-Rare in the olive Upper Bala shale of Coniston, Lancashire; common in the Bala sandstone of Mandinam, Caermarthenshire.

\section{Pentamerus microcamerus $\left(M^{c} \mathrm{Coy}\right)$.}

Syn. and Ref. = Spirifer? lavis Sow. Sil. Syst. t. 21. f. 12. (not Pentamemes loevis Sow. $)=$ Pent. microcamerus McCoy, Ann. Nat. Hist. 2nd Series, Vol. VIII. p. 390.

Sp. Ch.-Transversely elliptical, receiving valve depressed, gently convex, greatest depth near the beak, which is elevated nearly at right angles, the height being one-eighth the width of the hinge; entering valve gently convex; beak small, rather prominent, reaching to the plane of the lateral

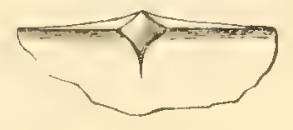
margins, with which the low, triangular area is nearly parallel; greatest depth slightly behind the middle; a broad, faintly marked, slightly convex, obsolete mesial ridge, and a few faint, broad, obsolete, irregular, lateral radiations; hinge-line slightly less than the width of the shell; side margins elliptically rounded, front margins very wide, gently convex; cardinal area nearly sixteen times wider than high ; surface apparently smooth, or with a very minute fibrous longitudinal striation; internal cast of receiving valve shewing the broad triangular boss of the foramen slightly keeled; the mesial

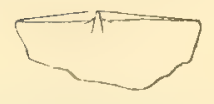

Upper Figure.-Internal cast of rostral part of receiving valve, shewing the cardinal area and by the converging of the dental lamellic. Lmecr Figme, - Rostral part of dinal area, and very small diverging lamellax. septum formed by the junction of the bounding lateral lamella of the foramen only reaching one-third the length of the shell, or a little more than equal to the width of the rostral chamber; cast of entering valve with a very narrow triangular area in the plane of the lateral margins, two very slightly diverging dental lamella, scarcely reaching twice the width of the area, (or one-eighth the length of the shell), exterior edges of which form two more diverging slits resembling cardinal teeth; a slight indication of a mesial septum, commeneing a little in front of the ends of the diverging lamellix, from letween the ends of which project two long spatulate muscular impressions, not reaching quite to the middle of the shell. Width two inches six lines, proportional length $\frac{55}{1+111}$, depth of receiving valve $\frac{19}{100}$, of entering valve about the same.

I have recently examined so great a number of specimens of this species from May Hill, that there can be no longer any doubt that it belongs, not to the genus Spirifer, as suggested by Mr. Sowerby, nor to the genus Orthis, as suggested by the Palieontologists of the Geological Survey, but is a distinetly defined species of Pentamerus, distinguished by the very small size of the rostral chamber in the receiving valve, and the extreme shortness of the diverging lamelle in the entering valve, which are not eren indicated in Mr. Sowerhy's figure thereof. As the species must be placed in the genus Pentamerus, and there is already a Pentamerus lcevis, I am obliged to propose a new specific name. In very young specimens three lines long the mesial septum exceeds half the length of the shell.

Position and Locality.-In the fine sandstone of Mandinam, Caermarthenshire. Very abundant in the sandstone of May Hill, Gloucestershire. 


\title{
Pentamerus oblongus (Som.)
}

\author{
Ref.-Sil. Syst. t. 19. f. 10.
}

$s p . C h$.-Longitudinally subtrigonal or ovate, both valves moderately convex, the middle third forming a wide, obscurely marked mesial elevation in each valve; surface smooth near the heak, radiated with obscure hroad, irregular furrows towards the margin; apical angle about $\frac{115}{1 \ldots}$; front and lateral margins level ; casts of the large valve shew a strong narrow medial slit extending three-fourths the length of the shell, the divaricating portions and included chamber of the beak very small (little more than one-third the height of the medial part), and its width rather less than half the height; in the small valve the septa reach little more than one-third the length of the shell, diverging at an angle of $12^{\circ}$. Length two inches three

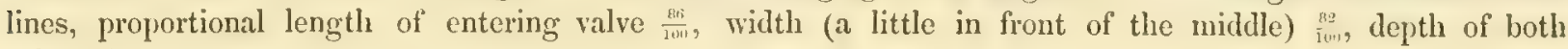
valves $\frac{35}{200}$.

Position and Locality.-Abundant in the Caradoc limestone of Acton Scott, Church Stretton, Shropshire; in the sandstone near Presteign, Radnorshire; schists of Castell Craig, Gwyddon, Llandovery, S. Wales; schists of Goleugoed, Llandovery, Mandinam, Caermarthenshire; Caradoc limestone, the Hollies, Chureh Stretton, Shropshire; abundant in the Caradoc sandstone of Horderly.

\section{Pentamerus undatus (Sow. $S p$.)}

\author{
Ref. and Syn.=Atrypa id. Sow. Sil. Syst. t. 21. f. 2.
}

Sp. Ch.-Transversely oval, gibbous, large valve most so, with a very wide, flattened, strongly defined hollow from the beak, widening towards the margin, which it elevates into a strong obtuse lobe in the small valve, on which a corresponding flattened, prominent, strongly marked ridge extends from the margin to the beak; sides convex, gradually sloping to the eardinal angles, which when well preserved are nearly rectangular, from the straight hinge-line extending almost the width of the shell, but more usually appear (from injury) elliptically rounded; heak moderate, apical angle (including the eardinal angles) $140^{\circ}$; substance of the shell very thick; casts very often shew a coarse longitudinal, oceasionally branched suleation, indicative of the ovaries; the beak of the large valve with a very short mesial septum (about one-fifth of the length of the shell), divaricating to include the beak of the small valve, which has a very minute diverging plate on each side of the beak, exterior to each of which is a transverse oval depression; surface smooth, or with fine lines of growth. Average width of small specimen eleven lines, proportional length of recciving valve $\frac{68}{100}$, of entering valve nearly the same, depth of both valves $\frac{49}{100}$.

The internal plates are excessively small, but formed on the usual plan of Pentamerus. I observe that in those species in which the plates are very small, the outward-curved marginal portion of the two diverging plates in the beak of the entering valve is unusually strong, giving to casts the appearance of four slits in the beak, or of two slits and two oblique teeth.

Position and Locality.-Very common in the greyish Bala schists of Matlyyafal, S. of Meifod, Montgomeryshire; common in the Bala schists of Pen y Craig, Llangynyw, Montgomeryshire; Bala schists of Golengoed, Llandovery, Mandinam, Caermarthenshire; common in the calcareous schists of Penlan, Llandovery, S. Wales.

\section{8th Family. ORTHISIDE.}

Shell fixed, fibrous, or punctured; an opening for the passage of the muscle of attachment between the beaks; (arms and other soft parts supposed to resemble Lingule;) a low triangular cardinal area in each valve, largest in the receiving valve. No spiral testaceous internal appendages.

Genera: 1, Porambonites; 2, Orthis; 3, Orthisina; 4, Leptana; 5, Strophomena; 6, Leptagonia; (7, Chonetes; see Leptcena). 


\section{Genus. PORAMBONITES (Pand.) 1830. \\ Syn. = Isorhynchus King 1850 (not of Schönherr).}

Gen. Char.-Subglobose, depressed, entering valve largest; beaks obtuse, subequal, separated by a small cardinal area in each valve; foramen in each valve small, triangular, reaching the hinge-line; two long slightly diverging dental lamelle in each valve, those of the receiving valve closest together; surface coarsely punctured in lines.

I am unable to state the true generic characters of these shells from the specimens I have examined. They form the group equirostres of Murchison, Verneuil, and Keyserling, in their section of "Abnormal Spirifers," and the genus Isorhynchus of King. Neither Pander nor these latter writers liave described the hinge, nor internal characters fully, but the group is obviously a very peculiar one, remarkable for the two long, slightly diverging dental lamella in each valve, and is, I think, most allied to Orthis, an opinion in which Murchison, Verneuil, and Keyserling, seem to coincide, though placing them among the Spirifers.

\section{Porambonites intercedens (Pand.)}

Ref. and Syn. = Porambonites alta + elevata + pentagona + lata + plana + trigona + subrecta + latissima + parva + rotunda + intercedens. Pander Beit, zur Geogn. = Spirifer porambonites Von Buch. M. V. K. Geol. Russ. t. 2. f. $3,4,5$.

Sp. Ch-Subpentagonal, depressed, greatest width about the middle of the length, sides elliptically rounded; greatest depth rather behind the middle of the shell; entering valve about one-third deeper than the receiving one, rostral portions tumid, gradually becoming compressed towards the margin; bealss very small, obtuse; apical angle about $120^{\circ}$; cardinal area very small; hinge-line short, forming a very obtuse angle with the lateral margins; lateral margins slightly sigmoid; front margin very abruptly raised into a rotundato-quadrate sinus, producing a wide, flat, abruptly defined mesial depression in the receiving valve scarcely extending within six lines of the beak; mesial ridge of the entering valve scarcely perceptible; surface marked with close, flattened, subequal, longitudinal strix (about eleven in the space of one line at the margin), separated by rather narrower sulci, very coarsely pitted. Width of large specimen one inch five lines, proportional length $\frac{70}{100}$, depth $\frac{45}{100}$.

Although perfectly agreeing with Murchison, de Verneuil, and Keyserling, that all the above specific names of Pander belong to one variable species, I do not think it desirable to add to the number, as they have done, by adopting Von Buch's name, Spirifer porambonites. I have used for the species the first specific name out of the synonyms used by Pander in his descriptions, although it is rather with the large depressed varieties named by him $P$. pentagona that our specimens have most analogy. It is very interesting to find this species in Great Britain, from its apparently very restricted geographical range, though occurring in such great profusion in the Lower Silurian strata about St Petersburg, and rarely in strata of same age at Christiania.

Position and Locality.-Not very uncommon in the limestone of Wrae Quarry, Upper Tweed, near Broughton.

\section{Genus. ORTIIIS (Dalman.)}

Gen. Char.-Subquadrate, or rounded; hinge-line generally less than the width of the shell; each valve has a triangular cardinal area, and mesial triangular foramen open, in the receiving ralve, closed in the other by its own prominent, bifid, rostral tooth; the receiving valve is the largest, and also is usually the most elevated, and gibbous in the middle; opposite valve usually smaller, less convex, and generally with a mesial sinus; surface generally marked with longitudinal strix or plaits; shell-tissue closely and very minutely punctured; interior surface of receiving valve with a short mesial septum, and a strong diverging hinge-tooth on each side, from which a semicircular dental plate extends, on the inside of which is often seen a large radiated muscular impression; entering valve with a prominent, small, bi- or tri-fid rostral 
tooth, and two short, prominent, very divergent cardinal teeth, each with a cardinal pit between it and the hinge, and a thick, obscure, mesial ridge, with usually two rounded, subequal, depressed muscular impressions on each side, the tumid boundaries of which sometimes form a cross.

The opening in area of the receiving valve being free, and without trace of pseudo-deltidium, distinguishes this genus perfectly from the others of the family; and in casts this produces a remarkable difference, the triangular rostral portion of the receiving valve being inseparably fixed to the flattened cardinal area, while in Stroplomena the triangular beak is separately defined all round, on account of the closing of the opening.

\section{Ortinis Actoniz (SOW.) \\ Ref.-Sil. Syst. t. 20. f. 16.}

Sp. Ch.-Truncato-orbicular; hinge-line equal to the width of the shell; cardinal angles acute; receiving valve very convex; entering valve flat; cardinal area in both valves low, nearly equal, slightly curved, both inclined inwards to the commissure, so that the beak of the convex receiving valve is nearly on a level with the lateral margins; valves radiated, with from eleven to twenty (in the latter case several ones on the ears abruptly smaller than the rest, total number most usually thirteen) large angular ribs, separated by angular hollows; ribs usually simple for about six lines from the beak, when most of them split irregularly into two or three less deeply-defined branches; surface crossed by fine imbricating strice of growth; casts of the convex or receiving valve shew at the beak two short, thick, cardinal tecth, diverging at an angle of $95^{\circ}$; the surface nearly smooth, with narrow definite ribs, separated by broad flat spaces, a few at the middle, reaching quite to the beak, the rest nearly so, their marginal extremities abruptly branching two or three times, and with occasional, short, intervening ribs; cast of entering valve with the diverging pits, of two small cardinal teeth, nearly parallel with the hinge-line, from which they are separated by two small projections for the cardinal pits, and in the centre of the beaks a small longitudinal depression for the rostrum; in front of these is a shallow mesial depression, flanked by two obtuse, obseure, rounded elevations, marking one pair of muscular impressions, the ribs not reaching quite to the beak. Width of small specimen ten lines, proportional length $\frac{65}{100}$ to $\frac{75}{100}$, depth $\frac{20}{100}$ to $\frac{25}{200}$, height of both areas $\frac{18}{100}$.

The entering valve seems concave in many specimens, but I think only from violence-the best specimens shew it flat. The large few angular rilss separate this from $O$. crilligramina and $O$. fabcllulum, even when the characteristic branched extremities cannot be seen.

Position and Locality.-Extremely common in the fine sandstone of Acton Scott, Church Stretton, Shropshire; Bala sandstone of Alt yr Anker, Meifod, Montgomeryshire; Bala schists of Gelli Grin, Bala, Merionethshire; schists of Blaen y Cwm, W. of Nantyr, Glyn Ceiriog, S. of Llangollen, Denbighshire; Bala limestone of Tyn y Cabled, Llanfyllin, N. Wales; Bala schists of Llansantfiaid, Glyn Ceiriog, Denbighshire; Bala schists of Maes Meillion, S. of Bala, Merionethshire; Bala schists of Cader Dinnael, near Corwen; Bala schists of Bryn Melyn, near Bala Merionethshire; Bala schists of Pont y Glyn, Diffiwys, W. of Corwen, Merionethshire. Ingleton and Thornton, Beck; Horton, in Ribblesdale, Yorkshire; Bala schists of Cwm of the Cymmerig; Coniston (Bala) limestone, of Coniston Water-Head, N. Lancashire; Bala limestone of High Haume, Dalton in Furness; Bala schists of Rhiwargor, near Llanwddyn, Montgomeryshire; Bala schists of Bryn Eithin, Penmachno, N. Wales; one doubtful variety in the Bala schists of Mathyrafal, S. of Meifod, Montgomeryshire, resembling Sowerby's figure of his O. flubellulum, var. $\beta$ (Sil. Syst. t. 19. f. 8), but with only fourteen ribs before their increase from the middle of the shell.

\section{Orthis biloba (Linn. Sp.)}

Ref. and Syn.=Anomia biloba (Linn.) Syst. Nat. 1154=Terebratula sinuata Sow. Linn. Trans. Vol. XII. t. 28. f. 5, 6. Delthyris cardiospermiformis Dal., = Spirifer sinuatus Sow. Sil. Syst. t. 13. f. 10. = Orthis biloba Davidson, Bull. de la Soc. Géol. de France, 2nd Series, Vol. V. t. 3. f. 18.

Sp. Ch.-Longitudinally obcordate, or subtrigonal; front wide, and very deeply bilobed; beak large incurved; cardinal area flattened triangular, twice as wide as high; hinge-line straight, less than the width 
of the shell, ears slightly flattened, rectangular, sides slightly convex, diverging at a variable angle, front divided into two narrow rounded lobes, from which a deep angular sinus extends to the beak in each valve; both valves moderately tumid, surface radiated with strong, sharply-marked, obtuscly angular, irregular, dichotomous ridges (five in one line at the margin). Length three lines, proportional width at front $\frac{95}{100}$, length of hinge-line $\frac{50}{1009}$ depth of both valves about $\frac{50}{100 .}$

The above-quoted figure of Mr Davidson shews the interior, with the rostral tooth flanked by two long, diverging, cardinal teeth, the margin strongly crenulated, and the two pairs of muscular impressions narrow, oblong, and obliquely elongated to two-thirds the length of the shell.

Position and Locality.-Calcareous Upper Bala schists of Cefn Coch, Glyn Ceiriog, Denbighshire.

\section{Orthis Callactis (Dal. $\beta$.)}

Ref.-His. Leth. Suec. t. 20. f. 9. Sow. Sil. Syst. t. 19. f. 5.

$S_{p}$. Ch. - Truncato-orbicular, both valves greatly depressed; hinge-line slightly exceeding the width of the shell; surface radiated with from sixteen to twenty radiating ribs, separated by broad concave spaces (forming very broad, rounded, smooth ribs in the interior); in most specimens the ribs are more or less divided into three by a pair of minor lateral furrows, reaching half way to the beak; cardinal area narrow in both valves, the entering valve with a slight concavity near the beak; receiving valve with a slight convexity near the beak; hinge-teeth of entering valve nearly parallel with the hinge-line, with a thick mesial ridge extending from between them nearly to the margin (coinciding with one of the external intercostal spaces). Width eleven lines, proportional length $\frac{66}{1009}$ depth $\frac{20}{100^{\circ}}$

There is a great contrast between the interior and exterior views of this species, the former being radiated with very wide, obtusely-rounded ribs (agreeing with Hisinger's figure), the exterior shewing narrow rounded ridges separated by wide concavities. The variety is extremely common and irregularly developed, in which the lateral sulci seem to render several of the ribs trifid, increasing the number and decreasing the size, particularly near the cardinal angles, and the margins of large specimens. The great depression of both valves easily separates the species from the $O$. Actonia, to which it is most allied. On the interior, three of the middle ribs often appear to converge before reaching the beak.

Position and Locality.-Rare in the Bala schists of Bala, Merionethshire; more common and of larger size in the Bala limestone of Gaerfawr, Welchpool, Montgomeryshire; very common and still larger (often an inch long) in the limestone of Wray Quarry, Upper Tweed, near Broughton.

\section{Ortis Calligramia (Dal. as defined by M. V. K.)}

\section{Ref. and Syn.-Geol. Russ. t. 13. f. 7. = 0. virgata, Sow. Sil. Syst. t. 20. f. 15.}

$S p . C h$.-Suborbicular, apieal angle about $145^{n}$; hinge-line slightly less than the width of the shell, greatest width about the middle of the length; receiving valve most convex, with a prominent beak, incurved nearly to the level of the lateral margins of the shell, greatest depth a little behind the middle; cardinal area moderate, triangular, inclining backwards at an angle of $145^{\circ}$; entering valve uniformly convex, or with a slight longitudinal depression in the middle, about one-third the depth of the receiving valve; cardinal area very narrow, beak not projecting; surface of both valves radiated, usually with from eighteen to thirty-two simple, very regular, sharply defined, round or subquadrate ridges, the twelve or fourteen middle ones of which reach the beak, the lateral ones reaching the hinge-margin, the intervening spaces usually equal to the ridges in size and shape, and having one or three fine longitudinal strixe towards the margin (never forming intermediate ribs); cast of the entering valve shewing the slit of a small rostral tooth in the triangular pad of the foramen; two small pits of the cardinal teeth; impressions of the posterior pair of alductors, obtuse, prominent, separated by a deep niesial suleus, which becomes wider and shallower towards the front margin; casts of the receiving valve shew two short, thick, subparallel dental lamellie, and sharp narrow elevated ridges, extending nearly to the beak. Width (of small specimen) eight lines, proportional length of entering valve $\frac{87}{100}$, width of cardinal area $\frac{15}{1, n,}$, depth of both valves $\frac{40}{100}$, (length occasionally one inch two lines). 
This species is excellently figured and described by MM. Murchison, de Verneuil, and Keyserling, in their Geology of Russia, but united with the old O. flabellulum of Sowerby, from which it is constantly distinguished by its more regular definite ribbing, and the fine longitudinal strix in the interspaces, without short irregular ribs, the sharp extension of the ridges more nearly to the beals on the casts, the greater inclination of the large eardinal area, and its being situated in the most convex instead of the flat valve.

The $O$. Dacielsoni (Vern.) of the Wenlock rocks, is distinguished by its area forming a considerable angle with the plane of the lateral margins, thus elevating the beak.

Pusition and Locality.-Very common in the sandstone of Tan y Craig, Builth; and sandstone of Goldengrove, Llandeilo; Bala schists of Blaen y Cwm, W. of Nantyr; Glyn Ceiriog, S. of Llangollen, Denbighshire; Bala schists of Llansantfraid, Glyn Ceiriog, Denbighshire; sandy schists of the Hollies, Church Stretton, Shropshire; a small variety, about seven lines wide and with sixteen or eightecn ribs, very abundant in the sandstone of Cerrig Cregyn, Anglesea, agreeing in striation and all other characters with the true type; rare in the Bala limestone of Coniston Water-Head, Lancashire; in the grey quartzite of Carn Goran, Cormwall: var. not uncommon in the Bala limestone, Horton in Ribblesdale, Yorkshire.

\section{Var. $a$. CALliptycha ( $\left.I^{c} \mathrm{Coy}\right)$.}

A beautiful variety, agreeing in the character of the area with the regular type, but rather more convex (depth of receiving valve $\frac{3}{1 \mathrm{in}}$ ), with sixteen or eighteen ribs, in the interspaces between which the stria are of unusual strength, wire-like, and also occurring on the ribs themselves near the margin.

Position and Locality.- Rare in the Bala limestone of Llansantfraid, Glyn Cciriog, Denbighshire.

\section{OrTHIS CONFINIS (Salt.)}

Ref.-Salter, Quart. Geol. Journ. Vol. V. t. 1. f. 4.

Sp.Ch.-Subquadrate, depressed, receiving valve with a slightly projecting conoidal beak, from which a slightly marked longitudinal lieel, or convexity, extends for a few lines towards the margin, and from which the surface slopes with little curvature in all directions towards the margin, the greatest depth being at the beak; margins in one plane, or in young specimens, with a minute, obtusely angular wave, in the front margin towards the receiving valve; entering valve gently convex, greatest depth about the middle of the length, with a very small depressed beak, from which a rather deep, narrow, undefined sinus extends for ahout four or five lines towards the margin, then gradually disappearing; cardinal area curved, triangular, six times wider than high in the receiving valve, with a narrow, triangular, open foramen, inclining backwards at $100^{\circ}$; area of entering valve rather less than half the width of that in the receiving valve, to which it is at right angles; both valves radiated with narrow, round, straight, prominent, rery sharply-defined ridges, separated by flat, smooth spaces, as wide or considerably wider than the ridges, and increasing irregularly in number by intercalation at a short distance from the beak, in well-developed specimens, in which at six lines from the beak there are five subequal ridges in two lines; in other specimens the ridges are closer, every third or fifth stronger than the others, producing a fasciculation, and seven in two lines, ridges much eloser on the sides than towards the middle. Width one inch one line, proportional length of receiving valve $\frac{80}{100}$, of entering valve $\frac{75}{100}$, depth $\frac{100}{100}$.

The great difference which I have above registered in the number and general character of the radiating ridges, may be traced in such a way among the Scotch specimens as leaves no doulbt of the specific identity of the forms, some of the specimens, with more numerous ridges, having them nearly uniform in size, while some of the specimens with the more distant ridges have them more or less fascieulated, as in the extreme forms above alluded to; in all cases, however, the species seems very distinet, by the narrow, very sharplydefined, round linear ridges, and smootl, flat, wide interspaces; the casts are strongly marked with radiating ridges round the margin.

Pusition and Locality.-Extremely common in the impure concretionary limestone of Bugon, Knocli- 
dollian, three miles from Ballintrae, Ayrshire; ditto Colmonel on the Stinchar; in the Bala limestone of Llandeilo, Caermarthenshire (finely-marked specimens); limestone of Trownscoed Gaerfawr. A fine-ridged variety in the limestone of Mulock Quarry, Dalquorhan, near Girvan, Ayrshire.

\section{Orthis Crispa $\left(M^{c} C O y\right)$. Pl. 1 H. fig. 43.}

$$
\text { Ref.-M } \mathbf{M}^{\mathrm{c}} \mathrm{Coy} \text {, Syn. Sil. Foss. Irel. t. 3. f. } 10 .
$$

sp. Ch.-Truncato-elliptical, length exceeding half the width. depressed, hinge-line as wide as the shell, cardinal angles nearly rectangular; cardinal area of receiving valve flattened, triangular, five times wider than high, and forming an angle of about $95^{\circ}$ with the lateral margins; area of entering valve linear, almost obsolete, bent inwards nearly in the plane of the lateral margins; receiving valve gently convex; entering valve nearly flat; surface of both valves covered with close, prominent, obtusely-angular, subequal ridges, six to eight in two lines at four lines from the beak, or forty-five to fifty at the margin, separated by slightly narrower spaces, and branching two or sometimes three times between the heak and margin, the ridges and interspaces crossed by regular, erect, squamose, concentric lines of growth, about the thickness of the ridges apart.

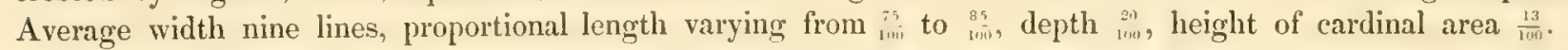

I think it possible that the Orthis scabrosa (Davidson), figured in the Lond. Geol. Journ. Vol. I. t. 13, f. $1 t$ and 15 , may be the adult of this species, which is remarkable for the strong, regular, scale-like transverse sculpturing of its branching ridges.

Position and Locality. - Not uncommon in the schistose and calcareous beds of the Bala rock of Bala, Merionethshire; Bala limestone of Helms Gill, Dent, Kendal.

Explanation of Figures.-Pl. 1. H. fig. 43. Natural size from the Upper Bala rock of Bala.-Fig. $43 \alpha$. Profile of entering valve, and cardinal area of receiving valve-_Fig. $43 b$. Surface magnified.

\section{Orthis Elegantula ( $D a l$.)}

Ref. and Syn.-Dalman, t. 2. f. 6. Davidson, Lond. Geol. Journ. t. 13. f. 10 (enlarged two diameters) = Orthis canalis Sow. Sil. Syst. t. 13. f. 12. and (Var, a. antiquior $\mathbf{M}^{\mathrm{C}} \mathrm{Coy}$ ) t. 20 . f. 8 .

sp. Ch.-Longitudinally obovate, hinge-line slightly less than the width of the shell, which is greatest at one-third the length from the beak of the entering valve, sides converging towards the front, which in old specimens is narrowed and produced in a small lobe; receiving valve very convex along the middle, from which the sides slope with slight convexity to the margins, greatest depth at one-third the length from the beak, which is very large and so much incurved as to reach the plane of the lateral margins; cardinal area triangular, sharply defined, height usually one-fouth the width, but varying slightly in inclination and curvature, nearly in the plane of the lateral margins; entering valve nearly flat, slightly convex on the sides, with a narrow mesial depression strongest near the beak, becoming gradually replaced, after two or three lines, by a slight mesial convexity, which gradually increases with age, so that this valve at three lines from the beak shews a slight wave in the front margin, convex towards the receiving valve; when about four lines the margin is horizontal, and when seven lines long, there is a slight wave, with the convexity towards the entering valve; strix very obtusely angular, nearly equal at the margin (intervening sulci much narrower than the ribs), increasing in number by occasional dichotomy, twelve or thirteen in two lines at three lines from the beak of entering valve; about ten in same space at margin of large specimens (six lines long), on which they are strongly arched in a divaricating manner from the beak and mesial line, leaving an irregular triangular packet of two or four strix down the middle finer than the rest; strix more equal on the receiving valve, with a mesial parcel of three or five finer than the adjoining ones; interior of entering valve, with two very large, diverging, cardinal teeth, bordering two deep, ovate, cardinal pits, and a small, triangular, rostral tooth; four rounded, subequal, very faintly marked muscular impressions, the posterior pair deepest but rather smaller than the anterior, occupy the visceral space, bounded ly very obtuse, doubly incurved, external ridges on each side, and an obseure, obtuse, longitudinal and transverse ridge, forming a crucial impression; margin marked with radiating im- 
pressions of the external striac. Average length six and half lines, proportional width $\frac{95}{1+n,}$, length of entering valve $\frac{8_{3}}{100}$, depth of both valves $\frac{62}{110}$. Shell under the lens granulo-punctate.

The obtuse subequal strix, not grouped in large bundles, and the few, fine, mesial strix, easily separate this, as M. de Verneuil has shewn, from the $O$. parva of the lower strata, with which it has often been confounded. The length increases considerably in proportion in old specimens, and the depth, owing to the curvature of the receiving valve, is sometimes (though very rarely) as low as $\frac{55}{100}$ in Gothland specimens. The specimens of var. $a$. (antiquior) from Sowerby's localities for his figure, t. 20, f. 8, are rather wider and flatter than those in the WVenlock limestone and Gothland strata: the lateral strie do not arch so much, the few finer ones are not distinct in the middle, and there is ratler a greater difference in size between the anterior and posterior pair of muscular impressions; still the strixe and slight variations of form may be so nearly paralleled in a handful of Gothland specimens, that although there may be a distinction, I do not feel able to express it.

Position and Locality.-Coarse schists of Moel Seisiog, Llanrwst, Denlighshire; very common in the Bala limestone of Corwen, Merionethshire; Bala schists of hills N. of Conway Falls : Bala schists of Mathyrafal, Meifod, Montgomeryshire; calcareous Bala schists, Maes y Fallen, Mala, Merionethshire: common in the Wenlock limestone of Dudley, Staffordshire; abundant in Bala schists of Bryn Eithin, Pennachno: sandstone of Mulock Quarry, Dalquorhan; Bala schists S. of Capel Cammon, Denlighshire: Bala sehists of Cefn y Coed, Llangedwyn, (Alyn Ceiriog, Montgomeryshire: Bala schists of Yspatty Evan, N. Wale's. Bala schists at hills S. of Cwm Lanerch, Bettws, Caernarvonshire; Upper Silurian schists of Mynydd y Gaer, S. side, Llanefydd, near Ruthin, Denlighshire; Bala schists of Cader Dinmacl, near Corwen, Denlighshire; Bala schists of Blain y Crrm (at junction), IV. of Nantyre, Glyn Ceiriog. S. of Llangollen, Denbighshire; Bala schists of. Pont y Glyn Diffwys, W. of Corwen, Merionethshire; Bala schists of Beaver's Grove, Bettws-ycoed, N. Wales: Bala limestone of Tyn y fridd, near Mathyrafal: Bala schists of Gaerfawr, Montgomers shire.

Var. a. (antiquior) sandy Bala schists of Pwllheli, Caernarvonshire; Bala schists of Llwyn y ci, N. WV. of Bala; fine Caradoc sandstone of Acton Scott, Church Stretton, Shropshire; Bala schists IV. of Llanfechan, Montgomeryshe; Bala sehists of Gelli Grin, Bala, Merionethshire; (aradoe sehists of Plas Madoc, N. of Llanrwst; near Girvan, Ayrshire; abundant in and almost composing a mass in Caradoc limestone and sandstone of Horderly; in the hard calcareous Bala schists of Capel Curig; Upper Bala schists of Bwlch y Groes, S. of Bala, Merionethshire; Bala schists of Bryn Melyn, near Bala, Merionethshire; very abundant in the Bala schists of Llansantfraid, Glyn Ceiriog, Denbighshire; Bala schists of Rhosfawr, N. of Glog, Llanfyllin, N. Wales; Bala schists of Miltir Cerrig, Llangynno, Montgomeryshire; Bala schists of Cefn Coedog, Corwen, Merionethshire; schists of Bwlch y Ciban; Bala schists of Rhiwargor, near Llanwddyn, 11 ontgomeryshire; Bala schists of ('wm of the C'ymmerig, E. of Bala, Merionethshire schists of I'en Cerrig Serth, two miles N. of Builth, Radnorshire; common in the Bala limestone of Bala; slates of Cefn Coedog, Corwen, N. Wales; Bala limestone and sandstone of Alt yr Anker, Meifod, Montgomeryshire; Bala schists of Coed y Bedw, Bala, Merionethshire; sandstone of Mulock Quarry, Dalquorhan, Ayrshire; I?ala schists of Bwleh y Groes, S. of Bala, Merionethshire.

\section{ORTHIs Expansa (Son.)}

Ref. and Syn. = O. expansa Sow. Sil. Syst. t. 20. f. 14.+ Orthis pecten Sil. Syst. t. 21. f. 9. (not of Dal.) + Orthis alternata* Sow. Sil. Syst. t. 19. f. 6.

$S p . C h$.-Semielliptical; hinge-line as wide as the shell; cardinal angles nearly rectangular; receiving valve flattened, slightly convex towards the beak, gradually flattening towards the margins, which are in one plane;

* All the specimens of this species whirl I bave examined from Sowerby's localities were exterior casts of the same shell of which his $O$. expansa was the internal cast. The outline varies from his figure of $O$. alternata to that of the specifically identical slell which he has figured as the $O$. pecten of Dalman. A few specimens with the proportional length only $\frac{70}{10 n}$, and with a few strong concentric waves of growth at the margin, agreeing with my O. pseudopecten (Sil. Foss. Irel. p. 33. t. 3. f. 16.), I now believe to be only a rariety of the present species.

[FASC. II.] 
cardinal area flat, low, triangular, ten times wider than high, inclining backwards at an angle of about $115^{\circ}$; internal casts of receiving valve minutely granulated and marked round the margin by sharp irregular traces of the external strix; muscular impressions extremely large, reaching slightly more than half the length of the shell, very coarsely sulcated, forming a rounded, or broad ovate, patch without a defining lateral, or anterior, boundary, divided along the middle by an obscurely marked trace of a flattened internal ridge, terminating close to the beak in two short subparallel slits from a pair of small internal ridges; cardinal teeth very short, bifid, diverging at $125^{\circ}$, enclosing the triangular boss of the open foramen undivided from the flat cardinal area; entering valve flattened, with a narrow cardinal area rather less elevated than in the receiving valve; interior large rostral tooth decply bifid, forming two very large deep pits in the beals of the casts, exterior to which are the two short, narrow, faintly-impressed sulci of the small cardinal teeth, diverging at an angle of $100^{\circ}$; muscular impressions forming two obliquely-diverging narrow lobes, on each side of a thick short mesial ridge, extending little more than half their length; surface radiated with very fine, transversely-striated elevated lines, separated by still finer punctured sulci, the ridges divaricatingly arched towards the cardinal angles at the sides, very irregular in size, usually with the coarser about half a line apart, and with from one to three or five finer ones between each pair, the odd one after four or five lines becoming as large as the prinary, and receiving fresh, smaller intermediate ones, so that the size and closeness of the striation is nearly uniform in all parts: there are about fifteen to nineteen strix in two lines at the margin of large specimens, but at six lines from the beak there are about twenty to twenty-five strice in two lines, about eight of which are larger than the rest, within an inch of the beak, but all becoming nearly equal towards the margin of larger examples; hinge-line at the sides often marked with a few short oblique wrinkles; width one inch eight lines, proportional length $\frac{92}{100}$, depth $\frac{10}{100^{\circ}}$

Some specimens of internal casts of receiving valve shew a subspinulose granulation, and two divaricating fan-shaped bundles of very slender, often-branched ovarian impressions, extending from the middle of the front of the great muscular impressions towards the front and sides of the anterior margins. The very large suite of specimens which I have carefully examined of casts of the receiving valve, shew in every case the triangular boss or impression of the foramen in the middle of the cardinal area, firmly united therewith to the apex, proving the foramen to have been open; for if it lad been closed by a pseudo-deltidium, there would have been a vacant space left between the conical cast of the beak and the cardinal area; the species therefore cannot be a Strophomene, (in the sense of Mr Sharpe's and this work,) but an extremely flat Oithis, a view also borne out by the size of the area in the entering valve.

Position and Locality.-Common in the Bala schists E. of Penmachno, Caernarvonshire; very common in the fine Bala sandstone and limestone of Alt yr Anker, Meifod, Montgomeryshire; Bala schists of Llansantfraid, Glyn Ceiriog, Denbighshire; in ditto, Alt y Gader, near Llanfyllin, Montgomeryshire; Bala limestone of Llanfyllin, Montgomeryshire; common in the Bala schists of Gelli Grin, Bala, Merionethshire: Bala schists of hills N. of Moel Uchlas, Montgomeryshire; fine Bala sandy schists of Gaerfawr, Montgomeryshire; fine sandstone of the Hollies, Church Stretton, Shropshire; Bala schists W. of Llanfechan, Montgomeryshire; Bala schists S. of Cwm Lanerch, Bettws, Caernarvonshire; schists, Keeper's Lodge, Goldengrove, Llandeilo; Bala schists of Das Eithin ridge, llimant, Montgomeryshire; Bala limestone of Coniston, N. Lancashire; Bala limestone of Mathyrafal, Meifod, Montgomeryshire; calcareous Bala schists of Llwyn y ci, N. W. of Bala; sandy schists of Middleton Park, Cacrmarthenshire; Bala limestone of Nant-y-arian, Llandeilo; common in the Bala limestone of Llandeilo, Caermarthenshire; calcareous Bala schists of Craig $\mathrm{y}$ Gilyn, N. of Thaider, near Llanarmonfach, E. of Berwys; ahundant in, and almost composing the mass of the Caradoc limestone of Horderly.

\section{OrTHis Flabellulum (Sow.)}

$$
\text { Ref.-Sow. Sil. Syst. t. 21. f. } 8 .
$$

Sp. Ch.-Transversely oval, or slightly subquadrate; hinge-line slightly less than the width of the shell; (ardinal angles oltuse; receiving valve flat, or with a slight concavity half way between the beak and margin, with a high, triangular eardinal area at right angles to the plane of the margins of the valves (or not exceeding 
$105^{\circ}$ ); beak slightly projecting, not incurved : entering valve very convex, evenly tumid, depth greatest half way between the beak and margin, varying in proportion; beak small, incurved quite to the level of the margin of the valve; cardinal area very narrow, bent inwards horizontally, parallel with the plane of the lateral margins, and at right angles to large area of receiving valve; surface of both valves radiated with about twenty to thirty (most usually about twenty-four) obtusely angular or rounded regular simple ribs, all extending to the beak, separated by spaces equalling them in size and shape, in which are usually developed towards the margin one or two short intermediate ribs (not strie, as in 0 . calligramma,) unequally developed, often appearing between some only of the ribs on a given specimen; substance of the shell thick, coarsely fibrous, the ends of the fibres, obliquely puncturing the surface, which is marked with very minute transverse lines of growth, but never having longitudinal strix: casts of the flat receiving valve with two strong dental lamellae diverging at an angle of $55^{\circ}$, enclosing a very prominent, subquadrate pair of muscular impressions, reaching nearly half way from the beak to the margin, bilobed by an undefined depression only at the posterior end; margin of the valves most usually with a border two or three lines wide of abruptly prominent casts of the ribs (often bifid), from which in a small number of specimens faint extensions or obsolete ribs approach the beak; casts of convex entering valve shew two short diverging pits for the thick cardinal teeth close to the depressed beak, with a mesial triangular pit produced by the rostral tooth dividing the triangular pad of the foramen in the small horizontal area: greatly elevated and a little in front of the cardinal teeth are the two obscurely rounded bosses from the posterior pair of muscles, deeply separated throughout by a wide defined suleus (not affecting the rest of the valve); anterior pair of muscles seldom perceptible, close in front of the large pair; surface nearly smooth, or striated with slight extensions of the ribs, which are abruptly prominent for a width of two lines round the margin, and often apparently very numerous, from the intercalated ribs being more

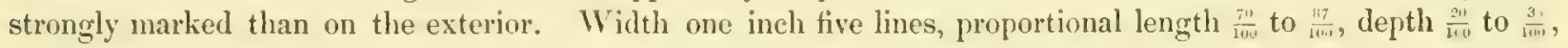
(sometimes less) length of area on convex entering valve $\frac{5}{100}$, on flat receiving valve $\frac{12}{100}$.

This species varies in the depth of the convex entering valve and slightly in the proportion of width to length. Mr Salter, (Mem. Geol. Surv. Yol. II.) has well pointed out that the entering or most convex valve of this species corresponds with the flattened valve of the 0 . calligramma, and its varieties. The width of the ribs as well as the size, presence or absence of the intermediary short ribs, varies much in different parts of one specimen.

Position and Locality.-Extremely common in the Bala sandstone of Bodean, Caernarvonshire; in ditto, Alt yr Anker, Meifod, Montgomeryshire; Coniston (or Bala) limestone of Coniston, N. Lancashire; depressed var. in Bala schists of Llyn Ogwen, N. Wales; Bala schists of Gelli Grin, Bala, Merionethshire; ditto of Llanwddyn, E. of Berwyn Mountains; in ditto S. of Cwm Lanerch, Bettws, Caernarvonshire; calcareous Bala flags, hill N. of Moel Uchlas, Montgomeryshire; Bala schists of Cader Dinmael, near Corwen. Denhighshire; in ditto of Cefn y Coed, Llangedwyn, Montgomeryshire: Bala schists, Glyn Ceiriog, S. of Llangollen, Denbighshire; Bala schists of Llansantfraid, Glyn Ceiriog, Denbighshire; Lower Bala schists of Moel y garned, Uchaf, WV. of Bala Lake, Merionethshire; Bala limestone of Applethwaite Common, Westmoreland.

\section{Ortuis Hirnantensis ( $I^{c}$ Coy). Pl. 1. H. fig. 11.}

$$
\text { Ref.-Id. McCoy, Ann. Nat. Hist. 2nd Series, Vol. VIII. p. } 395 .
$$

$S p . C h$.-Truncato-orbicular, depressed; cardinal area very low, triangular, nearly twelve times wider than high; hinge line slightly less than the width of the shell; cardinal angles slightly obtuse; lateral and front margins horizontal, almost uniformly curved; entering valve perfectly flat, with a slight longitudinal mesial depression near the beak; receiving valve slightly and gently convex, most so along the niddle at about one-third the length from the beak: both valves with numerous, slightly unequal prominent, angular, strongly fasciculated strie; each of the primary ridges branching near the middle into from five to seven smaller, forming in some specimens slightly angulated, divaricatingly arehed groups; eight or ten strice at the cardinal angles, smaller and straighter than the rest, running nearly parallel with the hinge-line; separating

$$
\text { F } F 2
$$


sulci narrow, marked with very coarse punctures or little pits, and crossed by coarse, obtuse, transverse strix; twelve to fourteen stric in two lines, at four lines from the beak; internal cast of receiving valve radiated with coarsely punctured impressions of the external striæ; cardinal teeth very short, thick, diverging at $80^{\circ}$. Width one inch, proportional length $\frac{70}{100}$, depth $\frac{16}{100}$.

This is an extremely beautiful species, remarkable for its flatness and broad divarieating bands of coarse, branched, strix, which are not at all arched along the hinge-line, as in the somewhat similar O. retrorsiatria (in which the depth is greater, the strix much more uniform, the surface smoother, and the internal casts quite different).

Position and Locality.-Very abundant in the oolitic limestone and decomposing schists over the Bala limestone at Aber Hirnant, E. of Bala, N. Wales; and in the similar limestone of Cwm yr Aethen above Llanrhaider" sandy Bala schists of Maes Hir, N. E. of Aber Hirnant, N. Wales; and oolitic Bala limestone of Maes-y-fallen, Bala, Merionethshire, rare in the Bala limestone of Cerrig-y-Druidion, Denbighshire.

Explanation of Figures.-Pl. 1. H. fig. 11. Natural size of rather small specimen, from the Bala limestone of Aber Hirnant; $11 \alpha$, portion of surface of ditto magnified to sliew the fasciculated striation; $11 b$, longitudinal section; $11 c$, portion of internal cast of receiving valve, shewing the hinge-teeth.

\section{Ortils hyBRIda (Sov.)}

\section{Ref.-Low. Sil. Syst. t. 13. f. 11.}

Sp. Ch.--Rotundato-trigonal; valves equal or nearly so; beaks very small; hinge-line very short, only half the width of the shell; greatest width near the front margin, which is slightly sinuate in the middle, but not raised into a wave; valves almost evenly convex, cuneiform, greatest depth at one-third the length from the beak, thence sloping towards the margins; entering valve with a very small mesial concavity; surface of both valves with a few thick varices of growth towards the margin; surface uniformly radiated with close, obtusely rounded strixe of nearly equal size and closeness in all parts of the shell, increasing in number towards the margin, principally by interpolation, very rarely by dichotomy, fourteen in the space of two lines at the margin of a specimen three lines long: interior of entering valve with two very prominent, thick, slightly diverging cardinal teeth, and rather large rostral tooth; margins crenulated for a short distance by the external ribs; cardinal teeth bordering the open foramen in receiving valve very strong. Average width four lines, proportional length of receiving valve $\frac{f u}{1 \cdots}$, length of entering valve slightly less, depth of both valves $\frac{61}{100}$.

Position and Locality.-Common in the Wenlock shale of Dudley, Staffordshire; Wenlock limestone of Wenlock, Shropshire.

\section{Ortilis lunata (Som.)}

Ref. and $S y n .=$ Orthis lunata Sow. Sil. Syst. t. 5. f. $15 .+$ O. orbicularis, t. 5. f. 16.

$s p$. Ch.--Suborbicular, or rotundato-quadrate; greatest width in front of the middle, the broad front margin being flattened or obscurely sinuate; valves very much depressed; receiving valve gently convex, most so at one-third from the beak; entering valve nearly similar, with a very faint, wide mesial depression towards the margin, not marked near the beak; linge-line nearly as wide as the shell; cardinal area very small, inclined so as to bring the smali beaks nearly in contact; surface of both valves covered with very fine, close, obtuse strix, very frequently branching so as to remain almost equal in size on all parts of the shell, or fiom the sudden branching the ribs often closer and more numerous at the margin, where a specimen four lines long, has eighteen or nineteen in the space of two lines: casts of receiving valve shew two, much incurved, narrow slits of dental lamelle, bordering the rostral portion, extending two-thirds the length of the shell; casts of entering valve shew two remarkably slender slits of cardinal teeth diverging at only $40^{\circ}$; muscular inipressions remarkably elongate, oblong, extending rather more than lualf the length of the shell, separated by a broad mesial sulcus, left by a thick mesial ridge, and bordered externally by a narrow slightly 
incurved slit of two smaller lateral ridges; division of the anterior pair from the posterior very slightly marked, the latter largest; surface closely granulo-punctate; average width six and a half lines, proportional length $\frac{86}{100}$, length of entering valve $\frac{88}{100}$, depth of both valves $\frac{36}{100}$.

The great depression and near equality of the valves, much finer strix, and singular elongate, narrow form of the muscular impressions in the entering valve, as well as the slightly-divergent, slender, hingeteeth of the entering valve, and width of the subsinuate front, easily distinguish this species from the O. elegantula.

Position and Locality.-Very common in the Upper Ludlow rock of Woolhope; abundant in the schists and limestone of the Upper Ludlow rock of Downton Castle, near Ludlow, Shropshire; schists of Dinas Bran, Llangollen, Uenbighshire; schists of Keeper's Lodge, Goldengrove, Llandeilo, Caermarthenshire; Upper Ludlow sandy flags of Benson Knot, Kendal, Westmoreland; var. in the Lower Ludlow schists of Erw Gillfach, Builth, Radnorshire; Upper Ludlow rock, near Ludlow, Shropshire; Upper Ludlow limestone of Kington, Herefordshire; Upper Ludlow limestone of Mortimer's Cross, Aymestry, Herefordshire: Ludlow mudstone of Parklane, Ludlow, Shropshire; Ludlow limestone of Leintwardine, Shropshire.

\section{Onthis parva (Pander. Sp.)}

Ref. and Syn. = Orthumbonites parra Pander, Beitr. zur Geogn. Russl. t. 26. f. 10. = Orthis parke + O. acellunu M. V. K. Geol. Russ. t. 13. f. 3 and 4.

Sp. Ch.-Obovate, or rotundato-quadrate, front often obtusely pointed in small very convex specimens, or wide and flattened in depressed ones; receiving valve very tumid along the middle, profile much curved, greatest depth about one-third of the length from the beak, sides sloping from the middle line, with little convexity to the margin, beak large, much incurved to the level of the lateral margins; entering valve gently convex about half the depth of the other, with a narrow mesial depression near the beak, gradually widening towards the front margin; cardinal area small in the entering valve, moderately high, triangular, curved, and very much inclined backwards in the receiving valve; linge-line slightly less than the width of the shell; both valves radiated with strong, sharply angular, uneçual, irregularly fasciculated ridges, very frequently dichotomising, and increasing in number also by intercalation towards the margin, arched towards the cardinal angles at the sides; the irregular multiplication of the ridges distinct at one or two lines from the beak, at which latter size there are fifteen to nineteen ridges in two lines, about thirteen in two lines at the lateral margin of large specimens six lines long; interstices strongly marked with transverse imbricating granules. Average width five lines, proportional length of receiving valve $\frac{88}{100}$, of entering valve ${ }_{100}^{86}$, depth of both valves $\frac{15}{100}$.

In the sharp, angular, fasciculated character of the striation, the large specimens in particular approximate to the 0 . testudinaria; but as the greater number of specimens of 0 . parra are little more than three lines long, it will be seen by the great number of the ribs in a given space, and their complex fission, that they differ totally from the young specimens of $O$. testudinaria, or from the ridging at the same distance from the beak of old specimens thereof. Some specimens in certain states of preservation, where the fasciculation is obscured, and the stria unusually numerous (forming the var. avellana of M. V. K.), very strongly approximate the var. $\alpha$. antiquior of the $O$. elegantula, which, however, has always more equal, obtuse, less-branched strix; their equality in thickness and prominence, particularly at the margin, contrasting strongly with the present species.

Position and Locality.-Common in the Bala schists of Llansantfraid, Glyn Ceiriog, Denbighshire; Bala sandstone of Ardwell, S. of Girvan, Ayrshire; Bala schists of (ielli Grin, Bala, Merionethshire: Bala schists of Cader Dinmael, near Corwen, Denbighshire; Bala schists of Llanfyllin, Montgomeryshire; calcareous Bala schists, Carnedd fawr, S. of Bala, Merionethshire; Bala schists of Maes Meillion, S. of Bala, Merionethshire; Bala schists of Bryn Melyn, near Bala, Merionethshire; Bala schists of hills N. of Moel Uchlas, Montgomeryshire; schists in stream above Llanfwrog, near Ruthin; calcareous Bala schists of Dinas Mowddy, Merionethshire; Bala schists of Rhiwargor, near Llanwddyn, Montgomeryshire; Bala sehists of 
Yspatty Evan, N. Wales; calcareous Bala schists of Craig y Glyn, N. of Rhaider, near Llanarmonfach, E. of Berwyn Mountains; Upper Bala rock of Capel Cerrig; Bala schists of Llwyn y ci, Bala, Merionethshire; schists right bank of Dee, Llangollen, Denbighshire; Bala schists of Conway Falls; Bala schists of Penlan, Llandovery; Bala schists S. of Capel Garmon, Denbighshire; Bala schists of Llyn Ogwen, N. Wales; Bala schists of Goleugoed, Llandovery, Mandinan, Caermarthenshire; Bala limestone of Corwen, Merionethshire; Bala schists of Dermydd Fawr, under Craig Bronbanog, Denbighshire; var, in the Tremadoc slate of Tremadoe, Merionethshire; ? var. in Caradoc sandstone of Horderly W.; ? var. Bala schists of Nant-y-arian, Llandeilo; sandstone of Mulock Quarry, Dalquorhan; Bala schists of Tan y Bwlch y groes; var, avellana common in the Upper Bala limestone of Horton in Ribblesdale, Yorkshire.

\section{Orthis Plicata (Son. Sp.)}

Ref. and Syn. Spirifer? plicatus Sow. Sil. Syst. t. 21. f. 6. + Orthis virgate Sow. Sil. Syst. t. 20. f. 15.

Sp.Ch.-Shell nearly semicircular or subquadrate; hinge-line slightly exceeding the width of the shell; cardinal angles acute; both valves gently convex; greatest depth at one-third the length from the beak; receiving valve deepest, with a moderately projecting beak, with a large flat triangular area, about onefifth of the width high, inclining backwards at an angle of about $120^{\circ}$; surface radiated with very numerous subequal, angular, radiating ridges, separated by spaces slightly less than their thickness in wilth, increasing in number by occasional dichotomy, and by interealation of new ridges, all nearly equal at the margin, where they usually amount to forty-eight or fifty, about five in the space of two lines at six lines from the beak, interstices marked with transverse stria; entering valve with a triangular area about eight times wider than high, inclined at about $130^{\circ}$ to the plane of the lateral margins: interior cast of entering valve shews the triangular boss of the opening in the area, divided by a slender longitudinal rostral tooth; the pits of the two cardinal teeth very small, rounded; a little in front of the hinge-teeth two obscurcly-rounded projections of the muscular impressions, divided by a wide deep furrow, becoming obsolete before reaching the margin; interior cast of receiving valve with two slightly incurved, subparallel, dental lamellix, bordering the beak; muscular impressions forming two large ovate patches, reaching more than half the length of the shell, separated by a wide space, divided by a very slender mesial septum, each impression surrounded by a delicate boundary, and filled with fine longitudinal furrows, branched at the end; in most casts a few broad branching pallial vessels approach the margin: the sharp subequal casts of the radiating ridges extend to, or over, the muscular impressions in both valves, becoming gradually more prominent towards the margin. Width eleven lines, proportional length of receiving valve $\frac{76}{100}$, of entering valve $\frac{72}{1100}$, depth about $\frac{27}{100^{\circ}}$.

The outline varies considerably in width and acuteness of the cardinal angles, allowing for the difference apparent between Sowerby's above quoted figures of the entering and receiving valves, to which he has given separate names, as was pointed out by $\mathrm{Mr}$ Salter (see note to page 287 of Memoirs of the Geol. Surv. Vol. II.) The particular figure given as S. virgata presents an unusual size and distance of the main ribs, with small ones between, characters however which may be oceasionally noticed in all parts of specimens of the ordinary type. The internal muscular and pallial impressions occasionally seen extending to the margin are usually effaced by the more or less distinct ribbing.

Position and Locality.-Common in the Bala schists of Gelli Grin, Bala, Merionethshire; abundant in the Bala schists of Bryn Melyr, near Bala, Merionethshire; Bala schists of Llansantfraid, Glyn Ceiriog, Denhighshire; Bala schists of Cwm of the Cymmerig, E. of Bala, Merionethshire; var. in the fine Bala sandstone and limestone of Alt yr Anker, Meifod, Montgomeryshire; rare in the Bala limestone of Bryn Evan, Yspatty, N. Wales; Bala schists of Rhosfawr, N. of Glog, Llanfyllin, N. Wales; Bala sehists of Das Eithin ridge, Hirnant, Montgomeryshire; Bala limestone of Meifod, Montgomeryshire; caleareous Bala selists of Bala, Merionethshire; Bala schists of Mathyrafal, Meifod, Montgomeryshire; sandy liala schists of Pwllheli, Caernarronshire; Bala schists of Maes Meillion, S. of Bala, N. IVales; a fine riblued var. in the Bala schists of Gaerfawr, Montgomeryshire; impure Eala limestone of Penlan, Llandovery; a wide, close-ribbed var. in calcareons Bala schists of Cader Dinmacl, near Corwen, Denbighshire; Upper Bala limestone, IIorton in Ribblesdale, Yorkshire. 


\section{Orthis porcata (MCOy). Pl. 1. H. fig. 41 and 42.}

\section{Ref. and Syn.-MCCoy, Sil. Foss. Irel.p. 32.t. 3. f. $14(1846)=0$. inflata Salt. Mem. Geol. Surv.}

Vol. 1I. p. 372.

S'p. Ch.-Transversely oblong, rounded; receiving valve flat, very slightly prominent towards the beak, which is small and not incurved, becoming slightly depressed in the middle of old shells, by a very wide, shallow, concavity, scarcely affeeting the margin; cardinal area varying in height, usually about eight times wider than high, flat, triangular, inclining back at $115^{\circ}$; foramen acute, open to the point of the beak : entering valve of very great but varial,le gibbosity; sides tumid, much arched from the very small beak to the front margin, which is raised by a scarcely perceptible, wide sinus, the greatest depth being a little behind the middle; cardinal area about one-third the size of that in the receiving valve, and lying nearly in the plane of the lateral margins; both valves radiated with coarse, angular, subequal ridges, separated by shallow angular sulci (about sixty at nine lines from the beak), straight and nearly simple on the sides, but towards the middle some bifurcating once or twice, some dividing at once into three or four, and a few remaining simple, about five in two lines, at six lines from the beak, but varying in this respect; all the ridges crossed by fine, close strix of growth; internal cast of entering valve shews the large triangular boss of the foramen, nearly occupied by the very large ovate pit of the rostral tooth; diverging on each side of which is a very broad pit of the short, thick cardinal tooth: posterior pair of muscular impressions large, ovate, slightly convex, marked with longitudinal or outward curved strix, separated by a wide rounded furrow of a mesial ridge, extending their length from the leak, and bounded externally by the faint depression of a slightly prominent margin ; anterior pair less than half the size of the posterior, obscurely defined into four or five radiating lobes faintly defined all round ; internal cast of receiving valve, with two thick dental short lamellac, diverging at $110^{\circ}$ : muscular impressions flat, quadrate, wider than long, faintly defined by the suleus of a slightly raised margin (formed by an extension of the dental lamellic) with nearly parallel sides, extending less than half the length of the shell, forming narrow lobes at the anterior lateral angles, projecting considerably in front of the nearly straight anterior boundary; interior of both valves marked nearly from the beaks with narrow branching impressions of the external strix, strongest at the margin; substance of the shell densely fibrous. Width one inch five lines, proportional length usually $\frac{70}{100}$ (rarely varying from $\frac{65}{100}$ to $\frac{75}{100}$ ), depth of both valves varying from $\frac{30}{100}$ to $\frac{45}{100}$.

I originally described and figured this species from the Coniston limestone of Portrane, near Dublin, from a great abundance of specimens, which however from the nature of the limestone could only be extracted in fragmentary condition, still the characters were plain enough to distinguish the species from all then linown. Upwards of a year afterwards Mr Hall, in his Palæontology of New York, carefully figured and deseribed, under the names $O$. occidentalis and $O$. sinuata, a species equally common in the limestone (Trenton) of the same age in America, a representative closely-allied form, distinguishable probably from ours by the great comparative depth of the receiving valve, and its deep mesial sinus, which abruptly indents the margin. I do not think it desirable therefore to suppress his species, as would be necessary, if, as Mr. Salter suspeets, they be identical with the present species, which he inadvertently redescribes in the Mem. Geol. Surv. under the name O. inflata. The principal forking of the ribs takes place at from two to four lines from the beak, and again near the margin about seven lines from the beak of the entering valve. The substance of the shell is thick.

By a peculiarity of weathering several of the specimens in the sandstone of Meifod shew a border of large, lacunose, pitting between the ribs, which are there extremely prominent: this appearance results from the imperfect removal of the substance of the shell; other specimens from the same mass of stone shewing the ordinary conditions as above described.

Position and Locrlity.-Very common in the Bala schists of Llansantfraid, Glyn Ceiriog, Denbighshire; Bala schists of High Haume, Dalton in Furness; Bala schists of C'ym y Brain, WV. of Wrexham, Denbighshire; Bala schists of Blain y Cwm, W. of Nantyre, Glyn Ceiriog, S. of Llangollen, Denbighshire; very aluundant in the P'ala limestone of Coniston, N. Lancashire; Caradoc limestone of Horderly S.; very common in the Bala sandstone of Alt yr Anker, Meifod, Montgnmeryshire; var. in Bala schists of Pen y Park, Llanfyllin, Montgomeryshire; calcareous Bala flags of Corwen, Merionethshire; Bala sandstone of Alt y Gadtr. near Llanfyllin, Montgomeryshire. 


\title{
Ortils protensa (Som.)
}

\author{
Ref.-Sow. Sil. Syst. t. 22. f. 8 and 9 .
}

Sp. Ch.-Truncato-elliptical cardinal area low, triangular in each valve; hinge-line equalling or slightly exceeding the width of the shell; depressed, varying from longitudinal to transverse; receiving valve nearly flat, with a slightly projecting flattened beak, from which a broad angular ridge extends to the margin; entering valve rather dceper in most specimens than the receiving one, gently arched, greatest depth about laalf way between the beak and margin; a deep longitudinal depression extends from the beak to the margin; both valves radiated with very numerons, oltusely-angular, fasciculated ridges, separated by narrower angular, sulci, branching twice or three times at irregular distances from the beak to the margin, where each of the original ones forms four or five more slender, about fourteen (eleven to fifteen) in two lines at four lines from the beak, alout six in one line at two lines from the beak, slightly arched on the sides, nearly or quite obsolete on the ears, which are marked by a few irregular concentric plice of growth: internal cast of receiving valve with two very short cardinal teeth diverging at $75^{\circ}$, slightly incurved at their extremities, which are connected by a transverse furrow completing the boundary of a trapezoidal muscular impression, less than one-fourth the length of the shell; the internal cast of entering valve with the narrow triangular boss of the foramen divided by a slender rostral tooth; cardinal teeth very short, parallel with the hinge-line; substance of the shell moderately thick, densely fibrous. Width seven lines, proportional length $\frac{80}{1009}$ depth $\frac{20}{100}$.

'The above proportional measurements seem to indicate the true form, although, as mentioned, specimens frequently occur in which the length equals or slightly exceeds the width.

Position and Lacality.-Very common in the Bala schists of Goleugoed, Llandovery, Mandinan, Caermarthenshire; Bala schists of (ader Dinmael, near Corwen, Denbighshire; very common (sometimes an inch wide) in the Bala limestone of Ash Gill, Westmoreland; Bala schists of Mathyrafal, S. of Meifod, Montgomeryshire; a blunt-angled wide variety in the olive shale of Llangynyw Rectory, near Welchpool, Montgomeryshire.

Orthis retronsistria $\left(M{ }^{\circ} C O y\right)$. Pl. 1. II. fig. 12.

Ref.-Id. Mc Coy, Ann. Nat. Hist. 2nd Series, Vol. VIII. p. 396.

Sp. Ch.-Rotundato-quadrate, depressed, no mesial ridge or furrow in either valve; hinge-line nearly or quite as wide as the shell; cardinal angles slightly obtuse; cardinal area flat, triangular, six or seven times wider than high in the receiving valve, and inclined backwards at about $120^{\circ}$; only one-third this height in the entering valve; rostral tooth of entering valve very large; triangular foramen of receiving valve, with an internal, semiconical, hood-shaped extension of the dental lamellæ within it; receiving valve gently convex; greatest depth about the middle of the length; entering valve flat round the margin, gently concave in the middle; both valves with a few concentric wrinkles of growth about a line apart, and radiated with slightly irregular obtuse strix, which branch into two or three at two or three intervals between the beak and margin, so that each of the strong primary ones forms from seven to ten at the margin, separated by a rather deeper sulcus from the adjoining ones, so as to produce a flat, indistinctly marked fasciculation; intervening sulci about the same size as the strix, (obscurely punctured in some specimens), which are straight in the middle, gradually assuming a divaricating curve on the sides, which is so great near the angles, that a large number of the lateral strix curve backward from the beaks to terminate along the distal half of each side of the hinge-line instead of at the lateral margin; all the strix crossed hy indistinct transverse lines of growth; the size of the strie does not vary much, in the various parts of the shell from fourteen to seventeen may be counted in two lines at four lines from the beak; cast of entering valve nearly smooth, except at the margin, which in the middle is marked with elose slightly dichotomous lines; the narrow triangular hoss of the foramen is eleft by a deep, narrow, elliptical pit of the rostral tooth, flanked by the pits of two short cardinal tecth, diverging at $70^{\circ}$, between which and the hinge-line are the smaller but more diverging bosses left by the cardinal pits; a deep straight sulcus extends from the rostral tooth nearly to the anteriur margin, marking a very long obtuse mesial ridge, on each side of the rostral part of which is a sub- 
quadrate pair of muscular impressions, reaching less than half the length of the shell, the length and width of the pair being nearly equal; the lateral boundaries are formed by the deep impressions of a sigmoidal ridge extending from the eardinal tooth on each side, each impression being slightly divided into two unequal lobes, anteriorly by the slight projection of an oblique narrow portion, diverging from the anterior lateral angles; in fine specimens, a faint, transverse, arched furrow separates the small posterior adductor impressions, which are longitudinally wrinkled, from the smoother and larger anterior portion: interior of receiving valve with two short cardinal teeth diverging at $105^{\circ}$, from which extend two extremely long, narrow, elliptical, muscular impressions, extending from more than half, to nearly two-thirds, the length of the shell, each lobe marked with faint radiating sulci, the pair being separated by a flat, acutely angular space, a little wider than one of the impressions at the anterior end, and extending to the point of the beak; a narrow space of the margin finely plicated, the rest of the surface nearly smooth, or very faintly radiated. Width ten lines, proportional length of receiving valve $\frac{9 !}{\mathrm{i} \text { ins }}$ of entering valve $\frac{82}{100,}$, depth $\frac{15}{100}$.

The backward curving of many of the lateral strie to terminate on the hinge-line, is more remarkable in this species than any other I lnow of, and suggests the specific name. Something of the same sort may be seen in a less degree in the O. subquadrata (Hall), and one of the shells figured in the Mem. Geol. Surv. (Vol. I1. pt. 1. t. 20. fig. 9.) as the O. testudinaria, from both of which the great general depression, the total absence of mesial fold, the concavity of the entering valve, great length of the narrow diverging muscular impressions in the receiving valve, \&ce, easily distinguish the present species. The same characters and backward curving of the lateral strie separate it from the O. protensa.

P'vition and Locality.-Occurs in extraordinary profusion in the Bala flags of S. end of Pen y Gaer, near Cerrig y Druidion, Holyhead Road, Denlightshire, closely covering extensive surfaces of the beds; Bala flags at Hafod Evan, Penmachno, Caernarvonshire; Bala schists of Cefn-y-coed, Llangedwyn, Montgomeryshire; Bala schists IV. side of Garn Brys, S. W. of Cernioge; abundant in the Bala schists of Bwleh, Llandrillo, Corwen, N. Wales; Dala schists of Llanwddyn, E. of Berwyn mountains; Bala sehists of Das Eithin ridge, Hirnant, Montgomeryshire; Bala schists of Pen Cerrig Serth, Builth, Radnorshire; Bala schists of Milltir Cerrig, Llangynnog, Montgomeryshire; Bala schists of Bwleh y Groes, S. of Bala, Merionethshire; Bala rocks of Ait yr Anker, Meifod, Montgomeryshire; schists of Alt tre Ffynnon; Bala limestone of Pentre ewm dda, S. of Gilyn Diffirys, N. Wales; Bala limestone of Llanfyllin, Montgomeryshire; common in the Bala quartzite of Carn Goran, Cornwall.

\section{Orthis REversa (Salt.) \\ Ref.-Salter in Sil. Foss. Irel. t. ว. f. 2.}

Sp. Ch.-Transversely broad-oval, or slightly quadrate when old, nearly orbicular when young; hinge-line very short; cardinal area low, triangular, three times wider than high, and inclined backwards at $130^{\circ}$ to the plane of the margins; opening narrow, triangular: receiving valve moderately convex towards the beak, which is small and pointed, with a wide flattened triangular depression, increasing in size towards the front margin ; sides slightly convex; entering valve much deeper than the receiving one; profile regularly arched; greatest depth about half way between the beak and front margin; obtusely subcarinated, rounded along the middle; sides slightly convex, and sloping rapidly to the margins; margins nearly level at the sides, raised at front towards the entering valve in a small rounded wave; surface radiated with narrow, minutely granular ridges, separated by flattened spaces, about equalling them in width; stria subequal in the rostral portion, but each pair receiving one, or sometimes two or three intermediate smaller ones, towards the margin, without distinet branching; fifteen or sixteen longitudinal strixe in two lines, at three lines from the beak; internal cast of receiving valve, with two very short divergent cardinal teeth, from which, on each side, a low tumid boundary to the muscular impressions (forming a shallow sulcus in the cast) extends forwards and outwards, enclosing a longitudinally oblong space, nearly half the length of the shell; cast of entering valve with a very small central pit of a rostral tooth, from which a shallow sulcus of an obtuse mesial ridge extends rather less than one-third the length towards the margin; interior of both valves nearly smooth, except towards the [FASC. II.] 
margins, which are marked by a narrow border of the external strix. Width eight lines, proportional length of receiving valve $\frac{80}{100}$, of entering valve ${ }_{1000}^{75}$, depth about $\frac{50}{100}$.

The striation of this species is minutely granular under the lens, as in the $O$. elegantula, with which imperfet specimens might very readily be confounded; but the strie are coarser, much more equal, obtuse and close together, in that species, dichotomise, and do not present the sulalternate character of the finer striation of this species, which is narrower, and very easily distinguished by the broad, flat, mesial depression in the receiving valve, when that part is seen. Some of the specinens shew the hinge-line more extended, and the mesial ridge in the entering valve defined, leading to the belief that the $O$. follax (Salt.) may be an extreme variety of the present species, mainly distinguished by a coarser striation.

Position end Locality.-Extremely abundant in the greenish sandstone of Mulock Quarry, Dalquorhan, near Girvan, Ayrshire.

\section{ORTHis Rigida (Davidson).}

\section{Ref.-Davidson, Lond. Geol. Journ, t. 13. f. 16 to 17.}

Sp. Ch.-Rotundato-quadrate; cardinal angles obtuse; hinge-line slightly less than the width of the shell, which is greatest about the middle; receiving valve evenly convex; greatest depth about the middle, with a very high, flat, triangular area, its height nearly one-third the width, inclined backwards at $95^{\circ}$; triancular foramen long, narrow, open; entering valve slightly convex, but the depth less than one-half of that of the receiving valve; cardinal area very narrow (one-third the heiglit of that in the receiving valve), inclining inwards at right angles, or nearly so, to the plane of the cardinal area of the receiving valve; both valves radiated with about fifty prominent, narrow, obtusely angular ridges, the primary ones usually branching at two or three lines from the beak, separated by equal and similar sulci, having sometimes three or four minute longitudinal strix in each sulcus under the lens, the whole being crossed by close, sharp, transverse strix. Width one inch, proportional length of receiving valve $\frac{95}{1+10}$, proportional length of entering valve $\frac{85}{1 \mathrm{Nu}}$, depth of both valves $\frac{45}{200}$.

This species is totally distinct from the Orthis calligramma and $O$. plicato, with which Mr Salter proposes to unite it (Mem. Geol. Surv. Vol. II. p.376), by its extremely large triangular cardinal area in the receiving valve placed at nearly right angles to the plane of the margins.

Position and Locality. - Not uneommon in the schists on the Bala limestone at Bryn Melyn Quarry, near Bala, Merionethshire; ? sandy Bala schists of Alt yr Anker, Meifod, Montgomeryshire; sandy Bala schists of Gaer Fawr, Welchpool, Montgomeryshire.

\section{ORTiIIS RUSTICA (Sow.)}

$$
\text { Ref.-Sow. Sil. Syst. t. 12. f. } 9 .
$$

Sp.Ch.-Totundato-quadrate, depressed; hinge-line equalling the width of the shell; sides subparallel, very slightly convex; front slightly convex; profile of receiving valve nearly straight, greatest height at the beak, from which the surface slopes gradually to the margins; cardinal area triangular, four times wider than high, inclined backwards at an angle of $103^{\circ}$; entering valve nearly flat, gently convex on the sides, obscurely channeled on the middle near the beak; surface of both valves radiated with thick subangular ridges, equal in thickness, and about fifty in number near the margin of a specimen nine lines long, simple, but of unequal lengths, separated by dcep concave spaces equalling them in width (six to seren ridges in a space of three lines, at nine lines from the beak); both ridges and sulci crossed by strong, regular, close, suberect lamine or lines of growth. Width one inch two lines, proportional length of receiving valve $\frac{76}{110}$, of entering valve ${ }_{i e n}^{70}$, depth of entering valve $\frac{8}{100}$, depth of receiving valve $\frac{22}{100}$.

I agree with Mr Davidson (Lond. Geol. Journ. p. 64) and Sowerby in thinking this species completely distinct fre 1! those in the Caradoe sandstone and Bala rocks $\mathrm{Mr}$ Sowcrby's figure represcnts the spaces between the ribs, and he omits the strong transverse sculpturing, which however is shern in Mr Davidson's figure, in the work above quoted.

Position and Locality.-Not uncommon in the Wenlock limestone of Wenlock, Shropshire. 


\title{
Orthis sagittifera $\left(M^{\circ} \mathrm{Coy}\right)$. Pl. 1. H. fig. $15,16,17,18,19$.
}

\author{
Ref.-Id. M Coy, Ann. Nat. Hist. 2nd Series, Vol. VIII. p. 398.
}

Sp. Ch.-Rotundato-quadrate, or oblong, length usually a little greater than the width, depressed; hingeline as wide as the shell; receiving valve obtusely subearinate along the middle, most so near the beak, which is projecting, pointed, very slightly incurved; apical angle $140^{*}$; profile only slightly curved; lateral margins horizontal, or with a slight mesial wave towards the receiving valve; cardinal area of receiving valve concave, triangular, four times wider than high, inclining backwards at $120^{\circ}$, triangular foramen narrow, open to the apex; entering valve gibbous, deeper than the other, greatest depth a little behind the middle, profile strongly arched; cardinal area very narrow (about one-third the height of the other, to which it is nearly at right angles, or in the plane of the margin; beak small, depressed, with a deep narrow mesial suleus, extending from it about half way to the margin : surface of both valves radiated with very close, numerous, obtuse, subequal, irregularly branching strix, separated by much narrower, deep, coarscly-punctured sulci; about nine in two lines at six lines from the beak, straight in the middle and along the hinge-line, slightly arched divaricatingly, and most branched at the sides; no fasciculation: internal cast of receiving valve without mesial septum; two short dental lamella diverging from the beak at $80^{\circ}$, forming part of the lateral boundaries of a short, strongly-defined, pruminent, flattened, undivided triangular pair of muscular inpressions slightly wider than long, scarcely one third the length of the shell, usually tripartite by a pair of wide longitudinal sulci; rest of surface finely radiated by inpressions of the external stric; cast of entering valve with the triangular boss of the foramen slit by a very slender rostral tooth, from which a narrow, obtusely-angular furrow (corresponding with the external one) extends about half the length of the shell ; cardinal teeth forming long deep sulei, rather more than ouefourth the length of the shell, and diverging at $60^{n}$, resembling the mark of a broad arrow-head, of which the mesial sulcus was the shaft; surface impressed by the external radiating striæ. Width (of small specimen)

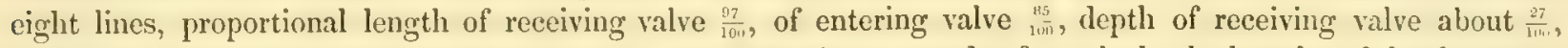
depth of entering valve varying from $\frac{25}{1+1}$ to $\frac{32}{11 \ldots}$. Length often upwards of one inch, the length and depth greater in proportion to the width in those old specimens.

This species is, perhaps, most nearly allied to the O. turgida ( $\left.\mathrm{I}^{\mathrm{c}} \mathrm{Coy}\right)$, from which it is listinguished externally by its flatter receiving valve, with nearly straight profile, and a cardinal area less than lialf the height, and a much more obtuse apical angle; the strice are thicker and coarser; internally the difference is still greater, the present species having much shorter and wider muscular impressions in the receiving valve, and the characteristic broad-arrow-shaped impressions of the rostral portion of the entering valve, produced by the comparatively long, diverging, dental lamelle, wholly separated from the mesial furrow. The gilsbous entering: valve, with its deep, narrow, mesial sulcus near the beak, coarser strie, and totally different internal characters, separate it from the $O$. retrosistria $\left(\Lambda^{\circ} \mathrm{Coy}\right)$, with which it also frequently occurs.

Position and Locality.-Extremely abundant in the decomposing sandy Bala schists of Aber Hirnant, E. of Bala, N. Wales.

Explanation of Figures.-Pl. 1. H. fig. 15. Natural size of rather small specimen of receiving valve, from the schists of Aber Hirnant.-Fig. $15 \%$. Portion of surface magnified.-Fig. 16. Fostral portion of entering valve, shewing the mesial suleus, cardinal area, and foramen.-Fig. 17. Internal cast of entering valve.-Fig. 18. Longitudinal section of both valves.-Fig. 19. Transverse section.

\section{Orthis sarmentos $\left(M^{c}\right.$ Coy). Pl. 1. H. fig. 25, 26, 27, 28.}

$$
\text { Ref.-MIC Coy, Silurian Foss. of Irel. t. 3. f. } 17 .
$$

$S p . C h$.-Transversely oblong, depressed; hinge-line as wide as the shell, ears rectangular ; receiving valve elevated towards the beak, which is prominent, flattened towards the margin; cardinal area large, triangular, inclining backward at $120^{\circ}$, its height (in narrow specimens) one-fourth of the width; entering valve gently convex along the middle, depth greatest at one-third the length from the beak, slightly exceeding that of the 
receiving valve, with a triangular cardinal area about half the height of that in the receiving valve, but placed nearly in the plane of the lateral margins: both ralves radiated with from fifty to sixty rather" thick, flexuous, rounded ridges, frequently and irregularly branching between the beak and the margin; finer, closer, and less branched towards the sides; about five in two lines in middle of front margin: internal cast of receiving valve with two very long, strongly-marked, dental lamella diverging at $40^{\circ}$, nearly straight, with a very slight inward curve at their extremities, forming the lateral boundaries of the very large triangular, prominent pair of muscular impressions, which reach rather more than two-thirds the length of the shell, finely sulcated longitudinally, and separated by a slender, indistinct impression of a mesial ridge; surface exterior to the muscular impressions strongly marked by the external ridges; internal cast of entering valve with a moderate elliptical pit of the simple rostrial tooth, and two short, triangular, strongly-diverging impressions of the cardinal teeth; immediately within and in front of which are the two obtuse obliquely conical bosses, produced by the muscular impressions, separated by an obtuse, short sulcus, from a rounded mesial ridge, not defined in front or at the sides; anterior pair of impressions invisible; surface sharply radiated with the external ridges.

This species varies so much in form from compression in the schistose rocks, that I can scarcely renture to give the proportions, but I believe the true form to be pretty nearly such as I have figured in the above work, namely, about three times wider than long, with a straight front margin, and nearly rectangular sides; but some specimens (distorted by pressure, in my opinion,) are as long as wide; the average length is ahout seven lines. The species is very easily recognized by the coarse, frequently-branched, twig-like ridges in all the middle part of the shell, the lateral ones being more nearly straight, smaller, and frequently simple, and internally in the great length and distinetness of the prominent muscular impressions. The great number of the ridges separates it from the $O$. Actonic, to which however it has no real affinity in any of its internal or external characters.

Position and Locality._Extremely common in the Bala schists of Llyn Ogwen, N. Wales.

Explanation of Figures.-Pl. 1. H. fig. 25. Natural size of transversely elongated specimen, from the sehists of Llyn Ogwen.-Fig. 26. Internal cast of receiving valve of possibly normal form, shewing the high cardinal area and long dental lamellx.-Fig. 27. Internal cast of entering valve, shewing the slender rostral and cardinal teeth.-Fig. 28. Longitudinal section of both valves.

\section{Ortiris testudinaria $(D a l$. $)$}

\section{Ref.-Dal. Act. Holm. 1827, t. 2. f. 4. Sil. Syst. t. 20. f. 9 and 10.}

Sp.Ch.-Truncato-orbicular or rotundato-quadrate, depressed, receiving valve obtusely subcarinate along the middle, from whence the sides slope with very slight convexity to the margins; hinge-line almost as wide as the shell, the greatest width being slightly in front of it; the sides of the shell subparallel, front wide, with a very faint sinus in the margin towards the receiving valve; beaks small, pointed, not much incurved, but reaching the level of the lateral margins, from the backward inclination of the cardinal area, the height of which is only one-eighth of its width; entering valve slightly convex on the sides, with a narrow mesial hollow from the beak, becoming wide and hollow towards the margin; surface radiated with numerous strong, irregularly unequal, obtusely angular ridges, subalternate in height, separated by sulci about equalling them in width; the ribs are nearly simple and subequal for three or four lines from the beak, increasing in number towards the margin, both by intercalation of new ridges and by the branching of the old into three or four smaller, fasciculated by the greater strength of the original sulci, usually including three or five of the smaller towards the margin, the size of the ribs being greatest about the middle of the shell; at three lines from the beak of receiving valve about five to seven (most usually the former) strix in the space of two lines, about the same or slightly more numerous (about seven in same space), at the margin of adult specimens; surface fincly granulo-punctate. Interior with sharply angular, narrow, extensions of the rilss nearly to the beak, separated by a wide space; receiving valve with two very small diverging slits of cardinal teeth, from the ends of which a faint furrow encircles the muscular 
impressions of the beak, less than one-third the length of the shell; entering valve with two very short pits for eardinal teeth. Width nine lines, proportional length $\frac{84}{100}$, length of entering valve $\frac{73}{100}$, depth $\frac{25}{100}$.

The slight convexity of the receiving valve, the wide and very low cardinal area, and the very much coarser, more separated, angular, and less equal ridging of the valves, easily separate the species from the O. elegantula, and the greater size and depression of the valves, as well as the less number of strix at a small distance from the beak, separate it from the $O$. parva. Gothland specimens agree in general form, proportional measurements, and in the remarkably low cardinal area, hut seem to have the entering ralve often almost entirely concave, the receiving valve more obtuse, and the ribbing slightly more regular, but the olserved varieties in the Gothland specimens shew these to be inconstant, and irregular peculiarities of a fer specimens. I have not observed any remarkable transverse intercostal strix spoken of by some writers, either in our British or Gothland specimens, both shew the usual transverse continuous lines of growth at the margin, as in all shells, but in some states of preservation the sides of the ribs are crenulated by imbricating exfoliations, sometimes very strongly marked in partial casts.

Position and Locality.-Very common in the Caradoc limestone and fine sandstone of Horderly; common in the limestone of the Hollies, Church Stretton, Shropshire; Eala limestone and sandstone of Alt yr Anker, Meifod, Montgomeryshire; very common in the partially oolitic Bala limestone of Mres-y-fallen, Bala. Merionethshire; fine Pala sandstone of Bodean, Pwllheli, Caernarvonshire; caleareous Bala schists of Dolydi Ceiriog, S.E. of Moel Ferna, E. of the Berwyn Mountains; Bala limestone of Fridd Corny, Llanwddyn; ? Rala schists of Bala, Merioncthshire; common in the Bala limestone of Mathyrafal, S. of Meifod, Montgomeryshire; ? Bala flags of Bryn Eithen, Penmachno, N. Wales (var. "with rather more numerous strix); Eala schists of Cyrn y Brain, W. of Wrexham, Denbighshire; var. ", Bala schists of Selattyn Road, S. of Llangollen, N. Wales; rare in the laala schists of Moel Uchlas, Montgomeryshire; Bala schists of Cader Dinmael (var.) near Corwen, Denbighshire; Bala schists of Pen y Park, Llanfyllin; Bala schists of C'wn Lanerch Bettws (S. of), Caernarvonshire; sandy Bala schists of Gaer Fawr, Montgomeryshire; rare in the sandstone of Dalquorhan, Ayrshire.

\section{Orthis turgida ( $\boldsymbol{M}^{\circ} \mathrm{Coy}$ ). Pl. 1. H. fig. 20, 21, 22, 23, 24.}

\section{Ref.-Id. McCoy, Annals Nat. Hist. 2nd Series, Vol. VIII. p. 399.}

S\%. C \%.-Longitudinally ovate, globose, margin very obtuse, greatest width slightly in front of the hingeline, which is slightly less than the width of the shell; receiving valve very gibbous, profile much arched by the large beak declining nearly to the level of the lateral margins; greatest depth about the middle of the length; in old specimens there is a faint, wide, shallow depression towards the front margin, which gradually changes into an obscure prominence towards the beak or in the young; sides tumid; beak long; apical angle $100^{\circ}$; entering valve extremely gibbous, snmetimes henispherical, in some specimes more depressed but remaining remarkably tumid towards the margins; a deep narrow sulcus extends from the beak about half way to the margin, becoming rapidly effaced by widening and flattening towards the front, which is depressed with a narrow sinus in young specimens (from the mesial sulcus), and rery slightly raised with a wide shallow wave (not affecting the surface) in old individuals (from the slight mesial depression of the old recciving valve); both valves covered with numerous fine, sharply defined, obtuse strix, separated by flattened spaces equalling them in width, bifureating two or three times between the beak and margin, where in old individuals they are a little finer than in the middle of the shell, eight to ten in two lines at six lines from the beak, about ten to twelve at the front margin ten lines from the beak; cardinal area in receiving valve very large, flat, nearly half as high as wide, inclining backwards at $130^{\circ}$; foramen narrow, triangular, entirely open; area of entering valve flat, triangular, about seven times wider than high: internal cast of receiving valve with strong dental lamellie, diverging at 50", forming the posterior lateral boundaries of a narrow, ovate, stronglydefined pair of muscular impressions, reaching half the length of the shell, not divided by any mesial septum, but having one or two strong sulci on each side; margin finely sulcated by the extcrnal strix, faint extensions: of which reach a variable distance towards the beak : cast of entering valve very tumid, nearly smonth, decply slit towards the beak by the very deep narrow sulcus left by a thick mesial septum, reaching half the length 
of the shell, and to which the lamellie of the very short thick cardinal teeth seem to converge, forming the mesial septum by their union; the wide triangular boss of the foramen slit by a slender rostral tooth. Length of small specimen nine lines, proportional length of entering valve $\frac{75}{10,}$, wilth $\frac{45}{100}$, depth of receiving valve $\frac{35}{100}$ to $\frac{45}{100}$, depth of entering valve $\frac{35}{100}$ to $\frac{25}{100}$, (length occasionally one inch).

From the great variation in the proportional depth of the entering valve in different specimens, I am uncertain which of the valves is the deepest, although I have little doubt the entering one is so. I have seen small specimens confounded with $O$. elegantula, from which the characteristic turgid appearance from the tumidity of the sides, larger mesial strise, \&c. distinguish it. In the adult state the tumid form, and deep short furrow in the rostral half of the entering valve, distinguish it easily from all I know.

Position and Locality.-Extremely common in the Bala schists of Craig y beri, Llanarmon-fach, Denbighshire; Bala schists of Coed Sion, Llangadoc, S. Wales; very common in the Bala sehists of Aber Hirnant, E. of Jala, N. Wales; Bala limestone and coarse schists of Goldengrove, Llandeilo, Caermarthenshire; Balaschists of hill half mile N. of Conway Falls; common in the Bala limestone of Llandeilo, Caermarthenshire; Bala limestone of Mathyrafal-fridd, Meifod, Montgomeryshire; sandstone of May Hill, Gloucestershire; Upper Bala limestone of Craigwen.

Explanation of Figures.-PI. 1. H. fig. 20. Natural size from the limestone of Llandeilo.-Fig. $20 \alpha$. Portion of surface magnified.-Fig. 21. Internal cast of receiving valve from Goldengrove.-Fig. 22_23. Internal casts of entering valve, the former from Craig $\mathbf{y}$ beri, the latter from the hills $\mathrm{N}$. of Conway Falls,-Fig. 24. End view.

\section{Orthis Vespertilio (Son.)}

Ref. and $S y n=0$. bilobata Sow. Sil. Syst. t. 19. f. 7. + Orthis Vespertilio Sow. Sil. Syst. t. 20. f. 11.

Sp. Ch.-Rotundato-quadrate, hinge-line slightly exceeding the width of the shell, sides subparallel, slightly convex, or a little concave close to the cardinal angles, which are thus rendered acute; front wide, obtusely bilobed by a shallow sinus in the middle; entering valve very gibbous, deeply bilobed by a strong obtusely angular sinus, dividing the beak and extending thence to the sinus in the margin, which it very slightly elevates towards the receiving valve; receiving valve flattened or slightly concave or convex, with a very strong, prominent, angular ridge, extending sharply from the beak to the sinus in the front margin; cardinal area rather narrow, triangular, flattened, height about one-eighth the width in the receiving valve, and inclined backwards at an angle of about $115^{\circ}$, parallel-sided and nearly in the plane of the margins in the gibbous entering valve, and rather more than half the height of that of the receiving valve; both valves marked with very numerous, close, sharply angular, radiating ridges, frequently dichotomising; the intervening sulci very variable in strength, which in many specimens produces a strong fasciculation; four or five small sulci between each pair of larger, (the larger sulci forming broad undulations on the cast, which is marked by the finer ones only near the margin), but in other specimens, or other parts of the same specimen, the sulcation is nearly uniform; angular interspaces about as wide as the ridges, transversely crenulated, about eight or nine strix in two lines at four lines from the beak, or six or seven in the same space at the margin, an inch from the beak: internal cast of entering valve having the triangular boss of the foramen divided by a large ovate pit of the rostral tooth; cardinal teeth short, triangular, very divergent, forming thick ovato-triangular pits close in front of the beak; separated by the deep mesial sulcus, are the two obtuse beaklike prominences of the posterior pair of muscular impressions, which have no visible anterior or lateral boundaries; receiving valve with two thick, short, dental lamella, diverging at an angle of $110^{\circ}$, and a very small mesial septum, with a faintly marked radiating muscular impression, reaching one-fourth the length of the shell. Width one inch eight lines, proportional length of either valve $\frac{15}{\mathrm{lnw}}$, depth most usually $\frac{25}{\mathrm{in}}$, but occasionally $\frac{10}{100}$ or $\frac{50}{100}$.

This species varies prodigiously in the amount of gibbosity of the bilobed, entering valve, ranging by imperceptible gradation from almost hemispherical to nearly flat: the receiving valve also varies but to a less extent; it is always approximately flat at the sides, but varies from convex to concave, and after the 
careful examination of a very extensive suite of fine specimens, I am accordingly convineed of the specific identity of the O. bilobata and $O$. Tespertilio of Sowerby, as suggested by Prof. Phillips and Mr Salter in the Memoirs of the Geological Survey.

Position and Locality.-Very common in the fine Bala slates of Blain y Cwm, WV. of Nantyre, Glyn Ceiriog, Denbighshire; common in the fine Caradoe sandstone of Acton Scott, Shropshire; very common in the Bala sandstone of Alt yr Anker, Meifod, Montgomeryshire; very common in the Bala schists of Bryn Melyn, near Bala, Meri nethshire; common in the Lala schists of Das Fithen ridge, Hirnant, Montgomeryshire; common in the calcareous Bala sehists and limestone of Cader Dinmael, near Corwen, Denbighshire; in the fine Caradoc sandstone of Horderly W.; in the Bala schists of Rhiwargor, near Llanwddyn, Montgomeryshire; very common in the Bala schists of Gelli Grin, Bala, Merionethshire; Bala schists of Cwm of the Cymmerig, Bala: in the lower Bala rock of Moel y Garnedd, Bala Lake; Bala schists of hill over Bala turnpike, N.E. of Bala Lake; Bala schists of Tan y Bwlch-y-Groes, S. of Bala, Merionethshire; Bala limestone of Gaer Fawr, Welchpool, Montgomeryshire; common in the Bala limestone of Coniston IVaterHead, Lancashire; schists of Bwlch y Ciban; one doubtful specimen in the Bala sehists near Corwen, Merionethshire; Bala schists of Moel Uchlas, Montgomeryshire; Bala schists of Llwyn-y-ci, N. W. of Bala;

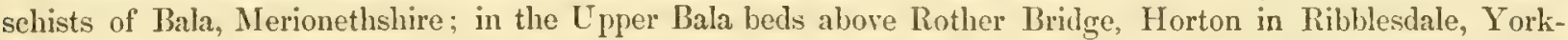
shire; Bala limestone, Llandeilo, Caermarthenshire; one doubtful specimen in the Bala schists of Pen Cerrig Serth, Builth; Bala schists of Wiifa, near Penmachno, N. Wales; a doubtful much depressed variety of the entering valve in which the dental lamellæ seem to diverge at a less angle, and the rostral tooth much more slender, occurs with the ordinary types in the sandy Bala schists of Das Eithen ridge, Hirnant, Montgomeryshire.

\section{Genus. ORTIIISINA $\left(d^{\prime} O r b.\right)$}

Gen. Char.-External characters of Orthis, but the triangular pit in the cardinal area of the receiving valve closed by a concave or convex cicatrix, with an oval perforation near the apex (as in Strigocephalus); interior of receiving valve with two broad dental lamella bordering the cardinal pit and converging to a mesial line at the surface of the shell; interior of entering valve with a trifid rostral tooth (as in Orthis), from which a small mesial septum extends towards the margin; lateral cardinal teeth as in Orthis.

As the lines of growth are convex towards the beak and formen on the deltidium-like inflexion of the shell, which as in Cyrtic fills the cardinal pit, the thought occurs that the foramen may be the result of disease; but $I$ can give no more than the suggestion from the specimens $I$ have seen.

\section{Orthisina ascendens (Pand. Sp.)}

Ref. and Syn.-Pronites adscendens Pander, Beitr. z. Geol. des Russ. Reiches, t. 17. f. 6.

$S_{p}$. Ch.-Rotundato-quadrate, hinge-line slightly exceeding the width of the shell, in very small pointed ears; sides subparallel; front broad, often slightly sinuate in the middle, gently curved; receiving valve subpyramidal, greatest height at the point of the beak, from which the surface slopes almost straightly to the margins, the evenness of the surface interrupted by flat step-like zones of growth, about a line apart; cardinal area triangular, twice as wide as high, nearly vertical, or inclining towards the front margin, at an angle of $60^{\circ}$; pseudo-deltidium extremely wide, prominent, convex, crossed by nearly direct lines of growth, leaving a large irregular opening between its apex and the point of the beak; surface radiated with coarse, narrow ridges, irregularly bifureating about once, separated by very deep sulci, narrower than the ridges (eight ridges in two lines at four lines from the beak). Width nine lines, proportional

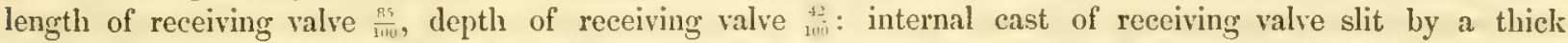
mesial septum, extending half the length of the valve, from which two dental lamella diverge with a considerable curve to form the hood-shaped lateral boundaries of the cicatrized opening.

I have not seen the entering valve of this species, but according to De Verneuil and Pander it is about laalf the depth of the receiving valve, gently convex in the middle, and with a nearly obsolete, linear, 
area. Our specimens correspond precisely with Pander's type-figure above quoted, but if, as M. de Verneuil supposes, the various other species, on that and the succeeding plate be only varieties, it is obvious that there is considerable variety in the depth of the valves, and that the cardinal area does not invariably lean forwards to the extent mentioned above, but has sometimes even a slight backward inclination, as in the Orthido generally; and in this case I think there could be no doubt that the whole might be well referred to the 0 . zonata of Dalman; but as I have not examined that species, I am unwilling (like $M$. de Verneuil) to make an uncertain approximation.

Position and Locality.-Not uncommon in the Bala slates of Cefn Coedog, Corwen, N. Wales; rare in the Bala schists of Cyrn y Brain, W. of Wrexham, Denbighshire.

\section{Ortuisina Scotica $\left(M^{\circ} C o y\right)$. Pl. 1. H. fig. 29.}

\section{Ref.-Id. Mc Coy, Annals Nat. Hist. 2nd Series, Vol. VIII. p. 400.}

$S p . C h$.-Subquadrate, valves evenly convex, much depressed; hinge-line as wide as the shell; apical angle $120^{\circ}$; sides subparallel, front with an obsolete emargination in the middle, entering valve gently convex, with an obscure narrow mesial depression from the beak to the margin; receiving valve with projecting beak, not ineurved, profile consequently nearly straight, very obseurely subcarinate along the middle, sides gradually sloping to the margins; cardinal area very narrow, parallel-sided in the entering valve, wide, flat, triangular and inclining backwards at only $120^{\circ}$ in the receiving valve; psendo-deltidium and deltidial pit concave, foramen oval, near the apex: surface radiated with twenty eight thick, simple, subequal ridges, separated by deep sulci, rather less than the ridges in width (three in two lines at six lines from the beak in the middle). Width one inch, proportional length of receiving valve $\frac{85}{100}$, length of entering valve $\frac{72}{100}$, greatest depth of both valves (about the middle) $\frac{45}{100^{\circ}}$.

There are two or three strong imbrications of growth at the margin, but I cannot distinguish any superficial striae in the specimens at my command. In form it is intermediate between the 0 . inflexa and the O. plana (Pander Sp.), but is more depressed, the beak of the receiving valve not at all incurved, the pseudo-deltidium concave outwardly, and is easily distinguished by its comparatively few, thick, simple ribs.

Position and Locality.-Very common in the concretionary limestone of Craig Head, near Girvan, Ayrshire; calcareous shales of Colmonel on the Stinchar.

Exptanation of Figures.-Pl. 1. H. fig. 29. Natural size from the limestone of Craig Head; $29 \alpha$, profile; $29 b$, end view.

\section{Genus. LEPT ENA (Dal.)}

$$
S y n_{0}=\left(\text { Leptcena restricted + Strophomena Raf. + Leptagonia } \mathrm{M}^{\mathrm{c}} \mathrm{Coy}+\text { Chonetes Fisch. }\right)
$$

Gen. Char.-Semicircular, depressed, entering valve concave, the other evenly convex from the hingeline, which is as long as the shell is wide; cardinal area distinct, slightly rhomboidal, about equally formed of both valves; the convex or receiving valve has a triangular opening nearly filled by the projecting angle of a rhomboidal, two or four-lobed, boss at the beak of the entering valve, leaving only a minute perforation, separated by a small pseudo-deltidium from the apex; punctured structure minute, often indistinct or obsolete: internal surface rough with little points; entering valve with a small, bifid tooth at the beak, in front of which are two small diverging ridges, between which is a moderate longitudinal septum. Some species shew a minute tubular foramen at the apex of the beak.

This genus may be said to embrace four sections or subgenera not worthy I think of generic rank, on careful study of a very extensive suite of specimens of most of the known species. These are :- 1 st, $L e p$ tene Dalman, restricted to the type of his last species the L.transecrsalis, in which the valves are almost equally curved in the same direction, the receiving or foraminated one convex, the other concave outwardly. 2nd, Strophomena, in which the valves are flat or very slightly convex when young, the margin in a few species 
becoming by age deflected usually towards the receiving valve: e.g. L. euglypha (Dal.) and Strophomena rugose (Raf.) 3rd, Leptagonia ( $\left.\mathrm{II}^{\mathrm{c}} \mathrm{Coy}\right)$, with both valves abruptly bent at right angles towards the entering valve, and the rostral portion concentrically wrinkled. 4th, Chonetes (Fischer), only differing from Leptance (as restricted) by having a row of spines on the hinge-line, thus approaching Productus. All the above types, including all Dalman's species, have a foramen between the beaks, contrary to his definition.

\section{Sub-genus. LEPTENA restricted (see remarks on Genus).}

\section{LEPT zena Alternata (Conrad.)}

Ref. and Syn.-Geol. Rep. New York, 1838, and Hall, Pal. New York, t. 31 a. f. 1. and t. 79. f. 2.

Sp. Ch.-Longitudinally semielliptical or transversely subquadrate; receiving valve gently convex, along the middle, with a very short mesial sulcus close to the beak, gently deflected at the side margins when old; entering valve flat, or slightly concave; cardinal area very narrow, inclined back at about $120^{\circ}$ : surface of both valves radiated with very fine linear thread-like strix, separated by equally wide, flat, coarsely punctured spaces, when partially decorticated; strix thicker and closer together, when the surface is preserved; strix of two, more or less distinct sizes, usually three of the finer, between each pair of the larger; the middle subsequently increasing in size, and a new pair of small strix being intercalated on each side; about eighteen strix in the space of two lines at six lines from the beak: interior of the valves marked with radiating external strix, and with very numerous, obtuse granules, nearly corresponding with the external punctures. Length one inch, width varying from a little more to a little less than the length, proportional depth about $\frac{20}{100}$.

It may, I think, be doubted, whether this will not ultimately prove a mere variety of Strophomena ? compressa, the internal characters both of the entering and receiving valve as figured by Hall, and of the muscular impressions and ridges, and cardinal teeth, agreeing precisely with those of the Strophomena? compressa, as I have observed; the only differences being that the larger strixe are more distinct, and the large valve more convex in the alternata than in the compressa; and in the latter $\mathrm{I}$ have not seen the small foramen in the apex of the beak.

Position and Locality.-Common in the Bala limestone of Balmae Shore, Kirkcudbright; ? a flattened variety in the limestone and sandstone of Dalquorhan, near Girvan, Ayrshire.

\section{Leptana connugata (Portk. Sp.)}

\section{Ref. and Syn.=Orthis Id, Portlock, Geol. Rep. t. 32. f. 17.}

Sp.Ch.-Semiorbicular; receiving valve gently convex; hinge-line slightly exceeding the width of the shell; surface radiated with strong, narrow, simple, prominent, slightly divaricating ridges, running straight along the hinge-line, increasing irregularly towards the margin by intercalation, about five in two lines at two lines from the beak, or six in the same space at four lines; intervening spaces flat with from three to seven fine, longitudinal strix between each pair of ridges, and crossed by large irregular wrinkles, about the width of the spaces apart, which do not cross the ridges nor form regular concentric lines; all the stria crossed by extremely minute, close, regular lines of growth. Width ten lines, proportional length $\frac{60}{100}$ to $\frac{70}{100}$.

I have not had an opportunity of examining either the entering valve, the interior, or the cardinal area of this extremely beautiful and distinct species, which however I place in Leptena on the authority of M. Barrande (see his Memoir, "Ueber die Brach. der Sil. Schich. von Bolmen," in Haidinger's Naturwissenschaftliche Abhandlungen, Band 2), where however he figures the large ribs both of this species and the adjoining $L$. sericea much too far apart: he represents the entering valve nearly as concave as the receiving is convex, and the cardinal area very low.

Position and Locality.-Rare in the schists of Goldengrove, Llandeilo, 


\section{LEPTENA DELTOIDEA (Conrad.)}

Ref. and Syn.-Conrad, Geol. Rep. 1838. Hall, Pal. New York, t. 13 A. f. 3. > L. semi-oralis (McCoy), Sil. Foss. Irel. t. 3. f. 6.

$S p . C h$.-Semioval ; hinge-line exceeding the width of the shell, forming short, convoluted, rounded ears; visceral disk obscurely defined, nearly semicircular, front narrow, rounded; receiving valve gently convex from the beak to the edge of the visceral disk, from which it is abruptly arched at an obtuse rounded angle, to form a deflected margin nearly as long as the visceral disk; cardinal area low, triangular, with a very wide, triangular, cicatrized foramen, and a small round aperture at the apex; surface of the visceral disk with more or less defined transverse wrinkles, usually nearly obsolete, but varying greatly in number, strength, and continuity, crossed by radiating, obtuse strix, twelve to twenty, or commonly about fourteen in tivo lines, at four lines from the beak, rarely subequal or alternate, most usually with every third or fifth line larger than the others about the middle of the shell : internal cast of receiving valve striato-punctate, the triangular boss of the foramen having a small tubular papillate tubercle on the apex (corresponding with the external foramen at the point of the beak); two short cardinal teeth border the foramen, diverging at $90^{\circ}$, with long subparallel or slightly incurved dental lamella, extending from their distal extremities from half to two-thirds the length of the visceral disk, enclosing the oblong pair of sulcated muscular impressions, which are nearly twice as long as wide. Width one inch five lines, proportional length of visceral disk $\frac{47}{110}$, depth of deflected front $\frac{35}{100}$, depth of receiving valve $\frac{30}{100}$.

This extremely variable species can scarcely be defined. Some of our Coniston specimens have scarcely a trace of transverse wrinkles, and have the profile gently arched from the beak to the length of the visceral disk, whence the front is rather more abruptly arched, the strix being equal on the sides, but every 3rd, 5 th, or 7 th being larger than the rest on the middle of the shell, agreeing exactly with IIall's figures $3 a$ and $3 d$ : to this variety it seems the $L$. complanata of Sowerby should be united. From these the passage is most gradual, in specimens from the same loeality, to those with a more abruptly deflected front, less convex visceral disk, and gradually developed more or less regular concentric wrinkles, agreeing with Hall's figures $3 e$ and $3 f$, and his figures 4 of the same plate, which he refers to the $L$. temistriata of Sowerby; from which all the varieties may be easily distinguished, by the narrow, rounded front giving the semi-oval instead of the rhombic outline to the disk, and the inequality of the strie, as well as the narrower, oblong muscular impressions, and the distinct tubular perforation of the beak, with its corresponding mamilla on the apex of the cast. This latter variety seems to include the still more strongly pronounced form which I have called $L$. semi-ovalis, and found very constant in its characters in the Bala limestone of Chair of Kildare, in Ireland. The different varieties of this species might be separated in the different subgenera Leptrena and Leptagonia, shewing these latter to be but sections of one genus.

Position and Locality.-Common in the Coniston (Bala) limestone of Coniston, Lancashire; Bala limestone and sandstone of Alt yr Anker, Meifod, Montgomeryshire; not uncommon in the Caradoc sandstone of Horderly.

\section{Var. $\beta$. undata $\left(M^{\circ}\right.$ Coy). Pl. 1. H. fig. 38, 39.}

Ref. and Syn.=Orthis undata (McCoy), Silurian Foss. Irel. t. 3. f. 21.

This apparently distinct shell is semioval, about one and half inches long, with a narrow deflected border rarely half an inch deep, the visceral disk gently convex, rugged, with twelve or fourteen very large undulating concentric wrinkles, sometimes much interrupted, and nearly obsolete (like the type I originally figured), crossed by radiating obtuse strice, which vary singularly in size in the different specimens, alike in all other respects-one specimen laving only ten stria in two lines at four lines from the beak, and another having twenty-four, and many specimens having the intermediate numbers: the lines are often subequal, or in all the middle portion towards the margin every 5 th or 7 th considerably larger than the rest. In the specimens I originally described the surface seemed smooth, except some faint traces which 
I mentioned of longitudinal strix; the better specimens now before me are all distinetly striated, but so much alike in other respects that I have no doubt of their identity, the geological position of each being alike. The specimens of this variety which shew the dental lamelle seem to have them more divergent, and the muscular impressions wider than the typical form. Some specimens of this variety have upwards of twenty concentric rows of faint, interrupted, concentric undulations, giving a curious rippled appearance to the surface, from which I named the species, when I believed it distinct.

Position and Locality.-Var. $\beta$. undata. Common in the Bala limestone of Llandeilo, Caermarthenshire; Bala limestone of Llwyn-y-ci, N.W. of Bala; Bala limestone of Pont y Glyn Diffirys, WV. of Corwen, Merionethshire; Bala limestone of Brynbedwog Quarry, near Bala; ditto Cymmerig, E. of Bala; Bala schists of Bryn Melyn, and Gelli Grin, Bala, Merionethshire; Bala schists of Cyrn-y-brain, W. of Wrexham, Denbighshire; Bala sandstone of Alt yr Anker, Meifod, Montgomeryshire; Bala limestone of Coniston, N. Lancashire; ? in olive shale of Coed Sion, Llangadoc, S. Wales.

Explanation of Figures.-PI. 1. H. fig. 38. Natural size of a variety with continuous wrinkles, from Llwyn-y-ci ; fig. 39, variety with interrupted wrinkles from Llandeilo; fig. 39 a, superficial strix of ditto magnified ; fig. $39 b$, profile of both valves; fig. $39 c$, internal cast of rostral portion of receiving valve, shewing the dental lamellæ, from Bryn Melyn, Bala.

\section{Lept ma lievigata (Sonv.)}

Ref. and Syn.-Sow. Sil. Syst. t. 13. f. 3. L. lepisma (Dalm. and Sow.) Salter in Mem. Geol. Surv. Vol. II. Part 1.t. 26. f. 3 and 4. (Not of Sow. Sil. Syst., and no such species described by Dalman).

Sp. Ch.-Shell gibbous, transversely oblong, or fusiform; hinge-line a little exceeding the widtl of the shell, forming short, abruptly contracted, slender pointed ears; cardinal area very narrow, triangular; sides and front nearly smooth, marked with excessively fine lines of growth, and towards the margin with extremely faint indications of very obtuse close ribs, separated by very narrow sulci, about nine in one line; margin forming a uniform short curve; surface fibrous, sulsstance thick, with rather distant, very large punctures on the internal cast: internal cast of receiving valve with an ovate, tumid pair of muscular impressions, extending scarcely one-third the length of the shell, cleft by the very deep slit of a prominent mesial septum from the beak, slightly exceeding them in length: internal cast of entering valve rough, with large spinulose puncta, and with a strong mesial septum, extending two-thirds of the length of the

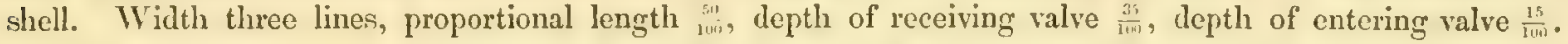

The figures given in the Memoirs of the Geol. Survey, as above quoted under the name Leptana lepisma (Dal.) var. minor, with reference to t. 8 . f. 7. of the Sil. Syst., certainly belong to this species, in which the faint broad stria are rarely to be found; and $M r$ Salter mentions that he doubts the distinction himself of the $L$. levigata. Further, I might mention, that there seems to be no such species as L. lepismce described in any of the works of Dalman; and the specimen so called by Sowerby I find agrees with Dudley specimens, which I have certainly determined to be the young of $L$. transversalis, on comparison with a number of Gothland specimens.

Position and Locality.-Not uncommon in the greenish mudstone of Clungunford, Shropshire; in the greenish sehists at Keeper's Lodge, Goldengrove, Llandeilo, Caermarthenshire; common in the schists of Mynydd-y-Gaer, Llanefydd, Denbighshire; in vast profusion in the decomposing schists of Dyffryn Castle, Devil's Bridge, N. Wales; also thickly covering the surface of thin gritty flags at Giwyddelwern, Derwen, Denbighshire; fine sandy flags near Welchpool, Montgomeryshire.

$$
\begin{aligned}
& \text { Leptema ? mindia (Son.) } \\
& \text { Ref.-Sow. Sil. Syst. t. 13. f. } 4 \text {. }
\end{aligned}
$$

Sp.Ch.-Semicircular, or obscurely quadrate; hinge-line slightly exceeding the width of the shell, forming very short pointed ears; cardinal area large, triangular, about five times wider than high in the receiving н II 2 
valve, nearly vertical, inclining backwards only at $115^{\circ}$; receiving valve subpyramidal, greatest depth near the point of the beak, which is only slightly incurved; a very obscure trace of mesial furrow; surface radiated with coarse angular ridges, dichotomising once or rarely twice between the beak and margin, separated by narrower sulci, which are strongly punctate; ten or twelve ridges in the space of one line near the margin: entering valve nearly flat, interior with a small prominent rostral tooth; a strong mesial septum, reaching nearly to the front margin, and two rather long eardinal teeth, diverging at $150^{\circ}$; the inner surface marked with four or five irregular rows of extremely large punctures or small pits. Average width two lines, proportional length $\frac{80}{100}$, depth about $\frac{20}{100}$.

Position and Locality.-Extremely common with the L. locvigata in the thin flaggy beds of Wenlock shale at Gwyddelwern, Derwen, near Corwen, Denbighshire; olive Wenlock shale of Llanfair, Welchpool; calcareous flags, bed of Dee, Llantsilio, S. of Llangollen; in decomposing bands of limestone above Rother Bridge.

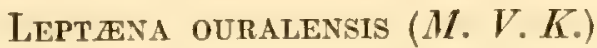

\section{Ref.-Murchison, de Verneuil, and Keyserling, Geol. Rus. t. 14. f. 1.}

$S p$. Ch._Subhemispherical, slightly depressed; front margin semicircular; hinge-line exceeding the width of the shell, forming obtusely rounded convoluted ears, separated by a shallow concavity from the body of the shell, which is evenly gibbous, strongly and regularly arched from the beak to the front margin, the greatest depth being at about the middle of the length; entering valve nearly as concave as the receiving one is convex; cardinal area low, triangular, nine or ten times wider than high: surface marked with strong filiform, radiating strix, between each pair of which are from five to nine much smaller, close, slightly undulating, parallel strix, the sulci between which are strongly punctured, the whole being crossed with extremely minute transverse lines of growth; about thirty-five strix in two lines at four lines from the beak, four of which are large (twentyfive in the same space at margin, three of which are large); interior surface closely and strongly pitted with minute punctures, and rather broad, (four or five in two lines from the margin,) slightly undulating, longitudinal, obsolete ridges, more or less branched towards the margin. Width two and half inches, proportional length $\frac{70}{100}$, depth $\frac{25}{120}$, distance between the valves one line.

This very remarkable species has exactly the form and size of the Producta hemisphorica of the mountainlimestone, and the same extremely narrow space for the animal between the valves, so that it might easily be confounded with it by a careless observer; the striation, however, as pointed out by the authors of the Geology of Russia, easily distinguishes the species, even when the distinct cardinal area is invisible; the substance of the shell is also very much thinner. Our specimens agree in every respect with those of the Oural, which are said to characterize the Upper Silurian rocks there.

Position and Locality.- Not uncommon in the limestone between Old Radnor and Presteign, Radnorshire.

\section{I.ePt ana quinquecostata ( $M^{\circ}$ Coy). Pl. 1. H. fig. 30, 31, 32.}

Ref. and Syn $=$ Orthis quinquecostata (McCoy), Sil. Foss. Irel. t. 3. f. 8.

Sp.Ch.-Nearly semicircular; hinge-line exceeding the width of the shell, forming acutely angular, convex ears; middle of receiving valve very gibbous; profile much curved from the inflection of the obtuse beak to the level of the lateral margins; cardinal area narrow, placed in the plane of the lateral margins; entering valve concave, about one-third the depth of the receiving valve, each valve with usually five, very large, prominent, angular ridges, about a line apart, radiating from the beak, each with a strong radiating line along its keel, intervening spaces between each pair concave, marked with ten or fifteen fine, sharp, longitudinal strix (sixteen in the space of one line in middle of front margin); close to the beak, and extending only one-third the length of the shell, are two short similar ridges, one on each side of the mesial one; in some specimens an additional pair of the large radiating ridges are developed at the sides, not reaching, however, to the beak : internal cast of receiving 
valve with a very short mesial septum, dividing the small, tumid, reniform pair of muscular impressions, reaching only one-fifth the length of the shell; from these five or six slender, branched impressions of the pallial vessels extend on each side to the margin, a broad border round which is very minutely and closely punctured under the lens, the rest of the cast seeming nearly smooth. Width seven lines, proportional length varying from ${ }_{100}^{40}$ to $\frac{65}{100}$ (the average being about ${ }_{100}^{50}$ ), depth $\frac{20}{100}$.

This species has some resemblance externally to certain varieties of the $L$. sericea, but is distinguished by the very small number of the large ridges, and their clevation on angular folds; these ridges, in by far the greater number of specimens, are only five, such being the case in all those I originally examined, giving rise to the specific name which I have adopted. This character is not so invariable as I supposed, for I have seen one specimen in which traces of two other lateral pairs were seen at the margin, and seven may be seen, not very uncommonly, but five is by far the most usual; internally it is easily distinguished from $L$. sericea by the extremely short muscular impressions. The affinity is perhaps greater with L.transcersalis, from which it differs externally in the same characters above noted, and internally by the much smoother casts, fewer delicate impressions of the pallial vessels, and the extreme minuteness of the punctation, differing remarkably from that of L.transersalis. Some specimens have small, oblique, concentric, undulating wrinkles on the sides of the beak, a few of which sometimes faintly pass across the rostral portion.

Position and Locality.-Bala schists of Cefn Rhyddan, Llandovery, S. Wales; very abundant in the Bala schists of Mathyrafal, Meifod, Montgomeryshire; Bala schists of Goleugoed, Llandovery, S. Wales; Bala schists of Penlan, Llandovery, S. Wales; Bala schists of Pen y Craig, Llangynyw, Montgomeryshire; Bala schists of Tyn y cabled, Llanfyllin, N. Wales; calcareous schists of Llangynyw Rectory, near Welchpool, Montgomeryshire (one specimen with oblique concentric wrinkles on the ears). Ordinary sized specimens, with the oblique wrinkles on the ears, not uncommon in the green, trappean, sandstone of Glenquaple, Ayrshire; in the similar rock at Ardwell, three and a half miles south of Girvan; one very large specimen (six lines long, with five principal stria, and one shorter additional one on each side, with minute, undulating, concentric wrinkles near the beak), from Colmonel, on the Stinchar; sandy schists of Craig Wen, Mathyrafal, Meifod.

Explanation of Figures.-Pl. 1. H. fig. 30. Natural size of transverse variety, with additional lateral ridges, from the schists of Mathyrafal; fig. 31, normal type, from the same locality ; fig. $3 \mathrm{~J}$ a, surface of ditto magnified; $31 \mathrm{~b}$, internal cast, shewing the short muscular impressions and the pallial ridges ; fig. 32 , very large depressed variety from Colmonel.

\section{LEPT AENA SERICEA (Sow.) \\ Ref-Sil. Syst. t. 19. f. 1, 2.}

Sp.Ch.-Transversely oblong, substance of the shell thick, very coarsely fibrous; hinge-line slightly exceeding the width of the shell; cardinal angles acute, sides gently convex, slightly converging; front nearly straight, wide; receiving valve much and regularly arched to the deflected margins; greatest depth at one-third from the beak; entering valve slightly flattened in the rostral portion, rather abruptly arched to the margin; greatest depth at two-thirds from the beak; often a few small converging wrinkles on each ear; both valves radiated with extremely fine, hair-like strix, separated by sulci equalling them in size, containing close rows of very minute punctures; at intervals of from one-half to one-fourth (near the margin) of a line apart, certain of the strixe become about twice the size of the others, including between each pair from five to ten smaller; about thirteen to sixteen strix in the space of one line, in the middle of front margin, at three lines from the beak; cardinal area in each valve low, triangular, that of the receiving valve about a third larger than that of the entering valve; rostral tooth very large, five-lobed, nearly filling the triangular foramen of the receiving valve, which is as wide as high, and the apex of which is closed by a small pseudo-deltidium : internal cast of receiving valve shewing two very short cardinal teeth, bordering the triangular boss of the foramen, diverging at about $135^{\circ}$, from the ends of which proceed two longitudinal, slightly incurved, slightly diverging ridges (forming slight furrows on cast), forming the outer boundaries of two long, prominent, obtusely ovate, muscular impressions, wide, and only separated near the beak by a very slender sulcus of a mesial septum, 
scarcely one-third the length of the shell; anterior boundaries sharp, diverging at about $70^{\circ}$, enclosing between them a prominent semielliptical, mesial space, and narrowing the anterior ends of the muscular impressions, from each of which extend four or five thick diverging and dichotomising impressions of the pallial and ovarian vessels, a couple of similar dichotomising impressions on each side of the mesial space, and three or four very short ones on each lateral margin; the rest of the surface marked with obscure traces of the external strix, punctured in lines, the punctures becoming much larger at the margin between the branches of the pallial vessels; interior of entering valve concave for two-thirds the length from the beak, the margin abruptly arched over, very closely punctured (not in rows), and marked at the edge with numerous short simple ridges; two very short cardinal teeth diverge from the rostral tooth; muscular impressions with very prominent boundaries all round, each one oblong, depressed, and nearly smooth in the middle, or subquadrate, slightly longer than wide; the two together transversely oblong, one-third wider than long, the width equalling the length of the valve; the two prominent inner boundaries leave a deep sulcus between them, at the anterior end of which only a very short mesial septum is developed, not reaching nearly to the beak; interior of the muscular impression nearly smooth, each divided by a faint diagonal ridge; the space immediately in front of the impressions coarsely pitted, and marked with a fer obscure branching impressions of pallial vessels, none of which are visible on the deflected front; cardinal angles irregularly punctured, and with minute wrinkles. Width eight lines, proportional length of receiving valve $\frac{5 s}{1+0}$, of entering valve $\frac{50}{100}$, depth of entering valve $\frac{15}{10,}$, depth of receiving valve $\frac{30}{100}$.

This species is totally distinct from the $L$. transversalis in its much coarser strix, very much finer and more numerous punctures, and in the proportional width and concavity (instead of convexity) of the muscular impressions within their prominent boundaries.

Position and Locality.-Greenish, sandy, Bala schists of Tan y Craig, Builth; Bala schists of Corwen, Merionethshire; Bala schists W. of Llanfechan, Montgomeryshire; Bala schists of Moel Uchlas, Montgomeryshire; Bala schists of Pen Cerrig Serth, Builth, Radnorshire; extremely common in the Bala sandstone of Alt yr Anker, Meifod, Montgomeryshire; common in the Bala schists of Cwm Lanerch, Bettws, N. Wales; common in the Bala schists of Cricor Mawr, S. E. of Llanelidan, Denbighshire; Bala schists of Llansantfraid, Gilyn Ceiriog, Denbighshire; common in the Bala schists of Cefn Coedog, Corwen, N. Wales; Bala sandstone of Bodean, Pwllheli, Cacrnarvonshire; common in the Bala schists and limestone of Rhosfawr, N. of Glog, Ilanfyllin, N. Wales; in the Bala schists of Cefn y coed, Llangedwyn, Montgomeryshire; a rather longer, extremely conrse variety, often an inch wide, extremely common, with the ordinary types, in the Bala schists of Gelli Grin, Bala, Merionethshire; impure Bala limestone of Goleugoed, Llandovery, S. Wales; Bala schists of Tan y Bwlch y groes, S. of Bala, Merionethshire; abundant in the Caradoc sandstone of Horderly, IV. and S.; Bala schists of Bryn Evan Yspatty, N. Wales; Bala limestone near Bryn Eithin, Penmachno, N. Wales; common in the calcareous Bala schists of Cader Dinmael, near Corwen, Denbighshire; Bala limestone of Tai yn y Nant, Bala; Bala schists of Milltir Cerrig, Llangynnog, Montgomeryshire; Bala schists of Selattyn Road, S. of Llangollen, N. Wales; Bala schists of Peniarth Meifod, Montgomeryshire; very common in the Bala schists and limestone of Pont y Glyn Diffirys, W. of Corwen, Merionethshire; very common in the Bala schists of Wilfa, near Penmachno, N. Wales; Bala schists S. of Llanfyllin, Montgomeryshire; Bala schists of Mathyrafal, S. of Meifod, Montgomeryshire; sandstone of the Hollies, Church Stretton, Shropshire; Bala schists of Das Eithin ridge, Hirnant, Montgomeryshire; sandy Bala schists of Pwllheli, Caernarvonshire; Bala schists of Cyrn y brain, WV. of Wrexham, Denbighshire; in the Upper Bala limestone above Rother Bridge; Bala schists of Gaer Fawr, Montgomeryshire; Bala schists of Beaver's Grove, Bettws-y-Coed, N. Wales; Bala schists and impure limestone of Pentre ewn dda, S. of Glyn Diffwys, N. Wales; schists of Penllys, W. of Meifod; ?var. in Bala limestone of Coniston Water-Head, Lancashire; var. spinangula common in Bala schists of Cwm of the Cymmerig, Bala; one doubtful specimen in the Bala schists of Tyn y cabled, Llanfyllin, N. IVales; var. in the Bala limestone of Craig Head, near Girvan, Ayrshire; in the Bala rock of Alt Goch, Llanfyllin, Montgomeryshire; rare in the hard calcareous Bala schists of Capel Curig; Bala limestone of Horton in Ribblesdale, Yorkshire; greenish Caradoc sandstone, top of Mocl Seisiog. 
Var, $\alpha$. RHOMBICA $\left(M^{\circ} \mathrm{Coy}\right)$.

In this variety the shell is more gibbous in the middle than in the true types, and less transverse, the proportional length varying from $\frac{65}{i m}$ to $\frac{\pi n}{1,0}$, as compared with the width, and the strong ridges fewer and often nearly a line apart, sometimes elevated on obtuse folds near the margin, in those respects approaching the L. transecrsalis, from which however it differs, in having the intervening strix of the same size and strength as the ordinary types, wanting the remarkably large punctures on the interior, dc.; the muscular impressions also agree rather with the $L$. sericea than with the $L$. transversalis.

Position and Locality (for rhombica).-Not uncommon in the Bala schists of Mathyrafal, S. of Meifod, Montgomeryshire; Bala limestone of Horton in Ribblesdale, Yorkshire; Bala schists of Tyn y cabled, Llanfyllin, N. Wales, and Bala schists of Pen-y-craig, Llangynyw, Montgomeryshire; Bala schists of Cefn Rhyddan, Llandovery, S. Wales; fine sandy Bala schists of Alt yr Anker, Meifod, Montgomeryshire; schists of Llyn Alwen, Denbighshire; Bala schists of Gelli Grin, Bala, Merionethshire.

\title{
Var. $\beta$. spinangula $($ Phil. $)$
}

The var. spinangula of Phillips (Mem. Geol. Surv.) has the length sometimes only $\frac{30}{100}$ in proportion to the width.

\section{Leptana tenuicincta ( $\left.\boldsymbol{I}^{\circ} \mathrm{Coy}\right)$. Pl. 1. H. fig. 40 .}

\author{
Ref.-Id. Micoy, Ann. Nat. Hist. 2nd Series, Vol. VIII. p. 401.
}

$S p . C h$. - Rotundato-quadrate; hinge-line as long as the shell is wide; cardinal angles forming nearly rectangular, small, flattened ears; sides subparallel, obtusely rounded, front, wide; receiving valve subhemispherical, very gibbous, greatest depth a little behind the middle of the shell : beak large, prominent, obtuse, incurved to the level of the lateral margins; cardinal area nearly in the plane of the lateral margins, very broad, flat, triangular, height rather more than one-fourth the width; triangular foramen narrow, closed by a convex pseudo-deltidium; entering valve very concave, with a mesial septum extending nearly to the margins; surface of both valves marked with very regular, minute, equal, rounded, concentric wrinkles, having a slight retral wave in the middle of the front, about twelve in the space of one line at the middle of the shell. Width about five lines, proportional length of receiving valve $\frac{90}{1009}$, of entering valve $\frac{75}{100}$, depth $\frac{65}{100}$.

This beautiful species seems almost identical in size, shape, and marking, with the Producta tenuicincta ( $\mathrm{I}^{\mathrm{C}} \mathrm{Coy}$ ), and Leptona enigma (Vern.), but has a very wide distinctly-marked cardinal area.

Position and Locality.-Olive Bala schists of Cefn Grugos, W. of Llanfyllin, Montgomeryshire.

Explanation of Figures.-Pl. 1. H. fig. 40. Natural size, shewing the entering valve, with the cardinal area and pseudo-deltidium of the receiving valve; fig. $40 \alpha$, profile of receiving valve; fig. $40 \mathrm{~b}$, longitudinal section ; fig. $40 c$, striation of surface magnified.

\section{Leptana tenuissimestriata ( $\boldsymbol{M}^{\circ}$ Coy). Pl. 1. H. fig. 44.}

\section{Ref. and Syn? $=$ Orthis lata Sow. Sil. Syst. t. 22. f. $10 ?=$ Orthis temuissimestriata $\mathbf{M}^{\mathrm{c}}$ Coy, Sil. Foss.}

Irel. t. 3. f. 20.

Sp. Ch.-Transversely oblong, or slighty fusiform, about twice as wide as long, moderately convex, regularly arched, profile nearly semicircular, greatest depth about the middle of the length; entering valve flattened, about one-third the depth of the receiving one; hinge-line equalling the width of the shell; cardinal angles very slightly acute in depressed specimens, but sometimes forming acute convoluted ears; beaks very small : surface of both valves radiated with very elose, fine, slightly unequal strix, often subalternate near the margin, every third or fifth being often a little larger than the others, increasing principally by intercalation of new strix, size nearly uniform from the beak to the margin; intervening sulci much narrower than the ridges, and 
marked with very large punctures, which form close punctured lines from the beak to the margin in casts; about thirty strix in the space of two lines at three lines from the margin: receiving valve with a very short mesial septum, about one-fifth the length of the shell, and two dental lamella diverging at about $100^{\circ}$, forming the anterior lateral boundaries of two very short, diverging, ovate, muscular impressions, reaching rather more than one-third the length of the shell. Width seven lines, proportional length $\frac{55}{100}$, depth of receiving valve $\frac{20}{100}$ to $\frac{27}{100}$, depth of entering valve $\frac{10}{100}$.

Mr Sowerby states that both valves of his shell are convex, which, if correct, would render his species distinct from that before us, which has the distinctly marked hinge of Leptena, with both valves curved in the same direction. In form it strikingly resembles the Leptena (Chonetes) lata of the Ludlow rocks, but is destitute of spines on the hinge-line, and is easily distinguished by the much greater fineness of the strix, or the greater number in a given space. When the larger strie can be distinctly seen, which is not often the case, the resemblance is very strong to Leptana scricea, from which it differs in the flatter entering valve, in the fine, more equal strix, without the larger strix, and in the distinct, radiating, coarsely-punctured lines of the interior, and the small size of the bilobed muscular impressions of the receiving valve, which however it resembles in form. If, as I suspect, the Orthis lata be a Leptona, it cannot bear that specific name already in use for one of the best-known species; and as I have little doubt that the $O$. temuissimestriata, which I originally figured from unusually large and much-compressed specimens, in which the striation was still more delicate, is referrible to an extreme variety of the same species, that name may be conveniently retained for the species. I cannot imagine why Mr. Salter (Mem. Geol. Surv. Vol. II. p. 289) unites this species to O. protensa, which has vastly coarser, fasciculated, strix, \&c.

Pasition and Locality.-Caradoc sandstone of top of Moel Seisiog, Llanrwst, Denbighshire; Bala limestone of Llandeilo, Caermarthenshire; common in the Caradoc limestone of the Hollies, Church Stretton, Shropshire; Bala sandstone of Pont y Meibion, S. of Llansantfraid, N. Wales; olive Bala schists of Cefn Grugos, W. of Llanfyllin, Montgomeryshire; Bala flags of Llandeilo; Bala schists of Y Foel Fawr, near Llanrhaider; Bala limestone of Coniston, Lancashire.

Explanation of Figures.-Pl. 1. H. fig. 44. Natural size from Llandeilo; fig. $44 a$, internal cast of ditto; fig. $44, b$, surface of ditto, magnified, shewing the punctured sulci left by the removal of the shell in the upper portion; fig. $44 c$, longitudinal section.

\section{Leptana transversalis ( $D a l$.)}

Ref. and Syn.-Dalman, Act. Holm. t. 1. f. 4. Sil. Syst. t. 13. f. 2 ;

+ L. duplicata Sow. Sil. Syst. t. 22. f. 2. (? L. lepisma Sil. Syst. Young).

Sp.Ch.-Transversely fusiform, globose; hinge-line as wide as the shell; cardinal angles acute, nearly smooth near the beaks; both valves radiated with several slender thread-like ridges, about half a line apart at the margin, and a line, or two-thirds of a line, apart at three lines from the beak, at which distance, in finely-preserved specimens, about twenty-three very minutely-punctured longitudinal strie may be detected in the space of one line, which are usually invisible, even with a moderately strong lens; cardinal area low, triangular in each valve; the two areas subparallel with each other at their point of union, curved nearly into the plane of the lateral margins, that of the receiving valve scarcely one-third greater than that of the entering valve; triangular foramen in the receiving area closed towards the apex by a small pseudodeltidium, and below by the large rostral tooth of the entering valve: cast of receiving valve with two short cardinal teeth, diverging at $90^{\circ}$, from the ends of which a W-shaped groove (impression of a ridge on the shell) forms the lateral and anterior boundary of the remarkably small, obscurely bilobed, pentagonal, muscular impressions, which are slightly wider than long, and their length less than one-third that of the shell, the sinus in the front margin short, diverging at about $105^{\circ} \mathrm{from}$ the muscular impression; hinge-line crenulated near the beak; inner surface coarsely radiated, between which are irregularly placed numerous pits, or extremely large punctures, the extreme margin being marked with fine longitudinal lines, and close, numerous, minute punctures: interior of entering valve with two very prominent, oval ridges, bounding the muscular impressions, 
which extend more than two-thirds the length of the shell, the width of the two together rather exceeding their length; a deep, rather wide, mesial hollow intervenes between their prominent boundaries, and in the included hollow space of each impression is a very thick pyriform boss, extending nearly its length, and reaching on all sides within a short distance of the prominent boundaries, which it exceeds in prominence; the deflected margin striated and punctured. Width seven and a half lines, proportional length of receiving valve $\frac{i 2}{100}$, of entering valve $\frac{60}{100}$, depth of receiving valve $\frac{47}{100}$, depth of entering valve $\frac{80}{100}$.

This is a considerably more globose shell than the Leptonce sericea, and distinguished externally by the fewer and more distant linear ridges, and the very much finer longitudinal strice between the thread-like ridges, and their being besides so faintly impressed as to be, in almost all cases, invisible to the naked eye, or a lens of low power, while the strix of Leptence sericee are visible at all times to the unaided vision; internally the cast of receiving valve is distinguished by the remarkable coarseness of a comparatively fer punctures, and the very short muscular impressions; the cast of the entering valve is equally distinguished by the great pyriform boss, nearly filling the cavity circumscribed for each muscular impression.

The young of this species, as I have observed in Dudley and Gothland specimens, seems to accord with the so-called $L$. lepisma (Dal.) of the Sil. Syst. t. 8. f. 7 ; and Dalman does not seem to have described such a species.

Position and Locality.-Not uncommon in the Coniston (Bala) limestone of Coniston, Lancashire; common in the Bala schists of Llansantfraid, Glyn Ceiriog, Denbighshire; a doubtful specimen in the Bala schists of Llwyn y ci, N. W. of Bala, N. Wales; Wenlock limestone of Dudley, Staffordshire; Bala limestone of Bala, Merionethshire; common in the sandstone of May Hill, Gloucestershire.

\section{Sub-genus. STROPHOMENA (Rafinesque) *.}

Gen. Char:-Shells subsemicircular, depressed; hinge-line as wide as the shell; flat, or the receiving valve slightly convex near the beak, becoming gradually concave or deflected at the margin; entering valve fiat, or in the deflected species gradually arched downwards with the curve of the opposite valve; surface striated, without spines; cardinal area triangular in the large valve, very narrow or obsolete in entering valve; deltoidal opening in the cardinal area of the receiving valve nearly closed by a prominent pseudo-deltidium, with lines of growth arched towards the beak; interior of receiving valve with a thick diverging tooth on each side of the closed foramen; a very short thick mesial ridge, and a narrow semicircular ridge from its end to the cardinal tooth on each side, including a radiated space, the rest of the space radiatingly furrowed; entering valve with the tip of the rostral tooth bilobed, with a strong diverging tooth on each side (like that of the other valve), a short mesial ridge, and a small semicircular radiated space on each side; the anterior pair of adductors being rarely visible.

Differs from Orthis in the foramen being almost closed by a pseudo-deltidium (which does not exist in that genus), and from the sub-genus $L$ epterna by the valves not being equally curved in one direction from the hinge.

\section{LEPTANA (Strophomena) antiquata (Sów. Sp.) \\ Syn. = Orthis antiquata Sow. Sil. Syst. t. 13. f. 13.}

$S p . C h$.-Truncato-elliptical, or subtrigonal, greatest width along the hinge-line; cardinal angles slightly acute; sides converging to a narrow, obtusely rounded front; entering valve with a gently curved profile, slightly flattened near the beak, most curved about the middle of length, greatest convexity along the middle, from which the sides slope rapidly to the lateral margins; receiving valve nearly as concave as the entering one is convex, but rather convex towards the beak, which is prominent; cardinal area of moderate height (about one-sixth of its wilth), flat, triangular, inclining backwards at about $120^{\circ}$; surface of both valves with three or four strong, scaly imbrications of growth, one to two lines apart, interrupting 
the radiating ridges, which are very prominent, irregular in size, from abrupt irregular swellings and diminutions of thickness in various parts of their length; irregularly branching three or four times so as to retain their average thickness throughout; seven or eight in two lines about the midale of the shell, about five in the same space at the margin at ten lines from the beak; very rugged, from close, strong, scaly lines of growth. Average width ten lines, proportional length $\frac{94}{100}$, depth $\frac{24}{100}$.

The above quoted figure very imperfeetly represents the sulcation of this species.

Position and Loculity.-Common in the Coniston (Bala) linestone of Coniston Water-Head, Lancashire; common in the Bala slates of Blaen y Ciwm, Nantyre, Glyn Ceiriog, S. of Llangollen, Denbighshire; common in the Bala slates of Llansantfraid, Glyn Ceiriog, Denbighshire; Bala limestone of Mathyrafal, S. of Meifod, Montgomeryshire.

\section{LEPT ÆNA (Strophomena) compressa (Son. Sp.)}

Ref. and Syn. = Orthis compressa Sow. Sil. Syst. t. 22, f. 12.

Sp. Ch. - Transversely oblong, subquadrate; hinge-line slightly exceeding the width of the shell, sometimes forming short acute ears, from a slight outward curve of the margins near the angles, in other specimens nearly rectangular; lateral margins slightly convex, subparallel, front margins slightly convex, nearly as wide as the shell; valves much depressed, and concentrically marked with two or three strong undulations of growth from one to two lines apart; receiving valve slightly convex, with a low triangular cardinal area, inclined backwards at about $120^{\circ}$; with a wide triangular foramen, apparently more than half closed by a pseudodeltidium: entering valve very slightly convex near the beak, flattened in the middle, and very slightly coneave towards the margin, with a linear, nearly obsolete cardinal area or line: strie of both valves slightly arched divaricatingly on the sides, close, obtuse, transversely striated, nearly equal or subalternate, increasing in number, but not much in size, towards the margin; eighteen in the space of two lines at six lines from the beak; the separating sulci narrower than the ridges, and regularly pitted with very large punctures, visible through all the thickness of the shell, to the internal cast, and so large as slightly to undulate the radiating strix; in some specimens faint traces of larger strie at every third or fifth line traceable: internal cast of entering valve nearly smooth, with faint punctured radiating lines, visible with a lens (corresponding with the external strix); one long elliptical pit produced by the simple rostral tooth, and two ovate pits of the thick cardinal teeth, only equalling the rostral tooth in length, and diverging at $95^{\circ}$; between them and the hinge-line a small elevation on each side for the cardinal pits; muscular impressions very small, reaching little more than two-fifths the length of the shell, subrhomboidal, obscurely divided by a few obtuse sulci on their anterior edges, separated by the broad sulcus of a flattened mesial ridge, not reaching quite their length; receiving valve with two short thick dental lamelle diverging at about $130^{\circ}$; muscular impressions very broad, faintly radiated with fine sulci, indistinctly defined except by the straight diverging dental lamella, divided by a long slender sulcus of a linear mesial ridge, reaching with the impressions about half the length of the shell. Width one inch, comparative length $\frac{85}{100}$, depth $\frac{13}{100}$.

The great compression of the valves, thinness of the shell, the marked concentric waves of growth, threadlike, subequal strie, and large punctures, easily distinguish this, in well-marked specimens, from the $0 . x^{2} p a n s a$ or $O$. alternate, as well as the difference in the cardinal area and foramen and muscular impressions, and simple rostral tooth. I have little doubt the shell figured by Sowerby as the O. anomala (Schlot.) Sil. Syst. t. 21. f. 10, is a very old specimen of this species, elongated by a compression, which has also increased its convexity. Such specinens are not uncommon, indicating apparently the thickened adult state, in which it often shews an approach to S. grandis, when, as sometimes happens, some of the strix in part of a specimen become more prominent than the others.

Position and Locality.-Very common in the fine Caradoc sandstone of Horderly W.; in the Bala limestone of Teirw river, S. of Llangollen, N. Wales; extremely common in the calcareous Bala schists and limestone of Craig y glyn, N. of Rhaider, near Llanarmonfach, E. of the Berwyns; Bala schists of Mocl Uchlas, Montgomeryshire; Bala schists of Bryn Eithin, Penmachno, N. Wales; Bala sehists of Cader Dinmael, near Corwen, Denbighshire; Bala ? limestone of Tyrnant, E. of LIanwddyn; Bala schists of the Cymmerig, E. of 
Bala, Merionetlishirc (a coarse variety); Caradoc sandstone, top of Moel Seisiog. Doubtful specimens in the Bala schists of Pwllheli, Caernarvonshire.

\title{
Leptana (Strophomena) euglypia (Dal. Sp.)
}

\author{
Ref.-Sow. Sil. Syst. t. 12. f. 5. Davidson, Bull. de la Soc. Géol. de France, 2nd Series, Vol. V. t. 3. f. 4.
}

Sp. Ch. - Young shells, and rostral portion of adults for nine or ten lines from the beak, flattened; very slightly concave in the entering valve, and very slightly convex near the beak of the receiving valve; linge-line exceeding the width of the shell; front obtusely narrowed; in the adult state the margins of both valves bent together with a rapid curve towards the receiving valve into a long semicylindrieal front, nearly at right angles to the rostral portion, with broad, slightly-flattened sides, and an obtusely-rounded, narrowed front: surface covered with slightly-rugged, irregular, filiform ridges, seven in three lines, at the eurved front, between the rostral and descending portions, and having there irregularly from one to four longitudinal stria between each pair; on the deflected front of old individuals the intervening strie gradually acquire the size of the primitive ones, but little more than their thicliness apart (ten or eleven in the space of three lines), with or without a single intervening line: cardinal area rhomboidal, narrow; a wide, triangular opening in the middle of the receiving valve nearly closed by the psendo-deltidium; area at the entering valve narrow, with a trifid rostral tooth in the middle; interior of receiving (coneave) valve without developed cardinal teeth, with a large pair of oblong, faintly-radiated, adductor impressions, the prominent boundaries of which form a waving incurved ridge on each side, occupying more than two-thirds of the length of the rostral part of the shell; between them is a small mesial septum, which in the cavity of the beak becomes much thickened, apparently to support the pseudo-deltidium; interior of entering convex valve with two bifid, diverging, cardinal teeth, and an obscure mesial septum, having on each side near the beak a circular pair of small adductors, immediately in front of which a pair of anterior adductors; substance of the shell with very large punctures. Width two inches two lines, proportional length of flattened rostral portion $\frac{45}{i v u}$, of deflected front in old individuals $\frac{55}{10 u}$, height of cardinal area $\frac{10}{100^{\circ}}$.

The Liptana imbrex of authors so closely allied to this species in general appearance, has the receiving instead of the entering valve the convex one, as may be well seen from the figure given by Mr. Davidson, in Bull. de la Soc. Géol. de France, 2nd Series, Vol. V. t. 3.f. 8, although the character has not, I believe, been noticed before.

Position and Locality.-Woolhope limestone of Littlehope; very common in the Wenlock limestone of Dudley, Staffordshire; Aymestry limestone of Leintwardine, Shropshire; limestone of Clungunford, Shropshire; common in the Wenlock limestone of Woolhope.

\section{LEPTÆNA (Strophomena) ? FILOSA (Sow. Sp.)}

Ref. and Syn.=Orthis filosa Sil. Syst. t. 13. f. 12. Davidson, Bull. Géol. S. de. France, 2nd Series, Vol. V. t. 3. f. 9.

Sp. Ch.-Transversely semielliptical, both valves nearly flat, very slightly convex, greatest width along the hinge-line; cardinal angles acute; cardinal area very narrow: surface of both valves radiated with fine sharp prominent ridges, having between them from three to five very much finer strix, the odd middle one of which becomes gradually larger torwards the margin; intervening sulei very narrow, minutely punctured, about thirty to forty in the space of two lines at four lines from the beak: interior of receiving valve with two rery long slightly incurved dental lamellæ, diverging at only $55^{\circ}$ to $65^{\circ}$, reaching about half the length of the shell, enclosing between them the very narrow bilobed nuscular impressions, which are defined anteriorly by a deep $\mathrm{V}$-shaped boundary, from the apex of which a sharp mesial ridge is continued to the beak: internal cast of entering valve with two small deep pits of the bifid rostral tooth, and two short slightly recurved slender cardinal teeth, diverging close to the hinge-line; two very short, deep, ovate, muscular impressions situated 
close to the beak; general surface very coarsely punctate, and marked, especially near the margins, with the external radiating strix. Width (of small specimen) nine lines, proportional length $\frac{55}{100}$, depth $\frac{10}{1+1,0}$.

I am doubtful of the genus of this very interesting shell, from not having clearly scen the cardinal area: it is extremely analogous in general form, and the character of the striation (the latter not well represented in Sowerby's figure), to the Orthis cxpansa, including the alternata of Sow.; but the large lines arch less on the sides, the whole striation is considerably finer, and the species is completely distinguished from that of the older rocks by the very long dental lamello of the receiving valve, and the very small angle at which they diverge, creating a total difference in the muscular impressions. In old specimens the strix become coarse and more equal, with the interspaces very coarsely punctured.

Position and Locality.-Abundant in the Upper Ludlow rock of Tulithwaite Hall, Underbarrow, Kendal, Westmoreland; doubtful specimens in the olive schists above the second grits of Keeper's Lodge, Goldengrove, Llandeilo; Aymestry limestone of Sedgley, near Dudley, Staffordshire; Upper Ludlow rock of Burton and Brockton, near Wenlock.

\section{ILePtena (Strophomena) FUniculata (MCoy).}

Ref. and Syn.=Orthis funiculata McCoy, Sil. Foss. Irel. t. 3. f. 11.

Leptona id. Davidson, Lond. Geol. Journ. t. 12. f. 6 to 8.

Sp.Ch.-Semicircular, twice as wide as long; entering valve flattened, slightly convex towards the beak, slightly concave about the middle, and abruptly deflected nearly at right angles, to form a narrow border at the margin, the angle obtusely rounded; hinge-line slightly exceeding the width of the shell; ears acute; cardinal area narrow, triangular in the receiving valve, linear in the entering valve; pseudo-deltidium very small; surface radiated with obtuse, cord-like stria, usually less than half their thickness apart, frequently dichotomising, but remaining nearly uniform in size over the whole shell, nine or ten in two lines, at four lines from the beak, crossed by fine strix of growth; internal east of receiving valve with two large longitudinally ovate or triangular, flattened, slightly elevated marks of the muscular impressions, extending nearly three-fourths the length of the flattened rostral portion, flanked by two long, slightly incurved dental lamellie diverging at $60^{\circ}$; a very slender impression of a linear mesial septum divides the muscles; internal cast of entering valve with two thick diverging pits, produced ly the lateral lobes of the trifid rostral tooth; from this a deep impression of an obtusely rounded mesial septum extends about half the length of the flattened rostral portion, flanked on each side by two obtusely rounded, slightly incurved furrows, from corresponding ridges on the valve; the rostral portion of the inner surface of both valves is spinulose, the angle and deflected front marked with punctured strix. Width ten lines, proportional length of flattened rostral portion $\frac{30}{100}$, deflected front $\frac{15}{100}$;

The close, obtuse, sub-uniform striae easily distinguish this species from dwarf examples of the $S$. eurlypha, with which I understand some observers have confounded it. The bilobed boundaries of the muscular impression in the concave or receiving valve are longer and narrower than in the S. englypha.

Position and Locality.-Common in the Wenlock limestone of Dudley, Staffordshire: conimon in the schists above white grits, Parklane, Ludlow, Shropshire; one doubtful fragment in the Bala schists of Cyrn y Brain, Wrexham, Denbighshire.

\section{LEPT zena (Strophomena) grandis (Sow. Sp.)}

Ref. and Syn.= Orthis grandis Sow. t. 20, f. 12 and 13.

Sp. Ch.-Truncato-elliptical, varying considerably in proportional length; hinge-line equalling or slightly exceeding the greatest width; cardinal angles slightly pointed; receiving valve very slightly convex near the beak, which is rather prominent, gently concave about the middle, and flattened along the margins, which are flattened, horizontal, 01 with a very faint wave towards the entering valve; cardinal arca low, triangular, about twelve times wider than high, inclined backwards at about $130^{\circ}$; cardinal opening partially elosed by a pseudo-deltidium; dental lamella slender, diverging at $105^{\circ}$ (less in one specimen), slightly ineurved at their 
extremities, partially defining the very small muscular impressions, which reach little more than one-third the length of the shell, (rarely two-fifths) : entering valve gently eonvex, with a linear, nearly obsolete cardinal area; a strong bifid rostral tooth, forming two small pits in the cast; two short, very divergent cardinal teeth, recurved so as nearly to touch the cardinal line with their distal ends, and having between them a very short obtuse mesial ridge, (leaving a short broad obtuse furrow in the east), only extending about one-sixth the length of the shell : striation of both valves coarse, strong, varying greatly in prominence of particular lines, (apparently from the state of preservation,) seeming in some specimens olsscurely alternate, while in others, or parts of the same specimen, every $3 \mathrm{rd}$, 5th, or 7 th line, much more prominent than the rest; all rugged with minute, close, transverse stria, the sulci marked each with a row of rery small punctures; from twelve to sixteen of the radiating lines at six lines from the beak in the space of two lines. Width one inch nine lines, proportional length usually ${ }_{100}^{75}$ or $\frac{80}{100}$ (occasionally only ${ }_{100}^{60}$ ) depth (greatest at a little in front of middle of entering valve) ${ }_{100}^{11}$.

This is distinguished from the $O$. expanse by the much coarser strix, the smaller muscular impressions, and the slight concavity of the receiving valve, as well as the characters of the cardinal area. Some of the varieties, if ill preserved, are scarcely distinguishable from certain states of $S$. comprossa.

Position and Locality.-Common in the flaggy limestone of Ravenstone Dale, Westmoreland; fine Caradoc sandstone of Horderly; Bala sandstone of Bodean, Pwllheli, Caernarvonshire; Bala schists of Cefn Coch, Gilyn Ceiriog, Denbighshire; ? Bala schists of Blaen y cwm, W. of Nantyre, Glyn Ceiriog, S. of Llangollen, Denbighshire; ? Bala limestone of Meifod; Bala sehists of Cyrn y Brain, IVrexham, Denbighshire; ? Bala schists of Cefn Coedog, Corwen, N. Wales; not uncommon in the IBala schists of Gelli Grin, Bala, Merionethshire; rare in the fine sandstone of May Hill, Gloucestershire; common of small size in the Bala quartzite of Llanwddyn, E. of the Berwyn Mountains.

\section{LEPTAEA (Strophomena) PECTEN (Limn. Sp.)}

Ref. and Syn.=Anomia pecten Linn. Syst. Nat.=Orthis pecten Dal. Act. Holm. 1827. t. 1. f. 6 . (not of Sow. Sil. Syst.) Davidson, Geol. Journ. t. 13. f. 8 to 23.

Sp.Ch.-Transversely semielliptical or obscurely subtrigonal; greatest widtin along the hinge-line, very much depressed; receiving valve slightly concave towards the margins, slightly prominent at the beak, which is elevated by the cardinal area, which is flat, triangular, about eight times wider than ligh, inclining backwards at an angle of $130^{\circ}$; triangular foramen half closed by a pseudo-deltidium, flanked on the cast by two very short, straight, dental lamelle, diverging at $100^{\circ}$, between which there are no visible muscular impressions; receiving valve slightly convex along the middle, most so near the beak, flattened towards the sides; cardinal area flattened, triangular, about twelve times longer than high, the foramen being closed by a large bifid rostral tooth : internal cast of entering valve with two deep, approximate, ovate pits (of the bifid rostral tooth) at the beak, from which on each side two very short, nearly straight dental lamellic, diverge at $120^{\circ}$, between which, and a very shallow, wide furrow, of a short mesial obscure ridge, may be observed the slight proninenee of the obtuselyangular muscular impressions; both valves radiated with about sixty strong, nearly equal, straight, sharplydefined, thread-like ridges (about six in two lines) at the margin, separated by flat spaces, rather wider than the ridges, in which a very slender mesial ridge may be detected, flanked (under a strong lens) by one or two irregular, minutely-punctured strie. Width one inch four lines, proportional length $\frac{10}{1010}$, depth about $\frac{13}{1+m}$.

This species is easily distinguished by its numerous, strong, straight, subequal ridges, between which there is rarely more than the single, fine, duplicating line to be distinguished; the additional strix mentioned being very rarely visible, while the rest are sharply and distinctly marked. The species is also remarkable for the near equality in size of the cardinal area in the two valves; the internal strix generally mark the cast nearly to the beak; the puncturing is very minute.

Position and Locality.-Common in the Coniston (Bala) limestone of Coniston, Lancashire; Bala schists ? Blain y cwm, W. of Nantyre, Glyn Ceiriog, S. of Llangollen, Denbighshire; limestone of Ravenstone Dale, Westmoreland; Coniston (or Bala) limestone of Applethwaite Common, Westmoreland; sandstone of Middleton Park, Caermarthenshire; Upper Bala rock of Capel Cerrig; sandstone of May Hill, Gloucestershire; Horton in Ribblesdale, Yorkshire; Woolhope limestone of Littlehope. 


\title{
Leptena (Strophomena) simulans $\left(M^{c} C o y\right)$. Pl. 1. H. fig. 33, 34, 35.
}

\author{
Ref.-Id. Mc Coy, Ann. Nat. Hist. 2nd Series, Vol. VIII. p. 403.
}

Sp. Ch.-Truncato-elliptical; hinge-line slightly exceeding the width of the shell, forming short, rounded, semicylindrical ears, from a more or less pronounced indentation of the lateral margins; front wide, elliptically rounded; entering valve gently and slightly convex for about nine lines from the beak, and then more rapidly arched towards the receiving valve, to a position sometimes nearly at right angles with the rostral portion; receiving valve nearly as concave as the entering valve is convex externally, except near the beak, which is convex; cardinal area rather low, triangular, and nearly at right angles to the plane of the lateral margins; foramen broad, triangular, closed by the pseudo-deltidium, except at the apex, where there is a tulbular perforation (leaving a little columnar stem-like portion of matrix projecting from the apex of the cast); cardinal teeth very small, bifid, diverging at $115^{\circ}$; the dental lamelle originating from them converge under the muscular impressions, so that their inner, gently-incurved edges touching the shell, diverge at about $65^{\circ}$; museular impressions undulate-orbicular, about a fifth wider than long, reaching rather less than half the length of the shell; surface sometimes with a few oblique concentric plice on the ears, regularly radiated with very fine, slightly-irregular strix, about twenty-five to thirty in two lines at six lines from the lyeak, and at that distance usually every fifth, seventh, or ninth of the stria larger than the others, but near the beak they often seem simply alternate in size, the intervening delicate sulci closely punctured. Width one inch ten lines,

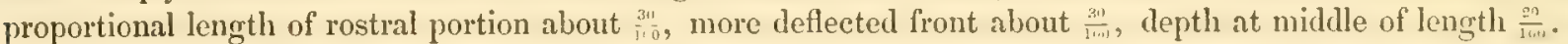

This species in size, form, striation, and tubular perforation of the apex of the beak, almost exactly resembles the Leptena alternata (Conrad), but differs in having the receiving or foraminated valve concave, instead of being the convex one; the striation is also finer and flatter, or nore uniform, which with the greater deflexion, or arching of the valves, also separate it from the $S$. grandis.

The specimens from Blain y Crm and Goldengrove are netted by a beautiful little species of Tioa branching frequently, nearly at right angles, forming straight, forking, or angularly-bending channels, one fourth of a millimetre in diameter, the branches being at a little more or less than a line apart, and either in the plane of the valves or at right angles to it, leaving round perforations.

Position and Locality.-Not uncommon in the Bala schists of Cefn Coch, Glyn Ceiriog, Denbighshire; in the olive schists of Goldengrove, Llandeilo, Caermarthenshire; Bala schists of Blain y Crrm, WV. of Nantyre, GIyn Ceiriog, Denbighshire; and one doubtful specimen in the sandy schists of the Malverns, Worcestershire.

Explanation of Figures.-Pl. 1. H. fig. 33, convex, or entering valve, natural size, from the schists of Cefn Goch, with a portion of strix magnified; fig. 34 , concave or receiving valve, shewing the cast of the tubular formen in the beak; fig. $34 \alpha$, longitudinal section ; fig. 35 , internal cast of muscular impression from Malvern.

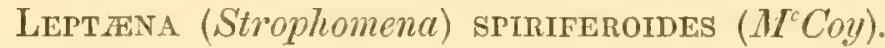

\section{Ref.-Id. II Coy, Ann. Nat. Hist. 2nd Series, Vol. VIII. p. 402.}

Sp. Ch.-Subrhomboidal; sides rather depressed; only slightly convex; hinge-line as wide as the shell;
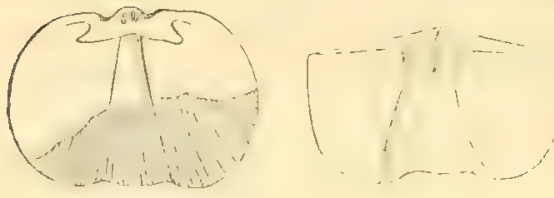

Lefl-hand Finure--Cast of entering valve, shewing the pits of the bitid rostral tooth, and the superticia sulcation on part of the shell in lower part.

limht-hand Figure. - Cast of receiving valve, shewing the impressions of the lateral teeth, and the slender arched cast of the apical foramen.

a long, slender, cylindrical extension of cardinal angles square, or slightly acute; sides subparallel, slightly rounded; front very abruptly raised into a quadrate sinus, onethird wider than high, from which a very prominent, rotundatoquadrate mesial ridge extends, sharply defined, to the beak; and an almost equally deep and strongly defined, flattened, mesial hollow extends to the beak of the receiving valve; both valves radiated with subequal, thread-like ridges, oceasionally dichotomising (about fourteen in three lines at six lines from the beak): easts of receiving valve shew the closed cicatrized formen, with 
hack, at one-fourth the length from the beak; and two thick, short, slightly-diverging cardinal tecth and lamelle: casts of entering valve shew two very short, thick, diverging pits of cardinal teeth; and a large double ovate pit, left by the great bifid rostral tooth, and a trace of a slender mesial septum. Average width one inch, proportional length of receiving valve $\frac{85}{100}$, of entering valve $\frac{69}{100}$, depth $\frac{60}{100}$.

This is so extremely like the Spirifer radiatus of the Wenlock limestone, that I have no doubt it has very often been confounded with it; and probably all the examples quoted by authors of $S$. radiatus, from the Caradoc and inferior strata, will be found referrible rather to the present shell, which abounds in these inferior rocks, where I have never seen the true S. rablutus (nor does this species occur to my knowledge in the Upper Silurian strata). Externally the present shell may be distinguished from the $S$. rudiutus by its longer hinge-line, flatter sides, and coarser striation; while the internal cast shews the generic difference by demonstrating the pit for the great rostral tooth in the beak of entering valve, and the slender, tubular filling of the apical foramen, as in the Leptona (Strophomena) sulcata (Vern.), Bull. de la Soc. Géol. de France, ?nd Series, Vol. V. p. 31. f. 4, to which it is in truth most nearly allied, but from which it differs by its greater gibbosity, and very prominent mesial ridge and hollow, extending from the beak, giving it exactly the appearance of a spivifer. The Orthis crspurtilio, when very finely sulcated, might be mistaken for this species, but has the mesial depression in the entering, and mesial elevation in the receiving valve, in which also the triangular foramen is open throughout.

Pusition and Locality.-Extremely common in the impure Bala limestone of Moel y Garth, Welchpool, Montgomeryshire; very abundant in the Bala limestone and schists of Bala, Merionethshire; very common in the Caradoc sandstone of Horderly; very ahundant in the Bala schists of Alt yr Anker, Meifod, Montgomeryshire; Bala schists of Tan y Bwlch y Groes, S. of Bala, Merionethshire; Bala schists, Bryn Melyn, and Gelli Grin, Bala, Merionethshire; Bala schists S.W . of Pwllheli, Caernarvonshire; Bala schists of Pen y Gaer, Cerrig y Druidion, N. Wales; Bala schists of Beaver's Grove, Bettws-y-Coed, N. Wales; Bala schists of Rhiwargor, near Llanwddyn, Montgomeryshire; Bala schists of Gaer Fawr, Welchpool, Montgomeryshire; Bala schists of Bryn Eithin, Penmachno, N. Wales; Bala schists, Garneld Uchaf, IV. of Bala Lake; Bala limestone, Dinas Mowddy, Merionethshire; Bala limestone of Coniston, Lancashire; Bala schists of Bwlch y Groes.

\section{Sub-genus. LEPTAGONIA $\left(\boldsymbol{I}^{\circ} \mathrm{Coy}\right) *$}

Gen. Char.-Shell rhomboidal; rostral portion of both valves flattened and concentrically wrinkled; the margin of both valves abruptly bent downwards at right angles to the flattened rostral portion; texture minutely but not closely punctured; surface longitudinally striated, generally without spines; cardinal area distinct, narrow, rhomboidal, formed of both valves; a wide deltoidal opening in the convex or receiving valve, nearly filled by the projection of a rhomboidal two- or four-lobed boss on the beak of the entering valve, leaving a small perforation for a pedicle, separated by a small pseudo-deltidium from the beak: internally, strongly punctured in the rostral portion, the front with dichotomising impressions of the pallial vessel: the receiving valve has its opening bordered by two strong diverging cardinal tecth, from which a semicircular ridge curves on each side, into a small longitudinal mesial septum, bounding the rounded, or triangular muscular impressions; the included spaces often strongly marked with radiating sulci; entering valve with a small depression below the projecting beak, for insertion of the adductors ; from this the mesial septum cxtends, leaving a circular impression with raised margin of the large anterior adductors close on each side; anterior to which, at the end of the septum, near the middle of the shell, are two close, longitudinal pear-shaped impressions of the anterior adductors, also with raised margins.

\footnotetext{
* See remarks on Leptcena, page 232.
} 


\title{
Leptana (Leptagonia) Depressa (Dal. Sp.)
}

\author{
Ref. and Syn. =Productus depressus Min. Con.t. 459.=Leptana depressa Sil. Syst. t. 12 f. 2. \\ + L. tenuistriata Sow. Sil. Syst. t. 22. f. 2a. + L. rugosa (Dal.).
}

$S p . C h$.-Square, prismatic; rostral portion quadrate; sides and front margin nearly straight, slightly undulated; slightly convex near the beaks; irregularly concave before reaching the angle, which is seldom as high as the surface near the beak; concentric wrinkles, about twelve to fifteen, strong, rounded, slightly undulated, and some of them occasionally interrupted in parts, following the direction of the margin, and turning abruptly outwards near the cardinal line; deflected front prismatic; sides subparallel, or slightly converging towards the front margin, which is flattened, or with few irregular longitudinal folds, dilated at the cardinal angles into flattened ears; longitudinal stria coarse, obtuse, equal, about nine to twenty (usually 12) in the space of two lines at the edge of the rostral portion: interior of receiving valve with two short cardinal teetl, diverging at $115^{\circ}$, from the ends of which a slender prominent ridge curves forwards and inwards on each side, forming the boundary of the rather large, ovate, adductor impressions, which reach about half the length of the rostral portion, the two being separated by a mesial ridge extending rather less than their length; interior of entcring valve with the rostral portion very concave, and sharply defined from the deflected front, by a prominent narrow margin; rostral tooth very large, and deeply bifid; the pits for the teeth of the opposite valve are flanked anteriorly by two thick ridges, which gradually incurve, forming the tubercular boundary to the rounded posterior pair of muscular impressions; anterior to which are the much sualler anterior pair of ovate impressions, with tumid boundaries; the mesial separating ridge extending two-thirds the length towards the deflected edge, which latter bears numerous fine, nearly straight, linear, simple or once-branched, pallial impressions, about twice the size of the external strie; inner surface of both valves with small spinulose tubercles; cardinal area moderately large in both valves. Average width of flat rostral portion at cardinal angles one inch three lines, proportional width of ditto at middle $\frac{72}{140}$, length of ditto ${ }_{i \lim }^{55}$, length of deflected front $\frac{55}{100}$.

In some states of preservation, or partial decomposition, each of the longitudinal strix seems divided into two, giving rise, I have no doubt, to the species L. tenuistriata (Sow.), but by far the greater number of specimens in the Caradoe and Bala rocks only shew, on accurate measurement, the same number of strice in a given space as the Wenlock specimens. Some specimens in which the front is gradually rounded into the sides agreeing with $L$. rugose (Dal.), differ in no other respect from the normal specimens, and the passage is so gradual and obviously unimportant, that I have no doubt of the specific identity of the forms. Some specimens have the muscular impressions narrower, and the dental lamelle diverging at a less angle than above, and varying in length from little more than one-third to nearly two-thirds the length of the visceral disk. The variety with wide muscular impressions, has them varying also from less than one-half to more than one. half the length of the visceral disk. These varieties do not at all accord with any of the changes of form or striation noted; nor is there any relation between the fineness of the striation and the geological position, although, generally speaking, the fine striation is most common in specimens from the old beds.

Position and Locality.-Common in the Wenlock limestone of Woolhope; very common in the Wenlock limestone of Dudley, Staffordshire; in the green Ludlow rock of Parklane, Llandeilo, Caermarthenshire; in the greenish Bala slates of Cefn Coedog, Corwen, N. Wales; Bala flags, three miles N. of Builth, Radnorshire; Bala schists of Rhosfawr, N. of Glog, Llanfyllin, N. Wales; Ludlow rock of Keeper's Lodge, Goldengrove, Llandeilo, Caermarthenshire; common in the Bala slates of Cyrn y Brain, Wrexham, Denbighshire; Bala schists of Gelli Grin, Bala, Merionethshire; schists of IVilfa, Penmachno, N. Wales; Bala slates of Blain y Cwm, IV. of Nantyre, Gilyn Ceiriog, S. of Llangollen, Denbighshire; in the Wenlock limestone of Wenlock, Shropshire; Bala schists of Penlan, Llandovery, S. Wales; Bala limestone of Coniston WaterHead, Lancashire; Bala slates of Llansantfraid, Glyn Ceiriog, S. of Llangollen, Denbighshire; Bala schists of Bryn Melyn, near Bala, Merionethshire; Bala schists of Corwen, Merionethshire; Caradoc sandstone of Horderly; common in the Bala limestone of Mathyrafal-firidd, S. of Meifod, Montgomeryshire; Bala schists, 
Selattyn Road, S. of Llangollen, Denbighshire; Bala schists of Alt Goch, Llanfyllin, Montgomeryshire ; Woolhope limestone of Littlehope; Bala schists of Rhiwargor, near Llanwddyn, Montgomeryshire; abundant in the Caradoc sandstone of Acton Scott, Church Stretton, Shropshire; Bala sandstone of Alt yr Anker, Meifod, Montgomeryshire; ?Bala limestone of Gaer Fawr, Welchpool, Montgomeryshire; Bala slates of Bwlch y Ciban; Upper Ludlow rock of Burton and Brocton, near Wenlock; fine sandstone of May Hill, Gloucestershire. Var. $\gamma$. Obscure specimens, possibly forming an extreme variety of this species, and seemingly referrible to the L.ptychotis ( $\mathbb{I}^{\mathrm{C} C} \mathrm{Coy}$ ), having the visceral disk semioval, and the wrinkles only distinct on the sides, occur in the Bala schists of Wilfa, Penmachno, N. Wales; Bala schists of Llanbedrog, W. of Pwllheli, Caernarvonshire; Bala schists, Cefn Coedog, Corwen, Merionethshire; Bala schists of Cader Dinmael, near Corwen, Denbighshire.

\section{Leptena (Leptagonia) ungula $\left(M^{c}\right.$ Coy). Pl. 1. H. fig. 36 and 37.}

\section{Ref.-Id. McCoy, Ann. Nat. Hist. 2nd Series, Vol. VIII.p. 404.}

Sp.Ch.-Semioval; hinge-line as wide as the shell, forming short, rounded, slightly projecting cars; cardinal area low, triangular, with a large tubular foramen at the apex of the beak; receiving valve horse-lioof shaped, from the slope of the deflected front being at a much more obtuse angle in the middle than at the sides; visceral disk depressed, very slightly convex towards the beak, rendered rugged by seven or eight large concentrie wrinkles (only three or four at the margin commonly seen); angle between the disk and the deflected front obtusely rounded, the depth of the latter being rather less than the length of the disk; entering valve flat, concentrically wrinkled like the receiving one, but with a narrow margin, equally deflected all round, and only one-fifth or onesixth the length of the disk; surface of both valves radiated with extremely fine, close, obtuse, punctate strix, about twenty-eight or thirty-two, in two lines at four lines from the beak, (every third, fifth, or seventh of which are usually considerably stronger than the others in all the middle portion) : interior of both valves closely punctured and striate; the close, straight pallial impressions resemble the external strie on the deflected front, but are only eighteen in the space of two lines; interior of receiving valve with two rather long, very slightly curved dental lamellæ, diverging at $105^{\circ}$, including the rotundato-trigonal pair of muscular impressions, which are one-third wider than long, and extend about half the length of the disk, being only separated by a slight indication of mesial septum at their anterior edge ; apex of the triangular boss of the foramen with a small, abrupt muero from the entrance of the matrix into the small tubular opening at the apex of the beak; interior of entering valve with two very short diverging cardinal teeth, and a minute rostral tooth. Width eleven

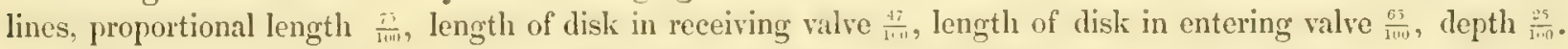

This so exactly resembles some of the small varieties of $L$. deltoidea and the $L$. camerata (Conrad), as figured by Hall, that I should not have thought of separating them, were it not for the very much finer strie, which very easily separate the species from our British specimens of $L$. elettvidea. The foramen of the apex of the beak is also larger, the dental lamellice more divergent, and the muscular impressions much wider. I find the peculiar hoof-like form and other characters of this little shell (unlike L. dettoidex) to ve extremely constant.

Position and Locality.-Gregariously in extraordinary abundance, completely filling some beds of the Bala limestone of Llansantfraid, Glyn Ceiriog, S. of Llangollen, Denbighshire; Bala limestone of Selattyn Road, S. of Llangollen, N. Wales.

\section{Sub-genus. CHONETES (Fischer).*}

\section{LEPT ENA (Chonetes) LATA (V.Buch. Sp.)}

Ref. and Sym.-Leptana late V. Buch. Abhand. der Kön. Akad. for 1831, t. 3. f. 1, 2. Id. Sil. Syst. t. 5. f. 13.

$S p$. Ch.-Transversely oblong; hinge-line as wide as the shell; ears rectangular or slightly acute; sides slightly convex, subparallel, or slightly converging; front margin wide, subparallel with the hinge-line; entering

\footnotetext{
* See remarks on the genus Leptena, page 233.
}

[FASC. II.] 
valve gently concave; receiving valve depressed, convex in the middle, considerably more arched than the entering valve, flattened at the ears, sometimes with a slight narrow mesial longitudinal sulcus, rather abruptly arched downwards at the margins, greatest depth about the middle of the length; beak very small, not projecting: surface of both valves radiated with very numerous coarse, rugged, strix, separated by sulci half their width ; strie branching once or twice at one or two lines from the beak; when decorticated, the intervening sulci marked with coarse punctures; about twenty stria in two lines, at two lines from the beak; usually two or three strong concentric imbrications of growth, and about four long, slender spines projecting from the hinge-line on each side of the beak, diverging obliquely outwards and backwards; interior marked with strong longitudinal lines of coarse punctures; with three thick, short, subequal ridges from the beak, one central, the others diverging at $100^{\circ}$. Width eight lines, proportional length $\frac{60}{100}$, depth of receiving valve $\frac{20}{100}$.

The strie are rather thicker at a line and half from the beak (before their first branching) than at any other part of the shell. In some old specimens the margins are faintly and irregularly undulated radiatingly.

Position and Locality.-Very common in the Upper Ludlow rock of Woolhope; very common in the Upper Ludlow rock, and limestone, of Mortimer's Cross, Aymestry, Herefordshire; schists of Cwm Craig ddu, Builth, Brecknockshire; Upper Ludlow limestone and mudstone near Ludlow, Shropshire; green quartzose Upper Ludlow of Benson Knot, Kendal, Westmoreland; Upper Ludlow rock of Downton Castle, Aymestry, Herefordshire; limestone of Kington, Herefordshire; Upper Ludlow micaceous quartzite of Lamb-rigg Fell, N. end of Potter's Fell, and limestone of Underbarrow, Kendal, Westmoreland; ? sandy schists of Middleton Park, Llandeilo, Caermarthenshire; Upper Ludlow rock of Burton and Brockton, near Wenlock.

\section{1th Family. LINGULIDE (D'Orb.)}

Arms free, fleshy, inrolled, without shelly supports from the valves, capable of being entirely protruded beyond the shell, provided with long, firm fimbria; valves unconnected by a hinge; pedicle of attachment passing out between the beaks of the two valves, neither of which are notched or perforated. Shell corneous, dense, fibrous, subequivalve, equilateral. There is a heart-like vessel on each side, about one-third the length from the beak, giving off one large trunk on each side; the subdivisions of the branchial vessels give off vascular loops, arranged as separate lobes of the mantle, resembling the gills of the higher Mlullusca, and subservient to respiration; elose to the beak are the conjoined impressions in each valve of the posterior pair of muscles; at about one-third the length of the shell in front of them are two small ovate, approximate ovaries, exterior to which are the large impressions of the decussating muscles which produce the sliding motion of the valves on each other. Just in front of the ovaries are two very large oval lobes of the liver, a third lobe of which is placed in the median line immediately in front of the posterior pair, and is flanked on each side by a rather small, oblique, ovate impression of the anterior pair of adductor muscles in each valve; considerably in front of these, in the median line, are the conjoined, triangular impressions of the anterior pair of muscles, which extend into the pedicle at the posterior end.

The Family contains Three Genera.-1st, Lingula; 2nd, Obolus; 3rd, Spondylobolus.

\section{Genus. LINGULA (Brug.)}

Gen. Char.-Subequivalve, equilateral, Iongitudinally ovate or subpentagonal, both valves channeled equally at the beaks, for the passage of the pedicle (one beak a little longer and more pointed than the other, which latter has a narrow internal flat area); internally each valve has a thickened pad in the middle, and the shorter ore has in front of it a prominent internal septum.

The species of this genus grow wider proportionally with age.

Professor Phillips mentions (Mem. Geol. Surv. Vol. II. Pt. 1. p. 370) that he is induced to propose a new genus, Glossina, for such Lingula as were not really equivalve; but no species of the genus either recent or fossil have the beaks really of equal length. 


\section{Lingula attenuata (Som.)}

Ref.-Sow. Sil. Syst. t. 22. f. 13.

Sp. Ch.-Obscurely subpentagonal, moderately and broadly convex from the beak along the middle nearly to the front, so that only a narrow margin all round is compressed, rather abruptly; sides subparallel, very slightly compressed; front obtusely subtruncate, gently convex; posterior lateral margins long, nearly straight, forming an obtusely rounded angle with the sides, converging to the beak at a clearly defined angle of $70^{\circ}$; surface with minute lines of growth, and with traces of delicate longitudinal strix about the middle under the lens when decorticated. Length five lines, proportional width $\frac{65}{1009}$ depth about $\frac{15}{100}$.

This species is perhaps most allied to the L.ovata ( $\left.1 I^{\circ} \mathrm{Coy}\right)$, but is considerably shorter and wider, and has longer posterior lateral margins, besides being very much smaller. These differences becoming greater as the specimens of the two species approach each other in size.

Position and Locality.-Thin sandy Bala beds, E. of Nant y Groes, S. of Bala, N. Wales.

\section{LiNGUla CORNEA (Sow.)}

\section{$R e f_{\circ}=$ Id. Sow. Sil. Syst. t. 3. f. 3. $+L_{0}$ minima Sow. Sil. Syst. t. 4. f. 49. and t. 5. f. 23.}

SP. Ch.-Longitudinally oblong; sides straight, parallel, rather abruptly inflected to form the posterior lateral margins, which are slightly convex, and join at the beak at an angle of $115^{\circ}$; anterior lateral angles abruptly rounded from the nearly straight sides to the nearly straight front; both valves broadly gibbous along the middle, so that only a narrow, nearly uniform space round the front and lateral margins slopes; greatest depth at rather more than one-third from the beak; surface marked with very numerous small, slightly and irregularly undulated, close wrinkles of growth, parallel with the margins; sulstance of the shell thick, often whitish, very glossy when partially decorticated; dull and yellowish brown when the periostraca is preserved, and then marked with very close, minute, slightly irregular, rugged, parallel strix (about twenty-four to twentycight in one line); no external radiating strix, but faint traces of extremely minute radiating lines on the middle of some internal casts; casts of one valve shew a very long, close pair of parallel sulci, one-fourth of a line apart (impressions of ridges on the shell) reaching nearly three-fourths the length to the anterior margin, the anterior extremity forming a rounded depression. Length of average specimens seven lines, proportional width $\frac{60}{100}$, depth $\frac{20}{100}$ (some rare specimens nine lines long).

This is an extremely constant and rather well-marked species, with an unusually thick shell, and remarkable for the nearly uniform gibbosity of the greater part of the valves; the proportional width is the only character which I have noticed to vary. The $L$. minima does not shew the slightest difference that I can perceive.

Position and Locality.-Very abundant and gregarious in the Upper Ludlow quartzite of Benson Knot. Kendal, Westmoreland; not uncommon in the Upper Ludlow rock near Ludlow, Shropshire.

\section{Lingula curta (Conrad).}

Ref.-Hall, Pal. New York, t. 30. f. 6. and Conrad, Journ. Nat. Sc. Phil. Vol. VIII. t. 15. f. 12.

Sp. Ch.-Outline very regularly broad-ovate, greatest width slightly in front of the middle; front clliptically rounded, broad; posterior lateral margins slightly arched, gradually converging to the small, sharppointed beak; valves flattened, slightly and evenly convex, becoming gradually compressed at the margins; surface with minute, subregular, imbricating lines of growth; under the lens when decorticated very fine, faint, longitudinal strix, principally traceable about the middle. Length four lines, proportional width $\frac{85}{1+1}$, depth $\frac{10}{1 \times 10}$.

The regular, broad-ovate form, narrow, pointed beak, and semielliptical front, easily distinguish this species from all others in the British rocks. The correspondence with the American Utica slate and Trenton lime species seems perfect in all respects.

Position and Locality.-Rare in the calcareous Bala flags of Wellfield, Builth. 


\section{Lingula davisi $\left(M^{c}\right.$ Coy). Pl. $1 . \mathrm{L}$. fig. 7.}

\section{Ref.-Id. MCoy, Ann. Nat. Hist. 2nd Series, Vol. VIII. p. 405.}

Sp. Ch._Ovato-pentagonal, or broadly subtrigonal, depressed, slightly and broadly convex near the beak, and about half way to the margins, which become gradually compressed; greatest width at about the middle of the length; front slightly narrowed, but very wide, subtruncate, and very slightly convex; obtusely rounded at the lateral angles to the subparallel, slightly convex, sides; posterior lateral margins rather long, forming an obtuse angle at the sides (usually nearly equalling half the length of the shell, nearly straight, and meeting at the beak at an angle of about $100^{\circ}$ in the short valve, and $95^{\circ}$ in the long valve); surface with numerous faint, concentric, rather wide, subangular undulations of growth, accompanied by irregular, concentric, imbricating laminx; stric ten in one line on the exterior of the shell; no trace of longitudinal external strix, but on the internal cast a few faint, obsolete, flattened, fibrous radiations, observable with the lens. Length seven lines, proportional width $\frac{77}{100}$, depth about $\frac{15}{100}$.

This curiously wide, satchel-shaped Lingula is the species discovered by Mr Davis in such profusion in the Lingula slates, near Tremadoc, in company with the large, elongate, $L$. ovata ( $\mathrm{M}^{\mathrm{c}} \mathrm{Coy}$ ), and I have great pleasure in dedicating the species to him; at the same time I must remark, that except for a slightly greater width, and perhaps less coarsely undulated surface, it seems scarcely to differ from the L. latc of Pander. As, however, this writer gives no description of his species, as his figure indicates at least the difference noticed, and as Mr Sowerby has unfortunately described a totally different Silurian species under the same name, I think (although this latter should not retain the name of $L$. late $)$ that it is better to give a distinct name to our very abundant and distinctly-marked species. The British species most allied to this is the L. attenuata (Sow.), which however is easily distinguished by its much longer, trigonal, retrally-narrowed form, rising from the gradual passage of the sides into the posterior lateral margins (without angulation), the very prominent narrow gibbosity from the beaks, \&c. The substance of the shell is very thin, and the traces $I$ have seen, apparently of the mesial ridge, extend little more than one-third the length of the shell.

Position and Locality.-Fxtremely abundant in the greenish Lingula slates of Penmorfa, Tremadoc, N. Wales; rare in the Bala schists E. of Nant y Groes, S. of Bala, N. Wales; rare in the Bala limestone of Coniston, Lancashire.

Explanation of Figures.-Pl. 1. L. fig. 7. Natural size, from the slates South of Penmorfa; fig. $7 a$, section of both valves about the middle; fig. $7 \zeta$, portion of surface and decorticated specimen magnified.

\section{Lingula granulata (Plill.)}

\section{Ref.-Phil. Mem. Geol. Surv. Vol. II. Pt. I. t. 25.}

Sp. Ch.-Shell pentagonal; sides parallel, rather abruptly rounded into the nearly straight or slightly undulated front, forming an obtuse angle with the remarkably straight posterior lateral margins, which unite at the beak in a well-defined apical angle of $120^{\circ}$ : surface very regularly marked, with nearly equal concentric wrinkles, or prominent lamine of growth, minutely undulated in the middle (about twelve in two lines in the middle of the shell, at six lines from the beak, abruptly diminishing at about seven lines from the beak to about ten in one line); crossed, particularly about the middle of the shell, by longitudinal strix (seven in one line), forming an obtusely tubercular reticulation, visible to the naked eye. Length eleven lines, proportional width $\frac{80}{100}$, depth $\frac{14}{100}$.

The thick, black, regularly wrinkled shell of this species is very easily recognized, even in fragments. The obtuse tuberculation is distinctly visible to the naked eye in good lights, and completely distinguishes this species from the L. temigranulata ( $\mathbf{I}^{\mathrm{c}} \mathrm{Coy}$ ), but on the other hand appearing identical with that of the L. cancelleta (Kutorga) from the Pulkova limestone (see Verhandlungen der Russ. Kaiserl. Min. Gesellschaft zu St. Petersburg for $18 \pm 5$, t. 7. f. 5), from which however its great width and straight front seem to distinguish it perfectly.

Position and Locality.-Common in the Bala limestone of Llandeilo, Caermarthenshire; Bala grits of Tre Gib, Llandeilo. 


\author{
Livgula Lata (Som.) \\ Ref.-Sow. Sil. Syst. t. 8. f. 11.
}

Sp. Ch.-Ovato-oblong, moderately and evenly convex; lateral margins gently convex, sulparallel, gradually passing into the posterior lateral margins, which are more convex, and converge to form an obtuse, semielliptical, posterior end; front margin obtuse, slightly convex and a little narrowed; surface usually white, marked with minute lines of growth. Length three lines and a half, proportional width $\frac{70}{100}$.

This little species is shorter and wider than the $L$. cornea, which it most resembles, and has more convex margins.

Position and Locality.- Very common in the olive Ludlow rock of Mortimer's Cross, Aymestry, Herefordshire; Upper Ludlow rock of Woolhope. Very abundant of small size in some layers of the Lower Ludlow sandstone of Leintwardine, Shropshire.

\title{
LINGULA LEWISII (Sow.)
}

\section{Ref.-Sow. Sil. Syst. t. 6. f 9.}

Sp. Ch. - Longitudinally oblong, subquadrate, with a flattened tumidity along the middle, gradually arching to the front margin, the sides abruptly sloping from the beak in a nearly straight line to the front lateral angle on each side; sides straight, parallel; front margin subtruncate, slightly rounded; posterior lateral margins straight, slightly more than half the length of the sides, with which they form an obtuse angle, converging to the obtuse beak at an angle of about $120^{\prime \prime}$; surface with minute, irregular, concentric wrinkles and striae of growth, and on the front a few broad, obtuse, radiating ridges (about five in the space of two lines) near the margin. Average length ten lines, proportional width $\frac{70}{100}$ to $\frac{75}{1009}$ depth $\frac{30}{100}$.

The front of this species is more truncate, and the radiating mesial ridges much fewer, wider, and farther apart, than in the L. quadrata of the lower beds of Russia and North America, with which it has been confounded.

Pusitiun and Loculity.-Common in the Aymestry limestone of Sedgley, near Dudley, Staffordshire; olive Caradoc shale of Cheney Longville, Shropshire; Lower Ludlow rock of Leintwardine, Shropshire.

\section{Lingula longissima (Pander).}

Ref.-Pander, Beiträge, \&c. t. 3. f. 21. Geol. Russ. t. 1. f. 11. Kutorga, Verhand. der Russ. Kaiserl. Min. Gesell. zu St. Petersburg, t. 7. f. 3.

Sp.Ch.-Very elongate, ovate; sides subparallel, very slightly convex, gradually passing into the slightly narrowed, blunt, elliptically rounded front, and more gradually into the narrower elliptically pointed posterior end; both valves very convex, rising evenly from the margins all round (not flattened); greatest depth about the middle of the length; cast of internal mesial ridge very long, reaching to within one-sixth of the length of the front margin; external surface with very minute, close, fine, concentric wrinkles, and internal casts with faint traces of obsolete, rather coarse, longitudinal strix in the middle. Length three lines, proportional width $\frac{s 5}{i m}$, depth $\frac{35}{\text { Ition }}$.

Although neither of the above writers mention the traces of longitudinal strix on the internal cast, there cannot be the slightest doubt in the identification of this species, rendered so distinct by its very narrow, ovate, tumid form.

Position and Locality.-In the Bala limestone, Mynydd Fron Frys, five miles WV. of Chirk, N. Wales.

\section{Lingula obtusa (Hall).}

\section{Ref.--Hall, Pal. New York, t. 30. f. 7.}

$S p . C h$.-Longitudinally ovate, very gibbous near the beaks which are obtusely rounded, the convexity extending for a narrow space about laalf the length of the shell, becoming much depressed and flattened towards 
the front margin, which is broadly rounded; greatest width about one-third of the length behind the front margin; sides slightly convex, gradually converging behind to the obtuse heaks; rather abruptly compressed at the sides of the posterior half of the shell; surface black, glossy, and nearly smooth to the naked eye, marked under the lens with sharp, irregular, minute, concentric lines, crossed by exceedingly fine, nearly obsolete, longitudinal strix. Length seven lines, proportional width $\frac{80}{100}$, depth of both valves about $\frac{20}{100}$.

This species seems perfectly identical in all characters with the Trenton limestone species, to which I refer it, and differs from Sorverby's measurement and figure of his $L$. attenuate in the greater proportional width, as well as much less acuminate, posterior end.

Position and Locality._Llandeilo flag (Bala rock) of Llandeilo, Caermarthenshire.

\section{Lingula ovata $\left(M^{c}\right.$ Coy $)$. Pl. 1. L. fig. 6.}

Ref.-M $\mathbf{M}^{\mathrm{c}} \mathrm{Coy}$, Synop. Silurian Fossils of Ireland, p. 24. t. 3. f. 1.

Sp. Ch.-Elongate, ovate, gently convex along the middle, gradually compressed towards the margins; greatest depth about the middle of the length; sides nearly parallel, very slightly convex; greatest width about the middle of the length; front scarcely narrowed, obtusely rounded, nearly straight; sides merging gradually into the slightly convex posterior lateral margins, which unite in a narrow elliptical point at the beak, forming an angle of about $60^{\circ}$ in the long and $80^{\circ}$ in the short valve; substance of the shell very thin, marked with delicate, close, irregular concentric plications of growth, the middle portion being occupied by fine, parallel, longitudinal strix, strongest at the margin, those at the sides turning outwards nearly at right angles to the lateral margins, where alone they are visible, (about twelve in the space of one line); mesial ridge separating the muscular impressions, apparently rather less than half the length of the shell. Length one inch three lines, proportional width $\frac{45}{100}$ to $\frac{s 5}{1+10}$ (most commonly the former in the long valve, the latter in the short valve, thus diminishing the amount of variation), depth about $\frac{15}{100}$.

This beautiful species is remarkable for its large size, slender depressed form, and delicate longitudinal lineation. I can add nothing of importance to my original description, in which I pointed out its differences from the $L$. Lewisi and $L$. attenuata, \&c. which it is scarcely necessary to do now.

Position and Locality. - Occurs in considerable abundance in the fine green Lingula slates, S. of Penmorfa, Tremadoc, N. Wales, along with the more abundant L. Davisi ( $\left.\mathbb{M}^{\circ} \mathrm{Coy}\right)$, from which it differs in its great size and slender form (age producing the opposite change of proportions in the Lingul(c), and the delicate longitudinal striation under the lens; common in the Lingula slates of Festiniog, N. Wales; rare in the Coniston (Bala) limestone of Coniston, Lancashire; one doubtful specimen in the Bala schists of Bryn Melyn, near Bala, Merionethshire.

Explenation of Figures.-Pl. 1. L. fig. 6. Natural size, from slates South of Penmorfa; fig. 6 a, section about the middle.

\section{Lingula tenutgranulata $\left(\boldsymbol{M}^{c} \mathrm{Coy}\right)$. Pl. $1 . \mathrm{L}$. fig. 8.}

\section{Ref.-Id. Ann. Nat. Hist. 2nd Series, Vol. VIII. p. 406.}

Sp. Ch.-Shell black, semielliptical, sides parallel, abruptly rounded to the wide, nearly straight front, gradually rounding into the undefined, arched, posterior, lateral margins, which unite elliptically in front of the beak, the curve being rather wider than a semicircle, in the small valve, more elongate from the projection of the considerably longer beak in the opposite one; valves with a moderate, flattened, triangular gibbosity, widening from the beak to the front, from which the sides slope rather abruptly to the margins, the greatest depth being at about the middle of the length; surface with irregular, flattened, concentric laminar wrinkles, strongest on the sides, nearly obsolete in the middle; entire surface covered with extremely minute, close, regular, equal, sharply granular, longitudinal, slightly undulated strix (about twenty-six in one line in the middle of the shell), the intervening spaces between the strix about equalling the strix in width. Length (of shorter valve) one inch nine lines, proportional width $\frac{70}{100}$, depth $\frac{25}{100}$. 
This species far exceeds the Lingula quadrata (Eichwald) in size, though that has hitherto been the largest species known; it is easily distinguished therefrom, as well as from the $L$. granulate (Phill.), to both of which it bears some resemblance, by the extremely minute granular lineation of the surface (which is quite invisible to the naked eye, or with a lens of low power only giving a dulness to the surface), and the semielliptical regular arch, formed by the union of the two posterior lateral margins of the shorter valve. In the $L$. quadrata also the front is much rounded, and narrower; and the rather strong mesial lineation of the decorticated specimens does not occur in our species, in which, when the surface is removed there are only seen traces of obsolete, broad, longitudinal, fibrous bands, not at all confined to the middle of the shell, nor linear in character. As usual in fossil Lingule, it is the beak only of the smaller valve which is seen most commonly; but two of our specimens shew the pointed beak of the larger valve extending a quarter of an inch beyond the rostral margin of the other, the two being undisturbed from their original position.

Pusition and Locality.-Common in the sandy and calcarcous Bala schists of Alt yr Anker, Meifod, Montgomeryshire; sandy Bala schists of Das Eithin ridge, Hirnant, Montgomeryshire.

Explanation of Figures.-Pl. 1. L. fig. S. Natural size of short valve, with dotted restoration of beak of large valve; fig. $8 \alpha$, view of beaks of both valves from another specimen; fig. 86 , transverse section of both valves about the middle; fig. 8 c, longitudinal section of both valves, shewing the inequality of the beaks; fig. $8 d$. surface magnified.

\section{Genus. SPONDYLOBOLUS $\left(M^{c} C o y\right)$.}

\section{Ref.-Id. McCoy, Ann. Nat. Hist. 2nd Series, Vol. VIII. p. 407.}

Gen. Char.-Suborbicular, slightly narrowed towards the indistinct, short hinge-line; nearly equivalve, flattened; small valve with a slightly eccentric apex, beneath which, on the interior, the substance of the valve is thickened into a wide, undefined boss; opposite valve slightly longer, from the apex being perfectly marginal, and slightly produced, channelled by a narrow, triangular groove below, the anterior end of which is flanked by two very prominent, thick, conical, shelly bosses, representing hinge-teeth: substance of the valves thick, testaceous, not glossy, minutely fibrous, but not distinetly punctured under a lens of moderate power, except by the ends of these filores.

One species of this genus is known already from the figures and deseriptions of Mr Davidson, under the name Crania Sedgwichii, the prominent, cardinal protuberances being taken for the posterior pair of muscular impressions; neither the tissue of the shell, nor the internal impressions have, however, any resenblance to those of Crania. The grooving of the beak of one valve, and the depressed orbicular form, shew the strongest affinity to the Russian genus, Obolus, which differs however by its glossy, corneous substance, peculiar internal impressions (as figured by Kutorga), and want of the conical cardinal bosses: these latter, as well as the terminal beak of one valve, and subcentral beak of the other, remind us of Trematis of Sharp, but neither of the specimens I have examined of the small valve shew the fissure of that genus, nor does Mr Davidson allude to any thing of the sort in his large species; and further, the coarse punctation of Trematis does not exist here. I think its zoological affinity very doubtful; the greatest affinity is probably with Siphonotrete, which it resembles very much if the tube in the beak be viewed as modified into a groove by a cleft or division of the internal rostral pad, the halves of which would thus correspond to the cardinal bosses of the present genus, forming a passage thus to Obolus. I think a peculiar family should be formed to include these three genera, the family being placed between Crania and Discina.

\section{Spondylobolus crantolaris $\left(\boldsymbol{M}^{c} \mathrm{Coy}\right)$. Pl. 1. H. fig. $4,5$.}

\section{Ref.-Id. M ${ }^{\mathrm{C}} \mathrm{Coy}$, Ann. Nat. Hist. 2nd Series, Vol. VIII. p. 408.}

Sp. Ch.-Suborbicular, depressed, slightly undulated, the width scarcely exceeding the length : front and sides broadly rounded, slightly acuminated behind; apex near the posterior margin; substance of the shell thick, calcareous, smooth, with very minute, faint, concentric stria, very minutely fibrous, but the punctation (if it exists) indistinct: beak of small valve small, obtusely pointed, at about one-fourth the length from the posterior 
margin; beneath the beak the shell is greatly thickened, forming an obtuse wide pad, internally reaching nearly to the margins: beak of larger valve terminal, slightly produced, apparently channelled below by a triangular groove, on each side of the base of which is a strong conical boss, projecting into the cavity of the opposite valve, like cardinal teeth; surface dull, nearly smooth, or shewing under very strong glasses an indistinct, very minute punctation (perhaps due to the fibrous tissue of the shell) and delicate concentric strix. Length four lines, width $4 \frac{1}{4}$ lines.

The specimens I lave examined are chiefly internal impressions, shewing two very deep, small, oval pits near the hinge-line, resembling the so-called Crania Sedquickii of Davidson (Bull. Géol. Soc. de France for Octover, 1848), from which it differs in the greater approximation of these impressions (which are clearly not analogous to the muscular impressions of Crania), smaller size, \&c.

Position and Locality.-Five or six specimens have occurred close together in the shale of Builth Bridge, Radnorshire.

Explanation of Figures.-Pl. 1. H. fig. 4. Group of three casts of inner surface of large valve, natural size; fig. $4 a$, wax cast from one of ditto, sherwing the appearance of the interior of the shell, magnified; fig. 5 , exterior of small specimen of small valve; fig. $5 a$, interior of ditto, shewing the thickening of the shell beneath the apex ; $5 b$, portion of external surface more highly magnified.

\section{3rd Class. LAMELLIBRANCHIATA.}

THrs class has the two shelly valves placed at right angles to their position in the Palliolianchiata, one valve being applied to each side; they are connected by a ligament, within which is an elastic substance termed cartilage, which forees the valves open; the valves are closed in the lower groups by one central adductor muscle, and in the higher types by two or more. Respiration (as the name implies) is effected by lamellar branchiae, or gills, which are four, crescent-shaped, and attached to the inside of the mantle; one pair on each side of the visceral mass. Each valve is lined by a lobe of the mantle, and the attachments of the muscular fibres for retracting its edges form the pallial scar in the shell; in the low types the lobes are open and disconnected, as in the Palliobranchs, and there is little or no foot; in the higher types the edges of the two lobes are united posteriorly, and produced into two tubular siphons; one branchial, through which the water enters to the gills, and earrying nutrient particles to the mouth; the other anal, through which the impure water constantly flows out, the currents in each case produced by vibratile cilix; the attachments of the line of muscular fibres for retracting the siphon form the "pallial sinus" in the shell of such as have the siphons. The animal is without head or ceplalic organs of sense; the mouth is at the anterior end, without organs of mastication, having two strap-shaped, sensitive tentacles on each side, the upper pair of which correspond, on a reduced scale, with the spiral arms of the Bractiopor a; the lower pair (which equal the upper in size) are analogous to the transrerse, brachial, fringed part below the mouth in the same; a short œsophagus leads into a pear-shaped stomach, leadiug to a convoluted intestine, the straight terminal portion, or rectum, perforating the lieart and terminating at the base of the anal siphon, or over the posterior adductor. "The liver is a large follicular mass, enveloping the stomach; a glandular mass, partially surrounding the rectum, is called firlney, by Owen, from urie acid laving been found in it, but is marked ocary by Milne Edwards (both agree that the ovary in the female, and testis in the male, surrounds the intestine). The foot, when it exists, is a symmetrical, fleshy, extensile organ, developed from the ventral aspect of the body; the enveloping muscular fibres are transverse, the action of which protrudes the foot, and longitudinal, the action of which retracts it. In the lower bivalves, (Monomyoria,) the lecert is of a single auricle, and one ventriele, perforated by the rectum; in the higher groups (Dimyaria) the veins from the gills open into two auricles, which open into one fusiform ventricle, perforated by the intestine (in Arca the ventricle is double). An artery from cach end of the ventricle 
distributes the blood. Neves: in the IIonomyaria the principal ganglion is on the ventral convex edge of the adductor, to which it sends branches, as well as to the gills and mantle; two yellow filaments extend to the mouth, where another pair of ganglia supply the tentacles, and give off a delicate ring round the oesophagus. In the Dimyarin the main pair of ganglia ("branchial") are at the under edge of the posterior adductor. sending, as before, cords to the supracsophageal ganglia, between the mouth and the anterior adductor; numerous other small ganglia are developed in various positions. Ilearing: Cyclas has at the anterior part of the labial tentacles a cavity, with a cretaceous, oscillating nucleus, considered by Dr Siebold to be the ear. Sight: Pectin has numerous small eyes round the edge of the mantle, but most of the types are blind. $D_{i}$. relopnent: the spermatic filaments discharged from the males are drawn in by the branchial currents of the females. The young, or embryo, of the dimyarian genus fnorlon have only a single adduetor, as in the monnmyaria, and possess a byssus. The shells are extravascular, of an external cellular, or fibrous, and a thin internal nacreous layer forming the hinge teeth, \&c.

The class is divisible into three Orders :-1 1st, Pleuroconcha, with unequal valves, unsymmetrical bodies, resting habitually on one side, lobes of the mantle disunited and never forming siphonal tubes, and the pallial impression heing consequently entire. 2nd, Isedrolutite, with equal valves and entire pallial sear. 3rd, Macrotrachia, with equal valves and a sinus in the pallial scar, indicating large, retractile, siphonal tubes. The two latter are the most highly organized, and retain a vertical position when alive, as pointed out by d'Orligny. The 1st and Ind groups are confounded under the name Atrachic by Swainson, whose group Macrotrachic contained all the other Lamellibranchs; M. d'Orbigny has distinguished the very natural group Pleuroconcha, but confounds the 2nd and 3rd groups together under the name Orthoconcha.

\section{1st Ord. Pleuroconcha ( $\left.D^{\prime} \mathrm{Or}^{\prime} \mathrm{b}.\right)$}

Shell inequivalve, unsymmetrical. Animal unsymmetrical; lobes of the mantle disunited, never forming siphonal tubes; pallial impression consequently entire. Natural position, resting on the side,

These shells are inferior to the Isedrolotile and Macrotiachic in general organization; they are not symmetrical like them, but one valve differs in size, \&c. from the other; and instead of being free and habitually assuming a vertical position, they lie on one side, and are fixed to foreign bodies either by a byssus, or by the sulstance of the lower valve; the shells in the latter ease being remarkable for the irregularity of their growth.

This Order contains the following families: 1st, Anomiide; 2nd, Ostreider ; 3rd, Etheride; 4 th, Chamider; 5th, Spondylidoe; 6th, Pectinidas; 7th, Aviculidee.

\section{7th Family. AVICULIDE.}

Shell very inequilateral and very inequivalve, obliquely elongate; the upper or left valve largest; a notch for the byssus under the anterior ear of the lower valve; pallial line entire; two muscular impressions in each valve, one large a little behind the middle, another very small and inconspicuous just under the beak (probably only a retractor of the foot); hinge linear, with or without teeth; cartilage internal or external, simple or transversely divided. Animal: mantle quite open, margin thick and ciliated; foot rudimentry, cylindrical, beneath which is a very large byssus for attachment; gills forming two crescent-shaped plates on each side; mouth with wide truncated lips.

The shells of this family differ from those of the family Pectinide by the obliquity of the shell, and by the structure of the hinge and ligament. They abound chiefly in the warm seas of the Tropics.

Genera.-1st, Avicula; 2nd, Pterinea ; 3rd, Pteronites; 4th, Aucella; 5th, Ambonychia; 6th, Streblopteria; 7th, Aviculopecten; 8th, Gervillia; 9th, Perna; 10th, Inoceramus; 11th, Pulvinites.

\section{Genus. AVICULA (Klein.)}

Gen.Char.-Very inequivalve and inequilateral, obliquely oval; hinge produced posteriorly into a flattened defined wing; the inferior or right valve flattened, notched for the passage of the byssus; anterior (? retractor) muscular impression very small and faintly marked; adductor large, superficial, a little behind the middle;

[FASC. II.] 
cartilage external, linear, simple, placed on a narrow marginal facet extending from the beak more or less towards the anal angle; hinge edentulous or with two small eardinal teeth beneath the beak in one valve, and one in the other, and a long, slender, posterior, bifid, lateral tooth in each; substance corneo-calcareous, lamellar without, pearly within.

The subgenus Meleagrina (Lam.) differs in its rotundato-quadrate form, undefined posterior wing, and the ligamentary or cartilage facet broadly dilated beneath and behind the beak, and the small anterior, retractor, muscular impressions, numerous, forming a vertical row from the beak towards the ventral margin. The two following species are referred with doubt to this genus, their internal characters being imperfectly known.

Avicula Danbyi $\left(M I^{c} C o y\right)$. Pl. 1. I. figs. 11 to 15.

Ref.-Id. MCoy, Ann. Nat. Hist. 2nd Series, Vol. VII. p. 59.

Sp. Ch. - Obliquely ovate, anterior end broadly rounded, posterior end more or less narrowed, rounded; ventral margin evenly convex; hinge-line rather less than half the width of the shell; posterior wing scarcely twice the length of the anterior; both wings nearly rectangular, with slightly concave margins; left valve gently convex, most gibbous near the beak, marked with minute concentric, irregular, interrupted strice and wrinkles, crossed by a variable number of obtuse ridges radiating from the beak, and generally becoming obsolete towards the margin; right valve flat, with slight irregular concentric wrinkles and strixe of growth, without radiating ridges. Average length from anterior to posterior margin 2 inches 3 lines, proportional width at right angles to middle of hinge line $\frac{70}{100}$ to $\frac{85}{100}$, length of hinge line including both ears $\frac{55}{100}$ to $\frac{50}{100}$.

This species varies much in the amount of its obliquity and transverse elongation, and the radiations of radiation on the left valve: these latter resemble the radiations of Pholadomya, for which that valve might be taken when the ears are concealed. Traces of a subcentral muscular impression occasionally visible. Some of the varieties are so slightly oblique as to assume a rotundato-quadrate form. Traces of two fine internal ridges diverging from the beak of the flat valve where the wings join the body of the shell (resembling those of $P_{e}$ cten). Mr Salter has suggested the specific name to me for this species in honour of one who first collected it, together with most of the other fossils of Kendal.

Position and Locality.-Very abundant in the greenish Upper Ludlow quartzites of Benson Knot, Kendal, Westmoreland.

Explanation of Figures.-PI. 1. I. fig. 11. Small quadrate specimen of the convex, radiated, or left valve; fig. 12, orbicular variety, natural size; figs. 13 and 1t, obliquely elongate varieties; fig. 15, unradiated, flat, or right valve, natural size.

\section{Avicula? orbicularis. Var. (Som.) Ref.-Sil. Syst. t. 20. f. 3.}

Sp. Ch.-Obliquely ovate, evenly gibbous, most so a little in front of the middle; posterior and ventral margins forming one broad elliptical curve; hinge straight, shorter than the shell, cardinal angle $115^{\circ}$; no defined wing nor posterior slope; anterior lobe compressed (? rounded), deeply defined from the body of the shell; surface marked with imbricating lines and waves of growth. Length from beak to posterior end two inches three lines; greatest proportional width, from middle of hinge-line to ventral margin $\frac{75}{1 \ldots \ldots}$; depth of one valve $\frac{20}{100}$.

There seems an obseure trace of an internal, slender, cartilage plate, extending considerably below the hinge-margin, indicating an affinity with Modiolopsis; but the imperfection of the specimen leaves ble uncertain of its true generic position, and I therefore leave it as placed by $\mathrm{Mr}$ Sowerby, without thinking it really an Avicula.

Position and Locality.-Fine Caradoc sandstone of Acton Scott, Church Stretton, Shropshire.

Genus. PTERINEA (Gold.)

Gon. Char.-Transversely trigonal, oblique, inequivalve*, left valve most convex, very inequilateral, beaks

* Goldfuss says equivalve, but, I am convinced, erroneously. 
near the small anterior end; hinge-line long, straight, forming a small anterior, and a large falciform posterior. wing, with a linear flattened marginal cartilage facet, longitudinally striated; shell thick, calcareous; two long, slightly diverging, posterior, lateral teeth, beneath the hinge in one valve, and one in the other (in some types very numerous and shorter); a few short cardinal teeth radiating beneath and in front of the beaks; dimyarian, anterior impression very strong just in front of the beak, posterior impression larger, but faintly marked, superficial; pallial scar simple; a shallow byssiferous concavity extends obliquely from the anterior part of the ventral margin towards the beak.

The strong impression of the anterior adductor is very risible in casts, and readily distinguishes this Palæozoic genus from A vicula, in which the little anterior accessory muscle is superficial and scarcely to be seen. The substance of the shell is generally thicker and more calcareous than in Acicula, as in it the hinge-teeth are sometimes absent and more often present, they are also generally more nearly equivalve.

\section{Pterinea? asperula $\left(\boldsymbol{M}^{c} \mathrm{Coy}\right)$. Pl. 1. I. fig. 5.}

\section{Ref.-Id. McCoy, Ann. Nat. Hist. 2nd Series, Vol. VII. p. 60.}

$S p . C h$.-Obliquely ovate; body of the shell evenly convex, abruptly defined from the anterior and posterior sides; beaks gibbous; anterior wing rounded, less than half the length of the posterior wing, which is Hat, acutely pointed, and extending a little beyond the shell, its posterior margin concave; posterior end of the shell broadly rounded; entire surface radiated with nearly equal, rough (obscurely tubereulated) ridges, separated by flat spaces rather greater than their diameter in width, (six ridges in one line at margin); those ridges are crossed on the body of the shell by fine wrinkles of growth, which on the wing and towards the beak become sharp, definite strice, parallel with the margin. Length from beak to posterior end three and half lines; width of posterior wing, from angle to side of shell, $\frac{52}{100}$; width from beak to margin $\frac{80}{100}$.

Position and Locality.-Common in the black Caradoc shale of Builth Bridge, Radnorshire,

Explanation of Figures,-Pl. 1. I. fig. 5. Left valve, natural size; fig. $5 \alpha$, ditto magnified.

\section{Pterinea Boyd (Comrad. Sp.)}

Syz. = Avicula Boydi Conrad, Journ. Acad. Nat. Sc. Phil. Vol. VIII. t. 12. f. 4.

Sp. Ch.-Obliquely ovate, depressed, gently convex, most so towards the beak; posterior slope straight. defined; anterior wing small; posterior wing large, broad, flattened, slightly exceeding the margin of the shell in length; posterior margin regularly, but slightly, coneave; anterior and ventral margin broally curved to the narrow respiratory angle; surface of sides and wing covered with slender, rough, filiform ridges, of irregular size, their own thickness apart (about five in two lines near the middle), crossed at small, nearly equal distances by sharp, scalloped concentric scaly lines, and large, obscure, irregular wares of growth. Greatest length (from beak to respiratory angle, along the straight posterior slope) one inch seven lines; proportional length from beak to end of hinge-line $\frac{77}{100}$; width of posterior wing $\frac{60}{100}$; depth of left valve about $\frac{10}{100}$.

This species is somewhat intermediate between the $P$. lineata and $P$. reticulata (Gold.), and it is possible that Sowerby's figure of his A cicula lineata (which is not the $P$. lineata, Gold.) may be an imperfect representation of it; this would require, however, that the figure should be less oblique, the posterior wing much larger, and the addition of the numerous concentric, scalloped lines, curving upwards between each pair of striae. The nearly allied $P$. fimbriata $\left(M^{\circ} \mathrm{Coy}\right)$, Syn. Sil. Foss. Irel. t. 2. f. 7, differs in its stronger sculpturing, and having no radiating ridges on the wings. In old specimens every fifth ridge is often larger than the others.

Position and Locality.-Upper Ludlow micaceous quartzite of Brigsteer, Kendal, Westmoreland. 


\title{
Pterinea demissa* (Comrad Sp.) Pl. 1. I. fig. 7.
}

\author{
Ref. and Syn, = Avicula demissa Conrad, Journ. Acad. Phil. Vol. VIII. t. 13, f. 3. Id. Hall, Pal. New \\ York, t. 80. f. $2 a b$. = Avicula ampliata (Phil.) Mem. Geol. Surv. Vol. II. t. 23. f. J.
}

$S p . C h$.-Subrhomboidal; moderately oblique; beaks small; left valve sigmoidally gibbous, most convex about the middle; right valve nearly flat; hinge-line extending generally a little beyond the shell; anterior wing forming a small, acute, rounded lobe, with the byssiferous sinus only about as far from the extremity as the beak is ; anterior and ventral margins broadly rounded; posterior end obtusely rounded; wing broad, compressed, the margin slightly concave to form the short acute angle; surface with fine, sharp, regular, concentric strix, separated by rather wide, slightly eurved spaces (about four in one line near the middle), abruptly closer and finer on the posterior wing: casts of the left valve, the strong anterior adductor impressions elose under the beak; a flat, narrow, longitudinally striated, ligamental facet along the hinge-line; two long, approximate, posterior lateral teeth extending from behind the beak, rather less than half way to the margin, eurving from the hinge-line at an angle of about $17^{\circ}$; in front of or just under the beak are a few short, strong teeth, directed towards the anterior end of the hinge-line. Greatest length, along the hinge-line one inch two lines, greatest proportional width at right angles to middle of hinge-line $\frac{85}{100}$.

This variety differs from the $P$. rectangularis by its long, curved posterior teeth, and small, acute, anterior lobe, and less distance of the sinus from the end; the cardinal teeth are larger, and diverge from the hinge more than in the type.

A specimen from the Malverns shews several small holes in the shell, from each of which radiate specimens of a small Cliona, or Fioa, burrowing into the substance of the shell, simply dichotumous at an angle varying from $45^{\circ}$ to $70^{\circ}$; the branches are rounded, two to three lines long, obtuse and slightly dilated at the tip, with a diameter of one-third of a line. As this is the oldest known boring sponge, I have named it Viac prisce, and figured it Pl. 1. B. fig. 1.

Position aud Locality. - Common at Middleton Park, Caermarthenshire; Upper Ludlow of Benson Knot, Kendal, Westmoreland; near Pont-ar-y-llechan, Llandeilo, Caermarthenshire; Malverns, Worcestershire.

Pterinea imans $\left(M \Gamma^{\circ}\right.$ Coy). Pl. 1. I. fig. 6.

Ref.-Id. $\mathrm{M}^{\circ} \mathrm{Coy}, \mathrm{Ann}$. Nat. Hist. 2nd Series, Vol. VII. p. 60.

Sp. Ch.-Rotundato-quadrate; slightly oblique; moderately gibbous, most so one-third the length from the beaks, which are one-third the length of the hinge-line from the anterior end ; anterior side large, defined by a deep hollow, extending nearly at right angles with the hinge-line from before the beak to the ventral margin, in which it produces a slight sinus; in front of this it is convex, and then nearer the slightly acute cardinal angle another smaller, shallow sinus, from the margin towards the beak: posterior wing broad, compressed, not abruptly defined from the body of the shell, slightly acute, and scarcely extending beyond the posterior end of the body of the shell, which is obtusely rounded; ventral margin nearly horizontal, slightly convex; surface with close, fine, equal, thread-like radiations, interrupted by slightly irregular, concentric inbrications, about half a line apart. Length along hinge-line nine lines; proportional width from beak to middle of ventral $\operatorname{margin} \frac{75}{100^{\circ}}$

This differs from the Avicula emaciata (Conrad) by the large, gaping, anterior side, with its double sinus; the same separates it from a small variety of the A. Boydii (Conrad); it is also more square and less oblique than either of these species. The large size of the anterior lobe also separates it from the Avicula quadrula (Conrad).

Position and Locality.-From the Aymestry limestone of Mortimer's Cross, Aymestry, Herefordshire.

Explanation of Figures.-PI. 1. I. fig. 6. Left valve, natural size; fig. $6 a$, ditto magnified.

* Probably an extreme variety of $P$. retrofiexa, which see. 


\title{
Pterinea lineata (Gold.)
}

\author{
Ref.-Id. Gold. Pet. Germ. t. 119. f. 6.
}

Sp. Ch.-Aliform, tumid; beaks rather large, obtuse; posterior wing very large, gradually compressed, acutely pointed, extending beyond the respiratory margin, its posterior edge nearly straight above, much curved below; respiratory angle broadly rounded; rentral margin oblique, gently convex; posterior slope obscurely defined in old specimens; entire surface uniformly radiated with close, fine, unequal lines (about five in one line near the middle of the shell), less than thcir thickness apart, crossed by occasional, small, concentrie waves of growth. Length from beak to respiratory angle one inch and half a line, from beak to end of hingeline one inch; proportional width at right angles to middle of hinge-line $\frac{80}{100}$.

The Avicula lineata, as figured by Sowerby (Sil. Syst. t. 5. f. 10), seems altogether different, by its greater obliquity, and its stronger, fewer, and more distant ridges-M. d'Orbigny proposes to call it A. lineatula (Prodrome, p. 33.)

Position and Locality.-Rare in the Upper Ludlow micaceous quartzites of Benson Knot, Kendal, Westmoreland; in the fine sandy schists of Middleton Park, Caermarthenshire.

$$
\begin{aligned}
& \text { Pterinea megaloba ( } \left.\boldsymbol{M}^{c} \mathrm{Coy}\right) \text {. Pl. 1. I. fig. 19, } 20 . \\
& \text { Ref.-Id. } \mathbf{M}^{\mathrm{c}} \mathrm{Coy} \text {, Ann. Nat. Hist. 2nd Series, Vol. VII. p. } 61 .
\end{aligned}
$$

$S_{p}$. Ch.-Obliquely subtrigonal; diagonally tumid from the beak to the posterior end (the curve amounting nearly to a semicircle in old specimens); hinge-line elevated into a compressed, nearly rectangular, broad wing, the angle rather nearer to the beak than to the posterior ventral end, which is obtusely rounded, and to which the margin is nearly straight; anterior end short, forming a very large rounded lobe ; a shallow concavity, which defines it from the body of the shell, extends from the beak to a little in front of the midlle of the ventral margin, where it forms a small sinus: beaks narrow, prominent, incurved; anterior muscular impression very strong in the casts; no teeth. Length from anterior to posterior ends one inch one line; proportional width

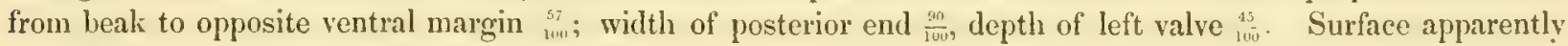
smooth, or marked with fine concentric strix.

The great size of the anterior lobe is the most remarkable character, and is produced by the byssiferous sinus extending backwards at an acute angle to the hinge-line (about $75^{\circ}$ ), unlike any other species I know. Only for the left valve being so much more convex than the right, the species might have been placed in Cypricardites; the general form is exactly that of the Pterinea rectungularis (Sow. Sp.), Sil. Syst. t. 3. f. 2. from which it seems to differ (nine specimens examined) in the want of the diverging cardinal teeth.

Position and Locality. - Not uncommon in the tilestone of Storm Hill, Llandeilo.

Explanation of Figures.-PI. 1. I. fig. 19 and 20. Small specimens of left valve, natural size.

\section{Pterinea pleuroptera (Conrad Sp.) Pl. 1. I. fig. 1. and 2.}

Ref. and Syn. = Avicula pleuroptera (Conrad) Journ. Acad. Sc. Phil. Vol. VIII. t. 13. f. 2.

$S p . C h$.-Body of the shell obliquely ovate, gently gibbous, most so towards the beaks, which are narrow and prominent above the hinge-line; anterior wing small, compressed, subtrigonal, strongly defined from the body of the shell; posterior wing about twice and half to three times the length of the anterior one, pointed, scarcely extending beyond the shell; its posterior margin concave, the posterior half of its dorsal edge thickened into a ridge, defined by an impressed line below; ventral margin obliquely rounded to the obtuse posterior end; surface (of left valve) with close concentric lines, sharpest on the wings, reticulated on about the middle portion of the shell by close, fine, subequal lines from the beak (about four in one line). Length from beak to posterior end ten lines (probably obliquely pressed); proportional length of hinge-line $\frac{71}{\frac{\pi}{10}}$; depth of both valves $\frac{45}{100}$; width at right angles to middle of hinge-line $\frac{5.5}{100}$. Larger and more quadrate specimen, from beak to posterior end one inch three lines, hinge from anterior to posterior wing the same, proportional width at right angles to middle of hinge ${ }_{100}^{183}$. 
I can scarcely doubt the identity of our shell with that figured and described (not very fully) as above by Mr Conrad, from the Upper Silurian shales of New York; but if any character not indicated in the American species should hereafter separate them, the name meso-clathrate might be applied to this one to indicate a character which separates it from the varieties of $P$. linecte or $P$. reticulatc, namely, the radiating lines being confined to the middle of the shell, not affecting the wings.

Position and Locality.-Bala schists, Cyrn y Brain, west of Wrexham, Denbighshire; the large variety from the Ludlow rock at Parklane, Llandeilo; one doubtful variety in the Upper Ludlow quartzite of Benson Knot, Kendal, Westmoreland.

Explanation of Figures.-Pl. 1. I. fig. 1. Natural size, left valve, large specimen from Parklane, Llandeilo; fig. 2 , small variety from Cyrn y Brain; fig. $2 a$, Ditto, profile of both valves, natural size; fig. $2 b$, part of surface of ditto magnified.

\section{Pterinea Retroflexa ( $W a h l . S p$.)}

Ref. and Syn.= Mytilites retroflexus Wahl. Upsal.=Avicula retroflexa Hisinger, Leth. Suec. t. 17. f. 12; id. 'Sil. Syst. t. 5. f. 9. Var. a. >? Avicula naviformis Conrad, Journ. Acad. Phil. Vol. VIII. t. 12. f. 11.

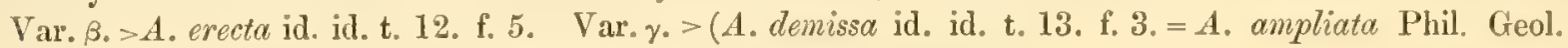
Surv. Vol. II. t. 23. f. 1.) = Avicula subretroflexa d'Orb. Prod. p. 33.

s\%. Ch. -Transversely subtrigonal, anterior side short, slightly pointed, tumid, with two faint sinuses in the margin, the lower (separating it from the body of the shell) nearly at right angles with the hinge-line, the other close to the extremities, inconspicuous; gently convex, posterior wing gradually flattened, the margin sigmoidally curved, the curve of the concavity of the dorsal part about equalling the convexity of the ventral portion; surface marked with sharp strie parallel with the margin; internally a strong bilobed anterior adductor just in finnt of the beak; two slender posterior teeth about two-thirds the length of the hinge-line, and slightly diverging from it; a few very small oblique ones beneath the beak. Length of average variety, from beak to anal angle, one inch three lines, to end of hinge-line $\frac{\pi 6}{1 w}$, width at right angles to hinge-line very variable.

I find this shell (from examination of many specimens) to vary extremely in the amount of obliquity, no two specimens being exactly alike in this respect; it also varies, in a less degree, in convexity and closeness of the striation. Whether the assumed typo figured as above by Sowerby is identical with the regularly lined shell figured by Hisinger under the same name, is, I think, doubtful. I formerly (Synop. Sil. Foss. Irel.) considered these certainly distinct, from having found in the slates of Kerry a species exactly agreeing with his, in the distant regular striation, Sce; a Leintwardine specimen in the Cambridge Collection is, however, exactly intermediate, as if in some states of the surface certain of the stria at regular intervals were more prominent than the rest. The characters above given embrace, first, the above types in which even the left valve is only gently convex, and the beak only slightly prominent, and valying in the closeness and regularity of the stria, (var. a.); sceond, a very convex transversely clongate furm, with large prominent beaks, and the dorsal and ventral margins subparallel, striation as in the first var. (var. $\beta$.) - to this Comrad has given the name Ariculd navifurmis, and I add two figures of it from Westmoreland specimens (Pl. 1. I. f. 9 and 10); third, a variety from the Upper Ludlow of Laverock Lane, agrecing with the A viculd erecto of Conrad in the body of the shell, being developed nearly at right angles to the hinge-line, but differing therefrom and agrecing with the ordinary types in the shorter hinge-line, and the posterior margin having the ordinary equal-ended sigmoidal curve (var. $\gamma_{.}$), and fourth, a broadly rounded, gently convex form, with a very small anterior lobe, and strong concentrie stric becoming closer and finer on the posterior ear, the margin of which latter is straighter and meets the convex curve of the body abruptly (var. $\delta$.) - this is figured by Conrad and Hall under the name of $A$ cicula demisse (for comparison with the good figure of the latter author, I subjoin a figure of a British specimen, 11. 1. I. f. T, and to shew its passage into the first types I give one intermediate in form and striation, Pl. 1. I. f. 8);--as this latter form is important, I have given a separate description of it under its specific name P. demissa.

Position and Locality.-(Var. a.) Aymestry limestone, Leintwardine, Shropshire; in Upper Ludlow 
rock, Benson Knot, Kendal, Westmoreland; High Thorns, Underbarrow, Kendal, WVestmoreland: (erect. var. $\gamma_{\text {. }}$ ) tilestone of Horeb Chapel, Llandovery, S. Wales; Upper Ludlow, Laverock Lane: (var. $\beta$. naciformis) Wenlock limestone, Dudley, Staffordshire; very common in the Upper Ludlow rock, Kirkby Moor, Kendal, Westmoreland.

\section{Pterinea Sowerbil ( I $\left.^{c} \mathrm{Coy}\right)$.}

Ref. and Syn. = Avicula reticulata (Sow.) Sil. Syst. t. 6. f. 3 (not of Hisinger nor Goldfuss).

$S p$. Ch.-Obliquely ovate, depressed, slightly convex, greatest length along the posterior slope, which is straight and defined; posterior wing gently arched, scarcely extending beyond the shell; its posterior edge slightly and uniformly concave; surface radiated by slightly irregular obtuse ridges, about their thickness apart (five in two lines about the middle, at one inch from the beak), partially interrupted by thin concentric imbrications from one to two lines wide, having the radiating ridges obsolete, or nearly so, on their rostral half; radiating ridges of the wing rather larger, strongly marked only about the middle. Length from beak to respiratory angle two inches six lines; length of posterior wing ${ }_{i=0}^{62}$, width of ditto $\frac{44}{1 \times 0}$; width from middle of hinge-line to ventral margin $\frac{97}{100}$, depth of one valve $\frac{20}{100}$.

This fine species differs from the Pterinca reticulata of the original continental authors, in its more elongate form, smaller posterior wing, with its gently concave posterior edge, and the complaratively few, broad, thin imbrications interrupting the radiating ridges.

Position and Locality.-Aymestry limestone, Leintwardine, Shropshire.

\section{Pterinea subfalcata (Conrad Sp.) Pl. 1. I. fig. 3.}

Syn. and Ref. = Avicula subfalcata (Conrad) Journ. Acad. Philad. Vol. VIII. t. 13. f. 4.

$S p$. Ch.-Body of the shell obliquely ovate, subfaleate, narrow, convex; beaks gibbous, prominent; anterior wing defined by a sinus, narrow, compressed, rounded, about half the length of the posterior wing, which is flat, abruptly defined from the body of the shell, and is acutely pointed with a concave posterior margin; entire surface radiated with subequal, thread-like ridges, about their thickness apart and about ten in the space of one line of the margin (more distant on the posterior wing), crossed by rather more distant concentric ridges, most distinct on the wings, and about equalling the radiating ones in thickness. Length from beak to posterior end four lines, of posterior wing $\frac{05}{100}$, width of ditto $\frac{40}{100}$, width from beak to opposite ventral margin $\frac{50}{100}$.

The narrow subfalcate figure of the body of the shell renders this little species easily recognisable. Mr. Conrad only figures the unradiated or right valve, though he describes the radiations of the other, which I figure.

Position and Locality.- Very common (small variety) in the shale of Howgill Fell, near Sedburgh, Kiendal, Westmoreland; the larger variety (nine lines from beak to posterior end) occurs in the grey micaceous flaggy quartzite at Benson Knot, Kendal, Westmoreland, and in a similar matrix near Pont-ar-y-llechan, Llandeilo.

Explanation of Figneres.-Pl. 1. I. fig. 3. Natural size, left valve, from Howgill Fell ; fig. $3 \alpha$, ditto, magnified.

\section{Pterinea tenuistriata $\left(M^{\circ}\right.$ Coy $)$. Pl. 1. I. fig. 4.}

Ref.-Id. Ann. Nat. Hist. 2nd Series, Vol. VII. p. 62.

Sp. Ch.-Subquadrate, rounded, slightly oblique, evenly giblous, left valve most so; length only slightly exceeding the width; beaks large, tumid; anterior wing half the length of posterior one, abruptly compressed, rounded; ventral margin and posterior end broadly rounded; posterior margin slightly concave towards the cardinal angle of the posterior wing, which is gradually compressed, and scarcely extends beyond the shell: surface with irregular concentric wrinkles of growth crossed by very fine, equal or subalternate radiating strit from the beak, strongest in the middle, about six in one line, less than their diameter apart; posterior lateral 
tooth or hinge-plate as long as the hinge-line, and close beneath it; a thick internal ridge (often leaving a sulcus in easts) curves from behind the beak towards the ventral margin at an angle of about $50^{\circ}$ to $60^{\circ}$ from the hinge-line; hinge-line crenulated, forming arca-like transverse teeth in front of the beak. Length four and half lines, width from beak to opposite ventral margin $\frac{94}{100}$.

This little species is much less elongate, and has a more obtuse posterior wing than the Avicula insueta (Conrad), which it otherwise much resembles. The abrupt bending down of the curved internal ridge, like a lateral tooth into the body of the shell, is a curious character in which, as well as general form, it agrees with the $7^{\prime}$. sublacis ( $\mathrm{M}^{\mathrm{C}} \mathrm{Coy}$ ) of the Irish silurian rocks, but from which it is distinguished by its fine close striation.

Position and Locality.-Common in the Upper Ludlow shale of Cwm Craig Ddu, Builth, Brecknockshire; Middleton Park, Caermarthenshire; Erw Gilfach, Builth; and in the Ludlow schists above Parklane, Llandeilo, Caermarthenshire; Upper Ludlow of Benson Knot, Kendal, Westmoreland; also in the sandy schists of Pont-ar-y-llechan, Llandeilo, Caermarthenshire; in the olive flags above Ravenstone Dale, Westmoreland; Upper Ludlow, Burton and Brockton; Upper Ludlow near Ludlow, Shropshire.

Explanation of Figures.-PI. 1. I. fig. 4. Natural size, left valve, from Benson Knot; fig. 4a, ditto, magnified.

\section{Genus. AMBONYCHIA (Hall).}

Gen. Chur.-Inequivalve*, inequilateral, obliquely ovate or suborbicular, inflated; beaks small, prominent, incurved; anterior side very short, rounded; ventral margin broadly rounded; posterior side broad, compressed, subalate; hinge-line less than the width of the shell, oblique, anal cardinal angle obtuse; surface either longitudinally sulcated, or with broad concentric wrinkles; one large subcentral muscular impression in each valve.

Often confounded with Twoceramus, from which it differs by wanting the transverse pits in the hinge; and with Pterinea and Acicula, from which it differs in its short hinge-line and having no anterior wing. Curdiola has not the angular posterior wing, and has an area between the beaks.

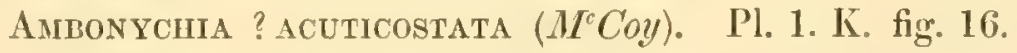

\section{Ref.-Id. $\mathrm{II}^{\mathrm{C}} \mathrm{Coy}$, Ann. Nat. Hist. 2nd Series, Vol. VII. p. 59.}

Sp. Ch.-Ovate, moderately and evenly convex, most so towards the beak; surface radiated with numerous angular ridges, only separated by the angular sulcus formed by the meeting of the steep sides of the ridges (about six ridges in one-fourth of an inch of the margin at half an inch from the beak).

In form and number of the ridges this resembles the small specimen of $A$. carineta (Gold. sp.) figured in Hall's Palæontology (Pl. 80. f. 5), but it is distinguished by its ribs being angular and close together-they being rounded and separated by flat interspaces in the American form.

Only one imperfect specimen has occurred, measuring seven lines from beak to ventral margin.

Position and Locality. - In the green schists of Dinas Bran, Llangollen, Denbighshire.

Explanation of Figures.-Pl. 1. K. fig. 16. Natural size; fig. $16 \alpha$, superficial ridges of ditto magnified.

\section{Ambonychia striata (Sow. $S p$.)}

\section{Ref. and Syn.=Cardium striatum Sow. Sil. Syst. t. 6. f. 2.}

$S p . C h .-O b l i q u e l y ~ o v a t e$, slightly convex, beaks very prominent, obtuse; surface covered with subequal, flattened, narrow, slightly flexuous ridges, their own thickness apart, separated by flat spaces, about six in two lines in the middle of the shell; posterior wing gradually compressed; anal angle $130^{\circ}$; length from beak to anal angle one inch eight lines, width at right angles to middle of hinge-line two inches six lines, depth of right valve about three and half lines; one or two distant concentric waves of growth near the margin; impression of a thin lateral tooth extending beneath the hinge-line.

* Hall says "equiralve," I suppose by mistake: 
Position and Locality.-Lower Ludlow mudstone of Green Quarry, Leintwardine; Lower Ludlow rock, Garden Quarry, Aymestry; schists above Park Lane, Llandeilo; Bala schists, Cyrn y Brain, Wrexham, Denbighshire.

\section{2nd Ord. Isedrolotila ( $\boldsymbol{M}^{c}$ Coy).}

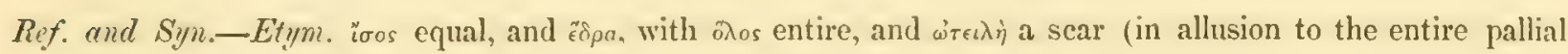
scar and equal valves).

Shell equivalve, symmetrical; natural position nearly vertical; animal having the mantle usually open throughout, not forming siphons; the pallial impression always simple and entire; two or more muscular impressions in each valve.

These shells resemble the Mucrotrachict in being equivalve and symmetrical, and maintaining when alive a nearly vertical position, but differ from them and agree with the Plevroconcha in the mantle being open and seldom forming even rudimentary siphons, and the shell always shewing the pallial impression entire, while they differ from the Pleuroconclu in being equivalve, symmetrical, and never attached by the sulstance of the valve, and but rarely by a byssus - thus naturally connecting the two extreme types, and, like most connecting groups, containing a greater variety of generic and specific types than the extreme groups which it connects. The greater number of known bivalves belong to the Isedrolotila.

The order contains the following families: 1, Limide; 2, Drytilide; 3, Arcides; $4, N$ uculide ; 5 ,

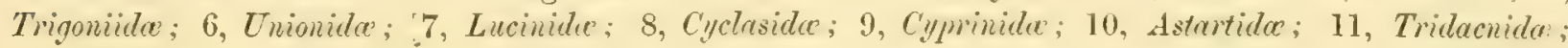
12, Cardiide.

\section{2nd Family. MY'TILID E.}

Shell elongate, oval, narrow in front, widening posterinrly, more or less closed, (equivalve, pallial impression entire), cartilage very long, marginal or nearly so, supported by an internal plate nearly parallel with the hingeline; beaks close to the anterior end or terminal; two or three muscular impressions in each valve. Animal: mantle more or less open; gills fringed or entire: mouth with appendages; foot narrow, tongue-shaped, with a fibrous byssus at its base to attach the shell to foreign bodies, having a small sinus in the anterior part of the ventral margin, from which an oblique impressed furrow extends towards the beak, defining the anterior lobe.

Distinguished from the Aciculicle by being equivalve and having a strong anterior as well as posterior adductor muscle.

Genera:-1, Mytilus; 2, Lithodomus; 3, Modiolopsis; 4, Dreisena; 5, Hippopodium; 6, Pinna ; 7, Dolabra; 8, Myrephoria; 9, Anoduntopsis; 10, Lyrodesma (Actinodonta); 11, Clidophorus; 12, Tellinomya; 13, Orthonotus.

\section{Mrtilus ? unguiculatus (Salt.)}

Ref.-Id. id. Salt. Mem. Geol. Surv. Vol. II. pt. 1. t. 20. f. 6.

A small specimen, too imperfect for description, in the decomposing schists of Plas Madoc. It does not seem to belong to the genus MIytitus.

\section{Genus. MODIOLOPSIS (Hall) as here restricted.}

\section{Syn. < Cypricardites Conrad.}

Gen. Char.-Shell equivalve, very inequilateral, transversely elongate, diagonally gibbous; beak small near the anterior end; anterior end small, rounded, often separated from the body of the shell by a shallow, oblique concavity, extending from the byssiferous sinus in the margin; posterior end very broad, obliquely' subtruncate, or rounded; hinge-line elevated, more or less compressed, nearly as long as the shell is wide; the margin simple and erect; shell very thin, only marked by minute lines of growth; one large, oval, muscular impression a little in front of the beak, and one large superficial posterior one.

[FASC. II.] 
Supposed by Hall to be monomyarian: but where only one adductor is present in a shell, it is always the posterior one; and I have detected a large shallow or superficial posterior impression besides the anterior muscular impression, which latter is very strong in casts, and often visible as a slight projection externally through the thin shell. The byssiferous sinus and oblique depression from it, and the increasing width of the posterior end, separate the species, at a glance, from Oithonotus. The name Morliolopsis was proposed by Hall (Pal. New York), simply as a substitute for Cypricardites of Conrad, on the grounds that the fossils were monomyarian, and therefore more allied to Modiole; but Modtiola is as clearly dimyarian as Cypricurtia. I propose, however, to retain the name for such types as the $M$. modiolaris (Conrad sp.), included by Conrad and Hall as part of their respective genera, Cypricardites and Modiolopsis, having the general form and byssiferous sinus of MLodiola, and agreeing therewith, and with Edmondia (differing from another section of those genera) in having the dorsal margin simple and erect, with a small internal ridge beneath it for the internal cartilage. Modiolopsis, as thus restricted, differs from Modiolo in its very strong anterior impression, from Sanguinolites in the shorter hinge, which if not straight is convex instead of concave, and the hinge-margin being ereet instead of inflected to form a concave lunette, containing an external cartilage near the beak, as in that genus.

\section{Modiolopsis? antiqua? (Sow. Sp.) \\ Ref. and Syn.-Modiola antiqua (Sow.) Sil. Syst. t. 13. f. 1.}

A specimen probably of this species, but too imperfect for description, is in the collection from the Bala schists of Gelli Grin, Bala.

\section{Modiolopsis complanata (Sow. Sp.)}

Syn. = Pullastra complanata Sow. Sil. Syst. t. 5. f. 7.

$S p$. Ch.-Oblong, widening to the posterior end, slightly more than twice as long as wide; beaks small about one-fifth of the length from the anterior end; anterior end elliptically rounded; dorsal margin slightly elevated; ventral margin with a slight concavity in the middle, posterior end obliquely subtruncate (at an angle of about $50^{\circ}$ with the ventral margin), slightly convex, the inferior angle obtusely pointed; sides flattened or slightly concave in the middle; an obtuse diagonal ridge from the beak to the posterior inferior angle; anterior adductor distinct, oval, with a strong, narrow, clavicular, internal ridge, extending from in front of the beak to its upper posterior margin; hinge-line half the length from the beak to the posterior inferior end, posterior lateral tooth or eartilage plate strong, extending its whole length; surface with small concentric lines of growth. Length eleven and half lines, proportional width from beak to opposite ventral margin $\frac{47}{1 w}$, width from cardinal angle to opposite margin $\frac{50}{100}$; (often one-third larger).

The greater length, more pointed and obliquely truncated posterior end, stronger diagonal ridge, and the hollowing of the sides and ventral margin, distinguish this species easily from the Anodontopsis lecvis (Sow. sp.) It varies a little in amount of pointing of the posterior end, rarely being quite so much so as in the above-quoted figure.

Position and Locality.-Abundant of small size in the green quartzite (Upper Ludlow rock) of Kirkby Moor, Kendal, IVestmoreland; larger in the whitish tilestone of Storm Hill, Llandeilo, Caermarthenshire.

\section{Modiolopsis inflata $\left(M^{c} \mathrm{Coy}\right)$. Pl. 1. I. fig. 16.}

$$
\text { Ref.-Id. McCoy, Ann. Nat. Hist. 2nd Series, Vol. VII. p. } 58 .
$$

Sp.Ch.-Longitudinally oblong, very gibbous; beaks obtuse, tumid, incurved, large, close to the anterior end, which is large and obtusely rounded; an obtuse sigmoidal ridge extends from the beak to the posterior inferior end, which is elliptically rounded to the very obtuse cardinal angle, which is slightly elevated; the hinge-line little more than half the length of the shell, with a slender cartilage ridge just below it; ventral margin very slightly concave in front of the diagonal gibbosity. Length one inch six lines, proportional width $\frac{\hbar 7}{10 u}$, greatest 
depth of one valve (about one-third the length from the beak) $\frac{26}{110 .}$. Surface with minute, irregular plications and lines of growth.

Distinguished from all the varieties of the $M$. modiolaris by its greater gibbosity, shorter linge-line, and broader anterior end.

Position and Locality.-Bala schists of Pen Cerrig, Serth, (very common); Bala schists of Cymmerig, E. of Bala, Merionethshire.

Explanation of Figure.-Pl. 1. I. fig. 16. Left valve, natural size, from Pen Cerrig.

\section{Modiolopsis modiolaris (Conrad Sp.) Pl. 1. I. fig. 17 and 18.}

\section{Ref. and $S_{y, n}=$ Pterinea and Cypricardites Modiolaris $+C$. angustifrons + C. ovatus Conrad; $=$ Mlodiolopsis Modiolaris Hall, Pal. N. York, t. 82.}

Sp. Ch.-Obliquely ovate, gradually widening to the posterior end, about two and half to three times longer than wide; a diagonal, slightly sigmoid gibbosity, from the small prominent bealss becoming gradually obsolete towards the inferior posterior angle; anterior end one-eighth to one-ninth of the length, narrow, rounded, often shewing a round boss indicating the insertion of the large anterior adductor; a shallow sinus in the anterior part of the ventral margin, from which a slight shallow hollow extends towards the beak; posterior end wide, elliptical, obliquely subtruneate, posterior slope gradually compressed; hinge-margin elevated, straight, or slightly convex, with a slender, internal cartilage plate a little below it, and extending about one-fourth of the length from the beaks to the posterior end; surface with obsolete concentric lines and waves of growth. Length two inches one line; width from beak to opposite margin $\frac{31}{1 m}$; greatest width (at end of hinge-line) $\frac{53}{1 \mathrm{~m}}$; greatest depth (at one-third from the beak along the diagonal ridge) varying from half to one-third of the width.

This differs from the $M$. expansa (Port.) in its smaller anterior lobe, more obtuse diagonal gibbosity, sinuate ventral margin, and shorter and more elevated hinge-line.

Position and Locality.-Not uncommon in the Caradoc sandstone of Horderly; also in Bala schist at Maes Hir, N. E. of Aber Hirnant, N. Wales; Bala schists of Cader Dinmael, near Corwen, Denbighshire.

Explanation of Figures.-Pl. 1. I. fig. 17. Right valve of normal variety, natural size, from Cader Dinmael ; fig. 18, depressed variety from Horderly.

\section{Modiolopsis expansa (Port. Sp.?) \\ Ref. = Modiola id. id. Geol. Rep. t. 33. f. 6.}

An imperfect specimen of the posterior end probably of this species has occurred in the blackish Bala schists of Cerrig y Druidion. It differs from the MI. Modiolaris in the dorsal and ventral margin being more nearly parallel, the posterior slope and sides flatter,' and meeting at a more angular ridge extending to the posterior inferior angle; the substance of the shell is also much thicker and the concentric lineation sharper and stronger.

\section{Modiolopsis Nilsoni (His. Sp.) Pl. 1. I. fig. 21.}

Ref. and Syn. = Modiola Nilsoni Hisinger, Leth. Suec. t. 18. f. $13=$ Modiola antiqua Sow. (not Goldf.) Sil. Syst. t. 13. f. 1 = Mytilus gradatus Salt. Mem. Geol. Surv. Vol. II. t. 20. f. 4.

$S p . C \%$.-Oblong, widening towards the anal angle, where the width is usually three-fifths of the length, rarely a little more, often something less; beaks small, narrow, prominent, anterior end about one-sixth of the length, elliptically rounded; anterior adductor strongly marked at the posterior edge; valves compressed; a narrow diagonal gibbosity of small amount extending from the beak towards the broad, obtusely-rounded, respiratory angle, from which the posterior slope gradually inclines to the hinge-margin, which is slightly elevated, and extends to about one-third the length of the shell from the posterior end (anal angle $120^{\circ}$ ); ventral margin nearly straight, with a wide, scarcely perceptible, sinus about the middle, from which a very shallow concavity 
extends towards the beak, just in front of the diagonal ridge; surface marked with concentric, fine, unequal strix, a few of which, at irregular distances, are much deeper than the rest, from a step-like change of level in the surface. Length of average variety one inch, width from beak to ventral margin $\frac{A_{i s}}{5 \cdots,}$, width from anal angle $\frac{64}{100}$, depth of one valve (greatest about the middle of the diagonal ridge) scarcely $\frac{18}{1000}$.

Hisinger's figure appears a little longer than usual, apparently from the imperfection of the thin dorsal margin, which only shews the full width in fine specimens. Sowerby distinguishes his Modiola antiqua (not the species previously so called by Goldfuss) from the M. Nitsoni, by being rather shorter and not quping. The gaping in Ilisinger's figure is obviously because the valves are not closed: if the shell really gaped he would not have placed it in Modiola. Mr Salter in describing (and well figuring) the species as new, makes no allusion to the above description or figures.

Position and Locality.-Common in the olive Ludlow schists above the white grits at Parklane, Llandeilo, Caermarthenshire, and in the similar strata at Middleton Park, Caermarthenshire; Sowerby's $\boldsymbol{M}$. antiqua in the Bala schists at Gelli Grin, Bala, Merionethshire, slightly narrower and more convex

Explanation of Figure.-Pl. 1. I. fig. 21. Natural size, left valve, from Parklane, Llandeilo.

\section{Modiolopsis PLATYPhyLla (Salt. Sp.)}

Ref. and Syn. = Mytilus platyphyllus Salter, Mem. Geol. Surv. Vol. II. pt. 1. t. 20. f. 13 and 14.

Sp. Ch.-Oblong; length about twice and half the width; sides compressed; anterior lobe very large, elliptically rounded, wide, gently convex, defined by a very wide, shallow sinus in the middle of the ventral margin, from which a wide, shallow depression extends towards the beak; posterior end slightly widening, very obliquely rounded; anal angle scarcely defined, diagonal ridge gently convex, posterior slope gradually compressed; respiratory angle narrow, elliptically rounded; beaks very small, inconspicuous; anterior muscular impressions small, close to the beak. Average length two inches; in proportion to length, greatest width (at end of hinge-line) $\frac{49}{i 00}$, from beak to opposite ventral margin $\frac{37}{1+m}$, length of hinge-line apparently $\frac{30}{1 m}$, length of

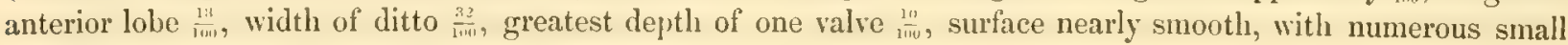
concentric wrinkles of growth towards the margin.

The much less convexity of the valves and considerably larger anterior side, as well as more posterior ventral sinus, separate this species from the $\boldsymbol{D} I$. modiolaris of the lower rocks.

I should imagine the upper part of the anterior lobe in the Survey figures had not been quite cleared from the matrix, as it seems narrower than $I$ have seen.

Position and Locality. - In the yellowish tilestone of Storm Hill, Llandeilo, Caermarthenshire.

\section{Modiolopsis postlineata $\left(M \Gamma^{c}\right.$ Coy $)$. Pl. 1. I. fig. 22.}

Ref.-Id. $\mathrm{I}^{\mathrm{c} C o y, ~ A n n . ~ N a t . ~ H i s t . ~ 2 n d ~ S e r i e s, ~ V o l . ~ V I I . ~ p . ~} 58$.

Sp. Ch._Oblong, twice as long as wide, shell thin, moderately convex; beaks small, near the anterior end, which is obtusely rounded; no byssal sinus or hollow from the beak; posterior end obtuse, obliquely rounded; dorsal and ventral margins nearly parallel, straight; linge-line two-thirds the length of the shell, with a nearly parallel, delicate hinge-plate running beneath it, with erect dorsal margins; surface with minute, obsolete, transverse wrinkles of growth, except on the flattened posterior slope, which is radiated with fine, close, equal strix from the beak. Length one inch; proportional width from the beak to the ventral margin $\frac{45}{100}$.

Some specimens have a rough general resemblance to the $N$ uculites poststriatus (Emmons), but they are distinguished by the parallelism of the dorsal and ventral margins, smaller beaks, greater transverse diameter, Stc. It also closely resembles the Cypricarlites sectifions of Conrad; but that is figured with radiating lines on the sides as well as the posterior slope; the anterior part of our specimen is unfortunately imperfect.

Position and Locality.-Bala rock, Alt yr Anker, Meifod, Montgomeryshire.

Explanation of Figure.-Natural size, of right valve. 


\title{
MIOdiolopsis SOLENOIdes (Sow. Sp.)
}

\author{
Syn. and Ref.=Cypricardia? solenoides Sow. Sil. Syst. t. 8. f. 2.
}

$S_{p}$. Ch.-Subcylindrical; dorsal and ventral margins subparallel; length two and half to three times the width, which is greatest from the beak to opposite margin; gently convex; posterior slope slightly convex, defining a slightly arched obtuse rilge from the beak to the posterior inferior angle; anterior end a little contracted below the beaks, elliptically rounded, one-serenth to one-eighth of the length; posterior end very oblique, subtruncated, elliptically pointed, the end obtuse; hinge-line not elevated at the end; ventral margin nearly straight, slightly concave; a little clavicular internal ridge from the beak to the posterior edge of the anterior adductor. Length one inch three lines, greatest proportional width (from beak to opposite ventral margin) $\frac{33}{1009}$ depth of one valve about $\frac{15}{100^{\circ}}$.

The greater proportional length, the hinge-line not being elevated, the narrow and more obliquely truncated posterior end, and greater convexity, distinguish this from the allied varicties of the 1 \%. complanata (Sow. sp.). The Leptodomus amygdalinus (Sow. sp.) to which Mr. Sowerby likens it, is distinguished by its much greater gibbosity, its shorter wedge-like outline (Mr. Sowerby's figure being unusually elongate from pressure), broad, subtruncate anterior end, with its deep lunette, \&c.

Position and Locality.-C'ommon in the hard, green, micaceous flags of the $\mathrm{L}^{\top}$ pper Ludlow of Benson Knot, Kendal, Westmoreland; also in the yellowish micaceous tilestone of Storm IIil, Llandeilo, Caernarthenshire.

\section{Genus. DOLABRA (M'Coy).}

Gen. Char.-Obliquely ovate, gibbous; left valve larger than the right; beaks large, obtuse, nearer the anterior than posterior end; hinge-line shorter than the shell, extending in a right line each side of the beaks (appearing crenulated in some species); a flat, narrow, ligamental area the length of the hinge-line, widest between the beaks; anterior end narrower than the posterior, rounded, no byssal sinus or furrows; ventral margin slightly convex; pesterior end obliquely truneated; posterior slope flattened, defined; surface smooth or finely striated; one thick, elongate, posterior lateral tooth or cardinal ridge in each valve, inclining at an acute angle from the hinge-line, that of the left valve sometimes bifid; anterior adductor impression ovate, superficial : pallial scar entire; posterior adductor moderate, irregularly rounded, superficial.

I am not certain of the nature of the obscure crenulations observed on the hinge-line of some species; if they be found to resemble those of Arca, the genus is still perfectly distinguished therefrom by the long, thick, diverging, posterior tooth within or beneath them, resembling almost exactly in fact the posterior teeth and hinge-crenulations of Geveillia, illustrating the suggestion of Phillips, that Dolabra was allied to Lyrodesmu or Actinodonta, in which the cartilage sinus seems to have been similarly divided; sone species have clearly entire (not crenulated) cardinal edges. The genus seems to me intermediate between Leptodomus and Edmondiu. but without the anterior lunette of either of those genera, but apparently having the thick cardinal ridges and strong shell of the latter.

\section{Dolabra elliptica $(M C$ Coy). Pl. J. L. fig. 10.}

Ref.-Id. M ${ }^{\mathrm{c}} \mathrm{Coy}$, Ann. Nat. Hist. 2nd Series, Vol. VII. p. 52.

Sp. Ch.-Elongate, elliptical, length slightly more than twice the width; beaks obtuse, moderate, onesixth of the length from the anterior end; anterior end small, elliptically rounded; ventral margin slightly convex; hinge-line slightly elevated; posterior end obliquely rounded; ralves moderately convex; diagonal ridge very obtusely rounded, posterior slope steep, but not abruptly flattened; surface apparently marked with fine lines of growth. Length one inch six lines, width from beak to opposite margin eight lines, width from ventral margin to end of hinge-line about the same, depth of one valve three lines.

The specimen described shews that in the left valve there were no other teeth but the thick, elongate, posterior one or ligamentary ridge, which is about a line below the hinge-margin. 
This differs from the D. obtus $\left(\mathrm{M}^{\mathrm{c}} \mathrm{Coy}\right.$ ) in its narrow, elongate, elliptical figure, and less gibbosity. Position and Locality.-Tilestone of Storm Hill, Llandeilo, Caermarthenshire.

Explanation of Figures.-Pl. 1. L. fig. 10. Natural size of right valve; fig. $10 a$, Ditto profile.

Dolabra obtusa (Mc Coy). Pl. 1. K. fig. 30.

Ref.-Id. $\mathrm{M}^{\mathrm{c}} \mathrm{Coy}, \mathrm{Ann}$. Nat. Hist. 2nd Series, Vol. VII. p. 53.

Sp. Ch.-Obliquely ovate, width about three-fifths of the length, gibbous; beaks large, obtuse, nearly in the centre of the hinge-line, and one-fourth of the length from the anterior end; anterior end small, gradually curving into the ventral margin, which is only slightly convex, oblique to the hinge-line; posterior end obliquely subtruncate, the inferior angle obtusely rounded; posterior slope abrupt, inclined, the diagonal ridge obtusely rounded; surface nearly smooth. Width ten lines, length one inch five lines, greatest depth of one valve (halfway between the beak and posterior angle) four lines.

This species is more obtusely rhomboidal, and is more obtusely keeled, has a longer hinge, and is much less elongated than the Cheulleca amygdatina (Phill.), which is however only a common variety of the C. unilaterelis (Sow.), from which this differs by its thick posterior tooth, \&c. The very thick, elongate, posterior tooth in the right valve is simple, and about two-thirds the length of that part of the hinge-line from which it declines; in some parts the hinge-line shews obscure traces of serrature, which may be owing to the roughness of the matrix.

Position and Locality.-Tilestone of Storm Hill, Llandeilo, Caermarthenshire.

Explanation of Figure.-Pl. 1. K. fig. 30. Natural size, of right valve.

\section{Genus. ANODONTOPSIS ( $\left.\boldsymbol{M}^{c} \mathrm{Coy}\right)$.}

\section{Syn. Microdon? Conrad (not Agassiz nor Meigen.)}

Gen. Char.-Equivalve, inequilateral, compressed; general form rotundato-quadrate or subtrigonal; posterior side wide, round, or obliquely subtruncate, anterior end slightly contracted in front of the beak; beaks small, prominent, nearer to the anterior than the posterior end; hinge-line shorter than the shell, with a posterior, long, slender, lateral tooth, or cartilage-plate, extending just below it, (double in the right valve), and annther similar but shorter one in front of the bealss: anterior and posterior muscular impressions simple, ovate, the latter longer and stronger than the anterior; occasionally a slight clavicular ridge extends from in front of the beak behind the anterior adductor impression, leaving a furrow in the cast; pallial impression entire; (occasionally one small cardinal tooth beneath the beak;) surface smooth or concentrically lined.

Except in their small size and marine habits these little fossils resemble the recent Anodons, from which there being but two simple adductor impressions separates them. They differ from Modiolopsis (or Cypricardites) in their rotundato-quadrate compressed form, and the posterior adductor impression like the anterior one, and they have no trace of the byssiferous sinus so common in that group between the body of the shell and the anterior side; from S'chizodus (Myophloria), with which Prof. King seems to have blended them, they are distinguished by the long, slender, posterior cartilage plate or lateral tooth, a little below the hinge-line. Except in form they are identical with Clidophorns, and should be considered but as a subgenus thereof, distinguished from those long narrow types by their broad rounded or oblique axe-like form, more prominent beaks, and less marked clavicular ridge. From the figure of Microdon bellastria (Conrad), I should have imagined it belonged to the present genus, but his deseription of the hinge renders it probable that this genus is different; and I accordingly give a description of my own clear types; besides which the name Nicrodun was applied long previously to a genus of Fish, and one of Insects. 
Anodontopsis Angustifrons (McCoy). Pl. 1. K. fig. 14 and 15. Ref.-Id. MICOy, Ann. Nat. Hist. 2nd Series, Vol. VII. p. 54.

$S p$. Ch. -Longitudinally subtrigonal, compressed (depth of both valves half the width), diagonally sul)carinate from the beaks to the respiratory angle; beaks small but prominent, rather more than one-fourth of the length from the anterior end, which is much narrowed and abruptly compressed beneath the beaks. produced, rounded, not separated from the body of the shell by any sinus; ventral margin nearly straight; hinge-line short, slightly elevated, forming a wide, compressed, posterior slope, the margin of which is almost uniformly arched from the beaks to the respiratory angle, which is obtusely pointed; surface nearly smooth, a few obscure concentric wrinkles of growth near the margin. Width from beak to ventral margin six lines. length one inch two lines, width from middle of dorsal to opposite ventral margin $\frac{5 i}{140}$, length of anterior end $\frac{25}{114}$. Pallial and muscular impression as in the generic characters.

The more arehed and elevated hinge-line and narrow anterior side separate this from the Pullastra lecis (Sow.), which seems to belong to the same genus; and the contracted anterior end and greater length separate it from the A. quadratus (Mc'oy). The posterior lateral tooth or plate extends almost to the end of the hinge-line and close to it.

Position and Locality.-Common at Benson Knot, Kendal, Westmoreland, and Kirkby Moor, Kendal. Westmoreland.

Explanation of Figures.-Pl. 1. K. fig. 14. Left valve, natural size; fig. 15, Ditto, right valve.

Anodontopsis bulla (Mc Coy). Pl. 1. K. fig. 11, 12, 13.

Syn。 = Lucina bulla $\left(\mathrm{M}^{\mathrm{c}} \mathrm{Coy}\right)$, Syn. Sil. Foss. Ireland. Pl. 2, fig. 1.

Sp. Ch._Orbicular, length slightly exceeding the width, evenly gibbous; beaks very small, acute, oblicue, not prominent, one-third the length from the anterior end, which is slightly contracted beneath them; surface with a few membranaceous concentric marks of growth; one small cardinal tooth beneath the beak, and a lateral tooth or plate each side of it nearly parallel with the cardinal margin; the posterior largest, double in the right valve. Width five lines, length five and half lines.

The muscular impressions are two, rounded, connected by an entire pallial scar.

The description is from Irish specimens from the green and purple micaceous sandstone of Galway, the British examples before me being less perfect.

Position and Locality.-Rare in the fine micaceous grits of the Upper Ludlow rock at Kirkby Moor. Kendal, Westmoreland.

Explanation of Figures.-PI. 1. K. fig. 11. Left valve, natural size; fig. 12, right valve, both from Kendal; fig. 13, internal cast from Galway.

\section{ANODONTOPSIS LeVIS (Sow. Sp.)}

Syn. and Ref. $=$ Pullastra levis Sow. Sil. Syst. t. 3. f. $1 \alpha$.

$S p$. Ch. - Subrhomboidal, length about one-eighth less than double the width; beaks small at about onethird the length from the anterior end; anterior end broad, rounded; dorsal and ventral margins subparallel, slightly convex; posterior end as wide as the shell, abliquely subtruncate, sides slightly and evenly convex, posterior slope slightly convex, defined by an obtuse diagonal ridge from the beaks to the posterior inferior angle; surface smooth or with minute lines of growth; casts shew the short cardinal tooth beneath the beak, in the right valve the short, slender, anterior, lateral tooth, the posterior lateral tooth or plate extending nearly to the end of the hinge-line and close under it; anterior adductor inpression distinct, ovate, with a small clavicular ridge extending from in front of the beak to its upper posterior margin. Length one inch one and half line, width from beak to opposite margin seven lines, depth of one valve about two lines. 
Distinguished from the $A$. quedratus $\left(\mathrm{M}^{\mathrm{c}} \mathrm{Coy}\right)$ by its greater proportional length, rather more oblique posterior end, \&ce.

Position and Locality.-Tare in the grey micaceous beds at Llechclawdd, Myddfai, near Llandovery, S. Wales.

\author{
Anodontopsis quadratus $\left(M{ }^{c}\right.$ Coy $)$. Pl. 1. K. fig. 10. \\ Ref.-Id. MI'Coy, Ann. Nat. Hist. 2nd Series, Vol. VII. p. 55.
}

Sp. Ch.-Rotundato-quadrate, slightly oblique, width about three-fourths of the length, compressed, slightly and evenly convex, the posterior ridge obtuse, and posterior slope obscurely marked; beaks very small, subcentral; anterior and posterior sides of nearly equal width, the former broadly rounded, the latter with an obscure, slightly oblique truncation; dorsal margin slightly arched, ventral margin nearly straight, slightly convex. Width nine and half lines; length one inch.

The peculiar figure produced by the shortness of the posterior side, and less convexity, easily distinguish this from the A. levis (Sow. sp.) Casts shew the anterior ovate adductor, with a faint clavicular ridge extending from in front of the beak to its upper posterior edge; a short cardinal tooth under the beak, and the slender anterior and posterior lateral teeth close under the margin, the latter cxtending almost to the end of the hinge-line.

Position and Locality.-Common in the tilestone of Storm Hill, Llandeilo, Caermarthenshire.

Explanation of Figure._Pl. 1. K. fig. 10. Natural size, right valve.

\title{
Anodontopsis securiformis $\left(M^{c}\right.$ Coy $)$. Pl. 1. L. fig. 9.
}

Ref.-Id. MCoy, Ann. Nat. Hist. 2nd Series, Vol. VII. p. 55.

Sp.Ch.-Subrhomboidal, compressed, sides evenly convex; diagonal ridge angular, sharply defined towards the beak; slightly coneave towards the posterior slope, which is flattened and steep; beaks small, prominent, about one-fourth of the length from the anterior end, which is semicircularly rounded; ventral margin regularly convex; posterior end narrowed, obliquely truncated, with a straight edge; hinge-line straight, as long as the truncated posterior edge; internal posterior cardinal ridge very delicate, close under the hinge-line; anterior adductor small, oval, with a short slender ridge from the beak to its posterior edge. Length ten lines, proportional width $\frac{68}{100}$, length of anterior end $\frac{25}{100}$, length of anal edge $\frac{45}{100}$, depth of one valve $\frac{13}{100}$.

There is some slight variation in the proportional width of this species; the shortest varieties of which are however much larger and with a more acutely truncated posterior end than the Cypricardia deltoidea or Isocardia axinifurmis (Plil.) of the carboniferous and ? Upper Devonian (of S. Petherwin) rocks, to which the species is most allied.

Position and Locality.-Common in the green micaceous quartzite (Upper Ludlow) of Benson Knot, Kendal, Westmoreland.

Explanation of Figures.-PJ. 1. L. fig. 9. Right valve, natural size, elongate variety; fig. $9 a$, left valve, of short variety.

\section{Genus. LYRODESMA (Conrad).}

$$
\text { Syn. = Actinodonta (Phill.) }
$$

Gen. Char.-Equivalve, inequilateral, subrhomboidal, anterior side rounded, posterior side obliquely truncated; two small muscular impressions and an entire pallial scar; about eight straight radiating teeth diverging from the beaks.

\section{Lyrodesita Plana? (Conrad). Pl. 1. K. fig. 17.}

Ref.-Annual Geol. Rep. and Hall, Pal. N. York, t. 82. f. 11.

$S_{p}$. Ch._Ovato-rhomboidal, compressed; beaks obtuse, prominent, rather nearer the anterior than posterior side; anterior side rounded; ventral margin convex, posterior end broad, obliquely truncated ; posterior 
slope narrow, steeply inclined, separated from the sides by an obtusely rounded ridge; surface apparently smootl ; about eight radiating hinge-teeth, two long anterior ones, three shorter cardinal ones, and three long posterior ones. Length about seven lines; in proportion to length, greatest width (from beaks to opposite margin) $\frac{67}{100}$, length of anterior side $\frac{30}{100}$, width of posterior end about $\frac{46}{100}$, depth of one valve $\frac{29}{100}$.

Position and Locality.-Rare in the sehists of Yspatty Evan, N. Wales (the American locality is in the shaly sandstone of the Hudson River group, near Rome, Oneida).

Explanation of Figures.-Pl. 1. K. fig. 17. Natural size, left valve; fig. 17 a, rostral portion magnified to shew the diverging teeth and cartilage pits.

\section{Genus. CL1DOPHORUS (Hall).}

Syn。 = Pleurophorus (King). -Etym. $k \lambda \epsilon i \delta o s$, a clavicle, \&c.

Gen. Char.-Equivalve, inequilateral, transversely oblong, diagonally gibbous; hinge straight, without crenulations, but having an internal cartilage-plate or lateral tooth nearly parallel with it, and a clavicular vertical ridge in front of the beak and behind the anterior adductor, both producing deep slits in the cast; in some species a small cardinal tooth behind the beak; hinge-margin sharp and erect.

This genus is clearly allied not to Nucula, but to Modiolopsis. In the Memoirs of the Geological Survey this genus is inadvertently made to consist of the shells with crenulated linge-teeth like Arca, which Hall expressly guards against. King's genus Pleurophorus, I find from examination of authentic specimens to be exactly equivalent to Clidophomes.

\section{Clidopionus ovalis $\left(M^{c}\right.$ Coy $)$. Pl, 1. K. fig. 7 and 8.}

\section{Ref.-Id. McCoy, Ann. Nat. Hist. 2nd Series, Vol. VII. p. 55.}

$S_{p} . C h$. Oval, width two-thirds the length; anterior and posterior ends almost equal, elliptically rounded; ventral margin gently convex; valves slightly and evenly convex, the posterior slope very slightly compressed; surface apparently smooth; clavicular ridge strong, reaching rather more than half way from the beak to the ventral margin. Length five lines; proportional width $\frac{75}{100}$.

This is distinguished from the $C$.plamulatus (Conrad) by its regular oval form, larger and more oblique clavicular ridge and less elongation, and from the Cucullaca antiqua (Sow.) by the flatness and oval outline of the valves.

Position and Locality.-Plas Madoc, N. of Llanrwst; abundant in the schists, Dolydd Ceiriog Waterfall, E. of the Berwyn Mountains.

Explanation of Figures.-Pl. 1. K. fig. 7. Natural size, right valve; fig. 8, left valve.

\section{Clidomiorus planulatus (Comrad Sp.) Pl. 1. K. fig. 9.}

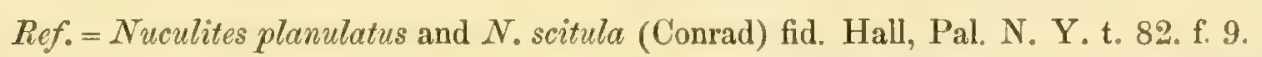

$S p . C h$. - Subelliptical, compressed, greatest width from the beaks to opposite ventral margin; about twice as long as wide; beaks small, rather less than one-third of the length from the anterior end; anterior end elliptically rounded; ventral margin gently convex; posterior end obliquely subtruneate; hinge-line straight, a little shorter than the shell, not elevated; valves uniformly and slightly convex, posterior slope compressed, obscurely defined: casts shew a strong oval adductor impression, with the sulcus left by the clavicular ridge, extending from the beak to its posterinr upper edge exactly half-way to the ventral margin; a strong posterior lateral tooth or cartilage-plate runs nearly to the end of the hinge-line, a little below the simple, erect, cardinal margin; another shorter one runs from the beak to the upper edge of the anterior adductor; one small oblique cardinal tooth in right valve. Length eleven lines, proportional width $\frac{49}{1 \mathrm{iw}}$, depth of one valve about $\frac{\mathrm{g}}{1 \mathrm{ven}}$.

There seems the most perfect identity of our Welsh and the American species, which is stated by Hall to [FASC. 11.] 
be abundant everywhere in the green shales and arenaceous schists just over the black Utica slates so rich in Graptolites.

Position and Locality.-In the olive arenaceous schists of Keeper's Lodge, Goldengrove, Llandeilo.

Explanation of Figure.-Plate 1. K. fig. 9. Natural size, right valve.

\section{Genus. TELLINOMYA (Hall).}

Gen. Char.-Equivalve, inequilateral, compressed towards the margin, convex towards the beaks, without angular ridges; beals small, inconspicuous; hinge without visible teeth or crenulations; muscular impressions two, near the dorsal margin; shell very thin, closely laminated.

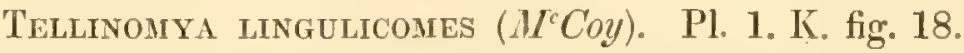

\section{Ref.-Id. MCoy, Ann. Nat. Hist. 2nd Series, Vol. VII. p. 56.}

Sp. Ch._Obovate, slightly and evenly convex; beaks small, compressed, not prominent, close to the anterior end, which is broadly rounded; dorsal and ventral margins slightly convex, converging towards the narrow posterior end, which is truncated more or less obliquely, about two-thirds the width of the shell under the beaks, and has an almost imperceptible sinus between its inferior angle and the ventral margin; surface with fine, irregular, imbricating plicx of growth. Length one inch one line; proportional width $\frac{52}{1 w}$.

This is much allied to the T. nasutc (Hall) of the Trenton group, but is smaller, shorter, and more regularly ovate. It has somewhat the form of Cardinia, with the delicate shell and edentulous hinge of Anodon. I believe this is about the oldest known Lamellibranch : occurring in considerable abundance among the Lingulce in the slates near Tremadoc, and from being about the same size and texture may be confounded easily with them when crushed.

Position and Locality._In the Lingula slates of Penmorfa, Tremadoc, N. Wales.

Explanation of Figure.-Pl. 1. K. fig. 18. Natural size, two right and two left valves.

\section{Genus. ORTHONOTUS* (Conrad).}

Gen. Char.-Elongate, oblong, equivalve, very inequilateral; hinge-line straight, not elevated, the margins erect, with an internal cartilage-plate running beneath them; ventral margin straight, or with a shallow sinus, from which when it exists a shallow depression extends toward the beaks; beaks moderate, near the anterior end, with a very deep, large, lunette beneath them, formed by the inflexion of the margins.

I have taken the three species of Orthonota given by Hall in his Palæontology of New York as types; and having on careful consideration added to them a few species of Cypricarelites of Conrad and Modiolopsis of Hall (e.g. M. nasuta), which are clearly congeneric, I found the group to include some of our British fossils, and offer the above generic character. They are distinguished from Modiolopsis proper by the deep, hollowed, anterior lunette, they also want the protuberant anterior adductor impression, it being inconspicuous. They must not be confounded with those hollow-backed shells forming the genera Grammysia (Vern.) and Sanguinolites ( $\mathrm{M}^{\mathrm{c}} \mathrm{Coy}$ ) in which the dorsal margins are inflected at right angles. They are, in fact, a sort of elongate Edmondia, differing merely in this point of habit and the existence of usually a more or less distinct sinus in the ventral margin and corresponding oblique hollow in the sides.

\section{Orthonotus cymbiformis (Son. Sp.)}

Ref. and Syn. = Cypricardia cymboeformis Sow. Sil. Syst. t. 3. f. 10 a. and t. 5. f. 6.

$S p$. Ch. - Rhomboidal, length rather more than twice the width; valves very deep, and strongly carinated along the slightly sigmoid, diagonal ridge, from the beak to the respiratory angle; bealss small, incurved over a

* Written Orthonota by Conrad. 
very deep, wide, sharply defined, cordate, anterior lunette; anterior side very small, scarcely extending as far as the beak; anterior half of the ventral margin slightly convex, a faint sinus in the posterior half; sides and posterior slope steeply inclined, slightly convex towards the anterior end; hinge-line about half the length of the shell, slightly elevated (the margins simple and erect, with a moderately slender lateral tooth, extending a little below it); posterior end obliquely truncated; cardinal angle very obtuse (about $150^{\circ}$ ), respiratory angle pointed (about $60^{\circ}$ ), length eleven lines; greatest width, in proportion to length, at end of hinge-line ${ }_{160}^{45}$, greatest depth of one valve (about the middle) $\frac{38}{j \times 1}$. (Larger specimen), length one inch five lines, proportional length of hinge-line ${ }_{100}^{55}$, width from middle of hinge-line at right angles to ventral margin $\frac{35}{100}$, width of posterior end $\frac{\mathrm{gn}}{\mathrm{ivu}}$, depth of one valve $\frac{25}{100}$.

Position and Locality.-Tilestone of Horeb Chapel, Llandovery, S. IVales; Upper Ludlow, Burton and Brockton, near Wenlock.

\section{Orthonotus nasutus (Comrad Sp.) Pl. 1. I. fig. 23.}

Syn. and Ref. = Cypricardites nasutus (Conrad) fid. Hall.=Modiolopsis nasuta id. Pal. N. Y. t. 18. f. 2.

Sp. CH.-Elongate, narrow, subcylindrical or elliptical; gently convex; dorsal and ventral margins subparallel; beaks moderate, nearly one-fourth of the length from the anterior end, which is greatly narrowed by the very large anterior lunette, rounded, and slightly recurved at the tip; sides gently convex; posterior slope steep but olscurely defined; posterior end obliquely subtruncate, elliptically rounded; surface with faint

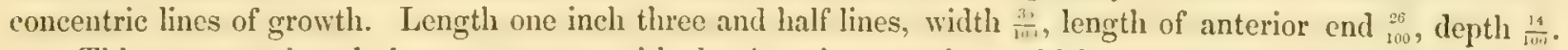

This agrees minutely in every respect with the American species; which according to Hall is common in the arenaceous strata near the top of the Hudson River group.

Position and Locality.-Rare in the Caradoc sandstone of Horderly IVest, Shropshire.

Explanation of Figure.-Pl. 1. I. fig. 23. Natural size, right valve.

\section{Orthonotus semisulcatus (Sow. Sp.) Pl. 1. K. fig. 25.}

$$
\text { Syn.=Modiola? semisulcata Sow. Sil. Syst. t. 8. f. } 6 .
$$

Fi. Ch.-Oblong, valves gently convex, most so from the beak towards the respiratory angle, behind which the posterior slope inclines rapidly to the hinge-line; side slightly flattened, or concave along the middle; beaks prominent, rather less than one-sixth of the length from the anterior end, which is compressed, subangularly narrowed in the middle, and abruptly sloping both from the beaks and ventral margin; anterior lunette deep and large, posterior end slightly narrowed, obliquely subtruncate, obtusely rounded; dorsal margin straight, not elevated, a thick cardinal ridge just behind it; ventral margin slightly concave in the middle; surface with fine concentric strix, a few irregularities of growth, nearly smooth, anterior end strongly wrinkled longitudinally. Length one inch four lines, proportional width $\frac{51}{1011}$, length of anterior end $\frac{16}{1001}$, depth $\frac{211}{1101}$, hingeline from beak to anal angle $\frac{55}{200}$.

The form and wrinkling of the anterior side approximate this species to the Grammysia triangulata, from which it differs in its more angulated anterior side, and in its want of the oblique divisional sulci from the beak. The dorsal edges are erect, with a thick internal ridge below them as in Edmondia, to which it also approximates by the large anterior lunette, differing from that genus only in the slight sinus (for byssus?) in the margin and corresponding hollow in the sides.

Pusition and Locality.-Not uncommon in the green quartzite (Upper Ludlow), Kirkby Moor, Kendal, Westmoreland; rare in the Bala sandstone of Mulock Quarry, Dalquorhan, near Girvan, Ayrshire.

Explanation of Figure.-PI. 1. K. fig. 25. Left valve, natural size; from near Kendal.

\section{3rd Family. CELONOTID 2 ( $\left.M^{\circ} \mathrm{Coy}\right)$.}

Shell elongate, gradually widening to the posterior end, which is slightly gaping; usually a shallow byssal furrow from the beaks to the anterior third of the ventral margin; hinge-line nearly as long as the shell; 
cartilage short, external ; cardinal margin inflected to form a defined, concave, dorsal lunette the whole length of the shell ; beneath the hinge-line, a long, posterior, lateral tooth or ridge in each valve, the place of which is sometimes marked by a slight depression outside; cardinal teeth usually obsolete; two strong muscular impressions at the anterior end and one faint posterior one; pallial scar entire.

The group of shells I unite under this name are only known in the fossil state; they are intermediate in many of their characters between the Mytilido and the Astartide, having the form, and usually the edentulous hinge and byssal furrow of the former, with the double, anterior, muscular impressions and hollowed back produced by the anterior and posterior lunettes, and the exterior cartilage of the latter.

Genera:- Ist, Sanguinolites; 2nd, Grammysia; 3rd, Leptodomus; 4th, Myoconcha.

\section{Genus. SANGUINOLITES $\left(\boldsymbol{M}^{c} \mathrm{Coy}\right)$.}

\section{Syn. $<$ Cypricardites (Conrad) < Allorisma (King).}

Gen. Char.-Subequivalve, oblong, very much elongated, dorsal and ventral margins subparallel, straight or a little arched upwards; sides compressed or diagonally gibbous, from the beak to the posterior ventral angle; beaks small, close to the anterior end, which is very short and rounded; posterior end subtruncate; byssiferous notch and furrow present, or obsolete; hinge nearly as long as the shell, margin inflected to form a long posterior lınette; surface generally marked with wrinkles parallel with the anal and ventral edges; one large oval adductor muscular impression in front of the beak surmounted by the small impression of the retractor muscle of the foot, both having a strong internal ridge behind them; shell thin; posterior adductor large, superficial; cartilage external; an internal thick cardinal ridge close to and nearly parallel with the hinge-line in both vălves in most species; pallial impression entire.

In the two anterior muscular impressions and internal and external characters of the hinge-line, \&c., this genus agrees so closely with $M$ Iyoconcha, that 1 have no hesitation in placing them in the same family. The pallial impression is entire, but very difficult to see in some of the species, in others ( $S$. regularis) it is clear, in some of the Lowick specimens in the Cambridge collection. Since I published this genus (Synop. Carb. Fos. Ireland), Prof. King published his genus Allorisma, including the present shells (the peculiarity of whose inflected dorsal margin he notices), but supposed them to be sinupallial, which certainly is not the case in the Palrozoic shells, and embracing at the same time the totally different oolitic fossils called Myacites by Schlotheim, Lutraria prisca (Gold.), and the like, which have simple erect dorsal margins, and deeply sinuate pallial impressions.

\section{Sanguinolites anguliferus $\left(M^{c}\right.$ Coy). Pl. 1. K. fig. 19 and 20.}

\section{Ref.-Id. M ${ }^{\mathrm{c} C o y}$, Ann. Nat. Hist. 2nd Series, Vol. VII. p. 56.}

$S p$. Ch. - Oblong, length three times the width; beaks small, half the width from the anterior end, which is subquadrate, rounded; posterior end subtruncate not oblique, scarcely wider than the width of the shell from the beak to the ventral margin; dorsal and ventral margins straight, almost parallel; a strong diagonal ridge runs from the beak to the inferior posterior angle, immediately in front of which is the deepest part of each valve; from the beak to the anterior end is marked by eight or ten narrow rounded ridges, running obliquely downwards and backwards towards the middle of the ventral margin, a few of them about the middle of the shell met at an acute angle by a few, more nearly vertical ridges, proceeding from the great diagonal ridge; most of both sets of ridges go towards the ventral margin; they are separated by flat spaces wider than their own diameter; the posterior slope is divided into three broad, rounded radiations by three shallow impressed lines, crossed by irregular wrinkles, parallel with the posterior margin: all the ridges are slightly nodulated by the faint plica of growth; posterior dorsal lunette very narrow, concave, horizontal (or perpendicular to the plane of the valves). Length one inch four lines; proportional width $\frac{20}{100}$.

Position and Locality.-A specimen of the right valve shews rather more of the angular ridges, though a smaller individual than one of the left side. Rare in the tilestone of Benson Knot, Kendal, WVestmoreland.

Explanation of Figures.-Pl. 1. K. fig. 19. Left valve, natural size; fig. 20, right valve. 


\title{
Sanguinolites decipiens $\left(M^{c} \mathrm{Coy}\right)$. Pl. 1. I. fig. 24.
}

Sp.Ch.-Elongate, oblong, dorsal and ventral margins subparallel; bealss incurved, small, depressed, about one-fifth the length from the anterior end; hinge-line long, not elevated, (the inflected edges forming a nearly horizontal posterior lunette extending its entire length); cardinal angle about $115^{\circ}$; anterior end rounded, narrowed by a large elongate, elliptic lunette; a strong sigmoidally contorted diagonal ridge extends from the beak to the respiratory angle; posterior slope stecply inclined; posterior end slightly oblique, subtruncate, rounded: ventral margin with a wide, rather deep sinus in the middle, from which a wide concavity extends nearly to the beak, and from the diagonal ridge to the anterior end, which is convex anterinr to the heaks; surface marked with sharp concentric wrinkles from the anterior lunette to the diagonal ridge. Length eight lines, in proportion to the length greatest width (from beak to opposite margin) $\frac{18}{\mathrm{iw}}$, length of

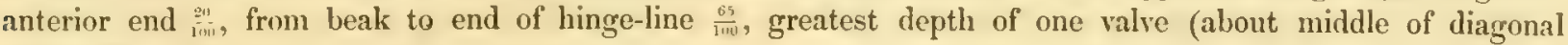
ridge) $\frac{25}{100}$.

I have seen numerous specimens of this species from the Upper Ludlow rocks usually confounded with the so-called Cypricardia cymbiformis (Sow.), which it strongly resembles at first sight, although the anterior end is considerably longer. That fossil, however, has simple erect dorsal margins, and belongs to the genus Orthonotus, as restricted in this work, while the distinctly inflected dorsal edges forming the elongate, concave, posterior lunette shew the present species to belong to the genus Sanguinolites.

Pusition and Locality.-Not uncommon in the Upper Ludlow rock of Benson Knot, Kendal, Westmoreland, and in the micaceous grits of Llechclawdd, Myddfai, near Llandovery, S. Wales; greenish schists of Balmae Shore, Kirkeudbright.

Explanation of Figure.-Pl. 1. I. fig. 24. Natural size, right valve.

\section{Sangunolites inornatus (Phill. Sp.)}

\author{
Ref. and Syn.=Orthonota inornata Phil, Mem. Geol. Surv. Vol. II. t. 19. f. 3.
}

Sp. Ch.-Elongate, oblong, slightly contorted sigmoidally; length about three times the width; beak narrow, about one-fifth of the length from the anterior end, which is slightly narrowed, subquadrate: posterior end not expanded, the margin slightly oblique, truncate: a strong rounded diagonal ridge extends from the beaks towards the respiratory angle with a gentle sigmoidal curve; behind this ridge the posterior slope is regularly flattened, and in front of it the sides are widely concave up to the gently convex anterior end; ventral margin slightly concave, dorsal margin slightly curved upwards; inflected portion concave, narrow; internal cardinal ridge strong; surface marked with concentric small plicx of growth. Width six lines, depth of one valve two and half lines, (specimen too imperfect to give the length).

This species reminds us of the large S. contortus ( $M^{\mathrm{C} C o y}$ ) of the Irish carboniferous limestone, by the sigmoidal twist of its diagonal ridge, $\mathcal{S}$. ; it is very distinct from all the other Lower Palieozoic forms.

Position and Locality.-Limestone of Balmae Shore, near Kirkeudbright.

\section{Genus. LEPTODOMUS $\left(\boldsymbol{M}^{c} \mathrm{Coy}\right)$.}

Gen. Char.-Shell excessively thin, short, oblong, tumid; subequivalve, very inequilateral; beaks large, tumid, incurved; anterior side very short, obtusely rounded, slightly gaping; a deep, sharply-defined, ovate lunette beneath the beaks; posterior end broad, rounded, gaping; dorsal and ventral margins with a slight upward curvature, posterior slope compressed, sides sulcated, parallel with the ventral margin; often a shallow depression from the anterior third of the ventral margin towards the beaks; dorsal margin inflected nearly at right angles to form a nearly parallel-sided concave posterior lunette as long as the hinge-line; no hingeteeth; a narrow sulcus in each valve runs from the beak towards the posterior end, nearly through the middle of the posterior slope, leaving a similar sulcus in the cast; (no cardinal ridge); impression of the two adductor muscles and similar pallial scar very faint. 
These fossils seem almost perfectly identical in form and thinness of the shell with Myacites (Pleuromyce) of the Mesozoic rocks, but are distinguished by the inflexion of the dorsal margins to form a posterior lunette as in Pholadomya, and differ both from the former and latter in the entire, or unsinuate, pallial impression and the two dorsal furrows. Their real affinity is with the genus Senguinolites, of which probably they merely form a subgenus, only distinguished by the short rhomboidal form, although this certainly gives them a very distinct aspect from the typical elongate forms; in addition to which the absence of the thick posterior cardinal ridge of that genus is to be noticed.

\section{Leptodomus amygdalinus (Sow. $S p$.)}

Syn. and Ref. = Cypricardia ? amygdalina Sow. Sil. Syst. t. 5. f. 2. + C. ?retusa id. t. 5. f. 5.

Sp.Ch.-Obovate, shell very thin, width varying from three-fifths to half of the length (in the latter case modified by pressure); very tumid towards the anterior end, where the depth of both valves about equals the width; beaks very large, tumid, close to the anterior end, which is subtruncate more or less obliquely, with a deep cordate lunette below the beaks; posterior end rounded or subtruncate, varying in obliquity with the length; ventral margin slightly convex, and with a faint concavity in the anterior third; hinge-line not elevated, the inflected portion of the edge narrow, concave, nearly at right angles to the plane of the valves; surface with fine lines of growth. Length of average size and shape eleven lines, proportional width $\frac{6,1}{1 \cdots}$, greatest depth of both valves (at one-third below the beaks) ${ }_{100}^{60}$.

T'his seems to vary greatly in the proportion of length to width and depth, owing to the extreme thinness of the shell offering little resistance to pressure; one specimen from near Ludlow exactly agrees in all respects with Sowerby's above-quoted figure, but it is obviously distorted by pressure, giving a greater length, narrowness and depth to the valves, a sharp diagonal ridge, and more pointed posterior end; but other nbviously identical specimens in the same mass not being so squeezed, seem much broader, shorter, and with a slight impression, affecting the anterior third of the ventral edges, and having the general proportions which I have given above, which were taken from a nearly unaltered specimen from Brigsteer, and which seems a fair average example. As a general rule the more compressed (or laterally flattened) the specimens are, the broader and shorter do they seem; and I have satisfied myself that the change from mere physical pressure of the form given by Sowerby as $C$. ainygdelina (exaggerated in length and depth by vertical pressure, or squeezing of the dorsal and ventral margins towards each other) into his $C$. retusa (in which the width is greater and the depth less than natural, from the opposite or lateral pressure) is to be traced with ease and certainty. The young is proportionally shorter and subtrigonal, nearly approaching the form of the C. retusce (Sow.), but without the depression behind the anterior end, and not so flattened.

Position and Loculity.-Common in the Upper Ludlow greenish mudstone near Ludlow, Shropshire, and in the hard micaceous quartzites of the same age, at Benson Knot, Kendal, IVestmoreland, and Brigsteer, Kendal, Westmoreland; in the dark schists of Cwm Craig Ddu, Builth, Brecknockshire.

\section{Leptodomus globulosus $\left(M^{c} \mathrm{C}\right.$ oy). Pl. 1. L. fig. 11.}

\section{Ref.-Id. $\mathrm{M}^{\circ} \mathrm{Coy}$, Ann. Nat. Hist, 2nd Series, Vol. VII. p. 57.}

Sp. Ch.-Globose, subtrigonal, width three-fourths of the length; beaks very large, a little nearer the anterior than posterior end; sides evenly tumid, most so in the niddle; posterior slope undefined, but very steeply sloped; anterior and posterior ends subequal, slightly contracted, rounded, ventral margin convex; linge-line a little shorter than the shell, not elevated, inflected portion narrow; surface with a few concentric lines of growth. Length seven and half lines, proportional width $\frac{85}{100}$, depth of one valve $\frac{80}{100}$.

This departs so widely from either the shortest or most gibbous varietics of the L. amygdalina (Sow. sp.), that it seems desirable to give it a distinctive name; there is no other closcly allicd form. The general appearance approaches that of the Nucula ocalis of the same rock, but in the latter the diagonal posterior ridge is more angular, and I have ascertained that it really possesses teeth as in Nucula. 
Position and Locality.-Hard green micaceous Upper Ludlow rock of Tenter Fell, Kirkby Moor, and Benson Knot, Kendal, Westmoreland.

Explanation of Figures.-Pl. 1. L. fig. 11. Natural size, left valve; fig. $11 \alpha$, end view.

\title{
LePTodomus impressus (Sow. Sp.)
}

\author{
Syn. and Ref. = Cypricardia? impressa Sow. Sil. Syst.t. 5. f. 3.
}

Sp. Ch.-Elongate, oblong, compressed, rather more than twice as long as wide; beaks large, broad, close to the obliquely subtruncate anterior end, a large, deep, ovate lunette beneath them; anterior end small, elliptically rounded; posterior end slightly contracted, obliquely truncated; hinge-line long, straight, not elevated; ventral margin nearly straight, with a wide shallow sinus in front of the middle, from which a shallow concavity extends obliquely to the beak; posterior slope smooth, obtusely defined; anterior end and sides of the shell marked with obtuse, irregular plicie, parallel with the ventral margin. Length one inch four and half lines.

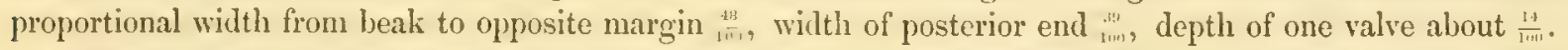

This is clearly distinct from either of the varieties of C. amygdaline (Sow.) or C. retuse (Sow.), being as long as the former (which see above), and as much depressed as the latter; agreeing also with the latter in the distinctness of the marginal sinus and the depression from it to the beak.

Position and Locality.-Upper Ludlow mudstone of Mortimer's Cross, Aymestry, Herefordshire.

\section{Leptodomus truncatus $\left(M^{c}\right.$ Coy). Pl. 1. K. figs. 21 to 24.}

\section{Ref.-Id. Mcoy, Ann. Nat. Hist. 2nd Series, Vol. VII. p. 57.}

$S_{p} . C h$.-Oblong or subtrigonal, compressed; beaks very large, gibbous, prominent, terminal; the anterior end being almost vertically subtruncate under it; width of the anterior end (where it is greatest) nearly twothirds the length of the shell; posterior end obliquely subtruncate or rounded; ventral margin gently convex, with a scarcely perceptible sinus a little behind the vertical line of the bealis; surface ridged with strong, thick. irregular wrinkles from the anterior end, becoming obsolete on the posterior slope. Length one inch five lines, proportional width from beak to ventral margin

This is somewhat allied to the Cypricardia retusa (Sow.), but has the anterior end even more vertically truncate; it is more elongate (although in this point it varies considerably), but it is most obviously distinguished by the strong wrinkling of the surface, parallel with the ventral edges, by which latter, as well as the great depth of the truncated anterior end, it also differs from the $C$. impressa (Sow.).

Position and Locality.-Upper Ludlow, Benson Knot, Kendal, Westmoreland.

Explanation of Figures.-PI. 1. K. fig. 21. Natural size of average form, right valve; fig. 22, end view of both valves, shewing the anterior lunette; fig. 23 , remarkably elongate variety; fig. 21 , unusually short variety.

\section{Leptodomus undatus (Sow. Sp.)}

\section{Syn. and Ref. = Cypricardia undata Sow. Sil. Syst. t. 5. f. 4 .}

Sp. Ch.-Oblong, very gibbous; beaks large, obtuse; anterior end short, broadly rounded; anterior lunette deep, ovate; a strong sinus a little in front of the middle of the ventral margin, from which a deep depression extends towards the beak; surface marked with strong, regular, subequal ridges (four in two lines at three lines from the beak), parallel with the ventral margin; strongest on the anterior end, and having one upward bend in passing over the sinal depression.

The specimen before me is small and not sufficiently perfect to give the true measurements, but quite enough to shew the species to be perfectly distinct from any of the preceding.

Position and Locality.-Rare in the green quartzose Upper Ludlow rock of Benson Knot, Kendal, Westmoreland. 


\section{Gemus. GRAMMYSIA (Vern.) emend.}

Gen. Char.-Equivalve, inequilateral, shell thick, oblong; anterior side short, contracted by a deep oval lunette beneath the beak; posterior end elliptically rounded; hinge-line straight; two large, strong, adductor impressions in each valve, the anterior rounded, posterior pear-shaped; pallial scar entire; cartilage external, short, in the anterior part of a deep longitudinal depression, formed by the inflexion of the hinge-margins; an oblique furrow extends from the beak to about the middle of the ventral margin, of the right valve, usually one or two additional ones in the left valve.

By the short external cartilage, and long, dorsal, concave lunette formed by the inflexion of the dorsal margin of the valves, \&c., this genus agrees with Sanguinolites ( $\left.\mathbf{M}^{\mathrm{C}} \mathrm{Coy}\right)$, and differs only in the few, strong, oblique, girth-like furrows which divide the valves from the beak to the ventral margin, being therefore probably a subgenus thereof.

\section{Gramiysia cingulata (His. $S p$.) $V a r . \alpha$.}

Ref. and Syn. = Nucula cingulata Hisinger, t. 39. f. 1.=Orthonota Id. Mem. Geol. Surv. t. 17. f. 3. Var. $\beta$.

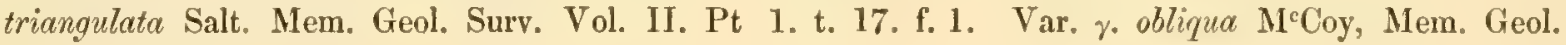
Surv. t. 17. f. 2.

$S p$. Ch.-Oblong, subcompressed, valves gently convex; beaks obtuse, moderate, close to the anterior end, which is short, oblique, rounded; anterior lunette ovate, deep; posterior lunette large, concave, as long as the linge; posterior end not narrowed, obliquely rounded; in the right valve one strong deep sulcus extends from the beak to a little in front or behind the middle of the ventral margin, often with a second sulcus in front of it, distinct and defining a narrow ridge between them near the beak, becoming obsolete towards the margin, or both nearly obsolete, leaving the ridge distinct; corresponding part of the left valve with three sulci, defining two narrow, oblique ridges; surface with small, unequal, irregular, concentric wrinkles and lines. Length one inch six and half lines, proportional width $\frac{51}{100}$, length of anterior end $\frac{18}{100}$, depth of both valves $\frac{46}{100}$.

The above description is from a specimen strongly resembling Hisinger's one, and a slight variety; the species is, however, very variable, and Mr Salter has given a particular name to the next variety.

\section{Var. $\beta$. (triangulata) Salt. sp. Pl. 1. K. f. 28.}

Ovate, or subtriangular from the narrowing of the posterior end; beaks large, from one-fifth to one-fourth from the anterior end, which is narrowed and strongly wrinkled concentrically, rest of surface with finer wrinkles and striae of growth; in the left valve two approximate rounded ridges run from the beak to a little behind the middle of the ventral margin, defined either by three sulci, or only the one between them; in the corresponding part of the right valve there is one strong sulcus, sometimes with a second in front of it defining a ridge. Length one inch nine lines, proportional width ${ }_{100}^{54}$, width at posterior end $\frac{41}{100}$, length of anterior end

I have given a figure and description of a strongly marked example of this form which is mainly distinguished from Var. $a_{0}$ by its narrow posterior end, and slightly longer anterior end; the wrinkles on the anterior end are often absent, the form and other characters remaining the same. The obliquity of the oblique sulci also varies considerably.

$$
\text { Var. } \gamma \cdot\left(\text { obliqua) } \mathbf{M}^{\mathrm{c}} \mathrm{Coy}\right. \text {. }
$$

Obliquely oval, anterior and posterior ends rounded; each valve with one very oblique, wide, deep suleus, bounded by two obseure ridges running from the beak to a little in front of the obtusely rounded respiratory angle; surface with small irregular plice and stria of growth, largest about the middle. Length one inch three lines, proportional width $\frac{56}{100}$, width at posterior end $\frac{52}{1 w 0}$, length of anterior end ${ }_{1 \ldots}^{15}$, depth of both valves $\frac{32}{100}$.

The short elliptical form, and very oblique or backward running sulci, distinguish this rare species or variety perfectly. The alove quoted figure of the Geol. Survey is very good. 
Position and Locality.-Var. a. Not uncommon in the Wenlock shale of Dudley, Staffordshire; Upper Ludlow of Benson Knot, Kendal, Westmoreland. Var. $\beta$. abounds in the green quartzose, Upper Ludlow of Benson Knot, Kendal, Westmoreland, and in the similar rock at Llechelawdd, near Llandovery, S. Wales; and in the yellowish tilestone of Storm Hill, Llandeilo, Caermarthenshire. Var, $\gamma$. High Thorns, Underbarrow, Kendal, Westmoreland.

Grammisia extrasulcata (Salt. Sp.) Pl. 1. K. fig. 29.

Syn.=Orthonota extrasulcata Salt. Mem. Geol. Surv. Vol. II. pt. 1.t. 17. f. 2.

Sp. Ch.-Elongate, oblong; beaks large, prominent, about one-fourth from the anterior end, which is obtusely rounded; dorsal and ventral margins subparallel; posterior end narrow, subtruncate, rounded; sides gibbous, left valve with three oblique furrows from the beak; the anterior one broad, shallow, extending to a little in front of the middle of the ventral margin; a broad obscure ridge behind it, behind which are the posterior pair, narrow, deep, approximate, inclosing a narrow ridge between them, about one-third from the posterior end; surface with small, irregular, concentric plice and lines of growth. Length one inch eight lines; in proportion to length, width $\frac{51}{100}$, width of posterior end $\frac{40}{100}$, depth of one valve $\frac{14}{100}$, length of anterior end $\frac{25}{100}$.

This form has the straight hinge-line and fine plication of the $G_{0}$ cingulata, Var. a., but has a much larger beak, longer anterior end, is longer, and easily distinguished by the very oblique narrow pair of sulci behind the shallow more nearly medial one.

The specimen before me, like that figured by the Survey, is a left valve.

Position and Locality.-Rare in the hard, green, micaceous tilestone of Benson Knot, Kendal, IVestmoreland.

Explanation of Figure.-PI. 1. K. fig. 29, left valve, natural size.

$$
\begin{aligned}
& \text { Gramirsia rotundata (Sow. Sp.) Pl. 1. K. fig. } 26 \text { and } 27 . \\
& \qquad y n_{0}=\text { MIya rotundata, Sow. Sil. Syst. t. 6. f. 1. }
\end{aligned}
$$

Sp. Ch.-.Subovate, oblong, slightly inflated; no defined posterior slope ; beaks obtuse, about one-fourth of the length from the anterior end, which is much narrowed by a rapid slope from the beak, from the inflexion of the margin forming the lunette; posterior end broadly rounded, nearly equalling the middle of the shell in width ; dorsal and ventral margins sulparallel, slightly convex; the even convexity of the valves interrupted in the left one by two oblique, nearly obsolete shallow furrows from the beak to the ventral margin, which they slightly bisinuate; the spaces between them nearly equal to the length of the anterior side; the right valve has but one still fainter furrow corresponding to the spaces between the two of the left valve; surface with small concentric undulations, stronger and more regular on the anterior end. Length one inch five lines; in proportion to length, anterior end $\frac{20}{100}$, width $\frac{60066}{100}$, depth about $\frac{15}{100}$.

The two obscure oblique furrows in the left valve approximate this species to Grammysia, but the posterior dorsal margins seem to be erect as in Edmondix and Modiolopsis, agreeing most with the latter in general form, but having the distinct anterior lunette with inflected margins of the former. As I have not clearly seen the dorsal edges, I leave the species in Grammysia.

It strikes me that Mr Sowerby's figure above referred to must be reversed, as it shews the two faint furrows in the right instead of the left valve. The obtusely rounded posterior end, shorter and wider anterior end, \&c., separate it from the Modiolopsis? semisulcata (Sow. sp.)

Position and Locality.-Not uncommon in the green quartzose, Upper Ludlow rock of Benson Knot, and Kirkby Moor, Kendal, Westmoreland.

Explanation of Figures.-Pl. 1. K. fig. 26, right valve, natural size; fig. 27, left valve, to shew the two oblique furrows.

\section{Genus. CARDIOLA (Broderip).}

Gen. Char.-Obliquely oval, or suborbicular, tunid, equivalve, inequilateral; beaks large, prominent, obliquely incurved towards the short anterior end; anterior and posterior ends subequal, rounded; ventral margin convex; hinge-line shorter than the shell, with a flattened cardinal area, widest between the beaks, extending its whole length; surface radiatingly ribbed; internal characters?

[FASC. II.] 


\title{
Catrdiola fibrosa (Sow.)
}

\author{
Ref.-Id. Sow. Sil. Syst. t. 8. f. 4 .
}

$S p . C h$-Obliquely ovato-rhomboidal, convex, most so about one-third from the beaks, which are large, prominent, obtuse; anterior side very short, searcely extending as far forward as the beals, ventral margin gently convex, posterior end very oblique, elliptical, the respiratory angle rounded; linge-line very short, and anal angle very obtuse; surface with a few deep, concentric wrinkles, about one line apart at six or eight lines from the beak; numerous fine, sharp, concentric strir crossed by equally fine, close, thread-like, rounded ridges from the beak, about five in the space of one line in the middle of the shell. Length from anterior to posterior end ten lines, proportional width at right angles to middle of ventral margin $\frac{85}{100}$, depth of one valve $\frac{20}{100}$.

The fineness of the longitudinal and smaller concentric suleation, as well as the more oblique form, easily separate this species from the more common $C$. intermpta. The two nearly equal, ovate, adductor impressions are often plainly seen in casts. Both the longitudinal and concentric markings extend quite to the beak, and must have been accidentally absent in Mr Sowerby's examples.

Position and Locality.-In the Lower Ludlow rock above Park-lane, Llandeilo.

\section{Cardiola interrupta (Brod.)}

Ref. and Syn.-Id. Broderip, Geol. Proc. 184t; Sil. Syst.t. 8. f. $5=$ Cardium corme-copice Goldf. Pet. Germ. t. $] 43$. f. 1 (1848)

Sp.Ch.-Ovato trigonal, slightly oblique, gently convex; bealis obtuse, prominent; ventral and posterior margins forming one semicircular or slightly elliptical curve; surface regularly radiated with subequal, close, obtuse ridges (four in two lines in the middle of the shell), slightly smaller at the sides, interrupted by deep, irregular, concentric sulci from one to two lines apart. Length one inch one and half lines, proportional width at right angles to middle ${ }_{1009}^{85}$, depth of one valve $\frac{17}{100}$.

Position and Locality.-Abundant in the green mudstone of the Lower Ludlow of Sugar-loaf, and at Green Quarry, Leintwardine, Shropshire; Yr alt, Welehpool; Cwn Craig Ddu, Builth, Brecknockshire; Erw Gill Fach, Builth; Llangynyw Rectory, Montgomeryshire; Troutheck, Applethwaite, Westmoreland ; and in the black schists of Cefn-ddu; hills WV. of Penny Bridge, N. Lancashire; Builth Bridge; Mynidd y gaer, S. side, I.lanefydd, near Ruthin, Denlighshire; Maen Coran, Llangollen, Denbighshire; Coniston flags, Helms Knot, Dent, Kendal, Westmoreland.

\section{3rd Family. ARCID $\mathrm{E}$.}

Shells equivalve, or subinequivalve, orbicular or oblong, quadrate, often with a thick-piled epidermis; a triangular, external, ligamentary facet under each beak, occupied by the ligament, which is external; linge of very numerous teeth on a straight or arched line; two muscular impressions in each valve: animal large, mantle entirely open; foot moderate, sometimes tendinous; gills filamentous.

Distinguished from the Nuculidae by the ligamentary facet beneath the beaks.

Genera:-Arca (including Byssoarca and Cucullca as subgenera), Pectunculus?

\section{Genus. ARCA (Linn.)}

Gen.Char.-Shell elongate, oblong, angulated, equivalve or slightly inequivalve, margin closed all round; one triangular, anterior, muscular impression, and one lengthened posterior one; ligament external, linear, on the inner edge of the ligamentary facet, which is striated and marked with angular sulci; hinge-line straight, with very numerous transverse teeth; aninal elongate, foot often truncate and bearing horny fibres instead of byssus; gills in long bands of free filaments.

There are several subgenera in Arca, as above defined, distinguisbed from Pectunculus by their elongate form and straight hinge-line. The subgenus Byssadrea has a sinus in the middle of the ventral margin for the passage of a large byssus. 


\section{Arca Edmondiformis $\left(M^{c} \mathrm{Coy}\right)$. Pl. 1. K. figs. 2 and 3. \\ Ref.-Id. MCoy, Ann. Nat. Hist. 2nd Series, Vol. VII. p. 52.}

Sp. Ch.-Oblong, obtusely subquadrate, very gibbous; beaks very large, tumid, about one-fourth of the length from the anterior end, which is obtusely rounded; ventral margin slightly sinuate in the middle; posterior end very slightly oblique, obtusely rounded; hinge-line nearly straight, as long as the shell, with numerous minute tecth inclinin.ry slightly towards the beak; surface smooth or with minute wrinkles of growth. Length seven and half lines, proportional width $\frac{65}{100} ;$ greatest depth of one valve (at middle) $\frac{39}{100}$.

This species resembles a small MIodiolopsis or Edmondia in form, but in some of the specimens the hinge-teeth are seen as in $A$ rca, except that they incline slightly towards the beak instead of from it.

Position and Localif!:- In the fine sandy beds near Llangynyw Rectory, near Welchpool, Montgomeryshire; sandstone of Alt y Gader, near Llanfyllin, Montgomeryshire; in the Upper Ludlow rock of Benson Knnot, Kendal, Westmoreland; Moel Seisiog, Llanrwst, Denbighshire; Coed y Bedw, Bala, Merionethshire; Aber Hirnant, E. of Bala, N. Wales.

Explanation of Figures.-Pl. 1. K. fig. 2, natural size, right valve; fig. 3, left valve.

\section{Arca prinitiva (Phill.)}

\section{Ref.-Id. Phillips, Mem. Geol. Surv. Vol. II. Pt. 1.t. 21. f. 5.}

Sp. Ch.-Subtrigonal, elongate; beaks large, obtuse, very prominent, nearer to the posterior than the anterior end; valves gibbous, most so towards the beaks, from which an angular ridge extends on each side towards the inferior, anterior, and posterior angles, defining at each end a steeply inclined slope ; anterior end long, narrow, obtusely subtruncate, rounded at the end; posterior end wide, obliquely subtruncate; hinge-teeth large, very slightly diverging from the beak; muscular impressions strong; surface with numerous concentric, step-like ridges of growth, about half a line wide, crossed by very numerous, close, fine, radiating striae; length five and half lines; in proportion to length, greatest width (from beak to opposite margin) $\frac{62}{100}$, from beak to anterior end $\frac{68}{100}$, width of anterior end $\frac{25}{100}$, width of posterior end $\frac{43}{800}$ g greatest depth of one valve $\frac{29}{100}$.

Position and Locality.-Rare in the Upper Ludlow rock of Benson Knot, Kendal, Westmoreland, and High Thorns, Underbarrow, Kendal, Westmoreland.

\section{Arca (Byssoarca) subequalis $\left(M^{c} C o y\right)$. PI. 1. K. fig. 1. \\ Ref.-Id. MCoy, Ann. Nat. Hist. 2nd Series, Vol. VII. p. 51.}

$S p . C h$. - (Cast) Oblong, equivalve, nearly equilateral, ends subtruncate, rounded, very gibbous in the middle, alout twice as long as wide; depth of hoth valves equal to the width; beaks very large, obtuse, tumid, marked on the sides with four or five large wrinkles: a shallow sinus for the byssus in the ventral margin a little nearer the anterior than posterior end, and slightly obliterating the simple pallial scar; adductor impressions deep, rounded; hinge-teeth very numerous, small, equal, at right angles to the hinge-line. Length one inch eight lines; proportional width $\frac{53}{100}$.

Mr. Sowerby seems to have united two different fossils (the differences between which have been noticed by various writers) under the one name ilrea Eastnori (see t. 20. f. 1 of the "Silurian System"): the fig. 1 r from Eastnor Park should, from the name, be considered the type of the species, and is a regular, subcompressed, oval shell, without ventral sinus: while the other, fig. 16 , of which Mr Sowerby says, "If it be not an old shell grown very thick, it may be a different species," may, I think, possilly be referred to the present species.

Position and Locality.-In the grey micaceous sandstone of Llechclawdd, near Llandovery, S. Wales.

Explanation of Fintres.-PI. 1. K. fig. 1, natural size, seen along the linge-line to shew the numerous equal hinge-teeth; fig. $1 \alpha$, same specimen, side view.

\section{Genus. CUCULLELLA ( $\mathrm{I}^{\circ} \mathrm{Coy}$ ).}

Ref.-Ann. Nat. Hist. 2nd Series, Vol. VII. p. 50.

Gen. Char.-Subrhomboidal, inequilateral, subequivalve; margin even; hinge-line entirely crenulated; muscular impressions two, with a simple pallial scar between them; a strong internal septum extends from 
before the beaks to the posterior margin of the anterior adductor, forming a deep slit in the casts. Surface generally smooth, or nearly so.

These Palæozoic shells have been confounded with Nucule (Sow. Phil. \&c.), from which they differ in the absence of the ligamentary pit in the hinge, and in the anterior internal septum; they have also been confounded with Cucullced, from which they differ in wanting the hood-like plate of the posterior adductor, and having the septum in the anterior end; and with Clidoploorus (Geol. Surv. of Great Britain), from which they differ in having the hinge crenulated as in $A r c a$.

\section{Cucullella antiqua (Sow. Sp.)}

$S y n_{0}=$ Cuculla $\alpha$ antiqua Sow. Sil. Syst. t. 3. f. $1 b$ and $12 a=$ Arca sub-antiqua d'Orb. Prod.

Sp. Ch.-Subquadrate, moderately convex; ventral margin slightly convex, subparallel with the hinge-line: anterior end rather large, rounded; clavicular ridge thick, slightly oblique, reaching rather less than half-way from the beak to ventral margin; numerous minute, slightly oblique teeth on the hinge-line; posterior end subtruneate, oblique; average length three and half lines; in proportion to length, greatest width (from beak to opposite ventral margin) $\frac{65}{100}$, depth of one valve about $\frac{30}{10,}$, length of anterior end about $\frac{3.1}{100}$, of clavicular ridge the same, from beak to end of hinge-line $\frac{45}{100}$.

I have not yet seen good specimens of this species, which is distinguished from the $C$. ocate by its smaller size, more quadrate form, longer hinge-line, and consequently wider posterior end; the elavicular ridge is also considerably shorter and thicker.

Position and Locality.-Tilestone of Storm Hill, Llandeilo, Caermarthenshire, and schists of Conway Falls.

\section{Cucullella conrctata (Phill. Sp.)}

\section{Ref. and Syn. = Nucula coarctatc Phil. Mem. G. Surv. t. 22. f. 1 to 4.}

$S p$. Ch.-Ovate, broadly rounded in front, gradually narrowing posteriorly, gibbous towards the beak, most so rather more than one-third from the anterior end, becoming gradually eompressed posteriorly: beak small, prominent; anterior end elliptically rounded; anal angle scarcely defined; posterior margin very obliquely rounded; respiratory angle narrow, rounded, with a small sinus between it and the gently convex ventral margin, from which a shallow impressed furrow extends nearly to the beak; teeth large, clavicular ridge slightly oblique, extending more than half way from the beak to the margin; length six lines; in proportion to length, greatest width (from beak to opposite ventral nargin) $\frac{65}{1 w}$, length of anterior side $\frac{17}{100}$, length of clavicular ridge $\frac{43}{100}$, from beak to end of hinge-line $\frac{47}{110}$; depth of one valve $\frac{2 n}{140}$; surface with extremely minute concentric lines, crossed by traces of longitudinal microscopic strix.

Position and Locality.-Common in the Upper Ludlow rock of Benson Knot, Kendal, IVestmoreland; also in the schists of Dinas Bran, Llangollen, Denbighshire.

\section{Cucullella ovata (Sow. Sp.)}

Syn. = Cuculloca ovata Sow. Sil. Syst. t. 3. f. $12 b=$ Arca subovata d'Orb. Prod.

$S p . C h$.- Regularly ovate, evenly gibbous; bealis obtuse, anterior end broadly rounded; ventral margin gently convex; posterior end narrow, elliptically rounded at the respiratory angle; cardinal angle very obtuse; hinge-line with numerous, very minute, transverse teeth; clavicular ridge extending perpendicularly, slightly more than half way from the beak to the ventral margin; surface crossed by minute concentric lines of growth: average length eleven lines; in proportion to length, greatest width (from beak to opposite ventral margin) $\frac{61}{1 .}$, length of anterior end $\frac{20}{i v i n}$, from beak to end of hinge-line $\frac{45}{100}$, greatest depth of one valve $\frac{20}{100}$, length of clavicular ridge $\frac{30}{100}$.

Position and Locality.-Common in the Upper Ludlow rock of Brigsteer, and Benson Knot, Kendal, Westmoreland; the similar micaceous greenish beds of Llechelawdd near Llandovery, S. Wales; tilestone of Horeb Chapel, Llandovery, S. Wales; and Storm Hill, Llandeilo; Upper Ludlow rock of Derby Arms, near Kendal, Westmoreland. 


\section{5th Family. NUCULID E.}

Shell equivalve, regular, closed all round, without external ligamentary facets between the beaks; hinge of very numerous small teeth; ligament internal or external, placed in a distinct pit under the beaks; pallial impression entire; two adductors; surface usually covered with periostraca. Animal large; mantle entirely open; foot very large, compressed, slit beneath, capable of dilatation at the end; gills forming fringes of free filaments.

Differ from the Arcide by the want of the ligamentary facets beneath the beaks, and having the cartilage in a separate internal pit.

Genera:-1st, Nucula; 2nd, Nuculina; 3rd, Limopsis (=Pectunculina).

\section{Genus. NUCULA (Lam.) (-Leda).}

Gen. Char.-Oval or oblong, inequilateral, equivalve; cartilage internal, placed in a pit under the beak: teeth very long.

Distinguished from Pectunculis' by the absence of ligamentary facets, the angulated hinge, and oblique cartilage-pit.

\section{Nucula Anglica (dOrb.)}

$S y n_{0}=N$. ovalis Sow. Sil. Syst. t. 5. f. 8 (not of Zieten).

Sp. Ch.-Ovate; beaks large, obtuse, very prominent; anterior side short, widely rounded; ventral margin slightly convex; posterior end obliquely subtruncate, narrow; valves very gibbous near the beak, becoming rapidly compressed towards the ventral margin and posterior end; posterior slope very steep, defined by an obtuse ridge; in the casts the adductor impressions very strong, posterior adductor surmounted by a minute accessory impression, two or three small accessory impressions in the cavity of the beak; hinge-teeth large, long, eight or nine behind the leak, and seven or eight in front; cartilage-pit beneath the beaks large; surface apparently smooth or with fine enneentric lines of growth; length five and half lines; in proportion to lencth, greatest width (from beak to opposite margin) $\frac{75}{100}$, length of anterior end $\frac{25}{100}$, depth of both valves $\frac{60}{100}$.

This is the first instance among Palrozoic fossils in which I have seen the cartilage-pit between the beaks interrupting the row of hinge-teeth, in the manner of the true Nuculoe.

Position aud Lorality.-Common at Long Sleddale, Westmoreland, and in the Upper Ludlow rock of High Thorns, Underbarrow, and Brigsteer, Kendal, Westmoreland.

\section{Nucula levata (Hall). Pl. 1. K. fig. 4 and 5.}

$$
\text { Ref.-Pal. N. York, t. 34.f. 1. }
$$

Sp. Ch.-Obliquely ovato-rhomboidal, a little longer than wide, very gibbous near the beaks, becoming rapidly compressed towards the margins; steep posterior slope undefined; beaks large, very prominent a little on the anterior side of the middle; anterior end broadly rounded; posterior end narrow, obliquely truncate; surface marked with small concentric, close ridges; teeth rather large, hinge-line obtusely angulated beneath the beaks, where a small cartilage-pit separates the anterior from the posterior teeth, six or seven behind the beaks; adductor impressions moderately strong, a small accessory impression over the posterior one; length (of short variety) four and half lines; in proportion to lengtl, greatest width (from beak to opposite margin) nearly the same, depth of both valves $\frac{63}{100}$, length of anterior side $\frac{20}{100}$, width of posterior end $\frac{51}{100}$.

The much greater height in proportion to length, and larger and more prominent beaks, separate this species constantly (though liable to some variation) from the $N$. Anglice (d'Orb.), and in a still greater degree from the $N$. lavis (Sow.), to which Hall supposes it analogous.

Position and Locality.-Common in the schists of Dinas Bran, Llangollen, Denbighshire; abundant in the schists of Milltit Cerrig, Llangynnog, Montgomeryshire; in the schists of Plas Madoc, N. of Llanrwst; and extremely abundant in the schists of Conway Falls (the American localities are from the middle of the Trenton limestone, and also the Hudson river group). 
Explanation of Figures.-PI. 1. K. fig. 4, natural size of elongate variety; fig. 5, shorter variety; fig. $5 a$, do. magnified to shew the hinge-teeth and muscular impressions.

\section{Nuculites post-striatus (Emmons)。 Pl. 1. K. fig. 6.}

Ref.-Geol. Rep., and Hall, Pal. N. Y.t. 34. f. 2, and t. 82. f. 10.

Sp.Ch._Ovato-rhomboidal; beaks small, pointed, compressed; anterior end short, broadly rounded, the curve passing into that of the convex ventral margin; posterior end narrowed, obliquely truncated; a sharp angular ridge extends from the beak to the respiratory angle, defining the flattened posterior slope; sides gently convex, most so a little in front of the middle of the diagonal ridge; posterior slope marked with strong, subequal, radiating rilges, six or seven in the space of one line. Length nine and half lines; in proportion to length, greatest width (from middle of ventral margin to opposite hinge-line) $\frac{65}{1 \mathrm{~min}}$, length of anterior side $\frac{12}{\mathrm{tan}}$, depth of one valve $\frac{16}{100}$.

As neither the American geologists nor myself have seen any trace of hinge-line, the genus is very doubtful.

Position and Locrelity.-In the calcareous schists of Gwyddelwern, Derwen, Denbighshire (the American localities are in the Trenton limestone and Hudson river group).

Explanation of Figure.-Pl. 1. K. fig. 6, left valve, natural size.

Teluinites affinis $\left(M^{c} \mathrm{Coy}\right)$. Pl. 1. K. fig. 31.

Ref.-Id. Mcoy, Ann. Nat. Hist. 2nd Series, Vol. VII. p. 5̃ .

$S p . C h$.-Elliptical, moderately convex; beaks small, about one-third the length from the anterior end, which is elliptically rounded, and with an undefined, olstuse, cardinal slope; ventral margin nearly straight, with a faint shallow sinus in the middle; posterior like the anterior end, rounded elliptically, with sometimes an almost imperceptible flexure (as in Tellinu), extending as a hollow in the left valve from a small sinus beneath the posterior end in the margin towards the beak; surface smooth or with a few obtuse marks of growth. Length one inch four lines and half, width (from beak to opposite margin) $\frac{15}{1+4}$, length of anterior end $\frac{34}{1 w 2}$, depth of valve $\frac{15}{100}$.

This has almost cxactly the shape of our recent Tellina rallicta, but the minute flexure above alluded to is in the longer end, which in that species is the anterior. The species is most allied to the Tellina oblique (Gold.), from the Grauwacke of Ems, from which it differs in heing less transverse, in the beaks not being mesial, and in the less angularity of the posterior slnpe; its greater length, less central beaks, and concave ventral margin, distinguish it from the Nuculites subemarginatus (Conrad).

Position and Locality.-Rare in the Upper Ludlow rock of Benson Knot, Kendal, Westmoreland.

Explanation of Figure.-Pl. 1. K. fig, 31, left valve, natural size.

\section{4th Class. PTEROPODA.}

Tins class is composed of small mollusea which float about in the Northern seas in millions, colouring the water for miles, and forming the chicf food of whales. They all have a distinet head, furnished with tentacula, and a month with horny jaws, and a tongue set with hooks, and two large wing-shaped expansions from the sides of the neck, from which they derive their name. The mouth is a longitudinal fissure, the wesophagus leads to a large globular stomach, from which the intestine takes a few turns, and ends at the right side of the neck; their liver is large; respiration is by a rascular net-work on the inside of the mantle, from whence the blood is transmitted to a heart of one auricle and one ventricle, from which it is sent to the rest of the body through two aortic. The nervous system is much more condensed and approximated towards the head than in the bivalves; a nervous collar surrounds the cesophagus, having two cerebral ganglia above, and four on the lower part sending nerves to the viscera and body. They are all hermaphrodite, 
the ovarium and testis are both large, and both terminate at an opening on the right side of the head. Some genera have no cephalic tentacles, others have two for touch and groups (sometimes thousands) of prehensile suckers. Some are blind, others have a small cye at the base of each tentacle. Some are naked, others are provided with a thin hyaline shell, of one or more pieces; when of two pieces one is dorsal, the other ventral.

\title{
Gemus. THECA (Son.)
}

\section{Ref.-Id. Morris, in Strzelecki, N. S. Wales.}

Gen. Char.--Shell straight, short, rapidly tapering to a point; monothalamous; section, and opening triangular; surface transversely or longitudinally striated.

\section{Theca Forbesil (Sharp).}

\author{
Ref:-Geol. Journ. Vol. II. t. 13. f. I.
}

Sp. Ch.-Margins of flat sides, converging at an angle of about $19^{\circ}$; surface marked with coarse transverse lines, more than their thicliness apart, and close strit'; section nearly an equilateral triangle; mesial ridge slightly rounded, about $92^{\circ}$; average length about nine lines, width of mouth about three lines.

This seems identical, so far as can be judged from the figure of Hall, with the American T. tricunularis, which is not however the Oithereres (Thece) trinugutere of Portlock, which latter is a much larger and more slowly tapering species.

Position and Lucality.-Not uncommon in the Upper Ludlow of Lambrigg Fell, Kendal, Westmoreland: and in the olive schists of Dinas Bran, Llangollen, Denbighshire.

\section{Genus. CONULARIA (Mill.)}

$$
\text { Ref.-Sow. Min. Con. Vol. III. p. } 107 .
$$

G'in. Char.-Shell thin, short, pyramidal, four-sided, each side bounded by a deep longitudinal suleus, transversely marked with ridge-like plices: each face usually divided by a longitudinal impressed line.

The small end seems not to taper to a point, but each face ends in a small rounded lobe: I follow the general impression in placing the Comularix with the Pteropoda. It is very unfortunate that in the original article in the Min. Con., giving the first descriptions and figures of these fossils, that at least two species belonging to different geological systems should have been classed under the one name $C$. quadrisulcata, a specific name which recalls a character common to all the genus as now restricted, and is therefore not in itself desirable; but when to this we add the confusion of opinion among authors as to whether the carboniferous or Silurian specimen should bear this name, the greater number agreeing to confine that name to the carboniferous species, although a reference to the description and principal figure ( $t$ ) would shew that it ought more properly perhajs to be applied to the Silurian one, I think it is the only satisfactory plan to follow the specific nomenclature of Sandberger, in his excellent Monograph in Leonhard and Bronn, Neues Jahrbuch for 1847 , and renounce entirely the name quatrisuleata, and the still more indefinite one (Sanerbyji). which M. Defrance chose to apply to Sowerby's figure.

\section{Conularia cancellata (Sandberger).}

Ref. and Syn.-Leonl. and Bronn, Jahrbuch, 1847, p. 20. t. 1. f. 11.

$=C$. quadrisulcata Sow. Sil. Syst. t. 12. f. 22.

$S p$. Ch.--Depressed, sides of each face converging at about $20^{\circ}$; the four faces equal, each divided by a faint longitudinal furrow, usually rather nearer the outer or marginal sulcus than the inner one, but varying in this respect, and sometimes partially obsolete; transverse plice bent upwards at an angle of about $130^{\circ}$ near the apex, $135^{\circ}$ in the middle, and upwards of $140^{\circ}$, or only slightly arehed towards the mouth; usually continuous across each face, meeting the sides at a more acute angle than the medial suture; about five in the space 
of one line in the middle of the shell (where the diameter of each face is about six lines), rather abruptly increasing to six or seven near the smaller and larger ends; intervening shallow spaces marked with coarse longitudinal strix; average length about two and quarter inches.

In this species I frequently observe the longitudinal furrow at the upward angle of the plice to be absent, sometimes absent and present in different parts of the same specimen; the difference of size and closeness above noticed is also taken from the examination of several specimens, each exhibiting the change. The specimens vary in the amount of depression, and consequently in the angle at which the sides converge; which therefore is of far less value as a specific character than the angle which the two sides of each face make with each other, care of course being taken that in the given species the faces be equal in width, or else their angles be separately given.

Position and Locality.-Common in the Upper Ludlow rock of Benson Knot, Kendal, Westmoreland; common in the Asterias bed of Underbarrow, Kendal, Westmoreland; in the fine gritty beds upon the Bala limestone of Bryn-Melyn quarry, near Bala, Merionethshire; in fine gritty olive schists above Parklane, Shropshire.

\section{Conularia subtilis (Salter, in Appendix). Pl. 1. L. fig. 24.}

Sp. Ch.-Pyramidal, section rhomboidal (the amount of the angles varying from pressure), each face divided by a fine longitudinal median line (or sometimes slightly approaching the inner or outer suture); sides of each face meeting at an angle of $12^{\circ}$ or $15^{\circ}$; transverse furrows very minute, broad, flattened, much less than their thickness apart; separated by very narrow impressed sulci, bent at an angle of about $130^{\circ}$; about eight, or near the extremity ten, in the space of one line.

This species is distinguished from the $C$. cuncelluta of the Silurian rocks, and the much more nearly allied Devonian C.tenuistriata, Sandberger (C. Gerolstinensis, d'Arch. and Vern.), by the smaller angle at which the sides meet, or more slender figure, very much finer transverse striation, and these angulated striae being rery much closer together in proportion to their own width. The striation is scarcely visible to the naked eye in most specimens, and it is therefore difficult to see, even with a strong lens, whether they are crossed by a longitudinal striation; a few points, however, seem to be minutely crenulated.

Position and Locality.-Upper Ludlow of Brigsteer, and Benson Knot, Kendal, Westmoreland.

Explanation of Figures.-Pl. 1. L. fig. 24, entire specimen, natural size; fig. 24 a, portion of surface magnified.

\section{6th Class. GASTEROPODA.}

Nearty all the Gasteropoda enjoy powers of locomotion, and receive their name from the gastric surface of the body being flattened into a disk-like foot for creeping; they inhabit salt or fresh water, or the land; they are all provided with a distinet head, usually furnished with two tentacles, and perfectly formed eyes; the mouth is provided with contractile lips, and two or three horny jaws; frequently the tongue is strap-shaped, and set with sharp, hooked points, serving either to rasp sea-weed food for the phytivorous groups, or capable of boring holes through shells to reach the food of the carnivorous genera; the mouth opens into a long winding asophagus, receiving at the sides the ducts of large salivary glands; this ends in a large oval stomach, from which an intestine extends, winding through the great liver and ovary, passing through the branchial cavity, along the base of the gills, terminating at the branchial opening, usually on the right side of the head; in some genera the stomach is armed with calcareous spines, or as in Bulla with three large grinding plates, concave outwardly. The liver is extremely large and lobulated; the ovaries are large granulated masses enveloping the intestine, opening into a large oviduct (which is also the uterus of the ovoviviparous species) running parallel to the inner edge of the rectum, separated from it by a slender renal duct, and all opening at the same point; the testis forms 
a more compact gland, farther back (in the apex of univalve shells) sending its vas deferens close along the oviduct. The heart is systemic, and has one auricle (or in Haliotis, Chiton, and Fissurella, two) receiving the oxygenated blood from the gills, which flowing into the ventricle, is thence distributed to the body through an aorta extending from its apex. The eyes never exceed two in number, but are perfectly formed, having a transparent cornea, a large, spherical, crystalline lens, with a small intervening space for the aqueous humour, and a circular pupillary opening left by the choroid or pigmental layer. The organ of hearing consists of two round vesicles, adhering to the anterior osophageal ganglia, and containing numerous calcareous, oscillating otolites. The shell varies greatly in form and position, according to the group, but is formed in all from the calcification of cells formed in layers under the epidermis, by the edge of the mantle, and irregularities in form of its edge, produce corresponding spines, tubercles, \&c. on the shell, which the animal is able to absorb again when they become internal by the spiral growth of the whorls: there are usually three distinct layers in the univalve shells. All the orders are hermaphrodite except the Pectinibranchiata, in which the sexes are distinct. The nervous system is greatly more centralised than in the Lamellibranchiata, and the principal ganglia approximated to the head, there being usually a great pair of supra-cesophageal ganglia or brains, supply the eyes, tentacles, \&c., and a great sub-osophageal mass of ganglia, giving off nerves to supply the foot, the gills, the viscera, \&c., connected by cords forming a nervous collar.

The class is divided into several orders, chiefly from consideration of the breathing organs, viz. 1st, $\boldsymbol{P u l}$ monaria, including all the air-breathing Gasteropods inhabiting the land or fresh water (never in the sea), and in which a vascular cavity at the side of the neck forms a sort of lung, fit for breathing air directly; 2nd, Nudibranchiata, composed of naked forms (not protected by a shell), having foliated naked gills, grouped in a rosette on the back or thereabouts; 3rd, Inferobranchiata, composed also of naked genera, but with the branchix at the lower part of the sides of the body, between the foot and the mantle; 4th, Cyclobranchiata, having the gills encircling the body between the foot and the mantle, and covered by a simple conical shell (Patella, \&c.), or by several transverse, imbricating, calcareo-corneous pieces (Chiton, \&c.*); 5th, Tectibranchiata, having the gills concealed by a fold of the mantle, containing a rudimentary shell, or covered by reflected process of the foot (Bulla, Sc.); 6th, Pectinibranchiata, or most highly organized of the class, having pectinated gills, usually placed in a wide cavity, and the body protected by a spiral univalve shell. This latter group includes nearly all the marine spiral univalves, and is here taken as including also the Tubulibrancliata, in which the shell is tubular and irregular, and Scutibranchiata, in which the shell is very wide and often depressed and simple (Fissurella, Haliotis, \&c.); 7th, Dentalina, in which the shell is tubular and the gills forming two bunches, one on each side of the neck.

\section{6th Ord. Pectinibranchiata.}

This order contains a very large number of shells, which are principally marine, a few being fresh-water and fewer still terrestrial. The order is divided into the following families:-1st, Fissurellides; 2nd, Crepidulides; 3rd, Vermetide; 4th, Buccinidee; 5th, Cassidee; 6th, Fusides; 7th, Nuricidae; Sth, Volutidor; 9th, Conida; 10th, Strombida; 11th, Olividar; 12th, Cyprocidos; 13th, Ianthinidos; 14th, Haliotidor; 15th, Trochida; 16th, Neritida; 17th, Naticida; 18th. Acteonida; 19th, Pyramidellida; 20th, Paludinidor; 21 st, Ampullaridoe; 22nd, Cyclostomidoe.

\section{2nd Family. CREPIDULID E.}

Shell wide, depressed, conoidal, with a slightly developed internal spire or none; apex simple, or slightly inrolled toward the posterior end; mouth very wide, irregularly undulated in the adult by the inequalities of the surface, to which it permanently adheres: (animal with a wide, rounded foot; mantle surrounding the shell, leaving a cavity at the head, in which the pectinated gills are lodged; tentacles wide, short).

Genera:-1, Capulus; 2, Infundibulum.

* Most probably Chiton, from its circulation, bilateral disposition of sexual organs, \&c., does not belong to the Mollusca, in which case the anomalous structure of the covering would not disturb the uniformity of the remaining cyclobranchs.

[FASC. II.] 


\title{
Genus. CAPULUS (Montf.)
}

\author{
Ref. and Syn。= Pileopsis Lam.= Hipponyx Defr. ?= Acroculia Phill.
}

Gen. Char.-Shell wide, cap-shaped, apex obliquely inclined backwards, and inrolled towards the left side: aperture broad, oval, with the edge irregularly sinuated; muscular impression, horse-shoe-shaped, open in front; animal as in the family characters.

Those species which secrete a round calcareous disk for the foot have been considered bivalves, and named IIipponyx by Defrance; but even the common Patella does the same thing occasionally, as may be well seen about Plymouth.

Recent in all latitudes, remaining permanently fixed to one spot of rock or shell during its life-time, also tertiary, cretaceous, oolitic, and palæozoic.

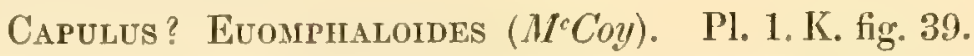

$S p . C h$.-Depressed, spirally inrolled, whorls rounded; spire depressed, of one and half turns; surface apparently smooth, or faintly marked by broadly undulated wrinkles of growth (indicating the waving of the right lip). Diameter one inch, proportional diameter of body-whorl $\frac{50}{100}$, height $\frac{57}{100}$.

This curious species is so much depressed, that were it not for the small size of the spire, and the undulation of the lip, as revealed by the flexuous lines of growth, it might be taken for a Euomplalus. I at one time thought it might be desirable to form a particular genus for these palrozoic species, such as the Nerita IIaliotis (Sow.), Pileopsis neritoides (Phill.), \&c. having the form of Nerita, but an undulating lip and lines of growth; on examining carefully the recent Pileopsis intortus and allied species, I found so gradual a passage from them to the ordinary cap-shaped forms, that I prefer leaving them all together for the present. None of my specimens of that type of shells shew the mouth elearly, so that it is possible they may want the inner lip, in which case the genus would be a very good one, and only found, I believe, in the older rocks.

Position and Locality.-Rare in the Lower Ludlow limestone at Green Quarry, Leintwardine, Shropshire.

Explanation of Figure.-Pl. 1. K. fig. 39, natural size.

\section{Capulus? Haliotis (Sow. Sp.)}

Syn.-Nerita Haliotis Sil. Syst. t. 12. f. 16.

$S p . C h$.-Mouth very wide, nearly orbicular, outer lip deeply and irregularly undulated; spire neritiform of two spirally inrolled, lateral, convex, whorls, scarcely rising above the level of the body whorl; surface covered with minute, slightly flexuous spiral strix, which near the spire, are so close and fine as to be almost invisible, but towards the base (or anterior part of the body whorl) they become a little coarser, and some at intervals are much larger than the intervening ones, all crossed by the waving lines of growth. Width one inch three lines; proportional length $\frac{77}{100}$; width of body whorl $\frac{60}{100}$.

In old individuals one or two interrupted spiral wrinkles often occur on the upper part of the body whorl. In the above-quoted figure the lines of growth are not sufficiently undulated to express the general character, and the finer spiral striæe are not seen.

Position and Locality.-Not rare in the Wenlock limestone of Ledbury, Herefordshire.

\section{4th Family. HALIOTIDE.}

Shell varying in form from elongate conic to depressed and ear-shaped; aperture wide, indented by the last whorl, nacreous, and (with one exception) having either a deep slit or row of foramina in the thin, simple, outer lip, leaving a band which extends back along the whorls of the spire: (animal usually too large for the shell: foot wide, oval; operculum rudimentary or none; eyes on long pedicles at the base of the tentacles; mantle 
notehed or perforated opposite the corresponding apertures in the edge of the shell, to admit the water to the respiratory cavity when the animal is contracted; pectinated gills nearly equal).

Differ from the Trochide by wanting the filaments to the foot, wanting the operculum, and by the band and respiratory slit or row of perforations in the shell.

Genera:-1, Haliotis; 2, Cirms; 3, Ditremaria ; 4, Pleurotomaria; 5, Murchisonia ; 6, Platyschisma ; 7 , Stomatia.

\section{Gemus. PLEUROTOMARIA (Defrance).$$
>\text { Ptycomphalus (Ag.) }
$$

Gen. Char.-Usually pyramidal, trochiform, more rarely globose, or depressed; aperture usually wider than long, with a deep narrow respiratory slit in the outer lip, leaving a defined, linear, spiral band, marked by retroflex striæ along each whorl of the spire; surface usually marked by strix arching backwards towards the band; columella simple, a little thickened in front, with or without umbilicus.

The trochiform species differ from Trochus by the sinus and band.

\section{Pleurotomaria crenulata $\left(M{ }^{\prime}\right.$ Coy $)$. Pl. 1. K. fig. 45.}

Sp. Ch._Obtusely trochiform, length and width nearly equal; apical angle $85^{\circ}$; spire of four obtuselyround whorls, most convex below the middle ; band broad, depressed, bounded by two delicate prominent keels, the upper edge being a little below the middle of the whorl; a space equal to the band in width is visible below it on the turns of the spire; base flattened, gently convex, slightly umbilicate; surface with close, sharp, irregular, interrupted stria, slightly arched backwards from the spire to the suture, and in the opposite direction beneath it; the oblique strixe faintly crenulated by very minute spiral strix, the band with coarse, irregular, backward-arched lines only. Length six lines, proportional width $\frac{86}{1009}$ length of body whorl $\frac{50}{100}$.

This bears some slight resemblance to the Turbo carinatus (Sow.) of the Upper Ludlow, but is generically distinct by its stria arched backwards to the band; its spire is also shorter, and there are no spiral ridges on the base.

Position and Locality.-In the Upper Ludlow rock of Brigsteer, Kendal, Westmoreland.

Explanation of Figures.-Pl. 1. K. fig. 45, natural size; fig. $45 \alpha$, magnified (the spiral striation not sufficiently distinct in this figure through a slight failure in the lithograph).

\section{Pleurotomaria lenticularis (Sow. Sp.)}

$$
\text { Ref. and Syn. = Trochus lenticularis Sow. Sil. Syst. t. 19. f. } 11 .
$$

sp. Ch._Lenticular, very much depressed, sharp-edged; whorls only slightly convex above and below ; apical angle about $135^{\circ}$; a small sharp keel encircles the circumference of the body whorl, and exactly coincides with the suture of the spiral whorls; immerliately above it is a moderately wide band, so slightly concave, and so obscurely defined, as to be scarcely visible; surface nearly smooth, under the lens (when the shell is preserved) very minute close strix arch backwards from the suture to the band, where the curve is reversed, these strix are crossed by equally fine and close spiral strix; umbilicus narrow, deep; diameter one inch five lines, proportional height about $\frac{25}{100}$.

This species very rarely exlibits the true surface preserved.

Position and Locality.-In the olive schists of the Lower Ludlow rock of Green Quarry, Leintwardine, Shropshire; a small, less depressed variety, in the Bala schists at Alt yr Anker, Meifod, Montgomeryshire.

\section{Pleurotomaria turrita (Portk.)}

$$
\text { Ref.-Id. Port. Geol. Rep. t. 30. f. } 7 .
$$

Sp.Ch.-Elongate, conic, turreted; apical angle about $60^{\circ}$, spire of about four or five strongly angulated whorls; the sutures slightly adpressed and prominent above, from a narrow subcentral keel, from whence P. 2 
the upper half of the whorl is steeply inclined and slightly concave to the large angulation, or keel, which is bounded by two thread-like ridges, and is a little nearer the lower suture than the upper; lower part of each whorl nearly vertical, or slightly inclined inwards; striæ inconspicuous, vertical on the prominent upper margin of the sutures, thence arching gently backwards to the keel, beneath which they take a slight forward curve; base convex, with delicate spiral, thread-like stria, and a shallow imperfect umbilicus. Length about one inch three lines, proportional width $\frac{88}{100}$, length of last whorl $\frac{67}{100}$.

Position and Locality._-In the greenish Bala schists of Llyn Ogwen, N. Wales, and Cyrn-y-Brain, six miles W. of Wrexham, Denbighshire; casts shewing no spiral striæ, and shewing a variety approaching $P$. subrotundata (Portk.) in the green Bala slates of Bala, Merionethshire.

\section{Pleunotomaria undata (Som.)}

$$
\text { Ref.-Id. Sow. Sil. Syst. t. 8. f. } 13 .
$$

$S p$. Ch.-Obtusely conical; apical angle $70^{\circ}$ to $65^{\circ}$; about four and half obtusely rounded whorls, most prominent about their lower third, beneath which, close to the suture, is an obtuse, small keel; sutural angle $60^{\circ}$; upper part of the whorls with broad obsolete waves, extending obliquely backwards from the suture towards the keel; base smooth, convex, umbilicate. Total length three inches four lines, proportional length of last whorl $\frac{53}{100}$, width $\frac{90}{100}$ (usually smaller).

The keel and markings are often effaced and the casts are even and smooth, but retain their proportions.

Position and Locality.-Common in the green mudstone (Lower Ludlow) of Green Quarry, Leintwardine. Shropshire.

\section{Genus. MURCHISONIA ( $d A$ rech. and Vern.)}

Gen. Char.-Shell elongate, spiral, of numerous gradually increasing convex or angulated whorls; aperture longer than wide, rounded in front, with a deep narrow sinus in the outer lip, from whence a defined linear sinal band exends along the whorls of the spire.

This genus only differs apparently from Pleurotomaria by its elongate, slender, turriculate form.

\section{Murchisonia angustata (Hall).}

Ref.-Id. Hall, Palæontology of New York, t. 10. f. 2.

Sp.Ch.-Very elongate, subulate; apical angle $20^{\circ}$; spire of about nine gradually increasing whorls, the lower ones obtusely angulated in the middle. Length about five lines, proportional length of last whorl $\frac{3 i}{1 m}$, width $\frac{60}{100}$.

This seems to agree precisely with the species above quoted, from the "Bird's-eye limestone " of New York, lying immediately over the chazy limestone near the bottom of the lower Silurian, or Cambrian system of New York.

Position and Locality.-In the concretionary "chazy limestone" of Knockdollian, three miles from Ballintrae, Ayrshire.

\section{Murchisonia cancellatula $\left(M^{\circ} \mathrm{Coy}\right)$. Pl. 1. L. fig. 20.}

$S p$. Ch.-Conic, apical angle about $50^{\circ}$; spire of four whorls, obtusely angulated a little below the middle; the part above the keel oblique, slightly convex near the sutures, slightly concave near the keel; portion below the keel convex; body whorl of moderate size; base apparently imperforate (but imperfectly seen), mouth, obscurely rhomboidal, a little wider than high. Length one inch two lines, proportional width $\frac{87}{1 * m}$, height of body whorl $\frac{45}{100}$; entire surface above and below the keel reticulated by nearly equal spiral and backward curved, oblique, transverse sulci, eight or nine in one line.

Mr Salter, on a casual examination of some of our specimens of this species, supposed them to belong to his 
Murchisonia scalaris (Greol. Journ. Vol. V.t. 1. f. 2), which he there says is a common Bala species, recognized by its elongate shape, \&c.; and perfect specimens of the exterior of which, he says, shew the fine strix curving back to the keel; but as the carinated species $I$ have seen from Bala are quite different from the present, and agree with the above figure in the elongate form, so different from the present shell, which also has strong spiral strixe, not said to exist in the $M$. scaluris, nor in the Bala forms which I have seen, I conceive this to be a perfectly distinct species.

Position and Locality.-In the Upper Bala rock of Alt yr Anker, Meifod, Montgomeryshire; abundant in the Caradoc sandstone of Mulock Quarry, Dalquorhan, near Girvan, Ayrshire.

Explanation of Figures.-Pl. 1. L. fig. 20, natural size; fig. $20 a$, portion of surface of ditto magnified.

\section{Murchisonia cingulata (His. Sp.)}

\section{Ref.-Id. Hisinger, Leth. Suec. t. 12. f. 6.}

Sp. Ch.-Very elongate, conical; apical angle $15^{\circ}$; whorls about twelve, very slightly convex (less than in the above figure); sutures simple, or with a very slight thread-like prominence of the upper edge; band about one line wide, flat, smooth, scarcely defined, rather more than its own width above the suture; strie rather distant, delicate, arching back to the band with a slight curve. Length about two inches eight lines, proportional width $\frac{34}{100}$, length of last turn $\frac{24}{100^{\circ}}$.

This large species is not likely to be confounded with any other that I know of, from its size, inconspicuous band, and slight convexity of the whorls. Mr Salter confounds it (Mem. Geol. Surv. Vol. II. part 1. p. 357) with the little Chemnitzia simuosa (Sow. sp.), which has an entirely different striation and has not the band of the present genus.

Position and Locality.-Aymestry limestone, Aymestry, Herefordshire; Pentamerus limestone of Leintwardine, Shropshire.

\section{Murchisonia gYrogonia (MCoy). Pl. 1. K. fig. 43.}

$S p$. Ch.-Acutely conical; apical angle $45^{\circ}$; spire of three and half whorls, very strongly angulated in the middle by the projection of an acute carina, the upper and under sides of the volution being flat and steeply inclined; sutural angle $70^{\circ}$ to $75^{\circ}$; body whorl rounded below, with an additional fine keel about half way between the principal one and the anterior end, which is almost hid by the suture on the spiral whorls; surface (when preserved) marked with sharp strix, which on the upper part of the whorl extends from the suture obliquely backwards to the keel, curving in the opposite direction below the keel. Length four and half lines, proportional length of last whorl $\frac{55}{100}$, width $\frac{70}{100}$.

This is most allied to the MUrchisonia perangulata (Hall) of the Bird's-eye limestone of the New York series, but is distinguished by the shortness of the spire in proportion to the body whorl, and by the additional keel below the band on the last turn. It is also closely allied to the $\mathbf{M}$. pulchra $\left(\mathrm{M}^{\mathrm{c}} \mathrm{Coy}\right.$, Sil. Foss. Irel. t. 1.f. 19), but is on comparison found to be distinct by the fewer, longer, and more produced whorls of the spire.

Position and Locality.-Very abundant in the fine sandy schists of Yspatty Evan, N. Wales; also in the calcareous strata W. of Llanfechan, Montgomeryshire.

Explanation of Figures.-Pl. 1. K. fig. 43, natural size, from the schists of Yspatty Evan; fig. $43 \alpha$, magnified.

\section{Murchisonia Lloydi (Som. Sp.)}

\section{Ref. $=$ Pleurotomaria id. Sow. Sil. Syst. t. 8. f. 14 .}

Sp. Ch.-Acutely conical; apical angle about $55^{\circ}$; spire of about four whorls; sutural angle about $60^{\circ}$; whorls convex, most prominent in the middle, where the band forms a prominent square keel; between this and the simple suture are two thin, thread-like ridges on each whorl, and below it on the body whorl are six or seven similar ones about a line apart, only one of which is visible on the spiral whorls; base imperforate; entire 
surface sharply lineated parallel with the keel, crossed by the strix of growth, which extend obliquely backwards to the keel. Length one inch four lines, proportional width $\frac{75}{100}$, length of last whorl $\frac{57}{100}$.

I have not seen specimens so elongate as Mr Sowerby's figure. There are eight or nine of the spiral strix in the space of one line. The Pleurotomaria percarinata (Hall) from the "Trenton limestone" does not seem clearly distinguished from this species.

Position and Locality.-Common in the green mudstone (Lower Ludlow) of Garden Quarry, Aymestry, Herefordshire.

Murchisonia pulcira ( $M^{c}$ Coy). Var. Pl. 1. K. fig. 42.

Ref.-Sil. Foss. Irel. t. 1. f. 19.

$S p$. Ch.-Ovate, spire pointed, of six whorls; apical angle $55^{\circ}$; whorls angulated in the middle by the projection of the thick keel of the band, which is either obtuse and simple, or divided by two medial fine sulci; a second much smaller keel encircles the sutures, which are slightly channelled, and a third small, thread-like keel is seen on the body whorl beneath the band; strix of growth fine, imbricating, irregular in size, directed to form the usual re-entering angle of the band. Length four and half lines, proportional width $\frac{t, i}{1+m}$, length of body whorl $\frac{50}{100}$.

The more compact ovate form produced by the whorls of the spire being more numerous, less angulated, shorter in proportion to their width, and the additional keel at the sutures, distinguish this species from the M. gyrogonia ( $\mathbf{M}^{\mathrm{C}} \mathrm{Coy}$ ).

The figure is from an Irish specimen of the typical characters. The less perfect English specimens differ in the greater size of the keel above the principal one, but do not seem more than varieties.

Position and Lucality.-In the Bala limestone of Alt yr Anker, Meifod, Montgomeryshire; in the slates N. of Tremadoc, Merionethshire, N. Wales; Bala schists, Mathyrafal, S. of Meifod, Montgomeryshire; sandstone of Mulock Quarry, Dalquorhan, Ayrshire.

Explanation of Figures.-Pl. 1. K. fig, 42, natural size; fig. $42 a$, magnified.

\section{Murchisonia simplex $\left(M^{c} C o y\right)$. Pl. 1. K. fig. 44.}

$S p . C h$. - Acutely conical; apical angle $55^{\circ}$; spire of alsout four or five whorls, angulated in the middle by the projection of an obtuse thick keel, another keel a little smaller between the suture and the keel above, and a third nearer the suture below on each turn; surface marked with fine stria of growth, arched back to the keel at a moderate angle above, and nearly vertical below; base imperforate; width of small specimens six lines, length of last turn five lines (imperfect specimens double this size).

The more elongate form and imperforate base distinguish this species from some of the "Trenton limestone" varieties of the Pleurotomaric umbilicata (Hall); and the same characters, and the absence of the spiral stria on the base distinguish it from the Euomplalus triporcatus ( $\left.\mathrm{M}^{\mathrm{c}} \mathrm{Coy}\right)$.

I should have supposed the M. scalaris (Sow. and Salt.), Geol. Journ. Vol. V.t. 1. f. 2, Ayrshire, belonged to this, but that one, instead of five keels, are indicated in the figure and text.

Position and Locality.-Limestone of Alt yr Anker, Meifod, Montgomeryshire; also in the Caradoc sandstone of Dalquorhan, near Girvan, Ayrshire; greenish trappean sandstone of Glenquaple, Ayrshire.

Explanation of Figure.-Pl. 1. K. fig. 44, internal cast, natural size.

\section{Murchisonia torquata $\left(M^{c}\right.$ Coy $)$. Pl. 1. L. fig. 19.}

Śp. Ch.-Acutely conic; apical angle about $26^{\circ}$; whorls six, having a thickened prominent suture, below which the upper portion of each is slightly concave, becoming very convex in the lower half; band narrow below the middle on the most convex part of the volutions; strix sharp, strongest on the thickened edge of the suture, arching obliquely backwards to the band. Length six lines, proportional length of last turn $\frac{4 !}{1 \cdots}$, width $\frac{50}{1000}$.

As the collar-like thickening of the upper edge of the suture, nor the greater projection of the lower 
part of each whorl, is indicated by Mr Sowerby in his figure or description (in the Sil. Syst.) of the $P$. Corallii, I suppose the present species to be distinct.

Position and Locality.-Common in the Upper Ludlow of Spital, and Benson Knot, Kendal, Westmoreland; tilestone of Storm Hill, Llandeilo, Caermarthenshire.

Explanation of Figures.-Pl. 1. L. fig. 19, from the Upper Ludlow rock, near Kendal, natural size; fig. $19 \alpha$, two whorls magnified.

\section{5th Family. TROCHIDE.}

Shell of several spiral, gradually increasing whorls, conic or depressed; aperture small, more or less rounded, without notch, nacreous within : (animal of moderate size, foot triangular, with long filaments from its upper part, distinguishing it from all other gasteropods; head with two tentacles, having the eyes on pedicles at their base; sexes separate; operculate).

Genera:-1, Turbo; 2, Trochus; 3, Phorus; 4, Pitonellus; 5, Solarium; 6, Straparollus ; 7, Euomphalus; 8, Maclureia; 9, Eccyliomphalus; 10, Delphinula; 11, Phasianella.

\section{Genus. TURBO (Linn.) restricted.}

Gen. Char.-Shell thick, of moderate or large size, ovate; body whorl rounded, ventricose; spire rather small, of several convex whorls, pointed; surface often spirally grooved or nodulated; aperture large, nearly circular, slightly produced and broadly rounded in front, more or less modified by the preceding whorl; outer and inner lips thin; operculum thick, shelly, rugged without; flattened, and spirally sulcated within; with or without an umbilicus.

These shells are larger than the Liturina, and are distinguished from those by their mouth being more dilated in front, nacreous within, and the columella not being flattened, as well as by their thick stony operculum; which latter, as well as the ventricose rounding of the base of the body whorl and circular mouth, distinguish them from Trochus.

Recent, herbivorous, a little below low-water mark in warm seas, and in all intermediate marine periods, from the Cambrian.

\section{Turbo crebiristria $\left(M^{\circ}\right.$ Coy). Pl. 1. K. fig. 36, and Pl. 1. L. fig. 22.}

$$
\text { Ref.-Id. McCoy, Ann. Nat. Hist. 2nd Series, Vol. VII. p. } 49 .
$$

Sp. Ch.-Ovate, of four very rapidly enlarging volutions; spire small; apical angle about 85 or $90^{\circ}$ : whorls convex, with an obtusely bounded narrow concave space at the sutures above; back broad, gently convex ; umbilicus narrow, deep, effuse at the edge, mouth very large, obseurely angulated retrally; shell thick, surface girt with sharp, spiral, thread-like rilges, nearly twice their thickness apart, about four in the space of one line on the penultimate whorl, with an occasional finer one between a regular pair, on the last whorl of old specimens, the 2nd, 3rd, 4th, or 5th, are irregularly larger, all crossed obliquely by very fine, regular, sharp lines of growth, eight in one line. Length (of small perfect specimen) one inch, proportional width $\frac{100}{110}$, length of body whorl $\frac{\% 0}{100}$ (grows to nearly two inches in diameter).

The large casts of this species are smooth, and resemble Sowerby's figure and description of $T$. Prycek, except that the beak is broad, and rather flattened, or slightly convex, instead of being angular in the middle, as that species is defined to be. The substance of the shell is thick, and its mode of striation resembles that of the so-called Pleurotomaria bilix of Conrad, as figured by Hall (Palæontology of New York), which is however distinguished by its smaller size, longer spire, and want of an umbilicus.

Position and Locality.-Common of large size in the calcareous Bala schists of Gelli Grin, Bala, Merionethshire; in the fine sandy schists of Mandinam, Caermarthenshire; in the fine Bala sandstone of Alt yr Anker, Meifod, Montgomeryshire; in the Bala limestone of Mynydd Fron Frys, five miles W. of Chirk, Denbighshire.

Explanation of Figure.-Pl. 1. K. fig. 36, small specimen, natural size. 


\author{
Turbo? Williamsi (Sow.) \\ Bef.-Id. Sil. Syst. t. 3. f. 6.
}

Sp. Ch. ( from casts.) -Obtusely trochiform, of about four gently convex whorls; apical angle about $90^{\circ}$; base of body whorl rounded; umbilicus narrow, deep; mouth oblique, ovate, a little longer than wide; surface apparently even. Width one inch four lines, length probably one inch three lines, length of body whorl eight lines.

I cannot distinguish the specimen before me from the above species quoted by Sowerby from the Upper Ludlow tilestone of Horeb Chapel, in which gisement, however, it will be remarked, there are several other lower forms.

Position and Locality.-In the fine micaceous sandstone of Mandinam, Caermarthenshire.

\title{
Genus. TROCHUS (Linn.)
}

Gen. Char._Shell conical, of several regularly increasing whorls, base of body whorl flattened, with the circumference obtusely carinated; aperture transversely oblong, wider than long, outer lip thin, oblique; columella short, usually twisted; with or without umbilicus; operculum round, horny, of very numerous spiral turns.

Distinguished from Turbo by the regular conical shape, flattened base, and transverse elongation of the mouth.

Recent in all seas, herbivorous, at and below low-water mark among rocks, and in the principal groups of strata from the Cambrian inclusive.

\section{Trochus celatulus $\left(M^{c} C o y\right)$. Pl. 1. K. fig. 40.}

Ref.-Id. McCoy, Ann. Nat. Hist. 2nd Series, Vol. VII. p. 49.

Sp. Ch.-Conical, apical angle $80^{\circ}$; spire of three and half flattened volutions, having a thick rounded keel forming the circumference of the basal whorl, and close to the suture on the spiral whorls; base flattened; surface marked with oblique scaly ridges. Width four lines, proportional length $\frac{65}{100}$; length of last whorl $\frac{30}{100}$.

Owing to the scaly nature of the ornament on the rather wide, oblique ridges of the surface, they usually adhere to the matrix, and breaking off from the shell leave it nearly smooth.

Position and Locality.-Very rare in the limestone of Old Radnor, Radnorshire.

Explantion of Figures.-Pl. 1. K. fig. 40 , natural size; fig. $40 a$, magnified.

Trochus constrictus (Mcoy). Pl. 1. K. fig. 41.

Ref.-Id. MCoy, Ann. Nat. Hist. 2nd Series, Vol. VII. p. 50.

$S p$. Ch, - Conical, apical angle about $70^{\circ}$, of four or five gradually increasing whorls, each with a shallow concavity or constriction below the suture, the lower portion strongly rounded, base flattened, circumference obtusely rounded; surface obliquely crossed by fine, unequal, often obseurely fasciculate lines of growth; mouth transverse, obliquely ovate. Length eight lines, proportional width $\frac{95}{100}$; length of mouth $\frac{47}{104}$, width of mouth $\frac{50}{100}$.

This seems allied to the Holopea symmetrica (Hall) of the Trenton limestone, but the spire is not so elevated, the base is more flattened, and the mouth is stated to be almost circular in that species, which besides has the whorls regularly convex from the simple sutures.

Position and Locality.-In the schists on the Bala limestone, Bryn-Melyn Quarry, near Bala, Merionethshire; Bala schists, Cymmerig, E. of Bala, Merionethshire.

Explanation of Figure.-PI. 1. K. fig. 41, natural size. 
Trochus Helicites (Sow.)

Ref.-Sil. Syst. t. 3. f. $1 c$ and 5 .

Sp. Ch.-Discoid, depressed; apical angle $130^{\circ}$; spire of four gradually increasing whorls, slightly convex alove, with simple impressed sutures; circumference obtusely rounded; base gently convex, with a small umbilicus; mouth wider than high, transversely oval; surface of the whorls nearly smooth, crossed by fine, slightly oblique strix of growth; width eight lines, proportional height $\frac{40}{110}$, height of last whorl $\frac{20}{100}$.

Internal casts have the volutions more convex.

Position and Lorality.-Common in the tilestone of Storm Hill, Llandeilo, Cacrmarthenshire; one specimen in the Bala limestone of Llandeilo, Caermarthenshire; and a cast, apparently identical, in the Bala sandstone of Dalquorhan, near Girvan, Ayrshire.

\section{Trochus Moorei (Mc Coy). Pl. 1. I. fig. 18.}

\section{Ref.-Id. MIc Coy, Ann. Nat. Hist. 2nd Series, Vol. VII. p. 50.}

Sip. Ch.-Acutely conical; apical angle $50^{n}$; of about five (four preserved) flattened, gradually increasing whorls; mouth transversely subquadrate; base flattened, moderately convex; umbilicus deep, narrow ; surface

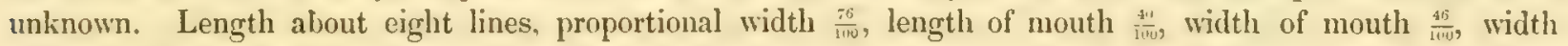
of umbilicus $\frac{15}{100}$.

I dedicate this very distinct species to J. Carrick Moore, Esq., Secretary of the Geological Society, who has devoted much labour to the elucidation of the older fossiliferuus rocks of Scotland.

Position and Locality.-In the fine Bala sandstone of Dalquorhan, near Girvan, Ayrshire.

Explanation of Figures,-Pl. 1. L. fig. 18, natural size; fig. $18 \alpha$, back view.

\section{Genus. EUOMPHALUS (Son.) as here restricted.}

Gen. Char,-Shell discoid, spire flattened or slightly elevated, of numerous, usually angulated whorls: umbilicus very wide, exposing the volutions; mouth with a nearly circular entire peritreme, not indented by the preceding whorl; surface usually sculptured.

All the typical species of Sowerby's genus Euomplatus (E. pentangulatus, catillus, \&s.) belong unfortunately to the genus Straparollus of Montfort (as M. d'Orbigny has remarked), in which the month is incomplete on the left side, and is indented by the penultimate whorl: as however such species as his $E$. runosus, $E$. discors, Sce. differ in having an entire peritreme, and often thickened nearly circular lip, as in Delphinula, I have thought it desirable rather than let the name Euomphalus drop out of use, to restrict it to the group of very distinct shells agreeing with the latter types; the genus as thus restricted being apparently intermediate between Delphinula and Turbo. The types first mentioned must of course be placed in De Montfort's genus.

\section{Euomphalus centrifugus ( $W a h l . S p$. .)}

Ref. and Syn. = Turbinites centrifugus Wahl. = Euom. substriatus, E. centrifugus, and Inachus sulcatus His. Leth. Suec, t. 12, f, 1.

$S_{p} . \mathrm{Ch}$.-Discoid, of three to four gradually increasing volutions, which are completely exposed on both sides; spire depressed a little below the level of the body whorl; whorls very convex above, back obtusely rounded; a thick, flattened, plate-like keel extends horizontally from the circumference on a level with the lower edge; its width rather less than half the width of the whorl; upper surface of whorls, with strong, subequal, spiral sulei, nearly one line apart; under surface and keel crossed by fine, slightly oblique, lines of growth. Diameter (exclusive of keel) two inches three lines, proportional diameter of last whorl $\frac{32}{100}$, height of ditto $\frac{28}{100}$. 
I think the whorls are only connected by the keel in this rare species, which would therefore form a connecting link between Euomplatus and those evolute species forming the genus called Eccyliomplirelus, Serpularia, and Phanerotinus, by different authors.

Position and Locality.-Rare in the Pentamerus limestone of Leintwardine, Shropshire.

\section{Euomphalus discons (Som.)}

Ref.-Id. id. Sow. Min. Con. t. 52. f. 1.

Sp. Cl.-Discoid, spire depressed below the level of the last whorl, of about three whorls in the adult (with a hole in the centre from which the dead, early turns of the spire have fallen); upper fourth of the basal whorl sloping downward and inward, slightly concave or convex, and bounded externally by an obtuse spiral ridge, from whence the sides (or second quarter) slope outwards to a similar thick ridge at the circumference, there being one less prominent ridge midway between these two; lower half of the volutions rounded; all the turns half exposed in the wide umbilicus; surface of upper half of the volutions crossed by slightly-flexuous, irregular, imbricating laminse (about six or seven in the space of one line). forming thick scales on the ridges; the under half of the turns has the striation abruptly finer and closer from the lower side of the ridge of the circumference. Diameter two inches five lines, proportional diameter of last whorl $\frac{35}{100}$, depth of last whorl $\frac{28}{100}$, diameter of umbilicus $\frac{36}{100}$.

Position and Locality._Common in the Wenlock limestone of Wenlock, Shropshire; Wenlock limestone of Woolhope.

\section{Euomphalus funatus (Som.)}

Ref.-Id. Sow. Min. Con. t. 450. f. 1. 2.

Sp. Ch.-Very obtusely conic; apical angle about $135^{\circ}$; spire of little more than two very convex whorls (rarely more than one and half present); mouth nearly circular, sutures deep, umbilicus very small, rounded: surface girt with about twenty round, subequal, cord-like spiral ridges, about equal in thickness to the space between them; the eight or nine on the upper aspect of the volutions a little larger than the others; three or four larger than the rest within the umbilicus; all crossed by fine, direct, sharp lines of growth. Average diameter one inch two lines, proportional height $\frac{59}{100}$, height of mouth $\frac{38}{100}$.

The wider spaces between the ridges and strong transverse sealy lines of growth distinguish this species from the E. sculptus, in which the ridges are very close and smooth.

Position and Locality.-Abundant in the Wenlock limestone of Wenlock, Shropshire; Wenlock limestone of Woolhope; common in the sandstone of May Hill.

\section{Euomphalus lyratus $(M c$ Coy). Pl. 1. L. fig. 23.}

S\%.Ch.-Spire only slightly elevated, of two very convex turns, each with three narrow spiral ridges, one at the upper suture, one considerably above the middle of the body whorl and corresponding to the lower suture on the spire, and the third half-way between these two; surface crossed by slightly oblique, thin, cord-like ridges, nearly trvice their thickness apart. Diameter about six lines, proportional height about $\frac{50}{100}$.

Only one imperfect specimen has occurred of this obviously distinct species, not allowing of the characters of the base or spire being completely ascertained.

Position and Locality._-Rare in the Bala schists at Llansantfraid, Glyn Ceiriog, Denbighshire.

Explanation of Figure.-PI. 1. L. fig. 23, natural size.

\section{Euompitalus rugosus (Sow.)}

Ref.-Id. Sow. Min. Con. t. 52. f. 2.

Sp. Ch.-Discoid, depressed, spire slightly elevated; apical angle $140^{\circ}$; of about three whorls (those forming the apex being absent through decay); upper half of the spiral whorls and upper third of the 
body whorl flattened, horizontal, bounded externally by a strong obtuse spiral keel; beneath which are two other keels less strongly marked, only one of which is visible on the spire, the lowest forming the circumference of the body whorl; umbilicus small, searcely shewing the inner whorls; base rounded; upper and under surface corered with equal, coarse, slightly undulating, irregular laminx of growth, forming thicker scales as they pass over the spiral keels. Diameter one inch ten lines, proportional diameter of last whorl t.... depth of ditto $\frac{38}{100}$, diameter of umbilieus $\frac{80}{100^{\circ}}$.

The clevation of the spire, and the small size of the umbilicus, constantly distinguish this species from the $E$. discors, as well as the difference of striation of the under side.

Pusition and Locality.-Not uncommon in the Wenlock limestone of Ledbury, Herefordshire, and near Ludlow, Shropshire; common in the Wenlock limestone of Wenlock, Shropshire; Wenlock limestone of Woolhope.

\section{Euomphalus sculptus (Sow.) \\ Ref.-Id. Sow. Sil. Syst. t. 12, f. 17 .}

$S_{p}$. Cho-Discoid, very much depressed, of about three round, slightly elevated whorls; mouth nearly circular; umbilicus very wide, exposing the volutions; surface covered with numerous smooth, very close, cord-like ridges, irregularly unequal in size (about seven in two lines on top of body whorl), separated by very narrow inpressed sulci, scarcely one-fourth the width of the ridges. Diameter about one incl three

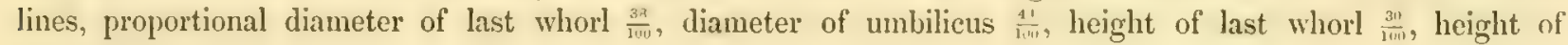
spire about $\frac{37}{100}$.

The absence of the transverse, scale-like sculpturing, and the very much more numerous and closer ridges, easily separate this from the $E$. funatus.

Position and Locality.-Rare in the Wenlock limestone of Wenlock, Shropshire.

\section{Euomphatus tricinctus $\left(\boldsymbol{M}^{c} \mathrm{Coy}\right)$.}

$$
\text { Ref.-Sil. Foss. Irel. t. 1. f. } 13 .
$$

Sp. Ch.-Conical, apical angle about $95^{\circ}$; spire of about three rounded volutions, those of the spire having three very narrow, thread-like, spiral kcels, one in the middle, one near the upper, and the third near the lower suture; the body whorl has a fourth similar keel surrounding the umbilicus; all crossed by fine, sharp, oblique strix; base rounded, mouth nearly orbicular (slightly longer than wide); umbilicus decp, narrow.

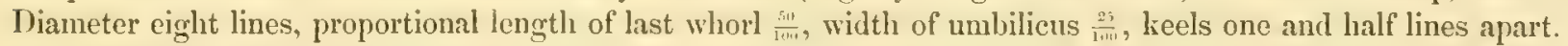

Position and Locality.-In a conglomerate of angular fragments at Dol Fan, Rhayader, S. Wales; Bala sandstone of Dalquorhan, near Girvan, Ayrshire.

\section{Euompinalus triporcatus $\left(M^{\circ}\right.$ Coy). Pl. 1. K. fig. 37 and 38.}

Sip. Ch.-Obtusely conic; apical angle about $95^{\circ}$; spire of about three or four flattened whorls, each bearing three nearly equal and equidistant thick, obtuse carina, one of which is at the suture, which it renders canaliculate, one in the middle, and one forming the circumference of the basal whorl, and partly concealed by the suture in the spiral whorls; base convex, with three smaller spiral carine, and a minute umbilicus: surface crossed by sharp, scaly, delicate, transverse strixe. Width one inch, proportional length about $\frac{7}{1,4}$, length of last whorl $\frac{13}{1013}$.

Col. Portlock has, I think, figured this species (Geol. Rep. t. 30. f. 3.) as the E. subsulcatus of Hisinger. which has double the number of spiral keels on the upper surface. I should have referred those specimens to the E. cormu-arictis (His.), but that secms to have four large ridges to each whorl, and no indication is given in the figure or description of the spiral earine on the base. It much resembles some of the varieties of the Plenotumaric umbilicate (Hall), from Bird's-eye limestone of New York, but is certainly distinguished by its smaller umbilicus, and the three additional spiral keels on the base; those latter are generally best seen in the concavity left when the upper whorls of a specimen are broken away (described from internal casts). 
Position and Locality.-Common in the Bala slates of Cyrn-y-Brain, Wrexham, Denbighshire, and in the schists of Goldengrove, Llandeilo, Caermarthenshire.

Explanation of Figures.-PI. 1. K. fig. 37, natural size, from schists of Cyrn-y-Brain; fig. 38, small specimen, seen from below.

\section{Genus. MACLUREIA (Leseur).}

Gen. Char.-Discoid, sinistral. of numerous exposed whorls, flattened above, rounded below; mouth usually longer than wide, spire flattened; surface smooth, or marked only by transverse lines of growth.

This genus differs from Straparollus or Eumphalus by being reversed and having a large shelly operculum, with a strong articulating tooth nearly as in Nerita; the species are at present only known in the lower Cambrian deposits of America and Scotland.

\section{Maclureia macromphala ( M $^{c}$ Coy). Pl. 1. L. fig. 12.}

Sp. Ch.-Discoid, sinistral, usually elliptical, of about three and a half rapidly enlarging whorls; spire depressed below the level of the outer turn, which bears an obscure, obtusely rounded angulation, bounding the slightly oblique upper plane of the shell; circumference obtusely rounded; under side having the middle of the whorls obtusely angulated, thus defining a wide, shallow umbilicus. Diameter ten lines, proportional diameter of last whorl $\frac{5 n}{10 n,}$, height of last whorl ${ }^{501}$, diameter of umbilicus ${ }_{100^{\circ}}^{25}$. Surface crossed by minute, thread-like lines of growth, extending obliquely backwards from the suture, and then crossing almost directly into the umbilicus.

This little species is easily distinguished from the $M$. magna by its very wide umbilicus (resembling that of the carboniferous Euomphalus pentangulatus), and by the more rapidly enlarging whorls, which also separate it from the imperfectly-known $\boldsymbol{M}$. matutina and $\boldsymbol{M}$. sordida (Hall), from the calciferous sandstone of New York.

Position and Locality.-In the concretionary and schistose limestone of Craig Head, near Girvan, Ayrshire. below.

Explanation of Figures.-Pl. 1. L. fig. 12, natural size, viewed from above; fig. $12 \alpha$, viewed from

\section{Maclureia magna (Leseur). Pl. 1. L. fig. 13.}

Ref.-Leseur, Journ. Acad, Nat. Sci. Philad. Vol. I. p. 312. t. 13. f. 1, 2, 3. Hall, Pal. New York, t. 5. f. 1.

$S p . C h$. - Sinistral, discoid, spire scarcely elevated, of four to five gradually increasing whorls, flattened above, with an obtusely rounded angle at the circumference, giving a depressed appearance to the sutures, and from which the slightly convex base of the last whorl slopes rapidly to the angular edge of the deep umbilicus, which partially exposes the whorls; mouth obtusely trigonal; surface crossed by fine imbricating lines of growth. Diameter three and a half inches, proportional height of last turn $\frac{45}{100}$, width of last turn $\frac{30}{100}$, width of umbilicus $\frac{35}{50.1}$.

I was greatly delighted, on Prof. Sedgwick bringing me a parcel of the unpromising-looking metamorphic concretionary, calcareous schists of Knockdollian Quarry, to recognize, for the first time in Europe, a number of specimens of this important fossil, so remarkable in America for its great geographical, and exceedingly small geological range; being confined to the chazy limestone (nearly at the base of the lower Palcozoic group of the United States), in which it abounds, and, according to Hall, characterising this bed from North-east of New York to Kentucky and Tennessee, and North-westerly nearly to Lake Superior. It is therefore of great interest to find this fossil in Britain, and to know, from the analogy of the New York section, that we are close to the first appearance of organised beings. As doubts have been thrown on my identification of the Scotch with the American species, I have thought it necessary to give figures of the former, demonstrating their precise accordance in all respects with the figures of Hall. 
Position and Locality.-Abundant in the irregularly calcareous schists of Knockdollian Quarry, three miles from Ballintrae, and at Aldens, on the Stinchar, Ayrshire.

Explanation of Figneres.-PI. 1. L. fig. 13, natural size, of rather small specimen, shewing the top and form of section of the whorls and umbilicus; fig. 14, small perfect specimen, viewed from below.

\section{Genus. ECCYLIOMPHALUS (Port.)}

\section{$?=$ Serpularia Römer $1843+$ Phanerotinus Sow.}

Gien. Char.-Shell discoid, of few rapidly tapering, widely disconnected whorls, the upper surface usually Hattened, in one plane, or slightly elevated; under surface rounded (no chambers).

Mr Morris, in the notes to his "Catalogue," stated this genus to be identical with Cyrtolites of Conrad, and he has been accordingly followed by succeeding writers; but as Mr Hall (Pal. New York, p. 308) informs us that the Cyrtolites ornatus was the type of Mr Conrad's genus, it follows that as that is a symmetrical shell, allied to, if not identical with, Bellerophon, Eccyliomphalus of Portlock is perfectly distinet; and I have great pleasure in restoring it to its place in the system.

\section{Eccyliomphalus Scoticus $\left(M^{c} C o y\right)$. Pl. 1. L. fig. 15.}

Sp.Ch.-Discoid, flat, of one and a half gradually enlarging, widely separated, spiral whorls; back obtusely subcarinate, rounded, lower side rounded, upper side with a flat space, bounded on each side by one obscure keel, the outer one most distinct; surface crossed by rather distant sharp lines of growth, each pair with four or five

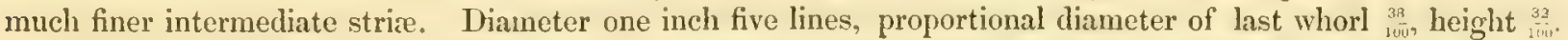

This species is more regularly involute than the E. Bucklandi (Portk.), and has the principal keel on the upper side nearer to the back. There are three or four of the larger strie in the space of one line about the middle of the under side of last whorl.

Position and Luculity.- Not uncommon in the schistose chazy limestone of Knockdollian Quarry, three miles from Ballintrae; also in the calcareous schists of Mulock Quarry, Dalquorhan, near Girvan, Ayrshire.

Explanation of Finures.-Pl. 1. L. fig. 15, natural size, under surface from the limestone of Knockdollian Quarry; fig. $15 a$, another specimen, upper surface; fig. $15 b$, section of whorl.

\section{7th Family. NATICIDE.}

Shell globose, body-whorl very large; spire usually very small, of few convex turns; aperture large, ovate, indented by the preceding whorl; onter lip thin, widely rounded in front, closed by an ear-shaped subspiral operculem; umbilicus usually large, and more or less closed by a thick callous pad: (animal large, foot very large, oblong; mantle very large, usually reflected on the shell behind, head with two depressed tentacles).

Genera:-1, Natica; 2, Narica; 3, Naticella; 4 Naticopsis; 5, Sigaretus.

\section{Genus. NATICOPSIS $\left(M^{c} \mathrm{Coy}\right)$.}

Gen. Char. - Shell strong, globose, elliptical; spire very small, of few convex whorls; surface smooth, or only marked by lines of growth, strongest at the sutures; aperture large, broad-ovate, modified by the preceding whorl, broadly rounded in front; columella thickened, callous, flattened (as in Purpera) in the anterior half, entirely concealing a minute umbilicus only visible in the casts.

This genus includes most of the Palrozoic so-called species of Ampullmriu, Natica, and Nerita. The former genus is terrestrial and pulmoniferous, and is therefore excluded from comparison with a marine genus, which bowever agrees with it in general form, with the exception of the flattened, callous, columella; this latter character also separates it from Natica, reminding us of Purpura, from which it is completely distinguished by the want of the anterior respiratory notch; from Nerita it is distinguished by the want of the teeth on the columella. 


\title{
Naticopsis? Glaucinoides (Sow. Sp.) Pl. 1. K. fig. 35.
}

\author{
Ref. and Syn。= Natica glaucinoides Sow. Sil. Syst. t. 3. f. 14, (not of the Min. Con.)
}

$S \%$. Ch._Spheroidal, depressed, spire very small, of three turns; apical angle about $100^{\circ}$; whorls most convex in the middle; suture, channelled; shell thick, crossed by numerous irregular, slightly oblique, rather distant, thread-like ridges, and fine intermediate strix. Length about two and half lines, width the same.

I have not seen the pillar-lip, so that there is some doubt of the genus, nor the "closed umbilicus" spoken of by Mr Sowerby.

Position and Locality.-Common in the reddish, calcareous, concretionary bed of Upper Ludlow rock, at Beckfoot, Kirkby Lonsdale, Westmoreland, and greenish tilestone of Benson Knot, Kendal, Westmoreland.

\section{9th Family. PYRAMIDELLIDA.}

Shell clongate, ovate, without periostraca; surface smooth and polished; columella thickened, often with prominent plaits; outer lip thin (animal hermaphrodite).

The shells of this family differ from the Paludinidx in their polished surface, without periostraca, and thickened columella.

Genera:-1,Eulima; 2, Chemnit:ia; 3, Odostomia; 4, Loxonema; 5, Macrochilus ; 6, Pyramidella ; 7, Bonellia; 8, Nerincea.

\section{Genus. LOXONEMA (Phill.)}

Gen. Char.-Shell narrow, very long; spire of very numerous convex whorls; apex simply pointed; body whorl small; aperture elongate, oblong, indented by the body whorl, much longer than wide, prolonged in front into a rounded lobe, not angulated behind; lips disunited behind, onter lip oblique, with a rounded backward sinus at base, convex in the middle; columella slightly thickened; surface of whorls crossed by close, oblique, sigmoid, thread-like ridges.

The anterior prolongation of the mouth and deeply sinuate lip, as well as the apex being simply in the line of the other turns, distinguish this Palæozoic genus from Chemnitzia.

Loxonema elegans $\left(M^{c}\right.$ Coy). Pl. 1. K. fig. 34.

Ref.-Id. $\mathrm{I}^{\mathrm{C}} \mathrm{Coy}, \mathrm{Ann}$. Nat. Hist. 2nd Series, Vol. VII. p. 48.

Sp. Ch.-Spire very slender, elongate conic; apical angle about $20^{\circ}$; of about six elongate, erenly convex volutions, erossed by thread-like stria arehing forward at their ends, and with a broad backward wave in the middle (about three in the space of one line); sutures deep, simple; sutural angle $100^{\circ}$. Length one incli eleven lines, proportional length of last whorl $\frac{19}{100}$, width $\frac{25}{100}$.

The greater length and slenderness of the whorls, and the broader and more shallow wave in the strix, separate it from the so-called Terebra sinuosa (Sow.)

Position and Locality. - In the Lower Ludlow of Green Quarry, Leintwardine, Shropshire.

Explanation of Figure.-Pl. 1. K. fig. 34, natural size.

\section{0th Family. PALUDINIDE.}

Shells elongate, turbinate, covered with periostraca; aperture entire, rounded, closed by a corneous or shelly operculum: (animal with two tentacles, eycs at their bases; no respiratory tube; fresh water and marine).

Genera:-1st, Paludina; 2nd, Paludestrina; 3rd, Valvata; 4th, Melania; 5th, Melanopsis; 6th, Turritella: 7th, Holopella; 8th, Scataria; 9th, Rissoa; 10th, Rissoina; 11th, Alcania; 12th, Litorina: 13th, Fossares; 14th, Lacuna; 15, Planaxis. 


\section{Genus. HOLOPELLA $\left(\boldsymbol{M}^{\circ} \mathrm{Coy}\right)$.}

Etym. o̊dos, entire, o̊mì, an aperture.

Cien. Clocr.-Shell spiral, elongate, slender, of numerous gradually increasing whorls, generally crossed by slightly arched strix; mouth circular, with the peritreme entire; base rounded, with or without a minute umbilicus.

Those shells have hitherto been confounded with the recent genus Turritella, from which they differ com. pletely in the entire peritreme and definite round margin to the mouth, thus approaching much nearer to Scalaria. From Chemitzie they differ in the smaller size of the body whorl, and in neither it nor the mouth being produced anteally.

\section{Holopella cancellata (Sow. Sp.) \\ Ref. $=$ Turritella Id. Sil. Syst. t. 20, f. 18 .}

Sp. Ch.-Acutely conic, whorls gently convex, with about five delicate, spiral threads, crossed by very fine close strix of growth. Width about three lines.

Only one imperfect fragment has occurred to us of this species, which is however easily recognized by the spiral threads cancellating the transverse strix.

Position and Locality.-Upper Ludlow quartzites of Lambrig Fell, Kendal, Westmoreland.

\section{Holopella conica (Sow. Sp.)}

\section{Ref. $=$ Turritella conica Sow. Sil. Syst. t. 3. f. $7 \alpha$ and 8.}

Sp. Ch. - Ovate, pointed, apical angle $40^{\circ}$; whorls six, most convex below the middle, crossed by fine, slightly arched strix, strongest at the suture. Length three lines, proportional width $\frac{6 n}{100}$, length of last whorl $\frac{40}{100}$.

Position and Locality.-Rather rare in the tilestone of Storm Hill, Llandeilo, Caermarthenshire.

\section{Holopella graciuion $\left(\boldsymbol{M}^{c} \mathrm{Coy}\right)$. Pl. 1. K. fig. 33. \\ Ref.-Id. Mc Coy, Ann. Nat. Hist. 2nd Series, Vol. VII. p. 47.}

Sp. Ch.-Very slender, spiral angle $15^{\circ}$; whorls smooth (number unknown), slightly and evenly convex, suture deep, simple, sutural angle $95^{\circ}$; width at base five lines, length of last whorl three lines.

This is distinguished from the $I$. obsoleta by its more slender spire (as indicated by the difference in their spiral angles, less convex whorls, \&c.)

Position and Locality._Schists of Dinas Bran, Llangollen, Denbighshire.

Explanation of Figure.-Pl. 1. K. fig. 33, natural size.

\section{Holopella gregaria (Sow. Sp.)}

\section{$R e f_{0}=$ Turritella gregaria Sow. Sil. Syst. t. 3. f. $1 f$.}

$S p . C h$.-Acutely conic, apical angle $25^{\circ}$; spire of about six whorls (four usually preserved), each obscurely angulated in the middle; shell thick, surface with sharp, rather distant transverse scaly lines of growth. Length five lines, proportional width $\frac{50}{1009}$ length of last whorl $\frac{35}{100^{*}}$.

This has much the shape of the Murchisonic torquata ( $\left.\mathrm{M}^{\mathrm{C}} \mathrm{Coy}\right)$, but has neither the band nor the collar to the sutures; its smaller size, more rapidly tapering form, and subangulated whorls, separate even casts easily from the $H$. obsoleta (Sow. sp.) It usually occurs as smooth casts, the sealy line of growth adhering to the matrix.

Position and Locality.-Common in the Upper Ludlow limestone of Beckfoot, Kirkby Lonsdale, Westmoreland; in the tilestone (Upper Ludlow) of Horeb Chapel, Llandovery, S. IVales; sandy schists of Plas Madoc, N. of Llanrwst; Upper Ludlow rock of Underbarrow, Kendal, Westmoreland. 


\title{
Holopella intermedia $\left(M^{c} \mathrm{Coy}\right)$. Pl. 1. L. fig. 16.
}

\author{
Ref.-Id. $\mathbf{M}^{\circ} \mathrm{Coy}$, Ann. Nat. Hist. 2nd Series, Vol. VII. p. 47.
}

Sp. Ch. I provisionally give this name to a species agreeing exactly, so far as I can see, with the II. olsoleta (Sow.sp.), but having an apical angle of $30^{\circ}$, being thus exactly intermediate between it and the II. conica (Sow. sp.), striking the eye as manifestly slorter than the former, and more slender than the latter. Length about seven lines, proportional width $\frac{47}{100}$, length of last whorl $\frac{38}{100}$.

Position and Locality.-Not uncommon in the state of casts in the Upper Ludlow of High Thorns, Underbarrow, Kendal, Westmoreland.

Explanation of Figure.-Pl. 1. L. fig. 16, natural size.

Holopella monile $\left(M^{c}\right.$ Coy). Pl. 1. K. fig. 32.

Ref.-Id. McCoy, Ann. Nat. Hist. 2nd Series, Vol. VII. p. 48.

sp. Ch.-Very slender, apical angle about $10^{\circ}$; spire of about nine whorls (six preserved); each turn a little wider than long, exceedingly convex; sutures deep, simple. Length three and half lines, proportional width $\frac{30}{100}$, length of last turn $\frac{28}{100}$.

The small size, extremely slender form, and very convex whorls, render it impossible to confound this with any other species.

Position and Locality.-Rare in Bala schists, Selattyn Road, S. of Llangollen, N. Wales.

Explanation of Figures.-Pl. 1. K. fig. 32, natural size; fig. $32 \alpha$, magnified.

Holopella obsoleta (Sow. Sp.)

Ref. $=$ Turritella Id. Sow. Sil. Syst. t. 3. f. $7 \alpha$.

$S p . C h$.-Elongate, spiral angle about $20^{\circ}$; whorls eight or nine (only five or six usually preserved), gently convex; sutures simple, deep; sutural angle $93^{\circ}$; surface crossed by very fine, slightly sigmoid strix. Length one inch two lines, proportional width at base ${ }_{100}^{45}$ length of last whorl $\frac{23}{1+1,}$, length of the penultimate $\frac{2}{1+\cdots 1}$.

Usually found in the state of casts, and may be distinguished from the casts of the Murclisonia torquate ( $\mathrm{M}^{\mathrm{c}} \mathrm{Coy}$ ), abounding in the same beds, by its more elongate form (smaller apical angle), less convex whorls, and the sharp simple sutural line. The last whorl near the mouth sometimes obscurely angulated.

Position and Locality._Common in the Upper Ludlow micaceous quartzite of Horeb Chapel, Llandovery. S. Wales; ditto (tilestone), Benson Knot, Kendal, Westmoreland.

\section{Holopella tenuicincta $\left(M^{c}\right.$ Coy $)$. Pl. 1. L. fig. 17.}

Ref.-Id. MCoy, Ann. Nat. Hist. 2nd Series, Vol. VIII. p. 408.

Sp. Ch. - Very elongate, spiral angle $20^{3}$, whorls probably eight or nine, but only five or six usually preserved, gently convex; sutures simple, deep; sutural angle $80^{\circ}$; surface girt with close, fine, sharp, subequal, spiral strixe (about thirty-five in the space of one line on the basal whorls), crossed by a few obsolete, sigmoidally arched lines of growth. Length about eight lines, proportional width at base ${ }^{40}$, length of last whorl $\frac{27}{100}$, length of penultimate whorl $\frac{20}{100}$.

I imagine this may be the Scotch fossil referred by Mr Salter (Quart. Geol Journ. for Aug. 1851) to the Upper Ludlow Turritella (Holopella) obsoleta of Sowerby, as it has very much the same size and shape, and the distinctive spiral lineation requires a good cross-light and some care to detect*, but with these, and a lens of low power, it may be always seen, even in the sandstone casts, and the species thus easily distinguished from that of the newer rocks. The sutures are also more oblique than in the $I$. obsoleta. The slight inequality of size of the strixe seems in part subalternate, and in part irregular.

* Since the above was in type Mr Salter shewed me the specimen alluded to by him, at the Jermyn Strcet Museum, and wo found the striation in question, confirming the above surmise. 
Position and Locality.-Common in the Bala sandstone of Mulock Quarry, Dalquorhan, Ayrshire.

Explanation of Figures.-Pl. 1. L. fig. 17, natural size; fig. $17 a$, part of one of the whorls of ditto magnified to shew the striation.

\section{Genus. LITORINA (Fer.)}

Gien. Char.-Shell thick, striated, ovate; spire short, pointed, rarely exceeding the body whorl in length: mouth oblique, longitudinally ovate, broadly rounded in front, slightly contracted retrally, indented by the preceding whorl; outer lip thin, inner lip thickened and slightly flattened towards the front, frequently deficient in the middle; base rounded, imperforate; operculum corneous, of few spiral turns, summit lateral: (animal resembling Scalaria, and wanting the filaments at the foot, of Turbo and Trochus).

Differs from Turbo in less size, not being perlaceous, the corneous operculum, \&c. and from Phasianella by the surface not being polished; known from Trochus by the tumid base and the mouth being longer than wide; and from גonodonte and its subgenera by there being no tecth on the pillar. All the species are phytivorous, feeding on the fuci on rocky coasts, only at, or a little below, low-water mark, in every quarter of the earth at the present day, but most abundant in cold regions. They seem to occur in every geological stage, gradually increasing in number from the Cambrian to recent period.

The genus Holoped of Hall is proposed for the Silurian species, but, with every disposition to adopt the genus, I do not think it can advantageously be employed till some difference of structure can be detected whereby to distinguish the species from the others.

\section{Litorina coralli (Som. Sp.)}

$$
\text { Ref. }=\text { Turbo corallii Sow. Sil. Syst. t. } 5 \text { f. } 27 .
$$

$S_{p}$. Ch.-Ovate, pointed ; apical angle $65^{\circ}$; spire of five slightly-flattened whorls, marked with fine close spiral strixe (about seven or eight to each of the latter whorls), two larger than the rest (like a band) on the circumference of the body whorl, and close to the suture of the spiral whorls; near the apex only one of the spiral threads at the upper suture and two near the lower suture are visible; base flattened, imperforate, with close spiral striæ, mouth broad ovate, little longer than wide. Length five lines, proportional width $\frac{85}{1 \cdots w}$, length of body whorl $\frac{65}{100}$.

Mr Sowerby's figure is rather more pointed, and has the whorls rather more convex than the examples I have seen, and the band-like strength of one pair of strix is not noticed. The fine spiral threads are crossed by very minute straight lines of growth. Usually found covered by the spheroidal growtls of the little coral Stenopora fibrosa, shewing that it dwelt, like recent Litorine, in shallow water.

Position and Locality.-Not uncommon in the Upper Ludlow sandstone of Benson Knot, Kendal, WVestmoreland.

\section{Litorina octavia (d'Orb. Sp.)}

Ref. $=$ Turbo carinatus Sow. Sil. Syst. t. 5. f. 28 (not of Min. Con. t. 240, nor Born.) = Turbo octavia d'Orb. Prod. Pal. p. 30.

Sp. Ch.-Ovate, pointed, apical angle $65^{\circ}$, of four very convex whorls; about three equidistant, delicate, thread-like, spiral ridges, on each whorl of the spire, to which three or four closer ones are superadded on the base of the body whorl, which is convex and imperforate; whorls erossed by fine, close, slightly oblique lines of growth. Length seven lines, proportional width $\frac{75}{100}$, length of body whorl $\frac{58}{100}$.

In Mr Sowerby's figure above referred to the transverse strix of growth are much too coarse and wide apart. Commonly found buried in investing growths of Stenopora fibrosa.

Position and Locality.-Not common in the Upper Ludlow quartzite of High Thorns, Underbarrow, Kendal, Westmoreland; Upper Ludlow rock of Woolhope; Upper Ludlow of Burton and Brockton, near Wenlock. 


\title{
Litorina undifera ( $M^{c}$ Coy). Pl. 1. K. fig. 46 and $46 a$.
}

\author{
Ref.-Id. McCoy, Ann. Nat. Hist. 2nd Series, Vol. VII. p. 48.
}

Sp. Ch.-Turretted, broad, ovate; spire pointed, about three-fourths the length of the body whorl; apical angle about $80^{\circ}$; sutures channelled, having a little below them a thick spiral ridge undulated by about eight vertical depressions, which cross the whorls of the spire and upper part of the body whorl; below this ridge is a wider concave space, bounded by a second thick undulating ridge, forming the most prominent part of the whorls : beneath this second ridge, on the body whorl, are about ten very delicate, subequal, spiral threads, distinctly separated by coneave spaces, about two of which only are visible on the turns of the spire; entire surface crossed by very close, minute, direct lines of growth. Length three lines, proportional length of body whorl "im., width slightly more than the length of the body whorl.

This resembles some of the small oolitic Pleurotomario, but there is clearly no sinus in the lip, as indicated by the direct lines of growth; and the shell is no doubt congeneric with the $L$. carinute, from the young of which the undulations, \&c. distinguish it.

Position and Locality.-In the Aymestry limestone of Mortimer's Cross, Aymestry, Herefordshire.

Explanation of Figures.-Pl. 1. K. fig. 46 , natural size; fig. $46 \alpha$, magnified (the undulation of the upper keel of the body whorl not sufficiently marked).

\section{5th Class. CEPHALOPODA (Cuvier).}

Tirese are the largest and most highly organised of all the mollusea: they are all carnivorous, and extremely voracious, gregarious, nocturnal, marine animals; and instead of being confined, like most Gasteropodu, to creeping on the ground, they have various powerful means of locomotion, and many of them live habitually in the open sea far from land, which they only approach yearly. The name expresses the most remarkable character, of the feet, tentacles, or arms, for creeping and prehension, surrounding the head, which is a cranial cartilage enclosing the great cephalic ganglia or brains, and furnished with powerful horny or testaceous mandibles, the longest below, otherwise like those of a parrot in shape (Rhyncholites), working vertically (the jaws of gasterpods, insects, \&c., act horizontally), for tearing their prey, and a large fleshy tongue, supplied with nerves for taste. The head also bears a pair of very large, highly developed eyes, equalling those of fishes in perfection and with a similar fibrous crystalline lens, generally moving freely in an orbital cavity, and supplied with nerves, from a special ganglion not existing in any lower mollusca; there are also more or less developed external ears. The body is an oblong, thick, muscular sack, closed posteriorly and open anteriorly, varying from spherical to cylindrical, or depressed, and perfectly symmetrical: the head and body are attached to each other by ligaments of great strength in the littoral cuttlefishes, but slender in the deep-sea species, in which there is a temporary contrivance, called the "apparatus of resistance," for increasing at any moment the strength of the attachment, and affording in its variations a good character for classification. The respiration is by gills contained in a large internal cavity, to which the water has aceess by a valvular opening on each side, external to the base of the funnel, and whence it is ejected, by the contraction of the mantle, in jets, through a peculiar ventral tube, named the "funnel," with sufficient force to drive the animal rapidly backwards, forming the chief means of locomotion. Some of the Ceplatoporla have external shells, others are naked and contain an internal so-called "bone," giving support to the body, like the bones of the vertebrata, but loosely placed in the back of the mantle, without muscular attachment of any sort to the animal. Sexes always distinet, and in different individuals. The mouth is followed by a wide erop, opening into a fleshy stomach or gizzard, from which extends an intestine, terminating in the base of the funnel or locomotive tube.

The class is divided into two orders:-1, Tetrabranchiata; 2, Acetabulifera. 


\section{1st Oid. Tetrabranchita (Owen).}

$$
=\text { Tentaculifera (d'Orb.) }
$$

Body without fins, always contained in an external shell, to which it is fixed by two large lateral muscles, and a narrow horny cincture to the abdominal part of the mantle. The septa are pierced by a siphuncle containing a tubular prolongation of the mantle; anterior edge of the mantle thickened and divided into several lobes, one semicircular dorsal fold resting against the inrolled spire, one triangular hood-shaped flap covering the lack or top of the head, and a large number (seventeen to ninetecn on cach side in Nautilus) of lobes, hearing numerous, short, transversely crenulated, slender tentacles; the eyes large, but projecting on peduncles, as in the Gasteropode, and with a short tentacle before and one behind cach, analogous to the four tentacles of some Gasteropods in position and origin of the nerves; there are also four labial processes with a large number of labial tentacles, like those of the mantle; cranial cartilage confined to the under side of the head, having a groove on the upper surface to support the annular brain, and giving off processes of attachment to the muscles of the funnel, and the lateral adhering muscles. Funnel slit along the ventral aspect, strongly contractile, with a valve at the opening. The nervous collar is stirrup-shaped, the supra-oesophageal portion very thick and simple, enlarging at the ends, and giving off twigs to the eyes, and lower tentacles of the eyes, and muscles of the mouth; the inferior portion double, the anterior inferior semi-ring giving twigs to the tentacles; the posterior one giving off flattened twigs to the muscles of the shell, a set of slender twigs to the stomach, and two long respiratory branches each with a ganglion at the base of the gills, which twigs go to the heart, \&c.; the posterior semi-ring is therefore the analogue of the pedial and branchial ganglia in the lower mollusca. The dorsum of the tongue is armed with a horny coat, covered with recurved hooks; the wesophagus, after passing through the neural collar, dilates into a large crop, which contracts to a slender tube before entering an oval gizzard, from which the intestine extends, with first an abrupt backward and then forward bend, to terminate in the branchial cavity, at the base of the funnel; near its origin is a round laminated biliary appendage or pancreas, receiving the bile from the ducts of the lobulated quinquepartite liver, which is large, extending from the crop to the gizzard; no ink-gland. The pericardium contains the dilated end of a rena cava, taking the venous blood from the head, mouth, tentacles, and funnel, \&c., and sending it to the two pairs of gills, by four branches, to which are clustered a number of (?) renal glands; each vein at the base of the gill having a valve to prevent the return of the blood; beyond this valve the vessel becomes the branchial artery, ramifies through the gill, ending in a branchial vein for each gill, taking the aerated blood to the four corners of a transversely oblong systemic ventricle, which gives off an anterior and a posterior aorta-the former small, supplying the nidamental gland, and extending backwards through the siphon; the latter large, with a muscular bulb at its origin supplying the body. The females have an ovary on the right side of the gizzard, the oviduct running beside the intestine, and terminating near the anus. In advance of the termination of the oviduct is a pair of (?) nidamental glands (as in the Pectinibranchiate Gasteropods), for adding the shell and connecting substance to the eggs.

The formation of each septum begins at the circumference and extends to the siphuncle, which it extends over backwards; the penultimate chamber is smaller in the adult than the preceding ones. The shell of the embryo Nautilus is simple and unchambered.

The apparent absence of an ink-bag induces Prof. Owen to class the Ammonitide with the Noutilide.

The order contains three families:-1st, Bellerophontidoe; 2nd, Nautilido; 3rd, Ammonitidos.

\section{1st Family. BELLEROPHONTIDE (McCoy).}

Shell thick, spirally inrolled, monothalamous; a defined siphonal band on the circumference (as in Argonauta); usually a distinct inner lip overspreading part of the inrolled spire, deposited by a dorsal flap of the mantle (as in Nautilus). 
There can be no doubt that the characteristic band, and its accompanying sinus at the edge of the aperture, lodged the funnel of the cuttlefish (as in Argonauta); but I think the great thickness of the calcareous shell, and beyond all the testaceous deposit (or inner lip) formed on the inrolled part of the spire, like the black mark on the recent $N^{T}$ autilus, formed as in them by a reflected lobe of the back of the mantle, indicate that the shell was really attached to the animal, and therefore more like Nautilus than Argonaute. We have many examples of the embryonic appearance of the recent types being the permanent characteristic of the ancient fossil analogues; and as the extremely young Nautilus is monothalamous, we only recognise an old law in placing Bellerophon in a new group; and as Prof. Owen and M. Valeneiennes have demonstrated how little superior Nantilus is to the Pectinibranchiate Gasteropods in several points of anatomy, we would by this new position of Bellerophon draw the connexion closer. The alsence of chambers would confine these heavy shells constantly to the bottom like the Gasteropods, or like the occasional habit of Nautilus.

\section{Genus. BELLEROPHON (Montf.) emend. by Defrance.}

$$
\text { Syn. } \left.->\text { (Bucania Hall. + Euphemus } \mathbf{M}^{\circ} \mathrm{Coy}\right) \text {. }
$$

Gen. Char.-Shell thick, symmetrical, involute, globose, or discoidally coiled with the whorls exposed; a sinus in the middle of the outer lip, from which a band extends backwards along the outer surface of the volutions; inner lip thickened, expanded on the inrolled spire.

The subgenus Bucania of Hall was proposed for the species with a wide umbilicus, but it seems impossible to draw the line between these and the species with very small umbilicus or none. The sulggenus Euphemus ( $\mathrm{M}^{\mathrm{c}} \mathrm{Coy}$ ) was proposed (Carb. Foss. Irel.) in 1844 for the species supposed to want the band, and also supposed to have thinner shells than the others; since then the group has been recognised and separately named by M. Barrande, and still more recently M. d'Orbigny has (in his Prodrome) also independently recognised the group, but confines to it Conrad's name, Cyrtolites; but as I have recently ascertained that some of the types of this group (e.g. B. bilobatus, sce.) have really got bands, when the external shell can be examined, and that in other, spirally sulcated, species, the band is merely obscured by the sculpturing, I think, contrary to my former opinion, and that of the above distinguished authorities, that the subgenus should again be merged into Bellerophon. As I have before remarked, the thickness and weight of the calcareous shells seems to me a decisive argument against the possibility of the Bellerophon belonging either to the Pteropala or Ileteropoda, when we consider the habits and the functions of the shell in these groups; the symmetry and completeness of their involution seems to me to separate them from any of the Gasteropodous genera to which they have been allied; and on the whole there would be less objection to Professor Owen's suggestion of placing them in the Octopodous group of Dibranchiate Cephalopods, close to Argonaute, than any other proposed arrangement, were it not for the distinct and often greatly thickened inner lip covering the part of the spire entering the aperture. No trace of this lip ever occurs in the Argonauts, which differ thus from all other involute shells, as well as in the mode of formation of their shell, which renders the occurrence of an inner lip impossible. As it is therefore clear that the shell of Bellorophon was secreted by the mantle, after the manner of $N^{2}$ autilus, 1 have preferred viewing it as a monothalamous Noutilus, agreeing with embryo Nautili in this respect, and rendering more perfect the passage from the Tetrabranchiata to the Gasteropoda.

\section{Bellerophon bilobatus (Sow.)}

$$
\text { Ref. and Syn.-Sil. Syst. t. 19.f. } 13=\text { (B. elongatus + B. gibbus Port.) Geol. Rep. t. 29. f. } 2 \text { to } 5 \text {. }
$$

Sp. Ch.-Globose, involute; sides and periphery very slightly flattened; mouth large, widely bilobed by a deep sinus, from which a wide flat band with arched stria extends (leaving no trace on the interior); umbilicus very small in the casts, closed in the perfect shell; surface marked with coarse, round, slightly irregular and flexuous close strix (seventeen or eighteen in one line), strongly arched from the unbilicus to the band, faintly decussated under the lens by very minute spiral strie, strongest at the umbilicus and sides of the band; casts smooth; diameter one inch two lines; proportional width of mouth $\frac{20}{100}$, depth of sinus $\frac{23}{100}$. 
The depth of the sinus in the outer lip gives a remarkable, decply.bilobed, form to the mouth. The figures of Sowerby and Portlock represent the ordinary appearance of the smooth internal casts, which shew no trace of the band or strix of the true surface, which I have however detected in fragments on numerous limestone specimens, and which may often be traced with a good lens and strong light on specimens preserved in shales. I think it possible $B$. cancellatus of Hall may be the same species; specimens are usually more compresserl from pressure than the above description indicates.

Position and Locality.-Common in the black Bala limestone of Teirw, S. of Llangollen, N. Wales; Wenlock shale of Cheney Longville, Shropshire; calcareous Caradoe sandstone of Horderly WV.; black Bala shale of Dinas Mowddwy, Merionethshire; Bala schists of Yspatty Evan, N. Wales; Bala limestone of Dolydd Ceiriog Waterfall, E. of the Berwyn Mountains; Upper Bala calcareous sehists, S. of Cwmlanerch. Bettws, Caernarvonshire; calcareous Bala schists of Llanwddyn, E. of Berwyn Mountains.

\section{Bellerophon carinatus (Som.)}

\section{Ref. and Syn-Sil. Syst. t. 3. f. $1 d$. and $4+B$. acutus Id. id. t. 19. f. 14 .}

Sp. Ch.-Lenticular, compressed, greatest thickness at edge of umbilicus, which is very small, but displays in the cast the edges of the two or three inner whorls; circumference acutely angulated; (? surface apparently with delicate transverse strix); mouth triangular, its greatest width about one-third less than the length of its side; diameter six and half lines; in proportion to the diameter the width is $\frac{45}{110}$, length of mouth $\frac{65}{100}$, diameter of umbilicus $\frac{16}{100}$.

As I perceive in several specimens that a slight amount of pressure produces the supposed difference between the $B$. carinatus and the $B$. acutus (Sow.), I am compelled to unite them, which I do with no doubt of their identity.

Position and Locality.-Common in the yellowish tilestone of Storm Hill, Llandeilo; calcarenus Upper Bala schists of Dolydd Ceiriog Waterfall, S. E. of Moel Ferna, E. of the Berwyn Mountains.

\section{Bellerophon dilatatus (Sov.)}

$$
\text { Ref--Sil. Syst. t. 12. f. } 23 .
$$

Sp. Ch.-Shell very thin, in the young state spirally inrolled, of three or four gradually increasing whorls, the section of each twice as wide as long, obscurely angulated in the middle, and ontusely rounded at the sides; keel narrow, flattened, only slightly projecting, nearly smooth; surface marked with coarse, unequal, obtuse, close, spiral ridges, increasing in width towards the mouth (about four in one line, at the width of one inch, ten in the same space at the diameter of two lines); umbilicus wide, exposing the whorls, with rounded margins; in the adult state (from a diameter of about one inch) the mouth suddenly expands into a nearly circular, horizontal. slightly reflected lip, averaging two inches nine lines long, and two inches six lines wide.

Sowerby's figure, above quoted, shews the usual appearance of this beautiful species, the radiated expansion being the cast (as he suggests) of the outside of the extremely thin shell. The strie or spiral ridges reach a diameter of about two-thirds of a line, and disappear before reaching the edge; they are crossed by very fine, oblique, undulating lines of growth, and the keel often becomes obscure in the old state; his figure does not shew the striation of the penultimate whorls, which is, however, shewn in Col. Portlock's litho. graph, as well as the nearly smooth appearance of the interior of the mouth.

Position and Locality.-Not uncommon in the fine Bala sandstone of Mulock Quarry, Dalquorhan. near Girvan, Ayrshire.

\section{Bellenophon expansus (Som.)}

Ref. and Syn. $=$ B. expansus Sow. Sil. Syst. t. 5. f. $32+$ B. globatus Id. id. t. 3. f. 15 .

$S p . C h .-\left(D e s c r i b e d\right.$ from internal casts) $Y_{0 u n g}(B$. glolutus) : length five lines; in proportion to length, width of mouth $\frac{90}{100}$, length of mouth $\frac{60}{100}$, width of umbilicus $\frac{25}{100}$, globose, sides often marked with a few transwerse 
wide furrows (traces of thickening of lip); sometimes obseure traces of coarse obsolete spiral furrows; from this size the mouth rapidly expands. Adult ( $B$. expansus): (small specimen) length six lines; in proportion to length, length of mouth $\frac{85}{100}$, width of mouth double its length; spire suall, globose, inrolled; umbilicus small; mouth large, transversely elliptical, bilobed by a wide V-shaped sinus; surface with obscure, lateral wrinkles, arching from the umbilicus towards the middle of the outer surface parallel with the double lobe of the outer lip.

In old specimens one inch long there is a long narrow slit about nine lines in length and less than half a line wide, continued from the apex of the $\mathrm{V}$-shaped sinus of the outer lip, which retains the form of the above description. There can, I think, be not the slightest doubt of the propriety of uniting the Belleroplon globutus and the B. expansus of Sowerby ; the excellent figure of the former given in the Silurian System, corresponding exactly with specimens before me, shews traces on the side, of the concentric wrinkles; it is the largest size before the rapid expansion of the mouth begins; the rather small figure of the latter species (equally good) shews the greater number of the lateral wrinkles developed and the form of the perfect mouth; and betwcen these I have traced all the gradations. The surface is unknown, but several of the casts shew a spiral sulcation similar on a small scale to that of the $B$. dilatatus.

Position and Locality.-Common in the Upper Ludlow rock of Underbarrow, and Benson Knot, Kendal, Westmoreland; tilestone of Horeb Chapel, Llandovery, S. Wales; Upper Bala schists of ? Dolydd Ceiriog Waterfall, E。 of the Berwyn Mountains; Upper Ludlow rock, near Ludlow, Shropshire.

\section{Bellenophon Murchisoni ( $d^{\prime} \mathrm{O} \cdot \mathrm{r}$.)}

Ref. and Syn. = B. striatus (Sow. not of Bronn) Sil. Syst. t. 3. f. $12 e$.

$S p$. Ch. - Involute, subcompressed, of about one and half very rapidly enlarging, completely exposed whorls; section of whorls obtusely cordate, the width slightly exceeding the length; sides tumid, very convex; circumference with an obtusely-defined, broad, prominent, flattened licel; umbilicus small; surface with fine, sharp strix, transverse on the sides and keel; average diameter five lines; in proportion to diameter, length of mouth $\frac{80}{100}$, width of umbilicus $\frac{15}{100}$.

The greater width and tumidity of the sides, fewer and more rapidly expanding whorls, and consequently greater size of the last volution, and wide obtusely-flattened keel, separate this species from the $B$. curinatus (Sow.)

Position and Locality.-In the tilestone of Horeb Chapel, Llandovery, S. Wales.

\section{Bellerophon ornatus (Comrad Sp.)}

Syn. and Ref. = Cyrtolites ornatus Id. Geol. Rep.; Hall, Pal. New York, t. 84. f. 1.

$A p . C h$.-(Spire exposed, of two and half or three volutions, Hall); whorls with a strong rounded licel; section subrhombic; sides marked with thick, prominent plaits, extending from the edge of the umbilicus nearly to the base of the keel, with a slight backward curvature; the intervening spaces are wide and concave, (a fragment of last whorl, with a diameter of four lines, is three lines wide, and the summits of the lateral plaits are one line apart).

The portions preserved of this species agree with the American specimens figured by Hall, in which the diameter of the perfect shell is nine lines, and the proportional diameter of the mouth $\frac{55}{10 n}$. Under a strong lens our specimens shew some traces of the minute net-like striation of the surface.

Position and Locality. - Not uncommon in the dark Bala limestone of Teirw river, S. of Llangollen, N. Wales. 


\title{
Belleropion subdecussatus $\left(M^{c} \mathrm{Coy}\right)$. Pl. 1. L. fig. 25.
}

\author{
Ref.--Id. McCoy, Ann. Nat. Hist. 2nd Series, Vol. VII. p. 47.
}

Sp. Ch.-Globose, of one and half or two very rapidly enlarging whorls, subeompressed towards the very obtusely angular, or rounded circumference; sides gibbous; umbilicus small, deep, partially exposing the whorls; surface with strong, transverse ridges, circling backward from the umbilicus to the undefined band, forming a wide $\mathrm{V}$-shaped sinus, (about four or five of these transverse ridges in the space of one line near the mouth); they are crossed by much finer spiral strix, about the same distance apart, from one to three of which are usually stronger than the rest near the band; diameter four and half lines; in proportion to

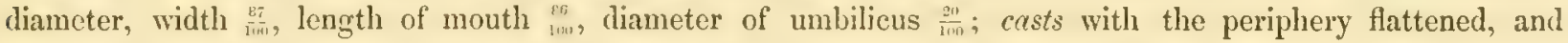
a very wide umbilicus exposing almost entirely the two and half or three whorls.

This species is extremely like the carboniferous $B$. decussatus (Flem.), but has the transverse ridges much stronger than the spiral ones.

Position and Locality.-Rare in the schists of Llanrwst; and fine Bala sandstone, Mulock Quarry,

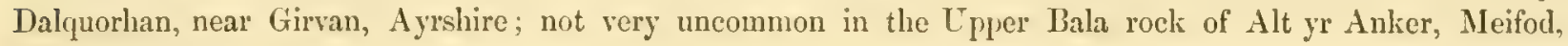
Montgomeryshire.

Explanation of Figures.-Pl. 1. L. fig. 25, natural size, from Mulock; fig. 25a, keel and portion of surface magnified, from Llanrwst.

\section{Bellerophon trilobatus (Som.) \\ Ref.-Sil. Syst. t. 3. f. 6.}

Sp. Ch.-Globose, umbilicus small, deep; whorls trilobed by two deep spiral furrows, the lateral lobes half the width of the mesial one; very convex, mesial lobe most prominent, slightly flattened; width (of small specimens) three lines, length the same; proportional width of umbilicus $\frac{32}{10 u}$, as compared with the diameter of the shell.

All the specimens I have examined were internal casts in sandstone; some shew apparently traces of sharp transverse lines of growth. The Devonian fossil quoted as this species in the works of British geologists is the totally distinct species $B$. bisulcatus (which see, in the Section on Devonian mollusea).

Position and Locality.-In tilestone of Storm Hill, Llandeilo, Caermarthenshire.

\section{Bellerophon Wenlockensis (Sow.)}

$$
\text { Ref.-Sil. Syst. t. 13. f. } 21 .
$$

$S p . C h$.-Gilobose, periphery and sides obtusely rounded; umbilicus very small, mouth transversely lunate, rounded at the sides, forming a deep, obtuse, $\mathrm{V}$-shaped sinus in the middle, the sides of which meet at an angle of $105^{\circ}$, which is also the angle at which the coarse, very irregular, close, subimbricating ridges of the surface meet the keel; keel about half a line wide, strongly defined, prominent (traces in parts of very minute spiral strix roughening the transversely arched ones). Width at mouth two and half inches, proportional diameter $\frac{68}{100}$, diameter of mouth $\frac{47}{100}$, diameter of umbilicus $\frac{13}{100}$.

Position and Locality.-Rare in the Wenlock limestone of Woolhope.

\section{2nd Family. NAUTILIDE.}

Shell strong, external, straight or inrolled; divided by numerous septa, with entire or simply lobed or angulated edges; last chamber much the largest; siphon large, varying in position from the centre to the outer or inner margin, usually subcentral.

The siphon of the recent Nautilus dissected by Owen and Valenciennes was inextensible and friable. and coated with a thin calcareous layer-in several fossil genera it is a thick continuous calcareous tube, rendering Dr Buckland's theory of its hydrostatic action untenable in both cases. 
The family contains the following genera and subgenera: 1, Nautilus; 2, Cyrtoceras; 3, Aturia; 4, Aganides; 5, Clymenia; 6, Subclymenia; 7, Orthoceras; (8, Cycloceras; 9, Poterioceras ; 10, Loxoceras.)

\section{Gemus. CYRTOCERAS (Gold.)}

Gen. Char.-Shell conic, gently arched; siphon at the outer edge or nearly so; septa simple.

The similarly-shaped species with subcentral siphon form the genus Aploceras (D'Orb.)

\section{Cyrtoceras multicameratum ( $/$ all).}

$$
\text { Ref.-Pal. New York, t. 42. f. } 4 .
$$

$S p . C h$. - Length of specimen nearly two inches, gently arched to within half an inch of the apex, which is abruptly curved to less than half a circle; antero-posterior diameter at mouth about six and half lines, moderately compressed laterally; section broad, oval; siphon obscure, but apparently near the external narrow und of the oval septa; septa very numerous, five in the space of two lines, at two to three lines in diameter at about four lines from the apex.

This species is remarkable for the great approximation of the slightly convex septa, which agree exactly in proportional distance, by measurement, with Hall's figure.

The American locality is "Lower Shaly beds of the Trenton limestone at Middleville."

Position and Locality.-In the shaly beds of the concretionary Lower Bala limestone at Knockdollian mountain, three miles from Ballintrae, Ayrshire.

\section{Genus. ORTHOCERAS (Breyn.) restricted.}

$$
\text { Syn. }=(\text { Molossus + Achelois Montf. })>(\text { IIuronia + Ormoceras Stokes = Actinoceras Bronn. })
$$

Gen. Char.-Shell conical, straight or nearly so, having the greater part of the posterior end traversed by convex, transverse septa, with simple edges, at right angles to the long axis of the shell; siphon calcareous, central or slightly eccentric, cylindrical or dilated between the chambers; external surface even.

In my Synopsis of the Carboniferous Fossils of Ireland (p. 6) I have proposed to restrict the term Orthocerus to such of the above as had perfectly central simple siphons, I now find however that it is absolutely necessary to include also the species which have it more or less eccentric, but agreeing in other respects; I also find that the gradation is so insensible from the species with narrow, simple, siphons to those in which it is more or less dilated between the chambers (forming the genus Actinoceras of Bronn and Stokes), or those in which the dilatations correspond with the septa and the constriction with the intervening spaces (forming the gencra IIuronia and Ormoceras of Stokes), that it is impossible even to separate them as subgenera. The genus Melia or Thoracoceras of Fischer is founded (Bulletin de la Soc. des Nat. de Moscou, Vol. XVII. p. 755) on Orthoceratites with lateral siphons, hut dissimilar generic characters in other respects; his notion that the septa do not entirely surround the siphon not being applicable to the bulk of his species, and especially the $T$. vestitum, the type of his genus has a small only submarginal siphon, agreeing in other respects with Orthoceras, and although the group is adopted by M. d'Orbigny in his "Prodrome" for some species having the latter character, yet they are very dissimilar among themselves, and are not analogons to the greater number of Fischer's species; it does not seem to me possible consequently to recognise the genus. Restricting therefore Orthocrens to plain species with central or slightly eccentric siphons, and the septa at right angles to the general axis, we get a second very good subgenus or genus, which in the before-mentioned work I have published under the name of Loxoceras ( $\mathrm{I}^{\mathrm{C}} \mathrm{Coy}$ ), in which the general form is the same, but the septa are oblique to the long axis, and have a deep wave in their edges on each side, and the siphon is either marginal or submarginal, varying however as in Orthoceras in thickness or inflation between the septa.

The name Endoceras is provisionally applied by Hall to such Orthoceratites as have young septate tubes 
developed within the siphon. Cameroceras (Conrad) is according to Hall an Orthoceras, inclosing a young shell which was mistaken for a lateral siphon.

\title{
Orthoceras angulatum ( $W a h l$.)
}

\author{
Ref. and Syn._His. Leth. Suec.t. 10. f. 1 = Orthoceras virgatum Sow. Sil. Syst. t. 9. f. 4.
}

Sp.Ch.-Conical, about six inches long, tapering at the rate of two and half lines in one inch, from a dianeter of nine lines, at which size the surface has about twenty-eight narrow, prominent, longitudinal ridges, separated by wide concave spaces, faintly and minutely striated transversely, (stria twenty-eight in one line), and varying from two-thirds to one and quarter lines in width; section broad-oval; siphon ecentric towards the upper end; septa scarcely oblique, about one and half lines apart.

The transverse strix are six to seven times more in a given space than in the 0 . calamiterm (Münst.), which induecs me to leave in this species as a provisional variety $(\beta)$, a fragment from the black shale of Builth Bridge, and another from the shale of Llangynyw, in which obscure indications of transverse annuli appear at the distance of those in that species, but which may be produced by the resistance of the edges of the septa to the crushing.

Position and Locality.-Common in the Upper Ludlow rock of Brigsteer, and Underbarrow, Kendal, Westmoreland; Lower Ludlow mudstone, Garden (Quarry, Aymestry, Herefordshire; mudstone (IVenlock shale) of Llangynyw Rectory, near Welehpool, Montgomeryshire; black Upper Bala shale of Builth Bridge.

\section{Orthoceras baculiforie (Salt.) Pl. 1. L. fig. 2\%.}

$$
\text { Ref.-Salter, in Appendix. }
$$

Sp. Ch.-Very elongate, conic, tapering at the rate of two-thirds of a line in one inch; section oval; siphon moderate, subcentral; septa gently convex, direct, with a slight backward wave on each side; a dozen septa at a diameter of six to seven lines, uniformly two lines apart.

A specimen four inches long, of which two inches three lines is unchambered, seems only to taper one and half lines, the commencement of the chambered portion being slightly narrowed and very slightly expanding towards the mouth; the surface cannot be seen, the only preserved portion being covered by a parasitic coral.

Position and Locality.-Rare in the Upper Ludlow rock of Brigsteer, Kendal, WVestmoreland.

Explanation of Figures.-Pl 1. L. fig. 27, natural size of fragment; $27 \alpha$, end view, shewing form of section and position of siphon.

\section{Orthoceras Brighti (Sow.)$$
\text { Ref.-Sil. Syst. t. 12. f. } 21 .
$$

Sp. Ch.-Tapering at the rate of two lines in one inch, from a diameter of one inch six lines; siphon very large, cylindrical, subeentral, having at the above diameter of the tube a diameter of four lines, and marked by slightly oblique constrictions, about four lines apart, from each of which an irregular lamellar extension forms a ring within the siphon about a line wide.

The fragment I have examined does not shew the internal structure of the siphon fully, nor is any trace visible of the external surface of the tube or septa, the form of the tube being defined by a mass of calcareous spar.

Position and Locality.-Common in the Wenlock limestone of Ledbury, Herefordshire.

\section{Orthoceras bullatum (Sow.)}

Ref.-Id. Sil. Syst. t. 5. f. 29. O. striatum Id. id. p. 612, not of Min. Con.= Orthoceratites substriatus D'Orb. Prod.

Sp. Ch.-Section broad-oval, tapering at the rate of three lines in two inches, from a diameter of one inch five lines, and having at that diameter the six or seven last septa about one and half lines apart and [FASC. II.]

$$
\text { S s }
$$


slightly oblique; siphon moderate, subcylindrical, nearly central; surface covered with fine, rigid, nearly equal, longitudinal strix, nearly twice their thickness apart, separated by flat spaces, about eight in one line.

Position and Locality.-Green, Upper Ludlow, quartzites of Lambrigg Fell, and Laverock Lane, Kendal, Westmoreland; whitish tilestone of Storm Hill, Llandeilo, Caermarthenshire; ?flags of Llyn Alwen, Denbighshire, the latter being a small fragment with closer and finer strix than usual.

\section{Orthoceras centrale? (His.)}

\section{Ref.-His. Leth. Suec. t. 9. f. 4 .}

Sp. Ch.-Conical, tapering at the rate of one line in one inch, from a diameter of six lines; section circular: siphon central, small; surface girt with sharp, slightly irregular striæ, eight or nine in two lines at a diameter of six lines, eighteen in same space at a diameter of one and lialf lines, separated by concave spaces slightly exceeding their thickness, with a fine parallel lineation under the lens.

This species resembles the Devonian 0 . striolaris (V. Meyer) in the occasional irregularities and junction of the strix, but tapers much more gradually.

Position and Locality. - Not uneommon in the flaggy Bala limestone of Llandeilo, Caermarthenshire.

\section{Orthoceras dimidatum (Som.)}

Ref. and Syn.-Sil. Syst. t. 8. f. 18 (Mala) =O. subdimidiatum d'Orb. Prod. p. 28.

$S p . C h$.-Slender, tapering at the rate of about half a line in half an inch from a diameter of two lines and one-third; section broad-oval; one of the convex sides smooth, the other girt (searcely half round) by thick, equal, slightly oblique ridges, five or six in one line, less than their thickness apart.

Position and Locality.-Rare in the Upper Ludlow rock of Brigsteer, and calcareous Upper Ludlow flags of Derby Arms, near Kiendal, Westmoreland. One very large specimen, just obtained, imperfect at each end, two inches four lines long, and four lines wide at large end, tapers two lines in two inches; and at the larger end has the semi-rings varying from four to five in two lines; - from the Lower Ludlow flags of Leiniwardine, Shropshire.

\section{Orthoceras filosum (Sow.)$$
\text { Ref.-Sil. Syst. t. 9. f. } 3 .
$$

$S p . C h$. -Gradually tapering, length one foot seven inches, tapering at the rate of three lines in two inches, from three inches in diameter (slightly less towards the mouth, and slightly more towards the apex); septa at three and half inches in diameter, rather less than four lines apart, six lines apart at two and a quarter inches diameter; surface marked with sharply-defined, narrow, obtuse, longitudinal ridges, about the fifth of a line thick, separated by flat spaces varying in width from half a line to one line, destitute of transverse stria, but sometimes shewing traces of longitudinal furrows; sometimes every fifth or sixth ridge is a little larger than the rest; section broad-oval; siphon rather large, very slightly eccentric.

The width at mouth, of the large individuals mentioned above, is about three inches eight lines, the wilth of the smaller end being about eleven lines, the extremity having the appearance of decay and gradual crumbling off during the life of the animal. Fragments of this species are distinguished from portions of the comparatively small $O$. aremlatem by the narrow, distinctly defined ridges, with the flat interspaces, the absence of the minute transverse striation, and the oceasional appearance of longitudinal intermediate furrows: when the septa are visible they remove all difficulty, as at the same liameter they are double the distance apart in the former that they are in the latter species.

Position and Locality.-Common in Lower Ludlow mudstone of Green Quarry, Leintwardine, Shropshire, and Garden Quarry, Aymestry, Herefordshire; in the Upper Bala flags of Coldwell, Westmoreland; black Bala shale of Builth Bridge, Radnorshire; Bala limestone of Coniston Water-head, Lancashire. 


\section{ORTHOCERAS IMBRICATUM ( $(T a h l$.)}

Ref.-His. Leth. Suec. t. 9. f. 9. (siphon too near the edge); Sil. Syst. t. 9. f. 2.

$S_{p}$. Ch.-Section broad-oval, very slowly tapering (from a diameter of one inch three lines tapers one and half lines in two inches); septa slightly oblique, with a shallow sigmoidal curve on the sides, and a shallow rounded wave on the dorsal and ventral aspects, the last ten or twelve septa (at a diameter of about an inch and a quarter) varying from one line to nearly a line and half apart; siphon rather large, about half its diameter from the centre towards the upper side.

In Hisinger's figure the siphon is erroneously represented close to the margin, but our specimen agrees with his description in having it subeentral; the dorsal wave of the septa is more curved in that figure than in our examples.

Pasition and Locality.-In the green Upper Ludlow quartzite of Kirkby Moor, Kendal, Westmoreland.

Orthoceras laqueatum (Hall).
Ref.-Hall, Pal. New York, t. 56. f. 1.

sp. Ch. - Tube slender, tapering at the rate of one line in one inch, from a diameter of five lines, at which size the septa are one line apart, direct, moderately convex; siphon cylindrical, central; surface covered with sharp, rigid, equal, longitudinal, elevated lines, separated by wide concave spaces, about four in the space of one line, with or without one or more fine intermediate strix.

This is easily distinguished from the $O$. filusem or $O$. angulatum, by its more gradually tapering form and much finer lineation. The $O$. subcostatum (Port.) is figured with fewer and more distant ridges, but seems very closely allied.

Pusition and Locality.-Upper Ludlow rock of Firkly Moor, Kendal, Westmoreland; Upper Bala flags of Coldwell, Westmoreland; schists of Dinas Bran, Llangollen, Denbighshire; in flags on road from Coniston to Hawkshead, Lancashire.

\section{Ortioceras LUdense (Sonv.)}

Ref. and Syn.-Sil. Syst. t. 9. f. 1. $?=$ = O distans Sow. Sil. Syst. t. 8. f. 17.

sp. Ch.-Tapering at the rate of one line in one inch, almost uniformly from a diameter of three inches three lines; a specimen of that size at the perfect mouth, and one foot three inches long, is one inch six lines in diameter at the broken smaller end; the straight septa throughout between these diameters having a distance of about seven lines apart; section almost circular; siphon large, very slightly eceentric; surface with a ferw obtuse, obscure, transverse ridges towards the nouth.

The large specimens are very instructive from demonstrating the uniform distance of the septa in a tube varying so greatly in diameter, rendering it probable that the $O$. distans may be the same species, as I have noticed nearly as great an eccentricity of siphon in some specimens of the ordinary character of O. Ludense.

Position and Locality._Conmon in the Lower Ludlow rock of Green Quarry, Leintwardine, Shropshire.

\section{Onthoceras (Actinoceras) Mocktreense (Sov.)}

Ref.-Sow. Sil. Syst. t. 6. f. 11.

Sp. Ch. Elongate, conic, tapering at the rate of one line in one inch from a diameter of one inch four lines, at which size the slightly eccentric siphon is three lines in diameter and spherically inflated between the septa, which with the siphonal constrictions are there three lines apart, and moderately convex; (surface nearly smooth, with irregular transverse lines of growth?).

This species differs from O. Brightii (Sow.), with which it is said (in the Memoirs of the Geol. Survey) that Mr Salter had identified it, by the tube tapering much more slowly, having a considerably smaller siphon, 
the joints of which instead of being cylindrical are globular, and having at the same diameter of the outer shell (one and half inch) three siphonal constrictions in the space occupied by two in the O. Briglti. Both species are usually found with the siphon well preserved, in a mass of calcareous spar, having the form of the outer shell, which with the septa has usually disappeared.

Position and Locality.-Wenlock limestone, Ledbury, Herefordshire.

Orthoceras politum $\left(M^{c}\right.$ Coy). Pl. 1. L. fig. 30 .

Ref.-Id. McCoy, Ann. Nat. Hist. 2nd Series, Vol. VII. p. 46.

Sy. Ch. - Very elongate, conic, regularly tapering at the rate of half a line in one inch from a diameter of seven lines, from which size to five lines the septa have a uniform distance of three lines apart; they are slightly oblique, convex, with even edges; section nearly circular; siphon moderate, eccentric, its own diameter from the centre; surface smooth.

One specimen with a glossy, horn-like external surface, slightly imperfect at each end, measures one inch four lines in diameter at the month, is one foot eight inches long, and measures two lines in diameter at the smaller end, where the septa are slightly oblique, and one and one-third lines apart. Its extremely slow rate of tapering and the regularity of the distant septa, separate it from the $O$. vagans (Salt.)

Position and Locality.-In the impure calcareous concretions (Bala rock) of Glenquaple, Ayrshire.

Explanation of Figures.-Pl. 1. L. fig. 30, portion of posterior end of very large specimen, natural size; $30 a$, end view of a septum shewing form of section and position of siphon.

\section{Orthoceras primervum ( \\ Ref. and Syn. = Creseis primava Forbes, Geol. Journ. Vol. I. p. 146.}

$S p . C h$-Very elongate, slender, apical angle about $6^{\circ}$; a nearly perfect specimen four and half inches long and pressed nearly flat has the chambered portion about two inches nine lines long, tapering to a point from a diameter (in compressed specimens) of three lines at the last septum, from which the last chamber rather abruptly widens to five lines (also compressed); surface smooth; septa very convex, about une line and half apart in the upper half of the chambered portion.

This species when uneompressed is very slender, and does not exhibit the abrupt widening of the last chamber, usually seen where the chambered part has resisted the pressure. It seems to have more distant septa than the figure named by Sowerhy (in Sil. Syst.) O. attenuatum, but of which no description is given, and of which he did not see the specimen, which however is stated to come from shales of the same age as the present fossil. The supposed longitudinal groove in the specimens I have seen, seemed to be only a crush in the last chamber.

Position and Locality.-Common in the black Upper Bala shale at Builth Bridge, Radnorshire; also in Wenlock shale of Cwm Bach, Builth; Upper Bala flags of Dry Ridge, near Horton.

\section{Ortioceras semipartitum (Som.)}

Ref.-Sow. Sil. Syst. t. 3. f. $9 a$.

Sp. Ch. - Regularly conic, tapering at the rate of nearly two lines in one inch from a diameter of two and half lines; septa slightly convex, at the above diameter slightly less than one line apart; siphon nearly central, connected with the outer tube by a thick lateral plate.

I have only seen one very ill-preserved portion of this extraordinary species, the septa of which seem to be figured too near each other in Mr Sowerby"s engraving above quoted. IIe states that the surface is smonth. but I have not been able to see it.

Position and Locality.-Tilestone of Horeb Chapel, Llandovery, S. Wales. 


\section{Orthoceras sub-undulatum (Portk.)}

Ref. and Syn.-Port. id. id. Geol. Rep. t. 28. f. 2 =Creseis Sedgwickii Forbes, Proc. Geol. Soc. p. 146.

$$
\text { f. } 2 \text { (mala). }
$$

$S p . C h$. Shell tapering at the rate of one line in one inch from a diameter of six lines, at which size the shell is girt with oblique, gently and very slightly, waving sharp strie, three in one line, scparated by flat spaces (shewing traces of parallel intervening stric under a strong lens) four or five times the width of the strix; at two inches from the apex the diameter is two and half lines, and there are seareely fumr oblique stria in one line.

'The septa in this species are indistinet and seem to coincide with the strie in direction. The strix sometimes appear elevated, sometimes impressed; but I should think this is owing to the mode of preservation. Some large specimens, varying from one and quarter to two and half iuches in diameter, seem to belong to the same species, having it striation very much of the same aspect, though disposed in irregular slightly oblique waves, varying in each specimen from six to eight in the space of two lines; in these the section is clearly a broad oval with the siphon of moderate size and less than its own diameter from the centre.

Position and Locality.-. () the large examples, Upper Ludlow quartzite of High Thorns, Underbarrow, Kendal, Westmoreland; Upper Tala (Coniston flag) of Helns Knot, Dent; greenish Upper Ludlow schists of Mortimer's Cross, Aymestry, Herefordshire; and green flags (Wenlock shale) of Clungunford, Shropshire.

The smaller and more usual types are from Upper Bala flags of Coldwell, Westmoreland, and olive sehists above the Coldwell flags, near the Castle; in calcareous schists, hill-top, on road from Cuniston to Hawkshead, Lancashire; Lower Ludlow flags of Craig ddu alt, Llangollen, Denhighshire; olive (Wenlock shale) flags of Howgill Fell, near Sedbergh, Kendal, Westmoreland; olive mudstone (Wenlock shale) of Llangynyw Rectory, near Welchpool, Montgomeryshire; Upper Bala flags of $\Lambda$ shı Gill, Westmoreland; black Upper Bala shale of Builth Bridge, Radnorshire; olive Lower Ludlow schists of Leintwardine, Shropshire; Hags of Moel Seisiog, Llanrwst, Denlighshire; mudstone of Lower Ludlow rock, Giarden (quarry, Aymestry, Hereforlshire : Wenlock shale of Wenlock, Shropshire: schists of Wellfekl, Builth; hlack Upper Bala (Coniston flans) (if Dry Ridge, near Horton, Yorkshire.

\section{Orthoceras texuicinctum (Porki.)}

\section{Ref.-Port. id. Geol. Rep. p. 371.t. 27. f. 5. (strie three or four times too far apart).}

$S p . C h$.-Shell very elongate, conic, tapering at the rate of half a line in one inch, from a diameter of ten lines, at which size the septa are five and half lines apart, two and half lines apart at a diameter of five lines, and slightly oblique, parallel with the strix, which are extremely fine (about sixteen in two lines, - or fourteen at a diameter of four lines), subequal, and scarcely their own thickness apart, and with a very gentle sigmoid wave on the sides, and wide dorsal and ventral curves.

This species differs from the O. bacillus (Eichw.) and O. lincaris (Miinst.) by tapering much more slowly and having much fewer strix in a given space. I have not seen the siplon distinetly, but it seems to be nearly central.

Position and Locality.-In the dark limestone of the hill-top on road between Coniston and Hawkshead. Lancashire; common in the Upper Bala flags of Coldwell, Westmoreland; in the Upper Lndlow rnek of Kendal, Westmoreland; schists of Dinas Bran. Llangollen, Denbighshire; Upper Ludlow rock of Woolhope.

\section{Orthoceras tenuistriatuin (Mïnst.) \\ Ref.-Münster, id. Beitr. 3. t. 19. f. 4.}

$S p . C h$. - Tapering at the rate of one line in one inch, from a diameter of five lines, at which size the septa are slightly more than one line apart: surface with close, equal, longitudinal strix, about twelve in one line: section broad-oval. 
The extreme fineness of the longitudinal striation distinguishes this species from the $O$. lineatum of Hisinger or $O$. laqueatum (Hall).

Position and Locality.-Bala sandstone, Mullock Quarry, Dalquorhan, near Girvan, Ayrshire.

\author{
Orthoceras vagans (Salt.) Pl. 1. L. fig. 28 and 29. \\ Ref:-Salter, in Appendix.
}

Sp. Ch.-Tube tapering regularly at the rate of one line in one inch, between the diameters of four and five lines; the septa are slightly oblique, varying irregularly from two to three lines apart (separate fragments seven lines in diameter have them five lines apart, and others one inch one line in diameter have them but two and half lines apart); they are very convex, with a small, nearly central siphon, broad oval section, and an irregular undulation on each side.

This species seems principally remarkable for the irregular relative distances of the septa; the surface has not been seen. It is impossible to characterize it satisfactorily at present; still it does not seem referrible to any described species.

Position and Locality.-Very common in the Upper Bala (Coniston) limestone of Coniston, Lancashire; impure Bala limestone of Llwyn-y-ci, N. W. of Bala, and Rhiwlas, N. of Bala, Merionethshire; calcareous Upper Bala beds of Cwm of the Cymmerig.

Explanation of Figures.-PI. 1. L. fig. 28 and 29, natural size, from the limestone of Coniston; $29 a$, end view, shewing form of section and position of siphon.

\title{
Orthoceras? Ventricosum (Shamp Sp.)
}

Ref. and Syn. =Creseis ventricosus Sharp. Geol. Journ. Vol. II. t. 13. f. 3.

$S p$. Ch.-Conical, regularly tapering at the rate of two lines in one inch; average length about one inch six lines; obscure traces of septa towards the smaller end, and of a thick ridge extending rather more than half way from the mouth towards the apex.

From the appearance of several specimens I think it probable that there were convex rather distant septa near the apex, but I cannot be quite sure of the fact: whether the longitudinal ridge is natural or not, is equally doubtful, the specimens being all much crished in the shales in which they oceur; the form is a little more slender than Count Münster's smaller figure of his $O$. conoidens (Beitr. t. 18. f. 5), to which it is otherwise very similar; and the more slender distinctly septate Orthoceratites carinatus of the same author, t. 19. f. 8, has got a distinct, very similar, longitudinal keel and elliptical seetion, with slightly eccentric siphon, agreeing nearly with one septum accompanying the present fossil in the schists of Bron Einion. If the appearance of septa be deceptive, the species might probably be placed in the genus $T$ heca.

Position and Locality.-Common in the black Upper Bala sehists of Bron Einion Quarry, under Pen y Big; Upper Bala schists; Upper Bala of Saw Mill, E. of Corwen, Merionethshire; Upper Bala schists of Builth Bridge, Radnorshire.

\section{Subgenus. CYCLOCERAS $\left(M^{c}\right.$ Coy). \\ Ref.-Id. Syn. Carb. Foss. Irel. p. 6.}

Gen. Char.-Shell straight, or slightly curved at the tip, tapering; section circular; girt with prominent transverse rings; siphon varying from subcentral to marginal; septa at right angles to the axis of the shell, with even edges; surface often sculptured with scaly laminæ, or decussated.

The external characters of this ringed and often sculptured group is so strongly marked, that it forms a useful, easily recognised subgenus, provisionally, apart from the true Orthoceras. 


\section{Orthoceras (Cycloceras) annulatum (Sow. Sp.) \\ Ref. and Syn. = Orthoceras Id. Sil. Syst. t. 9. f. 5; and Min. Con. t. 133 \\ $=$ ? Orthoceras undulatum His. Leth. Suec. t. 10. f. 2.}

$S p . C h$.-Shell tapering at the rate of three lines in two inches; section broad-oval; siphon large, between the centre and one of the broad sides; rings obtusely angular, prominent, slightly oblique, three in half an inch, at a diameter of nine lines, four in the same space, at a diameter of six lines, two in the same space at a diameter of one incl three lines, four lines apart, at a diameter of two inches; interannular spaces deep, concave, marked with six or seven transverse, imbricating strix, bent downwards into numerous waves, about a line wide, through which sometimes pass indistinct longitudinal ridges from one to two lines apart.

The longitudinal ridges of this species are rarely well marked, they pass throngh the obtuse parts of the undulations of the transverse stria. The siphon seems rather nearer the side than in Sowerby's figure, (Min. Con.), which I have no doult, however, from the striation of the lower part of the right-hand figure, represents an extremely smooth example of the same species.

Position and Locality.-Common in the Woolhope limestone of old Radnor, Radnorshire; Wenlock limestone of Ledbury, Herefordshire; calcareous Bala schists of Dermydd-fawr, under Craigg Bronbanog, Denbighshire; Caradoe shale, Chency Longville, Shropshire; Coniston (Upper Bala) limestone of Coniston, Lancashire.

\section{Onthoceras (Cycloceras) arcuoliratum (Hall Sp.)}

Ref. and Syn.=Orthoceras arcuotiratum Hall, Pal. N. York, t. 42. f. 7 .

Sp. Ch.-Slender, very slowly tapering, apical angle about $10^{\circ}$; section circular, or very broad-oval; siphon central; surface girt with very oblique obtuse rings, separated by concave spaces equalling thum in width, the lowest or posterior point of each ring about two interannular spaces lower on the shell than the most anterior curve or opposite point of the same ring, at the opposite circumference; four rings in the space of five lines in a specimen four lines in diameter; traces of very close, fine, longitudinal stria.

The fragment described is about two inches long, and only differs from the American species in a very slight, probably accidental, compression.

Pasition and Locality.-Rare in the limestone (Bala Group) of Wrae Quarry, Upper Tweed, near Broughton.

\section{Orthoceras (Cycloceras) bilineatum (Hall Sp.)}

Syn. = Orthoceras bilineatum Hall, Pal. N. Y.t. 43. f. 2 and 3.

Gen. Char.-Tube rapidly tapering (at the rate of two lines in two inches), gint with large, slightly oblique, subangular rings touching each other, or separated by re-entering angular spaces, four rings in the space of half an inch, at the diameter of half an inch; surface marked with strong longitudinal strix, thrce or four in the space of one line, usually with one much finer line between each pair, the whole being crossed by microscopic transverse strix; length of fragment, imperfect at each end, four and half inches, diameter at large end eight lines.

This species is readily distinguished from the Cycloceras $16 c x$, by its much more rapidly tapering figure, coarser longitudinal strie, and proportionally much thicker subangular rings, nearly separated by the narrow re-entering angular spaces, formed by the meeting of their sides. The section in our specimen is very broad-oval, agreeing with Hall's figure 3: according to that author the siphon is placed between the centre and the margin; the identity between our specimen and that of the American Trenton limestone is most perfect in all respects.

Position and Locality.-In the green Bala quartzite of Ardwell, S. of Girvan, Ayrshire.

\section{Orthocenas (Cycloceras) IBex (Sow.)}

Ref. and Syn.=Orthoceras Ibex Sow. Sil. Syst. t. 5. f. $31+0$. articulatum Id. id. f. 30 .

Sp.Ch.-Shell long, nearly cylindrical (tapering at the rate of about half a line in three inches at the 
diameter of eight lines), with occasional abrupt diminutions of diameter; girt with prominent, narrow, round, slightly oblique rings, about two-thirds of a line thick and four in the space of half an inch, at a diameter of eight lines, less than five in the same space (and same specimens), with a diameter of four and half lines; inter annular spaces concave; section broad-oval; surface with extremely fine, equal, longitudinal strixe, about ten in one line; septa one between every two rings; siphon a little eccentric.

It is obvious, from the alove description, that the character is not of any value, which led Mr Sowerby to separate his $O$. articulatum from his $O$. Ibex, namely, the relation between the distance of the rings and the diameter of the tube, as our specimens prove that the first does not vary in proportion to the latter. The Iongitudinal striation is so fine that in most specimens it can only be detected by the lens with great difficulty in specimens preserved in sandstones-many specimens appearing smooth exeept perhaps in some small portion; in limestone specimens the striation is distinct. The minute striation of the IIortolus Ibex is transverse as well as that of the 0 . tracheale (Sow. $=O$. perelegans Salt.), which is otherwise almost identical in appearance with this. Towards the small end a ferw transverse strixe appear on each ring decussating the longitudinal ones. Specimens from the Coniston limestune differ in having the longitudinal striation slightly flexuous and of irregular thickness.

Pusition and Lacality.-Common in the Upper Ludlow rock of Benson Knot, and Kirkby Moor, Kendal, Westmoreland; Coniston (Bala) limestone, Coniston, Lancashire.

\section{Orthoceras (Cyclozeras)? subannulatum (Mïnst. Sp.)}

\section{Ref. and Syn。=Orthoceratites subannulatus Id. Beiträge zur Pet.t. 19. f. 3.}

$S p . C h$. -Tube tapering at the rate of two lines in two inches, at the diameter of nine lines; section hroad-oval; siphuncle very slightly eccentric; septa moderately coneave; surface girt with close, obsolete, littleelevated, slightly oblique rings, with a widely-rounded upper and lower curve, three in three lines, at a diameter of seven lines, four in six lines, at the diameter of one and half inches, with parallel, strong, subimbricating strix, four or six in the space of one line, in a diameter varying from four lines to one inch nine lines.

On comparison with authentic specimens of Count Münster's species from his locality of Elbersreuth, I can find no difference, on the most careful comparison between them and our Silurian specimens. I find that his species has the section not circular, but slightly oral as in ours, and the siphon not perfectly central. The species, as he notices, is easily distinguished from the Orthoceras anmulatum of Sowerby by the very much flatter and more approximate rings. The slightly marked approximate rings and much coarser and less numerous parallel strie, and more rapidly tapering figure, distinguish it from the Orthoceras (Cycloceras) perelegans (Salt. $=O$. C. tracheale Sow.)

Position and Locality. - Not uncommon in the Upper Bala fligs of Coldwell, Westnoreland; in the dark flags on the road from Coniston to Hawkshead, Lancashire, in Upper Bala (Coniston flag) at Helms Knot, Dent; Upper Ludlow rock of Brigsteer, Kendal, Westmoreland; black Upper Bala shale, Builth Bridge, Radnorshire.

\section{Orthoceras (Cycloceras) Tenuiannulatum ( $M$ Coy). Pl. 1. L. fig. 31.}

$$
\text { Ref.-Id. M다, Ann. Nat. Hist. 2nd Series, Vol. VII. p. } 46 .
$$

S1. Ch.-Nearly cylindrical (tapering lhalf a line in two inches at a diameter of six lines); rings narrow, sharply-defined, half a line wide, slightly oblique, six in half an inch at the above dimensions; surface with very minute, longitudinal, equal strixe, twelve or fourteen in the space of one line; towards the small end a few circular strix on each ring decussating the longitudinal lines.

This species differs constantly from the $O$. (Cycloceras) Ibex by the narrower and more sharply defined rings, and their considerably greater number in a given space in specimens of the same size; the longitudinal striation is even finer than in that species.

Position and Locality.-In the green Lower Ludlow mudstone of Green Quarry, Leintwardine, Shrop- 
shire, and near Aymestry, Herefordshire; one specimen from the Upper Ludlow rock of Brigsteer, Kendal, Westmoreland.

Explanation of Figures.-Pl. 1. L. fig. 31, natural size; $31 \alpha$, portion of surface magnified to shew the fine longitudinal strix crossing the rings.

\section{Orthoceras (Cyclocercos) tracheale (Sow. Sp.)}

Ref. and Syn. = Orthoceras Sow. id. Sil. Syst. t. 3. f. $9 b=$ Orthoceras perelegans Salt. Mem. Geol. Surv. Vol. II. Part 1.t. 13. f, 2 and 3.

Sp. Ch.-Shell long, nearly cylindrical, with oceasional abrupt diminutions in diameter, girt with obtusely. rounded, slightly oblique rings, one line in diameter, and four in the space of half an inch, with a diameter of four to seven lines; about four rings in a space of three lines, at a diameter of three lines; interannular spaces concave, a little wider than the rings; surface girt with very fine, subequal, rough, transverse strix, alout eleven in the space of one line; septa one between each ring.

This species to the naked eye is scarcely distinguishable from the $O$. (Cycloceras) Ibex, the rings are however thicker and more obtuse, and as about the same number occurs in a given space, they are proportionally closer together than in that species, from which it is perfectly distinguished by the ninute striation being transverse instead of longitudinal. Sowcrby's figure (having the shade on the side which is lightest in the other figure) represents a hollow cast of the exterior, giving the rings a deceptive appearance of being wider than the interspaces.

Position and Locality.-Upper Ludlow rock of Kirkby Moor, Kendal; tilestone, Storm Hill; Upper Ludlow of Benson Knot, Kendal, Westmoreland; near Ludlow? Shropshire; olive schists of Dinas Bran, Llangollen, Denbighshire; flags of the Wenlock shale, Howgill Fell, near Sedbergh, Kendal, Westmoreland.

\section{Subgenus. POTERIOCERAS (M'Coy). 1844.}

Ref. and Syn. = Gomphoceras (Sow. not of Thunberg), = Bolboceras Fisch. (not of Leach), = Apioceras (Fisch.) 1844 .

Gen. Char.-Shell short, fusiform, section circular, mouth contracted; septa simple; siphon subcentral, moniliform.

Fischer's genus has nearly as early a date of publication as mine, but as the latter has been used in many works I continue to use it.

\section{Orthoceras (Poterioceras) ellipticum $\left(M{ }^{c}\right.$ Coy).}

Syn. and Ref.<Orthoceras pyriforme Sow. Sil. Syst. t. 8. f. 19. (lower and not upper figs.) and f. 20. Poterioceras ellipticum $\mathbf{M}^{\mathrm{c}} \mathrm{Coy}, \mathrm{Ann}$. Nat. Hist. 2nd Series, Vol. VII. p. 45.

Spp. Ch-E Elliptical, last chamber conoidal; greatest width at last septum, from whence the chambered and unchambered portions taper elliptically to the contracted mouth and attenuated extremity; septa nearly horizontal, the last three or four about two lines and half apart: greatest width of last chamber (at septum) two inches three lines, length of last chamber two inches four and half lines.

There are clearly two species confounded by Sowerby in the Sil. Syst. under the name Orthoceras pyriforme; the difference in form he supposed to be produced by the direction of pressure, but I find it to be constant in perfectly uncrushed specimens. To that represented by his upper figure I would restriet his specific name pyriforme, its characteristic pear-shaped form being mainly owing to the greatest width being in the middle of the last chamber or midway between the last septum and the mouth, the upper half of the last chamber being abruptly rounded, while the other portion of the shell tapers gradually; while in the other species the greatest width is at about the last one or two septa, from whence the last chamber tapers gradually to the mouth at about the same curve that the chambered portion tapers towards the apex, giving a very different regularly elliptical figure to the present species, which I have named accordingly.

Position and Locality.-Common in the Lower Ludlow rock, near Aymestry, Herefordshire.

[FASC. II.] 


\section{Orthoceras (Poterioceras) Pyriforme (Sow. Sp.)}

Ref. and Syn.< Orthoceras Id. Sow. Sil. Syst. t. 8. f. 19. (upper, but not lower figure).

$S p$. Ch.-Pyriform, greatest width about halfway between the last chamber and the mouth, curving abruptly thence to the contracted mouth, and tapering conically to the extremity of chambered portion; septa with a slight obliquity, the last three or four being about three lines apart; greatest diameter of last chamber two inches nine lines, length of last chamber the same; apical angle about $40^{\circ}$.

See Poterioceras ellipticum, for observations on the allied species.

Position and Locality.-Lower Ludlow rock, near Aymestry, Herefordshire.

\section{Genus. PHRAGMOCERAS (Brod.) $)^{*}$}

Gen. Char.-Shell short, arched, compressed; sides of the mouth lapping towards each other; septa simple, crossed by the sigmoidal lines of growth; siphon on the internal edge, dilate between the septa.

I think it is rery doubtful whether the opening of the shell is naturally contracted as much as usually represented, the form of the lines of growth and the appearance of such mouths as I have seen gives rathel the idea of the edges being very thin and fiexible, yielding easily to compression. M. d'Orbigny (Prodrome) refers this to Campulites of Deshayes, contrary to the express declaration of that author (Lam. Hist. Nat. Anim. S. Vert. 2nd edition, p. 53), who states Campulites on the contrary to be identical with Cyrtoceras (Gold.) + Gyroceras (V. Mey.)

\section{Phragmoceras intermedium $\left(M^{c}\right.$ Coy $)$.}

Ref. and Syn.-Id. McCoy, Ann. Nat. Hist. 2nd Series, Vol. VII. p. 45. < Phragmoceras arcuatum Sow. Sil. Syst. t. 11. f. 1. (not t. 10. f. 1a.)

$S p . C h$.- Slightly arched, tapering at the rate of four lines in one inch; section ovate, sides gently convex, outer and inner faces rounded. A specimen (not quite perfect) two inches five lines long, has the long (anteroposterior) diameter at the large end one inch four lines, at the small end nine lines, short (lateral) diameter at large end ten lines, length of last chamber one inch one line, the last five or six septa one and half lines apart in the middle of the side.

I have not clearly seen the siphon of this species, which is about as thick and slightly arched as the $P$. arcuatum (of which it is figured as a separate variety by Sowerby), but tapers much more slowly, as in the $P$. compressum.

Position and Locality.-Green mudstone (Lower Ludlow) of Green Quarry, Leintwardine, Shropshire.

\section{Phragaoceras ventricosum (Sow.) \\ Ref.--Sow. Sil. Syst. t. 10. f. 4, 5, 6 .}

S. 1 . Ch.-Gently arched, compressed, sides gently convex, most so in the last chamber; septate portion more flattened; antero-posterior diameter at last septum (and of last chamber) about three inches, width at same point one inch six lines; chambered portion tapering at the rate of eight lines in one inch (the length being taken along the middle of the side and the diameter along the septa); length of last chamber three inches, length of septate portion (measured along the convexity of the curve) about six inches; last few septa four lines apart (in middle of side); sigmoidal lines of growth crossing the septa, close, cord-like, about three or four in a quarter of an inch.

The septa lave a slight sigmoid wave on each side; the siphon is indistinct in the specimens before me. The published figures do not indicate sufficiently the flattening of the septate portion.

* This, and the remaining genera or subgenera have been omitted in the list at the end of the article Nautilidae, but Phragmoceras, Hortolus, and Lituites, should be placed near Cyrtoceras, and Trocholites near Clymenia. 
Position and Locality.-Not uncommon in the mudstone and nodules of the Lower Ludlow rock at Garden Quarry, Aymestry, Herefordshire.

\section{Genus. LITUITES (Breyn).}

Gen. Char.-Shell spiral ; last chamber produced, straight; whorls in contact on one plane; septa simple; siphon central; section circular.

Differs from Hortolus only by the whorls of the spire being in contact.

\section{Lituites articulatus (Sow.)}

$$
\text { Ref.-Sil. Syst. t. 11. f. } 5 \text { and } 7 .
$$

Sp. Ch.-Volutions about three, compressed, crossed by numerous ring-like costa, whose distance nearly equals their thickness; diameter of whorled portion one and a quarter inch (Sow.). Straight portion long, six lines in diameter, girt with narrow prominent rings, two and half lines apart, the wide intervening concave spaces being smooth. I have not myself seen the whorled portion, but the slightly curved terminal portion is easily distinguished from the Orthoceras ibex or O. reticulatum, by the wide intervening spaces between the narrow ridges.

Position and Locality.-Not uncommon in the Lower Ludlow rock of Garden Quarry, near Aymestry, Herefordshire; sandy Wenlock shale, near Welchpool, Montgomeryshire.

\section{Lituites CORNUARIETiS (SOW.)}

$$
\text { Ref.-Sow. Sil. Syst. t. 20. f. } 20 .
$$

Sp. Ch.-Discoid, volutions about four, diameter three inches nine lines, diameter of last whorl one inch two lines (compressed specimens); surface covered with numerous narrow ridges, curving outwards and backwards on the sides, about one line apart on the last whorl, about two-thirds of a line apart on the penultimate whorl, with numerous close, minute, scaly, flexuous, intervening strix, having the same general direction; edges of septa nearly even, siphon a little on the inner side of the centre.

The very large specimen which I describe seems to have no straight anterior portion, or if there be a separation of the kind it must be very short and obseured by the crushing: it would incline me strongly (with general resemblance in other respects) to put the species in the genus Trocholites, were it not for the nearly central siphon, which, as well as the rather fewer and more rapidly expanding whorls, distinguishes it from the American Trocholites ammonius of Conrad.

Position and Locality._Coniston (Upper Bala) limestone, Coniston, Lancashire.

\section{Genus. TROCHOLITES (Conrad).}

Gen. Char.-Shell discoid, whorls exposed, in contact; septa simple, or with a slight dorsal lobe; siphon at or near the inner edge.

Differs from Clymenia by wanting the lateral angulation of the septa, but includes several of Münster's species which want that angulation.

\section{Trocholites anguiformis (Salt. Sp.) Pl. 1. L. fig. 26. \\ Syn. and Ref. = Lituites anguiformis (Salt. in Appendix.)}

$S p . C h$. - Whorls about four; sides slightly flattened, each longer than wide; septa with a shallow backward wave on the sides, and a shallow lobe or backward wave on the exterior or periphery, the two intervening, forward, shallow sinuses being obtusely rounded. Diameter three inches four lines, length of mouth $\frac{35}{100}$, width of mouth $\frac{24}{100}$; septa in middle of last whorl two lines apart.

This is easily distinguished from the American T. ammonius and T. planorbiformis (Conrad), by the 
flattening of the sides, and by the antero-posterior diameter of each whorl exceeding its width. I have not seen the surface. The whorls are apparently not quite in contact.

Position and Locality.-Limestone of Mynydd Fron Frys, five miles W. of Chirk, Denbighshire.

Explanation of Figure.-PI. 1. L. fig. 26, natural size, shewing the siphon projecting slightly at the inner margin of the right-hand whorl.

\section{Trocholites planorbiformis (Conrad).}

Ref. and Syn.-Id. id. Conrad, Journ Acad. Nat. \&c. Philadelphia, Vol. VIII. t. 17. f. 1, and Hall, Pal. N. Y. t. 84. f. 3 =Lituites planorbiformis Salt. in Ap. = Nautilus primcevus Salt. Geol. Journ. Vol. I. p. 20.

Sp. Ch.-Whorls four and half, half exposed, in a very deep umbilicus, margins of the umbilicus rounded, but angular in the section at points of junction with the preceding whorl; circumference broadly rounded; septa gently convex; siphuncle large, less than half its diameter from the inner edge; section transversely reniform, indented by the periphery of the preceding whorl; surface marked with very delicate, transverse, interrupted strix (about seventeen in one line), having a broad backward wave in the middle of the periphery crossed by nearly obsolete spiral strix, about three times farther apart than the transverse ones; parallel with the transverse striæ are several broad obsolete waves, from one to nearly two lines wide, and a few stronger similarly curved constrictions, produced by periodic thickening of the lip. Diameter (of small specimen) ten lines, proportional diameter of last whorl $\frac{47}{100}$, width $\frac{65}{100}$, antero-posterior diameter of mouth $\frac{35}{200}$.

Position and Locality.-Rare in the Bala limestone of Cymmerig Brook, Bala.

\section{Genus. HORTOLUS (Montf.)}

Gen. Char.-Shell spiral, last chamber produced, straight; whorls in one plane, disjoined throughout; septa simple; siphon central, or nearly so.

Differs from Lituites in the whorls being disjoined.

\section{Hortolus giganteus (Sow. Sp.)}

Ref. and Syn. = Lituites giganteus Sow. Sil. Syst. t. 11. f. 4 .

Sp. Ch, - Volutions abont one and half, the perfect whorl about four and half inches in diameter; straight portion of last whorl upwards of five inches long; two inches in antero-posterior diameter, and one and half inches in width; section subquadrangular; sides flattened, marked with large rounded ribs (on the last whorl two lines in diameter), slightly arched very obliquely outwards and backwards, separated by concave spaces equalling them in width; the ribs disappear in the middle of both the inner and outer margins, the latter being flattened or slightly concave, crossed by the septa, which are arched nearly at right angles to the axis of the shell; the last two or three being from three to four lines apart; siphon large, a little eccentric towards the outer side.

A young specimen of this fine shell from Builth shews the nearly circular form of the whorl before the production of the straight portion; it is about three inches and half in diameter, the oblique ribs rather more than a line thick, and strongly marked on the first half of the shell which contains the chambers; on the anterior half, which is without septa, they are scarcely indicated; diameter of the mouth (the edge of which is obliquely sigmoidal, corresponding to the direction to the ribs and lines of growth) is in this specimen one and half inches, being the diameter also of adult specimens in the half volution before the straight terminal portion.

Position and Locality.-Common in the Lower Ludlow rock of Leintwardine, Shropshire; and Garden Quarry, Aymestry, Herefordshire; black Upper Bala shale, N. of Builth, Radnorshire.

\section{Hortolus ibex (Sow. Sp.)}

\section{Ref. and Syn。 Lituites Ibex Sow. Sil. Syst. t. 11.f. 6 .}

$S p . C h .-$ Arched, rapidly curved at the smaller end to a semicircular hook, rather less than an inch in 
diameter; diameter of tube at origin of straight portion four lines, width at same point three and half lines; surface marked with thin round ridges, extending obliquely outwards and backwards, increasing in strength and forming a round retral wave on the outer side, nearly twice their thickness apart, about four in three lines at three to four lines in diameter, the intervening concave spaces with three or four faint, minute, imbricating stri : having the same direction; arched end tapering at the rate of three and half lines in one inch.

Position and Locality.-Wenlock limestone, Ledbury, Herefordshire; Upper Ludlow of Underbarrow, and High Thorns, Kendal, Westmoreland.

\section{RESUMÉ OF THE DISTRIBUTION OF THE LOWER PALAOZOIC FOSSILS DESCRIBED IN THE PRECEDING PAGES.}

As much genlogical interest attaches just now to the distribution of the Fossils in the Lower Palrozoic groups of rocks, I have drawn up the following Lists, shewing the geological and gengraphical range of all the species of this age, above described, from the specimens in the Cambridge Museum. The first is a List of all the localities, arranged in alphabetical order, to facilitate reference; and to each locality Professor Sedgwick has added his geological interpretation of the age of the rock, there occurring, from which the specimens were obtained. Ill-health, and press of other occupations, prevented him furnishing me fully with his views on these points in time for the publication of the first fasciculus of this Work (comprising the first 184 pages), in which I therefore thought it desirable to omit the geological position of most of the Lower Palcozoic localities, but the reader can now supply this information from the Alphabetical List. Another use of this first List, and the main one for which it was drawn up, was to enable me to save a great deal of space in the second List, by designating by numbers the corresponding localities in which each fossil species is found-thus in the second, or systematic Fossil-list, 12 always stands for Aymestry, and 13 for Lala, \&c.: and as the numbers in the first List are in numerical order, as well as the corresponding localities in alphabetical order, it is easy by reference to ascertain either the locality denoted by any number, or the number indicating any required locality in the second List.

The second List is a systematic enumeration of all the Lower Palæozoic species described in the foregoing part of this Work. Each species is preceded by a number indicating the page at which it is described; under each specific name the localities from which Professor Sedgwick has obtained examples of the species, are brought together under his stratigraphical groups; and under each geological group all the localities he considers of that age are indicated by numbers, referring to the first, or alphabetic, List of localities.

As it is very important, in the discussions as to the relative ages of the rocks of the various localities, to he able to consult a complete list of all the species from each place by itself, I lave drawn up the third List on this plan, founded, like the others, on the specimens collected by Professor Sedgwick, and capable of being consulted in the University Collection. It takes the localities in alphabetic order, and under the head of each locality is given a complete list of the species occurring there, of which we possess sufficiently good specimens to be clearly identified.

Professor Sedgwick has furnished the geological data of these Lists, and to him belongs the task of explaining the geological bearings of the rocks of all the localities from his field-books and maps; my tasknow completed-having been, carefully to examine the whole of the collections, to determine the various species to the best of my ability, and to register them faithfully, wholly unbiassed by any stratigraphical considerations. 


\section{§ 1. ALPHABETICAL * LIST OF LOWER PAL EOZOIC LOCALITIES, \\ WITH THE AGE OF THE ROCK, AND THE NUMBERS BY WHICH THEY ARE REPRESENTED IN THE FOLLOWING LIST OF FOSSILS.}

\begin{tabular}{|c|c|c|}
\hline $\begin{array}{c}\text { Numbers by which } \\
\text { the localities are } \\
\text { indicated in list } \\
\text { of fossils. }\end{array}$ & Alphabetical List of Lower Palæozoic Localities. & Rock. \\
\hline 1 & Aber Hirnant, E. of Bala, N. Wales. & Upper Bala. \\
\hline 2 & Acton Scott, Church Stretton, Shropshire. & Caradoc sandstone. \\
\hline 3 & Aldens, on the Stincher, Ayrshire. & Lower Bala. \\
\hline 4 & Allt-ffair ffynnon, Llanfyllin, N. Wales. & Upper Bala. \\
\hline 5 & Allt Goch, Llanfyllin, Montgomeryshire. & Upper Bala. \\
\hline 6 & Allt tre Ffynnon, Parish of Llanrhayder. & Upper Bala. \\
\hline 7 & Allt yr Anker, Meifod, Montgomeryshire. & Upper Bala. \\
\hline 8 & Allt y Gader, near Llanfyllin, Montgomeryshire. & Upper Bala. \\
\hline 9 & Applethwaite Common, Westmoreland. & Upper Bala (Coniston limestone.) \\
\hline 10 & Ardwell, S. of Girvan, Ayrshire. & Bala Group. \\
\hline 11 & Ash Gill, Westmoreland. & Upper Bala. \\
\hline 12 & Aymestry, Herefordshire. & Aymestry limestone. \\
\hline 13 & Bala, Merionethshire (see Gelli Grin). & Upper Bala. \\
\hline 14 & Ballintrae, Ayrshire. & Bala Group. \\
\hline 15 & Balmae Shore, Kirkcudbright. & Bala or Wenlock Group. \\
\hline 16 & Beaver's Grove, Bettws-y-Coed, N. Wales. & Bala Group. \\
\hline 17 & Beckfoot, Kirkby Lonsdale, W Vestmoreland. & Upper Ludlow. \\
\hline 18 & Benson Knot, Kendal, Westmoreland. & Upper Ludlow. \\
\hline 19 & Bettws-y-Coed, Denbighshire. (See Beaver's Grove). & Bala Group. \\
\hline $19 a$ & Blain y Cwm, IV. of Nantyr, Glyn Ceiriog, Denbighshire. & Upper Bala. \\
\hline 20 & Bodean, Caernarvonshire. & Upper Bala. \\
\hline 21 & Braes, one and a half mile E. of Girvan. & Bala Group. \\
\hline 22 & Brathay, Lancashire. & Upper Bala (Coniston flag). \\
\hline 23 & Brigsteer, Kendal, Westmoreland. & Upper Ludlow. \\
\hline 24 & Bron Einion Quarry, under Pen y Big. & Upper Bala. \\
\hline 25 & Brynbedwog Quarry, near Bala. & Upper Bala. \\
\hline 26 & Bryn Eithin, Penmachno, N. WVales. & Upper Bala. \\
\hline 27 & Bryn Evan, Yspatty, N. Wales. & Upper Bala. \\
\hline 28 & Bryn Melyn, near Bala, Merionethshire. & Upper Bala. \\
\hline 29 & Bugon, Knockdollian, Ayrshire. & Bala Group. \\
\hline 30 & Builth, (3 miles N. of) Radnorshire. & Upper Bala. \\
\hline 31 & Burton and Brockton. & Upper Ludlow. \\
\hline 32 & Bwlch Llandrillo, Corwen, N. Wales. & Upper Bala. \\
\hline 33 & Bwlch y Cibau, N. of Meifod. & Upper Bala. \\
\hline 34 & Bwlch y Groes, S. of Bala, Merionethshire. & Upper Bala. \\
\hline 35 & Cader Dinmael, near Corwen, Denbighshire. & Upper Bala. \\
\hline 36 & Cairn Ryan, Ayrshire. & Lower Bala? \\
\hline 37 & Capel Currig, Snowdon, N. Wales. & Lower Bala. \\
\hline 38 & Capel Garmon, Denbighshire. & Upper Bala. \\
\hline 39 & Carn Goran, Cornwall. & Upper Bala. \\
\hline 40 & Castell Craig Gwyddon, Llandovery, S. Wales. & Upper Bala. \\
\hline 41 & Castle Grogan, N. of Pwllheli, S. Caernarvonshire. & Lower Bala. \\
\hline
\end{tabular}

* A few trifling irregularities in the alphabetic order of the names were observed in this List at too late a period to bo changed. Just as this sheet was going to press, Mr Salter very kindly forwarded a copy of this List corrected for the Welch orthography, \&c. from the great maps of the Surrey. 


\begin{tabular}{|c|c|c|}
\hline $\begin{array}{l}\text { Numbers by which } \\
\text { the localities are } \\
\text { indicated in list } \\
\text { of fossils. }\end{array}$ & Alphabetical List of Lower Palæozoic Localities. & Rock. \\
\hline $\begin{array}{l}42 \\
43 \\
44 \\
45 \\
46 \\
46 a \\
47 \\
48 \\
49 \\
50 \\
51 \\
52 \\
53 \\
54 \\
55 \\
56 \\
57 \\
58 \\
59 \\
60 \\
61 \\
62 \\
63 \\
64 \\
65 \\
66 \\
67 \\
68 \\
69 \\
70 \\
71 \\
72 \\
73 \\
74 \\
75 \\
76 \\
77 \\
78 \\
79 \\
80 \\
81 \\
82 \\
83 \\
84 \\
85 \\
86 \\
87\end{array}$ & $\begin{array}{l}\text { Cautley Craggs, above Sedbergh. } \\
\text { Cefn Coedog, Corwen, Merionethshire. } \\
\text { Cefn y Coed, Llangedwyn, Montgomeryshire. } \\
\text { Cefn ddu, Denbighshire. } \\
\text { Cefn Goch, Glyn Ceiriog, Denbighshire. } \\
\text { Cefn Grugos, W. of Llanfyllin, Montgomeryshire. } \\
\text { Cefn Hir Fynydd, near Llangynog. } \\
\text { Cefn Rhyddan, Llandovery, S. Wales. } \\
\text { Cerrig y Druidion, Denbighshire. } \\
\text { Cerrig Cregyn, Anglesea. } \\
\text { Ceiriog Waterfall, S. of Llangollen, N. Wales. } \\
\text { Cheney Longville, Shropshire. } \\
\text { Church Stretton, Shropshire. } \\
\text { Cyrn-y-brain, Wrexham, Denbighshire. } \\
\text { Clungunford, Shropshire. } \\
\text { Coed Sion, Llangadoc, S. Wales. } \\
\text { Coed y Bedw, Bala. } \\
\text { Coldwell, Westmoreland. } \\
\text { Collinfield, Kendal. } \\
\text { Colmonel, on the Stincher, Ayrshire. } \\
\text { Carnedd fawr (S. of) Bala, N. Wales. } \\
\text { Coniston Water-head, Lancashire. } \\
\text { Conway Falls (Hills, N. of). } \\
\text { Corwen, Merionethshire. } \\
\text { Cowan Head, Kendal, Westmoreland. } \\
\text { Cowny River, Montgomeryshire. } \\
\text { Craig ddu Allt, Llangollen. } \\
\text { Craig Head, near Girvan, Ayrshire. } \\
\text { Craig Wen, N. of Llanfair, Montgomeryshire. } \\
\text { Craig-y-beri, Llanarmonfach, Montgomeryshire. } \\
\text { Craig y Glyn, N. of Rhaidr, n Llanarmonfach. } \\
\text { Cricor Mawr, S. E. of Llanelidan, Denbighshire. } \\
\text { Cwm bach, Builth. } \\
\text { Cwmlanerch, Bettws (S. of) Caernarvonshire. } \\
\text { Cwm Craig Ddu, Builth, Brecknockshire. } \\
\text { Cwm of the Cymmerig, E. of Bala, Merionethshire. } \\
\text { Cwm yr Aethren, above Llanrhaidr. } \\
\text { Cymmerig, E. of Bala, Merionethshire. } \\
\text { Dee (S. of) Llangollen. } \\
\text { Das Eithin ridge, Hirnant, Montgomeryshire. } \\
\text { Derby Arms, Westmoreland, near Kendal. } \\
\text { Dermydd Fawr, under Craig Bronbanog, Denbighshire. } \\
\text { Derwen, Denbighshire. } \\
\text { Dinas Bran, Llangollen, Denbighshire. } \\
\text { Dinas Mowddwy, Merionethshire. } \\
\text { Docker Park, Kendal. } \\
\text { Dol Fan, Rhayader, S. Wales. }\end{array}$ & $\begin{array}{l}\text { Caradoc sandstone \& Upper Bala. } \\
\text { Upper Bala. } \\
\text { Upper Bala. } \\
\text { Wenlock shale. } \\
\text { Upper Bala. } \\
\text { Bala Group. } \\
\text { Bala Group. } \\
\text { Upper Bala. } \\
\text { Lower Bala. } \\
\text { Upper Bala. } \\
\text { Bala Group. } \\
\text { Caradoc shale. } \\
\text { Caradoc sandstone. } \\
\text { Upper Bala. } \\
\text { Wenlock shale. } \\
\text { Upper Bala. } \\
\text { Upper Bala. } \\
\text { Upper Bala. } \\
\text { Upper Ludlow. } \\
\text { Bala Group. } \\
\text { Upper Bala. } \\
\text { Upper Bala. } \\
\text { Upper Bala. } \\
\text { Upper Bala. } \\
\text { Upper Ludlow. } \\
\text { Bala Group. } \\
\text { Lower Ludlow. } \\
\text { Upper Bala. } \\
\text { Upper Bala. } \\
\text { Upper Bala. } \\
\text { Upper Bala. } \\
\text { Upper Bala. } \\
\text { Wenlock shale. } \\
\text { Upper Bala. } \\
\text { Ludlow Group. } \\
\text { Upper Bala. } \\
\text { Upper Bala. } \\
\text { Upper Bala. } \\
\text { Wenlock shale. } \\
\text { Upper Bala. } \\
\text { Upper Ludlow. } \\
\text { Bala Group } \\
\text { Wenlock shale. } \\
\text { Lower Ludlow and Wenlock shale. } \\
\text { Upper Bala. } \\
\text { Upper Ludlow. } \\
\text { Upper Bala. } \\
\text { Uta }\end{array}$ \\
\hline
\end{tabular}




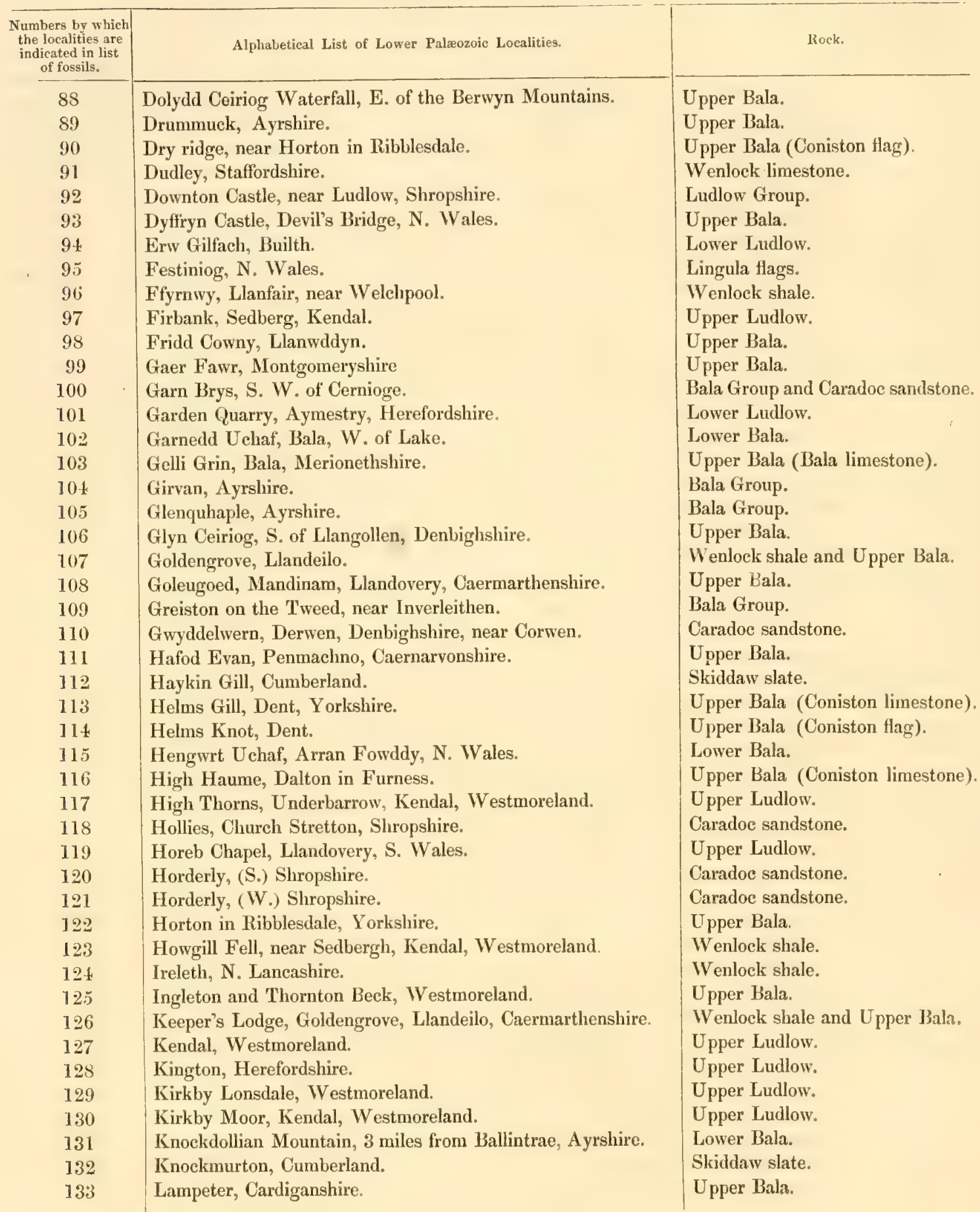




\begin{tabular}{|c|c|c|}
\hline $\begin{array}{c}\text { Numbers by which } \\
\text { the localities are } \\
\text { indicated in list } \\
\text { of fossils. }\end{array}$ & Alphabetical List of Lower Palæozoic Localities. & Rock. \\
\hline 134 & Laverock Lane, Westmoreland. & Upper Ludlow. \\
\hline 135 & Ledbury, Herefordshire. & Wenlock limestone. \\
\hline 136 & Leintwardine, Shropshire. & Lower Ludlow. \\
\hline 137 & Lightbeck, Underbarrow. & Upper Ludlow. \\
\hline 138 & Littlehope. & Woolhope limestone. \\
\hline 139 & Lambrigg Fell, Kendal, Westmoreland. & Upper Ludlow. \\
\hline 140 & Llanbedrog, S. Caernarvonshire. & Bala Group. \\
\hline 141 & Llandeilo, Caermarthenshire. & Upper Bala. \\
\hline 142 & Llandrillo, N. Wales (see Bwlch). & Bala Group. \\
\hline 143 & Llandiman on the Severn, Montgomeryshire. & Upper Bala. \\
\hline 144 & Llandovery Quarry, S. Wales, behind Half-way house. & Upper Bala. \\
\hline 145 & Llanfair Road, W. of Welchpool. & Wenlock shale. \\
\hline 146 & Llanfechan (W. of ), Montgomeryshire. & Upper Bala. \\
\hline 147 & Lanfwrog, near Ruthin. & Lower Ludlow, or Wenlock shale. \\
\hline 148 & Llanfyllin, Montgomeryshire. & Upper Bala. \\
\hline 149 & Llangedwyn, Montgomeryshire. & Upper Bala. \\
\hline 150 & Llangollen, Denbighshire. & Lower Ludlow and Wenlock shale. \\
\hline 151 & Llangynyw Rectory, near Welchpool, Montgomeryshire. & Wenlock shale. \\
\hline 152 & Llanrwst, Denbighshire. & Caradoc Group. \\
\hline 153 & Llansantfraid Glyn Ceiriog. & Upper Bala. \\
\hline 154 & Llanwddyn in the (E. of) Berwyn Mountains. & Upper Bala. \\
\hline 155 & Llechclawdd, near Llandovery, S. Wales. & Upper Ludlow. \\
\hline 156 & Llechwedd Llwyd, near Llanfyllin, Montgomeryshire. & Uppex Bala. \\
\hline 157 & Llyn Alwen, Denbighshire. & Wenlock shale. \\
\hline 158 & Llyn Ogwen, N. Wales. & Bala Group. \\
\hline 159 & Llyn 'Trillyn, Denbighshire. & Wenlock shale. \\
\hline 160 & Llwyn-y-ci, N. W. of Bala. & Upper Bala (Bala limestone). \\
\hline 161 & Lockerby, Dumfriesshire. & Lower Bala. \\
\hline 162 & Long Sleddale, Westmoreland. & Upper Bala and Wenlock shale. \\
\hline 163 & Ludlow, Shropshire. & Upper Ludlow. \\
\hline 164 & Maerdy Bach, one mile S. of Llandeilo. & Upper Bala. \\
\hline 165 & Maen Goran, Llangollen, Denbighshire. & Wenlock shale. \\
\hline 166 & Maes Hir, N. E. of Aber Hirnant, N. Wales. & Upper Bala. \\
\hline 167 & Maes Meillion, S. of Bala, N. Wales. & Upper Bala (Bala limestone). \\
\hline 168 & Maes y fallen, Bala. & Upper Bala. \\
\hline 169 & Malverns, Worcestershire. & Lower Ludlow or Wenlock shale. \\
\hline 170 & Mandinam, Caermarthenshire. & Upper Bala. \\
\hline 171 & Mathyrafal, S. of Meifod, Montgomeryshire. & Upper Bala. \\
\hline 172 & May Hill, Gloucestershire. & Wenlock grits and Caradoc sandst. \\
\hline 173 & Middleton Park, Caermarthenshire. & Wenlock shale. \\
\hline 174 & Milltir Cerrig, Llangynnog, Montgomeryshire. & Lower Bala. \\
\hline 175 & Moel Ferna, S. of Corwen, N. Wales. & Upper Bala. \\
\hline 176 & Moel Hebog, Caernarvonshire. & Bala Group. \\
\hline 177 & Moel Seisiog, Llanrwst, Denbighshire. & Caradoc sandstone. \\
\hline 178 & Moel Uchlas, Montgomeryshire. & Upper Bala. \\
\hline 179 & Moel y Garth, Welchpool, Montgomeryshire. & Upper Bala. \\
\hline [FASO & & $U_{U}$ \\
\hline
\end{tabular}




\begin{tabular}{|c|c|c|}
\hline $\begin{array}{c}\text { Numbers by which } \\
\text { the localities are } \\
\text { indicated in list } \\
\text { of fossils. }\end{array}$ & Alphabetical List of Lower Palrozoic Localities. & Rock. \\
\hline 180 & Moel y Garnedd Uchaf, Bala Lake. & Lower Bala. \\
\hline 181 & Mortimer's Cross, Aymestry, Herefordshire. & Upper Ludlow. \\
\hline 182 & Mullock Quarry, Dalquhorran, near Girvan, Ayrshire. & Upper Bala. \\
\hline 183 & Mynydd Mawr, Caermarthenshire. & Upper Bala. \\
\hline 184 & Mynydd Fron Frys, five miles W. of Chirk, Denbighshire. & Upper Bala. \\
\hline 185 & Mynydd-y-Gaer, Llanefydd, near Ruthin, Denbighshire. & Lower Ludlow. \\
\hline 186 & Nant Gwrhwyd Uchaf, S. of Llangollen. & Wenlock shale. \\
\hline 187 & Nant Morfydd, N. of Llangollen. & Wenlock shale. \\
\hline 188 & Nant-y-arian, Llandeilo. & Upper Bala. \\
\hline 189 & Nant y cwm, near Llangynog. & Upper Bala. \\
\hline 190 & Nant y Brain, IV. of Wrexham. & Upper Bala. \\
\hline 191 & Nant y Groes, S. of Bala, N. Wales. & Upper Bala. \\
\hline 192 & Nantyr, in Glyn Ceiriog, S. of Llangollen. & Upper Bala. \\
\hline 193 & Old Radnor, Radnorshire. & Woolhope limestone. \\
\hline 194 & Parklane, Llandeilo, Caermarthenshire. & Ludlow Group. \\
\hline 195 & Peebles, (S. IV.of). & Bala Group. \\
\hline 196 & Penmachno, Caernarvonshire. & Upper Bala. \\
\hline 197 & Pen Cerrig, Builth, Radnorshire. & Upper Bala. \\
\hline 198 & Peniarth Meifod, Montgomeryshire. & Upper Bala. \\
\hline 199 & Penlan Llandovery, S. WVales. & Upper Bala. \\
\hline 200 & Penllys, N. W. of Meifod, two miles $\mathrm{E}$. of Llanfihangel. & Bala Group. \\
\hline 201 & Penmorfa, Tremadoc, N. Wales. & Lingula flags. \\
\hline 202 & Penny Bridge (hills W. of) N. Lancashire. & Lower Ludlow. \\
\hline 203 & Pentre cwm dda, S. of Glyn Diffivys, N. Wales. & Upper Bala. \\
\hline 204 & Pen y Big, (see Bron Einion.) & \\
\hline 205 & Pen y Craig, Llangynyw, Montgomeryshire. & Upper Bala. \\
\hline 206 & Pen y $G \log (N$. W. of ), W. of Llanfyllin. & Upper Bala. \\
\hline 207 & Pen y Park, Elanfyllin. & Upper Bala. \\
\hline 208 & Pen y Gaer, Cerrig y Druidion, Denbighshire. & Lower Bala. \\
\hline 209 & Plas Madoc, N. of Clanrwst. & Caradoc sandstone. \\
\hline 210 & Pont-ar-y-llechau, near Llangadoc. & Upper Ludlow. \\
\hline 211 & Pont-y-Glyn Diffivys, W. of Corwen, Merionethshire. & Upper Bala. \\
\hline 212 & Pont-y-Meibion, two miles S. of Llansantfraid, on the Ceiriog. & Lower Bala. \\
\hline 213 & Porth Breiddin, below Welchpool. & Wenlock shale. \\
\hline 214 & Potter's Fell, Kendal, Westmoreland. & Upper Ludlow. \\
\hline 215 & Presteign, Radnorshire. & Lower Ludlow. \\
\hline 216 & Pump Saint, near Llampeter, Cardiganshire. & Upper Bala. \\
\hline 217 & Pwllheli, Caernarvonshire. & Upper Bala. \\
\hline 218 & Ravenstone Dale, Westmoreland. & Upper Bala (Coniston limestone). \\
\hline 219 & Rhiwargor, near Llanwddyn, Montgomeryshire. & Upper Bala. \\
\hline 220 & Rhiwlas, N. of Bala, Merionethshire. & Upper Bala. \\
\hline 221 & Rhosfawr, N. of Glog, Llanfyllin, N. Wales. & Upper Bala. \\
\hline 222 & Rother Bridge (above). & Upper Bala (Coniston limestone). \\
\hline 223 & Rother Bridge (below). & Upper Bala (Coniston flags). \\
\hline 224 & Rother Heath, Kendal, Westmoreland. & Upper Bala. \\
\hline 225 & Saint Helens, Low Furness. & Upper Bala (Bala limestone). \\
\hline 226 & Scawgill, Cumberland. & the \\
\hline
\end{tabular}


DISTRIBUTION OF THE LOWER PALAOZOIC FOSSILS.

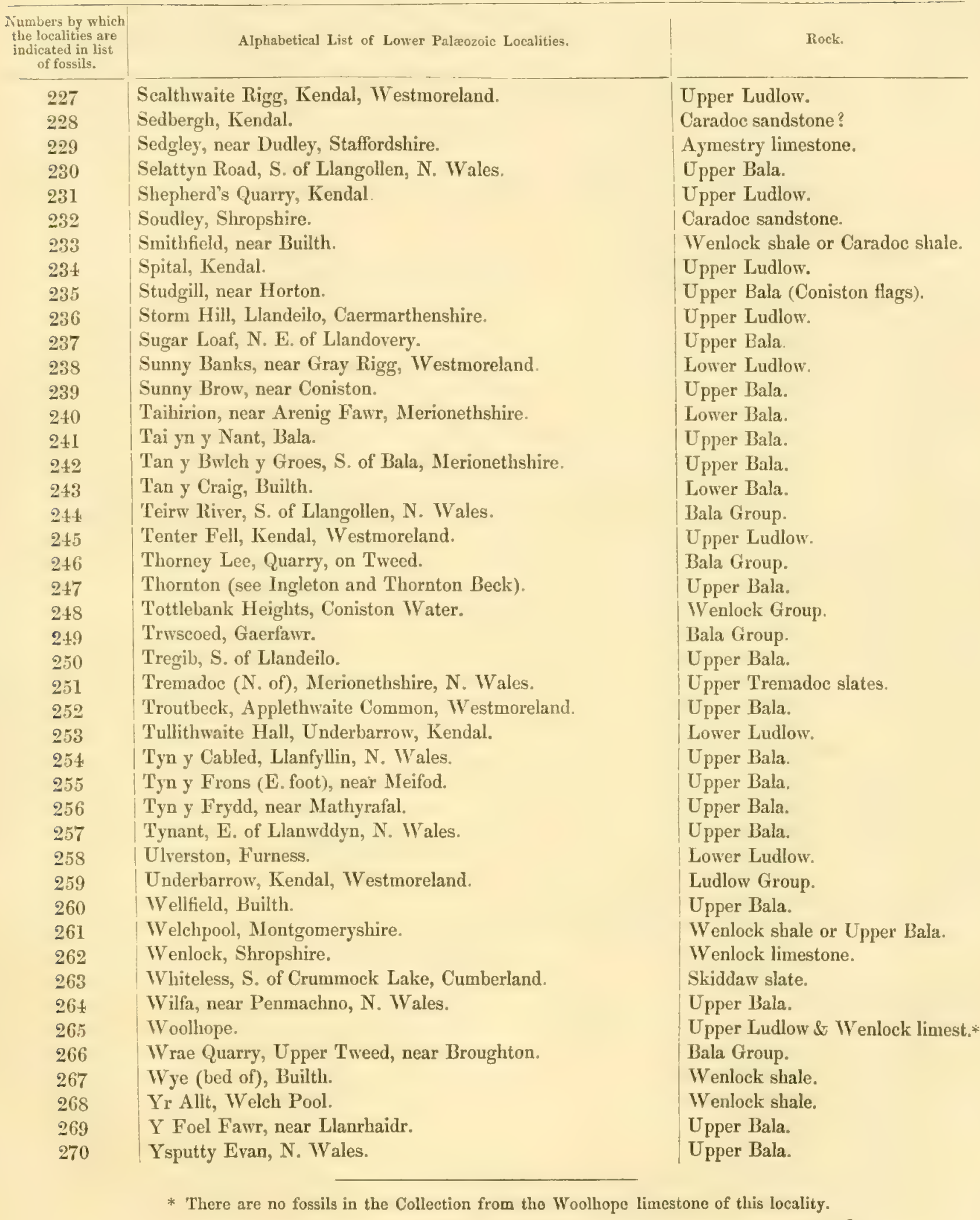




\section{§ 2. SYSTEMATIC LIST OF LOWER PALEOZOIC FOSSILS.}

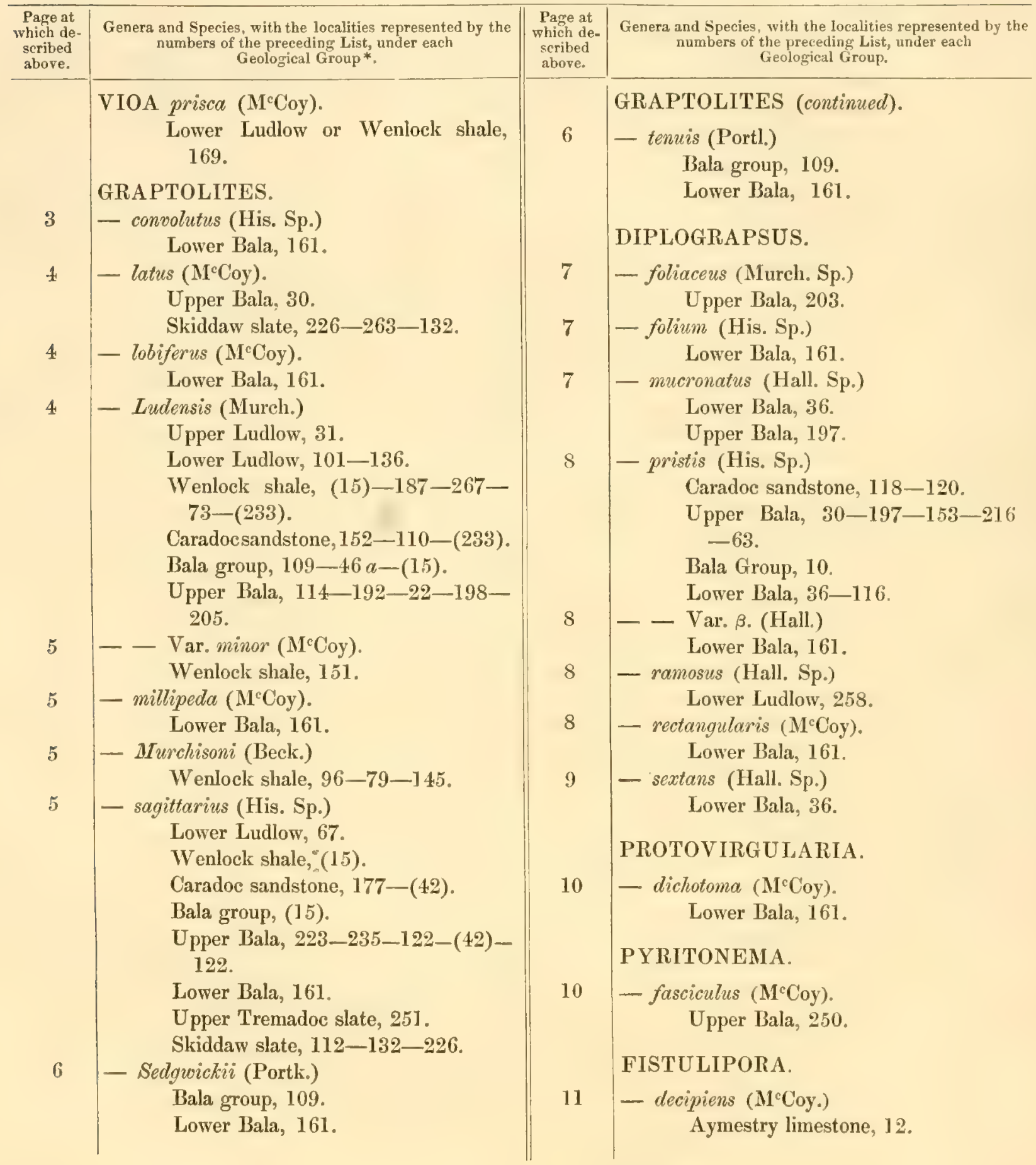

* When two rocks occur at any locality, or the age is doubtful, the corresponding number is repeated, between lreckets. under each of the Geological Groups to which it might probably be referred. 


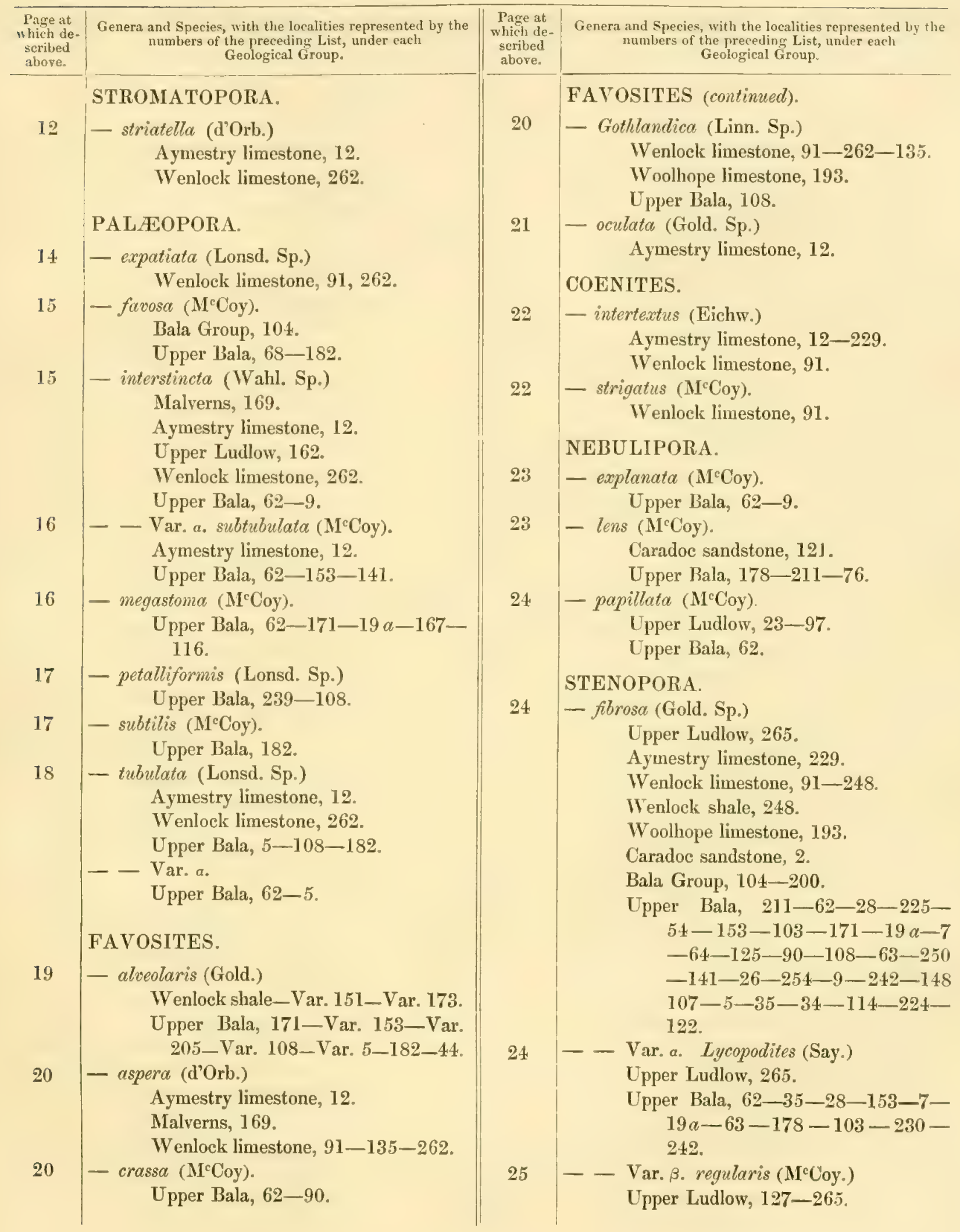




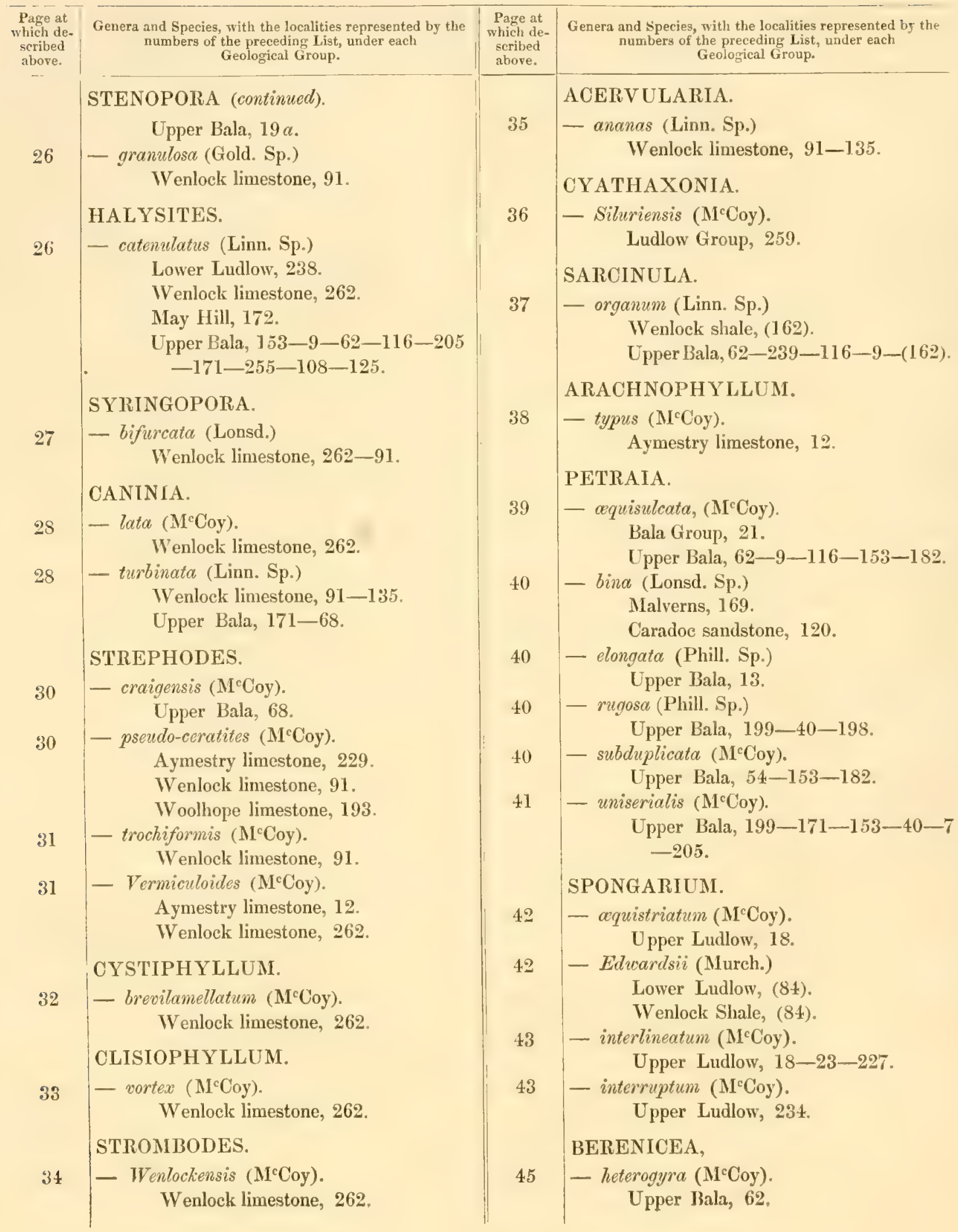




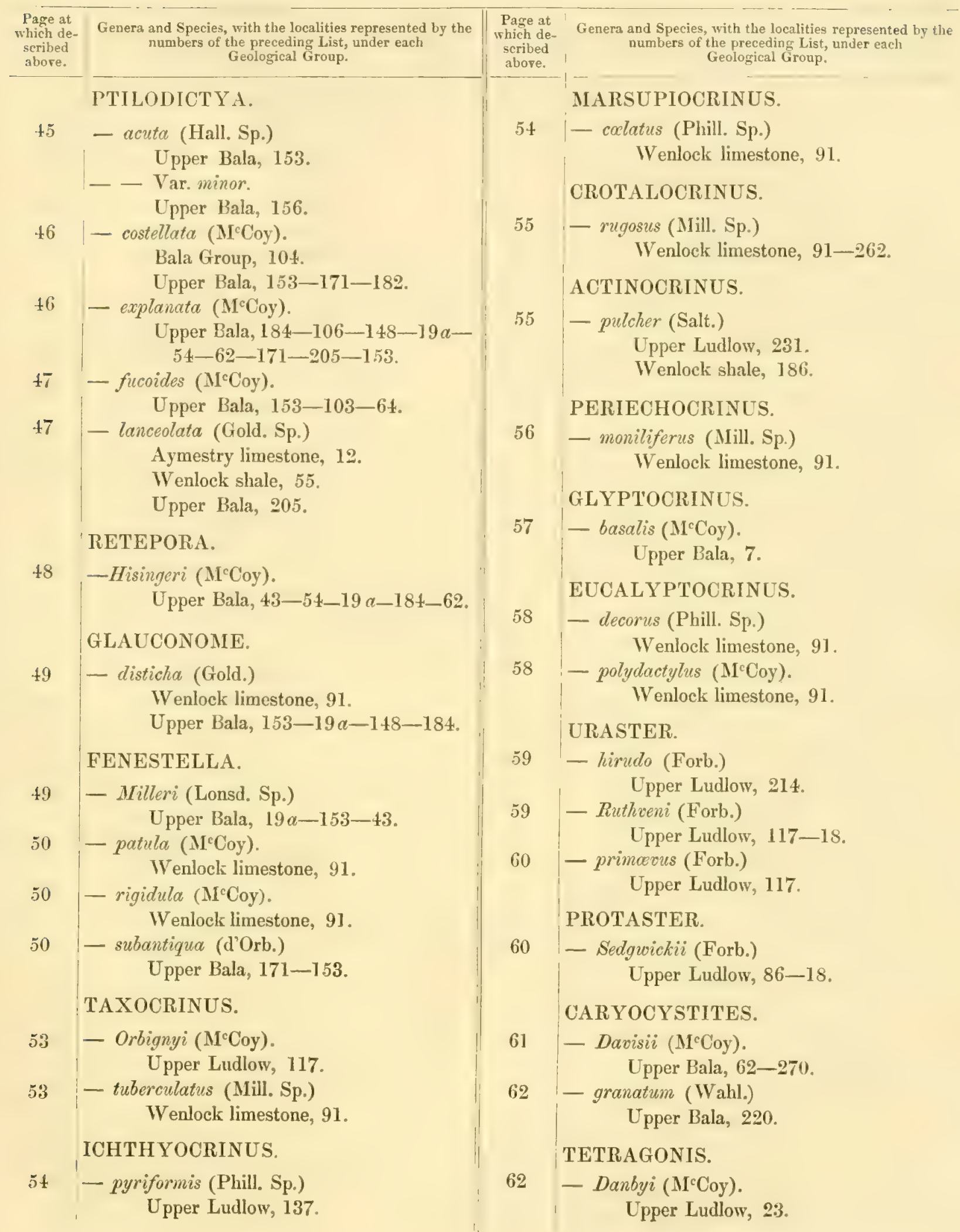




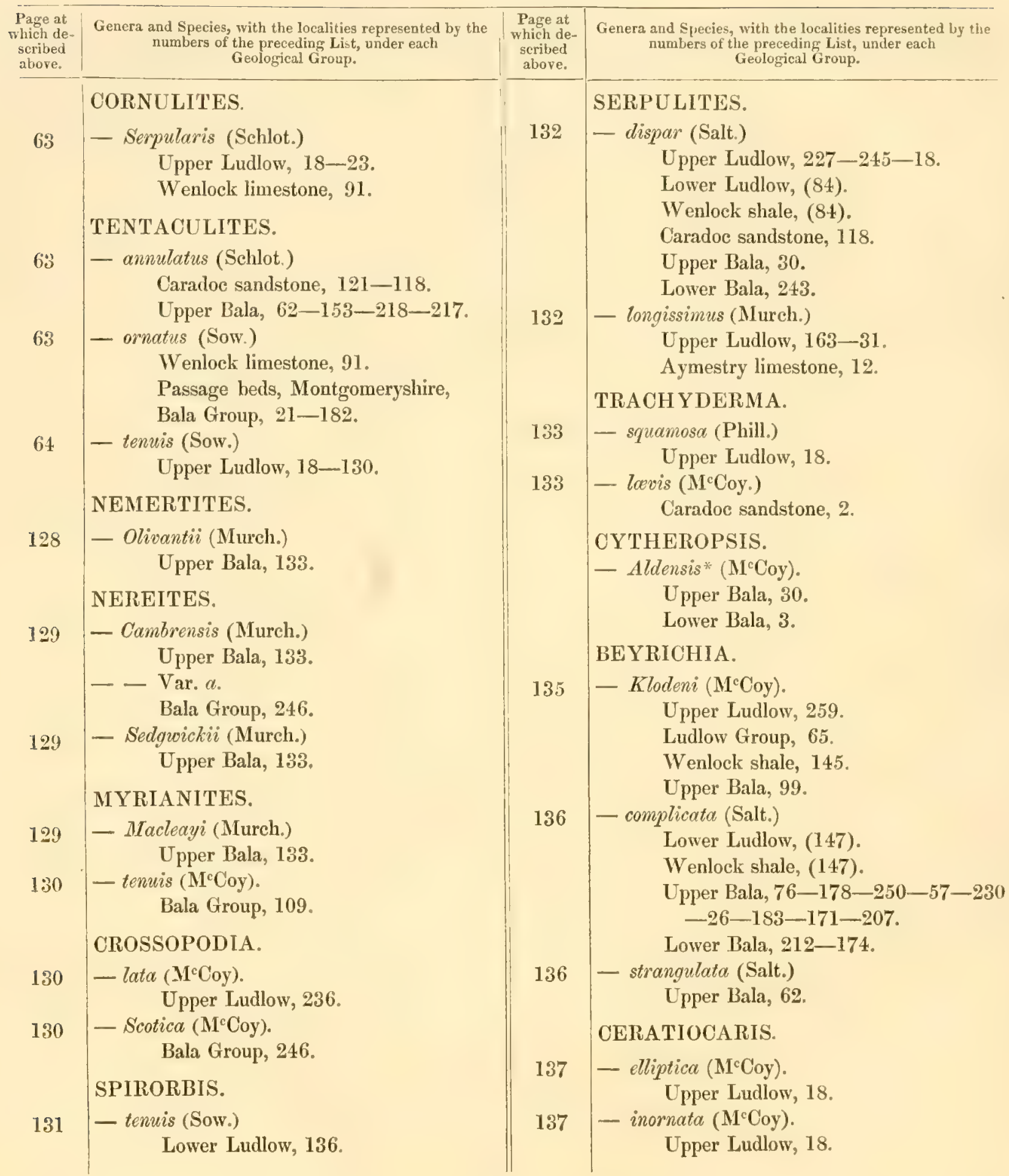

* This fossil was obtained, with several others, after the part on Crustacea was published, but if time should permit, an account of the additions to the Collection will be given in an Appendix. The IIarpes parvulus is figured on PI. 1. L. fig. 3, the Cytheropsis Aldensis is figured Pl. 1. L. fig. 2. 


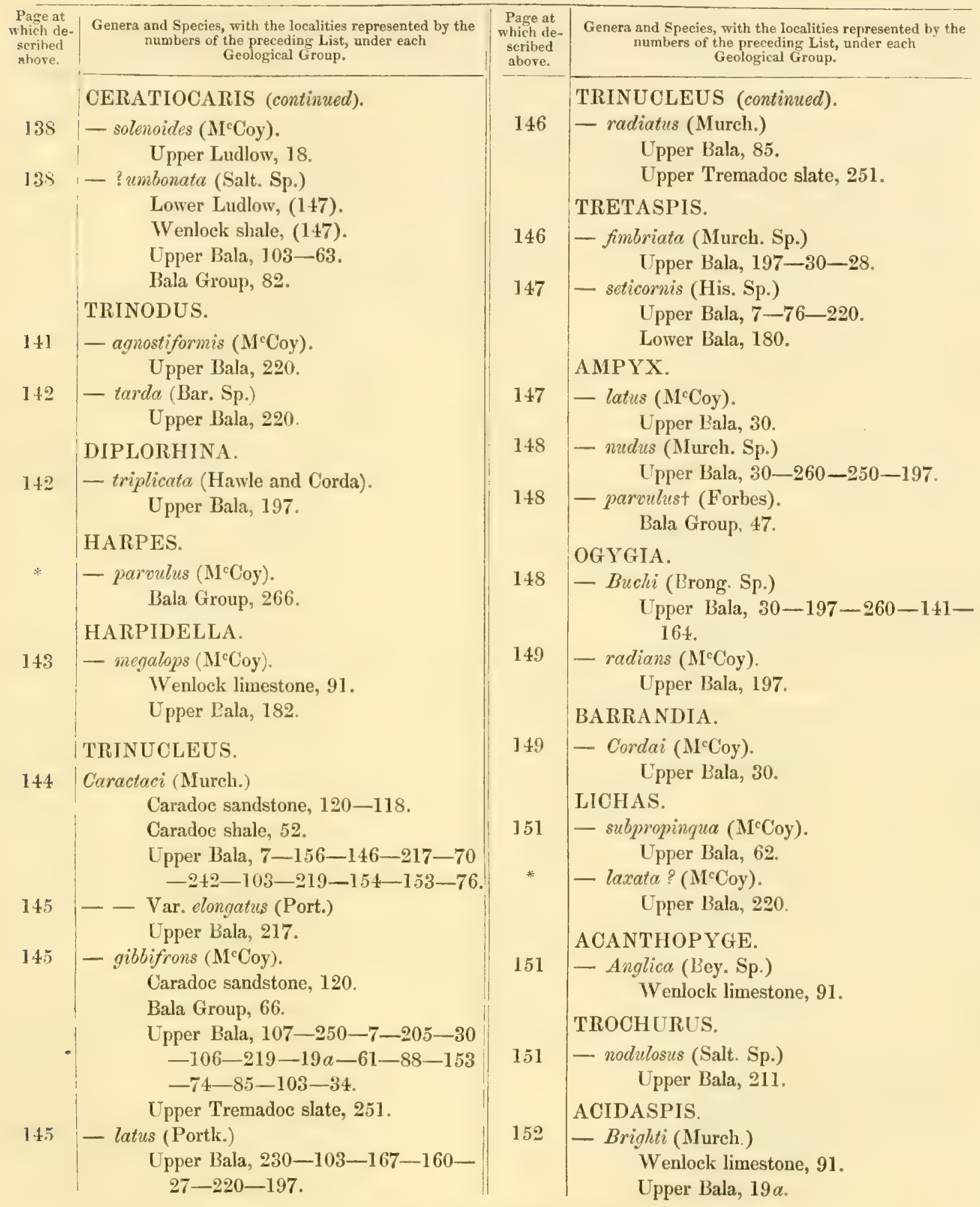

* See note at foot of page 336 . [FASC, II.]
+ Not described owing to tho imperfection of the specimen. $\mathrm{X} x$ 


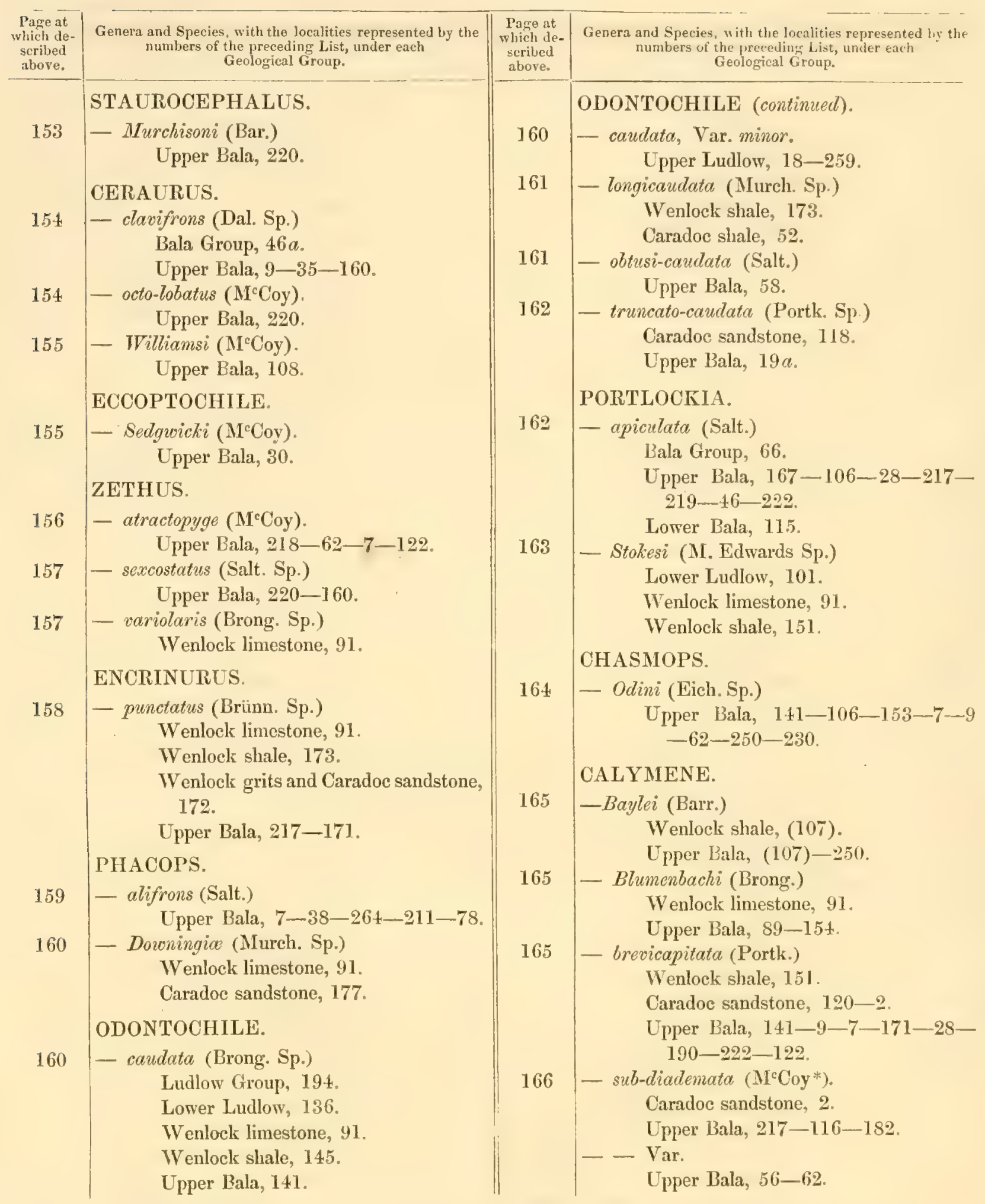

* A specimen, quoted from Leintwardine in the text, is found to be from Acton Scott. 


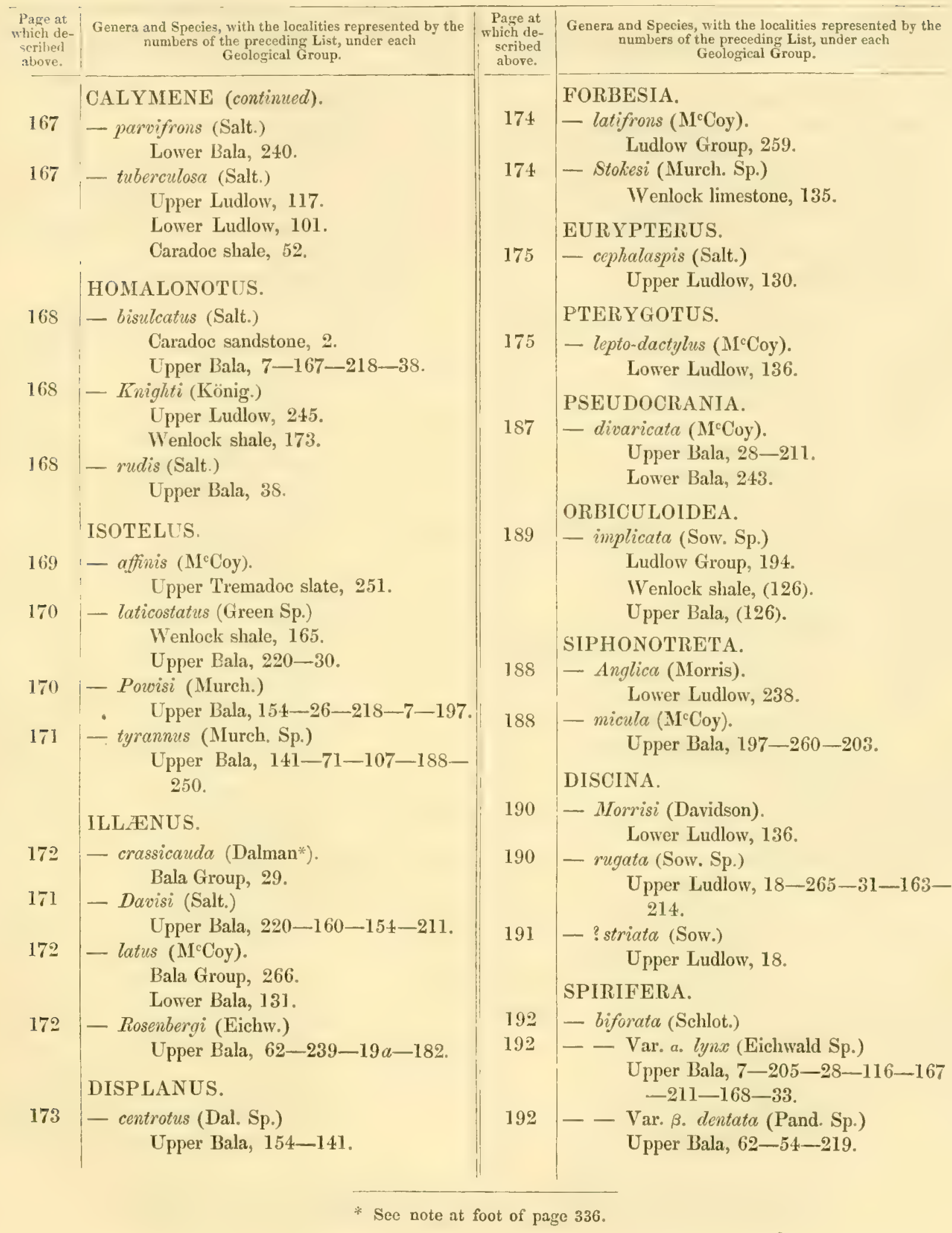




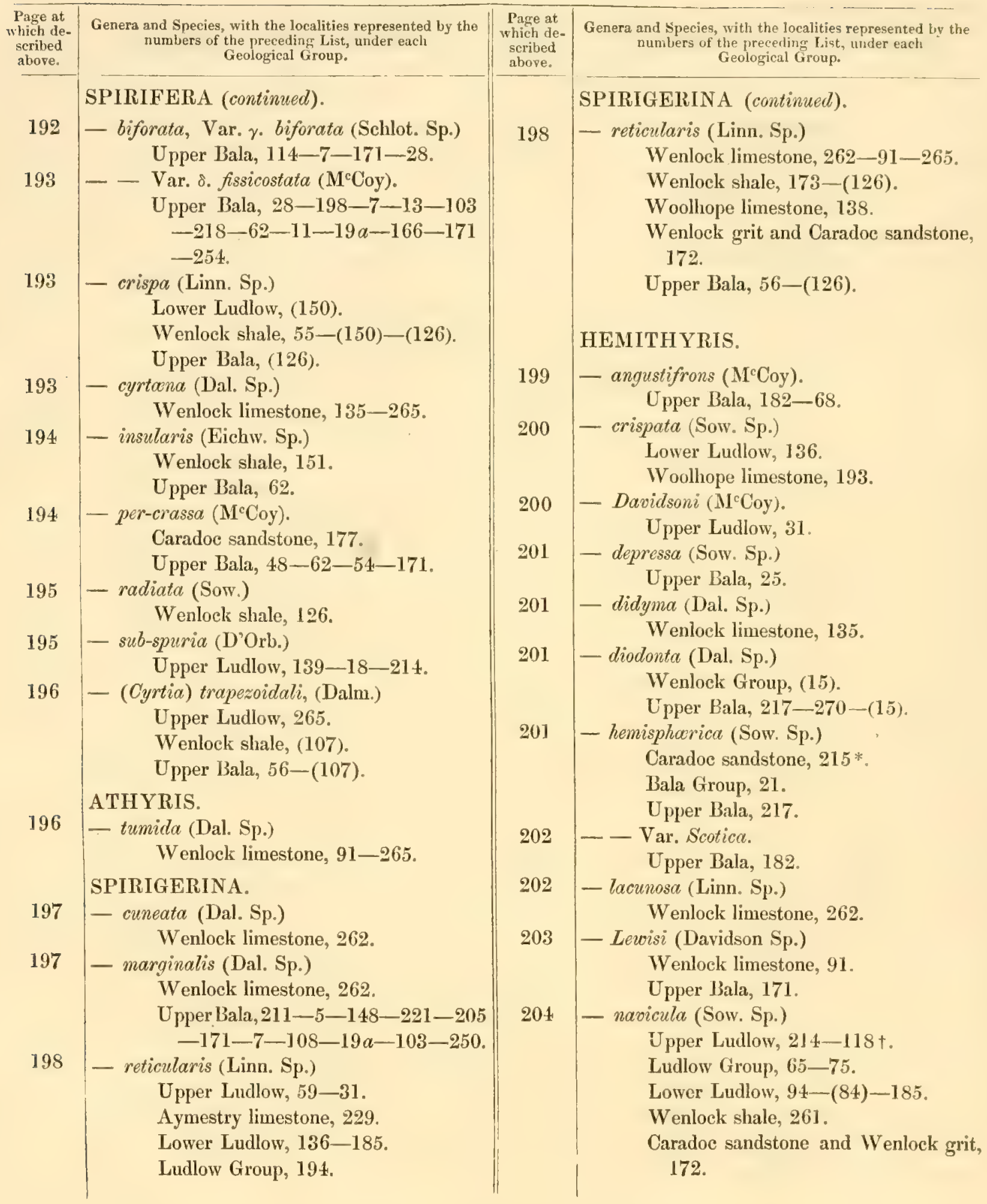

* The Caradoc sandstone near this locality has not been mentioned in the list of localities.

$\dagger$ A small bit of Ludlow limestone is found here which probably furnished this specimen. 


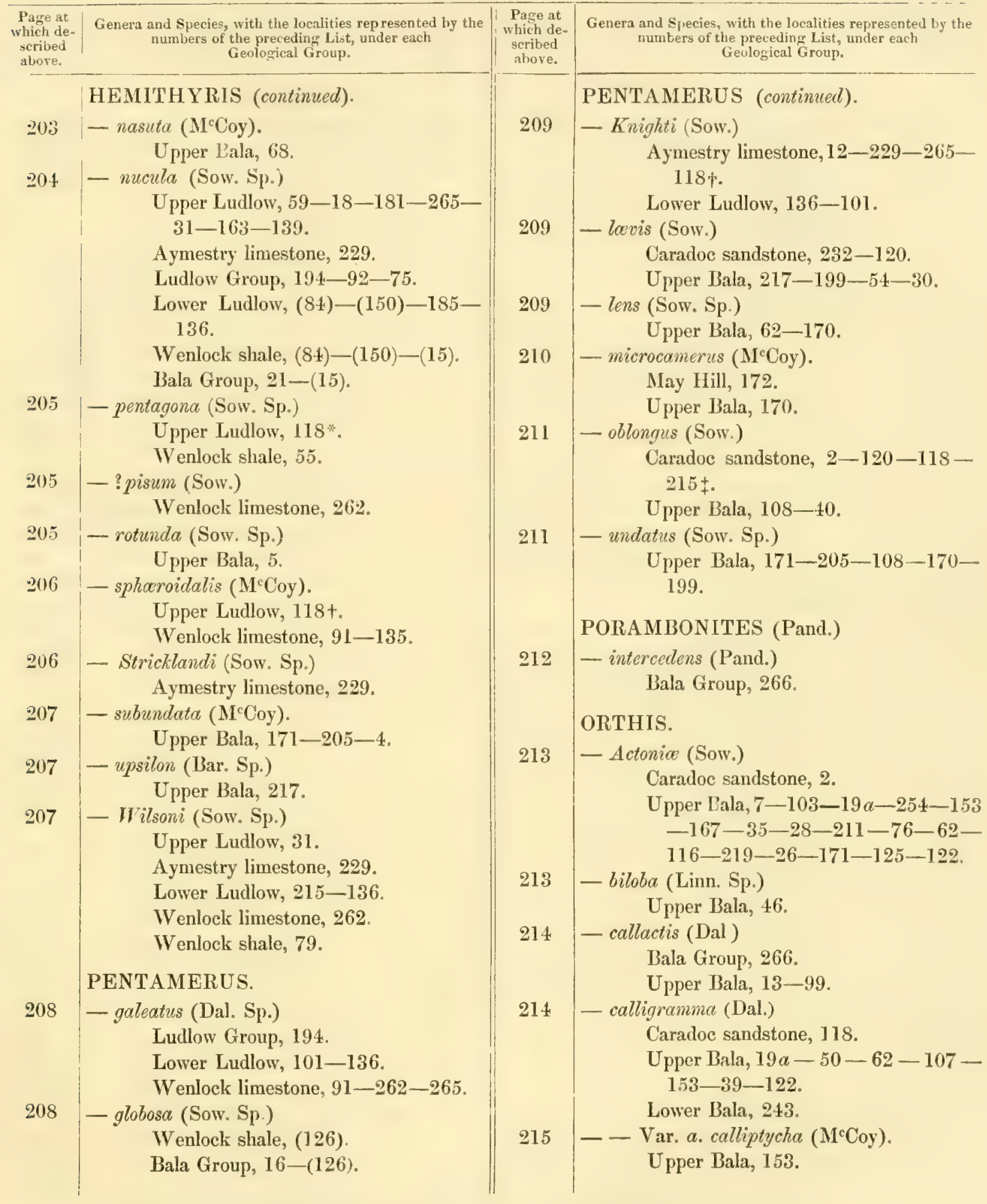

* See previous note, at foot of page 340 .

+ Seo note at foot of preceding page.

1. The Caradoc sandstone, near this spot, has not been noted in the list of localities. 


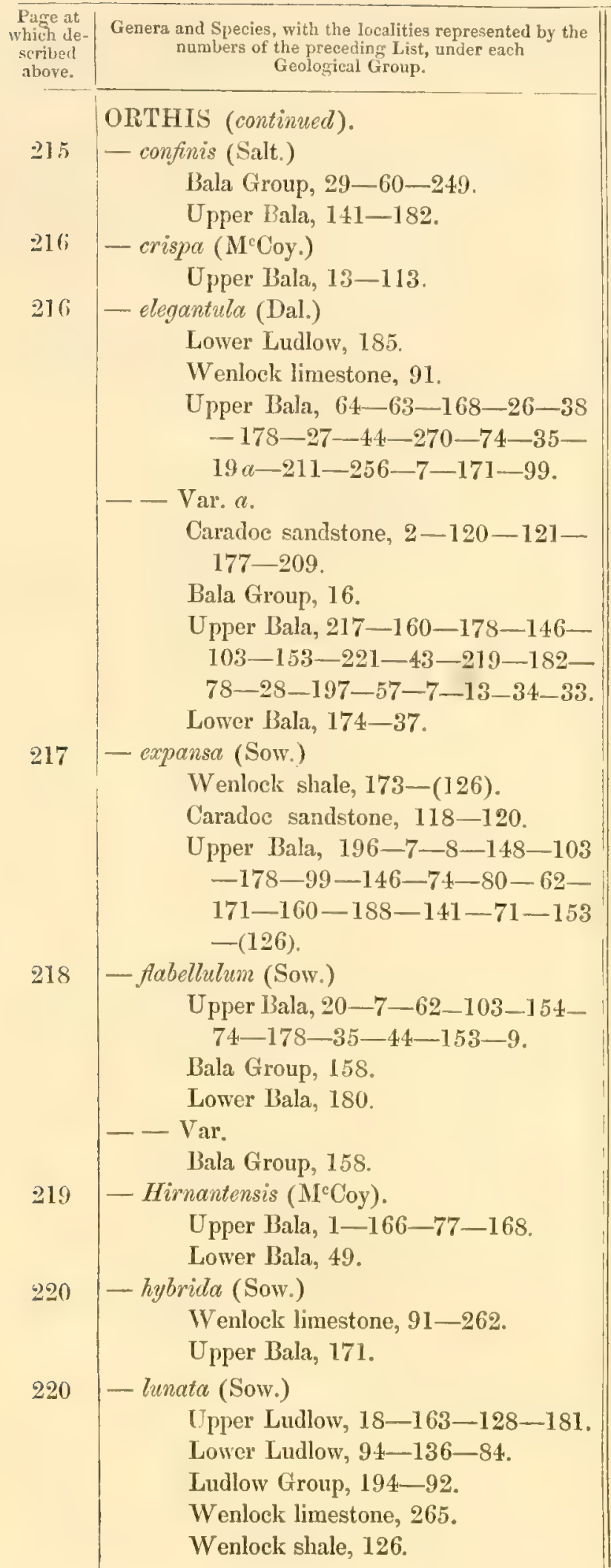

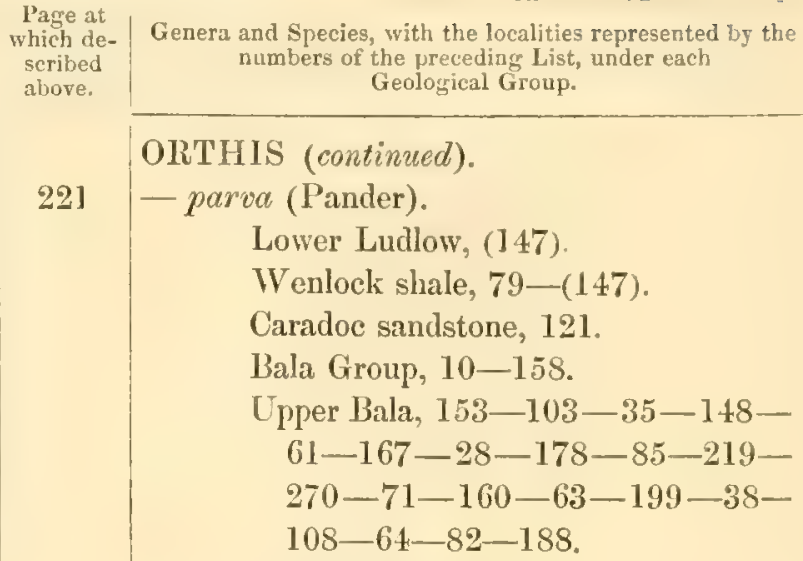

Lower Bala, 37.

- Var. avellana, M. V. K.

Upper Bala, 122-242-182.

Upper Tremadoc slates, 251.

- plicata (Sow. Sp.)

Upper Bala, 103-28-153-78-7 $-27-221-80-13-171-217-$ 167-99-199.-Var. 35-122.

223

- porcata ( $\mathrm{M}^{\mathrm{C}} \mathrm{Coy}$ ).

Caradoc sandstone, 120.

Upper Bala, 153-116-54-19a$62-7-64-8$.

- - Var.

Upper Bala, 207.

- protensa (Sow.)

Upper Bala, 108-35-11-17I.

Wenlock shale, 151 .

- reversa (Salt.)

Upper Bala, 182.

$22+$

- retrorsistria ( $\left.\mathrm{M}^{\mathrm{c}} \mathrm{Coy}\right)$.

Caradoc sandstone, (100).

Bala Group, (100).

Upper Bala, $111-44-32-154-80$ $-197-34-7-242-6-203-$ $148-39$.

Lower Bala, 208-17t.

226

- rigida (Davidson). Upper Bala, 28-7-99.

226

- rustica (Sow.)

Wenlock limestone, 262.

227

- sarmentosa (Mc Coy).

Bala Group, 158.

227

- sagittiferc ( $\mathrm{M}^{\mathrm{C}} \mathrm{Coy}$ ).

Upper Bala, 1.

228
- testudinaria (Dal.)

Caradoc sandstone, $120-118$. 


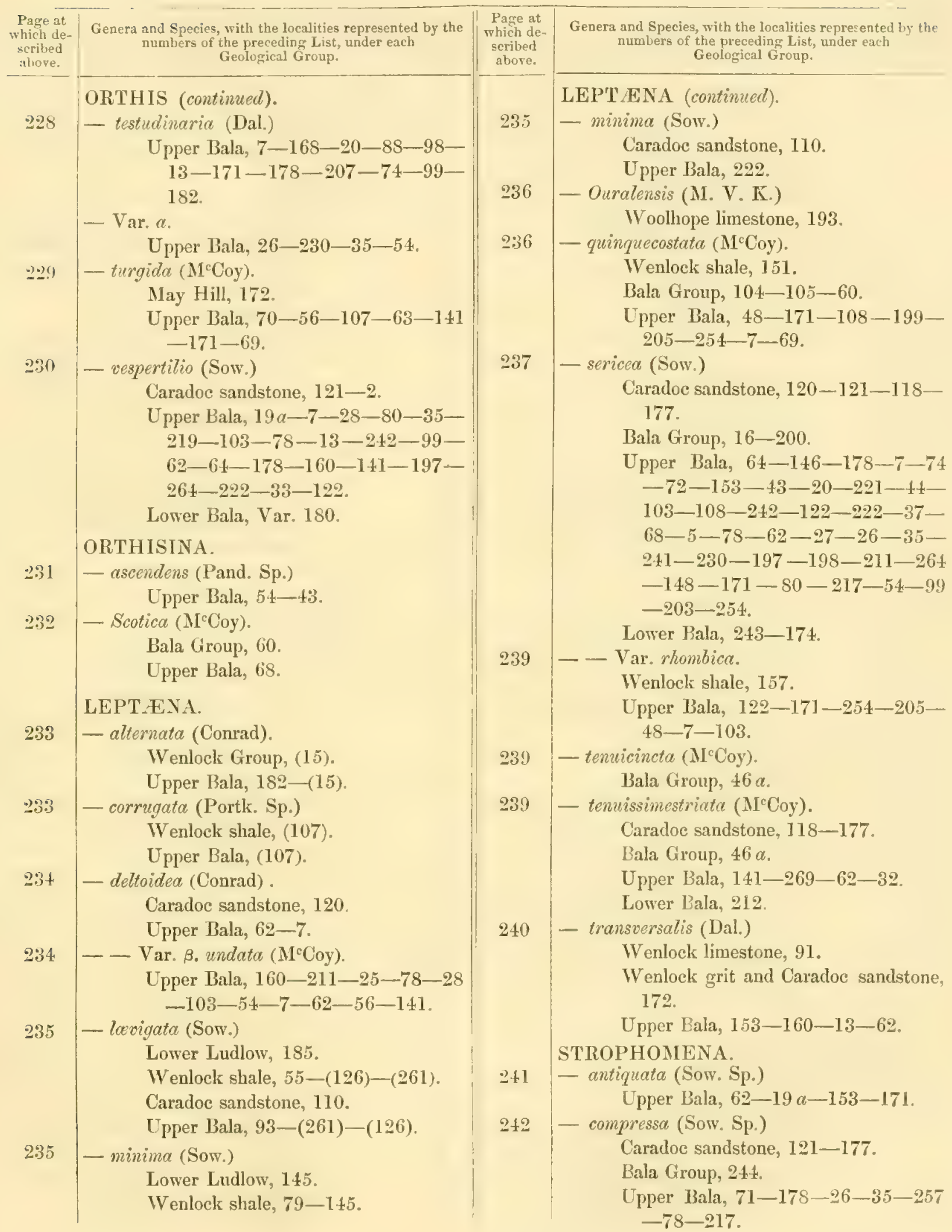




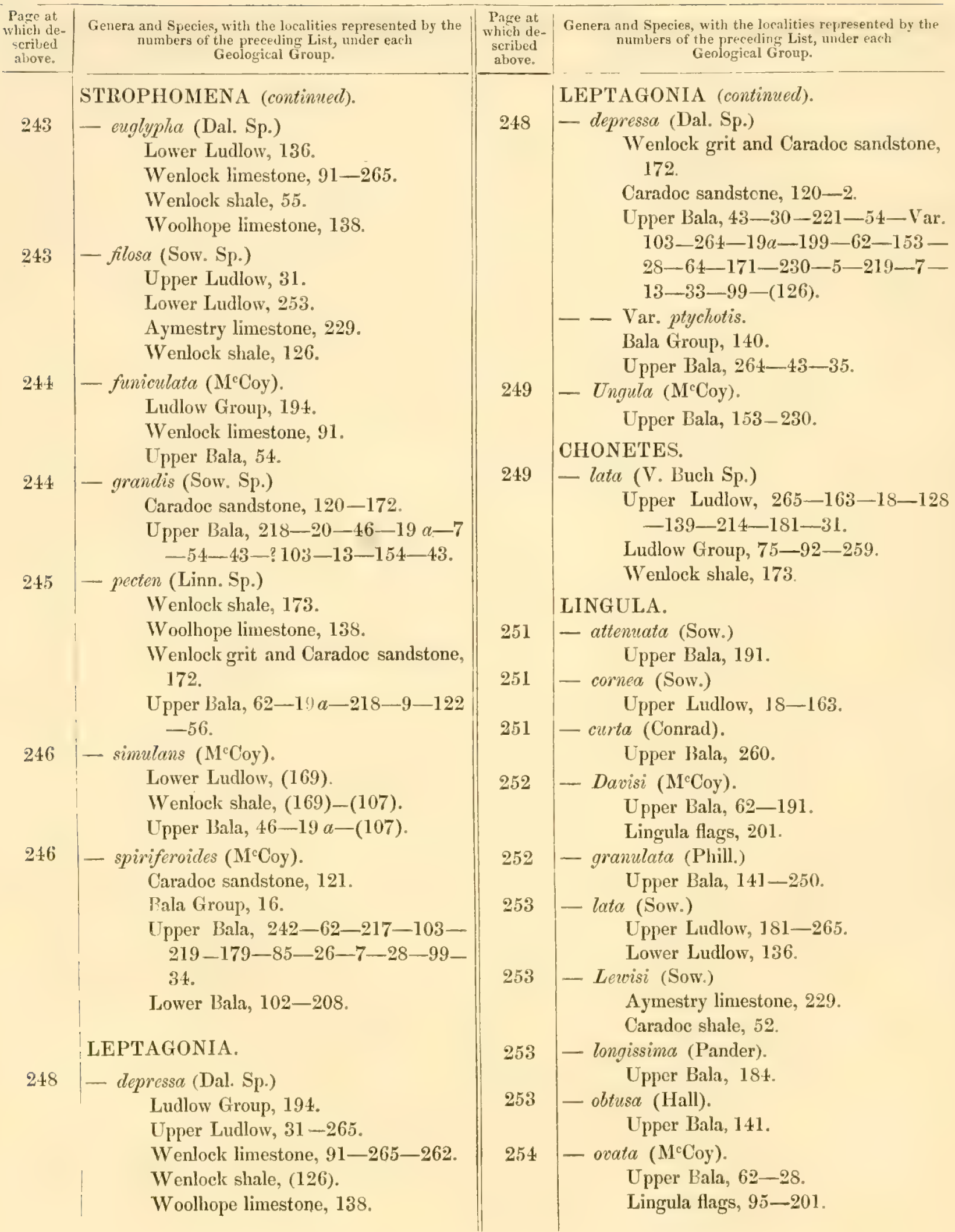




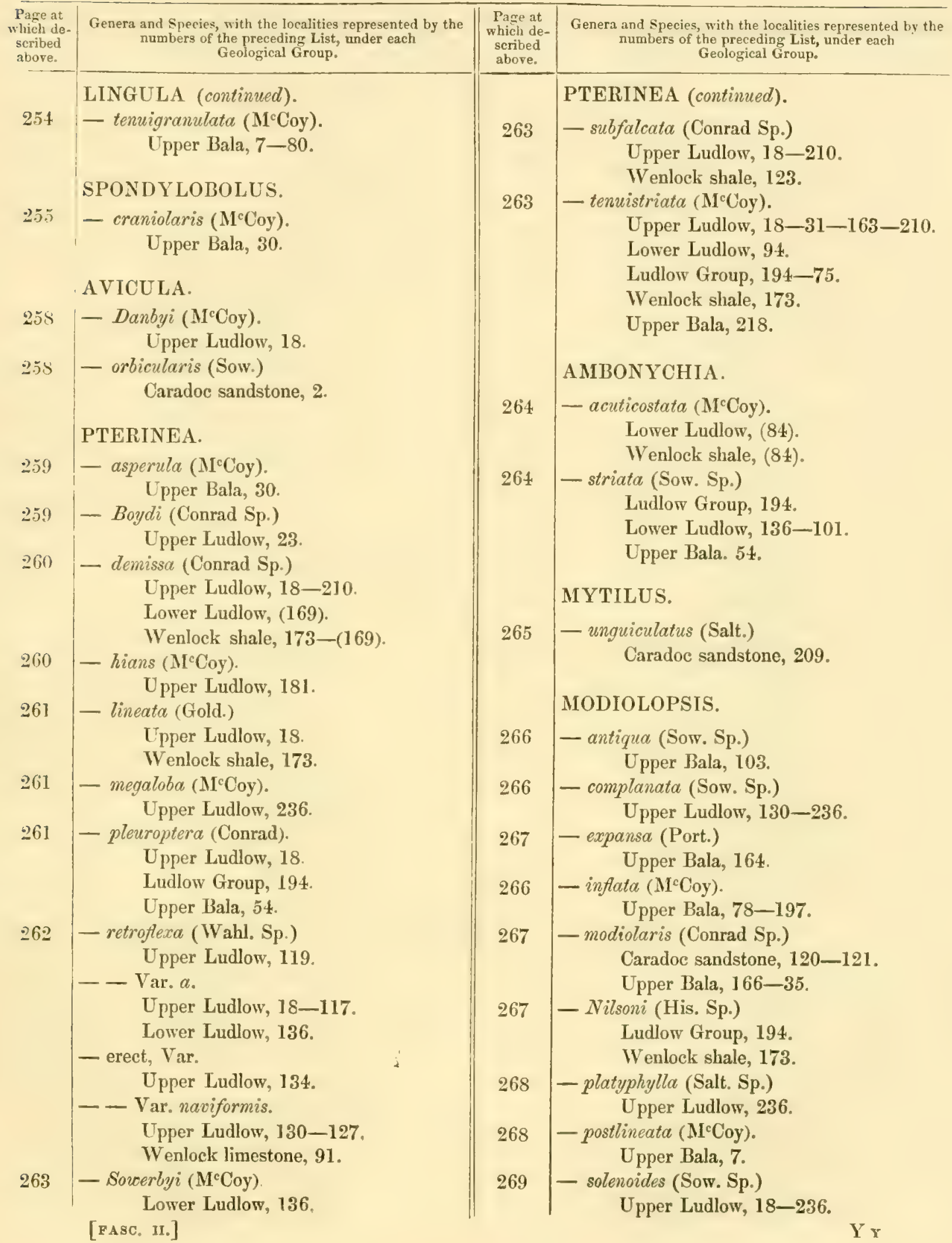




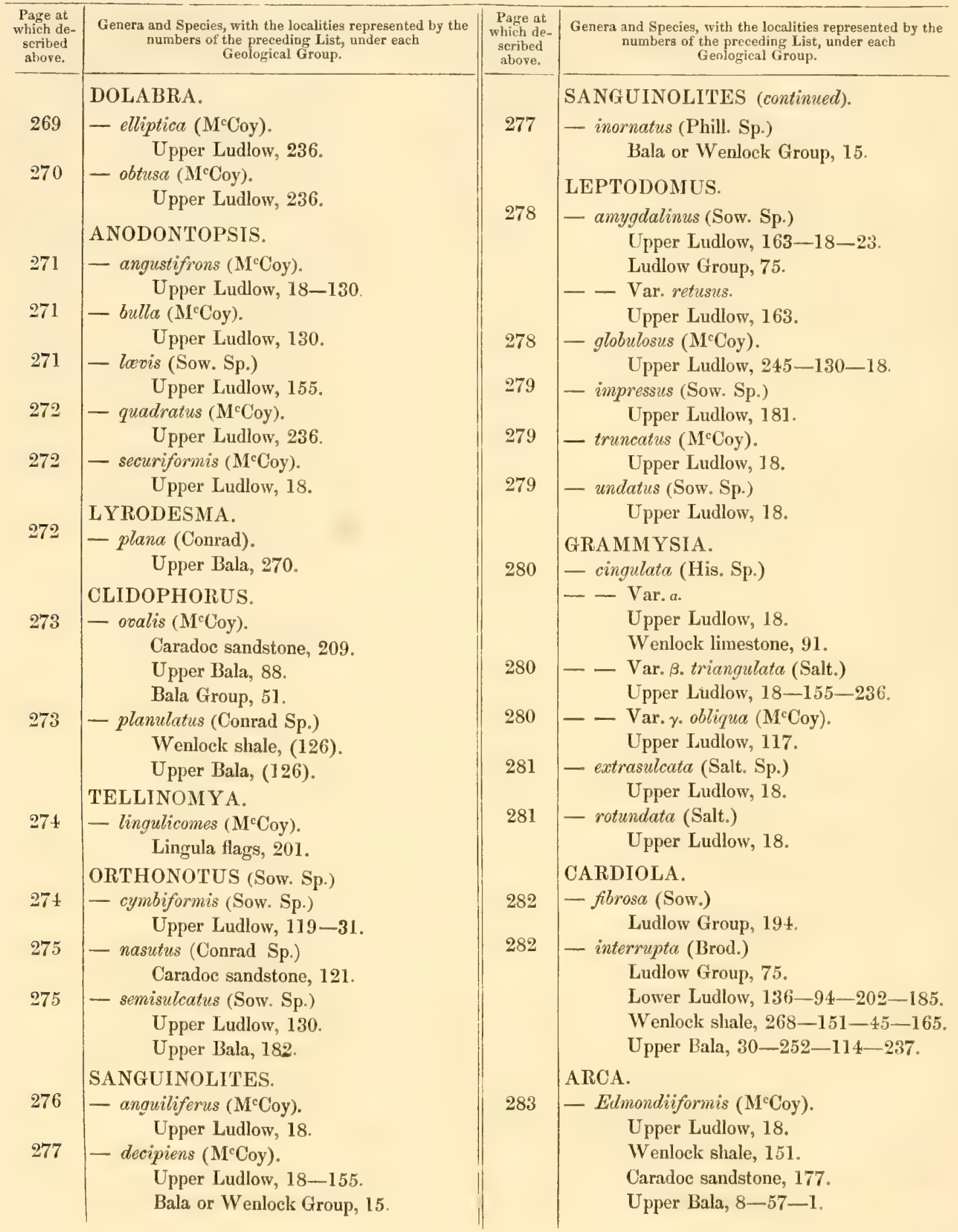




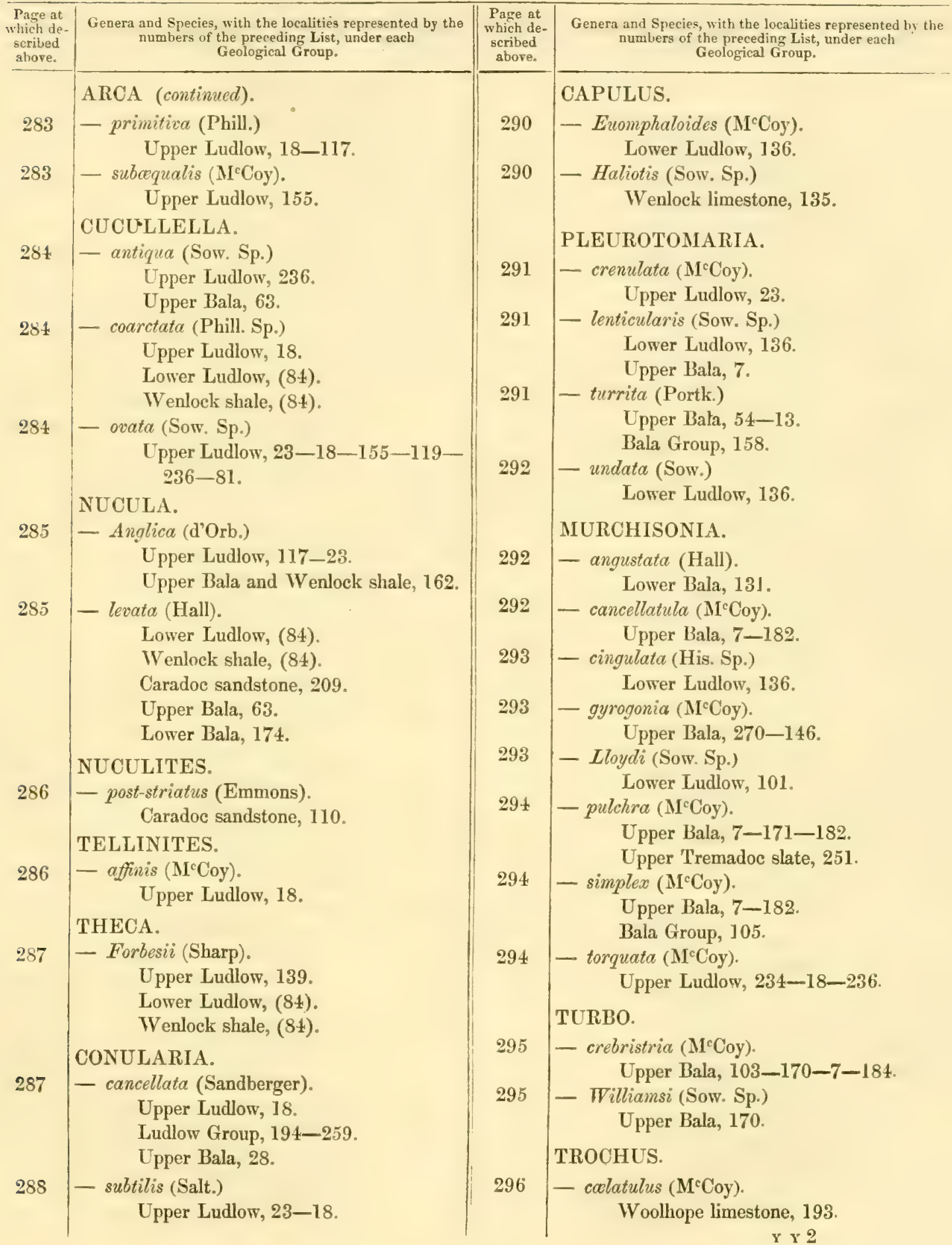




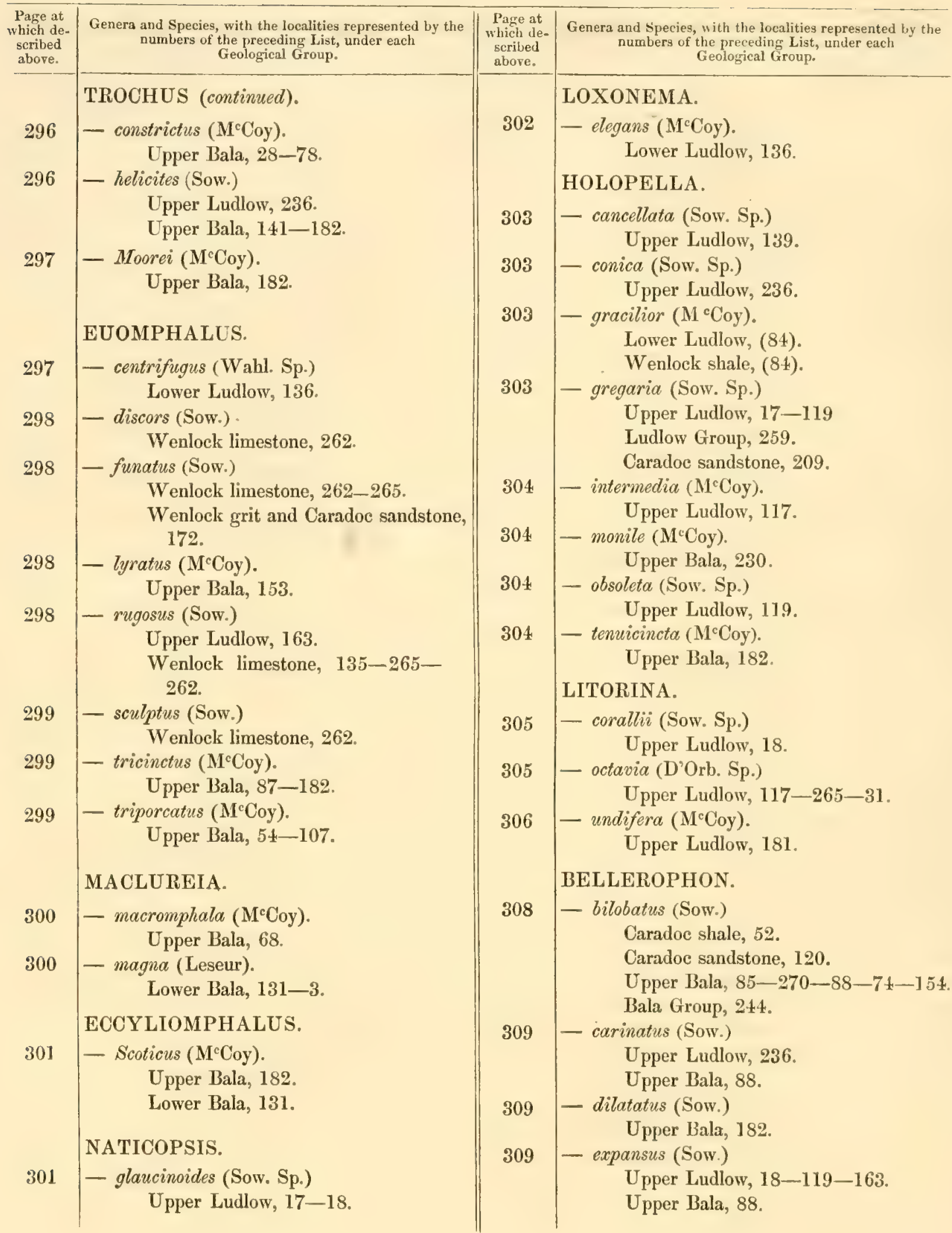




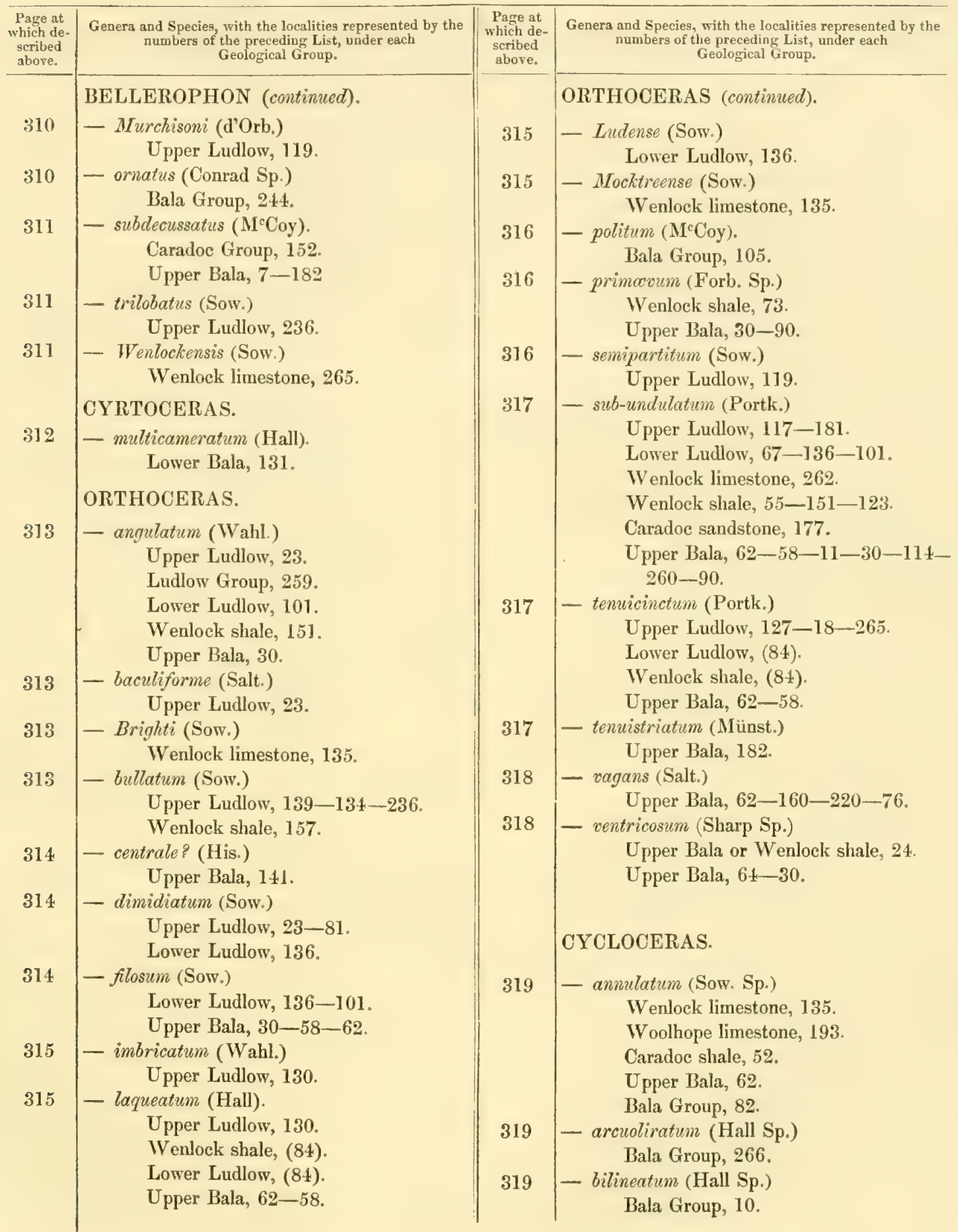




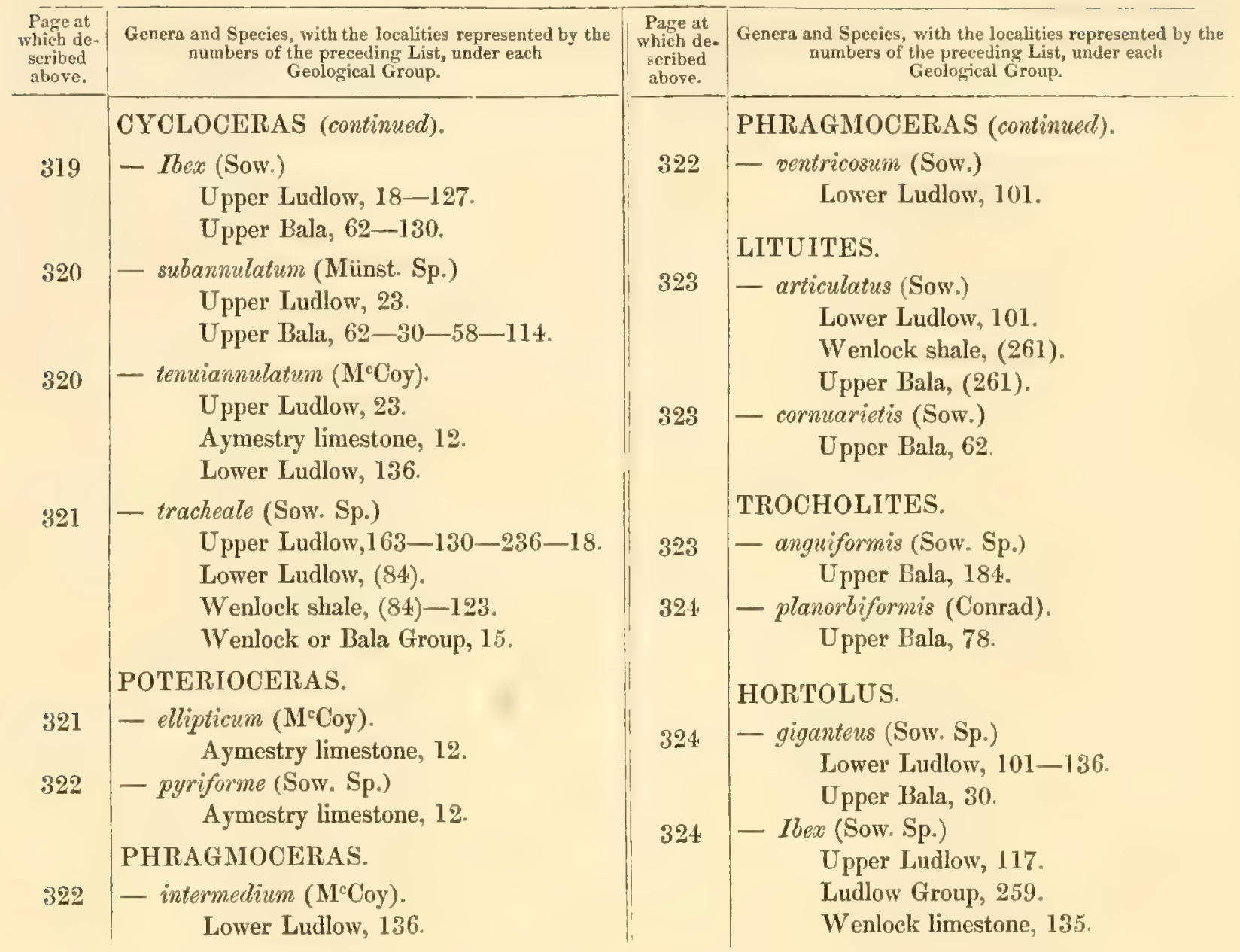




\section{§3. LISTS OF THE LOWER PALEOZOIC FOSSILS UNDER THE HEADS OF THE LOCALITIES, ARRANGED ALPHABETICALLY.}

Aber Hirnant, E. of Bala, N. Wales. Upper Bala. Allt yr Anker (continued).

Orthis Hirnantensis ( $\left.\mathbf{M}^{\mathrm{C}} \mathrm{Coy}\right)$.

- sagittifera ( $\left.\mathbf{M}^{\mathrm{c}} \mathrm{Coy}\right)$.

Spirifera biforata (Schlot.)

- - Var. fissicostata ( $\left.\mathbf{M}^{\mathrm{C}} \mathrm{Coy}\right)$.

Arca Edmondiiformis ( $\left.\mathrm{M}^{\mathrm{c}} \mathrm{Coy}\right)$.

Acton Scott, Church Stretton, Shropshire. Caradoc sandstone.

Stenopora fibrosa (Gold. Sp.)

Trachyderma lævis ( $\left.\mathbf{M}^{\circ} \mathrm{Coy}\right)$.

Calymene brevicapitata (Portk.)

- subdiademata ( $\left.\mathbf{I}^{\mathrm{c}} \mathrm{Coy}\right)$.

Homalonotus bisulcatus (Salt.)

Pentamerus oblongus (Sow.)

Orthis Actonix (Sow.)

- elegantula (Dal.) Var. a.

- Vespertilio (Sow.)

Leptagonia depressa (Dal. Sp.)

Avicula orbicularis (Sow.)

Aldens on the Stincher, Ayrshire. Lower Bala.

Cytheropsis Aldensis $\left(\mathrm{M}^{\mathrm{C}} \mathrm{Coy}\right)$.

Maclureia magna (Leseur).

Allt ffair ffynnon, Llanfyllin, N. Wales. Upper Bala.

Hemithyris subundata ( $\left.\mathbf{M}^{\mathrm{c}} \mathrm{Coy}\right)$.

Allt Goch, Llanfyllin, Montgomeryshire. Upper Bala.

Palæopora tubulata (Lonsd. Sp.)

- - Var. $a$.

Favosites alveolaris (Gold.) Var.

Stenopora fibrosa (Gold. Sp.)

Spirigerina marginalis (Dal. Sp.)

Hemithyris rotunda (Sow. Sp.)

Leptæna sericea (Sow.)

Leptagonia depressa (Dal. Sp.)

Allt tre Ffynnon, Parish of Llanrhaydr. Upper Bala. Orthis retrorsistria $\left(\mathrm{M}^{\mathrm{c}} \mathrm{Coy}\right)$.

Allt yr Anker, Meifod, Montgomeryshire. Upper Bala. Stenopora fibrosa (Gold. Sp.)
- - Var. a. Lycopodites (Say.)

Petraia uniserialis ( $\left.\mathbf{M}^{\mathrm{C}} \mathrm{Coy}\right)$.

Glyptocrinus basalis ( $\left.\mathrm{M}^{\mathrm{c}} \mathrm{Coy}\right)$.

Trinucleus Caractaci (Murch.)

- gibbifrons ( $\mathrm{M}^{\mathrm{C}} \mathrm{Coy}$ ).

Tretaspis seticornis (His. Sp.)

Zethus atractopyge $\left(\mathbf{M}^{\mathrm{c}} \mathrm{Coy}\right)$.

Phacops alifrons (Salt.)

Chasmops Odini (Eich. Sp.)

Calymene brevicapitata (Portk.)

Homalonotus bisulcatus (Salt.)

Isotelus Powisi (Murch.)

Spirifera biforata.

- - Var. a. lynx (Eichwald Sp.)

- - Var. c. biforata (Schlot. Sp.)

- Var. d. fissicostata $\left(\mathbf{M}^{\mathrm{C}} \mathrm{Coy}\right)$.

Spirigerina marginalis (Dal. Sp.)

Orthis Actoniæ (Sow.)

- elegantula (Dal.)

- Var. $a$.

- expansa (Sow.)

- flabellulum (Sow.)

- plicata (Sow. Sp.)

- poreata ( $\left.\mathbf{M}^{\mathrm{C}} \mathrm{Coy}\right)$.

— rigida (Davidson).

- testudinaria (Dal.)

- Vespertilio (Sow.)

Leptæna deltoidea (Conrad.)

- - Var. $\beta$. undata ( $\left.\mathbf{M}^{\mathrm{C}} \mathrm{Coy}\right)$.

- quinquecostata $\left(\mathbf{M}^{\circ} \mathrm{Coy}\right)$.

- sericea (Sow.)

- - Var. rhombica ( $\left.\mathrm{M}^{\mathrm{C}} \mathrm{Coy}\right)$.

Strophomena grandis (Sow. Sp.)

- Spiriferoides $\left(\mathbf{M}^{\mathrm{c}} \mathrm{Coy}\right)$.

Leptagonia depressa (Dal. Sp.)

Lingula tenuigranulata ( $\mathrm{M}^{\circ} \mathrm{Coy}$ ).

Modiolopsis postlineata ( $\left.\mathrm{M}^{\mathrm{C}} \mathrm{Coy}\right)$.

Turbo crebristria $\left(\mathbf{M}^{\circ} \mathrm{Coy}\right)$.

Pleurotomaria lenticularis (Sow. Sp.)

Murchisonia cancellatula ( $\mathbf{M}^{\mathrm{c}} \mathrm{Coy}$ ).

- pulchra ( $\left.\mathbf{M}^{\mathrm{c}} \mathrm{Coy}\right)$.

- simplex ( $\left.\mathbf{I}^{\mathrm{C}} \mathrm{Coy}\right)$.

Bellerophon subdecussatus ( $\mathrm{M}^{\mathrm{C}} \mathrm{Coy}$ ) 
Allt y Gader, near Llanfyllin, Montgomeryshire. Upper Bala.

Orthis expansa (Sow.)

- poreata ( $\left.\mathbf{M}^{\mathrm{c}} \mathrm{Coy}\right)$.

Area Edmondiiformis $\left(\mathrm{M}^{\mathrm{c}} \mathrm{Coy}\right)$.

Applethwaite Common, Westmoreland. Upper Bala. (Coniston limestone).

Palcopora interstincta (Wahl. Sp.)

Nebulipora explanata ( $\left.\mathbf{M}^{\mathrm{c}} \mathrm{Coy}\right)$.

Stenopora fibrosa (Gold. Sp.)

Halysites eatenulatus (Linn. Sp.)

Sarcinula organum (Linn. Sp.)

Petraia requisulcata ( $\mathrm{M}^{\circ} \mathrm{Coy}$ ).

Ceraurus clavifrons (Dal. Sp.)

Chasmops Odini (Eichw. Sp.)

Calymene brevicapitata (Portk.)

Orthis flabellulum (Sow.)

Strophomena pecten (Linn. Sp.)

Ardwell, S of Girvan, Ayrshire. Bala Group.

Diplograpsus pristis (His. Sp.)

Orthis parva (Pander).

Cycloceras bilineatum (Hall Sp.)

Ash Gill, Westmoreland. Upper Bala.

Spirifera biforata.

- - Var. fissicostata ( $\left.\mathbf{M}^{\mathrm{C}} \mathrm{Coy}\right)$.

Orthis protensa (Sow.)

Orthoceras subundulatum (Portk)

Aymestry, Herefordshire. Aymestry limestone and Ludlow rock.

Fistulipora decipiens $\left(\mathrm{M}^{\mathrm{c}} \mathrm{Coy}\right)$

Stromatopora striatella ( $\mathrm{d}^{\prime} \mathrm{O} \mathrm{rb}$.)

Palreopora interstincta (Wahl. Sp.)

- - Var. a. subtubulata ( $\mathrm{M}^{\mathrm{c}} \mathrm{Coy}$ )。

- tubulata (Lonsd. Sp.)

Favosites aspera (d'Orb.)

- oculata (Gold. Sp.)

Cœenites intertextus (Eichw.)

Strephodes vermiculoides $\left(\mathrm{M}^{\mathrm{c}} \mathrm{Coy}\right)$.

Arachnophyllum typus ( $\left.\mathrm{I}^{\mathrm{c}} \mathrm{Coy}\right)$.

Ptilodictya lanceolata (Gold. Sp.)

Serpulites longissimus (Murch.)

Pentamerus Knighti (Sow.)

Cycloceras tenuiannulatum ( $\left.\mathbf{M}^{\mathrm{c}} \mathrm{Coy}\right)$.

Poterioceras ellipticum ( $\left.\mathbf{M}^{\mathrm{c}} \mathrm{Coy}\right)$,

- pyriforme (Sow.Sp.)
Bala, Merionethshire (sce Gelli Grin). Upper Balr.

Petraia elongata (Phill. Sp.)

Spirifera biforata (Schlot.)

- - Var. fissicostata $\left(\mathrm{M}^{\mathrm{c}} \mathrm{Coy}\right)$.

Orthis callactis (Dal.)

- crispa ( $\left.\mathrm{M}^{\mathrm{C}} \mathrm{Coy}\right)$.

- elegantula. Var. $a$. (Dal.)

- plicata (Sow.)

- testudinaria (Dal.)

- Vespertilio (Sow.)

Leptæna transversalis ( $\mathrm{Dal}$.)

Strophomena grandis (Sow. Sp.)

Leptagonia depressa (Dal. Sp.)

Pleurotomaria turrita (Portk.)

Balmae Shore, Kirkeudbright. Bala or Wenlock Group. Graptolites Ludensis (Murch.)

- sagittarius (His. Sp.)

Henithyris diodonta (Dal. Sp.)

- nucula (Sow. Sp.)

Leptæna alternata (Conrad).

Sanguinolites decipiens $\left(\mathbf{M}^{\mathrm{C}} \mathrm{Coy}\right)$.

- inornatus (Phill. Sp.)

Cycloceras tracheale (Sow. Sp.)

Beaver's Grove, Bettws-y-Coed, N. Wales. Bala Group.

Pentamerus globosus (Sow. Sp.)

Orthis elegantula (Dal.) Var. $a$.

Leptæna sericea (Sow.)

Strophomena Spiriferoides ( $\left.\mathbf{M}^{\mathrm{c}} \mathrm{Coy}\right)$.

Beckfoot, Kirkby Lonsdale, Westmoreland. Upper Ludlow.

Holopella gregaria (Sow. Sp.)

Naticopsis glaucinoides (Sow. Sp.)

Benson Knot, Kendal, Westmoreland. Upper Ludlow.

Spongarium æquistriatum $\left(\mathbf{M}^{\mathrm{c}} \mathrm{Coy}\right)$.

- interlineatum ( $\mathrm{M}^{\mathrm{c}} \mathrm{Coy}$ ).

Uraster Ruthveni (Forb.)

Serpulites dispar (Salt.)

Protaster Sedgwicki (Forb.)

Cornulites serpularis (Schlot.)

Tentaculites tenuis (Sow.)

Trachyderma squamosa (Phill.)

Ceratiocaris elliptica ( $\mathbf{M}^{\mathrm{c}} \mathrm{Coy}$ ).

- inornata $\left(\mathbf{M}^{\mathrm{c}} \mathrm{Coy}\right)$.

- solenoides ( $\left.\mathrm{M}^{\mathrm{C}} \mathrm{Coy}\right)$. 
Benson Knot (continued).

Odontachile caudata (Brong. Sp.)

- - Var. minor.

Discina rugata (Sow. Sp.)

- striata (Sow. Sp.)

Spirifera sub-spuria (d'Orb.)

Hemithyris nucula (Sow. Sp.)

Ortlis lunata (Sow.)

Chonetes lata (V. Buch Sp.)

Lingula cornea (Sow.)

Avicula Danbyi ( $\left.M^{\circ} \mathrm{Coy}\right)$.

Pterinea demissa (Conrad Sp.)

- lineata (Gold.)

- pleuroptera (Conrad Sp.)

- retroflexa (Wahl. Sp.) Var. $a$.

- subfalcata (Conrad Sp.)

- tenuistriata ( $\left.\mathrm{M}^{\mathrm{c}} \mathrm{Coy}\right)$.

Modiolopsis solenoides (Sow. Sp.)

Anodontopsis angustifrons ( $\mathrm{MI}^{\mathrm{C}} \mathrm{Coy}$ ).

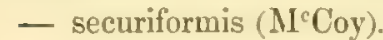

Sanguinolites anguiliferus $\left(\mathrm{M}^{\circ} \mathrm{Coy}\right)$.

- decipiens ( $\left.\mathbf{M}^{\mathrm{C}} \mathrm{Coy}\right)$.

Leptodomus amygdalinus (Sow. Sp.)

- globulosus ( $\left.\mathbf{M}^{\mathrm{C}} \mathrm{Coy}\right)$.

- truncatus ( $\left.\mathrm{M}^{\mathrm{c}} \mathrm{Coy}\right)$.

- undatus (Sow. Sp.)

Grammysia cingulata (His. Sp.) Var, $a$,

- - Var. $\beta$. triangulata (Salt. Sp.)

- extrasulcata (Salt. Sp.)

- rotundata (Salt. Sp.)

Arca Edmondiiformis ( $\mathrm{I}^{\mathrm{C}} \mathrm{Coy}$ ).

- primitiva (Phill.)

Cucullella coarctata (Phill. Sp.)

- ovata (Sow.)

Tellinites affinis ( $\left.\mathbf{I}^{\mathrm{c}} \mathrm{Coy}\right)$.

Conularia cancellata (Sandberger).

- subtilis (Salt. Sp.)

Litorina corallii (Sow. Sp.)

Naticopsis glaucinoides (Sow. Sp.)

Murchisonia torquata ( $\left.\mathrm{M}^{\mathrm{C}} \mathrm{Coy}\right)$.

Bellerophon expansus (Sow.)

Orthoceras tenuicinctum (Portk.)

Cycloceras Ibex (Sow. Sp.)

- tracheale (Sow. Sp.)

Blain-y-cwm, W. of Nantyr, Glyn Ceiriog, S. of Llangollen, Denbighshire. Upper Bala.

Palæopora megastoma ( $\left.\mathbf{M}^{c} \mathrm{Coy}\right)$. [FABC, II.]
Blain-y-ewm (continued).

Stenopora fibrosa (Gold. Sp.)

- - Var. a. Lycopodites (Say).

- - Var. $\beta$. regularis $\left(\mathrm{M}^{\mathrm{c}} \mathrm{Coy}\right)$.

Ptilodictya explanata ( $\left.\mathbf{M}^{\mathrm{c}} \mathrm{Coy}\right)$.

Retepora Hisingeri ( $\left.\mathbf{M}^{\mathrm{c}} \mathrm{Coy}\right)$.

Glauconome disticha (Gold.)

Fenestella Milleri (Lonsd. Sp.)

Trinucleus gibbifrons $\left(\mathbf{M}^{\circ} \mathbf{C o y}\right)$.

Acidaspis Brighti (Murch.)

Odontochile truncato-caudata (Portk. Sp.)

Illænus Rosenbergi (Eichw.)

Spirifera biforata (Schlot. Sp.)

- - Var. $d$. fissicostata ( $\left.\mathbf{M}^{c} \mathrm{Coy}\right)$.

Spirigerina marginalis (Dal. Sp.)

Orthis Actonix (Sow.)

- calligramma (Dal.)

- elegantula (Dal.)

- poreata ( $\left.\mathrm{I}^{\mathrm{c}} \mathrm{Coy}\right)$.

- Vespertilio (Sow.)

Strophomena antiquata (Sow. Sp.)

- grandis (Sow. Sp.)

- pecten (Linn. Sp.)

- simulans ( $\mathrm{II}^{\mathrm{C}} \mathrm{Coy}$ ).

Leptagonia depressa (Dal. Sp.)

Bodean, Caernarvonshire. Upper Bala.

Orthis flabellulum (Sow.)

- testudinaria (Dal.)

Leptæna sericea (Sow.)

Strophomena grandis (Sow. Sp.)

Braes, one-and-half miles E. of Girvan. Bala Group.

Petraia æquisulcata ( $\mathbf{H}^{\mathrm{c}} \mathrm{Coy}$ ).

Tentaculites ornatus (Sow.)

Hemithyris hemisphærica (Sow. Sp.)

- nucula (Sow. Sp.)

Brathay, Lancashire. Upper Bala (Coniston flag).

Graptolites Ludensis (Murch.)

Brigsteer, Kendal, Westmoreland. Upper Ludlow.

Nebulipora papillata ( $\mathbf{M}^{\mathrm{C}} \mathrm{Coy}$ ).

Spongarium interlineatum ( $\left.\mathrm{M}^{\mathrm{c}} \mathrm{Coy}\right)$.

Tetragonis Danbyi $\left(\mathbf{M}^{\mathrm{C}} \mathrm{Coy}\right)$.

Cornulites serpularis (Schlot.)

Pterinea Boydi (Conrad Sp.)

Leptodomus amygdalinus (Sow. Sp.) 
Brigsteer (continued).

Cucullella ovata (Sow. Sp.)

Nucula Anglica (d'Orb.)

Conularia subtilis (Salt.)

Pleurotomaria crenulata ( $\left.\mathbf{M}^{\mathrm{C}} \mathrm{Coy}\right)$.

Orthoceras angulatum (Phill.)

- baculiforme (Salt.)

- dimidiatum (Sow.)

Cycloceras subannulatum (Müinst. Sp.)

- tenuiannulatum ( $\left.\mathbf{M}^{\mathrm{c}} \mathrm{Coy}\right)$.

Bron Einion Quarry, under Pen-y-big. Upper Bala or Wenlock shale.

Orthoceras ventricosum (Sharp Sp.)

Brynbedwog Quarry, near Bala. Upper Bala.

Hemithyris depressa (Sow. Sp.)

Leptæna deltoidea (Conrad).

Bryn Eithin, Penmachno, N. Wales. Upper Bala.

Stenopora fibrosa (Gold. Sp.)

Beyrichia complicata (Salt.)

Isotelus Porvisi (Murch.)

Orthis Actoniæ (Sow.)

- elegantula (Dal.)

- testudinaria (Dal.) Var. a.

Leptæna sericea (Sow.)

Strophomena compressa (Sow. Sp.)

- Spiriferoides ( $\mathbf{M}^{\mathrm{C}} \mathrm{Coy}$ ).

Bryn Evan Ysputty, N. Wales. Upper Bala.

Trinucleus latus (Portk.)

Orthis elegantula (Dal.)

- plicata (Sow. Sp.)

Leptæna sericea (Sow.)

Bryn Melyn, near Bala, Merionethshire. Upper Bala.

Stenopora fibrosa (Gold. Sp.)

- - Var. $a$. Lycopodites (Say).

Tretaspis fimbriata (Murch. Sp.)

Portlockia apiculata (Salt.)

Calymene brevicapitata (Portk.)

Pseudocrania divaricata ( $\left.\mathbf{M}^{\mathrm{C}} \mathrm{Coy}\right)$.

Spirifera biforata (Schlot. Sp.)

- - Var. a. lynx (Eichwald. Sp.)

- Var. $c$. biforata (Schlot. Sp.)

- - Var. d. fissicostata ( $\mathbf{M}^{\mathrm{c}} \mathrm{Coy}$ ).

Orthis Actoniæ (Sow.)

- elegantula (Dal.) Var. $\alpha$.
Bryn Melyn (continued).

Orthis parva (Pander).

- plicata (Sow. Sp.)

- rigida (Davidson).

- Vespertilio (Sow.)

Leptæna deltoidea.

- - Var. $\beta$. undata ( $\mathrm{I}^{\mathrm{C}} \mathrm{Coy}$ ).

Strophomena Spiriferoides ( $\left.\mathbf{M}^{\mathrm{C}} \mathrm{Coy}\right)$.

Leptagonia depressa (Dal. Sp.)

Lingula ovata $\left(\mathrm{M}^{\mathrm{C}} \mathrm{Coy}\right)$.

Conularia cancellata (Sandberg.)

Trochus constrictus ( $\left.\mathrm{MI}^{\mathrm{c}} \mathrm{Coy}\right)$.

Bugon Knockdollian, Ayrshire. Bala Group.

Illænus crassicauda (Dalman).

Orthis confinis (Salt.)

Builth (three miles North of), Radnorshire. Upper Bald.

Graptolites latus ( $\left.\mathbf{M}^{\circ} \mathrm{Coy}\right)$.

Diplograpsus pristis (His. Sp.)

Serpulites dispar (Salt.)

Cytheropsis Aldensis ( $\left.\mathbf{M}^{c} \mathrm{Coy}\right)$.

Trinucleus gibbifions ( $\left.\mathbf{M}^{\mathrm{c}} \mathrm{Coy}\right)$.

Tretaspis fimbriatus (Murch. Sp.)

Ampyx latus $\left(\mathrm{M}^{\mathrm{C}} \mathrm{Coy}\right)$.

- nudus (Murch. Sp.)

Ogygia Buchi (Brong. Sp.)

Barrandia Cordai ( $\left.\mathbf{M}^{\mathrm{C}} \mathrm{Coy}\right)$.

Eccoptochile Sedgwicki ( $M^{c} \mathrm{Coy}$ ).

Isotelus laticostatus (Green Sp.)

Pentamerus lævis (Sow.)

Leptagonia depressa (Dal. Sp.)

Spondylobolus craniolaris $\left(M^{\mathrm{e}} \mathrm{Coy}\right)$.

Pterinea asperula ( $\left.\mathbf{M}^{\mathrm{c}} \mathrm{Coy}\right)$.

Cardiola interrupta (Brod.)

Orthoceras angulatum (Wahi.)

- filosum (Sow.)

- primævum (Forb. Sp.)

- subundulatum (Portk.)

- ventricosum (Sharp Sp.)

Cycloceras subannulatum (Münst. Sp.)

Hortolus giganteus (Sow. Sp.)

Burton and Brockton. Upper Ludlow.

Graptolites Ludensis (Murch.)

Serpulites longissimus (Murch.)

Discina rugata (Sow. Sp.) 
Burton and Brockton (continued).

Spirigerina reticularis (Linn. Sp.)

Hemithyris Davidsoni ( $\mathrm{M}^{\mathrm{C} C \mathrm{Coy}}$ ).

- nucula (Sow. Sp.)

- Wilsoni (Sow. Sp.)

Strophomena? filosa (Sow. Sp.)

Leptagonia depressa (Dal. Sp.)

Chonetes lata (V. Buch Sp.)

Pterinea tenuistriata $\left(\mathrm{M}^{\circ} \mathrm{Coy}\right)$.

Orthonota cymbiformis (Sow. Sp.)

Litorina octavia (Sow. Sp.)

Bwlch Llandrillo, Corwen, N. Wales. Upper Bala.

Orthis retrorsistria ( $\left.\mathrm{M}^{\mathrm{c}} \mathrm{Coy}\right)$.

Leptrena tenuissimestriata $\left(\mathrm{M}^{\mathrm{C}} \mathrm{Coy}\right)$.

Bwlch y Cibau, N. of Meifod. Upper Bala.

Spirifera biforata (Schl. Sp.)

- - Var. a. lynx (Eichwald Sp.)

Orthis elegantula (Dal.) Var. $\alpha$.

- Vespertilio (Sow.)

Leptagonia depressa (DaI. Sp.)

Bwlch y groes, S. of Bala, Merionethshire. Upper Bala.

Stenopora fibrosa (Gold. Sp.)

Trinucleus gibbifrons ( $\left.\mathrm{M}^{\mathrm{C}} \mathrm{Coy}\right)$.

Orthis elegantula (Dal. Var. a.)

- retrorsistria $\left(\mathrm{M}^{\mathrm{c}} \mathrm{Coy}\right)$.

Strophomena Spiriferoides ( $\left.\mathbf{M}^{\mathrm{c}} \mathrm{Coy}\right)$.

Cader Dinmael, near Corwen, Denbighshire. Upper Bala.

Stenopora fibrosa (Gold. Sp.)

- - Var. a. Lycopodites (Say).

Ceraurus clavifrons (Dal. Sp.)

Orthis Actonire (Sow.)

- elegantula (Dal.)

- flabellulum (Sow.)

- parva (Pander).

- plicata (Sow. Sp.) Var.

- protensa (Sow.)

- testudinaria (Dal.) Var. $\alpha$.

- Vespertilio (Sow.)

Leptæna sericea (Sow.)

Strophomena compressa (Sow.Sp.)

Leptagonia depressa (Dal. Sp.)

Modiolopsis modiolaris (Conrad Sp.)
Cairn Ryan, Ayrshire. ? Lover Bala.

Diplograpsus mucronatus (Hall Sp.)

- pristis (His. Sp.)

- sextans (Hall Sp.)

Capel Currig, Snowdon, N. Wales. Lower Bala.

Orthis parva (Pander).

— elegantula (Dal.) Var. $\alpha$.

Leptæna sericea (Sorv.)

Capel Garmon, Denbighshire. Upper Bala.

Phacops alifrons (Salt.)

Homalonotus bisulcatus (Salt.)

- rudis (Salt.)

Orthis elegantula (Dal.)

- parva (Pander).

Carnedd fawr (S. of), Bala, N. Wales. Upper Bala. Trinucleus gibbifrons $\left(\mathrm{M}^{\mathrm{c}} \mathrm{Coy}\right)$.

Orthis parva (Pander).

Carn Goran, Cornwall. Upper Bala.

Orthis calligramma (Dal.)

- retrorsistria $\left(\mathrm{M}^{\mathrm{C}} \mathrm{Coy}\right)$.

Castell Craig, Gwyddon, Llandovery, S. Wales. Upper Bala.

Petraia rugosa (Phill. Sp.)

- uniserialis ( $\left.\mathrm{M}^{\mathrm{C}} \mathrm{Coy}\right)$.

Pentamerus oblongus (Sow.)

Cautley Crags, above Sedbergh. (Caradoc sandstone and Upper Bala.)

Graptolites sagittarius (Lin. Sp.)

Cefn Coedog, Corwen, N. Wales. Upper Bala.

Fenestella Milleri (Lonsd. Sp.)

Retepora Hisingeri ( $\left.\mathbf{M}^{\mathrm{c}} \mathrm{Coy}\right)$.

Orthis elegantula (Dal.) Var. $\alpha$.

- ascendens (Pander Sp.)

Leptæna sericea (Sow.)

Strophomena grandis (Sow. Sp.)

Leptagonia depressa (Dal. Sp.)

Cefn ddu, Denbighshire. Wenlack shale.

Cardiola interrupta (Brod.) 
Cefn Goch, Glyn Ceiriog, Denbighshire. Upper Bala. Portlockia apiculata (Salt.)

Orthis biloba (Linn. Sp.)

Strophomena grandis (Sow. Sp.)

- simulans ( $\left.\mathbf{M}^{\mathrm{c}} \mathrm{Coy}\right)$.

Cefn Grugos, W. of Llanfyllin, Montgomeryshire.

Bala Group.

Graptolites Ludensis (Murch.)

Ceraurus clavifrons (Dal. Sp.)

Leptæna tenuicineta ( $\left.\mathbf{M}^{\mathrm{C}} \mathrm{Coy}\right)$.

- tenuissimestriata $\left(\mathrm{M}^{\mathrm{c}} \mathrm{Coy}\right)$.

Cefn Hir Fynydd, near Llangynog. Bala Group. Ampyx parvulus (Forb.)

Cefn Rhyddan, Llandovery, S. Wales. Upper Bala. Spirifer percrassus $\left(M^{c} \mathrm{Coy}\right)$.

Leptæna quinquecostata ( $\left.\mathrm{M}^{\mathrm{c}} \mathrm{Coy}\right)$.

Cefn y coed, Llangedwyn, Montgomeryshire. Upper Bala.

Favosites alveolaris (Gold.)

Orthis elegantula (Dal.)

- flabellulum (Sow.)

- retrorsistria ( $\left.\mathrm{M}^{\mathrm{C}} \mathrm{Coy}\right)$.

Leptæna sericea (Sow.)

Ceiriog Waterfall, S. of Llangollen, N. Wales. Bala Group.

Clidophorus ovalis ( $\left.\mathbf{M}^{\mathrm{c}} \mathrm{Coy}\right)$.

Cerrig Cregyn, Anglesea. Upper Bala.

Orthis calligramma (Dal.)

Cerrig y Druidion, Denbighshire (see Pen y Gaer). Lower Bala.

Orthis Hirnantensis ( $\left.\mathrm{M}^{\mathrm{c}} \mathrm{Coy}\right)$.

Cheney Longville, Shropshire. Caradoc shale.

Trinucleus Caractaci (Murch.)

Odontochile longicaudata (Murch. Sp.)

Calymene tuberculosa (Salt.)

Lingula Lewisi (Sow.)

Bellerophon bilobatus (Sow.)

Cycloceras annulatum (Sow. Sp.)
Clungunford, Shropshire. Wenlock shale.

Ptilodictya lanceolata (Gold. Sp.)

Spirifera crispa (Linn. Sp.)

- insularis (Eichw. Sp.)

Hemithyris pentagona (Sow. Sp.)

Leptæna lævigata (Sow.)

Strophomena euglypha (Dal. Sp.)

Orthoceras subundulatum (Portk.)

Coed Sion, Llangadoc, S. Wales. Upper Bala.

Calymene subdiademata (MCoy). Var.

Cyrtia trapezoidalis (Dal.)

Spirigerina reticularis (Linn. Sp.)

Orthis turgida ( $\mathrm{M}^{\mathrm{C}} \mathrm{Coy}$ ).

Leptæna deltoidea.

- - Var. $\beta$. undata ( $\left.\mathbf{M}^{\mathrm{c}} \mathrm{Coy}\right)$.

Coed y Bedw, Bala. Upper Bala.

Beyrichia complicata (Salt.)

Orthis elegantula (Dal.) Var.a.

Arca Edmondiiformis ( $\left.\mathbf{M}^{c} \mathrm{Coy}\right)$.

Coldwell, Westmoreland. Upper Bala.

Odontochile obtusicaudata (Salt.)

Orthoceras filosum (Sow.)

- laqueatum (Hall).

- tenuicinctum (Portk.)

Cycloceras sub-annulatum (Muinst.)

Collinfield, Kendal. Upper Ludlow.

Spirigerina reticularis (Linn. Sp.)

Hemithyris nucula (Sow. Sp.)

Colmonel, on the Stincher. Bala Group.

Orthis confinis (Salt.)

Orthisina Scotica ( $\left.\mathbf{M}^{\mathrm{C}} \mathrm{Coy}\right)$.

Leptrena quinquecostata ( $\left.\mathbf{M}^{\circ} \mathrm{Coy}\right)$.

Coniston Water-head, Lancashire. Upper Balce.

Palæopora interstineta (Wahl. Sp.)

- - Var. a. subtubulata ( $\left.\mathbf{M}^{\mathrm{c}} \mathrm{Coy}\right)$.

- megastoma ( $\left.\mathbf{M}^{\mathrm{c}} \mathrm{Coy}\right)$.

- tubulata (Lonsd. Sp.) Var, $\alpha$.

Favosites crassa ( $\left.\mathbf{M}^{\mathrm{c}} \mathrm{Coy}\right)$. 
Coniston Water-head (continued).

Nebulipora explanata ( $\mathrm{I}^{\mathrm{C}} \mathrm{Coy}$ ).

- papillata $\left(\mathrm{M}^{\mathrm{C}} \mathrm{Coy}\right)$.

Stenopora fibrosa (Gold. Sp.)

- - Var. $a$. Lycopodites (Say).

Halysites catenulatus (Linn. Sp.)

Sarcinula organum (Linn. Sp.)

Petraia æequisulcata ( $\left.\mathbf{M}^{\mathrm{C}} \mathrm{Coy}\right)$.

Berenicea heterogyra ( $\left.\mathbf{M}^{\mathrm{c}} \mathrm{Coy}\right)$.

Ptilodictya explanata $\left(\mathrm{M}^{\mathrm{C}} \mathrm{Coy}\right)$.

Retepora Hisingeri ( $\left.\mathrm{M}^{\circ} \mathrm{Coy}\right)$.

Caryocystites Davisi ( $\mathbf{M}^{\mathrm{C}} \mathrm{Coy}$ ).

Tentaculites annulatus (Schlot.)

Beyrichia strangulata (Salt.)

Lichas subpropinqua $\left(\mathbf{M I}^{\mathrm{c}} \mathrm{Coy}\right)$.

Zethus atractopyge $\left(\mathrm{M}^{\mathrm{C}} \mathrm{Coy}\right)$.

Chasmops Odini (Eichw. Sp.)

Calymene subdiademata ( $\left.\mathbf{M}^{\mathrm{C}} \mathrm{Coy}\right) . \mathrm{V}$ ar.

Illænus Rosenbergi (Eichw.)

Spirifera biforata (Schlot. Sp.)

- - Var. $\beta$. dentata (Pand. Sp.)

- Var. $\delta$. fissicostata ( $\mathrm{II}^{\mathrm{c}} \mathrm{Coy}$ ).

- insularis (Eichw. Sp.)

- percrassa $\left(\mathbf{M}^{\mathrm{C}} \mathrm{Coy}\right)$.

Pentamerus lens (Sow. Sp.)

Orthis Actonix (Sow.)

- calligramma (Dal.)

- expansa (Sow.)

- flabellulum (Sow.)

- porcata ( $\left.\mathrm{M}^{\mathrm{c}} \mathrm{Coy}\right)$.

- Vespertilio (Sow.)

Leptæna deltoidea (Conrad).

- - Var. $\beta$. unidata ( $\left.\mathbb{1}^{\circ} \mathrm{Coy}\right)$.

- sericea (Sow.)

- transversalis (Dal.)

Strophomena antiquata (Sow. Sp.)

- pecten (Linn. Sp.)

- Spiriferoides (M $\left.\mathbf{I}^{\circ} \mathrm{Coy}\right)$.

Leptagonia depressa (Dal. Sp.)

Lingula Davisi ( $\left.\mathrm{I}^{\mathrm{c}} \mathrm{Coy}\right)$.

- ovata ( $\left.\mathbf{M}^{\circ} \mathrm{Coy}\right)$.

Orthoceras filosum (Sow.)

- laqueatum (Hall).

— vagans (Salt.)

- sub-undulatum (Portk.)

- tenuicinctum (Portk.)

Cycloceras annulatum (Sow. Sp.)

- Ibex (Sow. Sp.)

- sub-annulatum (Münst. Sp.)

Lituites cornuarites (Sow.)
Conway Falls (Hills N. of). Upper Bala.

Diplograpsus pristis (His. Sp.)

Stenopora fibrosa (Gold. Sp.)

- - Var. $a$. Lycopodites (Say).

Ceratiocaris umbonata (Salt. Sp.)

Orthis elegantula (Dal.)

- parva (Pander).

- turgida ( $\left.\mathbf{M}^{\mathrm{C}} \mathrm{Coy}\right)$.

Cucullella antiqua (Sow. Sp.)

Nucula levata (Hall).

Conway River, Montgomeryshire. Bala Group.

Trinucleus gibbifrons ( $\mathbf{I}^{\circ} \mathrm{Coy}$ ).

Portlockia apiculata (Salt. Sp.)

Corwen, Merionethshire. Upper Bala.

Stenopora fibrosa (Gold. Sp.)

Ptilodictya fucoides ( $\mathbf{M}^{\mathrm{c}} \mathrm{Coy}$ ).

Orthis elegantula (Dal.)

- parva (Pander).

- porcata (M Coy).

- Vespertilio (Sow.)

Leptæna sericea (Sow.)

Leptagonia depressa (Dal. Sp.)

Orthoceras ventricosum (Sharp Sp.)

Cowan Head, Kendal, Westmoreland. Ludlow Group. Beyrichia Klödeni (M Coy).

Hemithyris navicula (Sow. Sp.)

Craig ddu Alt, Llangollen. Lower Ludlow.

Graptolites sagittarius (Lin. Sp.)

Orthoceras subundulatum (Portk.)

Craig Head, near Girvan, Ayrshire. Upper Bula.

Palæopora favosa ( $\mathbf{M}^{\mathrm{C}} \mathrm{Coy}$ ).

Caninia turbinata (Linn. Sp.)

Strephodes Craigensis (MCoy).

Hemithyris angustifrons ( $\left.\mathbf{I}^{\mathrm{C}} \mathrm{Coy}\right)$.

- nasuta ( $\mathbf{M}^{\mathrm{C}}$ Coy).

Orthisina Scotica ( $\left.\mathbf{M}^{\mathrm{c}} \mathrm{Coy}\right)$.

Leptrena sericea (Sow.)

Maclureia macromphala ( $\left.\mathbf{M}^{-} \mathrm{Coy}\right)$.

Craig Wen, N. of Llanfair, Montgomeryshire. Upper Bala.

Orthis turgida ( $\left.\mathrm{II}^{\mathrm{C}} \mathrm{Coy}\right)$.

Leptæna quinquecostata ( $\mathrm{M}$ Coy). 
Craig-y-beri, Llanarmonfach, Montgomeryshire. Upper Bala.

Trinucleus Caractaci (Murch.)

Orthis turgida ( $\mathbf{M}^{\mathrm{C}} \mathrm{Coy}$ ).

Craig-y-Glyn, N. of Rhaidr, near Llanarmonfach. Upper Bala.

Isotelus tyrannus (Murch. Sp.)

Orthis expansa (Sow.)

- parva (Pand.)

Strophomena compressa (Sow. Sp.)

Cricor Mawr, E. of Llanelidan, Denbighshire. Upper Bala.

Leptiena sericea (Sow.)

Owm bach, Builth. Wenlock slade.

Graptolites Ludensis (Murch.)

Orthoceras primæum (Forb. Sp.)

Cwm Craig Ddu, Builth, Brecknockshire. Ludlow Group.

Hemithyris navicula (Sow. Sp.)

- nucula (Sow. Sp.)

Chonetes lata (V. Buch Sp.)

Pterinea tenuistriata $\left(\mathrm{M}^{\mathrm{c}} \mathrm{Coy}\right)$.

Leptodomus amygdalinus (Sow. Sp.)

Cardiola interrupta (Brod.)

Cwm of the Cymmerig, East of Bala, Merionethshire (see Cymmerig). Upper Bala.

Nebulipora lens ( $\left.\mathrm{M}^{\prime} \mathrm{Coy}\right)$.

Beyrichia complicata (Salt.)

Trinueleus Caractaci (Murch.)

Tretaspis seticornis (His. Sp.)

Orthis Actonixe (Sow.)

Orthoceras vagans (Salt.)

Cwmlanerch Bettws (S. of), Caernarvonshire. Upper Bala.

Trinucleus gibbifrons ( $\left.\mathbf{M}^{\mathrm{c}} \mathrm{Coy}\right)$.

Orthis elegantula (Dal.)

- expansa (Sow.)

- flabellulum (Sow.)

- testudinaria (Dal.)
Cwmlanerch Bettws (continued).

Leptrena sericea (Sow.)

Bellerophon bilobatus (Sow.)

Cwm yx Aethren, Hirnant valley, E. of Bala Lake.

Orthis Hirnantensis $\left(\mathrm{M}^{\mathrm{c}} \mathrm{Coy}\right)$.

Cymmerig, E. of Bala, Merionethshire. Upper Bala.

Phacops alifrons (Salt.)

Hemithyris Wilsoni (Sow. Sp.)

Orthis elegantula (Dal.) Var. $a$.

- plicata (Sow. Sp.)

- Vespertilio (Sow.)

Leptæna deltoidea.

- - Var. B. undata (MC Coy).

- sericea (Sow.)

Strophomena compressa (Sow. Sp.)

Modiolopsis inflata ( $\left.\mathrm{M}^{\mathrm{C}} \mathrm{Coy}\right)$.

Trochus constrictus ( $\mathrm{M}^{\mathrm{C}} \mathrm{Coy}$ ).

Trocholites planorbiformis (Conrad).

Cyrn y brain, Wrexham, Denbighshire. Upper Bala.

Stenopora fibrosa (Gold. Sp.)

Petraia subduplicata $\left(\mathrm{M}^{\mathrm{C}} \mathrm{Coy}\right)$.

Ptilodictya explanata ( $\left.\mathbf{M}^{\mathrm{c}} \mathrm{Coy}\right)$.

Retepora Hisingeri $\left(\mathbf{M}^{\circ} \mathrm{Coy}\right)$.

Spirifera biforata (Schlot. Sp.)

- - Var. $\beta$. dentata (Pand. Sp.)

- percrassa $\left(\mathbf{M}^{\mathrm{c}} \mathrm{Coy}\right)$.

Pentamerus lævis (Sow.)

Orthis porcata ( $\left.\mathbf{M}^{\mathrm{C}} \mathrm{Coy}\right)$.

- testudinaria (Dal.) Var. $\alpha$.

Orthisina ascendens (Pand. Sp.)

Leptrena deltoidea $\left(\mathbf{M}^{\mathrm{c}} \mathrm{Coy}\right)$.

- Var. $\beta$. undata ( $\left.\mathbf{M}^{\mathrm{C}} \mathrm{Coy}\right)$.

- sericea (Sow.)

Strophomena funiculata $\left(\mathrm{M}^{\mathrm{c}} \mathrm{Coy}\right)$.

- grandis (Sow. Sp.)

Leptagonia depressa (Dal. Sp.)

Pterinea pleuroptera (Conrad).

Ambonychia striata (Sow. Sp.)

Euomphalus triporcatus $\left(\mathrm{M}^{\mathrm{C}} \mathrm{Coy}\right)$.

Pleurotomaria turrita (Portk.)

Das Eithin Ridge, Hirnant, Montgomeryshire. Upper Bala.

Orthis expansa (Sow.)

- plicata (Sow. Sp.)

- retrorsistria ( $\left.\mathbf{M}^{\mathrm{c}} \mathrm{Coy}\right)$. 
Das Eithin Ridge (continued). - Vespertilio (Sow.)

Leptæna sericea (Sow.)

Lingula tenuigranulata ( $\left.\mathrm{M}^{\mathrm{c}} \mathrm{Coy}\right)$.

Dee, S. of, Llangollen. Wenlock shale.

Graptolites Murchisoni (Beck.)

Orthis parva (Pander).

Leptacna minima (Sow.)

Derby Arms, near Kendal, Westmoreland. Upper Lnedlow.

Cucullella ovata (Sow. Sp.)

Orthoceras dimidiatum (Sow.)

Dermydd Fawr, under Craig Bronbanog, Denbighshire.

Bala Group.

Ceratiocaris umbonata (Salt. Sp.)

Orthis parva (Pander).

Cycloceras annulatum (Sow. Sp.)

Dinas Bran, Llangollen, Denbighshire. Lower Latdlow and Wenlock shale.

Spongarium Edwardsi (Murch.)

Serpulites dispar (Salt.)

Hemithyris navicula (Sow. Sp.)

- nucula (Sow. Sp.)

Orthis lunata (Sow.)

Ambonychia acuticostata $\left(\mathrm{MI}^{\mathrm{C}} \mathrm{Coy}\right)$.

Cucullella coaretata (Phill. Sp.)

Nucula levata (Hall).

Theca Forbesii (Sharp).

Holopella gracilior $\left(\mathrm{M}^{\mathrm{c}} \mathrm{Coy}\right)$.

Orthoceras laqueatum (Hall).

- tenuicinctum (Portk.)

Cycloceras tracheale (Sow. Sp.)

Dinas Mowddwy, Merionethshire. Upper Bala.

Trinucleus gibbifrons $\left(\mathbf{M}^{\mathrm{C}} \mathrm{Coy}\right)$.

- radiatus (Murch.)

Orthis parva (Pander).

Strophomena Spiriferoides ( $\left.\mathbf{M}^{\mathrm{C}} \mathrm{Coy}\right)$.

Bellerophon bilobatus (Sow.)

Docker Park, Kendal. Upper Ludlow.

Protaster Sedgwicki (Forb.)

Dol Fan, Rhayadr, S. Wales. Upper Bala.

Euomphalus tricinctus ( $\left.\mathrm{M}^{\mathrm{C}} \mathrm{Coy}\right)$.
Dolydd Ceiriog Waterfall, E. of the Berwyn Mountains. Upper Bala.

Trinucleus gibbifrons $\left(\mathrm{MI}^{\mathrm{c}} \mathrm{Coy}\right)$.

Orthis testudinaria (Dal.)

Clidophorus ovalis ( $\mathrm{I}^{\mathrm{c}} \mathrm{Coy}$ ).

Bellerophon bilobatus (Sow.)

- carinatus (Sow.)

- ? expansus (Sow.)

Downton Castle, near Ludlow, Shropshire. Ludlow Group.

Hemithyris nucula (Sow. Sp.)

Orthis lunata (Sow.)

Chonetes lata (V. Buch Sp.)

Drummuck, Ayrshire. Upper Bala.

? Calymene Blumenbachi (Brong.)

Dry ridge, near Horton. Upper Bala (Coniston flag).

Favosites erassa $\left(\mathbf{M}^{\mathrm{c}} \mathrm{Coy}\right)$.

Stenopora fibrosa (Gold. Sp.)

Orthoceras primæevum (Forb. Sp.)

— subundulatum (Portk.)

Dudley, Staffordshire. Wenlock limestone.

Palæopora expatiata (Lonsd. Sp.)

Favosites aspera (d'Orb.)

- ? Gothlandica (Linn. Sp.)

Cœnites intertextus (Eichw.)

- strigatus $\left(\mathbf{M}^{\mathrm{C}} \mathrm{Coy}\right)$.

Stenopora fibrosa (Gold. Sp.)

- granulosa (Gold. Sp.)

Syringopora bifurcata (Lonsd.)

Caninia turbinata (Linn. Sp.)

Strephodes pseudo-ceratites ( $\left.\mathbf{M}^{\circ} \mathrm{Coy}\right)$.

- trochiformis ( $\left.\mathrm{II}^{\mathrm{C}} \mathrm{Coy}\right)$.

Acervularia ananas (Linn. Sp.)

Glauconome disticha (Gold.)

Fenestella patula ( $\left.\mathrm{M}^{\circ} \mathrm{Coy}\right)$.

- rigidula ( $\mathrm{M}^{\mathrm{C}} \mathrm{Coy}$ ).

Taxocrinus tuberculatus (Mill. Sp.)

Marsupiocrinus celatus (Phill.)

Crotalocrinus rugosus (Mill. Sp.)

Periechocrinus moniliformis (Mill. Sp.)

Eucalyptocrinus decorus (Phill. Sp.)

- polydactylus ( $\mathbf{I}^{\mathrm{c}} \mathrm{Coy}$ ).

Cornulites serpularis (Schlot.)

Tentaculites ornatus (Sow.) 
Dudley (continued).

Harpidella megalops ( $\mathrm{M} C \mathrm{Coy}$ ).

Acanthopyge Anglica (Bey. Sp.)

Acidaspis Brighti (Murch.)

Zethus variolaris (Brong. Sp.)

Encrinurus punctatus (Brün. Sp.)

Phacops Downingire (Murch. Sp.)

Odontochile caudata (Brong. Sp.)

Portlockia Stokesi (M. Edwards Sp.)

Calymene Blumenbachi (Brong.)

Athyris tumida (Dal. Sp.)

Spirigerina reticularis (Linn. Sp.)

Hemithyris Lewisi (David. Sp.)

- sphæroidalis $\left(\mathrm{M}^{\circ} \mathrm{Coy}\right)$.

Pentamerus galeatus (Dal. Sp.)

Orthis elegantula (Dal.)

- hybrida (Sow.)

Leptæena transversalis (Dal.)

Strophomena euglypha (Dal. Sp.)

- funiculata ( $\left.\mathrm{II}^{\circ} \mathrm{Coy}\right)$.

Leptagonia depressa (Dal. Sp.)

Pterinea retroflexa (Wahl. Sp.)

- - Var. naviformis.

Grammysia cingulata (His. Sp.)

Dyffryn Castle, Devil's Bridge, N. Wales. Upper Bala.

Leptæna lavigata (Sow.)

Erw Gilfach, Builth. Lower Ludlow.

Hemithyris navicula (Sow. Sp.)

Orthis lunata (Sow.)

Pterinea tenuistriata ( $\left.\mathrm{M}^{\mathrm{C}} \mathrm{Coy}\right)$.

Cardiola interrupta (Brod.)

Festinioge. Lingula flags.

Lingula ovata ( $\left.\mathbf{M}^{\mathrm{c}} \mathrm{Coy}\right)$,

Ffyrnwy, Llanfair, Welchpool. Wenlock shale. Graptolites Murchisoni (Beck.)

Firbank, Sedbergh, Kendal. Upper Ludlow. Nebulipora papillata ( $\left.\mathbf{M}^{\mathrm{c}} \mathrm{Coy}\right)$.

Fridd Cowny, Llanwddyn. Upper Bala,

Orthis testudinaria (Dal.)
Gaer Fawr, Montgomeryshire. Upper Bala.

Beyrichia Klodeni ( $\left.\mathbf{M}^{c} \mathrm{Coy}\right)$.

Orthis callactis (Dal.)

- elegantula (Dal.) Var. $\alpha$.

- expansa (Sow.)

- plicata (Sow. Sp.)

- rigida (Davidson).

- testudinaria (Dal.)

- Vespertilio (Sow.)

Leptrena sericea (Sow.)

Strophomena simulans ( $\mathrm{M}^{\mathrm{c} C o y}$ ).

Leptagonia depressa (Sow. Sp.)

Garden Quarry, Aymestry, Herefordshire. Lower Ludlow.

Graptolites Ludensis (Murch.)

Portlockia Stokesi (M. Edwards Sp.)

Calymene tuberculosa (Salt.)

Pentamerus galeatus (Dal. Sp.)

- Knighti (Sow.)

Ambonychia striata (Sow. Sp.)

Murchisonia Lloydi (Sow. Sp.)

Orthoceras angulatum (Wahl.)

- filosum (Sow.)

— subundulatum (Portk.)

Phragmoceras ventricosum (Sow.)

Lituites articulatus (Sow.)

Hortolus giganteus (Sow. Sp.)

Garn Brys, S. W. of Cernioge. Bala Group and Caradoc sandstone.

Orthis retrorsistria $\left(\mathrm{M}^{\mathrm{c}} \mathrm{Coy}\right)$.

Garnedd Uchaf, Bala (W. of Lake). Lower Bala. Strophomena Spiriferoides ( $\left.\mathrm{M}^{\circ} \mathrm{Coy}\right)$.

Gelli Grin, Bala, Merionethshire. Upper Bala (Bala limestone).

Stenopora fibrosa (Gold. Sp.)

- - Var. $a$. Lycopodites (Say).

Ptilodictya fucoides ( $\mathrm{M}^{\mathrm{C}} \mathrm{Coy}$ ).

Ceratiocaris umbonata (Salt. Sp.)

Trinucleus Caractaci (Murch.)

- gibbifrons ( $\left.\mathbf{M}^{\mathrm{c}} \mathrm{Coy}\right)$.

- latus (Portk.)

Spirifera biforata (Schlot. Sp.)

- - Var. d. fissicostata ( $M^{c} \mathrm{Coy}$ ). 
Gelli Grin Bala (continued).

Hemithyris marginalis (Dal. Sp.)

Orthis Actonix (Sow.)

- elegantula (Dal.) Var. $\alpha_{\text {。 }}$

- expansa (Sow.)

- flabellulum (Sow.)

- parva (Pander).

- plicata (Sow. Sp.)

- Vespertilio (Sow.)

Leptrena deltoidea.

_ - Var. $\beta$. undata ( $\left.\mathrm{M}^{\mathrm{c}} \mathrm{Coy}\right)$.

- sericea (Sow.)

- - Var. rhombica (MCoy).

Strophomena grandis (Sow. Sp.)

- Spiriferoides (M Coy).

Leptagonia depressa (Dal. Sp.) Var.

Modiolopsis antiqua (Sow. Sp.)

Turbo crebristria ( $\mathrm{M} \cdot \mathrm{Coy}$ ).

Girvan, Ayrshire. Bala Group.

Palæopora favosa $\left(\mathrm{M}^{\mathrm{C}} \mathrm{Coy}\right)$.

Stenopora fibrosa (Gold. Sp.)

Ptilodictya costellata (Mc Coy).

Leptrena quinquecostata (Mc Coy).

Glenquhaple, Ayrshire. Bala Group.

Leptrena quinquecostata ( $\left.\mathbf{M}^{\mathrm{c}} \mathrm{Coy}\right)$.

Murchisonia simplex ( $\left.\mathbf{M}^{\mathrm{C}} \mathrm{Coy}\right)$.

Orthoceras politum ( $\left.\mathrm{M}^{\mathrm{C}} \mathrm{Coy}\right)$.

Glyn Ceiriog, S. of Llangollen, Denbighshire. Upper Bala.

Ptilodictya explanata ( $\left.\mathbf{M}^{\mathrm{C}} \mathrm{Coy}\right)$.

Trinucleus gibbifrons ( $\left.\mathrm{M}^{\mathrm{C}} \mathrm{Coy}\right)$.

Portlockia apiculata (Salt.)

Chasmops Odini (Eichw. Sp.)

Goldengrove, Llandeilo. Wentock shale and Upper Bala.

Stenopora fibrosa (Gold. Sp.)

Trinucleus gibbifrons $\left(\mathbf{M}^{\circ} \mathrm{Coy}\right)$.

Calymene Baylei (Barr.)

Isotelus tyrannus (Murch, Sp.)

Spirifera trapezoidalis (Dal.)

Orthis calligramma (Dal.)

- turgida ( $\left.\mathbf{M}^{\mathrm{c}} \mathrm{Coy}\right)$.

Leptæena corrugata (Portk. Sp.)

Strophomena simulans ( $\mathbf{M}^{\mathrm{C}} \mathrm{Coy}$ ).

Euomphalus triporcatus $\left(\mathrm{M}^{\mathrm{c}} \mathrm{Coy}\right)$.

[FASC. II.]
Goleugoed, Mandinam, Llandovery, Caermarthenshire.

Upper Bala.

Palæopora petalliformis (Lonsd. Sp.)

- tubulata (Lonsd. Sp.)

Favosites alveolaris (Gold.)

- Gothlandica (Linn. Sp.)

Stenopora fibrosa (Gold. Sp.)

Halysites catenulatus (Linn. Sp.)

Ceraurus Williamsi ( $\left.\mathbf{I}^{\mathrm{c}} \mathrm{Coy}\right)$.

Hemithyris marginalis (Dal. Sp.)

Pentamerus oblongus (Sow.)

- undatus (Sow. Sp.)

Orthis parva (Pander).

- protensa (Sow.)

Leptæna quinquecostata ( $\left.\mathbf{M}^{c} \mathrm{Coy}\right)$.

- sericea (Sow.)

Greiston on the Tweed, near Inverleithen. Bala Group.

Graptolites Ludensis (Murch.)

- Sedgrwicki (Portk.)

- tenuis (Portk.)

Myrianites tenuis $\left(M^{\mathrm{c}} \mathrm{Coy}\right)$.

Gwyddelwern, Derwen, near Corwen, Denbighshire.

Caradoc sandstone.

Graptolites Ludensis (Murch.)

Leptæna lævigata (Sow.)

- minima (Sow.)

Nuculites post-striatus (Emmons).

Hafod Evan Penmachno, Caernarvonshire. Upper Bala.

Orthis retrorsistria $\left(\mathrm{M}^{\mathrm{c}} \mathrm{Coy}\right)$.

Haykin Gill, Cumberland. Skiddaw slate.

Graptolites sagittarius (Linn. Sp.)

Helms Gill, Dent, Yorkshire. Upper Bala (Coniston limestone.)

Orthis crispa ( $\left.\mathrm{M}^{\mathrm{C}} \mathrm{Coy}\right)$.

Helms Knot, Dent. Upper Bala (Coniston fag.)

Graptolites Ludensis (Murch.)

Stenopora fibrosa (Gold. Sp.)

Cardiola interrupta (Brod.)

Orthoceras sub-undulatum (Portk.)

Cycloceras sub-annulatum (Munst. Sp.) 
Hengurt Uchaf, Arran Fowddy, N. WVales. Lower Bala. Portlockia apiculata (Salt.)

High Haume, Dalton, in Furness. Upper Bala (Coniston limestone.)

Palæopora megastoma $\left(\mathrm{M}^{\circ} \mathrm{Coy}\right)$.

Halysites catenulatus (Linn. Sp.)

Sarcinula organum (Linn. Sp.)

Petraia xquisulcata ( $\mathrm{M}^{\mathrm{c}} \mathrm{Coy}$ ).

Calymene subdiademata ( $\left.\mathrm{M}^{\circ} \mathrm{Coy}\right)$.

Spirifera biforata.

- Var. a. lynx (Eichw. Sp.)

Orthis Actoniæ (Sow.)

- porcata ( $\left.\mathbf{M}^{\mathrm{c} C o y}\right)$.

High Thorns, Underbarrow, Kendal, Westmoreland. Upper Ludlow.

Taxocrinus Orbigni ( $\mathbf{M}^{\mathrm{C}} \mathrm{Coy}$ ).

Uraster Ruthveni (Forb.)

- primævus (Forb.)

Calymene tuberculosa (Salt.)

Pterinea retroflexa (Wahl. Sp.) Var. a.

Gramnysia cingulata (His. Sp.)

- Var. $\gamma$. obliqua ( $\left.\mathrm{M}^{\circ} \mathrm{Coy}\right)$.

Arca primitiva (Phill.)

Nucula Anglica (d'Orb.)

Holopella intermedia $\left(\mathrm{MI}^{\circ} \mathrm{Coy}\right)$.

Litorina octavia (Sow. Sp.)

Orthoceras sub-undulatum (Portk.)

Hortolus Ibex (Sow. Sp.)

Hollies, Church Stretton, Shropshire. Caradoc sandstone.

Diplograpsus pristis (His. Sp.)

Tentaculites annulatus (Schlot.)

Serpulites dispar (Salt.)

Trinucleus Caractaci (Murch.)

Odontochile truncato-caudata (Portk. Sp.)

Hemithyris navicula (Sow. Sp.)*

- pentagona (Sow. Sp.)*

- sphæroidalis $\left(\mathbf{M}^{\mathrm{c}} \mathrm{Coy}\right){ }^{*}$

Pentamerus Knightii (Sow.)

- oblongus (Sow.)

Orthis calligramma (Dal.)

- expansa (Sow.)
Hollies, Church Stretton (continued).

- testudinaria (Dal.)

Leptæna sericea (Sow.)

- tenuissimestriata $\left(\mathrm{M}^{c} \mathrm{Coy}\right)$.

Horderly, S. and W. Shropshire. Caradoc sandstone.

Diplograpsus pristis (His. Sp.)

Nebulipora lens ( $\left.\mathbf{M}^{\circ} \mathrm{Coy}\right)$.

Petraia bina (Lonsd. Sp.)

Tentaculites annulatus (Schlot.)

Trinucleus Caractaci (Murch.)

- gibbifrons ( $\mathrm{M}^{\mathrm{c}} \mathrm{Coy}$ ).

Calymene brevicapitata (Portk.)

Pentamerus lævis (Sow.)

- oblongus (Sow.)

Orthis elegantula (Dal.) Var. $a$.

- expansa (Sow.)

- parva (Pander).

- porcata ( $\left.\mathbf{M}^{\mathrm{c}} \mathrm{Coy}\right)$.

- testudinaria (Dal.)

- Vespertilio (Sow.)

Leptæna deltoidea (Conrad).

Strophomena compressa (Sow. Sp.)

- grandis (Sow. Sp.)

- Spiriferoides ( $\left.\mathbf{M}^{\mathrm{C}} \mathrm{Coy}\right)$.

Leptagonia depressa (Dal. Sp.)

Modiolopsis modiolaris (Con. Sp.)

Orthonotus nasutus (Con. Sp.)

Bellerophon bilobatus (Sow.)

Horeb Chapel, Llandovery, S. Wales. Upper Ludlow.

Pterinea retroflexa. Var.

Cucullella ovata (Sow. Sp.)

Orthonota cymbiformis (Sow. Sp.)

Holopella gregaria (Sow. Sp.)

- obsoleta (Sow. Sp.)

Bellerophon expansus (Sow.)

- Murchisoni (d'Orb.)

Orthoceras semipartitum (Sow.)

Horton, in Ribblesdale, Yorkshire. Upper Bala.

Graptolites sagittarius (His. Sp.)

Stenopora fibrosa (Gold. Sp.)

Zethus atractopyge ( $\left.\mathrm{M}^{\circ} \mathrm{Coy}\right)$.

Calymene brevicapitata (Portk.)

* A small bit of Ludlow Limestone appears near this, and no doubt furnished these three specimens. 
Horton (continued).

Orthis Actoniæ (Sow.)

- calligramma (Dal.)

- parva (Pander). Var. avellana.

- plicata (Sow. Sp.)

Leptæna sericea (Sow.)

- Var. rhombica ( $\left.\mathbf{M}^{\mathrm{C}} \mathrm{Coy}\right)$.

Strophomena pecten (Linn. Sp.)

Howgill Fell, near Sedbergh, Kendal, Westmoreland. Wentock shale.

Pterinea subfalcata (Con. Sp.)

Orthoceras subundulatum (Portk.)

Cycloceras tracheale (Sow. Sp.)

Ingleton and Thornton Beck, Westmoreland. Upper Bala.

Stenopora fibrosa (Gold. Sp.)

Halysites catenulatus (Linn. Sp.)

Orthis Actoniæ (Sow.)

Keeper's Lodge, Goldengrove, Llandeilo, Caermarthenshire. Wenlock shale and Upper Bala.

Orbiculoidea implicata (Sow. Sp.)

Spirifera crispa (Linn. Sp.)

- radiata (Sow.)

Spirigerina reticularis (Linn. Sp.)

Pentamerus globosus (Sow. Sp.)

Orthis expansa (Sow.)

- lunata (Sow.)

Leptæna lævigata (Sow.)

- sericea (Sow.)

Strophomena filosa (Sow. Sp.)

Leptagonia depressa (Dal. Sp.)

Clidophorus planulatus (Conrad Sp.)

Kendal, Westmoreland. Upper Ludlow.

Stenopora fibrosa.

- - Var. $\beta$. regularis ( $\left.M^{\mathrm{c} C o y}\right)$.

Pterinea retroflexa (Wahl. Sp.)

- - Var. naviformis.

Orthoceras tenuicinctum (Portk.)

Kington, Herefordshire. Upper Ludlow.

Orthis lunata (Sow.)

Chonetes lata (V. Buch Sp.)

Kirkby Moor, Kendal, Westmoreland. Upper Ludloz.

Tentaculites tenuis (Sow.)

Eurypterus cephalaspis (Salt.)
Kirkby Moor (continued).

Pterinea retroflexa (Wahl. Sp.)

_- _ Var. naviformis.

Modiolopsis complanata (Sow. Sp.)

Anodontopsis angustifrons ( $\left.\mathrm{M}^{\mathrm{C}} \mathrm{Coy}\right)$.

- bulla $\left(\mathrm{M}^{\mathrm{c}} \mathrm{Coy}\right)$.

Orthonotus semisulcatus (Sow. Sp.)

Leptodomus globulosus ( $\left.\mathbf{M}^{\mathrm{C}} \mathrm{Coy}\right)$.

Orthoceras imbricatum (Wahl.)

- laqueatum (Hall).

Cycloceras Ibex (Sow. Sp.)

- tracheale (Sow. Sp.)

Knockdollian Mountain, three miles from Ballintrae, Ayrshire. Lower Bala.

Illanus latus ( $\left.\mathrm{I}^{\mathrm{c}} \mathrm{Coy}\right)$.

Maclureia magna (Leseur).

Eccyliomphalus Scoticus ( $\left.\mathrm{M}^{\mathrm{c}} \mathrm{Coy}\right)$.

Murchisonia angustata (Hall).

Cyrtoceras multicameratum (Hall).

Kinockmurton, Cumberland. Skiddaw slate.

Graptolites latus ( $\left(\mathrm{I}^{\mathrm{C}} \mathrm{Coy}\right)$.

- sagittarius (Linn. Sp.)

Lambrigg Fell, Kendal, Westmoreland. Upper Ludlove.

Spirifera sub-spuria (d'Orb.)

Hemithyris nucula (Sow. Sp.)

Chonetes lata (V. Buch Sp.)

Theca Forbesii (Sharp).

Holopella cancellata (Sow. Sp.)

Orthoceras bullatum (Sow.)

Lampeter, Cardiganshire. Upper Bala.

Nemertites Oliranti (Murch.)

Nereites Cambrensis (Murch.)

- Sedgrvicki (Murch.)

Myrianites Macleayi (Murch.)

Laverock Lane, Westmoreland. Upper Ludlovo.

Pterinea retroflexa (Wahl. Sp.)

- erect. Var.

Orthoceras bullatum (Sow.)

Ledbury, Herefordshire. Wenlock limestone.

Favosites aspera (d'Orb.)

- Gothlandica (Linn. Sp.)

Caninia tuxbinata (Linn. Sp.) 
Ledbury (continued).

Acervularia ananas (Linn. Sp.)

Forbesia Stokesi (Murch. Sp.)

Spirifera cyrtæena (Dal. Sp.)

Hemithyris didyma (Dal. Sp.)

- sphæroidalis ( $\left.\mathrm{M}^{\mathrm{C}} \mathrm{Coy}\right)$.

Euomphalus rugosus (Sow.)

Capulus Haliotis (Sow. Sp.)

Orthoceras Brighti (Sow.)

- Mocktreense (Sow.)

Cycloceras annulatum (Sow. Sp.)

Hortolus Ibex (Sow. Sp.)

Leintwardine, Shropshire. Lower Ludlow.*

Graptolites Ludensis (Murch.)

Spirorbis tenuis (Sow.)

Odontochile caudata (Brong. Sp.)

Calymene subdiademata ( $\left.\mathbf{M}^{\mathrm{C}} \mathrm{Coy}\right)$.

Pterygotus lepto-dactylus ( $\left.\mathrm{M}^{\mathrm{C}} \mathrm{Coy}\right)$.

Discina Morrisi (Davidson Sp.)

Spirigerina reticularis (Linn. Sp.)

Hemithyris crispata (Sow. Sp.)

- nucula (Sow. Sp.)

- Wilsoni (Sow. Sp.)

Pentamerus galeatus (Dal. Sp.)

- Knighti (Sow.)

Orthis lunata (Sow.)

Strophomena euglypha (Dal. Sp.)

Lingula lata (Sow.)

Pterinea retroflexa (Wahl, Sp.) Var. $\alpha$.

- Sowerbi ( $\left.\mathbf{M}^{\mathrm{c}} \mathrm{Coy}\right)$.

Ambonychia striata (Sow. Sp.)

Cardiola interrupta (Brod.)

Loxonema elegans $\left(\mathrm{MI}^{\mathrm{C}} \mathrm{Coy}\right)$.

Euomphalus centrifugus (Wahl. Sp.)

Pleurotomaria lenticularis (Sow. Sp.)

- undata (Sow.)

Murchisonia cingulata (His. Sp.)

Capulus Euomphaloides $\left(\mathrm{M}^{\mathrm{C}} \mathrm{Coy}\right)$.

Orthoceras dimidiatum (Sow.)

- filosum (Sow.)

- Ludense (Sow.)

- sub-undulatum (Portk.)

Cycloceras tenuiannulatum ( $\left.\mathrm{M}^{\mathrm{c}} \mathrm{Coy}\right)$.

Phragmoceras intermedium ( $\mathbf{M}^{\mathrm{C}} \mathrm{Coy}$ ).

Hortolus giganteus (Sow. Sp.)
Lightbeck, Underbarrow, Kendal. Upper Ludlow. Iethyocrinus pyriformis (Phill. Sp.)

Littlehope, near Woolhope. Woolhope limestone.

Spirigerina reticularis (Linn. Sp.)

Strophomena euglypha (Dal. Sp.)

- pecten (Linn. Sp.)

Leptagonia depressa (Dal. Sp.)

Llanbedrog, Caernarvonshire. Bala Group.

Leptagonia depressa (Dal. Sp.) Var.

Llandeilo, Caermarthenshire. Upper Bala.

Palæopora interstincta (Wahl. Sp.)

- - Var. $\alpha$. subtubulata ( $\left.\mathbf{M}^{\mathrm{c}} \mathrm{Coy}\right)$.

Stenopora fibrosa (Gold. Sp.)

Ogygia Buchi (Brong. Sp.)

Odontochile caudata (Brong. Sp.)

Chasmops Odini (Eich. Sp.)

Calymene brevicapitata (Portk.)

Isotelus tyrannus (Murch. Sp.)

Displanus centrotus (Dal. Sp.)

Spirifera biforata (Schlot.)

- - Var. c. biforata (Schlot. Sp.)

Orthis confinis (Salt.)

- expansa (Sow.)

- turgida ( $\left.\mathrm{M}^{\mathrm{c}} \mathrm{Coy}\right)$.

- Vespertilio (Sow.)

Leptæena deltoidea (Con.)

- - Var. $\beta$. undata ( $\left.\mathrm{M}^{\mathrm{c}} \mathrm{Coy}\right)$.

- tenuissimestriata ( $\mathrm{M}^{\mathrm{C}} \mathrm{Coy}$ ).

Lingula granulata (Phill.)

- obtusa (Hall).

Trochus helicites (Sow.)

Orthoceras centrale?(His.)

Llanfair Road, W. of Welchpool. W'enlock shale.

Graptolites Murchisoni (Beck.)

Beyrichia Klodeni ( $\left.\mathrm{I}^{\mathrm{c}} \mathrm{Coy}\right)$.

Odontochile caudata (Brong. Sp.)

Leptæna minima (Sow.)

Llanfechan (W. of), Montgomeryshire. Upper Bala.

Trinucleus Caractaci (Murch.)

Orthis elegantula (Dal.) Var. $a$.

- expansa (Sow.)

\footnotetext{
* The limestone specimens are not separately characterized as Aymestry limestone.
} 
Llanfechan (continued).

Leptæna sericea (Sow.)

Murchisonia gyragonia ( $\left.\mathrm{M}^{\mathrm{c}} \mathrm{Coy}\right)$.

Llanfwrog, near Ruthin. Lower Ludlow or Wenlock shale.

Beyrichia complicata (Schlot.)

Ceratiocaris umbonata (Salt. Sp.)

Orthis parva (Pander).

Llanfyllin, Montgomeryshire. Upper Bala.

Stenopora fibrosa (Gold. Sp.)

Ptilodictya explanata ( $\left.\mathbf{M}^{\circ} \mathrm{Coy}\right)$.

Glauconome disticha (Gold.)

Hemithyris marginalis (Dal. Sp.)

Orthis expansa (Sow.)

- parva (Pander).

- retrorsistria ( $\left.\mathbf{M}^{\mathrm{C}} \mathrm{Coy}\right)$.

Leptana sericea (Sow.)

Llangollen, Denbighshire. Lower Ludlow and Wenlock shale.

Spirifer crispus (Linn. Sp.)

Hemithyris nucula (Sow. Sp.)

Llangynyw Rectory, near Welchpool, Montgomeryshire. Wenlock shale.

Graptolites Ludensis (Murch.)

- - Var. minor ( $\left.\mathrm{M}^{\mathrm{c}} \mathrm{Coy}\right)$.

Favosites alveolaris (Gold.)

Portlockia Stokesii (M. Edwards Sp.)

Calymene brevicapitata (Portk.)

Spirifera insularis (Eichw. Sp.)

Leptrena quinquecostata $\left(\mathrm{M}^{\mathrm{c}} \mathrm{Coy}\right)$.

Cardiola interrupta (Brod.)

Arca Edmondiiformis ( $\left.\mathrm{M}^{\mathrm{c}} \mathrm{Coy}\right)$.

Orthoceras angulatum (Wahl.)

- subundulatum (Portk.)

Llanrwst, Denbighshire. Caradoc group.

Graptolites Ludensis (Murch.)

Bellerophon subdecussatus ( $\left.\mathbf{I}^{\mathrm{C}} \mathrm{Coy}\right)$.

Llansaintfraid Glyn Ceiriog, S. of Llangollen. Upper Bala.

Diplograpsus pristis (His. Sp.)

Palæopora interstincta (Wahl. Sp.)

- - Var. a. subtubulata ( $\left.\mathbf{M}^{\mathrm{C}} \mathrm{Coy}\right)$.
Llansaintfraid Glyn Ceiriog (continued).

Favosites alveolaris (Gold.)

Stenopora fibrosa (Gold. Sp.)

- - Var. a. Lycopodites (Say).

Halysites catenulatus (Linn. Sp.)

Petraia requisulcata ( $\left.\mathbf{M}^{\mathrm{c}} \mathrm{Coy}\right)$.

- subduplicata $\left(\mathrm{M}^{\mathrm{C}} \mathrm{Coy}\right)$.

- uniserialis ( $\mathrm{I}^{\mathrm{C}} \mathrm{Coy}$ ).

Ptilodictya acuta (Hall Sp.)

- costellata (Mc Coy).

- explanata ( $\left.\mathrm{I}^{\mathrm{C}} \mathrm{Coy}\right)$.

- fucoides ( $\left.\mathbf{M}^{\mathrm{C}} \mathrm{Coy}\right)$.

Glauconome disticha (Gold.)

Fenestella Milleri (Lonsd. Sp.)

- subantiqua (d'Orb.)

Tentaculites annulatus (Schlot.)

Trinucleus Caractaci (Murch.)

- gibbifrons ( $\left.\mathbf{M}^{\mathrm{C}} \mathrm{Coy}\right)$.

Chasmops Odini (Eich. Sp.)

Orthis Actoniæ (Sow.)

- calligramma (Dal.)

- - Var. $a$. calliptycha ( $\left.\mathbf{M}^{\mathrm{c}} \mathrm{Coy}\right)$.

- elegantula (Dal.) Var. a.

- expansa (Sow.)

- flabellulum (Sow.)

- parva (Pander).

- plicata (Sow. Sp.)

- poreata ( $\left.\mathrm{M}^{\mathrm{c}} \mathrm{Coy}\right)$.

Leptæna sericea (Sow.)

- transversalis (Dal.)

Strophomena antiquata (Sow. Sp.)

Leptagonia depressa (Dal. Sp.)

- ungula ( $\left.\mathrm{M}^{\mathrm{c}} \mathrm{Coy}\right)$.

Euomphalus lyratus ( $\left.\mathrm{M}^{\mathrm{C}} \mathrm{Coy}\right)$.

Llanwddyn in the (E. of) Berwyn Mountains. Upper

Bala.

Trinucleus Caractaci (Murch.)

Calymene Blumenbachi (Brong.)

Isotelus Powisi (Murch.)

Illsenus Davisi (Salt.)

Dysplanus centrotus (Dal. Sp.)

Orthis flabellulum (Sow.)

- retrorsistria $\left(\mathrm{M}^{\mathrm{C}} \mathrm{Coy}\right)$.

Strophomena grandis (Sow.)?

Bellerophon bilobatus (Sow.) 
Llechlawdd, near Llandovery, S. Wales. Upper Ludlow.

Anodontopsis levis (Sow. Sp.)

Sanguinolites decipiens ( $\mathbf{M}^{\mathrm{C}} \mathrm{Coy}$ ).

Grammysia cingulata.

- - Var. $\beta$. triangulata (Salt. Sp.)

Arca subrequalis ( $\left.\mathbf{I}^{\mathrm{c}} \mathrm{Coy}\right)$.

Cucullella ovata (Sow. Sp.)

Llechwedd LIwyd, near Llanfyllin, Montgomeryshire. Upper Bala.

Ptilodictya acuta (Hall Sp.)

- - Var. minor.

Trinucleus Caractaci (Murch.)

Llyn Alwen, Denbighshire. Wenlock shale.

Leptæna tenuicineta ( $\left.\mathrm{M}^{\mathrm{c}} \mathrm{Coy}\right)$.

Orthoceras bullatum (Sow.)

Llyn Ogwen, N. Wales. Bala Group.

Orthis flabellulum (Sow.)

- - Var.

- parva (Pander).

-. sarmentosa $\left(\mathbf{M}^{\mathrm{c}} \mathrm{Coy}\right)$.

Pleurotomaria turrita (Portk.)

Llwyn-y-ci, N. W. of Bala. Upper Bala (Bala limestone.)

Trinucleus latus (Portk.)

Ceraurus clavifrons (Dal. Sp.)

Zethus sexcostatus (Salt. Sp.)

Illænus Davisi (Salt.)

Orthis elegantula (Dal.) Var. $a$.

- expansa (Sow.)

- parva (Pander).

- Vespertilio (Sow.)

Leptæna deltoidea (Sow.)

- transversalis (Dal.)

Orthoceras vagans (Salt.)

Lockerby,* Dumfriesshire. Lower Bala.

Graptolites convolutus (His. Sp.)

- lobiferus ( $\left.\mathbf{M}^{\circ} \mathrm{Coy}\right)$.

- Millipeda ( $\left.\mathbf{I}^{\mathrm{C}} \mathrm{Coy}\right)$.

- sagittarius (Linn. Sp.)

- Sedgwicki (Portk.)
Lockerby (continued).

Graptolites tenuis (Portk.)

Diplograpsus folium (His. Sp.)

- pristis (His. Sp.)

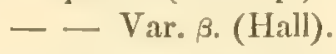

- rectangularis ( $\mathrm{M}^{\mathrm{C}} \mathrm{Coy}$ ).

Protovirgularia dichotoma (McCoy).

Long Sleddale, Westmoreland. Upper Bala and Wenlock shale.

Palæopora interstincta (Wahl. Sp.)

Sarcinula organum (Linn. Sp.)

Nucula? Anglica (d'Orb.)

Ludlow, Shropshire. Upper Ludlow.

Serpulites longissimus (Murch.)

Discina rugata (Sow. Sp.)

Hemithyris nucula (Sow. Sp.)

Orthis lunata (Sow.)

Chonetes lata (V. Buch Sp.)

Lingula cornea (Sow.)

Pterinea tenuistriata ( $\mathrm{I}^{\mathrm{C}} \mathrm{Coy}$ ).

Leptodomus amygdalinus (Sow. Sp.)

- - Var. retusus.

Euomphalus rugosus (Sow.)

Bellerophon expansus (Sow.)

Cycloceras tracheale (Sow. Sp.)

Maerdy Bach, one mile S. of Llandeilo. Upper Bala.
Ogygia Buchi (Brong. Sp.)
Modiolopsis expansa (Portk.)

Maen Goran, Llangollen, Denbighshire. Wenlock shale.

Isotelus laticostatus (Green Sp.)

Cardiola interrupta (Brod.)

Maes Hir, N. E. of Aber Hirnant, N. Wales. Upper Bala.

Spirifera biforata (Schlot.)

- var. D. fissicostata ( $\left.\mathbf{M}^{c} \mathrm{Coy}\right)$.

Orthis Hirnantensis ( $\mathrm{M}^{\mathrm{C}} \mathrm{Coy}$ ).

Modiolopsis modiolaris (Conrad).

* Under this locality Professor Sedgwick has just informed me he has placed the specimens collected, not only at Inckerby, but in all the black graptolite slate localities a few miles N., and a few miles S. of Moffatt and Beatock Bridge. 
Maes Meillion, S. of Bala, N. Wales. Upper Bala (Bala limestone).

Palæopora megastoma ( $\left.\mathrm{II}^{\mathrm{C}} \mathrm{Coy}\right)$.

Trinucleus latus (Portk.)

Portlockia apiculata (Salt.)

Homalonotus bisulcatus (Salt.)

Spirifera biforata (Schlot.)

- - Var. a. lynx (Eichwald Sp.)

Orthis Actonix (Sow.)

- parra (Pander).

- plicata (Sow. Sp.)

Maes-y-fallen, Bala. Upper Bala.

Spirifera biforata (Schlot.)

- - Var. a. lynx (Eichwald Sp.)

Orthis elegantula (Dal.)

- Hirnantensis ( $\left.\mathrm{M}^{\mathrm{C}} \mathrm{Coy}\right)$.

- testudinaria (Phill.)

Malverns, Worcestershire. Louer Ludlow, or IWenlock shale.

Vioa prisea $\left(\mathrm{M}^{\mathrm{c}} \mathrm{Coy}\right)$.

Palseopora interstincta (Wahl. Sp.)

Favosites aspera (d'Orb.)

Pterinea demissa (Conrad Sp.)

Strophomena simulans $\left(\mathrm{M}^{\mathrm{C}} \mathrm{Coy}\right)$.

Mandinam, Caermarthenshire. Upper Bala.

Pentamerus lens (Sow. Sp.)

- microcamerus $\left(\mathrm{M}^{c} \mathrm{Coy}\right)$.

- undatus (Sow. Sp.)

Turbo crebristria (M'Coy).

- Williamsi (Sow. Sp.)

Mathyrafal, S. of Meifod, Montgomeryshire. Upper Bala.

Palæopora megastoma ( $\mathrm{M}^{\mathrm{C}} \mathrm{Coy}$ ).

Favosites alveolaris (Gold.)

- - Var. multipora (Lonsd.)

Stenopora fibrosa (Gold. Sp.)

Caninia turbinata (Linn. Sp.)

Halysites catenulatus (Linn. Sp.)

Petraia uniserialis $\left(\mathrm{M}^{\mathrm{c}} \mathrm{Coy}\right)$.

Ptilodictya costellata ( $\mathrm{M}^{\mathrm{C}} \mathrm{Coy}$ ).

- explanata $\left(\mathrm{MI}^{\mathrm{c}} \mathrm{Coy}\right)$.

Fenestella subantiqua $\left(\mathrm{M}^{\mathrm{c}} \mathrm{Coy}\right)$.

Beyrichia complicata (Salt.)
Mathyrafal (continued).

Encrinurus punctatus (Brünn. Sp.)

Calymene brevicapitata (Portk.)

Spirifera biforata (Schlot)

- - Var. c. biforata (Schlot.)

- - Var. $d$. fissicostata ( $\left.\mathbf{I}^{\circ} \mathrm{Coy}\right)$.

- percrassa ( $\left.\mathrm{M}^{\circ} \mathrm{Coy}\right)$.

Spirigerina marginalis (Dal. Sp.)

Hemithyris Lewisi (Davidson Sp.)

- subundata ( $\mathrm{I}^{\mathrm{c}} \mathrm{C} \mathrm{Cy}$ ).

Orthis Actonix (Sow.)

- elegantula (Dal.)

- expansa (Sow.)

- hybrida (Sow.)

- parva (Pander).

- plicata (Sow. Sp.)

- protensa (Sow.)

- testudinaria (Dal)

- turgida $\left(\mathrm{M}^{\mathrm{e}} \mathrm{Coy}\right)$.

Leptæna quinquecostata ( $\left.\mathbf{M}{ }^{\circ} \mathrm{Coy}\right)$.

- sericea (Sow.)

- - Var. rhombica ( $\mathrm{M}^{\mathrm{C}} \mathrm{Coy}$ ).

Strophomena antiquata (Sow. Sp.)

- grandis (Sow. Sp.)

Leptagonia depressa (Dal. Sp.)

Murchisonia pulchra ( $\left.\mathrm{M}^{\mathrm{I}} \mathrm{Coy}\right)$.

May Hill, Gloucestershire. Wenlock grits and Carcdoc sandstone.

Halysites catenulatus (Linn. Sp.)

Encrinurus punctatus (Brünn. Sp.)

Spirigerina reticularis (Linn. Sp.)

Hemithyris navicula (Sow. Sp.)

Pentamerus microcamerus ( $\left.\mathrm{I}^{\circ} \mathrm{Coy}\right)$.

Orthis turgida? ( $\left.\mathrm{I}^{\prime} \mathrm{Coy}\right)$.

Leptrna transversalis (Dal.)

Strophomena pecten (Linn. Sp.)

Leptagonia depressa (Dal. Sp.)

Euomphalus funatus (Sow.)

Middleton Park, Caermarthenshire. Wenlock shale.

Favosites alveolaris (Gold.)

Encrinurus punctatus (Brünn. Sp.)

Odontochile longicaudata (IIurch. Sp.)

Homalonotus Knighti (Kinig.)

Spirigerina reticularis (Linn. Sp.)

Orthis expansa (Sow.)

Strophomena pecten (Linn. Sp.) 
Middleton Park (continued).

Chonetes lata (V. Buch Sp.)

Pterinea demisa (Conrad Sp.)

- lineata (Gold.)

- tenuistriata ( $\left.\mathbf{M}^{\mathrm{C} C o y}\right)$.

Modiolopsis Nilsoni (His. Sp.)

Militir Cerrig Llangynnog, Montgomeryshire. Lower Bald.

Beyrichia complicata (Salt.)

Orthis elegantula (Dal.) Var. $a$.

- retrorsistria ( $\left.\mathrm{M}^{\mathrm{c}} \mathrm{Coy}\right)$.

Leptæna sericea (Sow.)

Nucula levata (Hall).

Moel Seisiog, Llanrwst, Denbighshire. Caradoc sandstone.

Graptolites sagittarius (Linn. Sp.)

Phacops Downingiæ (Murch. Sp.)

Spirifera percrassa ( $\left.\mathrm{M}^{\mathrm{C}} \mathrm{Coy}\right)$.

Orthis elegantula (Dal.) Var. $\alpha_{0}$

Leptæna sericea (Sow.)

- tenuissimestriata $\left(\mathrm{M}^{\circ} \mathrm{Coy}\right)$.

Strophomena compressa (Sow. Sp.)

Area? Edmondiiformis ( $\left.\mathrm{M}^{\circ} \mathrm{Coy}\right)$.

Orthoceras subundulatum (Portk.)

Moel Uchlas, Montgomeryshire. Upper Bala.

Nebulipora lens ( $\mathrm{I}^{\circ} \mathrm{Coy}$ ).

Stenopora fibrosa (Gold. Sp.)

- - Var. $a$. Lycopodites (Say).

Beyrichia complicata (Salt.)

Orthis elegantula (Dal.) Var. $a$.

- expansa (Sow.)

- flabellulum (Sow.)

- testudinaria (Dal.)

- Vespertilio (Sow.)

Leptæna sericea (Sow.)

Stroplomena compressa (Sow. Sp.)

Pterinea lineata (Gold.)

Moel-y-Garth, Welchpool, Montgomeryshire.

Bala.

Strophomena Spiriferoides ( $\left.\mathbf{M}^{\mathrm{c}} \mathrm{Coy}\right)$.

Moel y Garnedd Uchaf, Bala Lake. Lower Bala.

Tretaspis seticornis (His. Sp.)

Orthis flabellulum (Sow.)

- Vespertilio (Sow.)
Mortimer's Cross, Aymestry. Upper Ludlow.

Hemithyris nucula (Sow. Sp.)

Orthis lunata (Sow.)

Chonetes lata (V. Buch Sp.)

Lingula lata (Sow.)

Pterinea hians ( $\left.\mathrm{M}^{\mathrm{C}} \mathrm{Coy}\right)$.

Leptodomus impressus (Sow. Sp.)

Litorina undifera ( $\left.\mathrm{M}^{\mathrm{c}} \mathrm{Coy}\right)$.

Orthoceras subundulatum (Portk.)

Mullock Quarry, Dalquorrhan, near Girvan, Ayrshire.

Upper Bala.

Palæopora favosa ( $\left.\mathbf{M}^{c} \mathrm{Coy}\right)$.

- subtilis ( $\mathrm{I}^{\mathrm{C}} \mathrm{Coy}$ ).

- tubulata (Lonsd. Sp.)

Favosites alveolaris (Gold.)

Petraia requisulcata $\left(\mathrm{M}^{\mathrm{c}} \mathrm{Coy}\right)$.

- subduplicata ( $\mathrm{I}^{\mathrm{c}} \mathrm{Coy}$ ).

Ptilodictya costellata.

Tentaculites ornatus (Sow.)

Harpidella megalops ( $\left.\mathrm{M}^{\mathrm{c}} \mathrm{Coy}\right)$.

Calymene subdiademata ( $\left.\mathrm{M}^{\mathrm{C}} \mathrm{Coy}\right)$.

Illænus Rosenbergi (Eichw.)

Hemithyris angustifrons $\left(\mathrm{M}^{\mathrm{c}} \mathrm{Coy}\right)$.

- hemisphrica (Sow. Sp.)

- - Var. Scotica ( $\left.\mathbf{M}^{\mathrm{c}} \mathrm{Coy}\right)$.

Orthis confinis (Salt.)

- elegantula (Dal.) Var. a.

- parva (Pander).

- - Var. avellana.

- reversa (Salt.)

- testudinaria (Dal.)

Leptrena alternata (Conrad).

Orthonotus semisulcatus (Sow. Sp.)

Holopella tenuicincta ( $\left.\mathrm{M}^{\mathrm{C}} \mathrm{Coy}\right)$.

Trochus helicites (Sow.)

- Moorei (McCoy).

Euomphalus tricinctus ( $\mathrm{M}^{\mathrm{c}} \mathrm{Coy}$ ).

Eccyliomphalus Scoticus ( $\left.\mathrm{MI}^{\circ} \mathrm{Coy}\right)$.

Murchisonia cancellatula ( $\left.\mathrm{M}^{\mathrm{c}} \mathrm{Coy}\right)$.

- pulchra ( $\left.\mathrm{I}^{\circ} \mathrm{Coy}\right)$.

- simplex ( $\mathrm{I}^{\mathrm{C}} \mathrm{Coy}$ ).

Bellerophon dilatatus (Sow.)

- subdecussatus (Mㄷoy).

Orthoceras tenuistriatum (Münst.)

Mynydd Mawr, Caermarthenshire. Upper Bald.

Beyrichia complicata (Salt.) 
Mynydd Fron Frys, five miles W. of Chirk, Denbighshire. Upper Bala.

Ptilodictya explanata ( $\left.\mathbf{M}^{\mathrm{C}} \mathrm{Coy}\right)$.

Retepora Hisingeri ( $\mathrm{I}^{\mathrm{C}} \mathrm{Coy}$ ).

Glauconome disticha (Gold.)

Lingula longissima (Pander).

Turbo crebristria ( $\mathrm{I}^{\mathrm{C}} \mathrm{Coy}$ ).

Trocholites anguiformis (Sow. Sp.)

Mynydd-y-Gaer, Llanefydd, near Ruthin, Denbighshire.

Lower Ludlow.

Spirigerina reticularis (Linn. Sp.)

Hemithyris navicula (Sow. Sp.)

- nucula (Sow. Sp.)

Orthis elegantula (Dal.)

Leptæna lævigata (Sow.)

Cardiola interrupta (Brod.)

Nant Gwrhwyd Uchaf, S. of Llangollen. Wenlock shale. Actinocrinus pulcher (Salt.)

Nant Morfydd, N. of Llangollen. Wenlock shale. Graptolites Ludensis (Murch.)

Nant y arian, Llandeilo. Upper Bala.

Isotelus tyrannus (Murch. $\mathrm{Sp}$ )

Orthis expansa (Sow.)

- parva (Pander).

Nant y Brain, W. of Wrexham. Upper Bala.

Calymene brevicapitata (Portk.)

Nant y groes, S. of Bala, N. Wales. Upper Bala.

Lingula alternata (Sow.)

- Davisi ( $\left.\mathrm{M}^{\mathrm{c}} \mathrm{Coy}\right)$.

Nantyr in Glyn Ceiriog, S. of Llangollen. Upper Bala. Graptolites Ludensis (Murch.)

Old Radnor, Radnorshire. Woolhope limestone. Favosites Gothlandica (Linn. Sp.)

Stenopora fibrosa (Gold. Sp.)

Strephodes pseudo-ceratites (M「Coy).

Hemithyris crispata (Sow. Sp.)

Leptæna Ouralensis ( M V. K.)

Trochus cælatulus (M Coy).

[FASC. II.]
Parklane, Llandeilo, Caermarthenshire. Ludlow Group.

Odontochile caudata (Brong. Sp.)

Orbiculoidea implicata (Sow. Sp.)

Spirigerina reticularis (Linn. Sp.)

Hemithyris nucula (Sow. Sp.)

Pentamerus galeatus (Dal. Sp.)

Orthis lunata (Sow.)

Strophomena funiculata ( $\mathrm{M}^{\mathrm{c}} \mathrm{Coy}$ ).

Leptagonia depressa (Dal. Sp.)

Pterinea pleuroptera (Conrad).

- tenuistriata ( $\mathrm{M}^{\mathrm{C}} \mathrm{Coy}$ ).

Ambonychia striata (Sow. Sp.)

Modiolopsis Nilsoni (His. Sp.)

Cardiola fibrosa (Sow.)

Conularia cancellata (Sandberger.)

Pen Cerrig, Builth, Radnorshire. Upper Bala.

Diplograpsus mucronatus (Hall Sp.)

- pristis (His. Sp.)

Diplorhina triplicata (Hawle and Corda).

Trinucleus latus (Portk.)

Tretaspis fimbriata (Murch. Sp.)

Anipyx nudus (Murch. Sp.)

Ogygia Buchi (Brong. Sp.)

- radians ( $\left.\mathrm{M}^{\mathrm{c}} \mathrm{Coy}\right)$.

Isotelus Powisi (Murch.)

Siphonotreta micula ( $\mathrm{M}^{\mathrm{C}} \mathrm{Coy}$ ).

Orthis elegantula (Dal) Var. $\alpha$.

- retrorsistria ( $\mathbf{M}^{\mathrm{C}} \mathrm{Coy}$ ).

- Vespertilio (Sow.)

Leptæna sericea (Sow.)

Modiolopsis inflata ( $\left.\mathbf{M}^{\mathrm{C}} \mathrm{Coy}\right)$.

Peniarth Meifod, Montgomeryshire. Upper Bala.

Graptolites Ludensis (Murch.)

Petraia rugosa (Phill, Sp.)

Spirifera biforata.

- - Var. D. fissicostata (McCoy).

Leptæna sericea (Sow.)

Penlan, Llandovery, S. Wales. Upper Bala.

Petraia rugosa (Phill, Sp.)

- uniserialis ( $\left.\mathbf{M}^{\circ} \mathrm{Coy}\right)$.

Pentamerus lavis (Sow.)

- undatus (Sow.Sp.)

Orthis parva (Pander).

- plicata (Sow. Sp.) 
Penlan, Llandovery (continued).

Leptrena quinquecostata ( $\left.\mathbf{M}^{*} \mathrm{Coy}\right)$.

Leptagonia depressa (Dal. Sp.)

Penllys, N. IV. of Meifod, two miles E. of Llanfihangel. Bala Group.

Stenopora fibrosa (Gold. Sp.)

Leptæena sericea (Sow.)

Penmachno, Caernarvonshire. Upper Bala.

Orthis expansa (Sow.)

Fenmorfa, Tremadoc, N. Wales. Lingula flags.

Lingula Davisii (M다).

- ovata (MCoy).

Tellinomya lingulicomes ( $\left.\mathbf{M}^{\mathrm{C}} \mathrm{Coy}\right)$.

Penny Bridge Hills W. of), N. Lancashire. Lower Ludlow.

Cardiola interrupta (Brod.)

Pentre cwm dda, S. of Glyn Diffwys, N. Wales. Upper Baia.

Diplograpsus foliaceus (Murch. Sp.)

Siphonotreta micula ( $\left.\mathrm{M}^{\mathrm{c}} \mathrm{Coy}\right)$.

Orthis retrorsistria ( $\mathbf{M}^{\mathrm{C}} \mathrm{Coy}$ ).

Leptæna sericea (Sow.)

Pen y Craig, Llangynyw, Montgomeryshire. Upper Bala.

Graptolites Ludensis (Murch.)

Favosites alveolaris (Gold.)

Halysites catenulatus (Linn. Sp.)

Petraia uniserialis $\left(\mathbf{M}^{\mathrm{c}} \mathrm{Coy}\right)$.

Ptilodictya explanata ( $\left.\mathrm{M}^{\mathrm{e}} \mathrm{Coy}\right)$.

- lanceolata (Gold. Sp.)

Trinucleus gibbifrons ( $\mathbf{M}^{\mathrm{c}} \mathrm{Coy}$ ).

Spirifela bilorata (Schlot.)

- - Var. a. lynx (Eichwald Sp.)

Spirigerina marginalis (Dal. Sp.)

Iemithyris subundata $\left(\mathrm{M}^{\mathrm{C}} \mathrm{Coy}\right)$.

Pentemerus undatus (Sow. Sp.)

Leptrena quinquecostata (McCoy).

Pen y Park, Llanfyllin. Upper Bala.

Beyrichia complicata (Salt.)

Orthis poreata (McCoy, Var.)

- testudinaria (Dal.)
Pen y gaer, Cerrig y Druidion, Denbighshire. Lower Bela.

Orthis retrorsistria ( $\mathrm{M}^{\mathrm{C}} \mathrm{Coy}$ ).

Strophomena Spiriferoides ( $\mathrm{M}^{\mathrm{C}} \mathrm{Coy}$ ).

Plas Madoc, N. of Llanrwst. Caradoc sandstone.

Orthis elegantula (Dal.) Var. $a$.

Mytilus unguiculatus (Salt.)

Clidophorus ovalis ( $\mathrm{M}^{\mathrm{C}} \mathrm{Coy}$ ).

Nucula levata (Hall).

Holopella gregaria (Sow. Sp.)

Pont-ar-y-llechau, near Llangadoc. Upper Ludlow.

Pterinea demissa (Conrad).

- subfalcata (Conrad).

- tenuistriata ( $\left.\mathbf{M}^{\mathrm{c}} \mathrm{Coy}\right)$.

Pont-y-Glyn, Diffivys, W. of Corwen, Denbighshire.

Upper Bala.

Nebulipora lens ( $\left.\mathbf{M}^{\mathrm{c}} \mathrm{Coy}\right)$.

Stenopora fibrosa (Gold. Sp.)

Trochurus nodulosus (Salt. Sp.)

Phacops alifrons (Salt.)

Illænus Davisi (Salt.)

Pseudocrania divaricata ( $\left.\mathbf{M}^{\mathrm{C}} \mathrm{Coy}\right)$.

Spirifera biforata (Schlot.)

- Var. a. lynx (Eichwald Sp.)

Spirigerina marginalis (Dal. Sp.)

Orthis Actoniæ (Sow.)

- elegantula (Dal.)

Leptæna deltoidea (Conrad).

- - Var. undata ( $\left.\mathbf{M}^{\mathrm{C}} \mathrm{Coy}\right)$.

- sericea (Sow.)

Pont-y-Meibion, two miles S. of Llansantfraid, on the Ceiriog. Lower Bala.

Beyrichia complicata (Salt.)

Leptrna tenuissimestriata ( $\left.\mathbf{M}^{\mathrm{c}} \mathrm{Coy}\right)$.

Porth Breiddyn, below Welelpool. Wenlock shale.

Homalonotus bisulcatus (Salt.)

Potter's Fell, Kendal, Westmoreland. Upper Ludlow.

Uraster hirudo (Forb.)

Discina rugata (Sow. Sp.)

Spirifera subspuria (d'Orb.)

Hemithyris navicula (Sow. Sp.)

Chonetes lata (V. Buch Sp.) 
Presteign, Radnorshire. Lower Ludlow*.

Hemithyris ? hemisphærica (Sow. Sp.)

- Wilsoni (Sow. Sp.)

Pentamerus oblongus (Sow.)

Pump Saint, near Lampeter, Caermarthenshire. Upper Bala.

Diplograpsus pristis (His. Sp.)

Pwllheli, Caernarvonshire. Upper Bala.

Tentaculites annulatus (Schlot.)

Trinucleus Caractaci (Murch.)

- - Var, elongatus (Portk.)

Encrinurus punctatus (Brïn. Sp.)

Portlockia apiculata (Salt.)

Calymene subdiademata ( $\mathbf{M}^{\mathrm{c}} \mathrm{Coy}$ ).

Homalonotus bisuleatus (Salt.)

Hemithyris diodonta (Dal. Sp.)

- hemisphærica (Sow. Sp.)

- Upsilon (Bar. Sp.)

Pentamerus lavis (Sow.)

Orthis elegantula (Dal.) Var. $a$.

- plicata (Sow.)

Leptrena sericea (Sow.)

Strophomena compressa (Sow. Sp.)

- Spiriferoides $\left(\mathbf{M}^{\mathrm{c}} \mathrm{Coy}\right)$.

Ravenstone Dale, Westmoreland: Upper Bala (Coniston limestone).

Tentaculites annulatus (Schlot.)

Zethus atractopyge $\left(\mathbf{M}^{\mathrm{C}} \mathrm{Coy}\right)$.

Homalonotus bisulcatus (Salt.)

Isotelus Powisi (Murch.)

Spirifera biforata (Schlot.)

- - Var. D. fissicostata ( $\mathrm{I}^{\mathrm{C}} \mathrm{Coy}$ ).

Strophomena grandis (Sow. Sp.)

- Pecten (Linn. Sp.)

Pterinea tenuistriata $\left(\mathbf{M}^{\mathbf{c}} \mathrm{Coy}\right)$.

Rhiwargor, near Llanwddyn, Montgomeryshire. Upper Bala.

Trinucleus Caractaci (Murch.)

- gibbifrons ( $\mathbf{M}^{\mathrm{c}} \mathrm{Coy}$ ).

Portlockia apiculata (Salt.)

Spirifera biforata (Schlot.)

- - Var. $\beta$. dentata (Pand. Sp.)

Orthis Actonix (Sow.)
Rhiwargor (continued).

Orthis elegantula (Dal.) Var.a.

- parva (Pander).

- Vespertilio (Sow.)

Strophomena Spiriferoides $\left(\mathbf{M}^{\mathrm{c}} \mathrm{Coy}\right)$.

Leptagonia depressa (Dal. Sp.)

Rhiwlas, N. of Bala, Merionethshire. Upper Bala.

Caryocystites granatum (Wahl.)

Trinodus agnostiformis ( $\left.\mathbf{M}^{c} \mathrm{Coy}\right)$.

- tarda (Bar. Sp.)

- latus (Portk.)

Tretaspis seticornis (His. Sp.)

Lichas laxata? ( $\left.\mathbf{M}^{\circ} \mathrm{Coy}\right)$.

Staurocephalus Murchisoni (Bar.)

Ceraurus octo-lobatus ( $\left.\mathbf{M}^{\mathrm{c}} \mathrm{Coy}\right)$.

- clavifrons (Dal. Sp.)

Zethus sexcostatus (Salt. Sp.)

Isotelus laticostatus (Green Sp.)

Illænus Davisi (Salt.)

Orthoceras vagans (Salt.)

Rhosfawr, N. of Glog, Llanfyllin, N. Wales. Upper Bala.

Spirigerina marginalis (Dal, Sp.)

Orthis elegantula (Dal.) Var. $\alpha$.

- plicata (Sow. Sp.)

Leptæna sericea (Sow.)

Leptagonia depressa (Dal. Sp.)

Rother Bridge (above). Upper Bala (Coniston limestone).

Portlockia apiculata (Salt.)

Calymene brevicapitata (Portk.)

Orthis Vespertilio (Sow.)

Leptæna minima (Sow.)

- sericea (Sow.)

Rother Bridge (below). Upper Bala (Coniston flags). Graptolites sagittarius (Linn, Sp.)

Rother Heath, Kendal, Westmoreland. Upper Bald. Stenopora fibrosa (Gold. Sp.)

Saint Helen's, Low Furness. Upper Bala (Bala limestone).

Stenopora fibrosa (Gold. Sp.)

* The Caradoc sandstone near this spot has not been noted in the list of localities, but doubtless furnished the specimen of Pentamerus oblongus. 
Scawgill, Cumberland. Skiddaw slate.

Graptolites latus ( $\mathrm{M}^{\mathrm{C}} \mathrm{Coy}$ ).

- sagittarius (Linn. Sp.)

Scalthwaite Rigg, Kendal, Westmoreland. Upper Lud1020.

Serpulites dispar (Salt.)

Sedgley, near Dudley, Staffordshire. Aymestry limestone.

Cœnites intertextus (Eichw.)

Stenopora fibrosa (Gold. Sp.)

Strephodes pseudo-ceratites ( $\left.\mathrm{M}^{\mathrm{c}} \mathrm{Coy}\right)$.

Spirigerina reticularis (Linn. Sp.)

Hemithyris nucula (Sow. Sp.)

- Stricklandi (Sow. Sp.)

- Wilsoni (Sow. Sp.)

Pentamerus Knighti (Sow.)

Strophomena ? filosa (Sow. Sp.)

Lingula Lewisii (Sow.)

Selattyn Road, S. of Llangollen, N. Wales. Upper Bala.

Stenopora fibrosa (Gold. Sp.)

Beyrichia complicata (Salt.)

Trinucleus latus (Portk.)

Chasmops Odini (Eichw. Sp.)

Orthis testudinaria (Dal.) Var。 $\alpha$.

Leptæna sericea (Sow.)

Leptagonia depressa (Dal. Sp.)

- ungula ( $\left.\mathbf{M}^{\mathrm{C}} \mathrm{Coy}\right)$.

Holopella monile $\left(\mathrm{M}^{\mathrm{C}} \mathrm{Coy}\right)$.

Shepherd's Quarry, Kendal. Upper Ludlow.

Actinocrinus pulcher (Salt.)

Smithfield, near Builth. Wenlock shale, or Caradoc sandstone.

Graptolites Ludensis (Murch.)

Soudley, Shropshire. Caradoc sandstone.

Pentamerus lævis (Sow.)

Spital, Kendal. Upper Ludlow.

Spongarium interruptum $\left(\mathbf{M}^{c} \mathrm{Coy}\right)$.

Murchisonia torquata ( $\left.\mathbf{M}^{\circ} \mathrm{Coy}\right)$.

Studgill, near Horton. Upper Bala (Coniston flag). Graptolites sagittarius (Linn. Sp.)
Storm Hill, Llandeilo, Caermarthenshire. Upper Ludlow.

Crossopodia lata $\left(\mathbf{M}^{\mathrm{c}} \mathrm{Coy}\right)$.

Pterinea megaloba ( $\mathbf{M}^{\mathrm{c}} \mathrm{Coy}$ ).

Modiolopsis complanata (Sow. Sp.)

- platyphylla (Salt. Sp.)

- solenoides (Sow.)

Anodontopsis quadratus ( $\left.\mathrm{M}^{\mathrm{C}} \mathrm{Coy}\right)$.

Dolabra elliptica ( $\left.\mathbf{M}^{\mathrm{c}} \mathrm{Coy}\right)$.

- obtusa ( $\mathbf{M}^{\mathrm{c}} \mathrm{Coy}$ ).

Grammysia cingulata (His. Sp.)

- Var. $\beta$. triangulata (Salt.)

Cucullella antiqua (Sow. Sp.)

- ovata (Sow. Sp.)

Holopella conica (Sow. Sp.)

Trochus helicites (Sow.)

Murchisonia torquata ( $\left.\mathbf{M}^{\mathrm{C}} \mathrm{Coy}\right)$.

Bellerophon carinatus (Sow.)

- trilobatus (Sow.)

Orthoceras bullatum (Sow.)

Cycloceras tenuiannulatum ( $\left.\mathrm{M}^{\mathrm{c}} \mathrm{Coy}\right)$.

Sugar-loaf, N. E. of Llandovery. Upper Bala. Cardiola interrupta (Brod.)

Sunny-banks, near Gray Rigg, Westmoreland. Lover Ludlow.

Halysites catenulatus (Linn. Sp.)

Siphonotreta Anglica (Morris).

Sunny Brow, near Coniston. Upper Bala.

Palæopora petalliformis (Lonsd. Sp.)

Sarcinula organum (Linn. Sp.)

Illænus Rosenbergi (Eichw.)

Taihirion, near Arenig Fawr, Merionethshire. Lover Bala.

Calymene parvifrons (Salt.)

Tai yn y Nant, Bala. Upper Bala.

Leptæna sericea (Sow.)

Tan y Bwlch y Groes, S. of Bala, Merionethshire. Upper Bala.

Stenopora fibrosa (Gold. Sp.)

- - Var. a. Lycopodites (Say).

Trinucleus Caractaci (Murch.) 
Tan y Bwlch y Groes (continued).

Orthis parva. Var. avellana.

- retrorsistria $\left(\mathrm{M}^{\mathrm{c}} \mathrm{Coy}\right)$.

- Vespertilio (Sow.)

Leptæna sericea (Sow.)

Strophomena Spiriferoides $\left(\mathbf{M}^{\mathrm{c}} \mathrm{Coy}\right)$.

Tan y Craig, Builth. Lower Bala.

Serpulites dispar (Salt.)

Pseudocrania divaricata ( $\mathrm{M}^{\mathrm{C}} \mathrm{Coy}$ ).

Orthis calligramma (Dal.)

Leptæena sericea (Sow.)

Teirw River, S. of Llangollen, N. Wales. Bala Group. Strophomena compressa (Sow. Sp.)

Bellerophon bilobatus (Sow.)

- ornatus (Conrad Sp.)

Tenter Fell, Kendal, Westmoreland. Upper Ludlow.

Serpulites dispar (Salt.)

Homalonotus Knighti (König).

Leptodomus globulosus ( $\left.\mathbf{M}^{\mathrm{C}} \mathrm{Coy}\right)$.

Thorney Lee Quarry, on Tweed. Bala Group.

Nereites Cambrensis (Murch.)

Crossopodia Scotica ( $\mathbf{M}^{\mathrm{c}} \mathrm{Coy}$ ).

Tottlebank Heights, Coniston Water. Wenlock Group. Stenopora fibrosa (Gold. Sp.)

Trwscoed, Gaerfawr. Bala Group.

Orthis confinis (Salt.)

Tregib, S. of Llangollen. Upper Bala.

Pyritonema fasciculus ( $\mathbf{M}^{\mathrm{C}} \mathrm{Coy}$ ).

Stenopora fibrosa (Gold. Sp.)

Beyrichia complicata (Salt.)

Trinucleus gibbifrons ( $\left.\mathrm{M}^{\circ} \mathrm{Coy}\right)$.

Ampyx nudus (Murch. Sp.)

Chasmops Odini (Eich. Sp.)

Calymene Baylei (Barr.)

Isotelus tyrannus (Murch. Sp.)

Spirigerina marginalis (Dal. Sp.)

Lingula granulata (Phill.)

Tremadoc (N. of), Merionethshire, N. Wales. Upper

Tremadoc slates.

Graptolites sagittarius (Linn. Sp.)
Tremadoc (continued).

Trinucleus gibbifrons ( $\mathrm{M}^{\mathrm{C}} \mathrm{Coy}$ ).

- radiatus (Murch.)

Isotelus affinis ( $\mathrm{M}^{\mathrm{c}} \mathrm{Coy}$ ).

Orthis parva (Pander).

Murchisonia pulchra ( $\left.\mathrm{M}^{\mathrm{c}} \mathrm{Coy}\right)$.

Troutbeck, Applethwaite Common, Westmoreland.

Upper Bala.

Cardiola interrupta (Brod.)

Tullithwaite Hall, Underbarrow, Kendal. Lower Ludlow.

Strophomena? filosa (Sow. Sp.)

Tyn y Cabled, Llanfyllin, N. Wales. Upper Bala.

Stenopora fibrosa (Gold. Sp.)

Spirifera biforata (Schlot.)

- - Var. D. fissicostata $\left(M^{c} \mathrm{Coy}\right)$.

Orthis Actonia (Sow.)

Leptæna quinquecostata ( $\mathbf{M}^{\mathrm{C}} \mathrm{Coy}$ ).

Tyn y Frons (E. foot), near Meifod. Upper Balc.

Halysites catenulatus (Linn. Sp.)

Tyn y Frydd, near Mathyrafal. Upper Bale.

Orthis elegantula (Dal.)

Tynant, E. of Llanwddyn, N. Wales. Upper Baln.

Strophomena compressa (Sow. Sp.)

Ulverston, Furness. $\overline{\text { Lower Ludlow. }}$

Diplograpsus ramosus (Hall Sp.)*

Underbarrow, Kendal, Westmoreland. Ludloro Group.

Cyathaxonia Siluriensis ( $\mathbf{M}^{\mathbf{c}} \mathrm{Coy}$ ).

Beyrichia Klodeni $\left(\mathbf{M}^{\mathrm{C}} \mathrm{Coy}\right)$.

Odontochile caudata (Brong. Sp.)

- - Var. minor.

Forbesia latifrons $\left(\mathbf{M}^{\mathrm{C}} \mathrm{Coy}\right)$.

Chonetes lata (V. Buch Sp.)

Conularia cancellata (Sandberger).

Holopella gregaria (Sow. Sp.)

Orthoceras angulatum (Wahl.)

Hortolus Ibex (Sow. Sp.)

Wellfield, Builth. Upper Bala.

Ampyx nudus (Murch. Sp.)

Ogygia Buchi (Brong. Sp.)

* This would be a "Bala" fossil according to the American indications. 
Wellfield (continued).

Siphonotreta micula ( $\left.\mathrm{M}^{\mathrm{c}} \mathrm{Coy}\right)$.

Lingula curta (Conrad).

Orthoceras subundulatum (Portk.)

Welchpool, Montgomeryshire. Wenlock shale or Upper Bola.

Hemithyris navicula (Sow. Sp.)

Leptæna lævigata (Sow.)

Lituites articulatus (Sow.)

Wenlock, Shropshire. Wenlock limestone.

Stromatopora striatella (d'Orb.)

Palæopora expatiata (Lonsd. Sp.)

- interstincta (Wahl. Sp.)

- tubulata (Lonsd. Sp.)

Favosites aspera (d'Orb.)

- Gothlandica (Linn. Sp.)

Halysites catenulatus (Linn. Sp.)

Syringopora bifurcata (Lonsd.)

Caninia lata ( $\mathrm{M}^{\mathrm{C}} \mathrm{Coy}$ ).

Strephodes Vermiculoides ( $\left.\mathbf{M}^{\mathrm{C}} \mathrm{Coy}\right)$.

Cystiphyllum brevilamellatum ( $\left.\mathbf{M}^{c} \mathrm{Coy}\right)$.

Clisiophyllum vortex $\left(\mathrm{M}^{\mathrm{c}} \mathrm{Coy}\right)$.

Strombodes Wenlockensis $\left(\mathbf{M}^{\mathrm{c}} \mathrm{Coy}\right)$.

Crotalocrinus rugosus (Mill Sp.)

Spirigerina cuneata (Dal. Sp.)

- marginalis (Dal. Sp.)

- reticularis (Linn. Sp.)

Hemithyris pentagona (Sow. Sp.)

- Wilsoni (Sow. Sp.)

Pentamerus galeatus (Dal. Sp.)

Orthis rustica (Sow.)

Leptagonia depressa (Dal. Sp.)

Euomphalus discors (Sow.)

- funatus (Sow.)

- rugosus (Sow.)

- sculptus (Sow.)

Whiteless, S. of Crummock Lake, Cumberland. Skiddaw slate.

Graptolites latus ( $\left.\mathbf{M}^{\mathrm{c}} \mathrm{Coy}\right)$.

Wilfa, near Penmachno, N. Wales. Upper Bala.

Phacops alifrons (Salt.)

Orthis Vespertilio (Sow.)

Leptrena sericea (Sow.)

Leptagonia depressa (Dal. Sp.)

- Ditto. Var.
Woolhope. Upper Ludlow and Wenlock limestone.

Stenopora fibrosa (Gold. Sp.)

- - Var. a. Lycopodites (Say).

- Var. $\beta$. regularis ( $\mathrm{M}^{\mathrm{c}} \mathrm{Coy}$ ).

Discina rugata (Sow. Sp.)

Spirifera cyrtæna (Dal. Sp.)

- trapezoidalis (Dalm. Sp.)

Athyris tumida (Dal. Sp.)

Spirigerina reticularis (Linn. Sp.)

Hemithyris nucula (Sow. Sp.)

Pentamerus galeatus (Sow. Sp.)

- Knighti (Sow.)

Orthis lunata (Sow.)

Strophomena euglypha (Dal. Sp.)

Leptagonia depressa (Dal. Sp.)

Chonetes lata (V. Buch Sp.)

Lingula lata (Sow.)

Litorina octavia (d'Orb. Sp.)

Euomphalus funatus (Sow.)

- rugosus (Sow.)

Bellerophon Wenlockensis (Sow.)

Orthoceras tenuicinctum (Portk.)

Wrae Quarry, Upper Tweed, near Broughton. Bala Group.

Harpes parvulus ( $\left.\mathbf{M}^{\mathrm{c}} \mathrm{Coy}\right)$.

Illonus latus ( $\left.\mathrm{M}^{\mathrm{c}} \mathrm{Coy}\right)$.

Porambonites intercedens (Pand.)

Orthis callactis (Dal.)

Cycloceras arcuoliratum (Hall Sp.)

Wye (bed of), Builth. Wenlock shale.

Graptolites Ludensis (Murch.)

Yr Allt, Welch Pool. Wenlock shale.

Cardiola interrupta (Brod.)

Y Foel Fawr, near Llanrhaidr. Upper Bala.

Leptæna tenuissimestriata ( $\left.\mathbf{M}^{\mathrm{c}} \mathrm{Coy}\right)$.

Ysputty Evan, N. Wales. Upper Bala.

Caryocystites Davisi ( $\left.\mathrm{H}^{\mathrm{c}} \mathrm{Coy}\right)$.

Hemithyris diodonta (Dal. Sp.)

Orthis elegantula (Dal.)

- parva (Pander).

Lyrodesma plana (Conrad).

Murchisonia gyrogonia $\left(\mathbf{M}^{c} \mathrm{Coy}\right)$.

Bellerophon bilobatus (Sow,) 
Sncr. VIII-MOLLUSCA OF MIDDLE PALEOZOIC (Devonian) ROCKS. 3rd Sub-kingdom. MOLLUSCA. See page 185. 2nd Class. PALLIOBRANCHIATA. See page 185. 2nd Order. Brachiopoda. See page 186.

5th Family. SPIRIEERIDE. See page 191.

Genus. SPIRIFERA (Sow.) See page 191.

\author{
SPIRIFera GRandeta (Phill.)
}

Ref.-Phillips, Pal. Foss. t. 30. fo 131.

Sp. Ch. - Subrhomboidal, depressed, cardinal angles acute, but not extending into spines; mesial fold large, rounded, very prominent, very strongly defined quite to the beak, forming an abrupt semielliptical sinus in the front margin; surface radiated with thick, obtusely-rounded, simple ribs, about five in the mesial sinus, and about nine on each side. Width one inch five lines, proportional length of receiving valve $\frac{60}{100}$.

The shell is wider, with more pointed angles than the S. aperturata, and the mesial ribs are not obviously smaller than the lateral ones. It seems very closely allied to the carboniferous $S$. trigonalis.

Position and Locality. - One specimen of the receiving valve collected by myself from the olive slate of Lanlake, Launceston, Cornwall.

\title{
Spirifera lexicosta (Valen. Sp.) \\ Ref. and Syn. = Terebratula loevicosta Valenciennes in Lamarck Anim. S. Vert. $=$ Terebratulites ostiolatus Schlot. Pet. p. 258, t. 17. f. 3 .
}

$S p . C h$.- Rotundato-quadrate, very gibbous; hinge-line scarcely as wide as the shell; sides subparallel, front margin raised into a deep semielliptical sinus; mesial fold broad, distinctly defined to the beaks, without ribs; the mesial ridge of the entering valve smaller than the mesial sinus of the opposite one; about fourteen simple obtusely-rounded ribs on each side; entire surface under the lens marked with very minute, close, regular, granular strix. Width one inch five lines, proportional length of receiving valve $\frac{85}{100}$, of entering valve $\frac{71}{1+1,}$, depth $\frac{65}{100}$.

Mr Davidson has figured Lamarck's (or Valenciennes') original type specimen in the Annals of Natural History for 1850 (t. 15. f. 41), so that no doubt can remain of its specific identity with that subsequently figured and described by Schlotheim.

Position and Locality.-In hard Devonian schists of Valley of the Rocks, N. Devon. 


\title{
Spirifera sieciosa (Schlot. Sp.)
}

\author{
Ref. and Syn. = Terebratula speciosa Schl. Tasch. 1831, t. 2. f. 9 (not Petrefac.)
} $=$ Trigonotreta id. Br. Leth. Geog. t. 2. f. $15 .=$ Spirifera costata Sow. G. T.2nd Series, Vol. V.t. 55. f. 5, 6, 7.

$S p . C h$.--Transversely fusiform, slightly compressed, valves gibbous in the middle; hinge-line very long, sides gradually attenuated, acute-angled, cardinal area broad, with nearly parallel sides, five, or sometimes six, large, obtusely-rounded, simple, radiating ribs, on each side of the mesial ridge, which is very prominent and rounded; mesial sinus very deep, rounded, distinct from the beak; surface crossed with sharp transverse lines of growth; beaks moderately incurved, rather small, lateral margins horizontal, front abruptly raised, with a narrow semielliptical wave. Width of moderate-sized specimen two inches, proportional length $\frac{45}{1+w}$, depth of valves $\frac{45}{1+0}$.

Having examined the original specimens described and figured by Sowerby, which are internal easts, I find that what he supposed to be two approximate ridges forming the mesial ridge, was really an impression of the slender internal septum of the entering valve, dividing the cast of the really simple mesial ridge; and a comparison of these and numeruus other specimens from the British localities with Eifel specimens, leaves no room for doubt of their identity.

Position und Locality. - Very common in the Devonian deconposing schists of Fowey, Cornwall; also in the similar schists of East Looe; rare in the hard, red, Devonian quartzite of Looe; Devonian schist of Polruan, Cornwall; in the quartzite of Highgate St Veep, Cornwall.

\section{SPIRIFERA Verneuili (Mlurch.)}

Ref. and Syn.-Murchison, Bull. de la Soc. Geol. de France, v. 11. t. 2. f. 3.= Spirifera calcarata Sow. G. T. 2nd Series, Vol. V.t. 53.f.7 (Young) + Spirifera disjuncta Sow. G. T. 2nd Series, Vol.V.t. 53.f. 8, and t. 54. f. 13, 14 (middle age) $+S$ gigantea Sow. Geol. Trans. 2nd Series, Vol. V. t. 55. f. 1 to 4 (old).

$S p$. Ch.-Shell transversely subrhomboidal when young (up to one inch long, calcarata, Sow.); the sides gradually attenuated, and extended into long spines; with age the sides becoming gralually more parallel, giving a quadrate figure (disjuncta, Sow.); valves gibbous, hinge-line exceeding the width of the shell, forming contracted acute ears, hinge-area broad, but of variable width; sides subparallel or very obtusely triangular in the receiving valve, flat or concave, marked with sharp reticulating strixe: mesial ridge of entering valve broad, moderately prominent, sharply defined, particularly near the beak, by two sulci, deeper than the rest, obtuselyrounded near the beak, becoming obtusely-triangular towards the margin, in which it forms a wide rounded sinus; recoiving valve with a deep mesial simus from the beak to the front margin, obtusely defined; radiating ribs rounded, sharply defined, and perfectly simple on the sides, twenty-four to thirty on each side, about fourteen slightly smaller and dichotomous on the mesial ridge and on the sinus; four of the lateral ribs near the mesial ritge, occupy the same space as five or six of the mesial ones. Width, exeluding the lateral spines, in a rather small or moderate-sized specimen, two and a quarter inches, proportional length of receiving valve tiva, of entering valve ${ }_{100}^{57}$, depth of both valves $\frac{45}{100}$, width of very old individual eight inches.

'This species is easily distinguished from the $S$ attenuata, by the constant simplicity of its lateral ridges, and the same character negatives the reference of $S$. gigantra to S. striata, as suggested by Mr. Sharpe. Having carefully compared specimens from the Pas-Boulonnais of the S. Verneuili of Sir $\mathbf{R}$. Murchison, with the type-specimens in the Cambridge collection of Sowerby's $s$. disjuncta, I ean state positively their perfect accordance to the most minute particular. Further, having exanined very great numbers of specimens from Cornwall of the $S$. calcarate, $S$. disjuncte, and $S$. giganted, I can state with certainty that there is no difference between them. The $S$. calcarata with attenuated sides is the form always assumed by the small or young specimens, and the cardinal area in these is as wide as in the $S$. disjuncta, there being no foundation for $\mathrm{Mr}$ Sowerby's supposition, that the area in this supposed species was narrow (he having only seen one valve); as the shell grows older the form becomes gradually quadrate, and is the S. disjuncta of Sowerby and Phillips, the latter author distinguishing those supposed species (Pal. Foss.) by stating the mesial ridge to be undefined in the latter: one of Sowerby's figures, however, (fig. 8, ) truthfully represents the mesial ridge sharply defined; 
and such $I$ have found to be the case in by far the greater number of unpressed specimens, and a few of the smaller specimens ( $S$. calcarata) also shew a slight want of definition in this part, shewing that no distinction could be based on this character. When the shell approaches its adult size it becomes the S. gigantea of Sowerly and Phillips, without the slightest change of character, so that many of the specimens, both at Petherwin and Tintagel could not be referred by a conscientious observer to the one species in preference to the other. The character supposed by Phillips to distinguish the S. gigantea from the S. disjuncta, viz, the mesial fold being " indistinctly furrowed or nearly smooth," is negatived by Mr Sowerby's original figures, by his typespecimens, and the great number of others which I have seen Sowerby has himself suggested the possible identity of S. disjuncte and S. gigantea, and Koninek and de Verneuil suspected the union possible of the four species here united.

Position and Locality.-Extremely common in the chloritic slates at Tintagel, Cornwall; and S. Petherwin, Cornwall, in the slates and subordinate limestone; slate of Lanlake, Launceston.

\title{
Subgenus. CYRTIA (Dal.) See page 191.
}

\section{Spirifera (Cyrtia) heteroclita (Defr. Sp.)}

\author{
Syn. and Ref. = Calceola heteroclita Defrance, Dict. Hist. Nat. t. 80. f. 3.
}

= Spirifer subconica Sow. Geol. Trans. 2nd Series, Vol. V.t. 57. f. 10.

$S p . C h$ - Receiving valve pyramidal, height usually two-thirds of the width of the hinge-line, but sometimes exceeding it; hinge-line as wide as the shell, cardinal area very large, flat, triangular; entering valve flattened, nearly semicircular, lateral margins horizontal, front margin abruptly raised into a very large angular sinus, from which a very wide, deep, angular sinus extends to the beak of the receiving valve, and a large prominent mesial ridge extends to the beak of the entering valve: five simple, obtuse, radiating ridges on each side; surface with sharp transverse lines of growth. Width seven lines, proportional length of receiving valve $\frac{10}{101}$ to $\frac{1 \mathrm{in}}{100}$, proportional length of entering valve $\frac{50}{100}$, apical angle varying from $90^{\circ}$ to $45^{\circ}$.

I have not clearly seen the cliaracters of the foramen or pseudo-deltidium. Although Defrance figures rather fewer lateral ribs, there can be no doubt of the identity of his species with the present fossil, which, on the other hand, seems to have no affinity whatever with the carboniferous limestone, C. subconica (Martin), to which Mr Sowerby refers it.

Position and Locality.-Common in the limestone of Plymouth.

\section{Subgenus. MARTINIA $\left(M^{c}\right.$ Coy $)$. See page 192. Martinia Urii (Flem. Sp.)}

\author{
Ref. and Syn. = Spirifer Urei Flem. Brit. Anim. p. 397 ; Ure's Rutherglen, t. 14. f. 12. = Atrypa \\ unguiculus Sow. G. T. 2nd Series, Vol. V.t. 54.f. 8.
}

Sp. Ch.-Subhemispherical, hinge-line considerably shorter than the width of the shell, sides rounded; margins nearly level all round, front usually slightly emarginate in the middle; entering valve slightly convex, with a deep narrow sulcus from the beak to the margin; receiving valve very gibbous along the middle, gradually sloping to the margins, and with a narrow, deep, mesial sulcus, extending from the beak nearly or quite to the front margin; beak very large, tumid, moderately incurved; cardinal area high, triangular ; surface smooth. Average width three and half lines, proportional length of receiving valve $\frac{93}{1+1}$, depth $\frac{50}{1100}$.

The internal casts shew traces of a small mesial septum in both valves.

Position and Locality.-Very common in the slates and associated limestone nodules of S. Petherwin. 


\section{Genus. ATHYRIS $\left(M^{c}\right.$ Coy). See page 196. \\ Atirytis concentrica ( $V$. Buch Sp.)}

Ref. and Syn.= Terebratula concentrica V. Buch, Bul. de la Soc. Geol. de France, Vol. XI.t. 2. f. 1.=Atrypa decussata Sow. G. T. 2nd Series, Vol. V. t. 5t. f. 5. + A. hispida Sow. same plate f. 4. + A. oblonga id. id. t. 53. f. 6. (crushed internal cast I find).

Sp. Ch. - Suborbicular when young, becoming rhomboidal or subpentagonal when old; valves almost equally convex, increasing in gibbosity with age; sides rounded; front evenly rounded in small specimens, but after seven lines long becoming produced into a broad lobe, which at an inch in length becomes a deep elliptical sinus, forming an undefined rounded elevation in the entering valve, and a wide concave sinus in the receiving valve, disappearing at about halfway to the beak; beak tumid, incurved, without trace of hinge. line or cardinal area, but slightly angulated on the sides; surface marked with close, imbricating, regular lamina of growth, about five in one line at three lines from the beak of entering valve, between each of which in some specimens appear two or three finer ones; towards the margin of old specimens some of the lamina become rugged and more prominent than the rest; and all, when finely preserved, project in fringelike lamine from the shell, which exhibit longitudinal or radiating furrows, and decompose in fringe-like lines and points. Length of small specimen (without mesial furrow) five lines, width the same, proportional depth of both valves $\frac{6 n}{100}$, width of old specimen one inch, proportional lengtlı of receiving valve $\frac{n 0}{100}$, of entering valve $\frac{k 2}{j w 0}$, depth of both valves $\frac{57}{100}$, but varying considerably.

On examining typical specimens, figured and described by Mr Sowerby from the limestone of S. Petherwin, I find the decussation he alludes to is only produced by the decomposition of certain of the concentric lamina, in radiating lines, according with their original fibrous texture, and it is not visible in sound specimens. The original specimen of his Atrypa hispida, from the shale of the same locality which I have examined, is manifestly the same species as his $A$. decussata, with one of the decomposing concentric lamine not quite broken off, but supported on a lamina of the shale: finally, on comparing both with young specimens, and the rostral portion of old specimens of the Terebratula (Athyris) concentrica (Von Buch) from the Eifel, I am able to state their positive identity. The edges of the lamine of Eifel specimens of the A. concentrica shew the longitudinal striation as well as any of the Devonshire ones. The Spirifer (Martinia) lineata of the carboniferous limestone is distinguished by its thicker and more obtuse concentric laminx, greater width, cardinal area, and hinge-line.

Position and Locality.-Very common in the slate and subordinate limestone of S. Petherwin and Lanlake, Launceston; brown grits of Barnstaple.

\section{Genus. SPIRIGERINA (D'Orb.) See page 197.}

\section{Spirigerina desquamata (Som. $S p$.)}

\section{Ref. and Syn. = Atrypa desquamata Sow. Geol. Trans. 2nd Series, Vol. V. t. 56. f. 19 to 23.}

$S p . C h$-O Ovate or subquadrate, nearly orbicular, and subequivalve when young, with a straight hinge-line, considerably less than the width of the shell; with age the outline becoming more quadrate, the front slightly narrowed, and very slightly elevated towards the entering valve in a wide, shallow sinus, not producing a ridge on the entering valve, or a sinus in the receiving valve; entering valve deeper than the receiving one, broadly gibbous along the middle, gradually arching to the margins; receiving valve moderately convex in all the middle portion, (a narrow portion very slightly concave towards the front lateral margins in old specimens); lateral margins nearly horizontal, slightly sigmoidal; eardinal area flat, triangular; aperture rounded, close under the pointed beak of the receiving valve, separated from the hinge-line by a large bipartite deltidium, the dividing fissure of which is often open in young specimens; surface of both valves radiated with close, rough, subequal, radiating ridges, separated by narrower, very deep sulci, the ridges increasing in number by intercalation, at about four lines from the beak; both the mesial and lateral ones usually dichotomising 
twice from thence to the margin without altering materially in thickness; four ridges in two lines in the middle of the shell, at an inch from the beak; no distinct regular scaly lamina of growth; muscular impressions in receiving valve forming an oblong defined space, rather longer than wide, extending about onethird the length of the shell. Length of average specimen one inch nine lines, proportional length of entering valve $\frac{04}{100}$, proportional width $\frac{97}{100}$, proportional depth of both valves $\frac{95}{100}$.

By cautiously breaking a specimen in the right direction, I have lad the pleasure of ascertaining the existence of the spiral appendages in this beautiful fossil, and to demonstrate their spiral convolution in the plane of the lateral margins, instead of at right angles thereto, as in the different groups of Spirifera; they are of rather small size, the diameter of the spires not exceeding half the width of the shell, so that they are not placed one behind the other, but each occupies its own side of the median line. The pallial vessels are large, composed of three or four main trunks on each side, branching once or twice to the margin.

Position and Locality.-Extremely abundant in the Devonian limestone of Plymouth and Newton Bushel; Devonian shale of Pridmouth, Menabilly; an obseure internal cast, probably of this species, from the schists of Fowey, Cornwall.

\section{Spirigerina Reticularis (Linn. Sp.) See page 198.}

I cannot pereeive the slightest difference between some of the Eifel and upper Silurian, and some of our Devonshire specimens of the first variety, specimens of which are in the collection from the reddish calcareous shales of Newton Bushel.

\section{Var. B. Aspera (Schlot. Sp.)}

Ref. and Syn. = Terebratula aspera Schlot. Min. Taschenbuch, Vol. VII. t. 1. f. 7. = Atrypa squamosa Sow. Geol. Trans. 2nd Series, Vol. V.t. 57. f. 1 and $1 a+$ Spirifera affinis Sow. same plate, f. 11.

This variety, which is at first sight so extremely different from the ordinary Silurian type, by its few very thick rounded ribs, with comparatively few branches, and distant, strong, concentric scales of growth, passes by the most insensible gradations into that species, when a large series either from the Eifel or Devon is examined. The most marked types of this peeuliar form are nearly orbicular; the length and breadth equal; length about one inch, the depth half the length; the entering valve moderately convex along the middle, raised into a small rounded sinus at the margin; receiving valve slightly convex at the sides and near the beak, becoming depressed in the middle towards the margin : about sixteen thick, rounded, radiating ribs, two or three only of which dichotomise (two occupying a space of two lines at six lines from the beak, and the concentric laminæe nearly a line apart at the same distance).

This highly typical form of the variety aspera is common in the Devonian limestone of Plymouth, and not uncommon in the Eifel; but with these in both localities occur specimens in which the depth in proportion to the length is $\frac{6 n}{1 \mathrm{va}}$; the ridges become gradually smaller, more numerous, and more often branched, and the concentric laminie of growth become more crowded; so that no character ean be assigned, so far as my observations go, which would serve to separate specifically the intermediate varieties; nevertheless I have not seen the var. aspera in Silurian rocks. The small triangular, flat, cardinal area may often be seen in the more depressed specimens, with small foramen separated by a deltidium from the hinge-line; these however being, as in the Eifel specimens, often concealed by the adpression of the beak. On examining the original specimen figured by Mr Sowerby as above, under the name Spirifera affinis, I find it is a young individual of the present species var. aspera, shewing the cardinal area rather less than in his figure, and not greater than is often seen in Eifel specimens.

Position aud Locality of Var. aspera.-Common in the Devonian limestone of Plymouth; Devonian shale of Pridmouth, Menabilly, and Fowey, Cornwall. 


\section{6th Family. UNCITIDE.}

This family was originally proposed by d'Orbigny for Uncites, Atrypa and Pentamerus; but as I propose to restrict it to the one genus, Uncites, the generic and family characters are given together, the latter being rather different from those of d'Orbigny, and no previous careful description of the genus having been published so far as I know.

\section{Genus. UNCITES (Defrance) as here defined.}

Gen. Char.-Shell elongate, ovate, slightly inequilateral; substance very thick, densely fibrous; beak of receiving valve very long, narrow, claw-shaped, gently incurved obliquely to one side, with a wide, concave, imperforate defined channel beneath; no internal septa, nor appendages, in either valve.

\section{Uncites LeVis ( $\boldsymbol{I}^{c}$ Coy). Pl. 2. A. fig. 6.}

$S p . C h$.-Longitudinally ovate, oblique; entering valve, when young, ovate, moderately convex, with the front and lateral margins broadly rounded; when old becoming very gibbous and subrhomboidal, from the convergence of the sides to a narrow rounded front; receiving valve obtusely subcarinate along the middle when old, by the nearly flat sloping of the sides; the front margin not perceptibly elevated, and the lateral margins nearly horizontal; beak very large, sharply pointed, and widely-arched inwards obliquely to one side, the under part of the beak widely channelled, with obtusely angular or rounded lateral margins; surface smooth, or only marked by the concentric lines or imbrications of growth towards the margin. Length of receiving valve two and half inches, proportional length of entering valve $\frac{\frac{55}{10}}{10}$, width $\frac{6 i t}{111}$, depth of both valves $\frac{55}{100}$; thickness of shell in beak of receiving valve two lines, above the beak of entering valve on one side five lines, on the other side four lines, diminishing the cavity to two lines in diameter; thickness of shell about the middle of the sides of receiving and entering valves three lines, diminishing to little more than one line along the middle, and gradually thinning to the margins. Length of young specimen nine lines; proportional length of entering valve $\frac{80}{100}$, width $\frac{80}{100}$, depth of both valves $\frac{45}{100}$.

The general narrow elongate form, and the oblique torsion of the long, narrow, claw-like beak in this species, exactly reminds us of the Uncites gryphus of Defrance, from which it is distinguished by the absence of the longitudinal sulcation. Having first ascertained the true internal characters of that curious Eifel genus, it gave me great pleasure to recognize in our British rocks a second species of this remarkable genus. I should have imagined that the smaller of the two figures given in Sowerby's Mineral Conchology, under the name of Terebratula porrecta, represented a young individual of this species, on account of the narrow produced front; but as Mr Sowerby himself has since stated (Geol. Trans. 2nd Series, Vol. V. exp. of t. 56) that those figures repressented specimens of Stringocplualus Burtini, and as all writers seem to coincide in that opinion, I have only to observe, that the present fossil, by the complete alssence of internal septa, and the external characters above enumerated, has no affinity whatever therewith.

Position and Locality.-Not uncommon in the Devonian limestone of Newton Bushel, Devonshire.

Explanation of Figures.-PI. 2. A. fig. 6, natural size; $6 a$, profile of ditto; fig. $6 b$, section of both valves at about one-third the length from the beak, shewing the thickness of the shell and alsence of internal apophyses; $6 c$, section of beak of receiving valve, shewing the great thickness of the shell reducing the internal cavity, and absence of internal septa.

\section{Tth Family. RHYNCHONELLID E. See page 199.}

\section{Genus. HEMITHYRIS (d'Orb.) See page 199.}

\section{Hemitmyis aCuminata (Mart. Sp.)}

Ref. and $S_{y n}=$ C. A. acuminatus Mart. Pet. Derb. t. 32 and 33. f. 7 and 8.+ C.A. pugnus id. id.t. 22. f. 4, 5. + Terebratula cordiformis Sow. Min. Con. t. 495. f. 2 and 4. + T. platyloba id. id. t. 496. f, 5 and 6. + (T. mesogona Plil. Geol. York. Vol. IJ.t. 12. f. 10 to 12. = Atrypa triangularis Sow. Geol. Trans. 2nd Series, Vol. V. t. 54. f. 9.) 
Sp. Ch.-Triangular, pyramidal; receiving valve flattened or slightly convex near the beaks and the narrow sides; apical angle about $115^{\circ}$; beak small, projecting with a small triangular foramen beneath it; front depressed into a very wide sinus, and abruptly curved towards the entering valve, nearly at right angles with the rostral portion (exceeding a right angle in the much elevated varieties, and considerably less in the depressed forms); lateral margins sigmoid, either entire or with two or three angular notches, from the ends of ridges extending a very short way towards the beak; front margin abruptly arched upwards into a sinus, varying from triangular or acutely elliptical, and higher than wide, to transversely semielliptical, and the height less than half the width, and either without plaits, or with from two to six, varying in the amount of angularity, but always becoming obsolete a considerable distance from the beak; entering valve with the profile only slightly arched, the greatest depth of all the varieties being at the front margin; rostral portion and sides slightly convex, the latter sloping rapidly towards the receiving valve, middle of the front varying from acutely angular to broadly arched; surface under the lens with fine, close, obtuse, concentric strie, varying from six to ten in the space of one line, crossed when finely preserved by longitudinal thread-like strix, five or six in the space of one line, separated by wider flat spaces.

There are four varieties which have been separately named, but which pass by the most insensible gradations one into the other, and certainly not distinguishable by any constant specific character. All the varieties are recognised by the marginal plaits disappearing a considerable space in front of the beaks. The T. reniformis, which in books is often confounded with this species, is perfectly distinct by the great inflection of the receiving valve. The texture of the shell gives a minutely flexuous fibrous appearance to the surface under the lens, when partially decorticated, as most specimens are, but infinitely finer than the rarely seen longitudinal striation above mentioned.

1st Var, acuminata (Mart.) - Front sinus very high, acutely angular, few or no trace of mesial plaits, nor lateral marginal plaits, except in very large specimens. Width two inches, proportional length of entering valve $\frac{84}{100}$, of receiving valve $\frac{95}{100}$, from plane of lateral margin to top of sinus $\frac{95}{100}$, depth from middle of entering valve at right angles to the surface $\frac{60}{100}$.

2nd Var. platyloba (Sow.) - Transversely ovate, plaits obtuse. Width one inch four lines, length of receiving valve $\frac{80}{100}$, from plane of lateral margins to top of sinus $\frac{45}{100}$.

3rd. Var. puguus (Mart.) - Rhomboidal tumid, three to six mesial, and three or no lateral, short, strong plaits. Width one inch, length $\frac{95}{100}$, from plane of lateral margin to top of sinus $\frac{80}{100}$, depth at right angles to middle of entering valve $\frac{65}{100}$. This is rather more tumid than the other varieties, and includes $T$. cordiformis, which M. de Verneuil supposed to be distinct by want of lateral plaits, although one of Sowerby's original figures of that supposed species shews them.

4th Var. mesogona (Phill. $=A$. triangularis Sow.) - Form and other characters exactly as in the type var. acuminata, but the width less than one inch. This cannot be the young of the large acute forms (which are depressed), but may be a diwarf variety.

Position and Locality.-Vars. 1, 2, and 3, not uncommon in the Devonian limestone of Plymouth, S. Devon; var. 4, rare in the slate of Petherwin, Launceston, Cornwall (the original specimen of $A$. triangularis has the apex of the sinus bifid, and traces of two minute lateral plaits, as in Phillips's description of T. mesogona).

\section{Hemthy ris cuboides (Son. Sp.)}

\section{$R e f_{0}=$ Atrypa cuboides Sow. Geol. Trans. 2nd Series, Vol. V. t. 56. f. 24.}

Sp. Ch.-Globose, subcuboidal; entering valve muderately convex in the middle, sides slightly convex, but abruptly sloping nearly at right angles with the middle, and subparallel to each other; lateral margins nearly horizontal, very slightly sigmoid; front margin abruptly elevated into a very large parallel-sided square sinus, slightly rounded at its end, which only produces a faint indication of a wide mesial ridge at the margin of wide specimens; entering valve nearly flat, with a small, pointed, incurved beak, beneath which is a very small triangular opening; mesial sinus only marked at the point where the lateral margins turn up, the large square extension of the front of the valve forming a slightly convex or very slightly concave filling to the sinus; 
surface radiated with very numerous, simple, equal, flattened, or slightly convex ridges (five in two lines at eight lines from the beak), fifteen to twenty occupying the sinus, and about twenty-two on each side. Length of rather small specimen eleven lines, proportional width $\frac{910}{100}$, width of sinus $\frac{50}{100}$, depth $\frac{811}{100}$; texture of the shell densely fibrous.

The margins are much sharper or more angular than in the Silurian 11 . Wilsoni, and the ribs simple; another difference is the small size at which the deflection of the margin begins in that species; there is no trace of it in the present one, which never acquires the great semicylindrical extension of the Silurian shell.

Position and Locality.-Common in the Devonian limestone of Plymouth and Torquay.

\section{Hemmithris pleurodon (Phill. Sp.)}

\section{Ref. and Syn.=Terebratula id. Phil. G. Y. Vol. II t. 12. f. 25 to 28. = Atrypa fallax Sow. Geol. Trans. 2nd Series, Vol. V.t. 54.f. 15.}

Sp. Ch.-Transversely elliptical, or subpentagonal; entering valve very slightly arehed from the beak to the front margin, which is much elevated into an oblong sinus, forming a flat mesial ridge, slightly marked at the margin; sides very much arched downwards towards the front, slightly excavated at the posterior or lateral margins; receiving valve with a narrow, prominent, slightly incurved beak, with a large triangular opening beneath it; sides nearly flattened; middle portion, forming the wide flattened sinus, semicircularly arched from the beak to the front margin; neither the mesial ridge nor sinus marked in the rostral portion; four to six large angular plaits, separated by very deep re-entering angles, raised with the front margin, with on each side five sharply angular much arched ribs, slightly larger than the mesial ones, and forming very deep angular indentations in the margins; behind these nearer the beak are usually two or three smaller ones, all the ridges continued sharply defined up to the beak; shell densely fibrous under the lens. Width ten lines, proportional length $\frac{8 \mathrm{~g}}{\mathrm{iw}}$, depth of both valves $\frac{57}{100}$.

In this species the two dental lamellix diverge at about $45^{\circ}$, and reach one-third the length of the shell in the receiving valve; the mesial septum in the entering valve seems somewhat longer. There is not the slightest difference in any respect between the varieties found in the slates and subordinate limestone of S. Petherwin, called Atrypa fallax by Sowerby, and those in the carboniferous limestone of Derbyshire. Mr Fischer's specimen of his $T$. pentatoma is so very defective at the sides, that neither the number nor character of the lateral ribs can be recognised, and I therefore prefer retaining Mr Phillips's specific name, the type for which is perfectly clear.

Position and Locality.-Common in the slates and subordinate limestone of S. Petherwin; ? in the green chloritic slate of Tintagel; slate in road-quarry, half a mile S. of Marwood.

\section{HemtimYRis protracta (Sow.Sp.)}

Ref. = Atrypa protracta Sow. Geol. Trans. 2nd Series, Vol. V. t. 56. f. 16.

$S p . C h$.-Elongate, obtusely triangular; apical angle $S 0^{\circ}$; greatest width near the front; posterior lateral margins long, front ride, obtusely rounded or subtruncate; the front margin abruptly raised into a large rounded sinus, only affecting the form of the valves near the margin, four large obtusely angular plaits raised with the front margin, but extending a very short way towards the beak; lateral margins minutely and obscurely crenulated; valves moderately and equally convex; receiving valve with a prominent, slightly incurved beak, from which an obscure tumid ridge extends to the mesial plaits of the sinus; entering valve moderately gibbous along the middle, sloping to the sides; surface smooth. Length (of small specimen) five lines, proportional length of entering valve $\frac{87}{100}$, width $\frac{00}{100}$, depth of both valves $\frac{65}{100}$.

Position and Locality.-Rare in the Devonian limestone of Plymouth. 


\section{HeMithYRIS SUBdentata (Son. Sp.)}

Ref. and Syn.=Atrypa subdentata Sow. Geol. Trans. 2nd Series, Vol. V.t. 54. f. 7.

$S p . C h$. Longitudinally ovate or subtrigonal (the two sides are broken off in Sowerby's figured specimen), with age the front becoming rather produced and elevated into a semielliptical sinus; entering valve considerably deeper than the receiving one; sides and rostral portion moderately convex and smooth; front towards the margin raised into an undefined broad rounded mesial ridge, bearing three obtusely-rounded ribs, becoming obsolete before reaching the beak, and forming angular indentations in the edge; receiving valve gently convex on the sides and near the beak, which is small and prominent, with the opening beneath it; middle portion towards the margin depressed into a wide deep sinus, containing two thick subangular ridges, which become very approximate, and extend obscurely nearly to the beak; surface smooth, densely fibrous under the lens. Length six lines, greatest width near the front about the same, depth of both valves $\frac{65}{100}$.

Count Munster figures this species (in his Beitrïge for 1840) from the black limestone of Schubelhammer as the Wenlock Atrypa rotunda of the Silurian system, from which it is certainly distinct by its more elongate form, angular teeth in the margin from the ends of the ridges, \&c.

Position and Locality.-Rare in the dark limestone of Petherwin.

\section{Genus. STRINGOCEPHALUS* (Defrance).}

Cien. Char.-Ovate, shell thick, fibrous, smooth; receiving valve with a large pointed beak (often a little oblique to the right side); cardinal area defined, flat, triangular, with a triangular deltidium, which encireles a round opening (which is finally filled up in the adult, according to Bronn, fe.) ; the interior of the receiving valve has a narrow mesial septum, and two dental lamellie diverging rapidly to a little in front of the cardinal angles, between which and the plate which is an internal prolongation of the cardinal area, a small chamber results on each side; entering valve with a large mesial septum curving towards the opposite valve, and composed of two diverging parts at its free edge (like that of the large valve of Pentamerus).

The pointed instead of inrolled beak, and cicatrised deltidium enclosing a foramen, distinguish this genus from Pentamerus, as well as the mesial septum in the entering calce, and the opposite valve having a simple, narrow, mesial septum, and very divergent instead of converging dental lamellie.

\section{Stringocepilalus giganteus (Sow.)}

\section{Ref.-Sow. Geol. Trans. 2nd Series, Vol. V.t. 56. f. 10, 11.}

$S p . C h$.-Transversely oval, depressed, a small sinus in front margin; beak of entering valve small; cardinal area flat, low, triangular. Width three inches nine lines, length three inches, depth of both valves one inch three lines.

I regret that having only one bad specimen at my disposal, I am unable to say more than that I have ascertained that the two diverging septa figured by Sowerby really exist, penetrating about two lines deep into the cavity of the shell; consequently the species cannot be a Stringocephatus. I have seen casts of the same shell in the Devonian shale of Looe, shewing the beak between these septa, two cardinal teeth, and a long bilobed pair of muscular impressions, as in Orthis.

If, as I suspect, there are two diverging lamellæ in each valve, the fossil would approach Porctubonites: but I have seen no punctured structure, and must, unwillingly, leave the matter undetermined for want of materials. I may add, that the great flatness of the valves would alone shew (as Mr Sowerby suggested) that, even externally, there is no specific relation between this shell and the stringocrphalus Burtini of the Eifel, with which most authors unite it.

Position and Locality.-Devonian limestone of Plymouth. 
Genus. PENTAMERUS. See page 208.

Pentamerus brevirostris (Phill. Sp.)

Syn. = Strigocephalus brevirostris Phill. Pal. Foss. f. 143.

$S p$. Ch.-Suborbicular or very broad-ovate, globose; entering valve nearly orbicular, evenly tumid, with an obtuse short beak; receiving valve gibbous, evenly convex, with a rather small, obtuse, incurved beak; beneath which is the usual triangular chamber-like opening, receiving the beak of the entering valve, and bounded by the converging lamellæ, which unite before reaching the inner surface of the valve into a strong mesial septum, reaching nearly to the front margin; in old specimens there is a faintly-marked, narrow, flat, mesial ridge; surface smooth. Length one inch, proportional length of entering valve $\frac{85}{100}$, width $\frac{103}{100}$, depth about $\frac{54}{104}$.

The internal plates of the beak are those of Pentamerus, and not of Stringocephalus, and therefore remove the species to the former genus.

Position and Locality.-Common in the limestone of Plymouth.

\section{8th Family. ORTHISID瓜. See page 211. \\ Genus. ORTHIS (Dal.) See page 212. \\ Orthis arcuata (Plill.) \\ Ref.-Phil. Pal. Foss. f. 107.}

$S p . C h$.-Transversely elliptical, front wide, slightly convex; hinge-line short, blending with the elliptically-rounded sides, depressed; surface radiated with very numerous, subequal, obtuse strix, divaricatingly arched backwards towards the ends of the hinge-line, crossed by minute, transverse lines of growth, and dichotomising at lengths of two lines; thirteen or fourteen ridges in the space of two lines at four lines from the beak, about ten in the same space at the margin of a specimen nine lines long. Width of old specimen one inch three lines, proportional length $\frac{60}{100}$.

The wide, regular, transversely elliptical outline, want of the minute interstitial line, and the much finer and more equal strix, as well as their backward or divaricating curve on the sides, separate this species from the $O$. interlineata of Sowerby.

Position and Locality.-Rare in the slates of S. Petherwin.

\section{Orthis interlineata (Som.)}

Ref. and Syn.-Id. Sow. Geol. Trans. 2nd Series, Vol. V.t. 53. f. 11. and t. 54. f. 14; Phill. Pal. Foss. t. 26. f. $106 a, b .=$ Atrypa striatula Sow. Geol. Trans. 2nd Series, Vol, V. t. 5t. f. 10.

Sp. Ch.-Suborbicular or rotundato-quadrate when young, transversely oblong or elliptical when old; hinge-line less than the width of the shell; cardinal angles very obtuse; valves gently convex; margins horizontal, or with a very slight wave in the front margin; front slightly convex, wide; sides rounded; both valves radiated with very numerous, subequal, obtusely-angular, radiating ridges, branching di- or tri-chotomously at distances of about two lines; ridges separated by narrow sulci, usually containing one or rarely three minute elevated lines; eight to twelve of the larger strix in the space of two lines, at four lines from the beak, about the same number at the margins of old specimens an inch and quarter long: internal cast of receiving valve with two thick dental lamella, diverging at $115^{\circ}$, from the ends of which an obscure boundary extends forwards and then inwards, inclosing a quadrate space for the pair of muscular impressions, nearly one-third wider than long, and divided in the anterior half by a slender mesial septum, which does not extend beyond their length: muscular impressions extending one half the length of a shell four lines long, about only one-third the length in a specimen one inch and quarter long; cast of entering valve with a small rostral tooth, and two thick, diverging, cardinal teeth; two pairs of muscular impressions inclosed by a rounded crucial boundary, as wide as long, the middle divided by a broad mesial ridge extending to the front in young specimens. Length of the typespecimens about five lines, but adult examples one inch three lines long; the length varies from $\frac{65}{100}$ to $\frac{85}{500}$ of the width, $\frac{70}{100}$ being the average. 
This species varies considerably in proportional width, but principally owing to pressure. The minute interstitial rilge, from which the species derives its name, and in some rare cases three minute ridges, are developed between a pair of larger near the margin; in impressions of the outer surface these of course appear as depressed lines dividing the ridges. On examining the type specimen of $\mathrm{Mr}$. Sowerby's Atrypa striatula, I find that specius is founded on an Orthis, an internal cast of a large specimen of the O. interlineato of the same writer, shewing on careful examination the same interlined ridging, same number of ridges in a given space, Sc.; in addition to which I myself have collected all the intermediate sizes in the original locality of both species at S. Petherwin. The internal casts alluded to by Mr Sowerby as Atrypu striatula from Fowey, is generically distinct, and probably Spirigerina desquamata.

Position and Locality._Extremely abundant in the slate of S. Petherwin, and Lanlake, Launceston.

\section{Orthis persarinentosa $\left(M^{c} \mathrm{Coy}\right)$. Pl. 2. A. fig. 0.}

$s p$. Ch.-Transversely oblong, hinge-line nearly as wide as the shell, ends obtusely subtruncate, slightly rounded: surface covered with thick, rurged, rounded, flexuous, radiating ridges, about half their thickness apart; about five in three lines in the middle of the shell at six lines from the beak, branching four or five times between the beak and margin, counting about 130 at the margin of a large specimen; those towards the sides straighter and finer than those in the middle. Average width three inches, length probably one-third of the width, but cannot be stated accurately orving to the distortion of all the specimens.

This species very closely resembles the $O$. sarmentosa $\left(\mathrm{M}^{\circ} \mathrm{Coy}\right)$ of the older rocks in form, and the peculiar twig-like mode of branching of the ribs on the middle of the shell, and the straighter and finer ones of the sides, but is distinguished by the very much greater number of the ridges $A$ s in the case of that species, the distortion is usually such, that $I$ ean make no probable approximation to the proportional length. The coarseness of the ridging separates the present speeies from the American strophomenu nerrose and S. bifurcate (Hall) of the Chemung group.

Position and Locality.-Common in the Devonian shale of Polruan, Cornwall; in the reddish Devonian schists of East Looe; schists of Forrey.

Explanation of Figures.-Pl. 2. A. fig. 9, from the Devonian shales of Polruan, Cornwall; natural size of a specimen shortened by crushing.

Genus. LEPTENA. See page 232.

Subgenus. STROPHOMENA. See page 241.

\section{Leptena (Strophomena) arachnoidea (Phill. Sp.)}

Ref.-Spirifer id. Phill. Geol. York. Vol. II. t. 11. f. 4.

$s \%$. Ch.-Truncato-orbicular, sides subparallel, slightly convex, front broadly rounded, slightly convex, much flattened; hinge-line as wide as the shell, cardinal area very narrow; ears rectangular; entering valve slightly convex, with a straight hinge-line; receiving valve with a narrow moderately prominent beak; rostral portion slightly convex, becoming flattened or very slightly concave towards the margins; surface of both valves radiated with very numerous, narrow, thread-like ridges, separated by wider, flat, or slightly concave spaces, crossed by minute lines of growth under the lens; the ridges increase very much in number (but not in thickness) between the beak and the margin by intercalation of one ridge at a time, which quickly assumes the thickness of the original pair between which it commenced, so that the strixe are all nearly equal at the margin, or rarely a single smaller between some of the pairs of ordinary size; nine or ten stria in two lines at eight lines from the beak, about the same at six lines from the beak; in the entering valve the lateral strix are nearly straight along the hinge-line, but in the receiving valve they are slightly arched divaricatingly. Average width one inch two lines, proportional length $\frac{92}{100}$.

$$
\text { [FAsC. II.] }
$$


This beautifully distinct species is easily distinguished from the O. crenistria by the near equality of all its strix, which are finer, closer, and want the number of fine intermediate longitudinal stria. From the $O$. subarachnoidea it differs in its wider, more quadrate form, and broad slightly convex front.

Position and Locality.-Not uncommon in the slate of Lanlake, Launceston, and in the same beds at South Petherwin.

\section{Leptena (Strophomena) gigas (McCoy). Pl. 2. A. fig. 7.}

Sp. Ch.-Rotundato-trigonal; hinge-line equal to the width of the shell; sides gently convex, converging to a narrow, much rounded front; valves much flattened, slightly convex; surface radiated with very numerous, fine, close, obtuse strix, separated by narrower, finely punctured, impressed lines, every fifth, seventh, or ninth of which seems larger than the rest; about sixteen strix in two lines at an inch from the beak, fifteen in the same space at the margin, three inches from the beak; cardinal area broad; internal casts of receiving valve in adult specimens shew the pair of muscular impressions, forming a slightly bilobed, or subtrigonal mass, about onethird wider than long, and reaching rather more than one-third the length of the shell, each side marked with six or seven very coarse radiating ridges; mesial septum very small. Arerage length three inches two lines, proportional width $\frac{95}{100}$ to $\frac{100}{100}$, width of cardinal area nearly two lines.

This gigantic species in its elongate, elliptical, or subtrigonal form, arising from the narrow rounded front, precisely agrees with Orthis subcrachoided of MLI. d'Arehiac and de Verneuil (Geol. Trans. 2nd Series, Vol. V'I. t. 36. f. 3), but differs from it in the larger strix at subregular intervals between the groups of smaller, as well as in its great size. I have seen and made drawings of a large number of specimens in the private collections of persons at or near Looe, although there is only one poor specimen in the university collection; I am therefore better prepared to decide on the characters of the species than I should otherwise have been.

Position and Locality._Common in the Devonian shale of Looe; Devonian shale of Polruan, Cornwall.

Explanation of Figures.-PI. 2. A. fig. 7, natural size of average specimen; the lower portion netted by a species of Viow.

\section{Leptzena (Strophomena) nobilis (Mc Coy). Pl. 2. A. fig. 8.}

Sp. Ch.-Semicylindrical; entering (?) valve very gibbous near the bealss, strongly-arched downwards into a subeylindrical, deflected front, the sides of which are slightly flattened to join the obscurely-defined ears, which project from the gibbous beak, and are nearly rectangular; front rounded; surface radiated with narrow, distinctly defined ridges, of about equal thickness throughout, about trenty originating from the beak, between each pair of which, after about the length of one inch, a new ridge equal to the primary in size is developed, so that nearly over the whole shell the subequal ridges are little more or less than a line apart, the intervening spaces slightly concave, three times wider than the ridges, crossed by very deep, strong, irregularly curved, concentric wrinkles, not crossing the ridges, scarcely four in a longitudinal space of three lines; entire surface, ridges and furrows, marked with very fine, slightly irregular, longitudinal, distant strix, nine in the space of one line, strongly punctured when the outer layer of shell is removed. Width at hinge-line two inches four lines, proportional length about the same, depth (greatest at one-third from the beak) $\frac{65}{100}$.

This fine species is so completely unlike any other, that it is unnecessary to point out the distinctions, the nearest analogue apparently being the comparatively little, flat, few-ribbed Oithis unduluta ( $\mathrm{II}^{\mathrm{C}} \mathrm{Coy}$ ) Synop. Sil. Fos. Irel. t. 3. f. 22. of the Silurian series, with which however it has no specitic affinity.

Position and Locality.-Rare in the Devonian limestone of Teignmouth.

Explanation of Figures.-Pl. 2. A. f. 8, natural size; fig. $8 \alpha$, portion of surface of ditto magnified, shewing the longitudinal striation of the surface, and the lines of punctures where the shell is decorticated.

\section{LEPT ÆNA (Strophomena?) SORDIDA (Sow.)}

Ref. and Syn.=Leptona sordida Sow. Geol. Trans. 2nd Series, Vol. V. t. 53. f. 5, 16.

$S p$. Ch.-Transversely oblong or senielliptical; depressed, or slightly convex, entering valve most so; front wide, slightly convex; lateral margins slightly convex, sometimes front and lateral margins uniformly 
arched; surface radiated with very delicate, straight, rough, simple, sharply defined ridges, almost uniform in size and closeness throughout, separated by flat coarsely punctured spaces, equalling them in width; strix increasing in number by intercalation only, giving rise to a slight appearance of alternation of size in some spots; about eleven striae in two lines about the middle, and nearly all parts of the shell when unpressed, but varying from eight to sixteen by distortion in the rock; casts of entering valve shewing the impression of a strong mesial septum, reaching rather more than half-way to front margin, and two short, thick, cardinal teeth ; receiving valve with two, noderate, straight, dental lamellae, diverging at $125^{\circ}$. A verage width about one inch, proportional length varying (most probably from pressure) from $\frac{60}{100}$ to $\frac{90}{100}$ (sometimes $1 \frac{1}{2}$ inch wide).

The coarse punctation of the sulci gives a rugged character to the strice; besides, I have noted also in parts a slight tuberculation of the strix, although I see no marked change of character in them towards the margin, as suggested by Phillips. I suspect the Linton shell referred by Prof. Phillips (Pal. Foss.) to the Silurian 0 . compressa, belongs to the present species.

Position and Locality.-Very abundant in the hard Devonian schists of Linton.

\section{Leptena (Strophomena) umbraculuar (Schlot. Sp.)}

$$
\text { Ref. and } S y n \circ=\text { Terebratulites umbraculum Schlot. Pet. p. } 256 .
$$

sp. Ch.-Truneato-orbicular; hinge-line nearly or quite equal to the width of the shell; ears rectangular, or slightly obtuse; cardinal area wide, inclined backwards at an angle of alout $140^{\circ}$; foramen slightly wider than a right angle, closed by a concave cicatrix; front and lateral margins nearly unifornly arched or slightly sulqquadrate: receiving valve convex near the beak, which is slightly prominent, becoming gradually concave, after four or five lines, towards the margins; entering valve convex, with a slight mesial depression; greatest depth ahout the middle; surface of both valves radiated by straight thread-like ridges, separated by slightly wider concave spaces, which are either smooth, or crossed by fine transverse lines of growth (not minute, irregular wrinkles, as in S. crenistria), usually each alternate line smaller (to allow for the increase of number towards the margin), very rarely near the margin of large specimens three smaller between some of the pairs of larger; six to eight strixe in the space of two lines at one inch from the beak; six in the same space at an inch and half from the beak. IVidth (of very large specimen) two inches four lines, proportional length receiving valve $\frac{85}{100}$, depth $\frac{25}{100}$.

This species is distinguished from the $O$. crenistria by the greater convexity of the entering valve with its slight mesial depression, also by the thicker, closer, and more equal strix, the narrow spaces between which are either quite smooth, or only marked by regular transverse lines of growth, totally different from the deep, minute, irregular wrinkles of the carboniferous species. I suppose the Orthis crenistric of Phillips's Palieozoic Fossils may possibly be this species, as well as the Spirifere crenistrie mentioned by Sowerby from Plymouth: but in neither case is the figure or description careful enough to allow of any definite opinion being formed.

Position and Locality.-Common in the limestone of Teignmouth.

\section{Subgenus. STROPHALOSIA (King). 1844.}

$$
=\text { Leptonalosia King. = Aulosteges Helmerson }(1847)=\text { Orthothrix Geinitz (1848). }
$$

Gen. Char.-Subhemispherical, both valves bearing scattered tubular spines; receiving valve convex; entering valve concave externally; hinge-line straight, nearly as long as the shell is wide; cardinal area distinct in one or both valves, the rostral tooth forming a boss in the middle of that of the entering valve, and the triangular foramen in the middle of the opposite area nearly closed by a psendo-deltidium. Interior of receiving valve with large, longitudinally ovate, muscular impressions in the cavity of the beak, and a strong pair of conical hinge-teeth, one on each side of the base of the aperture: interior of entering valve with a thick, prominent, rostral tooth, from which a mesial septum extends about half way to the margin; on each side of 
the rostral tooth is a deep pit for the cardinal tooth of the opposite valve; reniform impressions rather large, the outer edge prominent, commencing near the beak, gradually arching forwards and outwards on each side, then turning abruptly backwards for about half their length, and finally turning horizontally inwards to meet each other near the apex of the mesial septum; at their posterior origin two small, ovate, prominent bosses (? insertions of adductor muscles) close to the mesial septum.

The hinge-teeth of the large valve, cardinal area, and pseudo-deltidium, totally remove this genus from Productus; and I have not seen (nor does Professor King mention) any trace of the dendritic impressions of that genus; but I do not think there is any difference between the reniform impressions and those either of Producta gigantea or Leptcena transversalis. The group presents scarcely any difference from Leptana proper except its tubuliferous surface, and should be placed as a subgenus thereof.

\section{Leptana (Stroplealosia) caperata (Som. Sp.)}

Ref. and Syn.=Leptcena caperata Sow. Geol. Trans. 2nd Series, Vol. V.t. 53. f. 4. + L. membranacea Phill. Pal. Foss. f. $101 a, b$, and M. V. K. Geol. Russ. t. 15. f. $11 a, b$.

Sp. Ch.-Semielliptical, moderately and evenly convex, except towards the cardinal angles, which are gradually flattened, and rectangular or slightly produced into very small acute points ; cardinal area triangular, about one and a half lines high in specimen one inch three lines long in the receiving valve, narrow, and nearly parallel-sided in entering valve; triangular foramen rather wider than long; entering valve nearly flat, with a mesial septum reaching rather more than halfway towards the front margin; entire surface of both valves covered with very small, elose, round, subequal, undulated or zigzag, concentric wrinkles (about seven or eight in two lines at six lines from the beak), and numerous elongate, quineuncially arranged, spine tubercles, the latter often nearly obsolete, or when strongly marked obscuring the zigzag wrinkles, which appear stronger and straighter on the ears; often five or six long slender spines on the hinge-line. Width of adults one inch two lines, proportional length $\frac{50}{100}$, depth of receiving valve $\frac{20}{100}$, of entering valve about $\frac{10}{100}$.

All the specimens which I have examined of this species, named by Mr Sowerby himself, were certainly, specifically identical with the $L$. membranaced of Phillips; and I may observe, that it is only the entering valve of typical examples of that species that are nearly flat. The species varies greatly in the proportional strength of the two kinds of ornament, and when the beautiful concentric zigzag wrinkling is very strongly marked, the elongate tubercles can scarcely be seen; and on the other hand, when the quincuncial spine tubercles are strongly marked, the transverse wrinkling cannot be so distinctly seen; and this has perhaps given rise to the two species with Mr. Phillips, although, from examination of Sowerby's types and numerous specinens on the spot when they were first found, and where they abound, I readily traced every gradation between the supposed different types. None of the published figures do justice to the singular beauty and regularity of the minute, transverse wrinkling.

Position and Locality.-Extremely abundant both in the slate and subordinate limestone of S. Petherwin.

The var. approaching Producta scabricula in appearance, is not uncommon in the Upper Devonian slate in road quarry quarter of a mile S. of Marwood, also in the fine Upper Devonian grits at Earnstaple.

\section{LEPT Ana (Strophalosia) subaculeata (Murch.)}

Ref. and $S_{y} n_{0}=$ Id. Murchison, Bull. Geol. Soc. de France, Vol. XI. t. 11. f. 9, and Koninck, Monogr. Prod. t. 16. f. 4.=Leptoena Fragaria Sow. Geol. Trans. 2nd Series, Vol. V.t. 54. f. 3, and t. 56. f. 5 and 6.

Sp. Ch.-Subhemispherical or slightly quadrate; receiving valve very gibbous, with a rather narrow prominent beak; hinge-line rather less than the width of the shell; ears gradually flattened, obtuse-angled; cardinal area and foramen very small; front margin wide, gently convex, no mesial depression; surface with numerous, rather large, irregularly scattered, round, or slightly elongate tuhercles, each bearing at its apex a minute spine perpendicular to the surface; surface otherwise either perfectly smooth or marked with obsolete, 
irregular, interrupted, transverse wrinkles, rather stronger at the sides; entering valve very concave, similarly marked to the receiving valve, the projections being inward. Width of large specimen one inch, length of receiving valve $\frac{80}{100}$, of entering valve $\frac{67}{100}$, depth of receiving valve $\frac{33}{100}$, of entering valve $\frac{17}{100}$.

It is remarkable that neither Mr Sowerby nor Prof. Phillips, (Pal. Foss.), noticed the identity of our British fossil with that described by Sir R. Murchison from Boulogne. The elongation of the tubercles in $\mathbf{M r}$ Sowerby's figure, t 54. f. 3, is, I find, only produced by mechanical compression in the rock, the part of the specimen not crushed having them round. The young specimens rarely shew any of the obsolete concentric wrinkles, and in them also the spine bases are more nearly round; they are fewer, more distant, and less regular than in the $P$. spinulosa (Sow.), and the peculiar form of the tubercles, their number, and tuberculation of the entering valve, as well as less gibbosity, separate it from the $P$. aculeata. The spines are usually more than their diameter apart, and are slightly closer on the sides than on the middle of the shell.

The fewer and more distant rounded tubercles distinguish this from the P.gramulosa (Phill. $=P$. papillosa de Kon.)

Position and Locality.-Very common in the slate and subordinate limestone of S. Petherwin; and in the same slate at Lanlake, Launceston.

\section{Subgemus. LEP'TAGONIA. See page 247.}

\section{Leptana (Leptagonia) analoga (Phill. Sp.)}

Ref. and Syn. = Producta analoma Phill. Geol. York. Vol. II. t. 7. f. 10. Pal. Foss. f. $93 a>$ Leptana disturta (Sow.) Min. Con.t. 615. f. 3. ?> Leptocna nodulosa (Phill. Pal. Foss. f. 94), (and mugosa same plate, f. 95, not of Dal.)

The shell in the middle and upper Palieozoic rocks can scarculy be considered a distinct species from the L. depressa of the Lower Palieozoic strata (which see), and of which probably it is only a variety, not separable when the extremes are compared, but generally recognisable as a distinct variety, much in the same way as the Devonian variety, aspera, of the Silurian spirigerince reticularis, is usually distinguishable from the older varieties. The general characters of the species are exactly those of the $L$. depressa, and the description given in the Lower Palacozoic section of that species will suit the present in nearly all respects. The differuncen which strike an observer are, that the transverse wrinkles in the Lower Palcozoic $L$. depresse are usually from twelve to fifteen in number, but in this variety are from fifteen to twenty, nost usually about eighteen, and the longitudinal strixe are on the average considerably coarser in the $L$. cenclugu than in the $L$. depresert: in the uniddle of the front, at the angle betreen the visceral portion and deflected front of the Lower Palaozoic form, from nine to trienty of these strix may be counted in the space of two lines, twelve being the most common number; but in the $L$. analoga, in the same space, and at the same part, there are from four to ten, most usually eight. Thus, though one might procure specimens from the mountain-limestone or the Silurian rocks, to agree in either of these characters, yet from the lower strata I have never seen specimens approaching the coarseness of striation of the mountain-limestone or Upper Devonian ones, nor have I ever seen Silurian specimens with such numerous concentric wrinkles as are commonly seen in carboniferous ones. As to the varieties named Leptend distorte by Sowerby, and Lepteren nodulose by Phillips, I have in the mountain-limestone traced all the intermediate varieties to the more regular types, and no doubt exists in my mind of their specific identity.

Position and Locality.-Very coarsely striated var. in Upper Devonian slate, on road a quarter of a mile S. of Marwood.

\section{9th Family. PRODUCTIDE.}

Shell free, without cardinal area or perforation for a muscle of attachment ; no cardinal teeth to receivin 4 valve, nor free internal testaceous appendages to entering valve. Surface set with tubular spines (arms and other soft parts supposed to resemble those of Lingula). 
This family must either be limited to the genus Productus, or include (in accordance with Mr J. E. Gray's view) all the Orthisidar; the characters of Professor King's genus Strophalosia seem so perfectly to unite the characters of the two families, that it is quite possible the latter course may become inevitable. M. d'Orbigny proposes as a character for separating the Orthisida from the Productide, that the former have the shell fibrous and the latter punctured, but they are both punctured distinctly.

\section{Genus. PRODUC'IA (Sow.)}

Gen. Cher.-Very inequivalve; receiving valve subhemispherical, and covered with scattered nacreous hollow tubular spines; entering valve concave; hinge-line straight, usually as long as the shell is wide; no cardinal area nor foramen; internally, entering valve with a projecting bilobed lever-like beak, from which a long, low, mesial septum extends nearly to the front; about the middle of this is on each side a small pear-shaped apophysis or protuberance, probably giving rise to the arms; a little outside and anterior to those are two pear-shaped or sickle-shaped smooth impressions, usually with a raised outer margin, curving outwards and forwards, and probably marking the place of a pair of arm-like lobes, as in the recent Thecidec; exterior to these, the surface is punctured and spinulose; between the little apophyses at probable base of arms, and the beak, close to the septum on each side, is a complex dendritically-lobed impression, supposed by some to mark the ovaries, by others, the liver, and by others, muscular attachments. The receiving valve has near the beak two dendritic impressions like those of the opposite one, and on the most convex part of the valve on each side a pair of very large muscular inpressions so close together as only to form one protulorance on each side, but readily distinguishable; the anterior pair, or portion, largest, rounded, and more closely sulcated; the posterior pair or portion nearest the beak, smaller, depressed, triangular, and probably sending their filres to the prominent beak of the entering valve to open it.

I am uncertain of the points of insertion of the adductor muscles in the entering valve, but think it likely they were fixed to the little polished protuberance close to the middle of the septum on each side, from their close resemblance in density and structure to the boss on the beak of the valve, which we know received the tendons of the adductors. Each valve is composed of several parallel layers, separable in some states of preservation; punctures of the shell scattered, large; intervening strata dense.

\section{Producta prielonga (Som. Sp.)}

Ref. and Syn. Leptona prolonga Sow. Geol. Trans. 2nd Series, Vol. V. t. 53. f. 29 ? = Productus Christiani (de Kon.) Mong. du Prod. t. 17. f. 3.

Sp. Ch. - Subcylindrical, or oblong; hinge-line equal to the width of the shell, forming short, much dejressed, rectangular ears; receiving valve with a very large inflated beak, gradually arehing into the produced, rounded, semicylindrical front; a narrow, rounded, mesial ridge extends nearly from the beak to the margin; entering valve with the mesial disk flattened or slightly concave, the produced front bending rather abruptly downwards, the deep, narrow, concave, mesial sinus (corresponding to the ridge of opposite valve) very distinct nearly from the beak; visceral portion of both valves faintly and irregularly wrinkled concentrically; surface marked with fine, close, slightly irregular, longitudinal strixe (ten or twelve in two lines at one incls from the beak), and several small, ovate, scattered spine bases, principally on the rostral portion, where they are larger and closer, three or four of the largest on the mesial fold. Width (of small specimen) one inch one line, length of visceral portion of entering valve nine lines, length of deflected front seven lines, distance between the valves in rostral portion six lines.

I was greatly surprised to find, on examining the unique specimens of this species in the Cambridge collection, originally figured and described by Sowerby, that the impression of the entering valve (not figured) shews a strong, narrow, rounded mesial ridge of exactly the size and shape of that in the $P$. mesoloba (a very slight indication of which may be now recognised in a notch in the lower margin of Sowerby's end view), and further, that along the corresponding line on the middle of the receiving valve there was a narrow, rough, abraded space, from which there could be no doubt the narrow ridge had been either broken in extracting the 
specimen from the matrix, or it had been worn off from the soft sandstone in the carriage. The distinctness of this mesial fold in the mould of the entering valve would cause the specimen to be referred to the $P$. mesoloba, were it not for the distinct longitudinal striation; and as this is also the distinguishing character of the $P$. Christiani of de Koninck, I have little doubt of the identity of the species, allowance being made for difference in size, and the spines being rather more numerous than in the example figured by Koninck.

Position and Locality. - Rare in the sandstone of Croyde.

\section{3rd Class. LAMELLIBRANCIIIATA. See page 256.}

1st Ord. Pleuroconcha. See page 257.

7th Family. AVICULIDE. See page 257.

Genus. AVICULA. See page 257.

Avicula texturata (Phill.)

Ref.-Pal. Foss. f. 87.

Sy. Ch.-Obliquely ovate, tumid, evenly gibbons along the middle, posterior slope gradually compressed. obliquely subtruncate; anal cardinal angle obtuse; respiratory angle broadly rounded; anterior side small, acute, or rounded, very deeply divided from the body of the shell by an abrupt compression and a rounded sinus in the margin between it and the strongly convex ventral margin; entire surface covered with strong, prominent, concentrie, narrow ridges, three or four times their thickness apart (four to five in a space of two lines at six lines from the beak in middle of the shell), the interspaces cancellated by radiating ridges of about the same thickness as the concentric ones, but rather closer (five to six in same space and part of the shell as above mentioned), the points of intersection forming tubercles. Average length from anterior end to respiratory angle one inch three lines, proportional length of hinge-line from beak to anal angle $\frac{s i}{1+m}$, length of anterior side $\frac{12}{i \cdots+2}$, width from beak at right angles to hinge-line $\frac{20}{11}$, width of posterior end at right angles to end of hinge-line $\frac{1 .}{2 .}$. depth of left valve at one-third the length from the beak $\frac{17}{100}$.

Position and Lorulity.-Rare in the Devonian limestone of Plymouth; rare in the hard Devonian schists of Linton, North Devon.

\section{Subgenus. P'TERONITES $\left(\boldsymbol{M}^{\circ}\right.$ Coy). 1844.}

Ref.-Carb. Foss. Irel.

Gen. Char.-Subtriangular, depressed, hinge-line as long as the shell; beaks terminal or nearly so, forming a very narrow, obtusely-pointed, anterior end, from which the ventral margin extends uninterruptedly to the broad posterior end; left valve most convex; internally a very small tooth under the beak of the right valve, and a very slender, posterior, lateral tooth close to the hinge-line the whole length; no other teeth or muscular impressions visible.

Probably a subgenus of Avicula. Differs from Pterinea in the thinness of the shell, want of the ligamentary facet between the cardinal margins, absence of the hinge-tectl, and strong anterior adductor impression. Differ's from Avicula in general form and want of a defined anterior lobe or byssiferous sinus. and defined posterior wing; the nearly terminal beaks giving the narrow pointed character of the anterior end. Nyalina of Koninck is described as equivalve, and as having a broad, striated, ligamentary facet. 


\section{Pteronites subradiatus (Som. Sp.)}

\section{Ref. and Syn.=Avicula (Monotis Bronn.) subradiata Sow. Geol. Trans. 2nd Series, Vol. V.t. 54. f. 1.}

$S p . C h$. - Longitudinally aliform or subtrigonal, very slightly convex; beaks very small, inconspicuous, near the very narrow rounded anterior end, from which the margin is gradually and slightly arehed to the respiratory angle, which is obtusely rounded; posterior end very broad, the margin slightly signoid, sultruncate, with a slight obliquity; hinge-line nearly as long as the shell; cardinal angle nearly rectangular; a triangular space extending from the beak along the hinge-line, rather less than half the width of the posterior margin, marked with very fine, nearly obsolete, radiating strix, rest of the surface radiated with coarse, rugged, slightly unequal, narrow ridges, separated by spaces about equalling them in width (about five or six in the space of two lines at ten lines from the beak); whole surface crossed by delicate, subregular, concentrie, elevated, narrow plicæ, varying from a line to half a line apart on the middle of the shell. Length one inch six lines, proportinnal length of hinge-line $\frac{85}{1 w i}$, width from beak at right angles to hinge-line $\frac{18}{1 \times 1}$, length of anterior end $\frac{11}{110}$, width of posterior end about $\frac{50}{100}$.

Position and Locality.-Common in the slate of S. Petherwin.

\section{Genus. AVICULOPECTEN (MCOy).}

Gen. Char.-Inequivalve, more or less inequilateral; straight, or slightly extended obliquely towards the posterior side; anterior ear flattened, smaller than the posterior, sharply and deeply defined, with a deep notch in the right valve between it and the body of the shell for the passage of the byssus; posterior ear slightly pointed, extending about as far as the margin of the shell, defined or not; ligament confined to a narrow facet along the hinge-margin; no medial cartilage pit; muscular impression and pallial sear as in Pecten.

It was only on seeing the fine suite of fossils from the dark limestone of Lowick, Northumberland, recently presented by the Rev. Mr. Jenkins to Prof. Sedgwick, and now in the collection of the University of Cambridge, that I recognised the characters by which the great bulk of the so-called Pectens of the middle and upper Palseozoic rocks are distinguished from the true Pectens of the more recent formations and present sea. In the present fossils the posterior ear is largest, thus differing in an external character from Pecten and approaching A vicula, an affinity greatly increased by the internal structure exposed by the Lowick (and some of Mr. Griffith's Irish) specimens, shewing that there is no mesial ligamentary pit beneath the beak as in the former genus, but, as in the latter, the ligament is confined to the hinge-margin; while in general form and little or no obliquity of the shell, the resemblance this genus bears to Pecten is very striking.

The discovery of this character fixes the zoological place of numerous carboniferous shells constantly varying hitherto in the systems between Pecten, Avicula, and Meleagrina.

\section{Aviculopecten granosus (Sow. Sp.)}

\section{Ref. and Syn.=Pecten granosus Sow. Min. Con. t. 574. f. 2.}

$S^{\prime}$. Ch.-Truncato-orbicular, compressed, gently convex; hinge-line nearly equalling the width of the shell: anterior ear shorter than the anterior margin, strongly defined from the body of the shell by its abrupt depression, and a small sigmoid sinus in the margin, besides a narrow, nearly smooth space at the junction with the body of the shell destitute of radiating ridges; posterior ear broadly falcate, undefined; cardinal angle slightly acute, reaching as far as, or slightly beyond, the posterior margin of the shell; surface of the middle and posterior wing uniformly covered with thick, obtusely nodular, slightly irregular ridges, separated by deep, smooth, narrow concave spaces, with often a much smaller slightly tubereular ridge between some of the pairs of larger; four or five ridges on the anterior ear beyond the smooth space above mentioned; in the middle of the shell at one inch from the beak about seven to ten strix in the space of three lines. Length and width nearly equal. varying from one to nearly three inches, proportional length of posterior ear $\frac{60}{1 \mathrm{im}}$, of anterior ear $\frac{43}{1 \mathrm{ww}}$.

Position and Locality.-Rare in the slate of S, Petherwin. 


\section{Aviculopecten PeCtinoides (Son.Sp.)}

Ref. and Syn.=Avicula Pectinoides Sow. Geol. Trans. 2nd Series, Vol. V. t. 54. f. 2. ?= Meleagrina rigida $\mathrm{M}^{\mathrm{c}} \mathrm{Coy}$, Synop. Carb. Foss. Irel. t. 13. f. 16.

$S p . C h$. - Rotundato-quadrate; valves nearly flat, posterior ear very large, undefined, equalling or slightly passing the posterior margin in length; posterior margin slightly sigmoid, forming a short acute termination of the hinge-line; entire surface of the body of the shell and posterior ear radiated with subequal, obtuse, sharplydefined, narrow, rugged ridges, separated by flat smooth spaces, equalling or slightly exceeding them in width (at one inch from the beak); in the middle of the shell five or six ridges in the space of three lines, at one inch and half from the beak, and at two inches three or four in the same space. Average width from two to two and half inches.

In general outline, and the disposition, and general character of the ridging, this species agrees nearly with the Aciculopecten granosus and A. plicatus (Sow. Sp.), from which however it is clearly distinguished by the greater size, the fewer ribs in a given space on all parts of the shell, by their more near equality in size, and their wide flat interspaces; this latter character, however, is considerably exaggerated in Mr Sowerby's figure, as may be seen from the above accurate measurements taken from his original specimen. None of the additional fragments which I have seen shew any trace of the regular concentric ridging of Gioldfuss's figure of A. Neptuni, which is therefore, as Sowerby suggests, probably distinct. I strongly suspect, after seeing the difference between Mr Sowerby's type-specimen and his figure, that the Meleagrina (Aviculopecten) rigida of my volume on the carboniferous fossils of Ireland from the carboniferous slate of that country, should now be united therewith; in that case the anterior ear would be square, undefined, and ridged like the rest of the shell.

Position and Locality.-Rare in the soft olive slate of S. Petherwin, Cornwall.

\section{Aviculopecten transversus (Sow. Sp.)}

Ref. and Syn. = Pecten transversus Sow. Geol. Trans. 2nd Series, Vol. V. t. 53. f. 3.

Sp. Ch._Subelliptical, compressed; anterior ear small, subtrigonal; posterior ear larger, falcate; valves flattened, slightly convex towards the beaks; surface radiated with obtusely angular ridge-like groups, composed each of three angular subequal strie, without distinct interspaces (about seven in two lines in middle of ventral margin, at nine lines from the beak), all crossed by sharp scaly lines of growth, rendering the angles spinulose; ridging of the ears irregular. Length from anterior to posterior margin parallel with the hinge about one inch five lines, proportional length from beak to opposite margin ${ }_{100}^{75}$.

The proposed reference of this shell to the Pterinea radiata (Gold.) by Phillips, d'Orbigny, Bronn, \&c., I find, on examining the original specimen, to be incorrect, as the British species has radiated ears, and much more numerous and finer ribs of nearly equal size; besides their remarkable regularity of grouping.

Position and Locality.-Rare in the slate of S. Petherwin, Cornwall.

\section{Gemus. DOLABRA $\left(\boldsymbol{M}^{c} \mathrm{Coy}\right)$. See page 269.}

Dolabra angusta (Som. Sp.)

Ref. and Syn. = Cuculloca angusta Sow. Geol. Trans. 2nd Series, Vol. V.t. 53. f. 25.

Sp. Ch.-Subquadrate; length and width nearly equal; moderately gibbous, most so towards the beaks, gradually becoming depressed towards the margins; beaks a little on the anterior side of the middle, large, approxmiate; diagonal ridge obtusely rounded, only distinct near the beaks; posterior slope flattened, posterior margin straight, truncated, nearly at right angles with the hinge-line and ventral margin, which latter is slightly convex and subparallel with the hinge; anterior end broadly rounded, posterior cardinal tooth in left valve usually strongly marked, nearly as long as the hinge, from which it slightly declines, bifid in the right valve. Length from anterior to posterior margins one inch one line, width from beak to opposite ventral margin $\frac{9.5}{1 \ldots . .1}$ 
(sometimes exceeding the length), proportional length of hinge-line $\frac{70}{100}$, width of posterior margin $\frac{k 0}{100}$, depth of both valves $\frac{7}{1+\cdots}$, length of anterior end $\frac{45}{190}$; surface with a few small concentric wrinkles and lines of growth.

The nearly rectangular truncation of the posterior end, the quadrate form, and subcentral beaks, easily distinguish this species from its allies. The shell figured by Phillips (P'al. Foss.) as the C.trapezium of Sowerby, does not belong to that species, but is a well-marked example of the present one; the length varies from a little more to a little less than the width In only one specimen have I seen traces of the transverse pitting of cartilage area.

Position and Locality.-Not uncommon in the sandstone of Marwood, near Barnstaple; and, in probably the prolongation of the same bed, at Baggy Point.

\section{Dolabra? Damnoniensis (Sow. Sp.)}

Ref. and Syn. = Avicula Damnoniensis Sow. Geol. Trans. 2nd Series, Vol. V.t. 53. f. 22. and Phill. Pal. Foss. figs. 90, 91 and 92 .

Sp. Ch. - Obliquely elongate, ovate, or subtrigonal, slightly tortuous; left valve with a much larger beak and more gibbous than the right; beaks near the anterior end, which is small and rounded, except at the extrenity of the hinge-line, which is slightly acute: ralves most gilhous along a slightly sigmoid ridge, from the beak to the respiratory angle; posterior slope flattened or slightly coneave; posterior end wide, obliquely subtruneate, nearly straight, forming an angle of about $105^{\prime \prime}$ with the hinge-line; respiratory angle narrow, rounded; ventril margin slightly convex; entire surface marked with coarse, elose, subequal, thread-like strike, radiating from the beak (about eight in the space of two lines at middle of ventral margin). Length from anterior end to respiratory angle one inch seven lines, proportional length of linge-line $\frac{i 5}{i m}$, width from beak to opposite

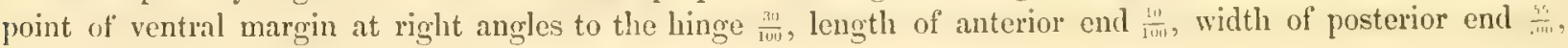
depth of left valve $\frac{20}{100}$, of right valve $\frac{10}{100}$.

The slender posterior lateral tooth or cardinal ridge is very long in each valve, and runs nearly parallel with the diagonal ridge; there is also a short distinct anterior one curving towards the ventral margin, from immediately in front of the heaks. Nlthough the typical varieties of this species depart considerably from those so-called Cuculloco in appearance, yet there seems no real generic distinction between them; there is the same inequality of valves, the same straight hinge-line in front as well as behind the beaks, the same transverse pitting of the cartilage-area, and the same long, internal, straight, lateral ridges, or cardinal teeth in both; and it is certain at least that this species is not a true Avicula. By a careful management of the light I have distinctly seen the radiating strie over the whole of the posterior slope in one of the specimens from which Mr Sowerby described the species.

Position and Locality. -Common in the sandstone at Marwood, near Barnstaple.

\section{Dolabra Depressa (Phill. Sp.)}

\section{Ref. and Syn.=Cuculloca depressa Phill. Pal. Foss. f. 71.}

$S p . C h$.-Longitudinally oblong; beaks obtuse near the anterior end, which is short and rounded; valves moderately convex, most tumid noar the beaks and anterior end; hinge-line long; ventral margin only slightly convex, subparallel with the hinge-line; posterior end obliquely truncate, straight, forming an angle with the hinge-line of only about $115^{\prime \prime}$; posterior slope flattened; diagonal ridge only obscurely marked; surface with a few, irregular, small, concentric wrinkles and lines of growth. Length from anterior end to respiratory angle

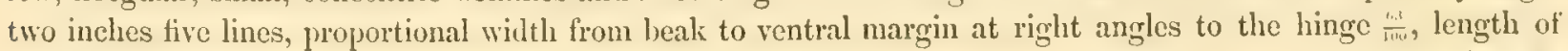

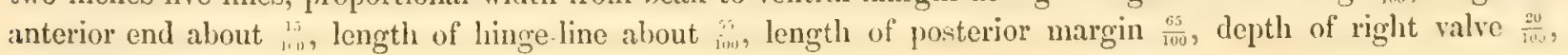
depth of left valve $\frac{15}{100}$.

Though P'rof. P'hillips describes the length and width to be nearly equal, yet his figure shews about the same proportions I have indicated above, and which I found to obtain in a number of specimens which I collected at Baggy Point, in the precise strike of the Marwood hed in which Phillips procured his species, but where I 
saw nothing analogous. On first sight it most neariy resembles the 1 . mitateralis, but is easily distinguished by its greater depression, which renders nearly obsolete the strong diagonal ridge of that species: it is also well distinguished by the character which first struck my eye, of the greater length of the hinge-line, its being more nearly parallel with the ventral margin, the less oblique truncation of the posterior end, and the consequently. shorter posterior margin.

Position and Locality.-Common in the sandstone of Baggy Point, North Devon; and in the schists quarter of a mile S. of Marwood.

\section{Dolabra Hardingt (Sow. Sp.) \\ Ref. and Syn.=Cucullea Hardingi Sow. Geol. Trans. 2nd Series, Vol. V. t. 53. f. 26, $27^{\circ}$ \\ + C. trapezium id. id. t. 53 . f. 24.}

Sp. Ch. - Transversely oblong, anterior end nearly one-third the length of the shell, narrowed, elliptically rounded, both valves very gibbous, left valve most so, and with the most prominent beak; diagonal ridge obtusely rounded; diagonal slope thattened, with a shallow radiating suleus rather nearer the diagonal ridge than its middle, extending from the beak to the margin, which it slightly simuates; ventral margin slightly convex, and slightly sinuate in the front of the diagonal ridge; posterior margin slightly sinuous, forming an angle of about $S 0^{n}$ with the ventral margin; surface marked with small obsolete, irregular, concentric wrinleles. and rather strong lines of growth. Length of rather small specimen one inch seven lines, jroportional width from beak to ventral margin, at right angles thereto, $\frac{55}{100}$, depth of both valves $\frac{55}{100}$, length of anterior end $\frac{27}{100}$, width of posterior end $\frac{59}{1+6}$, length of hinge-line $\frac{53}{100}$, width of the double area about one line.

This species is easily distinguished from the $C^{r}$. "nilaterulis by its longer anterior side, more obtuse diagonal ridge, narrower posterior end, from the respiratory angle being less obliquely produced, and the shallow; divisional hollow along the posterior slope. The posterior cardinal tooth is only seen in one-of the specimens of this species, the hinge-line of which presents numerous parallel pits at right angles to its length, as in Gemillix. The original type-specimens of Sowerby's C.trunzinm is a large cruslied example of this species, differing in no other respects from ordinary specimens.

Position and Locality.-Abundant, but not so common as the $C$. unilateralis in the sandstone, Marwood Quarry, near Barnstaple.

\section{Dolabra unilateralis (Som. Sp.)}

Ref. and Syn. = Cuculloca unilateralis Sow. Geol. Trans. 2nd Series, Vol. V.t. 53. f. 23. =Cucullaa amygdalina Phill. Pal. Foss. f. 66.

$S p$. Ch.-When young obliquely rhomboidal, when old becoming very obliquely ovate from the prolongation of the respiratory angle; valves very gibbous, left valve considerably more so than the right; beaks very large, oblingely tumid, approximate; rather more than one-third of the hinge-line in front of the beak: posterior slope flattened, very steeply inclined, forming an ohtuse diagonal ridge with the body of the shell; posterior margin nearly straight, obliquely truncated; respiratory angle narrow, rounded; anterior and rentral margins uniformly arched, surface marked with concentric, obtuse, irregular lines of growth. Length frum anterior end to respiratory angle of average-sized specimens two inches, proportional width from beak to

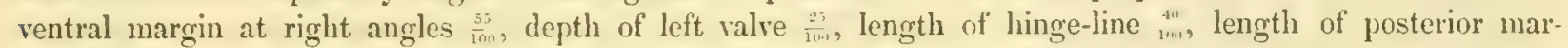
gin $\frac{i n}{1+1}$, length of anterior side $\frac{7}{1}$, angle between posterior and ventral margins about $65^{\circ}$ in young, varying in old to $60^{\circ}$, cardinal area rather more than two lines wide in the middle, gradually narrowing to each end.

The impression on the posterior slope of one of the specimens examined and figured by Mr Sowerby, supposed by him to be the internal impression of the peculiar internal lamina of Cuculleca, is manifestly the remains of a crush during the life of the animal, being crossed by the lines of grouth; it is, besides, straight. and diverging, having no analogy of shape or direction with the hood-shaped plate bounding the muscular impressions of Cuculloca. 
I have only seen the trace of the lateral hinge-tooth in two specimens; it is very delicate, and declines only slightly from the hinge-line, of which it runs the greatest part of the length; some very small specimens are as acutely and obliquely ovate as the large ones, but they are probably old dwarf specimens; others of larger size, which are less oblique and less acute at the posterior end, and which I imagine to be the young, have their outline exactly paralleled by the lines of growth near the beak of the large acutely ovate specimens.

Position and Locality._Extremely abundant in the decomposing sandstone of Marwood Quarry, near Barnstaple.

\section{Genus. ANODONTOPSIS. See page 270.}

\section{Anodontopsis deltoideus (Plill. Sp.)}

\section{Ref. and Syn.= Cypricardia deltoidea Phill. Pal. Foss. f. 59.}

$S p$. Ch.-Ovato.rhomboidal, compressed, smooth; anterior side and ventral margin semicircularly arched from the beaks as far as the middle of the length, the remainder of the ventral margin forming a tangent; posterior end obliquely subtruncate, the margin gently convex, inclined at alout $75^{\circ}$ to the ventral margin, the respiratory angle being narrow, rounded; angle between the hinge-line and posterior margin about $125^{\circ}$; greatest depth of the valies along a strongly marked, angular, diagonal ridge, distinet from the beak, to the respiratory angle; posterior slope and sides of the valves flattened, the latter slightly convex; hinge-line short, straight, slender, lateral tooth or cardinal teeth extending nearly its length, and close below it. Length from anterior end to respiratory angle of large specimen one inch three lines, proportional width from beak to ventral margin at right angles to the hinge $\frac{75}{100}$, length of hinge-line $\frac{35}{160}$, width of posterior margin $\frac{65}{100}$ to $\frac{71}{100}$, length of anterior end $\frac{15}{100}$, greatest depth of both valves $\frac{47}{100}$ in young, ${ }_{100}^{35}$ in old specimens.

Position and Lacality.-Not uncommon in the sandstone of Marwood, and in the prolongation of the same beds at Baggy Point.

\section{Gemus. LEPTODOMUS. See page 277.}

\section{Leptodomus constrictus $\left(M{ }^{c}\right.$ Coy). Pl. 2. A. f. $10 \%$}

$S p$. Ch.-Oblong, or subtrigonal from the projection of the very prominent beaks; valves very tumid towards the anterior side, greatest depth at about one-third from the beak; anterior end subtruncate, projecting but slightly towards the ventral portion beyond the line of the beaks; anterior lunette very large, ovate, deep, smooth; a deep narrow sulcus extends from the beak, slightly widening to the nearly straight ventral margin, which it meets at little more $\left(95^{\circ}\right)$ than right angles, forming a small sinus ; posterior side much compressed; posterior slope not defined; posterior end obtusely subtruncate, with a slight obliquity; hinge-line straight, rather shorter than the posterior side; anterior side and middle of the valves deeply marked with coarse concentric wrinkles, arising from the edge of the smooth anterior lunette, and most of them becoming abruptly obsolete on the posterior half of the shell, those near the margin of old specimens about one line wide, gradually diminishing towards the beak. Length one inch two lines, proportional width from beak to opposite ventral margin $\frac{77}{100}$, length of anterior lunette $\frac{87}{100}$, width of posterior end about $\frac{6 i}{10 m}$, depth of right valve ${ }_{100^{\circ}}^{40}$

This species in size, shape, subtruncate anterior end, and coarse concentric wrinkles of the anterior half, becoming obsolete on the posterior portion, almost exactly resembles the $L$. truncatus ( $\mathrm{I}^{\mathrm{c} C o y}$ ) of the Upper Ludlow rock, but may be distinguished easily by the strong divisional sulcus from the beak. I suspect the fossil from Baggy Point, referred by Phillips (Pal. Foss.) to the Silurian so-called Cypricardie impressa of Sowerby; may be found to belong rather to the present species.

Position and Locality.-One young specimen five lines long of the left valve, and two large specimens in apposition of the right valve, have occurred in the sandstone of Marwood, North Devon.

Explanation of Figure.-Pl. 2. A. fig. $10^{*}$, natural size, right valve. 


\section{Genus. NUCULA. See page 285. \\ Nucula Kracht瓜 (Römer). \\ Ref.-Harzgebirge, t. 6. f. 10.}

Sp. Ch.-Obliquely arched, subovate ; beaks very high, obtuse, prominent close to the anterior end, towards which the linge-line slopes rapidly, the lower portion semielliptically rounded; ventral margin very convex, the posterior end seeming slightly recurved; posterior end narrowed from the rapid sloping of the hinge-line from the beak, obliquely rounded; valves evenly tumid, about five strong teeth in front of the beak, and about eleven strong ones behind it (? surface with very sharp, fine, concentric strix). Length from anterior to posterior end five lines, proportional length of anterior end $\frac{20}{1 \times 0}$, width from beak to opposite point of ventral margin $\frac{75}{100}$, length of posterior hinge-line from beak $\frac{75}{100}$, width of posterior end ${ }_{100}^{35}$, depth of one valve about $\frac{25}{100}$.

The very high, tumid, nearly terminal beaks, and the narrow subrecurved appearance of the posterior end, from the great convexity of the ventral margin, easily separate this species from any other in the Palrozoic rocks.

Position and Locality.- I have collected several specimens of this species in the Devonian schists of Linton, North Devon.

\section{Nucula pullastriformis ( $\left.\boldsymbol{I}^{\mathrm{C}} \mathrm{Coy}\right)$.}

Ref. and Syn. = Pullastra antiqua Sow, Geol. Trans. 2nd Series, Vol. V. t. 53. f. 28.

$S p . C h$.-Ovate, moderately elongate, compressed; valves gently and evenly convex; beaks small, obtuse ; anterior lunette narrow, elliptical, deep; anterior end broad, semielliptically rounded; ventral margin gently convex; posterior end gradually narrowed, by the slight convergence of the cardinal and ventral margins; posterior slope extremely narrow; posterior margin elliptically subtruncate, rounded; surface covered with very regular, narrow, elevated, delicate, concentric ridges, separated by flattened spaces, about double their width (eight ridges in two lines, about the middle of the shell). Length nine and half lines, proportional width from beak to opposite ventral margin $\frac{62}{1 \mathrm{im}}$, length of anterior end $\frac{25}{1 \mathrm{vo}}$, length of hinge-line from behind beak $\frac{60}{\mathrm{iw}}$, width of posterior end about $\frac{39}{100}$, depth of one valve about $\frac{15}{100}$.

I see traces of the hinge-teeth of Nucula along both the posterior hinge-line and the anterior lunette of this beautiful shell, which certainly also wants the teeth of Pullastra, in which genus Mr Sowerby has placed it with the name Pullastre untipue. In placing it in the genus Nuculd I should have adopted his specific name, but it is already preoccupied by a species figured and described by Hisinger; I have therefore to propose a new specific name, and adopt one indicating the resemblance in form, anterior lunette, and sculpturing, which deceived Mr Sowerby.

Position and Locality.-Rare in the sandstone of Marrood.

\section{Sanguinolaria? Elliptica (Phill.)}

$$
\text { Ref.-Pal. Foss. f. } 53 .
$$

Sp. Ch.-Elliptical, beaks obtuse, a little nearer the anterior than the posterior end; length varying greatly, apparently from pressure, becoming sometimes nearly orbicular; anterior end obtusely rounded; posterior end obtusely rounded, slightly narrowed, obliquely subtruncate; valves moderately and evenly convex, becoming gradually compressed towards the margin; texture very thin, apparently corneous; surface with fine, concentric, close, imbricating lines, and minute, irregular, concentric wrinkles, reticulated by very minute, irregular, anastomosing plice under the lens. Average length five and half lines, proportional width from beak varying from $\frac{60}{100}$ to $\frac{70}{100}$.

There is no trace of hinge-teeth, nor sinuate pallial scar, in any of the very numerous specimens which I have collected with their valves expanded, but still connected; nor can I see any reasons for placing the fossil in the genus Sanguinolaria. The peculiar texture of the valves inclines one to suspect that they might be bivalve crustaceans allied to the large $C y c l a s$-shaped living Isaura.

Position and Locality.-Extremely abundant in the upper yellowish part of the slate at Lanlake, Launceston; more rare in a fine black layer of the same rock at $\mathrm{S}$. Petherwin. 


\section{5th Class. GASTEROPODA. See page 288.}

6th Ord. Pectinibranchiata. See page 289.

14th Family. HALIOTID E. See page 290.

Genus. PleURotomaria. See page 291.

Pleurotomaria mimbicata (Römer).

Ref.-Harzgebirge, t. 8. f. 1 .

Sp.Ch,-Obtusely conical; apical angle $95^{\circ}$; of four and half whorls, those of the spire rounded, or very obtusely subcarinate, from the projection of the broad square band, placed rather nearer the lower than the upper suture, and the lower margin of which is most proninent; body-whorl subquadrate from the upper third between the suture and the band, being obliquely and rather strongly flattened, the middle third below the band being nearly parallel with the axis, and the lower third rather abruptly sloping inwards; one or two spiral striec on the keel, the whole surface marked with similar thread-like spiral ridges, separated by rather more than their thickness, and irregularly subalternate in size, crossed by very fine, slightly oblique lines of growth, about eight or nine spiral strix on the keel, above the body-whorl. Length nearly eleven lines, proportional length of body whorl $\frac{60}{1100}$, length of penultimate whorl $\frac{26}{100}$, width $\frac{98}{100}$.

I believe there is no umbilicus, but am not quite sure of the fact.

Position and Locality.-Not uncommon in the Devonian limestone of Newton Bushel.

\section{Pleurotomaria interstrialis (Phill.)}

Ref. and Syn.-Phill. Geol. York. Vol. II. t. 15. f. $10=$ Pleurotomaria aspera Sow. Geol. Trans. 2nd Series, Vol. V.t. 54. f. 16.

$S p . C h$.-Obtusely conical; apical angle about $95^{\circ}$, sometimes a little higher or lower, spire of five uhtusely angulated, gently convex whorls; keel strong, thick, prominent, usually marked by four or five very fine spiral strix, but sometimes simple; usually about five, strong, regular, spiral, thread-like stria above the keel on the body-whorl, with a very minute one between each pair (but only three on the whorls of the spire, the middle one most prominent), the whole crossed by more regular, nearly equal, slightly oblique elevated lines, (meeting the keel at $65^{n}$ ) nearly twice their thickness apart (four in the space of one line on the body-whorl), which form spinulose tubercles at their intersection with the spiral ridges; surface beneath the keel marked in the way as above it, the keel being also similarly reticulated; umbilicus small, rounded, diameter alout seven lines, proportional length $\frac{87}{100}$, length of body-whorl $\frac{60}{100}$, diameter of umbilicus $\frac{15}{100}$.

There is considerable irregularity in the ridging of this fossil, but there is no doubt, I think, of the propriety of uniting Mr Sowerby's and Mr Phillips's species.

Position and Locality.-Very common in the slate of S. Petherwin.

19th Family. PYRAMIDELLIDE. See page 302.

Genus. MACROCHIIJUS (Phill.)

Ref.-Pal. Foss.

Gen. Char.-Shell short, ovate, gibbous; spire rather short, pointed, of several convex whorls; body-whorl large; aperture broad, ovate, rounded in front, pointed behind, indented by the preeding whorl; outer lip thin, 
slightly oblique, anterior half of columella thickened, flattened, posterior half often deficient; surface smooth or marked by fine lines of growth.

Allied to Loxonema, but much shorter, more ventricose, with larger body-whorl, smoother surface, and wide ovate mouth.

\section{Macrochilus ventricosus (Gold. Sp.)}

Ref. and Syn.-Buccinum acutum Sow. Geol. Trans, 2nd Series, Vol. V. t. 57. f. 23. (not Min. Con.) = Macrochilus imbricatus Phill. Pal. Foss. f. 194b. (not Sow. Min. Con.) = Phasianella ventricosa Gold. Pet. Germ. t. 198. f. 14.= Macrochilus subimbricatus d'Orb. Prod. Pal. p. 63.

$S p . C h$. - Ovate, spire slender, of about five or six whorls; apical angle about $60^{\circ}$; body-whorl abruptly wider than the spire, rounded; whorls of spire moderately convex, most so below the middle; surface marked with sharp, nearly direct lines of growth. Length nine lines, proportional length of body-whorl $\frac{57}{1,4}$, length of penultimate whorl $\frac{19}{100}$, width of body-whorl $\frac{65}{100}$, width of penultimate whorl $\frac{38}{110}$.

The greater abrupt convexity of the middle portion of the body-whorl, and the contracted, more slender spire, easily distinguish this species from the carboniferous Burcinum iulloricretum or ecutum (Sow.), with which it has been confounded.

Position and Locality.-Common in the Devonian limestone of Plymouth.

\section{Genus. LOXONEMA. See page 302.}

\section{Loxonedra Nexilis (Sow. Sp.)}

\section{lief. and Syn.= Terebra nexilis Sow. Geol. Trans. 2nd Series, Vol. V. t. 54. f. 17. = Terebra areuata} Münst. Beitr. 18t0. t. 15. f. 2.

$S p$. Ch.-Very elongate, conic; apical angle $17^{\circ}$; whorls about ten, slightly convex, most so below the middle; sutures deep, simple: surface fluted with backward-arched, longitudinal, slightly irregular strice, about eight in the space of one line, at a diameter of two lines. Average length eight lines, proportional length of body-whorl about $\frac{25}{107}$, length of penultimate whorl $\frac{20}{100}$, width about $\frac{30}{200}$.

There can be little doubt that the smaller of the two specimens figured by Sowerby is distinct from the large one, which I ehouse for the type of the speeies, having much thicker, straighter, and fewer longitudinal costie. I should think the S. Petherwin shell figured and described hy Phillips, Pal. Foss, as the Silurian Terebra simuosa of Sowerby, belongs to the present species.

Position and Locality.-Not uncommon in the limestone and shale of S. Petherwin. 


\title{
6th Class. CEPHALOPODA. See page 306.
}

1st Ord. Temrabranchinta. See page 307.

1st Family. BELLEROPHONTIDE. See page 307.

Genus. BELLEROPHON. See page 308.

\section{Bellerophon bisulcatus (Römer).}

\author{
Ref.-Harzgebirge, t. 9. f. 1.
}

Sp.Ch._Discoid, of three very thick whorls, almost entirely exposed in the large deep umbilicus, each whorl divided into three subequal lobes by two strong, shallow, spiral furrows, the middle lobe much more prominent than the others, and leaving a narrow keel-like indentation in the middle of the inner margin of mouth, and inner face of the outer whorls; umbilical margin of the whorls very convex. Diameter of large specimen one inch, proportional diameter of last whorl $\frac{47}{100}$, diameter of umbilicus $\frac{40}{100}$, width of last whorl about $\frac{85}{100}$.

This species is easily distinguished from the Silurian B. trilobatus with which most Palreontologists have confounded it, by its wide umbilicus, almost entirely exposing the whorls, the turns of the spire barely indenting, in a narrow line, the succeeding whorls.

Position and Locality.-Very common, but ill-preserved, in the dark Devonian schists of Polperro, Cornwall.

\section{Bellerophon striatus (Fer. and $d$ 'Orb.)}

\section{Ref.-Cephal. t. 1. f. 11, 13, 14, 17 ; Bronn. Leth. t. 1. f. 11.}

Sp. Ch.-Globose, very slightly compressed; umbilicus deep, narrow, rounded, not exposing the whorls; keel strong, narrow, from which strong thread-like strix arch regularly to the umbilicus, meeting at the keel at an angle of $110^{\circ}$, about two to three times their thickness apart, measuring usually three interspaces in the space of two lines; mouth transversely lunate. Diameter one inch, proportional diameter of last whorl $\frac{50}{100}$, diameter of umbilicus $\frac{18}{1010}$, width of mouth $\frac{83}{100}$.

This species is perhaps most allied to the B.tenuifascia, but has a very much thicker keel, and coarser strix; and from the $B$. costatus it differs in the more obtuse angles at which the transverse ridges meet the keel; and the distinctness of this angle separates it from $B$. tangentialis, in which they meet the keel nearly at right angles.

Position and Locality. - Not uncommon in the Devonian limestone of Plymouth.

\section{Bellerophon subglobatus ( $\mathbf{M}^{c}$ Coy).}

Ref. and $S_{y n}=$ Bellerophon globatus Sow. Geol. Trans. 2nd Series, Vol. V. t. 53. f. 30. (not of Sil. Syst.)

Sp.Ch.-Internal cast globose, slightly depressed; periphery obtusely rounded; mouth transversely lunate, deeply indented by the preceding whorl, sides rounded; umbilicus very small, not exposing any part of the inner whorls; sides very convex, without wrinkles. Diameter six lines, proportional diameter of last whorl $\frac{55}{1 m}$, diameter of umbilicus $\frac{10}{100}$, width of mouth $\frac{80}{100}$, length of mouth in middle $\frac{40}{100}$.

This may perhaps be the internal cast of some of the small carboniferous species, but I give it a provisional name, to distinguish it for the present from the Silurian B. globatus, with which Mr Sowerby in the above volume of the Geological Transactions, and Professor Phillips in his Palscozoic Fossils, confounded it, but from which it is certainly distinct, by its very minute umbilicus, not exposing a trace of the inner whorls, nor has it a trace of the strong transverse wrinkles of the sides of that species, in which the umbilicus is rather wide and exposes nearly half of the inner whorls.

Position and Locality.-Common in the sandstone of Marwood. 


\section{2nd Family. NAUTILIDE. See page 311. \\ Genus. AGANIDES (Montf.) \\ $=$ Goniatites (de Haan.)}

Gen. Char.-Discoid, whorls more or less embracing: septa angularly bent at the edges; mid-lobe distinct. single or double; siphon very small, on the external margin.

\section{Aganides vinctus (Som. Spr.)}

\section{Ref. and Syn $=$ Goniatites vinctus Sow. Geol. Trans. 2nd Series, Vol. V.t. 54. f. 18.} $=$ Goniatites insignis Phill. Pal. Foss. f. 228.

$S p . C h$. -Discoid, compressed; sides of the whorls flattened; periphery broad, subtruncate, obtusely rounded, with a narrow cord-like mesial keel; a narrow abruptly-sloped margin to the umbilicus, which exposes rather more than three-fourths of each whorl; whorls about five, each crossed by about twenty-seven obtuse, slightly oblique, obseurely defined, radiating folds, their outer extremities forming each an obtuse conoidal tubercle, the two rows of which flank the periphery; rather fine lines of growth mark the surface parallel with these ridges; septa, midlle lube long, acutely angular, slightly longer than wide; first sinus small, obtusely angular, rounded at its extremity ; first lobe obtusely angular, rounded at its extremity, about as wide as the first sinus, and rather less than half the length of the mid-lobe; second sinus rather narrower, slightly longer, and more oltusely rounded than the first sinus: sccond lube nearly three times the length of the first lobe, or onc-third longer than the mid-lobe, lingniform, elliptically pointed, acute at its extrenity; third sinus about as wide as the second, and reaching nearly the sane height, sides subparallel, end elliptically rounded, obtuse; third lobe semielliptical, one-half the length of the second, its outer edge curving obliquely forwards to the umbilicus, forming a nearly rectangular, or slightly acute angle, with the nearly straight outer margin; the point of each second lobe extends between the second and third sinus of the preceding septum as far as its first lobe. Diameter about four inches, proportional diameter of last whorl $\frac{30}{100}$, width at mouth at edge of umbilicus $\frac{20}{100}$, at periphery $\frac{15}{100}$.

It is strange that Professor Phillips did not perceive the identity in form, marking, and septal characters. between his Goniatites insignis and the previously described $G$. vinctus of Sowerby; the slight inaceuracy in the representation of the septa in Mr Sowerby's drawing being easily corrected by an experienced eye, and the absence of ridge and tubercles on the outer turn being due to the removal of the shell, and some thickness of the cast. The erenulation alluded to by Phillips, on the edge of the septa, is, I think, clearly owing to irregular disintegration; his diagram of the third lobe of the septa is not sufticiently angular, but it is correctly. represented on several parts of the shell. The resemblance to the G. subornatus of Münster alluded to by Sowerby is very strong, but that species seems to have more numerous and more gradually tapering whorls, the body-whorl forming a smaller proportion of the diameter, and to be without keel, as well as the differences in the form of the septa.

Position and Locality.-Rare in the Clymenia limestone of S. Petherwin.

\section{Genus. CLYMENIA (Münst.) \\ Syn。 $=$ Endosiphonites (Anst.)}

Gen. Char.-Shell discoid, whorls usually exposed, in contact; septa with a deep angular lobe on each side, middle portion nearly straight; siphon at inner edge.

\section{Clymenia bisulcata (Mïnst.)}

Ref.-Beiträge zur Petrefactenkunde, 3 Heft. t. 16. f. 6.

Sp.Ch,-Discoid, compressed, five to six whorls; gently convex on the sides, with a shallow, wide furrow on each side, strongly defining the narrowed, square, prominent periphery; margin of the umbilicus steep, rounded; whorls nearly flat, concealed; surface with strong, slightly irregular, subequal, sigmoidal strix on the 
sides, which are abruptly bent backwards at the outer lateral furrows, to form a deep retral lobe on the flat projecting periphery; seven strix in one line on the periphery, about ten in the same space on the sides; siphon very small, at the inner edge. Diameter about one inch, proportional diameter of mouth $\frac{35}{100}$, width of umbilicus $\frac{48}{100}$, width of mouth $\frac{21}{100}$.

According to Miinster the septa have got a sharply angular side lobe, somewhat as in C. undulata. The species is very strongly marked by the two broad sulci, defining the prominent, narrowed, flat periphery from the convex sides. I have only found a fragment of the last and penultimate whorl in the limestone of $\mathrm{S}$. Petherwin.

Position and Locality.-In the limestone of S. Petherwin.

\section{Clymenia lievigata (Minst.)}

\section{Ref.-Münst. Ann. des Sc. Nat. 2nd Series, Vol. II.t. 1. f. 1.}

Sp. Ch.-Discoid, compressed, of about seven or eight very gradually increasing, moderately convex whorls, scarcely one-fifth of which are concealed by the succeeding turn; surface smooth, or with a strong lens, fine obsolete transverse strix of growth crossing the whorls; periphery obtusely rounded; section of each whorl regularly oval, the outer turns slightly more compressed than the inner; septa with the middle portion forming a widely-arched mid-sinus (not lobe); sides forming a very broad obtusely-rounded first lobe, the inner extremity of which reaches the umbilicus at about the same height as the mid-sinus; siphon forming a thick funnel-shaped inflection of the inner margin of each whorl, extending half way to the next septum. Diameter of moderate-sized specimen two and half inches, proportional diameter of last whorl $\frac{27}{100}$, proportional thickness $\frac{24}{100}$.

This species is perfectly identical in all respects with that so common at Schubelhammer; in one imperfect fragment, and in one of Count Münster's specimens, I fancied I saw traces of the thread-like keel, but a number of more perfect specimens shew nothing of the kind. D'Orbigny places this species in the genus Trocholites.

Position and Locality.-Not uncommon in the Devonian limestone of S. Petherwin ; a compressed specimen, probably of this species, found by myself in the higher part of the slates of Lanlake, Launceston.

\section{Clumenia Muensteri $\left(M^{\circ} \mathrm{Coy}\right)$. Pl. 2. A. fig. 12.}

\section{Ref. and Syn. =Endosiphonites Ansted, Camb. Phil. Trans. Vol. VI. t. 8. f. 1; McCoy, Ann. Nat. Hist.} 2nd Series, Vol. VIII.

Sp. Ch.-Discoid, compressed; periphery slightly narrowed, subtruncate, obtusely-rounded, with a faint. narrow mesial keel, sides of the whorls flattened, with a steep narrow edge to the umbilicus, in which nearly three-fourths of each whorl is exposed; whorls upwards of six, all crossed by obsolete radiating ridges, each terminating at the edge of the umbilicus in a sharp, elongate, plait-like tubercle, and terminating at the distal end in an obscure, thick, conoidal tubercle; about twenty-six ridges and pairs of tubercles in each whorl; siphon very thick, close to the inner edge; septa with the middle portion nearly transverse, scarcely convex; first sinus scarcely marked, obtusely rounded; first lobe deep, semicircularly rounded; twice as wide as long, forming nearly a right angle with the second sinus, which is slightly oblique towards the umbilicus but nearly flat; a straight line drawn from the centre touches the top of the first and second sinus. Diameter three inches nine lines, proportional diameter of last whorl $\frac{33}{100}$, width of mouth near edge of umbilieus $\frac{22}{1001}$, width of periphery $\frac{12}{1100}$.

This is one of the largest Clymenia known, and most closely resembles the Clymenia binodosa of Miunster's Beitrüge zur Petrefactenkunde for 3839 , t. 2. f. 3; but that species has the last whorl very much smaller in proportion to the diameter $\left(\frac{35}{200}\right)$, has the periphery as broad as any other part of the whorl, and has consequently a considerably wider middle portion; otherwise in the form of the septa, general shape, and ornament, the species are closely allied, the ridges and tubercles in the British species being rather more numerous and less prominent.

Position and Locality.-Very rare in the Clymenia limestone of S. Petherwin.

Explanation of Figures.-Pl. 2. A. fig. 12, natural size; fig. $12 \alpha$, profile of mouth, and portion of periphery of penultimate whorl; fig. $12 b$, line of septum. 


\title{
Clymenia Pattisoni (MCoy). Pl. 2. A. fig. 11.
}

\author{
Ref.-McCoy, Ann. Nat. Hist. 2nd Series, Vol. VIII.
}

Sy. Ch.-Discoid, compressed, of about five whorls, rather more than one-third of each being concealed by the preceding turn; section of the whorls semielliptical, greatest thickness near the edge of the umbilicus, which is considerably wider than the last whorl; sides very slightly convex, gradually converging to the obtuselyrounded periphery, to which there is often superadded a very fine, thread-like, mesial keel, and two lateral ones : surface finely striated transversely; siphon large, close to the inner margin; septa about one-third the width of the side apart, with the middle portion nearly transverse; the edges, after about the middle of the side, arching backwards and then forwards again to the edge of the umbilicus, forming an obtusely rounded first lateral lobe, which extends backwards about half the space between the septa further than the middle portion. Diameter nine lines, proportional diameter of umbilicus $\frac{43}{100}$, of last whorl $\frac{40}{100}$, width of mouth $\frac{25}{100}$.

This species belongs to that very restrieted first group of Clymenia according to Miinster, in which the edges of the septa are only slightly arched; it is most nearly allied to the $C$. compresse Miinster, from which however, on comparing with authentic specimens, I find it differs by the great size of the umbilicus, which in that species is much less than the last whorl, forming scarcely in of the entire diameter. The septa differ from all of this group in the greater forward curvature of the umbilical end of the edge of the septa, thus forming a rounded lobe, remarkably close to the umbilical edge, from which the edge of the septum passes with very little curvature across the outer half of the sides and periphery, forming no other inflections as in the other allied forms. This flexion forward to the umbilicus distinguishes this part rery strongly from $C$. locigata, which also has very much more numerous whorls and larger umbilicus. I have much pleasure in dedicating this species to Mr Pattison of Launceston, to whose labours in collecting, I believe, is due the discovery of nearly all the British specimens of Clymenia.

Position and Locality. - Rare in the Devonian limestone of S. Petherwin.

Explanation of Figures.-PI. 2. A. fig. 11, natural size; fig. $11 \alpha$, view of mouth, shewing the siphon at inner edge; fig. $11 \mathrm{~b}$, line of septum.

\section{Clymenia quadrifera $\left(M^{c} \mathrm{Coy}\right)$. Pl. 2. A. fig. 13.}

\section{Ref.-Mc $\mathrm{M}^{\circ} \mathrm{y}$, Ann. Nat. Hist. 2nd Series, Vol. VIII.}

Sp. Ch.-Discoid, compressed, nearly two-thirds of the whorls concealed; whorls about four and half, crossed by very minute sigmoid stria; periphery narrow, obtusely rounded; septa with the middle portion crossing the periphery very broad, and with a slight forward curvature; first sinns small, oblique, very obtusely rounded; first libe nearly in the middle of the side, nearly square, slightly rhomboidal, length and width about equal, truncated at the liroad extremity-the angle next the umbilicus rather more obtuse, and the other slightly more acute than a right angle, sides subparallel; second simzs slightly higher than the first, extending with searcely any curvature to the umbilicus, its width double that of the lateral lobe, which is placed nearly in the middle of the side. Diameter one inch three lines, proportional diameter of last whorl ${ }_{100}^{5 *}$, width of mouth at edge of umbilicus $\frac{31}{100}$, width of periphery about $\frac{17}{100}$.

This species is easily distinguished from all others by the remarkably defined, nearly square form of the lateral lobe. It is most allied to the Clymenia striata (Münster), from which it is distinguished by the very obtusely rounded, obscurely defined first sinus, and the regular, almost square-formed lobe, and the scarcely curved margin of the second sinus. The cast of that species is also marked by sigmoidal ridges, of which there is not the slightest trace on the second species. I have seen traces both of the evanescent thread-like middle and lateral keels, occasionally seen on the other species.

Position and Locality.-Very rare in the limestone of S. Petherwin.

Explanation of Figures.-PI. 2. A. fig. 13, natural size; fig. $13 a$, line of septum; fig. 13 , portion of periphery. 


\section{Clymenia undulata (Münst.)}

Ref. and Syn. = Clymenia undulata $+C \cdot$ sublovis $+C$. inequistriata $+C$. sublinearis $+C$. linearis Münster, Ann. des Sc. Nat. 2nd Series, Vol. II.t. 1. f. 6, 7, 8, and t. 2. f. 1, 2+Endosiphonites carinatus + $E$. minutus Ansted, Camb. Phil. Trans. Vol. VI. t. 8. f. 1, 2, 3.

$S p$. Ch.-Discoid, compressed, of about seven very gradually tapering whorls, almost entirely exposed; whorls slightly convex on the sides, obtusely rounded on the periphery; all the whorls erossed by fine, slightly unequal, sharp, slightly sigmoid strix, the umbilical ends of which are abruptly curved back, and those near the periphery abruptly curved forwards, forming on the periphery a deep rounded lobe, curved forwards; each side of the band formed by this lobe of the stria, often bounded by a very delicate thread-like keel, a similar keel often running along the middle, but all three easily effaced, leaving the arched stria perfectly formed and uninjured beneath them; sometimes every fifth or sixth of the strix stronger than the others; and where this nccurs on the periphery, the intermediate ones are almost obsolete; above twelve strie in the space of one line under a strong lens; septa with the broad middle portion nearly direct, very slightly curved forwards; first sinus very small, angular, projecting slightly in front of the margin of the middle portion; first lobe abruptly marked, angular, extending two-thirds the distance to the next septum, outer margins of this lobe in the various septa very slightly convex, following a line parallel with the periphery and umbilicus; inner margin convex near the apex of the lobe to half its height, then extending nearly direct to the edge of the umbilicus; siphon large at the inmer edge. Diameter of moderate sized specimen one inch four lines, proportional diameter of last whorl $\frac{30}{100}$ to $\frac{35}{100}$, width $\frac{25}{100}$.

I imagined at first that our British species was distinct from the Clymenia linearis (Nïnst.), to which it had been referred, by the strix on the periphery being of the same closeness as on the sides; instead of the very remarkable appearance, figured and described by $\mathbf{M i n s t e r , ~ o f ~ t h e ~ s t r i a ~ o n ~ t h e ~ p e r i p h e r y ~ b e i n g ~ f o u r ~ o r ~ s i x ~ t i m e s ~}$ more distant than those on the sides, and forming a flattened band, limited by two thread-like keels. On examining a number of his original specimens, however, I find that although in parts the appearance he alludes to is very striking, yet with a good glass and a careful management of the light, fine stria, corresponding precisely in number with those of the sides, may be traced between the stronger distant ones; and other parts of the same specimens shew all the strix on the periphery and sides of equal size, strength, and number, in a.given space; in parts again of some specimens the two tillets mentioned by $M$ iunster may be seen, and even the third or mesial keel; while in other parts of the same specimen all three have disappeared, and the transverse striae pass without interruption across their site. I have, in short, satisfied myself that the supposed difference of all the above species cannot really be sustained even in different parts of the one specimen; for certain of the strix occasionally become more prominent than the others, and the apparent flatness, or roundness of the periphery, depends upon the presence or absence of the lateral fillets, which I find to be as inconstant as the mesial keel. The keel seems to be the foundation, so to speak, of the siphon, and the lateral fillets the foundation of the embracing edges of the coming whorl, indicating apprarently a great extension of the shell-depositing organs, as in each case these ridges are superadded upon the already formed and perfectly sculptured whorls, from whick they may be detached without injury. The convexity of the sides of the whorls varies slightly in the different specimens, and is rather greater in the inner than the outer whorls. The $C$.planorbiformis, which is united to the $C$. linearis by Professor Brom, I find, on cxamining authentic specimens, to be perfectly distinct by the very great number, and gradual tapering of the whorls, and the small proportion which the last whorl bears to the entire diameter.

Position and Locality.-Common in the Devonian limestone of S. Petherwin.

Genus. CYRTOCERAS. See page 312.

\section{Cyrtoceras? Bdeldalites (Phill.)}

Ref.-Phill. Pal. Foss. f. 223.

Sp. Ch.-Unciform, depressed; siphon near the outer edges continuous, moniliform. 
Neither of the specimens which seem to have occurred to Prof. Phillips, nor the one which I have myself seen, is in a fit state of preservation to afford even an approximation to the true characters.

The specimen in the collection is a fragment about six and half inches long, imperfect at each end, one inch eight lines in diameter at the large end, and with rather an abruptly unciform arch towards the small end, the septa varying from little more to little less than two lines apart.

Position and Locality.-In reddish calcareous Devonian shales of Torquay.

\section{Cyrtoceras reticulatum (Plill.)}

$$
\text { Ref.-Phill. Pal. Foss. f. } 224 .
$$

Sp. Ch. - Involute, section of the whorls nearly circular, but the periphery more arched than the inner edge; sides marked with very strong, obtusely-rounded, undefined wrinkles, rather more than their width apart, two interspaces ahout equalling the diameter of the volution, at six lines in diameter, the wrinkles becoming gradually almost obsolete as they pass across the periphery, ending more abruptly at the flanks of the inner face, which they do not cross; entire surface marked with longitudinal, thread-like, equal strix, twice their thickness apart, six in the space of two lines, reticulated by very fine sharp transverse strie; septa moderate, concave; siphon marginal; a fragment of an arched whorl seven lines in antero-posterior diameter, diminisher to five lines in antero-postero diameter in a length of one and half inches ; greatest width seven lines.

Position and Locality.-Devonian limestone of Newton Bushel.

$$
\begin{gathered}
\text { Cyrtoceras subornatum }\left(M^{c} \mathrm{Coy}\right) \text {. Pl. 2. A. fig. } 14 . \\
\text { Ref.-Mc } M^{\mathrm{c}} \mathrm{Coy} \text {, Ann. Nat. Hist. 2nd Series, Vol. Vili. }
\end{gathered}
$$

Sp. Ch.-Gradually arched, involute; section of the whorls a regular transverse ellipse, the shorter axis in the plane of involution; tapering at the rate of five lines in two inches, from a diameter of one inch five lines; periphery broadly arched, inner face rather more convex; sides elliptically rounded, bearing an obscure spiral ridge on each side along the most prominent part, bearing a row of large, olstuse, conical tubercles, nearly twice their diameter apart; on each side of this principal row of tubereles is a secondary obscure row, about half as far from the principal ridge as the tubercles of it are from each other; the outer of these rows most distinct, thic inner nearly obsolete; these three sets of tuluercles are connected by very obscure transverse wrinkles which d, not extend beyond them across either the inner aspect or periphery; entire surface crossed by very minute, imbricating, waving lines of growth, having a very obtusely-angular backward sinus in the middle of the periphery, all crossed by very faint longitudinal folds half a line apart, never assuming the prominence of stri: or ridges; siphon close to the outer margin. Proportional length of section compared to the width $\frac{80}{100}$.

This beautiful species is most closely allied in form, size, septa, siphon, and striation, to the C. ornatum Gold. as figured by d.Archiac and de Verneuil in the Geol. Trans. Vol. VI. t. 28. f. 5, but is rather less rapidly curved, and is completely distinguished by the two or three rows of tubercles being very small and entirely confined to the sides, leaving the broad periphery completely free of them.

Position and Locality. - One fragment three inches long from the Devonian limestone of Plymouth.

Explanation of Figures.-PI. 2. A. fig. 14, natural size, side view, shewing the three rows of tubercles on the sides, and the convexity of the septum at smaller end; fig. $14 \alpha$, end view of septum, shewing the position of siphon at outer margin.

\section{Genus. ORTHOCERAS. S'ee page 312.}

\section{Orthoceras striatum (Sow.)}

$R e f_{0}=$ Orthoceratites striatus Sow. Min. Con. t. 58. Orthoceras species Sow. Geol. Trans. 2nd Series, Vol. V. t. 54. f. 21 ? = O. tenuistriatus Münst. Beiträge, Heft. 3. t. 20. f. 4.

Sp. Ch-Elongate, conic, very slowly tapering (at an angle of about $9^{\circ}$ ), slightly compressed; section broad oval, its width $\frac{85}{v 00}$ of its length; siphuncle large, about half its diameter; eccentric towards one of its 
broad sides; a specimen one inch nine lines in diameter at the large end, and three inches long, tapers to one inch four and half lines; septa direct, concave, three lines apart at an inch in diameter; four lines apart at two inches in diameter; two and half lines apart at seven lines in diameter; surface covered with rough, very fine, elevated, thread-like strix, slightly varying in thickness irregularly; usually subequal and their own thickness apart; occasionally more distant, with one finer line between the larger; about fourteen longitudinal strix in the space of one line at an inch in diameter.

I have little doubt that the S. Petherwin and Marwood shell, referred by Prof. Phillips to the Silurian O. Ludense, belongs to this species, on which I have observed the striation on several parts of specimens collected by myself from the former locality.

Position and Locality.-Very abundant in the limestone associated with the slate of S. Petherwin, Cornwall.

\title{
Subgenus. CYCLOCERAS. See page 318. \\ Cycloceras striatulum? (Sow. Sp.)
}

Ref. and Syn. = Orthoceras striatulum Sow. Geol. Trans. 2nd Series, Vol. V.t. 54. f. 20.+ O. ibex Sow. Phill. Pal. Foss. f. 208 (not of Sow.) = O. calamiteus Münst.

$S p . C h$.- Rapidly but irregularly tapering when old at about an angle of $17^{\circ}$, more gradually tapering when young at an angle of about $12^{\circ}$, slightly compressed; surface with very prominent obtusely-angular rings, rather more than their thickness apart, slightly waved on the sides, crossed by strong, longitudinal, thread-like strix, nearly twice their thickness apart, with a very fine intermediate line between each pair; five of the larger stria in two lines at a diameter of one inch nine lines; six in the same space at a diameter of six lines; three rings and two interannular spaces in a space of one inch, at one inch 6 lines in diameter; three rings and two interaunular spaces in six lines at six lines in diameter; section broad, oval, its width $\frac{85}{100}$ of the length; siphon slightly eccentric towards one of the broad sides.

The longitudinal striation, if only the large strix be counted, is in this species of the same size and relative distance as in the $O$. tubicinella, so that this point of distinction given by Sowerby and Prof. Phillips does not hold good; but when specimens of the same size are compared 0 . tubicinella has closer rings. It is to this species that, I think, the $O$. calamiteus of Münster belongs.

Position and Locality.-Common in the limestone and shale of S. Petherwin.

\section{Cycloceras tubicinella (Som. Sp.)}

\author{
Ref.=Orthoceras tubicinella Sow. Geol. Trans. 2nd Series, Vol. V.t. 57. f. 29.
}

Sp.Ch.-Shell tapering at an angle of about $10^{\circ}$, crossed by very prominent, rounded, slightly oblique rings, their own thickness apart, crossed by strong, longitudinal, thread-like strie, nearly twice their thickness apart, five in two lines on nearly all parts of the shell; three annular ridgesiand two interannular spaces at seven lines in diameter, four ridges and three interannular spaces in three lines, at three lines in diameter: section nearly circular, very slightly compressed; siphon central. A specimen four and half lines in diameter at the large end, and two inches long, is three lines in diameter at the small end.

From the roughness of the stone $I$ cannot be quite sure whether there are any intermediate longitudinal strix between the strong ones which I mention. It is not probable that the subsequently described 0 . calamiteus (Münster) is identical with this species, as he figures his species with much more distant rings, and it is therefore, I think, more probably referrible to the $O$. striatulum.

Position and Locality.-Common in the Devonian limestone of Plymouth. 


\section{3rd Sub-kingdom. MOLLUSCA. See page 185.}

\section{2nd Class. PALliobrancitiatA. See page 185.}

2nd Ord. Brachiopoda. See page 186.

2nd Family. ORBICULIDE. See page 188.

Genus. DISCINA (Lam.). See page 190 .

Discina bulla $\left(M^{\circ}\right.$ Coy). Pl. 3. D. fig. 32.

Ref.-Ann. Nat. Hist. 2nd Series, Vol. X.

Desc.-Hemispheroidal, regularly ,tumid, inflated; base circular; antero-posterior profile nearly semicircular; greatest depth not at the apex, but at about the middle of the length. Surface glossy, smooth, or with very faint, obsolete, obtuse, concentric, and longitudinal strix; a small sulcus extends anteriorly a short way from the apex, which is obtuse, and nearly vertically over the posterior margin. Length seven and half lines, width the same, proportional depth $\frac{45}{100}$, distance of apex from posterior margin $\frac{85}{100}$.

The remarkably inflated bubble-like form of this species easily separates it from any I know. The beak is very little within the margin. The traces of concentric markings are rather broad and very obtuse lines, scarcely recognisable in the only specimen which has occurred; the traces of very fine longitudinal strix are only to be seen on one decorticated spot with a lens, the general aspect of the specimen being remarkably smooth.

Position and Locality.-Reddish sandy bed of carboniferous limestone at Lowick, Northumberland.

Explanation of Figures.-Pl, 3. D. fig. 32, profile, natural size; $32 \alpha$, do. same specimen seen from above

\section{Discina Nitida (Phill. Sp.)}

Ref. and Syn. = Orbicula nitida Phill. Geol. York. Vol. II. t. 11. fig. 10 to $12+$ O. cincta Portk. Geol. Rep. t. 32. f. 15.

Desc.-Broad-ovate, posterior end slightly narrower than the anterior; free valve conoidal; sides slightly compressed; greatest depth at or a little in front of apex, which is obtusely pointed, and marked with a very fine sulcus, about a line in length; flat valve with the fissure extending from a little behind the centre two-thirds of the distance to the posterior edge; margins of the fissure tumid; both valves very glossy, marked with small, irregular, concentric wrinkles, and intervening very fine strix; traces in parts of very fine longitudinal strix 
under the lens. Length six and half lines, proportional width $\frac{97}{100}$, depth of free valve $\frac{37}{100}$, distance of apex from posterior margin $\frac{40}{100}$.

Position and Locality.-Common in the upper part of the carboniferous limestone of Derbyshire; more rare in the dark carboniferous limestone of Lowick, Northumberland.

\section{3rd Family. TEREBRATULIDE.}

Arms fleshy, attached throughout their length to an internal shelly framework, bent in a double loop and attached to the beak of the entering (small) valve, they are incapable of protrusion beyond the shell, but provided with short fleshy fimbria; texture of the shell punctured. Two pairs of muscles arise from cach valve; in the small valve the anterior pair small, oval, arise close to the central septum, and a little belind the middle of the length their tendons converge below the stomach, and again dilate and pass into the pedicle; the posterior pair arise from a small depression close to the beak on each side of the central rostral tooth. In the large valve the two pairs of muscles are so approximate as to form only one pair of moderate oval impressions; the posterior pair go, to be inserted into the pedicle, and the anterior pair are inserted into the prominent beak of the small valve, and by their action open the valves. The mouth is behind the base of the arms, opening towards the cavity of the large valve; the oesophagus extends towards the small valve, suddenly dilates into a pear-shaped stomach, from the sides of which the hepatic follicles branch, forming a large green liver on each side; the intestine curves back towards the large valve, and making a slight bend forward, terminates between the lobes of the mantle on the right side.

This family is divided into the following genera: 1st, Terebratule (Llwyd); 2nd, Delthyridec**; 3rd, Terebrirostra; 4th, Fissirostra; 5th, Seminula (McCoy).

\section{Genus. SEMINULA $\left(M^{\circ} C o y\right) .1844$. \\ Ref. = Epithyris (King) not of Phillips.}

Gen. Char.-Ovate; a large oval perforation on the beak of the receiving valve, separated from the lingeline by a portion of the valve, but apparently without deltidium; dental lamellac strongly developed in beak of receiving valve, slightly diverging; entering valve with a faint trace of mesial septum, and two cardinal teeth, from whence a small loop, with a very slort recurved portion, arises; substance of the shell punctured, usually without plaits.

I originally proposed this genus, and gave a diagram of it in my Synopsis of the Carboniferous Fossils of Ireland, for "the Palxozoic Terebratula, having the beak perforated by a foramen distinct from the hinge-line, but without a deltidium," and naming the Terebratula seminula of Phillips, as the type (which see). Subsequent observations have enabled me to extend the genus much farther than I at first expected, particularly when I pereeived that the punctured texture of the shell would help to distinguish the species from the so-called Atrypa (Cliothyris of Phillips) when the beaks were broken. Lately, Professor King has given much excellent information on the genus in his volume on the Permian Fossils of England, under the name Epithyris of Phillips, and pointed out the valuable and easily ascertained character of the strong dental lamella in the beak, bordering the foramen. From the observations on the middle of page 5 t of Phillips's Paleozoic Fossils, it is obvious, however, that Epithyris was intended for the oolitic Terebratule, congenerice with the T.maxillata, having distinct deltidium, \&c. The dental lamelle leave slits in the beak of the casts, one on each side of the foramen, which are very characteristic of the genus, and in some states of exfoliation of the shell are likely to be confounded with edges of a deltidium; indeed, the appearance thus produced in many specimens is so puzzling, that I prefer leaving the existence or non-existence of a deltidium an open question; the genus being well distinguished meanwhile from the more recent Terelratule by the rostrum being tripartite, from the extension of the dental lamellæ, \&c. This generic type seems confined to the Palicozoic rocks.

* This Genus was briefly characterised and figured in my Synopsis of the Carboniferous Fossils of Ireland in $18 \pm 4$, and is equivalent to the subsequently formed genus Terebratella of d'Orbigny. 


\section{Semindua Elongata (Schlot. Sp.)}

Ref. and Syno = Terebratulites elongatus + T. complanatus + T. latus Schlot. Akad. Münch. Vol. VI. t. 7. f. 7, 8, 9, 12, 13, 14 + T. Qualeni (Fisch.) Kutorga, Verhand. der Min. Gesellschaft zu St Petersburg, t. 6. f. 2. $=$ Epithyris elongata King, Perm. Foss. t. 6. f. 30 to 45 .

Desc.-Longitudinally ovato-pentagonal, attenuated posteriorly; greatest width at a line varying from a little in front of the middle of the length, to two-fifths of the length from the anterior end; anterior lateral margins slightly convex; front sub-truncate, slightly convex; posterior lateral margins more nearly straight, converging to the large, wide, prominent beak of the receiving valve. Receiving valve flattened; profile gradually arched towards the front margin, more abruptly curved towards the apex of the beak, so that the greatest depth would be at one-third the length from the beak; rostral portion, and a narrow portion of the sides, slightly convex; the middle depressed by a very wide, shallow, mesial hollow, extending to within two lines of the beak, and occupying the entire width of the front, which is raised thereby into a wide rounded wave towards the entering valve, deepest in old shells; sides of the beak obtusely subangulated, the apex truncated by the large foramen; the large bounding dental lamelle searcely one-sixtl the length of the shell, and diverging at about $30^{\circ}$; entering valve with the mesial third, prominent, slightly convex, the lateral portions sloping rapidly to the sides, which are thus rendered acute: surface with moderately coarse, close punctures under the lens. Average length of receiving valve seven lines, proportional length of entering valve $\frac{B_{5}}{100}$, width $\frac{75}{100}$ to $\frac{85}{100}$, greatest depth of both valves (at one third from the beak) $\frac{47}{100}$.

Professor King, in the above-cited work, has figured the perfect loop of this species, as well as an instructive series of the principal varieties of form. I entirely agree with him in thinking they are all of one species.

Position and Locality.-Common in the magnesian limestone of Humbleton.

\section{Seminula ficus $\left(M^{c} \mathrm{Coy}\right)$. Pl. 3. D. fig. 22. \\ Ref.-M $\mathbf{M}^{\mathrm{C}} \mathrm{Coy}$, Ann. Nat. Hist. 2nd Series, Vol. X.}

Desc.-Longitudinally broad-ovate, gibbous; greatest width slightly in front of the middle; lateral margins slightly raised into a tri-undate, wide, flattened wave, towards the entering valve in old specimens (lines of growtl indicating a regular margin up to one inch long); no distinct ridge extends from this wave towards the beak of the entering valve, but the surface near the front slopes more rapidly away from it towards the lateral edges; on the receiving valve obscure indications of the mesial hollow and bounding ridges extend a short way towards the beak in specimens an inch and half long; receiving valve evenly tumid, regularly arched from the beak to the front margin; greatest depth about the mildle; beak moderate, obtuse, lateral angulation nearly obsolete; perforation large; surface closely granulo-punctate under the lens; dental lamella at sides of foramen large, diverging at $45^{\circ}$. Length one inch six lines, proportional length of entering valve $\frac{90}{100}$, width $\frac{85}{1 w 0}$, depth of receiving valve $\frac{28}{100}$, depth of entering valve $\frac{22}{200}$.

The broad-ovate, tumid form distinguishes this easily from the other carboniferous species, as well as the absence of any distinct mesial hollow or enargination of the front in either valve. The punctures of the surface are considerably smaller than those of the $S$. virgoides $\left(\mathbf{M}^{\circ} \mathrm{Coy}\right)$ or S. hastata.

Position and Locality.-Rare in the carboniferous limestone of Derbyshire.

Explanation of Figures.-Pl. 3. D. fig. 22, natural size, profile; fig. 22 $\alpha$, do. view of entering valve; fig. 22b, end view shewing the undulation of the front margin; fig. $22 c$, do. punctured surface, magnified.

\section{Seminula mastata (Sonv. Sp.) \\ Ref. and Syn.= Terebratula hastata Sow. Min. Con. t. 446. f. $2,3$.}

Desc.-Longitudinally ovate, depressed when young, obscurely pentagonal after an inch long, from the gradual straightening of the lateral anterior margins, and the front becoming gradually truncated, or concave in 
the adult; greatest width a little in front of the middle; receiving valve moderately gibbous, profile almost regularly arched, greatest depth at rather more than one-third from the beak; beak large, obtusely angulated on the sides from a longitudinal concave impression on each side near the edge; sides moderately convex, sloping rapidly to the margins; mesial portion flattened, becoming gradually concave towards the front margin, in old specimens (after one inch three lines long); foramen large, approaching close to the beak of entering valve. Entering valve similar in shape to the receiving one, but tapering more rapidly towards the beak, evenly and moderately convex; profile regularly arched, depth greatest in the middle, in small ovate specimens (half an inch long), after which the lateral portions slope rapidly to the margins, and the mesial somewhat elevated third flattened when the front edge is straight, or forming a wide mesial hollow, resembling in size and shape that of the receiving valve, when the front margin is concave; from the equal mesial hollow in both valves the front margin is not elevated, but remains in the plane of the lateral edges; surface marked with close, quincunciallyarranged granular perforations under the lens, sometimes shewing, when partially decorticated, a few thread-like longitudinal strix near the front of the lateral margins. Length of adult one inch seven lines, proportional length of entering valve $\frac{94}{100}$, width $\frac{75}{100}$, width of front $\frac{45}{100}$, depth of receiving valve $\frac{80}{100}$, depth of entering valve $\frac{25}{1100}$. Younger ovate specimens one inch three lines long have the proportional width $\frac{75}{100}$, depth of both valves $\frac{45}{100}$; front undefined.

This species is remarkable for the nearly equal flattening or concavity of the mesial portion in both valves, so that the front edge is not in the least raised. It is quite possible that this may be Anomites attenuatus of Martin, as suggested by M. de Vernevil; but as there is no figure given, and the description is not at all sufficient for recognising the species with certainty, it is but just to Mr Sowerby to use his name, as well as being the more certain course, and in accordance with common usage. It is wider and larger than the S. sacculus Mart. Sp., more depressed, and with much more acute margins, besides wanting the mesial hollow until after an inch from the beak, at considerably less size than which the greatly thickened margins shew the $S$. sacculus to be adult; the young of $S$. hastata being ovate, depressed, and with a thin rounded front, bears no resemblance to the $S$. sacculus, from wanting the notch in the front, and narrow mesial sulci. The internal appendages which I formerly figured (in my Synopsis of the Irish Carboniferous Fossils) were not complete, but should have had the recurved portion completing a loop, as in the generic character, as first mentioned to me by Mr Morris, from the observation, I believe, of Mr Davidson.

Position and Locality.-Common in the carboniferous limestone of the Isle of Man.

\section{Seminula juvenis (Son. Sp.)}

Syn. and Ref. $=$ Atrypa juvenis Sow. Geol. Trans. 2nd Series, Vol. V. t. 56. f. 8. ? Terebratula id. Phill. Pal. Foss. t. 35. f. 165 .

Desc.-Longitudinally obovate, the greatest width nearer to the beak than to the front margin ; posterior end broadly rounded, the long, anterior, lateral margins converging, so that in most specimens the narrow end of the ovate outline is towards the front; receiving valve depressed, gently and very evenly convex along the middle, without trace of mesial flattening or furrow; profile regularly arched from the front margin to within one-third the length from the beak, from which to the apex the curve is much more rapid : beak broad, much incurved, small, very slightly projecting, truncated by the moderately large foramen, which reaches very close to the margin; sides from the beak along the anterior lateral margins as far as half the length of the shell, with a narrow flattened space, defined from the broad slightly compressed beak, by an obtusely rounded nearly rectangular ridge; lateral margins with a broad, nearly uniform curve from the beak to the front margin, the convexity towards the receiving valve; front margin narrow, straight, or with a very faint wave towards the receiving valve; dental lamella nearly parallel, short, widely separated; trace of mesial septum in receiving valve at about half the length of the shell; entering valve flattened; profile nearly straight in the mesial portion, slightly sloping from the beak to the front margin; lateral portions sloping rapidly to the anterior lateral margins, but sloping very slightly on the posterior half till close to the edge, where they are obtusely deflected to meet the similar flattening of the sides of the other valve; surface smooth to the naked eye, or 
with a few fine concentric strix and interruptions of growth under the lens, closely reticulated with fine punctures, smaller than those of $S$. hastata. Length of very large adult specimen one inch six lines, proportional length of entering valve $\frac{90}{100}$, width $\frac{23}{100}$, depth of entering valve $\frac{201}{1100}$, depth of receiving valve $\frac{25}{1+0,}$, breadth of front $\frac{34}{100}$, proportional width of specimen ten lines long $\frac{77}{101}$, depth of both valves $\frac{40}{100}$, (probably a little crushed); proportional width of specimen eight lines long $\frac{80}{200}$, depth of both valves $\frac{47}{100}$.

It will be seen from the above proportional measurements, that according as the specimens decrease in size they gradually assume exactly the proportional width of Sowerby's figure, and as they increase in size the proportional length increases; the figures of Phillips are wider than Sowerby's figure, or any specimen I have seen. This species is distinguished from the others by the broad portion of the ovate outline being towards the beak instead of towards the front, owing to the great width of the rostral portion and the rather small depressed beak; the unusually long, anterior, lateral margins are nearly straight, and converge gradually to the narrow front; they being longer than the posterior lateral margins gives a curious peculiarity to the outline of the species; and as well as the perfect absence of mesial hollow on the receiving valve, and the strongly marked, elongate, flattened space or angulation at the posterior lateral margins, and general depression, distinguish it from its allies.

Position and Locality.-Not very uncommon in the carboniferous limestone of Derbyshire; the very small, but otherwise identical specimen figured by $\mathrm{Mr}$ Sowerby is quoted from the Devonian limestone of Plymouth.

\section{Seminula sacculus (Mart. Sp.)}

Ref. and Syn. = Anomites sacculus Martin, Pet. Derb. t. 46. f. 1, $2=$ Terebratula id. Sow. Min. Con. t. 416. f. 1. left-hand figure; Phill. Geol. York. Vol. II. t. 12. f. 2.

Desc.-Longitudinally ovato-pentagonal, small, very gibbous, margins very obtuse; greatest width at about one-third the length from the front margin; front rather abruptly narrowed, with a deep rounded notch, from which a moderately wide, concave, mesial sulcus, equally deep in both valves, extends to within about four lines of the beak of the entering valve, about the same length from the front margin, but not so near the beak in the receiving valve; front margin not raised, but perfectly in the plane of the lateral margins; receiving valve obscurely pentagonal or subtrigonal; beak very large, prominent, much incurved, with an obscure angulation on the sides; foramen rather narrow, oval; profile regularly arched; greatest depth about the middle of the length; middle portion gibbous, gently convex except towards the front, where it is indented by the mesial hollow; sides tumid, rapidly falling to the very obtuse margins; entering valve rotundato-pentagonal, very gibbous; profile slightly and regularly arched; sides tumid, sloping very rapidly from the mesial third, which is flattened towards the beak, impressed by the mesial furrow towards the margin; surface with occasional concentric, rather coarse lines of growth, minutely reticulo-punctate under the lens. Length of very old, large specimen, with much thickened margins, eleven lines; proportional length of entering valve $\frac{85}{100}$, width $\frac{75}{101}$, depth of receiving valve $\frac{40}{100}$, depth of entering valve $\frac{39}{100}$, width of front $\frac{45}{100}$; length of average-sized younger specimen seven lines, width $\frac{75}{100}$, depth of both valves $\frac{60}{100}$, width of front $\frac{35}{100}$.

This species is easily distinguished from the $S$. hastata by its small adult size, which is proved by the great thickening of the margins, at or under one inch in length, the deeper notch in the front, and it and the mesial sulcus existing at a much smaller distance from the beak than in that species; and above all, the species are distinguished by the great difference of angle at which the valves meet at the margin, the front and lateral margins of $S$. hastata being sharp and wedge-like, but those of $S$. sacculus being extremely blunt and obtuse. Several writers mention their inability to distinguish this species from some of the varieties of $S$. elongate ol S. sufflata of the Permian rocks; but specimens perfectly identical in form and size may be readily distinguished by a small but distinctly marked upward wave in the front margin towards the entering valve in the Permian fossil, while the margin of the carboniferous species is nearly or quite horizontal. In the $S$. suffluta also the mesial septum is much longer and more strongly marked in the receiving valve, extending to within one-third of the length of the front margin. The punctured instead of fibrous surface, under a good lens of three-fourths of an inch focus, distinguishes specimens from the Hemithyris didyma. 
Position and Locality.-Common in the carboniferous limestone of Derbyshire; carboniferous limestone of Malham Moor.

\section{Seminula seminula (Phill. Sp.)}

Ref. and Syn.=Terebratula seminuta Phill. Geol. York. Vol. II. t. 12. f. 21, 22, 23. = Spirifer nucleolus Kutorga, Verhandlungen der Russ. Kaiserl. Min. Gesellschaft for 1842, t. 5. f. 7. = Seminula pisum M'Coy, Syn. Carb. Foss. Irel. = Terebratula vesicularis de Koninck, Anim. Foss. Bel. Suppl. t. 16. f. 10.

Desc.-Ovato-pentagonal, very gibbous; front narrow, about as wide as the nearly straight anterior lateral margins; posterior lateral margins considerably longer and more convex than the anterior; receiving valve very gibbous, greatest depth in the middle of the length, from whence the profile slopes almost equally to the beak and front margin; after three lines long two equal obtusely rounded ridges extend to the front margin, separated by a deep rounded sulcus, equalling them in size; outer side of each ridge defined by a slight concavity, so that the front has a distinctly-marked W-shaped sinus; the convexity of two of the waves towards the receiving valve, the convexity of three of the waves, directed towards the entering valve (the middle one of which is only as large as the intervening ones); the middle portion tumid, sloping rapidly to the margins; beak moderately large, obtusely angulated on the sides, with the apex truncated by a moderate, circular, foramen. Entering valve, with the middle portion, evenly gibbous, and a narrow space round the margin, abruptly sloping to the edges; after two lines from the beak three equal, obtusely-rounded ridges, rather smaller than those of the opposite valve, become developed towards the front margin, separated by two equal concave furrows, the outer pair defined on their outer side by a shallow depression; surface nearly smooth, or with a few lines of growth at the margin; punctation under the lens extremely small. Length of large specimen five lines, proportional length of entering valve $\frac{\pi 5}{1 \text { ive }}$ greatest width (a little in front of the middle) $\frac{100}{100}$, depth of receiving valve $\frac{40}{110}$, depth of entering valve $\frac{30}{100}$.

This species is so like the Camarophoria globulina of the Permian rocks, that some writers (calling the present species by Kutorga's name) seem unable to distinguish them; the Permian fossil is, however, more rounded, has the two ridges on the entering instead of the receiving valve, and even when the beak cannot be examined, even fragments of the two might be discriminated by the tissue of the shell (under a strong lens) of the Permian species being densely fibrous, and that of the present one being closely punctured. I have ascertained the presence of the loop, which is little more than one-third the length of the shell. This is the original type of my genus Seminula; and, although it might be desirable to change the specific name, I am yet unwilling to do so, or in any way to interfere with the golden rule of the priority of specific nomenclature, although I formerly proposed for it the specific name pisum in the above-quoted work (the difference between the descriptions of the plaits being due to those I formerly examined having been immature). This species is allied to the S. rhomboidalis (Phill. Sp.), but is distinguished by its obtuse giblous form; it is also allied to the S. sacculus (Mart. Sp.), but is distinguished by its doubly indented and ridged front, \&c. Mr Sowerby's middle figure of Terebratula sacculus in the Mineral Conchology seems to belong to this species.

Position and Locality.-Not very uncommon in the carboniferous limestone of Derbyshire.

\section{Seminula sufflata (Schlot. Sp.)}

\section{Ref. and Syn.= Terelratulites sufflatus Schlot. Akad. Münch. Vol. VI. t. 7. f. 10, 11.= Epithyris id.} King, Perm. Foss. t. 7. f. 1 to 9.

Desc.-Longitudinally ovate, or very obseurely sub-pentagonal, moderately gibbous; margins rather tumid, obtuse; front narrowed; lateral margins nearly straight, with a slight, gradual arch towards the receiving valve; middle of front margin abruptly raised into a small rounded lobe towards the entering valve, slightly indenting the margin; receiving valve moderately convex, greatest depth at one-third from the beak; beak large, tumid, prominent, moderately incurved; sides rounded; foramen large, truncating the apex; a narrow mesial furrow extends nearly from the beak to the rounded wave in the front margin; in the casts the mesial septum is 
strongly marked, and extending nearly from the beak to within one-third of the length of the front margin; dental lamellæe strong; entering valve evenly convex in the middle, gradually arching to the margins, usually without trace of mesial ridge or hollow; but in old specimens of six lines long a very shallow obsolete indentation may be noticed at the edge; surface smooth, closely punctured under the lens, or with a few interrupting lines of growth near the edge of large specimens. Average length six lines, proportional length of entering valve $\frac{.5}{1+11}$, width $\frac{85}{100}$, depth of entering valve $\frac{30}{1009}$, depth of receiving valve $\frac{30}{100}$.

The greater gibbosity, more obtuse margins, small, definite lobe in the front margin, and the corresponding long, narrow mesial sulcus of the receiving valve, easily distinguish this species from the most nearly allied varieties of the S. elongata; the sides of the beak are also more obtusely rounded or less angulated. The distinct upward arching of the middle of the front margin, as well as the absence of mesial furrow on the entering valve, distinguish it from the $S$. sacculus of the carboniferous rocks, to which the receiving valve approximates very closely. I have found the adult specimens of this species distinguished in Count Miunster's collection from Gluicksbrunn, under the manuscript name $T$. subsinuosa.

The want of spirals, and the punctured, instead of the fibrous tissue, separate this species easily from certain narrow varieties of the carboniferous Athyris sublobate (Port. Sp.) or A. ambiguex (Sow.), to which, in outward form, it strongly approximates.

Position and Locality.-Common in the Permian limestone of Humbleton Hill.

\section{Seminula virgoides $\left(M^{c} \mathrm{Coy}\right)$. Pl. 3. D. fig. 23.}

Ref. and Syn.=Atrypa virgoides $\mathbf{M}^{\circ} \mathrm{Coy}$, Synop. Carb. Foss. Irel. t. 22. f. 21. ?= Terebratuta fusiformis

M. V. K. Geol. Russ, t. 9. f. 8. ?= T. hastiformis de Kon. Anim. Foss. Bel. Suppl. t. 56. f. 8.

Desc.-Longitudinally oblong, or very obscurely ovato-pentagonal, gibbous; front narrowed to nearly half the greatest width; anterior lateral margins considerably longer than the front, greatest width a little in front of the middle in most specimens. Receiving valve moderately gibbous, most so at one-third from the beak, from whence the profile arches gradually to the front margin, and more rapidly to the beak, which is large, prominent, and moderately incurved, having a very obtuse angulation on each side, and at its apex a large oval foramen; moderately convex in all the middle portion, sloping with a less convexity to the margins, which are moderately obtuse, and with a broad, regular curve towards the receiving valve from the beak to the front; after about four to nine lines from the beak, a shallow, wide, mesial concavity is gradually developed in most specimens, extending to the margin, which it raises with a gradual undefined curve of its whole width towards the entering ralve (those specimens in which the mesial hollow is not developed have the front margin straight); entering valve very tumid along the middle, arching gradually from the beak to the front margin, which is not affected by the wave in the margin, shewing no trace of mesial ridge or sinus; greatest depth about the middle, sloping rapidly with slight convexity to the side margins, (when decorticated exhibiting commonly three or five very strong, angular, longitudinal ridges, radiating from the beak); surface nearly smooth, or marked with coarse imbricating irregular concentric lines of growth, strongly reticulo-punctate under the lens. Length of very large specimen one inch six lines, proportional length of entering valve $\frac{90}{100}$, width $\frac{\tau 0}{1100}$, depth of entering valve $\frac{25}{110}$, greatest depth of receiving valve $\frac{20}{100}$; length of small specimen eight lines, proportional length of entering valve $\frac{85}{100}$, width $\frac{7}{1104}$, depth of both valves $\frac{55}{100}$.

Some small specimens, with the largely-marked mesial hollow, approximate so nearly to the Permian S. sufflata, that Professor King, in his book on the magnesian limestone fossils (for I suppose this is the species he alludes to at page 150 , as the mountain limestone-shell from Bolland), seems to consider them identical ; it is, however, distinct by its less tumid sides, by wanting the narrow, defined mesial sulcus of the receiving valve, and the corresponding distinctly marked upward indentation of the front margin; the punctation of the surface is also much coarser in the present species than in the magnesian limestone one. It is, perhaps, most closely allied to some specimens of the magnesian limestone, S. elongata; but the mesial hollow of the receiving valve, instead of being as wide as the entire front, rendering the greater part of the anterior portion of the valve concave, is either entirely absent, or comparatively narrow, confined to the middle portion of the shell defined by the 
tumid lateral portions, and not extending so near the beak: the margins of the Permian species are characteristically acute, from the much less angle at which the valves meet at the margin; in that species also the beak is much more incurved, and more strongly angulated on the sides. The want of the flattened mesial hollow on the anterior part of the entering valve easily separates the species from the S. hastata. The figure? of T. elongata, given by Römer in his Versteinerungen des Hatzgebirge, t. 5, f. 20, seems rather to represent this species. $T$. virgo, is distinguished by its radiating strix and unangulated beak.

Position and Locality.-Common in the dark carboniferous limestone, Isle of Man; rare in the dark lower limestone of Lowick, Northumberland; and in the similar limestone of Kendal, Westmoreland.

Explanation of Figures.-PI. 3. D. fig. 23, from the limestone of the Isle of Man, end view, natural size, (most specimens shew a greater upward curve in the front margin); fig. $23 \alpha$, do. same specimen side view; fig. $23 b$, do. receiving valve; fig. $23 c$, do. shewing traces of the internal ridges of the interior of the valve, with a portion of shell near the front edge; fig. $23 d$, do. surface magnified to shew the reticular marking between the punctures.

\section{5th Family. SPIRIFERIDE. See page 191.}

\section{Genus. SPIRIFERA. See page 191.}

\section{Spirifera alata (Schlot. $S p$.)}

Ref. and Syn. = Terebratulites alatus Schlot. Leonhard's Taschenb. Vol. VII. t. 2. f. 9. + Spirifer undulatus

Sow. Min. Con. t. 562. f. 1. = (Trigonotreta alata + T. undulata King, Perm. Foss. t. 9. f. 1 to 17.)

Desc.-Transversely fusiform or rhomboidal; hinge-line exceeding the width of the shell; cardinal angles acute, but the sides of the shell varying greatly in attenuation; cardinal area wide, with nearly parallel sides; receiving valve gibbous; beak large, prominent, much incurved, greatest depth at one-third from the apex; triangular foramen nearly closed, except at the base in the adult, by a strongly imbricated, convex, pseudodeltidium, sometimes visible externally; mesial hollow wide, strongly defined, concave, smooth, or with obsolete traces of one or three longitudinal ribs; each side with twelve or fourteen (only six in some small examples) strong, rounded, cord-like ribs, which have commonly been produced from little more than half their number near the beak, each primary one of which bifurcated once at a very variable distance between the beak and margin ; entire surface crossed by subregular, imbricating, concentric, scale-like lamina of growth (averaging seven in two lines), which seem undulated by passing over the ridges; crossed under the lens by rather coarse longitudinal fibres of shell-tissue. Entering valve varying greatly in convexity; beak prominent, incurved, with a rather large cardinal area nearly in the plane of the lateral margins; mesial elevation obtusely angular or rounded; ribbing of the sides and transverse lamination as in the other valve. Average width two inches, proportional length of receiving valve varying from ${ }_{100}^{40}$ to $\frac{60}{100}$, length of entering valve $\frac{35}{100}$ to $\frac{45}{100}$, depth of receiving valve $\frac{23}{100}$, depth of entering valve $\frac{10}{1100}$ to $\frac{20}{100}$, width of cardinal area of receiving valve $\frac{14}{100}$, of entering valve $\frac{6}{100}$.

Professor King is of opinion that this should be considered a punctated shell; but with a power of half an inch focus the tissue seems very distinctly and densely fibrous, and I do not think the excessively minute roughening produced by the ends of the fibres should be confounded with a true punctured tissue. He also thinks that the rather more longitudinal rhomboidal forms figured by Sowerby, and those with still shorter hinge-lines should be considered a distinct species under Sowerby's name, S. undulatus, from the very wide, attenuated fusiform varieties, to which he would restrict Schlotheim's name, alatus, the former of which he thinks is not found in Germany, and to be distinguished from Schlotheim's form by a less transverse elongation, and greater tumidity at the beaks. It is curious, however, that all the continental specimens in the Münsterian collection at Cambridge, under Schlotheim's name, alatus, are of the variety which Professor King would call S. unclulatus of Sowerby; and, on the other hand, all the original specimens of the English fossil, collected by Professor Sedgwick, and numbered by Sowerby, belong to the proposed distinct species, $S$. alatus. The proposed distinction of the tumidity of the beaks will not hold either, as the two greatest extremes which I have observed 
in the depth occurred in the very transverse forms. Some of the specimens from Gera shew as many as three obsoletely marked ribs in the mesial sinus, more usually however there is only one or none.

Var. a. Length about two-thirds the width; anterior lateral margins strongly convex.

Var. $\beta$. Nearly three times wider than long; lateral margins nearly straight or slightly concave (gradually passing into a).

Position and Locality.-Common in the Magnesian limestone of Humbleton.

\section{Spirifera cristata (Schlot. Sp.)}

Ref. and Syn.=Terebratulites cristatus Schl. Akad. München, Vol. VI. t. 1. f. $3=$ Trigonotreta id. King, Perm. Foss. t. 8. f. 9 to 14.

Desc._Entering valve nearly semicircular, moderately gibbous: linge-line scarcely as long as the shell is wide; cardinal angles obtuse; receiving valve very gibbous; beak large, only moderately incurved; profile regularly arched, so that the greatest depth is at about the middle of the length; cardinal area very large, slightly curved, triangular, height one-third of the width; triangular opening about one-third higher than wide, closed nearly to the base by a prominent convex pseudo-deltidium; cardinal area of entering valve very small; surface of both valves very deeply undulated by about eight very large, angular, simple, deeply separated ridges, the middle pair on the receiving valve, and middle one of the entering valve distinctly larger than the others: surface crossed at very irregular distances by strong imbricating lamina of growth, which seem undulated by crossing over the ridges; under a lens of three quarters of an inch focus, surface with very coarse, rather distant, granular punctures; casts shew a mesial septum in each valve, a little longer than the diverging dental lamella. Width six lines, proportional length of receiving valve $\frac{n 5}{1+11}$, of entering valve $\frac{15}{100}$, depth of receiving valve $\frac{47}{100}$, depth of entering valve $\frac{30}{100}$.

I have seen the spires of this species, which are of moderate size; the very coarse granular punctures occasionally seen, more than half their diameter apart. Professor King mentions that the only difference he could perceive between this species and the S. octoplicata is the greater width of the latter; but I observe that specimens of the latter have a proportionally much lower cardinal area, longer hinge-line, are of nearly double the average size, and have five or six lateral plaits on each side of the mesial sinus, which are comparatively so small that at the margin three of them would be required to equal the mesial ridge in width, while in the present species the mesial ridge is little wider than the adjoining lateral ones. The carboniferous Spivifera insculpta (Phill.) seems also to him to be undistinguishable from the Permian S. cristate; but besides the greater height of the cardinal area, I have never seen more than one or two lateral ribs on each side of the median one, and the punctation seems slightly closer. Many decomposing specimens present the strange appearance noticed by Professor King of the substance of the shell falling away from the surface of the cast, leaving the latter covered with vertical, short, cylindrical spines, which are casts of the punctures which passed through the substance of the valves.

Position and Locality.-Not uncommon in the Permian limestone of Humbleton.

\section{Spirifera duplictcosta (Phill.)}

Ref. and Syn.=Id. id. Phill. Geol. York. Vol. II. t. 10. f. $1 ;+S .($ Brachythyris) planicostata McCoy, Synop. Carb. Foss. Irel, t. 21. f. 5 ; ?+ (var. $a)$ S. crassa de Kon. Anim. Foss. Bel. t. 15 bis. f. 5 ; + S. fasciger Keyser. Wissenschaft. Beobach. Petschora Land. t. 8. f. 3.

Desc.-Transversely oval when old, or obscurely rhomboidal when young; hinge-line rather less than the width of the shell, forming obtusely-rounded cardinal angles; lateral margins nearly horizontal ; front raised into a deep sinus, triangular when young, becoming semielliptical or oblong when old. Entering valve gently convex when young, and for about half an inch from the beak in old specimens, after which the gently convex sides become gradually flattened towards the cardinal angles, and arched downwards on each side of the mesial lobe, which is thus left very prominent, and rounded, corresponding with the elevation of the mesial sinus at an angle

[EASC. III.] 
of about $100^{\circ}$ with the lateral margins; mesial lobe defined in most specimens near the beak by two sulci rather stronger than the rest. Receiving valve very gibbous, almost equally arched from the beak to the middle of the front margin, so that its depth is greatest in the middle; beak narrow, prominent, much incurved over the hinge-line; cardinal area rather wide, triangular, beaks approximate; dental lamella diverging at a very small angle $\left(10^{\circ}\right)$; surface of both valves covered with very numerous, subequal, very much branched ridges, which, when the surface is well preserved, seem smooth, flat, and separated by extremely narrow slightly marked sulei, those of the sides and mesial fold exactly similar and equal, ten or twelve in the space of six lines on all parts of the slell (eight or nine in the same space in the var. crassa); but when partially decorticated, the sulci become very much deeper and larger, and from the primary sulci being much more deeply grooved than all the subsequent subdivisions of the primary ridge the radiation in this state seems very strongly fasciculated; at nine lines from the beak there may commonly be counted nine strixe on the mesial fold, which unite into three at six lines from the beak, and subsequently into one; about nineteen ridges on each side, every two or hree of which are separated by much stronger sulei, and blend into seven or eight primary ridges near the beak; some of the extreme lateral ones being simple from this length to the adult size; the ridges increase in number by frequent branchings, but do not clange in size. Proportions of young specimen one inch wide, proportional length of receiving valve $\frac{85}{101}$, of entering valve $\frac{67}{10 u}$, height of area $\frac{16}{1,10}$, width of hinge-line $\frac{65}{100}$, depth of entering valve $\frac{20}{110}$, depth of receiving valve $\frac{25}{100}$, depth of sinus in front margin $\frac{25}{1+110}$. Adult specimen, width three inches, proportional length of receiving valve $\frac{80}{100}$, of entering valve $\frac{63}{100}$, height of area $\frac{13}{100}$, width of hinge-line $\frac{83}{100}$, depth of entering valve $\frac{30}{100}$, of receiving valve $\frac{83}{100}$, depth of front sinus $\frac{30}{100}$.

Although the large specimens with nearly smooth, well-preserved surface, and very close flat ribs, so common in the dark limestone of Killymeal, Dungannon, which I figured formerly under the name of S. planicostata as above, seemed to have no affinity with the smaller specimens from other localities, which agree perfectly with Phillips's original S. duplicicusta, with coarse sulci separating the strongly branched and fasciculated ridges, yet I now suspect the difference of striation is due to the amount of preservation of the shell, and the difference in form to age; and (although I may be wrong) I would now venture to unite them, from the study of abundance of variously preserved specimens of all ages in the collection from Derbyshire. M. d'Orbigny has suggested the union of the $S$. planicostata and the S. crasse of De Koninck, and a specimen from Derbyshire, perfectly according with the latter species, is so perfectly identical with the present fossil in all points save the flatness of the mesial ridge, and a somewhat greater width and depression (proportional length $\frac{\pi}{1 w}$, depth of both valves ${ }_{100}^{45}$ ), that I have no doubt it should only be classed as a variety of $S$. duplicicosta also.

Position and Locality. - Very common in the great scar carboniferous limestone of Derbyshire; not very uncommon in the black lower carboniferous limestone of Isle of Man; rare in the dark lower carboniferous limestone of Kendal; not rare in the limestone of Lowick, Northumberland.

\section{Spirifera fasciculata $\left(\boldsymbol{I}^{\circ} \mathrm{Coy}\right)$. Pl. 3. D. fig. 25.}

\section{Ref.-M당, Ann. Nat. Hist. 2nd Series, Vol. X.}

Desc.-Longitudinally very broad-ovate; length and width nearly equal, depressed; hinge-line only half the width of the shell; cardinal area rather more than one-third higher than wide; lateral margins horizontal, front margin abruptly raised into a defined, obtusely angular sinus; entering valve depressed slightly, and gently convex on the sides; mesial fold very strongly defined by a sulcus and depression of the surface on each side; convex, very obtusely angular, but not very prominent, having three ridges near the beak, which dichotomise into six as they approach the margin; each side has about seven to nine flat, smooth ridges near the beak, most of which branch into two or three as they approach the edge; the intervening sulci very narrow; receiving valve more convex, moderately gibbous along the middle, sloping rapidly towards the side margins; mesial hollow strongly defined, very deep, narrow, flattened near the beak, widening, and receiving about two plaits on each side of the middle one as it reaches the front sinus. Width of average-sized specimen nine lines, proportional length of receiving valve $\frac{30}{100}$, of entering valve $\frac{80}{100}$, width of cardinal area $\frac{53}{100}$, width of sinus in 


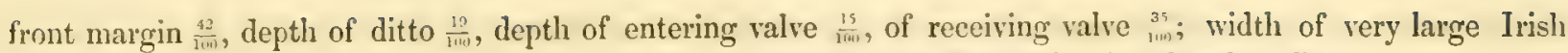
specimen one inch five lines, proportional length of receiving valve $\frac{80}{100}$, depth of both valves $\frac{50}{100}$.

Distinguished from the $B$. duplicicusta (Phill.) by the more longitudinally oval, depressed form, very short hinge-line, and cardinal area.

Position and Locality.-Not very uncommon in the carboniferous limestone of Derbyshire.

Explanation of Figures.-Pl. 3 D. fig. 25, profile natural size; fig. 25a, ditto same specimen, entering valve (the cardinal area seeming slightly too wide); fig. $25 \mathrm{~b}$, ditto ditto receiving valve; fig. $25 \mathrm{c}$, ditto ditto end view shewing the sinus in the front margin.

\title{
Spirifera grandicostata $\left(M^{\circ} \mathrm{Co} y\right)$. Pl. 3. D. fig. 29.
}

\author{
Ref.- $\mathrm{M}^{\mathrm{c}} \mathrm{Coy}, \mathrm{Ann}$. Nat. Hist. 2nd Series, Vol. X.
}

Desc.-Transversely subrhomboidal, sides abruptly attenuated and flattened, twice as wide as long, moderately convex; hinge-line acute-angled, cardinal area broad, with parallel sides; profile of receiving valve abruptly arched to the incurved beak in the posterior third of its length, much more gently arched in the anterior two-thirds, so that the anterior lobe projects much from the front margin; mesial hollow deep, corresponding ridge moderately prominent; radiating ridges very large, thick, angular, three strongly marked on the mesial hollow, of which the middle is much the broadest, and most depressed on the shell; the two lateral are imperfectly and obscurely triplicated towards the margin; corresponding sulci on mesial ridge faintly marked; on each side are about five great angular radiating ridges, sonı of which shew a faint tendency to imperfect division towards the margin; the narrow flattened sides, or cardinal angles, when preserved, shew five or six very much smaller obscure radiating ridges. Width about two inches six lines, proportional length of receiving valve..,+ , of entering valve $\frac{45}{1,4}$, width of cardinal area $\frac{8}{100}$, depth of sinus in front margin $\frac{10}{101}$, depth of both valves $\frac{34}{100}$.

This is allied to the $S$. trigonalis of Martin, but differs from it by its abruptly narrowed and attenuated sides, and by its few very large angular ridges occupying the body of the shell, and the abrupt diminution in size of the five or six outer ridges on each side. A very young specimen, nine lines wide, has the three ridges in the mesial hollow distinctly marked, but nearly as large as the lateral ones, of which there are three or four great ones on each side, but scarcely a trace of any additional ones on the flattened cardinal angles, which are strongly striated parallel to the margins.

Pusition and Locality.-Rare in the carboniferous limestone of Derbyshire, (but common in the Irish limestone at Ardagh, from whence there are also good specimens in the collection.)

Explanation of Figures.-Pl. 3. D. fig. 29, atural size receiving valve, the four or five ridges on each sideof the middle are not quite large enough to shew the abrupt change from them to the very small lateral ones; fig. $29 a$, ditto front view; fig. $29 b$, ditto entering valve, the four or five ridges, next the middle, on each side not quite large enough.

\section{Spirifera insculpta (Phill.)}

Ref. and Syn。=Id. id. Phill. Geol. York. t. 9. f. 2 and 3.=S. Koninckianus D'Orb. Prod. Pal. p. 149. S. crispus de Kon. (not of Lin.) Anim. Foss. Belg. t. 15. f. $8 a, b, c$ (not $d, e)$.

Desc.-Entering valve nearly semicircular; front and side margins regularly arched, very deeply plicated with large salient and re-entering angles, formed by the extremely large, angular, radiating ridges, and the equal deep, angular, intervening spaces; one or two lateral ridges on each side of the mesial ridge in the entering valve, the mesial ridge being only slightly larger than the adjoining ones; receiving valve seni-conical; cardinal area half as high as wide, triangular, only slightly curved; beak large, elevated, slightly incurved; from its apex the surface slopes gradually to the margin; two very strong angular ridges bound the very deep angular mesial sulcus, usually one, or rarely two lateral ridges on each side; surface crossed with coarse, suberect, subregular, scaly laminæ of growth, marked with coarse, rather distant punctures (under a lens of three quarters of an inch 
focus.) Width of small specimen six lines, proportional length of receiving valve $\frac{03}{100}$, length of entering valve $\frac{50}{100}$, height of area $\frac{30}{100}$, depth of both valves $\frac{65}{100}$.

The higher cardinal area, and somewhat larger and more deeply divided ribs, and, I think, less distinctly punctured surface, are the only points I sce to separate this species from the Permian S. cristata.

Position and Locality.-Rare in the carboniferous limestone of Derbyshire.

\section{Spirifera minma (Sow.)?}

\section{Ref.-Sow. Min. Con. t. 377. f. 1.}

Desc.-Rhombic; hinge-line shorter than the width of the shell ; cardinal angles obtusely rounded; anterior lateral margins slightly convex, converging towards the narrow front, which is sinuate, by the abrupt elevation at rather more than right angles of the front margin, into an acute sinus, about two-thirds as high as wide. Entering valve gently convex on the sides, arching towards the lateral margins; profile faintly sigmoid, from the elevation of the narrow, rounded, or obtusely-angular mesial ridge, which is smooth; eight or nine small, obtusely angular ridges on each side, extending simply nearly to the beak; beak narrow, prominent. Receiving valve moderately gibbous; beak large, very much incurved, channelled from the apex to the sinus in the front margin, by the deep, angular, defined, smooth, mesial hollow; cardinal area rather high, triangular; surface very coarsely granulo-punctate under the lens. Width five and half lines, proportional length of receiving valve $\frac{1.10}{100}$, length of entering valve $\frac{80}{1101}$, width of hinge-line about $\frac{60}{100}$, height of cardinal area $\frac{15}{100}$, width of sinus in front margin $\frac{25}{100}$, height thereof $\frac{25}{100}$, depth of entering valve $\frac{27}{100}$, depth of receiving valve $\frac{25}{100}$.

This shell seems to agree with the Spirifer minimus from the same locality, figured by Sowerby; but from its unridged mesial hollow seems quite distinct from the Anomites acutus of Martin, which most writers unite therewith.

Position and Locality.-Rare in the lower carboniferous limestone of Derbyshire.

\section{Spirifena octoplicata (Som.)}

\section{Ref.-Sow. Min. Con. t. 562. f. 2 to 4.}

Desc.-Subrhomboidal, gibbous; hinge-line slightly exceeding the width of the shell; cardinal angles acute; entering valve semicircular, twice as wide as long, with regularly arched margins, moderately convex; greatest depth about the middle; front margin abruptly raised into a very large rounded sinus; mesial ridge very large, prominent, obtusely angulated or rounded, five narrow, simple, cord-like ribs on each side, so much smaller than the mid-rib that three of them, with the two intervening spaces at the margin, only equal the width of the mesial ridge; receiving valve gibbous, rhomboidal, from the nearly equal production of the middle of the front and of the beak; beak large, clevated; mesial hollow wide, strongly defined by the lateral ribs, concave, produced into a rounded lobe in front to fill the sinus in the entering valve, usually with traces of two faint ribs towards the margin of large specimens; cardinal area wide, triangular, its height rather less than one-fourth its width; entire surface sculptured with coarse, suberect, subequal, scale-like lamina of growth, and coarsely granulo-punctate under the lens. Width ten lines, proportional length of receiving valve $\frac{57}{100}$, of entering valve $\frac{55}{100}$, height of cardinal area $\frac{19}{100}$, greatest depth of entering valve $\frac{20}{100}$, depth of receiving valve $\frac{30}{100}$.

The great proportional size of the mesial fold, compared with the lateral ridges, easily separates this fion the Spirifera cristata of the Permian rocks, as well as the points enumerated under that specific head.

Position and Locality.-Carboniferous limestone of Flintshire.

\section{Spirifera Ornithorhyncha $\left(M{ }^{c}\right.$ Coy $)$. Pl. 3. D. fig. 27.}

Ref.-Id. id. MCoy, Synop. Carb. Foss. Irel. t. 21. fig. 2.

Desc.-Transversely rhomboidal when young (six lines long), crueiform when old (one inch long) from the great prolongation of the compressed front, and abruptly contracted, nearly cylindrical sides; entering valve at 
six lines long semicircular or subtrigonal, twice as wide as long, depressed, with a very large, acutely angular, mesial ridge, and four or five large obtusely angular simple ridges on each side; lateral margins nearly horizontal, an acutely angular but slightly raised sinus in the middle of the front; receiving valve moderately convex; greatest depth in the middle, alnost regularly arched from beak to front margin; about five thick obtusely angular simple ridges on each side of the middle, the two middle ones bounding the mesial sinus largest; a narrower, strongly marked ridge in the centre of the mesial hollow, sharply defined from the apex of the beak, and more prominent than the rest towards the margin; beyond this size the lateral margins do not increase much in length, but by thickening their edges render the narrow sides cylindrical, from the centre of which the great mesial ridge of each valve forms a large, compressed, narrow, beak-like prolongation, elliptical in the profile; hinge-line as wide as the shell; cardinal area moderately wide, nearly parallelsided; beaks remote, that of the receiving valve large, much incurved. Young specimen nine lines wide,

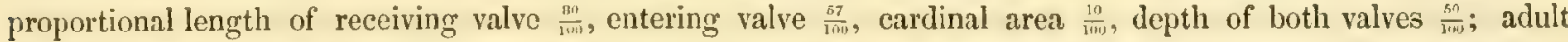
length of receiving valve about one inch, length of entering valve nine lines, projection of front beyond the lateral margins five lines, depth of both valves in the middle seven and half lines, depth in middle of side five lines, widtl of cardinal area two lines, width of mesial sinus at junction of lateral margins four lines.

This species when seen in front resembles the Roman letter $T$, from the long compressed extension of the central ridge of each valve at right angles to the cylindrical sides, and when viewed laterally, the resemblance to the beak of the little auk Alca Alle has suggested the specific name. The young might be confounded with the S. triangularis of Martin, particularly as figured by Sowerby (Min. Con. t. 562, and de Koninck, t. 15), but is easily distinguished by the much smaller number of the lateral ridges, and the strong angular ridge in the centre of the mesial sinus of the receiving valve extending, with sharp definition, quite to the apex of the beat, and at even six lines long much exceeding all the others in prominence. In the adult state, or at and after an inch long, its appearance is so peculiar that it can be confounded with no other species, from the compressed beaklike extension of the front.

Position and Locality.-Rather rare in the carboniferous limestone of Derbyshire.

Explanation of Figures.-Pl. 3. D. fig. 27, receiving valve of immature specimen, in which the mesial prolongation is not fully developed, the cylindrical sides both broken off; natural size; fig. $27 \alpha$, ditto profile of both valves.

\section{Spirifera ovalis (Phill.) Pl. 3. D. fig. 28.}

Ref. and Sym = Id. id. Phill. Geol. York. Vol. II. t. 10. f. 5. + S. (Brachythyris) hemispherica (MCoy) Synop. Carb. Foss. Irel. t. 19. f. 10. S. rotundatus and pinguis de Kon. Anim. Foss. Bel. t. 15. f 4. (not of Sow.)

Desc.- Very broad-oval, width very slightly more or less than the length of receiving valve; length of hinge-line much less than half the width of the shell, scarcely interrupting the orbicular outline of the entering valve; lateral margins nearly straight, abruptly raised in front into an obtusely-rounded sinus; entering valve with a rather prominent tumid beak; mesial ridge broad, depressed, rounded, very strongly defined by two deep sulci, either smooth, or sometimes very obscurely divided towards the margin by two faint obsolete sulci; ten or twelve thick, rounded, or very obtusely angular, usually simple ribs on each side. Receiving valve conoidal, or subhemispherical, very gibbous at one fourth of the length from the beak, from whenee it arches gradually to the front margin, and with a short but more rapid curve to the beak, which is narrow, small, moderately incurved, and much elevated by the triangular cardinal area, the height of which is considerably more than twofifths of its width; mesial hollow obsolete in all the rostral portion, becoming moderately concave as it approaches the front sinus, and there usually marked with one or two obsolete, broad, longitudinal ridges. Width of var. ovalis one inch four lines, proportional length of receiving valve slightly more; length of entering valve $\frac{90}{100}$, length of hinge-line $\frac{43}{10 u}$, height of cardinal area $\frac{18}{10,}$, depth of entering valve $\frac{18}{100}$, depth of receiving valve $\frac{40}{100}$, width of mesial ridge at front sinus $\frac{43}{i, n}$, height of sinus $\frac{15}{100}$. Width of var. hemispherica one inch five lines; proportional length of receiving valve ${ }_{100}^{86}$, of entering valve ${ }_{100}^{73}$, depth of entering valve $\frac{15}{100}$, of receiving valve $\frac{45}{100}$, width of mesial ridge at front sinus $\frac{85}{100}$, height of sinus $\frac{10}{100}$. 
The remarkable difference in aspect produced by the length slightly exceeding the width, and the entering valve being gently and evenly convex in the true var. ovalis (Phill.), and the flattening of the entering valve, greater width, and disproportionally deep receiving valve in the var. hemispherica ( $\mathrm{I}^{\circ} \mathrm{Coy}$ ), made me always consider them distinct species, until very recently seeing a specimen from Malham Moor, in which all the characters are intermediate, I therefore now unite the species, merely indicating the two forms as varieties. The shortness of hinge-line and height of the area between the beaks, as well as broad, simple, mesial fold, distinguish it from the S. integricosta (Phill.)

Position and Locality.-Var. ovalis common in the carboniferous limestone of Beith, Ayrshire; rare in the lower carboniferous limestone of Derbyshire; var. hemispherica, not uncommon in the dark carboniferous limestone of Isle of Man; intermediate variety in grey carboniferous limestone of Malham Moor; var. hemispherica not uncommon in the dark lower carboniferous limestone of Lowick, Northumberland.

Explanation of Figures.-PI. 3. D. fig. 28, var. hemispherica, side view, natural size from the Isle of Man, shewing the great inequality of the valves; fig. $28 \alpha$, ditto same specimen, shewing the entering valve and very small hinge line and cardinal area; fig. 28 , ditto same specimen, front view.

Spirifera paucicostata $\left(M^{c}\right.$ Coy $)$. Pl. 3. D. fig. 26.

$$
\text { Ref.-McCoy, Ann. Nat. Hist. 2nd Series, Vol. X. }
$$

Desc.-Globose, or very broad-ovate; hinge-line slightly shorter than the width of the shell; cardinal angles slightly obtuse, sides and front moderately rounded, very obtuse from the meeting of the valves at a large angle, front aluruptly raised into a wide semielliptical sinus. Entering valve evenly convex, sides tumid, with six or seven strong, rounded, obtuse simple ribs on each side; mesial ridge broad, prominent, very strongly defined from the beak, having three ridges about the size of the lateral ones, each of which dichotomises close to the margin. Receiving valve very gibbous, semicircularly arched from the beak to middle of front margin; mesial sinus deep, strongly defined from the beak, having at first three, subsequently six small olsscurely marked ribs; beak very large, incurved; cardinal area moderately wide. Width nine lines, pro. portional length of receiving valve $\frac{40}{1 m}$, length of entering valve $\frac{70}{100}$, depth of both valves $\frac{7 n}{100}$, width of mesial fold $\frac{47}{100}$, height of sinus in front margin $\frac{22}{100}$, width of cardinal area $\frac{15}{100}$.

This species is most nearly allied to the S. trigonalis, from which it is distinguished by the more spheroidal form, the obtuse rounding of the sides, and the very small number of its lateral ribs; the distinctly ribbed mesial ridge separates it from S. pinguis, as well as its more depressed form, and the ferver, and more prominent radiations.

Position and Locality.-Not very uncommon in the carboniferous limestone of Derbyshire.

Explanation of Figures.-Pl. 3. D. fig. 26 , end view, natural size; fig. $26 a$, ditto profile; fig. $26 b$, ditto front view.

\section{SPIRIFERA PInguis (Sow.)}

Ref.-Sow. Min. Con. t. 271.

Desc.-Globose, cardinal area narrow, beaks very approximate; lateral margins very obtuse, the edges of the valves meeting sometimes without angle; hinge-line less than the width of the shell; cardinal angles obtuse or slightly mucronate; lateral margins straight in young, sigmoidally eurved in old speeimens; front margin abruptly raised into a very deep oblong sinus. Entering valve inflated, moderately gibbous, tumid quite to the margins, which are deflected in old specimens; eight or ten thick, obtuse, convex, simple or oceasionally bifurcate ribs on each side, varying from two to three in a space of three lines at nine lines from the beak; the immediate vicinity of the hinge-line nearly smooth; mesial ridge very strongly defined by two sulci from the beak, broad, prominent, smooth, and rounded, or divided by a mesial sulcus. Receiving valve inflated, very gibloous on the sides, which are nearly vertical; semicircularly arched from the beak to the middle of front margin; depth greatest in the middle of the length; mesial hollow very deep, wide, concave or flattened in the middle, and strongly defined from the apex of the beak, containing three or five 
obscure ribs, somewhat smaller than those of the sides; shell under a strong lens, with very minute flexuns fibres. Average width of adult specimens one inch three lines, proportional length of receiving valve $\frac{15}{1.15}$ to

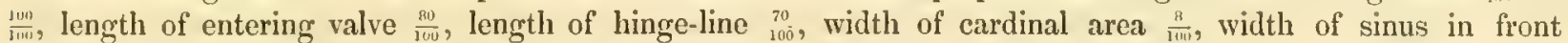
margin $\frac{45}{100}$, depth of ditto $\frac{30}{100}$, depth of entering valve $\frac{30}{100}$, depth of receiving valve $\frac{50}{100}$.

In some localities this species is extremely common, but on the other hand it is of local distribution. Two of the characters on which Mr Sowerby lays stress, viz., the narrow suleus dividing the mesial ridge of the entering valve, and the absence of plaits in the mesial hollow, are by no means important; for specimens are almost as often found in which the mesial ridge is undivided, and nearly all specimens shew the ribs I mention in the mesial hollow, although they are often very faintly marked. Professor Phillips's figure for this species appears to be rather the young of his $S$. rotundata, the $S$. subrotundata of this work. But even when specimens of the same size are compared, the $S$. pinguis may be distinguished from the latter species by the width very slightly or not at all exceeding the length, its much greater depth, inflated sides, and consequently obtuse edges.

Position and Locality. - Very common in the limestone of the Isle of Man.

\section{Spirifera recurvata (de Kon.)}

Ref.-de Kon. Anim. Foss. Bel. t. 16. f. 5.

Desc.-Longitudinally ovato-subtrigonal; moderately gibbous; hinge-line much shorter than the width of the shell; cardinal angles obtuse; greatest width a little behind the middle, from whence the sides converge with little convexity to the narrow front, which has a very narrow, abrupt, semicircular wave in the middle; lateral margins very slightly sigmoidal. Entering valve evenly gibbous, greatest depth about onefourth from the beak; mesial ridge very narrow, slightly convex, very little elevated, strongly defined by a decp sulcus on each side, having at six lines from the beak about four ribs on the mesial ridge slightly smaller than those of the sides, about seventeen obtusely angular subequal ribs on each side, produced by one or two bifurcations in that length from the beak; receiving valve evenly gibbous in the middle, rapidly sloping to the sides, greatest depth at one-third from the beak, from whence the profile arches gradually to the front margin, and rapidly to the apex; beak large, prominent, much incurved; cardinal area wide, triangular, about two-thirds wider than high; mesial sulcus very narrow, sharply defined from the apex of the beak, and containing about the same number of ribs as the opposite ridge. Length seven and half lines, proportional length of entering valve $\frac{85}{1104}$, width of hinge-line $\frac{60}{100}$, width of sinus in front margin $\frac{15}{100}$, depth of entering valve $\frac{25}{100}$, depth of receiving valve $\frac{42}{100}$.

The numerous, often branched, subequal, lateral ribs, and very narrow defined ribbed sinus, as well as elongate form, easily distinguish this species from its congeners. From the bifurcation of the rils M. de Koninck gives 8 or 9 ridges to the mesial fold, at 10 lines long, and 18 or 20 on each side.

Position and Locality. - Not very uncommon in the carboniferous limestone of Derbyshire.

\section{Spirifera sexradialis (Phill.)}

$$
\text { Ref.-Phill. Geol. York. Vol. II. t. 10. f. } 8 .
$$

Desc.-Rotundato-quadrate, gibbous, slightly longer or shorter than wide; hinge line very short; cardinal angles much rounded; anterior lateral margins rather straight, front obscurely narrowed. Entering valve obscurely ovato-trigonal, moderately gibbous; mesial ridge round, large, prominent, notched in front by the abrupt elevation of a small semielliptical sinus equalling it in width, at right angles to the plane of the lateral margins; very strongly defined from the beak by a deep, wide, concave sulcus on each side; two slightly smaller, obtusely rounded ribs on each side, having a third imperfectly defined on each outer side near the cardinal angles, which are smooth. Receiving valve very gibbous, with a deep, narrow, mesial hollow, strongly defined from the apex, bounded on each side by a thick, obtusely rounded ridge, more prominent than the lateral ones, of which there are two rather small on each side, leaving nearly half of each side towards the 
cardinal angles smooth; cardinal area moderately defined, triangular, about two-thirds wider than high. Surface smooth or marked with inconspicuous concentric lines of growth ; shell tissue finely fibrous under a strong lens. Width of average-sized specimen seven lines, proportional length of receiving valve ${ }_{100}^{90}$, length of entering valve ${ }_{100}^{80}$, length of hinge-line ${ }_{100}^{47}$, height of area about ${ }_{12 \mathrm{~m}}^{12}$, depth of entering valve $\frac{25}{110,}$, of receiving valve $\frac{40}{10 t}$, length of very large specimen ten and half lines, proportional width $\frac{80}{100}$, depth of both valves $\frac{70}{100}$.

Position and Locality. - Not uncommon in the carboniferous limestone of Derbyshire.

\section{Spirifera striata (Mart. Sp.)}

Ref. and Syn.= Anomites striatus Martin, Pet. Derb. t. 23; = Spirifer id. Sow. Min. Con. t. 270. + S. attenuatus Sow. id. t. 493. f. 3, 4, 5 ? + S. clathrata $\mathbf{M}^{c}$ Coy, Syn. Carb. Foss. Irel. t. 19. f. 9.

Desc.-General form varying from subrhomboidal to semicircular, usually depressed; cardinal angles acute, but varying from slightly so, to attenuated spines; hinge line as wide as the shell; cardinal area wide, concave, with subparallel sides. Entering valve subsemicircular, moderately convex, with a rather wide, very obtusely angular mesial ridge, varying greatly in prominence, and sometimes defined on each side by a deep sulcus, which is by no means constant; most strongly defined towards the margin of large specimens, where it is raised by the very deep, oblong, or semielliptical sinus, which raises the front margin nearly at right angles to the plane of the lateral edges, and gives a sigmoidal profile to the middle of this valve. Receiving valve moderately convex, flattened on the sides; beak moderate, slightly projecting; a deep, wide mesial hollow extends from its apex to the sinus in the front margin, to fill which the middle of the receiving valve in old specimens is produced into a long tongue-shaped lobe; profile gradually and regularly arched from the beak to the front margin in old specimens, but the posterior third most abruptly arched in small specimens. The entering valve at one inch from the beak commonly exhibits eight or ten mesial narrow, subequal, rugged ridges, produced by the di- or trichotomy of a pair of lateral ridges, and the fourfold division of a primary one from the beak; at the same length on each side are about twenty-five equal and similar ridges to the mesial ones, those eight or ten near the cardinal angles being commonly simple, those nearer the middle di- or tri-chotomising once or twice in that distance from the beak (averaging seven to ten in the space of half an inch); from this point to the margin the ribs increase in number by irregular forking at various distances, but do not vary materially in size, the above number of ridges in half an inch being found all over the surface of large specimens, the lateral ones remaining simple, but the sulci marking the divisions between the primary branching ridges remaining considerably deeper than the sulci separating the branches, so that a more or less distinct fasciculation is produced; surface when perfectly preserved shewing under the lens a very minute reticulation, composed of equal, transverse, obtuse striee (distinct from the lines of growth), crossed by straight, equal, obtuse, longitudinal strice, straighter and much coarser than the fibrous tissue of the shell. Average width three inches nine lines, proportional length of receiving valve $\frac{60}{100}$ to $\frac{85}{100}$, length of entering valve $\frac{55}{100}$, width of cardinal area $\frac{30}{100}$, width of mesial sinus at front $\frac{26}{100}$, height of sinus $\frac{10}{100}$ to $\frac{25}{100}$, depth of both valves $\frac{38}{100}$ to $\frac{50}{100}$, or in a very long gibbous variety (resembling M. Mrosquensis, but without the long dental lamellæ) $\frac{65}{100}$.

I for a long time thought that the Spirifere attenuata of Sowerby might be considered a distinct species by its snaller size, greater convexity of both valves, suddenly attenuated cardinal angles, strong pair of sulci defining the mesial ridge, more uniform, less branched and less fascieulated, and slightly smaller strix; but experience shews me (as MM. de Koninck and Murchison, de Verneuil and Keyserling have already found) that these characters do not occur together constantly, but are individual peculiarities, really affording no character not found in the large S. striata, with the exception of the spinose cardinal angles occasionally found in the S. attenuata, but which from analogy we should not expect in old individuals. The large number of examples from Derbyshire of the true S'. striata, which I have lately examined, shew that in those rare cases where the surface is preserved, the beautiful reticular sculpturing which I have figured in the S. clathrata may be found with a lens, and where it is absent the surface has manifestly lost some layers of shell; it is thus possible, that as this character has been hitherto overlooked in $S$. striata, that $S$. clathrata should be united thereto. Punc- 
tures as large as those of a pin, and sometimes with tumid edges, may occasionally be seen at intervals of about one-eighth of an inch, both in the sulci and more rarely on the ribs.

Position and Locality.-Both the var. striata and var. attenuata very common in the carboniferous limestone of Derbyshire.

\section{Spirifera subrotundata $\left(I^{c}\right.$ Coy).}

\section{Ref. and $S y n_{0}=S$. rotundatus Sow. Min. Con. t. 461. f. 1. (not of Martin.)}

Desc.-Transversely oblong or quadrato-ovate, moderately depressed; hinge-line less than the widtl of the shell; cardinal angles flattened, obtuse; sides gently convex, acute; lateral margins horizontal; middle of the front abruptly raised, at rather more than right angles from the plane of the lateral margins, into a deep, oblong, or semielliptical sinus; entering valve gently convex in the middle, becoming gradually flattened towards the margins; profile gently arched from the beak to one-third the length (half an inch), beyond which it is straight to the margin; mesial ridge very strongly defined from the beak by two deep sulci, prominent, gently convex or divided by a shallow mesial sulcus; each side with about eight broad, convex, simple ribs, some of which continue simple, and others dichotomise towards the margins of large specimens, where the ribs vary from one to nearly two lines wide in old individuals, there amounting to sometimes thirteen, the cardinal angles remaining smooth. Receiving valve very gibbous, most so at one-third from the heak, almost regularly arched from thence to the middle of the front sinus; mesial hollow very deep, wide, flattened, distinctly defined from the beak, and containing two obscure ribs, slightly smaller than the lateral ones, on each side of a flattened mesial space, slightly broader "than one rib; cardinal area narrow; beak moderate, approaching that of the entering valve. Average width two inches six lines, proportional length

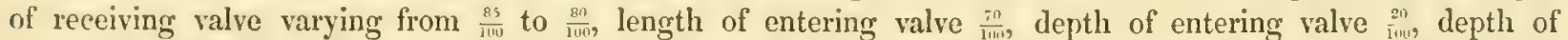

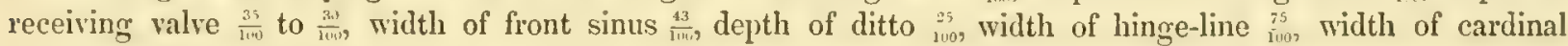
area $\frac{7}{100}$; young specimen one inch wide, length of receiving valve $\frac{80}{300}$, depth of both valves $\frac{55}{100}$.

The lateral radiations of this species are broad and flattened when well preserved, and vary greatly in width at margins of old specimens, according to whether the primary ridges remain simple or bifurcate. I regret that in my old volume on the carboniferous limestone fossils of Ireland (in which I pointed out that the Spiriferce rotundata of Phillips and Sowerby was not the true rotundata of Martin, which was figured by Phillips under the specific name planata) I did not give a separate name to this species, which by its broad, smooth, mesial ridge, deep sinus in the front margin, greater gibbosity, Scc. is very distinct from the original rotundatu of Martin. Public opinion lias since so strongly increased in favour of priority, that I no longer hesitate to do so. The depression of the sides or sharpness of the margins from the acute angle at which the valves meet each other, less gibbosity and greater proportional width, distinguish specimens of all sizes from the little Spirifei pinguis of Sowerby, with which in other characters it is identical.

Position and Locality.-Common in the carboniferous limestone of Bolland.

\section{Spirifera trigonalis (Mart. Sp.)}

Of this very common species there are several varieties, which I shall describe separately.

Var. a. TRigonalis (Mart. Sp.)

Ref. and Syn.= Anomites trigonalis Mart. Pet. Derb. t. 36. f. 1.= Spirifer id. de Koninck, Anim. Foss. Bel. t. 17. f. 1. + S. striatus id. id. (not of Martin) t. 16. f. $3 .+$ S. Strangwaysi M. V. K. Geol. Russ. t. 6. f. 1.+S. incrassatus Eichw. Sp. M. V. K. Geol. Russ. t. 6. f. 3.+ S. Pentlandi d'Orb. Voy. dans l'Amér. Mér. p. Pal. t. 5. f. 15̃. + S. rhomboidea Phill. Geol. York. t. 9. f. 8, 9; ?+ S. Fischerianus de Kon. Foss. Bel. t. 14, f. 3.

Desc.-Subrhomboidal, gibbous; hinge-line exceeding the width of the shell, forming cardinal angles of variable acuteness; receiving valve moderately gibbous, greatest depth at one-third from the beak, from which [EASC. III.] 
point the profile arches abruptly to the apex of the much incurved beak, but slopes gradually with very slight convexity to the elliptical lobe terminating the mesial sinus, which projects, so that from the beak to its middle is considerably more than from thence to its lateral edge; lateral edges only slightly convex; cardinal area wide, moderately concave, subparallel-sided, abruptly tapering at the ends; mesial hollow wide, concave, bearing three equal obtuse ribs, the same size as the lateral ones till after half an inch from the beak, beyond which the outer pair bifurcate, forming five (or sometimes, by trifurcation of the outer ribs on cach side, seven) ribs towards the margin in adult specimens, the two outer of which are less distinctly marked than the others; each side with from seven to fourteen rounded or obtusely angular ribs, usually simple, or one or two of them bifurcate at various distances from the beak; entering valve varying from triangular to semicircular, according to the width of the hinge-line and projection of the front lobe, moderately gibbous, becoming gradually flattened towards the cardinal angles; mesial ridge varying from triangular and half as high as wide, to flattened and scarcely elevated, its ridges less strongly defined than those of the sides or sinus, bearing three ridges close to the beak, which quickly become four by the bifurcation of the middle one till near the margin of large specimens, when the outer pair olsscurely divide into two, or in very large specimens into three; surface usually smooth, or crossed by delicate irregular lines of growth; but under a lens, when very finely preserved, reticulated. A verage ordinary

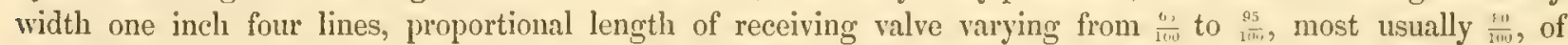
entering valve from beak to central edge of mid-lobe $\frac{67}{1+m}$, to front lateral margins $\frac{i 3}{1 m,}$; depth of receiving valve $\frac{4 m}{1 m}$, of entering valve $\frac{30}{100}$; cardinal angles commonly $70^{\circ}$, but varying from $55^{\circ}$ to $85^{\circ}$; width of cardinal area $\frac{10}{100}$ to $\frac{15}{1100}$. Occurs occasionally two inches eight lines wide, without further change of character.

The var. rhomboidea Phill. agrees in ribbing, area, and every particular with the above ordinary types, but the width reaches the proportion of twice the length. The muscular impressions are small, and the dental lamelle scarcely reach one-fifth the length of receiving valve. I have not quoted Sowerby's figure (Min. Con. t. 265), as it gives no definition to the mesial ridge, and makes the ribs so much broader than any of the great number of specimens I have examined, that it is searcely recongnisable as a portrait of the ordinary forms. The lateral ribs in by far the greater number of specimens are simple, and when one or two are branched on one side they often are not on the other. The remarkable projection in front of the mid-lobe does not occur in some specimens, otherwise similar. It will be seen that I find the common character of the ribs to be that supposed by Murchison, de Verneuil and Keyserling to characterise the S. Strangwaysi and S. incrassate, and not to occur in this species. From the traces of reticulation I have observed on those rarely seen spots where the surface is really perfect, I suspect the S. Fischeriunes may be referred to this species perfectly preserved.

Position and Locality.-This variety is extremely common in the lower carboniferous limestone of Derbyshire; less so in the dark carboniferous limestone of Lowick; in the dark carboniferous limestone of Dent, Yorkshire; in the red carluoniferous limestone of Breedon, Leicestershire; dark lower carboniferous limestone of Berwick-on-Tweed; carboniferous limestone of Malham Moor ; black carboniferous shale of Craige, Kilmarnock; and in the limestone of same locality rare specimens, with the cardinal angles attenuated into a spine, (S. Strangzecysi M. V. K.); rare in the lower carboniferous limestone of Kiendal; in the red lower carboniferous limestone of Closebourn, Dumfriesshire.

\section{Var. $\beta$. Bisulcata (Som.)}

Ref.-Sow. Min. Con. t. 494. f. 1, 2; id. Geol. Trans. 2nd Series, Vol. V. t. 39. f. 21.

Desc.-Subrhomboidal, hinge-line usually narrow, nearly parallel-sided; beaks approximate, often nearly in contact; cardinal angles only slightly acute; sinus in the front margin deep, and raised at right angles to the plane of the margins, rendering the mesial ridge shorter from the beak to its middle, than from the same point to its lateral front margins; lateral ribs obtusely rounded, usually simple, occasionally one or two of them dichotomous; the mesial rilges often obscurely defined, at first three near the beak, forming four by the bifurcation of the middle one, and towards the margin, after six lines from the beak, the outer one on each side branches, first into two, subsequently, in some specimens, into three; mesial sinus with three ribs ncar the beak, each of which, towards the margin of old specimens, di- or tri-chotomises, giving rise to at most nine often obseure ribs, slightly 
smaller than the lateral ones. Width one inch four lines, proportional length of receiving valve varying

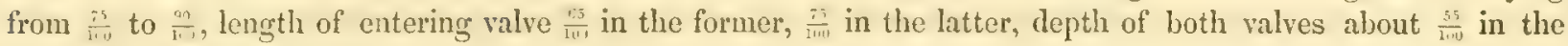
former, $\frac{70}{100}$ to $\frac{75}{100}$ in the latter.

The most remarkable character of this rariety, besides its gibbosity, is the abrupt raising of the mesial sinus at the margin, nearly at right angles to the plane of the lateral edges, shortening the length of the middle of the ridge, notching the front margin, and giving a nearly semicircular curve to the profile of the receiving valve, arched as abruptly towards the front edge as towards the beak, also the less transverse elongation, narrow cardinal area, and apyroximate healis, as well as perhaps one or two more rilus than ordinary in the sinus of old specimens; but in all these characters it varies, so that the gradual passage into the s. trigonalis is certain. Thus elongate suecimens, with subparallel sides, short hinge-lines giving nearly right angles with the sides, have, in some cases, only the ordinary three or four thick rils on the mesial ridge, and have the lobe of the receiving valve filling the sinus in the margin, projecting almost as much, and forming as acute an angle with the plane of the lateral edges, as in the ordinary $s^{\prime}$. trigonalis, in which latter also the beaks may occasionally be seen as approximate as in the S. bisulcutu. On the other land, all the characters of the typical varieties of $S$. bisulcata may be seen in specimens having the transverse elongation of S. trigonulis; so that although a very marked variety, I have no hesitation in saying that, as a species, it should be united with Martin's type. Some of the specimens shew the muscular impressions rather larger and more deeply marked than in the var. trigonalis; but this is a common character of the deep varieties of all shells. Outside the adductor impressions in the receiving valve (which are separated by a slender mesial septum not reaching the beali) is a coarsely punctured space, from which the very slender thread-like ovarian impressions extend towards the front. The sulei bounding the mesial ridge are strong, but not so remarkably so as to form a specific character, as $\mathrm{Mr}$ Sowerby thought. One Derbyshire specimen in the collection, agreeing perfectly with the ordinary types in other respects, is remarkable for having a short triangular cardinal area, as in S. crassa of de Koninck.

Position and Locality.-Common in the grey limestone of Derbyshire; rare in the dark limestone of Isle of Man; not uncommon in the dark carboniferous limestone of Dallmellington, Dumfriesshire; rare in the limestone of Lowick, Northumberland.

\section{Var. $\gamma$. SEMicincularis (Phill.) \\ Ref.-Phill. Geol. York, t. 9. f. 15, 16.}

Desc--Receiving valve nearly semicircular, twice as wide as long; cardinal area generally very wide, concave, sides subparallel, beaks widely separated; mesial ridge angular or depressed, with usually about six or eight ridges at the margin; each side with fourteen to seventeen strong, subangular ribs, which cither remain simple to the edge, or a few of them divide imperfectly into two or three by shallower sulci than divide the primary ones, (often imperfectly divided on one side of the shell and simple on the other). Width one inch nine

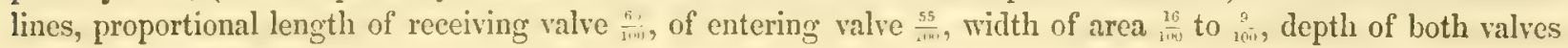
varying from $\frac{46}{100}$ to $\frac{50}{100}$.

This shell, which at first sight seems so distinct from $S$. trimonalis, passes into it by the diminution of the cardinal area and all other characters. The specimens in which most of the rilus imperfectly di- or tri-chotomise look remarkably different from the original types of $S$. trigonalis; but the specimens having the typieal characters in all other respects of the S. semicircularis, vary to a singular degree in this respect, some specimens having all the lateral ribs perfectly simple, others having a variable number subdivided; and still more interesting are the not uncommon specimens having simple ribs on one side and duplex ones on the other.

Position and Locality.-Common in the carboniferous limestone of Isle of Man. 


\section{Subgenus. CYRTIA. See page 191.}

\section{Spirifera (Cyrtia) cuspidata (Martin Sp.)}

Ref. and Syn. = Anomites cuspidatus Mart. Pet. Derb. t. 46.f. 3, 4.= Spirifer id. de Kon. Anim. Foss. Bel. t. 14. f. 1 .

Desc.-Pyramidal ; entering valve nearly semicircular, depressed, gently convex; mesial ridge very wide, obtusely rounded, smooth, strongly defined from the beak to the front margin, the sides of which it does not equal in length, owing to the sinus being abruptly raised at considerably more than a right angle from the plane of the horizontal lateral margins; from fifteen to twenty simple, slightly convex, radiating ridges on each side, gradually decreasing to the cardinal angles, becoming obscure by age; beak prominent; mesial septum about one-third of the length in old specimens, rather more in small ones. Receiving valve pyramidal; cardinal area very large, triangular, forming an acute angle at the beak of receiving valve in old specimens, lower and more curved in young, varying greatly in height, usually flattened, but varying to slightly concave, the beak being either vertical, slightly incurved, or very slightly recurved; triangular opening very large, nften displaying the internal deep-seated pseudo-deltidium (without perforation, leaving the only opening to the shell at its base); mesial hollow very wide, produced into a tongue-shaped lobe in front, sides flattened, lateral ribs as in entering valve; dental lamellie diverging at the same angle as the sides of the mesial hollow; surface smooth, or marked with irregular lines of growth. Width of very large specimen three inches three lines, proportional length of entering valve in middle $\frac{57}{100}$, at sides of mesial fold $\frac{65}{1100}$, width of mesial sinus $\frac{37}{110}$, height of

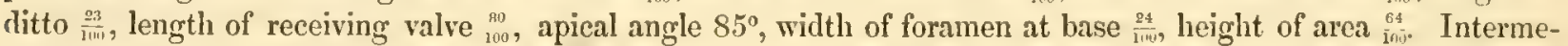
diate specimen, width two inches, length of entering valve $\frac{57}{160}$, of receiving valve $\frac{67}{200}$, apical angle about $85^{\circ}$. height of area $\frac{55}{100}$, width of opening at base $\frac{26}{100^{\circ}}$. Depressed specimen one inch seven lines wide, length of receiving valve $\frac{55}{100}$, cardinal angle about $95^{\circ}$ to $110^{\circ}$, height of area $\frac{35}{100}$ to $\frac{50}{200^{\circ}}$

The varieties found at Kendal with a comparatively low cardinal area, as well as that from Tournay figured by M. de Koninck as this species, are considered distinct by Mr Sharp, and referred by him to the Ameriean Devonian S. macronotus of Hall, characterized by a very narrow foramen, low wide cardinal area, thirty ribs on each side, and very strong concentric strix. But from the great number of specimens $I$ have examined, I have satisfied myself that the extremes of cardinal area, which I have noted above, pass in the most gradual manner from one to the other, and being unaccompanied by change in any of the other characters, cannot possibly be admitted as distinct species. The thirty lateral ribs on each side, narrow foramen, and strong transverse sculpturing characteristic of the American fossil, are not to be found, I think, in our English carboniferous species. The observations of M. de Koninck (op. cit.) exactly accord with my own as to the gradual variation of the cardinal area.

Position and Locality.-Not uncommon in the lower carboniferous limestone of Derbyshire; very common in the impure sandy lower beds of carboniferous limestone of Kendal.

\section{Spirifera (Cyrtia) laminosa ( $M^{c}$ Coy). \\ Ref.-Id. id. M'Coy, Carb. Foss. Irel. t. 21. f. 4.}

Desc--Subrhomboidal or pyramidal; entering valve semicircular, moderately convex; cardinal angles very slightly acute; mesial fold large, very prominent, rounded, produced into a long rounded lobe, the profile of which is very little arched, abruptly defined at the sides from the lateral front margins; five or six large angular ribs on each side. Receiving valve subrhomboidal, sides slightly convex; beak scarcely incurved, much elevated by the high, triangular, cardinal area; about six large, equal, angular ribs on cach side; mesial hollow wide. deep, strongly defined, produced in front when old into a long, tongue-slaped, flattened lobe; profile very slightly arched from the beak; surface of both valves strongly sculptured, with sulbregular, erect, seale-like, concentric lamine parallel to the margins, and undulated by passing over the large rilss. Width of old specimen one inch six lines; proportional length of receiving valve from beak to lateral margin at mid-lobe $\frac{\frac{\pi 5}{4+w}}{\text {, projection }}$ 
of mid-lobe beyond the side margins $\frac{25}{100}$, height of cardinal area ${ }_{100}^{45}$, width of foramen at base $\frac{30}{200}$, width of mesial sinus at front $\frac{45}{100}$, depth of entering valve $\frac{20}{100}$.

This is a very beautiful species when well preserved, from the elegant scale-like sculpturing of the surface, which gave it its name; the small number of the lateral angular ridges separates it from allied species.

Position and Locality.-Not uncommon in the carboniferous limestone of Derbyshire.

Subgenus. MARTINIA. See page 192.

Spirifera (Martinia) decora (Phill.)

Ref.-Phill. Geol. York. Vol. II. t. 10. f. 9.

Desc.-Suborbicular, very inequivalve and giblous; hinge-line equalling about half the width of the shell : cardinal angles and sides semicircularly rounded; entering valve rounded, evenly gibbous along the middle and near the beak, which is unusually large and prominent; surface arching rather quickly, with moderate convexity, to the side margins; lateral margins horizontal, straight; a rather wide, shallow, defined sinus in the front margin, producing no distinet mesial ridge; in most specimens a very narrow mesial sulcus extends nearly to the beak; cardinal area distinct; receiving valve extremely gibbous about the middle, greatest depth at about one-third the length from the beak, from whence the surface arches rapidly with moderate convexity to the front margin, and slopes very rapidly, with slight convexity, to the side margins; beak thick, elevated, very slightly incurved, having the appearance of being thrown remarkably back from the beak of the entering valve by the height of the cardinal area, which is triangular, slightly concave, sharply defined, and standing at an angle of about $95^{\circ}$ to $100^{\circ}$ with the plane of the lateral margins; foramen very large, triangular, as high as wide; a very narrow mesial sulcus extends from the middle of the wide shallow depression in the front margin nearly to the beak. When partially decorticated, surface marked from the beak to the margin with straight filiform ridges, separated by much wider, flat spaces (five to six in the space of three lines) ; shell-texture very minutely fibrous. Width of average specimen one inch six lines, proportional length of entering valve ${ }_{\text {bvo }}^{87}$, length of receiving valve $\frac{15}{1 * w}$, width of hinge-line $\frac{54}{100}$, height of cardinal area $\frac{90}{100}$, depth of entering valve $\frac{20}{100}$, depth of receiving valve $\frac{15}{100}$, width of sinus in front margin $\frac{50}{1 \ldots i}$, depth thereof $\frac{10}{1+w 1}$; of large, unusually wide specimens, widtl one inch nine lines,

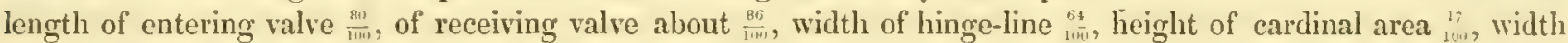
of sinus in front margin $\frac{40}{100}$, depth thereof $\frac{10}{100}$, depth of entering valve $\frac{18}{100}$, depth of receiving valve $\frac{45}{100}$.

This is a very distinct species, totally different from $S$. (IL.) glabra, with which most continental authors group it, by the singular elevation of the beak, from the leight of the cardinal area, at even more than right angles with the plane of the lateral margins, instead of the beaks approaching each other.

Position and Locality.-Very common in the lower black limestone of the Isle of Man; rare in the carboniferous limestone of Kendal; rare in the grey lower carboniferous limestone of Derbyshire.

\section{Spirifera (Martinia) Elliptica (Phill. Sp.)}

Ref. and Syn. = S. elliptica Phill. Geol. York. Vol. II.t. 10. f. 16. (not a good figure); = S. lineatus Var. de Kon. Anim. Foss. Bel. t. 17. f. $8 c$ (not the other figures).

Desc.-Transversely elliptical, moderately convex; hinge-line rather more than half the width of the shell : bealis remote, middle of front margin raised into a wide, rounded, or rotundato-quadrate sinus, at an angle of about $105^{\circ}$ with the plane of the lateral margins; sides narrow, semielliptically rounded; entering valve gently and evenly convex, the mesial ridge scarcely perceptible, except at the margin, from the more abrupt curve of the sides towards the lateral margins; greatest depth at about one-third from the beak, which is small, slightly prominent. Receiving valve moderately and evenly gibbous, with a rounded mesial hollow, extending distinetly to the apex of the beak; beak rather small, only moderately incurved, and rather remote from the beak of the entering valve by the height of the cardinal area; surface of both valves marked with concentric, nearly equal, regular, slightly prominent ridges (seven in three lines at six lines from the beak), becoming gradually obsolete 
towards the margin of large specimens; anterior half of each ridge fringed with rather coarse notehes (about fifteen in the space of two lines), scarcely visible without the lens, from which slight radiating strix extend across the posterior half; when decorticated, slender, radiating lines make their appearance. Average width two inches, proportional length of receiving valve $\frac{68}{1 m}$, of entering valve $\frac{57}{1,4}$, height of cardinal area $\frac{13}{1100}$, width of hinge line $\frac{60}{100}$, width of sinus in front margin about $\frac{37}{100}$, hoight thereof about $\frac{10}{110}$, depth of entering valve $\frac{15}{1+1}$, of receiving valve $\frac{30}{100}$. Width of young specimen one inch one line, proportional length of receiving valve $\frac{71}{1104}$, length of entering valve $\frac{63}{100}$, height of area ${ }_{100}^{10}$, depth of both valves $\frac{48}{100}$.

I agree with Mr Phillips in considering this quite a distinct species from the $s$. lineata with which M. de Koninck unites it; at all ages and sizes it is more transverse, more depressed, the beaks are further apart, and above all, the species is distinguished by the sinus in the front margin and strong mesial hollow, extending to the apex of the beak. It is only when the shell is removed that the comparatively strong, radiating strix, figured by Phillips, are seen; the reticulation exactly resembles that of $S$. lineatco

Position and Locality.-Not very uncommon in the lower earboniferous limestone of Kendal, Westmoreląnd.

\section{Spirifera (Martinia) Glabra (Mart. Sp.)}

Ref. and Syn. = Anomites glaber Martin, Pet. Derb. t. 48. f. 9, 10. = (S. glaler Sow. Min. Con. t. 269. f. 1. +\$. obtusus id. id. f. 2. + S. oblatus id. id. t. 268.)

Desc.-Transversely oval; hinge-line much shorter than the shell, sides and cardinal angles much, and regularly rounded; cardinal area moderate, variable, triangular; surface smooth, very finely fibrous under a strong lens; front margin raised into a sinus.

There are three moderately distinct varieties, which however certainly pass into each other, viz.

\section{Var. $\alpha$. GLABRA.}

Moderately depressed, varying considerably in width; mesial ridge (and hollow) rather narrow, round, or slightly flattened, distinetly marked nearly to the beak, sides rather depressed, beaks rather small, moderately approximate; old specimens occasionally shewing a few obseure radiating ridges, about a line wide near the margin. Width of rather wide specimen two inches nine lines, proportional length of receiving valve $\frac{70}{101}$, length of entering valve $\frac{56}{100}$, length of hinge-line $\frac{65}{101,}$, width of cardinal area $\frac{B}{100}$, depth of entering valve $\frac{17}{100}$, of receiving valve $\frac{25}{100}$, width of sinus in front margin $\frac{39}{100}$, depth thereof $\frac{26}{100}$.

Specimens of this variety occur commonly of less proportional width, and often with the mesial ridge and hollow becoming indistinct a considerable way from the beak, passing into the next variety.

\section{Var. $\beta$. oblata (Sow.)}

Ovato-rhomboidal, gilbbous; sinus in the front margin wide, shallow, subquadrate, the ridge and hollow from which are indistinctly marked, and nearly disappears within an inch from the beak; receiving valve with a very large tumid beak, much incurved, and approximating that of the entering valve. IVidth of average specimen

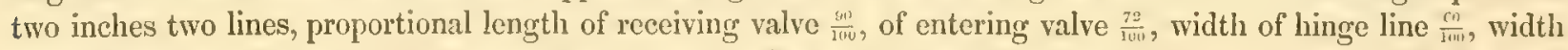

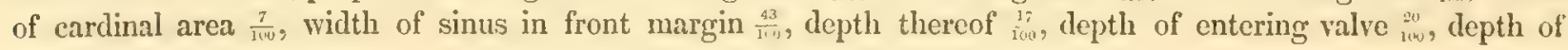
receiving valve $\frac{43}{100}$.

The obtusely-rounded rhomboidal form, and evanescent mesial fold, and obtuse, approximate, beals, distinguish this variety from the true variety glabra, and more strongly still from the next variety. In some specimens much more gibbous, and in some much flatter than the above measurements from the Isle of Man, the cardinal area becomes almost obsolete, and the beaks very approximate. One specimen also shews the spiral appendages as large, or nearly so, as in the typical spirifers.

\section{Var. $\gamma_{0}$ obTusA (Son.)}

Transversely oblong, very gibbous, sides tumid; sinus in the front margin very deep, as high as wide, rounded, angular, with a strongly raised narrow, rounded, mesial ridge extending nearly to the beak of the enter- 
ing valve, and very deep, wide, defined mesial hollow, extending to the beak in the receiving valve; cardinal area wide, triangular, curved; foramen very large, twice as wide as high; bealss remote. Width of average specimen two inches, proportional length of receiving valve of entering valve wing hidth of hinge-line height of

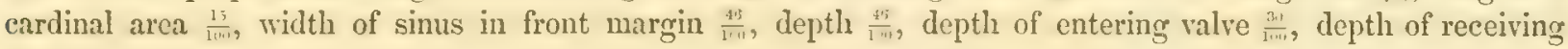
valve $\frac{35}{100}$.

In other less exaggerated specimens, the sinus in the front margin becomes gradually wider and lower, and the corresponding ridge and sinus less distinctly marked, approaching the var. glabre or var. oblate. In other specimens, too, the cardinal area becomes narrow, and the bealis more approximate; but on the whole, the variety is tolerably constant and strongly marked.

On occasional specimens of all the varieties traces of the obtuse, obseure, Iongitudinal ridging may be seen, sometimes at the margin of large specimens, but sometimes on young ones at five lines from the beak; sometimes a finer, flat, obsolete ridging (about five in one line) seen on portions of small specimens, from the corresponding parts of which it is absent. The shell is rather thin and the internal casts smooth.

Position and Locality.-The three varieties very common in the grey carboniferous limestone of Derbyshire; var. oblute and var. oltuse not uncommon in the lower carboniferous limestone of Kendal; var. ollate very common in the lower dark carboniferous limestone of the Isle of Man.

\section{Spirifera (Martinia) imbricata (Sow.Sp.)}

\section{Ref. and Syn。=Terebratula imbricata Sow. Min. Con. t. 334. f. 3, 4 .}

Desc.-Transversely very broad-oval or suborbicular, moderately convex; hinge-line half the width of the shell; cardinal area obscurely defined, triangular; bealis approximate, sides broadly rounded, front convex, lateral edges horizontal, middle of the front usually slightly raised into a wide shallow sinus; entering valve evenly and gently convex, greatest depth at about one-fourth from the beak, which is tumid and prominent; no trace of mesial ridge; receiving valve moderately gillbous, greatest depth at one-third from the beak; a very shallow, faintly marked, mesial hollow usually extends from the beak to the front margin; cardinal area low, heak rather large, mnch incurved over it; surface of both valves marked with faint, broad, oltuse, radiating strix, (three to five in two lines at eight lines from the beak), interrupted by strong, subequal, broad, flattened, thick, concentric ridges; three to five in three lines at six lines from the beak, the anterior edges of which they render obscurely nodular; shell tissue under the lens rery coarsely and irregularly fibrous. Average width one

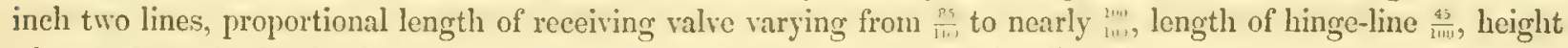
of area about $\frac{8}{100}$, depth of entering valve $\frac{15}{100}$ to $\frac{20}{100}$, depth of receiving valve $\frac{33}{300}$ to $\frac{35}{100}$.

This speeies is very easily distinguished from the $1 I$. lineata, with which some continental authors unite it, by the great width and coarseness of the concentric lamellar ridges, and the much fewer, broad, obtuse, longitudinal fimbriations in a given space; it is also less wide, has generally some trace of mesial hollow, and has an unusually coarse fibrous tissue under the lens.

Position and Locality.-Common in the lower carboniferous limestone of Kendal, WVestmoreland; rare in the lower carboniferous limestone of Derbyshire; rare in the lower carbonifcrous limestone of Malham Moor.

\section{SpIrifera (Martinia) Lineata (Mart. Sp.)}

Ref. and Syn.= Anomites lineatus Martin, Pet. Derb. t. 36. f. 3. = Terebratula lineata Sow. Min. Con. t. 334. f. 1, 2. = Spirifera lineata Phill. Geol. York. p. 219.

Desc.-Transversely oval, moderately convex; hinge-line half the width of the shell (or in the long varieties a little more); beaks approximate; cardinal angles and sides semielliptically rounded; front widely arched, no sinus in front; lateral and front margins in one plane. Entering valve gently and evenly convex, becoming gradually flattened towards the edges, which are acute; beak tumid, prominent, greatest depth at one-fourth from the beak, no trace of mesial fold: receiving valve moderately and evenly gibbous, greatest at one half from 
the beak; beak large, tumid, narrow, much incurved; cardinal area low, triangular, no trace of mesial fold; surface of both valves covered with subregular, concentric, obscurely imbricating lamelle (averaging eight in three lines near the margin), very obscurely angulated in the middle, the anterior slope of each marked with a row of strong, longitudinal, concave notches (averaging fifteen to seventeen in two lines), producing a very delicate imperfect reticulation, obscurely distinguishable by the naked eye; posterior slope of each sometimes with obscure radiating lines, continued from the narrow intervals, between the notches of the anterior slope. Average width eleven lines, proportional length of receiving valve ${ }_{i 00}^{80}$, of entering valve $\frac{80}{1401}$, length of hingeline $\frac{56}{110}$, height of cardinal area $\frac{10}{100}$, depth of entering valve $\frac{20}{100}$, depth of receiving valve $\frac{35}{11 w 0}$, length in some rare specimens equalling the width.

This species, from the peculiar structure of the surface, and the slight divergence of the dental lamellix, with their strong mesial septum, was originally combined in my Synopsis (of Carb. Foss.) witl the S. imbricata, S. veticulata, S. microgemma, \&c. into a little group called Reticularia. There is a fine submedial impressed line, apparently a fracture, visible in many specimens from the beak to the front margin.

Position and Locality.-Common in the main carboniferous limestone of Derbyshire; very common in the lower carboniferous limestone of Lowick, Northumberland; common in the dark lower carboniferous limestone, Isle of Man; in the dark carboniferous limestrne of Craige, near Kilmarnock; very common of small size in the carboniferous limestone of Berwick-on-Tweed.

\title{
Spirifera (Martinia) rhomboidalis (Mc Coy).
}

\author{
Ref.-Id. id. $\mathrm{M}^{\mathrm{c}} \mathrm{Coy}$, Syn. Carb. Foss. Irel. t. 22. f. 11.
}

Desc.-Sulbrhombic, gibbous, length and width about equal; cardinal angles rounded; cardinal area very small, triangular; beaks small, incurved, approximate; mesial fold very prominent towards the margin, narrow, rounded, or subangulate; mesial sulcus deep, wide, angular, continued to the beak; sinus in the margin rery large, abrupt, semielliptical or pointed; surface radiated towards the margin with numerous, obtusely rounded, nearly obsolete ridges; tissue under the lens very minutely fibrous. Width about seven lines; proportional length of receiving valve $\frac{93}{100}$, of entering valve $\frac{85}{100}$, width of hinge-line $\frac{55}{100}$, height of area $\frac{10}{110}$, depth of sinus $\frac{11}{11 \cdots+}$, width thereof ${ }_{100}^{60}$, depth of both valves $\frac{70}{100}$.

This species is allied (on a small scale) to the S. protensa. Phill, from which it differs in the length being equal to the width, and in the very small size of the cardinal area.

Position and Locality.-Rare in the carboniferous limestone of Derbyshire.

\section{Spirifera (Martinia) simlis $\left(\boldsymbol{I}^{c} \mathrm{Coy}\right)$.}

\section{Ref. and Syn.?= Spirifera plebia Phill. Pal. Foss. f. 121. (not A.plebia Sow.)}

Desc.-Longitudinally ovato-rhomboidal or subtrigonal, very gibbous; front narrow, much produced into a tongue-shaped elevation; mesial ridge wide, indistinct except towards the margin of the entering valve; little or no mesial hollow in the receiving valve; beaks small, approximate; surface smooth; cardinal area short, triangular. Average width ten lines, proportional length of receiving valve $\frac{95}{10 u}$, depth of both valves $\frac{70}{1+1}$, width of cardinal area $\frac{10}{1,0}$.

I provisionally give this name to a very small species, rarely attaining (even when apparently old) an ineh in length; it has been taken for the young of Martinia glabra, but is distinguished by its narrow produced front, the smallness of its beaks, and the usual want of the mesial sulcus in the larger valve; it is probably the S. plebia (Sow) of Plillips, but is distinguished from the true A. plebin by its cardinal area and hinge-line. Its length and traces of lineation on the cast make it very like the young of $S$. decora, but the narrow area and approximate beaks seem to separate it therefrom, while the length and gibbosity separate it from S. symmetriea, which it resembles in the beak and cardinal area. If those species should ultimately be found to be rarieties of one specific type, as suggested, this blending of their characters, with slight differences in the present form, would render it very probable that it was a divarf or young variety of the same. 
Position and Locality.-Common in the carboniferous limestone of Isle of Man; rare in the carboniferous limestone of Kendal, IVestmoreland.

\title{
Spirifera (Martinia) symaetrica (Phill.)
}

\author{
Ref.-S. id. Phill. Geol. York. Vol. II. t. 10. f. 13.
}

Desc.-General form rhombic, moderately gibbous, rather depressed; hinge-line slightly more than half the width of the shell; beaks approximate; cardinal angles narrow, rounded; anterior lateral margins long, and nearly straight or obscurely sigmoid, from being slightly convex near the cardinal angles and slightly concave towards the front, which is broad and produced; lateral margins not horizontal, but slightly sigmoid and abruptly raised in the front, at an angle of $105^{\circ}$, into a large rounded sinus, usually slightly notehed in the middle; entering valve subtrigonal, depressed, moderately and evenly convex in the posterior half; greatest depth about the middle; profile slightly sigmoidal from the raising of the front margin, which produces a faint indication of a broad, rounded, mesial ridge, seldom perceptible except at the margin; often a faint, very narrow, mesial sulcus, obscurely marked from the margin nearly to the beak, after six or seven lines from the beak; the sides abruptly arch downwards to the lateral margins, leaving the mesial ridge elevated and obscurely defined; beaks small, moderately prominent; cardinal area distinct. Receiving valve rhombic, moderately and evenly gilbbous; posterior lateral margins and anterior lateral margins nearly straight; the beak, the front and the cardinal angles, narrow, obtusely rounded; greatest depth at one-third the length from the beak, from whence the profile arches almost semicircularly to the apex, which is rather small, narrow, and much incurved, while from the same point the profile is more gradually arched to the produced front, filling the broad mesial sinus in the margin, which produces scarcely any indication of a corresponding broad mesial hollow, except in very old specimens; but there is usually a very faint, narrow, mesial sulcus resembling that in the entering valve, extending nearly to the beak; sides moderately convex. Shell thin, very minutely fibrous under the lens, indistinctly marked with longitudinal, subregular, thread-like strix, separated by much wider flat spaces (four to five in three lines at an incls from the beak), which appear to be seen through the substance of the shell from the interior, where they are much more strongly marked. Width of average specimens one inch seven lines; proportional length of entering valve $\frac{65}{11 w}$, length of receiving valve $\frac{80}{110}$, length of hinge-line ${ }_{100}^{67}$, width of cardinal area $\frac{10}{10 v}$, width of sinus in front margin $\frac{45}{100}$, depth thereof $\frac{15}{100}$, depth of entering valve $\frac{15}{100}$, depth of receiving valve $\frac{35}{\mathrm{rat}}$.

This beautiful and very distinct species varies very little in its characters from the above description; it is remarkable for the nearly regular, rhombic outline of the receiving valve, for the broad, often minutely notched sinus in the front margin, producing scarcely any distinct mesial ridge, and for the strong, filiform, subregular, distant, radiating lines from the beak to the margin of the interior, often appearing on the external surface. Two specimens differ remarkably (one from Lowick and one from Derbyshire), by the hinge-line being only ${ }_{100}^{4}$, as compared to the width; and one of them by the length nearly equalling the width, and the shortness of the beak of the receiving valve, so strongly approximates to the S. decord, that I suspect additional experience may unite these species. Both differ from all the varieties of Spirifera (Marinia) glabra by the strong, threadlike, subregular, internal ridging from the beak to the margin.

Position and Locality.-Very common in the lower carboniferous limestone of Lowick, Northumberland; rare in that of Derbyshire; rare in dark lower carboniferous limestone of Isle of Man; rare in the carboniferous limestone of Kendal; var, in carboniferous limestone of Beith, Ayrshire. 


\section{Genus. ATHYRIS. See page 196*}

\section{Atityris ambigua (Son. Sp.)}

Ref. and Syn. = Spirifer ambiguns Sow. Min. Con. t. 376.= Terebratula id. Phill. Geol. York. Vol. II. t. 11. f. 21. = Atrypa sublobata Portk. Geol. Rep.t. 38.f. 2; = Terebratula ambigua de Kon. Anim. Foss. Belg. t. 20. f. 2. =id. id. M. V. K. Geol. Russ. t. 9. f. 12.

Desc.-General form varying from elongate-ovate to rotundato-subtrigonal, and transversely pentagonal; edges of all the forms varying from acute to very obtuse (in rare very old examples); lateral margins very rarely in one plane (in the ovate varieties), more usually (in the pentagonal varieties) with a very deep rounded sinus towards the entering valve in the middle, with sometimes nearly as strong a sinus on each side towards the receiving valve; generally a minute notch in the middle of the front margin. Entering valve varying from ovate to pentagonal, of moderate but variable convexity, evenly convex near the beaks and posterior sides, and either evenly convex also in the anterior portion, or a very broad quadrate mesial ridge, left by the abrupt bending downwards of the lateral margins into a sinus on each side; in nearly all specimens a deep, narrow, more or less defined, mesial sulcus extends from the notch in the front margin nearly to the beak. Receiving valve moderately convex; greatest depth about the middle of its length; with a deep, angular, mesial sulcus usually extending nearly or quite to the beak, widening towards the front margin; generally defined by an obscure angularity on each side, extending the width of the broad mesial sinus in front; beak moderate, obtuse, with a rounded perforation in the apex; spiral appendages very large. Surface smooth, rarely with a slight radiating lineation, minutely fibrous under a strong lens. Width of pentagonal examples about eleven lines; proportional length of receiving valve varying from $\frac{90}{100}$ to $\frac{95}{10 u}$, length of entering valve $\frac{80}{1100}$, depth of both valves varying from $\frac{55}{1000}$ to $\frac{65}{100}$ (the latter very rare, width of sinus in front margin $\frac{65}{1100}$, depth thereof varying from $\frac{13}{10 * t}$ to rarely $\frac{25}{100}$; length of ovate specimens about eight lines, width varying from $\frac{85}{100}$ to more than $\frac{100}{100}$, depth of both valves varying from $\frac{70}{100}$ to $\frac{50}{100}$.

This species, as will be seen from the above description, is extremely variable: the original figures in the Mineral Conchology represent two of the most common pentagonal forms, the larger unusually flattened, the two upper figures more near the average of ordinary specimens. In the Isle of Man limestone the pentagonal typical forms are common, with specimens gradually assuming a greater depth and obtuseness of edge than I have seen elsewhere, and the lateral and front sinus in the margins very strongly pronounced.

In the Derbyshire limestone the rather flattened, pentagonal, wide forms, with scarcely any lateral sinus in the margins, and a very wide, moderately elevated front sinus, are not uncommon, gradually passing into the ovate forms, in which the length is sometimes greater than the width, and in which even the sinus in the front margin is faintly marked, althotgh usually notched, and giving rise to a narrow mesial sulcus in each valve. I have at length succeeded in tracing, in the most gradual manner, the passage of all the forms figured by Col. Portlock, under the name of Atryza sublobata, into each other, and into the ordinary types of the present species. When decorticated a few straight pallial ridges are seen near the beak, radiating towards the front margin. Col. Portlock notices the resemblance of some of the varieties to the S. unguiculus of Sowerby, but the want of area between the beaks and hinge-line separates the species. The ends of the fibres give a very minutely granular appearance to the surface under a strong lens, but I think there is no true punctation.

Position and Locality.-Very common in the lower carboniferous limestone of Derbyshire; very common in the lower carboniferous limestone of Isle of Man; not uncommon in the carboniferous limestone of Flintshire; strongly marked specimens of small size common in the lower carboniferous limestone of Lowick, Northumberland; in the carboniferous limestone and shale of Beith, Ayrshire; common of small size in the carboniferous limestone of Berwick-on-Tweed.

* I see that by some accident, in the character given at the aboro page, this genus is stated to be without foramen, from my old diagnosis, which escaped observation in correcting the proofs. I formerly supposed, with Professor Phillips, that the minute opening at the apex of the beak of the receiving valve was caused by fracture; continued observations have, however, since shewn me that it is a natural character of the genus as the continental authors contended. 


\section{Athyris De-Roissyi (L'Eveillé Sp.)}

Ref. and Syn. = Spirifer, id. id. Mém. de la Soc. Géol. de France (1835) Vol. II. t. 2. f. 18 to 20.= Terebratula id. de Kon. Anim. Fos. Bel.t. 20. f. 1 and t. 21. f. 1 (excl. e. f. i.) ; ? = Athyris depressa $\mathbf{M}^{\mathrm{C}} \mathrm{Coy}$, Syn. Carb. Foss. Irel. t. 18, f. $7 ; ?=$ Spirifera fimbriata Phill. Geol. York. Vol. II. p. 220.

Desc.-Transversely oval, depressed, or moderately gibbous; lateral and front margins nearly in one plane, till after half an inch in length, when in some specimens a semielliptical sinus becomes developed in the front margin, with a corresponding concave mesial hollow in the receiving valve, and a smaller, undefined, rounded, mesial ridge in the entering valve, both becoming stronger with age, but in some specimens not making their appearance at one inch from the beak; entering valve gently convex; greatest depth about one-third from the beak, which is tumid and prominent. Receiving valve moderately convex; greatest depth at about the middle of the length; beak narrow, small, tumid, ineurved, with a moderate opening at the apex. Surface of both valves (in limestone specimens) almost smooth, or with very fine, concentric, imbricating strice, every fifth or sixth of which (at about half a line apart) are more prominent than the rest: when finely preserved the concentric laminx form broad fringes of equal, obtuse, narrow, flattened spines, united at their bases, to the concentric laminx, which are separated, after about one-third of a line, by spaces varying from one-fourth to rather more than the width of the spines, lying close to the surface (about eight in two lines, at six lines from the beak, twelve in same space at tro lines from the beali), giving either a spinulose, tubercular, or longitudinally sulcated, appearance to the surface, according to the perfection of the preservation; the radiatingly-lined appearance of some of the specimens being produced by the spines of the several concentric rows overlapping each other often in regular lines. Width of average specimen one inch three lines, proportional length of receiving valve $\frac{90}{1 w}$, of entering

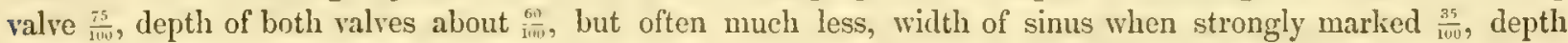
thereof $\frac{20}{100}$, length of spines occasionally one line.

This species varies extremely in the appearance of the surface according to the mode of preservation; some rare specimens, like the original one figured by l'Eveills, seeming smooth even under' a moderate lens, with a few distant imbricating lines of growth; and these are so unlike the forms well preserved in shales, that I formerly supposed them different. The equal, thick, longitudinal spines, which fringe the narrow, concentric lamellae of shale specimens, form an extremely marked character, and by their great strength and coarseness separate the species certainly from the Devonian A. concentrica, V. Buch. Sp.

I have sometimes seen this confounded with the spivifere (Martinia) lineata, and imbricata, from which the complete want of cardinal area between the beaks distinguishes it. It is very probable that the Spirifera fimbriata of Phillips is founded on the depressed shale specimens of this species from the shales of Florence Court.

Position and Locality.-Very common in the carboniferous shales of the Isle of Man.

\section{Athyris expansa (Phill. Sp.)}

Ref. and Syn.= Spirifera id. Phil. Geol. York. Vol. II. t. 10. f. $18=4$ trypa id. Sow. Min. Con. t. 617. f. 1. (only the larger figures) and A. fimbriata (not of Phill.) same plate, f. 4.

Desc.-Transversely elliptical, greatly depressed, nearly equivalve; beaks very small, adpressed; sides narrow, semielliptically rounded; front very widely arched, most prominent in the middle; no sinus in the margins, which are in one plane; edges obtuse, greatly thickened; entering valve slightly and evenly convex, without mesial ridge or hollow, greatest depth about the middle; receiving valve slightly and evenly convex near the beak, which is very small and adpressed; surface of the valves becoming gradually flattened towards the margins; greatest depth at about one-third from the beak; surface of both valves with fine, subequal, concentric, imbricating strix, about eight or nine in two lines on all parts of the shell, crossed by equal, very obtuse, radiating, thread-like strie, most distinct near the beaks, about twelve in the space of two lines, some of which 
occasionally appear double from a slight decortication. Width of rather large specimen one inch eight lines,

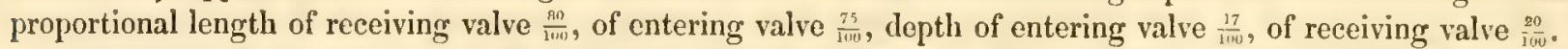

This species is most nearly allied to the Athyris glabristria, but wants the mesial fold, which in that species is very prominent; it is greatly more depressed, and the edge, instead of loeing acute, is remarkably oltuse and thickened, except in the very young specimens, often leaving very prominent, concentric, rugged waves of growth.

Position and Locality.-Common in the lower carboniferous limestone of Derbyshire; common in the lower carboniferous limestone of Kendal, Westmoreland.

\section{Atimris glabristria (Phill. Sp.)}

Ref. and Syn.= Spirifera id. Phill. Geol. York. Vol. II. t. 10. f. 19.

Desc.-Transversely elliptical, or slightly rhomboidal; lateral margins very slightly sigmoidal, strongly raised into a broad, deep, rounded wave in front; sides rather narrow, semielliptically rounded. Entering valve gently and evenly convex, without mesial ridge, except an undefined indication near the margin from the elevation of the mesial sinus; beak prominent, pointed. Receiving valve moderately convex, with a broad, mesial hollow obseurely defined on the sides, but extending faintly from the beak to the large sinus in the front margin; profile much, and regularly arched, greatest depth about the middle of the length; beak very small, depressed. Surface even, covered with obsolete, obtuse, thread-like strix (ten in two lines) and a few inconspicuous concentric lines of growth. Width of average specimen two inches, proportional length of receiving valve $\frac{100}{1100}$, of entering valve $\frac{75}{100}$, width of sinus in front margin $\frac{50}{100}$, depth thereof $\frac{25}{100}$, depth of both valves $\frac{50}{10 i}$.

The absence of cardinal area casily separates this fossil from the Spirifera glabra, of which it often assumes the form. The internal spiral appendages are very large.

Position and Locality.-Not common in the carboniferous limestone of Derbyshire.

\section{Athyris globularis (Phill. Sp.)}

Ref. and Syn.= Spirifera id. Phill. Geol. York. Vol. II. t. 10. f. 22.

Desc.-Rhombic, rounded, moderately gibbous; lateral margins obtuse, forming thickened edges at several stages of growth; lateral margins nearly straight, front margin raised into a deep rounded sinus, producing little or no ridge on the entering valve, but a deep mesial hollow, running distinctly to the apex of the beak in the receiving valve. Entering valve evenly gibbous, orbicular when young, without trace of mesial ridge; becoming rhombic after half an inch long, with the middle portion corresponding to the sinus in the front margin obscurely defined as a rounded ridge by the more abrupt bending down of the sides towards the lateral margins; profile very slightly arched, greatest depth about the middle. Receiving valve moderately and evenly gibbous, greatest depth at one-third from the beak; mesial hollow deep, narrow in the rostral portion, gradually widening towards the front; beak obtuse, much incurved, with a small rounded perforation at the apex. Surface smooth, with numerous, irregular, thickened interruptions of growth; tissue fibrous under the lens. Internal cast with a few straight, radiating linear impressions. Width of large specimen ten lines, proportional

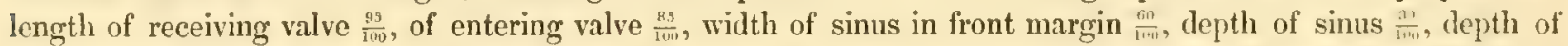
both valves $\frac{60}{1001}$, length and width of ordinary sized Scotch specimens seven lines, depth of both valves $\frac{61}{1 \cdots}$, depth of sinus in front margin $\frac{80}{100}$.

Several writers refer this species, as a variety, to the Athyris ambigua, but I have seen a considerable number of specimens apparently very constant in their characters, and certainly distinct therefrom, by the want of sulcus on the entering valve, \&c.; it has also been referred to the A. De-Roissyi, but the size is always much less, and the concentric lineation is never fimbriated nor marked with longitudinal strix.

Position and Locality.-Common in the carboniferous shale of Glasgow; common in the carboniferous shale of Craige, near Kilmarnock; rare in the carboniferous limestone of Dalmellington, Ayrshire. 


\title{
Athyris gregaria $\left(M^{c}\right.$ Coy).
}

\author{
Ref. and Syn。=Atrypa id. $\mathbf{M}^{\circ} \mathrm{Coy}$, Carb. Foss. Irel. t. 22. f. 18.
}

Desc.-Longitudinally trigonal, greatest width near the front margin; lateral anterior angles rounded; lateral margins with a small rounded wave towards the entering valve, thence remaining nearly in one plane till the middle of the front margin of specimens exceeding five lines long, in which it is raised into a very shallow, wide sinus; valves nearly equal in depth, sometimes the receiving and sometimes the entering one deepest. Entering valve moderately convex along the middle, most tumid close to the beak in many specimens, no distinct mesial ridge. Receiving valve with a very large, projecting, moderately incurved thick beak, with a small foramen at the apex; the sides near the beak are inflected to form an obtusely-defined, elongate, flattened, or slightly concave space on each side, which is also slightly marked in some specimens of the entering valve, but nearly absent from both valves in some specimens; the long posterior lateral margins very obtusely rounded; middle of the valve, after five lines long, depressed into a very wide shallow sinus, corresponding with the wave in the front margin. Surface under the lens shewing fine, concentric, obtuse strixe of growth, crossed by obsolete, obtuse, longitudinal strix, nearly equalling them in size, but very much larger than the fibrous tissue of the shell. Length of average specimen eight lines, greatest proportional width (near the front margin) $\frac{87}{100}$, length of entering valve $\frac{85}{100}$, depth of both valves $\frac{55}{100}$.

\section{Var. $a$. trapezoidalis $\left(M I^{c}\right.$ Coy $)$. Pl. 3. D. fig. $20^{*}$.}

Form varying from very broad-orate, to trapezoidal; greatest width a little in front of the middle; length equalling or considerably exceeding the width; lateral inflection of the margins nearly obsolete; beak of receiving valve small, abruptly incurved; the produced narrowed front scarcely raised at the margin, even at seven or eight lines long, and producing no distinct mesial hollow in the receiving valve. Other characters as in the above type.

It is only after much hesitation that I venture to unite the Kendal and Derbyshire fossils with my originally-described A. aregaria; that species occurring gregariously in immense profusion in the limestone of Church Hill, Fermanagh, also forming great masses in that of Ballyeastle, Antrim, and being remarkably constant in its singular trigonal form, wide front, and very obtuse, nearly straight sides and large beak: some of the Kendal specimens however agree exactly with the Irish ones, although the more common variety there has the front narrowed, and produced, and the lateral inflections of the margins near the thickened beaks are less marked; these seem to pass insensibly into the ovate forms, with the small beak, a most extreme example of which I have figured Fl. 3. D. f. 20*.

The trapezoidal variety with the narrow rounded front, long posterior lateral margins meeting the straightened, anterior, shorter lateral margins at the obtusely-rounded, narrowed, lateral angles, which are only a little in front of the middle, and in which the beak is also smaller than in the principal type, seems to abound most in the Derbyshire limestone, but seems to pass gradually into both the ovate and trigonal forms. The spiral appendages are of moderate size. When decorticated several strong longitudinal impressions are often seen radiating from the beak toward the front.

Position and Locality.-Gregarious in considerable abundance in the lower carboniferous limestone of Kendal, Westmoreland; also in the lower carboniferous limestone of Derbyshire; rare in the lower carboniferous limestone of Lowick, Northumberland.

Explanation of Figures.-Pl. 3. D. fig. 20\%, abnormal ovate variety, with small beak, front view, natural size from the limestone of Kendal; fig. $20^{*} \alpha$, do. end view, shewing the very slight wave in the front margin; fig. $20^{*} b$, do. profile; fig. $20^{*} c$, surface strongly magnified, shewing the fibrous tissue, and the longitudinal obtuse striæ. 


\section{Athyris paradoxa $\left(M^{c} C O y\right)$.}

Ref. and Syn. = Actinoconchus parculoxus MI'Coy Syn. Carb. Foss. Irel. t. 21. f. 6. Atrypa exy, ansa Sow. Min. Con. t. 617. f. 1. lower right-hand figure (not the middle nor left-hand figures) =Terebrutula De-Roissyi de Vern. Bul. de la Soc. Géol. de France, Vol. XI. t. 3. f. $1 a$ and $e$ (not of l'Eveillé) = Terebratula planosulcata de Kon. Anim. Foss. Belg. t. 21. f. 2. (not Spirifera planosulcata Phill.)

Desc.-Almost orbicular, sides and front forming three-fourths of one circle; beaks very small, slightly projecting, perforation in receiving one small; valves almost equally deep; entering and receiving valves gently and evenly convex, without trace of mesial ridge or hollow; lateral and front margins perfectly in one plane, without trace of sinus. Surface of both valves occasionally shewing traces of faint, obscure, interrupted, obtuse, equal, radiating lines, (eight in two lines at four lines from the heak, four in two lines, at eight lines from the beak); also marked with slightly irregular, concentric, imbricating strix, obsolete near the beak, becoming gradually stronger towards the margin, where they are prolonged into flat, continuous, nearly semicircular plates, often half or three-fourths of an inch in width; when preserved these extended lamelice have a smootl space, about half a line wide, where they join the convex part of the valves, the remaining portion being marked with flat, radiating sulci; when broken off they merely leave concentric lines of growth, which at the adult length of nine lines are greatly thickened. Average width eight lines, proportional length of receiving valve $\frac{95}{100}$, length of entering valve ${ }_{100}^{90}$, depth of both valves together $\frac{60}{100}$.

When the extended flattened lamellæe are broken off, as is the case in the greater number of specimens, they only leave traces of obscure lines of growth (about ten in two lines) so nearly obsolete in all the rostral portion that it seems smooth, but shewing by their thickness, and the extreme obtuseness of the edge in specimens approaching nine lines in length, that that is the ordinary adult size, although I have seen some rather larger, not bearing such marks of age. It is only close to, or immediately at the margin, that we find these paradoxical, greatly-extended shelly, flat, radiated lamelle, which if perfect would considerably exceed the length of the shell in width. I imagine that they are found at the margins because there the corresponding lamella of the two valves would come in contact and support each other; but, by growth of the shell, they would become separated when a new edge was formed between them, leaving them erect, insulated, and liable to be broken off by the slightest accident. The same thing can be seen in the recent Tridacia squamusa, where the great scale-like laminxe near the beak are always effaced, while those near the margin are perfect; the rather close, flattened, radiating suleation of those lamina is not divided into spines, as in the A.De-Roissyi; the traces of longitudinal radiation occasionally seen on the valves is very partially developed; the spiral appendages are very large, the apices of the cones placed at about one-third the length of the front margin. Mr Sowerby seems to confound this species with the $A$. expanse, which however his own figures truthfully shew to be much larger, and (by the lines of growth) of a totally different wide, transversely-elliptical figure, at all ages. M. de Koninck has confounded it with the Spirifera planosulcata of Phillips, from which it totally differs in figure and want of the deep mesial hollow in each valve characteristic of that species. The want of mesial fold in the adult, and the lamellic not forming narrow, spinous fringes as well as the regular, obtuse ralves, separate it from the A. De-Roissyi, with which M. de Verneuil originally united it.

Position and Locality.-Common in the dark lower carboniferous limestone of Lowick, Northumberland; rare in ditto, Kendal; rare in ditto, Derbyshire. Doubtful specimens in the earboniferous shale of Beith, Ayrshire.

\section{Athyris pectinifera (Sow. Sp.)}

Ref. and Syn. = Atrypa pectinifera Sow. Min. Con. t. $616=$ Cliothyris id. King, Perm. Foss. t. 10. f. 1 to 10. $?=$ Terebratula De-Roissyi M. V. K. t. 9.f. 2 (not of l'Eveillé) $=$ T. pectiniferc id. id. t. 8. f. 12.

Desc.-Transversely, very broad-ovate; beaks small, slightly prominent; scarcely any trace of mesial ridge or hollow, or sinus in front margin at six lines long, the margins being in one plane; valves almost equally deep, sometimes one, and sometimes the other slightly deeper; greatest depth of each a little behind the middle; each valve evenly convex, marked with narrow, imbricating, concentric lamine of growth, which when 
well preserved are at a slight distance from the base, divided into fringe-like rows of slender spines, lying flat on the surface, arranged in almost continuous radiating lines, and leaving a faint obtuse lineation on the shell in their absence (about ten of these strix in the space of two lines at four lines from the beak); beak of receiving valve moderately incurved, with a small round perforation at the apex, sometimes appearing open to the hinge. Width about seven lines, proportional length of receiving valve $\frac{07}{101}$, of entering valve $\frac{80}{100}$, depth of both valves $\frac{05}{100}$ to $\frac{70}{100}$.

If the large, wide, depressed, Permian shell, with the strong mesial sinus in the margin beyond six lines long, figured in the Geology of Russia under the name T. De-Roissyi, belongs to the present fossil, it would be exceedingly difficult to separate the Permian and carboniferous species, the only apparent difference being the rather finer radiating fimbriation. None of the English specimens, however, of $A$. pectinifera have been observed of the size at which the mesial ridge and furrow of A.De-Roissy $i$ begin to be developed; this character alluded to by M. de Verneuil and Professor King as distinctive therefore fails. The only difference which strikes me between the species being a slightly greater coarseness of fimbriation in the carboniferous one; but all Sowerby's and King's figures represent this radiation as too coarse when compared with the specimens I have examined from Humbleton. Professor King does not secm to have found the mesial septum of the entering valve; I have seen it however distinctly marked.

Position and Locality. - Not uncommon in the Permian magnesian limestone of Humbleton.

\title{
Athyris squamigera (de Kon. Sp.)
}

Ref. and Syn.= Terebratula id. id. De Koninck, Sup. Anim. Foss. Bel. t. 56. f. 9 .

Desc.-Rotundato-rhombic, or transversely very broad-oval, tumid; lateral margins slightly sigmoidal, front very abruptly raised into a semielliptical sinus at an angle of about $100^{\circ}$, therefore slightly indenting the middle of the front margin of the entering valve. Entering valve very gibbous in the middle, greatest depth a little behind the middle, gradually arching to the margins; beak obtuse, prominent; after a length of five lines a narrow, rounded, or rotundato-quadrate mesial ridge, extends to the abrupt sinus in the front margin; receiving valve gibbous, gradually arched towards the lateral margins, with a deep, concave, mesial hollow, commeneing at $\mathrm{or}^{\circ}$ within a line of the apex of the beak, becoming more strongly defined by two obtuse ridges near the front margin; beak large, tumid, much incurved; foramen large. Surface of both valves covered with regular radiating, obtuse, equal, flattened strix (averaging twelve or fourteen in two lines over the surface), crossed under the lens by faint, rather closer, subregular, concentric strix, a few of which towards the margin after half an inch in length become strong, imbricating, interruptions of growth. Average width ten lines, proportional length of receiving valve ${ }_{1 \mathrm{n}}^{87}$, length of entering valve $\frac{75}{10 u}$, depth of entering valve $\frac{30}{100}$, of receiving valve about $\frac{80}{100}$, width of sinus in front margin $\frac{45}{100}$, depth thereof $\frac{30}{100}$.

The specimens which I have examined are rather more tumid at the sides, and slightly less wide than Professor de Kioninck's figures; but there can be no doubt of their identity. The species has a general resemblance to the $A$. concentrice and $A$. De-Roissyi in form, but is rather more obtuse, and has the mesial hollow in the receiving valve stronger, and nearer to the apex of the beak, than in those species, from which it is completely distinguished by the beautifully regular, obtuse, longitudinal striation, and the less marked concentric sculpturing.

Position and Locality.-Not very uncommon in the carboniferous limestone of Derbyshire.

\section{Genus. SPIRIGERINA. See page 197.}

\section{Spirigerina? Mantia (Som. Sp.)}

\author{
Ref. and Syn. = Terebratula id. Sow. Min. Con. t. 277. f. 1.
}

Desc.-Longitudinally ovate, valves almost equally deep; commissure of the valves deeply reflexo-dentate by the extremities of about thirteen or fourteen very strong, prominent, subequal, angular ridges, separated by 
very deep acutely angular sulci, rather more than one half of the front margin and one lateral margin elevated much above the level of the right lateral margin, and its five or six ridges. Entering valve moderately gibbous; profile regularly and gently arched, so that its depth is greatest in the middle; middle and left side more tumid than the right side, which falls with the corresponding depression in the margin; lateral ridges gradually and slightly smaller than the middle ones; beak rather prominent, obtuse. Receiving valve slightly unsymmetrical, the right half or rather less being manifestly more tumid, and longer than the middle and left side; beak large, prominent, only slightly incurved; profile with the greatest depth rather nearer the beak than the front margin, but regularly arched towards both ends; cardinal area high, flat, triangular. Surface closely reticulo-punetate under a strong lens. Length seven lines, proportional width $\frac{95}{100}$, length of entering valve $\frac{100}{j 00}$, depth of both valves together $\frac{70}{100}$.

I have not perfectly seen the spircs in this species, but from the large, flat, cardinal area, and punctured shell-tissue, I have little doubt of the genus.

Position and Locality.--Rare in the lower carboniferous limestone of Derbyshire.

\section{Spirigerina? Radialis ( $P$ hill. Sp.)}

$R e f$. and Syn. = Terebratula id. Phill. Geol. York. Vol. II. t. 12. f. 40 and 41.

Desc.-Longitudinally broad-ovate; greatest width about the middle of the length; front and anterior lateral margins forming parts of one semicircular curve; posterior lateral margins converging to the beak, at an angle of about $80^{\circ}$; lateral and front margins in one plane, without trace of mesial sinus; valves almost equally convex. Entering valve slightly and evenly convex, longitudinally ovate; beak small, prominent; surface radiated with from fourteen to sixteen very strong, simple, rounded, subequal ridges, continued perfectly simple to the apex of the beak; intervening sulci very deep, angular. Receiving valve slightly and evenly convex; profile regularly arehed, greatest depth about the middle; beak very prominent, slightly incurved; cardinal area flat, triangular (no straight hinge-line); deltidium bipartite; foramen near the apex. Surface smooth to the naked eye, granulo-punctate under a strong lens. Length of small specimen two and half lines, proportional width $\frac{90}{100}$, length of entering valve $\frac{85}{100}$, depth of both valves $\frac{55}{100}$.

(Professor Phillips figures a specimen five lines long, in which the proportional depth of both valves together is $\left.\frac{m i n}{1 m}\right)$. The bipartite deltidium beneath the foramen in the flat area under the beak, and the coarselypunctured tissue, as in the $S$. reticutaris and $S$. desquamata, leave little doubt on my mind of the true genus of this shell, although I have not yet seen the spires.

Position and Locality. - Rare in the carboniferous limestone of Derbyshire.

7th Family. RHYNCHONELLIDE. See page 199.

Genus. HEMITHYRIS. See page 199.

IEmitiyris acuminata (Mart. Sp.) See page 380.

1st Var. acuminata (Martin Sp.) See page 381.

Position and Locality.-Very common in the main, grey, or lower, carboniferous limestone of Derbyshire; in several varieties; similar specimens very common in carboniferous limestone of Malham Moor.

\section{2nd Var. platyloba (Son.) See page 381.}

Position and Locality.-Common in the carboniferous limestone of Derbyshire.

\section{3rd Var. Pugnus (Sow.) See page 381.}

Position and Locality.-Common in the carboniferous limestone of Derbyshire; common in the dark lower carboniferous limestone of Isle of Man; common in the lower carboniferous limestone of Lowick, Northumberland; in the carboniferous shale of Glasgow. 


\section{4th Var. mesogona (Phill.) See page 381.}

Position and Locality.-Rare in the lower carboniferous limestone of Derbyshire.

\section{Hemititris angulata (Limn. Sp.)}

Ref. and Syn.=Anomia angulata Linn. Syst. Nat.=T. excavata Phill. Geol. York. Vol. II. t. 12. f. 24.

Desc.-Longitudinally subtriangular, greatest width along the front margin; posterior lateral margins of both valves depressed, forming a broad, oval, concave space, extending from the beak rather more than half the length of each side; lateral and front margins nearly in one plane in young specimens five lines long, after which the whole front becomes greatly raised into a deep subquadrate sinus. Entering valve rather flattened except at the beak, which is very obtuse and abruptly incurved; profile nearly straight, very slightly arched, the long posterior lateral margins abruptly deflected nearly at right angles; surface even for about one to two lines from the beak, after which three very large acutely-angular ridges become developed, extending to the wide sinus in the front wargin, which they very deeply indent with acutely-angular teeth, the middle ridge slightly larger than the lateral ones; intervening hollows very sharply angular, slightly larger than the ridges; two slightly smaller, similar, large, acutely-angular ridges on each side. Receiving valve flattened in the young shell of five lines long, with a nearly straight profile, beyond which all the middle portion is semicircularly arched to fill the large sinus in the front margin, the narrowed portion corresponding to the two lateral plaits on each side remaining straight; beak very large, prominent, pointed, scarcely incurved; posterior lateral margins abruptly deflected at right angles to form part of the ovate depression on each side, which is defined by a sharp angulation; foramen triangular, moderate; lateral margin having a very small curve towards the entering valve near the beak, but a strong semicircular curve towards the receiving valve in the remainder of the depressed lateral portion; edges between the plaits very deeply and angularly indented. Shell-tissue coarsely fibrous under the lens, marked, principally in the hollows between the ridges, with longitudinal obtuse striæ, about ten in one line, crossed by faint, obtuse, concentric lines of growth, about equalling them in size. Length of average specimen ten lines, proportional length of entering valve $\frac{911}{100}$, width $\frac{70}{1+10}$, width of sinus in front margin $\frac{62}{100}$, depth thereof $\frac{50}{100}$, length of posterior, lateral, depressed spaces $\frac{47}{100}$, depth of entering valve (greatest near the front) $\frac{60}{1010}$, depth of receiving valve $\frac{20}{100}$; length of young specimen six lines, proportional length of entering valve $\frac{90}{100}$, length of posterior lateral depressed spaces $\frac{75}{100}$, width $\frac{85}{100}$, depth of entering valve and depth of sinus $\frac{20}{100}$, depth of receiving valve $\frac{15}{100}$.

This very remarkable species is not likely to be confounded with any other. The original specimen described by Linnæus, and ticketed in his handwriting, is in the collection of the Linnæan Society of London. Young specimens are depressed, nearly equivalve, the outline being an isosceles triangle, without sinus in the front margin, and with the great angular ridges only marked at the edge: with age the sinus in the front margin and depth of the entering valve increase very rapidly.

Position and Locality.-Rare in the carboniferous limestone of Yorkshire; very common in the dark lower carboniferous limestone of Isle of Man.

\section{Hemteryris flexistria (Phill. $S p$.)}

\section{Ref. and Syn. = Terebratula flexistria Phill. Geol. York. Vol. II. t. 12. f. 33, 34.}

Desc.-Transversely broad-ovate, or rotundato-rhombic; lateral margins nearly straight; sinus in front margin abruptly raised, very wide, oblong. Entering valve moderately gibbous, flattened, or slightly concave in all the middle portion; beak obtuse, much incurved, tumid, from whence the profile is nearly straight in the middle portion, and abruptly arched downwards towards the margin, so that the greatest depth is at about twothirds the length from the beak; sides very abruptly arched downwards, nearly vertical; posterior lateral margins with an obscurely-defined, slightly concave, elliptical space (sulcated like the rest), extending nearly one-half the length; about eight or nine strong, angular ridges raised with the mesial sinus, which only interrupts the evenness of the valve close to the margin; about seven to ten slightly larger, very much curved 
ridges on each side; those of the middle simple, those of the sides occasionally duplicate near the margin, all continued simply to the beak. Receiving valve moderately and evenly convex in the rostral portion for three or four lines long, after which the narrow sides are continued straightly to the margin, but the wide mesial portion is regularly arched downwards, to fill the mesial sinus; lateral ridges straight; beak very small. Average width eight lines, proportional length of receiving valve ${ }_{100}^{87}$, length of entering valve ${ }_{100}^{85}$, width of mesial sinus ${ }_{100}^{87}$, depth thereof ${ }_{10 i}^{35}$, depth of entering valve $\frac{45}{100}$, depth of receiving valve in middle of side $\frac{15}{100}$.

This species differs from $H$. pleurodon, in its much more numerous and smaller ridges, and the great curvature of the lateral ones of the entering valve, as well as the remarkable depression of all the middle portion; from Terebratula (Camerophoria) sulcirostris and $C$. ventilabrum it is distinguished by all the ridges extending to the beak. The two distinctly separated diverging dental lamellie in the receiving valve, and mesial septum in entering valve, are small.

Position and Locality.-Not uncommon in the carboniferous limestone of Derbyshire.

Hemithyris meteroptycha $\left(M^{\circ}\right.$ Coy). Pl. 3. D. fig. 19.

Ref.-Id. id. McCoy, Annals of Nat. Hist. 2nd Series, Vol. X.

Desc.-Transversely oval, very gibbous; hinge-margin obtusely arched; front much elevated into a deep, subquadrate, oblong sinus, inclining backwards from the line of the lateral margins at about $80^{\circ}$, which only affects the even convexity of the entering valve near the margin. Entering valve evenly gibbous, slightly flattened, or even concave, in the mesial line near the beak; profile abruptly incurved at the beak, and rather abruptly curved downwards near the front margin ; intervening portion nearly straight, the greatest depth being at about two-thirds the length from the beak; sides very abruptly arched downwards to the lateral margins, which are very slightly sigmoid at the sides; the commissure obtusely angular up to the beak, having on each side of the rostral portion a very slight narrow depression; three mesial ridges occupy the width of the top of the sinus, very large, obtusely angular, deeply indenting the margin, and continued simply to the beak; lateral ribs dichotomising at from one to two lines from the beak, unequal in size, fifteen or sixteen on each side near the margin, scarcely half the size of the mesial ridges, very strongly arched at the sides. Receiving valve with the lateral third on each side, and the rostral portion slightly convex, the middle portion after about two lines long very abruptly curved downwards into a very wide mesial hollow, to fill the oblong sinus in the front margin, the profile of the middle being nearly semicircular; the lateral ridges all bifurcate at about three lines from the beak; the two large mesial ridges simple, having besides a small dichotomous pair on each side in the sinus. Width six lines, proportional length of receiving valve about $\frac{85}{100}$, length of entering valve $\frac{80}{1100}$, width of sinus in front margin about $\frac{60}{100}$, depth thereof $\frac{55}{100}$, depth of receiving valve at middle of side $\frac{20}{100}$, greatest depth of entering valve $\frac{45}{100}$; the three mid-ridges at margin occupy a space of two lines, six of the lateral ones occupy the same space; surface smooth.

The great number of small, obtuse, dichotomising plaits on the sides distinguishes this from any of the varieties of $I I$. flexistria, C. ventilabrum, \&c., as well as their extending quite to the beak, and the disproportionally large mesial ridges, separate it from the $H$. bifera and $H$. cuboides. I have not seen the dental lamellæ.

Position and Locality.-Rare in the carboniferous limestone of Derbyshire.

Explanation of Figures.-Pl. 3 D. fig. 19, front view, natural size; (the two mesial ridges should be slightly wider, and the lateral ones slightly narrower); fig. $19 a$, ditto receiving valve; fig. $19 b$, profile of ditto ; (the top of the sinus should incline slightly more towards the beak, and the middle behind the front edge should be more elevated from the front, and flattened in the middle); fig. $19 c$, view of entering valve of ditto magnified two diameters, to shew the difference in character between the mesial and lateral ridges.

Hemithyris longa $\left(M^{c} \mathrm{Coy}\right)$. Pl. 3. D. fig. 24.

Ref.-Id. id. McCoy, Annals of Nat. Hist. 2nd Series, Vol. X.

Desc.-Longitudinally trigonal, length exceeding the width or depth, greatest width at one-third from the front margin; lateral anterior margins obtusely rounded; front very obtusely angulated in the middle; posterior 
lateral margins long, nearly straight, converging to the beak at an angle of $80^{\circ}$; commissure with a slight wave towards the entering valve in the posterior half of the lateral margins; anterior half of the lateral margins nearly straight, with a very faint indication of one plait on each side; middle of the front margin elevated at an angle of $85^{\circ}$ with the plane of the lateral margins, into a wide. tongue-shaped sinus, with sigmoid sides, acutely angular in the middle. Entering valve with the profile very slightly arched, greatest depth about the middle of the length; sides convex, arched abruptly downwards on each side from the obtuse mesial line. Receiving valve flattened, or very slightly convex, for about three lines from the beak, after which the very narrow sides alone are continued nearly straight to the obtusely rounded anterior lateral angles, the wide mesial portion being strongly depressed, to fill the sinus in the front margin; beak rather large, very slightly incurved. Surface smooth, with a few obtuse imbrications of growth near the margin; tissue very coarsely fibrous, almost visible to the naked eye. Dental lamellæ in beak of receiving valve very short, subparallel, slightly divaricating; mesial septum of entering valve very minute. Length nearly six lines, proportional width $\frac{9 m}{1+m}$, length of entering valve $\frac{0,1}{100}$, depth of entering valve $\frac{45}{100}$, depth of receiving valve $\frac{15}{100}$, width of sinus $\frac{80}{100}$, depth thereof $\frac{50}{100}$.

By the great thickening of the margins it is obvious that this little shell is adult. It only approximates, in the most remote degree, to one other Hemithyris that I know of, viz. one of the varieties of H. acuminata, from which it is distinguished by its very small size, and the length exceeding both the width and the depth.

Position and Locality.--Very rare in the carboniferous limestone of Derbyshire.

Explanation of Figures.-Pl. 3 D. fig. 24, front view, natural size; fig. $24 \alpha$, do. profile; fig. $24 b$, do. front view of entering valve; fig. $24 c$, do. fibrous tissue of the surface, magnified.

\section{Hemitiyris pleurodon (Phill.) See page 382.}

I might add to what is stated at the above page, that the commissure of the valves is sharply angulated all round to the beak on each side. The lateral plaits are sometimes as few as three on each side; there is often a shallow, mesial, longitudinal indentation near the beak of the entering valve; and that the length in proportion to the width varies from ${ }_{100}^{75}$ to $\frac{85}{1000}$. The young at a couple of lines long have the same number of ridges as the adult, but are much flattened, with slight trace of sinus, and seem rather longer. The sharp angular extension of all the strong simple ridges to the apex of the beak, separates this species from the $H$. pugnus and $C$. sulcivostris. The two diverging dental lamello in the receiving valve are moderate in size, but distinctly separated throughout; the mesial septum in the entering valve is small.

Position and Locality.-Common in the carboniferous limestone of Derbyshire; not uncommon in the carboniferous limestone of the Isle of Man; a variety rare in the carboniferous limestone of Lowick, Northumberland; a variety with three mesial plaits, common in the carboniferous shale of Craige near Kilmarnock; carboniferous limestone of Berwick-on-'T'weed.

\section{HeMitityris RENiformis (Sow. Sp.)}

\section{Ref. and Syn. = Terebratula, id. Sow. Min. Con. t. 496. f. 1 and 2.}

Desc.-Transversely reniform or obtusely bilobed. Entering valve very gibbous; profile greatly arched to the beak, and rather more abruptly to the sinus in the front margin; mesial ridge square, flattened at top, prominent, strongly defined, and bearing three or four large angular ridges, all becoming obsolete at about five lines from the beak; sides very tumid, inflated, much prolonged into elliptical lateral lobes, very steeply sloped from the sides of the mesial ridge to the lateral margins, which are faintly arehed towards the entering valve and very abruptly raised into a very deep oblong sinus, inclining backwards, nearly at $125^{\circ}$ from the plane of the lateral margins. Receiving valve with a very short adpressed tumid beak; a nearly straight convex portion extends from the beak to the base of the sinus on each side, from which it slopes rapidly to the lateral margins (giving the characteristic appearance to the sides of the receiving valve, of hanging below the edges); very wide middle portion depressed, after two or three lines from the beak, into a very wide concave hollow, which receives two or three large angular ridges after about nine lines from the beak, which extend to the middle of the sinus, 
which they deeply reflexo-dentate; no lateral ribs. Surface smooth, or with obsolete, obtuse, thread-like striæ, about eight in one line under the lens, crossed by similar obsolete stria of growth; shell tissue of moderately coarse flexuous fibres. Dental lamella in receiving valve very slightly diverging, about one and half lines long; mesial septum in entering valve about three and half lines long. Average width about one inch six lines, from beak of receiving valve to middle of front sinus $\frac{i{ }^{\prime}}{\text {, }}$, from beak of entering valve to same point $\frac{75}{110}$, from beak of receiving valve to lateral front margins $\frac{k B}{10 \prime}$, width of sinus $\frac{511}{50,}$, depth thereof about the same, but often less, depth of entering valve from middle of side margins $\frac{45}{100}$, depth of receiving valve from same point ${ }_{100}^{20}$.

This species is extremely constant in its characters, and certainly distinct from all the varieties of $I I$. acuminata, to which M. de Koninck unites it, by the remarkable character pointed out by Sowerby, of the inflation of the receiving valve, giving it the appearance of hanging much below the commissure.

Position and Locality.-Not uncommon in the carboniferous limestone of Derbyshire.

\section{Genus. PENTAMERUS (Son.) See page 208.}

\section{Pentamerus carbonarius $\left(M^{c} \mathrm{Coy}\right)$. Pl. 3. D. figs. 12 to 18.}

\section{Ref.-id. id. $\mathrm{M}^{\mathrm{C}} \mathrm{Coy}$, Annals of Nat. Hist. 2nd Series, Vol. X.}

Desc.-Globose, more or less inequilateral; hinge-line nearly as wide as the shell; cardinal angles obtuse, lateral and greater portion of front margins in one plane; middle of front margin abruptly raised into a very narrow, short, oblong or rounded sinus; commissure blunt from the meeting of the valves at a very obtuse angle. Entering valve varying from semicircular to rhombic, very gibbous; beak large, prominent; profile regularly arched from the apex to its front margin, its greatest depth about the middle of the length; mesial ridge narrow, flattened, prominent, and strongly defined from the front margin to the apex of the beak, either simple, divided by one mesial hollow, or divided into four narrow ridges near the margin; each sile with about seven very large, rugged, angular, irregular, subequal ridges, at six lines from the beak, beyon which they are either continued simple to the margin, or some or all of them dichotomise. Surface rather rugged, and very coarsely granulopunctate, or minutely pustular under the lens, with strong thickened interruptions of growth at the niargin, after nine or ten lines long. Receiving valve extremely gibbous; beak very large, usually slightly inclined to one side, varying greatly in its inrolment, according to the form of the cardinal area, which is sometimes nearly half as high as wide, triangular, very slightly coneave, and nearly at right angles with the plane of the lateral margins, in which case the beak is prominent, and only slightly incurved, the greatest depth of the valve being a little in front of its apex, and the profile arching very gradually from thence to the front margin; in other specimens the beak is incurved so as nearly to touch that of the entering valve, when the cardinal area is greatly reduced, very concave, and lying nearly in the plane of the lateral margins, the profile being more than semicircularly curved; mesial hollow very strongly defined by two thick ridges from the apex to the narrow sinus in the front margin, either simply hollowed, or bearing four ridges, much smaller than the lateral ones; lateral ridges about ten or twelve on each side at seven or eight lines from the beak, beyond which they are either simple, or more frequently di- or tri-chotomised, as they approach the margin, more rugged and irregular in direction than those of the entering valve, varying from three to six in three lines at one inch from the beak, according to the amount of bifurcation; transverse irregularities of growth more rugged than in the entering valve. Internal mesial septum of receiving valve very long, reaching nearly to the front margin, the lines of growth slightly arched towards the beak; rostral divaricating portions scarcely two-thirds the length of the combined mesial portion, but of slightly greater width where they are in contact; two mesial septa of entering valve narrow, scarcely one-third the depth of the mesial septum of the receiving valve, anterior broad ends very obliquely truncated, but reaching rather less than half the length of the valve. Average width one inch two lines, proportional length of entering valve ${ }_{10 i \pi}^{75}$, length of hinge-line $\frac{87}{100}$, length of receiving valve varying from $\frac{100}{100}$ to $\frac{95}{100}$, height of cardinal area varying from $\frac{13}{100}$ in the former to $\frac{47}{101}$ in the latter, width of mesial ridge and sinus in the front margin $\frac{25}{100}$, depth of entering valve $\frac{20}{100}$ to $\frac{23}{100}$, depth of receiving valve $\frac{50}{100}$ to $\frac{65}{100}$.

Some of the specimens of this species so nearly resemble Spirifers, that it was not until I made sections in various directions of several specimens, demonstrating the invariable presence of the two narrow, longitudinal, 
subparallel septa in the entering valve, and the wide, extremely long, mesial septum in the receiving one, with its internal divaricating portions flanking the triangular opening in the cardinal area, perfectly agreeing with $P$ entamerus, as well as the absence of spiral appendages, that I was convinced of its true genus. I have had the pleasure of demonstrating these specimens to M. de Verneuil, who, like myself, was fully satisfied of their being true Pentameri, and saw in them the first example of the genus in carboniferous rocks (the Pentamerus Sella and P.plicatus of Kutorga being obviously Camerophoria).

Pusition and Lacality.-Not very uncommon in the impure lower carboniferous limestone of Kendal, Westmoreland.

Explanation of Figurcs.-Pl. 3 D. fig. 12, natural size, front view, shewing the very small sinus in the front margin of a specimen in whic! the mesial fold is nearly simple; from the carboniferous limestone of Kendal; fig. 13, do. fragment of one side of the beak of receiving valve, shewing the width of the mesial septum on the left-hand side, one of the concave diverging portions in the middle, and part of the cardinal area on the right hand side, the apex of the beak being downwards; fig. 1t, do. longitudinal fracture of large specimen, shewing the great length of the mesial septum and portion of the divaricating part thereof in the receiving valve, and one of the short narrow septa of the entering valve; fig. 15, do. entering valve of specimen with much branched ridges, and much incurved, slightly oblique, beak to the receiving valve; fig. $15 a$, do. magnified surface of the ridges to shew the minute pustulation of the surface; fig. 16, do. variety with very high cardinal area, and only slightly incurved beak to the receiving valve, and having the lateral ribs simple; fig. 17, do. profile of variety with very gibbous entering valve and very much incurved beak to the receiving valve; fig. 18, do. transverse section of both valves shewing below section of the two small septa of the entering valve, and above, the brond mes al septum, with portion of the divaricating parts.

\section{Genus. CAMEROPHORIA (King).}

Gen. Char.-Shell with the general form of Rhynchonella; entering valve with a thick, short, mesial septum from the beak, and a slender hinge-tooth on each side, the septum dilated at its free edge into a spatula-shaped process; dental lamella of the receiving valve converging to form a pyramidal chamber in the beak, and a short mesial septum in contact with the surface of the valve. Shell-tissue fibrous.

Differs from Pentamerus in the small size of its internal plates, and in having but one, thick, central septum in the entering valve.

\section{Camerophoria globulina (Phill. Sp.)}

Ref. and Syno = Terebratula globulina Phill. Encyc. Metrop. Art. Geol. Vol. IV. t. 3. f. 3. =T. corymbosa How. T. N. F. C. Vol. I. = Camerophoria globulina King. Perm. Foss. t. 7. f. 22 to 25.

Desc.-Pisiform, smooth, lateral margins nearly straight, front margin abruptly raised into a wide W-shaped sinus; commissure sharp. " ering valve very globose, much deeper than the receiving one; greatest depth a little behind the mid le: after two lines from the beak two obtusely angular or rounded ridges extend to the two salient angles of the mesial sinus, separated by a rather wider, deep, angular sulcus; side margins at and after three lines from the beak, with traces of one or two slightly smaller ridges on each side. Receiving valve rather depressed, smooth and gently convex for nearly two lines from the beak, after which the middle becomes abruptly depressed to fill the sinus in the front margin, and at the same time one strong, subangular, mesial ridge becomes developed, the lateral margins having one or two shorter similar ridges on each side; beak small, gently incurved. Fibrous tissue under the lens rather coarse. Triangular chamber in beak of receiving valve large; its mesial septum one line long; mesial septum of entering valve rather smaller. Average length three lines, proportional length of entering valve $\frac{\mathrm{gur}}{\mathrm{ivu}}$, greatest width (a little in front of the middle) ${ }_{100}^{100}$, depth of receiving valve ${ }_{100}^{30}$, depth of entering valve ${ }_{100}^{45}$.

This species is not quoted from the continent by Professor King, but I find numerous specimens of it from Glucksbrünn in Count Münster's collection, under the manuscript name Terebratula bisinuata; a name already used by Lamark for a Tertiary Terebratula.

Position and Locality.-Not uncommon in the magnesian Permian limestone of Humbleton. 


\title{
Camerophoria isoryncha $\left(M^{c} C o y\right)$.
}

\author{
Ref. and Syn. = Atrypa id. MCoy, Syn. Foss. Irel. t. 18. f 8.
}

Deic.-Globose, subcuboidal; adult specimens slightly deeper than wide; lateral margins nearly straight; commissures very blunt, scarcely angulated in the adult, at the sides strongly toothed; front margin abruptly raised into a rotundato-quadrate sinus; a large, sharply defined, broad, ovate, concave space, sulcated like the rest, formed partly of the posterior lateral margins of each valve, extending from the beak rather more than half the length. Receiving valve flattened near the beak, and nearly straight from thence along the margins of the very wide concave sinus, which begins to be formed after four or five lines from the beak; front, after about eight or nine lines from the beak, abruptly arched upwards, nearly at right angles to the plane of the rostral portion, to form part of the front; beak thick, obtuse, scarcely incurved; apical angle about $88^{\circ}$; posterior lateral margins abruptly deflected at right angles with the mesial portion; about three strong, angular, straight ridges extend on each side from the beak to the front margin at base of sinus, very deeply and angularly indenting the edge; six or seven smaller ones on the deflected flattened or concave portion, strongly arched at their extremities; three or five simple angular ridges in the mesial hollow, resembling those of the sides; sides of the hollow steeply inclined, but each divided by one of the ridges, so that there is no remarkably wide smooth space between the sulcation of the middle and of the sides. Entering valve very much elevated; beak large, obtuse; posterior lateral margins on each side of the beak abruptly deflected at rather more than right angles, forming a strongly defined concave area on each side; whole surface for a length of ten lines from the beak evenly and slightly convex, the profile being very slightly arched from a straight line, and the mesial ridge being scarcely indicated even at the margin; beyond this length the front and side margins are abruptly arched over, forming a nearly vertical front, at much more than a right angle with the plane of the rostral portion, and meeting the reflected portion of the opposite valve almost without angulation; four or six strong, simple, angular ridges very slightly raised with the front sinus, four or five strong similar ridges on each side, and several (about four or five) abruptly smaller ones in the concave, posterior, lateral space; all the ribs of both valves continued sharp and distinct to the beak. Average width of adult specimens one inch, proportional length of the nearly straight rostral portion of entering valve $\frac{85}{100}$, depth of deflected front of ditto ${ }_{10}^{75}$, greatest depth of entering valve $\frac{k 0}{110,}$, greatest depth of receiving valve (at one-third from the front margin) ${ }_{\mathrm{i} 00}^{3 n}$, length of flattened rostral portion of receiving valve $\frac{77}{100}$, width of sinus at base $\frac{60}{100}$, depth thereof ${ }_{100}^{60}$, length of lateral concave space ${ }_{200}^{50}$, width of middle in entering valve $\frac{30}{100}$, at middle in receiving valve $\frac{15}{100}$.

The above description is from a fine Irish specimen from the original locality of Cookstown, Tyrone, where it is common in the red arenaceous limestone, like that of Dumfries, underlying the main limestone of the country. The English specimens, although exactly identical, are not so perfect. The mesial septum in the entering valve is strong, and about half the length of the flattened rostral portion; the mesial septum in the receiving valve is nearly as long, and diverges to form a large wide chamber at the beak.

Position and Locality. - Very common in the brownish siliceous carboniferous rocks near Shap Toll-bar.

\section{Camerophoria laticliva $\left(M^{c}\right.$ Coy $)$. Pl. 3. D. fig. 20 and 21.}

$$
\text { Ref. and Syn.=Atrypa id. McCoy, Carb. Foss. Irel. t. 22. f. } 16 .
$$

Desc.-Transversely rhomboidal, wide, very deeply trilobed, rounded; triangular sinus in the front margin often as high as the entering valve is long, and either forming a right angle with the lateral margins or inclined backwards at an angle sometimes of $115^{\circ}$; middle of the sinus very deeply and angularly indented by three large, acutely-angular ridges, which extend from within two or three lines of the beak; sides very small, anterior lateral margins very deeply reflexo-dentate by the ends of about three, large, acutely-angular ridges, which extend from within two or three lines of the beak; posterior lateral margins nearly straight, converging to the small beak at an angle of about $110^{\circ}$, having a shallow, very wide wave towards the entering valve, and a slightly flattened, narrow, elliptical space on each side very imperfectly defined. Entering valve with a 
smooth slightly convex space, from two to three lines long round the beak, beyond which three, strong, sharply angular ridges extend to the front margin along the top of the sinus, separated by very deep, acute, re-entering angles; smooth spaces forming the defined sides of the mesial ridge, very highly sloped, and about a third wider than the top of the sinus; sides moderately convex, depressed, with about three large angular ridges, slightly smaller than those of the middle, arching gradually from the margin towards the smooth space near the beak; after six lines long these lateral ridges obscurely dichotomise; profile nearly straight from the beak to the front margin, with a very slight downward curve at each end. Receiving valve, beak very small, closely incurved or adpressed to the beak of the entering valve; triangular foramen small, rostral space for about two lines round the beak smooth and nearly flat, without mesial sinus; beyond this the very narrow sides are produced nearly in a straight line, and are gradually divided by the three great ridges; after about the same length the middle is abruptly curved downwards to fill the very wide strongly defined sinus in the margin; sides of the sinus steep, smooth; middle with two great angular ridges. Surface under the lens marked with fine, irregular, imbricating strix of growth, and coarse, flexuous, longitudinal fibres of the shell-tissue. Width of typical specimen eight lines, proportional length of receiving valve ${ }_{i 100}^{87}$, of entering valve ${ }_{100}^{87}$, width of mesial sinus at base ${ }_{100}^{93}$, height thereof $\frac{85}{100}$, width of smooth steep side of mesial ridge in entering valve $\frac{37}{100}$, depth from receiving valve to top of sinus $\frac{85}{100}$.

This species is very remarkable for its few ribs, deep trilobation (accounting for the wide, steep, smooth space on each side of the mesial ridge), and the very small beak. The smooth rostral space, free from ridges, extending nearly to the beak, clearly separates this species from any of the varieties of $I I$. pleurodon, and their great size and small number are distinctive characters from the $C$. ventilabrum. Some very large specimens from Derbyshire, nearly ten lines long, shew an obscure duplication of some of the great ridges near the margin. The very small depressed sides, wide space free of ridges defining the mesial elevation, and the extremely sharp angular definition of the ridges, separate the species from the obtuse $H$. pugnus. The mesial septum in the receiving valve, in specimens of the above size, is from three to four lines long, the divarication forming the chamber in the beak is very distinct, but remarkably narrow, being upwards of a line long, but considerably less than half a line wide.

Position and Locality.-Carboniferous limestone, Derbyshire; carboniferous limestone of Lowick, Northunberland.

Explanation of Figures.-Pl. 3 D. fig. 20, extremely large specimen from the earboniferous limestone of Derbyshire, shewing the narrow straight sides, and extremely wide, defined, mesial hollow of the receiving valve; natural size, shewing one short unusual additional ridge in the sinus, and one or two at the side margins, from the extreme age; fig. $20 a$, ditto portion of fibrous shell-tissue, magnified; fig. $20 \mathrm{~b}$, entering valve of same specimen, shewing the smooth space near the beaks, form of ridges, and the slight, unusual appearance of a branch or supplementary rib at the margin; fig. $20 \mathrm{c}$, profile of same specimen; fig. 21 , slightly typical specimen, shewing the great height of the sinus, \&c.; from the limestone of Lowick.

\section{Camerophoria Schlotheimi ( $V$. Buch $S p$. )}

Ref. and Syn.< Terebratulites lacunosus (pars) Schlot. $=$ T. Schlotheimi V. Buch, Ueber Terebrateln, t. 2. f. 32= Camerophoria Schlotheimi + C. multiplicata King, Perm. Foss. t. 7. f. 10 to 21, and f. 26 to 32.

Desc.-Transversely rhombic; lateral margins nearly in one plane; front margin abruptly raised into a very wide, deep oblong sinus, slightly narrowed above; commissure acute all round. Entering valve gibbous along the middle; beak small, prominent ; profile regularly arched, its greatest depth in the middle of its length; smooth, evenly convex, without ridges or mesial fold for about two lines from the beak, after which the sides arch much more abruptly to the margins than the middle, leaving a square, broad, mesial ridge, increasing in prominence and sharp definition with age, its sides very steep and smooth; mesial ridge with from two to eight subangular, subequal, longitudinal ridges; each side with from three to eight similar ridges, sometimes appearing at two lines from the beak, and often not till after six lines. Receiving valve moderately and evenly convex for about three lines from the beak, which is prominent and slightly incurved, beyond which the middle becomes depressed into a very wide, flattened, hollow, rounded by steep smooth sides to fill the sinus in the front margin, 
and at the same time receives from one to nine subangular, usually simple, plaits; sides of the valve flattened towards the margins and nearly straight, receiving the same number of ridges as in the entering valve, at a distance varying from two to five lines. Width of rather large specimen one inch two lines, proportional length of receiving valve $\frac{80}{100}$, of entering valve ${ }_{100}^{65}$, width of sinus at base $\frac{64}{100}$, depth thereof ${ }_{1000}^{31}$, depth of entering valve ${ }_{100}^{35}$, depth of receiving valve ${ }_{10 w}^{15}$, length of rostral chamber $\frac{30}{1100}$, width $\frac{22}{100}$, length of mesial septum in entering valve $\frac{20}{100}$.

The above measurements give the ordinary proportions of this very common species, but many specimens are proportionally longer, and some more depressed. I have traced the passage so perfectly between the $C$. Schlotheimi with one, two, three, four, or five mesial ridges to the large $C$. multiplicata of King, in which they vary from four to nine, that I can have no doubt of the latter species being founded merely on very fully grown examples of the former one. In very old specimens, intermediate ridges make their appearance betiveen several pairs of the primary ones, and even in small specimens, at four or five lines from the beak a bifurcation is oceasionally seen of one or other of the ridges.

The greater number of specimens have the greatest width slightly in front of the middle, but in the most elongate form it is at two-thirds the length from the beak. Professor King figures some specimens shewing a shelly flattened expansion, more than a quarter of an inch wide round the margin (as in Athyris paradoxa, $A$. planosulcata, \&c.), and also the very much branched impressions of the pallial vessels, the main trunks of which he represents as forming a small, nearly circular, loop on each side, starting from the end of the mesial septum and arching successively forwards, outwards, and backwards, nearly to the point of starting, the branches towards the margin being given off from the outer side of these loops.

Position and Locality.-Very abundant in the Permian magnesian limestone of Humbleton.

\section{Camelzophoria sulcinostris (Phill. Sp p.)}

Ref. and Syn. = Terebratula sulcirostris Phill. Geol. York. Vol. II. t. 12. f. 31 and $32+$ T. ventilabrum id. id. t. 12. f. $36,38,39$.

Desc.-Rotundato-trigonal, or subovate; lateral margins nearly straight, commissures acute; middle of front margin very abruptly raised into an oblong or slightly rounded sinus. Entering valve moderately and evenly gibbous, the broad mesial ridge only slightly defined or elevated near the margin; profile regularly arched from the beak to the front margin, so that the greatest depth is about the middle of its length, mesial ridges five to nine, angular, simple, or in old specimens the outer one on each side with a slight bifurcation at the margin; lateral ridges five to seven on each side, about equal to the mesial ones, also simple except at the edge of very large individuals; all the ridges obsolete on the rostral portion, leaving a space round the beak, of three or four lines, smooth. Receiving valve with a very large prominent beak, to which the sides converge at an angle of $87^{\circ}$; the posterior lateral margins abruptly deflected near the beaks, to form a flattened space, confined to this valve, and defined by an obtusely rounded angulation; the smooth rostral portion (about three or four lines from the beak) convex, moderately tumid, beyond which the sides are flattened or slightly coneave, each bearing seven or eight straight angular ridges; mesial sinus abruptly formed after two or three lines from the beak, at the same time that the mesial ridges appear, which are usually four in number; middle of the mesial hollow flattened; sides steep, smooth. Width of small specimen eight lines, proportional length of receiving valve ${ }_{100}^{p 0}$, length of entering valve $\frac{77}{i=0}$, depth of entering valve at two-thirds from the beak ${ }_{i=0}^{40}$, greatest depth of receiving valve at one-fourth the length from the beak ${ }_{100}^{25}$, width of mesial sinus $\frac{63}{100}$, height thereof ${ }_{100}^{30}$; greatest depth of both valves at right angles to plane of lateral margins $\frac{653}{100}$.

The large smooth rostral space of each valve from the ribs not extending more than from two to three lines from the apex, separates this species from $I I$. pleurodon or $I$. fexistrix. The above deseription is from an Irish specimen in the collection; the English ones being considerably larger, but crushed and imperfect. The chamber in the beak of the receiving valve is very small, but the mesial septum formed by the junction of its walls is strong, and nearly as long as the mesial portion; the mesial septum in the entering valve is only about two lines long.

Position and Locality.-Not uncommon in the black limestone overlying the main limestone of Derbyshire. 


\section{Genus. ORTIIIS. See page 212.}

\section{Ortuis Connivens (Phill.Sp.)}

Tef. and Sym. = Spirifer id. Phill. Geol. York. Vol. II. t. 11. f. 3. = O striatula Schlot. de Koninck, Foss Bel. t. 13. f. 12 (not of Schlotheim).

Desc--Rotundato-oblong, very inequivalve. Entering valve deeper and longer than the receiving one, extremely gibbous in old specimens; lateral margins nearly straight, very faintly sigmoid; middle of front margin with a very shallow wide elevation towards the entering valve; hinge-line much less than the width of the shell; sides broadly rounded, greatest width about the middle, middle of front slightly sinuate; beals very large, obtuse, inflated, extending considerably beyond the hinge-line and a little beyond the beak of the receiving valve; profile very much arched; greatest depth at one-third from the beak; a faint, shallow, mesial depression to the slight sinus in the middle of the front; sides steeply arehed towards the margins. Receiving valve with a small, slightly prominent beak; cardinal area triangular, nearly at right angles to the plane of the lateral margins; rostral portion very slightly convex for four or five lines round the beak: sides flattened, sloping rather aloruptly towards the margins, after five or six lines from the beak, the middle is depressed into a wide, plano-coneave, shallow sulcus, corresponding with the sinus in the front margin. Surface with numerous, rather strong, concentric imbrications of growth about a line apart; surface longitudinally marked with very irregularly unequal, subequal, longitudinal sulei, rather less than their thickness apart, of nearly equal size on all parts of the shell (averaging ten or eleven in two lines, at six lines from the beak), the elevated strie rounded, or very obtusely subangular, occasionally di- or tri-chotomising at irregular distances, often with the branches reuniting, those on the sides divaricatingly arched; here and there some of the strixe hecome rather rapidly more prominent, as if to rise into spines, then are abruptly reduced to less than their former size; ridges and sulci under the lens minutely granulo-punctate. Width of large specimen one inch one line,

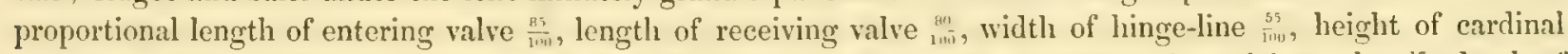

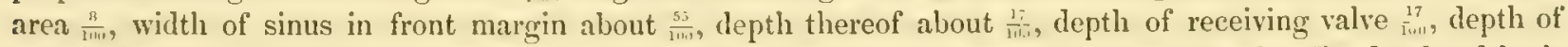

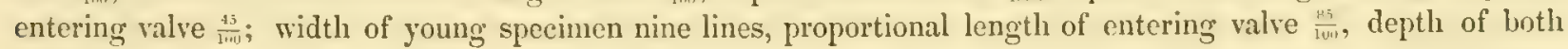
valves $\frac{50}{100}$.

It is difficult to say positively whether this is or is not a distinct species from the 0 . resupinata; the entering valve distinctly exceeding the receiving one in length, its very great gibbosity, more distinet mesial hollow, and slightly coarser strix, with less distinct and less numerous spine-like truncated thickenings of the strix, as well as the slight notch in the front margin, from both valves having a slight mesial hollow,-all these characters seem so much more strongly marked in the 0 .connivens, than in the $O$.resupinata, that it is very probable they are distinct species, more especially as the former fossil becomes so rugose from the number and strength of the concentric imbrications of growth, that it is olvious it reaches its adult size at about one half the linear dimensions of the O. resupinata. This species differs from the Devonian Terebratulitis striatulus of Schlotheim, to which it has been referred by M. de Koninck, by the very much greater depth of both valves in moderately large specimens, the great gibbosity of the entering valve, as weil as its less definite mesial hollow, and less regular striation.

Position and Locality.-Rare in the carboniferous limestone of Derbyshire, and in the lower carboniferous limestone of Lowick, Northumberland.

\section{Orthis gibbera (Portk. Sp.)}

Ref. and Syn.= Atrypa gibbera Portk. Geol. Rep. t. 3s. f. 1. Orthiz id. $\mathbf{I}^{\circ} \mathrm{Coy}$, Syn. Carb. Foss. Irel. t. 18. f. 9.

Desc.-(Young) truncato-orbicular, convex, front margin slightly raised: (adult) semicylindrical, depth excceding the width; sides subparallel, rostral portion of the shell flattened or moderately convex; front of both valves, after about nine lines from the beak, deflected nearly at right angles, much produced, rounded at

[FABC. III.] 
the sides, flattened in the middle; hinge-line rather less than the width of the shell; cardinal angles obtuse; lateral and front margins nearly in one plane in young specimens; in old individuals the lateral margins are very slightly sigmoid, and the middle of the front raised into a small, narrow, rotundato-quadrate sinus, from which a slightly elevated flattened ridge extends a short way on both valves of most specimens, but often obsolete. Receiving valve with a moderate, slightly eurved, triangular area, nearly at right angles to the plane of the lateral margins; beak slightly tumid, prominent; surface sloping to the margins with slight convexity for alont nine or ten lines, after which the margin is obtusely deflected nearly at right angles. Entering valve muclı deeper than the receiving one, beak large, obtuse; whole surfnce moderately convex for nine or ten lines, after which the margin is obtusely deflected nearly at right angles, the rounded intervening angle being the deepest part of the valve in old specimens; greatest depth of the rostral portion, at about one-third from the beak. Surface with very fine, nearly regular, longitudinal strixe (averaging twenty in two lines at six lines from the beali), some of them at irregular intervals abruptly thicker than the rest; concentric lines and imbrications of growth slightly marked. Width of adult specimen one inch three lines, proportional width of hinge-line height of cardinal area ${ }_{\text {luo }}^{17}$, length of moderately convex rostral portion of each valve ${ }_{i, m}^{i n}$, depth of deflected front of entering valve to side of mesial sinus $\frac{\pi}{i m}$, depth of deflected front of receiving valve to same point of sinus in front margin $\frac{47}{100}$, depth of do. $\frac{25}{100}$.

The beak of the entering valve is slightly more prominent than that of the receiving one, if measured from the front margin. The very great gibbosity of the adults, and the extremely fine striation, separate this species from either the $O$. connivens, or $O$. resupinata; the inflated portions of the stria are not placed so regularly alternate as in the $O$. resupinata, nor are they so rapidly thickened nor truncated after so short a length; but instead of the triangular, drop-like appearance which they present in that species, they rather resemble thickened strix continued for a great length, often with considerable regularity.

Position and Locality._One obscure specimen from the lower carboniferous limestone of Kendal, Westmoreland.

\section{Orthis Michelini (Lév. Sp.)}

Ref. and Syn.=Terebratula id. Léveillé Mém. de la Soc. Géol, de France, Vol. II. t. 2. f. 14 to $17=$ Spirifera filiaria Phill. Geol. York. Vol. II. t. 11. f. 3 = Orthis Mlichelini M. V. K. Geol. Russ. t. 13. f. 1.

Desc.-Longitulinally sulutrigonal or obovate; greatest width a little behind the front margin, equal to the length; front broad, nearly straight; lateral margins long, very slightly convex, converging posteriorly to the very narrow hinge-line, depressed; lateral and front margins nearly in one plane, without distinct sinus. Entering valve deeper than the receiving one, gently convex along the middle; beak very small, depressed, slightly prominent; profile gently arched, greatest depth at one-third from the beak; a very faint, wide, mesial flattening or concavity extends nearly from the beak to the front margin; sides rapidly sloping with gentle convexity to the margins. Receiving valve rather tunid near the beak, which is of moderate size and prominent; profile sloping from a little in front of the beak, with very slight convexity, to the front margins; sides flattened, abruptly sloping to the margins from the middle portion, which is wide and flattened after a few lines fiom the beak. Surface of both valves marked with rather coarse irregular imbrications of growth, radiated by rather coarse subequal strie of nearly uniform size over the whole shell (usually ten in two lines at six lines from the heali), wceasionally dichotomising at irregular distances, and at moderately rare intervals set with short, solitary, pointed tubercles, nearly as thick as the ridges on which they are placed (but not preceded by any remarliable thickening, nor followed by any marked diminution of the ridge, as in O. resiphinatu); granulo-punctation under. the lens, moderately coarse. Cardinal area of entering valve very small, in the plane of the lateral margins; area of receiving valve somewhat larger, inclined at about $40^{\circ}$. Average length and width eleven lines, length of entering valve slightly less, proportional depth of receiving valve $\frac{20}{1+0,}$, of entering valve depth of area about $\frac{7}{100}$ (one specimen one inch six lines long).

The form of this species is very peculiar, from the greatest width being near the wide subtruncate front margin, and the posterior end scening narrowed, from the long slightly curved sides converging to the very 
small hinge-line; the striation somewhat resembles that of the $O$. comnirens, but is more regular; it differs from that of the $O$. resipinate in wanting the peeuliar gradual dilatation of certain parts of some of the strie before the necurrenee of a spine-like projection, and the remarkable abrupt diminution of the swollen ridge beyond the spine; the spines in the present species being difficult to see, and never producing those elongate, drop-like marks of that species. The front is sometimes very faintly sinuate in the middle, and oceasionally with an almost imperceptible wave towards the entering valve. The elongate subtriangular form, and general depression of the valves, as well as the difference noted in the striation, separate it from both the 0 . resupinatce and $O$. connicins.

Position and Locality.-Extremely common in the lower carboniferous limestone of the Isle of Man, very common in the carboniferous shales of Beith, Ayrshire.

\section{Orthis resupinata (Mart. Sp.)}

Ref. and $S_{y n}=$ Anomites resupinatus Martin, Pet. Derb. t. 49. f. 13 and $14=$ Terebratula resupinata Sow. Min. Con. t. 325=Orthis id. de Koninck, Foss. Bel. t. 13. f. 9.

Disc.-Transversely oval, one of the long sides slightly truncated by the hinge-line, which is of moderate length; cardinal angles obtuse, sides semielliptically rounded; front wide, broally arehed; lateral and front margins in one plane in young specimens, raised with a very slallow wide wave towards the entering valve in old oncs. Entering valve deeper than the receiving one, broally and nearly uniformly convex, flattened at the posterior lateral margins; beak obtuse, prominent, ineurved to the level of the hinge; profile regularly arehed, greatest depth at about one-third from the beak; in some specimens an exeecdingly faint, narrow, mesial eoncavity, extends nearly from the beak to the front margin. Receiving valve very slightly longer than the entering one: beak small, slightly prominent; rostral portion for about six lines from the apex rather tumid, sloping rapidly to the sides and front margin, so that beyond the above length the sides and front of this valvo ar: generally flattened, or sometimes even slightly coneave either in the middle or at the sides. Surface of botir valves uniformly covered with close, fine, slightly unequal, thread-like strie (averagging twenty in two lines at six lines from the beak), at irregular alternating distances some of the strix rather rapielly inerease in thicknesis and prominence, giving origin to a slight spine-like projection at the distal end, beyond which the ridge cither dichotomises, or is continued of abruptly diminished size; concentric imbrications of growth small, moderately numerous; surface under the lens very minutely granulo-punctate. Average width one inch six lines, propor-

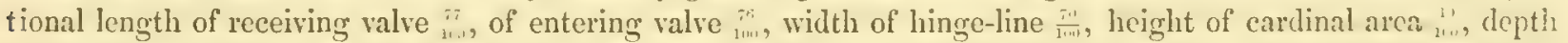
of receiving valve ${ }_{11,4}^{17}$, depth of entering valve ${ }_{11 \text { ini }}^{35}$; width occasionally two inches six lines, proportional depth of both valves varying from $\frac{38}{100}$ to $\frac{52}{100}$.

This species is more depressed and more finely striated than the $O$. comnicens, and has the entering valvo shorter and very much less tumid; it is wider and considerably more tumid near the beaks than the $O$. Michelini, and from both it is distinguished by the beautiful peculiarity of certain of the strie, heing irregularly. swollen and abruptly truneated, resenbling the appendages to ermine fur. One crushed Isle of Man specimen is almost as gibbous in the entering valve and with as distinct a sinus in the front as the 0 . connivens, but haring the striation of $O$. resupinate. The cardinal area of the entering valve is small, and placed in the plano: of the lateral margins, the triangular opening is flanked by two very strong dental lamellie, diverwing with its sides at $95^{\circ}$, and forming deep slits in the cast; in the middle of the apex of the opening is a very suall hificl rostral tooth, the sides of which diverge at $35^{\circ}$, from which a slight mesial septum extends a short way from the beak.

Position and Locality.-Small specimens in the black carboniferous shale of Craige, near Kilmarnock; very rare in the dark lower carboniferous limestone of Lowick; very common in the lower carboniferous limestone of the Isle of MIan; beautifully marked specimens are common in the carboniferous limestone of Malham Moor ; not uneommon in the lower carboniferous limestone of Derbyshire; very small specimens in the carboniferous limestone of Glasgow. 


\title{
Genus. LEPT ENA. See page 232.
}

\section{Subgenus. S'TROPHOMENA. See page 241.}

\section{Leptana (Strophomena) crenistria (Phill.Sp.)}

\author{
Ref. and Syn. = Spirifera crenistria Phill. Geol. York. Vol. II. t. 9. f. 6, and Port. Geol. Rep. 1. 37. f. 5. \\ $=O$. Sharpei Mor. Cat.
}

Desc.-Truncato-orbicular; hinge-line slightly exceeding the width of the shell, in short slightly acute ears; flat when young; when old the receiving valve is convex at the slightly prominent beak, flat in the middle and gently concave or deflected at the margin. Entering valve flattened, slightly concave at the beak, and all the rest slightly convex. Cardinal area linear or obsolete in the entering valve, large, triangular in the receiving valve, inclining backwards at about $115^{\circ}$, and with a large triangular mesial foramen, the sides of which meet at right angles, nearly closed by a convex pseudo-deltidium. Radiating stria strong, (from six to eleven in two lines at eight lines from the beak of the ridges, more constantly six in the same space at the margin in same specimens at two inches from the beak) thread-like, unequal in thickness, increasing in number towards the margin by intercalation of one or three finer ridges, rapidly acquiring the size of the others; spaces between the radiating stria flat, considerably wider than the ridges, but varying greatly in this respect, closely marked with small, deep, irregularly transverse wrinkles (distinct from the much finer transverse regular lines of growth) and under the lens, in some states of preservation, sharply striated longitudinally (five or seven stria between each pair of ridges). One obscure mesial and two obtuse dental lamella in the receiving valve, diverging at about $95^{\circ}$, forming the posterior boundaries of a broad, ovate, faintly defined, muscular space, irregularly sulcated, about as wide as long, and about half the length of the shell (at two inches long). Width three inches, proportional length $\frac{75}{100}$, depth $\frac{10}{200}$, height of cardinal area about $\frac{8}{100}$.

The striation is very variable, according to the state of preservation; in some the principal stria, being nearly a line apart, and the intervening flat spaces having very distinct longitudinal fine lines, internally punctured, the middle one largest, and crossed by fine, close, deep, irregularly transverse wrinkles; in others the intervening strix nearly equal the principal ones in size, and the shell appears more closely and coarsely striated subalternately, but both extremes may be seen on the one specimen, and the differences are clearly the result of the loss of one or more layers of shell. In some rare cases the transverse wrinkles are the same size and distance apart as the longitudinal ridges. I have no doubt the $O$. Shurpei of Morris is synonymous. The great size, more slender ridges, small, irregular, transverse wrinkles independent of the lines of growth, great depression or flatness of both valves, and less inclined cardinal area, separate this certainly from the Devonian S. umbraculum (Schlot. Sp.)

Position and Locality.-Common in the lower carboniferous limestone of Kendal; common in the black upper carboniferous limestone of Derbyshire; in the black impure lowest beds of the carboniferous limestone of Ronalds-way, Isle of Man.

\section{LEpt Ana (Strophomena) Cylindrica $\left(M^{c}\right.$ Coy).}

\section{Ref. and Syn $=$ Orthis id. McCoy, Syn. Carb. Foss. Irel.t. 22. f. 1.}

Desc.-Subcylindrical when adult; hinge-line considerably less than the width of the shell, forming inconspicuous, obtuse-angled, broadly rounded ears. Entering valve evenly giblous, almost hemispherically arched for rather less than an inch from the beak, beyond which the front is gradually defiected into a vertical semicylindrical front, with subparallel sides; front more convex than the sides; cardinal area obsolete. Receiving valve with a wide, triangular, cardinal area, inclining backwards at about $125^{\circ}$; pseudo-deltidium very convex, one-third higher than wide, moderately convex in all the rostral portion, becoming gradually concave where it approximates the deseending front of the entering valve, the profile forming a strong sigmoidal curve, leaving a large space between the valves for the animal. Radiating strixe filiform, alternately larger and smaller on the 
greater part of the shell in most specimens (nine to eleven in two lines at eight lines from the beak), towards the margin every fifth becoming more prominent than the rest; on all parts the radiating strix have the intervening wider concave spaces crossed by subregular concentric ridges, usually the same distance as the strire apart, and sometimes nearly equalling them in strength, producing a slight nodulation of their sides; intervening spaces under the lens coarsely punctured. Width of average-sized specimens one inch seven lines, proportional

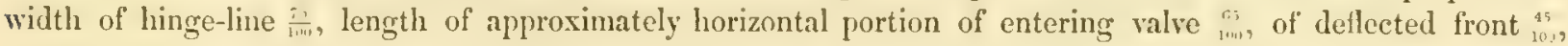
depth of entering valve $\frac{35}{100}$, space between the valves about $\frac{20}{100}$, height of cardinal area about ${ }_{100}^{28}$.

This species seems to have the striation closer and more uniform than the $S$. crenistria, from which it is totally distinguished by the nearly hemispherical form and semi-cylindrical produced front of the adult entering valve, as well as the different inclination of the cardinal area and strong sigmoidal flexure of the receiving valve. When small specimens under an inch long are eompared (before the front is developed), the entering valve is completely distinguished from the corresponding part of the s. crenistric by its great gibbosity, and by its short linge-line, regularly arched into the rounded sides, corresponding specimens of the S. crenistrit being flat, and with acute ears extending beyond the sides.

Position and Locality.-Common in the dark lower limestone of Lowick, Northumberland. The original Irish locality (in which the species is very common) is the red limestone, resembling that of Closeburn, at Castle Espie, co. Down, near the base of the Irish carboniferous system.

\section{Leptena (Strophomena) Kelayi (Mc Coy).}

\section{Ref. and Syn.=Orthis Kellyi $\mathrm{I}^{\mathrm{C}} \mathrm{Coy}$, Synop. Carb. Foss. Irel. t. 22. f. 4.}

Desc.-Truncato-orbicular, or nearly quadrate; from the very slight convexity of the sides, and from the nearly straight or slightly sinuate wide front; nearly equivalved; linge-line as wide as the shell or nearly so, forming slightly obtuse or nearly rectangular cardinal angles; entire margins nearly in one lorizontal plane. Entering valve slightly convex, becoming gradually flattened towards the cardinal line, divided in the niddle by a wide, rounded, mesial hollow, which extends from the beak to the front margin, which it slightly sinuates. Receiving valve slightly convex near the beak, becoming gradually flattened or very slightly concave towards the side margins, middle elevated into a wide, obscurely defined, obtusely angular ridge, extending from the beak to the front margin; cardinal area moderate, inclining backwards at about $130^{\circ}$; hoth valves radiated with fine filiform ridges, alternately larger and smaller near the beak, more usually three smaller (the middle one largest) between each of the prineipal pairs near the margin; flat intervening spaces very minutely striated longitudinally under the lens, and coarsely punctured (sometimes seven or eight of the microseopic longitudinal stria) between each pair of ridges at the margin; in other states of preservation the stria seem closer and of more nearly equal thickness over the whole surface; transverse wrinkles usually much closer and finer than in the S. crenistria; specimens after one inch and quarter long shew the thick imbricating interruptions of growth marking the adult

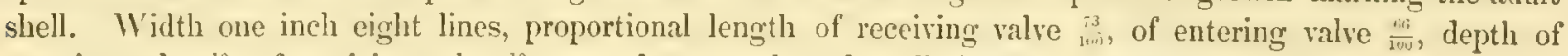
entering valve $\frac{10}{100}$, of receiving valve $\frac{10}{100}$, space between the valves $\frac{20}{100}$, height of cardinal area $\frac{10}{100}$.

This species occurs in rast profusion in that part of the carboniferous series called the arenaceons limestone by Dr Richard Griffith, developed under part of his carboniferous slates, nearly at the base of the carboniferous series of Ireland. It seems to be constantly distinguished from the S. crenistive by its rounded mesial furrow, which indents the front margin, also its more quadrate outline, shorter hinge-line, and small size, the largest specimens scarcely exceeding an inch and half long: and these and even sualler are shewn to have attained their usual adult size hy the imbricating thickened interruptions of growth near the margin. The $S^{\prime}$. crenistria grows frequently to donble this size without shewing the same signs of age; the sides of the entering valve are also more convex, and the eardinal angles obtuse. The striation is so variable in these shells, according to the state of preservation of the surface, that it is of little use in specific distinctions; the strix, however, of the S. Kellyi, although resembling in character those of s. crenistria, are usually somewhat finer, closer, and more equal than in that species. 
Position and Locality.-Rare in the black, also in the grey, carboniferous limestone of Derbyshire; not very uncommon in the shelly masses of lower carboniferous limestone of Berwick-on-i'weed, where the fragmentary specimens may be recognised by the medial ridge from the beak of the receiving valve, sce.

\section{Lept Aena (Strophomena) Pelargonata (Schlot. Sp.)}

Ref. and S'yn. = Terelvatulites pelargonatus Schlot. Akad. Mïnch. Vol. VI. t. 8. f. 21, 24 = Stspitorliynchus id. King, Perm. Foss. t. 10. f. 18 to 28.

Desc.-Semiconical, hinge-line slightly less than the width of the shell, which is greatest a little in front of the middle; cardinal angles slightly obtuse. Receiving valve semiconical; beak large, elevated, so that the profile, from its apex to the front margin, slopes irregularly without distinet arehing; beak irregularly inclined sometimes to the right, sometimes to the left hand, and sometimes sigmoidally; sides sloping rather rapidly; surface rendered irregular by one or two concentric, wide, concave irregularities of growth; cardinal area triangular, its height varying from one half to two-thirds the width of the shell; psendo-deltidium strongly defined, very convex externally. Entering valve subquadrate, convex, more regular than the receiving valve, indented by a deep, wide, mesial hollow from the beak (which is often searcely visible in the receiving valve); cardiual area very narrow, linear, or obsolete. Surface of both valves marked with numerous, subangular, sulequal, longitudinal strie, divaricatingly arehed on the sides, each branched two or three times between the beak and margin, where they are irregular in size, and averaging thirteen in the space of one line, at two lines from the beak (about the same in same space at one line from the beak), crossed by rather strong concentric strie. Average length of receiving valve five lines, proportional width $\frac{85}{100}$, length of entering valve $\frac{m}{1 \ldots}$, depth of receiving valve $\frac{30}{100}$ to $\frac{40}{100}$, depth of entering valve $\frac{25}{100}$.

Internal casts of entering valve shew two thick, very diverging dental lamelle, extending one-third the length of the shell. The apex of the beak of receiving valve in all the specimens I have examined is broken, so that I am uncertain whether there is an apical foramen or not. Professor King's figures represent the striation as considerably ton coarse. It is rather coarser in the foreign than in the British specimens; averaging in the former eight or nine ridges in the space of one line at margin of large specimens. The specimens collected by Professor Sedgwick, and called in his paper Spirifer minutus by Mr Sowerby, supposed by Professor King to belong to this species, are unfortunately not in the collection.

Position and Locality.-Not uncommon in the Permian magnesian limestone of Humbleton Hill.

\section{Lept ENA (Strophomena) SEniLis (Plill. Sp.)}

\section{Ref. and Syn. = Spirifera senilis Phill. Geol. York. t. 9. f. 5.}

Dese.-Semiconical, hinge-line slightly less than the width of the shell, forming almost rectangular cardinal angles; lateral margins slightly convex, gradually blending with the nore rounded front, the entire edge heing approximately in one horizontal plane. Receiving valve irregularly semiconic; beak very large, but not incurved, usually inclined obliquely to one side, and so much elevated that the profile is very little arched, sloping gradually from the apex to the front margin, except at the step-like interruptions, produced by two $0 \mathrm{l}^{\circ}$ three very large irregular concentric undulations or interruptions of growth, which give a very irregular aspect to the shell; cardinal area slightly concare, inclining backwards from the plane of the margins at an angle of from $95^{\circ}$ to $125^{\circ}$, its height varying from one-half to one-third the width of the hinge-line; pseudo-deltidium very prominent, convex, the height exceding the width at base by one-third to one-half in different specimens. Entering valve more evenly convex than the receiving one, and less distorted by the large concentric interruptions of growth; profile regularly arched, greatest depth about the middle; cardinal area linear, obsolcte. Surface of both valves marked with narrow filiform stria (averaging four in two lines at six lines from the beak) in the broad flat spaces between which are developed, first one, then three, and towards the margin five, the additional ones being very fine at first, but towards the margin gradually nearly equalling the others in size, or 
appearing only alternately larger and smaller (about twelve to fourteen in two lines), separated by concave spaces, about equalling them in width. Casts shew the dental lamelle in the entering valve diverging at an angle of $75^{\circ}$, and reaching about one-fourth of the length of the shell; the mesial septum between them just the same length; the dental lamellie of the beak of receiving valve diverge at only $26^{\circ}$, and reach rather less than one-third the length of the shell ; the mesial septum between them is only three-fourths of their length. WVidth

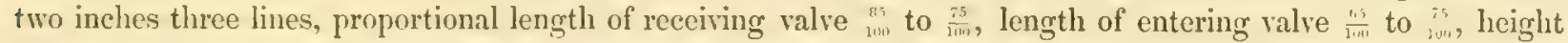
of cardinal area $\frac{95}{100}$ to $\frac{30}{100}$, depth of receiving valve $\frac{25}{100}$ to $\frac{30}{100}$, depth of entering valve $\frac{17}{100}$.

This species is so totally different from the $S$. crenistria, by its greatly elevated area, strongly convex entering valve, and irregularly convex receiving one, oblique distortion of the beak, and extremely irregular distorted mode of growth, evineed by the two or three great concentric irregular undations, that it is difficult to conceive how they could be confounded. The shell is extremely thin, so that traces of the striae and all the irregularities of the surface are reproduced on the cast. This is one of the irregular growing species, for which Professor King forms his genus Streptorhynchus. I am unable to say whether there is, or is not, a small foramen in the apex of the beak. The striation has a general resemblance to that of the S. crenistric, but the rough matrix of the specimen renders me uncertain whether there is any sharp concentric striation.

Position and Locality. - Not uncommon in the lower carboniferous limestone of Kendal.

\section{Subgenus. LEPTAGONIA. See page 247.}

\section{Leptena (Leptagonia) analoga (Phill.) See Devonian Section, p. 389.}

Pusition and Locality.-Common in the lower carboniferous limestone of Derbyshire; common in the dark carboniferous limestone of Ronalds-way, Isle of Man.

$$
\begin{aligned}
& \text { Var. a. Distonta (Son.) } \\
& \text { Ref.-Sow. Min. Con. t. 615. f. } 3 .
\end{aligned}
$$

Position and Locality._Common in the middle carboniferous limestone of Poolwash, Isle of Man.

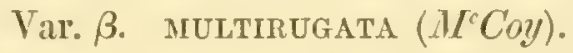

$$
\text { Ref.-M } \mathrm{I}^{\mathrm{C}} \mathrm{Coy} \text {, Synop. Carb. Foss. Irel. t. 18. f. } 12 .
$$

It is quite possible that this shell, which $\mathrm{I}$ at one time thought a distinct species, may form an extreme variety of the present species. It is characterised by the regular flatness of the visceral disk, and the great number and regularity of the coneentric wrinkles, which are from twenty-two to twenty-four on a visceral disk eight lines long; the ridges usually unite in pairs as they approach the hinge-line. The longitudinal strive are nine or ten in two lines at the front margin of disk.

Position and Locality.-Rare in the carboniferous limestone of Kendal.

\section{Lettena (Leptagonia) sinuata (de Kon.)}

\section{Ref.-Leptana id. de Kon. Anim. Foss. Bel. Sup. t. 56. f. 2.}

Desc.-Subquadrate; visceral disk rhomloidal, flattened, entirely covered with numerons, strong, irregular, occasionally interrupted, concentric wrinkles (ahout fourteen or fifteen); a wide, deep, mesial hollow extends nearly from the beak, the sides are slightly convex, but again separated from the abruptly-flattened ears by a marked depression, the line of junetion between the ears and the body of the slell occasionally marlied by a few large spine tubercles; beak searcely projecting beyond the hinge-line, which slightly exceeds the width of the shell in flattened rounded ears; front short, abruptly deflected nearly at right angles from the visceral disk, and deeply indented by the wide mesial furrow. Whole surface marlied with coarse, obtuse, subequal, longitudinal stria, eight in two lines at angle of front. Entering valve resembling the receiving one in shape and markings, leaving a rery small space for the animal; cardinal area ten times wider than high; 
foramen and pseudo-deltidium wide. Wilth eleven lines, proportional width of visceral disk $\frac{85}{\mathrm{im}}$, length of visceral disk of receiving valve $\frac{50}{100}$, length of front $\frac{30}{100}$, space between the valves $\frac{15}{100}$.

This species is easily distinguished from $L$. analoga by the deep, wide, longitudinal mesial hollow, giving it a strong resemblance to the Producte plicatilis, from which it differs in its coarse longitudinal sulcation; the resemblance however to the Producte Griffithi of de Koninck is so great, that but for the known accuracy of that observer, we might suppose the cardinal area had been overlooked in that species, the more so as I observe in our specimens traces of the spinose tubercles, represented between the body of the shell and the ears in $P$. Griffithi, but not alluded to in his description of the present fossil.

Position and Locality.-Rare in the carboniferous limestone of Derbyshire.

\section{Subgenus. CHONETES. See page 249.}

Leptena (Chonetes) crassistria (Mc Coy). Pl. 3. II. fig. 5.

Ref. and Syn. = Leptana id. McCoy, Syn. Carb. Foss. Irel. t. 20. f. 10.

$D$ esc.-Nearly semicircular, middle portion of the shell subhenispherical; greatest depth nearly at middle, of length, from whence the surface gradually slopes towards the front and sides, arehing more rapidly towards the broad beak, which scarcely projects beyond the hinge-line; hinge-line exceeding the width of the shell, forming narrow, rounded, very slightly convex ears; about five slender tubular spines on the hinge-line on each side of the beak. Surface longitudinally fluted by about twenty-four coarse, slightly rugged, equal, sharplyrlefined, rounded, very prominent, simple ridges, five in two lines at four lines from the beak, marked by coarse transverse lines; intervening sulci very deep, concave, and about equalling the ridges in width; the ears are nearly destitute of ridges. Width eight lines, proportional length $\frac{67}{100}$, depth $\frac{.95}{100}$.

The comparatively few and perfectly simple or unbranched ridges easily separate this species from my L. sulcate and $L$. gibberula, with which M. de Koninck united it in his Monograph on the genus. It is in fact the most strongly marked species of the genus, and cannot be confounded with any other.

In my original figure there seem, unfortunately, a few ridges too many, and owing to this erroneous crowding, their curious simplicity is not sufficiently apparent. Here and there on the ridges towards the margin may be observed some minute tubercular spines, resembling those alluded to by $M$. d'Orbigny in his Lepténa variolate, in the Palaontologieal part of his Voyage dans l'Amérique Méridionale, and where absent they leave rather distant, small, scattered, broken pits, too few and far apart however to form a marginal band, or other marked feature, being besides only visible with a lens.

Position and Locality.-Rare in the carboniferous limestone of Derbyshire.

Explanation of Figure-CP. 3. II. fig. 5, natural size, receiving valvo; fig. $5 a$, portion of surface magnified.

\section{Leptana (Chonetes) Hardrensis (Phill. Sp.)}

Ref. and Syn.= Orthis Hardrensis Phill. Pal. Foss. t. 58. f. $104^{*}, b, c, d$, not $\alpha$, and t. 60. f. 104*.

M. V. K. Geol. Rep. t. I5. f. 10; de Kon. Monog. Chonetes, t. 20. f. 2.

Desc.-Subsemicircular, depressed; hinge-line slightly exceeding the width of the shell, forming pointed cardinal angles. Receiving valve gently convex in the middle, passing gradually into the flattened ears; side margins very slightly sigmoid; front wide, widely convex, or flattened, or even slightly coneave, in which latter case a wide, shallow, obscurely marked, mesial depression extends nearly to the beak. Surface radiated with rather coarse, slightly unequal, subangular ridges, all of which either branch, or receive fresh ridges of nearly the same size, at two or three perfectly irregular distances, betwcen the beak and the margin; the ridges often shew under the lens scattered, rather distant, ovate punctures, resembling spine bases; intervening angular sulci narrower than the ridges, often coarsely punctured; ridges nearly efulual on all parts of the shell, areraging twenty in two lines at three lines from the beak; four or five slender spines on each side of the beak on the edge of the hinge-line, directed obliquely outwards and backwards, and having a smooth space, as wide as three or four strix between them; in some specimens towards the margin the strice are slightly rugose; substance of 
the shell very thick; internal surface marked with close, quincuncially arranged, very large, spinulose tubercles. Width seven lines, proportional length $\frac{65}{100}$, depth (greatest a little in front of middle) $\frac{20}{100}$ to $\frac{25}{100}$.

M. de Koninek is of opinion that this species should be referred to the Leptene cariolute of d'Orbigny, but the characters which M. d'Orbigny gives to separate that species from Leptume sarinulatu separate it equally from this; and I feel unwilling to make the rapprockement. At the same time it is peculiarly unfortunate that Mr Phillips should have mixed up the Devonian and carboniferous species in his figures and descriptions of this species; however, I think with MM. de Koninck, Murchison, Verneuil and Keyserling, and other continental writers, that his Devonian specimens were the $C$. sarcimulate (Schlot.); the name IIardrensis, and the figures I have quoted, are clearly stated to be of the carboniferous form, which may well bear this name.

Position and Locality. - In the carboniferous limestone of Craige, near Kilmarnock.

\section{Leptema (Chonetes) papilionacea (Phill. Sp.)}

Ref. and syn.= Spiriferce papilionacea Phill. Geol. York. t. 11. f. $6=$ Chonetes prpilionacea de Koninek. Monog. Chonetes, t. 19. f. 1. + C. comata id. id. f. 2. (not Productus comoides Sow.)

Desc.-Semicircular, flattened when young; hinge-line equal to the width of the shell, forming acute semielliptical cars; the hinge-line and sides meeting at an angle of $70^{\circ}$; the beak is very small, and scarcely projecting beyond the hinge-line; convexity of the middle of the shell varies considerably, but is generally small, and passes gradually into the flattened sides; at about an inch from the beak, or as the shell begins to acquire its adult form, a few irregular rounded longitudinal waves appear at the margin, the most regular and largest one being in the middle, and from this point the margin becomes regularly arched with a semicircular profile, giving the adult shell a very gibbous, transversely fusiform figure, sometimes rendered slightly rhomboidal by the prominence of the middle, the gibbosity of the middle of the shell gradually passing into the conoidal ears; cardinal area of both valves rhomboidal if taken together, ten times wider than high, that of the receiving valve nearly twice as wide as that of the entering valve, and its edge set with about nine or ten small, short, triangular spines, directed strongly outwards and backwarls on each side of the beak. Entering valve nearly as concave as the receiving one is convex. Surface of both valves marked with fine, close, flexuous, rounded strie, crossed by microseopic lines of growth, separated by very narrow, strongly punctured, impressed lines, almost uniform in size on all parts of the shell (fourteen in two lines at ten lines from the beak, the same number in the same space at four inches from the beak); substance of the shell thick. Internal casts of receiving valve in old specimens marked with coarse pits, and small elongate lacunæ, forming a very coarse, interrupted, irregular sulcation near the margin; adductor impressions large, ovate, but not very deeply defined. Proportions of small specimens two and half inches wide, proportional length $\frac{6 \mathrm{in}}{1 \mathrm{im}}$, depth of both areas $\frac{8}{110}$, depth of receiving valve greatest at one-third from the beak, varying from $\frac{10}{100}$ to $\frac{15}{1 \mathrm{mw}}$; adult specimens seven inches wide, proportional length $\frac{55}{100}$, depth $\frac{25}{100}$, thickness of the shell at this latter size two lines.

This beautiful species seems extremely different in its young and old stages, the young being semicircular and flattened or only moderately gibbous in the middle, and very regular; while the adult has some of the irregular, unsymmetrical, rounded, longitudinal folds, as well as the size and general form of Proclucte gigantea. Even in the young state, however, as I have mentioned, there is great variation in the depth of the receiving valve, no two specimens being exactly alike. To the flattened ones M. de Verneuil and M. de Koninck retained Mr Phillips' specific name of Papilionacea, and to the more gibbous forms they apply Sowerby's name, comoides. This latter species of Sowerby I think to be an entirely different shell of great rarityl(of which a specimen exists in the Bristol Museum), having coarser strix, broad, nearly parallel-sided, cardinal area, \&c. In all its varieties the very fine, uniform, close, flexuous stria distinguish this species from any others of similar size. Even the limits in the dimensions of the stria given by M. de Koninck in his Monograph of Chonetes for papilionacea, shew that there is no difference in this respect between that and the shell he gives as $C$. comoides, although he seems to consider this supposed difference a distinguishing character for the two species; the other distinction, viz. the young being wider than the old, is commonly seen in the allied species.

$$
\text { [FASC. III.] }
$$


I know of no figure representing the large, subrhomboidal, or fusiform adult. I think I sce a trace of small dendritic impressions between the adductor impressions, as in Productus, but an not sure.

Position and Locality.-Common in the lower carboniferous limestone near Kendal; the dark, lower, limestone of Ronalds-way, Isle of Man; dark carboniferous limestone of Dalton in Furness, Lancashire.

\section{Leptena (Chonetes) polita (Mc Coy). Pl. 3. D. fig. 30. \\ Ref.-Id. MCoy, Ann. Nat. Hist. 2nd Series, Vol. X.}

Desc.-Transversely fusiform; hinge-line exceeding the width of the shell, forming narrow, semicylindrical, convoluted ears, each bearing four or five small spines. Receiving valve nearly hemispherical, very gibbous in the middle and towards the beak, which is large, inflated, and seems considerably to overhang the hinge-line from the abrupt contraction of the ears, which are separated by an abrupt curve from the steeply sloped sides; front margin slightly elevated in a broad wave, extending its whole width; no mesial furrow. Entering valve almost as concave as the receiving one is convex; cardinal area about ten times wider than high; substance of the shell thick. External surface of both valves perfectly smooth, or, under a strong lens, with minute concentric strix of growth near the margin; internal cast of receiving valve marked with very large quincuncially arranged punctures, usually about twice their diameter apart; rostral portion divided by a narrow slit left by the mesial septum, extending less than half the length of the shell. WVidth of large specimen four and half lines, proportional length of receiving valve $\frac{70}{100}$, depth $\frac{35}{100}$.

This species has much the form of Leptance (Chonetes) rolva ( $\left.\mathrm{MI}^{\mathrm{c}} \mathrm{Coy}\right)$, but is not so wide, it is more gibbous, and it is the only carboniferous species I know at this date that has a smooth surface. The measurements above are from a large Irish specimen in the collection from Mount Rath, the English one being only two lines wide.

Position and Locality.-Rare in the dark carboniferous limestone of Lowick, Northumberland.

Explanation of Figures.-PI. 3. D. fig. 30. Magnified four diameters, shewing the very coarse scattered punctures, and small mesial septum of the internal cast; and the thick shell, and the smooth external surface on the lower right hand portion. The line above indicates the natural size.

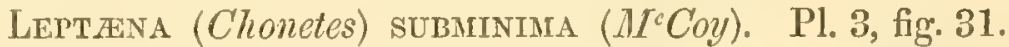

\section{Ref.-Ann. Nat. Hist. 2nd Series, Vol. X.}

$D e s c$ - Rotundato-quadrate, length three-fourths or four-fifths of the width. Receiving valve very gibbous in the middle, greatest depth a little behind the middle; hinge-line as long as the shell is wide, forming flattened ears, slightly acute from the sigmoid outline of the sides, having three or four moderately long, slender spines on each side of the beak, extending backwards as usual in the plane of the margin; front margin moderately convex. Surface uniformly covered with close obtuse stria, once or twice branched, but nearly uniform in size on all parts of the shell, and so fine, that twelve at the margin only occupy half a line when decorticated; the impressed lines between the strix of the surface very coarsely punctured, and the beak slit by the deep impression of the mesial septum, extending half the length of the shell. Entering valve nearly as concave as the recciving one is convex; surface similar in both valves, the strix being crossed by fine close lines of growtl. Average width one and half lines, the depth seems about half the width.

This little species is so extremely like the Silurian Leptence minima, that it required a comparison of the specimens to distinguish them, more especially as the spines of the hinge-line of the present species are not often seen; the carboniferous fossil has more miform and less branched stria, and they are so much finer than in the Silurian species, that double the number is uniformly found to occur in the same space of half a line near the margin. It is possible that this may prove identical with the Leptena gibberula of my volume on the mountain limestone fossils of Ircland, t. 20. f. 11. (which certainly has no relation to my L. cressistria and sulcato, with which MI. de Koninck unites it); but as I there described the width as rather greater, and do not give the absolute dimensions of the fine strix, I hesitate to unite them without a comparison of specimens. 
Position and Locality. - Very abundant in a piece of the black upper carboniferous limestone of Derbyshire. Erplanation of Figurcs.-Pl. 3. D. fig. 31. Magnified six diameters; the lower and right hand portions shew the external shell, and longitudinally sulcated surface, the remainder of the figure shews the close lines of strong punctures, and small mesial sulcus of the beak, as exhibited on internal casts; the line above sherrs the natural size.

\section{Subgenus. STROPHALOSIA. See page 387. \\ LEPT zena (Strophalosia) CANCRini (M. V.K.Sp.)}

$R \cdot f$. and Syn. = Productus Cancrini Murchison, de Verneuil and Keyserling, Geol. Rus. p. 273. and de Koninck, Monog. Prod. t. 11. f. $3=$ Strophalosia DIorrisiana King, Perm. Foss. t. 12. f. 18 to 32?=Orthothrix lamellosus Geinitz, Verst. t. 5. f. 16.

Desc.-Rounded, greatest width about the middle; hinge-line rather less than the width of the shell, forming obtuse-angled, inconspicuous, flattened ears. Receiving valve slightly longer than wide, evenly gibbous, most so in the middle, without mesial sinus; varying greatly in depth, the posterior or rostral half more arched in the profile than the front; no mesial hollow; beak small, obtuse, strongly incurved, and slightly projecting beyond the hinge-line; cardinal area low, triangular; foramen and pseudo-deltidium higher than wide. Surface covered with very fine, filiform, equal, oceasionally interrupted strie (about twenty in two lines at six lines from the beak), about the same size in all parts of the shell, with very irregularly seattered spine bases, which are round on the sides, but form eylindrical, very prominent, longitudinal ridges, one to two lines long, and as thick as two or three of the strie on the middle portion of the shell. Entering valve moderately concave, leaving a considerable space for the animal, with a very narrow cardinal area; surface usually with strong concentric lines of growth, which obseure the longitudinal strix and the spine tubes, which latter are more rounded than in the receiving valve; cardinal teeth and internal impressions as in the generic character. Average length one inch, width a little more or a little less than the length, proportional depth $\frac{52}{100}$.

Professor King distinguishes his S. 1Iorrisiana from the Russian S. Cancrini by its being, wider than long, and more depressed, but nearly all his figures of receiving valve are longer than wide; and a specimen presented by him to the Cambridge collection has a greater proportional depth than one of the proportional measurements given for $P$. Cencrini in the Geology of Russia. I have little doubt therefore of the identity of the species, and would have none, but that MM. Murchison, de Verneuil, and Keyserling, seem to deseribe the strixe as coarser than I observed them in the English species.

The absence of the ears gives most specimens an ovate outline, widest in front.

Position and Locality.-Common in the Permian magnesian limestone of Humbleton Hill.-(In Russia it seems to abound everywhere in the lower stage of the Permian).

\section{Leptana (Strophalosia) Excavata (Geinitz Sp.)}

Ref. and Syn. = Orthis excarata Geinitz, Neues Jahrbuch for 1842.t. 10. f. 12, 13= Orthothrix id. id. Versteinerungen, t. 5. f. 30 and 37. t. 6. f. 20 = Strophalosia id. King, Perm. Foss. t. 12. f. 13 to 17.

Desc.-Rounded or transversely very broad-oval, the greatest width at about the middle of the length; hinge-line scarcely two-thirds the width of the shell, forming scarcely perceptible ears. Receiving valve evenly gibbous, greatest depth rather behind the middle, rostral portion broad, tumid; beak small, scarcely passing the hinge-line. Entering valve deeply coneave; cardinal area of both valves together about four times wider than high. Surface of both valves with a few concentric lines of growth, and covered with rery numerous, minute, tubular, spine-bases, a little more than their diameter apart, arranged subquincuncially, or sometimes in obscure lines, divaricatingly arched from the beak to the lateral margins (seven or eight in two lines at four lines from the beak). Width seven or eight lines, proportional length of receiving valve $\frac{25}{1 w}$, length of entering valve $\frac{z}{i m}$, depth of receiving valve $\frac{46}{14}$, depth of entering valve $\frac{33}{1 v 0}$. Internal impressions as in $S$. Guldfussi, but the reniform impressions longer. 
I have not quoted the Proluctus Geinitzanus of de Koninck as a synonym of this species, as Professor King recommends, because I think that species is clearly the young of Strophlatosin horrescens, as Professor de Koninck himself suggests; nor have I, as the author of the MIonograph of English Permian Fossils also suggests, quoted de Koninck's $P$. Levisi as a synonym, although it seems very closely allied, because I have not seen the distinct, narrow, mesial hollow in any of the English specimens; but as Mr Lewis collected the type specimens at Humbleton, I have little doubt that that species must ultimately be merged into the present one. I find this species in Count Münster's collection from Gliicksbrunn under the very characteristic manuscript name Producta spinosissima, which well expresses the character which distinguishes the species from all others, namely, the very small size and great number of the spines. The more regular rounded form, broad, short rostral portion, and comparatively low cardinal area, separate this species well from the accompanying $\$$. Goldfussi.

Position and Locality.-Common in the Permian magnesian limestone of Humbleton.

\section{Lepterna (Strophalosia) Goldfussi (Miinst. Sp.)}

Ref. and Syn.= Spondylus Goldfussi Münster, Beitr. Vol. I. t. 4. f. 3 = Productus Goldfussi de Koninek, Monog. Prod. t. 11. f. 4 = Strophalosia Goldfussi King, Perm. Foss. t. 12. f. 1 to $12+$ S. parva id. id. f. 12. f. 33.

Desc.-Receiving valve moderately convex, longitudinally ovato-trigonal; greatest width near the front margin, gradually pointed towards the beak, which is large, obtusely pointed, projecting much beyond the hinge, but very slightly incurved, the cardinal area being about twice as high as wide, triangular, and very little curved; beak often inelined to one side; sides often unsymmetrical; hinge-line much less than the width of the shell; a more or less distinct mesial furrow extending from the beak to the front margin. Entering valve slightly concave, leaving a considerable space for the animal. Surface of both valves with rather strong, small, irregular, concentrie lines and waves of growth, and closely set with minute, subquincuncially arranged, round, or ovate spine-bases, usually three or four times their diameter apart, and nearly uniform in size on all parts of the shell (about five or six in two lines measured transversely), concentric imbrications strongest on the entering valve, spines when preserved, slender, crowded, interlacing, those of the receiving valve directed backwards towards the beak, and serving to attach the shell to foreign bodies, those of the entering valve converging towards a central point; interior of entering valve with a strong, prominent, rostral tooth, from which the mesial septum extends nearly half the length of the shell; at about half its length close on each side is a prominent, rather large, ovate boss, from which the prominent edge of the large reniform impressions curve outwards and forwards on each side, returning with a sigmoid curve to the anterior extremity of the septum; pits for the cardinal teeth of the receiving valve strongly marked. Length of average specimen eight, lines, proportional length of entering valve ${ }^{8 /}$ in, greatest width $\frac{95}{100}$, depth of receiving valve $\frac{40}{100}$, depth of entering valve $\frac{15}{100}$.

The form of this species is very variable and often unsymmetrical. The attenuated posterior end (from the length of the beak) distinguishes it easily from its allies. In some spots the spine-bases are more crowded than is indicated above. I observe small, much twisted tracks of a Permian Tioa in this sleell not uncommonly.

Position and Locality.-Common in the Permian magnesian limestone of Humbleton.

\section{Genus. PRODUCTA (Sow.) See page 390.}

\section{Producta aculeata (Mart. $S p$.)}

Ref. and $S y n_{0}=$ Anomites aculeatus Martin, Pet. Derb. t. 37. f. 9 and $10=$ Productus id. Sow. M. C. t. 68. f. 4

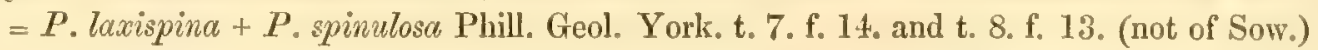

Desc.-Receiving valve elongate, ovate, extremely gibbous, front and sides regularly tumid; bcak very large, tumid, much incurved, projecting beyond the hinge-line; hinge-line rather less than the width of the shell, forming very small, flat, easily broken, obtuse-angled, inconspicuous ears. Surface with delicate, thin, imbricating laminar lines of growth, at irregular distances; surface covered with irregularly scattered, rather distant, pointed spine bases, which towards the margin of the older specimens give origin each to an obscurely marked, broad, 
rounded, longitudinal ridge, varying in strength and persistence in different specimens, but generally short and faintly marked; most of the spines have the appearance of being directed towards the beak, but some of them are at right angles to the surface, and the spines to which thcy give origin are gently arched towards the front. Entering valve transversely oblong, very concave, and nearly smooth in many specimens, but in all, the spinebases and short longitudinal furrows therefrom, as in the receiving valve, may be observed. Length of receiving

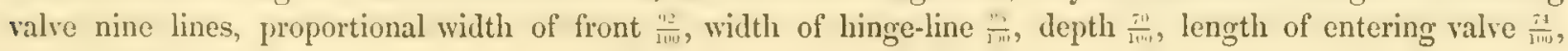
depth of entering valve ${ }_{100}^{30}$.

Although the adpressed character of the spines, or their points sceming to be directed towards the beak, noticed by Martin and Sowerby, is very striking in typical Derbyshire specimens, yet even in them some few of the spines will be noticed to be at right angles to the surface, and others slightly inclined the contrary way, as the spines themselves always are, and as M. de Koninck seems to think is always the case. Old specimens are even more elongate, arehed, and narrower in the receiving valve, than the above averaged proportions, and in such specinens the obsolete ribbing from the spine-bases becomes more regular and continuous. The Prodlucte laxispinu of Plillips is clearly the impression of the entering valve of this species, as well as his $P$. spinulosc (Sow.), which has too few and irregularly placed spine-bases to be referred to that species; such impressions commonly shew the spine marks more strongly than the concavity of the shell itself.

Position aul Loculity.-Rare in the carboniferons limestone of Craige near Kilmarnock; not uncommon in the impure earboniferous limestone of Lowick, Northumberland; not uneommon in the middle limestone of Poolwash, Isle of Man.

\section{Producta corrugata ( I $\left.^{\circ} \mathrm{Coy}\right)$.}

Ref. and Syn.-Id. id. MIcCoy, Carb. Foss. Irel. t. 20. f. $13 ;=P$. tenuistriatus M. V. K. Geol. Russ. t. 16. f. $6=P$. Cora de Koninek, Monog. Prod. t. 4. f. 4. (not d'Orb.)

Desc.--Senicylindrical, very gibbous; visceral portion of receiving valve hemispherieal, passing gradually into the front, which descends at an angle of $45^{\circ}$; beak tumid, broad, incurved; hinge-line very short, inconspicuous in the receiving valve; cardinal angles obtuse, giving rise to three or four very large rounded wrinkles, which become rapidly effaced on the tumid sides before reaching the front, across which only very faint interrupted waves of growth may be oceasionally seen. Surface covered with slightly flexuous, regular, narrow, rounded, thread-like strix (about twelve in two lines at one inch from the beak), alternately larger and smaller on many parts of the surface, from the new intercalated strise remaining for the greater part of their length less than half the thickness of the original ones; intervening sulci deep, much narrower than the strix, except when the outer layer of shell is removed, when they nearly equal them in width (as in my figure); no spines

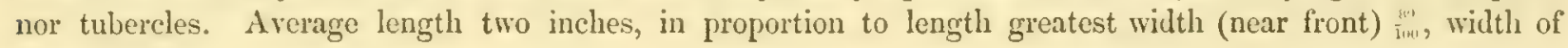
linge-line $\frac{45}{100}$.

It is only in cases where the shell has been probably fractured during the lifetime of the animal, that the irregularities, mutual absorption, \&e. of the strix alluded to by M. de Verneuil occur, for in ordinary cases, as M. de Koninck observes, the strix in this species are remarkable for their rigid regularity; they remain about the same size on all parts of the surface, and do not seem ever to bifureate. M. de Koninek, in his Monograph of Productus, refers this species with the $P$. Nefiedievi of de Terneuil to the Producter Cora of d'Orbigny, a rapprockement which I find it impossible to agree with, as the South American shell is figured with a long lingeline, acute ears, none of the very large characteristic lateral wrinkles of this species, and the surface with large scattered spinose tubercles, and the strize separated by furrows much wider than their own thickness, agreeing in general shape and this latter character of the strix with the $P$. Neffedicri, to which it may possibly be allied, although that species seems also to want the great scattered spine bases, which never occur on my specics, in which also, even when the shell is removed, the sulci between the strix are less than the strix in width, which M. de Verneuil states is not the case in the $P$. Neffedieri. In general form this slightly resembles the $P$. hemingluerica, but the front is more produced and less curved in the profile; the striae are narrower and more distant, and the great size of the few wrinkles on each side separate this species at a glance from all others 
that I know. I have not seen the entering valve, but MI. de Koninck states it to be flattened and concentrically wrinkled in the visceral part, and to follow the receiving valve closely on the descending front.

Position and Locality.-Rare in the lower limestone of Kendal; small, more finely striated variety, with a few little spines, rare in the dark carboniferous limestone of Lowick, Northumberland.

\section{Producta costata (Sow.)}

Ref.-id. Sow. Min. Con. t. 560. f. 1 ; id. id. M. V. K. Geol. Russ. t. 15. f. 13.

Desc.-Scmicylindrical, short, suloquadrate, sides subparallel, the front a little wider at margin than at its junction with the visceral disk; sides slightly convex, rapidly sloping to the thick inrolled conical ears, which project abruptly from them; each ear with a large, rugged, semicircular ridge set with large spines, and separated from the side of the shell by a nearly smooth sulcus. Receiving valve with the profile of the front gently convex, but abruptly arched over, nearly at right angles, to form the moderately convex visceral disk; a very deep, wide, obtusely angular sinus extends nearly from the beak to the front margin; whole shell with eighteen to twenty very thick, broad, convex, irregularly unequal, longitudinal ribs (measuring three in four lines on the front), some of which support a single, strong, cylindrical spine; intervening sulci deep, concare, much narrower than the ribs; the longitudinal ribs smaller, more equal, and more numerous on the rostral portion (two, three, or four of these often coalescing to form one of the ribs of the front), where they are crossed by regular concentric wrinkles, equalling them in size and distance from each other, thus producing a regular reticulate tubcreulation, between which the transverse or the longitudinal furrows seem largest according to the direction of the light. Greatest width (along the hinge-line) one inch eleven lines, proportional length of front $\frac{55}{1011}$, length of visceral disk $\frac{33}{200}$, width of front $\frac{65}{100}$.

As M. de Koninck has already observed in lis often-quoted Monograph of this genus, the circumstance that M. de Verneuil described internal casts sufficiently accounts for the differences in the proportional difference in the ribs and sulci, as given by that excellent writer and other people. The ribs being so very large, and the shell being thin, gives an appearance to the internal casts nearly like that of the exterior, with the difference that the ribs seem much narrower, and the sulci much wider. The remarkable character of the more numerous ridges of the visceral disk, uniting to form the fewer and thicker ribs of the front, is generally seen most strongly about the middle of the specimens, where as many as three or four commonly unite to form a rib of the front; on either side of this set there are not more than two coalescing to form a front rib, and the greater number of ribs are simple from the front margin to the beak. The thick conical ears are nearly smooth, except the thick, rugged, spinose ridge near their base. The transverse lines of growth alluded to by most writers are very close, fine, and barely perceptible to the naked eye, not comparable to the transverse lines of Sowerby's figure, which, together with the perfect flattening represented therein, may have been produced by wear. I have not seen the entering valve, but it is described as resembling the receiving one except in the flatness of the visceral disk, leaving as great a space between the valves as in the $P$. semireticulata.

Position and Locality.-Rare in the dark carboniferous limestone of Lowick, Northumberland.

Producta elegans $\left(M^{\circ} \mathrm{Coy}\right)$. Pl. 3. H. fig. 4.

Ref.-McCoy, Synop. Carb. Foss. Trel. t. 18. f. 13.

Desc.-LLongitudinally ovate; receiving valve extremely gibbous, arcuato-conical; beak very large, rounded, incurved below the hinge-line; hinge-line rather less than the width of the shell, cars very small, slightly obtuse, not abruptly defined. Surface with about sixteen, regular broad, subequal, transverse ridges, rery obtusely angulated in the middle, each having three or four rows of small, close-set, spinulose puncta on the rostral portion, which is considerably narrower than the anterior unpunctured portion, which forms a broad, smooth, or concentrically striated band between each of the narrow spinulose bands (two punctured and two smooth bands in a space of two lines at five lines from the beak). Entering valve very slightly and regularly concave, with 
very regular coneentric ridges, smaller and closer than those of the receiving valve (four punctured and four smooth bands in the space of two lines at four lines from the beak). Length seven lines, proportional width $\frac{87}{100}$, length of entering valve $\frac{80}{100}$, depth of receiving valve $\frac{47}{100}$, depth of entering valve $\frac{15}{100}$.

This species is intermediate in all its characters between Producta punctata and Producta finlbriete, but is perfectly distinct from both as a species: it agrees with the former in the muerous, instead of single rows of spinules on each concentric band, while it differs from it, and agrees with the $P$. finlriata, in the elongate-ovate form, absence of mesial furrow, and very great gibbosity of the receiving valve, differing however from it in the smaller size, greater number of concentric bands in a given space at the same distance from the beak, and in having several rows of minute punctures, instead of a single row of elongate tubercles on each band. M. de Koninck, without jrobably having seen the species, refers it to the young of $P$. menctata, but it is greatly more gibbous, has more angular transvere loands, which are very different from those of $P$. punctata by their very narror punctured space on the rostral edge compared with the wide unpunctured portion, the reverse of what is seen in that species.

Position and Locelity.-Not uneommon in the dark carboniferous limestone of Lowick, Northumberland, and the similar limestone of Kendal, Westmoreland.

Explanation of Figures.-Pl. 3. H. fig. 4, entering valve natural size; fig. $4 \alpha$, do. profile of receiving valve; from the carboniferous limestone of Lowick, Northumberland; fig. $4 b$, do. front view ; fig. $4 c$, portion of surface magnified.

\section{Producta finibriata (Sovv.)}

\section{Ref.-Id. Sow. Min. Con. t. 459. f. 1; de Koninck, Monog. Prod. t. 12. f. 3. ’}

Desc.-Longitudinally ovate; hinge-line slightly less than the width of the shell. Receiving valve very convex in the middle; profile greatly arched; beak very large, prominent, and incurved below the hinge-line; cars very small, flattened, obtuse-angled. Surface regularly traversed by concentric prominent bands, each becoming obtusely angular in its middle towards the sides of the shell, and being throughout its rostral half fringed by a single row of elongate tubereles, each punctured at its distal extrenity (about five in two lines in middle of shell); the anterior half of each band marked with fine, waving, concentric lines of growth (two bands occupy three lines at six lines from the beak). Entering valve truncato-orbicular, gently and slightly concave, with regular concentric ridges (about four in three lines at six lines from the beak), on each of which is a single row of tubercles, more rounded than those of the receiving valve; no mesial furrow in either valve. Average length ten lines, proportional length of entering valve ${ }_{i \ldots,}^{n,}$, width valve $\frac{15}{100}$.

There heing but a single row of rather large spine-bases, instead of the numerous rows of minute spines and punctures on each concentric band, separates this species easily from $P$. punctata, and its great gibbosity from the $P$. laciniata ( $\triangle^{\mathrm{e}} \mathrm{Coy}^{\mathrm{C}}$ ); the small size, elongate form, fewer, and more distinct, spiniferous ridges with the tubercles only crossing half of their width, and their occurring on the sides as well as on the middle of the shell, separate it from $P$. pustulos $\alpha$.

Position and Locality.-Abundant in the dark carboniferous limestone of Lowick, Northumberland; in the similar limestone of Kendal, Westmoreland; conmon in the lower part of the carboniferous limestone of Derbyshire; carboniferous limestone of Poolwash, Isle of Man; carboniferous shale of Beith, Ayrshire.

\section{Producta Flemingi (Sow.)}

Ref. and Syn.=(P. longispinus Sow. M. C. t. 68. f. $1+P$. Flcmingi id. id. t. 68. f. $2+P$. lubatus id. id. t. 318. f. 2 to $6+P$. sulcatus id. id.t. 319. f. $2 ; ?+P$. costellata $M^{c}$ Coy, Syn. Carb. Foss. Irel. t. 20 . f. $15+[P$. purilis Phill. Geol. York. t. 8. f. $6=P$. tuburius Keyserling, Reise in das Petschora Land, t. 4. f. 6]) = P. Flemingi de Koninck, Monog. Prod, t. 10. f. 2.

Desc.-Subcylindrical, elongate, quadrangular; sides steep, nearly parallel; front flattened or slightly convex, usually a narrow mesial furrow, varying very much in strength, or sometimes absent, becoming obsolete 
at about half the length of the visecral disk from the beak, but always increasing in depth on the descending front to the margin when present; hinge-line as wide as the shell, forming very small conical ears, projecting from the steep sides of the shell, with usually a large spinose ridge between them. Receiving valve with the visceral portion gilbbous, much arched, crossed by numerous, small, obtuse, slightly undulating, and interrupted concentric wrinkles, about twice as far apart as the longitudinal striæ, which are not interrupted by them. Strix coarse, rounded, nearly of equal size on all parts of the shell, separated by deep, very narrow sulci (except when the outer layers are removed, when they about equal the strix in size), dichotomising at irregular distances into two equal ones, quickly acquiring their original thickness; several large spines scattered irregularly over the surface, and often causing two or more of the strice to join at the point of their insertion. Entering valve deeply inserted, flattened at the ears, moderately coneave at the sides, and with a mesial furrow corresponding with the more or less developed one of the opposite valve; the visceral portion with rather more numcrous and regular wrinkles than the receiving valve, which it joins at about one half the length of the deflected front, leaving a large space for the animal.

The shell I have called $P$. costellate in the above volume on the Carboniferous Limestone Fossils of Ireland resembles the $P$. sulcata in form, but is very spinose, and the ridges are remarkable for their irregular inequality in size, and greater coarseness and prominence; it is probably distinct, but possibly a varicty of the present species. There are three tolerably distinct varieties of this species, which, however, the examination of a couple of hundred of good specimens shews, pass insensibly into cach other in various ways: these varieties are:

1st $\operatorname{var} . P$. longispina.-In which there is scarcely any mesial furrow, the size is small, the concentric wrinkles on the visceral portion imperfectly marked, the striae slightly smoother and finer than usual. Its average

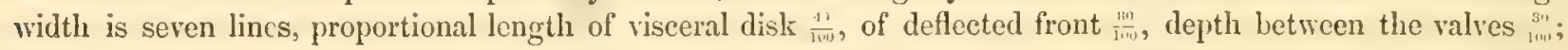
about nine or ten strix in the space of two lines near the front margin, the seattered spines seven or eight lines long, considerably thicker than the strix from which they originate.

This variety passes to the $P$. Flcmingi by getting the strie a little coarser, which again passes into the next by the most insensible and varied gradations.

2nd var. $P$. lobata (Sow.) - The extreme forms of this variety have the strixe coarser than the preceding (about six in two lines on middle of front), and a very deep, narrow, mesial sulcus from about the middle of visceral disk, gradually deepening to the front margin. The average width eight lines, length of visceral disk $\frac{53}{1 w 4}$, Iength of front $\frac{90}{100}$, the spines about equalling the thickness of the strix on which they are placed.

No two specimens of this variety agree in the depth of the sinus, which may be observed gradually to vanish in a handful of specimens, passing by this and the varying fineness of the stria into the preceding variety: when the specimens acquire a greater size, the two next varieties are observed to be produced in the most gradual manner.

3rd. var. P. sulcata (Sow.) - In this the average width is one inch seven lines, proportional length of visceral disk ${ }_{10+1}^{55}$, length of front ${ }_{111}^{72}$; about six strie in two lines on middle of front, depth between the valves $\frac{2 n}{1+11}$. In this variety there is generally a shallow mesial furrow from the middle of the visceral disk to the front margin, the strixe and general surface are even and regular, and there are few or no spines, except a semicircular row of very large ones on a rugged ridge between the ears and the steep sides of the shell. This variety is rare, and passes insensibly into the next, which is the most common of them all.

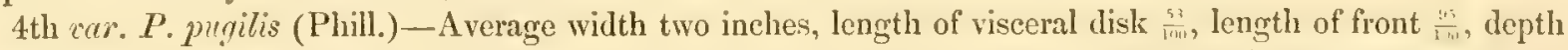
between the valves $\frac{30}{110}$. Strixe averaging six in two lines on middle of front. This varicty is remarkable for having the thick spine-bases scattered over the deflected front, about equal to two or rather more of the strix in width, and raising a bundle of four or five strix into a longitudinal ridge from one to two lines wide, extending from its base to the front margin, giving to well-marked specimens a strongly fluted character. This is the woll developed adult, and, by the diminution of size, less distinct fluting, smaller spines, \&c. may be gradually. seen to pass into all the preceding varieties: the spines on the semicireular ridge at the base of the ears are upwards of two inches long. For difference from $P$. semireticulata, see that species.

Position and Locality.-All the varieties common in the carboniferous limestone of Derbyshire; carboni- 
ferous limestone of Beith, Ayrshire; carboniferous limestone of Lowick, Northumberland; middle limestone of Poolwash, Isle of Man. Var. pugilis and var. Flemingi, carboniferous shale, Berwick on Tweed; carboniferous shale, Glasgow. Var. pugilis, carboniferous limestone, Dent; carboniferous limestone, Dalmellington, Ayrshire; coal shale, Glasgow; carboniferous limestone, Flintshire; red carboniferous limestone, Closeburn, Dumfriesshire.

\section{Producta gigantea (Mart. Sp.)}

Ref. and Syn.=Anomitcs gigantens Martin, Pet. Derb. t. $15=$ Productus giganteus Sow. Min. Con. t. $320+$ $P$. latissima Sow. id. t. 330 (Young) $+P$. crassa Mart. Sp. (variety with short ears) ; ? P. Edelburgensis Phill. Geol, York. t. 7. f. 5 (young of last vár.) + P. Scotica Sow. Min. Con. t. 69. f. 3, and t. 561. (This latter plate was originally published separately by Mr. Sowerby with the name $P$. Scotica, but was subsequently given as a number of the Min. Con. as $P$. hemisphervece, with which it is probably not identical).

Desc.-Transversely oval; hinge-line exceeding the width of the shell, forming ears which are semielliptically pointed, flattened when young, becoming semicylindrically enrolled with age, and either passing gradually and conoidally into the body of the shell ( $P$. latissime Auct.), or more commonly separated abruptly from the highly inclined sides of the very gibbous body of the shell ( $P$. niganted Auct.), oceasionally the gradual passage on one side, and the abrupt definition on the other, of a single specimen; body of the shell of great but rery variable gibbosity; profile greatly arehed from the beak to the front margin; beak usually very large, gibbous, except at the apex, and not much orerhanging the hinge-line. Surface entirely covered with thick, obtuse, flexuous stria, dividing and anastomosing irregularly, nearly as coarse at the beak as at the front margin, varying from eight to thirten in a space of three lines, the intervening sulei being usually less than the strix in width, all crossed by microsenpic lines of growth; the general surface is even fur about one inch from the beak of the receiving valve, beyond which there are usually a very variable number of perfectly irregular, fold-like, rounded ridges, increasing in strength towards the margin, commonly a little more or less than onefourth of an inch wide, and separated by concave spaces about the same size; spines few or moderately numerous, small, but thicker than the strix, which they often interrupt and deflect, irregularly scattered. Entering valve almost as concave as the receiving one is convex, (greatest intervening space only two lines in a specimen six inches wide), and marked similarly in all respects, exeept a slightly flatter beak, and the longitudinal folds not developed till about two inches from the beak. Internal casts: receiving valve with the two bosses left by the large adductor impressions, finely sulcated longitudinally, moderately prominent, each rotundatoquadrate (in most specimens the finely suleated portion at least as long as wide, very rarely the width one-third greater than the length), and about their length apart; from their posterior margin, the triangular, comparatively smooth, broadly suleated space (alductor impressions), extends to the beak, having between them the large and very complexly lobulated dendritic impressions; in front of the adductor impressions may often be seen the impressions of two large, nearly circular, shallow envities, the obtuse boundaries of which are larger on the outer than on the inner margin, obviously corresponding to the circularly inrolled, arn-like lobes, the impressions of which are scen on the opposite valve; beyond these are traces of obseure, straight, longitudinal impressions of pallial ressels; internal surface beyond the visceral impressions spinulose, with sharp tubercles having an irregular quineuneial arrangement, falling gradually into rugged lines towards the margin ; interior of entering valve with a stronger septum than the other, with a large cardinal boss, the dendritic impressions more regular and ovate than in the other; near the end of the septum on cach side a rather large, smootl, oval boss (? insertion of adductors), from the outer side of each of which a narrow, strap-shaped, smooth, impression with prominent edges curves outwards, forwards, and a little inwards at its rounded extremity, from which an obscurely-defined smoothness of the surface forms a circular continuation, probably indicating the place of the inrolled fimbriated arm-like lobes of the animal; beyond these the surface is spinulose. Average width seven

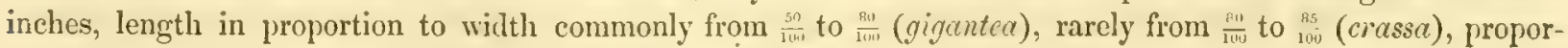
tional deptl about $\frac{30}{100}$ in var. gigantea, varying from $\frac{\dot{\circ}}{\frac{0}{000}}$ to $\frac{45}{100}$ in var. crassa.

The magnificent suite of this species presented by the Rev. Mr Jenkinson to Professor Sedgrwick, and [FASC, III.] 
now in the University collection, enables me to state positively that the distinetions relied on by M. de Verneuil in the Geology of Russia, and M. de Koninck in his Monograph of Productus for separating the P. latissima from the $P$. gigantea, do not really exist; several specimens in the collection shewing in one individual the gradual conoidal passage of the ear into the body of the shell (as in P. Tatissima) on the one side, and a narrow subcylindrical ear, projecting abruptly from the side of the defined gibbous body of the shell (as in the P. gigantec) on the other; the other characters mentioned as distinctive by them and the older authors, such as thinness of the shell, and few or no longitudinal folds, greater dcpression of the cars, Ste., are characters of the young shell, and particularly of the entering valve; further, both forms (contrary to what those authors suppose) occur together in abundance in the same bed in Northumberland. The careful proportional measurements which I have made of a great number of specimens, the extremes of which I have given above, prove in like manner what I could not otherwise have anticipated, that the P. crossc of Martin is only an extreme variety of the $P$. giganted; as that acute observer himself thought probable, and as I have now traced the passage in the most gradual manner. Young specimens six lines long are rather more than twice as wide as long, only slightly convex, transversely elliptical, with obtusely elliptical ears, having coarse rounded sulci (about seven in three lines at four lines from the beak, where they first dichotomise); after this size the beak and ears, particularly of the entering valve, begin to inroll rapidly. I believe the form called $P$. Eidelburgensis by Phillips cannot be kept apart when many specimens are examined; for I have counted the same number of stria in a given spot on highly typical specimens of $P$. giguntea, which M. de Verneuil gives as distinetive for P. Edelburgensis; the flattening of the ears given by him and Phillips is manifestly variable in the specimens before me, and spines certainly also oceur on specimens otherwise agreeing with $P$. Edelturgensis. The variety named $P$. Scotica seems certainly to be founded on young examples of the less transverse varieties, and to be distinguished by its spines, coarse irregular strix, and form of the muscular impressions, \&c., from the true $P$.hemisphorica; which see.

Position and Locality.-Common in the black carboniferous limestone of Dalmellington, Dumfriesshire; common in the grey lower carboniferous limestone of Derbyshire; very abundant in the dark limestone of Lowick, Northumberland; common in the limestone of Corwen; black limestone of Craige, near Kilmarnock; red limestone of Closeburn, Dumfriesshire; in the limestone of Kendal; dark limestone of Ronalds-way, Isle of Man.

\section{Producta hemispitarica (Sonv.)}

Ref. and Syn. Id. id. Sow. Min. Con, t. 328. < Producte aurita Phill. Geol. York. t. 7. f. 6.

Desc.-Shell hemispherical, regular, margin even. Receiving valve evenly gibbous in the middle, and gradually and equally sloping towards the front and side margins. Entering valve nearly as concave as the receiving one is convex; hinge-line equal to the width of the shell, forming short, obtusely-rounded, convex ears, passing gradually into the margin, but rather abruptly defined from the body of the shell; the hinge-line often with a crowded pectinated row of short, slender, curved spines. Radiating striae close, obtuse, convex, regular, scarcely flexuous, scparated by very slender impressed lines (averaging eight or nine, rarely six, in two lines, at one inch from the beak) nearly equal; the young intercalated strixe reaching the thickness of the others at about half an inch from their origin, smooth without spines; ears with small, short, irregularly transrerse plien, becoming quickly olssolete. A rerage width two inches six lines, in proportion to width, length of receiving valve $\frac{67}{100}$, of entering $\frac{63}{100}$, depth $\frac{40}{100}$, space between the valves $\frac{7}{100}$.

In this species the entering valve is almost as concave as the receiving one is convex, so that there results hetween them an excedingly small space for the animal; the $P$. personute (Sow.) is probably an internal cast of this species. The internal casi of receiving valve is very different from that of the $P$.gigantea, even when specimens of the same size are compared, most remarkably so in the proportion of the closely sulcated or anterior portion of the great muscular impressions, which in the present species are twice as wide as long, and separated by a space equal to about twice the height of that portion, while in $P$. gigantec the same closely striated anterior muscular impressions are at least as long as wide, and sciparated by a space only equal 
to once the length of those impressions. The regularity of the strix, even. hemispherieal form, and want of the numerons thick, scattered, spine tuhereles, separate this species externally from all the varieties of the $P$. giganted (Sow.); the less gibbous form, more obtuse and closer strix (which are also more equal from the greater rapidity with which the interealated strix arrive at the thickness of the others), and want of the great lateral wrinkles, separate it from the $P$. corrugata $\left(\mathbf{M}^{\mathrm{c}} \mathrm{Coy}\right)$.

Position and Locality.-Common in the carboniferous limestone of Kendal; lower carboniferous limestone of Derbyshire; carboniferous limestone near Chepstow, Gloncestershire; in the dark lower carboniferous limestone of Ronalds-way, Isle of Man.

\section{Producta horrida (Som.)}

Ref. and Syn $=$ Grypthites aculeatus Schlot. Taschenb. t. 4. f. 1. and 2. (not Prod. aculeatus Sow. $)=($ Prod. horrida Sow. Min. Con. t. 319. f. 1. +P. calva id. id. t. 560. f. 2. to 6.) =P. Hoppei König, Icon. Foss. t. 9. f. 108. $=P$. tubuliferus Deshayes $=P$. horridus (Sow.) King, Perm. Foss. t. 10. f. 29. to 31. and t. 11. f. 1. to 13 .

Dese-Quadrate, hinge-line as long as the shell is wide, forming Jarge, obtusely rounded, slightly convoluted ears in the adult (but small rectangular ones in the young). Receiving valve extremely giblons, with a deep, wide, rounded, mesial furrow, commencing near the apex of the beak, and extending to the front margin; jrofile almost semicireularly arehed, but the curve of the visceral portion smaller and more abrupt than that of the front; beak small and only slightly projecting beyond the hinge-line; sides very steep, or nearly rertical in some specimens; one or two rows of large cylindrical spines running nearly parallel with the hinge-line on each side, the rest of the valve either without spines or with a few large scattered ones, or more rarcly having obscurely longitudinal rows of eight to ten rather smaller ones, those nearest the margin always largest. Surface crossed by rather strong, irregular, imbricating lines of growth, and either even or obscurely and irregularly ridged longitudinally. Entering valve also with one or very rarely two long cylindrical rows of spines, projecting externally like those of the receiving valve; convex externally near the ears, and obtusely rounded longitudinally, mesial furrow and the intervening spaces on each side only moderately concave, leaving a very deep space letween the valves for the animal. Average width one inch seven lines, proportional length of receiving valve $\frac{200}{1100}$, of entering valve $\frac{67}{100}$, depth of receiving valve $\frac{15}{100}$, depth of entering valve $\frac{20}{100}$.

Some specimens of this species are considerably higher, narrower, and more parallel-sided than others; and though some authorities believe those varieties characteristic of separate localities, I have found them together in the limestone of Humbleton. Some varieties are nearly free of large spines on the body of the shell, forming the P. Culve of Sorrerby, while others identical have them in all the varieties noted above. The internal easts of the receiving valve have the muscular impressions in the cavity of the beak, apparently very prominent, from the great depth of the sulcus between them, of a longitudinally ovate form, and about half their width apart. Casts of the entering valve shew the large bifid rostral tooth, from which the septum extends two-thirds the length of the shell; the dendritic and smooth reniform impressions, nearly resembling those of $P$. semireticulata, the surface beyond which is closely marked with small spinulose points. Prof. King las given a valuable series of figures in his Memoir on the English Permian fossils, shewing both the external and internal characters very perfectly. He also notices that the layer of shell beneath the outer transversely striated one is composed of coarse longitudinal fibres. Prof. King suggests that this species may be found in the carboniferous rocks of Fermanagh; but though I have examined probahly hundreds of Productre from that neighbourhood, I have never seen a trace of it.

Position and Locality.-Very common in the Permian magnesian limestone of Humbleton. 


\title{
Producta Keyserlingtana (de Kon.)
}

\author{
Ref.-Id. id. de Koninck, Monog. Prod. t. 14. f. 6.
}

Dosc--Rotundato-quadrate, transverse, depressed. Receiving valve with the beak narrow, very prominent, visceral portion gently gibbous, rather abruptly arched to the short front, so that the profile, though nearly semicircular, is slightly flattened and elongate towards the produced beak; ears moderately large, nearly rectangular, rather strongly defined at the sides of the beak, but gradually blending with the body of the shell towards the margin; middle of the front with a slight mesial depression; whole of the visceral portion rugged, with very small, round, irregular concentric wrinkles, bearing thickly crowded, very large, obtuse, spine tubercles, rounded on all the posterior portion, becoming elongate near where the abrupt arching of the front begins, and diminishing in size and prominence on the narrow front, where also the concentric wrinkles give place to fine concentric strix of growth. Entering valve flattened, very slightly concave in the middle, flattened on the ears, strongly marked with the concentric wrinkles and rounded pits, representing the tubercles of the opposite valve. Average width six lines, length of receiving valve ${ }_{100}^{87}$, length of entering valve $\frac{80}{1109}$, depth of receiving valve $\frac{45}{100}$, depth of entering valve $\frac{14}{100}$.

The concentrically and minutely wrinkled visceral portion, with the very large crowded spine tubercles, abruptly becoming smaller or almost obsolete at the edge, as well as the small size and flattened entering valve, easily distinguish this from any other species. The wrinkles are very small and only visible between the spines, but they, as well as the flatness of the entering valve and more crowded tubereles, and less gibbous receiving valve, separate it from the $P$. aculeata; and the greater proportional width, \&c. separates it from the $P$. Deshayesianc, which latter, however, I have not seen. I have compared the English with authentic Belgian specimens, to be certain of the identity.

Position and Locality.-Rare in the carboniferous limestone of Derbyshire.

\section{Producta margaritacea (Phill.)}

Ref. and Syn. = P. margaritacea Phill. Geol. York. t. 8. f. $8 .+P$.pectinoides id. id.t. 7. f. $11 ;$ ? $+P$. flexistria de Kon. Monog. Prod. t. 17. f. 1. (not of $\mathrm{M}^{\mathrm{c}} \mathrm{Coy}$ ).

Desc.-Suborbicular, varying from longitudinal to transverse; hinge-line slightly less than the widtl of the shell, forming small, brittle, nearly rectangular ears, not strongly defined from the body of the shell. Receiving valve evenly gibbous, but varying greatly in depth, most gibbous in the middle, gradually sloping towards the sides and front margin, more abruptly arched towards the beak, which is generally large, very obtuse, and overhanging the hinge-line, but varies greatly in size. Surface corered with thick, subequal, obtusely-rounded ridges (about four in two lines at six lines from the beak), separated by much narrower shallow sulei; the ridges increase in thickness from the beak for a length of seven or eight lines, after which most of them fork into two, the branches being equal, and divided by a smaller sulcus than that separating the primary ridges; surface crossed by thin, obsolete, foliaceous, imbricating strix of growth; very few or no spine-bases on the body of the shell, but usually one or three on each ear. Entering valve moderately and evenly concave, with the concentric imbricating lines of growth more strongly marked than on the receiving valve, but the ridging often almost obsolete; substance of the shell very thin, foliaccous, and often nacreous. Length of very gibbous old specimen one inch three lines, proportional width $\frac{90}{100}$, length of entering valve $\frac{75}{1+1+1}$, depth of receiving valve $\frac{50}{1, w i}$, depth of entering valve $\frac{35}{100}$; width of wide depressed rariety, young specimen, 11 lines, proportional length of

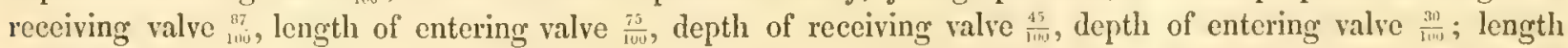
and width of receiving valve of intermediate specimen one inch three lines, length of entering valve receiving valve $\frac{50}{100}$.

This species varies extremely in the relative proportions of the deptl of the receiving valve, so that a comparison of intermediate specimens makes me now think with $\mathrm{M}$. de Koninek, that the $P$. margaritacea 
and $P$. prectinoides of Phillips are but varieties of one species; and in the same way I find a shell exactly agreeing with de Koninck's $P$. Alexistria (which is not identical with my species of that name) is only an extreme gibbous form of the same species. The more gibbous the receiving valve, the larger and more incurved the beak seems to be, and the greater seems to be the space for the animal between the valves, as the entering valve, though also variable in depth, does not vary in so great a proportion as the receiving one. In perfectly typical specimens the length and brealth of the receiving valve are about equal, but the old gibbous specimens are generally a little longer than wide, and the depressed varieties a little wider than long.

Position and Loculity. - Not uncommon in the carboniferous limestone of Derbyshire; rare in the carboniferous limestone of Kendal.

\section{Producta? marginalis (de Kon.)}

\section{Ref.-Id. id. de Kon. Monog. Prod. t. 14. f. 17.}

$D_{i s c}$. Often slightly unsymmetrical ; receiving valve quadrato-hemispherical, visceral portion very gibbous in the middle from the arched deflection of the front, but only moderately convex towards the beak, which is very swall and not prominent; hinge-line rather shorter than the width of the shell, forming very small, nearly rectangular cars, from which a strong concentric sulcus extends nearly parallel with the front margin, defining a slightly projecting front, about two lines long, which is ribbed by thick, rounded, longitudinal costie (about three in two lines), the rest of the surface being marked by fine, irregular, concentric wrinkles, and numerous irregularly scattered, oval, spine bases; substance of the shell very thin, leaving the exterior ornaments usually impressed on the east, with the very superficial traces of the two broad, ovate, muscular impressions. Width nine lines, proportional depth $\frac{55}{100}$.

The narrow, prominent, longitudinally ribbed front margin, so different from the minutely wrinkled and tuberculated other parts of the shell, easily distinguishes this remarkable species. I have only seen the receiving valve, but according to M. de Koninck the entering valve has no longitudinally-ribbed margin, is only slightly concave, and shews occasional traces of rudimentary area, which would probably place the species in Strophalosia of King.

Position and Locality.-Rare in the carboniferous limestone of the Isle of Man.

\section{Pronucta Martini (Son.)}

Syn. and Ref. $=$ Anomites productus Martin, Pet. Derb. t. 22. f. 1 to 3. = (Producta Martini Sow. Min. Con. t. 317. f. 2. + P. concinna id. id. t. 318. f. 1.)

Desc.-Subcylindrical, very elongate, front margin slightly dilated, irregularly undulated in old specimens; hinge-line less than the width of the shell, forming inconspicuous square ears, not projecting from the sides; visceral portion very convex, nearly vertical, passing by a nearly semicircular curve into the vertically extended front, with or without a shallow, irregular, mesial hollow; nine or ten very small, slightly marked, concentrie wrinkles on the sides, which become nearly or quite obsolete across the middle, not interrupting the thick, obtuse, nearly smooth, broadly waving, longitudinal strix, which are separated by very much narrower sulei and di- or tri-chotomise irregularly on various parts of the shell, but principally at the front margin (averaging five to seven in two lines at one inch from the beak); a very few small spines on the body of the shell, not wider than one of the strix, a small group of five or six larger ones close to the cardinal angle on each side. Entering valve with the visceral disk flat, with a very faint mesial furrow, or none, crossed by nine or ten small, faintlymarked, concentric wrinkles, not interrupting the thick, radiating strie; margin of the visceral disk bending downwards, and then abruptly outwards at right angles, to touch the interior of the descending front of the receiving valve, with which the remaining portion of the descending front is in contact, the geniculation producing a flat, horizontal margin, about a line and a half wide, a little below the level of the visceral disk, and marked with fainter strix than the rest of the shell. Average length one inch seven lines, proportional width of 


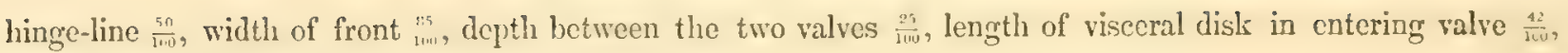
width of ditto $\frac{45}{100}$, width of flattened border to ditto $\frac{8}{100}$.

The character of the remarkable geniculation forming the narrow flattened border to the visceral disk, is so well shewn in Martin's figures, that it is surprising that it has heen overlooked by modern writcrs, lueing supposed probably to represent the thickness of stone between the two valves: an attentive examination will shew, however, that this is not the case, a portion of the shell smoother than the rest being bent at right angles to the preceding, and to the following parts of the valve, covering over that peculiar margin represented in Martin's plate. This character seems to be only developed in the adult, or when the visecral disk of the entering valve is seven or eight lines long, when the width of the border is rather more than a line. This internal character entirely separates the species from the $P$. scmireticulata, with which the continental writers unite it; from which it also differs in its small size, narrow elongate, and undulated front, and broadly-waving closer and smoother strix, and by the very few, and nearly obsolete concentric wrinkles, which even on the casts of the entering valve produce no scnsible interruption of the longitudinal strix. The irregular waving strix contrast strongly with the direct sulcation of $P$. sulcata, semireticulata, \&c.

Position and Locality. - Not unconmon in the lower limestone of Derbyshire; and middle limestone of Poolwash, Isle of Man; rare in the carboniferous limestone of Berwick on Tweed.

\section{Producta iesoloba (Plill.)}

\section{Ref.-Id. id. Pliill. Geol. t. 7. f. 12; de Koninck, Monog. Prod. t. 17. f. 2.}

Dese.-Subquadrate; hinge-line slightly exceeding the width of the shell; receiving valve with the rostral portion for about seven lines from the heak moderately convex, and marked with small irregularly undulating, interrupted, rounded, concentrie wrinkles (four in two lines about middle of disk); beak small, slightly projecting; ears flattencd, of moderate size, slightly acute, obscurely defined from the body of the shell ; from the concentrically wrinkled rostral portion, the front descends with an abrupt eurve nearly at right angles to its plane, slightly flattened in front, and obscurely compressed on the sides from about three lines from the beak; a thick rounded mesial ridge, one line wide throughout, extends to the front margin, defined by a rather wide shallow depression on cach side; spine-bases thick, large, conic, rather few, very irregularly distributed orer the whole shell, four or five on the ridge. Surface smooth or with very fine undulating transverse strix of growth. Entering valve almost following the curvature of the receiving one, and similarly marked in all respects in intaglio, but the visceral disk rather more flattened, and the mesial furrow less sharply defined. Average width one inch six lines, length of visceral disk $\frac{85}{1009}$ of smooth front $\frac{40}{100}$ (longer when old).

The shell is extremely thin, and when partially decorticated, a very minute longitudinal lineation is seen with the lens. This species is so strongly marked by its narrow mesial ridge, that it cannot be confounded with any but the $P$. prelonge (Sow.) $=P$. Christiani (de Kon.), from which it is distinguished by the want of the longitudinal sulcation of the surface.

Position and Locality. - Not uncommon in the dark carboniferous limestone of Kendal, Westmoreland; not rare in the lower carboniferous limestone of Derlyshire; also in the red carboniferous grits of Breedon Hill, Leicestershire; dark lower carboniferous limestone of Poolwash, Isle of Man.

\section{Producta Plicatilis (Son.)}

\section{Ref.-Id. id. Min. Con. t. 459. f. 2; de Koninck, Monog. Prod. t. 5. f. 6.}

Dese-Hemiprismatic, transversely oblong; hinge-line equalling 'the width of the shell. Receiving valve having the visceral disk subquadrate or nearly scmicircular, moderately convex in the middle, rather abruptly rounded to the large flattened ears, on the sides entirely covered up to the hinge-line with strong, narrow, rounded, slightly undulating concentric wrinkles (three to four in two lines in middle), crossed in parts of some specimens by fine regular thread-like strix (ten in two lines); beak rely small, scarcely passing the hinge-line; 
the nearly straight front descends by an abrupt curve, nearly at right angles to the plane of the visceral disk, and is usually quite smooth, or with exceedingly delicate transverse lines of growth or minute longitudinal strix, when the thin shell is partially decorticated; a very obseurely defined shallow mesial hollow extends from about four lines from the beak to the front margin; a few spine-bases on the ears near the hinge-line. Entering valve similar to the receiving one, but with a very short dellected front portion, leaving a large internal space between the valves, without much difference in curvature of the rostral portions. Width one inch four lines, proportional length of viseeral portion of either valve $\frac{50}{1 m}$, length of deffected front of receiving valve $\frac{50}{j+m,}$, ditto of entering valve $\frac{10}{100}$.

This speeies ly its comparatively flattened, concentrically wrinkled visceral disk, and nearly smooth produced front abruptly arched nearly at right angles, approaches a Leptrguniu in appearance, but has no cardinal area. It is not likely to be confounded with any other species known.

Position and Locality.-Rather rare in the grey or lower carboniferous limestone of Derbyshire.

\section{Producta punctata (Mart. Sp.)}

Ref. and Syn.=Conch. Anomites punctatus Martin, Pet. Derb. t. 37. fig. 6 to 8. =Anomites thecarins Schlot. Nacht. Pet. Vol. I. t. 14. f. 1.= Productus punctatus Sow. Min. Con. t. 323 ; id. id. de Koninck, Monog. Prod, t. 13.

$D_{t} s c$-Rotundato-(puadrate; hinge-line rather less than the width of the shell ; receiving ralve moderately gibbous; bcak prominent, tumid, narrow, much incurved below the hinge-line; a shallow mesial sulcus extends from about six lines from the beak to the front margin. Entering valve flattened, slightly concave, with a slight, undefiner mesial ridge corresponding to the hollow in the opposite valve, and reaching to about four lines from the beak; cars flattened, scarcely defined, obtuse; shell very thin. Surface of both valves coneentrically marked by flat imbricating subregular bands of growth, varying from half a line to a line and half in width, each closely and variously punctured or marked with numerous rows of perforated spinulose bases of the very numerous, small, crowded, hair-like spines, which are extremely slender, commonly three or four lines long. the largest being situated near the posterinr portion of each of the transverse bands, which are separated from each other by narrow, smooth, concentrieally lined spaces on the most posterior part of each. IVidth about two

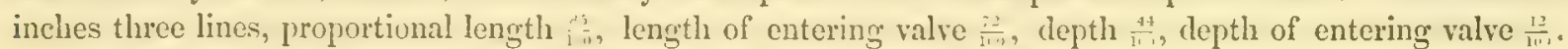

The transverse bands are narrower, more regular, and have rather fewer and larger spines on the entering valve; there are commonly from twenty to twenty-four of these bands on average-sized specimens, the surface appearing as if closely punctured with a pin, when the little spines are broken off, as is usually the case. There are from two to three concentric bands in a space of two lines at six lines from the beak. M. de Koninck, in his

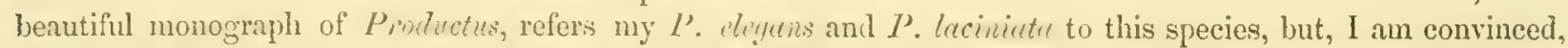
erroneonsly, as I have now seen many specimens of the former, and under that name in the present work I give descriptions and figures of the large, as well as of the small, valve which I only knew on the first publication. The $P$. elegans is more allied to $P$. fimbriata; the $P$. laciniata is clearly distinguished by the characters $I$ have already published, but it is to the $P$. fimbriata, and not $P$. punctata, which it is allied.

Position and Locality.-Common in the carboniferous limestone of Derbyshire; not uncommon in the dark carboniferous limestone of Lowick, Northumberland; dark carbuniferous limestone of Ronalds-way and Poolwasls, Isle of Man; red carboniferous limestone of Closeburn, Dumfriesshire ; dark carboniferous limestone of Dalmellington, Dunfriesshire.

\section{Producta pustulosa (Phill.)}

Ref. and Syn.-Id. id. Geol. York. Vol. II. t. 7. f. 15 ; id. de Koninck, Monog. Prod.t. 12.f. 4 a, $b, c$ (not f $c$, nor t. 13.f. 1); t. 16. f. 8 and 9.> P. pyxidiformis de Koninck, Monog. Prod. t. 12. f. 1; t. 16. f. 2.

Desc.-Rotundato-quadrate; substance of the shell very thin; hinge-line nearly as wide as the shell, forming nearly rectangular flattened ears, strongly defined in the large valie. Receiving valve extremely gibjous. 
side margins subparallel, front margin wide, with a shallow, rounded sinus in the middle, from which a wide, undefined mesial hollow extends to within an inch of the beak, which is of moderate size and curvature; sides and front in old individuals, nearly vertical, short, subcylindrical. Surface usually covered (in well-marked examples) with nearly regular, slightly undulating, continuous, concentric, rounded wrinkles, closely set each with a single row of subequal, longitudinally elliptical tubercles (spine-bases), becoming very small, or obsolete, on the sides and ears; in other specimens the wrinkles are less strongly marked, interrupted, and more undulated; the spines at the same time becoming subquincuncially scattered; tubercles not confluent in longitudinal rows. Entering valve, quadrate, gently coneave, with a slight, broadly rounded, undefined mesial ridge, extending from the margin to within about nine lines of the beak; concentric wrinkles narrow, subregular, set with quincuncially arranged oval pits, tubercles on the interior closer and more rounded than those of the receiving valve. Average width, 2 inches 9 lines, in proportion to width, length of receiving valve $\frac{90}{110}$,

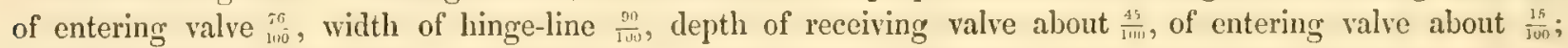
wrinkles varying from rather less than two to nearly three in a space of two lines at about an inch from the beak of receiving valve.

After great hesitation, and a careful examination of numerous specimens, I have come to the conclusion that the P. pyxidiformis of M. de Koninck should be united to the P. pustulose of Plillips, so that the restriction hitherto of the latter name to specimens with strong, regular, uninterrupted wrinkles bearing the spine-bases, has led to the difficulties with regard to the true $P$. scabricula. As a matter of fact, scarcely any two examples of $P$.pustulos a agree in the strength or directness of the transverse ridges: in specimens perfectly typical in this respect near the beak, the ridges will be often found indistinct, undulated, and interrupted on other parts; and when this is the ease the tubereles generally increase in size, and become quincuncially arranged. I have traced the pasage from the most regularly wrinkled type (like Koninck figure, op. cit. t. 12, f. t), with the spines on the sumnits of the transverse ridges, through those in which the spines do not coincide with the (still well marked) ridges (like his t. 16. f.9), to those in which the wrinkles gradually become irregular, interrupted, and nearly obsolcte, as in his $P$. pyxidiformis (op. cit. t. 16. f. 2. and t.12. f. 1), by the most imperceptible gradations. In all these varieties the isolation of the tubereles, instead of their being mere inflations of distinct, longitudinal stria or ridges, distinguishes the species from the true $P^{\prime}$. scalricula. There is considerable variety in the depth of the entering valve. By some chance M. de Koninck in his monograph of Prochectus marks in his synonyms that I have described the $P$. punctata for this species in my volume on the Carboniferous Limestone Fossils of Ireland, which is not really the case. The tubercles vary considerably in size in specimens otherwise similar.

Position and Locality.-Common in the dark carboniferous limestone of Kendal, Westmoreland; carboniferous limestone of Derbyshire.

\section{Producta scabricula (Mart. Sp.)}

Ref. and Syn.=Anomites scabricutus Martin, Pet. Derb. t. 36. f. $5 ;=$ Productus id. Sow. Min. Con. t. 69. f. 1.= P. quincuncialis Phill. Geol. York. t. 7. f. S ; P. scubricula de Koninck, Monog. Prod.t. 11. f. $6 a$ and 6 b.

Desc.-Rotundato-quadrate, side margins subparallel, very gibbous, with or without a wide, shallow, undefined mesial hollow in the receiving valve, and still slighter corresponding ridge in the entering one (not reaching usually within an inch of the beak, and not seen in specimens that size) slightly sinuating the margin; hinge-line slightly less than the width of the shell, forming large, flat, nearly rectangular ears. Receiving valve with a large obtuse beak, the pointed apex extending beyond the hinge-line; front flattened or coneave; sides when old with nearly perpendicular sides. Surface covered with thick, close, subregular, rounded, longitudinal strix (averaging four in two lines at six lines from the beak), swelling at irregular intervals into oval, prominent tubereles (from each of which a curved spine half an inch long projects towards the margin when well preserved), which are subquineuncially arranged without interrupting the continuity of the little ridge on which they are developed, on which latter when strongly marked the tubereles seem mere nodular swellings; a few irregular concentric wrinkles on the ears and sides, becoming obsolete on the front. Entering valve quadrate, flat- 
tened at the ears, moderately concave at the sides, and often slightly convex along the middle, marked with quincuncially arranged, elongate, oval tubercle-pits, and concentric wrinkles, smaller, closer, and more regular than those of the receiving valve. Width of small specimens one inch, proportional length $\frac{50}{1100}$, depth $\frac{50}{100}$, length of entering valve $\frac{\mathrm{T}^{0}}{1 \mathrm{~km}}$, depth of entering valve $\frac{10}{100}$. At one inch from the beak about four longitudinal rows of tubercles in the space of two lines.

The original Anomites scabriculus of Martin was strongly sulcated longitudinally, the elevated lines swelling into alternating elongate tubercles, and thus coincided with the $P$. quincuncialis of Phillips, which species should therefore be suppressed. In my volume on the Carboniferous Fossils of Ireland, I let the P. scabricula and $P$. quincuncialis as understood by Phillips stand, but under both heads I distinetly stated that one of his distinctions, namely, the presence in one, and the absence in the other, of a mesial furrow would not hold; it is unfortunate, therefore, that in M. de Koninck's monograph of the genus I should be made to rely on this character for distinguishing the species. The connexion of the elongate spine-bases by strong longitudinal sulci easily distinguishes this species from the shell named $P$. pyxilliformis by M. de Koninck (which is probably Phillips' $P$. scabricula) and from all the varieties of $P$. pustulosa.

Position and Locality. - Not uncommon in the dark carboniferous limestone of Lowick, Northumberland.

\section{Producta semireticulata (Mart. Sp.)}

Ref. and Syn.=Conch. Anomites semircticulatus Martin, Pet. Derb. t. 32. f. 1. and 2. t. 33. f. 4. = P. antiquatus Sow. Min. Con. t. 317. f. 5, 6. = Producta antiquata Koninck, Monog. Prod. t. 9. f. 1.

Desc.-Rotundato-quadrate when young; extended front becoming prismatic when old; the profile semicircularly arched from the beak to the middle of the descending front; the sides subparallel, rather flattened and nearly vertical; the front only slightly coneave; the whole shell and margin nearly regular; hinge-line equal to the width of the shell, forming rectangular flattened ears. Receiving valve very gibbous; with a broad, shallow, mesial hollow on the middle of the visceral portion, becoming obsolete towards the beak and on the descending front; visceral portion marked by very numerous (upwards of forty) narrow, slightly undulating, concentric wrinkles, which raise tubercles on the longitudinal strie at their intersections, becoming much coarser and spinose on the sides; longitudinal strix direct, coarse, rugged, rounded, subequal, separated by sulci of nearly their own width (averaging four to six in three lines at two inches from the beak), without flexures, simply dichotomising occasionally; no spines on the body of the shell, or only a few small ones, not exceeding the strix in width, and producing no irregularities in the striation; a group of six or seven very long thick spines on a nearly smooth space near the side margin beneath each ear. Entcring valve with the visceral portion nearly at right angles to the front; beak and sides moderately concave, with a distinct, wide, undefined, mesial furrow, becoming obsolete on the descending front, and reaching only within half an inch of the beak; concentric wrinkles as strong and nearly as close as the longitudinal strix, producing a tubercular or pitted, irregular reticulation; the wrinkles become larger and fewer on the ears, joining the hinge-line at an obtuse angle. Interior of entering valve with a very large, prominent, rostral tooth, from which a mesial septum extends nearly to the commencement of the deflected front; interior of receiving valve, with the striated anterior portion of the muscular impressions nearly twice as wide as long, and about a third less than their length apart; dendritic impressions small, and unusually far from the beak, lying just between the striated anterior portion of the muscular impressions. Average width of adult specimens two inches eight lines, proportional length of visceral portion $\frac{70}{100}$ in the receiving valve, $\frac{75}{201}$ in the entering valve, depth between the visceral portion of the two valves $\frac{42}{100}$, length of adult unreticulated front $\frac{80}{1 \mathrm{im}}$.

Martin's figures represent the young shells, which are obscurely trigonal (excluding the ears), and entirely reticulated. This is by no means so common a shell as the varieties of the P. Flemingi with which it is frequently confounded, but from which it is distinguished by its broader and more cubic form, instead of the long, narrow, parallel-sided form of the $P$. Flemingi var. sulcuta; it has no spines except a patch on the sides, (not disposed on a ridge as in that species), has not the small conical ears with large ridge at base, as usually seen in that shell, has no mesial furrow near the margin of the deflected front; and finally, the visceral disk is less gibbous and arched, and much more strongly and numerously crossed by concentric wrinkles.

$$
\text { [FASC. III.] }
$$


Position and Locality.-Common in the carboniferous limestone of Derbyshire; red carboniferous limestone of Breedon Hill, Leicestershire; middle carboniferous limestone, Poolwash, Isle of Man.

\section{Producta setosa (Phill.)}

Ref. and Syn.=Id, id. Phil. Geol. York, t. 8. f. 9 and 17.= P. carbonarius de Koninck, Anim. Foss. Bel. t. 12. bis f. $]$.

Desc.-Oblong, rounded; hinge-line equal to the width of the shell, forming flat, nearly rectangular ears, abruptly defined nearly at right angles to the sides of the shell, so that they are usually broken off, leaving the body of the receiving valve longer than wide. Receiving valve very gibbous, without trace of mesial sinus, sides tumid, nearly vertical; visceral portion globose, marked with obscure concentric wrinkles, nearly obsolete in the middle, arched to a semicircle with the middle of the front; beak tumid, projecting very little beyond the hingeline; surface with nearly regular, fine, close, subequal, longitudinal strie (nine or ten in two lines at six lines from the beak); spines rather numerous, particularly on the ears and rostral portion, (but also on the front) slender, their bases seldom much exceeding the thickness of the strix on which they are placed, and frequently producing no interruption in the striation, rather larger towards the margins of old individuals. Entering valve deeply inserted, with the visceral portion flattened, concentrically wrinkled, and joining the receiving valve about the middle of its front, leaving a large space for the animal; striation as in the receiving valve. Width of hinge-line eleven lines, proportional width of sides $\frac{93}{101}$, length of receiving valve $\frac{100}{100}$, depth of receiving valve $\frac{65}{1000}$, length of visceral disk $\frac{60}{104}$, length of front $\frac{84}{110}$, depth of entering valve $\frac{47}{j 01}$, length of visceral portion $\frac{60}{100}$, length of front $\frac{45}{100}$.

In all the characters of form, proportion and mode of insertion of entering valve, \&c. this agrees with the young of $P$. Martini, but I do not believe it ever assumes the long undulated front of that species, and the striæ are much finer and more regular, and the generality of the spines very small. I have carefully examined authentic Belgian specimens of M. de Koninck's species, and find it perfectly identical in all respects with Phillips's older species; both the Belgian and British specimens occasionally shew a few spine-bases at the sides and near the front margin, as thick as two of the stria, contrasting in this respect with those on the rest of the surface, and a row of intermediate size parallel with the hinge-line.

Position and Locality.-Not uncommon in the limestone associated with the coal of Glasgow; dark carboniferous limestone of Craige near Kilmarnock; and middle carboniferous limestone of Poolwash, Isle of Man; dark carboniferous limestone of Berwick-on-Tweed.

\section{Producta spinulosa (Som.)}

Ref. and Syn.=Id.id. Sow. Min. Con.t. 68. f. 3.= P.granulosa Phill. Geol. York.t. 8. f. 15 (bad).= P. papillatus de Kon. Anim. Foss. Bel. t. 10. f. 6, and t. 12. f. 9.

Desc.-Transversely broad-oval; front margin even, convex, side margins convex; hinge-line shorter. than the width of the shell, forming inconspicuous, gradually flattened, obtuse-angled ears. Receiving valve moderately and evenly gibbous; beak small, narrowed, incurved to the level of the hinge-line. Entire surface covered with subregular, nearly equal, quincuncially arranged, small, prominent, elongate, elliptical spine-bases, (usually four or five in the space of two lines, measured transversely, at three lines from the beak); in young shells, or within four or five lines of the beak, the tubercles are but little longer than wide and about twice their thickness apart, but towards the margin of larger specimens they give origin to short obseure ribs (as in $P$. aculeata), and become rather more crowded. Entering valve decply and evenly concave, having the surface quincuncially marked with regular, nearly round pits, twice their diameter apart, representing the tubercles of the opposite valve. Average width eight lines, proportional length of hinge-line $\frac{17}{\mathrm{i} w \bar{u}}$, length $\frac{85}{100}$, length of entering valve $\frac{75}{100}$, depth of receiving valve $\frac{40}{100}$, depth of entering valve $\frac{20}{100}$.

The much more numerous, regularly placed, and smaller spine-bases distinguish this species from the $P$. aculeata, as well as the less gibbosity and more transverse form of the valves. 
M. de Koninck's figures under the above name papillatus are very good, and will enable people to recognize this species more easily than when only that of Mr Phillips was accessible. He has, however, in his fine monograph on the genus Productus, figured and described an entirely different species under the name Productus spinulosus, viz. the species named $P$. Koninckianus by MI. de Verneuil, and which is far more gibbous, and marked with distinct longitudinal sulci; and he makes the remark that "il est assez probable que M. $M^{\circ} \mathrm{Coy}$, dont la déseription ne fait pas mention de côtes longitudinales, a aussi confondu ce Productus avec une espèce voisine," as well as MMI. de Buch and Phillips, who also considered the $P$. spimulosus of Sowerby to be without longitudinal ridging. I believe that in my volume on the mountain-limestone fossils of Ireland, to which M. de Koninck alludes, I have accurately identified the true $P$. spimelosa of Sowerby; but in that work I also retained the name Producta granulosa of Phillips for those specimens resembling $P$. spinulosa, but having the granules extremely crowded and obtuse. The great number of Scotch specimens which I have recently examined prove to a certainty that these are merely varieties of one species; and the only question remained as to whether M. de Koninek or myself were correct in our notions of the true Producta spinulose; and to set this question at rest I wrote to Mr Sowerby, who had the lindness immediately to reply, that he rather agreed with me that there was no longitudinal sulcation in the species; but that as the original type specimen was in the collection of the Rev. Dr. Fleming, he could not be sufficiently certain to decide the point. On this I wrote to Prof. Fleming as to the characters of the original type specimen, and enclosing in the letter a small specimen, intermediate between the variety $P$. granulose of Phillips, and what I considered the true type of $P$. spinulosa (Sow.), requesting his decision as to whether it was, or not, the latter species. I have just received a most full and satisfactory reply, in which Dr. Fleming says: "My most perfect specimen of Productus spinulosus, and the one figured by Sowerby, is мот sulcated longitudinally;" the underlining of the latter words being his own; and further on he adds: "The shell now returned is certainly a young $P$. spinulosus." The specimen so authenticated from the Beith limestone is especially marked in the University collection for the examination of those interested in the discussion.

Position and Locality.-Common in the carboniferous limestone of Derbyshire; carboniferous limestone of Beith, Ayrshire.

\section{Producta striata (Fischer Sp.).}

Ref. and Syn.= Mytilus striatus Fisch. Oryct. Moscow, t. 19. f. 4.=Pinna infata Phill. Geol. York. t. 6. f. I. $=$ Lima Valdaica and Productus limiformis V. Buch. Ueber. Productus, t. 1. f. $\$$ to $6 .=$ Leptena anomala Sow. Min. Con. t. 615. figs. $1 a, c, d$ (not $b)=$ Productus striatus de Kon. Monog. Prod. t. 1. f. I.

Desc.-Form very irregular, usually triangular, greatly elongated, nearly in one plane, increasing very irregularly towards the front margin; some specimens being broad, ovate, and others very narrow, trigonal, and sometimes slightly arched to one side or the other; beak pointed; the side and front margins in general rather abruptly, but very irregularly, sloped and waved without symmetry, the surface being in consequence marked with short, very irregular, interrupted indentations of growth, marking the former irregularities of the margin : hingeline generally almost obsolete, so that the posterior end is gradually pointed; in some rare, short, wide specimens it is dilated into obscurely defined, obtuse-angled ears, bearing one or two rows of slender bristle-like spines, two or three lines long; shell extremely thin. Entering valve almost in contact with the receiving one, and resenbling it in all respects; strixe harsh, rugged, rounded, or slightly flattened, coarse, irregularly waving, and increasing very frequently in number by interpolation of new strix, nearly equalling the others in size (about seven strix in two lines, at one inch from the beak, sometimes rather finer towards the margin, but nearly equal on all parts of the shell); intervening sulci very deep, but much narrower than the stria; no spine-bases on the body of the shell. Muscular impressions very faintly marked on the casts.

This shell is so extremely variable in form that it is useless to attempt to give any proportional measurements; perhaps the most common sizes are three or four inches long and two inches wide at the front, and the beak and front margin and all the intervening part of the shell being approximately in one plane; and of this type, which generally forms closely packed masses, I have seen Irish specimens one foot long and five inches 
wide, the posterior end being pointed and without hinge-line. The opposite extreme of form is not uncommon in the Isle of Man, where specimens occur two or three inches long and two wide, with a depth of nearly an inch, and with an obtuse-angled hinge-line; and between these extremes all the intermediate forms may be noticed. Under all these varieties, the species is easily recognised by the extreme irregularity of its growth, as in IIinnites, there being nothing of symmetry between the marginal irregularities of the two sides, nor any regularity in the corresponding depressions, and obscurely concentric undulations of growth, which seem to produce or greatly increase the flexures of the striæ. The great irregularity of growth distinguishes the most nearly allied varieties from $P$. hemisphcorica, and the same character and want of spines separate it from the var. Scatica of the $P$. gigantea, to which some unusual varieties approach.

Position and Locality.-Common in the lower carboniferous limestone of Derbyshire; in the dark middle carboniferous limestone of Isle of Man;? rare in the dark carboniferous limestone of Lowick, Northumberland.

\section{Producta tortilis $\left(M^{c} C O y\right)$.}

Ref. and Syn. = Id. id. MIC Coy, Syn. Carb. Foss. Irel. t. 20. f. 14.=P. undatus (Defr.) de Kion. Anim. Foss. Bel. t. 12. f. 2. = P. undatus (Defr.) M. V. K. Geol. Russ. t. 15. f. 15,? (not of Defrance).

Desc.-Very broad-ovate; receiving valve rounded, gibbous, with a large, prominent, moderately incurved beak, extending very little beyond the hinge-line; hinge-line rather less than the width of the shell, forming short, flattened, obtuse cars. Entire surface covered with broad, irregular, undulating, concentric, subangular ridges, having their scarp or narrow steep side towards the beak, either uninterruptedly continuous from one ear to the other, or short and irregularly interrupted in their passage across the middle, giving a largely crumpled appearance to the shell; ridges crossed by sharply defined, narrow, rounded, thread-like stria, separated by very narrow sulci, very regular in size (twelve to fourteen in two lines at six lines from the beak), except where small spine-bases occur, immediately before each of which one of the strix swells to the width of two, and from the base of the spine such strix being split into two or three nearly or quite as large as the adjoining ones; intercalated short strie assuming almost immediately the thickness of the primary ones; spine-bases small, very variable in number, sometimes tolerably numerous, and subquincuncially arranged, but more often nearly absent. Entering valve exactly resembling the receiving one, except in its less deptl. Average width eleven lines, proportional length $\frac{80}{100}$, depth of receiving valve $\frac{45}{100}$, depth of entering valve $\frac{80}{100}$.

This species is easily distinguished from all others of the carboniferous period by having the whole surface crumpled with large, undulating, irregularly angular folds, the short steep side of which is directed towards the beak. I originally figured and described this fossil from the mountain-limestone under the above name, but almost at the same date M. de Koninck, and shortly after, MM. Murchison, de Verneuil, and Keyserling figured it as the Producius undatus of Defrance, stating that they supposed his principal locality (Chimay) to be erroneous, as it contained only Devonian strata. The more I consider MI. Defrance's description, however, the more strongly inclined I am to suppose he meant to indicate the really Devonian $P$. caperatc of modern writers, which not only agrees with his gisement, but with his description of form of concentric wrinkles and léger strix; which latter term could never have been applied to the remarkably harsh, strong, thread-like strix of the present species of the carboniferous rocks, to which I therefore restore my old name.

Position and Locality.- Not very uncommon in the lower carboniferous limestone of Lowick, Northumberland; middle carboniferous limestone of Poolwash, Isle of Man; rare in the black upper beds of carboniferous limestone, Derbyshire.

\section{Genus. LINGULA (See page 250). \\ Lingula Credneri (Geinitz).}

Ref. and Syn. =Id, id. Geinitz Versteinerungen, t. 3. f. 23, 24; King, Perm. Foss. t. 6. f. 25 to 27.

Desc.-Longitudinally oblong, elliptical; side margins very slightly convex in the middle, slightly narrowed and elliptically rounded at the anterior end, posterior end of small valve broad, subtruncate, the angles rounded, 
posterior end of the larger valve more pointed, the sides gradually converging at an angle of about $84^{\circ}$, the beak being terminal ; greatest width about the middle; middle portion of both valves evenly convex, most so at onethird the length from the beak, from whence the surface slopes gradually to the front and more rapidly to the compressed lateral margins; shell very thin, marked with very fine, inconspicuous, irregular, concentric lines of growth, and traces of radiating, extremely minute, fibrous strix. Average length four lines, proportional greatest width $\frac{65}{100}$, depth of one valve about $\frac{10}{100}$.

This species is very closely allied to the $L$. mytiloides of Sowerby, but is generally a smaller and more delicate species, and is perhaps rather wider at the posterior end.

Position and Locality.-Occurs in great numbers on the surface of the Permian marl-slate at Thrislington gap.

\section{Lingula elliptica (Phill.)}

\section{Ref.=Id. id. Phill. Geol. York, Vol. II. t. 11. f. 15.}

Desc.-Elongate; large valve elliptical, small valve regularly ovate; greatest width at about one-third the length from the beak, from whence the margins are semielliptically rounded in the small valve, and elliptically pointed in the long valve at an angle of about $85^{\circ}$, but without distinct straightening or definition of the posterior lateral margins, which curve imperceptibly into the sides; from the widest point both valves are regularly elliptically attenuated to the middle of the front, which is rather narrow and very convex; middle third of the valves convex from the beak to the front margin, the sides sloping rather abruptly to the lateral margins; a small sulcus usually in the apex of the beak. Surface with a few concentric waves of growth, and numerous, very fine, sharp, irregular, concentric strixe under the lens, crossed by much finer, microscopic, close, radiating strixe in certain states of preservation; short valve flatter than the long one. Average length three and half lines, proportional width $\frac{60}{100}$ to $\frac{55}{100}$, depth about $\frac{10}{100}$.

The more lengthened, narrow, elliptical form of this small species, and its less proportional width and narrow front, distinguish it from the $L$. mytiloides (Sow.), in which the proportional width is about $\frac{70}{100}$.

Position and Locality.-Not uncommon in the black carboniferous limestone of Derbyshire.

Lingula latior ( $M^{c}$ Coy). Pl. 3. D. fig. 33.

$R e f_{:}=\mathrm{Id}$. id. McCoy, Ann. Nat. Hist. 2. S. Vol. X.

Desc.-Broad-ovate anteriorly, gradually acuminated posteriorly; moderately convex towards the beak, very gradually flattened towards the margins; sides meeting at the beak at an angle of about $75^{\circ}$; front wide, semielliptically rounded; greatest width at about the middle of the length, from whence the posterior end is rapidly narrowed to the beak. Surface with fine, sharply defined, strong, close, elevated, obtuse, concentric strix, slightly irregular from occasional branchings and interruptions; crossed in parts by longitudinal microscopic strix. Length four and half lines, proportional width $\frac{80}{100}$.

Distinguished from the other described carboniferous Lingulo by the very wide ovate form of its anterior end, and the great comparative length and straightness of the posterior lateral edges, which by their convergence at so small an angle give the remarkable posterior attenuation or pointed beak characteristic of the species. In general appearance and surface it closely resembles some of the Russian Ungulites.

Position and Locality.-Not very uncommon in the black limestone over the main limestone of Derbyshire. Explanation of Figures.-Pl. 3. D. fig. 33. Natural size.

\section{Lingula SQUAMIFORMIS (Phill.)}

\section{$R_{e f}=$ Id. id. Geol. York, Vol. II. t. I1. f. 14.}

Desc.-Longitudinally oblong; sides nearly straight, subparallel; greatest width near the anterior end, which is subtruncate, with the lateral angles obtusely rounded; posterior end wide, rounded in the short valve; posterior lateral margins short, straight, and meeting at $110^{\circ}$ to form the short beak of the long valve; valves 
slightly convex from the beak to the anterior lateral angles; sides flattened, and sometimes the middle of the front depressed; often three diverging sulci from the beak to the front margin, forming obscure ridges on the exterior. Surface with close, irregular, minute plications of growth. Length of small example five lines, greatest proportional width near the anterior end, $\frac{85}{100}$ in the short valve, $\frac{70}{100}$ in the long valve.

The wide, short, oblong form of this species easily distinguishes it from the others in the upper Palreozoic rocks. The more elongate, narrow, oblong species well figured in Portlock's Geol. Rep. t. 32. f. 5, under this name, might be called L. Portlocki ( $\mathrm{M}^{\mathrm{C}} \mathrm{Coy}$ ); its proportional width is only $\frac{55}{100}$ in the long, and $\frac{60}{100}$ in the short valve.

Position and Locality.-Not uncommon in the black carboniferous limestone of Carluke, Lanarkshire.

\section{3rd Class. LAMELLIBRANCIIATA (See page 256).}

\section{1st Ord. Pleunoconcha (See page 257).}

\section{3rd Family. PECTINID庇.}

Shell inequivalve, inequilateral, solid (not foliaceous), regular or subregular, fixed by a byssus or by the substance of the valve; hinge-line straight and usually eared; pallial line entire, outside the adductor; one large, oval, muscular impression near the middle on the anal side of each valve; cartilage small, internal, in a pit beneath the beak; hinge with or without teeth. Animal: the margin of the mantle fringed with fleshy contractile filaments, studded at regular distances with brilliant eye-like tubercles; foot rudimentary, slender, clavate, with a bundle of fibres or byssus at the base; mouth with lips ; gills very large, of few filaments.

Differs from the Limince in being inequivalve, in the oculiform tubercles, and the internal cartilage (not exposed in a notch).

Genera: 1, Pecten; (including as subgenera Amusium, IIinnites, and Janeria); 2, Spondylus ; 3, ?Plicatula; the two latter having hinge-teeth, no byssus, and being attached by the substance of the valve, form the Fam. Spondylida.

\section{Genus. PECTEN (Brug.)}

Gen. Char.-Shell depressed, the upper valve most convex, slightly inequilateral; beaks contiguous; hingeline produced into ears on each side of the beak, the anterior largest, and separated from the body of the shell in the lower valve by a deep notch for the passage of the byssus; ligament of two distinet parts, one internal in the triangular pit beneath the beak, the other external, forming a narrow line along the linge-margin; with $\mathrm{Ol}^{\circ}$ without radiating hinge-teeth.

This genus contains as subgenera, first, the above described type; 2nd, Janira; 3rd, Amusium; 4th, Ifimites; 5th, Pedum. The two latter are identical in shell and animal with Pecten when young; Hinnites becomes afterwards distorted and fixed by the lower valve, and Pedum is distorted from growing in corals (not fossil). The genus has not been yet quoted from the lower Palrozoic rocks; I doubt its occurrence in the Devonian; and the greater number of those shells hitherto called Pecten in the carboniferous rocks, I now find to have no cartilage pit, and by other characters to form a particular genus of Aviculide; they are common in the oolitic rocks, and increase in number to the present day. I leave with doubt in this genus a few carboniferous species with the anterior ear longer than the posterior, and the internal structure of which I have not seen. 


\title{
Pecten? fimbriatus (Phill.). \\ Ref. $=$ Pecten fimbriatus Geol. York, t. 6. f. 28.
}

\begin{abstract}
Desc.-Ovate; valves slightly and almost equally convex, apical angle $90^{\circ}$; ears large, anterior left one square, extending as far as the edge of the shell, with coarse imbricating strix parallel with the end; anterior ear of right valve long, narrow, subtruncate at the end, and with a very deep narrow notch between it and the body of the shell, having three or four obscure radiating ridges crossed by imbricating strix of growth; posterior ears very short, obtuse. Surface of each valve radiated with a variable number of obscurely marked obtuse ridges, crossed by close, minute, obsolete, scalloped strix, strengthened, at intervals of about half a line to one line apart, into fine imbricating lamellar lines of growth, scalloped between the ridges which they cross. Width from beak to opposite margin one inch eight lines, proportional length at right angles thereto $\frac{90}{100}$, length of anterior ear $\frac{37}{100}$, posterior ears about $\frac{16}{140}$.

There is considerable variety both in the strength and number of the radiating ridges of this beautiful species; from four to eight being the extremes of number I have seen (about the middle of the shell) in a space of three lines, the former in a left, the latter in a right valve.
\end{abstract}

Position and Locality.-Common in the dark argillaceous carboniferous limestone of Lowick, Northumberland.

\section{Pecten pusillus (Schlotheim).}

Ref. and Syn $=$ Discites id. Schlot. Akad. München, Vol, VI. t. 6. f. 6, = Pecten id. King, Perm. Foss. t. 13. f. 1, 2, 3 (too oblique).

Desc.-Ovate, not oblique; valves of nearly equal depth, moderately and evenly convex; greatest depth a little above the middle; beaks prominent; ventral margin semicircularly curved; sides converging to the beaks, straight, and forming narrow slopes nearly vertical to the plane of the margins, and deeply defining the ears on each side; posterior ear very small, nearly rectangular; anterior ear much longer, narrow, triangular, and separated by a deep narrow notch from the body of the shell in the right valve, nearly rectangnlar and confluent with the margin of the shell in the left valve. Surface smooth, with a few fine lines of growth near the edge, and sometimes shewing very faint obtuse radiations from the beak. Average width from beak to opposite margin five lines, proportional length at right angles thereto $\frac{90}{100}$, length of posterior ear $\frac{20}{100}$, of anterior ear $\frac{30}{100}$, depth of left valve $\frac{25}{100}$.

From the anterior ear of this little species so obviously exceeding the posterior one in length, I have no doubt of this being a true Pecten, although I have not seen the cartilage pit.

Position and Locality.-Common in the Permian limestone of Humbleton Hill.

\section{Pecten subelongatus $\left(M{ }^{c} C o y\right)$.}

Ref. and Syn. = Pecten elongatus $\mathrm{M}^{\mathrm{c}} \mathrm{Coy}$, Syn. Carb. Foss. t. 16. f. 9 (not of Lamark).

Desc.-Regularly ovate; apical angle $100^{\circ}$; gently convex near the beak, gradually flattening towards the margins; surface smooth or minutely striated concentrically; ears nearly equal, small posterior one square, slightly defined, the anterior rather longer, with a few obsolete radiations, rounded, deeply separated from the body of the shell. Width from beak one inch six lines, proportional length at right angles thereto $\frac{90}{100}$, length of anterior ear $\frac{32}{100}$, of posterior ear $\frac{28}{100}$, depth of left valve $\frac{15}{100}$.

This fine species appears smooth to the naked eye, but in finely preserved specimens, or with the aid of a lens, very minute, regular, impressed, concentric strix are visible. From the $P$. Sowerbyj $\left(\mathbf{M}^{\circ}{ }^{C}\right.$ Coy), which has somewhat similar strie, it is distinguished by its greater size and the form of its ears, while from the $P$. filatus ( $\left.M^{\circ} \mathrm{Coy}\right)$, which to the eye appears nearly as smooth, and has the same general form, it is distinguished by having the minute striation concentric, instead of longitudinal, as in that species.

Position and Locality.-Not rare in the dark carboniferous limestone of Lowick. The original Irish locality is Millicent, Kildare. 


\section{Genus. AMUSIUM (Megerle). = Pleuronectia (Sw.) < Pecten (Brug.)}

Gen. Char-Orate, depressed, nearly equivalve, perfectly equilateral; ears small, equal, their upper angle elevated above the level of the beak, so that the hinge-line forms a re-entering angle, along which is a narrow facet for the external ligament, and under the beak a small triangular pit for the internal cartilage; two long, diverging, internal ridges from the beak in each valve, originating within the tooth-like processes; margin gaping at the sides; surface without radiating ridges.

The recent Pecten pleuronectes forms the type of Swainson's genus Pleuronectia, but the smooth Triassic fossil species previously separated by Schlotheim, under the name Pleuronectites, were true Pectens of the type of the recent $P$.obsoletus (with deeply notehed anterior ear and straight hinge). I use the generic name Amusium (= to Pleuronectio), although many years ago I separated in MSS the fossil under the name Tsopecten.

It is remarkable that so peculiar a generic type should not have been generally recognised; the species differ from $P$ ecten in being equilateral, and their hinge-line, instead of being straight, forming at the beak a re-entering angle; an arrangement which impeding the opening of the valves is compensated for by the gaping of the margins, which only touch at the hinge and opposite point of the circumference, while in Pecten they are closed all round, except where one ear is notched for the byssus; there is no notch in the present genus. From the similarity of shape and smooth or concentrically lined surface of all the species, they are very difficult to discriminate.

\section{Amusium? deornatum (Phill. Sp.)}

\section{Ref. and Syn. = Pecten deornatus Phill. Geol. York. t. 6. f. 26.}

Desc.-Ovate, apical angle about $105^{\circ}$, slightly convex, most so near the beaks; ears small, equal, nearly square; surface with irregular, small, concentric, obtusely-rounded, smooth wrinkles, obsolete at the sides (five in the space of one line in the middle of the shell). Width from beak to opposite margin four lines, length slightly less.

The only specimen I have at hand of this rare species is rather imperfect about the beak and ears, yet I think I see traces of the cartilage pit and elevation of the ears, sufficient to warrant my placing it provisionally in this genus. It differs from the Amesinem Sowerbyi ( $\mathrm{M}^{\mathrm{C}} \mathrm{Coy}$ ) in its smaller size and irregular, concentric, obtuse wrinkles, and from the young of the Pecten Sibericus (de Ver.), by the same points and the form of the ears.

Position and Locality.-Rare in the carboniferous limestone of Lowick, Northumberland.

\section{Amusium Sowerbyi $\left(M^{c} C o y\right)$.}

\section{Ref. and Syn. = Pecten Sowerbyi MCCoy (not Nyst) Syn. Carb. Foss. Irel. t. 14. f. 1.=Pecten Bathus} D’Orb. Prod. p. 139.

Desc.-Elliptical; apical angle $110^{\circ}$, slightly convex in the middle of the rostral third, most so at onethird the length from the beak, gradually arching to the front margin and to the apex, but the sides abruptly flattened, or slightly concave in the rostral half; ears small, equal, acute, conate, considerably elevated above the beak, defined from the body of the shell by a sharp sulcus on each side; surface finely striated concentrically, eight strix in one line in the middle of the shell. Width from beak to opposite margin one inch one line, proportional length $\frac{90}{100}$, depth of one valve $\frac{10}{100}$, length of ears from beak to apex $\frac{10}{100}$.

When the very thin superficial layer is removed a number of small interrupted, zigzag, and divaricating scrateh-like markings appear; the divaricating internal ridges are very thick, diverge at an angle of $75^{\circ}$, and are two-thirds the width of the shell in length; the hinge-teeth are only one-third the length of those ridges and diverge at $105^{\circ}$, coinciding with the line of junction of the ears and body of the shell. The muscular impression is large, and a little on the posterior side of the middle and a little nearer the beak than the 
opposite margin. A line connecting the apices of the two ears would lie nearly half their length above the beak.

Position and Locality.-In the carboniferous limestone of Derbyshire, and Lowick; in the carboniferous shale of Craige, near Kilmarnock. The original Irish localities are, in the yellow sandstone of Bruckless; common in the carboniferous slate of Linsapaste; Calp of Bundoran, Ballintrillick.

\title{
Family. AVICULID E (See page 257). \\ Genus. PTERINEA (See page 258). \\ Pterinea? informis $\left(M^{c} \mathrm{Coy}\right)$.
}

\author{
Ref. $=$ Avicula id. M ${ }^{\mathrm{C}}$ Coy, Syn. Carb. Foss. Irel. t. 13. f. 21.
}

Desc.-Obliquely trigonal, very gibbous from the beaks to the respiratory margin, from which line the surface arches rapidly towards both the dorsal and rentral margins; no defined posterior slope: posterior wing flattened, slightly pointed, extending nearly as far as the posterior end of the shell; its posterior margin moderately concave; posterior end obtusely rounded; ventral margin moderately convex; byssal sinus small, variable, at about one-third the length from the anterior end; anterior end very small, rounded; beaks very large, tumid, prominent; surface with two or three large, obtuse, concentric, rounded wrinkles or waves of growth, near the posterior end. Length from beak to posterior margin about eight lines, greatest proportional width at right angles to middle of hinge-line about ${ }_{100 i}^{60}$, depth of left valve $\frac{25}{100}$, length of posterior wing about $\frac{65}{100}$, width thereof $\frac{25}{100}$; one rather thick posterior lateral tooth rumning a little below a greater part of the length of the hinge-line.

The few obtuse wrinkles on the posterior portion of the shell, and its general bluntness of form, distinguish this species from the more nearly allied ones. The originally described specimens were smaller than the present examples, which have also the extremity of the posterior wing rather more pointed than in my abovecited figure; the anterior end in all our specimens is unfortunately broken off, so that $I$ have not seen the great anterior adductor impression, and have therefore some slight doubt of the genus.

Position and Locality.-Not very uncommon in the carboniferous limestone of Poolwash, Isle of Man.

\section{Pteninea lefigata ( $\left.\boldsymbol{I}^{c} \mathrm{Coy}\right)$.}

Ref. and Syn. = Avicula id. McCoy, Syn. Carb. Foss. t. 13. f. 23.

Desc.-Obliquely falciform, trigonal, gently and moderately convex from the beak towards the respiratory margin, from which line the surface slopes gradually to the ventral margin, which is much curved and to the dorsal margin, which is undefined and nearly straight: posterior wing flattened, but not separated from the body of the shell by a defined posterior slope; its posterior margin concave, the apex extending about half the length of the shell in old specimens, rather more in young ones; beak moderately gibbous; anterior side forming a short rounded lobe; an obtuse byssal sinus at the anterior third of the ventral margin, from whence a shallow concavity extends towards the beak; surface nearly smooth, with a few lines of growth, coarsest at the edge of the byssal sinus, sharp and regular, parallel with the end of the posterior wing. Posterior adductor impression large, shallow; anterior adductor impression a little below and in front of the beak, transversely oval, deep, strongly marked; two or three minute accessory impressions extend from the anterior adductor to the beak; no hinge-teeth, hinge-line narrow. Average length three inches, greatest transverse proportional width from ventral margin to middle of dorsal slope at right angles thereto $\frac{\mathrm{m}}{100}$, width of posterior wing $\frac{23}{100}$, length thereof about $\frac{55}{100}$, length of anterior side about $\frac{7}{100}$, depth of left valve $\frac{13}{100}$.

This fine shell bears some resemblance to Gervillia lunulata of Phillips, but is easily distinguished by its greater size, wider posterior end, smooth surface, and the total absence of the steep posterior ridge, which in 
that species separates the posterior ear from the body of the shell; the posterior or dorsal slope is also straighter, and the posterior wing shorter than in that species.

I place this fossil in Pterinea rather than Avicula, from the large, strongly marked, anterior adductor impression, although it has no hinge-teeth.

Position and Locality.-Carboniferous limestone of Derbyshire; two small specimens (about one and half inches long) from Lowick, Northumberland, seem to be the young of this species, although they have the posterior wing rather longer than in the normal ones. The original locality was lower carboniferous limestone of Millicent, Clane, Kildare (not uncommon).

\section{Pterinea lunulata (Phill. Sp.)}

Ref. and Syn. =Gervillia id. Phill. Geol. York, Vol. II. t. 6. f. 12.

Desc.-Obliquely elongate, narrow, gently arched upwards; posterior slope slightly arched upwards, sharply defined, smooth, nearly vertical to the body of the shell and to the posterior wing, becoming gradually obsolete at the posterior end; beaks moderately tumid, small, separated by a wide triangular cartilage facet in the left valve, marked with coarse sulei angulated towards the beak: anterior end small, obtusely pointed, defined from the body of the shell by a narrow oblique sulcus, extending from the beak to the byssal sinus, which is rather less than one-fourth the length from the anterior end; the ventral margin moderately convex from thence to the posterior end, which is semielliptically pointed: linge-line about half the length of the posterior slope, the flattened posterior wing having its posterior margin so concave near the angle as to render it pointed, but the margin slopes obliquely from thence to the posterior extremity of the shell; surface marker with coarse, irregular, slightly imbricating lines of growth parallel with the margin. Length from beak to posterior end one inch six lines, proportional length of anterior end $\frac{13}{100}$, greatest width from middle of posterior slope (at right angles thereto) to the ventral margin $\frac{43}{104}$, width of posterior wing $\frac{\frac{21}{100}}{10}$ length thereof along the hinge-line about $\frac{44}{100}$, depth of left valve $\frac{85}{100}$, of right valve $\frac{15}{100}$.

The anterior adductor impression is strongly marlied, and on this account I provisionally place this shell in the genus Pterinea, although I have not been able to see any traces of hinge-teeth; the most nearly allied shell is the Gervillia (Pterinea) laminosa of Phillips, which has the same large cartilage facet to the left valve, but is specifically distinguished by the shorter and more obtuse outline, and most remarkably by the posterior wing being only gradually defined from the body of the shell, instead of the sharply defined, vertical posterior slope of the present species.

Position and Locality.-Carboniferous limestone of Derbyshire.

\section{Genus. PTERONITES. See page 391.}

Pteronttes persulcatus $\left(M^{c}\right.$ Coy). Pl. 3. F. fig. 1.

Ref: $=\mathbf{M}^{\mathrm{c}} \mathrm{Coy}$, Ann. Nat. Hist. 2nd Series, Vol. VII.

Desc.-Transversely trigonal, right valve gently convex, left valve diagonally tumid, posterior end broad, rounded; posterior wing flattened, large, pointed, reaching nearly as far as the posterior end of the shell; posterior margin concave, and forming a gentle sigmoid curve with the posterior end of the shell; anterior end and beak forming a small, convex, obtusely pointed extremity; a small space of the anterior extremity smooth, all the rest of the shell covered with small, coarse, rugged, flexuous, irregular, slightly interrupted ridges, for the most part alternately larger and smaller, and less than their thickness apart; those of the posterior wing nearly straight, radiating, those of the body arching downwards towards the ventral margin; three or four broad, obscure, concentric waves of growth, strongest on the ventral half of the body of the shell, interrupting the ridging. Length from beak to posterior margin one inch four lines, proportional length of hinge-line from beak to posterior end of wing about $\frac{n 5}{1110}$, width of posterior wing $\frac{3 n}{100}$, from middle of hinge-line (at right angles thereto) to ventral margin $\frac{70}{100}$, depth of left valve $\frac{26}{100^{\circ}}$. 
This species is distinguished from the $P$. sulcatus $\left(\mathrm{II}^{\mathrm{c}} \mathrm{Coy}\right)$ and the $P$. semisulcatus $\left(\mathrm{M}^{\mathrm{c}} \mathrm{Coy}\right)$ (of which latter it has the exact form) by having all the posterior part of the shell striated; in its ridging it agrees with the Lanistes rugosus ( $\mathrm{II}^{\mathrm{C}} \mathrm{Coy}$, Synop. t. 10, f. 8), but the oblong form, and broad beak and anterior end seem to separate the latter. It grows larger than the above measurements. The adductor impression is moderately large, rounded, placed a little in front of the middle of the posterior slope, partly on the posterior wing; and partly on the body of the shell.

Position and Locality. - Not uncommon both in the main limestone of Derbyshire and the black limestone resting on it; also in the impure limestone of Lowick, Northumberland.

Explanation of Figures.-Pl. 3. F. Fig. 1. Right valve, natural size: from the carboniferous limestone of Lowick, Northumberland.

\section{Genus. AUCELLA (Keyserling). 1846.}

Gen. Char.-Obliquely ovate, very inequivalve, and inequilateral; left valve very convex, with a large beak spirally inrolled towards the anterior side; hinge-line forming a short, flattened, obtuse wing on the posterior side; anterior wing almost obsolete, not defined from the body of the shell by any byssiferous sinus; right valve flat or slightly convex, with a small distinct triangular ear, as in Pecten, separated from the body of the shell by a deep, narrow, byssiferous notch; hinge edentulus and without cartilage facet; adductor impression single, rounded, a little behind and above the middle; several small retractor impressions near the beak. Texture of the shell pearly within, prismatic-fibrous without.

The great inequality of the valves and inrolled beak of the left one, Sc. separate these shells from Aviculopecten, while the byssiferous sinus being confined to one valve and forming in it a deep noteh defining a long anterior ear as in Pecten, \&c., distinguish then from Avicula.

\section{Aucella speluncaria (Schlot.Sp.)}

Ref. and S:m. = Gryphites speluncarius Schlot. Akad. Münch. for 1816, t. 5. f. 1. = Avicula gryphaoides Sow. Encye. Metrop. Vol. IV. t. 3. f. 6. = Monotis speluncarius (Schlot.) King, Perm. Foss. t. 13. f. 5 to 21.

Desc.-Subhemispherical, slightly obliquie towarts the posterior side, which is largest. Left valve very gibhous along the middle, greatest depth ahout the middle; beak very large, obtuse, much incurved; anterior side extremely small, nearly rectangular, flattened; posterior wing obtusely angular, tumid, and defined from the posterior slope by an obtuse sulcus, sometimes obsolete near the beak; anterior and ventral margins semicircularly curved to the small sinus at the junetion of posterior wing, the margin of which is moderately convex; surface of old specimens nearly smooth towards the margin, strongly marked for about six or eight lines from the beak by narrow, filiform, slightly irregular ridges, either subequal and separated by slightly wider spaces, or having either one slightly smaller ridge, or three strie between each larger pair, often rendered subspinulose by seale-like projections of the imbricating lines of growth (averaging seven of the larger strixe in two lines at six lines from the beak). Right valve flat, suborbicular; the posterior wing defined by a slight ridge from the beak to a minute sinus in the margin, corresponding with the sulcus on the opposite valve; anterior car narrow, triangular, completely separated up to the beak from the body of the shell by a deep triangular byssiferous notch; surface having the concentric strix stronger, and the radiating strix usually fainter than the opposite valve. Average widtlı from beak to middle of ventral margin one inch three lines, proportional length of anterior ear $\frac{20}{1 \text { inti }}$, length of posterior side $\frac{45}{100}$, width of posterior wing from sulcus $\frac{50}{100}$, depth of left valve $\frac{50}{100}$.

This species varies considerably in the sculpturing of the surface, most of the specimens seeming nearly smooth, except towards the beaks, others having the longitudinal ridging remarkably strong, but varying in their relative size, while others are remarkably distinguished by the vaulted scale-like, or subspinulose charncter given by the concentric, imbricating strix. Although Count Keyserling does not place this in his genus $A$ ucella, still from the accordance of all those characters which can be seen by the naked eye, $I$ have little hesitation in placing it there.

Position and Locality.-Very common in the Permian limestone of Humbleton. 


\section{Genus. AMBONYCHIA. See page 264. \\ Ambonychia vetusta (Sow. Sp.)}

Ref. and Syn. = Inoceramus vetustus Sow. Min. Con. t. 584. f. 2.= Inoceramus (or Posidonia) vetustus Phill. Geol. York. Vol. II. t. 6. f. 3, 4 .

Desc.-Obliquely-ovato-oblong; beaks narrow, gibbous, prominent, terminal at the anterior end; anterior margin, slightly oblique, long, nearly straight, (slightly concave near the beaks, slightly convex towards the ventral margin); ventral margin semicularly rounded; posterior side scarcely convex, joining the hinge-line at an angle of about $110^{\circ}$; hinge-line entirely confined to the posterior side of the beak, straight, oblique, with a slender lateral tooth running below its margin for about two-thirds of its length; right valve deeper than the left; both valves most convex near the beaks, gradually arching from thence to the ventral margin, more rapidly sloping to the compressed small posterior wing, and very alsruptly rounded or sloping nearly at right angles to the sides along the narrow, steep, anterior margin. Surface marked with subregular, concentric wrinkles, three in two lines at six lines from the beak, gradually increasing with the size of the specimen to two lines wide in adults; obscure parallel concentric lines of growth visible on some specimens. Width of very small example from beak to ventral margin one inch, proportional length of anterior slope, measured from the beak towards the ventral margin $\frac{60}{100}$ to $\frac{75}{100}$, length of hinge-line $\frac{45}{500}$ to $\frac{60}{100}$, greatest length from a little below the middle of posterior side to opposite point of anterior side $\frac{85}{100}$, depth of left valve about $\frac{20}{100}$, depth of right valve $\frac{25}{100}$, (adult length about two inches).

Our specimens of this species are very small and ill-marked, but one of them is particularly valuable for shewing for the first time the nature of the hinge, and that it has no relation to the genus Inoceramus on the one hand, nor to Posidonia on the other, but it is really a one-eared Avicula of the remarkably thick-shellerl genus Ambonychia of Hall.

Position and Locality.-Carboniferous limestone of Kendal, Westmoreland.

\section{Genus. STREBLOPTERTA (MICOy).}

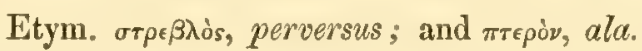

Gen. Char.-Ovate or rounded, obliquely extended towards the anterior side; posterior wing broad, undefined, nearly rectangular, extending nearly as far as the posterior margin of the shell; anterior ear small, deeply defined; surface smooth, or radiatingly ridged; one large, faintly marked, muscular impression a little behind the middle; one short, narrow, tooth slightly diverging from the hinge-line on the posterior side of the beaks; ligament confined to a narrow, simple facet on the hinge-margin.

These shells differ from some of the short-winged group of Avicula (or Pteria), to which they are most allied, by the obliquity of the body of the shell being towards the anterior instead of the posterior side-the reverse in fact of what oceurs in nearly all shells except the Limc. There are many species in the carboniferous limestone, to which the genus seems at present confined, unless the Ptcrinea posidoniiformis ( $\mathrm{IL}^{\circ} \mathrm{Coy}$ ) of the Upper Silurian belongs to it.

\section{Streblopteria levigata $\left(\boldsymbol{M}{ }^{c}\right.$ Coy $)$.}

\section{Ref. and Syn. = Meleagrina laevigata $\mathrm{M}^{\mathrm{c}} \mathrm{Coy}$, Syn. Carb. Foss. t. 12. f. 5.}

Desc.-Suborbicular, oblique, evenly convex, greatest depth a little above the middle, smooth; posterior ear undefined, slightly more than rectangular $\left(110^{\circ}\right)$, rather less than half the length of the shell long; anterior ear very small, square, deeply divided from the body of the shell by an abruptly curved slope; anterior margin much more convex than the posterior, forming, with the front and part of the posterior side, nearly three-fourths 
of a circle. Length of very large specimen three inches nine lines; in proportion thereto, width from beak to ventral margin $\frac{1,1 .}{110}$, length of hinge-line from beak to posterior angle $\frac{44}{100}$, depth of right valve $\frac{19}{100}$.

The smoothness of the surface will at once distinguish this species from its congeners; the surface is slightly but uniformly convex; the anterior ear is less than half the length of the posterior; the anterior side is dilated, so as to give a slight obliquity to the outline. Except the difference in size I do not see any difference between the English and Irish specimens, the latter being only an inch and half long.

Position and Locality.-Rare of large size in the impure carboniferous limestone of Lowick, Northumberland. (The original localities were lower limestone of Millicent, Kildare; Curkeen Rush and Howth, Dublin; limestone, Ardagh).

\section{Streblopteria pulchella $\left(\boldsymbol{I}^{c} \mathrm{C}\right.$ Cy).}

Ref. and Syn.=Mleleagrina pulchella $M^{\mathrm{C} C o y}$, Syn. Carb. Foss. t. 12. f. 6.

Desc.-Obliquely orate, gently convex, greatest depth a little above the middle; anterior side long, straight, abruptly deflected, forming a narrow, highly inclined slope; posterior side and ventral margin semicircularly rounded : hinge short; ears obtuse; middle of the shell with about twenty radiating ridges in pairs, each pair separated from the rest by a broad shallow concavity, equalling the pair of ridges and intermediate furrow in width, the ridges rendered slightly nodular by minute, obsolete, concentric ruga; a narrow portion of the anterior and posterior ends of the shell smooth. Length about six lines, proportional width from beak to ventral margin rather more, depth of right valve ${ }_{100}^{24}$, length of posterior wing ${ }_{100}^{25}$.

This pretty little shell may be known from the other mountain-limestone species by its large angular ribs, running in pairs from the beak to the margin; they are obscurely nodulose on the convex middle part of the body, where they are faintly crossed by minute, obtuse, concentric furrows, becoming obsolete at the sides. This is a scarce fossil; the specimen I have figured is more tubercular than the English one.

Position and Locality.-Rare in the lower limestone of Lowick, Northumberland. (The original locality was lower limestone, Millicent).

\section{Gemus. AVICULOPECTEN. See page 392.}

\section{Aviculopecten celatus $\left(\boldsymbol{M}^{\circ} \mathrm{Coy}\right)$. Pl. 3. E. fig. 5.}

Ref. and Syn. = Pecten colatus $\mathbf{M}^{\mathrm{e} C o y}$, Synop. Carb. Foss. t. 18. f. 2.

Desc.-Gently convex, most so at one-third from the beak, gradually flattening to the margins, rounded; apical angle $110^{\circ}$; length and width almost equal; about sixty simple, subequal, narrow, rounded, radiating ribs, their own thickness apart, (at one inch from the beak in the middle of the shell there are five in two lines), each closely set with small, arched, imbricated scales, slightly more than the thickness of the ridge apart; ears moderate, slightly pointed, with five or six narrow radiating ridges, nearly twice their thickness apart, crossed by rather closer, strong, curved ridges, parallel to the margin. Width one inch nine lines, length of ear nine lines, proportional depth of one valve $\frac{13}{100}$.

The very numerous, simple, nearly equal ribs, and the remarkably sharp, regular, vaulted scale-like seulpturing, distinguish this rare species.

Position and Locality.-CRare in the impure carboniferous limestone of Lowick, Northumberland. The original Irish localities were, red limestone, Armagh; lower limestone, Red Barn, Cookstown.

Explanation of Figures.-Pl. 3. E. fig. 5, left valve, natural size; fig. $5 \alpha$, do. portion of surface magnified.

\section{Aviculopecten cancellatulus $\left(\boldsymbol{I}^{\circ} \mathrm{Coy}\right)$. Pl. 3. E. fig. 3.}

Ref. and Syn. = Pecten cancellatulus $\mathrm{N}^{\circ} \mathrm{Coy}$, Syn. Carb. Foss. t. 14. f. 9.

Desc.-Ovate, gently convex towards the beak; apical angle $95^{\circ}$; ears large, deeply defined from the body of the shell; posterior ear large, falcately pointed, extending nearly as far as the edge of the shell, crossed 
by thick close strix, parallel with its concave margin and terminating in little club-shaped scales on the hingeline; anterior ear only half the length of the posterior, rounded, marked with thick, close ridges parallel with the end; body of the shell radiated with about twenty thick obtuse ridges, obscurely alternate in size, crossed by equally thick, concentric ridges, irregular, but about the same distance apart as the others, the points of intersection forming little tumid bullæ, or large tubercles occasionally rising into spines. Length four and half lines, width from beak slightly more than four lines, length of posterior ear two lines, proportional depth of one valve $\frac{17}{1,10}$.

I imagine the greater size of the English specimens and a small portion apparently broken off the side of the Irish one, will satisfactorily account for the difference in apical angle and number of ridges between the present more perfect example and that I originally figured. The species is strongly distinguished from all others by the very large spherical or conoidal nodules at the intersection of the concentric and radiating ridges.

Position and Locality.-Rare in the carboniferous limestone of Lowick, Northumberland. (My original locality was Killymeal, Dungannon).

Explanation of Figures.-Pl. 3. E. fig. 3, left valve magnified three diameters; fig. $3 \alpha$, outline of do. natural size.

Aviculopecten concavus $\left(M^{c}\right.$ Coy). Pl. 3. E. fig. 2.

Ref. and Syn. = Pecten concavus $\mathbf{M}^{\mathrm{E} C o y}$, Syn. Carb. Foss. t. 15. f, 10.

Desc-CQuadrato-orbicular, flattened; apical angle, including the undefined posterior ear, $150^{\circ}$; right valve gently convex, depressed; left valve flattened, slightly convex near the beak, very slightly concave outwardly towards the margin; covered by about one hundred and fifty to two hundred rough, radiating, threadlike ridges, less than their diameter apart, alternately larger and smaller on the body and posterior wing, about twenty-nine on the anterior ear; anterior ear nearly as long as the margin of the shell, nearly square, the edge slightly sigmoid; posterior ear undefined, extending slightly beyond the margin of the shell, the end slightly pointed by an obtuse re-entering angle in the posterior margin at one-third of its length below the tip. Length from anterior to posterior margin three inches nine lines, proportional width from beak to opposite margin $80^{\circ}$, length of anterior ear $\frac{4 n}{1+1+1}$, depth of do. $\frac{17}{100}$, length of posterior ear ${ }_{100}^{50}$, depth of left valve $\frac{5}{100}$, of right valve about $\frac{10}{100}$; seven or eight ridges in the space of two lines at an inch from the beak.

This large species has the left valve concave outicardly in most specimens (though only in a very slight degree towards the margin), in which it differs from all the other Palicozoic species. The opposite valve is slightly more convex, the whole appearing of a rather irregular growth (approaching IIinnites), and of a thin substance.

Position and Locality.-Not uncommon in the impure limestone of Brigsteer, and in the similar beds at Lowick, Northumberland. The original Irish locality was, very rare in the arenaceous limestone at Killala, Killogunra.

Explanation of Figures.-Pl. 3 E. fig. 2, left valve natural size; fig. $2 \alpha$, do. portion of surface magnified.

\section{Aviculopecten concentrico-striatus (Mc Coy).}

\section{Ref. and Syn.=Pecten id. McCoy, Synop. Carb. Foss. Irel, t. 14. f. 5.}

Desc.-Ovato-orbicular, slightly and evenly convex; apical angle varying from $105^{\circ}$ to $110^{\circ}$; ears large, flattened, nearly equal, both strongly and abruptly defined from the body of the shell; anterior ear separated from the body of the shell by a deep acute notch, obliquely rounded at the extremity, reaching nearly as far as the margin of the shell, marked with six or seven strong, radiating ridges, crossed by slightly scaly lines of growth; posterior car falcate, acutely pointed, extending slightly beyond the posterior margin, from which it is separated by a rounded sinus, its surface radiated with twelve or more close, subequal stria, smaller than those 
on the anterior ear; body of the shell nearly smooth, marked with fine, close, concentric lines under the lens. Length about ten lines, proportional width from beak to opposite margin $\frac{90}{100}$, length of posterior ear $\frac{56}{100}$, of anterior ear $\frac{45}{200}$, depth of one valve $\frac{15}{100}$.

The radiating lines on the ears, and their absence on the concentrically lined, nearly smooth body of the shell, easily distinguish this species. I have some doubts of the true grenus of this fossil, as the interior of one of the Derbyshire specimens shews a small cavity, which I cannot be certain is an accidental fracture, or the cartilage pit of Pecten.

Pusition and Locality.-Not uncommon in the black beds over the main earboniferous limestone of Derbyshire.

\section{Aviculopecten conoideus $\left(M^{c}\right.$ Coy).}

Ref. and Syn. = Pecten conoideus M McCy, Syn. Carb. Foss. t. 17. f. 2.

Desc.-Ovate, slightly oblique, subtriangular, left valve very gibbous, especially at one-third the length from the beak, which is narrow, but prominent; very strongly defined from the ears by an abrupt slope on each side; apical angle about $80^{\circ}$; posterior ear large, flattened, defined, slightly pointed, and with fine radiating close ridges; body of the shell with numerous smooth, equal, rounded, radiating strix, about their own diameter apart, spaces between them flat, smooth, (about eight in the space of one line at half an inch from the beak). Width (of small specimen) from beak to opposite margin seven lines, proportional length $\frac{80}{100}$, depth of left valve $\frac{95}{100}$.

The Lowick specimen seems to differ from the one I originally described in the radiation of the ears, but this may have been obscured by the mode of preservation of the latter in an oolitic bed near the base of the carboniferous series.

Position and Locality.--Impure limestone of Lowick. The original Irish locality was, oolitic beds of lower limestone of Townplots, Killala.

\section{Aviculofecten docens $\left(M^{c} C o y\right)$. Pl. 3. E. figs. 6 and 7.}

\section{Ref. and Syn。 $=$ Pecten flexuosus $\mathrm{M}^{\circ} \mathrm{Coy}$, Syn. Carb. Foss. t. 18. f. 1. (not Pecten flexuosus Lamk.)}

Desc.-Gently convex, right valve less so, broad-ovate, nearly orbicular; apical angle $105^{\circ}$, with from forty-five to sixty irregular, rounded, narrow, subequal (except at the sides near the beak where they alternate) radiating ribs, slightly roughened by small laminæ of growth, and about their own thickness apart, with an occasional slight, irregular flexuosity; ears strongly defined, moderate, the posterior one falcate, pointed, sharply imbricated, parallel with the outer margin, crossed by three or four obscure, radiating, narrow ribs, a little longer than the anterior ear; anterior ear nearly square, or with a slightly oblique, sigmoid termination, flattened and very abruptly defined by a narrow, vertical, smooth flexure from the body of the shell, with imbricating strix parallel to the margin, crossed by two or three obscure narrow ridges near the linge-line; a deep rounded notch separates this ear from the body of the shell. Length one inch eleven lines, proportional width

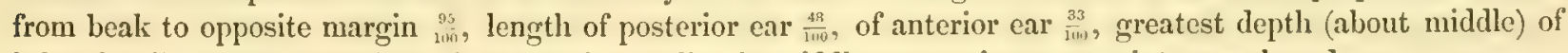
left valve ${ }_{100}^{15}$, width of cartilage facet nearly one line in middle, narrowing to a point at each end.

All the ridges are continued to the beak, they are therefore very fine and close in the rostral part of the shell, there being about ten in three lines at an inch from the beak, and about four in the sane space at the margin. The internal impressions are nearly smooth, with a broad fringe of short radiating ridges, like those of the exterior, round the margin, and frequently shewing the pallial line and large, single, muscular impression a little on the posterior side of the middle, likewise the narrow facet of the external cartilage along the hingeline, and the absence of any cartilage pit under the beak, and thus as it were teaching me the generic difference from Pecten, I have, as above, changed my old specific name, which was preoccupied. 
Position and Locality.-Common in dark carboniferous limestone of Lowick, Northumberland; carboniferous limestone, Derbyshire (with straight ridges). The original Irish locality was Ballygasey, Loughgall co. Armagh (very rare).

Explanation of Figures.-Pl. 3. E. fig. 6, from carboniferous limestone of Lowick; left valve, natural size, internal cast, shewing the long cartilage facet (without central pit) along the hinge-margin; also the pallial and muscular impressions; fig. 7, do. var. from Derbyshire, with remarkably straight and regular ridges. The radiating ridges are effaced on the ears of this specimen, but by changing the light may be seen as described.

\section{Aviculopecten granosus (Sow. Sp.)}

Ref. and Syn. = Pecten granosus Sow. Min. Con. t. 574. f. 2. = Avicula granulosa d'Orb. Prod. p. 135.

Desc.-Nearly orbieular, slightly oblique, moderately convex in the middle, areling gradually to the anterior and front margins, becoming rapidly compressed towards the posterior wing; apical angle about $125^{\circ}$, or $145^{\circ}$ including the undefined posterior car; ears unequal, anterior one small, decply defined, posterior one undefined, extending as far as the margin of the shell. Surface with about forty or fifty tuberculated ribs, between each pair of which is usually a smaller one; when the intermediate rib is absent, the spaces are wider than the ridges, slightly concave and smooth; they seem deeper and narrower than the ribs, when they are alternate in size; usually five tuberculated ridges in the middle of the shell in the space of two lines, at six lines from the beak (before the secondary ribs commence). Length two inches, proportional width from beak to opposite margin ${ }_{100}^{80}$, length of posterior ear $\frac{50}{100}$, depth of left valve $\frac{20}{100}$.

This species varies considerably in the number of its ridges and in the relative strength of the intervening ones.

Position and Locality.-Carboniferous limestone of Derbyshire and Lowick.

\section{Aviculopecten illegalis (de Kon. Sp.)}

Ref. and Syn. = Pecten plicatus? Phill. Geol. York. t. 6. f. 11. (not Sow.) = Pecten illegalis de Kon. Anim. Foss. Belg. t. 4. f. 6.

Desc.-Suborbicular, moderately convex, most so at one-third the width from the beak; ears flattened, strongly defined from the body of the shell; anterior ear abruptly defined by a narrow, nearly vertical sharpedged slope, slightly arching forwards and upwards in the old shell; anterior ear obtuse, with a slightly sigmoid margin, parallel to which it is coarsely striated; posterior ear falcately pointed, extending slightly beyond the posterior margin of the shell, strongly striated, parallel with the posterior edge, defined by a rather rapid slope; no radiating ridges on either of the ears; apical angle about $105^{\circ}$; body of the shell with about forty coarse, rounded, subalternate rils, separated by much narrower spaces, nearly equal at the margin at one inch long, where there are about six in three lines; one half of the ridges extend only within four lines of the beak; one half of the remainder disappearing at about two lines from the bcak; surface crossed by few inconspicuous, minute lines and waves of growth. Length one inch two lines, proportional width from beak to opposite margin $\frac{90}{100}$, length of posterior ear about $\frac{55}{100}$, depth of left valve $\frac{90}{100}$, (left valve only described).

This shell bears some slight resemblance to the Pecten plicatus of Sowerby, but has coarser and more regular ribs, no marked obliquity, and unradiated cars. These are the eharacters on which M. de Koninck mainly establishes his Pecten illegalis, referring to the Pecten plicatus? of Plillips. The figure which he gives does not bring out the inequality of the ridges, which however he mentions, and Phillips's figure imperfectly shews. Both figures represent the posterior ear rather less pointed than it is in nature. The species is much smaller than the $A$. docens, and at the same distance from the beak has the ribs much coarser, fewer in number in a given space, and more unequal: the radiation of the ears is also different.

l'osition and Locality.-Rare in the carboniferous limestone of Malham Moor. 


\title{
Aviculopecten incrassatus $\left(M^{c} \mathrm{Coy}\right)$.
}

\author{
Ref. and Syn. = Pecten incrassatus $\mathbf{M}^{\mathrm{c} C o y, ~ S y n . ~ C a r b . ~ F o s s . ~ t . ~ 16 . ~ f . ~} 1$.
}

Desc.-Suborbicular, evenly convex, most so about the middle; apical angle about $110^{\circ}$; posterior ear obscurely defined, extending slightly beyond the edge of the shell, pointed, compressed; anterior ear much shorter, ohliguely rounded, abruptly defined from the body of the shell, acute; about twenty-five thick, rounded, radinting ribs, separated by slightly concave spaces rather wider than the ribs, on the body of the shell; ears nearly smooth or marked with lines of growth; surface with fine, irregular, obsolete, concentric wrinkles or strice of growth. Length ten lines, proportional width (from beak to opposite margin) $\frac{v i}{1 \omega}$, length of posterior ear $\frac{53}{100}$, depth of left valve $\frac{17}{100}$.

This boldly marked shell is easily recognised by its numerous, strong, rounded, simple ribs, most of which are continued distinetly to the beak; the ears are sharply striated, parallel to the margin, but rery indistinctly radiated; the londy of the shell has very delicate, short, discontinuous, membranous, concentric markings, which become larger towards the margin, where they give the ribs a slightly rugose character. The Pecten without a name, figured by M. de Verneuil (Geol. Russ. t. 21.f. 4.), from the pisolitic carboniferous rocks near Vitegra, seems to belong to this species.

Position and Locality.-Not uncommon in the carboniferous limestone of Derbyshire. The original Irish localities were, Calp, Bundoran, Donegal (rare); carboniferous slate, Lisnapaste, Ballintra.

\section{A viculopecten interstitialis (Plill. Sp.)}

Ref. and Syn. = Pecten interstitialis Phill. Geol. York. t. 6. f. 24. (?+ Pecten intercostetus II Coy, Syn. Carb. Foss. t. 18. f. 4.)

Desc-Obliquely ovate; apical angle about $100^{\circ}$; surface with nine to eightecn narrow, sharp, radiating ribs; between these are from three to nine smaller, the middle one of which is usually larger than the rest; all the rilus have fine, compressed, hooked spines at close regular intervals, which, when broken, give them a tubercular aspeet, and are separated by flat spaces about the width of the fine ridges; ears with fine radiating ridges, and strong spincs on the dorsal margin, both deeply defined from the loody of the shell; anterior one nearly square, posterior one a little longer, pointed. Length eight lines, proportional width from the beak to opposite margin $\frac{85}{100}$, length of posterior ear $\frac{30}{100}$, of anterior one nearly the same.

This beautiful little shell appears to be very variable both in the number of the large ridges and the number of small ribs between every two large ones. It is very seldom that any of the delicate spines are preserved, the ribs more frequently presenting a roughened or tuberculated aspect, from their fractured bases. The great difference between the extremes of the varicties of this species induced me to separate them as above in my work on the fossils of the Irish mountain-limestone; I feel however, on examination of a still greater number of specimens, that it is necessary to reunite them, as the most, and least, simple forms of a singularly variable species.

Position and Locality.-In the black beds overlying the main limestone of Derbyshire. The original localities of the var. intereostutus were: lower limestone, Little Island, Cork, and abundant in the black upper limestone of Killymeal, Dunganuon, so remarkable for the abundanee and beauty of its reticulated corals.

\section{Aviculopecten mactatus (de Kon. Sp.)}

Ref. and Syn. $=$ P. mactatus de Kon. Anim. Foss. Bel. t. 5. f. 5 .

Dese-Orlicular, slightly convex; apical angle $105^{\circ}$; ears large, deeply defined by narrow steep slopes: surface uniformly cancellated by nearly equal radiating and concentric elevated stria (three or four in the space of one line on all parts of the body of the shell); ears without radiating strix. Length one inch four lines, proportional width from beak to opposite margin $\frac{10}{10 u}$, length of anterior ear

[FASC. III.] 
The anterior ear of the right valve is narrow, truncate at the end, and with a very large notch between it and the body of the shell; posterior ear large, defined, falcate, and marked with strong lines parallel with the concave end. Both sets of strix are closer than in do Koninck's figure.

Position and Locality.-Rare in the carboniferous limestone of Derbyshire.

\section{Aviculopecten papyraceus (Som. Sp.)}

Ref. and Syn.=Pecten id. Sow. Min. Con. t. 354.

Desc.-Semiovate, truncated by the hinge-line, slightly oblique; beak small, slightly convex, posterior car large, slightly pointed, scarcely extending beyond the posterior edge of the shell, from which it is not defined by any notch in the margin, which is nearly straight at the junction, becoming slightly concave towards the point of the ear, and gradually convex towards the ventral margin; anterior ear in the left valve obtusely rounded, marked from the body of the shell by a shallow sinus in the margin; in the right valve it is smaller, and separated from the body of the shell by a deep narrow notch extending nearly to the beak; surface entirely covered with coarse, flattened, irregularly unequal, prominent ridges, separated by flattened spaces, usually rather less than the width of the ridges; the ridges increase in number but not much in size towards the margin, both by occasional branching and interpolation, all crossed by fine concentric stria scarcoly visible to the naked eye except on the cars, where they become strong and regular, and about as far apart as the ridges. From beak to posterior ventral margin about two inches, proportional width at right angles thereto $\frac{17}{10}$, length of posterior ear $\frac{65}{100}$, of anterior ear $\frac{30}{100}$.

From all the specimens being pressed quite flat, I have been unable to note the proportional depth, and perhaps it is from the same reason that there is no visible line of demarcation between the body of the shell and the ears. Our specimens are from the same locality as Sowerby's original ones, so there can be no doubt of the identity. The anterior ear in Sowerby's figure is made too pointed, and there should not be a marked definition of the margin between the body and the posterior ear: his upper and lower figures also only represent the two sides of one valve-the right valve having a very different anterior ear.

Position and Locality.-Very abundant in the coal shale near Bradford, but not in the same beds with the so-called Unio's (Carbonicola).

\section{Aviculopecten pera ( $M \Gamma^{\circ}$ Coy).}

Ref. and Syn. = Pecten pera McCoy, Syn. Carb. Foss. t. 15. f. 19.

Desc.-Ovate, moderately convex, front broad, apical angle $105^{\circ}$; ears very strongly defined from the body of the shell on each side, flattened, small, nearly equal; anterior one nearly rectangular, slightly acute; posterior larger, but not extending more than two-thirds as far as the margin of the shell, pointed, its posterior end deeply sinuate near the middle; surface radiated with very numerous, close, fine, rugged, thread-like stric, alternately larger and smaller on most parts of the shell, separated by slightly wider flat spaces, crossed near the margin by sharp, concentric lines; about twelve longitudinal strix in the space of two lines at six lines from the beak: ears with about ten or twelve sharp, radiating strix, similar to those of the body, and crossed by very delicate strix. Length one inch three lines, proportional width from beak to ventral margin $\frac{85}{100}$, length of posterior ear $\frac{130}{100}$, length of anterior ear $\frac{23}{100}$.

From the width, and slight convexity of the ventral margin, the outline resembles a bag or satchel, whenee the name. I am not sure whether the radiating stria are spinose; in some lights they seem to be so, but the character is donbtful; many specimens have the strixe more nearly equal than subalternate. From the greater perfection of the English specimens I have no doubt a jortion of the ventral margin must have been absent in the specimens I originally figured, making the ears appear too large; the perfect outline more resembling that of the $P$. micropterus ( $\mathrm{I}^{\mathrm{C}} \mathrm{Coy}$ ), Synop. \&c. t. 15 . f. 12.

Position and Locality.-Not uneommon in the black beds overlying the limestone of Derbyshire. The original Irish locality was Townplots, Killala. 


\title{
Aviculopecten plano-radiatus ( $\left.\mathbf{I}^{c} \mathrm{Coy}\right)$. Pl. 3. E. fig. 8.
}

\author{
Ref. $=\mathrm{Id} . \mathrm{M}^{\mathrm{e}} \mathrm{Coy}$, Ann. Nat. Hist. 2nd Series, Vol. VII.
}

Desc-C Ovate, apical angle $80^{\circ}$ in young specimens, $95^{\circ}$ in adults from an upward curve of the anterior side; length and width nearly equal; gently convex, most so at one-fourth from the beak; beaks narrow, prominent; ears on each side very deeply defined from the body of the shell by narrow, very steeply-inclined planes, flattened; left anterior one rotundato-quadrate, obseurely radiated, very deeply divided from the body of the shell by an abrupt vertical, slightly concave space extending to the beak; posterior ear longer, falcately pointed, radiated by a few slender ridges crossed by the lines of growth; surface radiated with numerous ribs (thirty to forty at one inch and a half from the beak), which are smooth, broad, flat, or slightly convex, more or less irregular in width, and separated by a very narrow impressed line towards the margin and body of the shell, but nearer the beak they are sharp, narrow, and alternately larger and smaller, ten in one line at two lines from the beak, but each rib varying from one to two lines wide at two inches from the beak, separated only by very narrow impressed lines; the ears are sharply striated, parallel with the margin, and have a few narrow distant radiating ridges. Width from beak to ventral margin from one and a half to nearly four inches, proportional length $\frac{87}{100}$, depth of left valve $\frac{25}{300}$.

The radiations vary from one and half lines to half a line wide in different specimens at the margin. The species differs from the $P$. planicostatus ( $\mathrm{I}^{\circ} \mathrm{Coy}$ ) in not being oblique, and the much greater number of its ribs.

Position and Locality.-Common in the carboniferous limestone of Derbyshire. margin.

Explanation of Figures.-Pl. 3. E. fig 8. Left valve natural size, of specimen brolien along the ventral

\section{Aviculopecten Rutheni ( $\left.M{ }^{\circ} \mathrm{Coy}\right)$. Pl. 3. E. fig. 4. $R e f_{0}=I d$. M Coy, Ann. Nat. Hist. 2nd Series, Vol. VII.}

Desc.-Rotundato-quadrate, suborbicular; apical angle about $110^{\circ}$ in the adult, from the upward curve of the sides, only $95^{\circ}$ in the young; length slightly exceeding the width, tumid; surface radiated by about fifteen thick, rugged ridges, between each pair of which are usually three (rarely seven) smaller ridges, each pair of which are separated by a concave space about equal to the thickness of the ridges; ears large, the posterior one broad, extending as far as the margin of the shell, with three or four distant radiating ridges, crossed by coarse lines parallel with the coneave extremity; anterior ear similar, but slightly smaller, both defined by a rather rapid flattening from the body of the shell. Width from beak to opposite margin about two inches, length (at right angles to the width) about the same, proportional depth of one valve $\frac{20}{100}$.

Fragments of this species bear some resemblance to portions of the Pecten? quinquelineatus ( $\mathrm{II}^{\circ} \mathrm{Coy}$ ), but it is distinguished by the much less number of the ridges, \&s. I have dedicated this species to John Ruthven of Kendal, the well-known enthusiastic collector of Palreozoic fossils.

Position and Locality.-Rare in the impure carboniferous limestone of Dent, and one small specimen from the similar limestone of Lowick.

Explanation of Figures.-Pl. 3. E. fig. 4. Left valve; natural size.

\section{Aviculopecten segregatus ( $M^{\circ}$ Coy). Pl. 3. E. fig. 1.}

Ref. and Syn. =Pecten segregatus $\mathbf{M}^{\mathrm{c}} \mathrm{Coy}$, Syn. Carb. F'oss. t. 17. f. 3.

Desc.-Ovate or rotundato-subtrigonal ; apical angle $75^{\circ}$; right valve slightly convex, left one conoidal, very gibbous, most so at one-third from the beak; front rounded, dorso-lateral margins deflected nearly at right angles to form a steep concave boundary from the ears; ears unequal, very deeply defined from the body of the shell, 
gently convex; posterior one falcate, extending nearly as far as the edge of the shell, with few, distant, radiating ridges; the other rounded, and with four or five obscure ridges; beak narrow, much elevated, incurved. Surface radiated with about six strong, narrow, obscurely rugged ridges; between each pair of which are three smaller, the middle one largest, and alone extending to the beaks along with the six primary ridges, which they there nearly equal in size; intervening spaces flat or slightly concave, alout as wide as the ridges. WVidth from beak one inch one line, proportional length $\frac{99}{100}$, depth of one valve $\frac{33}{100}$.

This strongly-marked species is easily recognised by the great distance which the primary radiating ridges are asunder, and the flat, smooth spaces between them. I cannot see on what grounds M. de Verneuil proposes to distinguish his $P$. Kokcharofi, of the Permian marls of Archangel, which seems to me, judging from his figure and description, to be identical, except perhaps in liaving more ridges on the ear.

Position and Locality.-Rare in the carboniferous limestone of Lowick, Northumberland. The original Irish locality was Manor Hamilton.

Explanation of Figure.-Pl. 3. E, fig. 1. Left valve; natural size.

\section{Genus. BAKEWELLIA (King).}

Gen. Char.-Aviculoid, obliquely aliform; right valve smaller than the other; anterior side small, separated from the body of the shell by a strong byssal sinus; beaks separated by a distinct triangular cardinal arca, tapering to the ends of the hinge-line, marked with longitudinal sulei angulated under the beak, crossed by several transverse cartilage pits; teeth diverging, variable, generally two short diverging teeth on the anterior side, and one or two posterior ones running along the hinge nearly to the extremity; anterior and posterior adductor impressions strongly marlied, connceted by the simple pallial scar'; an accessory impression over each adductor.

This closely rescmbles the mesozoic genus Gervillia, but is separated by the strong anterior adductor.

\section{Barewellia ceratophaga (Schlot. Sp.)}

Ref. and Syn.= Mytilus ceratophagus Schlot. Akad. München. Vol. VI. t. 5. f. 2.= Avicula id. Goldf. Pet. Germ. t. 116. f. 6. =Bak. id. King, Perm. Foss. t. 15. f. 24 to 27. + Avicula antiqua Münster, Gold. Pet. t. 116. f. 7. + B. bicarinata King, Perm. Foss. t. 14. f. 41, 42.

Desc. (Var. Ceratopherge vera.) - Obliquely aliform, body of the shell evenly tumid, most so from the beak (which projects prominently beyond the hinge-line) to the posterior end, which is elliptically rounded; posterior wing pointed, extending slightly beyond the end of the shell, flattened and aloruptly defined from the body of the shell by a narrow, highly-inclined slope; postcrior margin deeply sinuated near the dorsal portion, oblique towards the end of the shell; anterior lobe small, triangular, obtusely pointed at the apex, separated by a strong, very oblique byssal sinus from the body of the shell. Surface marked with small sharp, irregular, imbricating stria parallel with the margins; cardinal area very narrow, nearly parallel-sided. Length of hinge from anterior to posterior end five lines, proportional length of posterior wing $\frac{1 \mathrm{gt}}{1 \mathrm{nin}}$, greatest width of the body at right angles to middle of posterior slope ${ }_{100}^{45}$; width of posterior wing ${ }_{1,1}^{25}$, (rather small specimen) from beak to posterior end $\frac{80}{100}$; depth of left valve $\frac{20}{100}$, width of cardinal area about $\frac{5}{100}$.

Var. bicarinate King. Only differs from the above type by having the tumid anterior lobe bisected nearly in the middle by a slight sulcus from near the beak, not seen in right valve. A specimen was presented by Prof. King to the Woodwardian Museum with $B$. antiqua under the same name.

Var, antiqua. The type specimens of this species in Count Münster's collection are clearly marked examples of the first var. ceratophaga in striation, pointed end to the posterior wing, and its decply concave posterior edge, \&c. 
A'l the specimens, both British and foreign, which I have examined, agree rather with the figures of Goldfuss than of King, in having the cardinal area scarcely more than the third of a line wide, and nearly parallelsided.

Position and Locality.-Common in the Permian limestone of Humbleton.

\section{Batewellta inflata (Brown Sp.)}

Ref. and $S y n_{0}=$ Avicula inflata + A. discors + A. Binneyi Brown, Manchester Geol. Trans. Vol. I. t. 6. f. 25 to 28 ; = Bakewellia antiqua (not of Münster) King, Perm. Foss. t. 14. f. 28 to $34 .+B$, tumida id. id. t. 14. f. 35 to 37 .

Desc.-Ohtusely trigonal, diagonally gibbous; beals large, tumid, projecting beyond the hinge; posterios: wing slightly pointed, extending as far as the posterior end, gradually sloped from the body of the shell, withont being abruptly flattened or defined; posterior margin very slightly sinuate; anterior lobe obtusely rounded, tumid, scareely defined from the body of the shell by a very obseure, shallow, byssal sinus; surface marked with slightly imbricating, concentric lines of growth ; cardinal area in each valve rather wirle, triangular, with alout two cartilage pits in front, and three behind the beak. Average length from beak to respiratory margin five lines, in proportion thereto length of hinge-line from anterior to posterior end width of body at right angles to posterior slope $\frac{i n}{i n,}$, width of posterior wing both cardinal areac ${ }_{100}^{20}$.

The main differences between this species and the $B$. ceratophaga are the greater width, obtuseness, and tumidity of the present species, and the posterior wing not being abruptly flattened or defined, and being less deeply sinuated in the posterior margin, the anterior lobe also being more broadly rounded, and the byssal sinus comparatively obscure. It is quite possible, however, that they may be varieties of one species, as the strength of the byssal sinus varies very materially even in different parts of the same specimen: meanwhile, as it is easily recognised, I keep it distinct for the present, but place it under C'apt. Brown's carliest British name, as I find, from authentic specimens in Count Münster's collection, that his Avicula antiqua is perfectly identical in all respects with the internal casts of the $A$. ceratophaga in its most typical form, some of the specimens even shewing the seulpturing of the surface of the latter species, though under the former name. Neither from the figures nor description, nor the examination of authentic specimens, can I find any grounds for the specific separation of King's Bakevellia tumida; the depth even by his own admission being subject to great variation; but authentic specimens shew no approach to the great depth, apparently represented in his figure, of the cardinal area. I have very indistinctly seen the cartilage pits. In the Manchester specimens the cavity of the beak shews two or three small accessory muscular impressions; but the cast of the wide area between the beaks shews neither the cartilage pits nor hinge-teeth, so I must suppose that Prof. King had better specimens.

Position and Locality.-Common in the Magnesian limestone of Humbleton (often nine lines long); very common, but very small (varying from one to four lines long) in the red Permian marls near Manchester.

\section{Genus. MYALINA (de Koninck).}

Gen. Char.-Very inequivalve*, olliquely trigonal, diagonally tumid; beaks anterior, terminal; a slight sinus in the anterior part of the ventral margin for the byssus; anterior side obsolete; posterior end wide, obliquely truncate or rounded; hinge-line of moderate length, erect, simple; cartilage facets within it usually striated lengthways, inclining outwards, bounded by an internal ridge running along and a little below the hinge-

* M. de Koninck says equivalve, but I entirely concur with Prof. King in supposing that they will all be found to be inequiralve when perfect specimens, such as we have seen, are examined. 
line; no hinge-teeth, but a triangular septum in the cavity of each beak, parallel with the plane of the lateral margins (leaving deep slits under the beaks of the casts); dimyarian, each adductor surmounted by a small accessory impression, the anterior adductor attached to the inner face of the rostral septum.

The width of the cartilage facet, and the great inequality of the valves, separate this palrozoic genus from even those of MIytili, which have a similar internal septum in the beak; but from its affinity in other respects it helps to blend the two groups of Pleuroconche and Isedrolotila. The small impression over the large anterior adductor I find (in the recent Mytili with rostral plates) is the scar of the insertion of the adductor from the opposite valve, instead of retractors of the foot, as commonly supposed, the larger impression being the scar of the origin thereof.

\section{Mralina acuminata (Sow. $S p$.)}

Ref. and Syn. = Modtiole acuminata Sow. Geol. Trans. 2nd Series, Vol. III. p. 119. = Mytilus septifer King, Perm. Foss. t. 14. f. 8 to 13 (> Ostrea? pusilla + O? Tayloriana id. olim).

Desc.-Deltoidal; bealss tumid, narrow, moderately curved; greatest depth a little in front of the middle, from whence the surface slopes, very abruptly, or almost vertically to the ventral margin, and gradually to the posterior end and broadly dilated wing; hinge-line of moderate length, elevated, the anal angle obtuse; posterior end very wide, convex; anterior end projecting slightly in front of the bealss as in Modiola, and with a very small byssal sinus a little in front of the middle of the ventral margin; surface marked with moderately strong, irregularly-unequal, slightly imbricating laminac of growth; rostral plate in the casts moderately strong, bearing the comma-shaped impressions for the origin and insertion of the adductor muscles; two or three minute retractor impressions at the apex of the beak. Length from beak to respiratory posterior margin nine lines, proportional length of hinge-line from beak to anal angle $\frac{60}{100}$, greatest width from anal angle to ventral margin $\frac{85}{110}$, depth of left valve $\frac{38}{101+}$.

According to Prof. King, this species increases in proportional width by age, but it is at all times easily distinguished from the $\lambda I$. squamose by the very much wider and more obtuse form; the larger anterior end, more elevated and compressed hinge-margin, and the less rugged, concentrie imbrications of the surface.

Position and Locality.--Not uncommon in the Permian magnesian limestone of Humbleton.

\section{Mralina squamosa (Som. Sp.)}

Ref. and Syn.= Mytilus squamosus Sow. Geol. Trans. 2nd Series, Vol. III. p. 120. = Mytilus Hausmanni

Gold. Pet. t. 138. f. 4. = Mytilus squamosus King, Perm. Foss. t. 14. f. 1 to 7.

Desc.-Obliquely ovato-trigonal ; anterior end tapering to the very large, prominent, pointed, widely separated bealss; valves very gibbous from the beaks towards the posterior end, which is semielliptically rounded; ventral margin very obtuse, from the abrupt arching over of the valves nearly at right angles to the plane of the margins; hinge-line slightly elevated; cardinal angle very obtuse, wing moderately and gradually compressed; byssal sinus in the ventral margin very small, slightly in front of the middle of the length; surface marked with very coarse, irregular, concentric, prominent, imbricating strix and interruptions of growtl. Average length from beak to posterior end nine lines, in proportion thereto length of hinge-line $\frac{6 !}{100}$, greatest width from cardinal angle to opposite ventral margin $\frac{6_{2}}{110}$, depth of left valve (greatest a little in front of the middle) $\frac{30}{100}$, depth of right valve $\frac{25}{100}$.

This species is easily distinguished by the extreme coarseness and irregularity of its concentric strix and imbrications of growth. When imperfectly preserved the surface appears more even and smoother, and then approaches very closely to some of the carboniferous species.

Position and Locality.-Common in the Permian limestone of Humbleton. 


\title{
2nd Order. Isedrolotila. See page 265.
}

\author{
2nd Family. MYTILIDE. See page 265. \\ Genus. LITHODOMUS (Cuv.) \\ < Modiola Lam.
}

Gen. Char.-Elongate, cylindrical (section circular); anterior end obtusely rounded; posterior end compressed; margins closed all round, no byssal ventral sinus; one small anterior adductor, and one large superficial posterior one, connected by the entire pallial scar; no hinge-teeth; cartilage on a very small ridge nearly parallel throughout with the hinge-line; beaks minute, inrolled, close to the anterior end. Animal: mantle open in the middle, closed anteriorly, and prolonged posteriorly into two very long, extensile tubes (not indenting the pallial scar) joined together, the anal one only open at the end, the other slit throughout, its edges continuous with those of the mantle; gills forming long fringes of free filaments; mouth with lips: foot rery small, bilobed; byssus on a separate tubercle in advance of it.

Live burrowed in stone and corals, which they often line with a calcarcous tube, having two openings at the narrow posterior onter end. Differs from Modiolv in eylindrical shape, lithophagous habit, inrolled beaks, structure of the gills, closed anterior part of 'the mantle, siphons, \&c.

\section{Lithodonus Jenkinsoni ( $\left.\boldsymbol{I}^{c} \mathrm{Coy}\right)$. Pl. 3. F. fig. 2.}

Desc.-Longitudinally oblong, or oval, subcylindrical; beaks small, much incurved, obliquely inrolled over the wide, deep, cordate, anterior lunette; anterior end very short, extending very slightly in front of the beaks, obtusely rounded; posterior end slightly wider than the anterior, obtusely rounded; dorsal margin nearly straight, gradually rounding into the posterior end; ventral margin very slightly convex; valves evenly tumid, most so along an undefined line from the beaks to the respiratory margin a little in front of the middle of the length; surface with irregular, coarse, concentric lines and plicie of growth. Casts shew the large anterior and posterior adductor impressions distinctly, connected by the simple pallial scar, together with faint traces of the concentric plice of the surface, crossed by microscopic, close, diagonal strite from the beaks towards the respiratory margin, also impression of the small cartilage ridge within the dorsal margin. Length one inch seven lines, proportional greatest depth at middle of length $\frac{45}{1004}$, depth of posterior end $\frac{4.1}{110}$, from apex of beaks to ventral margin $\frac{20}{100}$, length and width of anterior lunette $\frac{12}{10,2}$ greatest depth of both valves $\frac{42}{10 u}$, length of anterior end $\frac{10}{100}$.

This is a smaller and much more obtuse species than the L. dactyloides ( $\mathbb{I}^{\circ} \mathrm{Coy}$ ), the anterior end being proportionally broader and more obtusely rounded; the posterior end is also less pointed, and the anal angle not elevated. I have not seen the external shell of this species except near the margins, and there, there is no trace of the distinct longitudinal or radiating striation of that species, traces of which are however seen on the internal casts.

I dedicate this species to the Rev. Mr Jenkinson, of Lowick, to whose labours we owe the most extensive and beautifully perfect local collection perhaps ever made in these rocks-particularly instructive by the frequent exhibition of internal characters.

Position and Locality.- Not uncommon in the impure carboniferous limestone of Lowick, Northumberland.

Explanation of Figures.-PI. 3. F. fig. 2. Left valve natural size; exhibiting faintly the large adductor impressions, and entire pallial sear. 


\title{
Genus. ANODONTOPSIS. See Page 270.
}

\author{
ANOdONTOPSIS? PRISTINA $(\boldsymbol{M}, V . K . S p$. \\ Ref. and Syn.=Amplidesma pristina M. V. K. Geol. Russ. t. 20. f. 5.
}

Desc.-Rounded, obscurely rhombic; beaks moderate or small, obtuse, prominent, submedian; anterior side from beak to opposite point of ventral margin almost semicircularly arched; posterior end broad, very obsemrely sultruneate, slightly convex from the respiratory angle to the anal angle, where it forms an obtuse junction with the hinge-line; ventral margin very regularly convex, most so in the middle; valves gently and evenly convex, most so ahout the middle, from whence the valves arch gradually in all directions; the posterior slope only defined at the anal angle near the beak, where a small portion of it is abruptly compressed. Surface nearly smooth, with very faint, obtuse, concentrie lines. Internal casts shew the oval muscular impressions joined by the simple pallial scar, the anterior one having a faint sulcus (from a ridge) behind it; also the slender anterior and posterior lateral teeth of the genus. Length one inch three lines, proportional width from beak to

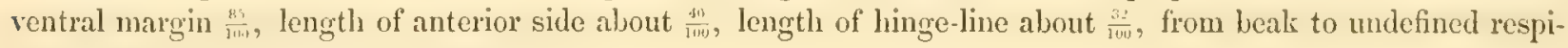
ratory angle $\frac{85}{100}$, depth of one valve $\frac{20}{200^{\circ}}$.

I put a note of interrogation to the genus because I have not seen the cardinal tooth; the two lateral teeth, however, and other internal characters agree well with the genus, and prevent the fossil being referred to Myophtoria. The figure in the Geology of Russia has the posterior side rather too much narrowed and elliptically rounded; it should rise a little higher, where however the alorupt compression of that part of the posterior slope only is well shewn.

Position and Locality.-Rare in the dark carboniferous limestone of Lowick, Northumberland.

\section{Genus. MYOPHORIA (Bronn, Leth. 1825).}

Syn. = Schizodus King $<$ Axinus Sow.

Gen. Char.-Equivalve, compressed; beaks submedian, small, prominent, incurved towards the anterior or posterior side; anterior side broadly-rounded, sharp-edged (no lunette); posterior end narrowed, obliquely truncated, with a distinct flattened posterior slope; hinge-line forming an olstuse angle at the beak, rounded towards the anterior, and sloping obliquely to the posterior end; cardinal teeth small, that of the left valve largest, and cleft or bifid at its edge, and received between the two teeth of the right valve: one long, smooth, internal ridge extends from the base of the anterior tooth in each valve, diverging from the beaks at an acute angle with the curved anterior dorsal margin (two almost imperceptible projections in the left valve, one on each side of the bifid tooth, are counted as teeth by Professor King); ligament external on the sharp margin of the long posterior slope; adluctor impressions two in each valve, small, pyriform, cach surmounted by a small accessory one, connected by an entire pallial scal.

From the examination which I liave been able to make in the Cambridge collection of a number of specimens of various species of Mryophoria, from the Muschelkalk, I have satisfied mysnlf of the perfect identity in generic character between them and the British magnesian limestone types named Schizodus by King. The characters of the last-named genus were communicated to M. de Verneuil, and by him published in the Geology of liussia, but at the same time he pointed out the resemblance to one of the valves of My/ophoria, as figured by Goldfuss and Bronn. Only knowing the figure of one valve he stated he could not complete the comparison; but, as alove mentioned, I have completely ascertained their identity from the examination of the objects themselves. In the British species the anterior teeth are less developed than in the more common of Muschellalk ones. The inclination of the beaks is not invariably to the anterior side, they sometimes lean slightly backwards. Professor King las given reasons, in his volume on the Permian Fossils of England, for confining the name Aximes to the London clay forms, congeneric with $A$. angulutes, and not applying it to the Permian types, for which and their carboniferous allies he proposes the name Schizodus, which must now give 
way to Professor Bronn's prior name. The extremely minute projections in the hinge of the left valve bounding externally the pits for the teeth of the right valve, seem too insignificant to be counted as teeth, even in the most strongly marked cases, and generally they are quite inappreciable. In two of the carboniferous species (11. axinifumis Phill. sp. and M. carbonaria Sow. sp.) Professor King has found the thick tooth of the left valve undivided.

\section{MYopitoria carbonarta (Sow. Sp.)}

Ref. and Syn. =Venus carbonaria Sow. Geol. Trans. 2nd Series, Vol. V. t. 39. f. 2; ?+ Donax sulcatus id. id. f. 1. (not Venus (Amphidesma) carbonaria Portk. Geol. Rep.)

Disc.-Var. a. Rotundato-rhombic; beaks very large, obtuse, prominent, subcentral; anterior side very broadly rounded; posterior end short, subtruneate, with slight obliquity, narrowed loy the convergence of the hinge-line and ventral margin; ventral margin slightly convex in the anterior half, gently concave in the posterior half in front of the diagonal ridge; valves very gibbous near the beaks, gradually arching from thence to the ventral margin, and rapidly arching to the anterior margin; a wide, shallow concavity extends from near the beak to the shallow sinus in the posteriou part of the ventral margin; posterior slope abruptly flattened, leaving an obtusely rounded diagonal ridge. Surface with a few obseure concentric plice and lines of growth; a slender suleus usually bisecting the posterior slope nearly along the middle. Length one inch three lines, width the same, proportional width of posterior end about $\frac{50}{\mathrm{kw}}$, length of hinge-line about ${ }_{i=0}^{45}$, length of anterior end about $\frac{27}{100}$, depth of one valve $\frac{33}{100}$.

Var. ß. Ovato-ollong; beaks very large, tumid, oblique towards the anterior end; anterior end very short, rounded; posterior end elongate, gradually compressed; posterior margin obliquely subtruncate, slightly convex; posterior slope abruptly flattened, leaving an obtuse diagonal ridge from the beak to the respiratory angle (bisected nearly along the middle by a small sulcus); ventral margin convex in the anterior half, nearly straight in the posterior half; valves very tumid at half the width from the beaks, and at one-third the length from the anterior end, from whence the valves arch rapidly towards the beak, the ventral and the anterior margins, gradually flattening towards the posterior end (no distinet sinus in the margin, nor hollow in front of the diagonal ridge). Length one inch three lines, in proportion to length greatest width from beak to opposite

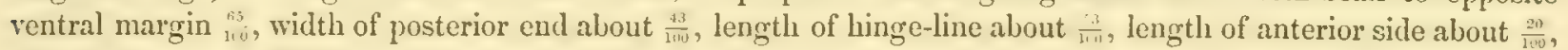
depth of one valve $\frac{30}{100}$.

The first of these varieties is even shorter in proportion than Sowerby's figure of his renus carbonaria, and with a rather more strongly marked sinus in the posterior ventral margin, and corresponding hollow in front of the diagonal ridge; while the second variety is even more elongate and inequilateral than his figure of his Donax sulcatus, and has the same elongate posterior end, straight posterior ventral margin, and all the other characters, yet I am absolutely certain that the two extremes pass insensibly into each other, and are specifically identical. Professor King found the original specimens to belong to his genus Schizuelus (= Myophoria), and both have the sulcus from which the Donax sulcatus received its name. All our specimens seem covered with a thick, brownish, periostraca. Muscular impressions as in the generic character.

Position and Locality.-Common in a carboniferous limestone resembling that of Burdiehouse, at the coalpits S. of Berwick-on-Tweed.

\section{Myopitorta depressa (Portk. Sp.)}

\section{Ref. and Syn. = Amphidesma or Mactra depressa Portk. Geol. Rep. t. 36. f. 8. (beak too near the} posterior end).

Desc.-Rotundato-rhombic; bealis moderate, prominent, a little nearer the anterior than the posterior end; anterior end rounded, compressed; ventral margin gently convex in the anterior part, with a rery faint constriction in front of the respiratory angle, which is obtusely rounded; posterior end obliquely subtruncate, gently 
arched from the beak to the respiratory angle; posterior slope slightly convex, so that the diagonal ridge separating it from the body of the shell is very broadly rounded; valves gently and evenly convex, most so near the middle; muscular impressions, pallial scar, and hinge-teeth, as in the gencric character. Surface nearly smooth, with obsolete, obtuse, concentric plica (four in two lines at middle of shell). Length one inch two lines, proportional width from beak to opposite ventral margin $\frac{85}{100}$, length of anterior end $\frac{411}{100}$, from beak to respiratory angle $\frac{20}{100}$, depth of both valves $\frac{50}{100}$.

Colonel Portlock's figure above quoted represents the beak too nearly central, and the compression of the anterior side slightly too abrupt. The species differs entirely from the 11 . carbonaria, by the slight and uniform convexity of the valves, the broadly-arched diagonal ridge, and less compression of the posterior slope, smaller beaks, \&c.

Position and Locality.-Common in the lower carboniferous limestone of Lowick, Northumberland.

\section{Myophoria obliqua $\left(M^{c}\right.$ Coy).}

Ref. and Syn. =Axinus obliquns MCoy, Synop. Carb. Foss. Irel. t. 8. f. 29.

Desc.-Obliqucly ovate; beaks prominent, close to the anterior end; anterior side short, forming from beak to opposite point of ventral edge a nearly semicircular curve, slightly flattened torwards the bealss; posterior end elliptically pointed, very obliquely truncated; the posterior margin only slightly convex from the beak to the respiratory angle; posterior slope flattened, very steep, strongly separated by an angular ridge from the body of the shell, which is moderately and evcnly convex, most so near the middle; ventral margin gently convex; muscular impressions strong; entire pallial sear strongly marked on casts. Length eleven and half lines, proportional width from beak to ventral margin ${ }_{100}^{89}$, length of anterior end about $\frac{30}{100}$, from beak to respiratory angle $\frac{80}{100}$, depth of both valves $\frac{50}{100}$.

This species has the shell rather thick, and the internal impressions well marked; the hinge-teeth and muscular impressions are seen to be as in the generic character, and the unsinuate pallial scar is remarkably distinct in most specimens. I have not seen the surface of the English examples; but in my Volume above quoted I note the surface as smooth, with concentric, fine, thread-like strix on the anterior side, and that the periostraca in shale specimens often extends for a line or more beyond the margins. Col. Portlock's figure (Geol. Rep. t. 36. f. 6.) of his Amphidesma axiniformis (which is not however the Isocardia axiniformis of Phillips) resembles this species very closely, but has rather straighter anterior side, and less oblique truncation of the posterior end, and the diagonal ridge is not so strongly marked.

Position and Locality.-Common in the lower carboniferous limestone of Lowick, Northumberland.

\section{Myopionia obscura (Sow. Sp.)}

Ref. and Syn. = Aximus obscurus Sow. Min. Con. t. 314. (?+A. parvus + A. undatus Brown, Manch. Trans.

Vol. I.t. 6. f. 30, 31. according to King) = Schizodus obscurus (Sow. sp.) King, Perm. Foss. t. 15. f. $23,24$.

Desc.-Obovate, anterior side broad, from beak to opposite point of ventral margin, almost scmicircularly arched; beaks large, prominent, tunid, with a slight oblique inclination towards the posterior side; posterior end narrowed by the convergence of the dorsal and rentral margins, and subtruncate rather obliquely (the narrowness and obliquity increasing with age); hinge-line oblique; ventral margin moderately convex, or with a slight concavity in front of the respiratory angle in old specimens; valves moderately convex, most so at one-third the width from the beak, from whence the surface declines gradnally to the anterior and ventral margins; diagonal ridge from the beak to the respiratory angle obtuse, moderate; posterior slope flattened. Shell moderately thick, marked with obtuse, concentric, irregular strie, most regular and distinct on the anterior third. Casts shew the tecth, and muscular and entire pallial impressions, as in the generic character. Length of very large specimen one inch eight lines, greatest proportional width from beak to opposite ventral margin $\frac{50}{1 m}$, length of anterior end $\frac{45}{100}$, length of hinge-line $\frac{45}{100}$, width of posterior end $\frac{36}{100}$, depth of each valve $\frac{23}{100}$ to $\frac{25}{100}$. 
By examining the lines of growth of old specimens laving the narrow, subacuminate, obliquely truncated posterior end, with the slight sinus in front of the respiratory angle, it will be noticed that the outline at younger stages of growth differed by lhaving a rather wider and less obliquely truncated posterior end, and no sinus in front of the respiratory angle, from which we may doubt the distinctions of form on which the Axinus rotundatus and Schizortus truncutus of King have been founded, to be really distinctive. Of the S. Schlotheimi of Geinitz I forbear to speak, having no specimens; but the character of greater elongation and obliquity of the posterior end may possibly only indicate aged dwarf specimens. I have examined the small specimens from the red Permian marl of Manchester, described by Capt. Brown, and I have no doubt of their being young and dwarf specimens of the species more largely grown in the limestone beds. Prof. King, on examining the original specimen of A. undatus of Brown, finds the flexure to be a break in the margin, not coinciding with the lines of growth.

Position and Locality.-Common in the Permian magnesian limestone of Humbleton Hill.

\section{Myophoria rotundata (Brown Sp.)}

Ref. and Syn. = Axinus rotundatus Brown, Manch. Geol. Trans. Vol. I. t. 6. f. 29. (? + A. mesillus and Lucince minima id. id. fig. 32, 33.) = Schizodus Rossicus M. V. K. Geol. Russ. t. 19. f. 7, 8. + Schizodus truncatus King, Perm. Foss. t. 15. f. 25 to 29. (and fig. 30, as S. rotundatus.)

Desc.-Ovato-rhomboidal, anterior side very broadly rounded; posterior end obliquely subtruncate, broad; hinge-line slightly oblique; ventral margin gently convex, nearly straight towards the respiratory angle; beaks moderately large, prominent; diagonal ridge from beak to respiratory angle obtusely rounded; posterior slope slightly coneave; valves moderately tumid, most so at a little more than one-third the width from the bealis, from whence the surface arehes gradually to the margins; posterior half of the shell nearly smooth, marked with subregular lines of growth, which rise abruptly on the anterior side, into thread-like elevated lines, nine in two lines at six lines from the beak. Teeth and muscular impressions as in the generic character. Length of rather small specimen nine lines, in proportion to length greatest width from beak to opposite ventral margin $\frac{n 7}{1 m}$, length

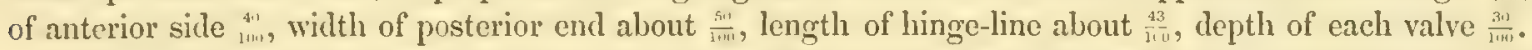

The more rounded form, the broader and less obliquely truncated posterior end, and the consequently less ovate form, and shorter posterior side, are the characters supposed to separate this species from the $M$. obscura; the shell is also said to be thinner; but all these are characters shared by the young specimens of 11 . otscura; and as the size of the present species is less than that of the typical $M$. olscura I am by no means certain that they should be considered specifically distinct, and rather incline to the opinion that a larger suite of specimens than I have at command may shew their identity. The figures given by Prof. King seem to support this view; some of the latter shew the original colouring in small triangular dark blotches.

Position and Locality.- Not common, usually under an inch in length, in the Permian magnesian limestone of Humbleton Hill; also in the red Permian marls near Manchester.

\section{Genus. CLIDOPHORUS. See page 273.}

\section{Clidophorus costatus (Bromn $S p$.)}

Ref. and Syn. = Arca costata Brown, Trans. Manch. Geol. Soc. Vol. I. t. 6. f. 34, 35.=Pleuropliorus costatus King, Perm. Foss. t. 15. f. 13 to 17.=Cypricardia IFurchisoni Geinitz, Grundr. t. 19. f. 2.

Desc.-Elongate, oblong, or subelliptical; dorsal and ventral margins subparallel, very slightly convex or almost straight; hinge-line nearly as long as the shell; anterior end very short, semielliptically rounded; posterior end obtuse, rounded, very slightly oblique; beaks small, very slightly projecting, inclined obliquely, and approximate over the anterior end: casts shew a very strong sulcus of the clavicular ridge, extending from the front of the beak along the posterior edge of the large anterior adductor, and the strong cartilage plate running 
the whole length of the hinge-line a little below the simple erect dorsal margins; traces of two minute cardinal teeth under the beak of each valve; surface with from three to six strong, subequal, narrow ridges, radiating from the beak over the posterior half of the shell; the ridges rather less than half a line wide, and nearly a line apart at the margin; the anterior portion of the shell destitute of radiating ridges, but all the surface covered with very minute concentric plice of growth. Average length one inch one line, proportional width (greatest about the middle of the length) $\frac{15}{100}$, length of anterior end $\frac{10}{100}$, depth of both valves $\frac{30}{100}$.

I have purposely omitted referring to King's figures of the short unridged variety, which seems distinct; I might remark that the specimens I have examined shew only the most minute traces of the cardinal teeth, represented so strongly in Professor King's figures. The near parallelism of the dorsal and ventral margins, and want of byssal sinus in the latter, separate this fossil from the ridged varieties of Mytilus Pallasi de Verneuil.

Position and Locality.-Not uncommon in the Permian limestone of Humbleton.

\section{Gemus. PINNA (Linn.)}

Gen. Char.-Shell very long, triangular, equivalve; beaks pointed, terminal; posterior end very broad, truncate, widely gaping; one large, subtrigonal, posterior muscular impression, and one very small reniform one at the beaks; cartilage very long, narrow, internal, supported by a very slender ridge close within the cardinal edges; no teeth; shell of one internal laminated layer, and an external vertically fibrous layer. Animal long, mantle quite open, with ciliated edges; mouth with two foliaceous lips and two pairs of short palpi, united in part of their length; foot narrow, conical, with a large silky byssus at its base.

Differs from Nytilus by the fibrous texture, the gaping of the posterior end of the shell, and the absence of any siphons to the animal.

The recent species abound most in temperate and warm seas, fixed by their byssus, with the beak downwarls, to foreign bodies, or sunk in the sand with only their truncated end exposed, a little below low-water mark. (D'Orb.)

\section{Pinna flabelliformis (Martin).}

Ref. and Syn. $=$ Conch. Pinnites flabelliformis Martin, Pet. Derb. t. 6. = C. P. nudus id. in the Syst. Arrangement; ? = Pinna costata Phill. Geol. York. Vol. II. t. 6. f. 2.

Desc.-Valves elongate, triangular, nearly three times longer than wide; sides covered in their whole width by wide, nearly straight, rounded, or slightly flattened ridges, of irregular, unequal size (varying, at six inches from the beak, from half a line to two lines, but more commonly a line and half, wide), separated by decp, concave sulci, varying from little less than the width of the ridges to one-third of that width irregularly; section obscurely rhomboidal near the beaks, the valves becoming more flattened towards the posterior end; surface crossed by close, obtuse, obscure lines of growth, the ridges rendered very slightly flexuous by occasional subtubular rugosities, seattered at wide intervals over the ridges and furrows; within an inch from the beak the radiating ridges become obsolete. Average length eight inches, proportional width about $\frac{45}{200}$.

This species not unfrequently exceeds a foot in length; some of the ridges, particularly those near the hinge-line, remain simple throughout, while others dichotomise irregularly, the pair thus produced being recognisable to the end by the much narrower and shallower divisional sulcus. The small, subtubular, nodosities are very rarely to be seen, they break off so readily in the matrix. The deptlı near the beaks considerably exceeds the width, and at three inches from the beaks the ridges are so reduced in size as only to measure six in the space of half an inch.

Position and Locality.-Not uncommon in the carboniferous limestone of Derbyshire; not unenmmon in the dark lower carboniferous limestone of Poolwash, Isle of $\mathrm{Man}$; in dark earthy carboniferous limestone of Craige near Kilmarnock. 


\section{Pinna flexicostata ( ${ }^{\circ}$ Coy). Pl. 3. E. fig. 11, 12, 13.}

Ref.-McCoy, Syn. Carb. Foss. Trel.t. 19. f. 1.

Desc.-Triangular, nearly three times Ionger than wide, very gilbous along the middle; section elliptical, the ventral third of each valve free of ribs its entire length, and crossed obliquely by large wrinkles or undulations of growth, which beeome nearly obsolete on the ridged portion of the shell; beak smooth for six or seven lines, beyond which the middle and dorsal thirds of the surface are covered with strong unequal ridges, separated by rather narrower, deep, concave sulci, straight and nearly simple along the dorsal third, occasionally interrupted and more flexuous along the middle third, where several of them are also divided by a small intervening sulcus, (at two and half inches from the beak, about seven ridges in half an inch). Average length about three inches, proportional greatest width at posterior end $\frac{40}{100}$, depth of both valves in the middle $\frac{20}{100}$.

This is a much smaller and more gibbous species than the $P$. flabelliformis, it has smaller and more flexuous ridges, and is particularly distinguished by the rentral third of the whole length of each valve being free of longitudinal ridges.

Pusition and Loculity.-Very common in the impure carboniferous limestone of Lowick, Northumberland; very common in the red millstone-grit of Honey-Pen Hill; in the red carboniferous grit of Brandon Hill.

Explanation of Figures.-Pl. 3. E. fig. 11, left valve, natural size, from Lowick; fig. 12, right valve; fig. 13, section of both valves.

\section{Pinna spatula $\left(M^{c} C^{\prime} o y\right)$. Pl. 3. E. fig. 9 and 10. Ref.-McCoy, Ann. Nat. Hist. 2nd Series, Vol. XII.}

Dese.- V Valves very narrow and much elongated, about four times longer than the width of posterior end, very slightly convex except at the beaks, which are pointed and almost cylindrieal; the sides gradually flattening as they approach the posterior end, which is subtruneate or slightly rounded obliquely; cardinal margin slightly thickened, with the cartilage ridge very close within its edge; surface perfectly surooth, or with very faint laminar lines of growth parallel with the margins. Length of large rather imperfect specimen five and half inches, proportional greatest width at posterior end about $\frac{3 y}{100}$; greatest depth $\frac{8}{100}$, or $\frac{9}{100}$.

Fragments of this species might be taken for a Solen, and the S. silinuoides (Kon.) may have some affinity with it, though specifically distinguished. The muscular impression is rather large, though superficial, quadratoreniform rather behind the middle of the length, and nearer to the cardinal than the ventral margin.

Position and Locality. - Specimens of the abore large size rare in the carboniferous limestone of Derbyshire; specimens about three inches long, and slightly more convex, in the carboniferous limestone of Lowick.

Explanation of Figures.-PI. 3. E. fig. 9, left valve, natural size, from the carboniferous limestone of Derbyshire; fig. $9 a$, section near anterior end; fig. $9 b$, profile, near posterior end; fig. 10, smaller and more perfect specimen from Lowick, Northumberland.

\section{Genus. EDMONDIA (de Koninck).}

Gen. Char.-Shell equivalve, inequilateral, tumid, short, oblong or rounded, closed all round; dorsal and ventral margins slightly convex; beaks tumid, with an impressed lunette beneath them; surface with concentric stria or wrinkles; no teeth, but an internal lamellar cartilage support, which is much dilated within the cavity of the beaks, the broad end forming the slits in casts coinciding with the edges of the anterior lunette, and the posterior end running nearly parallel to and close within the hinge-line; dorsal margins erect and simple; two simple adductor impressions, often with an accessory impression over each; pallial sear simple, entire.

The remarkable state of preservation of the Lowick fossils in the Cambridge collection enabled me to detect the characters of the muscular and pallial impressions, and to demonstrate, by the integrity of the latter, that the genus has no affinity to the LIactride, as M. de Koninek supposed; and instead of belonging to that family it is clearly referrible to a different and lower order. The genus is closely allied in appearance to the short species of Sancuinolites, but differs by the dorsal margins being erect and compressed, instead of inflected to form a hollow lunette for the external cartilage, and the margins being closed. 
Edmonda compressa $\left(M^{c} \mathrm{Coy}\right)$.

Ref.-McCoy, Syn. Carb. Foss. Irel. t. 13. f. 10.

Desc.-Ovato-oblong, beals rather tumid, small, rounded, oblique, close to the anterior end; anterior end very short, rounded; ventral margin moderately convex; dorsal margin nearly straight; posterior end slightly narrowed, obtusely rounded; no posterior slope nor-diagonal gibbosity; valves evenly and gently convex, most so near the beaks about half-way between them and the ventral margin, from thence arching aloruptly to the anterior edge, and more gently towards the ventral, dorsal, and posterior edges; anterior lunette beneath the beaks small, deep, rounded; surface smooth or marked with a few small, obsolete, concentric wrinkles of growth. Length about two inches three lines, proportional width from beak to ventral margin $\frac{53}{1 \mathrm{wi}}$, width of posterior end $\frac{43}{100}$, length of anterior lunette $\frac{30}{100}$, depth of one valve $\frac{20}{100}$.

Some of the above measurements are taken from the original Irish specimen, the English one in the collection being imperfect; the latter however shews the thick internal cartilage ridge, beneath the simple erect dorsal margin, of Edmondia.

Position and Locality.-Rare in the lower carboniferous limestone of Isle of Man.

\section{Ediondia Egertoni (McCoy).}

Ref. and Syn. = Cyprina Egertoni McCoy, Syn. Carb. Foss. Irel. t. 10. f. 9.

Desc.-Quadrato-orbicular, moderately and evenly convex; beaks large, tumid, obliquely inclined to the very large, deep, ovate, anterior lunette; hinge-line short, gradually rounded into the rotundato-quadrate posterior end; anterior end large, semicircularly rounded, broad; ventral margin evenly convex; substance of the shell very thick; surface concentrically grooved by slightly irregular, subequal, obtuse, cord-like ridges (averaging seven in two lines at an inch and half from the beak). Length of small specimen two inches two lines, proportional width from beak to ventral margin $\frac{8 \pm}{110}$, length of anterior end thereof $\frac{17}{1 \cdots}$, depth of one valve (greatest at one-third from the beals) $\frac{24}{1, w i}$; (adult specimens three inches nine lines long), thicliness of the shell rather more than one line.

The nearly orlbicular form, close, cord-like coneentric ridging, subcentral beaks, and large size, easily distinguish this from other species of the genus, giving it much the external appearance of Cyprinc. Casts shew the very large anterior and posterior adductor impressions strongly marked when the shell is entirely removed, connected by the strong, simple, pallial scar, also the thick cartilage ridge beneath the hinge-margin on the posterior side, and bordering the edge of the lunette on the anterior one. A few elongate points or scratchlike markings, arranged in regular radiating lines, are seen with a glass on most of the specimens of internal casts.

Position and Locality.-Not very common in the impure carboniferous limestone of Lowick, Northumberland.

\section{Ediondia Josepita (de Kon.)}

Ref.-de Kon. Anim. Foss. Bel. t. 1. f. 5.

Disc.-Oblong, moderately compressed; beaks rather large, oblique, compressed, approximate, close to the anterior end, which is very short, subtruncate, rounded; posterior end slightly narrowed, subtruncate, obtuse, rounded; ventral margin very slightly convex; hinge-line nearly as long as the shell; anterior lunette small, ovate; valves rather flattened, moderately and evenly convex, most so at about one-third the width from the beaks, gradually arching from thence to the ventral and posterior margins, abruptly sloped to the anterior end, and abruptly rounded to the cardinal margin, but no posterior slope or diagonal ridge; surface with numerous subregular, obtuse, concentric wrinkles (about three or four in two lines near the margin), and coarse strix of growth. Length ten lines; in proportion thereto greatest width (from beak to ventral margin) $\frac{70}{100}$, width of posterior end $\frac{55}{100}$, length of anterior end $\frac{15}{200}$, length of anterior lunette $\frac{15}{200}$, depth of both valves $\frac{60}{100}$. 
It is doubtful whether this species be perfectly identical with that of De Koninck, as it is concentrically ridged as well as striated; the proportions however agree, and the species is distinguished from all ages of the E. unioniformis by the narrower and much less tumid valves. Casts shew the internal cartilage ridge below the erect cardinal edge, as in the other Edmondice, its broad anterior end coinciding with the edge of the anterior lunette.

Position and Locality.-Rare in the impure carboniferous limestone of Lowick, Northumberland.

\section{Edmondia Murchisoniava (King).}

\section{Ref.-King, Perm. Foss. t. 14. f. 14 to 17.}

Desc._Oblong, dorsal and ventral margins nearly parallel, and nearly straight; anterior and posterior ends subtruncate, obtusely rounded; beaks tumid, obliquely incurved, prominent near the anterior end, with a small, very deep, wide, cordate lunette beneath them; valves evenly tumid, arehing gradually to the ventral and posterior margins, more abruptly to the anterior, and to the dorsal margins; surface sharply sculptured, with equal, rery prominent strix, parallel with the margins (averaging ten in one line at two lines from the beak), two or three of which, near the edge of old specimens, are more prominent than the rest, and slightly imbricated, forming slight wrinkles. Casts shew the thick cartilage plate beneath the anterior part of the dorsal line, dilating within the beak to the edge of the anterior lunette. Length five lines, proportional width $\frac{1 .}{10 u}$, width of posterior end $\frac{64}{200}$, length of anterior end $\frac{15}{100}$, depth of one valve $\frac{30}{100}$.

According to Prof. King, specimens occur occasionally one inch long; but I have never seen any exceeding half an inch. It is a beautifully-marked and very distinct species.

Position and Locality.-Rare in the Permian limestone of Humbleton.

\section{Edionda oblonga ( $\left.M^{\circ} \mathrm{Coy}\right)$. Pl. 3. F. fig. 10.}

\section{Compare Sanguinolaria oblonga Portk. Geol. Rep. t. 36. fig. 2.}

Desc.-Elongate-oblong, tunid, sides slightly flattened; posterior slope undefined, anterior and posterior ends broad, subquadrate, rounded; dorsal and ventral margins subparallel, nearly straight, slightly convex; beaks large, near the short anterior end, which is abruptly compressed in front of them; lunette beneath the beaks small, oval; surface with numerous small, rounded, subequal, concentric wrinkles (about four or five in quarter of an inch at the middle of the shell). Length two inches two lines, proportional width from beaks $\frac{05}{10}$, width of posterior end $\frac{56}{100}$, length of anterior end $\frac{19}{100}$, depth of both valves $\frac{52}{100}$.

Var. $\beta$. brevis, proportional width $\frac{75}{100}$.

In the casts extremely faint indications of oblique, radiating, minute strixe are seen, and the cardinal ridge is very thick, extending nearly as long as the hinge in each valve, leaving the cardinal edges erect between them; also the large anterior and posterior adductors with the simple pallial impression, and traces of a small accessory impression over the posterior adductor. In a few specimens the concentric ridges are somewhat larger and less regular on the posterior slope. The var. $\beta$. brevis differs in nothing but the shorter figure above given, and I have seen most of the intermediate grades. The Senguinolaria oblonga Portlock (Geol. Rep. t. 36. f. 2) seems to be more compressed, to have a more defined posterior slope, and to have large regular imbrications in addition to the small concentric markings; they may however be identical. The so-called Isocardic unioniformis (Phil.) scems to differ by its narrow posterior end, and wrinkles confined to the posterior slope. The dilated cartilage plate within the cavity of the beak of each valve is about two lines wide, being continued as usual from the thick ridge below the hinge-margin, and the broad end abutting against the anterior lunette; it is marked with rather strong marginal lines of growth, and very faint, fine, radiating strix.

Position and Locality. - Abundant in the dark, impure carboniferous limestone of Lowick, Northumberland.

Explanation of Figures.-PI. 3. F. fig. 10, right valve, natural size, internal cast, shewing the large adductor impressions, connected by the simple pallial scar (the thick cartilage plate beneath the simple cardinal margin too faintly expressed); fig. $10 \alpha$, end view to shew the anterior lunette (the indications of the thick cartilage plate on each side of the linge-line too faint). 


\section{Ediondia pitaseolina (Gold. Sp.) \\ Ref. and Syn. = Sanguinotaria phaseolina Gold. Pet. t. 159. f. 15.}

Desc.-Oblong, compressed, sides gently convex, posterior slope undelined; beaks moderate, prominent, about one-fourth from the anterior end, which is gently compressed, elliptically rounded; posterior end slightly oblique, subtruncate; anterior lunette narrow; ventral margin slightly convex; casts have the surface marked with fine, close, radiating strix, crossed by nearly obsolete, obtuse, irregular, slightly undulating concentrie wrinkles. Length one inch one and half lines, proportional width from beaks $\frac{71}{100}$, width of posterior end $\frac{55}{100}$, length of anterior end $\frac{95}{300}$, depth of both valves $\frac{42}{100}$.

I have little doubt that the slight sinus in the ventral margin given by Goldfuss results from an imperfection (as we might suspect cven from his figure), numerous specimens before me agreeing otherwise with his figure and description shewing no trace of it. I have not seen the external surface; the casts shew the two adductors and simple pallial sear faintly marked, and the sulcus of a strong cardinal ridge running close under the cardinal margin, dilating within the cavity of the beak, the broad end terminating along the edge of the narrow lunette. The smaller size, compression of the valves, longer anterior end, and nearly obsolete undulated wrinkles separate it from the $E$. oblonga.

Position and Locality. - Not uncommon in the carboniferous limestone of Lowick, Northumberland.

\section{Edmondia Rudis $\left(M^{\circ} \mathrm{Coy}\right)$. Pl. 3. F. fig. 9.}

Ref.-MCoy, Ann. Nat. Hist. 2nd Series, Vol. XII.

Desc.-Rotundato-quadrate, very gibbous, beaks very large, obtuse; posterior end broad, subtruncate, very slightly oblique; posterior slope flattened, steep, undefined; anterior end sulstruncate, abruptly compressed; ventral margin gently convex; hinge-line nearly as long as the shell, slightly raised; middle of the shell with very unequal rugged plica parallel with the ventral margin; anterior and posterior slopes nearly smooth. Length one inch one line, proportional width $\frac{85}{1+w}$, width of posterior end $\frac{130}{1+10}$, length of anterior end $\frac{15}{10 u}$, depth of one valve $\frac{26}{100}$,

The short, quadrate, extremely gibbous form and unequal rugged plica, distinguish this species from all other carboniferous fossils that I know, at a glance. There is often a sort of large, obscure, pitting between the plice. The cardinal cartilage ridge is very thick, and nearly as long as the hinge-line, or simple, erect, cardinal margin.

Position and Locality. - Rare in the impure carboniferous limestone of Lowick, Northumberland.

Explanation of Figures.-PI. F. fig. 9, right valve, natural size.

\section{Edmonda scalaris ( $M^{c}$ Coy). Pl. 3. H. fig. 6.}

Ref. and Syn. = Venerupis scalaris $\mathrm{M}^{\mathrm{C} C o y}$, Syn. Carb. Foss. Irel. t. 12. f. 6.

Desc.-Oblong, short, very tumid; beaks very large, tumid, incurved, greatest depth at about one-third the distance between their apex and the ventral margin, the sides gradually sloping from thence to the ventral edges, abruptly sloping posteriorly to form the imperfectly defined posterior slope, also abruptly sloping to the anterior edges; anterior side very small, compressed, rotundato-quadrate; anterior lunette short, orate, deep; posterior end subquadrate, obtuse; hinge-line nearly as long as the shell; surface marked with about ten regular, very large, angular, coneentric ridges, separated by obtusely angular interspaces. Length eleven lines, proportional width from beak to ventral margin $\frac{80}{100}$, length of anterior end $\frac{18}{100}$, depth of both valves $\frac{63}{100}$.

Casts shew the very thick cartilage ridge running nearly the length of the hinge-line a short way below the simple, erect, dorsal margins.

This is one of the most strongly-marked fossils of the carboniferous limestone, from its large, smooth, angular, concentric ridges.

Position and Locality.-Very rare in the carboniferous limestone of Lowick, Northumberland.

Explanation of Figures.-Pl. 3. H. fig. 6, left valve, natural size. 


\section{Edmondia sulcata (Phill. Sp.) \\ Ref. and Syn. Sanguinolaria sulcata Phill. Geol. York. t. 5. f. 5. = Sanguinolaria concentrica Gold. in De la Beche, Man.}

Desc.- Oblong, rather more than twice as long as wide, uniformly convex; depth of both valves about twothirds the width fron the heak to opposite ventral edge: posterine slope convex, undefined; posterior end subtruncate, not oblique, rounded, slightly gaping; anterior end short, rounded, no trace of depression from beak to ventral margin; a small ovate lunette beneath the beaks, which are of moderate size; surface with large wrinkles on the posterior slope about two in a quarter of an inch at one inch from the beak, each of which divides into a bundle of two or three sharp narrow sulci on the body and anterior end of the shell. Length two inches two lines, proportional wirth from beak to opposite margin $\frac{44}{1 m}$, width of posterior end $\frac{4 n}{100}$, length of anterior end $\frac{15}{100}$, depth of both valves $\frac{3 B}{100}$.

This species is almost always found with the two valves together. The large posterior wrinkles dividing each into a number of small ones, as they cross over the body of the shell, give a curious character to the surface; but sometimes the original ridges remain so strong as nearly to obliterate the minor ones. I have not seen the surface perfectly preserved, but the easts shew obseure, punctured lines radiating from the beak to the ventral margin. Numerous fincly preserved Lowick specimens in the Cambridge enllection shew the anterior and posterior large oval adductor impressions, connected by a perfectly entire and distinetly marked pallial scar, (so that Mr King must have been deceived in this respect,) also the small accessory impression over each adductor, and the small deep slit left by the ridge bounding the lunette in front of the beaks and behind the retractor which is so short as not to reach even the upper edge of the adductor; it forms the anterior boundary of the internal dilated cartilage plate, the posterior portion of which is continuous with the slit left by the internal cardinal posterior cartilage ridge, which extends about two thirds the length from the beaks to the anal angle, running a little within the simple, erect, dorsal margin.

Distinguished from the Sanguinolites sulcatus Flem. sp. (= Allorisma sulcata + A. regularis King sp.) by the greatest gibbosity being, where the hollow from the marginal sinus in the anterior ventral margin occurs in that species; also by the splitting up of the wrinkles on the sides and their greater strength on the posterior slope, the strong internal cardinal-ridge, the erect dorsal edges, want of the parallel stria on the diagonal convexity, \&c. I have occasionally seen a rare variety almost as finely plicated as the S. plicatus, from which however the convexity and obscure definition of the posterior slope will help to distinguish it.

Position and Locality. - Extremely abundant in the dark carboniferous limestone of Lowick, Northumberland; also, though less abundant, in the impure carboniferous limestone of Kendal.

\section{Edmondia unioniformis (Phill. Sp.)}

\section{Ref. and Syn. = Isocardia unioniformis Phill, Geol. York. Vol. II. t. 5. f. 18.}

Desc.-Ovato-oblong, evenly gibbous; bealis large, obliquely inclined to the anterior side, approximate; anterior lunette very large, oval, deep; anterior side very short, rounded; posterior end slightly narrowed, obtusely rounded; ventral margin very slightly convex; linge-line nearly as long as the shell; posterior slope convex from the middle of the sides, no diagonal ridge; substance of the shell very thick; surface concentrically marked with coarse strix and small irregular plice (about four to six in two lines near the margin) parallel with the edges. Casts shew an extremely thick cartilage ridge, running beneath the simple, erect, cardinal margin, and dilating within the eavity of the beaks, also the anterior and posterior adductor impressions connected by the simple pallial sear. Length one inch nine lines; in proportion thereto, greatest wilth (from

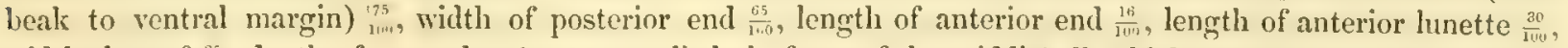
width thereof $\frac{25}{i v i}$, depth of one valve (greatest a little in front of the middle) $\frac{32}{110}$, thickness of the shell nearly one and haif lines.

Although the great prominence of the beaks makes the anterior end considerably wider than the posterior, yet this latter, in perfect specimens, is not quite so narrow as in Prof. Phillips's figure, nor do I find the plica-

[EASC. III.] 
tion confined exclusively to the posterior slope, as he seems to indicate. M. de Koninck's figure, on the other hand, is too nearly orbicular, the anterior end being too long and the ventral margin too much arched to agree with the present species; the substance of the shell is most unusually thick in the adult; the internal cast displaying all the generic characters well. Young specimens eight lines long are not uncommon, retaining all the proportions of the adult, and towards their margin the obsolete concentrie wrinlles are about six in one line; these also have the depth of both valves a little above $\frac{r^{m}}{\mathrm{j} m}$, and not equal to the width, as in De Koninck's specimen. Specimens in some states of preservation shew faint traces of close, radiating, microscopic striæ.

Position and Locality. - Rare in the limestone of Lorvick, Northumberland.

\section{Family. CELONOTIDE. See p. 275.}

Genus. SANGUINOLITES ( $\mathrm{FCOy}^{\mathrm{C}}$ ). See p. 276.

$$
\begin{aligned}
& \text { Sanguinolites clava ( } M^{\circ} \text { Coy). PI. 3. F. fig. } 12 . \\
& \text { Ref.-M } M^{\circ} \text { Coy, Ann. Nat. Hist. 2nd Series, Vol. VII. }
\end{aligned}
$$

Desc.-Elongate, clavate or subpyriform; anterior end large, very short, obtusely rounded; dorsal and ventral margins with a slight upward curvature, slightly converging to the posterior end, which is slightly narrowed, subtruncate, rounded; beaks large, obtuse, a broad-ovate striated lunette beneath them on the anterior side; posterior lunette the length of the hinge-line, wide, hollow, bounded by the obtuse ridges of the dorsal margins; ventral margin gently convex; valves very convex in front, most so a little behind the beaks, half-way between them and the ventral margin, from thence abruptly sloped to the anterior margin, and gradually becoming more compressed towards the posterior end; posterior slope gently cunvex, undefined; diagonal ridge not marked. Surface covered with thick, rugged, subequal ridges, arising a little behind the anterior lunette, and slightly thickening towards the posterior slope, where they average three to four in half an inch in the middle of the shell; posterior slope obscurely defined by their termination, and only marked by fine stria of growth parallel with the end, and faint extensions of the concentric waves; anterior lunette and a small portion of the anterior extremity also nearly smooth; the ridges where the outer surface is preserved are covered with a minute, irregular striation approximately parallel with the margin. Length from anterior to posterior end about five inches two lines, proportional width from beak to opposite ventral margin ${ }_{\mathrm{i} \text { iu }}^{45}$, length of anterior end $\frac{12}{100}$, depth of both valves (greatest a little behind the beaks) $\frac{33}{100}$, length of anterior lunette $\frac{1}{10 i}$, width of posterior lunette $\frac{10}{100}$, depth of posterior end about $\frac{30}{100}$.

This fine species is remarkable for the clavate form produced by the gibbosity of the valves near the anterior end and the tapering towards the posterior extremity. Of the internal impressions I lave only seen the anterior adductor, which is broad, rounded, and shallow, with a slight ridge above its anterior margin. The only approximation to this species published, that I know, is an indeterminate fragment of one end of a shell called S. maxima by Portlock, Geol. Rep.t. 36. f. 1, which is flatter, with smaller beaks, a more truncate anterior end, \&c.

Position and Locality.-Not uncommon in the carboniferous limestone near Llangollen, N. Wales.

Explanation of Figures.-Pl. 3. F. fig. 12, left valve, natural size, shewing the impression of the anterior adductor at the anterior end; fig. $12 a$, back view, to shew the wide anterior and posterior lunettes, or inflected margins for the external cartilage.

\section{Sanguinolites Iridinoides $\left(M^{c} C o y\right)$. Pl. 3. F. fig. 11.}

$$
\text { Ref.-McCoy, Synop. Carb. Foss. Irel, t. 12. f. } 1 .
$$

Desc.-Shell much flattened, very elongate, oblong; anterior side short, compressed, semielliptically rounded. no byssal furrow defining it from the body of the shell; ventral margin slightly convex; posterior end slightly narrowed, obliquely truncate, the slightly oblique angles rounded; anterior side and body of the shell 
marked with fine, crowded, mequal wrinkles (averaging four to six in three lines at the middle of the shell), which change into broad, obsolete undulations on the posterior slope (three in six lines at two inches from the beak) after passing over the obseurely marked, diagonal ridge which runs from the beak to the respiratory angle; posterior end broader than the anterior, obliquely subtruncate; slightly gaping at both ends; hinge-line with a very slight upward curvature, nearly as long as the shell, the margin inflected to form a broad, concave, posterior lunette, or enneare horizontal cartilage support, with prominent, obtuse, external boundaries. Casts shew in each valve a deep furrow from the beak nearly to the posterior end, left by the thick internal ridge running close under the dorsal margin: impression of the anterior adductor large, strong, ovate, surmounted by the small acccssory impression; a nearly vertical, slightly curved ridge from the beak behind them leaves a sulcus in the cast; posterior adductor and posterior part of pallial scar superficial, leaving scarcely any trace. Substance of the shell excessively thin (alout one-fifth of a line); periostraca sharply and irregularly striated concentrically. Length about six inches, proportional width from beak to ventral margin ${ }_{1 m}^{25}$, width of posterior

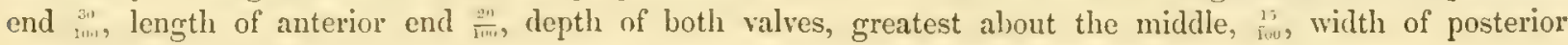
lunette $\frac{?}{100}$.

This shell resembles an. Iridina in form. The substance of the valves is extremely thin, and when wellpreserved, of a brown horny appearance, minutely plicated parallel with the margin. There is a slight depression parallel to and a little below the hing-line; the oblique posterior ridge is much better marked in some specimens than in others; alove it the undulations of the surface are broad, and slightly convex, but immediately below it suddenly diminish in size and increase in number, and beconing less prominent, continue so to the anterior end; the depth of the shell gradually but slightly increases from the anterior to the posterior extremity. This shell is distinguished from the $S$. undata (Portk.) by that species having numerous, strong, prominent ridges, continued without any visible increase in number or diminution in size across the body of the shell; the anterior side is also much narrower and rounded. The difference from the S. transeersce (Portk.) is the narrowness of the posterior end in that species, in which also the superfieial markings continue as small fine plice and lines over the whole shell, instead of forming strong, broad, undulations on the posterior side as in this. The thick internal ridge below the cardinal margin, which leaves a strong sulcus in the cast, is thickest at the posterior end, and gradually tapers to a point, and disappears before reaching the beak, so that it is in no way homologous with the cartilage ridge of Edmondia.

Position and Loculity.- Tery abundant (usually with the valves connected and open) in the dark limestone of Lowick, Northumberland. The original Irish localities were Roughan, Dungannon, north of Ireland, in a precisely similar limestone to that of Lowick, and in the Calp of Ballintrillick.

Explanation of Figures.-Pl. 3. F. fig. 11, right valve, natural size, shewing a patch of the extremely thin shell near the middle of the dorsal margin, the remainder of the specimen being an internal cast, shewing the thick cardinal ridge close under the hinge-line in the posterior portion, and the large anterior adductor surmounted by its accessory impression at the anterior end; from the limestone of Lowick, Northumberland; fig. $11 a$, lack view, to shew the wide, concave, inflected dorsal margins, and the sulcus left by one of the cardinal ridges, tapering to a point before reaching the beak, with two small patches of the very thin shell adhering.

\section{Sanguinolites lunulatus (Keyserling $S p$. )}

Ref. and Syn $=$ Amplidesma lunuletu Keyserling, Petschoraland, t. 10. f. 16. = Allorisma elegans King, Perm. Foss. t. 16. f. 3 to 5.

Desc.-Longitudinally oblong, very gibbous diagonally, most so along an obscurely-angular sigmoid ridge, from the beaks to the respiratory angle; beaks broad, tumid, oblique, compressed; anterior side rather long, obtusely pointed, rounded, much narrowed by a very long, oblique, large, elliptical lunette, extending nearly to the ventral margin; ventral margin slightly and irregularly convex, without distinet sinus; posterior end slightly narrowed, obtuse, obliquely subtruncate; sides gently convex, often with a slight oblique flattening or concavity near the middle, crossed by irregular, obtuse, obsolete wrinkles of growth (about four or five in three lines at six lines from the beak); posterior slope slightly concave, smooth, the concentric wrinkles at the sides stopping

$$
3 \text { т } 2
$$


at the diagonal ridge; hinge-line not quite so long as the shell; inflected margin slightly concave, moderately wide; surface under the lens covered with very minute granules, less than their dianeter apart. A verage length one inch two lines, in proportion thereto greatest width from beak to ventral inargin $\frac{60}{100}$, width of posterior end $\frac{45}{100}$, length of anterior end $\frac{30}{100}$, length of anterior lunette $\frac{20}{100}$, depth of both valves $\frac{50}{100}$.

Professor King mentions the pallial sinus of this species being shallow, and figures it very distinctly. A specimen sent to the Woodwardian Museum, supposed to exhibit this character, shews a mark very different in form, and in my mind not due to the pallial scar at all, nor have I ever seen a sinuated pallial scar in any shells of the kind. As Count Keyscrling's figure and description seem to have long had the priority over I'rofessor King's first description (in his catalogue), I think it but just to adopt his name.

Position and Locality.- Rare in the Permian limestone of Humbleton.

\section{SANGUinolites Striato-Lanellosus (de Kon. Sp.)}

Ref. and Syn. =Cypricardia striato-Zamellosa de Kon. Anim. Foss. Eel. t. H. f. 8.

Desc.-Elongate, oblong, compressed, increasing slightly in width towards the posterior end, which is obliquely bitruncate; beaks moderate, pointed, oblique, moderately incurved; anterior side short, compresserl, semielliptically rounded, with a very deep orate lunette beneath the beaks; hinge-line considerably shorter than the shell, rendering the anal angle very obtuse; cardinal margins inflected nearly at right angles to form the moderately wide, narrow, posterior lunette or cartilage support, which is bounded by a strong ridge; ventral margin nearly straight, sometimes with a very minute obsolete sinus in the middle, from which a faint obsolete sulcus extends towards the beak; sides very slightly convex; diagonal ridge from beak to respiratory angle very sharply defined throughout, angular; posterior slope flattened, divided in the middle by a strong angular ridge, the projection of which forms an obtuse angulation in the middle of the posterior margin. Surface marked with sharp, regular, concentric lines of growth, and after about three lines from the beak, with flat imbricating lamine, averaging one line wide, most strongly marked towards the margin of old specimens. Casts shew the impressions of the large anterior and posterior adductors connected by the distinctly marked, simple, pallial scar. Average length of the British specimen, from anterior to posterior end, nine lines, in proportion thereto width from beak to opposite ventral margin $\frac{44}{100}$, width of posterior end $\frac{50}{100}$, length of hinge-line from

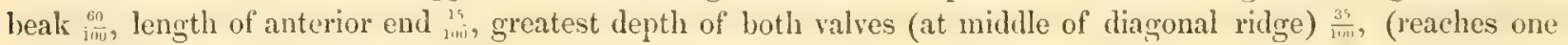
inch four lines long in Belgium).

The single specimen described by de Koninck was larger than any of ours, and shews the broad concentric lamellæe more distinctly for this reason. As I have seen all the generic characters there can no longer be any doubt of the genus. The small byssal furrow is remarkable for its backward position, but is obsolete on several specimens, as in M. de Koninck's type.

Position and Locality.-Common in the shales of the carboniferous limestone of Craige near Kilmarnock; rare in the impure carboniferous limestone of Lowick, Northumberland.

\section{Sanguinolites subcarinatus ( $\mathrm{M}$ Coy). Pl. 3. F. fig. 4.}

Ref.-- $\mathbf{M}^{\mathrm{C} C o y}$, Ann. Nat. Hist. 2nd Series, Vol. VII.

Desc.-Elongate, oblong, tumid; beaks very large, obtuse, near the small, rounded, anterior end, in which there is an abruptly hollowed lunette beneath the beaks; posterior end narrow, square, truncated; diagonal ridge angular, slightly sigmoid, strongly defined from the beals to the respiratory angle; posterior slope smooth, slightly concave, divided nearly in the middle by a ridge-like fold from near the beak, beeoning nearly obsolete at the end; sides slightly flattened, with coarse irregular strie and irregularities of growth parallel with the margin; ventral margin nearly straight, slightly convex; hinge-line as long as the shell; its inflected margin broad, slightly concave, nearly at right angles to the plane of the margin of the valves; length one inch four

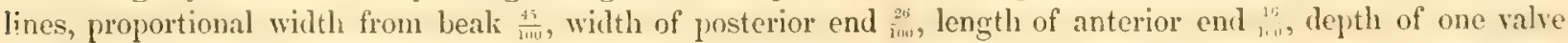
(greatest about the middle of the diagonal ridge) $\frac{15}{100}$.

This rare species is remarkable for its narrow, square, posterior end, and strong angular diagonal ridge. 
It is proportionally shorter, and less regularly ridged than the S. angustatus (Phill.). Goldfuss' figure, under this latter name, nearly agrees with our shell, and is no doubt identical.

Position and Locality.-In the impure carboniferous limestone of Lowick, Northumberland.

Explanation of Figures.-Pl. 3.F. fig. 4, right valve, natural size (the diagonal ridge not sharp enough), exhibiting portion of the inflected cartilage supports along the hinge-margin.

\section{Sanguinolites sulcatus (Flem. Sp.)}

Ref. and s'yn.= IIiatella sulcata Flem. Brit. Anim., not Sanguinolavia id. of Phillips. = Allorisma regularis King, in M. V. K. Geol. Russ. t. 19. f. 6.

Des.-Oblong, dorsal and ventral margins subparallel, slightly arched upwards; very slightly gaping at each end; beaks prominent; the anterior end short, contracted by the oblique ovate lunette beneath the beaks; a shallow sinus in the anterior part of the ventral margin opposite the beaks, towards which a wide faint hollow (undulating the ridges) extends therefrom; dorsal lunette, or cartilage support, of moderate width, concave, nearly horizontal; sides with subequal, concentric wrinkles (three to four in a quarter of an inch, about the middle of the shell), sometimes slightly irregular in passing over the sinal hollow below the beaks, widening towards the olscure bounding convexity of the posterior slope, where they wre mixed with numerous coarse striae parallel with them; in young specimens and towards the beaks of all, the virinkles pass over the posterior slope to the hinge-line, but in old specimens towards the posterior end they leave it nearly smooth. Length, two inches ten lines, proportional width from beak to ventral margin $\frac{40}{100}$, width of posterior end $\frac{43}{100}$, length of anterior end $\frac{13}{1 \cdots}$, depth of both valves $\frac{32}{1 \ldots}$, width of each cartilage plate one and half lines. Substance of the shell very thin : surface marked with longitudinal, membranous, irregular strie, and obscure radiating lines of minute rough puncta under the lens, when finely preserved.

This species is distinguished from the Edmondia sulcata (Phill. sp.) by the ridges not being split up into bundles on the sides and anterior part, by their becoming partially obsolete on the posterior slope, and by the shallow depression from the sinus in the margin towards the beak, of which no trace exists in the $E$. sulcata, as well as in the generic peculiarities of the hinge. Young specimens of this species with the ridges crossing the posterior slope have been sent by Prof. King to the Cambridge collection, marked $A l$. sulcutu, agreeing perfectly with his A. regularis as above; so that although it is not clearly so stated at p. 196 of his "Permian Fossils," it is certain that with his views of the s'. sulcutu (Flem. sp.) his Allorismu regulteris becomes a synonym thereof.

Position and Locality.-Common in the impure carboniferous limestone of Lowick, Northumberland.

\section{Sangunolites tricostatus (Portk. Sp.)}

Ref. and $S_{y, n}=$ Cypricardia? tricostata Portk. Geol. Rep. t. 34. f. $17 ?=$ Pholadomya Visetensis de Ryck. Mél. Pal. t. 10. f. 1 and 2.

Desc.-Elongate oblong, slightly dilated posteriorly from the elevation of the hinge-line, which is a little less than the length of the shell; posterior end obtusely rounded; anterior end very small, oblique, the anterior lunette being extremely large, and extending nearly to the ventral margin; rentral margin nearly straight, without sinus; beaks moderately large, obtuse ; valves tumid, most so about the middle of the very obtusely rounderl diagonal ridge, which extends from the beak to the respiratory angle; posterior slope moderately flattened, divided by three small equidistant ridges radinting from the beak; surface marked with very numerous, close, irregular, small, concentric plicæ, and coarse strix, on the sides, parallel with the ventral margin, the coarse strie alone crossing the posterior slope, slightly scolloped between the radiating ridges, which they render spinulose by crossing; when the periostraca is preserved, rows of minute dots are seen radiating from the beak across the concentric plice (about four rows in the space of one line). Length, one inch eight lines, proportional width from beak $\frac{45}{100}$, length of anterior end $\frac{12}{100}$, width of posterior end $\frac{50}{100}$, depth of one valve $\frac{20}{1000}$.

The number of the ridge-like radiating folds on the posterior slope, and the number and small size of the concentric plice, distinguish this rare species from all others.

Position and Locality.-Very rare in the impure carboniferous limestone of Lowick, Northumberland. 


\section{Sanguinolites variabilis $\left(M^{c}\right.$ Coy). Pl. 3. F. figs. $6,7,8$. \\ Ref.-MI'Coy, Ann. Nat. Hist. 2nd Series, Vol. VII.}

Desc._-Oblong, tumid, nearly closed at the ends; averaging twice as long as wide (sometimes a little more, sometines a little less); beaks large, tumid, oblique, close to the anterior end, which varies from oneninth in large to one-seventh of the length in smaller specimens; anterior lunette large, smooth, oval, contracting the rounded anterior end; ventral margin nearly straight, or commonly with a wide, shallow, mesial sinus, very rarely with a slight convexity; valves evenly tumid, or with a slight broad mesial concavity or flattening; posterior slope flattened, smooth; defined by a diagonal, slightly sigmoid ridge, sharp and angulated near the beak, gradually becoming rounded and olsscure towards the inferior posterior angle in old specimens; greatest depths of the valves along this line, and at about half way from the beak; hinge-line with a slight upward curvature; posterior lunette very wide, concave, nearly horizontal; surface marked by concentric wrinkles variable in size and strength, usually thickening slightly on reaching the diagonal posterior ridge, almost always undulated and irregularly interrupted about the middle and anterior third of the sides, (averaging five or six in the space of three lines from the beak, about the middle of the shell); periostraca sharply marked with close interrupted strie and a few minute scattered points, very rarely falling into close regular radiating lines; usual length about two inches, proportional width from beak to ventral margin ${ }_{100}^{4}$, width of posterior end $\frac{45}{100}$, length of anterior end $\frac{13}{100}$, depth of both valves $\frac{40}{100}$.

The irregular interruption and undulation of the concentric wrinkles in front of the middle of the sides is often very striking and beautiful, and is always recognisable. It is very variable in the thickncss and regularity

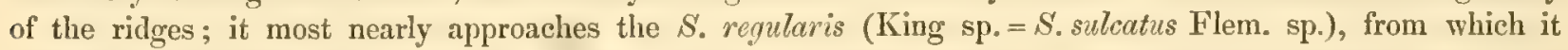
differs in the undulatory interruption of the ridge at the place mentioned, and in being rather shorter and more arched, and the greatest gibbosity of the shell being along the anterior boundary of the posterior slope, it being much nearer the anterior end, and the posterior portion being compressed in that species, in which also the greatest gibbosity is nearer to the dorsal margins, giving a much less tumid character to the lower part of the valves; it is possible, however, that they are varieties. From the Edmondia sulcata it differs in the wrinkles not uniting into few large wrinkles in passing to the posterior slope, in their disappearing on the posterior slope, and in the generic characters.

Position and Locality.-Rare in the lower carboniferous limestone of the Isle of Man; not uncommon at Lowick, Northumberland; rare in the carboniferous limestone of Berwick-on-Tweed.

Explanation of Figures.-Pl. 3.F. fig. 6, right valve natural size, from the limestone of Lowick, Northumberland; fig. $6 a$, seen from behind, to shew the inflected dorsal margins; fig. 7 , ovate variety, without byssal sinus, and with very fine concentric plica; fig. $7 \alpha$, small portion of surface of another specimen, highly magnified, shewing the lines of rough puncta crossing the concentric wrinkles and membranous striae of the periostraca; fig. 8 , oblong variety.

\section{Genus. LEPTODOMUS $\left(M^{c} C o y\right)$. See page 277.}

\section{Leptodonus costellatus $\left(\mathbb{I}^{c} \mathrm{Coy}\right)$. Pl. 3. F. fig. 5.}

\section{Ref.-McCoy, Ann. Nat. Hist. 2nd Series, Vol. VII.}

Desc.-Ovato-oblong, very tumid; denth of both valves about equal to the width; anterior and posteriol lunettes large, defined, shallow; beaks very large, tumid, obliquely incurved, terminal; anterior side obtuse, subtruneate, slightly oblique beneath them; a small sinus in the ventral margin close to the anterior end, from which a narrow, slightly marked concavity extends nearly to the beaks, close to the anterior edge; linge-line nearly as long as the shell, with a slight upward curvature; posterior end contracted, arehed upwards, slightly oblique, subtruneate; ventral margin strongly convex behind the sinus; posterior slope abruptly compressed, smooth, or with a few lines of growth parallel with the margin, divided nearly in the middle by a small sulcus from behind the beaks; sides marked with numerous small, regular, close, narrow, subangular 
ribs parallel with the margin (about four in the space of two lines on all parts of the shell), those abruptly disappear on reaching the edge of the posterior slope, and unite on the anterior edge in front of the sinus, in parcels of two or three, to form a row of short thick wrinkles on that part. Length one inch five lines; proportional width from beak to ventral margin $\frac{65}{1 * 0}$, length of hinge-line from beak about ${ }_{10 u}^{53}$, width of posterior end about $\frac{40}{100}$, greatest depth of both valves $\frac{\beta_{0}}{100}$.

It differs from the Eclmondix sulcata (Phill. sp.) in its extremely thin shell, short inflated form, want of the thick internal cardinal ridges, the more regular sharp rilus on the sides, and their uniting into large wrinkles on the anterior instead of the posterior end. The sulets bisecting the posterior slope must not be supposed to indicate a ridge, as it is a mere linear indentation of the shell.

Pusition and Locality.-Common in the carboniferous shales of Craige, near Kilmarnock; carboniferous shales near Glasgow; in the shale-beds at Lowick, Northumberland.

Explanation of Figures.-PI. 3. F. fig. 5, left valve natural size from carboniferous shales of Craige, near Kilmarnock; fig. 5 a, seen from the back, shewing the anterior and posterior lunettes or cartilage supports, and the small mesial sulcus of the posterior slope.

\section{Genus. CARDIOMORPHA (de Kon.)}

Cien. Char.-Shell very thin, equivalve, inequilateral; margins closed; obliquely, very tumid; beaks very tumid, produced, spirally inrolled to the anterior side; no hinge-teeth; hinge-margin inflected nearly at right angles to form a hollow lunette, running from the beak nearly to the anal cardinal angle; two adductor impressions in each valve; pallial scar simple, very faintly marked; a shallow anterior depression beneath the beaks, but the margin sharp and prominent.

Resembling the recent Isocardic exactly in form, but perfectly distinguished by the want of teeth, which character, and the inflection of the cardinal margin, approximates the genus to the Leptodomi ( $\mathbf{I}^{\circ} \mathrm{Coy}$ ), from which they differ by their large inrolled beaks, and closed margins, without byssal furrow, \&c. From the extreme thinness of the shell the muscular and pallial scars are rarely visible.

\section{Cardiomorpita? Modioliformis (King).}

$$
\text { Ref.-King, Perm. Foss. t. 14. f. } 18 \text { to } 23 .
$$

Desc.-Oblong, extremely gilbbous diagonally from the beaks to the respiratory angle, from which line the valves slope rather abruptly and flatly to the dorsal and rentral margins; beaks very large, obliquely incurved over the anterior end; anterior end forming an obtuse lobe, scarcely or not at all projecting in front of the beak, having a deep semicordate depression beneath the beak in each valve; ventral margin nearly straight, usually with a shallow byssal sinus a little in front of the middle, from which when it exists a shallow concavity extends obliquely forwards towards the beak; posterior end obliquely subtruncate; the respiratory angle obtusely rounded; hinge-line slightly elevated, shorter than the shell, inflected; cartilage margin rather broad, the angle of inflection forming a strong ridge; posterior slope flattened or slightly concave. Surface marked with coarse, close, obtuse, unequal lines of growth, usually crossed on the posterior and ventral portion, by rather distant, obscure, narrow, radiating lines, elevated near the beak, but beeoming impressed towards the margin of old specimens; separated by flat spaces about half a line wide at three or four lines from the beak; about three times wider than the ridges. Average length six inches, proportional width (greatest at middle of length) ${ }_{\text {wive }}^{\text {in }}$, depth of one valve (greatest a little in front of the middle) $\frac{30}{100}$. Casts shew the sulens of a clavicular ridge behind the anterior adductor.

The obscure radiating ridges do not constantly appear, and are seldom seen close to the beak. The distinctness of the anterior adductor, and its bounding ridge, as well as the occasionally well-marked byssal sinus, would incline me to place this species in Sanguinolites rather than in Cardiomorpha.

Position and Locality. - Not uncommon in the Permian limestone of Humbleton. 


\author{
Cardionorpha oblonga (Som. Sp.) \\ Ref. and Syn.=Isocardia oblonga Sow. Min. Con. t. 491. f. 2.
}

Desc.-Longitudinally oblong, obliquely gibbous from the beaks towards the respiratory angle, from which line the valves arch gradually to the anterior and ventral margins, flatter and more abruptly sloped towards the posterior and dorsal margins; beaks moderately large, inflated, very oblique, approximate, inrolled over the anterior end, having a semi-cordate depression beneath them in each valve; anterior end scarcely projecting in front of the beaks, very small, subquadrate; ventral margin nearly straight; posterior end long, dilated, obtusely subtruncate, with the anal and respiratory angles rounded; hinge-margin slightly elevated, nearly as long as the shell, inflected at right angles to form an external cartilage support, of nearly two lines wide, extending nearly from the heak almost to the cardinal angle. Length two inches six lines, proportional width

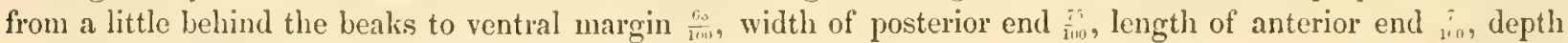
of both valves $\frac{63}{100}$, (greatest about one third from the beaks).

The thickness of the shell of this species in specimens of the above size is about one fifth of a line. The species is casily distinguished by the extremely small size of the anterior end, and the elongate, oblong, dilated posterior end.

Position and Locality._-Not uncommon in the dark lower carboniferous limestone of Isle of Man.

\title{
Cardiomorpma orbicularts ( $M^{c}$ Coy). Pl. 3. I. fig. 41.
}

\section{Ref.-MI'Coy, Ann. Nat. Hist. 2nd Series, Vol. XII.}

Desc.-Suborbicular; anterior end moderately large, semicircular, compressed; ventral and posterior margins very convex, regularly curved; posterior side small, rounded, gradually compressed; beaks very large, tumid, obliquely inrolled towards the anterior end, projecting greatly beyond the hinge, nearly over which is the deepest part of the shell; valves becoming gradually flattened towards the margin; surface smooth, even; substance of the shell very thin; hinge-margin inflected at right angles, forming a cartilage support rather less than two lines wirle. Length three inches two lines, proportional width from beak to ventral margin $\frac{911}{11}$, length of anterior end ${ }_{1, \ldots}^{1,4}$, width half way between the beak and posterior end $\frac{65}{1 w}$, depth of one valve (greatest near the beak) $\frac{23}{100}$.

This is only likely to be confounded with the $C$. oblonga (Sow. sp.), but is distinguished by its large anterior and small posterior sides, extremely large beals, and flattened orbicular valves. The young of the $C^{\prime}$. cormegatu $\left(\mathrm{M}^{\mathrm{c}} \mathrm{Coy}\right)$, which is nearly like in form, is distinguished by the large corrugation of the sides.

Position and Locality.-Seems not uncommon in the carboniferous limestone of Derbyshire.

Explanation of Figures.-Pl. 3. I. fig. 41, left valve, natural size; $41 a$, ditto, seen from behind, to shew the inflected dorsal margins.

Family. ARCIDE. See page 282.

Genus. ARCA (Linn.) See page 282.

\section{Subgenus. MICRODON (Lycett.)}

Cien. Char.-Shell oblong; very inequilateral, moderately tumid, a byssal sinus in the anterior third of the ventral margin. Anterior edges of the adductor impressions prominent (as in Cuculleca); linge-teeth at the anterior end few, slightly oblique, or nearly at right angles to the hinge-line beneath the beak, becoming more oblique towards the anterior end; all the posterior part of the hinge-line, from the beak to the anal angle, occupied by from one to three long lateral teeth nearly parallel with the hinge

The following species of this genus has been referred to Byssoarce of Swainson, by Prof. King; in that subgenus, however, the entire hinge-line, from one end to the other, is crossed nearly at right angles by very numerous, nearly uniform, subequal teeth; thus differing entirely from the dentition of the fossil in question, and the present sulgenus, in which the posterior three-fourths of the hinge-line shew but two or three extremely long teeth at right angles to the position of the very numerous ones occupying the same $p^{\text {lace }}$ in Byssoarca. 


\section{Macrodon striatus (Schlot. Sp.)}

Ref. and Syn.= Nytilus striatus Schlot. Münch. Akad.Vol. VI. t. 6. f. 3.= Cucullca sulcata Sow. Geol. Trans. 2nd Series, Vol. III. p. 119. (according to King) = Arca antiqua (Münst.) Gold. Petref. t. 122. f. 8. = Arca Loftusiana Howse, Trans. T. N. F. C. Vol. I. p. 246.=Arca tumida Sow. M. C. t. 474. f. 3. $=$ Byssoarca striata (Schlot. sp.) +B.tumida (Sow. sp.) King, Perm. Foss. t. 15. f. 1 to 9 ? + Arca Kingiana (de Vern.) King, Perm. Foss. t. 15. f. 10, 11, 12.

Desc.-Shell oblong, subrhomboidal, very gibbous when old, less so when young: beaks very prominent, incurved; separated by a triangular area in each valve, increasing in width with age, and marked by the fine cartilage sulci, angulated beneath the beak; anterior side short, nearly rectangular, compressed at the angle, moderately rounded; ventral margin only slightly convex, with a variable byssal sinus in its anterior third; posterior end obliquely truncated, very slightly sigmoid; posterior slope rather flattened, very abruptly compressed, a strong sulcus separating it from the prominent, obtuse, diagonal ridge extending from the beak to the respiratory angle; entire surface covered with coarse, narrow, filiform ridges, usually simple, but occasionally bifurcate, crossed by strong concentric scaly lines of growth, rendering them transversely nodular under the lens when well preserved; there are also several irregular stronger interruptions of growth, coarser and more numerous near the margins of old speeimens; the intervening sulci are deep, and almost as wide as the ridges. Average length ten lines, proportional width from beak to ventral margin $\frac{57 \%}{100}$, length of anterior end from beak $\frac{25}{100}$, length of hinge-line from beak $\frac{53}{100}$, from beak to respiratory angle $\frac{85}{1 w 0}$, width of posterior end $\frac{4 n}{100}$, depth of both valves $\frac{61}{i w 0}$; five ridges in the space of two lines on the middle of the shell at two lines from the beak.

I have very carefully examined a considerable suite of specimens of this fossil, including specimens named by Prof. King Byssoarca tumida and $B$. striata, and I can state positively that the differences between those species are merely the natural changes produced by age in the genus, that is to say, in any series of specimens the larger are always much more tumid, more round in the ventral margin, and rather shorter proportionally than the smaller; the ridging being perfectly the same in both, and the width of the hinge-area separating the beaks increasing regularly with the size, age, and tumidity of the specimens. It is only because I have not seen the specimens themselves, that I hesitate to quote the Arca Kingiana (de Verneuil) as the young of this species, as Prof. King has found in it the sulcation of the present fossil, and distinguishes it only by its smaller size, narrower cardinal area, and other characters which collectively agree in the indication of youth.

Position and Locality.-Very common in the Permian magnesian limestone of Humbleton.

\section{Family. NUCULIDE. See page 285. \\ Gemus. NUCULA. See page 285. \\ Nucula? Attenuata (Flem.)}

Ref. and Syn.-Flening, Brit. Anim. p. 403.=Nucula claviformis (Sow.) Phil. Geol. York. Vol. II. t. 5. f. 17, (not of Sow.).

Desc.-Clavate, anterior side of moderate length, regularly rounded semielliptically from the beak to opposite ventral margin; posterior end elongate, gradually compressed, tapering to an obtuse point; beaks very small, much incurved, not prominent; anterior lunette elongate, elliptical, small ; posterior lunette or corslet very narrow, steeply sloped, strongly marked, extending nearly to the end of the shell, bounded by a prominent obtusely rounded ridge from the beak to the posterior extremity; valves gently and evenly convex, most so at equal distance from the beak, anterior end, and ventral margin. Surface sculptured with extremely regular, fine, concentric, thread-like, elevated ridges (ten or eleven in one line at three lines from the beak), extending from the anterior margin, as far as the obtuse ridge bounding the posterior lunette, which ridge is left nearly smooth by their abrupt cessation. Average length about ten lines, proportional width from beak to opposite ventral margin $\frac{45}{100}$, length of anterior end $\frac{30}{100}$, depth of one valve $\frac{17}{100}$.

[FASC. MII.] 
This beautiful species is of the general form of Leda, but I have formerly seen specimens with the pallial line entire. Prof. Phillips probably overlooked Prof. Fleming's description, and identified the species with the Liassic $N$. claviformis of Sowerby, which it somewhat resembles in form. I have seen the hinge-teeth of this species, but mark the genus with doubt, as I have not satisfied myself as to whether there is or is not a cartilage pit beneath the beaks.

Position and Locality._Common in the carboniferous shale near Glasgow.

\title{
Nucula clavata (Mćoy).
}

\author{
Ref.-McCoy, Synop. Carb. Foss. Irel. t. 11. f. 25.
}

Desc.-Ovate or subclavate, moderately gibbous; beaks moderately prominent, obtuse, anterior lunette ovate, narrow; anterior end moderately large, obtusely rounded; posterior end nearly twice the length of the anterior, very obtusely rounded at the pointed extremity, no posterior slope, the cardinal edge being rather tumid; ventral margin most convex in the middle, much less so towards the anterior and posterior ends: valves moderately convex, most so in an oblique line from the beak to the middle of the ventral margin, from whence the valves are gently compressed towards the extremities. Surface marked with very fine, obtuse, subequal, concentric strix (fifteen in one line at four lines from the beak), and a few stronger parallel interruptions of growth. Length about eleven lines (large specimen), proportional width from beak to opposite ventral margin $\frac{50}{100}$, length of posterior end from beak $\frac{16}{100}$, length of anterior end from beak ${ }_{i n i}^{31}$, depth of both valves $\frac{40}{1100}$.

This species is intermediate between the Nucula attenuata Flem. and $N$. Phillipsi $\mathrm{M}^{\circ}$ Coy. It is distinguished from $N$. attenuata by the much shorter and more obtuse posterior end, and from both species by the absence of any trace of the posterior slope. M. D'Orbigny in his Prodrome, p. 120, places this species in the genus $L e d d$, but I have no reason for thinking there is any sinus in the pallial impression. I have seen the hinge-teeth very obscurely.

Position and Locality.-Rare in the carboniferous shale of Glasgow.

\section{Nucula gibbosa (F'lem.)}

Ref. and Syn.-Fleming, Brit. Anim. p. 403.=Nucula tumida Phill. Geol. York. Vol. II. t. 5. f. 15.

Desc.-Ovato-oblong, very gibbous, most so about the middle, from whence the surface arches in all directions; beaks very tumid, much incurved towards the anterior end; anterior end very small, contracted, only extending slightly in front of the beaks; a large deep cordate depression beneath the beaks; posterior end moderately lengthened, semielliptically rounded, no defined or flattened posterior slope, ventral margin nearly straight at the anterior end, very convex a little behind the middle, and arching then upwards towards the posterior end. Surface with numerous fine, concentric, thread-like lines of growth (eight in one line at two lines from the beak), and a few stronger interruptions of growth near the margins; hinge-teeth numerous, interrupted at the beak by the cartilage-pit. Length from anterior to posterior end seven lines, proportional width from beak to same point $\frac{95}{100}$, greatest width at right angles to middle of hinge-line $\frac{70}{100}$, depth of both valves $\frac{75}{1010}$.

The great gibbosity easily distinguishes this species from the other palacozoic forms. M. D'Orbigny in his Prodrome, p. 130, places this species in the genus Cypricardia, but I have clearly ascertained the presence of the angulated line of hinge-teeth, and the intermediate cartilage pit of $N u c u l a$.

Position and Locality.-Very common in the carboniferous shale of Glasgor, common in the carboniferous shale of Craige, near Kilmarnock.

\section{Nucula luciniformis (Phill.)}

\section{Ref.-Phill. Geol. York, Vol. II. t. 5. f. 11.}

Desc.-Subovate, beaks tumid, oblique, moderately prominent, having an obseure cordate depression in front of them; anterior end short, regularly rounded; posterior end obliquely subtruncate, very slightly convex; anal 
angle obtuse, angular ; respiratory angle prominent, obtusely rounded, from whence a strong, rounded, diagonal ridge extends to the beak; ventral margin very convex a little behind the middle, but with a slight sinus in front of the respiratory angle, from whence a shallow depression extends in front of the diagonal ridge to the beak; portion of the ventral margin from the middle to the anterior end less curved than the rest; valves moderately tumid, most so about the middle and obliquely from the beak to a little behind the middle of ventral margin; posterior slope flattened. Surface nearly smooth, with extremely delicate concentric strix, and a ferw stronger irregular lines of growth. Length six lines, greatest proportional width (at right angles to middle of hingeline) $\frac{80}{100}$, length of anterior end ${ }_{100}^{19}$, length of hinge-line from beak $\frac{60}{100}$, from beak to respiratory angle $\frac{90}{100}$, depth of both valves $\frac{65}{100}$.

In Prof. Phillips's figure the little sinus in front of respiratory angle, and corresponding sinus in front of the diagonal ridge, are not, I think, sufficiently marked, and the anterior part of the ventral margin is rather too convex, diminishing the apparent obliquity. As M. d'Orbigny in his Prodrome, page 133, refers this fossil to the genus Cardiomorpha, I thought it proper to cut down a part of the hinge-line of one of the valves of the University specimen, and had the pleasure of finding the hinge-teeth, and determining the disputed point as to the genus.

Position and Locality.-Rare in the carboniferous shale of Glasgow.

\section{Nucula Vintr (King Sp.)}

Ref. and $S_{y n}=$ Leda Vinti King, Perm. Foss. t. 15. f. 21, 22; and Geol. Russ. p. 224. = Nucula speluncarin Geinitz. Verst. t. 6. f. 6.

Desc.-Subclavate; beaks almost central, obtuse, moderately prominent, and strongly inclined torards the posterior side; anterior side very large, obtuse, semielliptically rounded; posterior end very abruptly contracted by a very deep cordate depression immediately behind the beaks, which passes gradually into the obscurely defined, posterior slope; hinge-line and ventral margins slightly converging to the obtusely pointed posterior end, which has an obscure, oblique truncation; ventral margin moderately convex in the anterior half, nearly straight in the posterior half; valves moderately tumid, most so about the middle. Surface marked with extremely fine concentric elevated lines (fifteen in one line at three lines from the beak), slightly irregular in some parts, and abruptly ceasing on the posterior third of the valves, which is smooth. Internal casts shew the muscular impressions and entire pallial sear, and the angulated row of hinge-teeth, of which there are about nine before the beak, and six behind it, with a shallow transverse sulcus extending about one-third the width from the beak to the ventral margin. Length seven lines, proportional length of anterior end $\frac{49}{100}$, of posterior end $\frac{51}{100}$, greatest width from beak to ventral margin $\frac{65}{100}$, depth of both valves $\frac{51}{100}$.

This is a well-marked species, remarkable for the great size of its anterior end, and the backward direction of its beaks, Sc. The entire pallial sear renders Prof. King's reference of the fossil to Leda incorrect.

Position and Locality.- Not very uncommon in the lowest beds of the Permian magnesian limestone of Humbleton.

\section{7th Family. UNIONIDE.}

Shell inequilateral, very variable in shape and thickness, pearly inside; beaks usually eroded; margin closed or slightly gaping at each end; hinge with or without teeth; ligament external; usually two buccal and one anal muscular impressions in each valve; often a thick periostraca. Animal large; mantle open, or defining two short tubes at the anal end; foot short and compressed, or very long and terminating in a button-like swelling

Live in fresh water.

The family contains numerous genera: 1st, Unio; 2nd, Monocondylea; 3rd, Anodon; 4th, Myectopus; 5th, Castalia; 6th, Iridina; 7th? Carbonicola, \&c. 


\section{Genus. CARBONICOLA ( $M^{\circ}$ Coy).}

Gen. Char.-Shell moderately elongate, ovate, thick; beaks moderate, not eroded; a strongly marked ovate lunette in front of the beaks; cartilage and ligament thick, external ; periostraca thick; surface usually coarsely imbricated concentrically. One very thick cardinal tooth in the right valve diverging obliquely towards the posterior side, one long anterior, and one long posterior lateral tooth; pallial scar entire; one moderate, oval, adductor impression at each end, each surmounted by a small accessory impression; no lunate small impression below the anterior adductor as in Unio.

From the time of Martin's Petrefacta, and the first volume of Sowerby's Mineral Conchology, many persons have strongly expressed their conviction that the bivalves occurring in such numbers as to form regular beds in the shale of our coal-fields, and in the accompanying ironstone and "mussel-bind," were truly congeneric with the recent $U$ nios of our rivers. More recently certain shells of the lias and other marine strata of newer date, also called Unio by Sowcrby, were erected into a genus under the name Pachyodon by Stuchbury, from an examination of the hinge; and he supposed, from the great similarity in external appearanec between the so-called Unios of the lias and those of the coal, that the dental characters which he had discovered in the former existed in the latter, and that they belonged to one genus: this view was adopted by the describer of the greater number of these coal-shells, Capt. Brown, in his Memoir, in the Annals of Natural History for 1843. The name Pachyodon having been preoccupied, was changed to Cardinia by Agassiz, who in his translation of Sowerby's Mineral Conchology gives that generic title to both the marine oolitic, and the coal-measure fossils, and in this he has been followed by de Koninck and all the other palæontologists of note. Shortly after Agassiz proposed the name Cardinia, M. de Christol proposed that of Sinemuria (from Sinemuerium, Sémur, Côte d'Or) for the same group, his typical species being of the ordinary lower oolitic marine type, or true Cardinia. Prof. Bronn and Prof. King are the only persons I know of who entertained the prowability that the coal-shale fossils in question might be distinct from Cardinia; the former in his Index Palcontologicus, replacing them in Unio, and the latter having, in the Annals of Natural History for 184t, stated that he intended to use the word Anthracosia for a genus he intended establishing at some future time for the Unios of the coal-measures; this intention seems to have been given up, as the genus was never characterised, and neither of these authors seem to have possessed any knowledge of distinctive characters between these shells and Cardinia proper, except perhaps the difference of habitat. I have now however, after great trouble, succeeded in developing the internal characters of the present fossils, and find them distinguished from Unio by the large cardinal tooth diverging towards the posterior instead of towards the anterior end, by each of the adductors having one small accessory impression over it, without the lunate impression on the rentral margin of the anterior adductor of that genus, and the beaks not being eroded; from Cardinia it differs entirely in having the long lamellar lateral teeth of Unio, and wanting the thick remote conical lateral teeth of that genus. I only know this genus at present in the shales and ironstones of the coal-measures (where there are nearly twenty species), and associated exclusively with fresh water and terrestrial remains. The cardinal tooth separates the genus from Edmondia, with which it might sometimes be confounded.

\section{Carbonicola acuta (Sow. Sp.)}

Ref. and Syn. $=$ Unio acutus Sow. Min. Con. t. 33. f. 5 to $7 .=U$. aquilimus id. Geol. Trans. t. 39. f. 12. $=$ Pachyodon lateralis Brown, An. Nat. Hist. Vol. XII. t. 15. f. 3.=P. exoletus id. ib. t. 16. f. 4. $=P$. antiquus id. ib.t. $16^{*}$. f. $4 .=P$. transversus id. ib. t. $16^{*}$. f. $5 .=P$. levedensis id. ib. t. $16^{*}$. f. 8 .

Desc-Elongate, ovato-oblong; anterior side short, rounded; anterior lunette moderately small; beals small, very obtuse, not prominent; valves tumid and very obtusely rounded close to the hinge-line; sides nearly flat, slightly convex; ventral margin nearly straight, very slightly convex near the anterior end; posterior end elongate, narrowed obliquely, subtruncate, rounded at the angles; surface marked with coarse, irregular, concentric strice of growth; external cartilage prominent, about half the length of the hinge-line. Length one inch nine lines, in proportion thereto length of anterior end ${ }_{100}^{13}$, greatest width from a little behind the beak to 
opposite ventral margin $\frac{55}{100}$, width of posterior end $\frac{29}{100}$, depth of both valves about the middle $\frac{32}{100}$ (young shells more tumid and less elongate).

The lengthened form and straight unsinuate ventral margin, and the side without any oblique concavity, distinguish this species with tolerable ease, as well as the greatest width being a little behind the beak, instead of from their apices. The specimen figured under the name Unio aquilinus of the Geological Transactions is broken at the posterior end, so as to appear a little shorter than it ought, but having the shell preserved it shews the remarkable tumidity of the dorsal margin, and the characteristic want of prominence of the beak, which is not so obvious in the internal casts originally figured by Sowerby. The short variety, or Sowerby's figure 5 as above, is possibly a distinct species, and seems identical with the $P$. agrestes of Brown. The bifid anterior end, or cleft termination, alluded to by Capt. Brown in his $P$. antiquus is merely the impression of the anterior adductor, rendered visible by the removal of part of the shell.

Position and Locality. - Not uncommon in the carboniferous shale at Lowmoor near Bradford.

\section{Carbonicola subconstricta (Son. Sp.)}

Ref. and Syn.=Unio subconstrictus Sow. Min. Con. t. 33. f. 2, 3.= Pachyodon Amygdala Brown, An. Nat. Hist. Vol. XII. t. 16. f. 3. = P. subtriangularis id. ib. t. 16. f. 6.=var. $\beta_{0}$. P. Embletoni id. ib. t. 16. f. 9 ; var. $a_{0}=$ P. agrestis id. ib.t. 16. f. 11 ; var. robusta $=U$ nio id. Sow. Geol. Trans. Vol. V. t. 39. f. 14.

Desc.-Ovato-subtrigonal; anterior side short, rounded; beaks large (most prominent and widely separated in the casts); posterior end obliquely subtruncate, narrowed by the convergence of the dorsal and ventral margins; ventral margin convex in the anterior half, concave in the posterior half, forming a gentle sinus in front of the respiratory angle, from which sinus a shallow depression extends obliquely forwards to within half or three-quarters of an inch of the beak, most strongly marked towards the margin of old individuals; valves moderately convex, most so a little below the beaks, becoming gradually compressed towards the margin; posterior slope very convex near the dorsal margin in easts, but obtusely angulated along the same line when the shell is present; substance of the shell very thick; surface concentrically marked with coarse, irregular, unequal strix, and small plicre of growth, most prominent towards the margin of large specimens. Casts shew the thick cardinal tooth, and slender, elongate, lamellar, lateral teeth; simple pallial sear; and two adductors, each surmounted by a small accessory impression, as in the generic character. Length of small specimen (corresponding with Sowerby's original type) one inch four lines, proportional width from beak to opposite point of ventral margin $\frac{69}{100}$, width of posterior end $\frac{37}{100}$, length of anterior end about ${ }_{100}^{25}$, depth of both valves $\frac{45^{\circ}}{100}$.

This species varies slightly in the strength of the sinus and proportional width. When the shell is preserved there is always the obtuse angle along the dorsal margin, alluded to by Goldfuss and de Koninck as a characteristic of their Unio tellinaria, which I suspect will be found referrible to this one species.

The somewhat larger specimens, the references for which I have marked above as var. $\beta$, seem a little longer in proportion (length one inch nine lines, proportional width of casts without the shell ${ }_{100}^{60}$, depth of both valves $\frac{37}{1100}$ ); but $I$ have no doubt they are an advanced age of the same species, and are intermediate between Sowerby's original type and his species $U$. robustus.

Position and Locality.-Very common in the coal-shale of Bradford, Yorkshire.

\section{Var. Robusta (Sow. Sp.)}

Ref. and Syn.=Unio robustus Sow. Geol. Trans. t. 39. f. 14.

This variety is in fact, in my opinion, only the adult age of the species originally figured as Unio subconstrictus by Sowerby, or when it attains a width from beak to margin of one and half inch. The figure of $U$. robustus in the Geological Transactions seems much shorter and deeper than natural from the posterior end being broken off obliquely; the true outline may be seen by following the lines of growth in the same figure at one and half inch or nine lines from the beak. 
Length two inches three lines, proportional width ${ }_{200}^{65}$, depth of both valves ${ }_{100}^{10}$, length of anterior end about $\frac{27}{100}$, width of posterior end $\frac{23}{100}$.

Position and Locality.-Very common in the coal-shale of Bradford, Yorkshire.

\section{Carbonicola turgida (Brown $S p$.)}

Ref. and Syn. = Pachyodon turgidus Brown, Ann. Nat. Hist. Vol. XII. t. 16. f. 13, 14.

Desc.-Subquadrate, obtusely oblong, very gibbous; beaks large, obtuse, tumid, approximate, close to the anterior end; cordate depression in front of them broad, deep, with obtusely rounded edges; anterior side projecting very little beyond the beaks, broad, and but little convex or obscurely subtruncate at the margin; posterior end short, broad, obtuse, obliquely subtruncate, the angles broadly rounded; ventral margin nearly straight; hinge-line only slightly converging to the posterior end; valves very tumid, gradually compressed torvards the ventral margin, abruptly rounded towards the anterior margin; posterior slope flattened, extending from the hinge-line to the respiratory angle, the diagonal ridge very obtusely rounded; surface with irregular strie and minute concentric plice of growth, and a few short, thick, extremely irregular, oblique wrinkles (apparently due to a thick periostraca). Length of small specimen one inch, proportional greatest width from heak to opposite ventral margin $\frac{75}{100}$, width of posterior end about $\frac{52}{100}$, length of anterior end about $\frac{2 n}{100}$, length of hinge-line from beak about $\frac{55}{100}$, from beak to respiratory angle $\frac{90}{100}$, depth of both valves $\frac{56}{100}$.

This species is easily distinguished from all others by its short quadrate form, and evenly-gibbous, very tumid valves.

Position and Locality.-Rare in the coal-shale of Bradford.

\section{(Family uncertain). \\ Genus. CONOCARDIUM (Bronn). \\ Syn。 = Pleurorhynchus (Phill.)}

Gen. Char.-Equivalve, very inequilateral, hemifusiform; beaks prominent, incurved, close to the anterior end, which is broad, flattened, more or less truneate nearly at right angles to the straight hinge-line, which is prolonged as an abruptly-contracted, slender, tubular wing from the dorsal part of the anterior face; body of the shell diminishing conoidally from the edge of the anterior face towards the posterior end, which is attenuated, rounded, and widely gaping; substance of the shell very thick, of a minute quadrangular cellular tissue, with strong internal ribs radiating from the beak, and often smaller external ones, strongest on the anterior face.

In several species there is a keel-like expansion projecting forwards at right angles to the anterior face from its margin. Bronn and most palicontologists have considered this genus to be most closely allied to Cardium, from which the tubular anterior wing separates it: Conrad insists on the remarkable resemblance to Pterined, from which it is however separated by being equivalve; in Professor Phillips's opinion Tridacna is the nearest analogue, and this is also the last opinion of M. de Koninck: but I have been unable to ascertain with certainty whether the adductor impressions are distinctly separated, or are united in the middle, as this affinity would require. I might mention however that four internal casts in the collection from Lowick all have the stone strongly adhering at the deepest part of each valve in the middle towards the beaks, making the latter very probable. Professor Agassiz refers the genus to the Brachiopoda, without stating fully the reasons for a rapprochement, which seems at variance with all its characters. The cellular tissue of the thick shell reminds us of certain Rudistes, but the analogy holds good in no other respects.

\section{Conocardium aliforme (Sow. Sp.)}

Ref. and Syn.= Cardium aliforme Sow. Min. Con. t. 55̃2. f. 2.=Pleurorhynchus minax Phill. Geol. York. Vol. II. t. 5. f. 27.

Desc.-Subtrigonal or deltoidal; hinge-line straight; beaks narrow, obtuse, prominent, much incurved at the anterior end; anterior end subtruncate, forming a cordate space, bounded by a distinct angulation, near 
which in old specimens it is gently concave, rising conoidally near the hinge-line, to form the slender, anterior rostrum; ventral margin convex, most so near the bounding angulation of the anterior space; posterior end compressed, rotundato-trigonal, slightly rounded at the posterior gaping margins, which are separated from the ventral margin by a very slight sinus, from whence to a little behind the beaks is a very faint concavity or posterior slope, where the compressed posterior end joins the body of the shell, which is very gibbous, most so about the middle. Surface when well preserved nearly smooth, or with fine concentric stria of growth; when partially decorticated, shewing strong, regular, radiating ridges, extending from the beak to the margin (six in two lines at four lines from the beak), abruptly smaller on the anterior depressed space (twelve in two lines). Average length of posterior end from beaks seven lines, proportional length of anterior rostrum about $\frac{40}{\mathrm{iu}}$, its width at base about $\frac{35}{1 w}$, depth from beak to opposite point of ventral margin $\frac{95}{1 w}$, from beak to extremity of cordate space $\frac{75}{100}$, width of cordate space $\frac{65}{100}$, depth of both valves $\frac{85}{100}$.

On looking carefully to Mr Sowerby's original figures, I think with M. de Koninck (and as Professor Phillips partially thought) that the true Cardium aliforme is the mountain-limestone species called Pleurowhynchus minax by Phillips; but I think, with Professor Phillips, that Goldfuss and most authors have confounded two species under the name $C$. aliforme. The true $C$. aliforme of Sowerby is a distinctly carboniferous type, and his figure agrees with $P$. minax; the Eifel, and generally Devonian, form to which Professor Phillips in his Palrozoic Fossils proposed to transfer the name $C$. alifurme, might perhaps retain the name given it by Schlotheim (C. hystericus). The strongly defined, depressed, anterior space, with its abruptly finer and more numerous ridges than oceur on the rest of the shell, mark the species very distinetly, the boundary of the cordate space not forming the deepest part of the shell, the anterior profile of which is therefore obtusely rounded close to the bounding angulation. In some internal casts from Lowick I have seen a trace of the single cardinal tooth, and an anterior and posterior lateral tooth, as well as the entire pallial scar; but I cannot be sure of the position or number of the muscular impressions. M. d'Orbigny, in his Prodrome, makes the Cumlium Ouralicum a synonym of this species, I suppose by mistake, as it agrees rather with $C$. rostratum, and has none of the characters of the present species.

Position and Locality.-Common in the carboniferous limestone of Derbyshire; in the carboniferous limestone of Malham Moor, Yorkshire; in the impure carboniferous limestone of Lowick, Northumberland.

\section{Conocardium rostratum (Mart. Sp.)}

Ref. and $S_{y n}=$ Conch. Arcites rostratus Martin, Pet. Derb. t. 44. f. 6.=Cardium elongatum Sow. Min. Con. t. 82. f. 3. = Pleurorhynchus elongatus (Sow.) Phill. Geol. York. Vol. II. t. 5. f. 28. = Cardium Ouralicum M. V. K. Geol. Russ, t. 20. f. 11.

Desc.-Subfusiform or subclavate; anterior end obtusely conical, extending into a short, thick, triangular rostrum, from the base of which the surface slopes gradually to the deepest part of the shell, which is opposite the beak, at right angles to the hinge line, and forms an obtusely rounded prominence, from whence the body of the shell slopes rapidly, with little convexity, towards the posterior end, from which it is separated by an oblique shallow sulcus, extending from a little behind the beaks to the posterior third of the ventral margin, which it sinuates; beyond which sinus the narrow, posterior, gaping extremity is strongly rounded at the margin, and slightly convex on the sides; beaks narrow, tumid, prominent, at about the anterior third of the shell; shell when well preserred thick and nearly smooth, only marked with fine concentric lines of growth; when decorticated the whole surface is covered with rather coarse sulci and ridges, radiating from the beak, being nearly equal, but those of the posterior extremity rather narrower, more rugged, and alternate in size. Length from beaks to posterior extremity nine lines, proportional length of anterior rostrum from beak about $\frac{4 n}{1+1}$ (slightly broken), depth from beak to opposite ventral margin $\frac{70}{100}$, greatest depth of both valves $\frac{\gamma 0}{100}$, depth of both ralves half way between the beak and posterior end $\frac{43}{100}$.

If it were not for the shortness of the anterior rostrum in the figure t. 20. f. 11. of the Geology of Russia, I should have no doubt that the Curdium Ouralicm of MM. Murchison, de Verneuil, and Kerserling, was identical with this species, because I have constantly found the oblique sulcus between the body and 
posterior end sinuating the margin (which they look upon as distinctive of the Russian species) in our Derbyshire examples, and it is slightly indicated in Sowerby's figure, under his synonymous $C$. elongalum. The other character which these authors rely on for separating the Russian and English species, viz. the smoothness of the posterior end, I find to be also of no value; for one of our specimens shews that the unworn shell is smooth, and without external radiating ridges from one end to the other, the ridges making their appearance here and there in patches wherever the external shell is worn through; the ridges seeming sharp, narrow, and distant when much worn, but broad, flat, and close together, when slightly worn.

Position and Locality.-Rare in the carboniferous limestone of Derbyshire.

\section{3rd Ord. Macrotrachia (Swain.)}

Shell usually equivalve or nearly so, holding a vertical position when alive*, symmetrical; animal symmetrical, mantle open in front, closed behind and forming two projecting tubes, either separated or united, forming a deep anal sinus in the pallial impression; two or three adductor muscles; gills forming two double laminæ along the sides of the body.

This group includes all the shells which have a sinus in the pallial impression. The families are: 1st, Corbulide; 2nd, Venerides; 3rd, Tellinides; 4th, Saxicavides; 5th, Solecurtidee; 6th, Solenellides; 7 th, Anatinida; 8th, Myida; 9th, Pholadida; 10th, Clavagellida.

\section{8th Family. MYID瓜.}

Shell, regular, very inequilateral, equivalve, oblong or elliptical, gaping at both ends; pallial scar strong, with a very deep sinus; hinge and ligament variable; animal, mantle nearly closed, leaving a small slit for the protrusion of the foot; siphons enclosed in one very large extensile tube; two muscular impressions in each valve.

Like the Pholadidce all those shells have their siphons enclosed in a large, fleshy, very extensile tube ; they live deeply buried in the sand or mud, rising or sinking in their holes by the siphons and the foot, but never changing their places during their lives.

Genera:-1st, Solen; 2nd, Leguminaria; 3rd, Panopcea; 4th, Pholadomya; 5th, Glycimeris; 6th, Solenimya; 7th, Mya; 8th, Lutraria; 9th, Mactra.

\section{Genus. SOLENIMYA (Lamk.) = "Solemya" (Lamk.}

Gen. Char.-Elongate, oblong, equivalve, very inequilateral, posterior end much the shortest; dorsal and ventral margins subparallel; anterior and posterior ends rounded, gaping; surface covered with a very thick, glossy, horny periostraca, extending in jagged portions beyond the ventral margins; beaks very minute, inconspicuous, close to the small posterior end; cartilage forming a thick triangular mass, partly external and partly internal, close behind the beaks, supported internally on an oblique ensiform narrow plate, one edge of which is attached to the interior of each valve, extending from the beak backwards and downwards about halfway towards the respiratory margin; long, anterior, cardinal margin simple, erect, without teeth; posterior adductor small, ovate, within the cartilage plate ; anterior impression large, comma-shaped, both superficial; pallial scar scarcely defined, with a minute sinus before joining the adductor at the short end. Animal, having the mantle closed in the short posterior part, and terminating in a short, inextensile siphon, open in front for the exit of a very large foot, the end of which is truncated and fringed; one deeply pectinate gill-plume on each side.

The sinus in the pallial scar is so minute that most observers describe it as entire. The posterior side being so very much shorter than the anterior, and the gills instead of being lamellated, forming two pinnate

* Except the Corbulide, which are inequivalve, and rest in the sand in an oblique position (d'Orb.) 
plumes, separate Solenimya from even the most nearly allied forms, except Glycimeris, with which it has much similarity in the shell.

Recent; very few rare species in the Mediterranean and Australian seas; quoted doubtfully in the Upper Palrozoic rocks, as the following species or varieties are inequivalve.

\section{Solenimya? primeta (Phill.) Pl. 3. F. fig. 3. \\ Ref.-Phill. Geol. York. Vol. II. t. 5. f. 6.}

Desc.-Elongate-oblong; posterior end only one-fourth the length of the shell, narrowed by a long, wide, concave cartilage lunette from the beaks, obtusely rounded at the extremity; beaks small, very much compressed, not prominent, oblique towards the posterior end; dorsal margin very slightly convex; hingeline nearly as long as the shell; anterior end slightly narrowed, subtruncate, rounded, gaping; ventral margin nearly straight, slightly convex, or sometimes faintly concave a little behind the middle; valves gently convex, deepest a little in front of the middle, becoming gradually compressed towards the ventral margin, and rather abruptly arched towards the anterior cardinal margin (resembling the posterior slope of many shells). Surface glossy, faintly radiated from the beak towards the Iong anterior end, by flat, not prominent, irregular ridges, averaging their width apart, and from one-third to half a line wide, usually flat in the middle with prominent edges, appearing like a pair of narrow striac; rarely a third intermediate raised line: surface under the lens with extremely fine, radiating, slightly flexuous strix (sixteen in half a line), crossed by concentric, extremely minute plications or strie of growth, about equalling the microscopic longitudinal striation in size. Internal casts shew slight indications of the external radii ; anterior muscular impression large, faintly marked, with a faint sulcus diverging from a little in front of the bealis towards its posterior superior extremity (only visible in some specimens); posterior muscular impression at the short end very strongly marked, with a thick oblique ridge, leaving a sulcus in the cast running from the beak along its anterior or inner margin; on its outer or posterior margin the slight thickening of the external cartilage support is clearly scen, and the reflected gaping edge of the lunette in some specimens, as well as the impression of the internal part of the cartilage within the apex of the beak; immediately within the long anterior cardinal edge is the shallow sulcus of the slight thickening of the dorsal margin. Average length one inch eight lines, proportional length of posterior end measured along the slope $\frac{35}{1 m}$, width from beak to ventral margin $\frac{33}{1 m}$, ditto in middle of length $\frac{13}{100}$, width of anterior end $\frac{30}{100}$, depth of both valves $\frac{30}{100}$, (occasionally two inches three lines long).

The agreement seems so perfect between this fossil and the recent Solenimya, except in being slightly inequivalve and the greater strength of the posterior muscular impressions, that I think with Prof. King that lis genus Jeneie is not required for it, at the same time that I do not think with him that Phillips's observations tend to prove that the short end of the shell is the anterior; and I have used the terms anterior and posterior as they are used by other writers in describing Solenimya, and contrary to the way in which they are used in other shells. The pallial line meets the anterior sdge of the posterior adductor at a very acute angle, forming a short angular sinus, directed almost angularly upwards towards the beak; not, I think, a siphonal sinus. In all our numerous specimens the left valve is larger at the beak than the right one, as has been remarked by $\mathbf{M}$, de Verneuil.

Position and Locality.-Very common in the impure carboniferous limestone of Lowick, Northumberland.

Explunution of Figures.-Pl. 3. F. fig. 3, left valve, natural size; internal cast, shewing the large muscular impressions, faint anterior oblique ridge from the beak, and (imperfectly) the casts of the ridges behind and before the posterior muscular impression; fig. $3 \alpha$, ditto, back view, shewing the eartilage supports behind the beaks, as well as the faint divergent ridges in front of them. 


\section{Var. $\beta$. Puzosana (de Kon.) \\ Ref. and Syn. =Solenimya Puzosiana de Kon. Anim. Foss. Belg. t. 5. f. 2.}

In this variety the fine pairs of radiating lines of the typical forms of $S$. primceva become elevated and combined into thick, prominent, obtuse ridges, varying from half a line thick, with wide interspaces, to nearly a line wide, and with very narrow sulci. I have, however, traced all the varieties in the most gradual manner passing into each other, and have no doubt that M. de Koninck's species is but an extreme variety of Phillips's. Some of the specimens shew the ribs thick and prominent in one part, and divided into two lines with a flat interspace, as in $S$. primeva, in another. The microscopic striation and other characters are the same in both.

Position and Locality.-Not uncommon in the black beds of the carboniferous limestone of Derbyshire; in the dark carboniferous limestone of Lowick, Northumberland; but not so common as the Var. $a$. primova.

\section{4th Class. PTEROPODA. See page 286.}

\section{Genus. CONULARIA. See page 287.}

\section{Conularia quadrisulcata (Miller, MSS.)}

Ref. and Syn.-Ure, Hist. Rutherglen, t. 20. f. 9 ;=Conutaria quadrisulcata Sow. Min. Con, t. 260. f. 5. Geol. Trans. 2nd Series, Vol. V.t. 40. f. 2. =C. tubericosta Sandberger, Neues Jarhbuch für Min. und Geol. \&c. 1847. t. 1. f。 12.

Desc.-Moderately tapering, section rhomboidal; when held with one of the obtuse lateral angles in front, and the apex downwards, the left face is a little smaller than the right-hand one; longitudinal furrows at the angles strongly marked; a delicate fissure runs down each face nearly in the centre, corresponding with the salient angles of the transverse plic:e, of which latter it often interrupts the continuity; salient angles of transverse plice $145^{\circ}$ at about one inch from the apex, at which distance there are about three plice and two intervening hollows in the space of one line; the intervening hollows nearly twice as wide as the ridges, and marked with coarse longitudinal strie, twice their thickness apart, which granulate the angulated ridges; apical angle of the two broad faces about $20^{\circ}$, of the two narrow ones about $13^{\circ}$. Length of rather small specimen one inch nine lines.

The adult length is about two and half inches, and at that distance from the apex the transverse plice meet at a more obtuse angle than is given above. There is considerable difficulty in getting the angles at which tlıc lateral edges of the faces meet, from an irregular sigmoid flexure which is often present. The only certain specimen in the collection is so badly preserved that I cannot give the measurements of the longitudinal strix, nor the angles of the transverse section. If the specific name quadrisulcate be retained at all, it must, I think, be confined to the mountain-limestone species which now oceupies us; and to make sure of this I only quote of the original figures in the Mineral Conchology that one from the Bristol mountain-limestone belonging to Miller himself, the author of the species. The coarseness of the transverse angulated plicie (or their smaller number in a given space at a given diameter) easily distinguishes the species from the Silurian ones.

P'osition and Locality.-One specimen in the collection from the earboniferous sandstone near Shap tollbar, accompanied by Lepidodendice and other remains of plants. One small curved specimen from Lowick is possibly the young incurved tip of this same species; its section is quadrangular, the curve being from one of the broad sides to the other, the tip is absent, the length about four lines, width of broad face at apex one line, at front two lines, width of narrow faces at front slightly less than two lines, nine ridges in one line at two lincs from the apex. 


\title{
6th Class. GASTEROPODA. See page 288. 5th Order. Tectibranchiata. See page 289.
}

\author{
Genus. POSIDONIA.
}

\author{
Syn $=$ Posidonomya (Bronn.)
}

Gen. Char.-Obliquely oval, slightly convex, usually subtruncate at one end, close to which is a bealk-like point, about which as a centre the substance is concentrically waved and plicated; texture extremely thin, semimembranous, flexible, and elastic.

"It seems exceedingly probable, as M. Deshayes has already suggested, that Posidonia may be the internal plate of an animal allied to Aplysia. I was particularly struck with the resemblance while dissecting some large specimens of the Aplysia depilans of our coast this summer; the gill-covers of these animals, when observed in the recent state, or before being dried, are precisely similar to a Posidonia in shape, and with somewhat similar concentric wrinkles, but more faintly marked; their consistence is intermediate between that of thin horn and membrane, bending readily, and without injury, in any direction, and capable of receiving very slight impressions, but with sufficient elasticity to regain the original shape on the pressure being removed. This seems to Jave been also the state of the Posidonix, as they impress each other in all directions in the shales without injury. The fine shales in which they occur must have been deposited in deep water, which is also the habitation of the recent Aplysice. The large proportional size of the soft portion of the animal, when compared with the small shell, would account for the general dark colour of the Positoniz shales. If the above views were correct, the Posidonior should be removed to the Gasteropoda" (Synop. Carb. Foss. Irel. p. 77). Since writing the above in 1844, I have been strengthened in that view by every sulsecquent examination both of the fossils and the, in my mind, recent analogues; it is, of course, necessary to remove from the true semimembranous $p_{0 \text { osi- }}$ donice such thick-shelled, undoubted bivalves as the Inoceramus vetustus, Sce. which have been confounded with them, but which truly belong to the genus Ambonychia (Hall). There is no evidence of the true Posidonia being bivalve; what seem right and left valves being only the two sides of the one plate*.

\section{Posidonia Becheri (Bromn.)}

\section{Ref.-Gold. Pet. Germ. t. 113. f. 6; Sow. Geol. Trans. 2nd Series, Vol. V.t. 52. f. 2, 3, 4.}

Desc.-Obliquely subovate to subrhomboidal; beaks close to the anterior $\mathrm{f}$ end, which is very short, rounded, with a slight ear-like angulation in front of the beak; posterior dorsal edge nearly straight, varying from concave to slightly elevated; posterior end varying from very broadly rounded to obtusely and very obliquely subtruncate; ventral margin moderately convex; surface marked with subregular, obtusely angular concentric ridges, varying from two to four in three lines on the middle of the shell, smaller and closer on the anterior and rentral portion, largest on the posterior and dorsal half; abruptly diminishing to small strix, or minute, irregular plice of growth, for a narrow space along the posterior dorsal margin; a minute membranous striation usually visible with a lens, parallel to the ridging of the surface. Average length from beak to posterior end two inches five lines, proportional width at right angles thereto at middle $\frac{m}{100}$, depth $\frac{10}{i v u}$, length of nearly straight portion of dorsal margin on both sides of the beak $\frac{25}{100}$.

* As this sheet was passing through the press Dr Griffith sent me a drawing of a specimen shewing two Posidonice connected by the straight margin like a bivalve; but I fancied I had found in my old dissections of large Aplysice that instead of one plate there were often several, placed one over the other and connected by the straight edge which forms the posterior margin; this if established, I thought, would explain Dr Griflith's specimen. A reference to books failed to gire any information on the matter, but at the last moment $I$ hare been fortunate enough to get a specimen from my friend Dr Dickie, and a fresh dissection proved the accuracy of my recollection by shewing (although a small young individual) two distinct Posidonit-like lamince, conneted by the posterior purt, or "hinge" as it would be called by thoso who believed the fossil to be a bivalte.

p The species aro described in the same way as bivalves of similar shape. If the genus be allied to Aplysia, the part called "dorsal edge" would be posterior. 
There is great variety in all the characters of this extremely variable fossil : the ridging of some specimens, is larger, and of many smaller, than the above; the larger the ridges the more regular are they in their distribution and size; some are more nearly orbicular, and some more oblique and angulated; but these changes are so irrelative to each other, that it is obvious they all belong to one species, which, from the extreme thinness and flexibility of its substance, was liable to accidental variations from mechanical causes, in addition to those to which it was probably liable when living. Some of the specimens also shew, here and there, faint radiating puckerings, giving rise to the supposed species $P$. tuberculata (Sow.), which I am satisfied is but a slight variety.

Position and Locality.-Extremely abundant in the black culm limestone, in some parts at Venn, near Barnstaple; equally common in the black limestone and sliales over the main limestone of Derbyshire; common in the black limestone and shale of Poolwash, Isle of Man.

\section{Var. $\alpha$. Tuberculata (Son.)}

Ref. and Syn.= Posidonia tuberculata Sow. Geol. Trans. 2nd Series, Vol. V.t. 52. f. 5.

Agrees in all respects with the ordinary types of $P$. Becheri, except in having a fer obscure, radiating furrows from the beak, faintly tuberculating the concentric ridges; these are, however, so indistinct, irregular, and uncertain in their development, as searcely to entitle the specimens having them to rank eren as a moderately constant variety; those specimens in which the radiations appear near the beak frequently want them on the posterior half of the length, so that one half of the specimen might be referred to $P$. Becleri, and the other half to $P$. tulerculate, if that form were to be admitted as a distinct species; other specimens again shew these radiations on the posterior portion, and not near the beak.

Position and Locality.-Not uncommon with the plain P. Becheri in the black culm limestone near Barnstaple.

\section{Posidonia lateralis (Som.)}

\section{Ref.-Sow. Geol. Trans, 2nd Series, Vol. V. t. 52. f. 1.}

Desc.-Oblongo-elliptienl, very much elongate obliquely; beaks close to the anterior end, which is very short and semielliptically rounded; dorsal margin very slightly convex, extremely thin; compressed, raised considerably above the level of the beaks; greatest width near the posterior end, which is semielliptically rounderl, the curve passing gradually into that of the dorsal and ventral margins, the latter being gently convex or nearly straight in old specinens; sides moderately convex from the beaks, and marked with subregular, large, concentric angular ridges; narrow and sharp on the middle and anterior part, broad and obtuse on the posterior portion, becoming abrupily obsolete near the dorsal margin, along which a narrow space is left smooth, or only marked with lines of growth, parallel with the dorsal edte; sometimes a few obscure radiating furrows decussate the ridges on the posterior slope. Length of old specimens four inches, proportional length of anterior end $\frac{R}{1 \text { ive, }}$, proportional width from beak to opposite ventral margin $\frac{30}{10 m}$, width near posterior end $\frac{43}{100}$, greatest depth (about the middle) ${ }_{1 \cdots}^{\prime \prime}$. At one inch from the beak, near the anterior ventral margin, six or seven ridges occupy three lines; at the same distance from the beak on the posterior slope, there are but two in the same space in one strongly-marked specimen; the ridges retain nearly the same dimensions at all further distances, but at the extreme posterior end there are four ridges in the same space; a second specimen, of equal dimensions and the same shape as above, has about seven ridges in three lines anywhere between the beak and ventral margin, and about three in about the same space on the middle of the posterior slope, or four in the same space nearer to the beak or to the posterior end.

The few radiating furrows on the posterior portion of one of the specimens are analogous to those on the variety of $P$. Becheri, forming the so-calied $P$. tubereulate of Sowerby. The long dorsal margin should by no means be enfounded with a hinge-line, as it is marked with lines of gronth parallel to its edge. The figures given by Professor Phillips (Pal. Foss. f. 74) would induce a belief that this may only be an extremely oblique, elongate, old variety of $P$. Becleri. The substance is excessively thin, and the surface is marked with obsolete minute lines of growth, parallel to the ridging.

Position and Locality.-Common in the black culm limestone of Venn. 


\section{6th Order. Pectivibranchiata. See page 289.}

2nd Family. CREPIDULIDE. See page 289.

Genus. CAPULUS. See page 289.

\section{Capulus auricularis (Mart. Sp.)}

Ref. and Syn.=Conch. Melicites auricularis Martin, Pet. Derb. t. 40. f. 3, 4.=Pileopsis vetustus ? (Sow.) Phill. Geol. York. Vol, II. t. 19. (not of Sowerby); ? P. angustus Phill. ib. f. 19? + P. neritoides Phill, ib. f. 16 to 18 .

Desc.-Discoid, tumid, periphery obtusely angulated, rounded; spire giblous, of very variable size, spirally inrolled to the right side, of one and a half volutions, not projecting beyond the tumid boundary of the depressed suture of the body-whorl; mouth elongate, oval, oblique (left side highest), slightly expanded or reflected on the left side, forming there an imperfect, oblique umbilicus; edge broadly and irregularly sinuated. Surface with moderately strong, irregularly sinuous, transverse lines of growth, crossed on the left or umbilical side by a few obtuse, obscure, longitudinal or spiral strie. Diameter of average specimen one inch, proportional width of last whorl varying from $\frac{47}{100}$ to $\frac{70}{100}$ according to the size of the spire, thickness of last whorl $\frac{55}{100}$.

As M. de Koninck has well observed, this species is strongly distinguished from the $P$. vetustus (Sow.) by the much greater size, tumidity, and perfect enrolment of the oblique spire. The proportion which the spire bears to the whole diameter is very variable. I have observed the spiral strixe on the base, alluded to by Mr Phillips in his description of his $P$. neritoides, obscurely on parts of one of our specimens. None of the modern writers seem to have noticed the description and figures of Martin, which well represent two varieties in size of the spire.

Position and Locality.-Not uncommon in the carboniferous limestone of Derbyshire.

\section{Genus. METOPTOMA (Phill.)}

Gen. Char.-Shell depressed, conical, very slightly inequilateral, left side steeper and smaller than the right, truncated behind, and the apex inclined backwards nearer to the posterior than the anterior end; base truncato-elliptical or subtrigonal. Muscular inpression horse-shoe-shaped, with dilated pyriform ends extending scarcely halfway to the front, surrounding the truncated posterior end; margin in one plane except in the middle of the posterior end, where it is raised, with a more or less distinct sinus.

The position of the muscular impression marks the posterior end, and shews that the apex is directed backwards and near the posterior end, the reverse of what is found in Patella, as M. de Koninck has already noticed in the supplement to his Animanx Fossiles. The same characters convince me that the proper place for the genus is near Cupulus, in which all these characters are seen, and which in fact only differs from Metoptoma in having the apex more inrolled, and the lateral edges less regular, and no distinct truncation. On this view there would be no evidence, from these fossils, for the occurrence of the Cyclolranchiate mollusea in the Palrozoic rocks, as it is now obvious they should be arranged with the recent and Palrozoic Capuli in the Pectinibranchiate order.

\section{Metoptoma eldiptica (Phill.)}

Ref. and Syn.-Phill. Geol. York. Vol. II. t. 14. f. 9. = Patella elliptica de Kon. Anim. Foss. Belg. t. 23 bis. fig. 3.

Desc.-Elongate-oblong, elliptically rounded in front, truncated and very slightly dilated at the lateral angles behind; middle of the posterior margin slightly notched by a broad, moderately deep, doubly angulated 
sinus, the angles being separated by a slight lobe (not reaching nearly to the plane of the lateral margins), the cicatrix of each leaving a slight sulcus extending to the beak, the space between the converging pair of sulci being convex; beak small, conoidal, depressed, almost overhanging the posterior margin; profile gently arched from the beak to the anterior margin; greatest depth considerably in front of the beak, nearly in the middle of the length; sides flattened, left one more steeply sloped than the right; longitudinal middle third from the beak to the front margin obtusely rounded. Shell of moderate thickness, nearly smooth, or marked with very minute concentric wrinkles of growth. Length one inch three lines, proportional greatest width $\frac{62}{500}$, from beak (shell absent) to anterior end $\frac{95}{100}$, depth $\frac{39}{100}$. Muscular impressions reach to within $\frac{60}{100}$ (of the length) of the anterior end.

The beak being slightly within the margins, according to my measurements, instead of being terminal, as said by Phillips, or overhanging, as said by de Koninck, is probably due to the absence of the shell on that part of our specimen.

Position and Locality.-Tare in the carboniferous limestone of the Isle of Man.

14th Family. HALIOTIDE. See page 290.

Genus. PLEUROTOMARIA*. See page 291.

Pleurotomaria altavithata? $\left(M^{c} \mathrm{Coy}\right)$. Pl. 3. H. figs. 9, 10.

Ref. and Syn.? M McCoy, Synop. Carb. Foss. Irel, t. 5. f. 11.

Desc.-Obtusely conical, broad-ovate, spire of four rapidly increasing whorls, and eitler depressed or moderately elevated; apical angle varying from $150^{\circ}$ to about $100^{\circ}$; whorls flattened, slightly convex above, sloping inwards and moderately convex below; the angle, which is situated in the upper third of the spiral whorls and upper fourth of the body-whorl, is very obtusely rounded, and bears the broad flattened keel on its upper or spiral aspect, so that it is at or slightly above the middle on the spiral whorls, and slightly above the most prominent part of the angulation of the body-whorl; surface nearly smootl, with obtuse, slightly irregular lines of growth, curving backwards to the keel on the upper portion, slightly forwards and then downwards on the lower portion of the whorls; on very old specimens a few, obscure, distant, spiral ridges appear on the bodywhorl, most distinet towards the base or anterior end; no umbilicus. Width of average specimen one inch four lines, proportional height $\frac{92}{10 m}$ (of rather elevated variety), proportional height of mouth in, height of penultimate whorl ${ }_{1110}$. Proportions of depressed variety, width one inch four lines, proportional height ${ }_{100}^{\mathrm{g}}$, height of mouth $\frac{175}{100}$, height of penultimate whorl $\frac{8}{100}$.

This species almost exactly resembles the Plourotomaria tumida of Phillips, as figured in the Mineral Conchology, t. 610, in general form, band, striation, and the appearance of spiral ridges at the base; but in all the varieties the upper part of the whorls is more flattened, the band is broader, and the species is remarkably distinguished by the great height at which the band is placed; in the $P$. tumida it is so low as to be entirely concealed by the sutures on the spiral whorls; while in the present species it is placed in the middle of the spiral whorls, rather nearer to the upper or posterior than the lower or anterior suture. I only put a mark of doubt to my reference to this species, on account of the great comparative size of the English ones, and the appearance of olscure spiral ridges on the base of very old examples. The general form strongly recals the undetermined Janthina, figured in the Geology of Russia, t. 23. f. 14. In young specimens half an inclu long there is a trace of a very minute umbilicus.

* M. de Koninck calls the anterior parts of these shells, the superior, contrary to the custom of most writers. I have described them in the old and more natural way as cones with the base downwards, and calling the apex (or posterior end), and parts near the apex, upper, and parts near the base or mouth lower. 
Position and Locality.-Not uncommon in the earboniferous limestone of Lowick, Northumberland; very rare in the lower carboniferous limestone of Derbyshire.

Explanation of Figures.-Pl. 3. H. fig. 9, natural size, depressed variety, front view; fig. 10, do. elevated variety, natural size, back view.

\section{Pleurotomaria angulata (de Kon.)}

Ref. and Syn.-de Kon. Anim. Foss. Bel. t. 37. f. 2.=Trochus acutus id. Olim.

Desc.-Conical, periphery of body-whorl sharply angulated; spire of five and half flattened whorls, very slightly convex near the upper suture, and very slightly coneave near the lower one; suture a moderately impressed line; apical angle $95^{\circ}$; base very obtusely conoidal, slightly convex, sloping from the carinated periphery to the angular edge of a wide, deep, smooth, conical umbilicus. Surface covered with slightly unequal, elevated, thread-like, spiral strix, separated by flat spaces rather wider than the strix; about twelve spiral lines on each whorl, and about the same number on the base: band narrow, smooth, placed on the angle; mouth wider than long, rhombic. Diameter of average specimen four lines, proportional height $\frac{65}{100}$, height of mouth $\frac{51}{1 w^{\prime \prime}}$, width of umbilicus about $\frac{45}{100}$.

The striation of this species is scarcely visible to the naked eye. From the small size of the band, and its coinciding with the keeled periphery, it is very difficult to distinguish. Possibly the Trochus pyramidatus may be only an elevated form of the same species (corresponding to the two varieties of Pleurotomaria Yvani), the elevation of the spire accounting for the diminished size of the umbilicus.

Position and Locality.-Rare in the carboniferous limestone of Derbyshire.

\section{Pleurotomaria antrina (Schlot.)}

Ref. and Syn. $=$ Trochilites antrinus Schlot. Akad. Münch. Vol. VI. t. 7. f. 6 c.=Pleurotomaria Permiana King, Catal. = P. Sedgwickiana How. T. T. N. F. C. Vol. I.;?=P. Verneuili Geinitz, Verstein t. 3. f. 17, 18. $=P$. antrina (Schlot.) King, Perm. Foss. t. 17. f. 1, 2, 6. P. Tunstallensis id. ib. f. 3, 4, 5.

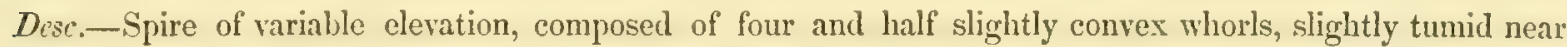
the sutures above, and rather more so below; sinal band depressed, flat, rather narrow, bounded by two fine, elevated, thread-like lieels, the lower keel being about half the width of the band above the suture on the spiral whorls, and slightly above the most convex part of the periphery on the body-whorl; base rather flattened, with a very small umbilicus; pillar long, slightly oblique; mouth transversely oblong, rounded. Surface marked with fine, obscure, unequal lines of growth arehing backwards to the band, often thickened at intervals near the suture, forming an obscure, obtuse plication; occasionally a few faint, obtuse, spiral strix, rather smaller than those bounding the band, and their own thickness apart, may be seen on parts of some specimens. Length of average variety seven lines; in proportion thereto, length of mouth $\frac{54}{1+10}$, width of mouth $\frac{5 \pi}{1+1}$, depth of penultimate whorl $\frac{31}{\mathrm{i} u}$, apical angle varying from $70^{\circ}$ to $100^{\circ}$, the former usually large specimens, the latter extreme usually of small size, $75^{\circ}$ being the most common angle, and agreeing with the above measurements.

The spiral stria are searcely ever distinctly visible, requiring apparently some peculiar state of preservation or decay to render them visible. I have traced all the gradations between the extremes of height and depression of the spire noted above, so as to render it certain they are of one species. The obliquity of the pillar lip marked by Professor King as distinguishing his $P$. Tulstallensis from the present species is equally seen in both.

Position and Locality.-Common in the Permian magnesian linestone of Humbleton.

\section{Pleurotomaria callosa (de Kom.)}

Ref.-de Kon. Anim. Foss. Bel. t. 36. f. 7.

Desc-Globose, obtusely conic; body-whorl large, rounded; spire short, of about four or five gently convex whorls; apical angle $100^{\circ}$; sinal band of moderate width, convex, bounded by two narrow sulci, of which 
the upper or posterior one is much more strongly marked than the other, and interrupts the outline from the more abrupt convexity of the part of the whorl between it and the suture; the band is a little above the middle of the body-whorl, and a little above the suture on the spiral whorls, where its lower bounding sulcus often becomes obscure, and its upper sulcus nearly equals the sutures in depth, and from being but very little below the middle, gives the appearance of twice the actual number of whorls in the spire; base convex, with a very large callosity, filling the place of the umbilicus, divided by a medial spiral sulcus; mouth broad-ovate, slightly longer than wide. Surface smooth. Diameter of average specimen one inch tliree lines, proportional height from base $\frac{45}{100}$, height of last whorl $\frac{60}{100}$, proportional height of penultimate whorl $\frac{15}{100}$, width of callus ${ }_{100}^{40}$, width of mouth ${ }_{\mathrm{i} 00}^{55}$.

I do not know why M. de Koninek describes this species with eight whorls to the spire, while his figures agree with all our specimens in having only four to five, unless he may perhaps have counted by accident the strong upper suleus of the band as one of the sutures. The species is very easily recognised by its Ilelix-like form, obtuse convex band, and large callosity on the base.

Position and Locality.-Not very uncommon in the carboniferous limestone of Arnside, Kendal.

\section{Pleurotomaria cirriforms (Sow. Sp.)}

Ref. and Syn. = Helix cirriformis Sow. Min. Con. t. 171. f. 2.= Pleurotomaria vittata Phill. Geol. York. t. 15. f. 24. = Pleurotomaria cirriformis (Sow.) de Kon. Supp. Anim. Foss. Bel. t. 58. f. 8.

Desc.-Acutely conic, apical angle $80^{\circ}$; spire of six whorls, sloping and gently convex above; sutures simple, impressed; base of last whorl sloping, gently convex; band rery broad, flat, only slightly projecting from the surface, its upper edge forming the most prominent part of the spiral whorls, the lower edge being concealed by the suture, on the body-whorl it is placed a little above the middle, the lower edge coinciding with the most prominent part of the outline; mouth slightly longer than wide, obtusely trapezoidal; umbilicus distinct, deep, rounded, narrow; surface marked with rather coarse, irregular lines of growth extending with slight obliquity towards the band arched near the sutures, crossed under the lens by extremely minute spiral strie, scarcely visible to the naked eye; band crossed by very faint minute arched strix. Length one inch one line, proportional height of mouth $\frac{60}{100}$, height of penultimate whorl $\frac{21}{1+1+}$, diameter at base diameter of umbilicus ${ }_{100}^{17}$, width of band on last whorl $\frac{8}{100}$.

The great width and flatness of the band are the most remarkable features of this species, as well as the partial concealment of this latter by the edge of the sutures. The extreme minuteness of the spiral strix, and the alssence of the two or three equidistant, strong, spiral grooves on the base, separate it from the $P$. tornatilis (Phill.)

Position and Locality.-Rare in the carboniferous shale of Craige near Kilmarnock.

\section{Pleunotomania conica (Phill.)}

Ref. and Syn.=Phill. Geol. York. Vol. II. t. 15. f. 22.; ?+ P. decussata McCoy, Synop. Carb. Foss. Irel. t. 5. f. 13 .

Dese.-Acutely conical ; apical angle varying from $62^{\circ}$ to $72^{\circ}$; spire composed of about seven gradually increasing, flattened whorls, slightly tumid towards their lower edge, where they have a very narrow band bounded by two strong thread-like keels, a little less broad than the band, and so much depressed as to form a deep sulcus between them; the pair of keels are about the width of the band above the suture, the intervening space being so depressed as to resemble a second sinal sulcus, and sometimes a third sulcus appears over the upper keel; body-whorl with the periphery obtuscly angulated, and bearing two or three narrow keels, divided by deep sulci, one of which contains the slit of the mouth; umbilicus small, rounded, deep in the casts, nearly closed when the shell is perfect. Surface of the whorls above the band sculptured with fine, sharp, 
regular, oblique lines; those extending from the band to the umbilicus on the base of the body-whorl are obtuse, irregular, and slightly flexuous; most specimens shew fire or six spiral strie beneath the keels on the bodywhorl, and some shew traces of them above the band on the spiral whorls. Length one inch, proportional height

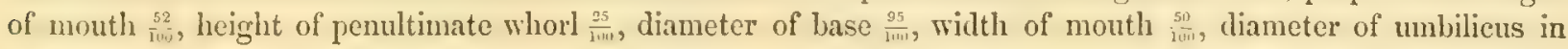
casts $\frac{91}{1110}$.

Most specimens shew the transverse, sharp, regular, oblique strix very strongly marked, with no trace of spiral lineation. Specimens agreeing with my $P$. decuszrtu as above have the surface regularly reticulated by nearly equal spiral and transverse strie, and such I considered at one time spccifically distinct. Seeing, however, in some of the Isle of Man specimens, traces of spiral strixe on parts of the surface, and not on other parts, I venture to unite the species as varieties, the more readily as Prof. Phillips mentions in his original description that some specimens have spiral strix.

Position and Locality.-Not uncommon in the carboniferous limestone of Poolwash, Isle of Man.

\section{Pleurotomaria consobrina (de Kon.)}

Ref. and Syn.-de Kon. Supp. Anim. Foss. Bel..p. 691 = Murchisonia angulata (Phill.) Portk. Geol. Rep. t. 31. f. 5 (not of Phillips).

Desc.-Acutely conic; apical angle 55\% ; spire composed of six gradually increasing whorls, each very strongly angulated in the middle, where it bears a very prominent, thick, single lieel, above (or behind) which the volutions are flat and sloping to the keel, beneath which they are gently concave and nearly vertical, or sloping slightly inwards to the suture; on the body-whorl a second thick ridge, or keel, appears below (or in front) of the former one, and slightly nearer to it than it is to the suture; the second keel is exactly covered by the edge of the suture, and concealed in the whorls of the spire (in some states of preservation these two keels seem split into two or three very fine ones); base flattened from the anterior keel, slightly convex; umbilicus small, rounded, deep; surface marked with coarse, irregular, oblique strie, which arch backwards from the upper sutures, and rather strongly crenulate the mesial keel of the spiral whorls, below which they bend forwards, and on the body-whorl crenulate the anterior lieel, and are then rather abruptly directed into the unbilicus. Length of small specimen ten lines, height of last whorl ${ }_{1 \ldots}^{43}$, height of penultimate whorl $\frac{20}{1 v}$, width of base $\frac{83}{100}$, width of mouth $\frac{33}{100}$, width of umbilicus ${ }_{100}^{18}$; length of large specimen one inch five lines.

From the direction of the strixe it would seem as if the sinus was obliquely angular, and occupied all the space between the two keels seen on the body-whorl. This species is so strongly marked that it is needless to point out its distinctions from any of the others, with the exception, perhaps, of the $P$. laticincter de Kon. which is distinguished by its less acute spire (if his figure be correct), also loy its spiral strie and the two distant keels being visible on the spiral whorls. The shell is thick, and one of the specimens shews the nacreous inner layer, which militates against King's approximation of the genus to Emarginule, and favours d'Orbigny's comparison with Haliotis.

Position and Locality. - Not uncommon in the carboniferous limestone of Derbyshire.

\section{Pleurotonaria decipiens $\left(M^{c} C o y\right)$. Pl. 3. H. fig. 13, 14.}

\section{Ref.-McCoy, Ann. Nat. Hist. 2nd Series, Vol. XII.}

Desc.-Var.a. Spire acute, regularly conie, apical angle about $40^{\circ}$, composed of about seven or eight gradually-increasing flat whorls; suture a simple impressed line; base of body-whorl flattened, forming a strong angle with the spire; no unbilicus; pillar-lip slightly thickened, arched; mouth oblong, angulated, a little wider than long; surface marked with narrow thread-like, spiral ridges, separated by flat or slightly concave spaces about three times their width; about eight or nine spiral ridges on each whorl, and seven or eight more, rather stronger, on the base; the intervening spaces rery irregularly cancellated by obscure, unequal, obtuse,

[EASC. III.] $3 \mathrm{Y}$ 
longitudinal wrinkles, very slightly oblique to the band, forming an obscure, irregular, quadrate pitting, occasionally visible on the east; these transverse plice closer and more oblique on the base; band about the width of the ordinary spaces between the spiral lines, flat, very inconspicuous, and bounded by very delicate, impressed lines, destitute of the obtuse cancellating plice of the rest of the surface, situated two inter-spiral spaces above the lower suture of each whorl. Width ten lines, proportional height of last whorl ${ }_{100}^{0 s}$, height of penultimate whorl $\frac{40}{100}$, width of mouth $\frac{70}{100}$.

Var. $\beta$. Very clongate, conic, apical angle about $\frac{40}{100}$; whorls moderately convex; base of basal whorl gradually prolonged, not flattened nor separated by any angulation from the sides; mouth a little longer than wide. Length of last whorl eleven lines, proportional width $\frac{15}{100}$, proportional height of penultimate whorl $\frac{40}{109}$.

It will be seen that this species has two extreme varieties somewhat resembling those of the $P$. I vanni; the variety a so exactly resembles a Trochus, that it requires the most careful examination to detect the extremely obscure though definite band, to convince the observer that it is a Pleurotomaric; the var. with the basal whorl elongate, and rounded in front or at base, like the corresponding varicty of $P$. $I$ canni, is so like a Mracrockilus that it is only by carefully tracing the intermediate forms, and detecting the very obseure band, noting the same number of spiral ridges on the whorls, Sce, that I have become satisfied of their identity. Both varieties have usually only four whorls preserved; the posterior end of the animal at that length depositing convex, imperforate diaphragms, and becoming naturally decollated.

Position and Locality.-Both varieties rare in the impure lower limestone of Lowick, Northumberland; the var. $\beta$ rare in the similar limestone of Kendal, Westmoreland.

Explanation of Finures.-Pl. 3. H. fig. 13, natural size, conical variety, from the carboniferous limestone of Lowick; fig. 14, ditto, elongate variety, with rounded whorls.

\section{Pleurotomaria erosa ( $M^{c}$ Coy). Pl. 3. I. figs. 38 and 39.}

$$
\text { Ref.-McCoy, Ann. Nat. Hist. 2nd Series, Vol. XII. }
$$

Desc.-Orbicular, depressed, very obtusely conical ; apical angle $105^{5}$; spire of four and a half rapidly enlarging whorls; flattened, or very slightly convex; sutures, fine, simple, impressed lines; body-whorl flattened, or slightly envex in the upper two-thirds; periphery very obtusely rounded close to the broad, flattened, gently convex base; umbilicus entirely closed, with a large, very thick, semicireular, shelly pad; band narrow, obscure, bounded by two fine impressed lines; surface glossy, eroded with deep, obtuse, excarated markings, without regularity in size, shape, or direction; lines of growth arching backwards to the band, scarcely visible.

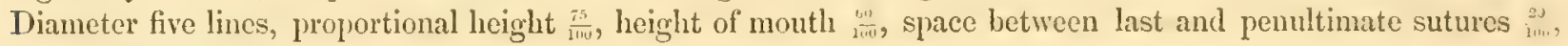
width of umbilical pad $\frac{45}{200}$.

The band of this species is often almost invisible on the periphery of the body-whorl, and lines of growth can only be traced here and there with a lens. The substance of the shell is very thick, and with the glossy surface, general form, and large umbilical pad, recalls Rotelle (= P'ithontlus) very strongly. The peculiar "worm-enten" appearance of the irregular pitting of the surface is equally marked in the two specimens before me.

Position and Locality.-Rare in the carboniferous limestone of Lowick, Northumberland.

Explanation of Figures.-Pl. 3. I. fig. 38, magnified half a diameter, under side, from carboniferous limestone of Lowick; fig. 39 , profile, natural size ; fig. $39 a$, ditto, scen from above; $39 b$, ditto, magnified half a diameter.

\section{Pleurotomaria griffithi $\left(M{ }^{\circ} C o y\right)$.}

Ref.-M대, Syn. Carb. Foss. Irel. t. 6. f. 1.

Desc.-Acutely ennical, apical angle $85^{\circ}$, spire of five or six whorls, cach very acutely angulated by the sloping of the upper and under surfaces to an extremely prominent, flat lieel; truncated or quadrate at its 
narrow outer edge, and having the sinal band along its upper flat side, bounded internally by a faint obtuse ridge; the whorls alove the keel have a sigmoidal profile, being gently convex in the middle from the upper suture, and becoming concave, or curving outwards, in the lower third, to blend with the upper side of the thin flat keel; below the keel the whorl slopes rapidly into the suture, slightly concave near the keel, convex at the suture; keel rather below the middle of the basal whorl, and at one-third from the lower suture in the spiral whorls; base very convex; umbilicus moderately large, open, conical, deep; mouth transversely cordate, angular externally; surface almost smootl, with membranous, minutely wrinkled, or irregular striæ of growth, slightly arching obliqucly backwards to the leel; recurved on its flat upper surface, and thence extending almost directly into the umbilicus; a few fine spiral strix at the edge of the umbilicus, under the lens. Diameter of suall specimens two inches nine lines, proportional height $\frac{17}{100}$, height of last whorl $\frac{17}{1 \mathrm{~m}}$, height of

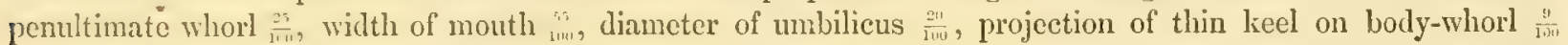
(occasionally six inches in diameter).

M. de Koninck, in the supplement to his Fossils of Belgium, figures what seems the Pleurotomaria carinata of Sowerby as this species, apparently on the supposition that my original figures and description were totally inaccurate in all respects. A specimen in the University collection from Lowick, however, shews the smooth (not spirally sulcated) surface, and the extremely prominent, peculiar, compressed lieel, exactly according with my original figures and deseription, as also a less perfect fragment from Ireland.

Position and Locality. - Very rare in the carboniferous limestone of Lowick, Northumberland.

\section{Pleurotoliaria helicinoides $\left(\mathrm{M}^{\circ} \mathrm{Coy}\right)$.}

Ref. and Syn.-McCoy, Synop. Carb. Foss. t. 7. f. 6.=Trochus subhelicinoides d'Orb. Prod. p. 119.

Desc.-Discoid, lenticular, depressed; spire very obtusely conic ; apical angle $126^{\circ}$, composed of four and half turns; body-whorl sharply carinated in the middle, the sharp projecting keel having the narrow band placed flatly on its upper side, defined within by a fine impressed line; this keel and band touch the simple suture on all the whorls of the spire, all of which shew the band distinctly; surface of each whorl slightly coneave near the band, and slightly convex near the upper suture; base of body-whorl depressed, gently convex; umbilicus narrow, rounded. Width one inch four lines, proportional height ${ }_{1,4}^{+5}$, height of last whorl $\frac{3 n}{201}$, height of penultimate whorl $\frac{3}{1+1}$, wilth of mouth $\frac{11}{1 w}$, width of cumbilicus ${ }_{1 v 0}^{17}$, width of band about half a line. Surface apparently smooth.

As the spccimen in the collcetion was crushed, I have taken the apical angle and measurements from the nriginal Irish one. I know not why M. d'Orbigny has changed the genus and specific name of this species.

Position and Locality.-Rare in the black beds of the carboniferous limestone of Derbyshire.

\section{Pleurotomaria striata (Sow. Sp.)}

\section{Ref. and Syn. = Helix striata Sow. Min. Con. t. 171. f. 1 .}

Desc.-Shell depressed, conical; apical angle about $90^{\circ}$; spire low, of five flattened, or slightly convex, rapidly enlarging whorls; periphery of body-whorl angulated; base flattened, gently convex; no umbilicus; mouth transversely rhombic; band broad, decply hollowed, bounded by two strong prominent keels on the angle of the body-whorl, the lower of which is concealed by the suture on the spiral turns. Surface strongly sculptured with regular, simple, subequal, oblique, very slightly arehed, thread-like ridges, about their own thickness apart above, forming arched, scale-like strixe in the hand, and slightly sinuous and dichotomous on the base of the body-whorl (about seven strice in two lines on the body-whorl). Average width one inch, proportional height ${ }_{100}^{80}$, height of last whorl $\frac{50}{100}$, height of penultimate whorl $\frac{15}{100}$, width of mouth $\frac{60}{100}$.

The want of umbilicus and spiral strix separate this species from the $P$. carinata Sow.

Position and Locality.-Rare in the carboniferous limestone of Bolland. 


\section{Pleurotomaria submonilifera ( $\left.D^{\prime} O r^{\prime} b.\right)$}

\section{Ref. and Syn. $=P$. monilifera Phill. Geol. York. Vol. II. t. 15. f. $10 a$ (not of Zieten), = P. submonilifera} d'Orb. Prodrome, p. 123.

Desc.-Conical, globose; spire of about seven rapidly increasing whorls; apical angle $75^{\circ}$; band strong, deeply hollowed, bounded by two strong prominent keels placed a little above the middle of the body-whorl, the lower one touching the deeply-channelled suture on those of the spire; a strong sulcus below the lower keel on the body-whorl; base very convex; umbilicus small, rounded; whorls above the prominent band flattened, marked with two, or rarely three, strong spiral, equidistant rows of granules, the upper one coinciding with the edge of the suture; base covered below the band on body-whorl with very numerous, close, subequal, obtuse, granulated strix; fine oblique strix cross the spiral lines on the base, and rather more distant and stronger ones arch from the suture to the band on the upper part of the whorls. Average length three lines, width about the same or slightly more, proportional height of last whorl $\frac{70}{100}$, of penultimate whorl $\frac{30}{100}$.

Position and Locality.-Common in the mountain-limestone of Derbyshire; not uncommon in the carboniferous shales of Glasgow.

\section{Pleurotomaria undulata (Plill.)}

$$
\text { Ref.-Phill. Geol. York. Vol. II. t. 15. f. 14. }
$$

Desc_-Globose, spire very small, obtuse, of four and half whorls; apical angle about $107^{\circ}$; band very broad, flat, very prominent, bounded by narrow vertical sides, situated on the middle or most prominent part of the body-whorl, and its lower edge corresponding with the suture on the spiral whorls, of which it nearly equals half the width; ahout twice its width from the upper suture of the body-whorl. Surface with extrenely coarse transverse plicx, about their thickness apart, semicircularly arched on the band, arehing slightly backwards to the keel on the upper part of the whorls, and nearly direct on the base of the body-whorl after a slight curve near the band; between each of the plice are two or three fine irregular lines; whorls tumid above the band; base of the body-whorl very tumid, rounded; umbilicus very small, rounded; mouth rounded. Average width two lines, proportional length about $\frac{\frac{s m}{1 m}}{1 m}$, height of last whorl about $\frac{75}{1 m}$, height of penultimate whorl about $\frac{20}{200}$; width of band one-third of a line.

This very strongly-marked species cannot be confounded with any other, from the great width and prominence of its band, and the coarseness of its sculpturing. The very small size of the species renders the proportional measurements rather uncertain.

Position and Locality.-Not uncommon in the lower carboniferous limestone of Isle of Man.

\section{Pleurotomaria Yvanni (L'Eveillé Sp.)}

Ref. and Syn.=Trochus Yvanni l'Eveillé, Mém. de la Soc. Géol. de France, Vol. II. t. 2. f. 24. =Pleurotomaria concentrica Phill. Geol. York. Vol. II. t. 15. f. $23 ;$ ? + Buccinum parallele id. ib. t. 16. f. 8; ?+ Pleurotomaria canaliculata $\mathrm{M}^{\circ} \mathrm{Coy}$, Synop. t. 6. f. 3; P. Yvannide Kon. Anim. Foss. Bel. t. 37. f. 1 and 7.

Desc.-Conical, spire of six to seven whorls; apical angle varying from $60^{\circ}$ to $85^{\circ}$; band coinciding with an angulation of the whorls, which is a little nearer to the upper than the lower suture; the space above this angulation flat or slightly coneave, sloping at an angle of $45^{\circ}$ in the long varieties, becoming more nearly horizontal in the short varieties. Surface below the angulation nearly vertical or parallel to the axis of the shell, flat or very slightly convex; base of body-whorl tumid, rounded; umbilicus small, conical, almost obsolete in the very long varieties; surface marked with coarse, subequal, spiral stria (three to four in two lines on bodywhorl at nine lines in (liameter), those above the angulation much finer than those below it, usually four to five below the angulation, and five or six finer ones above it on the spiral whorls; band scarcely distinguishable from the other sulei between the pairs of ridges; surface, when finely preserved, crossed by minute oblique 
lines of growth. Average length of rather small elongate specimens one inch, height of last whorl ${ }_{i o u}^{59}$, height of penultimate whorl $\frac{20}{100}$, diameter at base ${ }_{100}^{82}$.

I have seen such extreme varieties of this species lately, that I suspect my $P$. canaliculata will turn out an unusually depressed variety, with the peculiarity of a channelled band. The Buccinum parallele (Phill.) may probably be considered the extreme of the elongate variety.

Position and Locality.-Not uncommon in the lower carboniferous limestone of Kendal; common in the red carboniferous limestone of Closeburn, Dumfriesshire; rare in the carboniferous limestone of Derbyshire.

\section{Genus. MURChISONIA. See p. 292.}

\section{Murcitronia angulata (Phill.)}

Ref. and Syn. = Rustelluria angulate Phill. Geol. Iork. t. 16. f. 16.=11urchisonia angulate Phill. Pal. Foss. f. 189.

Desc.-Very elongate, conic; apical angle about $32^{\circ}$; spire of numerous gradually increasing whorls, very strongly angulated a little below the middle by the convergence at an acute angle of the upper and lower surfaces, both of which are strongly concave; the angulation is surmounted by a strong, prominent, single or double keel; another distinct lkeel, but considerably smaller in size, is on the lower part of each whorl, immediately above the suture, being most strongly marked on the body-whorl; the upper sutural edges are also slightly thickened so as to form occasionally another very much smaller obseure licel. Surface with strong. subequal, nearly straight lines of growth, converging backwards to the keel.

The specimen in the collection is too imperfect to give either the number of whorls or the measurements, or to shew whether the species is umbilicate or not; it shews, however, very distinctly the strong characteristic of the species, which is the thin distinct keel below or on the aperture side of the band, which distinguishes it from the M. Verneuilana and the forms M. de Koninck has confounded with it.

Position and Locality.-Rare in the black beds over the lower limestone of Derbyshire.

\section{Murchisonia dispar $\left(M^{c} C^{\prime}\right.$ oy). Pl. 3. I. fig. 37.}

$$
\text { Ref.-McCoy, Ann. Nat. Hist. Ind Series, Vol. XII. }
$$

Desc.-Elongate, very acutely conic; apical angle $30^{\circ}$; spire of about eight very gradually increasing tunid whorls, having a very thick, obtusc, prominent band, forming a rounded keel much nearer the lower than the upper suture; upper and lower surfaces slightly tumid, convex, the lower portion most stecply sloped; the band is either simple or rarely with three spiral stric; two strong spiral hines below the keel, and six slightly smaller ones above it on each whorl; base of body-whorl rounded, convex, with an obtuse angulation at such a distance below the lieel that it is just concealed by the suture on the spiral whorls; lines of growth fine, unequal, obscure, slightly arehed, oblique to the band. Length seven lines, proportional width $\frac{50}{1+u}$, height of last whorl $\frac{45}{100}$, height of penultimate whorl $\frac{20}{100}$.

This species is easily distinguished from its allies, the $1 \%$. subsulcata and $M$. Archirecana de Koninck and MI. Larcomi MICoy, by the disparity in width of the parts of the whorls above and below the band, and the disparity in number of the keels or spiral stria which ornament those parts. berland.

Pusition and Locality. - Not very uncommon in the impure carboniferous limestone of Lowick, Northum-

Explanation of Figures.-Pl. 3. I. fig. 37, natural size; $37 \alpha$, portion of do. magnified.

\section{Murcinisonia quadricarinata $\left(M^{c}\right.$ Coy).}

\section{Ref.-II Coy, Synop. Carb. Foss. Irel. t. 5. f. 9.}

Desc - Very elongate, conic; apical angle 220; spire composed of eight or nine very gradually increasing whorls, separated by very deep sutures, each very tumid and strongly angulated by a thick sinal lieel a little below the middle; above the principal keel are two considerably smaller ones, the upper forning the tumid 
edge of the suture, and beneath it one or two smaller ones, increasing to four or five on base of body-whorl, which is very convex but not umbilicated. Length six lines, proportional width $\frac{15}{100}$, height of body-whorl $\frac{46}{100}$, height of penultimate whorl $\frac{20}{100^{\circ}}$.

Position and Locality.- Rare in the carboniferous limestone of Derbyshire.

\section{Murciisonia sulcata $\left(\mathrm{M}^{\circ} \mathrm{Coy}\right)$.}

Ref.-MI Coy, Syn. Carb. Foss. Irel. t. 5. f. 10.

Desc.-Acutely conical; apical angle $62^{\circ}$; spire of five gradually increasing, very convex whorls, each angulated a little below the middle; hase very convex; umbilicus rery small; mouth rounded; surface girt with thick, clnse, subequal, thread-like ridges, the two larger of which on the angulation include the band between them; ridges crossed lyy rather strong, oblique lines of growth, very obseurely retroflexed on the band, to form a small sinus; about three ridges on each whorl of the spire above the band (or five altogether), and about thirteen on the body-whorl. Length six lines, proportional width $\frac{87}{100}$, height of last whorl $\frac{50}{100}$, height of penultimate whorl $\frac{25}{100}$.

The band is scarcely to be distinguished in this species, which so strongly resembles the Permian Turbo helicinus, that it might almost be considered a variety of it, if found in the same rock, I lave traced on internal easts, however, the retroflexion of the lines of growth in the carloniferous shell at the most prominent part of the whorls, and find the corresponding lines straight and oblique in the Permian one, thus separating them generically. The Turbo pigmecus of de Koninck also seems closely allied, but differs apparently by its fewer whorls, more depressed spire, globose form, and more numerous spiral ridges.

Position and Locality.-Very common in the black carboniferous shales of Craige, near Kilmarnock.

\section{Munchisonta Verneuilana (de Kon.) Var. Kémdalensis (MCoy). Pl. 3. II. figs. 11 and 12.}

Ref. and Syn. = M. angulata d'Arch. and de Vern. Geol. Trans. Vol. VI. t. 32. f. 6. (not of Phill.) $=$ II. Vernexilana de Kon. Anim. Foss. Bel. t. 38. f. 5 .

Desc.-Very acutely conic; apical angle about $35^{\circ}$; spire elongate, of twelve very gradually increasing whorls, each strongly angulated a little below the middle by a very prominent thick band, which is either flat. and bounded by two very fine sulci, or hollowed in the middle, leaving two thick approximate keels; the spaces abore and helow the kcel on each whorl nearly flat; the former slightly wider than the latter and slightly concave, the Iatter slightly convex; base of body-whogll very convex, evenly rounded; umbilicus very small, rounded; sutures deep, simple, upper edge often slightly tumid. Surface marked with coarse, irregular, imbricating striæ, very slightly arehed sigmoidally, extending obliquely backwards to the keel above, and forwards from it below; arched backwards on the band; mouth small, slightly longer than wide, ovate, angulated in the middle of the nuter edge. Length ahout two inches, proportional width $\frac{55}{100}$, height of last whorl $\frac{3 n}{100}$, height of penultimate whorl $\frac{18}{100}$, width of mouth $\frac{20}{100}$, width of umbilicus $\frac{7}{100}$.

This fine species differs from the $M$. Tomenilana, as figured by M. de Koninek, only in having the band almost invariably a thick, undivided, flattened keel, in having the spire slightly longer and of more numerous whorls, and in having a small umbilicus. As I have observed, however, the band replaced by two keels on some of the upper whorls of one or two specimens, I think it best to consider the English fossil as merely a variety of the continental one, giving the variety, however, a distinet name for the convenience of those who may think otherwise. The M. angulate Phill. is distinguished by a strong keel on each whorl below the band, close to the suture, and distinetly isolated on the body-whorl.

Position and Locality.-Very abundant in the impure limestone of Kendal.

Explanation of Figures.-PI. 3. H. fig. 11, natural size, back view of elongate variety; fig. 12, front view of, slightly shorter variety. 


\section{Genus. POLY'TREMARIA ( $D^{\prime} O r^{\prime} b$.)}

Gen. Char.-Form and general characters as in Pleurotomaria proper, but the band constricted at short intervals, so as to form a row of approximate, oval foramina, as in IIaliotis, the last ten or twelve of which commonly remain open.

\section{Polytremaria catenata (de Kon. Sp.)}

Ref. and Syn.=Pleurotomaria catinate de Kon. Anim. Foss. Belg.t. 32. f. 1.=Polytromaria catenata (de Kon.) d'Orb. Prodrome, p. 122.

Desc. - Spire conical; apical angle about $80^{\circ}$; of about six whorls, cach strongly angulated a little above the middle; the part above the angle slightly concave, sloped, or nearly horizontal; the part below the lieel flattened and nearly vertical; base rounded; umbilicus very small; mouth rotundato-ruadrate; surface strongly marked with coarse, unequal, spiral, thread-like strice, about thrce or four above the keel, and four or five below it on the penultimate whorl, about the same size, and covering the base of the body-whorl, crossed by fine striae of growth, oblique above the band, nearly vertical below it; band thick, the transversely oval apertures numbering about sixteen in each turn. Length about eight lines, proportional wilth seight of last whorl $\begin{gathered}55 \\ \text { voin }\end{gathered}$, height of penultimate whorl 25. A specimen five lines long has the proportional width

M. de Koninck's figure is rather broader at the base, has the band lower, and the volutions more rounded and less angulate than in our examples, or in his description. The proportional width seems to increase with age.

Position and Locality.-Tare in the impure lower limestone of Lowick, Northumberland.

\section{Genus. PLATYSCHISMA ( I ${ }^{c}$ Coy) 1844.}

Ref.-Synopsis Carb. Foss. Irel.

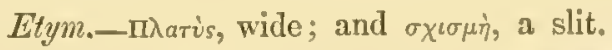

Gen. Char.-Obtusely conical, ventricose; spire short, obtuse, of few whorls; aperture very oblique, large, lunate, deeply indented by the preeding whorl, rounded anteally, narrow retrally; witl a very wide, shallow sinus in the middle of the outer lip, not forming a defined band, ani sometimes obsolete; no trace of inner lip; pillar thin, a little reflected; surface smooth, or only marked by the retrally waved lines of growth; umbilicus small, rounded, open.

This group of shells is very distinet from Pleurotomaria (with which they have been classed by most writers) in several important characters, of which the want of a definite mesial band is the most striking; they are also recognized by their obtuse form, smooth surface, without keels of any lind, the great width, obliquity, and shallowness of the sinus, as indicated by the lines of growth, which are sometimes even nearly straight, and the comparative thinness of their shell. They resemble the recent Janthine strongly in gencral shape and striation, but differ from them in the thickness of the shell, in having the mouth rounded anteally instead of being angulated, and not having the pillar lengthened as in that genus. From Stroparollus (with which many of them are grouped by d'Orbigny, \&c.) they differ by their fewer whorls, greater obliquity of outer lip, and total absence of inner lip. They seem most allied to Sigcuretus, and might probably with advantage be placed in the same family, instead of near Stomatia in the present one. The species appear confined to the carboniferous limestone.

\section{Platyscimisma glabrata (Phill. Sp.)}

Ref. and Syn.=Pleurotomaria glabrata Phill. Geol. York. t. 15. f. 28.

Desc.-Discoid, or obtusely lenticular, much depressed; profile of spire convex from the depression of the apex; tangents to the middle of the outline on each side give the apical angle of $130^{\prime \prime}$, which from the depression of the apex would be much larger in young specimens; spire very obtuse, of six gradually increasing, 
slightly convex whorls; body-whorl very obtusely rounded at the periphery; base moderately convex; mouth very oblique, considerably wider than high; umbilicus sniall, rounded; sutures slightly imbricated, inconspicuous, forming a fine impressed line, deepest towards the apex; surface very smooth. Diameter of large specimen two inches, proportional height ${ }_{100}^{57}$, licight of last whorl $\frac{4 i}{1 \%}$, from suture of last, to suture of penultimate whorl $\frac{16}{1 \ldots}$, width of mouth $\frac{65}{100}$, width of umbilicus $\frac{18}{100}$.

It is almost impossible to detect the lines of growth of this species, the surface is so very smooth; they are, however, very oblique, and with a very faint backward wave at the periphery. M. de Koninck considers this species a mere variety of $P$.helicoides, but of the many specimens of both species which $I$ have examined none seem to be intermediate in apical angle.

P'osition and Locality.-Common in the lower carboniferous limestone of Kendal, Westmoreland. Several very small specimens (from one to four lines in diameter), apparently the young of this species, from the lower limestone of Lowick, Northumberland.

\section{Platyschisma helicoides (Son. Sp.)}

Ref. and Syn. = Ampullaria (and Globulus) helicoides Sow. Min. Con. t. 522. f. 2 (left-hand figure).

Desc.-Globose, profile of spire slightly convex; tangents to the penultimate whorl giving an apical angle varying from $87^{\circ}$ to $105^{\circ}$, very rarely the former, most usually $100^{\circ}$, the obtusely depressed apex not reaching to this angle; spire of six gently convex whorls; sutures very delicately marked simple lines; surface extremely smooth, polished; periphery very obtusely rounded; base very tumid, rounded; umbilicus small, rounded; mouth slightly longer than wide. Width of average specimen one inch two lines, proportional lheight $\frac{\mathrm{ks}}{\mathrm{viv}}$, height of last whorl $\frac{16}{100}$, from last to penultimate suture $\frac{22}{100}$, width of umbilicus about $\frac{20}{100}$.

From the extremely glabrous surface it is almost impossible to detect the lines of growth; the edge of the lip seems, however, to have been gently sigmoid and oblique. Our specimens do not shew the spiral striation said to mark the edge of the umbilicus, probably from the absence of the outer shell on that part.

Position and Locality.-Common in the impure lower carboniferous limestone of Lowick; not uncommon, of small size, in the carboniferous shale of Craige, near Kilmarnock.

\section{Platyschisira Jamest $\left(M^{c} C o y\right)$.}

Ref.-McCoy, Syn. Carb. Foss. Irel. t. 5. f. 20 (strix and tumidity of suture slightly too strong).

Desc.-Conical, very depressed when young, becoming more elevated and acute with age, the tip of the spire always remaining obtuse; apical angle $140^{\circ}$ at three lines in diameter, $100^{\circ}$ at five lines in diameter, and $95^{\circ}$ at the adult diameter of eight lines; spire of six flat, imbricating, gradually inereasing whorls, the edges of the sutures slightly thickened, and the lower part of each whorl slightly rounded obtusely into the sutural line; base flattened, sloping gradually to the small, rounded umbilicus; periphery obtusely rounded. Surface with very fine, oblique, obtuse, unerual, inconspicuous lines of growth, having a slightly sigmoidal flexure, indicating a convexity in the outer lip at the upper or posterior end, and a sliallow backward wave at the circunference of the body-whorl seen just above the sutures of the spire. Diameter of adult specimen eight lines, proportional height of the same $\frac{85}{117 i}$, height of mouth $\frac{47}{1 \times n}$, distance between last and penultimate sutures $\frac{25}{1+m}$, width of mouth ivo, width of umbilicus $\frac{2 n}{100}$; ordinary sized young specimens five lines in diameter lave a proportional height of only $\frac{60}{100}$.

This species is remarkable for the great and regularly progressive difference of the apical angle with the age or size of the individual.

Position and Locality.-Common in the lower carboniferous limestone of Kendal; in the carboniferous limestone of Malham Moor. 


\section{Platyscimsma ovoinea (Phill. Sp.)}

Ref. and Syn. = Pleurotomaria oroidea Phill, Geol. York. Vol. II. t.15.f. 27.

Desc._Obliquely subovate; base subtruncate, convex, very obtusely rounded into the small umbilicus; spire of about five very rapidly enlarging, imbricating, only slightly convex whorls; the sutures very slightly indented; apical angle $100^{\circ}$; surface very smooth; mouth elongate ovate. Width of small specimen eleven lines, proportional height $\frac{80}{100}$, height of mouth and last whorl $\frac{70}{100}$, between last and penultimate sutures $\frac{10}{100}$, width of mouth $\frac{47}{100}$, width of umbilicus $\frac{23}{100}$.

Like most of the other species of Platyschisma the surface is so extremely smooth that it is almost impossible to detect the lines of growth; when seen, however, they are in accordance with the very oblique edge of the mouth, much inclined obliquely, and with a slight shallow sinus, corresponding with the most prominent part of the surface near the base. This is considered a variety of the $P$. helicoides by M. de Koninck, but, as far as I have seen, I agree with Prof. Phillips in thinking them distinct; that species being globose, the middle of the body-whorl being the most convex portion, the whorls of the spire are convex in the middle, and consequently the sutures form distinct re-entering angles, much indenting the profile. In the present species, on the contrary, the general form is more conoidal; the whorls flattened, or only slightly convex, the sutures imbricating, and the most prominent part of the body-whorl close to the base.

Position and Locality.-Rare in the lower carboniferous limestone of Poolwash, Isle of Man.

\section{Platyschisila tiara (Som. Sp.)}

Ref. and Syn. = Turbo tiara Sow. Min. Con. t. 551. f. 1.; Phill. Geol. York. t. 13. f. 9.

Desc.-Globose, conoidal, apical angle about $95^{\circ}$ (but cannot be given with certainty); turreted spire of about six or seven gradually-increasing whorls; whorls very tumid towards the sutures, which are thus rendered broadly canaliculate, the most tumid sutural portion of the whorls being crowned by a row of large, obtuse, obliquelyelongate nodules, extending with a slight forward direction rather more than half-way across the whorls of the spire, and a proportional distance on those of the body-whorl (about fourteen nodules on half a whorl at two inches and a half in diameter; about eleven in the same space at one inch and a-half in diameter); base of body-whorl flattened, moderately convex; umbilicus deep, rounded; space between the coronated sutural edge and the periphery and the corresponding part of the spiral whorls moderately convex and sloping outwards. Surface smooth and even below the nodules. Diameter two and a half inches, proportional height $\frac{80}{1 n 0}$, height of mouth $\frac{55}{100}$, width of mouth about the same, diameter of umbilicus ${ }_{j 00}^{25}$, height of penultimate whorl $\frac{83}{100}$.

From the structure of the mouth, the outer lip, umbilicus, and smooth shell, I incline to place this species in the genus Platyschisma, to which it is certainly more allied than to Turbo. The large nodules are not solid as in Turbo, but are merely modelled by an inflexion of the shell.

Position and Locality.-Rare in the lower carboniferous limestone of Kendal, Westmoreland.

\section{Genus. TURBO. See page 295.}

\section{Turbo? biserialis (Phill. Sp.)}

Ref. and Syn. = Turbo biserialis Phill. + T. semisulcatus Phill. Geol. York. Vol. II. t. 13. f. 10, 11. $=$ Litorina biserialis de Kon. Anim. Foss. Bel. t. 40, f. 6 .

Desc.-Ovato-conic; apical angle about $70^{\circ}$; spire of four gradually increasing, moderately convex whorls, slightly flattened in the middle; sloping rather rapidly to the sutures, which are sharply marked; base of bodywhorl abruptly rounded; a row of strong, subequal, compressed, obliquely elongate tubereles (about fourteen to each whorl) on the upper or sutural edge of the whorls, those of the spire extending rather more than half way across the space between the sutures; faint extensions from those of the body-whorl rise abruptly on the most convex part of the base into a second row of tubercles, similar to those near the sutures; surface with incon- 
spicuous oblique lines of growth; mouth longitudinally ovate; columella thickened, flattened; no umbilicus. Length of small specimens four and a half lines, proportional width $\frac{80}{1 v 0}$, length of last whorl, or mouth, ${ }_{100}^{20}$, space between the last and penultimate sutures $\frac{19}{500}$, width of mouth $\frac{55}{100}$.

Occasionally, as $M$. de Koninck remarks, the two rows of tubercles on the body-whorl are connected by tolerably distinct ribs, and sometimes the anterior row of tubercles disappears, leaving only the row round the sutures, forming the variety called Turbo semisulcatus by Phillips. I lave not yct clearly' seen the columella.

Position and Locality.-Very rare in the lower carboniferous limestone of Derbyshire.

\section{Turbo? helicinus (Schlot. Sp.)}

Ref. and Syn. $=$ Trochilites helicinus Schlot. Petrefactenk. p. 161. = T. minutus Brown, Manch. Geol. Trans. Vol. I. t. 6. f. 4, $5 .=T$. Mleyeri Münst. Goldf. Pet. t. 192. f. 14. (an elongate variety has the MS. name T. bistriata Münster, in his collection) =T. Mancuniensis Brown, Manch. Geol. Trans. Vol. I. t. 6. f. 1, 2,3. King, Perm. Foss. t. 16. f. 19, 20. + (T. Thompsonianus King, Perm. Foss. t. 16. f. 23, 24. = T. Tunstal. lensis Howse, Trans. Tyn. Nat. F. Club, Vol. I. p. 240) + T. Taylorianus King, Perm. Foss. t. 16. f. 25, 26; T. Helicinus (Schlot.) King, Perm. Foss. t. 16. f. 21, 22.

Desc.-Ovate; spire short, conic, varying in acuteness; apical angle varying from $60^{\circ}$ to $86^{\circ}$ (most usually the latter); whorls, about five, tumid, rounded, rapidly enlarging ; body-whorl tumid, and rounded below into a very small, elongate narrow umbilicus, immediately behind the pillar-lip, which is thickened and slightly flattened in the anterior half, thinner or obsolete behind; mouth very broad, ovate; sutures deeply channelled. Surface with strong spiral ridges, three on each of the spiral whorls, separated by broad, subequal, flattened or concave spaces; the upper ridge much smaller than the other two; body-whorl with eight or nine strong spiral ridges, the two or three on the most prominent part of the whorl largest, gradually diminishing on the base; the spaces between the ridges marked with obliquely longitudinal fine plicre of growth. Length and width of average specimen three and a half lines, height of mouth $\frac{15}{100}$, height of penultimate whorl $\frac{39}{1100}$, width of mouth $\frac{50}{110}$.

In this species the spiral whorls often seem to have only two keels, from the small upper keel becoming obscure; in partially decomposed specimens, such as that figured by Goldfuss, the spiral ridges on the base become obseure. I have seen in some specimens traces of a small spiral ridge between each of the larger pairs. Specimens named Turbo DIancunionsis by Prof. King, and sent to the Cambridge Collection, agree exactly with the original description, but differ in no respect from the $T$. helicina.

Position and Locality.-Common in the Permian magnesian limestone of Humbleton.

\section{Genus. S'TRAPAROLLUS (Montf.) 1810.}

Syn. $<$ Euomphalus Sow. 1814< Cirrus Sow.

Gen. Char.-Discoid, depresso-conic, generally smooth or transversely striated; umbilicus very wide, exposing the whorls, which are either rounded or angulated; mouth indented by the penultimate whorl; peritreme simple, thin, most so on the left side.

M. de Koninck and M. d'Orbigny have drawn attention to de Montfort's name Straparollus, having the priority over Sowerby's Euomphalus; and from his description and figure there ean be no doubt of his genus embracing some of Sowerby's types of Euomphalus and Cirrus; I have retained the name Euomplatus for certain Delplinula-like species, with thick, circular, entire peritremes, and confined Straparallus to those with the thin peritreme and indented mouth, \&c., as in de Montfort's original type the S. Dionysii. They most nearly resemble Solarium, but have neither the strongly crenulated edge to the umbilicus, nor the notch in the anterior edge of the lip which produces it. 


\title{
Straparolius acutus (Sow. Sp.)
}

\author{
Ref. and Syn.=Cirrus acutus Sow Min. Con. t. 141. f. 1; Phill. Geol. York. Vol. II. t. 13. f. 12 ; \\ ? Cirmes tabulatus (Phill.) Sow. Min. Con. t. 638, f. 2.
}

Desc.-Conical, spire of seven to eight whorls; apex obtuse; apical angle $\frac{85}{100}$ to $\frac{10 n}{101}$; whorls of the spire divided nearly in the middle by an angulation or keel, which is rectangular, the portion of shell above it flat or concave on the body-whorl, but becoming obtuse on the penultimate, the surface below it convex, the angulation gradually disappearing on the whorls near the apex, which are simply rounded; surface below the keel nearly flat, except on the periphery of the body-whorl, which with the under side is very convex, and without angulation; umbilicus deep, conical, with a rounded margin. Surface marked with direct, slightly irregular lines of growth. Diameter one inch seven lines, proportional width of last whorl $\frac{35}{100}$, width of penultimate whorl $\frac{15}{100}$, total height $\frac{93}{100}$ to $\frac{63}{100}$, height of last whorl $\frac{40}{100}$ to $\frac{35}{100}$, diameter of umbilicus $\frac{40}{100}$ to $\frac{65}{100}$.

This species seems closely allied to the $S$. tabulatus, almost the only difference being the rather more numerous whorls, smaller size, and above all the much higher spire, owing to the comparatively small apical angle. The above quoted figure of $S$. tabulatus, from the Mineral Conchology, seems undoubtedly to belong to the present species, the two lower fragments on the same plate belonging to my S. crotalostomus. Some specimens shew a few obscure, spiral, obtuse striae on the periphery. The depressed specimens in which the angulation even of the body-whorl is sometimes obscure, seem to merge imperceptibly into the approximate varieties of the $S$. Dionysii, and from the great width of the umbilicus apparently include my Euomplealus anguis (Synop. Carb. Foss. t. 3. f. 11), which merges imperceptibly into such wide varieties of S. Dionysii as de Koninck figures (Anim. Foss. Bel. t. 24.f. 1 and 2); all these variations are exhibited by the specimens in the Cambridge collection.

Position and Lacality.-Not uncommon in the carboniferous limestone of Derbyshire; in the black lower carboniferous limestone of Isle of Man; in lower carboniferous limestone of Kendal, Westmoreland.

\section{Straparollus? calyx (Phill. Sp.)}

Ref. and Syn。 = Euomphalus calyx Phill. Geol. York. Vol. II. t. 13. f. 3 ; Min. Con. t. 633. f. 8, 9, 10.

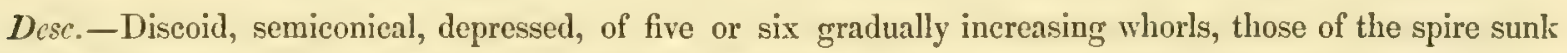
rather below the level of the outer whorl; periphery very broad, sloping outwards and forwards with slight convexity, bounded by nearly equal, narrow, obtuse, prominent keels, that of the under side bounding the umbilicus, and marking the greatest diameter of the shell; on the upper side the shell slopes at about $80^{\circ}$, with slight concavity from the keel to the simple sutures, the keel being a little outside the middle on the turns of the spire; umbilicus very wide, steep, conical, sloping with little convexity from the keel to the centre, the sutures coinciding with the leel on the spiral turns. Surface crossed by nearly direct, irregular, obscure lines of growth; mouth subtriangular, the lower side longer than the upper. Greatest diameter and width of umbilicus one inch six lines, proportional diameter across the upper keels $\frac{80}{160}$, proportional width of last whorl $\frac{32}{100}$, width of penultimate whorl $\frac{15}{100}$, depth of last whorl $\frac{50}{100}$.

The great width of the steep conoidal umbilicus, and its bounding keel forming the greatest diameter of the shell, and the consequent regular outward slope of the periphery, and greater proportional depth of the last whorl, separate this species easily from the $S$. catillus. I have never clearly seen the inner lip of this species, but it is figured by Sowerby as continuous.

Position and Locality.-Rare in the carboniferous limestone of Derbyshire.

\section{Straparollus carbonarius (Sow. Sp.)}

Ref. and Syn. = Euomphalus carbonarius Sow. Min. Con. t. 633. f. 4 to 7. = Euomphalus quadratus $\mathrm{M}^{\circ} \mathrm{Coy}$, Synop. Carb. Foss. Irel, t. 5. f. 22.

Desc.-Discoid, depressed, of four or five rapidly enlarging whorls; spire depressed below the level of the body-whorl; whorls quadrate, flattened above and below; periphery bounded by two equally strong, prominent

$$
3 \mathrm{z} 2
$$


keels, the under or left one of greatest diameter, so that the periphery slopes slightly forwards and outwards, being very convex in the middle, becoming concave near the bounding keel on each side; umbilicus not bounded by the lower keel, but by the narrow, steep, inner edge of the flattened body-whorl, exposing all the turns of the spire; mouth subquadrate or trapezoidal from the slight convergence of the upper and lower edges. Surface crossed by rather strong, minute, transverse lines of growth. Average diameter five or six lines, proportional diameter of last whorl ${ }_{\mathrm{i} 00}^{30}$, height of do. $\frac{35}{100}$, width of umbilicus $\frac{55}{100}$.

As this species grows large, for instance eight or nine lines in diameter, the whorls become more nearly trigonal in section, from the under side sloping rather more to the umbilicus than in the more ordinary specimens, making some approach to Straparollus catillus, in appearance, or to S. calyx, on a very small scale; but it is distinguished from the young of the former by the greatest width being across the edges of the lower keel, and from the latter it differs in its greater depression or less height of the body-whorl.

Position and Locality.-Rare in the black carboniferous limestone of Derbyshire.

\section{Straparollus? catillus (Mart. Sp.)}

\section{Ref. and Syn.=Helicites catillus Martin, Pet. Derb. t. 7.f. 1 and 2.= Euomphalus id. Sow. Min. Con.} t. 45. f. 3 and 4 .

Desc.-Discoid, depressed, of five to six whorls, spire sunk considerably below the level of last whorl; periphery very convex a little below the middle, becoming slightly concave near the two strong, nearly equal, narrow, prominent, bounding ridges; umbilicus very wide, the sutures nearly coinciding with the bounding keel of the spiral turns; surface within the keel very slightly convex; surface from the upper keel sloping rapidly with slight concavity to the simple sutures; keel rather outside the middle on the spiral whorls; mouth subtrigonal, upper and lower edges nearly equal. Diameter about one inch six lines, proportional width of umbilicus from bounding ridge $\frac{80}{100}$, diameter across upper ridge $\frac{15}{109}$, width of last whorl $\frac{35}{100}$, of penultimate whorl $\frac{18}{100}$, depth of mouth $\frac{45}{1100}$. Surface crossed by slightly sigmoidal, slightly oblique, lines of growth, obscurely decussated on the periphery, and within the edge of the umbilicus by obsolete spiral strix.

This species is intermediate between $S$. calyx and $S$. pentangulatus; it differs from $S$. caly $x$ in the less height of the body-whorl, and in the greater convexity of the periphery, and the keel forming the edge of the umbilicus being considerably less than the greatest diameter of the shell, while from the S. pentangulutus it differs in the sharp angular ridge bounding the umbilicus, being at least as marked as that on the upper side.

Position and Locality.-Rare in the lower carboniferous limestone of Kendal, Westmoreland, and Lowick, Northumberland.

\section{Straparollus costellatus $\left(M^{\circ} C o y\right)$. Pl. 3. H. fig. 3. \\ Ref.-MI'Coy, Ann. Nat. Hist. 2nd Series, Vol. XII.}

Desc.-Discoidal, depressed, very obtusely conic; spire of rather more than six very gradually increasing whorls, each slightly convex above, strongly indenting the suture, which is an impressed sharp line; apical angle $110^{\circ}$ (from the obtuseness of the apex its angle would be larger in very young specimens); umbilicus very wide, rounded, half exposing all the whorls; base of body-whorl very convex, rounded, with a very obscure angulation at the edge of the umbilicus; periphery narrowed, obtusely rounded; upper surface of the whorls marked with sharp, slightly sigmoid, rather unequal ridges, arehed obliquely backwards, becoming abruptly very much finer and more numerous on passing the circumference to the base (ten of the upper ridges in two lines on the body-whorl), each separated, by a sulcus, about its own diameter from the next. Diameter ten lines,

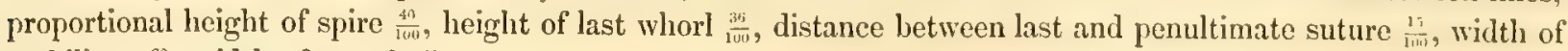
umbilicus $\frac{60}{100}$, width of mouth $\frac{40}{1 \text { fin }}$.

This species is distinguished from its congeners by the beautifully sharp costellation, or transverse sculpturing of the whorls of the spire, which abruptly ceases on the base of the body-whorl, or becomes there confounded with the lines of growth. The inner lip is complete, but thin, as in other species of Straparollus, distinguishing them from Platyschisma. 
Position and Locality.-Rare in the lower carboniferous limestone of Lowick, Northumberland.

Explanation of Figures.-PI. 3. H. fig. 3, natural size, seen from above; fig. $3 a$, profile; fig. $3 b$, portion of surface magnified two diameters; fig. $3 c$, viewed from below.

\section{Straparollus? crotalostomus $\left(M^{c}\right.$ Coy).}

Ref. and Syn.= Euomphalus id. $\mathbf{M}^{\circ}$ Coy, Synop. Carb. Foss. Irel. t. 7. f. 4. (very small specimen).

Desc.-Discoid, very much depressed; spire originally of about six whorls (rarely more than one and half preserved); spire varying from the very slight elevation of $190^{\circ}$ to depressed below the level of the body-whorl; upper portion of each turn obscurely flattened, the flattened or slightly convex portion bounded by a very obtuse, obscure angulation, placed at the outer third of the upper aspect of the whorls; periphery very convex in the middle, under side broadly convex; umbilicus completely exposing all the turns, its margin convex, undefined: mouth transversely oval, scarcely, if at all, indented by the preceding whorls ; edge dilated, trumpet-shaped, with a shallow sinus, coinciding with the obscure angulation bounding the flattened upper part of the whorls. Surface at all ages crossed by exceedingly coarse, rugged, irregular imbrications of growth (remains of the dilated lip). Average diameter eight inches, proportional diameter of last whorl ${ }_{1 \text { ivi }}^{33}$, diameter of penultimate whorl ${ }_{1 v 0}^{20}$, diameter of umbilicus $\frac{60}{100}$, height of last whorl $\frac{28}{100}$.

This species is distinguished from the S. tabulatıs, to which it is most allied, by its great size, the depression of its spire, the very obscure keel, and its being placed so much nearer the outer margin of the whorls, the greater depression of the whorls, and consequently wider transversely oval mouth, and above all, by the extremo rugosity of its surface, (which in specimens of even three or four inches in diameter almost equals that of the Silurian Euomphalus discors, ) which is produced by the edges of the peculiarly dilated margin of the mouth: this character is represented in the lower figure of t. 638 of the Mineral Conchology under the name Cirmus tabulatus, being confounded with the upper figure representing a large example of that comparatively smooth, high-spired, and strongly-angulated species. As from the transverse septation common in the terminal whorls of this genus so large a species as this would rarely lave one, or one and half turns perfect, the dealers frequently adapt the spires of three or four different specimens of various ages, to render the shell apparently complete, often terminating the centre of the spire with a specimen of $S$. tabulatus, which may lave deceived Mr Sorverby, and which would have deceived me had I not known the species before.

Position and Locality.-Not uncommon in the lower carboniferous limestone of Kendal, Westmoreland.

\section{Straparollus dionysil (de Montf.)}

Ref. and Syn.-De Montf. Conch. Syst. Vol. II. p. 17t=Cirms rotundatus Sow. Min. Con. t. 429. f. 1 and 2; Phill. Geol. York. Vol. II. t. 13. f. 15.

Desc.-Conical, spire of six or seven gradually increasing whorls, varying greatly in height; apical angle varying from $75^{\circ}$ to $120^{\circ}$, usually simply rounded below, and gently convex above and on the turns of the spire, with the sutures sharply impressed; sometimes a very slight flattening observed on the sutural third of the bodywhorl, and occasionally the sutures slightly adpressed; mouth obliquely oval, nearly circular; umbilicus very large with a rounded margin, exposing all the whorls. Surface marked with slightly irregular, slightly oblique, obsolete lines of growth. Average diameter one inch" three lines, proportional width of last whorl $\frac{25}{1 m}$, total

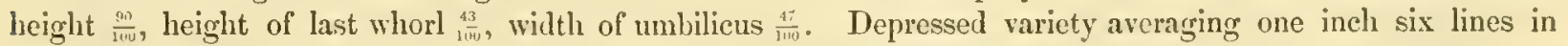
diameter, proportional width of last whorl $\frac{33}{100}$, total height $\frac{f 1}{100}$, height of last whorl $\frac{35}{100}$, width of umbilicus $\frac{47}{100}$.

Under the head of $S$. acutus I have made some observations on the gradual passage apparently indicated by many specimens between that species and the present, and also the approximation of both forms to that which I figured under the name $E$. anguis. A variety with the base slightly flattened oceurs in the Lowick limestone. All the varieties of form have occasional examples shewing a few obtuse obscure spiral lines.

Position and Locality.-Very common in the lower carboniferous limestone of Kendal, Westmoreland; not uncommon in that of Derbyshire; rare in the dark lower limestone of Lowick, Northumberland; in the red carboniferous limestone of Closeburn, Dumfriesshire; in the red siliceous limestone of Breedon, Leicestershire. 


\title{
Straparollus nodosus (Son. Sp.)
}

\author{
Ref. and Syn. = Euomphalus nodosus Sow. Min. Con. t. 46.
}

Desc.-Discoid, of five to six gradually increasing whorls, the spire slightly depressed below the body-whorl, upper surface with a strong prominent keel, which runs along nearly in the middle of the spiral whorls, and from which the surface slopes to the simple suture; periphery and under side of the whorls very convex, regularly rounded, without keel; a row of very large, obtuse, irregular tubercles or nodular swellings runs along a little within the middle of the under aspect of the body-whorl, nearly concealed by the suture on the whorls of the spire; these tubercles are irregularly unequal in size and shape, slightly lengthened cither longitudinally or transversely, about twelve to each turn. Surface with moderately strong, slightly oblique transverse lines of growth, becoming coarser on the under side at the edge of the umbilicus. Diameter of very large specimen three inches eight lines, proportional width of last turn $\frac{25}{110}$, height of last turn $\frac{30}{100}$, diameter across the margin of the upper keel ${ }_{100}^{85}$, across the row of nodules on the under side $\frac{75}{100}$.

From the great size, small number, and irregular nodular character of the tubercles on the under side, and want of connecting ridge between them, I think this species perfectly distinct from all the varieties of $S_{\text {. }}$ pugilis from which of course it obviously differs in the entire absence of tubercles on the upper side.

Position and Locality.-One very large imperfect specimen of this rare species is in the collection from the lower carboniferous limestone of Kendal.

\section{Straparollus pentangulatus (Sow. Sp.)}

Ref. and Syn. = Euomphalus pentangulatus Sow. Min. Con. t. 45. f. 1, 2. + Eumphalus Bronni Portk. Geol. Rep.p. 417.

Desc.-Discoid, depressed, of five or six gradually increasing whorls, those of the spire most usually sunk below the level of the body-whorl, but occasionally slightly raised above it; middle of the periphery very convex, from whence the surface slopes with little convexity to a prominent keel a little outside the middle of the upper surface on all the whorls, from whence the surface slopes with often a slight concavity (at an angle of about $110^{\circ}$ ) to the suture which is simple; on the under side the surface slopes with slight convexity from the periphery to a very obtusely rounded keel nearly in the middle of the under side, from whence the surface cxtends into the umbilicus, with considerable convexity; umbilicus very wide, exposing the inner half of all the whorls; mouth very slightly indented by the preceding whorl, giving an obscure pentangularity to the section; inner lip very thin, or interrupted in the middle. Surface crossed with fine obtuse direct or slightly oblique lines of growth, sometimes decussated on the middle of the periphery by a few obtuse, obscure spiral strix. Diameter two inches, pro-

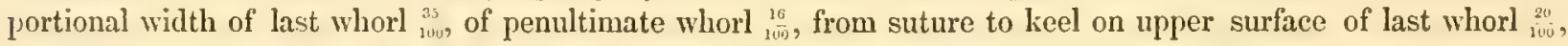
height of last whorl $\frac{37}{100}$, width of umbilicus (measured from the inferior keel) $\frac{65}{200}$.

The variety in which the spire is a little elevated above the body-whorl has received the name E. Bronni from Col. Portlock, but merges in the most imperceptible manner into the more ordinary variety in which the middle of the spire is depressed. In very young specimens the inner lip is continuous, although very much thinner than the other parts of the peritreme. There is no sinus in the lines of growth, although they are slightly thickened in passing over the upper keel. The transverse septa cutting off the old posterior whorls are very strongly marked in this species, leaving only one whorl and half to be tenanted by the animal.

Position and Locality.-Common in the lower carboniferous limestone of Derbyshire and Isle of Man; several internal casts probably of this species in the dark lower carboniferous limestone of Lowick, Northumberland.

\section{Straparollus pileopsideus (Phill. Sp.)}

Ref. and Syn. = Euomphatus id. Phill. Geol. York. Vol. II. t. 13. f. 6. = E. clausus Sow. Min. Con. t. 633. f. 1. Desc.-Discoid, of about five gradually increasing, much cmbracing whorls; spire truneated, all the whorls rising to the level of the sutural edge of the last one; suture canaliculate with a tumid margin, periphery very 
convex, leaving a slight concavity between it and the tumid margin to the channelled sutures; under side of bodywhorl convex; umbilicus scarcely exposing the inner whorls, deep with rounded margin; mouth very deeply indented by the preceding whorl. Surface marked with fine, nearly direct, transverse irregular lines of growth. Diameter nine lines, proportional height of spire and last whorl $\frac{47}{100}$, width of mouth $\frac{39}{100}$, width of penultimate whorl $\frac{15}{100}$, width of umbilicus $\frac{35}{100}$.

I can see no trace of inner lip in the specimen before me of this very distinct species.

Position and Locality.-Rare in the carboniferous limestone of Poolwash, Isle of Man.

\section{Straparollus pugilis (Phill. Sp.)}

Ref. and Syn. =Euomphalus id. + E. bifrons Phill. Geol. York. Vol. II. t. 13. f. 4; Sow. Min. Con. t. 621. f. 2 to 4 . and t. 633 . f. 2 .

Desc.-Discoid, spire depressed below the level of the body-whorl, of about five gradually increasing whorls: mouth vertically oval, middle of upper and under sides traversed by nearly equal obtuse keels, between which the periphery is very convex; upper ridge set with subequal, slightly compressed, blunt tubercles, strongest on the body-whorl, becoming obsolete on the central ones; about sixteen tubercles to each whorl; under keel bordering the umbilicus sometimes set with tubercles, resembling those of the upper side in size and number (var. pugilis); on other specimens the tubercles on the under keel are nearly or quite obsolete (var. bifrons); umbilicus very wide, exposing the keel on the inner whorl. Surface faintly crossed by minute direct lines of growth. Average diameter one inch six lines, proportional width of last whorl $\frac{31}{i v w}$, depth of last whorl $\frac{25}{100}$, diameter of umbilieus $\frac{80}{20}$, diameter across upper lieel $\frac{80}{100}$.

Mr Sowerby has clearly shewn that the two species, E. bifrons and E. pugilis of Phillips, depending on whether the upper keel only, or the upper and under are tuberculated, are only varieties of one species. The Euomphalus tuberculatus of de Koninck differs in having the spire a little elevated, and rather smaller and more numerous tubercles (about twenty to each whorl), the under side like the present species being sometimes tuberculated and sometimes plain.

Position and Locality.- Not uncommon in the carboniferous limestone of Derbyshire.

\section{Straparollus tabulatus (Phill. Sp.)}

Ref. and Syn. = Cirrus tabulatus Phill. Geol. York. Vol. II. t. 13. f. 7; Sow. Min. Con. t. 63S. f. 1. (not the other figures.)

Desc.-Depresso-conical; apieal angle about $130^{\circ}$; spire of about six whorls, rapidly enlarging so that a line from the apex to the edge of the body-whorl will not touch the other whorls of the spire; upper portion of each whorl flat, nearly horizontal, (slightly inclined inwards and downwards on the body-whorl, and slightly outwards and downwards on the whorls of the spire, bounded by an obtuse, strongly-marked keel, very slightly outside the middle of the spiral whorls; outside of which the whorls are flattened, and sloping downwards and outwards on the spire, and on the body-whorl till near the base, where they are abruptly rounded into the umbilicus, making the periphery and under side very convex; mouth oval, obliquely transverse. Surface crossed by moderately strong, slightly sigmoid lines of growth; substance of the shell very thick. Diameter of small specimen two inches eight lines, proportional diameter across the lieel $\frac{83}{100}$, width of last whorl $\frac{33}{100}$, depth of ditto $\frac{33}{100}$, width of penultimate whorl $\frac{16}{100}$, height of spire $\frac{55}{100}$, diameter of umbilicus about $\frac{55}{100}$.

Prof. Phillips's figure has an unfortunate sharpness in the lower line, which gives the base the appearance of being carinated, and is probably the reason why Prof. de Koninck has figured apparently the S. calyx as this species, although in his specimen the spire was sunk below the level of the body-whorl. Mr Sowerby on the plate above cited has united to this species my $S$. crotalostomus, which however is a very distinct, extremely large rugged species, with depressed spire; a mistake which may have been produced (as he mentions Kendal) by some specimens I have seen made for sale by the dealers there, where the last whorls of S. crotalostomus have specimens 
of S. tabulatus cut and neatly cemented to their centres to form a spire. Sinall specimens are very analogous to some of the varieties of $S$. pentangulatus with elevated spire, but seem distinct by the outward sloping of the upper tabulated portion of the whorls at that age.

Position and Locality.-Common in the dark lower carboniferous limestone of Kendal, Westmoreland; not uncommon in that of Lowick, Northumberland.

\section{Genus. ENCYLIOMPHALUS. See page 301.}

\section{Encyliomphalus equalis (Som. Sp.)}

Ref. and Syn. = Planorbis id. Sow. Min. Con. t. 140. f. 1 ; ? = Porcellia lovigata l'Eveill. Mém. de la Soc. Géol. de France, Vol. II. t. 2. f. 12 and 13; ? = Bellerophon lavigatus d'Orb. Monog. Bell. t. 6. f. 24 and 25.

Desc.-Discoid, of five or six slightly disconnected whorls; spire sunk below the level of the last turn; mouth circular, entire; whorls almost perfectly cylindrical, an almost imperceptible flattening on the upper third of the body-whorl; surface crossed by direct, minute strixe of growth. Diameter one inch three lines, proportional width of last whorl $\frac{30}{100}$, space between last and penultimate whorl $\frac{5}{100}$, depth of last whorl $\frac{35}{100}$.

The distance separating the whorls of this species is so small that it seems to have been overlooked by the various authors alluding to it.

Position and Locality.-Rare in the carboniferous limestone of Isle of Man; in the carboniferous limestone of Kendal, Westmoreland.

\section{Encyliomphalus cristatus (Phill. $S p$.)}

\section{Ref. and Syn.= Euomphahus id. Phill. Geol. York. Vol. II. t. 13. f. 5. = Phanerotinus id. Sow. Min. Con.} t. 624 . f. 1 .

Desc.-Spire of about three very widely disjoined whorls, not raised as high as the edge of the basal whorl (rarely more than one and half turns preserved); under side of the volutions moderately and evenly convex; upper and outer aspects much more gibbous than the under, from an obtuse ridge between them; the outer aspect moderately inclined and smaller than the upper; the periphery obtusely angulated considerably below the middle, and giving off there in all the whorls a strong, obscurely double, largely-dentated crest, flattened in the plane of the volutions, the denticles seeming subalternate, triangular, about twice as long as the width of their base, the length nearly twice the diameter of the whorl from which they originate; section of each whorl slightly oblique, ovate (with the exception of the obscure angulation between the upper and outer aspects), the pointed portion corresponding with the crest at the periphery; shell thick, marked with strong imbrications of growth, arching forwards towards the crest on the under side, and backwards towards the obtuse keel, and then forwards to the crest on the upper side. Diameter of large specimen, excluding the crest, eight inches six lines, proportional width of last whorl ${ }_{j=0}^{27}$, distance between last and penultimate whorl $\frac{311}{100}$, diameter of penultimate whorl $\frac{7}{1011}$, depth of last whorl about $\frac{26}{100}$.

The spire of this species scarcely ever rises to the level of the obtuse keel near the middle of the upper aspect, from which the outer and upper aspects slope with moderate convexity. Very rarely more than one whorl is preserved in most specimens, from the tube after that length being divided by strong, transverse, imperforate septa, as in many other slender Gasteropods. The great size and the large double strong shelly keel of flat triangular denticles easily distinguish this species from all others. Mr Sowerby, in proposing the genus Phanerotinus for this shell, supposes Encyliomphalus to be less curved, and to differ besides in having a thinner shell; but the Encyliomplialus Scoticus (MCoy) has as thick a shell in proportion to its size, and there is no tangible generic difference in the amount of curvature.

Position and Locality.-Not very uncommon in the dark lower limestone of Kendal, Westmoreland. 


\section{Genus. NATICOPSIS $\left(M^{c} \mathrm{Coy}\right) 1844$. See page 301.}

Syn. = Naticodon de Ryckholt (1852).

The operculum (which I have seen several times) differs entirely from that of any of the family Naticidoc, and agrees with Ampulleriu in being concentric, and not spiral. A specimen of N. Phillipsi (M Coy) is in the British Museum, shewing the operculum with the laminx more distinct than in my old figure. Very recently (Mém. Acad. Roy. Bruxelles, 1852) M. de Ryckholt forms of these shells a genus which he names Naticodon, from the existence of a tooth on the internal face of the pillar-lip, which I have not as yet seen.

\section{Naticopsis ampliata (Phill. Sp.)}

Ref. and Syn. = Natica ampliata Phill. Geol. York. Vol. II. t. 14. f. 21 and 24; de Kon. Anim. Foss. Bel. t. 42. f. 2 .

Desc - Obliquely trigono-ovate, wider than long; spire and upper third of body-whorl flattened together, of two volutions, not strongly defined, very rapidly enlarging towards the mouth; base (or front) convex, narrowed conoidally; mouth very large, rotundato-trigonal; pillar-lip broad, callous, flat. Surface crossed by close, regular, equal, thread-like, obtuse stric (fifteen in two lines), crossed under the lens by microseopic spiral striæ; substance of the shell thick. Width of small specimen ten lines, proportional length $\frac{85}{10,1}$, length of mouth or last whorl $\frac{80}{100}$, width of mouth $\frac{75}{100}$, space between last and penultimate suture $\frac{15}{100}$.

The flattened spire, extremely wide mouth, and regular filiform striation, distinguish this species very readily from the others of the genus. The stric deserve the name of minute ribs from their regularity and distinetness even to the naked eye.

Pusition and Locality.-Not very uncommon in the carboniferous limestone of Kendal; rare in the carboniferous sandstone with Lepidodendra at Shap Toll-bar.

\section{Naticopsis plicistria (Phill. Sp.)}

Ref. and Syn.=Natica plicistria Phill. Geol. York. Vol. II. t. 14. f. 25; Portk. Geol. Rep. t. 31. f. 6, 7. $?+N$. elongata Phill. Geol. York. t. 14. f. 28.

Desc.-Ovate, globose when young, obliquely elongate when old; apical angle about $105^{\circ}$ to $115^{\circ}$, but cannot be taken well from the convexity of the outline; spire very short, obtuse, of two and a half gently convex whorls, rather abruptly rounded towards the upper sutures, which latter are sometimes strongly defined and nearly rectangular, sometimes strongly imbrieating; body-whorl evenly convex in young specimens, but with age gradually acquiring a wide, shallow concavity nearly along the middle, above which the surface is obtusely convex to the imbricating (or occasionally sub-canaliculate) sutures, and below which it arches rapidly to the very convex base; pillar-lip thick, callous, flattened, and slightly concave in front, sharp-edged, arched gradually into the front margin; outer lip thin except at its posterior junction with the suture; substance of the shell extremely thick. Surface with fine irregular lines of growth, abruptly changing near the sutures into fine, sharp, equal, obliquely-arched, thread-like strix, separated by rather wider coneave sulci, forming a plicistriate border about two lines wide on the body-whorl, and extending over rather more than half the space between the sutures on those of the spire (fourteen or fifteen in a space of two lines). Length of adult specimen three inclies, proportional width $\frac{75}{1 \cdots \cdots}$, length of mouth $\frac{70}{1 \cdots}$, space between last and penultimate sutures $\frac{\frac{25}{1 \cdots}}{1 \cdots}$. Proportions of specimens one inch long, width $\frac{85}{1 \cdot v}$, length of mouth $\frac{\pi 6}{10}$, space between last and penultimate sutures $\frac{15}{100}$.

The colouring is often preserved in this species, and shews as two or more rows of large, oblong, brown and whitish blotches. From the great thickness of the shell the easts seem umbilicated, and have the whorls separated by deeply excavated sutures: the internal casts are often marked with more regular (though faint and obtuse) strix than the exterior. I agree with $\mathrm{M}$. de Koninck in thinking the $N$. elongatu may be referred [FASC.III.] 
to this species, as it lengthens much with age, but his figure and description do not seem to agree with it. Col. Portlock's figure 6 is a good representation of the middle age when the body-whorl is becoming concave: his figure 7 is of a younger specimen.

\title{
Naticopsis spirata (Sow. Sp.)
}

\author{
Ref. and Syn. = Nerita spirata Sow. Min. Con. t. 463. f. 1, 2.
}

Desc.-Semiglobose, of three very rapidly enlarging whorls; turns of the spire small, slender, rounded, prominent; apical angle about $130^{\circ}$; body-whorl very convex in the middle, flattened or widely concave on the upper or sutural quarter in old specimens; mouth very large; columella much arehed, narrow; lines of growth fine, irregular, imbricating, inconspicuous, not much stronger near the sutures than elsewhere. Length and

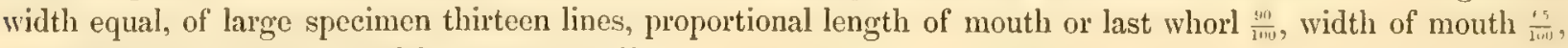
space between last and penultimate sutures $\frac{18}{100}$.

The little, sharply-defined, prominent spire of tumid whorls, and the surface being nearly smooth from the inconspicuous strice of growth, as well as less expanded mouth, separate this species from $N$. ampliatu, to which it is most allied. The strie are not connected into sharp regular plice near the suture, as in several species of the genus, and Sowerby's words do not bear that interpretation, as subsequent writers seem to think: he says. "the lines of growth are sometimes rather conspieuous on the flat part of the whorls, in other parts they are very slight;" which is a proper statement of the characters, as most usually the stria are quite evanescent on the sutural parts of the whorls.

Pusition and Locality.-Rare in the lower carboniferous limestone of Derbyshire; not very uncommon in the lower carboniferous limestone of the Isle of Man.

\section{Naticonsis variata (Phill. Sp.)}

\author{
Ref. and Syn. = Natica variata Phill. Geol. York. Vol. II. t. 14. f. 26, 27.
}

Desc.--Obliquely oval, globose; spire very small, slightly pointed, of two and a half gently convex whorls: sutures slightly concave and imbricating; surface with extremely minute, (fifteen or sixteen in one line), slightly undulating, spiral strix, obscure on the spire; crossed by slightly larger, moderately oblique lines of growth. deepening near the sutures into sharp, regular, slightly coarser plice; pillar-lip as in the generic character. Length and width of large specimen seven lines, proportional length of last whorl $\frac{\mathrm{kz}}{\mathrm{lum}}$, space between last and penultimate suture $\frac{15}{100}$.

This is a very rare species, much resembling the young of $N$. plicistria, but with the plicistriation of the sutures finer, and easily distinguished from it and all other species by the close, minute, spiral lineation of the surface. This spiral striation is supposed by $\mathbf{M}$. de Koninck to be a deceptive appearance due to a spathose condition of the shell; but I agree with Mr Phillips that it is a true sculpturing, and further, I suspect that the large shell figured and described under this name by M. de Koninck is some different species, both from its great size, more numerous whorls, and want of the characteristic lineation.

Position and Locality.-Two well-marked specimens from the dark carboniferous limestone of Lowick, Northumberland.

\section{Genus. LOXONEMA (Phill.)}

Gen. Char.-Shell narrow, very long, spire of very numerous convex whorls, apex simply pointed; bodywhorl small; aperture elongate, oblong, indented by the body-whorl, much longer than wide, prolonged in front into a rounded lohe; lips disunited behind; onter lip oblique, with a rounded backward sinus at the sutures, conver in the middle; columella slightly thickened; no umbilicus; surface of whorls crossed by close, oblique, inversely sigmoid, thread-like ridges or lines of growtl. 
The anterior prolongation of the mouth, and deeply sinuate lip, as well as the apex being simply in the line of the other turns, distinguish this Palæozoic genus from Chemitzia. It should be only considered, I think, as a sulggenus of Lacruchilus, as the thread-like strength of the strie and more elongate form are both so liable to variation that it is difficult to decide in which of the groups to place several species.

\section{Loxonema Fasciata (King).}

Ref. and Syn.-King, Perm. Foss. t. 16. f. $30 ; ?+L$. Geinitziana, id, ib. f. 31.

Desc.-Very elongate, conic, of ten very gradually increasing whorls, separated by deep simple sutures: each whorl strongly convex, most so a little below the middle; apical angle about $255^{\circ}$; surface smooth, or with very faint inversely sigmoidal lines of growth under the lens. Length of average specimen four lines, proportional width $\frac{40}{100}$.

The authentic specimen of this species (reccived from Prof. King), which I describe, agrees so much more precisely with his $L$. Geinitzicne, that I cannot help thinking them the same. The present species receives its name from some coloured spiral and transverse bands which I have not seen.

Position and Locality.-Not uncommon in the Permian limestone of Humbleton.

\section{Loxonema IMPENdens $\left(M{ }^{c} \mathrm{Coy}\right)$. \\ Ref.- $\mathrm{M}^{\mathrm{c} C o y, ~ S y n o p . ~ C a r b . ~ F o s s . ~ t . ~ 3 . ~ f . ~} 3$.}

Desc.-Very elongate, conic, spire of numerous (about nine or ten) very gradually increasing whorls; apical angle alont $23^{\circ}$; surface quite smooth; whorls flat and sloping in the upper threc-fourths, tumid, and aloruptly rounded into the lower suture on the lower fourth; base moderately convex. Length of last six whorls of large specimen (not in the collection) two inches one line, proportional width of body-whorl in, cliameter of penultimate-whorl $\frac{42}{100}$, space between last and penultimate sutures $\frac{23}{100}$, length of mouth about $\frac{39}{100}$.

This species differs from $L$. constricta and Lefebvrei in the surface being perfectly smooth, the sutures being snooth and simple, and not at all constricted or imbricating, as well as the peculiar overhanging appearance which the whorls have from the flatmess of their upper three fourths, and the abruptly rounded projection of the narrow lower portion beyond the sutures.

Position and Locality.-Rare in the carboniferous limestone of Derbyshire.

\section{LOXONEMA RUGIFERA (Phill.)}

Ref. and Syn.= Melania rugifera Phill. Geol. York. Vol. II. t. 16. f. 26. = Loxonema rugifera Phill. Pal. Foss. f. 188.

Desc.-Very elongate, spire composed of about thirteen very gradually increasing whorls; apical angle $20^{\circ}$. sutures very strongly marked, imbricating, simple; each whorl flattened, and sloping from the upper and posterior suture to the lower third, where they are very prominent, and from whence they slope very abruptly inwards to the lower or anterior suture; each whorl crossed by a row of very thick, slightly oblique, longitudinal ribs, gradually thickening from the upper suture towards the most prominent lower fourth of each whorl, where they abruptly terminate, leaving the narrow lower slope smooth in old specimens, but entirely crossing the whorls in young ones; about fourteen ribs on each of the adult whorls, eleven or twelve on the younger ones, separated by slightly larger, deep, concave spaces; body-whorl very little larger than the preceding one, the base obscurely concave, produced and smooth; mouth rotundato-quadrate, little longer than wide. whorl $\frac{17}{1000^{\circ}}$.

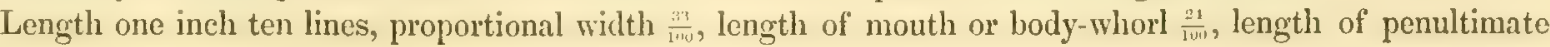

Position and Locality.-Rare in the black beds overlying the main carboniferous limestone of Derbyshire; very rare in the carboniferous limestone of Lowick. 


\title{
Loxonema scalaroidea (Phill. Sp.)
}

\author{
Ref and Syn.= Melania scalaroidea Phill. Geol. York. Vol. II. t. 16. f. 3.= Chemnitzia scalaroidea \\ de Kon. Anim. Foss. Bel. t. 41. f. 4.
}

Desc.-Elongate, conic, of about eight gradually increasing whorls; apical angle $27^{\circ}$; sutures deep, simple ; volutions moderately convex near the upper and lower sutures, rather flattened in the middle, crossed by numerous, regular, nearly equal, acute, slightly arched, thread-like, slightly oblique ridges, their own thickness apart, separated by deep concave sulei, about twenty ridges on each whorl at a diameter of one line (upwards of thirty at a diameter of two lines); base of last whorl smooth, moderately convex. Length of small specimen two and half lines, proportional width $\frac{40}{100}$.

The ridges of this species extend right across the whorls, with a slight forward obliquity towards the lower sutures, simply arched (not sigmoid). The very small size of our specimen renders it impossible to give any further proportional measurements with accuracy.

Position and Locality._-Rare in the black beds overlying the main carboniferous limestone of Derbyshire.

\section{Loxonema tenuistria (Phill. Sp.)}

Ref. and Syn.=Turitella? tenuistria Phill. Geol. York. Vol. II. t. 16. f. 4; ?=Ulima Phillipsiana de Kon. Anim. Foss. Bel. t. 41. f. 8.= Loxonema lavigata de Kon. (Ap. Dumont.)

Desc.-Shell very regular, smooth, even, acutely conic; apical angle $30^{\circ}$; spire composed of about ten (seven or eight usually preserved) gradually increasing whorls, flat or slightly prominent near the lower suture: sutures very fine, simple, linear; body-whorl obtusely-angulated at the circumference between the flattened upper portion and the convex base; mouth obliquely rounded, slightly longer than wide. Surface under a strong lens marked with very faint, slightly oblique lines of growth, very slightly inversely sigmoid towards the mouth, crossed by close, extremely minute, slightly flexuous, and slightly unequal spiral stria (twenty-five in a space of one line). Length of last seven whorls of rather small specimen eleven lines, proportional length of bodywhorl $\frac{40}{100}$, diameter of body-whorl $\frac{47}{1003}$, space between last and penultimate sutures $\frac{18}{100}$, diameter of penultimate whorl $\frac{33}{1111}$.

In most specimens this species to the naked eye is so smooth that as it agrees in spiral angle, outline and proportions, with the Ulima Phillipsiana de Kon. (Loxonema levigata of the same author formerly), I have little doubt that species should be referred, as a synonym, to the present one. Generally the whorls are flat and the surface remarkably even, owing to the sutures entirely concealing the angulation, which is visible on the base of the body-whorl, but sometimes the sutures are a little lower down, slightly exposing this angulation on some of the spiral turns, as in Mr Phillips's figure; the former condition rather agreeing with M. de Koninck's figure. The mouth and columella agree with those of ordinary species of Loxonema.

Position and Locality.-Common in the impure carboniferous limestone of Kendal.

\section{Loxonema tumida (Phill.)}

Ref. and Syn.=Melania tumida Phill. Geol. York. Vol. II. t. 16. f. 2.= Loxonema tumida Phill. Pal. Foss. f. 186.

Desc.-Acutely conic; apical angle $36^{\circ}$; spire of ten gradually increasing whorls, separated by deep, linear, simple sutures; whorls moderately convex, most so a little below the middle; base flattened, convex: mouth nearly orbieular; surface of the whorls crossed by strong, oblique, straight, or slightly arched, thread-like strix of growth, becoming irregularly stronger towards the mouth of old specimens. Length of rather small specimen nine lines, proportional width of body-whorl $\frac{54}{100}$, length of body-whorl or mouth $\frac{30}{100}$, width of mouth $\frac{27}{100}$, space between last and penultimate sutures $\frac{20}{100}$.

This species is easily distinguished by its deep, simple, non-imbricating sutures, short conical form, and numerous convex whorls, with their strong strixe of growth, or minute costulæ.

Position and Locality.-Tare in the carboniferous limestone of Kendal, Westmoreland. 


\section{Genus. MACROCHILUS (Phill.)}

Gen. Char.-Shell short, ovate, gibbous, spire rather acute, of moderate length, pointed, of several convex whorls; body-whorl large; aperture broad, ovate, rounded in front, pointed behind, indented by the preceding whorl; outer lip thin, slightly sinuate in front and oblique; anterior half of columella thickened, flattened; posterior half often deficient; no umbilicus; surface smooth, or marked by fine, oblique, inversely sigmoidal lines of growth.

These shells strongly resemble the recent Phasianella in almost everything; no trace, however, of the great round, stony opereulum of the later genus has been found in those rocks which contain Macrochilus in abundance.

Allied to Loxonema, but much shorter, more ventricose, with larger body-whorl, smoother surface and wide ovate mouth.

\section{Macrochilus acutus (Sow. Sp.)}

Ref. and Syn.=Buccinum acutum Sow. Min. Con.t. 566. f. 1.=B. imbricatum (not of Sow.) Phill. Geol. York. Vol. II. t. 16. f. 9, 17, 19, $20 ; ?+$ B. rectilineum Phill. ib. f. 10.

Desc-Ovato-conic; apical angle averaging $55^{\circ}$, varying from $50^{\circ}$ to $65^{\circ}$; spire acute, of about seven slightly convex, gradually increasing whorls; sutures simple, slightly imbricating; body-whorl most convex about the middle, sloping gradually to the suture, and to the moderately convex elongate base; mouth elongate, ovate; anterior half of inner lip only slightly thickened. Surface polished, with nearly obsolete striæe of growth crossing the whorls with very slight obliquity, having a faint backward curve near the sutures, and a broad slight forward curve from them to the base. Length of rather small specimen one inch; proportional average

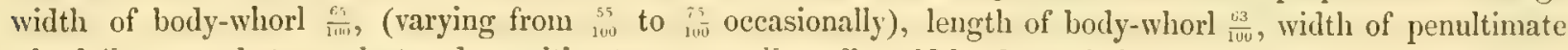
whorl $\frac{45}{100}$, space between last and penultimate sutures $\frac{15}{100}$ to $\frac{20}{100}$, width of mouth $\frac{33}{100}$.

In the shorter varieties especially, the spire is a little convex when viewed in profile, and in those cases the apical angle is measured by tangents to the middle of the penultimate whorl. I think with Prof. Phillips that his $B$. rectilineum is most probably only a variety of this species; but I do not think that the true $B$. imbricutum of the Devonian limestones of Devon occurs in the mountain-limestone; the figures given loy Phillips, as above quoted under that name, belonging clearly to the B. acutum of Sowerby, and his figures of B. arutum belong, I have no doubt, to a different and much more long spired species. M. de Koninck notices one or two folds on the columella which I have not yet seen. The extremes of proportional measurements which I have given indicate the long and short varieties; the apical angle varies only slightly, owing to the outline of the species being convex.

Position and Locality.-Common in the carboniferous limestone of Lowick; not uncommon in the dark lower carboniferous limestone of Ronaldsway, Isle of Man; rare in the lower carboniferous limestone of Derbyshire; very common cast in pyrites in the carboniferous shales of Craige, near Kilmarnock.

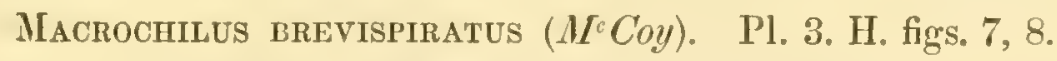

\section{Ref.-M $\mathbf{M}^{\mathrm{c}} \mathrm{Coy}$, Ann. Nat. Hist. 2nd Series, Vol, XII.}

Desc-Elliptical, moderately gibbous, most so about the middle of the length; spire about one-fourth of the total length, pointed, of four whorls, gently convex in the middle; sutures slightly imbricating: apical angle varying from $100^{\circ}$ to $82^{\circ}$; anterior portion or base produced, moderately convex; surface smonth. with very faint, fine, strix of growth, visible near the mouth, being scarcely sinuous, and very slightly oblique: mouth elongate ovate, indented by the posterior part of body-whorl; anterior half of columella thickened,

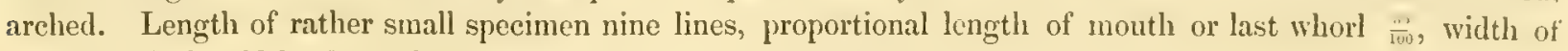
body-whorl $\frac{66}{100}$, width of mouth $\frac{45}{100}$, space between last and penultimate sutures $\frac{15}{110}$.

The extreme shortness of the spire separates this from all of the genus at once, except the $M$. Michotimus (de Kon.); from that glohose species it is distinguished by its much more elongate slender form (indicated 
by the much less proportional width of the body-whorl when compared with the total length), fewer spiral whorls, less convexity, and the whorls sloping gradually to the sutures.

Position and Locality.-Rare in the lower carboniferous limestone of Derbyshire; rare in the carboniferous limestone of Lowick, Northumberland.

Explanation of Figneres.-Pl. 3. H. fig. 7, small specimen, natural size, front view, from Lowick; fig. 8, larger specimen, from Derbyshire, back view.

\section{Miacrochilus curvilineus (Phill.)}

\section{Ref. and Syn. =Buccinum curvilineum Phill. Geol. York. Vol. II. t. 16. f. 13.}

Desc.-Very elongate, conic; apical angle about $33^{\circ}$; spire of numerous very gradually incrensing whorls, (number unknown, the last five commonly preserved,) each moderately convex towards the sutures, rather flattened in the middle; sutures deep, simple, distant; diameter of penultimate whorl rather less than the height of that and the preceding one torgether. Surface nearly smooth, marked with fine oblique lines of growth. Lencth of last five whorls one inch seven lines, proportional length of body-whorl $\frac{4 i}{1 w}$, space between last and penultimate sutures ${ }_{100}^{25}$, width of body-whorl $\frac{5 \pi}{300}$, width of penultimate whorl $\frac{35}{100}$.

Distinguished from the $M$. sigmilineus principally by the greater distance of the sutures apart and the Hatter whorls.

Position and Locality.-Rare in the carboniferous limestone of Kendal, Westmoreland.

\section{Macrochilus liminatformis ( $M^{\circ} \mathrm{Coy}$ ). Pl. 3. I. fig. 40.}

Ref.-McCoy, Ann. Nat. Hist. 2nd Series, Vol. XII.

Desc.-Elongate, fusiform, very acutely rhomboidal, greatest width at about the middle of the total length, from whence the anterior or basal part is conoidally attenuated or rapidly sloped to the greatly narrowed front of columella, and very rapidly sloped to the suture, which is simple and slightly imbricating; spire very abruptly attenuated, long, very slender, sides very concave in the profile, of about six or seven whorls (usually five, preserved); apical angle $54^{\circ}$. Surface polished, very smooth, with occasionally fine traces of olsolete direct lines of growth; mouth narrow, elongate, contracted before and behind; anterior part of columella very. slightly thickened. Length about one inch seven lines, proportional length of mouth of body-whorl zo, width of hody-whorl $\frac{5 T}{\mathrm{i} i 0}$, width of penultimate whorl $\frac{3 n}{\mathrm{viv}}$, space between last and penultimate sutures $\frac{13}{1+1,1}$, width of mouth $\frac{30}{100}$.

This beautiful species is so totally distinct in form from any of those described, that it is unnecessary to compare them. The very abrupt attenuation of the elongate spire gives so nuch the outline commonly seen in Limnee, as to suggest the specific name; in addition to this remarkable peculiarity, the species differs from its congeners in the conoidal attenuation of the produced front, from the line of greatest width of bodywhorl, which is at about one-third its length below the suture.

Position and Loselity.-Not very uncommon in the carboniferous limestone of Lowick, Northumberland.

Explanation of Figure.-Pl. 3. I. fig. 40, natural size.

\section{Macrochilus michotianus (de Kon.)}

\section{Ref.-de Kon. Anim. Foss. Bel. t. 41. f. 14.}

Desc.-Globose; spire short, pointed, of five or six whorls, slightly convex, and sloping in the lower tro-thirds, obtusely tabulated and horizontal in the sutural third of each; apical angle $100^{\circ}$ or $105^{\circ}$; bodywhorl very large, tumid; mouth longitudinally ovate, much indented by the body-whorl behind; rather less than the anterior half of the columella, marked, thickened, and slightly arched. Surface with nearly direct, obscure lines of growth. Length one inch, proportional length of mouth or body-whorl $\frac{13}{104}$, width $\frac{22}{1+w 1}$, width of mouth $\frac{40}{100}$, space between last and penultimate sutures $\frac{15}{100}$.

The subtabulate flattening near the sutures and great proportional width and gibbosity distinguish this species from the $\boldsymbol{D I}$. brevispiratus ( $\left.\mathrm{M}^{\mathrm{c}} \mathrm{Coy}\right)$.

Position and Locality.-Tiare in the upper black beds of the carboniferous limestone of Derbyshire. 


\section{Miacrochilus sigmilineus (Phill. Sp.)}

Ref. and Syn. = Buccinum sigmilineum Phill. Geol. York. Vol. II. t. 16. f. 12.+B. acutum id. ib. f. 11. (not Buccinum acutum of Sow.)

Desc.-Very elongate, conic; apical angle varying from $33^{\circ}$ to $40^{\circ}$; number of volutions unknown (six commonly preserved), very gradually increasing, each strongly convex, most so below the middle; sutures very oblique, deep, simple; width of the penultimate whorl slightly exceeding the length of it and the preceding one together; surface highly polished, with faint, sigmoidal strix of growth; base rather abruptly narrowed at the front margin. Length of the last six whorls of small specimen one inch (sometimes upwards of three inches), proportional length of body-whorl ${ }_{201}^{\text {nom }}$, space between last and penultimate sutures $\frac{19}{i v 0}$, width of bodywhorl $\frac{60}{100}$, width of penultimate whorl $\frac{33}{100}$.

This species is easily distinguished from the true $M$. acutus of Sowerby, by the great length and slenderness of the spire, more oblique sutures, more convex whorls, dec. The species however figured as Buccinum acutum by Phillips, is perfectly identical in all respects; the Macrochilus curritineus differs in the greater proportional space between the sutures as compared with the diameter of the whorls, \&ic.

Position and Locality.-Rare in the carboniferous limestone of Lowick, Northumberland.

\section{Macrochilus? spiratus $\left(M^{c} C o y\right)$. Pl. 3. H. figs. 1, 2.}

R.f. and Syn.=Turbo spiratus $1 \mathrm{~L}^{\circ} \mathrm{Coy}$. Synop. Carb. Foss. Irel. t. 5. f. 29. = Natica M Cayana d'Orbigny, Prodrome, p. 118.

Desc.-Elongate, ovato-conic; spire acute, of five, gradually increasing, moderately convex whorls, each of which has a subtabulate or gently coneave narrow space just below the sutures, which are simple and imbricating; apical angle $75^{\circ}$; body-whorl moderately convex, base much rounded; mouth ovate, anterior half of the thickened inner lip forming a small, sub-semicircular pad, or extension on the body-whorl. Surface smooth, with fine obsolete, direct lines of growth. Casts shew a very deep rounded umbilicus, and have the sutures strongly channelled and with obtusely rounded edges (the suture of the shell corresponding nearly with the middle of the spiral whorls of the east). Length of rather small specimen eleven lines,

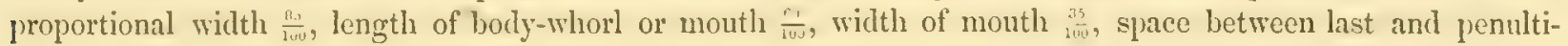
mate sutures $\frac{25}{100}$.

This species is distinguished from the $1 /$. reutus (Sow. sp.) by its subtabulate sutures, greater thickness of the anterior half of the pillar-lip, \&c.

Position and Locality -Common in the dark carboniferous limestone of Lowick, Northumberland.

Explanation of Figures.-Pl. 3. H. fig. 1, moderate-sized specimen, natural size, partially decorticated; shening the relative position of the channelled sutures of the cast, and those of the exterior: fig. 2 , small specimen with shell perfect, shewing the pad of the umbilicus.

\section{Macrochilus symatricus (King).}

Lief. and $S_{y n}=$ King, Perm. Foss. t. 16. f. 32 and 33, (bad, 一whorls too strongly angulated, and body-whorl a little too small).

Desc.-Very elongate, subconic, or hemifusiform, of six very gradually increasing wherls, separated by deeply impressed, simple sutures; diameter of penultimate whorl slightly less than the length of it and the pre. ceding one taken together; each whorl very gently conves, most so about, or a little below, the middle; apical angle about $33^{\circ}$; base of body-whorl gradually rounded; surface smooth. Length of average specimen five and half lines, proportional width of body-whorl $\frac{5 ! \prime}{10 \prime \prime}$, space between last and penultimate sutures $\frac{20}{1+1,}$, diameter of penultimate whorl $\frac{40}{100}$, length of body-whorl $\frac{48}{100}$.

This species is distinguished by its eonstantly smaller size, drc., from the II. currilineus of the carboniferous limestone, which it much resembles in proportion.

Position and Locality.-Rare in the Permian limestone of Humbleton. 


\section{7th Ord. Dentalina.}

This order contains but one family, Dentalidoe, of one Genus, Dentalium.

\section{Genus. DENTALIUM (Linn.)}

Gen. Char--Shell tubular, elongate conic, arched, open at both ends; usually a dorsal slit at the smaller end, and often two lateral retractor muscular impressions; aperture round, simple. (Animal conic, head distinct, lips with tentacles, gills in two symmetrical bunches, one each side of the neck; anus at the smaller end; foot proboscidiform, with a shelly appendage at the end.)

Allied by the shell to a greatly elongate Fissurella.

Recent on sandy and rocky bottoms in all latitudes, particularly warm ones.

\section{Dentalium dentalotdeum (Phill. Sp.)}

Ilef. and Syn. =Orthoceras dentaloideum Phill. Geol. York. Vol. II. t. 21. f. 12.= Dentalinm ornutum de Kinn. Anim. Foss. Bel. t. 22, f. 3.

Desc.-Very elongate, conic, gently arched, section almost circular, very faintly compressed; shell very thick except at the anterior edge; surface sculptured with very small, sharp, prominent, subequal, longitudinal, thread-like ridges (eight in one line at three lines in diameter), crossed by slightly ollique lines of growth of variable strength. Casts are generally snooth, abruntly dilated towards the anterior end, and marked with a longitudinal groove down the dorsal and another down the ventral aspect, commonly bounded by two obseure ridges, but sometimes prominent in the middle, or even triple; very faint traces of longitudinal stria towards the smaller end. Length of average specimen, imperfect at the smaller end, three inches; diameter at anterior end six lines, diameter at smaller end two and a half lines, thickness of shell at smaller end one line.

M. de Koninck mentions having found the small end covered in great part by a diaphragm having a slit from its middle to the dorsal edge; I have not seen this most curious charncter. The transverse strix, according to Baron de Ryckholt, are in some specimens as strong or even stronger than the longitudinal ones, producing $a$ reticulated surface. Owing to the closely sculptured surface adhering to the matrix, specimens usually shew only the internal casts.

Position and Locality.-Very common in the carboniferous limestone of Lowick, Northumberland.

\section{Dentaluum ingens (de Kon.)}

\section{Ref.-de Kon. Anim. Foss. Bel. t. 22. f. 2.}

Desc.-Elongate, conic, very gradually tapering, gently arehed; section with a scarcely perceptible ellipticity; shell extremely thick, coarsely laminated concentrically; surface with coarse, irregularly imbricating transverse lines of growth. A specimen (imperfect at each end) six inches and nine lines long, is one inch and half a line in diameter at the larger end, and four and a half lines in diameter at the smaller end, where the thickness of the shell is one and a half lines, and the diameter of the internal cavity about two lines; the thickness of the shell at the larger end is two lines on the inner side of the curve, and one and a half lines on the convex side.

M. de Koninck states that the small end is simple, and that the anterior aperture is oblique, as well as the concentric imbricating strix. I believe it is so in our specimen, but $I$ cannot see all parts of it. By the help of Mr Carter I submitted a fragment, prepared as a transparent microseopic olject, to a high magnifying power, doubting that this gigantic species could be a real Dentalizm, but the intimate structure proved perfectly analogous to that of the living small Dentatia.

Position and Locality.-Rare in the carboniferous limestone of Kendal, Westmoreland. 


\title{
5th Class. CEPHALOPODA. See page 306. 1st Ord. Tetrabranchiata. See page 307.
}

\author{
1st Family. BELLEROPHONTIDE. See page 307.
}

Gemus. BELLEROPHON. See page 308.

\author{
Bellerophon cornu-ARIETis (Som.) \\ Ref.-Sow. Min. Con. t. 469. f. 2.
}

Desc-Casts, composed of two whorls; rapidly enlarging, and abruptly expanding at the mouth; mouth bilobed, and with a deep, narrow, : ngular sinus in the edge, elevated to form an obtusely angular ridge, which is continued, but more obscurely marked, to the apex, near which, from being bounded by two obscure sulci, it gives a faintly trilobate contour to the exterior; the whorls widely separated from each other; umbilicus very large, obtusely excavated within. Diameter three inches, proportional diameter of last whorl $\frac{52}{1+v}$, diameter of un-

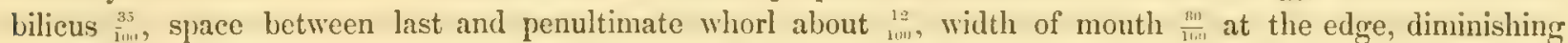

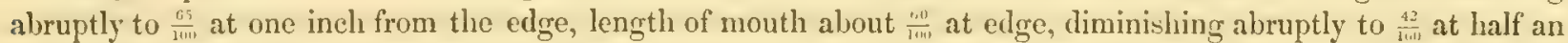
inch within the edge. Exterior: shell extremely thick; mouth dilated, retroflexed at the inner corners when young, and overhanging a slight semielliptical depression, not forming a true umbilicus, which with age becomes entirely filled by a great, smooth, rounded callosity, extending over the sides of the mouth; beyond this callosity the surface is marked with coarse, obtuse, irregularly unequal, arched ridges, meeting at a moderately acute angle $\left(60^{\circ}\right)$, the undefined, obtusely prominent keel, over which they arch; callosity on the inner lip very large, rhombic, obtusely keeled in the middle of the outer margin. Diameter two and half inches, proportional width of mouth and lateral callosities $80^{\circ}$.

MII. d'Orbigny and de Koninck, in their several works, suppose the B. cornu-arietis and $B$. tangentialis to be the internal casts and the exterior of one species. I have clearly ascertained, however, that this is not the case, by carefully removing the external shell from one side of one of the Cambridge specimens, so as to be absolutely certain of the cast being Sowerby's species, and shewing that its external shell has not hitherto been recognized. It has no resemblance to $B$. tangentialis, but is very like de Koninck's figure of the adult $B$. costatus (Anim. Foss. Belg. t. 26. f. $2 a, b, c$ ) in form, costation, obtusely rounded undefined keel, and callosities; but the arched ridges do not meet the keel at so acute an angle in the present species, and there is no trace of umbilicus, or umbilical depression, in specimens of much less size than he figures; while it agrees with that, and differs from $B$. tungentialis, in the arehing of the ribs, broad, rounded, undefined keel, with shallow depression on each side, de.; differing from them, and all other species, in the great thickness of the shell, size of umbilicus, and great separation of the whorls in the casts.

Position and Locality.-Common in the carboniferous limestone of Kendal, Westmoreland.

\section{Bellerophon costatus (Sow.)}

Ref.-Sow. Min. Con. t. 470. f. $4 .=B$. Blainvillei d'Orb. Monog. Bel. t. 3. f. 1. to 3.

Desc.-External shell; globose, moderately expanded: very slightly compressed on the sides, obtusely rounded on the prominent periphery; keel broad, very obtuse, undefined ; umbilicus small, deep, open; surface covered with subregular, imbricating, obliquely arched, lamellar ridges (averaging four in two lines, near the band at an inch in diameter), shewing under the lens a very fine, irregular, subparallel lineation; ridges meeting the keel on each side, at an angle of about $40^{\circ}$. Casts; smooth, globose, without marked ridges or furruws; umbilicus narrow, deep, with rounded sides, partially exposing the volutions. Diameter of casts, one inch, proportional diameter of umbilicus of the same $\frac{30}{100}$. 
In this species, according to M. de Koninck, the inner lip and sides of the mouth become greatly thickened; the keel (although still undefined) more prominent, and the obliquely arched lamellar costae larger, but more irregular in the adult specimens of two or three inches in diameter; I have not seen, however, any specimens in this condition. M. de Koninck supposes the $B$. apertus of Sowerby to be the internal cast of this species, but the umbilicus is manifestly of greater proportional diameter in the true $B$. apertus, of which I have examined large numbers from the original locality. In the moderately young specimens the band is quite flat, and almost smooth; in older specimens it is distinctly crossed by arched imbrications of growth. The acute angle at which the transverse ridges meet the band, and the wide, undefined keel, separate the species easily from the $B$.tangentialis, with which it is confounded in d'Orbigny's Monograph.

Position and Locality.-Rare in the carboniferous limestone of Derbyshire ; casts in the red carboniferous limestone of Breedon, Leicestershire.

\section{Bellerothon decussatus? (Flem.)}

Ref. and Syn.-? Flem. Brit. Anim. p. 33S.=B. elegans D'Orb. + B. clathratus d'Orb. Monog. Bellerophon, t. 7 . f. 12 to 18. and t. 5. f. 24 to $27 .=B$, reticulatus $M^{\circ}$ Coy, Synop. Carb. Foss. Irel. t. 2. f. 2.

Desc.-Globose; umbilicus very small, deep, rounded, exposing the edge of the inner whorls; margin of the sides and umbilicus very tumid; mouth transversely reniform; keel broad, obtuse; moderately prominent, sharply defined; surface covered with sharp, subequal, subregular, thread-like spiral ridges (eight or nine in one line at two lines in diameter), separated by flat spaces, slightly exceeding their own width, reticulated by slightly arched transverse strixe usually nearly equalling the spiral ones in size, but slightly further apart, and in general direction nearly at right angles to the keel, except close to the point of junction, where they are slightly bent backwards; the points of intersection of the spiral and transverse threads are slightly turbercular; keel with from three to five longitudinal strix like those of the sides, and similarly reticulated; semicircular callosity of the inner lip very thin; substance of the shell very thin. Diameter of small specimens about three lines, proportional width at mouth (no abrupt dilatation) $\frac{90}{j w 0}$, antero-posterior diameter of mouth $\frac{45}{100}$, diameter of umbilicus nearly $\frac{30}{100}$.

According to de Koninck this species, when adult, reaches two inches in diameter, and loses the reticulation near the sides of the umbilicus, the edges of the mouth and the inner lip becoming greatly thickened. I have seen no specimens exhibiting those characters. In my volume on the Mountain Limestone Fossils of Ireland, I describe this species under the new name B. reticulatus, on account of Plillips's statement, that the axis in Fleming's species was solid; de Koninck and D'Orbigny, however, agree now in ascribing an umbilicus to the true $B$. decussatus; and I think it better therefore to abandon my name and follow them.

Position and Locality.-Common in the black beds over the main carboniferous limestone of Derbyshire; common in the carboniferous limestone of Fifeshire. Very large specimens (one and quarter inches in diameter) are not very uncommon in the impure carboniferous limestone of Lowick, but having the surface so imperfectly preserved, that the reticnlation can only be seen in spots near the edge.

A few remarkable specimens in the collection from the black marble beds of Derbyshire are possibly adults of the above species, having a very thin, curved, reflected margin three lines wide round the mouth; width, including margin, one inch eight lines, entire length, including mouth and reflected margin, about $\frac{r_{0}}{1 \mathrm{w}}$, length of mouth exclusive of margin ${ }_{100}^{40}$, width of do. $\frac{55}{100}$, diameter of umbilicus $\frac{25}{100}$; surface indistinetly preserved, but the spiral strice averaging eight in the space of one line, band prominent, rather more than half a line wide. Small specimen seven lines in diameter, with traees of broad reflected lip overarehing the umbilicus, as in the adult. Proportional width of mouth (the reflected edge broken off) $\frac{18}{1+0}$, length of mouth $\frac{16}{1 w 1}$, diameter of umbilicus $\frac{34}{100}$.

The B. hyalimus of de Ryckholt (Mélange Paléont. t. 3. f. 26) seems to agree very closely with the adult specimens, but has not the keel so strongly marked. 


\title{
Bellerophon Duchastelli ( $L^{\prime} E v$.
}

Ref. and Syn.-L'Eveillé, Mém. de la Soc. Géol. de France, t. 2. f. 8, 9; de Kon. Anim. Foss. Bel. t. 27. f. 6.

Desc.-Discoid, laterally compressed, greatest thickness at the margin of the umbilicus, from whence the sides converge to the narrow, prominent, obtusely carinated periphery, being gently concave in the middle near the keel, and very convex at the obtusely rounded edge of the umbilicus; umbilicus large, with steeply sloped sides; mouth elongate, subtrigonal, with a very small supplemental lobe at each inner angle. Surface crossed with subregular, obtuse, strong, subimbricated ridges (five in two lines at seven lines in diameter), very strongly arched (more than a semicircle) on the sides, and meeting the keel on each side at an angle of

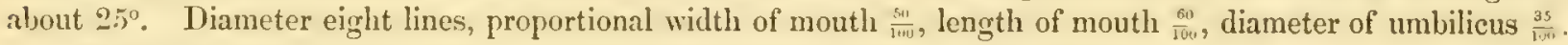

This remarkable species does not seem to have been noticed in Britain before.

Position and Locality.-Rare in the carboniferous limestone of the Isle of Man.

\section{Bellerophon Dumonti $\left(d^{\prime} O r b\right.$. )}

\author{
Ref.-d'Orb. Monog. Belleroph. t. 2. f. 16 to 20.
}

Casts apparently of this remarkable, elongate, narrow, species occur occasionally at Lowick. They are intermediate between $B$. corm-arictis and $B$. apertus in appearance, the whorls being entirely exposed as in the former, but much less widely separated, and increasing gradually as in the $B$. apertus, and with an umbilicus little larger than that of that species.

\section{Bellerophon hiulcus (Mart. Sp.)}

Ref. and Syn.=Conch. Nautilus? hiulcus Martin, Pet. Derb. t. 40. f. 1, 2.= Bellerophon hiuleus Sow. Min. Con. t. 470. f. $1 .+$ B. bicarenus.

Desc.-Very globose; periphery and sides regularly rounded, moderately expanded towards the mouth, the reflected corners of which have a minute, partly closed umbilicus; mouth transversely reniform, broadly rounded in the middle, with narrow rounded sides; band very broad, flat, sharply defined on each side by a sharp threadlike keel, varying greatly in strength, and sometimes partially effaced, leaving the band apparently bounded by impressed lines. Surface marked with very numerous, close, slightly irregular imbricating ridges, separated by wider flattened spaces, arching from the minute umbilicus at an arerage angle of $50^{\circ}$ on each side of the keel, near which, however, their extremities are abruptly arched backwards, so that the angle at the point of junction is often not more than $20^{\circ}$; band either smooth or marked with strongly arched, imbricating lines of growth. Width and diameter of small specimen one inch one line, umbilicus too small to be measured; about seven transverse ridges in two lines near the mouth and keel, width of band one line.

This species is remarkable for the very great width of the band, which although always wider than that of any other species, varies a little in this respect. I have no doubt that the B. bicarcnus is only founded on specimens of the present species, having the bounding keels very strongly marked. In both Sowerby's and Martin's figures a keel marked with double lines is represented on one side of the band, though obsolete on the other, and this is by no means uncommonly the case, and some specimens which have the keels so strongly marked as to answer to the $B$. bicaremus in some parts, have the band bounded apparently by impressed lines (as stated by Sowerby) from their absence in other parts.

Position and Locality.-Rare in the carboniferous limestone of Derbyshire. 


\title{
Bellerophon Larcomi (Portk.)
}

\author{
Ref.-Portk, Geol, Rep. t. 29. f. 13. (reduced one half linear).
}

Desc.-Globose; subhemispherical; casts of about two very rapidly enlarging whorls, entirely exposed in the umbilicus, which is extremely deep, from the rapid enlargement of the whorls; edge of the umbilicus obtusely angulated, steeply sloped, slightly convex, and excavated along the middle; periphery very broadly rounded without any distinct ridges or furrows; mouth moderately dilated, bilobed at the outer edge, and with a short angular sinus in the niddle; shell extremely thick; callus on inner lip, very large, flattened, smooth. Surface imperfectly seen, but apparently without distinct keel, marked with obscure, moderately arched sulci or ridges of growth, and apparently a small, open umbilicus. Width of nearly adult specimen at mouth six inches, proportional diameter $\frac{\frac{n 5}{100}}{100}$, antero-posterior diameter of month $\frac{40}{100}$, diameter of umbilicus $\frac{37}{100}$. Diameter of casts before the abrupt dilatation of the mouth three and half inches, proportional width of such imperfect specimens ${ }_{100}^{90}$, or nearly equal to the diameter; diameter of umbilicus $\frac{40}{110}$, antero-posterior diameter of mouth $\frac{49}{100}$. Width of small old specimen, with external shell, at mouth five inches three lines, proportional antero-posterior diameter of entire shell $\frac{95}{100}$; antero-posterior diameter of dilated mouth $\frac{59}{100}$.

This is by far the largest species of Bellerophon known. The shell is extremely thick (considerably upwards of an inch at the sides of mouth in old specimens). In general characters small specimens much resemble the $B$. apertus; but instead of two-thirds of the inner whorls being concealed by the outer ones, when looking directly into the umbilicus of casts, they are entirely exposed, though not to such an extent as in $B$. cormiarietis, the easts of which, by their remarkably slender, widely separated whorls, have no resemblance whatever to the $B$. Larcomi. The present species differs both from the $B$. apertus and $B$. corme-arietis in the extreme width of the whorls compared with their diameter, and the very rapid increase of the whorls in size, causing their remarkably steep-sided, obtuse, angular-edged umbilicus. The periphery is very broadly rounded, most prominent in the middle, and without any distinct ridges or sulci either on the outer surface or internal casts.

Position and Locality.-Not uncommon in the impure carboniferous limestone of Kendal; one small slightly narrower specimen, possibly of this species, in the collection from Lowick.

\section{Belleropion Phillipsi.}

An apparently smooth species, probably the $B$. apertus of Phillips, occurs abundantly in the state of casts at Kendal, and more rarely at Dent and Lowick. The casts much resemble those of the true $B$. apertus and $B$. costatus, but having the proportional wilth of the umbilicus $\frac{35}{1+1}$, as compared with the diameter; being therefore intermediate between those species: if distinct from any known form when perfect exteriors are found, it might be called B. Phillipsi.

\section{Bellerophon recticostatus (Portk.)}

Ref.-Portk. Geol. Rep, t. 35. f. 5.

Two casts, too obscure for description, one from Lowick and one from Kendal, probably belong to this species, as they agree with $B$. apertus in the proportional width of the umbilicus $\left(\frac{40}{100}\right)$, but differ in being marked with two large spiral sulci coinciding with the band, and one or two fainter ones on each side.

\section{Belleropion tangentialis ( Phill.)}

\section{Ref.-Phill. Geol. York. Vol. II. t. 17. f. 6, 7, and 4.}

Desc.-Globose; periphery broadly rounded, slighty flattened; umbilicus wide, deep, rounded, with very tumid sides; keel forming a single, strong, prominent, narrow ridge. Surface crossed by strong, irregular, subimbricated ridges, separated by wide flat spaces; transverse ridges usually joining the keel at right angles. 
(very rarely with a slight backward inclination at the extremity), uniting obliquely into bundles at the edge of the umbilicus, to which they form tangents; averaging four or five transverse ridges in three lines near the keel at one inch in diameter; mouth transversely reniform, rounded at the sides. Width of mouth of small specimen one inch one line, proportional diameter ${ }_{i v}^{p 5}$, antero-posterior diameter of mouth $\frac{35}{j u}$, diameter of umbilicus $\frac{25}{10}$, width of keel rather less than half a line.

MM. d'Orbigny and de Koninck believe the $B$. cormu-arietis (Sow.) to be the internal cast of this species. but $I$ have ascertained that this is not so (see description of $B$. cornu-arietis, p. 551).

Position and Locality.-Not uncommon in the carboniferous limestone of Derbyshire.

\section{Bellerophon tenuifascia (Sow.)}

Ref.-Sow. Min. Con. t. 470, f. $2,3$.

Desc.-Globose; periphery and sides very convex; umbilicus small; mouth transversely reniform, slightly reflected at the sides. Surface often almost smooth, with fine, obsolete, very slightly arched strice, having a small backward curve at the point of junction with the keel, which they meet at an angle of $75^{\circ}$; keel simple, prominent, very delicate, thread-like (imperceptible in parts of many specimens); shell thin. Diameter of rather small specimen ten lines, width of mouth the same, proportional length of mouth $\frac{47}{10,}$, width of umbilicus ${ }_{i \text { ini }}$, width of keel one fourth of a line. Cast very gibbous, sides slightly flattened, sloping, with a small, rounded, prominent-edged umbilicus.

I have not myself seen perfect casts of this species, but Sowerby's figure of the cast indicates a proportional diameter of the umbilicus of only ${ }_{i 00}^{16}$ at most.

Position and Locality.-Rare in the carboniferous limestone of Derbyshire.

\section{Bellerophon Urei (Flem.)}

Ref. and Syn.-Flem. Brit. Anim. p. 338; Phill. Geol. York. Vol. II. t. 17. f. 11, 12; Portk. Geol. Rep. t. 29. f. 9. = B. atlantoides d'Orb. Mon. Bel.t. 4. f. 1 t to 19 .

Desc.-Globular; periphery very broadly rounded; umbilicus only marked by a small shallow depression; mouth wide, transversely reniform, not abruptly expanded. Surface (at five lines in diameter) covered by abont twenty-eight strong, nearly equal, spiral ridges (about six in two lines at the above diameter), separated by rather narrower, deep sulci, the two middle ridges marking the band slightly smaller than the adjoining ones. Cast having the periphery slightly flattened, the umbilicus large, and the surface almost smooth, or with faint traces of spiral sulci. A verage diameter five or six lines, width of mouth slightly more, length of mouth about $\frac{3 .}{i, j}$, proportional width of umbilicus in casts about $\frac{45}{100^{\circ}}$.

According to de Koninck, the adult specimens become smooth near the mouth.

Position and Locality. - Not uncommon in the coal-shale near Glasgow; a variety with more distinct umbilicus and wider sulci between the ridges, in the black beds over the main limestone of Derbyshire.

\section{Genus. PORCELLIA. (L'Eveillé).}

Gen. Char.-Discoid, depressed; whorls very slightly embracing, exposed in a very wide umlilicus, slightly deeper on one side than the other, from a trifling obliquity of the first one or two turns; a narrow band extends along the middle of the exterior, ending in a narrow slit in the lip; surface often nodular. and ornamented with rough strix.

The depressed discoid form, and a very slight obliquity of the enrolment of the young whorls, distinguish this genus from Bellerophon. 


\section{Porcellia Puzosi ( $L$ 'Ev.)}

Ref.-Mém. de la Soc. Géol. de France, Vol. II. t. 2. f. 10, 11 ; de Kon. Anim. Foss. Bel. t. 28. f. 1.

Desc.-Discoid, whorls four, subpentagonal, barely touching; periphery very broad, moderately convex, with a strongly marked, narrow, median, cord-like keel; sides steeply sloping into the umbilicus, most prominent at the junction of the sides with the periphery, where the two outer whorls are crowned with very prominent conoidal tubereles, lengthened in the direction of the centre about half way to the edge of the umbilicus; compressed anteriorly and posteriorly, and separated by rather wider concave spaces; about fourteen tubercles on the outer whorl at a diameter of one inch three lines, about ten on the outer whorl at seven lines in diameter, the two inner whorls destitute of tubercles. Surface marked with strong spiral lines of small equal tubercles, the rows in large specimens imperfectly alternating in size (eleven or twelve rows in the space of one line), the granules so arranged that they fall into lines either spirally or transversely. Diameter of average specimen one inch three lines, width of mouth at apex of tubercles ${ }_{116}^{49}$, at inner edge ${ }_{100}^{15}$, width of umbilicus at inner edge of body-whorl $\frac{40}{100}$, antero-posterior diameter of penultimate whorl $\frac{19}{100}$.

Position and Locality.- Not uncommon in the dark carboniferous limestone of the Isle of Man; abundant of small size in the the carboniferous shales of Craige, near Kilmarnock; rare in the carboniferous limestone of Derbyshire.

\section{2nd Family. NAUTILIDE. See page 311. Genus. NAUTILUS. (Linn.)}

Gin. Char.-Shell globose, involute, more or less compressed laterally; last chamber very large, usually much embracing the preceding ones; septa simple, or gently waved backwards on the sides and periphery; siphon usually subcentral, but varying from the inner to the outer edge.

Common from the Paleozoic to the Eocene tertiary inclusive, rare in the newer tertiaries and recent seas.

There are three subgenera: 1. Discites $\left(\mathrm{M}^{\mathrm{c}} \mathrm{Coy}\right)$, formerly proposed for those compressed species with flattened, quadrate whorls, exposed in a wide umbilicus, having the siphon near the outer edge, the periphery narrow, often concave, and the septa arched backwards on the sides and periphery. This section, in which the last whorl often becomes slightly disjoined, occurs in the Devonian, and very commonly in the Carboniferous rocks. 2. Cryptoceras (d'Orbig.), in which the whorls are cntirely embracing, and the septa nearly simple, as in the true Noutilus, but the siphon placed at the outer margin. This section has few species all Palcozoic. 3. Aturia (Bronn), having the general form of the true Nautilus, but the siphon at the inner edge, and the septa with a deep, tongue-shaped lobe on each side; this section is exclusively Eocene Tertiary. The typical Soutili have the whorls entirely embracing, or nearly so; the septa simple or slightly waved, and the siphon subcentral.

\section{Nautilus bilobatus (Sow.)}

Ref. and Syn.-Sow. Min. Con. t. 249. f. 2, 3.=Nuutilus clitellarius Sow. Greol. Trans. 2nd Series, Vol. V.

t. 40. f. 5 ; M. V. K. Geol. Russ. t. 25. f. 11.

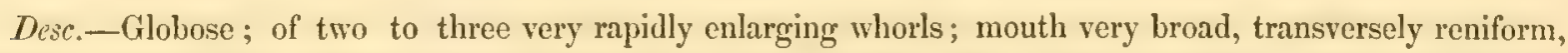
obtusely rounded at the sides; greatest width of the shell at the edge of the umbilicus; periphery broadly rounded, with a nearly semicircular section, very slightly flattened at the middle; umbilicus small, very deep, exposing about a third of the inner turns; surface of the inner whorls marked with fine spiral strix, crossed by very fine transverse striæ of growth (the spiral stria seem to disappear on the large specimens); septa very numerous, about two lines apart in the middle, at an inch and half in width, one line apart at five lines in width, their edges extending from the umbilicus towards the periphery, with a broad slight curve, the convexity backwards; on reaching the middle third of the periphery, they abruptly bend forward with a tongue-shaped semielliptical curve, extending so far forwards, that a straight line extending from the septum at the middle of the 
periphery to the umbilical edge of the same septum, would touch the middle of the following septal edge; internal surface of each septum divided into two deep, rounded, hemispherical pits, one on each side, separated by a narrow, very prominent, rounded elevation, extending from the tongue-shaped sinus of the outer margin to the opposite point of the inner margin, nearly in the middle of which elevation is the very large siphuncle. Diameter of very small specimen about seven lines, proportional width of mouth $\frac{87}{100}$, antero-posterior diameter of mouth $\frac{311}{1 \cdots 1}$, diameter of umbilicus $\frac{125}{100}$.

Why Mr Sowerby should have re-described this species under the new name $N$. clitellarius in the Geological Transactions, and why authors generally should have adopted it in preference to the one given so long before, with a very good figure in the Mineral Conchology, I am unable to explain. The species is so strongly marked by the conformation of its septa, that it is needless to compare it with any other. The external form is nearly that of the $N$. globatus; occasionally a thin mesial ridge is perceived on some parts of the casts. The umbilicus is too small, I think, in the figure in the Geological Transactions; but those of the Mineral Con chology and Geology of Russia are correct.

Position and Locality.-Rare in the carboniferous limestone of Lowick, Northumberland.

\section{Nautilus cariniferus (Som.)}

\section{Ref.-Min. Con. t. 4£2. f. 3.}

There is but one fragment of this species in the collection; it is too imperfect for description.

Position and Locality.-In the carboniferous limestone of Kendal.

\section{Nautilus (Discites) complanatus (Sow.)}

Ref.-Sow, Min. Con. t. 261.

The originally figured type specimen of this species, collected by Prof. Henslow, is now in the Cambridge Collection; and I examined it with great interest, as it was the only Nautilus of the subgenus Discites, which was supposed to have had a convex periphery, and it was also (judging from the figure) remarkable for having an angular sinus in the edges of the septa at some distance from the edge of the umbilicus, where they seem to incline in a direction contrary to that of all known species. I find, however, that there is no reasonable ground for supposing these characters to exist. The specimen is preserved in the Posidonic limestone beds, and, like the other fossils of those beds, squeezed flat by pressure, and obviously very much flatter than natural. The substance of the specimens is only a thin film, of one side, and giving no materials for Mr Sowerby's engraved section of the periphery, which may as well have been concare as convex.

The edge of the umbilicus is not sharply defined on the chambered portion, as in Mr Sowerby's figure; and on the contrary, the probability is rather that the angulated edge of the umbilicus exactly coincided with the angular sinus of the septa which he represents. The measurements of the figure in question are not quite exact; and as the proportions of the sides of the whorls to the umbilicus are not very remote from those of $M$. discus, I feel more inclined to suppose that $N$. complanatus is a specimen of that species somewhat distorted by compression, than to admit it as a species with the charncters heretofore assigned to it.

Position and Locality.- Not very uncommon in the black carboniferous limestone of the Isle of Man.

\section{Nautilus coronatus ( $\left.M^{\circ} \mathrm{Coy}\right)$.}

$$
\text { Ref.- } \mathrm{I}^{\mathrm{c}} \mathrm{Coy} \text {, Synop. Carb. Foss. Irel. t. 4. f. } 15 .
$$

Des._Discoid, of about three very rapidly enlarging whorls, half exposed in a very deep, wide, conical umbilicus; edge of the umbilicus carinated by the meeting of the very broad, slightly convex periphery at an acute angle with the slightly convex steep sides of the umbilicus, the line of junction being slightly rounded, and divided into numerous blunt, oval, compressed tubercles, elongated in the direction of the spiral edge of the umbilicus, rather less than their own length apart; septa moderately numerous, their edges with a slight, shallow forward wave in the middle of the periphery, (generally one septum coinciding with each tubercle, and one 
between each pair, but not regularly, ) moderately and evenly convex; siphon large, central. Surface of the inner whorl coarsely striated spirally, the outer whorls smooth, with very faint, transverse lines of growth, having a broad backward wave on the periphery; form of section of whorls almost regularly elliptical, the acute lateral ends coinciding with the edge of the umbilicus. Diameter of average specimen two inches nine lines, antero-posterior diameter of mouth ${ }_{100}^{40}$, width of ditto $\frac{84}{\mathrm{ivo}}$, diameter of inner edge of umbilicus $\frac{3 .}{500}$, width of exposed portion of penultimate whorl $\frac{14}{100}$.

This exceedingly rare species is distinguished completely from the $N$. tuberculatus by the great thickness, or width of the mouth as compared with the diameter, the much more rapidly enlarging whorls, much deeper and narrower umbilicus, direction of the flattening of the tubercles, acutely elliptical form of the transverse section of the whorls, and forward instead of backward wave of the edge of the septa at the middle of the periphery. The external form is almost exactly that of the $N$. cariniferus except for the tuberculations of the edge of the umbilicus.

Position and Locality.-Very rare in the carboniferous limestone of Lowick, Northumberland.

\section{Nautilus costato-coronatus ( I $\left.^{c} \mathrm{Coy}\right)$. Pl. 3. H. fig. $15^{*}$. \\ Ref.-M드, Ann. Nat. Hist. 2nd Series, Vol. XII.}

I give this provisional name to a fragment too imperfect to allow of full deseription, but so strongly marlied, and unlike all described types, that I wish to call attention to it. The franment is seven lines long, and is divided into seven equal chambers with simple edges; the surface exposed is the periphery, which is broadly rounded, moderately and evenly convex, the sides divided into large conoidal tubercles, each tubercle on one side coincides with one chamber, and there are two chambers between each pair of tubercles; the width of the periphery in our specimen is six lines, and it is marked with ten narrow, equal, cord-like, closely tuberculated ridges, separated by slightly wider flat spaces.

It strongly resembles the $N$. tuberculutus, Sow., but is distinguished by the costellation of the surface.

Position and Locality.-Very rare in the carboniferous limestone of Lowick, Northumberland.

Explanation of Figure.-Pl. 3. H. fig. 15*, periphery of fragment, natural size.

\section{Nautilus (Discites) discus (Sow.)}

Ref.-Sow. Min. Con. t. 13.

Disc-Discoid, much compressed laterally; spire of about three whorls, entirely exposed in the shallow, very wide umbilicus; sides flattened, scarcely convex; umbilicus almost vertically sloped, with a rounded edge; periphery very narrow, deeply concave, bounded by two acutely angular keels; septa moderately numerous, with a deep backward lobe on the periphery, and a larger one on each side; last chamber occupying about half of the last whorl. Diameter about seven inches, proportional diameter of umbilicus $\frac{40}{110}$, antero-posterior diameter of

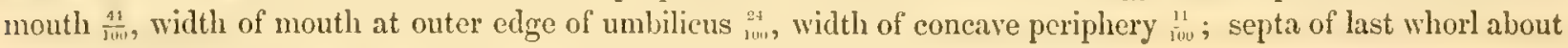
four and half to three and half lines apart at middle of sides of last chamber.

I have not been able to see any portion of the surface, nor the siphuncle of this species; the latter, however, is represented at about half way between the centre and the inner edge, by Sowerby. Under the head $\Lambda$. trochlea I have given the distinctive characters of the two species. See also $N$. complanatus (Sow.).

Position and Locality.-Rare in the carboniferous limestone of Kendal, Westmoreland.

\section{Nautilus globatus (Som.)}

Ref. and Syn.-Sow. Min. Con. t. 481. =N. Wrighti Flem. Brit. Anim. p. 230.+ N. bistrialis Phill. Geol. York. Vol. II. t. 17. f. 21. (young).

Desc.-Very globose, greatest width near the edge of the umbilicus, which is tumid, and abruptly rounded; periphery broadly rounded with a nearly semicircular section; whorls two and half or three, very rapidly 
cnlarging, their edges exposed in the very deep narrow umbiliens; first whorl an oblique, obtusely pointed cone. reticulated by strong spiral and transverse strie (two or three of which seen on the edge of the umbilicus gave rise to the species $N$. bistrialis of Phillips); the spiral stria disappear on the large whorls which are almost smooth, or marked with slight lines of growth; mouth transversely reniform, obtusely rounded at the sides, and having a deep semielliptical sinus in the middle of the edge when perfect, as also indicated by the lines of growth. Septa moderately numerous, evenly convex, with simple transverse edges ; siphuncle large, central. Diameter of moderate specimen two inches one line, proportional width of mouth $\frac{83}{100}$, antero-posterior diameter of mouth $\frac{10}{100}$, diameter of umbilicus $\frac{29}{100}$.

Some of the internal casts shew a small mesial ridge in parts of the periphery. The umbilicus is a little wider in proportion in the young shells.

Position and Locality. - Very rare in the dark carboniferous limestone of Poolwash, Isle of Man; not very uncommon in the carboniferous limestone of Lowick, Northumberland; rather rare in the Ulack beds over the main limestone of Derbyshire; very rare in the limestone of Kendal, Westmoreland.

\section{Nautilus ingens (Mart. Sp.) \\ Ref. and Syn.=Conch. Naut. A. ingens Martin, Pet. Derb. t. 31. = Nautilus id. Phill. Geol. York. Vol. II. t. 18. f. $4+N$. pentagonus Sow. Min. Con. t. 249. f. 1 .}

Desc.-Discoid, gibbous, of about four whorls (rarely more than one and half preserved), about one half of each whorl of the spire concealed by the involutions; umbilicus wide, usually with sloping sides, and then defined by an obtuse angulation from the sides of the shell, or (in other specimens, or other parts of same specimen) moderately convex and undefined; volutions thick, sides either very convex or slightly flattened; periphery either broadly rounded or obtusely carinate along the middle; edge of the mouth with a rounded, angular sinus in the middle; septa simple, moderately convex; siphon nearly central, a little nearer the inner than the outer margin. Dimensions of small specimen, diameter five inches, proportional

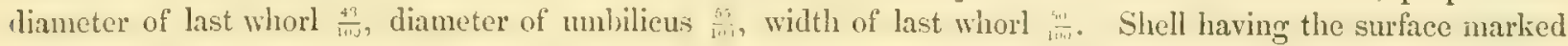
with fine, obsolete, transverse lines of growth. Last few septa, with a diameter of one inch and half, four lines apart; with a diameter of four inches, one inch apart. Adult diameter about nine inches.

The examination of a great number of large specimens induces me to propose the union of Nautilus pentagonus (Sow.) with this species, because out of a great number of specimens with rounded periphery, some have the inner whorls convex on the sides, and the outer ones flattened, and there are all gradations between the broadly rounded periphery of the true $N$. ingens, and the keeled exterior of the $N$. pentagonus; but it curiously happens that the two widest extremes which $I$ have seen are at the two ends of one large fragment from Closeburn, which in itself would set the question completely at rest; further, this latter specimen so strongly lieeled in its unseptate portion, shews the impression of simply rounded whorls of the spire on its inner margin.

Position and Locality.-Common, of large size, in the impure limestone of Lowick, Northumberland; common in the red carboniferous limestone of Closelurn, Dumfricsshire; rare in the carboniferous limestone of Kendal; rare in the carboniferous limestone of Derbyshire.

\section{Nautilus Luidi (Martin).}

Ref. and Syn。=Conch. N. A. Luidi Martin, Pet. Derb. t. 35. f. 1, 2.

Desc.-Discoid, of two and half gradually increasing whorls, not embracing; (centre pervious;) mouth transversely oval; periphery very broad, convex, sides narrow, rounded, sloping rapidly with slight convexity, to form the wide umbilicus. Entire surface marked with about thirty-six subequal, narrow, thread-like keels, slightly smaller on the sides of the umbilieus, scparated by wider, slightly concave, spaces; about five ridges in three lines on middle of body-whorl, at an inch and half in diameter, closer at smaller size, and fewer in [FASC. 111.] 
the same space when larger; all the ridges set with small spinulose tubercles, about as far from each other as the ridges are apart, and slightly extended transwersely so as to form indistinct rows across the whorls, nearly direct on the sides, and with a slight backward wave on the periphery. Septa moderately coneave, with nearly simple edges, having a slight backward wave on the prominent middle of the sides, nearly direct across the periphery. Diameter of rather small specimen one inch six lines; proportional antero-posterior diameter of last whorl ${ }_{100}^{25}$, diameter of inner edge of umbilicus $\frac{45}{100}$, width of penultimate whorl $\frac{12}{110}$, width of mouth (greatest at middle) $\frac{4 t}{160}$.

This species seems to be liable to considerable variation in form from pressure, and especially a flattening of the sides, which, however, is certainly not the normal form. I have not seen the siphon, but Martin places it a little within the outer edge.

Position and Locality.-Not very uncommon in the black beds over the main carboniferous limestone of Derbyshire

\section{Nautilus oxystonus (Phill.)}

Ref.-Phill. Geol. York. Vol. II. t. 22. f. 35, 36; de Kon. Anim. Foss. Bel. t. 49. f. 3.

Desc.-Lenticular, very much compressed laterally; greatest thickness at the edge of the small shallow umbilicus, from whence the sides slope, almost flatly, to the thin, very acutely carinated periphery; whorls about four, their edges distinetly visible in the umbilicus; the mouth very elongate, lanceolate, embracing three-fourths of the sides of the penultimate whorl. Surface of inner whorl spirally sulcated, of the outer turns smooth, or with extremely fine, obsolete transverse lines of growth, having a very strong forward wave in the middle, and a small, slightly marked one at the sloping edge of the umbilicus. Internal casts shew the septa strongly arching forwards from the umbilicus to a flat, solid band, about two or three lines wide, produced by the internal cavity not quite reaching the edge; the last chamber occupies rather less than half the last whorl, and is marked by a narrow, deep sulcus, a little on the inner side of the middle, produced apparently by a corresponding ridge on the interior of the shell, of which there is no trace on the outside. Diameter of average specimen three inches, proportional antero-posterior diameter of mouth to the lateral edges the umbilicus $\frac{5}{1 \text { min, }}$, width of umbilicus $\frac{5 n}{10 u}$, greatest transverse diameter of mouth about $\frac{10}{100}$, distance of the septa in the last whorl from each other tro and a half lines.

I have not been able to observe the siphuncle in this species, but according to de Koninck it is very small and nearly central a little outside of the middle. The inner whorl is scarcely embraced by the succeeding one, is not compressed, and has a broad, convex periphery; the next has a much more acute periphery, and is correspondingly embraced by the succeeding turn.

Position and Locality.-Rare in the carboniferous limestone of Lowick, Northumberland.

\section{Nautilus (Discites) Quadratus (Flem.)}

Ref. and Syn.-Flem. Brit. Anim. = (N. bicarinatus M. V. K. Geol. Russ. t. 25. f. 10. =N. Ternenilanus d'Orb. Prod. p. 110.) $=$. subsulcatus Phill. Geol. York. Vol. II. t. 17. f. 18 and 25; Geol. Trans. Vol. V. t. 40. f. 7 ; de IKon. Anim. Foss. Bel. t. 30. f. 6 ; t. 47.f. 9 ; t. 49. f. 4 .

Desc.-Discoid, compressed, of little more than two volutions; section of the whorls subquadrate; the sides and periphery nearly equal in width, flattened, and at right angles; the sloped sides of umbilicus very steep, and about as wide as the inner margin between them; periphery usually flat in the middle, and very slightly sloping at the sides towards the lateral angles, each lateral fourth bearing from one to five fine thread-like ridges (most usually the former number); sides sometimes nearly flat, on the half near the umbilieus moderately convex ; and the outer half moderately concave; but many specimens having each side obtusely ridged along the middle by two broad shallow sulci, while a few rare specimens have the sides divided into five coarse, subequal ridges, by three wider concave sulci; occasionally also the middle part of the periphery more prominent than the lateral 
thirds, and concave (sometimes all these varieties in a single specimen). Surface crossed by very minute sigmoid stric on the sides, arched backwards on the inner half, also strongly arehed backwards on the middle of the periphery (where in perfect preservation the transverse strie are crossed by minute spiral ones under the lens). cepta moderately numerous, their edges gently arehed backwards on the sides and periphery; body chamber nccupying half of the last whorl; siphon small, close to the outer edge. Diameter one inch seven lines; proportional thickness, or width of mouth at edge of umbilicus, $\frac{35}{100}$, width of periphery $\frac{31}{10 u}$, diameter of inner edge of umbilicus ${ }_{100}^{45}$, antero-posterior diameter of mouth ${ }_{100}^{82}$, distance of septa apart in last whorl one line.

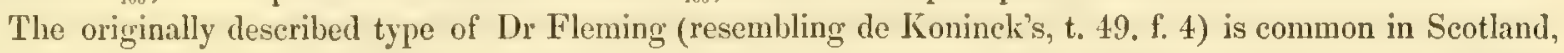
and has the periphery almost or quite as wide as the sides, its lateral keels being very fine, and the lateral fourths not perceptibly sloping; the sides also being flat and without distinet sulci; the passage, however, is imperceptible between such specimens and those with an obtuse spiral ridge in the middle of each side; and from these again into the forms with the lateral fourths of the periphery sloping, lcaving the middle half elevated and concave. The variety with five sulei on the sides is very rare, but one of the lowick specimens combines most of the above varieties; and having the middle of the periphery elevated and channelled on the inner whorls, but flat on the outer ones, shews that this difference is independent of age. Like many of this subgenus (Discites) the body-whorl in old specimens is slightly disjoined.

Position and Locality.-Common in the carboniferous shale of Craige, Kilmarnock; carboniferous limestone of Lowick, Northumberland.

\section{Nautilus. (Discites) sulcatus (S'on.)}

Syn. and Ref.-Sow. Min. Con. t. 571. f. 1 and 2; Phill. Geol. York. Vol. II. t. 22. f. 31, 32; ?= (N. sulcifer $+N$. dorsatus) L'Ev. Mem. de la Soc. Geol. de France, Vol. II. t. 2. f. 1 to 4.

Desc.-Discoid, moderately compressed ; of two and a half gradually increasing whorls, completely exposed in the deep, almost vertical-sided umbilicus; greatest thickness of the whorls at the edge of the umbilicus, from whence the sides gradually converge to the sharply-defined, narrow periphery, which is moderately concave between the two bounding kcels; the outer half of each side of the whorls is occupied by two deep, concave, spiral sulci, each only slightly narrower than the periphery, the inner more prominent half of each side, towards the umbilicus, seems simple in ill-preserved specimens, but is split into three equal ridges by two narrow sulci in all moderately well-preserved examples; all the sulci indistinct near the mouth of old specimens. Surface crossed by very fine, transverse striae of growth; retroflexed on the periphery and on the middle of each side, the flexures strongest in old specimens; last chamber occupying half of the body-whorl; septa moderately numerous. Diameter of average specimen one inch seven lines, proportional antero-posterior diameter of mouth

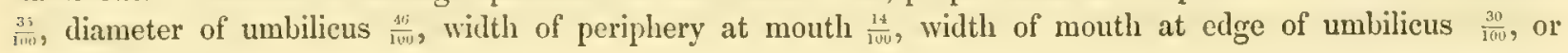
slightly more.

This species is easily distinguished by its narrow, sharply-defined periphery, and the two very broad and two small spiral grooves on each side. All authors describe the siphon at some point between the centre and outer margin, but I have not been able to see it.

Position and Locality.-Rare in the carboniferous limestone of Kendal, Westmoreland.

\section{Nautilus (Discites) trochlea (McCoy). Pl. 3. H. fig. 16.}

$$
\text { Ref.-Mc } \mathrm{M}^{\mathrm{C}} \mathrm{Cy} \text {, Synop. Carb. Foss. Irel.t. 3. f. } 4 .
$$

Desc.-Discoid, of two and a half rapidly enlarging whorls, almost entirely exposed in an umbilicus, with vertical sides; sides of the shell nearly flat, sloping with slight convexity from the rectangular edge of the umbilicus to the narrow, deeply-concave periphery, which is bounded by two acutely angular edges; mouth widely trigonal, notched at apex by the concavity of the periphery; septa moderately numerous, having a broad backward curve on the sides, and a more abrupt one on the periphery, the two separated by an acute forward 
angulation on the lateral edge of each side; last chamber occupying nearly half of the body-whorl. Diameter five inches, proportional diameter of umbilicus ${ }_{16 n}^{36}$, antero-posterior diameter of mouth $\frac{41}{1+m}$, wilth of penultimate whorl $\frac{15}{100}$, width of mouth at outer edge of umbilicus ${ }_{100}^{28}$, width of concave periphery at mouth $\frac{14}{100}$.

This species (of which only a fragment of the body-whorl has heen hitherto figured) is distinguished from the $N$. discus (Sow.) by the much shorter and wider mouth, and smaller and deeper umbilicus, and the consequent much greater thickness, or less lateral compression, in proportion to the diameter.

Position and Locality.-Rare in the carboniferous limestone of Kendal, Westmoreland.

Explanation of Figures.-Pl. 3. H. fig. 16, side view of specimen, reduced one half linear; $16 a$, section natural size.

\title{
Nautilus tuberculatus (Sow.)
}

\author{
Ref.-Sow. Min. Con. t. 249. f. 4 ; Phill. Geol. York. Vol. II. t. 22. f. 29 ; M. V. K. Geol. Russ.
}

Vol. II. t. 25. f.' 12.

Desc.-Discoid, of one and a lalf or two whorls commonly preserved, inner whorls rery slightly concealed hy the following ones; greatest thickness at the edge of the periphery, which is very broad and gently convex, and usually marked along the middle of internal casts by a faint, cord-like, mesial ridge; edges of the periphery broadly flattened, slightly sloped towards the umbilicus, and divided into obtuse tubereles, which are cither conoidal or slightly elongated in the direction of the centre of the umbilicus, beyond this aren the inner margin of the umbilieus slopes with slight convexity very rapidly to the tubereulated edgre of the preceding whorl; about sixteen tubercles on each side of each whorl; the septa moderately convex, the edges moderately concave towards the mouth, hoth on the sides and periphery, forming a forward rounded angle on the line where the tubereles are placed; siphuncle very large, central; last chamber oecupying rather more than one-third of the last whorl. Width of mouth eleven lines, proportional antero posterior diameter of ditto $\frac{75}{100}$.

Our specimen only exhilits one septum, and the last chamber of this species, but it agrees perfectly with the chambered portions as figured by Phillips and Murchison, de Verneuil, and Von Keyserling, and tolerably well with the figure in the Mineral Conchology, with the exception of an apparent concavity in the periphery of the latter, and the want of the fine medial ridge. On writing to $\mathrm{Mr}$ Sowerby, however, he most kindly furnished me with exact measurements and outline of the original specimen, which agree exactly with our example, in the broadly-convex periphery, trace of the medial ridge, \&c. In the Geology of Russia a portion of the external shell is mentioned, proving the surface to have been marked by fine transverse lines of growth, arched backwards on the periphery, to correspond with the sinus in the outer lip. According to both those authorities there is a septum at cach tuberele, and one between each pair; and taking the entire dinmeter as 100 , the proportional diameter of the inner edge of the umbilicus is $\frac{45}{100}$ (to $\left.\frac{53}{200}\right)$, the width of the exposed portion of the penultimate whorl is $\frac{10}{100}$ (to $\frac{12}{100}$ ), the antero-posterior diameter of the mouth $\frac{33}{100}$ (to $\frac{37}{100}$ ), and the width thereof is ing; the proportions in brackets being those of Phillips's figure, the others from Murchison, de Verneuil. and Von Keyserling.

Position and Locality.-Rare in the carboniferous shale of Halifax.

$$
\begin{aligned}
& \text { Nautilus tuberosus ( } M^{\circ} C^{\prime} 0 y \text { ). Pl. 3. H. fig. } 15 . \\
& \text { Ref.-M['Coy, Ann. Nat. Hist. 2nd Series, Vol. XII. }
\end{aligned}
$$

Desc-Discoid, greatest width of the whorls at the angle bounding the periphery, which latter is very wide, moderately concave in the middle, and having the angle on each side undulated into large, obtuse, tubercles (about an inclu and half from tip to tip on last whorl); sides sloping rapidly with slight convexity to the umbilicus; mouth, subquadrate, angles rounded, inner side smaller than the other three. Diameter seven inches, nine lines; width of last whorl, two inches, two lines; width of periphery two inches, ten lines; at inner edge one inch, ten lines; diameter of umbilicus about three and half inches.

I have not distinctly seen the surface of this very large species, but it scems to be smooth. The comparative flatness and wilth of the sides, more quallate mouth, and deeply coneave periphery, easily distinguish it 
from the $N$. tuberculatus (Sow.), which is the only allied form. In the figure in the Mineral Conchology of Tautilus tuberculatus ( $t .249)$ there is an apparent concavity of the section of the periphery; but as this did not agree with the inner outline, I doubted its correctness, and on writing to $\mathrm{Mr}$ Sowerby he very kindly furnished me with the exact form of the section of the original specimen, proving that the periphery is convex, and regularly rounded, contrasting in the strongest manner with the present species, which also wants the medial line of the $N$.tuberculutus. I have only indistinctly seen the septa, which seem to be regular, moderately arehed, and rather close. The position of the siphon is unknown.

Position and Locality.-Very rare in the carboniferous limestone of Derbyshire.

Explanation of Figures.-Pl. 3. H. fig. 15, transverse section of whorl, natural size; fig. $15 \mathrm{a}$, view of periphery, reduced one half in diameter; fig. $15 \mathrm{~b}$, side viow of half of last whorl, reduced half a diameter.

\section{Genus. AGANIDES. See p. 401.}

\section{Aganides Barbotanus $(\boldsymbol{M}, V . K, S p \cdot)$}

Ref. and $s y n_{0}=$ Goniatites Barbotanus M. V. K. Geol. Russ. t. 27. f. 3 .

Desc.-Globose, whorls greatly embracing, umbilicus very minute, or closed; surface crossed by very fine, flat, slightly sinuous striæ; greatest thickness near the inner edge of the whorls; periphery very broadly rounded convex; sides very slightly convex, sometimes slightly compressed; mouth transversely lunate; septis moderately numerous; mid-lobe long, rather narrow, trifid, but not very deeply notehed, extending as far back as the upper edge of the first lateral sinus of preceling turn; first lateral sinus very large, muclı wider than the mid-lobe. semicircularly arched at its anterior extremity; first lateral lobe snall, linguiform, pointed, shorter than the mid-lobe, extending slightly farther back than the upper edge of the first lateral sinus; second lateral sinus as broad as the first, semicircularly arched into the umbilicus. Diameter 9 lines, diameter of umbilical depression $\frac{20}{100}$, width at inner edge of mouth $\frac{75}{100}$.

This species much resembles the Gomiatites micronotus and G. implicatus of Phillips, but is distinguished by its more globose form, hy the mid-lohe not extending within the level of the first lateral sinus on each side of the preceding septum. Our specimens have the depression marling the umbilicus slightly larger than in the figure of the Geology of Russsia; but as this character varies in all the allied species, I lave no doubt of the identity of the furm; the mid-lobe agrees exactly with the septa as represented on the above figure $3 b$, rather than with the magnified septum $3 c$, in being narrower and less deeply cleft than the latter. 'Two specimen: in the collection of Count Mliunster, marked Yorkshire, though more probably Isle of Man, bear the manuscript name Goniatites Verneuili.

Position and Locality.-Not uncommon in the black carboniferous limestone of Isle of Man; rare in the carboniferous limestone of Craige, near Kilmarnock.

\section{Aganides carbonarius (Son. Sp.)}

The original specimens in the collection, from the Culm limestone of Venn, Swimbridge, described by Sowerby under the name Goniatites carbonarius, in the Transactions of the London Geological Society (2nd Serjes, Vol. V.t. 52.p. 89), are fragments, the specific characters of which cannot be recognised; and the name (even if it had not been used by continental writers for a different species) should be erased from our lists.

\section{AGANIDES DIADEMa (Gold. Sp.)}

Ref. and Sym. = Goniatits (Ammonites) diedena (Gold.); Dumont, Dese. de Liege, 1. 356 ; Beyrich, Croniat. t. 2. f. 8 to $10 ; ?+$ Goniatites striolatus Phill. Geol. York. Jol. II. t. 19. f. 15 to 18.

Desc.-Discoid, periphery very convex, broadly rounded, sides gently convex, more or less flattened, the width being very variable (but greatest in the young of all varietics); umbilicus rather large, deep, with an angular, prominent margin, which is either smooth or crenulated by the ends of the transwerse strix: 
mouth semielliptical, deeply indented by the preceding whorl; surface crossed by transverse strix, very variable in size ( $\mathrm{six}$ in two lines on average specimens, one inch in diameter, but often finer), nearly direct and simple on the young whorls, but di- or tri-chotomous near the edge of the umbilicus on the old ones, in which they are gently sigmoid on the sides, and have a broad, shallow, backward wave on the periphery ; occasionally two or three constrictions on the cast, coinciding in direction with the strie. Septa : mid-lobe slightly broader than long, with diverging sides, trifid; the middle lobules less than half the length of the lateral ones, which are only half its whole length; first lateral sinus broadly rounded at the end, with sub-parallel sides narrower than the mid-lobe; first lateral lobe small, linguiform, pointed, a little longer than wide, scarcely exceeding the mid-lobe in length; second lateral sinus reaching nearly to the height of the first, extending with slight convexity into the umbilicus. Diameter of average specimen one inch two lines, diameter of umbilicus $\frac{34}{100}$, width of mouth at edge of umbilicus $\frac{56}{100}$ to $\frac{65}{100}$.

The extreme flattened varieties noticed on the continent have a width of mouth at umbilicus of only ${ }_{j 0 u}^{50}$, and a diameter of umbilicus of only ${ }_{100}^{20}$; these are generally large specimens. The thickest extremes have the umbilicus ${ }_{i 00}^{40}$, and the width of mouth at umbilicus $\frac{65}{100}$. Our specimens do not shew the septa distinctly, but in external characters are perfectly identical with the continental examples. Most foreign authors quote the Goniatites striatus of Phillips as a varicty of this species, of which his small figures are very possibly the young, but his figures 14 and 19 by no means agree with the species in question. The last chamber occupies nearly all of the last whorl. The greater compression, smaller umbilicus, finer strix, and want of the large tubercles on the edge of the umbilicus, distinguish this species from the A. Listeri.

Position and Locality.-Very common in the limestone nodules of the coal-shale near Halifax.

\section{Aganides Gilbertsoni (Phill. Sp.)}

\section{Ref. and Syn.=Goniatites Gilbertsoni Phill. Geol. York. Vol. II. t. 20. f. 27 to 31.}

Desc.-Lenticular, much compressed, sides gently convex, greatest thickness close to the umbilicus, sloping gently from thence to the periphery, which is narrow and rounded; umbilicus very minute, not exposing the inner whorls; surface nearly smooth, crossed with microscopic sigmoid strix. Septa close, regular; mid-lobe extremely wide, deeply bilobed, the intervening sinus bifid, oblong, a little longer than wide, and alone occupying the periphery; lateral portions of the mid-lobe broader than the sinus on the periphery, deeply bilobed, and placed upon the sides; first lateral sinus narrow, parallel-sided, rounded at tip, extending about as far forward as the end of the notch in the lateral part of the succeeding mid-lobe; usually two strong lateral spiral sulci on the casts coincide with the outer sides of the mid-lobe and first sinus; first lateral lobe of moderate length, elliptically pointed, obtuse, scarcely as long as the lateral parts of the mid-lobe; second lateral sinus hroad, strongly arched. Average diameter six and half lines, proportional diameter of umbilicus $\frac{10}{10}$, width of mouth at umbilicus $\frac{45}{100}$, width of periphery about $\frac{15}{100}$.

The septa of this species are very anomalous in any point of view, but less so if we view the bifid portion of the septa on the periphery, and the next bifid portions on the sides as parts of one great mid-lobe, as I have done above, than if we follow Professor Phillips, and consider the bifid peripheral portion as the homologue of the bifid mid-lobe of other species of the genus, which on this latter view would be directed towards the mouth instead of from it: the direction of the large second lateral sinus at the margin of the umbilicus is entirely in favour of my proposed mode of viewing these inflections.

Position and Locality.-Not uncommon in the black carboniferous limestone of the Isle of Man.

\section{Aganides Henslowi (Som. $S p$.)}

\section{Ref. and Syn.=Ammonites Henslowi Sow. Min. Con. t. 262.}

Desc.-Discoid, compressed, of five or six very gradually increasing whorls, entirely exposed in the very wide, shallow umbilicus; sides flattened, very slightly convex, with an abrupt, nearly vertical, narrow slope at the edge of the umbilicus; periphery as broad as the mouth at edge of umbilieus, evenly rounded, very convex; surface unknown; septa rather distant; mid-lobe large, very acutely angular, simply pointed, nearly as wide 
as the periphery at base; first lateral sinus broad, semielliptically rounded; first lateral lobe narrower than the first sinus, lanceolate, acuminate at the end, rery slightly passing the radial line; second lateral sinus resembling the first lateral lobe in size and shape; second lateral lobe larger than the rest, similar to the first in shape, but passing the radial line by rather more than half its width; third lateral sinus resembling the second in shape, but rather smaller; third lateral lobe smaller than the rest, less acutely pointed, and barely touching the radial line; fourth lateral sinus semielliptically pointed, a little exterior to the edge of the umbilicus. Diameter of average specimen four inches, proportional antero-posterior diameter of last whorl $\frac{43}{\mathrm{In}}$, diameter of umbilicus $\frac{40}{100}$, width of mouth $\frac{24}{100}$, diameter of penultimate whorl $\frac{18}{100}$.

The siphon of this species is not distinctly visible in the specimens in the collection, one of which formed the originally figured type of the species. The septa are remarkable for the near similarity of the lobes, and sinuses (= saddles of continental writers) in size and shape; the lobes are however rather more pointed. This is one of the few Aganides of the carboniferous period with simple mid-lobes.

Position and Locality.- Not very uncommon in the dark carboniferous limestone of Scarlet, Isle of Man.

\section{Aganides implicatus (Phill.)}

\section{Ref. and Syn.= Goniatites implicatus Phill. Geol. York. Vol. II. t. 19.f. 24, 25.}

Desc.-Discoid, sides gently convex, flattened, greatest thickness close to the umbilicus, which is very: minute, or almost obsolete; periphery very broad, obtusely rounded; surface nearly smooth, with very delicate, transverse strix, nearly straight on the sides near the umbilicus, slightly waved forwards near the edge of the periphery, and arched backwards on the middle of the periphery. S'pt $\alpha$ : mid-lobe oblong, twice as long as wide, trifid, the middle lobule very small, much shorter than the lateral ones, which are less than one-third the length of the mid-lobe; first lateral sinus much broader than the mid-lobe, widely rounded in front, the outer line diverging, but the inner one (common to the mid-lobe) parallel with that of the other side; the anterior end of the first lateral simus passes nearly one-third of the length of the succeeding mid-lobe in height; first lateral lobe small, triangular, pointed, with converging straight sides, scarcely equalling the mid-lobe in length; second lateral sinus little more than half the height of the first, and passing into the umbilicus. Diameter of large specimen one inch seven lines, diameter of umbilical depression $\frac{\mathrm{g}}{\mathrm{im}}$, width of periphery $\frac{\mathrm{gh}}{\mathrm{liw}}$, width of mouth at edge of umbilicus $\frac{41}{110}$ (greater in smaller specimens), $\frac{50}{100}$ at one inch three lines in diameter, $\frac{55}{1 n}$ at eleven lines in diameter.

The septa are remarkable for the parallelism of the sides of the mid-lobe and first lateral sinus on each side. and for the encroaching of these on each other in succeeding septa in such a way that there is often an appearance on casts of two parallel continuous spiral lines on the sides of the periphery.

Position and Locality.-Not uncommon in the carboniferous limestone of Poolwash, Isle of Man.

\section{Aganides Listeri (Mart. Sp.)}

Ref. and Syn.=Conch. Naut. Am. Listeri Martin, Pet. Derb. t. 35. f. 3.=Ammonites Listeri Sow. Min. Con. t. 501. f. 1; de Kon. Anim. Foss. Bel. t. 51. f. 4; Phill. Geol. York. Vol. II. t. 20. f. 1.= A. sacer Dumont $=A$. carbonarius Von Buch, Ueber. Amm. und Gon. t. 2. f. 9.

Desc.-Globose, subdiscoid, of about five rapidly increasing whorls; sides and periphery regularly arched, very convex; unbilicus large, conical, deep; mouth transversely reniform, greatest width at the edge of the umbilicus, which is marked with about twenty-two small rounded tubercles on each side of each whorl, from which short obtuse ribs extend about half-way down the umbilicus, the remainder of which is smooth; on the exterior each tubercle gives rise to a small bundle of two, three, or four obscure, obtuse, unequal ridges, having a broad shallow wave on the periphery, parallel to which are thicker constrictions on the casts, at distances of about a quarter of a volution; the external shell is thin, and, when preserved, shews a strong, transverse, subimbricating striation (about sixteen stria in two lines on large specimens, five of the internal ribs in the same space), crossed by some very faint, more distant, regular, spiral strix under the lens, slightly crenulating the transverse 
strix. Stpta: mid-lobe trifid, the lobules pointed, the middle one one-fourth the length of the lateral ones: first sinus large, semicircularly rounded at the end, with subparallel sides, twice as long as the indentation in the mid-lobes; first lateral lobe lanceolate-acuminate at apex, as long as the mid-lobe, but rather narrower than the first sinus; second sinus scarcely marked, about two-thirds the length of the first sinus, coinciding with the edge of the umbilicus, into which its outer side extends nearly at right angles with its inner one. Diameter of

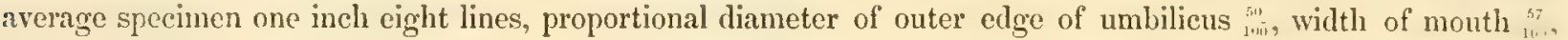
antero-posterior diameter of mouth $\frac{30}{110}$. A young specimen five lines in diameter has the umbilicus $\frac{\text { in, and }}{104}$ width of mouth ${ }_{100}^{65}$.

In very young specimens the umbilicus is rather larger, and the tubercles or crenulations on the edges give rise each only to one or two transverse ridges, which are more strongly marked and more sinuous than in the adult, and scem in this state to coincide with the Goniatites Mariamu, Murchison, Terneuil and Keyserling, Gen]. Russ. t. 27. f. $\alpha$. The substance of the shell is excessively thin, and on the exterior the fasiculate ridges are obscured by the transverse stria.

Position and Locality.-Not uncommon in the coal-shale of Halifax.

\section{Aganides reticulatus (Phill. Sp.)}

\section{Ref. and Syn. = Goniatites reticulatus Phill. Geol. York. Vol. II. t. 19. f. 26 to 32.}

A crushed fragment from the carboniferous limestone of Lowick, and two from that of the Isle of Man, possibly belong to this species, but shew no septa, and are too imperfect for description.

\section{Aganides spHziricus (Mart. $S p$.}

Ref. and Syn.=Conch. Naut. spharicus Martin, Pet. Derb. t. 7. f. 3 to 5 ; de Kon. Anim. Foss. Bel. t. 50. f. 9.

Desc.-Gilobose, subsphreroidal, very slightly flattened towards the umbilicus, which is small, very deep, rounded, and exposes the edge of the inner whorls. Septa: mid-lobe trifid, narrow, the middle lobule short, pointed, about one-third the length of the lateral ones, which are very acutely angular; first sinus broad, acutely angular, nsually olstuse at the tip, and not extending quite so far forward as the centre lobule of the succeding micl-lobe, about twice and half the length of the divisional sinus of the mid-lobe; first lateral lobe tonguesiaped, abruptly attenuated, and acutely pointed at the extrenity, scarcely exceeding the mid-lobe in length, al wont equal in width to the mid-lobe at base; second sinus obtusely rounded, not extending quite so far forward as the first, its outer margin extending with slight curvature into the umbilicus. Surface crossed by nearly direct, regular, transverse, fine, broad, flat, slightly imbricating strix, serrated on their free edge (about eight to ten strix in one line). Diameter of small specimen ten lines, proportional diameter of umbilicus $\frac{16}{100}$, width of transverse reniform mouth $\frac{97}{100}$, antero-posteriol diameter of mouth in middle $\frac{26}{30}$.

There is no trace in the typical Derbyshire specimens of the coarse spiral sulcation, represented in Prof. I'hillips's larger figure of the species; the transverse crenated strix, on the contrary, being strongly marked under the lens, and agreeing exactly with the surface of his Goniatites crenistria.

As M. d'Orbigny has found a more, and a less, compressed variety of most of the common Ammonites (indicating in his opinion the sexes of the species), I think there ean be little doubt of the propriety of uniting the A. spluericus with what Martin called the compressed variety thereof, and what Sowerby and other writers call the G. striatus; more particularly as I find that the first lateral sinus is pointed in both when well marked (contrary to the supposition of Phillips), and that the difference of length noted in the first lateral lobe by M. de Koninck as distinctive of the species, varies to the slight extent alluded to in different parts of one specimen. 


\title{
Var. $\beta$. crenistria.
}

\author{
Ref. and Syn.= Goniatites crenistria Phill. Geol. York. Vol. II. t. 19. f. 7, 8, 9.
}

$D_{e s c}$-Septa and striation as in the typical form, but the sides moderately compressed: and sometimes slight extensions of the serrated edges of the strixe form interrupted spiral lines. Average diameter one inch seven

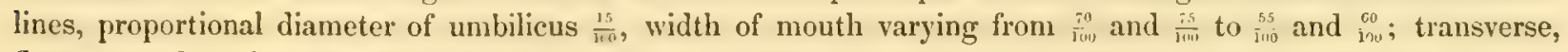
flat, serrated, strix averaging seven in one line, at middle of specimen one and laalf inches in diameter.

The only difference between this and the typical A. spharicus is the more compressed form, which the proportional measurements given above, of specimens differing little in size, shew to be very variable. I at one time thought the proportion of the mid-lobe which would be cut by a line connecting the apices of the first lateral sinus of each side, might serve to separate the species from the true sphoricus, but I now find that this character, depending on the closeness of the septa, varies irregularly in different parts of the one specimen.

The variety $\gamma_{0}$ striatus (A. striatus of Sowerby) is not in the collection; it only differs from the var. crenistria by having spiral strix stronger than the transverse ones; it has been united with the G. crenistria by de Koninck, with much propriety, I think. The Ammonites minutus Sow., supposed by de Koninck to be the young of the A. sphoricus, is a cretaceous fossil.

Position and Locality.-Common in the carboniferous limestone of Derbyshire; common in the carboniferous limestone of the Isle of Man.

\section{Aganides spirorbis (Gill. $S p$.)}

Ref. and Syn。=Goniatites spirorbis Gilb. Phill. Geol. York. Vol. II. t. 20. f. 51 to 55.

Desc.-Discoid, flattened, of seven and a half rounded whorls, moderately embracing, but leaving one half of their width exposed in the very wide shallow umbilicus; the innermost half whorl dilated, forming a Nautiloid nucleus; sides of the whorls very convex; edge of the umbilicus very narrow, abruptly rounded; mouth semielliptical, indented by the preceding whorl; periphery narrow, rounded. Surface crossed by fine transverse strix. Septa (indistinctly seen) : mid-lobe wider than long, with converging sides, and broad obscurely trifid extremity; first lateral sinus obtusely trigonal, rounded at the extremity, rather wider at base than long; first lateral lobe wide, rotundato-trigonal, shorter than the mid-lobe; second lateral sinus scarcely arched, nearly perpendicular to the edgre of the umbilicus, into which it runs. Average diameter from two to three lines, proportional width of umbilicus about $\frac{\hat{D}^{00}}{100}$, width of last whorl ${ }_{100}^{40}$.

Position and Locality.-Not very uncommon in the black carboniferous limestone of the Isle of Man.

\section{Genus. ORTHOCERAS. See p. 312.}

\section{Orthoceras (Loxoceras) Breyni (Mart. Sp.)}

Ref. and Syn.=Conch. N. Orthoceratites Breynii Martin, Pet. Derb. t. 39. (not of Sow. Min. Con.).

Desc.-Rapidly tapering (at an angle of about $14^{\circ}$ ); moderately depressed, section broad-oval. Septa from last chamber, to four lines in diameter, averaging five to six in the space equal to a diameter; very slightly oblique on the narrow sides, slightly higher or more anterior on one of the broad sides, which they cross with a scarcely perceptible wave towards the mouth; a little lower or more posterior on the other broadside, in the middle of which is a strong backward wave, near to which the siphuncle is placed on the conjugate axis. Siphuncle small, and a little within the margin, where it passes through the septa, but dilated between them into depressed spheroidal beads, about twice as wide as long, and touching the surface throughout the length of the shell; interior of the siphon traversed by a small continuous tube, attaclsed to the inner walls of the dilated portion by radiating, vertical, shelly partitions (about eight in a whorl), constricted by transverse stronger partitions in the middle of each dilatation (or intermediate between the septa). Surface (indistinct) apparently marked with fine, obtuse, transverse stria. The proportion of the long and short diameter of the [FASC, III.] 
section is as 100 to 85 . A specimen five inches long is one inch three lines wide at the large end, and two lines wide at the apex, the dilated part of the sighon at the latter point equalling the whole diameter of the shell, but being only five lines wide at the anterior end, where two chambers occupy a space of slightly less than half an inch, while six chambers occupy the same space at the smaller end.

The internal structure of the siphon is that of Actinoceras of Stokes, though it is marginal in position, and the septa are oblique. Sowerby's figure under this name has the septa too oblique and too close to agree accurately with the species.

Position and Locality.-Very common in the red carboniferous limestone of Closeburn, Dumfriesshire; rare in the dark carboniferous limestone of Isle of Man; common in the black beds overlying the main carboniferous limestone of Derbyshire, more rare in the underlying white beds; not uncommon in the dark carboniferous limestone of Lowick, Northumberland.

\section{Orthoceras (Poterioceras) condifonme (Sow.)}

$$
\text { Ref.-Sow. Min. Con. t. } 247 .
$$

Dese. - Very broad, ovate, short; chambered portion very rapidly tapering, obtusely conical; last chamber slightly shorter than the chambered part, abruptly constricted to a short narrowed neck near the mouth; greatest width near the last septum. Length of small specimen, imperfect at the apex, nine inches, width (probably increased from compression) seven inches, width of mouth five inches, distance of the septa from each other five to six lines, length of perfect last chamber four inches.

This species grows very much larger than the above measurements, which are taken from a specimen from which probably nearly two inches of the posterior end is absent, Mr Sowerby's figure giving very nearly the true proportions of the septate part. I am unable to say how much of the obvious compression of our specimens is natural; one of them shews very distinctly the new character of the narrow, contracted, neck-like mouth. I have not ascertained the position of the siphon, which, according to Mr Sowerby, is inflated between the septa.

Position and Locality.-Rare in the carboniferous limestone of Lowick, Northumberland.

\section{Orthoceras (? Poterioceras) connu-vaccinum ( $\left.M^{c} \mathrm{Coy}\right)$. Pl. 3. H. fig. 17.}

\section{Ref.-Mc Coy, Ann. Nat. Hist. 2nd Series, Vol. XII.}

Desc.-Conical, rapidly tapering to an obtusely rounded point, very slightly arehed; section perfectly circular throughout; septa very oblique, flattened, slightly convex, moderately approximate, extending much farther forward on the inner side of the general curve than on the outer or convex aspect, the lateral edges being very slightly sigmoidal; on account of their obliquity the septa are broad-oval in form, the longest diameter being in the antero-posterior direction; siphon large, about its own diameter within the outer edge (corresponding with the convexity of the general curve of the shell). Surface horny in appearance, marked with irregular, scratchlike, longitudinal markings, and fine, nearly regular, transverse, impressed strix, separated by rather wider, flattened spaces; thirteen transverse strix in two lines at an inch and quarter in diameter, about twenty in the same space at nine lines in diameter. Length of average specimen five inches nine lines; two inches three lines in diameter at the anterior end, and regularly tapering to the obtusely pointed apex in the above length; average distance of the last few septa two lines.

The above measurements are of average-sized specimens, although examples occasionally occur a couple of inches longer; the peculiar, slightly curved, obtusely pointed, rapidly tapering form, and peculiar, horny-looking texture, have suggested the specific name. The only described fossil it has any resemblance to is the Cyrtoceras Verneuilanum of de Koninck (Anim. Foss. Bel. t. 48. f. 6), but is easily distinguished by that species having a broad-oval, transverse section, while the section of the present fossil is perfectly circular, and the septa, which from their obliquity appear oval, have their long axes placed in the opposite direction; the curvature is also less in our fossil. Some of the specimens shew a very slight contraction at the mouth, which renders it 
probable that the species belongs to the subgenus Poterioceras, with which all the other characters agree exactly, and better than with any other section of Orthoceras.

Position and Locality.-Not very uncommon in the carboniferous limestone of Lowick, Northumberland.

Explanation of Figures.-Pl. 3. H. fig. 17, side view of septate portion of specimen (wanting the last chamber), reduced one-half linear; fig. $17 \alpha$, portion of ditto, natural size, to shew the striation of the surface; fig. 176 , end view of portion of ditto to shew the difference between the oval septa, and the circular section.

\section{Orthoceras CyLindraceum (Flem.)}

Ref:-Flem. Ann. Philos. Vol. V.t. 31. f. 3.

Desc.-Very gradually taperiug; section nearly circular; siphon large, nearly central; chambers numerous; septa very slightly waved; surface very minutely striated transversely. A specimen eight inches long is one inch five lines in diameter at the large end, and three lines in diameter at the imperfect small end; another fragment nearer the apex five lines in diameter at the large end and three inches long, is only one line and half in diameter at the small end; at from one to two lines in diameter there are three chambers in a space equalling the diameter; there are three chambers and a half in a space equal to the diameter in a specimen five lines in diameter, and four and a half in a diameter when the diameter is one inch.

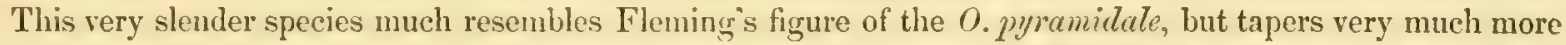
slowly, and has the chambers obviously more numerous. The septa of the O. inequiseptum of Phillips are represented considerably eloser than in this species. The original Devonshire specimens figured by Sowerby in the Geological Transactions ( 2 nd Series, Vol. V.t. 52. f. 6, 7) under the name 0 . cylindraceum are indeterminable fragments in the collection, and cannot be referred with certainty to this or any other species.

Position and Locality.-Rare in the black beds over the main limestone of Derbyshire; rare in the impure limestone of Lowick, Northumberland; rare in the carboniferous shale of Craige, near Kilmarnock.

\section{Orthoceras (Cycloceras) Flemingi $\left(M{ }^{c}\right.$ Coy). Pl. 3. H. fig. 18.}

$$
\text { Ref.-M당, Ann. Nat. Hist. 2nd Series, Vol. XII. }
$$

Desc.- Very gradually tapering; section (? broad-oval); siphon subcentral, large, slightly eccentric; septa numerous, moderately convex, one coineiding with each of the external rings; surface girt with close, obtuse, prominent, transverse rings, little more than their own thickness apart, nodulated by about fourteen or fifteen strong, longitudinal costre, slightly further apart than the transverse rings (so that the oblong, intervening spaces are wider than long) and nearly equalling them in thickness; both transverse rings and intervening spaces marked by strong, transverse, imbricating strie, six or seven between the centre of one transverse ring and the next. A specimen (fragment), five lines long and two lines in diameter at the smaller end, has twelve rings.

This species can only be confounded with the $O$. (C.) rugosum of Fleming, from which it is distinguished by its much more numerous and closer rings, fewer and larger longitudinal costa, stronger transverse strix, and large siphon, far removed from the margin.

Position and Locality.-Very rare in the carboniferous limestone of Lowick, Northumberland.

Explanation of Figures.Pl. 3. H. fig. 18, side view of fragment, natural size; fig. $18 \alpha$, surface of ditto magnified; fig. $18 b$, end view of septum, shewing position of siphon.

\section{Orthoceras (Poterioceras) fusiforme (Son.)

$$
\text { Ref.-Sow. Min. Con. t. 588. f. } 1 \text { and } 2 .
$$

Desc.-Slender, fusiform, gradually arched towards the apex; lateral outlines gradually tapering from the base of the last chamber to the apex, and very slightly tapering from thenee to the mouth; dorsal outline regularly and gently arched; ventral outline gradually arched from the base of the last chamber to the apex, but very abruptly sloping inwards, with slight convexity from thence to the mouth, which is thus much narrowed. Septa very numerous, with a slight sigmoid obliquity on the sides, crossing without wave at a more posterior 
level on the inner, or concave, side of the general curve, and advanced correspondingly forwards on the dorsal, or convex, side; septa, in the greater part of the length, about a line and a half apart; the penultimate chamber, as usual, being smaller than the rest, and the septa only a line apart when the diameter is reduced to half an inch, and increasing to two lines apart when the diameter is one inch; transverse section broadoval; siphon a little eccentric towards the inner or most posterior edge of the septa. Surface of the shell moderately thick, marked with fine transverse impressed strix, nearly parallel with the septa in direction, separatcd by flat spaces (about four in the space of one line). A verage length of last chamber one inch two lines, lateral diameter of ditto at base one inch four and half lines; antero-posterior diameter at mouth ten lines. A specimen with the above dimensions has the chambered portion four lines in lateral diameter at three inches from the base of the last chamber, and very slightly less in antero-posterior diameter.

This very elegant species can only be confounded with the rare $O$. (Poterioceras) ventricosum $\left(\mathrm{M}^{\mathrm{c}} \mathrm{Coy}\right)$, from which it is distinguished by its much more slender proportions. The last chamber is very commonly found apart, and owing to the sudden inward sloping of the ventral surface, the position of the siphon might very easily be mistaken, as what is really the concave face of the general curvature seens, in such a fragment, to be the exterior or convex side of the curve. The siphon is dilated between the chambers into spherical beads.

Position and Locality.-Not very uncommon in the carboniferous limestone of Lowick, Northumberland; jare in the red carboniferous limestone of Breedon, Leicestershire.

\section{Orthocerns (Campyloceras) Gesneri (Mart. Sp.)}

Ref. and Syn. = Conch. N. Orthoceras Gesneri Martin, Pet. Derb. t. 38. f. 1; de Kon. Anim. Foss. Bel t. 47. f. 4; (?) incurved young, Mart. ib. f. $2 ;=0$. Gesneri (Mart.) Phill. Geol. York. Vol. II. t. 21 . f. $6 ;=$ Cyrtoceras Gesneri de Kon. Anim. Foss. Bel. t. 60. f. 5 ; = C. tuberculatum M Coy, Synop. t. 4. f. 2.

Desc.- Very elongate, ennic, very gradually tapering (at about an angle of $7^{\circ}$ ) (? slightly arched in the young state towarls the posterior end); surface with from twenty-two to thirty-six strong, equal, regular, narrow, prominent ridges, regularly tuberculated, and separated by smooth, slightly concave spaces, averaging twice the width of the ridges (a little less in young, a little more in old stages of growth). Septa simple, moderately numerous; the penultimate and ante-penultimate little more than half the size of the preceding chambers; section nearly circular, most so in young specimens, very broad.oval, in old ones; siphon about twice its diameter from the elge in young specimens, and slightly more in old ones. A specimen, imperfect at each end, three and half inches long, and one inch cight and lialf lines in diameter at the large end, tapers to one inch four and half lines at the smaller; the septa average two lines apart, except the two preceding the last chamber, which are only one line apart.

There is much difference of opinion among authors as to whether the small slightly arched specimen figured by Martin (fig. 2) is the same species, or not, as his larger shell (fig. 1). M. de Koninck separates them generically; and I should at one time have done the same, but observing that the only difference hetween them is a slight curvature of the smaller ones, and the siphon of such specimens being very slightly nearer to the edge, I am led to the conclusion that the small specimens are merely the incurver posterior ends of the latger straight examples (somewhat as in the $O$. unguis), and the slight difference in the position of the siphon would probably admit of the same explanation, as we know that the siphon of Nautilus imperialis and others is marginal in the young, and gradually becomes nearly central with age; the difference in number of ridges which $I$ have mentioned above is independent of the size or other characters of the specimens. Since examining Derbyshire specimens of this species I perceive that Martin and Phillips have omitted the tuberculation which really exists on the fine ridges; and as my $C$. tuberculutum was founded on the presence of this character, it must now merge into the old species of Martin, as has been already recognized by M. de Koninck in his supplement.

Position and Locality.--Rare in the black marble beds of Derbyshire; rare in the carboniferous limestone of Kendal, Westmoreland; and in the carboniferous limestone of Poolwash, Isle of Man. 


\section{Oithoceras (Actinoceras) giganteum (Son.)}

Ref. and Syn. = Orthoceras giganteum Sow. Min. Con.t. $246=$ Actinoceras Simmsi Stokes, Geol. Trans. 2nd Series, Vol. V.t. 59. fig. 4 and 5.

Desc.-Tery large; section nearly circular; gradually tapering in most part of the length, but sometimes abruptly diminishing considerably in diameter in a short space; septa moderately convex, distant, but irregularly unequal in distance and in the direction of their edges, which most usually however are even, and at right angles to the long axis of the shell; siphon large, slightly (less than its diameter) eccentric, greatly dilated into depressed, spheroidal beads between the septa, each swelling twice as wide as long, and longitudinally marked with close, small, coarse, irregular plice; surface apparently smooth, or with very fine transverse strie of growth. Diameter of the dilated interseptal first siphon one inch when the shell is three and a half inches in diameter.

A small regular specimen, inperfect at each end, containing part of the last chamber, five inches in diameter at the large end, and sixteen inches long, is one inch eleven lines in diameter at the small end, where, for five inches, the septa are slightly more than half an inch apart; at four inches in diameter the septa are nine lines apart; one very unusual fragment, about four inches in diameter at the large end, and about five inches long, is two inches three lines in diameter at the small end, the tapering being so rapid that the profile of the sides is concave; the edges of the septa are slightly oblique, but unequally so, the two chambers nearest the larger end are only six and four lines wide between their septal edges, while the septa towards the small end are regularly nine to ten lines apart: in another specimen, one inch ten lines in diameter, the septa are regularly nine lines apart; the siphon where it perforates the septum of the large end is four lines in diameter, and three lines in diameter at the small end. Some compressed specimens, eight inches in diameter, have seven or eight septa in succession, one inch and half apart. Some perfect terminal chambers in the collection having only two or three of the penultimate chainbers adhering to then, shew the perfect last ehamber alone 13 inches in length, and rather more than a foot in diameter, the lateral measurements being exaggerated by compression. Sections shew the siphon, in some specimens, to be rather more eccentric at the small than at the large end, and each of the dilated portions between the septa to be divided in the middle by a transrerse partition; the space between the internal tube and the dilated wall being filled by vertical, fan-shaped, testaceous, radiating lamella. One very young fragment, imperfect at each end, one inch five lines in diameter at the small end, and two inches four lines at the larger, tapers very regularly, and has a regular, broad-oval section, with the small diameter $\frac{n 3}{200}$ of the larger, and has the septa four lines apart at the large end, and about haif a line less at the smaller.

This gigantic shell seems to lave the section more nearly circular in old specimens than in young ones; and in the former also the siphon is more nearly central; the size of the siphon varies very little with the diminution in size; so that the dilated portion occupies a much larger proportion of the small than of the large specimens. The septa are moderately convex, much less so generally than in Sowerby's large figure.

Position and Locality.-Very common and of great size in the dark carboniferous limestone of Lowick, Northumberland; very common in the red carboniferous limestone of Closeburn, Dumfriesshire.

\section{Orthoceras inequiseptum (Phill.)}

$$
\text { Ref.-Phill. Geol. York. Vol. 1I.t. 21. f. 7. }
$$

Desc.-Very gradually tapering; section very broad-oval, nearly circular; a specimen one inch long is four lines in greatest diameter at the large end, and two lines in diameter at the small end; lesser diameter at the large end one fourth of a line less than the greater diameter; septa very numerous, five occupying the space of one diameter in specimens varying from a little more than three to a little more than two lines in diameter (about four in a diameter when a little smaller), moderately coneave, their edges nearly even, and at right angles to the long axis of the shell, but very slightly waved; surface not distinetly seen, but apparently smooth; last chamber occupying half an inch of the above sized specimen; siphon moderately large, nearly central. 
This species is distinguished from the $O$. cylindraceum by the greater number of chambers in a space equal to the diameter at the same size. Mr Phillips's name and deseription indicate a disproportionately great distance between the septa of the young shell; but his figure, and the still younger specinens which I have examined, agree in having five septa to a diameter in the larger specimens throughout, and four, or slightly less, in a diameter when so small as two lines in diameter. The section is more nearly circular than in the $O$. ovale, and the septa much more numerous in a given space, at a given diameter.

Position and Locality.-Clare in the carboniferous limestone of Lowick, Northumberland; rare in the carboniferous limestone of the Isle of Man.

\section{Orthoceras (Loxoceras) Laterale (Plill.)}

Ref. and Syn.-Phill, Geol. York. Vol. II. t. 21. f. 8; Pal. Foss. f. $205 a($ not $c) ;=0$. subimbricatum Portk. Geol. Rep. p. 391. (not O. undulatum Sow. Min. Con.).

Desc.-Gradually tapering (at the rate of one and half lines in an inch, from five lines to two inches in diameter); section very broad, oval; septa moderately numerous (four in a diameter at half inch, and six to seven at one and half to one and three-fourths of an inch in diameter, eight in adult diameter of two and half inches), oblique, slightly sigmoid on the sides, crossing the anterior face with a very slightit forward convexity, and crossing the opposite face with a stronger backward wave on their posterior edge; siphon on, or nearly on the conjugate or smaller axis, a little eccentric (about half its diameter from the centre); surface crossed by fine, imbricating, slightly irregular strix (six in the space of one line); last chamber with a narrow constriction a little behind the edge of the mouth.

This large species tapers more gradually than the $O$. Breynii, to which it is allied, and has the wave on the more posterior edge of the septa less strongly marked; it is also closely allied to the $O$. undulatum of Sowerby, with which Phillips supposed it identical, but from which Col. Portlock distinguished it by the very tangible characters of the much less approximate septa at a given size, and the more nearly central siphon.

Position and Locality.-Rare in the carboniferous limestone of Derbyshire; not uneommon in the carboniferous limestone of Lowick, Northumberland; rare in the carboniferous limestone of Kendal, Westmoreland.

\section{Orthoceras ovale (Phill.)}

\section{Ref.-Phill. Geol. York. Vol. II. p. 238; M. V. K. Geol, Russ. t. 25. f. I.}

Desc.-Very gradually tapering; section very broad, oval, or almost circular; septa with simple edges, and a scarcely perceptible obliquity; siphon moderately large, almost central, or less than half its diameter eccentric towards the most posterior edge of the septa; shell thick; surface nearly smooth, crossed by very minute, close, slightly flexuous strix of growth (twenty-six in a space of one line) under the lens. A specimen one inch three lines in diameter at large end, and three inches long, is one inch in diameter at the smaller broken end (two and half inclies being occupied by the last chamber); there are three interseptal spaces in a diameter when it equals eleven lines, and the same number in a diameter when the latter is five lines.

This species is distinguished from the $O$. inequiseptem and other allied forms by the greater distance which the septa are apart at any given size. There is a strong constriction about half an inch wide, at one-third the length of the last clamber from its anterior edge. The description in the Geology of Russia is correct, but the figure places the siphon too far from the centre; according to that work also there are rather less than three interseptal spaces in a diameter when that equals eight millemetres (or about four lines). The 0 . affine of Portk. (Geol. Rep. t. 27. f. 9) seems to belong to the same species.

Position and Locrlity.-Not uncommon in the carboniferous limestone of Poolwash, Isle of Man; carboniferous limestone of Molerstang. 


\section{Orthoceras (Trigonoceras) PaRadoxicum (Sow.) \\ Ref.-Sow. Min. Con. t. 457 .}

Desc.-Rapidly tapering, abruptly incurved towards the smaller end, forming about half of a volution ; external face gently concave, bounded by strong angles (slightly less than rectangular); lateral faces equal to the external one in width, converging to a strong keel along the middle of the inner face, the outer half of the lateral faces flattened, the inner half of each abruptly rounded nearly to a quarter of a circle; surface under the lens marked with minute, subequal, slightly flexuous longitudinal stria (about thirty in the space of two lines); a few stronger longitudinal ridges on the lateral keels of the external face; lines of growth indistinet, broadly arched backwards on the external face, and converging at a very acute angle, directed backwards, on the internal keel. A specimen of last chamber, imperfect at each end, two inches long, has the lateral faces one inch four lines wide at the large end, and one inch wide at the smaller, the exterior face being one inch three lines wide at the large end; septa moderately convex; siphon a little eccentric towards the external side.

I have seen only one perfect specimen, in the collection of my friend the late Major Sirr: it exhibits the inrolled posterior extrenity above alluded to. The specimen in the University collection shews the striation of the surface preserved, which I had not seen before.

Position and Locality.--Rare in the dark carboniferous limestone of the Isle of Man.

\section{Orthoceras (Cycloceras) Rugosum (Flem.)}

Ref.-Fleming, Thomson's Annals of Phil. Vol. V. t. 31. f. 9.

Desc.-Subcylindrical, and nearly straight when old, abruptly and irregularly tapering, and moderately curved towards the small end; section circular; surface girt with equal, obtusely rounded, very prominent, irregularly waved, slightly oblique rings (having two septa in the space between each pair of rings); interannular spaces flat, and slightly more than twice the thickness of the rings in width; rings nodulated by the crossing of about twenty-six equal, filiform, slender, tuberculated ridges, separated by flat spaces, nearly twice their width, such spaces being at least twice as long as wide (four ridges and three intervening spaces equalling the space from the centre of one transverse ring to the other); septa moderately convex; siphon very minute, close to the margin (coinciding with the convex aspect of curved specimens, and at the higher edge of the septa and external rings). Specimens five lines in diameter have their rings two lines from centre to centre; specimens one inch in diameter have their rings on the sides, about tlıree lines from centre to centre, but five lines on the exterior, and only two lines on the inner aspect of curved specimens.

This species tapers so irregularly, and the fragments are so short, that any measurements of their proportions would be deceptive. Some of the large specimens shew traces of very fine, close, transverse strix.

Position and Locality.-Rare in the black marble beds over the main limestone of Derbyshire; rare in the carboniferous limestone of Lowick, Northumberland.

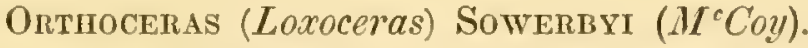

Ref. and Syn. = O. undulatum Sow. Min. Con. t. 59. (not of Schlot. nor O. laterale Phill.).

Desc.-Gradually tapering at the rate of about two lines in one inch; section usually oval, but the amount and direction of the compression variable. Septa very approximate, oblique, very slightly waved forwards on one side, and backwards on the other, with a slight sigmoid curve on the sides; moderately coneave, averaging ten interseptal spaces in the mean diameter, when that varies from one inch and half, to one inch; siphon moderately large, about one sixth of the diameter from the most posterior edge. Surface marked with minute stria of growth, obliquely inclined in the opposite direction to the septa.

The compression of this species being so variable, and all our specimens having the siphon on the transverse, instead of on the conjugate axis, I am inclined to believe the elliptical section in some measure 
accidental. I have been obliged to give a new specific name to this species, as Phillips's 0 . luterale proposed as a substitute (in consequence of Sowerby's specific name having been previously used by Schlotheim) differs from the true species of Sowerby in having much more distant septa, and more nearly central siphon. To the present species may probably, however, be referred the $O$. imbricatum from Marwood, figured in Phillips's Palæozoic Fossils, which is probably distinct from the Silurian one of that name. In the present shell specimens having the long diameter one inch seven lines, have eleven septa in that space, but the shorter diameter at the same point being only one inch five lines, there are only ten septa when compared with it; in most specimens, the mean between the long and short diameters will equal ten interseptal spaces throughout, at least down to a diameter of eight lines. There is a slight constriction near the anterior end of the last chamber.

Position and Locality.-Not very uncommon in the carboniferous limestone of Lowick, Northumberland; rare in the carboniferous limestone of Closeburn, Dumfriesshire.

\section{Orthoceras (Cycloceras) undatum (Flem.)}

Ref. and $S y n .=0$. undata Flem. Ann. Philos. Vol, V.t.31, f. $7=$ O. annulatum Phill. Geol. York. Vol. II. t. 21. f. 9, 10 (not of Sow., subsequently O. lineolatum Phill. Pal. Foss.); ?= O. dactyliophorum de Kon. Anim. Foss. Bel. t. 47. f. 2.

Desc.-Conoidal, rather rapidly tapering; section very broad-oval, nearly circular; septa very convex, distant; siphon of moderate size, almost exactly central, or less than half its diameter, eccentric towards the upper broad side. Surface marked with very slightly oblique, strong, prominent, rounded rings, with a faint sigmoid undulation on the sides; interannular spaces considerably broader than the rings; two interannular spaces, or two rings, between each pair of distant septa; usually five interannular spaces in a space equal to the diameter (rarely half an interannular space, more or less); surface, when well preserved, marked with fine, sharp, transverse strix (nine or ten from the centre of one ridge to the next); the rings seem to become partially obsolete at the anterior end of old specimens of an inch and half in diameter. One specimen, two inches eleven lines long, and one inch six lines in diameter at anterior end, tapers regularly to seven and half lines in diameter at the smaller imperfect end; the proportion of the lateral to the antero-posterior diameters of the section are as one hundred to ninety.

Most of the specimens seem smooth, as the Rev. Dr Fleming describes them, but when well preserved they are distinctly striated transversely, and all the smooth specimens manifestly want the external surface. Prof. Fleming alludes to an "obscurely striated epidermis," which may be a portion of the true surface, and it is just possible that his $O$. sulcata may belong to the same species, although it tapers more slowly than any thing I have seen of this type.

Position and Locality. - Not very uncommon in the carboniferous limestone of Lowick, Northumberland; rare in the black beds over the main carboniferous limestone of Derbyshire; not uncommon in the coal-shale near Glasgow. 


\section{SECT. X.-VERTEBRATA OF LOWER PALEOZOIC ROCKS (Cambrian and Silurian).}

\section{4th Sub-kingdom. VERTEBRATA.}

Body symmetrical, supported by an internal skeleton, composed of a median, dorsal, spinal column, formed of numerous vertebre or joints, which protect a continuous spinal cord, from the side of which the nerves of sensation and voluntary motion are given off to supply the body; the anterior end of the spinal cord is dilated into a large mass or brain, inclosed in a skull or dilated modification of the four anterior vertebra. Mlouth anterior, provided with two jaws acting rertically in the line of the body, the lower jaw below or behind the upper. Blood red, from rounded disks; one muscular heart below, or in front of, the osophagus and spinal cord. Respiration by gills, or lungs, supplied with water or air through the mouth. Sexes separate.

The greater number have two pairs of limbs for locomotion, but never more. The bones are vascular, and continue to grow and be absorbed during life by the action of internal ressels (unlike the hard parts of Incertebrata), developed from cartilaginous or fibrous internal tissue hardened by phosphate of lime, \&c.

This sub-kingdom contains four Classes: 1st, Pisces; 2nd, Reptilia; 3rd, Aves; 4th, Mammalia.

\section{1st Class. PISCES.}

The fishes form the lowest class in general organization of the Vertebrete, and were probably the first created examples of that sub-kingdom. They live in water and breathe by gills. The blood is cold and with rather large disks; the heart normally of one auricle and one ventricle. The bones have less earthy matter than in the other classes, and sometimes none; the Purkinjinian cells are long and slender. The limbs, when they exist, are developed only in the form of paired fins; the skull is frequently an undivided cartilage-like box, and in several groups the spinal column remains during life a continuous mucous cord, undivided into vertehral centres or joints, resembling the foctal condition of these parts in the other groups; in many fishes, however, both head and spine are ossified and divided into all their elementary parts. It is not the lowest types. in general organization, which retain in the adult state this embryonic condition of the skeleton.

The classification of Fishes by M. Agassiz, into Cyeloid, Ctenoid, Ganoid and Placoid, is now found by anatomists to be so very imperfect that it is abandoned almost universally, and some modification, such as the following of Müller's arrangement, is usually adopted. Only the two highest groups in the scale are found in the Palæozoic Rocks.

Tribes:-1st, Leptocardii; 2nd, Cyclostomata; 3rd, Teleostea (=Cycloida + Ctenoida Ag.); 4th, Ganoidu: 5th, Placoida; 6th, Syrenoidea.

\section{5th Order. Placoida.}

$S_{y n}=($ Placoida Ag.-Cyclostomata $)=($ Chondroptérygien Cuv. -Accipenseridec $)=$ Elasmobranchii Miill.

Endo-skeleton cartilage-like (mucous), the skull of one undivided box; bodies of the vertebre large, processes small; exo-skeleton never scaly, often of osseous points, plates or spines. Teeth with large bases [FASC, III.] 
without osseous adherence to the jaws, as in other fishes, nor placed in alveoli, succeeding each other from behind forwards by the rotation of their basal membrane; heart with a muscular bulbus wrteriosus with many rows of valves; intestine straight, with an internal spiral valve.

Owing to the softness of the skeleton, it is only disjointed teeth, bony fin-defences, and rarely integument and vertebre, which are usually found fossil. In some sharks the discoidal bodies of the vertebre are ossified, but the spinous processes are not.

Fossil teeth of sharks were anciently called Glossopetra; those of Cestracions and Pycnodonts were called Bufonites.

The Order is divided into two Tribes:-1st, Holocephala; 2nd, Plagiostoma.

Examples of the Order are found recent in all latitudes, and in most formations from the Palrozoic inclusive.

\section{2nd Tribe. Plagiostoma.}

This Tribe, containing the whole groups of Sharks and Rays, is easily distinguished from the IIolucepllorle by the jaws, which bear the teeth, being loosely suspended, and moveable from the rest of the head. The bodies of the vertebree usually form distinct discoid joints; the gills open to the external water in the adult by a row of apertures on each side. They are all exclusively marine.

There are two families:-1st, Squalida or sharks; 2nd, Rajidw or rays.

\section{1st Family. SQUALIDE.}

Body elongate, fusiform, slightly compressed, slender, passing insensibly into the thick fleshy tail; gillapertures lateral; pectoral fins of small or moderate size.

There are four Sub-families:-1st, Squaline; 2nd, Hybodontinas; 3rd, Cestracionince; 4th, Squatina.

The two following fossils cannot be satisfactorily referred to their subfamilies.

\section{Titelodus parvidens $(A g$.}

Ref.-Ag. Sil. Syst. t. 4. f. 34, 35, 36; $\mathbf{M}^{\mathrm{c} C o y, ~ Q u a r t . ~ G e o l . ~ J o u r n a l, ~ V o l . ~ I X . ~ p . ~} 14$.

Dese.-Very small quadrate granules, each averaging about one-third of a line in diameter; height about equal to half the diameter; angles and lateral edges obtusely rounded; upper surface flattened, highly polished (usually of a bhek colour); under surface slightly smaller than the upper one, not covered with ganoine, separated from the upper portion by a deep encircling lateral constriction; in the middle of the under surface is a rounded pit, equalling one-third of the whole diameter, penetrating as a conical eavity nearly to the upper surface, being widest below. Vertical sections shew in the mieroseope very loose, tubular, slightly waved tissue, the lines arching upwards and outwards from the base, and from the sides of the conical internal cavity towards the part of the granules above the lateral constriction, becoming indistinct at a short distance from the polished surface.

In a short memorandum written by me for Sir R. Murchison, (on the supposed Fish remains in his Silurian System) and published in the above volume of the Geological Journal, I made the following observations, "All the specimens of the Downton Castle rock which I have examined, impress me strongly with the conviction that the last name on the list, the Thelodus parvidens, should be considered not as that of a fish-tooth, but of granules of the skin or shagreen of the same fish, in all probability, of which fragments of the bony dorsal rays (Onchus tenuistriatus) are so commonly intermingled in the same mass. MI. Agassiz, judging only from the drawing (figs. $34,35,36$, supposed these magnified and isolated specimens to resemble teeth of the general character of Lepidotus; but one glance at the specimens would dissipate this notion, when we find that they are square and not rounded, that they are as small as grains of fine sand, and oceur in such great abundance over large patches of rock as to resemble thick layers of sand. All these points 
speak against their being teeth, but are in accordance with the supposition of their being the earthy grains or shagreen of the skin of large cartilaginous fishes; and finally, having made an examination of transparent sections in a powerful miscroscope, I found, instead of the close dentine of the teeth of Lepidotus, only the loose divaricating tubular structure, usually found in such dermal armature as has no grinding duty to perform." On the day the alove paper was read to the Society, the late Prof. Strickland also brought up a paper on the Ludlow bone-bed, in which he had independently suggested (from their immense profusion and small size) that these little objects were not teeth, but shagreen granules, without having however proved it structurally as I had done.

Position and Locality.-Occurs in immense numbers in the bone-bed of the upper Ludlow rock near Downton Castle, forming masses some inches thick, and extending for miles; also in the bone-bed, Ludford, near Ludlow.

\section{Genus. ONCHUS $(A g$.}

Gen. Char.-Fin-ray compressed, tapering, gently arched backwards towards the apex; anterior face obtusely lieeled, posterior face destitute of rows of denticles; surface longitudinally sulcated; numerous intermediate small ridges smooth. Base of insertion small, longitudinally striated, rapidly tapering.

The absence of the two rows of denticles on the posterior face separate these fin-defences from those of the genus Hybodus; the same character and smoothness of the lateral sulci separate them from Ctenacenthus.

All the species are Palæozoic.

\section{Oncilus tenuistriatus $(A g$.}

\section{Ref.-Murchison, Sil. Syst. t. 4. f. 57 to 59 .}

Desc.-Usual length about one inch nine lines along the front from base to apex, which is rather abruptly tapered, and curved backwards more or less strongly; the anterior face more curved than the posterior; width near base slightly exceeding two lines; posterior face apparently smooth, slightly concave; anterior face obtusely angulated, rounded, the sides of the undefined keel forming a smooth space on each side, equal in width to the two next rilus; longitudinal ridges very unequal, smooth, flattened, separated by deep narrower sulci (five ridges in the width of two lines at about the middle of the spine, and they vary irregularly at any given length from one-half to one-fourth of a line in width); covered part of base short, abruptly tapered.

As well as I can make out, there are about eight longitudinal ridges on each side of the widest part of the spine, and they, of course, diminish in number towards the apex; they are remarkably unequal in size, and irregular in the relative positions of the small and large ones. The substance is very thick, with a moderate internal cavity. I have examined portions prepared as transparent microscopic objects, under a high magnifying power, and find the characteristic structure and radiated cells of true bone distinctly marked.

Position and Loculity.-Common, mingled with what I conceive to have been the grains of their shagreen (Thelodus parcidens Ag.), in the bone-bed of the Upper Ludlow rock at Ludford, near Ludlow. 


\title{
4th Sub-kingdom. VERTEBRATA. See page 575.
}

\section{1st Class. PISCES. See page 575.}

\author{
4th Order. Ganoiden ( $A g$. restricted).
}

Scales, very rarely thin and without ganoine, usually composed of a thick, bony or corneous layer, covered by a dense polished enamel-like external layer of ganoine; usually rhomboidal and finely punctured, in some groups rounded, sculptured or spinulose. Endl-skcleton sometimes ossified, more usually incompletely ossified, often not ossified, but the pieces of the head always distinct. Bulbus arteriosus of the aorta with several rows of valves, and capable of muscular contraction like a second auricle to the heart. Intestine with a spiral valve.

The recent ganoids have a swim-bladder with an air-duct, and the optic nerves do not cross. Most ganoids have "fulcral" scales along the anterior ray of each fin, and no other fishes have them. Most ganoids have quadrate bony scales polished with ganoine and articulated to each other, no other fishes having the same character. In the numerous valves to the bulbus witeriosus, and in the spiral valve to the intestine, these fishes resemble the sharks, but the distinet bones of the head are broadly distinguished from the undivided cartilaginous cephalic box of the latter. They are the only operculated fishes in which the bodies of the vertebre are frequently undivided one from the other to form a continuous cord.

Professor Müller has separated from this order (as originally defined by Agassiz), 1st, the Lophutwronchii as a distinct order, having the gills tufted, a small opereular aperture, and no air-duct to the swin-bladder: 2nd, the Sclerodermi and Gymnolunti, to form the Order Plectognathi (Cuv.), having the maxillaries and intermaxillaries fixed together, no air-duct, and the exo-skeleton composed of ganoid plates or spines.

In all the formations below the chalk the Ganoids are the only known bony fishes (except the doubtful group of Leptolepis, Thrissops, \&ce, which Heckel suggests may possibly be Teleustecn), being associated in all those periods with Placoids.

The Tribe is divisible into the following Families: 1st, Lepidoidi; 2nd, Acouthodii; Brd, Seurrodipterini;

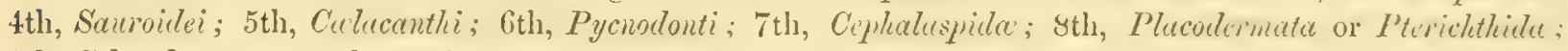
9th, Sclerodermata; 10th, Accipenseridce, \&c.

\section{2nd Family. ACANTHODIDE.}

Body small, short, fusiform, with very minute rhomboidal granulose seales; head large and bony, mouth wide, the latter armed with numerons minute teeth, among which a few larger conical ones are irregularly: interspersed; eyes large, approximate, on the top of the head; fins of very numerous, fine, articulated rays, but generally the first ray in each fin very thick, strong, and bony; tail heterocereal; skeleton partially ossified.

The family is confined to the Devonian and Carboniferous rocks.

The Genera are Avanthodes, Clirolepis, Chiracanthus, Diplacanthus. 


\section{Genus. CHIROLEPIS* $(A g$.)}

Gen. Char.-General form of body, elongate, ovate; one dorsal fin, a little belind the line of the anal fin; anal resenbling the dorsal; ventrals small, half-way between the pectorals and anal; pectorals large, slightly pointed; all the fins destitute of the bony spinous ray usual in the family, each having the anterior edge set with fulcral scales instear.

The mouth is nearly horizontal, and its margin is formed, according to Agassiz, of the maxillary bone; who also has had an opportunity of noting that the large and small teeth are in one row, and not the latter forming a continuous row outside the others, as in the Sauroidea and Coelacanthi.

The fin-rays of this genus are always better preserved than those of the allied Acanthodes or Chiracrunthus.

The Genus is named from the very fine articulated fin-rays, having a deceptive resemblance to the scales of the body.

\section{Chirolepis curtus $\left(M^{\circ} \mathrm{Coy}\right)$. Pl. 2. D. fig. 1.}

$$
\text { Ref.-McCoy, Ann. Nat. Hist. 2nd Series, Vol. II. }
$$

Desc.-Short, fusiform, mouth very oblique; head very large, nearly one-third the entire length of the fish; body rapidly tapering from the head to the tail, which is very small, and with a shallow concave posterior margin; fins small, ventrals nearly three times longer than high, reaching to the anus, where the anal begins; the anal is about twice the height of the ventral fins, and not quite so long, rather less than its own length in advance of the caudal; the dorsal is slightly less in all directions than the anal, and is about one-third of its length behind it; scales rhomboidal, four in the space of one line, each with a long, prominent, oval tubercle in the middle, parallel with the posterior margin (some of those on the tail are diagonally sulcated in the direction of the length of the fish).

In the form and position of its fins this much resembles the $C$. Cummingice (Ag.), from which it differs in its larger head, more oblique mouth, smaller tail, and much shorter and more rapidly tapering body and tuberculated scales; by the latter character it approaches the $C$. Traillii (Ag.), from which it differs in the position of its fins, and equally with the $C$. Cummingice (Ag.) in the other characters mentioned above. Length seven and half inches, greatest depth of body one and half inch. Fulcral seales broad, oval, two lines long and three-fourths of a line wide.

Position and Locality.-Rare in the Old Red sandstone nodules of Lethen Bar.

Explanation of Figures.-Plate 2. D. fig. 1. Natural size; $1 a$, scale from near the tail, outer surface magnified twenty-four diameters; $1 b$, scale, impression of inner surface, from near the middle of the fish, shewing a prominent oval boss in the middle arising from a corresponding articular depression in the scale; magnified twenty-four diameters.

\section{Chirolepis macrocephalus $\left(M^{\circ} \mathrm{Coy}\right)$. Pl. 2. D. fig. 3.}

\section{Ref.-McCoy, Ann. Nat. Hist. 2nd Series, Vol. II.}

Desc.-Body thick, fusiform; tail short, abruptly narrowed from behind the anal fin to half the depth of the body at the pectorals; head very large, nearly one-third the entire length; teeth nearly equal, conical, pointed, width of the base two-thirds of the height, their bases nearly in contact; pectoral fins narrow, oval; ventrals nearly central, of moderate size, half their length distant from the anal, which is triangular, its height two-thirds its length, although less than haif the depth of the body at its base; the dorsal is only two-thirds the length of the anal, but its height slightly exceeds its length; its anterior extremity is vertically over the middle of the anal fin, the posterior extremity extending slightly behind the extremity of the anal; caudal very large, deeply forked, but the upper lobe twice the length of the lower; fulcral scales very slender, about 
half an inch long and half a line wide, granulated; scales rhomboidal, four in the space of one line, gibbous. strongly sulcated diagonally except at the posterior angle. Total length eleven inches.

The great proportional size of the head distinguishes this from all its congeners, except the $C$.curtus, (M Coy), from which it differs in the form and position of its fins, large tail, and diagonally sulcated scales.

Position and Locality.-Rare in the black flags of the Old Red sandstone of Orkney.

Explanation of Figures.-Plate 2. D. fig. 3. Natural size; $3 a$, scale magnified twenty-four diameters.

\section{Chirulepis Tramlit $(A g$.}

$$
\text { Ref.-Ag. Poiss. Foss. t. } 1 d \text {. }
$$

Desc--Length about one foot, greatest depth (behind the pectoral) about three inches; head one-fourth the length; dorsal and anal fins equal, higher than long, the former ends at its own length from the caudal fin, and its height is equal to two-thirds the depth of body at its base; the anal is haif its length in advance of the dorsal; ventrals very small, only half the length and height of the anal fin, and placed half-way between that and the pectorals, which are also small; scales rhomboidal, about ten or twelve in a quarter of an inch. each with a very prominent, sharp, oval, lengthened tubercle in the middle, parallel with the oblique posterior margin.

Position and Locality.-Common in the black flags of the Old Red sandstone of Orkney.

\section{Cimrolepis uragus $(A g$. \\ Ref.-Ag. Poiss. Foss. t. 1 c. fig 1, 2, 3.}

Desc.-Length about seven inches, depth one and quarter inch; head one-fifth of the length; tail lengthened, slender, abruptly narrowed from the middle of the anal fin; anal scarcely half its length in advanee of the caudal fin, and about one-third of its length in advance of the dorsal, seales rhomboidal, convex, five or six diagonal, waved, (?) converging strix on anterior edge, abont four in the space of one line; caudal fin very obliquely concavo-subtruncate.

Position and Locality.-Old Red sandstone, Orkney.

Chirolepis velox $\left(M^{c} \mathrm{Coy}\right)$. Pl. 2. D. fig. 2.

Ref.-M $\mathbf{M}^{\mathrm{c}} \mathrm{Coy}, \mathrm{Ann}$. Nat. Hist. 2nd Series, Vol. II.

Desc.-Very slender; head slightly longer than the greatest depth of the body at the base of the pectorals. but less than one-fifth the entire length of the fish; body tapering gradually from the head; tail deeply forked. lobes narrow; pectorals very large, broadly rounded, height two-thirds the depth of the body at their base: ventrals nearly equalling the pectorals in length, and two-thirds their height; there is only one-third of their length interval between those fins; at the same distance behind the ventral is placed the large triangular anal; it is larger than the dorsal, which is scarcely one-third of its length posterior to it ; both of those fins exceed in height the depth of the body at their base, and are more than their own length in advance of the caudal; scales very convex, rhomboidal, diagonally sulcated, four in the space of one line. Isength nine inches. Fulcral scales of tail very slender, from two to three lines long, and about one-third of a line wide.

From its slender form, very large fins and forked tail, this would seem to have been one of the swiftest swimming fishes of the Old Red period, and the above specific name will remind the ichthyologist of those characters. Its lengthened body and small head distinguish it from all of the genus except the $C$. wranus ( $\mathrm{Ag}$.), from which it differs in the great size of all the fins, their height in proportion to the depth of the body. the deeply forked tail, and the dorsal and anal fins being so far removed from the caudal. (Described from two beautifully perfect specimens).

Position and Locality.-Rare in the Old Red bituminous flags of Orkney.

Explanation of Figures.-Plate 2. D. fig. 2. Natural size; 2 $a$, scale magnified twenty-four diameters. 


\section{Genus. CHIRACANTHUS* $(A g$.}

Gen. Char.-Body of moderately small size, ovate; one dorsal fin placed consiterably in front of the anal, opposite the space between anal and ventral fins; anal fin rather smaller than the dorsal; ventral fin equalling the anal one in size, a little in front of the middle of the body; pectorals moderate, pointed; all the fins with a strong bony ray in front; upper lobe of the tail much longer and more pointed than the lower.

\section{Chiracantuus grandispinus $\left(M^{c}\right.$ Coy $)$. Pl. 2. B. fig. 1.}

Ref.-McCoy, Ann. Nat. Hist. 2nd Series, Vol. II.

Desc.-Elongate, fusiform; tail slender; caudal fin large, moderately lobed; bony spines of the anal, ventral and pectoral fins of great size, their length being about three-fourths of the depth of the body at their lase; the spine of the anal fin is gently curved backwards, those of the ventrals and pectorals straight; dorsal spine also of great thickness, but its length unknown, situated a little behind the line of the ventrals; scales rhomboidal, length and width nearly equal, about seven in the space of two lines, convex, strongly striated diagonally in the direction of the length of the fish, one of the diagonal gronves generally much deeper than the rest in the middle. Length from the base of pectoral fin to extremity of tail nearly eight inches, depth of body at base of dorsal fin two inches; pectoral and ventral spines nearly one and three-fourths of an inch long, and one and half line wide at base, all apparently smooth.

In the great size and strength of its spines this resembles a great Diplacantlus rather than a species of the comparatively feebly armed genus Chiracanthus; it has however no second dorsal opposite the aual fin, and is clearly a peculiar species of the latter genus; from all the species of which the very large spines and strongly striated scales distinguish it.

The Iranchiostegous rays are rery numerous, slender, and distinctly ossified. The cincture supporting the pectorals is very strong and bony.

Position and Locality. - Rare in the bituminous flags of the Old Red at Orkney.

Erplunation of Figures-Pl. 2. B. fig. 1, natural size; at the point of greatest curvature of the back the single dorsal fin and its thick spine are partially preserved; fig. $1 a$, scale from near the tail, magnified twentyfour diameters.

\section{Chiracantuus lateralis $\left(M^{e} C o y\right)$.}

\section{Ref.-MICloy, Ann. Nat. Hist. 2nd Series, Vol. II.}

$D \in s c$.-Slender, fusiform; dorsal nearly intermediate between the anal and ventral fins, slightly nearer the latter; spines of the ventral and anal fins very small, slightly eurved, not more than half the depth of the body at their base, the dorsal spine about one-fifth longer than the others; sides of the body impressed by a strong, straight, lateral line, rather nearer the ventral than the dorsal margin; scales rhomboidal, a little higher than wide, smooth, each with a vertically diagonal, strong, angular, mesial gibbosity, about six scales in the space of one line; length of anal spine seven lines; depth of body at base of dorsal fin one and a quarter inch.

I have only seen two tolerably good specimens of this species, which in size and general form, both of body and spines, resembles closely the $C . p u l v e r u t e n t u s\left(M^{c} \mathrm{Coy}\right.$ ), from which it is distinguished by its smaller and more pointed, vertically gibbous, smooth scales, and having slightly smaller spines; and the ventral and anal spines bcing proportionally further apart, being about equal to the depth of the body at the ventrals in the former, but exceeding it in the present species. What renders the $C$. lateralis most remarkably distinct from the other species of this and the allied genera, is the presence of a very strongly marked lateral line.

Position and Locality.-Rather rare in the Old Red sandstone flags of Orkney.

$$
\text { * Spelt Cheiracanthus, by Agassiz. }
$$




\section{Cimiracanthus microlepidotus $(A g$. \\ Ref.-Ag. Old Red Fish, t. 15. f. 2.}

Desc. - Length ahout five inches; head one-fifth of the length ; greatest depth (in front of the ventrals) one inch; dorsal about midway between the anal and ventral fins, the bony ray very strong, its length equalling the depth of the body at its base; other rays of the fin about half the depth of the body at its base: seales (seven or eight in two lines) rhomboidal; posterior margin rounded and marked with minute, sharp, radiating striæ crenulating the edges.

Position and Locality. - Not uncommon in the nodules of the Old Red sandstone at Lethen Bar.

\section{Chiracantiuus minor $(A g$.)}

$$
\text { Ref.-Ag. Poiss. Foss. Vol. II. t. I c. fig. } 5 .
$$

Desc.-Length eight inches, depth about one inch; head short, obtuse, one-eighth of the length: scales minute, rhomboidal, convex, gibbous, smooth; about five or six in the space of one line; bony ray of the pectoral about equalling the depth of the body at its base, strong, slightly curved, longitudinally sulcated; dorsal and anal spines about three-fourths the depth of the borly at their base; lobes of the tail very unequal, lower lobe triangular, length and width of its base about equal; upper lobe only laalf the widtl, and nearly three times the length of the lower.

As M. Agassiz founded this species on a small fragment of the anterior part, the above description, from numerous perfect examples, may be useful. The species is almost invariably found doubled up into a loop, like the Acanthodes pusillus, the tip of the snout touching the middle of the back.

Position and Locality.-Very common in the bituminous flags of the Old Red sandstone of Caithness.

\section{Cimracanthus Murchisoni $\left(A g_{3}\right)$ \\ Ref.-Ag. Poiss. Foss. Vol. II. t. 1 c, f. 3 \& 4.}

Desc.-Length about six and half inches; greatest depth about one and half inches; bony rays of dorsal or anal fins not exceeding two-thirds the depth of the body at their base; scales rhomboidal, about nime or ten in two lines, marked with very numerous minute, close, sharp, diagonal strix, edges entire.

Position and Locality.-Not uncommon in the nodules of the Old Red sandstone at Gamrie.

\section{Chiracanthus pulverulentus ( $\boldsymbol{M}^{\circ}$ Coy.) Pl. 2. B. fig. 2.}

$$
\text { Ref.-M다, Ann. Nat. Hist. and Series, Vol. II. }
$$

Desc.-Elongate, fusiform, tapering very gradually from the pectorals, where the depth is little more than one-sixth of the length; tail moderate, Iunately forked; the bony ray of the dorsal fin is slightly nearer the anal than the ventral fins, those latter being half way between the pectorals and anal; the ventral spines are about half the depth of the body at their base, the others are about two-thirds of the depth : scales flat, rhomboidal, but the length and width nearly equal, apparently not imbricated, the posterior, inferior angle tumid, pointed; seven scales occupy a space of two lines; surface dull, covered with an exceedingly minute, crowded granulation (only visible under a strong lens). Length eight inches.

The squamation of this species is so peculiar that a comparison with its congeners is rendered unnecessary; in general appearance it resembles the $C . M$ Iurchisoni $(\mathrm{Ag}$.$) . The head is imperfect, but seems rather pointed,$ and almost one-sixth of the entire length.

Position and Locality.-Rare in Old Red flags of Orkney.

Explanation of Figures.-P1. 2. B. fig. 2 ; small perfect individual, natural size; fig. $2 \alpha$, scales from middle of somewhat larger specimen, magnified twenty-four diameters.

[FASC, III.] 


\title{
Genus. DIPLACANTHUS (Ag.)
}

Gen. Char.-Body of moderate, or rather small, size, ovate: two dorsal fins; the first or bony ray of one a little behind the line of the pectorals, and the bony ray of the other exactly opposite that of the anal fin; anal fin about the size and shape of the posterior dorsal; ventrals smaller than the anal, placed slightly behind the middle of the body; pectorals moderately large, pointed; all the fins with a strong bony ray in front; besides those connected with the fins there are usually a strong pair of bony spines projecting from the thoracic cincture under the throat, and a much sinaller pair from the ventral line between the ventral and pectoral fins.

The fins are, I think, truly covered with scales, and had each originally but the one ray, as the impression of the delicate sail-like menbrane is often preserved perfectly. I have never seen the least trace of a bony vertebral column.

\section{Diplacanthus crassispinus ( $A g$.)}

\author{
Ref.-Ag. Old Red, t. 13. fig. 1 and 2. and t.14. f. 6 and 7.
}

Desc.-Length about three and half inches; depth about one inch; scales subrhomboidal, gibbous, nearly twice as high as long; posterior margin rounded, about nine or ten in the space of two lines, surface obscurely granulated; defensive spines very strong, and coarsely sulcated longitulinally, the dorsal with seven or eight furrorvs.

Position and Locality.-Common in the black flags of the Old Red sandstone of Caithness.

\section{Diplacanthus gibdus $\left(M^{\circ} C o y\right)$. Pl. 2. B. fig. 4. Ref.-MeCoy, Ann. Nat. Hist. 2nd Series, Vol. II.}

Desc.-Very thick, fusiform; depth of the hody behind the pectorals equal to the distance between the two dorsal spines; the dorsal spines are equal, about one inch long and one line wide; the first dorsal less than the depth of the body at its base; anal spine much shorter than the second dorsal; scales rhomboidal, length and width nearly equal, each with a large, vertically diagonal, oval gibbosity, occupying nearly its entire area, about five scales in one line; surface seems very minutely granular. Length about four and half inches; greatest depth one and half inch.

This species has more equal-sided scales than the D. striatus (Ag.), and is of nearly double the proportional depth; the spines are longer and more slender than in the D. crassispinus (Ag.), beside the difference in the scales.

Position and Locality.-Very rare in the Old Red flags of Orkney.

Explanation of Figures.-PI. 2. B. fig. 4, natural size of specimen, wanting the head. (The small patch of scales does not clearly shew their mesial prominence); fig. $4 \alpha$, scales of do., from near the middle, magnified 2t diameters.

\section{Diplacanthus longispinus $(A g$.)}

\section{Ref-Ag. Old Red, t. 13. fig. 5. and t. 14. fig. 8 and 9.}

Desc.-Length about eight or nine inches; greatest depth of body two inches nine lines; bony spines of the anal and dorsal fins very strong, about equalling the depth of the body at their bases (measured along the profile of the back); upper lobe of the tail rather short and wide; scales large, convex, rhomboidal; anterior margin rounded, posterior margin obtusely pointed, surface with very fine numerous strix converging towards the posterior apex; about seven scales in a quarter of an inch at the middle of the body.

Position and Locality.-Not uncommon in the Old Red sandstone of Lethen Bar. 


\section{Diplacanthus perarmatus $\left(M^{c}\right.$ Coy $)$. Pl. 2. B. fig. 3. Ref.-McCoy, Ann. Nat. Hist. 2nd Series, Vol. II.}

Dese.-Body thick, short, fusiform; tail very short, nearly square, its width only two-thirds the length of the second dorsal spine, the upper lobe projecting lut little beyond the lower; spines smooth, extremely long, first dorsal equal in length to the space betreen the first and second dorsuls, slightly less than the depth of the body at its base, gently curved; posterior spine straighter, and about one-eighth longer than the anterior; pectoral spines half the length of the second dorsal; anal spine curved, only twn-thirds the length of the second dorsal; ventral, medial, and thoracic spines slightly curved and of moderate length; scales slightly higher than wide, nearly flat, minutely granulated (the impressions only seen), about three in the space of one line. Length, from the base of the pectoral fin to the tip of the tail four and half inches.

This is most allied to the D. longispinus (Ag.), but has still longer spines, the second dorsal being especially remarkable; the dorsal spines are much longer in proportion to the distance between them and the depth of the body; the anal spine being, on the other hand, comparatively shorter; the tail is still smaller, and more equal-lobed, and the seales much smaller, and, with the proportion of length to width, reversed: I am doubtful about their surface, but the impressions seem distinetly, though minutely and irregularly granulated.

Position and Locality.-Rare in the Old Red sandstone flags of Orkney.

Explanation of Figures.-Pl. 2. B. fig. 3, natural size of specimen wanting the head; fig. $3 \alpha$, scales of do. from near the middle, magnified 24 diameters.

\section{Diplacanthus striatus $(A g \circ)$ \\ Ref.-Ag. Old Red, t. 14. fig. 1 to 5.}

Desc.-Length about two and half inches; greatest depth about seven or eight lines; first ray of each dorsal slightly longer than the depth of the body at their base, the first dorsal ray, which is the largest, about one line in diameter; the bony ray of each fin finely sulcated longitudinally, about ten sulci on each side, slightly curved backwards; lobes of the tail pointed, the upper lobe twice the length of the lower; scales very suall, smooth, obtusely rhomboidal, having a large vertically diagonal oval protuberance nearly in the middle of each.

Position and Locality.-Old Red sandstone flags of Orkney.

\section{3rd Family. SAURODIPTERIDE $(A g$.}

Desc.-Body fusiform, robust; scales large, strong, polished by a thick layer of ganoine, rhomboidal, not imbricating, but either with their edges in juxtaposition, or articulated with each other, by distinet bony processes, with in general a finely punctured surface (through which the minute nutrient vessels passed to the external integument); head wide, flattened; teeth numerous, conical, equal (? with simple pulpy cavity), and set in the intermaxillaries (as in ordinary fishes), thus differing from the Acanthodida; pectoral fins moderate, rentrals small, at about the middle of the body; behind which are two large anals, having two similar dorsals opposite, or alternating with them; none of the fins have bony spines; tail heterocereal or diphycercal*; skeleton partially ossified.

Genera: 1st, Diplopterax; 2nd, Osteolepis; 3rd, Triplopterus, \&ce.

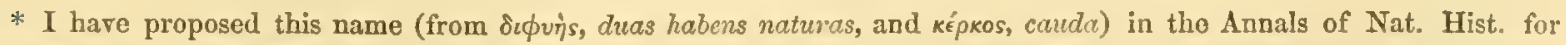
November 1848, to designate the peculiar structure and form of tho tail in Diplopterax, and Gyroptychius, which is intermediate in some respects between the homocercal and heterocercal types of tail described by Agassiz. In the "homocercal" or ordinary form of tail of most recent, and the newer fossil fishes, we usually find a few of the last vertebrio anchylosed, and from the terminal mass so formed, the greater portion of the caudal fin is developed, as much from the upper as from the lower aspect, and only the few short rays at the commencement of the fin being intercalated with the spinous processes 


\author{
Genus. DIPLOPTERAX. \\ $=$ Diplopterus (Ag. not of Boie).
}

Gen. Char.-Very large, elongate, fusiform fishes; two subtruncate dorsals, opposite two similar anal fins, they are about their own length apart; numerous rays of the caudal above as well as below the very slightly elevated lobe of the tail; the caudal fin is obtusely pointed nearly in the middle, (and not forked nor obliquely truneated, as figured by Agassiz, in his restored figure); teeth nearly equal in size, simply conic, not plaited, and having a simple pulpy cavity; branchiostegous rays, replaced by two long sultrigonal plates under the throat, not quite meeting along the middle; scales large, simply rhomboidal, very minutely and closely punctured, (merely fastened by their edges and external integument?); lateral line elevated.

As the name Diplopterne of Agassiz had been previously used for another genus, it is necessary to give a new termination to the present group.

\title{
Diplopterax affinis $(A g . S p \cdot)$ \\ Ref.-Ag. Old Red, t. $31 \alpha$, fig. 27 and $27 \alpha$.
}

The small fragments which are yet known of this species have a strong resemblance to the $D$. macrocephalus, but with a much closer and more minute puncturing of the surface.

Position and Locality._Old Red sandstone-Gamrie.

\section{Diplopterax Agassizit (Trail $S p$.)}

Syn. and Ref.-Trail, Trans. Roy. Soc. Edinb. Vol. XV.=D. borealis, Ag. Old Red. t. 18.

Desc.-About fifteen inches long and three wide, tapering insensilly from the head to the tail, which is nearly half the greatest width of the body; head semielliptical, one-fifth the entire length of the fish, depth about the same; seales more closely attached than in the $D$. macrocephalus, rhomboidal, one-third higher than long, the anterior and posterior margins straight; upper margin convex, and lower coneave, with the inferior angles slightly produced; those of the flanks about two and half lines high, and two lines long, acutely rhomboidal, with their length and breadth nearly equal; surface finely punctured; dorsal fins small, narrow, pointed; first anal longer than deep, second shorter, and one-third deeper than the first; caudal fin rather large, slightily pointed in the middle, very slightly unsymmetrical, nearly as much fin above as below the spinal extremity, which does not reach to the end of the fin.

Position and Locality.-Old Red sandstone, abundant at Orkney.

\section{Diplopterax gracilis $\left(M^{\circ} \mathrm{Coy}\right)$. Pl. 2. C. fig. 1.}

\section{Ref.-M대, Ann. Nat. Hist. 2nd Series, Vol. II.}

Desc.--Very slender, depth about one-eighth of the length, and nearly equal from head to tail; head narrow, subtrigonal, obtusely pointed, abont one-fourth longer than wide; pectorals placed rather far back, small,

of the preceding normally formed vertebræ; in the "heterocercal" type the vertebra do not coalesce into a terminal mass, but diminish gradually in size to the last, forming a very slender prolongation of the body, inclining upwards, and the rays of the caudal fin are developed from the under side only, and are intercalated with the spinous processes of a great number of vertebrx; the "diplycercal" type agrees with the "homocercal" in the nearly mesial position of the termination of the body, and the nearly equal development of the caudal fin aboro and below; in those points it differs from the "heterocercal," while it agrees with the latter and differs from the former in the gradual attenuation of the spinal prolongation, the terminal vertebræ not being anchylosed into a vertically dilated mass, and the rays of the caudal being manifestly connected with the spinous processes of a large number of vertebre. Those who think the theory of "progressive development" worth refuting, may be glad to find that some of the oldest known perfect remains of fishes have not exclusively heterocencal or embryonic types of tail, as was hitherto supposed. 
narrow, ovate, about three-fourths the depth of the body, their base covered with scales as large as those of the tail, but more square; dorsal and anal fins nearly equal, opposite each other, their own length apart; they are triangular and pointed, their height exceeding their length; tail diphycercal, of moderate size; attenuated prolongation of the body nearly medial, the caudal fin itself being rhomboidal, pointed in the middle retrally; scales rhomboidal, those of the flanks about two and half lines high, and one and half long, those of the tail smaller, more obliquely rhombic, but still with nearly equal sides; all appear under the lens minutely and closely punctured, the under side with a strong mesial articular ridge extending about two-thirds the length. Total length about fourteen inches; head about one seventh of the length.

Its small head and extremely narrow elongate form easily distinguish it from the other species.

Position and Locality.-Old Red sandstone flags of Orkney.

Explanation of Figures.-Plate 2. C. fig. 1, natural size; I $\alpha$, scale of ditto magnified two diameters, shering the punctured external polished surface; fig. $1 b$, internal surface of scale of ditto, shewing the articular ridge.

\section{Diplopterax macrolepidotus (Sedg. \& Murch. Sp.)}

Ref. and Syn. = Dipterus mecrulepidotus Sedgwick and Murehison, Geol. Trans. Vol. III. t. 16. f. 4 and 5. = Diplopterus macrocephalus, Ag. Old Red, t. 16 and 17.

Disc.-Abont two feet long, and five inches wide; narrowed abruptly towards the tail ; scales irregular, rhomboidal, loosely attached, about three lines high and two lines long on the flanks; surface very finely: and closely punctured under the lens.

Its greater size, particularly of the head, and the loosely attached scattered condition of the scales, distinguish this from the $D$. Agassizi; there is also less disproportion between the size of the anal fins.

I find, on examining the original specimens of the Dipterus mecrolepidotus, that in size, form, and minute punctuation of the surface of the scales, as well as their imperfect connexion with each other, they are identical with those subsequently described and figured by M. Agassiz, under the name of $D$. macrocephalus, which latter name therefore becomes a synonym of this species as above.

Position and Locality.-Not uncommon in the black flags of the Old Red sandstone of Caithness.

\section{Genus. OSTEOLEPIS ( $\mathrm{Val}$. and Pent.)}

Gen. Char.-Slender; first dorsal opposite the space between the ventral and first anal, second dorsal opposite the space between the two anal fins; minute tubular puncturing of the seales close and distinct over the surface, distinguishing them from those of Palconiscus; the upper margin of each scale has a narrow articular process, which is hid under the inferior border of the scale next above; teeth very irregular in size.

\section{Osteolepis arenatus $(A g$. \\ Ref.-Ag. Poiss. Foss. t. $2 d$, fig. $1-4$.}

Desc.-Very elongate, slender, six to nearly seven inches long and one deep; length of the head equalling the depth; first dorsal a little behind the middle of the body, small, its length and height equal; second dorsal opposite the space between the two anals, larger than the first; caudal rounded; scales one-half higher than long, finely granulo-punctate, (the height little more than one line).

Position and Locality.-Not uncommon in the Old Red sandstone of Orkney.

$$
\begin{aligned}
& \text { OsteolePIs Brevis }\left(M^{\circ} C o y\right) . \text { Pl. 2. D. fig. } 4 . \\
& \text { Ref.-M'Coy, Ann. Nat. Hist. 2nd Series, Vol. II. }
\end{aligned}
$$

Desc.- Very short, fusiform; length about five inches; body broadest at the anterior part, where the width is rather more than one-fourth the length, tapering abruptly to the tail, the pedicle of which is about one- 
third the depth of the body; head very obtusely rounded, nearly semicircular, depressed, trice as wide as long, the length being only two-thirds the depth of the body; scales thick, nearly equilateral except on the flanks, where they are one-third higher than long, length of each about one line, surface minutely and uniformly punctured under the lens, the pores rather distant; two anal fins very small, ovate, their own length apart, the second touching the caudal; one large triangular dorsal fin, longer than high, opposite the space between the two anal fins (anterior dorsal not seen).

Easily distinguished from the other species of Osteolepis by its very wide, short figure. From the great width of the head it is almost always found with the anterior part of the body crushed vertically. The teeth are very small, close and slender.

Position and Locality.-I have seen five specimens from the Old Red nodules and schists of Caithness and Orkney.

Explanation of Figures.-Plate 2. D. fig. 4, natural size; fig. $4 \alpha$, scales of ditto, magnified two and half diameters; the two lower scales shewing the external polished and punctured surface with their articular margins; the two upper being impressions of the inner surface, to shew the narrow longitudinal sulcus corresponding to the articular ridges on the under side of the scale.

\section{Osteolepis Macrolepidotus ( $V a l$. and Pent.)}

$$
\text { Ref.-Ag. Poiss. Foss.t. } 2 b \text {, fig. 1. (not 2). }
$$

Desc.-About six inches long and one inch deep; body nearly of equal depth throughout, the pedicle of the tail being more than half the greatest depth of the body; head obtusely subtrigonal, about one-fifth the length of the body: scales about a line long, those of the body twice as high as long, those of the tail equilateral; puncturing of the surface very fine, close, uniform: first dorsal about a third less than the second, and its own height in advance of it; second anal touching the caudal fin, which is very obliquely concavo-truncate.

Position and Locality.-Not uncommon in the Old Red sandstone of Orkney.

\section{OSTEOLEPIS Major $(A g$.}

$$
\text { Ref.-Ag. Old Red. t. 19. fig. } 1 \text { to } 3 .
$$

Desc.-Very slender, of nearly equal depth from head to tail; length about nine inches, depth one inch four lines; head small, obtusely pointed, little more than one-sixth the entire length; scales of the body about three lines long, and about two high, punctures of their surface few, large, irregularly scattered, and three or four times their diameter apart; tail small, short, slightly forked; dorsal and anal fins small, their height and length about equal.

Position and Locality.-Not uncommon in the Old Red sandstone of Lethen Bar.

\section{Osteolepis Microlepidotus (Val. and Pent.) \\ Ref.-Ag. Poiss. Foss. t. $2 c$, fig. 1 to 4 .}

Desc.-Length about five inches; fusiform, deepest in the middle, tapering slightly to the head, and rapidly to the tail, the depth being one-fifth of the length; tail shorter and less obliquely truncate than in the O. macrolepidotus; scales about one line long and about one-third higher; surface under the lens very minutely and uniformly punctured.

Deeper, shorter, and more rapidly tapering than the 0 . macrolepidotus, but having seales pretty nearly similar both in size, shape, and puncturing; the fins slightly more remote from each other than in that species.

Position and Locality.-Not uncommon in the Old Red sandstone flags of Orkney. 


\title{
Gemes. TRIPLOPTERUS $\left(M^{C} C y\right)$.
}

\author{
= Tripterus $\mathrm{I}^{\mathrm{C} C o y}$, Ann. Nat. Hist. 2nd Series, Vol. II.
}

Gen. Char.-General shape of the body and form of the plates of the head and body as in Osteolepis, but having only one dorsal fin, which is precisely over the first anal fin.

The fishes of this genus are very much allied to Osteolepis in general habit, but instead of having two dorsal alternating with two anal fins, there is but one dorsal, which instead of alternating with or being vertically over the interval between the anal fins (as would be the case in Ostcolepis, if only one fin were preserved), is precisely ocer the first anal, as in Diplopterax, (= Diplopterus Ag.), which it also greatly resembles, but from which it differs in wanting the second dorsal, and in having a perfectly heterocercal tail-a character which I have ascertained does not exist in Diplopterax. The name Tripterns having been preoceupied, I have changed it as above.

Triploptenus Pollexfeni $\left(M^{c}\right.$ Coy). Pl. 2. D. fig. 5.

\section{Ref $f_{0}$ Tripterus Pollexfeni MCoy, Ann. Nat. Hist. 2nd Series, Vol. II.}

Desc.-Ovate, gradually tapering from the head, which is broad, depressed, semi-elliptical, obtusely pointed in front, its width at base equal to its length, and being about one-fifth the entire length of the fish; pectoral fins small, broad, ovate, their leeight about two-thirds the width of the body at their base; tail small, perfectly heterocercal, retral margin very coneave, and the upper lobe twice the length of the lower; two anal fins nearly equal, triangular, one-third higher than long, rather more than their own height apart, the second almost touching the caudal fin; dorsal fin narrow, ovate, almost twice as high as long, precisely over the first anal; scales rhomboidal, those of the body flat, about one-third higher than long, those of the tail longitudinally gibhous, lozenge-shaped, and about twice as long as high; under the lens they are all very minutely and uniformly punctured, as in Osteolepis and Diplopterns. Total length about seven inches, greatest width of body one and quarter of an inch, length of body-scales one and half line.

So completely identical are the plates of the head of this fish with those of the large imperfect example figured by Agassiz, (Poiss. Foss. Vol. II. Plate 2 b, fig. 2), that 1 cannot help suspecting that that figure may represent a portion of a fish of the present species, the imperfection of the retral part of the borly having perhaps permitted MI. Agassiz to refer it to the Osteolepis mucrolepidutus; although even without seeing the fins we might distinguish it by its wide, rapidly tapering figure from that species, which is correctly represented by the figure 1 of the same plate, so far as it goes. The teeth are minute, slender, conical, rather distant, apparently in several rows, and of irregularly unequal size. I have examined three perfect specimens of this species presented to the University collection by the Rev. W. Pollexfen, by whom nearly all the Orkney fishes here noticed were collected, and whose zeal I am happy to commemorate by dedicating this to him.

Position and Locality. - Not uncommon in the Old Red sandstone at Orkney.

Euplenation of Figures.-Pl. 2. D. fig. 5, small specimen, natural size; fig. $5 \alpha$, scale of ditto magnified three diameters, shewing the polished, punctured surface, and broad articular margin; 56 , scales of ditto, natural size, from another specimen.

\section{5th Family. CELACANTHI.}

Scales polished, variously ornamented, rounded, largely imbricated; tecth conical, longitudinally plaited at the base, of two sizes, the smaller very numerous, the larger few, far apart, and set rather within the line of the smaller ones.

The scales composed of a bony plate covered with ganoine; bones of the head also polished and generally granulated. A transverse slice of a tooth magnified shews the medullary cavity sending off innumerable radiating, vertical, branching fissures, about which the dentine is folded. 
The Catacanthi can only be distinguished from the Sauroids by the imbrication of the scales. As at first defined, the principal characters were, the hollowness of the bones and rays (which were cartilaginous within, coated with a thin calcareous shell), the tapering of the spinal column into the middle of the tail, and the rays of the caudal fin having interapophysary bones like the dorsal (these are well seen in our figure of IIoloptychius Sedgwicki); the first definitions also include some teeth of the Pycnoid type.

Genera:-1, Coclacanthus; 2, Glyptolepis; 3, Holoptychius; 4, Gyroptychius; 5, Dendrodus; 6, Lamnodus; 7, Asterolepis, \&c.

\section{Genus. GLYPTOLEPIS (Ag.)}

Gen. Char.-Scales thin, subquadrate, rounded; surface nearly smooth, concentrically imbricated round a central point; interior shewing a finely radiated, cellular structure; teeth sharp, conical, deeply furrowed longitudinally, implanted in imbricating plaited sockets; one detached ventral fin, surrounding a pointed, scaly process, directed backwards; two dorsal and two anal fins close to the heterocereal tail, nearly equal and opposite each other, the posterior pair largest; the caudal is broad and truncate.

These are moderate sized fishes, with blunt, flat, rounded heads, and two large triangular plates covering the throat in place of the branchiostegous rays. I much doubt the propriety of separating this genus from Dipterus, since I have examined the original types of this latter genus.

\section{Glyptolepis leptopterus $(A g \cdot)$}

Ref.-Ag. Old Red Fish, t. 20 and 21.

Dcsc.-Body ahout three inches thick and twelve long, covered with dull, nearly circular, strong, slightly convex scales, about five or six lines in diameter, each marked with small, sharp, irregular, concentric wrinlles, round a nearly central, prominent point, crossed on the anterior part by a few radiating ridges: when the surface is destroyed the scales are seen to have a very minutely-radiated structure, about thirty-five radiating lines in the space of one line. Teeth about one line long, nearly uniform, close, conical, coarsely sulcated at the basal portion.

There is but one sort of teeth seen in the jaw externally.

Position and Locality.-Old Red sandstone, Lethen Bar.

\section{Genus. DIPTERUS (Sedg. and Murch.)}

$$
\text { Syn. = Dipterus Ag. = (? Glyptolepis Ag. })+ \text { Polyphractus Ag. }+ \text { Ctenodus A } g .
$$

Gen. Char._-Small fusiform fishes, with compressed heads, and perfectly heterocercal tails, and two dorsal fins precisely opposite two similar anal fins, the second of each largest, placed rather close and far back; a strongly marked lateral line; scales circular, thickest in the niddle, variously carved, either with concentric lines round a nearly central point, or, more rarely, with fine longitudinal ridges on the exposed part. Lateral line impressed.

This genus was first described in a joint memoir, "On the Deposits contained between the Primary Rocks and the Oolitic Series in the North of Scotland," published by the Rev. A. Sedgwick and Mr Murchison, in the 3rd Vol. 2nd Series of the Transactions of the Geological Society of London (1835), and named by them from the double dorsal fins. In the excellent figures by Mr Scharf, which accompany this memoir, we also find the character of the double anal fins opposite the dorsals clearly represented; the heterocereal structure of the tail is also noticed, and the scales are stated to be round and imbricated. Thus far the characters are generic, and in accordance with the views of Baron Cuvier, and of MM. Valenciennes and Pentland, who agreed with the authors in their interpretation of the specimens. Three species were figured, and characterized by their dimensions, the size of the scales, and the proportions of the fins-namely the D. brachypygopterus, D. macropygopterus, and $D$. Folenciemuesi, and certain fragments were provisionally named $D$. macrolepidotus, although with the express caution that they considered the generic reference quite uncertain, from the imperfection of the specimens. 
Shortly after appeared the 2nd Vol. of M. Agassiz' Recherches sur les Poissons Fossiles, in which he refers to the above paper (p. 3); but conceiving that the two dorsal fins, which had struck Cuvier as at once distinguishing the present fishes from the Palconisci of the copper-slate, did not really exist, he proposed to change the name of the genus to Catopteres, supposing it to have one anal and one dorsal fin. The four species there described and figured he also suggested to be imperfectly observed, and proposed to unite them all under the one name Catopterus analis (Ag.). He also denies the correctness of the views of Cuvier and of Sedgwick and Murchison as to the roundness and imbrication of the scales (p. 24); and stating them to be, on the contrary, rhomboidal and flat, he places the genus in the Family Lepidostei. In p. 113 of the same work M. Agassiz states that he had examined some of the original specimens figured by the above writers, and that he found his corrections as to the continuity of the dorsal fins were not correct, that Messrs. Sedgwick and Murchison had correctly described and figured those fins, and that his generic name Catopterus could no longer be retained in preference to their Dipterus; on a second examination he discovered the two anal fins pretty nearly as they had figured them, but still retained his view of the form and arrangement of the scales; and now viewing the imperfect and doubtful fragment named Diptemes macrolepidotus as the type of the whole, he proposes that the three well-known species should be united under that name, on the supposition that the large flat rhomboidal plates, figured in the Geological Transactions under the latter name, became converted into the small rounded ones, of the more perfect fishes, there noticed (under the other names) by abrasion. This is the more remarkable, as at p. 113 (loc. cit.) he refers to the figures given of that species by Messrs. Sedgwick and Murchison as examples of his new genus Diplopterus. I have since found this to be truly the case, although in his last ichthyological work, Mononograplie des Poissons Fassiles du Fieux Grès Rouge, \&c., he does not give this reference for the Diplopterus, but quotes the Dipteri collectively under the specific name given to these fragments as above.

Before recording my own observations I must remark that the above brief résumé of the literature of the genus Dipterus is not intended as a reflection on M. Agassiz-for whose labours no one can entertain a more profound respect than I do,-but merely as a necessary record of the various changes which have been proposed in the views of the original describers of the genus, and which I believe, after an attentive examination, to have been altogether unnecessary, as some of them are already admitted to have been.

On examining a large suite of the different species of Dipterus described by Prof. Sedgwick and Sir $\mathbf{l}$. Murchison, now deposited in the Geological Collection of the University, I find that in all the examples of all the species, except the $D$ ? macrolepilotus, the scales, when attentively examined, are circular and distinctly

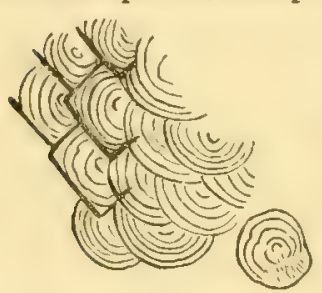
imbricated; they are marked on the surface with fine, elevated, concentric lines; thickest in the middle and very thin and brittle at the edges, from which latter circumstances, combined with their quincuncial arrangement, they are of course liable to break into a more or less regular rhombic shape when the fish is crushed. This may have possibly misled M. Agassiz' draughtsman, or even himself on a hasty view ; but in those cases where this rhomboidal appearance is strongest, it will be found that, 1st, the lines of the surface are not as Agassiz represents them (Poissons Foss. Pl. 2 , Vol. II.), quadrangular, and parallel with the margin, but curved. 2nd, These pseudo-rhombic scales are never regular, like those of the true Sauroid fishes, but are extremely diverse in shape, and frequently present large notches, where one part of a scale has retained its true circular margin, and another part broken straight off, giving the deceptive quadrate appearance. Those specimens which, like most of those figured in the Memoir quoted, retain their scales comparatively uninjured, with their imbricated rounded margins, are, on the other hand, quite regular. But what places the fact of the circularity and consequent imbrication of the scales beyond all doubt, is the circumstance that I have repeatedly noticed single scales separated from the body, in which the outline was perfectly round; and I subjoin a rough sketch of those various conditions, about one-third larger than nature, as seen in a specimen of the $D$. brachypygopterus.

Taking for granted, what the suite of specimens in the Cambridge Museum proves beyond a doubt, that the scales of the Dipteri are really rounded and imbricated, we find that the genus must be removed from the group of Sauroid fishes in which it has hitherto been placed on the supposition that the seales as in [FASC. III.] 
Ostcolepis were quadrate, and simply in contact by their edges, and we must class it with Hotoptychins, Glyptolepis, Stc. in the family of Coclacanths, according to the last definition of that group in M. Agassiz' Monograph on the Fishes of the Old Red Sandstone; in fact the relation to this latter genus becomes in this light so close that I do not at present see how to distinguish them; and although the great depressed $G$. leptopterus (Ag.), with its strong, bony, lenticular scales, seems distinct from the small Dipteri, yet the smaller, lateral compressed specimens of the same species come much closer in appearance; and in either case the characters of the number and position of the fins, form and surface of the scales, and the external characters of the teeth, are identical in both, pointing to a union of the genera Glyptolepis and Dipterus. The latter being much the oldest, would, in this case, of course, be retained.

The perfectly heterocercal tail and circular imbricated seales now widely separate these fishes from Diplopterax (=Diplopterus Ag.). According to Mr Miller (IVitness newspaper, Dec. 23, 1848) the genus Polyphiractus (Ag.) is formed on the occipital plates of this genus, and he also there states that the teeth are exclusively palatal, "blunt, squat, and arranged in two rectangular patches," identical with those forming the genus Ctenodus (Ag.), which he unites thus to the present genus.

\section{DiPterus BRACHyPygopterus (Sedg. and Murch.)}

Ref.-Sedg, and Murch. Geol. Trans. 2nd Series, Vol. III. Pl. 17.

Desc.-Gradually tapering from the base of the head; length about seven inches, depth nearly one and Lalf inches; head small, only one-fifth of the length; posterior anal wider and shorter than in the $D$. macropygopterus, not extending more than half way to the angle of the lower lobe of the caudal; lateral line much nearer the dorsal than the ventral margin; scales of the flanks two lines in diameter, varying towards the abdomen to nearly three lines; height (diameter) of the exposed portion of each scale when in situ about twice the length thereof; surface strongly marked with concentric imbricating wrinkles on the exposed part, and with a radiated puncturing on the rest of the scale finer than in the D. macropygopterus.

By its much smaller scales and head, and wider and shorter anal fin, this is fully distinguished from the D. macropygopterus with which Agassiz has united it. I have carefully verified these characters in several specimens, and feel satisfied that they are not the result of age or accidental injuries, as has been suggested.

Position and Locality. -Old Red sandstone. Abundant at Caithness.

\section{Dipterus Macropygopterus (Sedg. and Murch.)}

\section{Ref.-Sedg. and Murch. Geol. Trans. 2nd Series, Vol. III. Pl. 15.}

Desc.-About nine inches long and nearly two inches deep behind the pectorals, from whence the body tapers gradually both towards the head and tail; head pointed, rather more than one-fourth the entire length; upper lobe of the tail long, pointed; posterior margin very obliquely concavo-subtruncate; posterior anal nearly reaching to the angle of the lower lobe of tail, narrower than the dorsal, exceeding by nearly one-third the depth of the body at its base; lateral line nearer to the dorsal than the ventral margin; scales nearly circular when detached; those of the flanks three lines, and of the belly four lines in diameter, densely imbricated when in situ; the height (diameter) being nearly three times greater than the length of the exposed portion; surface of each scale with strong imbricating concentric wrinkles on the exposed portion, the remainder being very minutely punctured and granulated in a close radiating manner.

Position and Locality. - Old Red sandstone. Common in the flags at Caithness.

\section{Dipterus Valenciennesil (Sedg. and Murch.)}

Ref.-_Sedg. and Murch. Geol. Trans. 2nd Series, Vol. III. Pl. 16. fig. 1 and 3.

Desc.-Fusiform, depth greatest a little in front of the middle, being nearly one-fourth of the lengtl, which varies from three to five inches; head small, pointed; scales of the sides of the body scarcely one and half lines in diameter, two or three rows on the belly nearly double this size; exposed portion when in situ about one-third 
higher than long, conentrically imbricated; fins as in the D. brachypygopterus, pectorals long, narrow (generally laid against the sides).

The small fusiform body and very small size and proportion of the scales, which I find constant in four specimens now before me, easily distinguish this from the D. macropygopterus and D. braclypygopterus, with which M, Agassiz has proposed to unite it.

Position and Locality._-Old Red sandstone. Not uncommon in the flags of Caithness.

\section{Genus. CONCHODUS $\left(M^{\circ}\right.$ Coy $)$.}

Ref.-McCoy, Ann. Nat. Hist. 2nd Series, Vol. II.

Gen. Char.-(Teeth in pairs in each jaw as in Ceratodus?); each tooth large, somewhat semicircular, pointed in front, subtruncate behind, deeply concave on the grinding surface; internal margin straight, thickened, and with an abruptly deflected edge; external border convex, much raised and strongly undulato-plicate, the ridges being largest in front, and gradually dininishing towards the external and posterior portion of the tooth; the plica are produced by a thickening of the substance of the ridges and a scooping-out of the intervening hollows, so that the under side of the tooth remains even; under surface coarsely osseous; upper surface polished, with small obscure undulations, and minutely porous.

This genus is closely allied to Ceratodus and Ctenodus, but differs in the grinding surface being concave; the tooth resembling the inside of a plicated oyster. The internal microscopic structure was developed for me by the lindness and skilful manipulation of my friend Mr Anthony, of Caius College, Cambridge; it was very complex and peculiar, but the prepared fragment has unfortunately been mislaid by him, so that I am unable now fully to describe it. I only know one species, the following.

\section{Conchodus ostreiformis $\left(\boldsymbol{M}^{c} \mathrm{Coy}\right) \mathrm{Pl}$. 2. C. fig. 7. \\ Ref.-McCoy, Ann. Nat. Hist. 2nd Series, Vol. II.}

Desc.-About one and half inch long, one inch wide, and one line and a half thick; the grinding surface deeply concave, the surface of attachment equally convex; the external semicircular margin gives origin to six or seven coarse, rugged, converging ridges, the most anterior about seven lines long, and slightly inclined to the straight inner margin, the most posterior is about two lines long, and at right angles with the inner margin; the ridges are separated by deep wide hollows.

Position and Locality.-Found along with Dendrodus latus (Ow.), Holop. giganteus (Ag.), and Hol. princeps ( $\left.\mathbf{M}^{\mathrm{c}} \mathrm{Coy}\right)$, in the Old Red conglomerate of Scat Craig.

Explanation of Figures.-PI. 2. C. fig. 7, palatal tooth, natural size.

\section{Genus. HOLOPTYCHIUS $(A g$.$) restricted.$}

$$
\text { Syn. }=(\text { Holoptychius Ag.-Rhizodus Ow.) }
$$

Gen. Char.-Body thick, short, rounded; bones of the head granulated; scales large, very thick, subrhomboidal, rounded, imbricating, composed of numerous bony layers, exposed surface marked with large, longitudinal, flexuous wrinkles and tubercles; teeth small, numerous, conical, longitudinally sulcated at base: tail heterocercal, caudal fin triangular, obliquely truncated; one lengthened, elliptical, dorsal fin, opposite a similar anal fin, close to the base of the caudal; ventrals behind the middle of the body.

I have proposed (Ann. Nat. Hist., July, 1848, page 2) to restrict this genus in the above manner, which makes the group much more natural and definite by removing from it those species (principally carboniferous) which have very large, thin, quadrate scales, with the minute reticulated structure of Glyptolepis, without the longitudinal wrinkles, \&ce., and having very large sharp-edged elliptical teeth of two very different sizes in each jaw, to which latter I have proposed confining the name Rhizodus (Owen), hitherto considered a mere synonym of Holoptychius. 


\section{Holoptychius Animersoni ( $\left.A g_{0}\right)$ \\ Ref. and Syn-Ag. Old Red, t. 22. f. $3+H$. Flemingi id. ib. f. 1 .}

$D_{c s c}$.-Fusiform, abruptly contracted at the pedicle of the tail; head rather small, its length from snout to edge of operculum slightly less than its height; depth of body at origin of dorsal fin about one-fifth more than the length of the head; dursal fin small, originating about one-fifth more than the length of the head behind the edge of operculum; lateral line running beneath the upper third of the sides, commeneing at about onefourth the depth from the dorsal outline at the nape, but descending to two-fifths the depth from the dorsal outline at the origin of dorsal fin; ventral fins moderate, situated twice the length of the head from the operculum; scales of moderate size, nearly circular; in a specimen two inches nine lines in depth the exposed portions on the middle of the sides average five to six lines in depth and four lines in length, they are marked each with about twenty very variable, fine, thread-like ridges, sometimes nearly parallel, less than their thickness apart, and scarcely branching or anastomosing; at other times separated by broader concave spaces and more or less flexuous, and anastomosing once or twice as they approach the posterior edges, to which in all the varieties they extend (averaging eight in the space of two lines), sometimes they seem smooth and often are finely granular, in all cases the anterior part is occupied by a patch of rather coarse radiatingly disposed granules, from whence the ridges arise that go to the free edge; the smooth overlapped portion is marked under the lens with very minute, close, punctured, radiating lines; the scales of the belly are larger than those of the sides, and much more coarsely sculptured, with thicker, more widely separated, and more flexuous ridges than those of the sides (averaging four or five ridges in two lines), the bones of the head are coarsely granulated (about three granules in the space of one line), with an imperfect radiating disposition towards the margin of some of the plates.

The very numerous, although fragmentary, specimens which I have examined, prove what I for some time suspected, that the more finely and straightly ridged scales on those specimens of Holoptychius from Duraden shewing the lateral lines, and forming the type of $H$. Flemingi, were really identical with those similar fishes intermingled with them, but having much more coarsely sculptured scales figured by M. Agassiz under the name $H$. Andersoni. The latter coarsely sculptured species I find is in fact the ventral aspect of the more delicately ridged specimens, which are compressed laterally, and it is certain that the two triangular plates in M. Agassiz' figure are the branchiostegal plates, such as we see in the $H$. nobilissimus, and not of the cranium. as Agassiz supposed. The ridges as he states extend to the posterior edge, but, contrary to what he states, though in agreement with parts of his figure, they not unfrequently anastomose twice, even three times in their passage from the little anterior patch of granules (which he does not represent, probably because they are fiequently covered by the preceding seales close to the edge). Some very large specimens shew the exposed part of the scales eleven lines in depth, and nearly six in length, the ridges averaging five in two lines. The sculpturing of the scales is very irregular, and one specimen of the ventral aspect, having several of the scales seulptured in the usual way of $H$. Andersoni, has the ridges on two or three scales broken into tubercles nearly resembling those of $H$. Murchisoni.

Position and Locality.-Extremely abundant (sometimes nine perfect specimens in a slab two feet square) in the yellow uppermost beds of the Old Red sandstone at Duraden.

\section{IIoloptychius giganteus $(A g$.}

$$
\text { Ref.-Ag. Old Red, t. 24. figs. 3, 4, } 8 .
$$

Desc.-Scales very thick, about one inch and half wide; length of exposed portion two-thirds the width, posterior margin truncato-elliptical; surface with close, thick, irregularly, tortuous, longitudinal ridges on the middle portion, posterior part largely tuberculated

The great size is almost the only difference between this and the H. Murchisoni, with which perhaps it may be hereafter united. The under surface has the usual radiating minutely ceilular structure.

Position and Locality.-OOld Red sandstone, Scat Craig. 


\title{
HoloptychiUs NoBILISSIMUS $(A g$ )
}

\author{
Ref.-Ag. in Murch. Sil. Syst. t. 2 bis, fig. 1; Ag. Old Red, t. 23.
}

Desc.-Length rather more than two feet, with a thickness of about ten inches; scales of the body thick, about one and half inches wide; exposed part about a fourth wider than long; posterior margin elliptical; surface with irregular, very coarse, slightly waving, interrupted, longitudinal ridges and furrows, the latter deeply pitted, and the former obscurely nodular, giving a coarse reticulated character to the surface.

As Sir R. Murchison states this to be named after its discoverer, the Rev. J. Noble, would it not be well to change the spelling of the specific name to Noblei?

Position and Locality.-Old Red sandstone, Clashbennie.

\section{Holoptychius PRINCEPS $\left(M^{c} C o y\right)$.}

\section{Ref.-McCoy, Ann. Nat. Hist. 2nd Series, Vol. II.; Sil. Syst. t. 2 bis, fig. 3.}

Desc.-Scales subquadrate, slightly convex, each about three inches wide, and two and half inches long; anterior concealed margin widest, convex; posterior exposed portion about one-third narrower, subtruncate, rounded, sides slightly concave; whole of the exposed surface closely covered with irregular tubercles, about half a line in diameter, and half their diameter apart; most of the tubercles are a little elongated, but in irregular directions, and towards the anterior margin a few of them are generally confluent at their bases, forming short, irregularly twisted, strongly tuberculated ridges; concealed anterior portion and interval between the tubercles minutely porous.

This species far exceeds the $H$. nobilissimus (Ag.) or $H$. giganteus (Ag.) in size; it is easily distinguished by its entirely tuberculated surface. A fragment of this species is well figured (without a name) in Murchison's "Silurian System," pl. 2 bis, fig. 3 , and as $H$. gigantens in t. 36 of his "Siluria."

Position and Locality._-Old Red conglomerate of Scat Craig.

\section{Holoptychius Sedgtickir ( $\left.\boldsymbol{M}^{\circ} \mathrm{Coy}\right)$. Pl. 2. D. fig. 6.}

\section{Ref.-McCoy, Ann. Nat. Hist. 2nd Series, Vol. II.}

Desc.-Body fusiform, very thick, depth in the middle one-third of the length, abruptly narrowed towards the tail, the pedicle of which, at the base of the anal and dorsal fins, is scarcely half the depth of the body; head more than one-fourth of the length; tail very short, nearly square, the thick, articulated, frequently branched, rays dereloped from the under side, forming a broad triangular caudal fin, obliquely truncated on its posterior margin; dorsal rather larger than the opposite anal fin; both semielliptical, twice as high as long; the anal about one-third the length of its base in advance of the caudal; ventral fins broad; their length about equalling their height, rather more than the length of their bases in advance of the anal fin; lateral line nearly medial, strongly marked. Scales thin, rounded; those of the flanks half an inch in diameter, subtrigonal, posterior margin semicircular, concealed anterior margin very broad, subtruncate, with very minute, radiating punctate striæ; a small space towards the middle of the scale is covered with a distinct granulation (frequently but not always seen when the scales are in situ); all posterior to this, or the constantly exposed portion, covered with a minute, longitudinal, irregularly flexuous, striate punctation, intermixed with numerous sharp, narrow, irregularly interrupted, longitudinal, thread-like ridges, of very irregular number and length, but usually two or three times their diameter apart; the exposed part of the scales of the flanks, when in situ, is about one-third higher than long. Teeth conical, one-third longer than wide, half the diameter of their bases apart. Length eleven inches, depth nearly four inches; length of teeth three-fourths of a line.

This species, like the II. Flemingi (Ag.), is remarkable for being found on its side, indicating apparcntly a compressed, instead of a depressed form; it also resembles that species in the sculpturing of the scales, but 
has them (in the same parts of the body) smaller, more rounded, and the exposed portions much less high in proportion to their length.

Position and Locality.-Not uncommon in the Old Red sandstone flags of Orkney.

Explanation of Figures.-Pl. 2. D. fig. 6, natural size; the dotted restored outlines of the fins are from other specimens in the collection; fig. $6 a$, seales of ditto magnified one and half diameters.

\section{Genus. GYROPTYCHIUS ( $M^{c}$ Coy).}

\section{Ref.-M들, Ann. Nat. Hist. 2nd Series, Vol. II.}

Gen. Char.-Slender elongate ganoid fishes, with large, semioval, depressed heads, from which the body gradually tapers to the tail, which is diphycercal, the caudal fin being rhomboidal, pointed in the middle of the retral margin, and the prolongation of the body extending a little above the medial line, nearly to the end; two small elliptical dorsal fins exactly opposite two similar anal fins; pectoral fins broad, rounded, placed rather far back. Scales of the flanks subrhomboidal, nearly oval on the back, imbricated, the exposed portion of each with minute rough ridges, which converge towards the retral end, and seem to gyrate round a nearly central point; the anterior concealed portion nearly smooth (or under a strong lens minutely radiated as in IIoloptychius); under surface of each scale nearly smooth, with a strong mesial leel, which extends from the anteal edge, only as far as the central point, where it abruptly terminates to allow of the imbrication of the remainder of the scale on the next behind; bones of the head covered with granules, which are sometimes confluent into short ridges; teeth small, conical, nearly equal.

In form, number, and position of the fins, and structure of the tail, these fishes resemble Diplopterax, while the imbrication of the scales, as well as their sculptured, instead of simply porous surface, places them close to Holoptychius, and in a different family of Agassiz' system from the former; while from the latter they differ in form and number and position of the fins, structure of the tail, and in the ridge on the under side of the scales, which reminds us of what we see in Osteolepis and many other fishes with juxtaposed scales; but instead of extending entirely across the scale it only reaches half-way, the half-ridge of one seale joining that of the next behind and before when in their natural imbricated position. The Gyroptychii are thus intermediate between Holoptyclius and Diplopterax, and serve to connect the great groups of Colacanth and Sauroid fishes to which those genera respectively belong, having at the same time a style of sculpturing of the scales peculiar to themselves and easily recognizable.

There are two imperfectly known and imperfectly characterized genera of M. Agassiz, Glyptopomus and Platygnatleus, which require a few words in connexion with the present fishes. The first of those genera is founded on a short, thick, fusiform, sauroid fish with simply juxtaposed, rhomboidal, granulated scales; the fins being nearly unknown. The slender form of the present fishes, and the shape, sculpturing, and imbrication of the scales are sufficient distinctions therefrom, the fins being unknown. Platygnathus is a genus founded by Agassiz on the jaw of one fish and the tail of another; the jaw agrees nearly with Bothriolepis, but has fewer laniary teeth, and needs no comparison with Gyroptyctives; the tail portion is more analogous, but the great scales seem to have simply the structure of Holoptychius, and the fins are developed beyond all comparison; further, this genus is founded on such imperfect and perhaps discordant materials, and the jaw seeming to have been most in view in naming and defining the group, it is obvious that even an identity between one of those elements and the present perfectly known type would not invalidate Gyroptychius as a genus. Judging from the figure and description of M. Agassiz, however, there seems, as above noted, to be no great affinity between them.

\section{Gyroptychius angustus $\left(M^{c}\right.$ Coy). Pl. 2. C. fig. 2.}

\section{Ref.-MeCoy, Ann. Nat. Hist. 2nd Series, Vol. II.}

Desc.-Head semioval, obtusely pointed, about one sixth the entire length; depth of the body greatest immediately behind the head, where it is one-seventh of the length, tapering very gradually from thence to 
the tail, the pedicle of which is about one-third the greatest depth of the body; caudal fin large, rhomboidal, obtusely pointed behind, lower side largest, the supramedial spinal prolongation extending nearly to the end; posterior anal fin semielliptical, equalling the depth of the body at its base in height, which is about double the length; both the posterior anal and dorsal fins nearly touch the caudal, and are fully their own height behind the anterior anal and dorsal fins, which are about one-third less in size; the pectoral fins are broad, ovate, scarcely two-thirds the depth of the body at their base in height, and placed nearly their own height behind the head. Scales about two lines high (or wide) and about one-third longer, elliptical, and with a small nearly central boss, round which seem to gyrate very numerous minute rough ridges, less than their own diameter apart, which are arranged in converging curved lines parallel with the margin of the elliptical free end of the scale; the small portion of the ridges anterior to the central boss are frequently broken into little tubercles; the more anterior coneealed portion is smooth or very minutely radiated, the (? articular) ridge on the under side strongly marked; bones of the head closely sculptured with small granules and short vermicular ridges. Length nearly one foot; length of exposed portion of scales slightly more than two lines.

This beautiful fossil most resembles the Diplopterax gracilis (M.Coy) in form, but is at once distinguished by the structure and sculpturing of the scales.

Position and Locality.-Rare in the Old Red sandstone of Orkney.

Explanation of Figures.-Plate 2. C. fig. 2, natural size; fig. 2 a, one scale from the back of another specimen, magnified three diameters.

\section{Gynoptychius diplopteroides $\left(M^{c} \mathrm{Coy}\right)$. Pl. 2. C. fig. 3.}

$$
\text { Ref.-MICoy, Ann. Nat. Hist. 2nd Series, Vol. II. }
$$

Desc.-Head semielliptical, depressed; sides flattened, slightly longer than wide, pointed in front, about one-fifth of the entire length; body tapering rapidly from the head to the tail, the pedicle of which is less than half the width of the body; caudal fin rather large, rhomboidal, nearly medial spinal prolongation slender; posterior dorsal fin elliptical, twice as high as long, close to the base of the caudal, and reaching about half the length of its lateral angle; anterior dorsal little more than half the size of the posterior; pectorals short, broadly-rounded, placed rather more than their own length behind the head. Scales of the back oval, imbricated; concealed portion, anterior to the subcentral point, smooth or very minutely radiato-punctate, all the posterior or exposed portion rough, with small, irregular, minutely flexuous ridges, those of each side running parallel with the curved margin of the scale, and of course converging towards the middle, they are crossed by fine radiating strix ; scales of the sides rhomboidal, nearly square and juxtaposed, each scale articulated to the preceding and superior one by a narrow, smooth border on the superior and anterior sides, extending into an angular articulating process at the anterior superior angle (as in Osteolepis, \&c.); the quadrate exposed portion has a small central point, round which the little rough ridges gyrate diagonally; bones of the head sculptured with small vermicular ridges and granules.

Length about eleven inches, greatest width of body two inches; length of exposed portion of scales about two lines.

The different shape of the scales, and the wide, short, rapidly tapering figure, easily distinguish this from the last.

Position and Locality.-Not uncommon in the Old Red bituminous schists of Orkney.

Explanation of Figures.-Pl. 2. C. fig. 3, natural size; with a lens of low power the gyrate marking can be seen on the figure; fig. $3 \alpha$, two lateral scales of do., shewing the gyrate sculpturing of surface, and the two articular margins, magnified three diameters.

\section{Genus. DENDRODUS (Owen) pars.}

Syn.? = Asterolepis Eichw.

Gen. Char.-Teeth large, thick, conical, straight or sigmoidally curved; surface covered with fine Iongitudinal ridges from the apex to the base; base dilated into an oblique, subsemicireular, rounded, flattened prad. 
Microscopic structure: longitudinal medullary tubes numerous, irregular, largest towards the centre, giving off numerous branches (or vertical slits) to the circumference, which are simple towards the apex, but give off lateral branches lower down; these lateral ramules of the branches terminate in little cells; from all these cavities the calcigerous tubes proceed at right angles; there is a thin outer layer of ganoine, the external furrows of which correspond to the internal rows of medullary cavities.

The genus Dendrodus of Owen has been divided by Agassiz into Dendrodus, Lamnodus and Cricodus, but Mr Miller seems to have ascertained that it should be united to Asterolepis: he figures a close row of small equal teeth on the edge of the dentary bone, behind which the few great laniary teeth (those formerly described as Dendrodus) are far apart, and planted in large, shallow pits on an internal, broad, projecting, horizontal ledge.

\section{Dendrodus latus (Owen).}

Ref.-Ag. Poiss. Foss. Vol. II. t. 55 a, figs. 19, 20 ; Old Red, t. 28. fig. 1, 2.

Desc.-Tooth about two inches long, conical, with a slight sigmoidal curve, slightly keeled towards the apex, which is obtuse; section circular towards the base, which is nearly two-thirds the length of the tooth in width; surface with nearly equal obtuse longitudinal striæ, about three in one line at the middle.

Position and Locality. - Old Red sandstone, Scat Craig.

\section{8th Fam. PLACODERMATA.}

Body enclosed in a short, oblong case or carapace, composed of large, strong bony plates, either lateral in pairs and nearly symmetrical, or odd and placed in the median line on the upper or lower surfaces; spinous processes of the vertebre usually ossified, but the bodies not; no distinct caudal nor pectoral fins; teeth conical, simple, equal.

I originally proposed this group (Annals Nat. Hist. July, 1848, p. 6) for all the genera included in the Fam. Cephalaspidee of Agassiz except his Cephalaspis, to which I proposed to restrict that family name, the latter differing from the present fishes in having the body covered with scales of the ordinary Ganoid construction, distinct heterocercal tail, \&c.; but I also suggested that some fragments of other genera, the essential characters of which were then unknown, might have the same position, which subsequent researches shew really to possess the characters of the Coclacanthi, to which group they should rather be approximated, leaving the definition of this family unchanged.

\section{Genus. PTERICHTHYS (Ag.)}

\section{Syn. $=($ Pterichthys Ag. [under side] + Pamphractus Ag. [upper side]) $=$ Homothorax (Ag.)}

Gen. Char.-Body covered by an oblong carapace, flat on the under aspect, vertical on the sides, elevated and obtusely keeled along the mid-line of the dorsal aspect, the sides sloping thence to the vertical margins, the most elevated point being a little in front of the middle; tail thick, conical, covered witl rhomboidal granulated scales; one small (? anal or dorsal) fin close to the posterior margin of the carapace, having a small thick spine at its front edge, the fin-membrane granulated, without distinct rays; head rounded, of moderate size; at its junction with the carapace, two large falciform, pointed, pectoral appendages are articulated by a ginglymoid joint, one on each side, exceeding half the carapace in length, thickest about the middle, where there seems to be a joint, and having their anterior edge tuberculo-serrate; entire surface of the strong bony exo-skeleton covered with coarse granules.

The carapace, as is clearly proved by Sir P. Egerton and Mr Miller, has invariably the ventral side flattened, and the dorsal side lreeled or elevated (Agassiz having in some cases described the keeled side as inferior). Miller's observations as to the number of the bony plates in the carapace exactly agree with my own; although Agassiz and Sir P. Egerton in their restored figures give a larger number. The whole carapace seems to be, as Miller says, composed of eleven thick, bony plates, five on the ventral aspect, i.e. one central rhombic plate 
which is bevelled from without with broad squanose sutures, so that it is overlapped by the other four, the two anterior lateral of which would be nearly square, but for the truncation of the inner angle by the central plate; the posterior lateral plates are much longer than the anterior, elliptically pointed at the posterior end, each marked at about a third from the posterior end by a transverse depression, which is counted as a suture by Agassiz and Egrerton, the former again bisecting each of the triangles so defined by a second suture, of none of which however have I seen any trace, but on the contrary, I think I have seen the parts entire in many specimens, as stated by Miller; the outer third of both the anterior and posterior lateral ventral plates is bent upwards at right angles, to form a portion of the vertical sides of the carapace. The dorsal aspect has six large plates, two median and two lateral on each side. The anterior median plate is obscurely ovato hexagonal, truncated in front, patelliform or obtusely conoidal, and occupying the anteriorly eccentric apex of the back; its anterior latcral margins are bevelled from within so as to overlap the anterior lateral plates, the lateroposterior edges are lievelled on the outer edge, so as to be overlapped by the posterior lateral plates; the narrow posterior edge being however bevelled from within, so as to overlap the posterior median plate; posterior median plate ovate, narrow in front, where it is overlaid by the posterior end of the anterior median plate, its long anterolateral edges bevelled from within by a broad squamose suture to overlap the posterior lateral plates; posterior lateral plates large, extending not quite so far forward as the middle of the anterior median plate, truncated in front, where they join the anterior lateral plates by a transwerse suture; their outer third abruptly bent down. wards at right angles to meet the posterior lateral plates in the middle of the vertical sides; anterior lateral plates truncated in front and behind, deflected about their middle at right angles to join the anterior lateroventral plates on the vertical sides; their concave anterior margin thickened by a bony internal ridge; a similar thick bony ridge is within the concave posterior edge of the posterior dorso-lateral plates, from which two internal ridges run, one nearly to the internal apex of the anterior medio-dorsal plate, the other running along the angle of the sides as far as the anterior margin of the plate. The head is covered by several irregular. polygonal pieces, the exact form of which is still doubtful. The lateral diverging appendages are supposed by some to be pectoral fins, and by others to be cephalic spines; their being articulated by the ginglymoid joint alluded to, is against the supposition of their being fins; and against both suppositions is apparently the existence of a joint at alout the midlle of their length, where they are widest, and from whence they gradually taper towards the body, and are abruptly pointed towards their extremities. The single small fin is supposed by Miller to be either dorsal or ventral, and by Sir P. Egerton to be dorsal; I have invariably found it howerer on the ventral aspect; and as my observations agree with Miller's in the point of its not being paired, I believe it to be an anal fin. Sir P. Egerton's own figure (Geol. Journ. Vol. IV. t. 10) represents this fin on the ventral aspect of the tail, for it will be remembered that the dorsal plates there represented are seen from within. A ridge of angulated scales extends from this fin to the extremity of the tail, and it is apparently part of this ritge originally described by Miller which Sir P. Egerton designates as caudal fins in the above figure, no trace of caudal having been seen in other specimens. The restored figure of Pampluractus, in Agassiz' Olil Red Fish, t. 6.f. 2, represents the dorsal aspect of a true Pterichthys, the Iongitudinal suture in the posterior median plate being an accidental fracture. The plates are composed of three layers, an under swooth one, a middle coarse osseous one, and a very dense, polished, granulated, superficial one, which is easily separated.

\section{Ptericithys cancriformis $(A g$ )}

$$
\text { Ref.-Ag. Old Red, t. 1. fig. 4, } 5 .
$$

Disc.-Head prominent, rounded; pectoral appendages narrow, slightly longer than the width of the body at their base, terminating in a slender point; length of head and body about three inches, greatest width (immediately behind the pectoral appendages) about one and half inches, tapering rapidly from thence to the tail, which equals the end of the carapace in width, being little more than one-fourth the width behind the pectorals; tail the length of the pectorals; central ventral plate acute-angled, rhombic, a fourth longer than wide, length equalling the width of the anterior lateral plates; plates of the body and pectorals coarsely [EASC. 1II.] 
granulated, plates of the tail very minutely granular; anal (or dorsal) fin about as high as long, its anterior spine rather more than one line thick at base, five lines long; membrane of the fin granular.

The above description is drawn up from finer specimens than M. Agassiz apparently had access to.

Position and Locality. - Abundant in the Orkney schists of the Old Red sandstone.

\section{Pterichthys latus $(A g$.}

$$
\text { Ref.-Ag. Old Red, t. 3. figs. } 3 \text { and } 5 .
$$

Desc.-Oblong, carapace about three inches long, width two-thirds its length ; pectorals narrow, gradually tapering to a point, curved uniformly with the side of the carapace, the width of which they slightly exceed in length; plates of the tail subquadrate, about one and half lines wide, arranged in transverse (? or alternate) rows. Central plate subpentagonal, gibloous, rounded, about equal to the anterior lateral plates in wilth.

In all the specimens I lave seen the tail-plates seemed to me in alternating rows, and tuberculated more finely than the body. What Agassiz has described as the under surface of this species, Sir P. Egerton has shewn to be the lateral aspect, so that there is no anomalous absence of central plate.

Position and Locality._-Old Red sandstone, Orkney.

\section{Pterichthys oblongus $(\boldsymbol{A} g$.}

$$
\text { Ref.-Ag. Old Red, t. 3. figs. } 1 \text { and } 2 .
$$

Disc.-Carapace high, narrow, about three and half inches long, oblong, with nearly straight, subparallel, plane, perpendicular sides; width (greatest about the middle) one inch nine lines; central plate suboval, gibbous, about one-third longer than wide; pectorals about one-fourth longer than the width of the body, abruptly pointed; tail as wide at the base as the extremity of the carapace; head small, rounded, prominent; granulation coarsest at the ends and margin of the carapace.

Remarkable for its large perpendicular sides and lengthened form.

Position and Locality.-Old Red sandstone, Gamrie, and common at Orkney.

\section{Pterichthys productus $(A y$.)}

$$
\text { Ref.-Ag. Old Red, t. } 5 \text {. }
$$

Desc.-Head and carapace suboval, about three inches long, the greatest width being about half their combined length; central ventral plate rather less than the width of the anterior lateral plates, its length and width equal, having four slightly curved cqual sides and blunt angles; head small, rounded; tail conical, as wide at the base as the posterior end of the carapace (that is, nearly half the greatest width), which it about equals in length, covered with several longitudinal rows of subquadrate or rounded scales about a line wide; pectorals broad, slightly excecding the width of the body in length; posterior margin slightly concave: anterior margin nearly parallel with the posterior for two-thirds of its length, then abruptly curving down to meet it at a sharp point; granulation coarse, very crowded.

Position and Locality.-Old Red sandstone, Orkney.

\section{Pterichthys testudinarius $(A g \cdot)$}

$$
\text { Ref.-Ag. Old Red, t. 4. figs. 1-3. }
$$

Desc.-Carapace about three inches long, ovate, pointed behind, subtruncate but narrorved in front, gibbous along the middle; central ventral plate small, longer than wide, with four straight sides and sharp angles, its width being little more than half that of the anterior lateral plates. 
Distinguished from the P. latus (Ag.) by the narrowing of the front, and the very small, quadrangular, central plate of the lower side. The dorsal central plate is (as usual in the genus when seen) very large (about half the widtl of the carapace) and hexagonal; granulation resembles that of $P$. latus; pectorals very small, pointed, scarcely reaching the bottom of the little ventral central plate; tail large and thick.

Position and Locality.-Old Red sandstone, Orkney.

\section{Genus. COCCOSTEUS (Ag.)}

Gen. Char.--Head and body not distinctly separated; together forming an ovate carapace, broadly-rounded in front, and tapering behind; one nearly transverse suture marks the posterior limit of the nearly semicircular head, which is covered by the "facial plate" of Agassiz, which latter is divided into three triangular lobes (sometimes forming separate plates), widest at their outer ends, the middle one having a deep semielliptical fissure in the front margin; the space between the middle and lateral lobes of the facial plate on each side is filled by nearly equal and similar plates, called the "lateral anterior plates" by Agassiz; the plate called "nuchal plate" by Agassiz, is, I think, the homologue of the anterior median dorsal plate of Pampluractus (=back of Pterichthys) ; it is a broad, slightly tumid, trapezoidal plate, having two equal oblique sides, one rather wider posterior margin, and the anterior margin shorter than the others; the posterior margin is articulated to the very large subpentagonal, shield-shaped, dorsal plate, the broad anterior end of which is truncated, the long sides subparallel with a slight sigmoidal curve, and abruptly tapering to a sharp point behind; this plate is obtusely keeled along the middle, from whenee the flattened sides slope. On each side of the nuchal plate is the large trigonal "posterior lateral plate" of Agassiz, the base in front articulating with the cephalic plate, the inner margin articulating with the nuchal plate, to the base of which its apex extends; this plate I think should be considered the homologue of the anterior latero-dorsal plate of Pterichthys, and be called by the same name; behind the apex of the last plate are the uuch narrower and longer triangular plates, which I have called the posterior, latero-dorsal plates, which extend about two-thirds the length of the posterior dorsal plate on each side; these are omitted by Professor Agassiz in his restoration, though represented by Miller. The jaws are small, curved, and set with sereral pointed, equal teeth, confluent with the bone of the lase, and equally destitute of ganoine. Agassiz figures three narrow marginal plates extending from the onter culde of the anterior, lateral, cephalic plate, to the outer angle of the nuchal plate, these I have not seen distinctly; between the posterior end of the under jaw, and posterior angles of nuchal plate, covering the cheek on each side, is a rather large, triangular, "articular plate." The under side of the body is covered by five plates (the plates, if any, beneath the head being unknown), two posterior ventral plates uniting along the middle by a broad squamose suture, which shews them when dislocated to be non-symmetrical, the left one being the largest and always overlapping the right; they are elongate, oblong, truncated behind, but with the posterion: lateral angles produced backwards in short falcate spines; the outer sides are nearly straight, the inner angle being cut off by the small, acutely rhombic, central, ventral plate, which has broad, squamose bevelling from mithout, so as to underlie the other four plates; the lateral obtuse angles coincide with the transrerse suture between the anterior and posterior latero-ventral plates; anterior lateral plates as wide, but only about onc-third the length of the posterior ones, transversely rhomboidal, the anterior margins nearly straight, and coinciding with the apex of the central plate; the outer margin oblique, with the anterior angle rounded, the five together forming an elongate, oblong shield. T'ail as long as the head and body together; the apophyses of the vertebre strong, bony, but the bodies rarely ossified, usually, as suggested by Agassiz, forming a soft continuous cord, as in the recent Lepidosiren, and leaving no trace in the fossil state. There is a dorsal fin close to the end of the carapace. Surface of all the plates pustulated, the granules radiatingly striated at the base.

According to Agassiz there is also an anal fin directly under the dorsal one, but after the examination of a large number of finely preserved examples belonging to three species of the genus, I have never seen any trace of it; in the position indicated I have always observed the apophyses of the vertebra much longer than 
in other parts of the tail, producing something of the appearance of a fin, but without a second or interapoplysary set of bones, such as support true fins, and such as we see in nine cases out of ten in the dorsal fin of those same specimens. I therefore strongly doubt the existence of an anal fin in this genus. Mr Miller has also figured pectoral appendages to the C.cuspidatus $(O . R . S . t .3)$, of which I have never seen a trace; besides which they are figured in a wrong situation for pectoral appendages, and are, I think, more probably some of the dislocated marginal plates. The microseopie structure of the plates resembles that of Pterichthys, but the cells are smaller and more irregular in shape. The teeth have the middle occupied by a coarse network of irregular, tortuous, medullary canals, from which the fine caleigerous tubes radiate. I think I have satisfied myself of the existence of a short thick spine on the posterior third of the dorsal plate of all the species.

\title{
Coccosteus latus $(A g$.
}

Ref. and Syn.=C. latus Ag. Brit. Ass. Rep. 1842; Poiss. Foss. Vol. I. p. 32 ; = C. decipiens Ag. Old Red, t. 7 to 10 .

Desc.- Head and carapace clavate; entire length about one foot, width about four inches; nuchal plate about one and half inches wide at base, one inch two lines long, and seven lines wide in front; the facial plate prolonged backwards into two triangular processes one-fourth of an inch long, one on each side of the narrow front of the nuchal plate; dorsal plate about three inches long and one and three-fourths wide; anterior third of the lateral margin concave, middle third convex, posterior third slightly concave in converging to form the posterior point; at about one-fourth the length from the apex is a long ovate giblosity (supporting a short thick spine?), from whence to the anterior margin runs a small mesial ridge; ventral plates very long, narrow, the outer posterior angle produced into a narrow curved process upward of half an inch long; mesial ventral plate acute-angled, rhomboidal, one and half inches long and one inch wide in the middle; all the plates with an irrregular, scattered granulation, the interspaces with minute vermicular ridges.

Position and Locality._Old Red sandstone; very common in the black flags of Orkney.

\section{Coccosteus microspondyus (Mc Coy). Pl. 2. C. Fig. 4.}

\author{
Ref.-M McCoy, Ann. Nat. Hist. 2nd Series, Vol. II.
}

Desc. - This species resembles the C.oblongus (Ag.) in size and granulation, but has a much shorter dorsal plate, and the posterior external angles of the posterior ventral plates are produced into long curved processes as in the C. latus (Ag.), from which it differs in its strong, regular, close granulation; it differs besides from both species in the plates of the carapace being shorter, and most remarkably in the much smaller size and slight ossification of the vertebræ, giving a peculiarly weak and slender appearance to the tail. The bodies of the vertebrie have all left their separate impressions, so that the vertebral column was certainly not in this case a continuous cartilaginous cord, as suggested by M. Agassiz in the case of the $C$. latus, in which they leave no trace. There is evidence of a thick spine, about an inch long, being attached to the tuberosity of the dorsal plate. The dorsal plate is two and lalf inches long and one and a quarter wide, with straight parallel sides, not being perceptibly narrower in front than at the lateral angles, in which it differs from the C.pusillus $\left(M^{\mathrm{c} C o y}\right)$, as well as in size.

Position and Locality.-Rare in the black flags of Orkney.

Explanation of F"igures.-PI. 2. C. fig. t, natural size. On the lower left-hand portion of the dorsal plate at upper portion of figure, is seen apparently the remains of a spine attached thereto; the left-hand extremity of the figure shews the remains of the vertebral column, shewing the separately ossified bodies of the vertebre, with several neurapophyses, and a few distinet traces of the lower spinous processes or hxmapophyses, and below them the dermal bones of the dorsal fin in reversed position. 


\title{
Coccosteus oblongus $(A g$.
}

\author{
Ref.-Ag. Old Red, t. 11.
}

$D_{t s c}$-Size and general shape of the $C$. latus, but shorter and less clarate, the facial plate not prolonged backwards into little angular processes at the sides of the nuchal plate; the dorsal plate is more gradually pointed retrally, and the posterior ventral plates shorter, truncated retrally, and the external posterior angles terminating in short, obtuse, mucronate points. The granules are radiated at the base, rather larger, more regular and closer than in that species, and the intervening spaces minutely dotted; teeth about a line long, close set, smooth, conical, the width of their base equalling their height; mesial ventral plate large, broad, and obtusely ovate.

Position and Locality.-Old Red sandstone; common at Lethen Bar and at Orkney.

\author{
Coccosteus pusillus $\left(\mathrm{M}^{\circ} \mathrm{Coy}\right)$. Pl. 2. C. Fig. 5. \\ Ref:-M $\mathrm{M}^{\mathrm{C}} \mathrm{Coy}$, Ann. Nat. Hist. 2nd Series, Vol. II.
}

Desc.- Head and carapace orbicular, width about two and half inches, length three inches; tail about as long as the head and carapace, of very numerous small, weak (? slightly ossified) apophyses; dorsal fin small, weak; dorsal plate subpentagonal, one inch and five lines long, greatest width (at the lateral angles) eight lines, tapering to a sharp point retrally, also narrowing about one-sixth towards the subtruncate anterior margin; all the margins concave, the anterior most so ; middle of the plate obtusely keeled, the tuberosity and fossa (for lodging the dorsal spine?) rather more than one-third the length from the posterior apex; all the plates of the carapace minutely and regularly tuberculated, granules nearly equal, about their orwn diameter apart, fourteen in the space of a quarter of an inch, intervening spaces very minutely granulated; teeth slender, cylindrical, pointed, their own diameter apart, one-third of a line in diameter, nearly a line long.

The very small size and imperfect development of the vertebral apophyses, together with the small size and orbicular form of the cephalothorax, easily distinguish this species. The peculiar proportions of the dorsal plate, as well as the distance of its tuberosity and fossa from the apex, and the minuteness and regularity of the tuberculation, distinguish it from the young of the other species; besides, I find all the characters constant in five nearly perfect specimens which I have examined.

Position and Locality.-Not uncommon in the black flags of the Old Red sandstone at Orkney.

Explanation of Figures.-Pl. 2. C. fig. 5, natural size of full grown specimen; the lower part of the figure shews two posterior, united, latero-ventral plates, under and immediately above which is seen the extremity of the dorsal plate. The remains of the vertebral column seem only to have the spinous processes ossified; the right-hand or anterior end of the figure (which shews the ventral aspect) exposes the two dislocated halves of the lower jaw, with their teeth; fig. $5 \alpha$, single perfect dorsal plate of ditto, from another specimen, natural size.

\section{Coccosteus? trigonastis $\left(M^{c} \mathrm{Coy}\right)$. Pl. 2. C. Fig. 6. \\ Ref.-Mc $\mathrm{I}^{\mathrm{C}} \mathrm{y}, \mathrm{Ann}$. Nat. Hist. 2nd Series, Vol. II.}

Desc.-Mesial ventral plate subtrigonal, slightly convex, thirteen lines long and seven lines wide at the lateral angles, which are only two lines behind the rounded or very obtusely-angular anterior end; lateral posterior margins straight, converging to form the retral point; four or five irregular rows of tubercles, laalf a line in diameter, and less than their diameter apart, run round the margin, leaving a central, ovate, convex space more obscurely tuberculated; each tubercle consists of a hemispherical, smooth centre (frequently perforated in the midrle), surrounded by a thickened base, which is radiatingly ridged, intervening space irregularly dotted. 
This beautiful species is easily distinguished from all others by the shortness of the anterior end of its ventral mesial plate, which is the only part yet known. The tubercles resemble those of a small Cidaris or Asterolepis.

Explanation of Figures.-Pl. 2. C. fig. 6, probably mesial ventral plate, natural size; fig. 6 a, tuberculation of do. magnified. 


\title{
4th sub-kingdom. VERTEBRATA. See page 575.
}

\section{1st Class. PISCES. See page 575.}

\author{
4th Order. Ganoidea. See page 579.
}

\section{1st Family. LEPIDOIDEA.}

Teeth very minute, and in numerous rows en brosse, or obtuse and in one row. Scales flat, rhomboidal, of moderately large size. Skeleton bony. Ventral fins near the middle of the body; tail small.

These are all rather clumsy fishes, with moderate-sized fins. They are united with the Sauroidea by Müller. All the examples are extinct. There are two groups; first, with heterocercal tails, confined, with one exception (Coccolepis), to the Palscozoic Rocks, and of which the following genus, Palcouriscus, is an example. Second, with homocercal tails, confined to the Mesozoic and Tertiary rocks.

\section{Genus. PALEONISCUS (de Blainv. extended by Ag.) \\ Syn. $=($ Palcooniscus + Palcoothrissum $)$ De Blainv.}

Gen. Char.-Size moderate or small, body fusiform, deep between the ventral and pectoral fins; tail heterocercal, forked, large, upper lobe longer and narrower than the lower, with the body extending to its extremity. Fins rather small, particularly the pectorals and ventrals, none of them reaching to the origin of the next behind; but all with strong fulcral scales. Anal fin commonly smaller than the dorsal, which latter occupies the space over the origins of the ventral and anal fins. The jaws are large, but the teeth en brosse so minute as to be scarcely visible; the muzzle projecting beyond the jaws from an expansion of the pre-frontal and nasal bones. Scales moderate, rhomboidal, smooth or finely striated longitudinally.

The species with small scales are more slender than those with large ones. In some of the species (e.g. P. Blainvillei and $P$. Voltzi) the fins are covered with rows of scales, each of which rest on two adjacent rays, so that when removed, the impressions of the mesial articulating ridge alternates with the impressions of each true fin-ray,-there is no scaly covering to the fin-rays of Amblypterne, nor in other species of Palceoniscus (e.g. P. Freicslebeni), in which however the ordinary scales seem gradually to change into the articulated rays.

Very common in the Carboniferous, Permian, and Triassic formations.

\section{Paldeniscus elegans (Sedgwick Sp.)}

Ref. and Syn.= Palcothrissum elegans Sedgrwick, Geol. Trans. 2nd Series, Vol. III. t. 9. f. 1.= Palconiscus clenans Ag. P. F. Vol. II. t. J0 b. f. 4, 5.

Desc.-General form elongate-lanceolate, scarcely varying in depth from the nape to end of dorsal fin; head small, semielliptical, a little less than one-fourth of the entire length to cxtremity of tail, its length 
exceeding the depth of the body by one-third; orbits large; lateral line strongly marked slightly nearer to the dorsal than to the ventral margin; scales oblong, a little deeper than long, nearly equal all over the body, except on the upper lobe of the tail, where they become acutely rhombic, and about twice as long as deep; all about the middle of the body a space of two lines would include four seales in depth and five in length; a space equal to the depth of four scales is exceeded four and half times by the depth of the body at same place (Agassiz' figure having the scales too large, but Prof. King's being correct); surface of the scales when strongly magnified shewing a few faint longitudinal strix and minute punctures; posterior edge crenated except ' avards the end of tail, where they become smooth; the upper and lower margins almost straight, very slightly sigmoid; fins small, space between origin of pectorals and origin of ventrals slightly less than from origin of ventrals to origin of caudal; from the origin of ventrals to origin of anal fin, equal to the depth of the body at ventrals; caudal deeply forked; lobes narrow, elliptical, equal, length of the lower lobe equalling the depth of body at the nape or at the ventral fins; average length five inches two lines, greatest depth of body eleven lines, diameter of orbit two and half lines.

The above description is from the original specimen, but the state of the surface is such that I cannot distinguish the radiating furrows said to mark all the bones of the head.

Position and Locality.-Very rare in the Permian marl-slate of East Thickley.

\section{Palmoniscus Freieslebeni (De Blain.)}

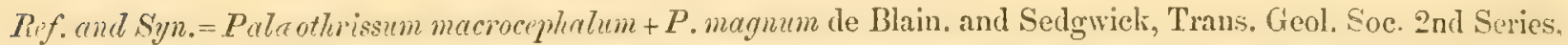
Vol. III. t. 8. f. 1, 2. t. 9. f. 2.= Palooothrissum Freieslebense de Blain. Dic. d'Hist. Nat. Vol. XXVIII. $=$ Palconiscus megacephalus Germ. $=$ P. Freieslebeni. Ag. P. F. Vol. II. t. 11, 12. +P. comptus Ag. id. t. 10 b. f. 1, 3; King, Perm. Foss. t. 21. f. 1.

Desc.-Tery elongate, ovate, or lanceolate; head large, nearly one-fourth the entire length (the upper lobe of tail extending one-third the length of the head beyond four lengths of the head from the snout); length of head exceeding the depth of the body at nape by about one-fifth; lower jaw short; pectorals small; the space from origin of pectorals to origin of ventrals exceeds the greatest depth of the body between these fins by onetenth; from origin of ventrals to anal fin exactly equalling the depth of body at origin of the former; from origin of anal to origin of caudal fin slightly less than from origin of rentral to origin of anal, but exactly equalling the depth of the body opposite the latter point; dorsal fin small, situated a little behind the ventrals, triangular, slightly rounded; depth of pedicle of tail at origin of caudal equal to half the depth of body to origin of ventral fins; tail deeply forked; upper lobe narrower and considerably longer than the lower. Scales, oblong, very uniform over nearly the whole body, about one-third deeper than long on the flanks in front of the ventrals, where a space equalling four scales in depth, or seven in length, is about equal to one-fourth the depth of the body (within the size of one scale); behind the ventrals their length remains exactly the same, nearly to the origin of the caudal, but the depth is reduced to an equality therewith; on the upper lobe of the tail the scales as usual assume a very elongate acutely rhombic form; all the scales marked with fine, irregular, slightly flexuous ridges, and finely fringed on the posterior margin; the upper and lower edges of the scales nearly straight, or with a very faint sigmoid curvature. Iength of average specimen eight inches five lines; depth of body one inch six lines; in middle of flanks in front of ventrals three scales in depth, or six in length, occupy a space of four lines over anal fin; the same space includes the same number in lengtl, but rather more than five in depth.

The entire of the above description was drawn from one of Prof. Sedgwick's typical specimens from East Thickley, and every portion of it compared at the same time, both in measurements, proportions and seulpturing of the body, fins, and scales, with a specimen of the same size of the P'alconiscus Freieslebeni from the lichelsdorf copper-slate, and they agree to the most minute particular; I have therefore no hesitation in asserting confidently the perfect identity of the English marl-slate species, and that of the German copper-slate, contrary to the writings of M. Agassiz, but fully bearing out the statement to this effect by Prof. Selgwick and M. de Blainville, in the above quoted Memoir of the former on the Magnesian limestone of England. 
The upper and lower margins of the scales are said by M. Agassiz and Sir P. Egerton to be arched, but they are not in the slightest degree more so than in the German copper-slate species.

Position and Locality.-Extremely abundant in the Permian marl-slate of East Thickley.

\title{
Palæoniscus glaphyrus $\left(A g g_{0}\right)$
}

\author{
Ref.-Ag. Poiss. Foss. Vol. II, t. 10 c. f. 1, 2.
}

Desc.-General form, deep-ovate, increasing from the head to the origin of dorsal fin, and abruptly attenuated behind the anal fin to form the pedicle of the tail, which is there only half the depth of the body in front of the dorsal; head very small, little more than one-sixth the entire length; mouth small; orbits very large; from the origin of the pectoral to origin of ventral fins rather more than from the origin of ventral to the origin of anal fin, from the origin of which to the origin of the caudal is considerably less than the space between the origin of the ventral and anal fins, but exactly equals the depth of the body at the latter point; greatest depth of body (at middle of length) equal to one third of the length, from the edge of the opereulum to the extremity of lower lobe of caudal fin; scales very large, oblong, about one-third longer than wide on the flanks, where near the head three occupy a space in depth of little more than three lines, and four occupy the same space in length; the depth of the body equalling about three and half times a space equal to a depth of three scales, on all the anterior parts of the body. Surface of the scales smooth and polished, posterior edge coarsely serrated with about eight denticles. Arerage length little more than three inches, depth of body ten lines.

This little species is very easily distinguished, by its broad thick form, abruptly attenuated torards the tail, and its very small obtusely angular head, but most particularly by the great proportional size and the coarse notching of the posterior edges; this latter character is more strongly marked than in M. Agassiz' figure, there being in our specimens fewer denticles to the length of a scale: the scales are very thin and brittle, with the usual strong articulating process projecting internally from their upper edge, and forming the usual internal ridge along the middle. In all the specimens yet known the caudal fin is imperfect, so that the precise form of the upper lobe is not known. The bones of the head are marked with few obtuse, diverging sulci.

Position and Locality.-Rare in the Permian marl-slate of Ferry Hill.

\section{Palzoniscus macrophthalisus $(A g$ )}

\section{Ref.-Ag. Poiss. Foss. Vol. II. t. 10 c, f. 3 ; King Perm. Foss. t. 22 . f. 2}

Desc.-Elongate, slender, body of nearly uniform depth from the head to origin of anal fin, from whenee it tapers rapidly to the origin of the caudal; head very large, obtuse, slightly exceeding the body in depth and width, its length from the nape to the tip of snout is comprised four and half times in the total length; from the latter point to the extremity of tail, measured from snout to origin of pectorals, the head is comprised about three and half times in the total length; depth and width of head slightly greater than that of the body; lower jaw short, slender; orbits large, their anterior margin nearly over the anterior end of the lower jaw; from nape to origin of dorsal fin the same length as from the latter point to the origin of the caudal, so that the whole of the dorsal is nearer to the tail than to the head, and is vertically over the interval between the rentral and anal fins; pectorals rather small, elliptical; from origin of pectorals to origin of ventral fins slightly more than from the latter point to origin of anal, the distance between the origin of the two latter fins being equal to the depth of the body at the same point; caudal moderately forked; all the fin-rays cxtremely slender. Scales very small, nearly oblong, and uniform over the whole body, slightly deeper than ling in the anterior half, nearly equilateral in the posterior half, diminishing in size, very acutely rhombic, and much longer than deep on the upper lobe of the tail; about the middle of the body six seales in length and four in depth occupy a space of two lines, the space including such number being comprised three and lialf times in the depth of the body at same place. Surface marked with very deep, coarse, short, interrupted grooves, very 
irregular in direction, forming wide, imperfect ridges, nearly obsolete on the anterior part of the trunk, most strongly marked on the tail; posterior edges of the scales very minutely crenulated, each with about twelve notehes. Average length four inches three lines, depth of body about eight lines (specimens occasionally oceur five and half inches long).

I have not been able to see, any more than M. Agassiz, the articulating process of the scales in this species; but I easily see in several specimens the minute crenulation of the posterior edges, which escaped him. The oval imbricating scales, forming a row along the middle of the back, are rather large, the others are remarkably small, and form, as M. Agassiz and Sir P. Egerton observe, a strong contrast with those of the $P$. glaplyyrus. The lower jaws are sculptured with slightly flexuous oblique ridges; the other bones of the head are irregularly granulated and marked with short vermicular ridges.

Position and Locality.-Not very uncommon in the Permian marl-slate of Ferry Hill.

\section{4th Family. SAUROIDII (Ag.)}

Tecth of two kinds in each jaw, a few large, conical, pointed, laniary ones alternating with very numerous, subequal, minute, teeth en brosse. Scales thick, bony, polished by a layer of ganoine, flat, rhomboidal, of moderately large size; not imbricated, articulated by their edges. Endo-skeleton bony.

These are slender, swift, carnivorous fishes, with large fins. They are united by Miiller with the Lepidoidii.

The family is divided into two sections, first, with heterocercal tails, confined to the Palacozoic rocks; second, those with homocercal tails, extending from the lias to the present seas inclusive. The genera of this family extend from the Devonian to the recent periods inclusive, but are most numerous in the Mesozoic Rocks.

\section{Genus. PYGOPTERUS (Ag.)}

Gen. Char.-Body large, elongate, ovate; fins very large, with fulcral scales; anal fin of moderate depth, but very long; dorsal of moderate length, nearly opposite, or a little in front of the anal fin; ventrals small, slightly in front of the middle of the body; pectorals moderately small, falcate; caudal very large, deeply notched; upper jaw a little longer than the lower; endo-skeleton strong; vertebre usually wider than long; seales proportionally rather small, rhomboidal, smooth, and minutely punctured or diagonally striated, extending over the pedicles of the fins, and particularly over the thick upper lobe of the tail to the extremity, having a moderately wide articular margin, sometimes prolonged at the upper angle, and having a medial, internal, articular ridge, which forms a prolongation from the middle of the upper margin.

\section{Pygopterus mandibularis $(A g$.}

Ref. and Syn $=$ Fossil Fish, Sedgwick Trans. Geol. Soc. 2nd Series, Vol. III. t. 10. f. 1, $3=$ Nemoptery $x$ mandibularis and Sauropsis Scoticus Ag. MSS. names in collections=Pygopterus mandibularis Ag. Poissons Fossiles, Vol. II. t. 53. and $53 a ; ?+P$. sculptus id. ib. p. $77 ;=P$ ygopterus Scoticus, Bronn. Lethoca; King Perm. Foss. t. 23.

Disc.-Body very elongate; head (much shattered, but apparently) trigonal, and as deep as long; pectorals large, falcate, two-thirds the length of the space between their base and the origin of the rentrals, which space is about equal to the depth of the body at the nape; ventrals of moderate size, triangular, their length about two-fifths the depth of the body at their origin; from the origin of ventrals to origin of anal fin slightly le:s than from the same point to the origin of the pectorals, and about equalling the depth of the body at the origin of the anal, which is vertically under the middle of the dorsal fin; dorsal and anal fins nearly equal, considerably higher than long, the anal narrower and more faleate than the dorsal; pedicle of the tail rapidly attenuated from these fins, elongate slender; from origin of anal to middle of base of lower lobe of caudal equal to twice the depth of the body between the dorsal and anal fins: caudal very deeply forked, with narrow nearly cqual lobes; length of the lower lobe equal to one and half the depth of the body between anal and 
dorsal; its width at hase of the lobe slightly less than that of the pedicle of the tail at its origin, which is equal to one-fourth the space between the origin of the anal, and origin of the caudal; body prolonged nearly to the extremity of the upper lobe of the tail; all the fins with strong fulcral scales on their anterior edges. The fulcral scales on the upper lobe of the tail rery large. Scales small, quadrate, nearly uniform over the whole body, the greater number of them rhombic, with the length and width nearly equal, but on the uprer lobe of the tail becoming very acutely rhombie, with the length two or three times greater than the denth; those on the flanlis near the head are oblong and nearly twice as deep as long; on all parts of the boly five seales occuny a space nearly equal to one-fifth the depth of the body at that part; surface of scales near and in front of the ventrals marked with about six or eight coarse, irregular, slightly flexuous longitudinal ridges; on all the posterior parts of the body these ridges become almost imperceptible strix, even under a strong lens. and the surface is very minutely punctured; on all the middle of the body the seales average one line long: the arerage size of the specimens is usually about one foot five or six inches, and the depth near the middle from three and half to four inches.

The bodies of the vertebre and spinous processes are strongly ossified, the latter inclining backwards at an angle of about $35^{\circ}$ under the dorsal fin. The dorsal is as much in front of the anal as in the P. IInmboldti, contrary to the supposition of M. Agassiz. The proportions of this large species are difficult to ascertain. owing to the great contortions of most of the specimens, permitted by the small size of the scales. Sir P. Egerton suggests, with great probability, that the anterior part of the body of this species, with the sculptured scales, was the foundation of Agassiz' $P$. sculptus, the posterior half being his $P$. mandibularis.

Position and Locality.-Not very uncommon in the Permian marl-slate of East Thickley.

\section{Genus. ACROLEPIS (Ag.)}

This genus differs from Pygopterus principally in the shorter anal fin, the dorsal being a little m... anterior in position, and the scales being more strongly liceled and sulcated diagonally; but in size, form, and general characters, as far as linown, they are so identical, that I greatly doubt the propriety of separating them.

The genus is found in the carboniferous and Permian rocks.

Acrolepis Hopkinsi ( $M^{\circ}$ Coy $)$ PI. 3. G. fig. 10. (lower figure).

Syn. and Ref.=Holoptychius Hopkinsi MCoy, Ann. Nat. Hist. 2nd Series, Vol. II.

Desc. - Scales elongate, narrow, elliptically pointed, very thick, convex; exposed portion strongly polished, covered with numerous thick, rounded, slightly flexuous, anastomosing, longitudinal ridges; concealed s uooth portion very large, deeply bifurcated, generally seeming to be bent laterally at a considerable angle with the exposed portion, from the extension of the posterior margin being much greater than that of the superive margin. Average length of polished external portion six lines, width three lines.

The thick narrow form and strong longitudinal ridges of the surface distinguish this species easily from its congeners. The specimens described were collected from the Derbyshire limestone by W. Hoplins, Esq., who presented them, with a suite of fossils from that district, to the Cniversity Collection. I have great pleasure in dedicating it to one who, as a mathematician, and as an observer in the field, has so materially advaneed the science of Geology. I originally described this species under the genus Iloloptychius, but the more perlect examples I have since seen induce me to place it in Acrolepis. Just as these sheets were going through the press, I have seen at the British Museum the specinen figured by M. de Koninck (Foss. Bel. t. 5j. f. ju) as undetermined fish-scales, and I find it belongs to the present species.

Pusition and Locality.-It abounds in some parts of the black impure beds intercalated between the car'soniferous limestone and overlying shale of Derbyshire.

Explanation of Figures.-Plate 3. G. fig. 10 (lower figure), portions of two scales, natural size. 


\title{
Genus. MEGALICHTHYS $(A g$.
}

(For synonyms, see Rhizodus Hibberti).

\author{
Megalichthys Hibberti $(A g$ )
}

Ref. and Syn.-Ag. Poiss. Foss. Vol. II. t. 63, 64.

The only examples of this genus (as defined in the Poissons Fossiles of Agassiz) are a few plates of the head, and some large quadrate scales measuring about three-quarters of an inch across. Both these parts are thick and bony, covered with an unusually thick lustrous coat of ganoine, the surface of which is very minutely and closely punctured under the lens, and many of them have, in addition, several much larger, irregularly scattered minute pits (like those produced by the point of a pin). The scales are remarkable for having the ganoine separated from the concealed part of the scale at the posterior and superior edges by a deep groove, into which a corresponding marginal ridge of the adjoining scale fits. With these scales are mingled numerous others of about half their size, or less, and with the articular sulcus nearly obsolete; these seem to belong to the manuscript species Diplopterus carbonarius of (Ag.), and one small portion of the posterior end of the fish, shewing some portion of the fins, seems to favour this generic reference, although the medial prolongation of the body is much shorter than in the Devonian species, as in Colacanthus, but with two remote dorsals; at the same time it is impossible to avoid suspecting that they both belong to the same fish. I greatly regret, however, that the meagreness and imperfection of the specimens at my disposal, compared with those which are understood to exist in other collections, prevent me coming to any definite opinion on the point.

Pusition and Locality.-Carboniferous limestone of the coal-measures at Burdiehouse, near Edinburgh, and Shott's Iron-works, Lanarkshire.

\section{Genus. CENTRODUS $\left(M \Gamma^{\circ}\right.$ Coy $)$.}

(Etym. kévтpov, galli calcar, and ỏooùs, dens.)

\section{Ref.-Id, Mc Coy, Ann. Nat. Hist. 2nd Series, Vol. II.}

Gen. Char.-Tooth simply conical, gradually tapering, slightly curved backwards, apex pointed; section circular thronghout; medullary cavity large, conical, simple, so wide at base that the tooth is reduced to a thin edge; surface even, very finely striated longitudinally. Microscopic structure:-exceedingly fine calcigerous tubes radiating directly from the pulp-cavity towards the periphery, near which they terminate in numerous very minute calcigerous cells, beyond which is a narrow clear layer, bounded by a definite dark line, outside of which is a coating of glass-like enamel, without perceptible organic structure under a magnifying power of three-hundred diameters.

Externally these teeth slightly resemble Rhizodus (Ow.), and lately $I$ have seen a slight trace of plication at the base, as in that genus, but they are distinguished by their circular section, and very wide, simple pulp-cavity, which latter distinguishes it from nearly all paloezoic teeth except the Old Red sandstone genus Cricorlus (Ag.), from which it is known by its more slender conical form, and wanting the strong longitudinal ridges of the surface, as well as by possessing the distinctly defined enamel layer, which has all the appcarance of having been secreted by a distinet organ, and is quite different from the condensed dentine which forms the false enamel or ganoine of most fish-teeth. Since the above description was written, I have seen a similar if not identical tooth attached to a head closely resembling the Leeds fish figured as Megalichthys IIibberti by Agassiz, in the Bristol Museum; but having no opportunity of examining the matter further, I can only throw out the hint for future observers to follow up. The teeth of Megaliclithys, according to Agassiz, are minute and uniform, and have no resemblance to the present type. 


\title{
Centrodus striatulus $\left(M{ }^{c}\right.$ Coy). Pl. 3. G. fig. 1.
}

\author{
Ref.-Id. M I Coy, Ann. and Mag. Nat. Hist. 2nd Series, Vol. II.
}

Desc.-Tooth about seven lines long and one and half line in diameter at base; conical, gradually tapering to the pointed apex, with a slight backward curve; about one-fifth of the surface towards the apex perfectly smooth; the remainder, under the lens, is minutely and irregularly striated longitudinally.

This remarkable tooth, the only species I as yet know of the genus, seems to present (as far as yet known) all the characters, external and miscroscopic, of a true Saurian reptile.

Position and Locality. - Common in the bituminous carboniferous shale of Carluke, Lanarkshire*.

Explanation of Figures.-Pl. 3. G. fig. 1, perfect tooth, natural size, on lower corner of matrix; on upper end, a rough section of a smaller tooth shews the great size of the pulp-cavity and its width at base. From the carboniferous shale of Carluke. Fig. $1 \alpha$, magnified view of the lower tooth of fig. 1 . Fig. $1 b$, section of base of last specimen, shewing the great size there of the pulp-cavity; fig. $1 c$, section of ditto at one-third the length from the apex; fig. $1 \pi$, portion of last section, highly magnified as a transparent olject, shewing portion of central pulp-cavity, the dentine tubes, calcigerous cells, and ? enamel layer of surface.

\section{5th Family. CEELACANTHI. (See page 589.) Genus. RHIZODUS (Ow.)}

The fishes of this genus are very imperfectly known, but the premandibular bones have been described by Prof. Owen in his Odontography, and the structure of the accompanying tecth gave rise to his generic name Rhizodus for the Holoptychius Hibberti of Agassiz' list. The teeth differ from Holoptychius in being very unequal in size, having three to five very large laniary teeth on each side in each jaw, with numerous smaller ones, and in having an elliptical (instead of round) section, with sharp cutting edges. Like Holoptychius, all the teeth are fluted near the base, and are set in deep cylindrical hollows in the jaws. The internal structure presents a small central pulp-cavity in the smooth part of the tooth, but which splits up into a number of vertical slits at the lower sulcated part, one corresponding to each of the external sulci, as in the Labyrinthoid types, the sides giving off dentine tubes at right angles; these slits with their folds of dentine are separated below by intrusions of osteo-dentine, with bone-cells, and finally they become broken up into rootlike canals, blending with the cancellous bony structure of the bottom of the sockets. The scales are very large, rather thin, rotundato-quadrate or subtrigonal, deeply imbricating as in Holoptychius, but thinner, and with a minutely reticular internal structure; the under surface is nearly smooth, with a few concentric lines of growth, and an ovate, flattened articular tubercle, a short distance from the middle.

\section{Rhizodus gracilis $\left(\mathrm{I}^{\circ} \mathrm{C}\right.$ Cy). Pl. 3. G. fig. 17.}

Dcsc.-Dentary bone about eleven and half inches long, and only one inch four lines in greatest depth; surface of the bone covered with a close, obtuse, small tuberculation (about four tubercles in three lines). A pparently four laniary teeth in each dentary bone (but only the anteriol one distinctly linown); all the teeth much more slender than in the R. Hibberti. First laniary tooth slightly arched backwards, sharp-edged, width only one-fourth of the length (length above the bone one inch nine lines, width at base five lines, length of plicated portion three to four lines); the socket for the second laniary tooth is about the length of the first one behind it, with eight intermediary teeth resembling the large ones, but only about three to six lines long irregularly; from eight to eleven similar teeth are behind the apparent place of the other laniary teeth, which are broken off in our specimen.

* This is also the locality of the first observed example of a true carboniferous Reptile in British Rocks-the Parabatrachus Colei $(\mathrm{Ow}$.$) , the Reptilian characters of which, and affinity to the Reptiles of the German coal-measures, I$ had the pleasure of first pointing out in the collection of Lord Enniskillen, at Florence Court; those views were subsequently acquiesced in by Professor Owen, and illustrated in his paper in the Quarterly Journal of the Geological Socinty of London. 
This species is strongly distinguished from the R. Itibberti by the remarkable slenderness of the dentary bone, and the slenderness of the teeth, or small proportion which the width of the base bears to their length.

Position and Locality.-Very rare in the carboniferous shales of Gilmerton.

Explanation of Figures.-Pl. 3. G. fig. 17, dentary bone and teeth, natural size (wanting a little of the posterior end); the letters $\alpha, b$, and $c$, mark the apparent places of the posterior laniary teeth.

\section{Ruizodus Hibienti ( $A g$.}

Ref. and Syn. = Megalichthys IIibberti Ag. and Hibbert Trans. Roy. Soc. Edinb. (1836) Vol. XIII. p. 202. t. 8. f. 1, 2. t. 9. f. 2, 3, 9, 10. fig. on page $\mathbf{1 8 3}=$ Holoptychius Hibberti Ag. (name). Poiss. Foss. ; ? $=H_{0-}$ loptychius Portlocki Ag. Portk. Geol. Rep.t. 13. f. 5 to 11.

Desc--General form unknown, (but supposed to resemble that of Holoptychius). Dentary bone in moderate-sized individuals about fifteen inches long, and about three inches deep at the third laniary tooth; apparently five laniary teeth on each dentary bone, irregular in size, the anterior one much larger than the rest, and the posterior one smallest; the distance between the laniary teeth either a little more or less than their own lengtl, but irregular; each laniary tooth is nearly straight, having an elliptical section, leaving a cutting anterior and posterior edge; the distal two-thirds of each tooth smooth, the basal exposed portions varying from one-fourth to one-third, the length of the exposed part coarsely plicated longitudinally; between the laniary teeth very numerous irregular ones of the same structure, varying from one-fifth to one-half the length of the adjoining laniary ones, having a rather shorter proportion of the base plicated; average width of the base varying from rather more than one-third to two-fifths the length of the tooth, but varying slightly and irregularly in different parts of the mouth of the same specimen; laniary teeth set in deep cylindrical sockets, about two-thirds the length of the exposed portions. Surface of the jaw-bones covered with a small, close, vermicular tuberenlation, averaging five to seven tubereles in three lines. In the above dentary bone the anterior laniary tooth is about three inches in length above the edgre of the socket, the width of base being about thirteen lines, about ten lines of the base is longitudinally plicated, the plice being about one line wide; a fracture shews the cylindrical base of the same tooth fourteen lines in diameter at two inches in depth, strongly distinguished from the surrounding mass of bone in colour, of a moderately coarse cancellous texture, with the pulp-cavity obsolete. The average length of the following intermediary teeth is half an inch; owing to a fracture the size of the second laniary tooth is uncertain, but the third one is about two inches long; immediately preceding intermediary teeth being about five lines long, the fourth, or last laniary tooth, is rather less than one inch long; between it and the third are two half-grown laniary tecth at irregular distances. Intemal stmeture: a vertical section shews a conical, moderately large pulp-cavity in the centre of the suooth portion of the tooth, increasing in width as far down as the commencement of the external plicx of the surface, which latter indicate externally so many inflections of the substance of the tooth, impinging on the pulp-cavity, and dividing it first into vertical radiating fissures, which ultimately are reduced into numerous medullary canals, blending at last with the general, small, subuniform cancellous structure of the root near the base of the socket; a transverse section of the smooth part of the tooth shews a central round pulp-cavity, from which the fine dentine tubes radiate to the surface, where they are covered by a thin layer of ganoine; lower down through the plicated portion the central pulp-cavity is broken up as before described: first laniary tooth of other specimens four inches seven lines long, and one inch eight lines wide at base, about two-fifths of the length longitudinally plieated. Seales rotundato-subtrigonal, bony, rather thin, varying from nine lines to five inches in diameter, (the large scales proportionally thinner than the small ones); inner surface ncarly smooth, with obtuse concentric lines of growth, and a small, flattened, prominent, orate boss of attachment, slightly excentric towards the base of the seale, and sometimes with a very few, smaller, scattered granules (? from disease); intimate structure shewing an extremely minute reticulation (as in CII//l)tolepis); about nine of the reticulations in one line barely visible to the naked eye, but most distinct on the part of the seales overlapped by the others; exposed portions of each seale (about two-thirds of its surface) entirely covered with a very close vermicular tuberculation; about five of these gramules in the space of one line. 
I am quite certain, from a comparison of the specimens, that the Itoloptychines Portlocki (Ag.) of the fishheds at Cultra, Holywood, near Belfast, and Draperstown, \&c., are identical in all characters both of the teeth and seales with the $I$. IIbberti of the Burdiehouse and Gilmerton beds. The granulated surface adheres so firmly to the matrix, that all the figures of the seales published by Dr. Hibbert and Col. Portlock represent only the inner surface.

The genus Megalichthys of Agassiz and Hibbert was founded originally upon the great teeth of this species, which are well illustrated in the 13 th volume of the Trans. R. S. of Edinburgh, t. 8, 9, and 10; similar teeth are figured under the same name, Megrichthys Hibberti, on Agassiz' authority, by Dr. Buckland, in his Bridgewater. Treatise, and Agassiz' first allusion to Megaticlethys, at page 87 of his second volume of the Poiss. $F^{\prime} u s$ s., refers to the same plates and figures just mentioned, which leaves no doubt that these gigantic teeth and scales were the true original types of Megalichtlys. At page 90 of the second part of the same volume of his work, horvever, M. Agassiz describes and figures a totally different, comparatively small, fish, with rhombic scales, and tecth about two lines long, as the true Megalichthys; and this latter type unfortunately has so monopolised the name that $I$ am advised, against my judgment, to leave it to it. Subsequently Prof. Owen, in his Odontographly, figured some of the present large teeth as the type of his new genus Rhizodus, stating them to be identical with the Holoptychius Hibberti of Agassiz' MS. list.

Position and Locality. - The large scales and teeth very common in the limestone of the coal-measures at Burdiehouse near Edinburgh, also in the fish-beds of Cultra, Holywood, near Belfast, in the similar beds at Fermanagh, Draperstown, the large jaws and teeth not uncommon in the similar beds at Gilmerton.

\section{(Systematic place uncertain.)}

\section{Genus. OSTEOPLAX ( $\left.\boldsymbol{M}^{c} \mathrm{Coy}\right)$.}

Gen. Char.-Dermal plates large, flat, osseous, polygonal, with straight sides; surface irregularly and minutely wrinkled, with scattered pores. Microscopic structure:-Vertical section shewing large, distant, cylindrical, branched, vertical tubes (? Haversian canals) terminating in the pores of the surface; the spaces between these tubes containing numerous oval bone-cells, rather more than their own length apart, fron each of which short radiating branches extend on all sides, about six to the length of a corpuscle. Horizontal sections:- -large, circular, distant openings of the vertical tubes, with numerous intervening minute, radiated Purkinjinian cells, the tubuli of which do not anastomose with those of the adjoining cells in either section. One species.

\section{Osteoplax erosus $\left(M^{\circ}\right.$ Coy). Pl. 3. K. fig. 12.}

\section{Ref,-M McCoy, Ann. Nat. Hist. 2nd Series, Vol. II.}

Desc.-Bony plates one to two inches wide and one line thick; edges square; surface with close, short, irregularly flexuous, smooth grooves, visible to the naked eye, and with distant irregularly scattered oval pores.

The remarkable bony plates to which I have given the above name vary in the number of their sides and the amount of the angles at which they meet; but the sides are always straight, and the surfaces flat and of uniform thickness. It is clear from their form that they cannot belong to the head, but must be viewed as dermal bones, covering some part of the body of a mailed fish. Of known genera they can only be compared with $P$ sammosteus of the Old Red sandstone, to one species of which, the $P$. meandrinus (Ag.), the resemblance is particularly close; but the ridges of the surface are smooth in the present species, and crenulated in the former. The two genera are well distinguished by the internal microscopic structure, Psammosteus being composed of horizontal layers of large irregular cells, while Osteoplax has well developed, radiated bonecorpuscles.

Position and Locality. - Not uncommon in the schists belonging to the base of the carboniferous series at Cultra, Holywood, county Down, Ireland

Explanation of Figures,-Pl, 3. K. fig. 12, portion of one of the plates natural size, from the lower carboniferous shales of Cultra, Holywood, county Down; fig. $12 \alpha$, ditto portion of surface magnified. 


\section{6th Fam. PYCNODON'TI.}

Tceth, obtuse rounded, or obtusely polygonal, depressed, root hollowed and adhering to the jaw (thus differing from those of Cestracion), placed in several rows.

Scales, large, flat, rhomboidal; articulated by a medial projecting ridge on the under surface.

Skeleton, bony.

Body, compressed, flattened, sub-rhomboidal, or broad ovate.

The appearance produced by the continuous, internal, articulating ridges of the scales, forming oblique ridges across the interior of the fish, deceived M. Agassiz, who describes them as parts of the endo-skeleton under the name of sternal and nuchal pieces; Sir P. Egerton was the first to rectify this point.

Short, compressed fishes, with small fins, and teeth fitted for crushing crustacea and shells.

\section{Genus. PLATYSOMUS (Ag.) \\ $?=$ Globulodus (Münst.)}

Gen. Cher.-Rhomboidal, much compressed; dorsal and anal fins nearly equal and opposite cach other, the former extending from the middle of the back nearly to the tail; pectorals small; ventrals small, nearly under the pectorals; teeth clavate, crown dilated, flattened, base slender, a strong constriction marling the lower boundary of the ganoine. Scales large, oblong, having a strong bony articular internal ridge along the anterior edge, terminating in a bevelled spine at the upper corner, received into a notch in the lower end of the adjoining scale (these articular ridges most strongly marked along the dorsal margin).

Sir P. Egerton has recommended the classing this genus with the Pycnodontoid fishes, rather than with the Lepidoidei, from the mode of articulation of the scales, and from the teeth.

The genus is found in the carboniferous and magnesian limestones.

\section{Platysomus striatus $(A g$.}

Ref. and Syn-Ag. Poissons Fossiles, Vol. II. t. 17. f. 1, 2, 3; King and Egerton, Perm. Foss, t. 27, and

t. 28. f. 1 = Uropteryx striatus Ag. olim + Platysomus parvus, Ag. Poissons Fossiles, Vol. II. t. 18. f. 3.

Desc.-Greatest width (or depth) of body, which is at the origin of the anal fin, slightly less than from the same point to the end of the mouth; dorsal fin commencing a little behind the line of the anal, the profile from the origin of the dorsal to the occipital crest nearly straight, moderately sloped with very slight convexity, obtusely deflected at the occipital crest at an angle of $145^{\circ}$, continuing thence almost directly to the tip of the snout with little more convexity than the dorsal line; line of back straiglit and abruptly sloped at an angle of $120^{\circ}$; from the origin of the dorsal to the pedicle of tail at end of dorsal, a line equal in length to that from the origin of dorsal to occipital crest; length and width of the broad portion of the base of tail about equalling one-seventh of the greatest depth of the hody, the upper angle prolonged into an abruptly attenuated support to the upper lobe of the caudal fin, which is deeply forked; the lower lobe rather longer than the upper, the length of the upper being about three and half times the width of the pediele; ventral margin less angulated than the dorsal, more convex in its anterior and posterior portions, and more broadly rounded in the middle; anal and clorsal fins nearly equal, in each the tenth or twelfth ray being the longest, the preceding ones rapidly diminishing in size to the first, and the twelve or fourteen succeeding ones rather rapidly diminishing in size, after which they taper very slightly towards the posterior end, presenting a nearly straight edge with a higher anterior portion; ventrals placed between the anterior and middle third of the space between the head and origin of anal fin; form of pectoral and ventral fins unknown; scales closely marked with fine, obtuse, suberual, irregularly interrupted undulating strix, either nearly parallel with the longer margins, as in the deep scales of the flanks, or diagonal in position, rumning from the upper and posteriur edges towards the anterior and inferior, as on the more nearly equilateral seales (about twelve strice in the space of one line). Average greatest depth of boly from five to six inches; proportions, taking the greatest depth of the body at origin of anal fin as 1:50; length from posterior edge of head to posterior end of anal fin or pediele of tail ivin,

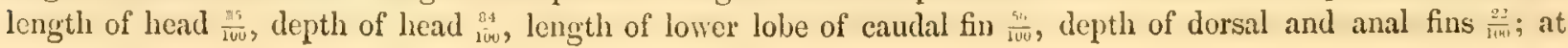


middle of body the oblong scales are three times deeper than long, their proportional length being about in , (or one-tenth of the greatest depth of the fish at that region): toward the ventral margin at base of anal fin the scales are nuch smaller and more nearly square; they are acutely rhombic, and longer than dcep on the pedicle of the tail; about three of the anterior anal or dorsal fin-rays in a space equal to the width of one of the oblong scales on the middle of the body; fulcral scales on upper edge of tail strongly developed; bones of the head finely marked with rermicular ridges and granules, and in parts striated like the scales; articulating claw of seales very large, and articular ridge strongly marked, rounded.

This species is most nearly allied to the $P$. macrurus, from which it differs in the more obtuse angulation of the profile of the occipital crest, and the consequently greater slope both of the back and line of the face, it also differs in the smaller size of the tail, and very obrionsly in the anal and dorsal fins extending much nearer to the head, and being narrower, wanting the large, broad, falcate anterior expansion of that species, ste. Prof. King has examined the original specimen, figured by $\mathrm{Mr}$. Winch, in the Transactions of the Greulogical Society of London, (Vol. IV.t. 2), on which figure M. Agassiz founded his $P$. parvus; he finds that the pullished figure is very inaceurate, and that the specimen is certainly the young of $P$. striatus. The head is very slightly larger than that of the $P$. gibbosus, to which it is proballe the species should be united, as I do not find the difference of inclination of the spinous processes alluded to by $A$ gassiz to exist. The articulations of the dorsal and anal fins are said by Agassiz to be twice as long as wide, but in reality only a few at the base have this proportion, the succeding and more numerous ones having the length and breadth about equal, and by far the largest number being considerably wider than long (at least double).

Position and Locality.-Rare in the Permian marl-slate of East Thickley.

\section{5th Order. Placoida. See page 575.}

The following species of fish are universally referred to the tribe of Plagiostomous fishes, (see page 576,) and most of them I have no doubt are rightly so referred; but some of them I think may reasonably be suspected of belonging to other groups, and most of the disjoined portions known present characters of such obscure systematic relation, that I think it better not to attempt to group them into families, nor to adopt the groupings which have been published, which I think separate forms which probably helonged to different parts of one fish, and connect forms which have no intimate relations. In the present state of linoriledge of these fragmentary genera, therefore, I prefer giving them simply in alphabetical order. I have taken great trouble to ascertain what genera and species were intended by the MSS. names of the lists in Agassiz' Poissons Fossiles, Vol. III., so as to give him credit for them as if they had really been described or figured, which however is here done for many of those species for the first time.

\section{Genus. ASTEROPTYCHIUS (Ag. name only).}

Gen. Char.-Bony fin-ray compressed, long, slender, gradually tapering to a point at the distal end, and abruptly tapering at the striated proximate end, or base of insertion; sides moderately convex, converging to the anterior edge, which is strongly keeled; posterior face with a moderate cavity, each lateral edge having a row of snall pointed tecth, directed upwards. Surface of the sides with several smooth, thread-like ridges, separated by broader, flat, longitudinally striated spaces, on which are irregularly scattered, smooth, spinous tubercles.

The posterior teeth being directed upwards, and the tubercles set between the longitudinal ridges of the surface, separate these species from Leptacanthus.

They are only known at present in the carboniferous rocks.

Asteroptychius ornatus (Ag. name only). Pl. 3. K. fig. 23, 24.

Desc. - Arerage length about four inches; greatest widkh at base three and half lines, tapering upwards at the rate of one line in one inch; sides with three (or rarely fou when about three lines wide) narrow, smooth, longitudinal ridges, exclusive of the anterior keel; between each pair of ridges is a wider flat space, [FASC. III.] 
marked with from three to six punctured, impressed, longitudinal strix, and in most parts of each of the spaces is found a scattered, irregular row of the smooth, pointed, rather distant tubercles of the genus.

Position and Locality.-Not very uncommon in the lower carboniferous limestone of Armagh.

Explanation of Figures.-PI. 3. K. fig. 23, portion of spine near base imperfect at each end, natural size, from the carboniferous limestone of Armagh ; fig. $23 \alpha$, ditto section near base; fig. 24 , ditto nearer to the apex; fig. $24 \alpha$, ditto portion of surface magnified.

\section{Asteroptychius semornatus $\left(M^{c} \mathrm{Coy}\right)$. Pl. 3. K. fig. 22.}

Desc.-Ray slightly arched, about three lines wide, and tapering at the rate of about one line in one inch ; section much compressed, the sides being flattened, and the thickness about one-third the width; about seren or eight narrow longitudinal smooth ridges on each side, separated by flat spaces nearly twice the width of the ridges; all the spaces are marked with two or three obsolete longitudinal strix, but only the anterior one on each side contains a row of irregularly placed tubercles.

This species strongly differs from the $A$. ornatus by having at the same size double the number of longitudinal ridges on each side, they are also closer and more regular. This is also rather more compressed and arched than the $A$. ornatus (Ag.), and differs besides in having but one row of tubercles on each side, while that species has a row in nearly every space.

Position and Locality.-Rare in the Armagh limestone.

Explanation of Figures.-Pl. 3. K. fig. 22, portion of spine imperfect at each end; fig. $22 a$, ditto portions of surface magnified, shewing the single row of tubercles.

\section{Genus. CHIRODUS $\left(M^{\circ} \mathrm{Coy}\right)$.}

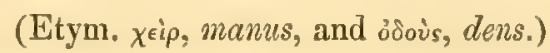

Gen. Char.-General form of Ceratodus, that is, more or less fan-shaped, thick, flattened, with the anterior hroad margin deeply divided into lobes; but the inner nearly straight margin has a small, recurved, thumb-like lobe projecting nearly at right angles from the middle of its length (preventing the mesial junction of the tritors of each side of the jaw); the inner marginal lobe is the longest; surface minutely punctured.

The only specimen which has occurred to me of this genus presents merely two lobes in the anterior nargin, but as the outer edge is imperfect there may have been another lobe, but I think not more. I should have referred the tooth to the Permian genus Ceratodus, but that the inner margin (which in Ceratodus is straight to fit the similar edge of the tootl on the other side of the jaw) has got a small lobe projecting horizontally inwards from its middle, which would prevent such a union; or if it he viewed as possibly the outer margin, we should have the equally singular charaeters not only of so great a disparity in size between two adjacent lobes, but the principal marginal lobes would incresse in size from within outwards, which wonld be contrary to all analogy. Hence, independent of the geologieal importance of not extending unnecessarily the vertical range of a genus, we find it zoologically impossible to group together teeth so differently constructed that they could not be similarly arranged in the mouth. I have named the gents from the general rescmblance to a hand, or still more to the foot of a Chirotherium, in miniature.

Cimnodus pes-rande (McCoy). Pl. 3. G. fig. 9.

$$
\text { Ref.-Id. McCoy, Ann, and Mag. Nat. Hist. 2nd Series, Vol. II. }
$$

Desc.-Length eight lines, narrow; anterior lobes narrow, prominent, rounded, arehed, separated by deep concave furrows; the inner lobe about a line longer than the next outer one; at the base of the former, or about half the length of the whole tooth, there projects horizontally inwards from the inner margin a short, wide, slightly recurved, flattened lobe, about one line long; posterior part of the tooth flattened; surface finely punctured under the lens. 
This little specics is something the size and shape of the foot of our common frog, whence the specific name.

Position and Locality.-Tare in the black slaly beds of the carboniferous limestone of Derbyshire.

Explanation of Figures.-Pl. 3. G. fig. 9, natural size; fig. $9 \alpha$, ditto magnified.

\title{
Genus. CHOMATODUS (Ag.)
}

Gen. Char.-Teeth transversely elongate, oblong, compressed; base of the crown encircled with several narrow imbricating folds of ganoine, deseending lower on the inner than on the outer side; root also compressed in the same direction as the crown.

This genus has, I think, no claims to be retained: the blunt-coned, thick species (as $C$. cinctus, \&c.) might be advantageously classed with Hclodus, most of the species of which, with the same form and punctured surface, have more or less perfectly developed imbricating folds at the base of the crown; and the thin, unpunctured species with a cutting edge belong to Petalodus (Owen), in which the folds always exist. I use the genus here for some intermediate types provisionally, and for Agassiz' species.

The genus is only at present known in carboniferous rocks.

\section{Chomatodus (Helodus) cinctus ( $A g$. .)}

\author{
Ref.-Ag. Poiss. Foss., Vol. III. t. 15. f. 13 and 21.
}

Desc.-Elongate, oval, or sub-rhomboidal, moderately convex on the sides; an obtusely rounded prominence nearly in the middle of the crown, but usually closer to one of the sides than the other, the surface between them forming in that case a nearly vertical area; surface poroso-granular, margin of the crown surrounded by a variable number of fine flexuous wrinkles, most numerous on the narrow ends. Average length of rather small specimens about seven lines, width five lines, height three lines.

Position and Locality.- Not uncommon in the carboniferous limestone of Belsey, Northumberland.

\section{Chomatodus clavatus $\left(M^{c} \mathrm{Coy}\right)$. Pl. 3. K. fig. 10.}

\section{Ref.--M다이, Ann. Nat. Hist. 2nd Series, Vol. II.}

Desc.-Tooth clavate, moderately compressed; crown obtusely rounded at upper edge, and depressed or moderately convex exteriorly, the grinding surface marked under the lens with a very minute vermicular granulation, coarser near the edge; the imbricating bands separating the crown from the root on the outer side numerous (six or seven), undulating, and punctured on their edges, but so minute as to require the lens for their perception; root hard, polished, abruptly narrowed and flattened, nearly smooth ; profile of front sigmoidally rounded. Inner side of the tooth concave from the upper edge to the very prominent ridge separating the crown from the root, which ridge is placed about half the width of the crown below the cutting edge. Length six lines, width six and half lines, from cutting edge to coronal ridge on outer face one and half lines, on inner face two lines.

The clavate form and peculiar sculpturing of the crown easily distinguish this from others of the genus; the only near ally is the $C$. truncatus, which is parallel-sided, not clavate, has strong simple coronal bands, \&c.

Position and Locality.-Very rare in carboniferous limestone of Armagh. One specimen in the University Collection, and another in that of Capt. Jones.

Explanation of Figures.-Pl. 3. K. fig. 10, front view of average tooth (slightly imperfect on one side); fig. $10 a$, ditto profile shewing the coronal ridge at a low level on the posterior side; fig. $10 b$, ditto portion of crown magnified. 


\section{Chomatodus (Helodus) denticulatus $\left(M^{c} C o y\right)$. Pl. 3. K. fig. 9. \\ Ref.- $\mathbf{M}^{\mathrm{c}} \mathrm{Coy}$, Ann. Nat. Hist. 2nd Series, Vol. II. p. 124.}

Desc.-Transversely oral, base about three times wider than long; middle elevated into a compressed obtusely pointed cone, about equal in height to the short diameter (length) of base, from which a sharp, much compressed mesial ridge extends on each side to either end, its cutting edge being broken into numerous, obtuse, compressed denticles, decreasing in size towards the ends; the notches which separate the little cones on the edge give rise to obtuse sulei, defining them a short way down the sides; surface smooth; base surrounded with three or four imbricating folds of ganoine, irregularly jagged at their edges. Average length of tooth about nine lines, height of crown four lines, width five lines.

This species is rather smaller, more elevated, and more compressed than the C. cinctus (Ag.), from which it is principally distinguished by the number of minor cones set on the mesial ridge.

Position and Locality.-Rare in the red carboniferous limestone of Armagh.

Explanation of Figures.-Pl. 3.K. fig. 9, side view natural size (the extremities broken); fig. $9 a$, do. seen from above.

\section{Chomatodus (Helodus) linearis $(A g$. \\ Ref-Ag. Poiss. Foss. Vol. III. t. 12. f. 5, 9.}

Desc.-Tooth very elongate, narrow, subparallel-sided; crown flattened, or with a slight mesial gibbosity; finely punctured, and bordered by two or three strong imbricating folds of ganoine.

There is but one doubtful specimen of this species in the collection, which is not sufficient for a full description.

Position and Locality.-Very rare in the carboniferous limestone of Armagh.

\section{Chomatodus (Helodus) obliquus $\left(M^{c} \mathrm{Coy}\right)$. Pl. 3. K. fig. 3. \\ Ref.-Mc $\mathrm{M}^{\mathrm{C}} \mathrm{y}, \mathrm{Ann}$. Nat. Hist. 2nd Series, Vol. II. p. 124.}

Desc.-Obliquely rhomboidal, transversely elongate; apex marginal, obtusely pointed; middle of the tooth (h) hiquely tumid or convex; attenuated sides flattened or slightly concave; ends obtusely pointed or rounded; surface highly polished and perfectly smooth except at the apex, which is coarsely punctured; basal margin surrounded by a broad imbricating fold of ganoine * increasing to three or four on the ends of some of the teeth.

This specics differs from the $C$. cinctus (Ag.) in its obliquely rhomboidal fiattened form and marginal apex, as well as having but one fold of ganoine at the middle of the basal margin. In some examples the ends are equal, and the width three times the length; in others the ends are unequal, and the length two-thirds of the widtlı; but in all the apex is marginal, and the general form obliquely rhomboidal, the basal margin having a downward curve nearly opposite the apical projection of the anterior margin, and between the two extends the oblique mesial convexity. Length averaging four lines.

Position and Locality.--Rare in the carboniferous limestone of Armagh.

Explanation of Figures.-Pl. 3. K. fig. 3, natural size, front view.

\section{Chomatodus (Petalodus) truncatus (Ag. name only). Pl. 3. I. fig. 1.}

Desc.-Tooth longitudinally oblong, sides of crown and root subparallel except at the upper and lower ands, where they rather abruptly converge to form the subtruncate, slightly rounded, cutting edge at top, and the

* I provisionally used (loc. cit.) this term (from yávos, splendour), to designate that peculiar denso modification of deritine which forms the highly-polished surface of most fish-teeth, and which is not unfrequently confounded with the true enamel of the teeth of the higher animals; the latter is, however, secreted by a distinct organ, quite external to and independent of the dentine, while the false enamel, which I have proposed to call ganoine, is merely produced by the calcigerous tubes of tho dentine becoming suddenly straighter, closer, and more numerous, as they approach the surface. 
rather more pointed lower end of root; crown flattened, bent at an angle of $120^{\circ}$ with the long ront, which is nearly straight in profile; surface of the crown finely punctured, as in Psemmodus; root hard and polished, with two or three obscure longitudinal furrows, almost entirely surrounded by a raised marginal extension of the thick, prominent, simple, coronal ridge; the posterior side is concave. Length six and half lines, width six lines. length of crown two lines.

Besides its oblong form this species is very remarkably distinguished by the continuation of the coronal ridge into a raised margin to the outer face of the root, which Jatter was in consequence mistaken for the grinding surface by Agassiz, and thus gave rise to his specific name. Capt. Jones, on partially clearing the true grinding surface (sce Portlock, Geol. Rip. P. 46:), supposed it to be a Psammodus, but I have now cleared and figured the whole crown and concave posterior side, proving it to be of the Petaloid section of Chomatodus.

Position and Locality.-Rare in the carboniferous limestone of Armagh.

Explanation of Figures.-Pl. 3. I. fig. 1, front view, natural size, of average tooth; fig. $1 a$, do. profile.

\section{Genus. CLADODUS (Ag.)}

Gen. Char.-Teeth with a broad, horizontal, semicircular, thick, bony, coarsely fibrous base, rounded behind, truncated in front; crown divided into long, sharp, subulate conical points, arranged along the straight truneated edge of the base; medial cone much larger than the secondary ones, which latter increase in size from the mid-cone to the ends; all the cones suleated longitudinally, and either circular in section, or with simple cutting edges slightly compressed. Fin-rays unknown.

Viewed in front those teeth resemble Hybodus, but the small lateral cones increase in size from the great mid-cone to the ends, instead of decreasing; and when seen behind the great dilated base of the present genus separates it completely. This dilated base is not alluded to in Agassiz' generic character.

\section{Cladodus lävis $\left(M^{c}\right.$ Coy $)$. Pl. 3. K. fig. 5.}

Ref.-MCoy, Ann. Nat. Hist. 2nd Series, Vol. II. p. 133.

Desc.-Principal cone very thick, slightly oblique, its height equal to half the width of the root; secondary cones two on each side, very strong, the outer largest and divaricating, nearly half the length of the principal cone; all the cones obtusely rounded at the summit, very slightly tapering, and the height of each slightly exceeding the width of its own base; base of the crown and osseous root concave; surface of all the cones smooth, highly polished. Width of crown nine lines, height of prineipal cone from the basal margin five lines.

This closely resembles the $C_{\text {. marginatus ( }} \mathrm{Ag}$.) in size and form, but the cones taper less, and the species is fully distinguished by its smooth surface, destitute of the coarse longitudinal plaits or striae of that or the allied species.

Position and Locality.-Carboniferous limestone of Armagh.

Explanation of Figures.-PI. 3. K. fig. 5, avernge-sized tooth, natural size; middle cusp worn; lateral cusps broken at apex.

\section{Cladodus mirabilis $(A g$.}

Ref. and Syn. = C. mirabitis Ag. Pal. Foss. t. 22 6, f. 9 to $13+C$. marginatus id. ib. fig. 18 to 20 .

Desc.-Semicircular, base very thick and coarsely osseous; crown having the middle cusp very thick at base, and only slightly compressed, the lateral edges being less acute than in the C. striatus; abruptly tapering towards the apex, and slightly inclined backwards; ridges of the surface coarse, thread-like, widely separated, sis that three or four occupy a space of one line; secondary cones very thick, tumid, very abruptly tapering to their apices, very rarely more than two on each side, their surface striated like that of the principal cone. Average 
length of base one inch three lines, height of principal cone nine lines, its width at base four and half lines; width of outer secondary cone two lines, height three lines; width of semicircular base about four lines.

This species is easily distinguished from the $C$. striatus by the very great thickness, convexity, and abrupt tapering of the principal cone; and very obviously by the far greater coarseness and separation of the longitudinal ridges; the secondary cones are also very much larger, thicker, and fewer in number. The Cladodus marginatus of Agassiz is founded on worn specimens of this species, as I have ascertained by examining the type specimens. I have little doubt that the $C$. acutus is a young specimen of the same species.

Position and Locality. - Not very uncommon in the limestone of Armagh.

\section{Cladodus striatus $(A g \cdot)$}

$$
\text { Ref. and Syn.-Ag. Poiss. Foss. Vol. III. t. } 22 \text { b, f. 14, } 17 .
$$

Desc.-Base semicircular, large, moderately thick, and undulated at the rounded edge with a few obtuse, irregular, radiating furrows below, and obscurely nodose above. Average width one inch one line, from middle of flat side to middle of convex margin seven lines, main cusp moderately compressed, slightly sigmoid, nine lines long, and inclined towards the convex margin at an angle of about $70^{\circ}$; lateral edges smooth, sharp and cutting; apex smooth for about three lines from the point, remainder of the cusp marked with very fine longitudinal slender strix, about nine in one line, irregularly alternate or nearly equal in size; lateral cusps extremely small, rarely visible, five or six very slender ones on each side, less than a line in length, the terminal one thicker (scarcely one line at base) and rather more than three lines long when perfect, and is usually the only one seen.

The examination of a great number of specimens of this species convinces me that M. Agassiz is incorrect in supposing that the $C$. acutus is the only species with cutting edges, as they are distinctly marlsed in the prese' st species. The very small lateral cusps and fine striation easily separate this species from $C$. mirabilis, and the others of the genus.

Position and Locality. - Not uncommon in the carboniferous limestone of Armagh, rare in the carboniferous limestone of Lowick, very rare in the carboniferous limestone of Derbyshire, very rare in the carboniferous limestone of Brigsteer, Kendal.

\section{Genus. CLIMAXODUS $\left(M^{c} \mathrm{Coy}\right)$.}

(Etym, $k \lambda i \mu a \xi$, a flight of steps, and ỏoois, a tooth).

Ref.-Id. McCoy, Ann, and Mag. Nat. Hist. 2nd Series, Vol. II.

C'en. Char.-Tooth longer than wide, gradually narrowing towards the front, with nearly straight sides; anterior part of the crown crossed by broad, imbricating, transverse ridges at right angles to its length; surface minutely punctured.

The above generic name has reference to the remarkable step-like character of the ridges which cross the anterior part of the tooth at regular intervals. The broad posterior part of the tooth is without ridges, and resembles a Pscmmodus. In the fact of being as it were small, ridged, Pzammodi, these teeth are allied to the genus Pacilodus, but all the true Pucilodi are inequilateral musscl-shaped teeth, consequently placed in pairs in the mouth, and have the ridges oblique; the Climaxodi, on the contrary, are equilateral, and were therefore most probably mesial in position, and the ridging is transverse.

I am aware of one species in the Armagh limestone, and the following.

Climaxodus imbricatus $\left(M I^{\circ}\right.$ Coy.) Pl. 3. G. fig. 5.

Ref.-Id. Mc Coy, Ann. and Mag. Nat. Hist. 2nd Series, Vol. II.

The only specimen I have access to at present of this species is imperfect at each end, being seven lines long, five and half lines wide at the broad end, and three lines wide at the narrow anterior end; the anterior 
portion of the crown is crossed by seven transverse imbricating ridges in a space of four lines, the posterior ones are three-fourths of a line apart, and have a double curvature arising from a small backward wave in the middle. the anterior ones are closer, and pass with a slight forward curve across the tooth; all the imbrications lave a backward curve at their extremities, giving them the appearance of lapping round the crown, and all have their free edges directed backwards, so as to resemble a row of I'etalodi or other shark's teeth soldered together in the position they usually nceupy, one behind the other; the posterior half is without ridges, the whole crown is slightly convex at the sides and concave in the middle; the surface is dull, and seen by the lens to be finely punctured.

Position and Locality.-Rare in the dark impure limestone overlying the main carboniferous limestone of Derbyshire.

Explanation of Figures.-Pl. 3.G. fig. 5, natural size; fig. $5 a$, portion of surface of ditto magnified.

\section{Genus. COCHLIODUS $(A g$ )}

Gen. Char.-Lower jaw thick, short, bony, $V$-shaped, bearing on each ramus two obliquely twisted and obtusely ridged semicylindrical teeth, strongly inrolled on the outer margin, convex abore, concave below, with porous grinding surfaces as in Psommodus, from the termination of the vertical medullary canals (young teeth replacing the old vertically as in the Pycnodonts).

The general form of the tecth on a perfect jaw found by Capt. Jones, and the cast of which was examined and figured by Profs. A gassiz and Owen, recalled in their opinion the arrangement in Cestracion; but an almost equally perfect specimen presented by Mr Stokes, of Caius College, to the collection, enables me to state that there can be no real affinity with Cestracion or any of the sharls; for, first, the teeth are supported on a strongr bony jaw as in Placodus (which also agrees in having three teeth on cach side of the lower jaw, although differing in microscopic structure); sceondly, the inrollment of the teeth is on the outside of the jaw, and not as in sharks on the inside to allow the succession of teeth from behind forwards; and finally, a broken tooth of another species, the $C$.oblongus, also given by $\mathbf{M r}$ ' Stokes, enables me to prove the succession of the tecth was not by revolution from behind as in the Plugiostomons fishes, but vertically from below uprards, as in the $P_{y-1}$ nodonts. See our Plates, 3. H. fig. 19, and 3. I. fig. 28.

The genus is confined to the carboniferous rocks.

\section{Cochliodus acutus ( $\mathrm{Ag}$. name only). Pl. 3. I. fig. 24.}

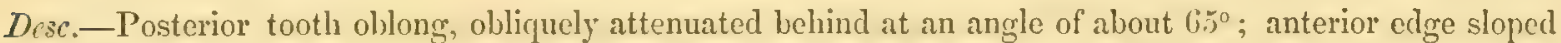
backwards and inwards at about $60^{\prime \prime}$; surface with three very strongly marked, oblique ridges, separated by deep concavities; the first ridge most prominent, narrow, acutely angulated, coinciding with the anterior edge. which is very steeply sloped, usually separated from the adjoining concavity ly an obscure narrow suleus: middle ridge much broader, and placed rather behind the middle of the tooth, sloping gradually towards the base of the anterior ridge, but abruptly rounded into the deeper and narrower concavity, which separates it from the posterior marginal ridge, which is prominent, narrow, and rounded, forming the posterior point of the tooth. Middle tooth unknown. Anterior tooth small, triangular, marked with three narrow, prominent, very oblique ridges, the first coinciling with the posterior margin, and forming an angle of $50^{\circ}$ with the outer edge, the anterior part of which forms the third ridge; the secondary ridge is more obtuse than the other two, and a little on the posterior side of the middle, the interrening spaces deep, concave. Entire surface minutely: granulo-punctate by the extremities of the vascular canals (averaging eight in one line), covered in some places with a very thin layer of ganoine. Average length of posterior tooth one inch two lines, width at anterior margin eight lines, length of anterior tooth seven lines, width of posterior margin six lines.

This species is distinguished from the other's by the strongly-pronounced oblique ridges, and their approach to angularity, which is most distinet in the anterior ridge of the posterior tooth, which ridge is also remarkable for being more prominent than the middle one in that tooth. There are one or two marginal sulci round both the interior and the obliquely inrolled exterior edges. It is only by some misunderstanding that Capt. Jones is 
made to sugrest this species as probably the filling up of the space between the teeth of $C$. contortus, in Portlock's Geol. Report, p. 466, as I know that that excellent authority holds them to be well separated species; and further 1 might add, that it would be very unusual to find any teeth of the kind in the position indicated.

Position and Locality.-Not very uncommon in the carboniferous limestone of Armagh.

Explanation of Figures.-Pl. 3. I. fig. 24, right posterior tooth, natural size, seen from above; fig. 24a, profile of same specimen seen from the outer or convoluted side; fig. $24 b$, transverse section of No. 24 ; fig. 25 , larger and more sharply marked specimen; fig. $25 \%$, profile of last specimen (convolution of the margin concealed by the matrix); fig. 26, anterior tooth natural size viewed from above.

\section{Cochliodus contortus $(A g$.}

$$
\text { Ref.-Ag. Poiss. Foss. t. 19, f. } 14 .
$$

Dese.-Sides of jaw and lateral rows of teeth converging at an angle of about $60^{\circ}$; positerior tooth oblong, obliquely truncated on the outer side of the posterior end to form the posterior point; the posterior edge rather abruptly raised to form the posterior oblique ridge behind, sloping into a rather deep, oblique hollow, which defines the middle oblique ridge, which is much the most prominent, and strongly rounded of the three; anterior ridge coinciding with the anterior margin, very slightly raised, little tumid, separated by a moderate coneavity from the steeply rounded side of the middle ridge, and forming an angle of $80^{\circ}$ with the outer margin; second tooth narrow, its posterior half very convex, forming a prominent, rounded ridge, rising abruptly from the posterior margin, but sloping sigmoidally to the anterior margin, which is not again relieved; anterior teeth unknown; surface either smooth or finely granulo-punctate, by the openings of medullary canals, as in the $C$. acutus. Average length of posterior tooth one inch five lines, greatest width eight lines, width of middle tooth five lines.

The two posterior teeth are very strongly inrolled spirally on their outer margins, especially the middle one. The anterior teeth are as yet unknown, but I have no doubt that they resemble those which I have described in C. acutus. The posterior tooth was supposed by Agassiz to be two separate tecth, supposing (from the cast) that the hollow between the middle and posterior ridges was a suture; this is however not the case manifestly, when specimens are examined. The bony jaw extends for three lines in deptl below the teeth, and extends a little in front of the anterior ones. The species is easily distinguished from the $C$. acutus by the greater breadth, size, and obtuse rotundity of all its oblique ridges, and having the anterior ridge of the posterior tooth much smaller than the middle one, while it is much more prominent in that species.

Position and Locality.-Rather rare in the carboniferous limestone of Armagh.

\section{Cocmliodus magnus ( $A g$. name only).}

$$
\text { Ref.-Portk. Geol. Rep. t. 14a, fig. } 4 .
$$

Desc.-Postcrior tooth irregularly rounded, subrhomboidal, broadly convex, and moderately arched from side to side, but less inrolled at the outer margin than in the other species; anterior margin broad, and forming an angle of about $\$ 5^{\circ}$ with the outer margin; outer and inner margins diverging from the front for about half the length of the tooth, where the outer margin is abruptly bent inwards at a very obtuse angle, to form the oblique posterior truncation of the genus, leaving at the angle a sort of obtuse beak-like prominence, corresponding to the middle diagonal ridge of the other species, and from whence a very ill-defined diagonal gibbosity extends obliquely towards the inner posterior margin, chiefly marked by the abrupt sloping of the surface posterior to it, while the surface in front of it slopes very gradually to the anterior suture; no other diagonal ridge or sulci. Niddle tooth obscurely trapezoidal, having a broad, moderately convex inner margin, from whence the surface is uniformly and gently arehed towards the opposite very short side, or obtuse, slightly-inrolled outer margin; anterior and posterior sutural edges diverging obliquely from the short outer margin; posterior one longest; anterior tooth subtrigonal, obliquely semielliptically pointed in front, and with an oblique nearly straight sutural edge marking the posterior face of the triangle. Surface uniformly and cvenly convex; surface of all the teeth with a slightly smaller porosity than the $C$. cunturtus; the edges of 
most specimens crenulated. Average length of the posterior tooth is about one inch four lines, and its width one inch.

This species varies considerably in the outline of the different specimens, and I think it is very doubtful whether it is truly of the genus, on account of the flatness and slight inrollment of the teeth, and the little definition of the characteristic oblique ridges; the strong crenulation of the margin is also a character which I do not recollect to have seen in Cochliodus, but recalls the observation of Capt. Jones, (in Portk. Geol. Rep.) that the Coclliodus magnus, he thinks, pass into the Heluclus planus, which may be borne out by a large suite of specimens, although I have not yet myself seen the passage.

Position and Locality.-Common in the lower carboniferous limestone of Armagh; in the lower limestone of Lowick, Northumberland; and in the carboniferous limestone of Kendal.

\section{Cochlodus oblongus $\left(A g_{0}\right)$ Pl. 3. H. fig. 19. and Pl. 3. I. fig. 28.}

$$
\text { Ref.-Portk. Geol. Rep.t. } 14 a \text {, fig. } 5 .
$$

Disc-Posterior tooth elongate, narrow, subcylindrical, oblong, obliquely subtruncate, elliptically pointed at about an angle of $45^{\circ}$ behind; anterior margin nearly at right angles to the long axis of the tooth; anterior ridge very small, almost obsolete, scarcely defined from the equally wide flattened space between it and the second oblique ridge, which is strongly defined on each side, but narrow and only moderately convex; posterior ridge very large, excceding twice the width of the middle ridge, separated from the middle one by a broad, moderately concave sulcus, rather more prominent than the middle ridge, broadly and moderately convex, abruptly rounded at its anterior edge, but gradually sloping towards the posterior end; surface as in the $C$. acutus. Length of rather small specimens about one inch two lines, of middle ridge only two lines. Middle and anterior teeth unknown.

This species is very easily distinguished from all the others by the great size of the posterior ridge, which is frequently twice and half as wide as the middle one, and rarely only double, while in the $C$. acuters and contortus it forms a mere narrow, raised margin. The form of this species is also narrower and more cylindrical. Although a common species I have not yet seen the anterior or middle teeth. It was in a specimen of this species collected by the Rev. W. Stokes, M.A. of Caius College, that I first saw the vertical mode of succession of the teeth, the young one being distinctly visible beneath the level of the old one from a transverse fracture; one end of the specimen magnified half a diameter is represented on our Plate 3. I. fig. 2S, and shers on the upper surface of the old tooth the anterior and middle ridges, and the oblique sulcus, which separates the latter from the posterior ridge, which is broken across by the section; the fractured edge shews the inrollment of the outer margin of the tooth, and the whole thickness of its substance, shewing the vertically tubular structure of the superficial half, and the two denser layers which form its concave under or dorsal surface. At about the thickness of the substance of the old tooth lower down is seen the young tooth, exactly concentric to it in outline, and having its structure similarly displayed in the section; and on its upper surface is seen not only the same punctured surface, but the same oblique ridge as in the old one (this requires a magnifying glass to be seen distinctly in the figure). I might here caution the observer that the inrollment displayed by the old tooth is the extreme extent to which it occurs; so that it would be impossible (as was suggested to be by an excellent authority) that the supposed young tooth could be a continuation of a large inrollment, which is also rendered impossible by the appenrance of the oblique sulcus noted on the little tooth. The other half of the same specimen I have had polished, and it is represented on our Plate 3. H. fig. 19.

Position and Locality.-Common in the lower carboniferous limestone of Armagh.

Erplanation of Figures.-Pl. 3. H. fig. 19, transverse polished section magnified, two diameters of specimen shewing the succession of the tecth. Pl.3. I. fig. 2S, posterior tooth, rough fracture, shewing the rertical succession of the teeth, with young tooth in situ magnified one and half diameters. 


\section{Cochliodus striatus ( $A g$. name only). Pl. 3. I. fig. 27.}

Desc.-Terminal tooth aliform, triangular, very much broader than long; long articular margin forming an angle of about $35^{\circ}$ with the outer edge; along this articular margin is the most prominent part of the surface, forming an obtusely rounded, slightly sigmoid ridge ; the remainder of the surface being flattened and extending with a slight concavity to the terminal point, which is nearly rectangular, and obtuse. Surface with a fine, sharp, granulo-punctation, having the usual quincuncial arrangement on the long, obtuse convexity of the articular ridge, and on the opposite, flattened, terminal angle; but on all the intermediate portion the puncta fall into regular, slightly flexuous lines, extending longitudinally nearly at right angles to the articular side; about twelve of the lines of punctures in the space of one line. Length of tooth at right angles to articular ridge three and half lines; length of articular ridge, or greatest width of tooth, seven lines.

I only know the terminal wing-shaped teeth of this species, the sulallest fragments of which are easily recognised by the striated appearance of the surface under the lens, orving to the linear disposition of the puncta.

Position and Locality.-Rare in the lower carboniferous limestone of Armagh; very rare in the dark lower carboniferous limestone of Lowick, Northumberland.

Explanation of Figures.-Pl. 3. I. fig. 27, natural size, terminal tooth, viewed from above; fig. $27 a$, portion of surface of ditto, magnified; fig. $27 b$, sketch of smaller perfect specimen (in collection of Captain Jones, R.N., M.P.).

\section{Genus. CTENACANTHUS $(A g$.}

Gen. Char.-Fin-spine of moderate and large size, compressed, gradually tapering, moderately arched backwards; anterior face narrow, rounded; posterior face concave, with a moderate cavity, the lateral edges bordered by two rows of eurved denticles inclined downwards. Surface marked with strong, longitudinal ridges and furrows, pectinated by transverse seales or tubercles. The concealed base of moderate size, rapidly tapering, finely striated.

The fin-defences of this genus are confined to the Devonian and carboniferous rocks, where they seem to represent the genus Hyborlus of the Micsozoic strata. They are distinguished by the decussation of the ridges of the surface.

\section{Ctenacanthus crenatus ( $A g$. name only). Pl. 3. I. fig. 31.}

Desc.-Fin-spine gradually tapering, moderately compressed; sides rather flattened, converging to a narrow, rounded, anterior, face; each side with about ten or eleven nearly equal, regular, rounded ridges, separated by sulci, alout their own width apart, (at six lines wide there are five ridges in two lines) each ridge with a row of small transverse tubercles, strongly crenating the sides, down which they extend obliquely; those of each side usually opposite, but sometimes subalternate, generally leaving the middle of each ridge smooth, but occasionally in some spots the small tubereles from each side of a ridge meet on the middle, forming transversely rhomboidal tubercles, attenuated at the lateral cxtremitics; five lateral tubercles in the space of one line. The posterior cavity is rather large.

The length of this species is unknown, but it is probably at least four inches. The species is easily recognised by the regular ridges being crenated, or milled like the edge of a coin, by the small elongate tubercles projecting at right angles from the sides of the ridge, and usually not encroaching on its centre.

Position and Locality.-Very rare in the carboniferous limestone of Armagh.

Explanation of Figures.-Plate 3. I. fig. 31, fragment, natural size; fig. $31 a$, ditto, section; fig. $31 b$, portion of surface magnified. 


\title{
Ctenacanteus denticulatus $\left(M^{c} C o y\right)$. Pl. 3. K. fig. 16.
}

\author{
Ref.-M[Coy, Ann. Nat. Hist. 2nd Series, Vol. II. p. 116.
}

Desc.-Spine nearly straight, slightly curved towards the apex; length of naked portion five and half inches, length of the rapidly tapering base two inches, width near base nine lines; section truncato-elliptical, sides slightly convex, front narrow, rounded; posterior face wide, depressed, coneave at both sides, with an obtuse ridge in the middle, the lateral angles closely set with a row of numerous, small, conical, downward curved teeth on cach, their own length apart; longitudinal ridges rounded, less than their own diameter apart (about four in two lines in the middle of the ray); they are a little wider at base than towarls the apex, increasing in number downwards by dichotomy; the sides of each ridge are denticulated with sharp, recurved teeth extending half way across the intervening spaces, the denticle of one side connected with its fellow on the other by a slightly oblique fold across the ridge, each pair being separated from that alove and below by about the thickness of the ridge; near the posterior margin on each side are four or five ridges much smaller than the rest, crossed by oblique blunt tubercles.

This species slightly resembles the $C$. crenatus ( $\mathrm{Ag}$.) in its ornament, but instead of the short, close notches in the sides of the ridges of that species, this is distinguished by the more distant, tooth-like denticulation and narrow transverse plicr.

Position anel Locality.-Not uncommon in the dark shale (of the age of the yellow sandstone) of Monaduff, Drumlish, in the North of Ireland.

Explanation of Figures.-Pl. 3. K. fig. 16, dorsal spine natural size, from the yellow sandstone shale of Monaduff; fig. $16 a$, ditto, some of the ridges near the anterior face magnified.

\section{Ctenacanthus distans $\left(M^{c} \mathrm{Coy}\right)$. Pl. 3. K. fig. 15.}

\section{Ref.-M $\mathbf{I}^{\mathrm{C}} \mathrm{Coy}, \mathrm{Ann}$. Nat. Hist. 2nd Series, Vol. II. p. 116.}

$D e z c$-Spine compressed, gently arched, very long, slender, tapering at the rate of only three lines in five inches; posterior face with two rows of numerous, small, short, conical, compressed teeth, slightly bent downwards, rather more than the width of their base apart; sides flattened with about ten or twelve close, flattened, longitudinal ridges of irregular width, the broadest occasionally subdividing as they approach the base, all the rilges crenulated by small tubereles, about double the thickness of the ridge from each other; those on the anterior ridges are transverse and slightly oblique, while those nearer the concare margin are smaller, and assume the appearance of lengthened nodulose swellings, as in Physonemus.

This is a remarkably long and slender ray; one specimen in the University Collection, of which a considerable portion of the apex must be lost, measures six inches in length, and only six lines in width at the broadest part near the base, the broken distal extremity being three lines wide, which would probably indicate a further inch and half of length. The portion of the base inserted in the flesh is small and gradually tapering. I am not certain of the exact form of the section.

Position and Locality.- Not uncommon in the red limestone of Armagh.

Explanation of Figures.-Pl. 3. K. fig. 15, dorsal spine natural size, imperfect at the tip, shewing the elongate tapering base of insertion and internal cavity in lower part; fig. $15 \alpha$, ditto, portion of surface magnified, shewing the variable width and mode of tuberculation of the ridges.

\section{Ctenacanthus heterogyrus (Ag. name only). Pl. 3. I. fig. 32.}

Desc.-Tery short, rapidly tapering; length of exposed portion two inches three lines, at which length it forms an obtuse point from a width at base of five lines (measured at right angles to the length), very slightly arched, the posterior outline nearly straight, the anterior one convex. Sides flattened, converging to the narrow anterior face, which is occupied by a flattened smooth ridge, about twice as wide as those of the sides; lateral ridges extremely irregular in size, shape, and marking; rather thick, separated by deep sulci less than half their width; ridges averaging four in two lines at four lines in diameter, some 
of them thinning out above at irregular distances, other pairs uniting branchwise into one above, some appearing to taper to both ends; most of the ridges are nearly smooth in a great part of their course, or shewing a more or less distinct crenulation on their sides (about three in the space of one line), from small opposite lateral tubercles; in certain irregular spots these lateral tubercles increase in size and strength, and distinetly cross the ridges, by becoming connceted across them; in several of the ridges, particularly towards the base, the transverse tuberculation and notehing becomes so distinct, that the ridge is separated into a row of triangular tubercles, about half a line long.

The extreme irregularity of the ridges of this species, no two of them being quite alike, and several of them totally changing their aspect after short distances, easily distinguish this species from its congeners. The finely striated base is of rather small size, and rapidly tapering, the line of separation between it and the ridged exterior being very oblique.

Position and Locality - Rare in the lower carboniferous limestone of Armagh.

Explanation of Figures-PI. 3. I. fig. 32, fragment of base natural size, shewing part of the base of insertion and commencement of ridging, with few tubercles; fig. 33 ditto, fragment near middle, shewing the irregular character of the ridging and tuberculation; fig. $33 \alpha$, portion of surface of last specimen, magnified; fig. $33 \mathrm{~b}$, ditto section, shewing the broad ridge of anterior face.

\section{Genus. CTENOPTYCHIUS $(A g$.}

Gen. Chur.--Tecth small, highly polished, strongly compressed, rounded or obtusely pointed, edge divided into several strorg denticulations; base of crown with a few imbricating folds of ganoine; bony root oblong, flattened in the same direction as the crown.

This genus differs from Petalodus chiefly in its larger denticles of the edge.

It is found in the Devonian and carboniferous rocks.

\section{Ctenoptychius apicalis $(A g$.}

Ref. and Syn $=$ C. apicalis Ag. Poiss. Foss. t. 19. f. 1. and Binney, Trans. Manch. Geol. Soc. Vol. I. t. 5. f. 19. = Petalodus dentatus Ow. Odont. p. 62. = Cten. macrodus Ag. name in lists, and Portk. Geol. Rep. t. 14.f. 7 .

Desc.-Crown transversely oval, thick, highly polished; upper edge semielliptically rounded, divided into six or seven very thick, elliptically pointed lobes, diminishing rapidly in size to the exterior one on each side, which is very small, the largest tooth being usually a little one side of the middle, having three denticles on one side, and four on the other, regularly diminishing in size from the central one; imbricating fold of ganoine at base of crown gently arehed downwards, single or double, forming the most prominent part of the profile of the tooth, the surfice sloping with slight convexity to the cutting edge above, abruptly depressed to the dull, bony, root below; the root about as deep as the crown is high, fibrous, but much thinner than the crown. When well preserved the surface of the crown is smooth. Average width of moderate-sized specimen four lines, greatest height of crown two and half lincs, depth of root the same, widtl of root about three and half lines.

The names $C$. macrodus $\mathrm{Ag}$, and $P$. dentatus Owen were applied to the same specimens in Capt. Jones's collection, and I am perfectly satisficd of their identity with $C$. "quicalis; the Irish specimens having quite as near an approximation to a median point as the English ones.

Position and Locality.-Not very uncommon in the carboniferous limestone of Armagh.

$$
\begin{gathered}
\text { Ctenoptychus serratus (Ow.) Pl. 3. I. fig. 21, 22, } 23 . \\
\text { Ref.-Owen Odontog. p. 62. }
\end{gathered}
$$

Desc.-Tooth wide, much compressed, upper cutting edge having a gentle but variable convexity; usually divided into about thirty rounded notches, or obtuse pointed denticles, slightly larger in the middle than at the ends, and from between each pair of which a more or less distinct sulcus extends towards the base of the crown, rarely reaching more than half way, and forming a fringe-like plication, and sometimes nearly obsolete; apiees of the denticles minutely crenulated under the lens; front surface of crown flat, highly polished, 
sloping outwards, and terminating in an obtuse angle in the middle, and directed downwards, and outwards; the very prominent base of the crown being surrounded by three or four flat imbricating bands of ganoine: root abruptly flattened, also narrower than the crown, and about equalling it in depth. Average width of limestone specimens six lines, depth of crown two lines, depth of root the same, width of root four and half lines; rarely one inch wide, when the deptlı of root and crown together is seven lines.

The coronal bands of ganoine are broader and apparently more numerous on the inner side, and there descend so low with a gentle curvature, that the root is only half the depth of the crown. This species is figured under the name $C$. pectinatus Ag. by Mr Binney, in the Trans, of the Manchester Geol. Soc. Vol. I. t. 5. f. 20, 21; but it seems distinct from the C.pectinatus as given in Agassiz, Poiss. Foss., like which figures I have never seen anything in nature; but if they be accurate, I think (as I believe M. Agassiz does also) that the present species must be distinct.

Position and Locality. - Not uncommon in the lower carboniferous limestone of Armagh ; rare, of large size, in the black carboniferous limestone shales of Derbyshire.

Explanation of Figures.-PI. 3. I. fig. 21, view of average-sized tooth, on inner aspect (the transverse folds at base of erown broken off'); fig. 21 a, portion of crown and cutting edge magnified, shewing a serration of the denticulations; fig. 22, smaller specimen, natural size, front view; fig. 22 a, portion of ditto magnified, shewing the variety with smooth lobes to the cutting edge; fig. 23, large specimen, inner view, root perfect in depth, but imperfect at the sides.

\section{Genus. DIPRIACANTHUS $\left(M{ }^{c}\right.$ Coy $)$.}

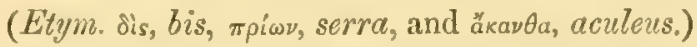

Gen. Chur.--Spine small, arched, tapering, much compressed, minutely and irregularly tuberculated; two rows of small conical tecth on the posterior margin, and two rows of larger adpressed teeth on the anterior face directed upivards.

The spines for which I propose this name, are easily recognised by their small size, curved form, and having the anterior as well as the posterin margin armed with rows of teeth. These characters, while they separate them widely from the other fossil spines, strongly reeal to our mind the Pinclodes and Synodonts of the Nile; in fact, the synuluntes strratus described by Riippell* is a perfect prototype in its spinous defences of our Dipriacanthus falcatus, except that both the anterior and posterior rows of teeth are single on the recent spines. In their compressed section and irregularly tuberculated surface the Dipriacanths resemble the Oracanths, but are distinguished by their arched figure and rows of teeth.

\section{Dipriacantinus Stolesil $\left(M{ }^{\circ} \mathrm{Coy}\right)$. Pl. 3. K. fig. 18.}

Desc._Slightly arched, much compressed, sides flat, anterior and posterior margins narrow, obtusely rounded; section oblong, the long diameter being from four to five times longer than the short; teeth of the posterior margin slender, conieal, projecting at right angles to the spine; tecth of the anterior margin large, thick, smooth, the upper sharp edge widest, closely adpressed to the surface; surface closely covered with small, irregular, snooth granules, which under a strong lens are found to be radiatingly striated at their base, and with the intervening narrow spaces very minutely granulated.

When highly magnified the granulation of this spine resembles on a small scale the star-like style of ornament of the bony plates of Asterolepis (Eich.). The base is imperfect, but apparently dilated in a remarkable degree, and in its present state the lower portion seems bent at a considerable angle from the curve of the rest. of the spine.

Collected from the carboniferous limestone of Armagh by the Rev. WV. Stokes, of Cains College, Cambridge, and by him presented to the University Collection. I have associated his name with this interesting form as a slight memorial of the zeal with which he has collected these remains, and the liberality with which he has mate them available for public instruction.

Explanation of Figures.-Pl. 3. K. fig. 18, natural size; fig. $18 \alpha$, ditto, portion magnified.

* Beschreibung und Abbildung neuer mehrero Fische, im Nil entdeckt. Frankfort a. M. 1829, plate 2. fig. I. 


\title{
Genus. ERISMACANTHUS $\left(M^{\circ} \mathrm{Coy}\right)$.
}

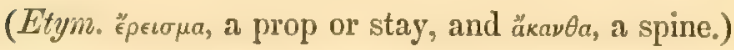

Desc.-Spine of three divarieating portions; first, a large compressed, finely striated base, which entered the flesh; sccondly, a short, strongly compressed, rapidly tapering spine, curved directly backwards, the sides marked with strong, smooth, longitudinal ridges, and having two rows of short, downward curved teeth on the posterior coneave margin; thirdly, a peculiar prop-like portion extending directly forwards nearly at right angles with the base, gently arched downwards, compressed at the basal half, depressed at the distal half, closely corered with blunt, smooth, oval tubereles, and with some large, irregular spines on the under side; the portion of the base above the flesh, and from which these two portions branch, is irregularly tuberculated.

The long anterior prop or stay-like branch renders this ichthyodorulite so unlike any described form, that I sliould have hesitated to describe it, but for the number of examples which I have recently examined. Something slightly analogous I observe in the articulation of the spines of the recent fish allied to Synodontus, in which a shorter but similarly curved and directed prop-like process may be observed, but which is concealed beneath the soft parts, and not external, as in the fossil. I know but one species of the genus, which $I$ have great pleasure in dedicating to Capt. Jones, R. N., M. P. \& c., who is in possession of more extensive and exact lnowledge of the fossil fishes of the mountain-limestone, than I believe any other observer. It is to his acumen in recognising the true characters of the species, zeal in collecting, and liberality with which both his cabinet and information are made available to those studying the subject, that we are mainly indebted for the extended lists which have been published of the Ichthyolites of this formation.

\section{Erismacantuus Jonesil ( $M^{c}$ Coy). Pl. 3. K. fig. 26, 27.}

Ref.-McCoy, Ann. Nat. Hist. 2nd Series, Vol. II. p. 119.

Desc.-Posterior spine little more than twice as long as wide, slightly curved, compressed, sides flattened, with about eight or nine longitudinal ridges, which are smooth and less than their own diameter apart; the intervening spaces finely striated longitudinally; posterior concave face with two regular, close rows of small pointed teeth directed very obliquely downwards, the surface towards the base is marked with small, scattered, oval, smooth tubercles; anterior branch thrce times as long, and about the same size at its origin as the posterior spine; the part of the spine from which those two portions take their common origin is equal to the width of their united bases, and covered with scattered round tubercles; the height of the anterior branch is double its width at the basal half, but it becomes depressed, so that its width is double the height in the section of the distal half; it is covered above and on the sides with close, quincuncially arranged, smooth, oval tubercles; the compressed, finely striated base which enters the flesh seems abruptly truneated below. Length of posterior spine one inch, width at base six lines; length of anterior process (imperfect at extremity) two inches nine lines, depth at base four lines, at tip one line; width at base tivo lines, at tip three lines; length of the common base one and half inch, width nine lines.

Position and Locality. - Not very uncommon in the carboniferous limestone of Armagh.

Erplanation of Figures.-Pl. 3. Kr. fig. 26, dorsal spine shewing the posterior spine, imperfect at the apex, and the anterior prop-like branch, denuder of some of its tubercles, the base of insertion also absent; fig. 27, ditto dotted outline shewing the perfect form (from the collection of Capt. Jones, R. N., M. P.) shewing the base of inscrtion, anterior and posterior branches, and denticulation of the latter; fig. $27 a$, ditto compressed section of base of anterior branch; fig. $27 b$, ditto portion of anterior branch with the tuberculation perfect; fig. $27 c$, ditto depressed section of extremity of anterior branch; fig. $27 d$, section of posterior spine, natural size. 


\title{
Genus. GLOSSODUS $\left(M^{c} C o y\right)$.
}

\author{
Ref.-McCoy, Ann. Nat. Hist. 2nd Series, Vol. II. p. 127.
}

Desc.-Tooth tongue-shaped, oblong, quadrangular, much higher than wide; crown elevated, slightly recurved, narrowing from the base to a small subtruncate apex; surface porous, puncta generally seeming confluent towards the apex; punctured surface terminating below in a notch, or arched line, the convexity upwards; root long, as wide as the crown, coarsely fibrous.

The Cilosiodi are distinguished from the Ilclorli, with which alone they have any affinity, by the quadrangular form of the horizontal section of the tooth, the sides being flattened as well as the anterior and posterior faces; also by the great height of the crown in proportion to its width. The long root-like base of the tooth. which resembles that of some Pctalodi (e.g. P.psittecinus Ag. MSS.) rather than that of IIeloctus in form, is of an open lacunose structure, being permeated by very large, flexuous, medullary canals, producing irregular openings on the surface. The ridge scparating the punetured surface from the base forms a sinus directed upwards, which is the reverse of what we find in P'taludus, approaching the ordinary sharks, and also conforming to what we see in IIclodus and Stropledus, when the separating line in those genera is not straight. As in Petalodus, the basal margin of the surface is much nearer the apex on the convex anterior side than on the concave posterior or internal face, the latter being generally about twice the length of the former.

The characters alove given as distinguishing those teeth from the IIclodi also separate them from the genuine Petalodi of Owen, as also the want of the imbricating folds at the base.

\section{Glossodus marginatus $\left(M^{\circ}\right.$ Coy). Pl. $3 . \mathrm{K}$. fig. 1.}

Ref.-McCoy, Ann, Nat. Hist. 2nd Series, Vol. II. p. 128.

Desc.-Crown about one-third higher than wide, having a slight antero-posterior signoidal curve; thickness from before backwards, little more than one-fourth of the width; lateral margins subparallel, prominent on the posterior face, which is gently coneave in the middle; apex narrowed, rounded, curved backwards: surface glossy, fincly punctured, marked towards the tip with minute anastomosing longitudinal wrinkles; a few obtuse plicre. Length of crown five lines, width three lines.

Easily distinguished from the $C^{\prime}$. lingua-bovis by its more finely-punctured, glossy surface, rounded tip, and prominent lateral margins.

Position and Locality.-One of the rarest fossils of the carboniferous limestone of Armagh.

Explanation of Figures.-Pl. 3. K. fig. 1, natural size; fig. $1 \alpha$, ditto magnified.

\section{Genus. GYRACANTHUS (Ag.)}

Gien. Cher.-Fin-spines very large, gradually tapering to the apex, and slightly arehed backwards; inserted base small, rapidly tapering; posterior margin feebly armed with two rows of small denticles; surface of the sides covered with very oblique rugged ridges, which meet at an angle on the anterior face.

The genus is confined to the carboniferous rocks.

\section{Griacanthus obliquus $\left(M^{\circ}\right.$ Coy $)$. Pl. 3. K. fig. $13,14$.}

Desc.-Dorsal ray nearly straight, about one foot long, and one and a quarter inch wide at base; section heart-shaped, width two-thirds of the antero-posterior diameter; anterior face narrow, rounded; posterior face broad, coneave, having near the apex a row of small hooked teeth on each side; sides slightly convex, marked with numerous very ollique crenulated ridges or rows of tubercles, which meet the anterior face at an angle of about $35^{\circ}$ (those of opposite sides meeting at an angle of 7()$\left.^{\circ}\right)$; the ridges become gradually more oblicye, smooth and entire near the apex; they are about half a line in width and slightly more than their own diameter apart. The line of separation between the ridged external surface and the finely striated part which enter's the flesh is very oblique and with a slight sigmoidal curve. 
This large ray is most allied to the G.tuberculatus (Ag.), from which it is distinguished by the much greater obliquity of the seulptured ridges, and the more compressed form of the section; the G. Alnxicensis $(\mathrm{Ag}$.$) has ridges nearly as oblique as the present species, but they are smooth and entire, instead of being$ strongly crenato-tuberculate.

Position and Locality.-Very common in the dark shale (at the base of the carboniferous system), supposed to be of the age of the yellow sandstone in the valley of the Moyola, at Moyheeland, Draperstown, in the north of Ireland.

Explanation of Figures.-Pl. 3. K. fig. 13, spine natural size, side view shewing part of the base of insertion, but broken at each end, from the yellow sandstone shale, Moyheeland, Draperstown; fig. 13 a, ditto section, a little above the middle; fig. 14, ditto terminal portion, natural size, shewing the comparative smoothness of the ridges towards the apex, and the presence in that part of the posterior rows of denticles; fig. $14 a$, ditto portion of anterior face magnified.

\section{Genus. HELODUS ( $A g$.)}

Gen. Char.-Transversely elongate, crown convex, elevated along the middle into an obtuse conical ridge, sometimes divided into a line of several compressed cones diminishing from the centre; surface porous as in Psammolus; margin of the crown raised in the middle on both the inner and outer sides, and it and the root vertically plicated.

This is manifestly but a subgenus of Psammodus, from which it is only separated by the gibbosity of the crown.

\section{Helodus didyaus ( $A g$. name only). Pl. 3. I. fig. 18, 19, 20.}

Desc.-Crown of tooth usually much elevated in the middle into a very prominent cone, more or less deeply notched at the apex, and having from that noteh a more or less distinct sulcus extending towards the base of the crown, the border of which is elevated in the middle, particularly the posterior side close to, or vertically over which, the double apices of the cone usually incline. Surface, coarsely granulo-punctate, most so on the end of the middle cone, leaving the ends of the tooth nearly smooth (the granules being closed and elevated in the unworn tooth, but inpressed puncta in old ones). Width of average, or rather small specimen, four lines, height two a half lines, but sometimes more, and often less.

The notching of the apex of the submedian cone, and the still more rarely seen sulcus therefrom, constitute the only differences between this species, and the more elevated varieties of $I I$. turgiclus, to which I have no doubt it should be referred as a variety.

Position and Locality.-Rare in the lower carboniferous limestone of Armagh.

Explanation of Figures.-Pl. 3. I. fig. 18, obscurely notched, punctured specimen; natural size; fig. $18 a$, profile of ditto, shewing the posterior margin at a much higher level than the interior one; fig. 19, deeply cleft specimen, front view; fig. 20 , very narrow pointed specimen, back view; $20 \mathrm{a}$, ditto, front view.

\section{Helodus l zevissimus ( $A g$.) Pl. 3. I. fig. 17.}

$$
\text { Ref.-Ag. Poiss. Foss. Vol. III. t. 14. fig. } 1 \text { to } 15 .
$$

Dese.-Tooth polymorphous, some specimens having the form described for, 1st, II. turridus ; 2nd, that of 11. mammillaris; 3rd, others are transversely oval, and moderately convex; the surface of all is usually smooth, and highly polished, but this character is only partial; and I have no doubt that the gibbous specimens should be referred to the $I I$. turgiclus, in which, as I have observed in the Psammodonts generally, a lustrous, thin layer of ganoine, in certain states of the surface, conecals the punctation; the forms like mameilluris might be referred to that species. The remaining transversely oval, moderately convex specimens, which cannot be referred to any other species, are sometimes as strongly punctured as the $H$. planus. 
I figure as alove a longitudinal, slightly curved, row of teeth, found in situ, of this latter form; they gradually diminish in size from behind, forwards. Agassiz figures a similar row of three teeth, of the second or mammillaris form. The transversely oval forms vary from two lines to six in length, and are nearly twice as wide as long.

Position and Locality. - Not very uncommon in the lower carboniferous limestone of Armagh.

Explanation of Figures.-Pl. 3. I. fig. 17, group of four teeth in situ (Captain Jones's collection), natural size; fig. $17 a$, profile of ditto.

\section{Helodus mammllaris ( $A g$. name only). Pl. 3. I. fig. 16.}

Desc-Crown very much elongated, narrow, abruptly pointed at each end, having a moderately large rounded, abruptly tumid, gibbosity, rather nearer to one end than the other, and sometines having an obscure beaklike projection, with an underlying vertical area, over one of the long, lateral margins; short end even and pointed; long end with one or two very faint, small, secondary gibbosities. Surface of the large prominent boss coarsely granulo-punctate, the punctations being finer, and often obscured by a polished surface of ganoine, on the ends. Average length seven lines, greatest width two lines, height of crown, one and a half lines.

This species of M. Agassiz is founded on specimens which scarcely can be said to differ, except in size, from his $H$. subteres, and I expect that additional specimens will prove their perfect identity. The more slender form is the only difference from his $H$. giblerulus, which I think will also be found to belong to the same species.

Position and Locality.-Rare in the lower carboniferous limestone of Armagh.

Explanation of Figures.-Pl. 3. I. fig. 16, natural size; fig. $16 a$, profile of ditto.

\section{Helodus planus ( $A g$. name only). Pl. 3. I. figs. 12 to 15.}

Desc.-Tooth irregularly elongate, oblong, with a slight oblique diagonal twist, narrowed, and rotundatosubtruncate at the ends, between which the crown widens; widest nearer to one end than the other; surface flattened obtusely, slightly convex, very coarsely granulo-punctate, while parts of some punctate examples and the whole of others are polished and smooth; sides of the crown and osseous base strongly plicated vertically. Average length about ten lines, greatest width about five lines, depth of crown about two lines, depth of root one and a half lines.

The characteristic oblique torsion of this species inclines Captain Jones to class it with the Cochliodus magnus (see Portk. Geol. Rep. p. 462).

Position and Locality.-Common in the lower carboniferous limestone of Armagh; rarer in the carboniferous limestone of Kendal, WVestmoreland; rare in the lower carboniferous limestone of Lowick, Northumberland.

Explanation of Figures,-Pl. 3. I. fig. 12, narrow oblong specimen, natural size; fig. $12 \alpha$, profile of same specimen; fig. 13, shorter oblong specimen; fig. 14, irregular subrhombic, worn, punctured specimen; fig. 15 , subclavate specimen.

Helodus Rudis $\left(M^{c} \mathrm{Coy}\right)$. Pl. 3. K. fig. 4.

Ref.-McCoy, Ann. Nat. Hist. 2nd Series, Vol, II. p. 123.

Desc.-Irregularly oblong, subquadrate; sides steep, irregularly nodulose, or undulato-plicate; crown irregularly gibbous, the highest point a little nearer one end than the other; surface polished, coarsely punctured. Length seven lines, width four and half lines, height two and half lines.

[FASC. III.] 
The curiously irregular lumplike figure and quadrate base of the species distinguish it casily from its congeners; the steep striated margin is also peculiar. The puncturing of the surface is rather coarser than that of the $I$. turgidus (Ag.)

Position and Locality.-Rather rare in the carboniferous limestone of Armagh.

Explanation of Figures.-Pl. 3. K. fig. 4, natural size, shewing the upper surface and part of margin.

\section{Helodus turgidus $(A g$.}

Ref-A -A. Poiss. Foss. Vol. III. t. 15. fig. 1 to 12.

Desc.-Tooth varying in form, but usually unsymmetrically elongate, oval, one of the long sides being much more curved than the other; ends abruptly narrowed, depressed, obtusely rounded; middle raised into a large gibbosity, which is either obtusely conoidal and very gibbous, or more or less compressed in the direction of the length of the tooth, but in all cases obliquely inclined over the straighter of the long sides; surface of the medial gibbosity coarsely granulo-punctate, depressed sides nearly or quite smooth. Length of average or rather large specimen, one inch; width, five lines; height of crown about the same.

The obtusely conoidal specimens strongly resemble Chomatodus cinctus, but the concentric, imbricating folds at the base of the crown of the one are replaced by the vertical marginal plice of the root of the other. M. Agassiz' figures, 8, 9 of the above quotation, would probably belong to his so-called species, II. didymu, the distinction of which I very much doubt.

Position and Locality-Not uncommon in the lower carboniferous limestone of Armagh.

\section{Homacantuus $(A g$.}

Gen. Char.-Fin-spine small, rather rapidly tapering, moderately arched backwards; sides flattened, converging to the anterior face, which is obtusely kecled; sides covered with few, very coarse, longitudinal ridges, and fine strix in same direction; posterior margin with two rows of denticles arehed downwards.

This genus differs from Leptacanthus and Ctenacanthus in its small size, and the sides being covered with very few, strong, nearly smooth ridges. The genus is by no means a well-defined one, but when confined to the two following species, and the Russian Devonian one already published, it has a sufficiently distinct facies. The base of insertion has not been observed.

\section{Homacanthus macrodus $\left(M^{\circ} C o y\right.$. $)$ Pl. 3. K. fig. 20. Ref.-McCoy, Ann. Nat. Hist. 2nd Series, Vol. II. p. 115.}

Desc.-Spine about eight lines long and two lines wide at base, slightly arched and tapering to a point; section compressed, trigonal; anterior face formed by a narrow rounded keel; posterior concave face bounded on each side by a large rounded ridge, between which and the anterior keel there is on each side a still smaller rounded longitudinal ridge; the two posterior ridges on each side dichotomise near the base; of the two intervening spaces, the anterior is rather wider and the posterior rather narrower than the ridges, which they separate; they are concave, and very finely striated longitudinally; posterior face with twelve or fourteen very large, compressed falcate teeth, alternating in two rows, the alternating bases touching, keeled on their convex edge, their length nearly equalling the width of the side of the ray at their base.

The small size, few ridges, and great posterior tecth, easily distinguish this from the other rays of the carboniferous period, while the two latter characters easily distinguish it from the 11 . arcuatus (Ag.) of the Old Red sandstone. This genus has not been noted before in the carboniferous period.

Position and Locality.-Rare in the carboniferous limestone of Armagh.

Explanation of Figures.-PI. 3. K. fig. 20, dorsal spine natural size; fig. 20 a, ditto portion magnified. 


\section{Homacanthus mirrodus $\left(M^{c} \mathrm{Coy}\right)$. Pl. 3. K. fig. 19.}

Ref.-McCoy, Ann. Nat. Hist. 2nd Series, Vol. II. p. 115.

Desc.-Spine about one and quarter inch long, and two lines wide at base; very slightly arehed, gradually tapering; section ovate: anterior face formed of a narrow rounded keel, each side with two slightly flattened, nearly equal lieels, the posterior one dichotomous at its base; they are their own width apart, the intervening space being flat and marked with about three longitudinal striae; posterior face with two rows of numerous conical hooked teeth, their length scarcely one-fifth the width of the ray at their base.

The more slender form, flattened ribs and inter-spaces, and numerous small, conical teeth, distinguish this from the last, with which alone it is likely to be confounded.

Position and Locality.-Carboniferous limestone of Armagh.

Explanation of Figures.-Pl. 3. K. fig. 19, dorsal spine imperfect at each end, natural size; fig. $19 a$, ditto portion magnified.

\section{Genus. LEPTACANTHUS (Ag.)}

Gen. Chn:-Fin-spine very long, narrow, gently arched backwards, very gradually tapering, greatly compressed, sildes flattened; anterior face thin, keeled; surface covered with very numerous, close, longitudinal ridges and stria, posterior side set with two rows of very numerous, close, small, downward-curved denticles.

M. Agassiz, in his work on the Old Red fishes, states one of the generic characters of Leptacanthus to be a smooth space free of ridges on each side, near the posterior row of denticles; but no such character exists in the greater number of his typical species, nor is it alluded to in his former work, where the Leptacuntli are more particularly treated of, except in the case of the common Stonesfield $L$. scmistriatus, it being the distinguishing peculiarity of that particular species.

The genus is Carboniferous and Oolitic.

\section{Leptacanthus? Junceus $\left(M I^{c} \mathrm{Coy}\right)$. Pl. $3 . \mathrm{G}$. fig. 13.}

\section{Ref.-MIcCoy, Ann. Nat. Hist. 2nd Series, Vol. II. p. 122.}

Desc.-Nearly straight, about one and half lines wide: section semielliptical; sides gently convex, meeting in front to form a sharp anterior edge, and converging behind to a narrow posterior sulcus, bordered on each side by a row of strong, conical, downward-curved teeth, little longer than wide, and about the width of their bases apart; each side with about seven longitudinal, narrow, equal, thread-like ridges, twice their diameter apart, and having between each pair two or three obsolete longitudinal striæ.

This is put in Leptacanthus rather than in Homacenthus from the great number and regular delicacy of the ridges.

Position and Locality.-Rare in the black beds at the top of the carboniferous limestone of Derlyshire.

Explanation of Figures.-PI. 3. G. fig. 13, fragment of fin-ray natural size; fig. 13 a, portion of ditto magnified.

\section{Leptacanthus Jenkinsont ( $\mathrm{I}^{c} \mathrm{Coy}$ ). Pl. 3. G. figs. 14 to 16.}

Desc.-Fin-spine very long, slender, tapering at the rate of one line in two inches, very much compressed ; sides flattened; anterior face surmounted by a strong keel. Sides with about fourteen or fifteen subequal ridges, averaging six in two lines; about twenty ridges when six lines wide, and about ten when two lines wide (in the latter ease near the apex a smooth band runs along the posterior edge), separated by narrow, shallow sulci: ridges often inconspicuous, and singly interrupted or discontinued at irregular distances; both the ridges and sulci obscured by a longitudinal, slightly irregular striation, posterior edges set with very numerous, and very: small, much-hooked denticles, nearly twice the width of their bases apart, three in three lines at four lines wide. 
Length unknown, but upwards of five inches; greatest observed width six lines, at which size the thickness is only two lines.

This species in size, shape, and inconspicuous ridging, agrees perfectly with the Leptacanths of the Oolitic rocks.

Position and Locality.-Not very uncommon in the dark lower carboniferous limestone of Lowick, Northumberland.

Explanation of Figures.-PI. 3. G. 14, portion of ray, natural size; imperfect at each end, shewing the anterior keel and some of the posterior denticles, and the interruption of the ridges above; fig. $14 \alpha$, small portion of surface magnified, shewing the occasional interruption of the ridges, and the intervening punctured strix ; fig. 15, ditto, portion nearer to the distal extremity, natural size; fig. $15 \alpha$, portion magnified from near the apex, shewing the form of the section, \&c.; fig. 16, fragment, natural size, from near the apex.

\section{Genus. ORACANTHUS $(A g$.}

Gen. Char.-Dorsal rays very large, conical, without solid base, hollow from the extremely large internal cavity, and thin walls; surface covered with oblique rows of tubercles, or tuberculated ridges; no posterior rows of denticles.

The great size of the internal cavity and consequent thinness of the walls, renders the form of the section of these large rays very uncertain.

\section{Oracanthus Milleri $(A g$.}

Ref.-Ag. Poiss. Foss. Vol. III. t. 3. f. 1 to $4 ;=0$. confluens. Ag. Id. p. 177.

Desc.-Ray conical, gradually tapering, hollow nearly to the apex; very thin, so that most of the specimens are pressed flat, but the long sides of the triangle of such specimens having no fixed relation to the anterior or posterior faces; length of such flattened specimen six inches, width at the base (compressed) two inches nine lines; apex solid with an elliptical section, nearly smooth for six or eight lines from the obtuse point, and then ornamented for a few lines more, with small, scattered, oval tubercles, without any order of arrangement, about half a line in length; a little lower down the tubercles increase in size, and become conico-pyramidal, nearly as high as deep, gradually increasing in size towards the base, near which they become confluent in thick undulated ridges; the lines of separated tubercles on the distal portion of the spine, and the tuberculated ridges of the base, are separated by deep concave spaces, minutely striated longitudinally, averaging four ridges in six lines on the basal half, about five rows in the same space nearer to the apex; the rows are irregular in direction, slightly sigmoid, but have a tendency to meet on the anterior face, in an upward angle of $120^{\circ}$.

I have examined specimens bearing M. Agassiz name $O$. confluens in the collection of Capt. Jones, R. N., M.P., and find they have the cliaracters always assumed by the basal portion of O. Milleri, with which they are certainly identical. The extremely puzzling and protean character of the surface, proportions, and fiequent distortions of this ray are certainly due to its most extraordinary character, which has entirely escaped M. Agassiz, viz. the extreme thinness of the substance and great size of the internal cavity; a specimen an inch in diameter having a thickness of only one line, so that the whole ray forms a thin, casily compressed, hollow cone nearly to the apex, which alone is solid. The tuberculation extends to the extreme edge of the base, which has no solid longitudinally striated insertion, like most Ichthyrodorulites. It is owing to this thin hollow construction that some specimens are flattened laterally, shewing oblique ridges, and some flattened from before backwards, shewing the ridges meeting at a salient angle. This explanation also dispels all the difficulties under which M. Agassiz laboured, as to the direction of the ridges, and position of the faces of the spine. The ridges pass round the posterior face without marked interruption. I have no doubt the $O$. minor Ag. is the apex of a young specimen of this same species, which might be expected to have the apex of very large specimens more solid than small ones, and the tuberculation agrees with that of the apex of a moderate sized $O$. Milleri in the collection.

Position and Locality.-Not uncommon in the carboniferous limestone of Armagh. 


\section{Genus. PETALODUS (Owen).}

Gen. Char.-Teeth transversely elongated, usually much compressed, thin, petal-shaped; cutting edge serrated; base of crown with several narrow, imbricating folds of ganoine, descending lower on the posterior than on the anterior face; root large, oblong, thin, truncated below; lower edge obtuse, tumid.

The dentine of the crown of these teeth is of extreme hardness, almost defying the lapidary, and having no comparison with the comparatively soft Psammodi, Sc. Most of the longitudinal medullary canals extend to the surface only at the cutting edge, to which they give a fibrous character under the lens; the highly-polished surface of the crown being left without punctures, which however appear on the edge of the ganoine folds at the base of the crown.

The genus is only carboniferous.

\section{Petalodus acuminatus (Ag.) Pl.3. G. fig. 4.}

Ref. and Syn.-Ag. Poiss. Foss. p. 174.t. 19. f. 11, 12, 13. + Petalodus rhombus $\mathbf{M}^{\mathrm{C}} \mathrm{Coy}, \mathrm{Ann}$. Nat. Hist. 2nd Series, Vol. II. p. 125.

Desc.-Crown sharp, compressed; anterior face of variable height, regularly rhombic, the upper and lower margins sometimes symmetrical, the lateral portions of each being nearly straight or slightly arched downwards, and meeting in the middle at an obtuse angle, or more frequently the angle both of the apex and coronal ridge more or less rounded; the cutting edge is obscurely undulato-dentate in some specimens by short obsolete vertical furrows, and minutely crenulato-striated, more commonly without the vertical plice, from the faint undulations of the edges; the lower margin is prominent and surrounded by five or six small imbrications of ganoine, thiese descend lower (as usual) on the posterior face, where also the mesial angulation is less; surface smooth, with a few fine irregular longitudinal strix; root moderately large. Height of the middle of the crown six lines; width about one inch nine lines; depth of root about seven lines; the proportional height of the crown being however variable, frequently greater than the above.

I originally described the rare variety, in which the coronal folds are angulated in the middle so as to give a very wide, narrow, rhombic form to the crown, and having the cutting edge longitudinally undulated, under the name of $P$. rhombus. A considerable number of specimens now before me incline me at present, however, to consider it a variety of the present species.

Position and Locality.-Rare in the carboniferous limestone of Derbyshire; not uncommon in the dark carboniferous limestone of Lowick, and Belsey, Northumberland.

Explanation of Figures.-Pl. 3. G. fig. 4, inner aspect of tooth, natural size; fig. 4a, outer side of same tootl.

\section{Petalodus Hastngsi (Owen).}

Ref. and Syn.-Owen, Odon. t. 22. f. 3, 4. = Petalodus loevissimus Ag. lists.

Desc.-Crown very thin, scale-like, gently convex along the upper edge, turning abruptly downwards at the extremities; base of the crown with a broad series of five or six imbricating folds of ganoine, towards which the crown slopes without convexity downwards and outwards so that they form the thickest and most prominent part of the tooth; they are arched downwards in the middle, but abruptly curved upwards, and downwards again at the lateral fourths of the length; root abruptly narrowed, flattencd, tongue-shaped, one third decper than the crown on the outer side. Surface highly polished, and smooth when perfect, the cutting edge alone being marked with a row of punctures (twelve in one line); when worn, however, a fine line extends from each of these punctures lialf way down the crown, producing a striation searcely visible to the naked eye. Average width of crown, six lines; depth on the outer side two lines; depth of root, three lines; width, four lines. 
The $P$. locvissimus and $P$. Hastingsii as admitted in Agassiz' list are the smooth and striated states above allnded to of this species, and which states I am absolutely certain may be found in different parts of the one tooth, and indicate no specific difference. Col. Portlock's figure of $P$. Hastingsii does not, I think, represent that species, but more probably the $P$. acuminatus.

Position and Locality. - Not uncommon in the carboniferous limestone of Armagh; very rare in the carboniferous limestone of Lowick.

\section{Petalodus psittacinus $(A g$.$) name only. Pl. 3. I. fig. 4$.}

Desc.-Root very large, cylindrical, coarsely osseous, one half deeper than the crown is high; crown scmiconical, very convex, highly polished, rapidly tapering to a point, which when worn is marked with fine notehed strixe; base of the crown with about three strong imbricating folds of ganoine. Average height of crown six lines; width at base seven lines; antero-posterior thickness three lines.

The thick conical pointed form of the crown of this tooth easily distinguishes it from all others. When greatly worn the upper edge becomes obscurely tricuspid, and coarsely striated vertically.

Position and Locality.-Rare in the carboniferous limestone of Armagh.

Explanation of Figures.-Pl. 3. I. fig. 4, front view of average tooth, natural size, with the large bony roots slightly imperfect at base.

\section{Petalodus nectus $(A g$.) name only.}

Ref.-Portk. Geol. Rep.t. 4. f. 9, (the vertically-striated elevated part of this figure represents a portion of the matrix, and not the crown of the tooth).

Desc.-Tooth very broad, greatly flattened, crown thin, rectilinear, or nearly so; in some specimens slightly undulated, and marked with vertical stria near the elge in others; crown surrounded by a broad band of four or five imbricating lamelle of ganoine; root deeper than the crown and coronal folds together; concave in its upper half, tumid and longitudinally rugged below; average length of rather small specimen one inch; height of crown about one line; width of coronal bands three-fourths of a line; depth of root two and a half lines.

The great width and slight elevation of the knife-like crown of this species easily distinguish it from any others. The name $C$. rectus of Agassiz' published lists applies to the perfect, nearly straight-edged specimens, while his name, $P$. marginclis, applies to the slightly worn examples, in which the edge is striated and undulated, and I have traced the perfect passage of one form to the other.

Position and Locality.-Not uneommon in the dark carboniferous limestone of Lowick, Northumberland: very rare in the lower carboniferous limestone of Armagh.

\section{Petalodus sagittatus ( $A g$. name only). Pl. 3. I. fig. 2, 3.}

Desc.-Crown acutely angular above, pointed in the middle, with straight sides in old individuals, but obscurely tricuspid in worn ones; ends arching considerably downwards; surface moderately convex and sunooth, except when worn, which gives a coarse, fibrous, vertical striation to the margin; middle portion of the coronal ridges one-fourth the width of the tooth, and very prominent, the two or three bands of ganoine extending sigmoidally upwards from it on each side, and then arching abruptly downwards to the lateral angles of the crown; posterior side concave, with the coronal bands broadly arched, and twice as far from the cutting edge as the front ones are; root extremely long, narrow, and prominent in the middle, sloped along the sides. Length of crown on the outer side averaging five lines, width six lines, length of root commonly double that of the crown.

This species is most nearly allied to the $P$.psitfacinus, from which however it is casily distinguished by the broad spear-like form of the crown, produced by the greater flatness of the tooth, and the curious, narrow, 
very prominent middle portion, or shaft, of the spear-head, produced by the peculiar curvatures of the coronal bands; the coronal bands of the $P$. psittacimus being simply transverse, or slightly arched.

Position and Locality. - Not very uncommon in the red lower linestone of Armagh.

Explanation of Figres.-PI. 3. I. fig. 2, front view of old much worn tooth, natural size, shewing the very long root, the truncation of the apex by wear, and the unusual puncturing of the surface from the same cause; fig. 3 , ditto, view of the inner side of a less worn specimen, shewing that the transverse folds at the base of crown are more numerous and much lower in position on the inner than on the outer part; part of the root broken off; fig. $3 a$, front view of same tooth; $3 b$, profile of the same tooth ; $3 c$, ditto, part of cutting edge magnified.

\section{Genus. PETRODUS ( $M^{c}$ Coy).}

Ref.-Mㄷoy, Ann. and Mag. Nat. Hist. 2nd Series, Vol. II.

Gen. Char.-Teeth conical, supported on a nearly circular osseous base, concave beneath; crown with a dense compact surface, height not exceeding the width, deeply furrowed with rough radiating ridges. Microscopic structure: vertical and horizontal sections nearly similar, shewing the centre to be composed of exceedingly coarse irregular medullary fissures, irregularly branching and anastomosing as they approach the periphery, and sending out at right angles minute, flexuous, calcigerous tubes into the large, irregular clear interspace; the enamel-like surface forms a wide, dark-coloured band of fine, straight, parallel, calcigerous tubes at the circumference of the magnified sections.

The above generic name brings to mind not only the peculiarly rugged crag-like aspect of those teeth, but also their relation to the genera Orodus and Acrodus ( $\mathrm{Ag}$.), from both of which they are distinguished by a simply conic form, the base being nearly circular, and not greatly lengthened in one direction as in those genera, as well as the dense stony character of the surface, and great depth, coarseness, and star-like disposition of the superficial vertical ridges. The base is slightly hollowed in the middle below, of a coarsely osseous texture, penetrated with numerous small vascular canals. It is interesting to observe that of all the fossil teeth yet made known the microscopic structure of the Petrodi appronches nearest to the internal characters of the recent Cestracion.

\section{Petrodus patelliformis $\left(M^{\circ} \mathrm{Coy}\right)$. PI. 3. G. figs. $6,7,8$.}

$$
\text { Ref.-M[Coy, Ann. and Mag. Nat. Hist. 2nd Series, Vol. II. }
$$

Desc.-Conical, height one-half to two-thirds the width of the base, which is round or rarely subtrigonal; apex rudely pointed, hecoming flat by wear; sides radiatingly ridged with about thirteen or fourteen very strong, single or dichotomous ridges, the sides of which are usually cut by numerous deep oblique sulci; the ridges are highest at the base, where they terminate abruptly; osseous base a little wider than the crown. Diameter of base three to four lines.

This tooth presents considcrable variations in the proportions of height to width of the base, and also in the number and relative thickness and complexity of the ridges; there is no variety however sufficiently striking to require particular notice, or occasion any difficulty in the identification of the species.

It seems abundant in some parts of the Derbyshire limestone.

Explanation of Figures.-Pl. 3. G, fig. 6, single perfect tooth, viewed in profile, natural size; fig. $6 a$, ditto, magnified; $6 b$, vertical section from grinding surface to base, highly magnified, shewing the numerous, irregularly branching, medullary canals, giving off dentine tubes at right angles, and the superficial coat of dense ganoine, without canals; fig. 7 , tooth, natural size, seen from above, the apex worn down by use; fig. 8 , tooth, natural size, under side of base. 


\section{Genus. PHYSONEMUS ( $A g$. name only).}

Gen. Char.-Fin-spine of small or moderate size, much compressed, with a variable backward curvature; base of insertion large; posterior edge with two rows of small denticles. Surface covered with very numerous cord-like longitudinal ridges, which swell at short regular intervals into smooth bubble-like tubercles.

\section{Physonemus arcuatus ( $M^{\circ}$ Coy.) Pl. 3. I. fig. 29.}

Desc.-Ray wide, much curved, with a broad, dilated, bilobed base; a specimen imperfect at the tip, four and a half inches long, measured along the anterior curve, is regularly arched the fourth of a circle; the width at the broken distal end is five lines; the width at point of entry into the flesh eleven lines; length of base one inch nine lines; width of base one inch one line; longitudinal rounded ridges very numerous, about twelve to fifteen in the space of half an inch, less than their own diameter apart, dilated into rounded, smooth, bubble-like tubercles, which are nearly twice their diameter apart; some of the tubercles occasionally flattened and transversely oblong; the narrow sulei between the ridges have usually two or three obscure longitudinal strix; on the posterior edge are two irregular alternating rows of obtusely-pointed tubercles finely stellated by radiating strix at base, and about one line in diameter.

Distinguished from the Physonemus subteres (Ag.) by its much greater size, more numerous ridges, and wide arcuate form.

Position and Locality.-Very rare, from the carboniferous limestone of Armagh.

Explanation of Figures.-Pl. 3. I. f. 29, large specimen, shewing the perfect base, natural size; fig. $29 a$, portion of surface magnified; $29 b$, one of posterior teeth, magnified.

\section{Physonemus subteres ( $A g$. name only). Pl. 3. I. fig. 30.}

Our specimen of this species is unfit for description, being a fragment five lines long, straight, without perceptible tapering, one and half lines wide, about four ridges in the space of one line; the intervening spaces being rather wider than the ridges themselves, which swell at regular alternate intervals into oval, smooth tubercles, about their own diameter apart; intervening spaces with about three longitudinal punctured strix.

I have seen specimens about trice the above size, and the species is easily distinguished from the $P$. arcuctus by its small dimensions, slender tapering form, and straightness; two small rows of teeth on the posterior side.

Position and Locality.-Rare in the carboniferous limestone of Armagh.

Explanation of Figures.-Pl. 3. I. fig. 30, fragment natural size; fig. $30 \alpha$, portion of surface magnified.

\section{Genus. PCEILODUS (Ag. name only).}

Cien. Char.-Teeth formed and disposed as in Cochliodus; terminal tooth obliquely trigonal, slightly convoluted; median tooth narrow, much convoluted; all the teeth longitudinally marked with thick, step-like, oblique, flattened wrinkles, apparently at right angles to the articular edges; surface porous.

This should only be viewed as a subgenus of Cochliodus, for the number and form of the teeth, with the strong inrollment, particularly of the median tooth over the outer part of the jaws, seems to be the same in both; the only tangible difference of the present teeth being the more or less distinct longitudinal ridges, which cross the teeth, parallel to the inner margin.

$$
\text { Poecilodus aliformis }\left(M I^{\circ} \mathrm{Coy}\right) \text {. Pl. 3. G. Zug. } 10 \text { (matergy.) }
$$

Ref.-McCoy, Ann. Nat. Hist. 2nd Series, Vol. 11.

Desc. - Wing-shaped, or contorto-subtrigonal, narrow before, broad and subtruncate behind; inner straight margin thin, higher in the middle than at each end, the surface seeming concave from thence to the external oblique margin, which is abruptly deflected, much thickened; rounded, strongly arched downwards at 
each end, with a slight sigmoidal curve; this ridge is crossed by seven or eight large, obtusely rounded wrinkles, which become obsolete as they approach the thin inner margin; surface finely granuloso-punctate under the lens.

This species most resembles some of the wing-shaped forms of the $P$. sublocvis, but the whole tooth is more strongly contorted sigmoidally ; the external oblique margin is more thickened, ridge-like, and deflected; and above all, the great size of the transverse waves or wrinkles easily distinguishes it. The length of a perfect specimen is one inch three lines, width of the broad posterior end nine lines, depth of the middle of the external margin four lines, width of the transverse wrinkles rather more than one and half line.

Position and Locality.-Rare, from the black upper limestone of Derbyshire.

Explanation of Figures.-Pl. 3. G. fig. 10 (upper figure), natural size.

\section{Peeilodus foveolatus $\left(M^{c} \mathrm{Coy}\right)$. Pl. 3. G. fig. 11. \\ Ref.-M다, Ann. and Mag. Nat. Hist. 2nd Series, Vol. II.}

Desc.-Longitudinally clavate, depressed, nearly three times longer than wide; terminal end narrow, subtruncate; surface obliquely crossed by nine or ten thick, flat, imbricating ridges, varying from one line to half a line wide; they run nearly straight, but each has got an abrupt angular bend about the middle, which makes the posterior half of each edge seem about half a line further out than the anterior half; each imbrication has one, or rarely two rows of large, equidistant puncta, or small pits.

This differs from the $P$. Jonesii $(\mathrm{Ag}$.$) in its very narrow, elongate form, more numerous, flat, imbri-$ cating ridges, the row of notch-like curves one in the edge of each, and the regular rows of great puncta. The specimen described is imperfect, but seems to have been about one and quarter inch long and four lines wide.

Position and Locality.-From the upper black beds of carboniferous limestone in Derbyshire.

Explanation of Figures.-Pl. 3. G. fig. 11, natural size.

\section{Pecilodus Jonesil ( $A g$. name only.)}

\section{Ref. and Syn. $=P$. Jonesii $+P$. transversus Ag. lists; Portk. Geol. Rep. t. $14 a$, f. 6, 7.}

Desc.-Posterior tooth longitudinally and obliquely sub-elliptical, tumid, moderately convex; rather flattened towards the posterior elliptically pointed end; moderately convoluted towards the outer anterior corner; one very deep oblique concavity, about one-third the length from the anterior margin, divides the surface into two large oblique lobes, the anterior of which slopes gradually so as to be most prominent along the anterior articular margin; the posterior one obtusely rounded, scarcely defined from the posterior edge, except at the posterior extremity, where it is very slightly reflected, giving an indication of the third ridge of Cochliodus; surface marked with subequal, very deep, longitudinal hollows; leaving strongly marked projecting ridges, averaging three in the space of two lines in the middle concavity (rather more on the anterior ridge, and less on the posterior one); in old teeth a considerable space of the inner posterior corner is without these longitudinal indentations, which extend over the rest of the tooth; surface coarsely granulo-punctate; average length nine lines, width of anterior margins four and half lines.

This species is most nearly allied to the $P$. obliques, but the oblique ridges are much broader and more obtuse, and the middle one is not separated from the posterior margin by a marked concavity. It is possible, nevertheless, that they may be the upper and lower teeth of the same fish; but as $I$ have no independent knowledge of the dentition of the upper jaw in either Pacilodus or Cochliodus, this can only be a vague suggestion, founded on some general accordance of the teeth.

Position and Locality.- Not uncommon in the lower carboniferous limestone of Armagh; very rare in the lower carboniferous limestone of Lowick, Northumberland.

[FAsC. III.] 


\section{Pecilodes obliques (Ag. name only). Pl. 3. I. fig. 5.}

Desc.-Terminal posterior tooth sub-cylindrical, obliquely attenuated semielliptically at the posterior end, abruptly truneated at an angle of $80^{\circ}$ in front, strongly convoluted with three very strongly marked, very prominent, nearly equidistant ridges, the lateral ones formed by the thickened reflected margins of the anterior and posterior edges; the middle one thicker than the others, and slightly more prominent, bounded on each side by a very broad, deep concavity; the concavities are crossed by strong, subequal, slightly irregular longitudinal wrinkles, separated by deep sulci (four in two lines), which only indent the oblique transverse ridges of the convoluted outer portion: whole surface strongly granulo-punctate. Average length six and half lines, greatest width four lines.

This beautifully distinct species is easily distinguished by the strength and obliquity of the three ridges found in Cochliodus. The punctation is rather finer than in the Psammodus cormutus, and in places, is entirely concealed by superficial patches of ganoine, such as I have drawn attention to in the Psammodonts generally.

Position and Locality.-Rare in the lower carboniferous limestone of Armagh.

Explanation of Figures.-Pl. 3. I. fig. 5 , left posterior tooth, natural size; fig. 5 a, portion of surface magnified.

\section{Pegcilouds parallelus (Ag. name only). Pl. 3. I. fig. 6.}

Desc.-Middle tooth only known, narrow, very much inrolled spirally, the curve exeecding a semicircle; anterior and posterior margins forming narrow rounded ridges, sharply defined by narrow impressed sulci, and converging towards the much inrolled external apex; the posterior margin longer and more oblique than the anterior; middle ridge about three times the width of the lateral ones; abruptly raised above their level, so as to be very much more prominent, though only moderately convex; middle lobe crossed about its middle or most prominent part of the general convexity of the tooth, by about five or six narrow, deep, longitudinal sulci, which also, though less strongly, indent the lateral ridges, to which they are nearly at right angles; leaving intermediate ridges about half a line wide, not raised above the general level of the surface. Average width from base to opposite point of the outer margin (not to the inrolled apex) seven lines, greatest length of base fire lines; length of middle lobe at same point three and half lines; length of the three lobes together at opposite points of the exterior, two lines; punctation of the surface very coarse.

The teeth which have received this name are remarkable for the excessive incurvation of their external apices, as represented in our figure, as well as the patch on the uppermost part of the surface of the longitudinal inconspicuous ridging. From the character of this ridging, and from the parts on the inner and outer sides of it, and the general agreement of the margins, \&c., I have little doubt that this will ultimatcly prove to be the middle tooth of the $P$. sublavis. I am not however in a position to absolutely demonstrate the truth of my conviction. In the transverse fractures the vertical medullary canals are found to be excessively coarse.

Position and Locality. - Rare in the lower carboniferous limestone of Armagh.

Explanation of Figures.-PI. 3. I. fig. 6, front view of penultimate tooth natural size; fig $6 a$, ditto, shewing the spiral inrollment of the crown for the armature of the exterior of the jaw.

\section{Pocilodus sublezis ( $A g$. name only). Pl. 3. I. figs. 7, 8, 9.}

Desc.-Posterior tooth aliform, very oblique; articular margin forming an angle of $40^{\circ}$ with the straight inner edge; tumid anterior margin defined, very narrow; sigmoidal middle ridge close behind it, broadly rounded, occupying half the length of the tooth, and forming its most convex part, narrowing gradually to the convoluted, beak-like, prominent, outer end; behind the middle ridge the surface slopes with moderate concavity, to the small flattened, acutely angular, posterior end, the outer margin of which is slightly tumid. Surface coarsely granulo-punctate, the middle third crossed longitudinally by five or six obseure, sigmoidal, sulei and intervening ridges, about three-fourths of a line wide, which are not more elevated than the general surface. Length along the inner edge ten lines; greatest width seven lines; anterior tooth having the posterior margin 
very slightly oblique to the median line, and not separated by a concavity from the adjoining broad convexity, which occupies two-thirds of the tooth, the anterior third flattened, abruptly narrowed, and obliquely pointed nearly at right angles. Surface in parts coarsely granulo-punctate, and marked with numerous, obscure, longitulinal, arched sulci, parallel to the convex inner margin. Length of rather small specimen seven lines, greatest width six lines.

As I have mentioned before, I think the $P$. parallelus will ultimately prove to be the middle tooth of this species. Our figures of very large anterior teeth, Pl. 3. I. fig. 7, 8, are not quite complete at the anterior ends, forming the upper parts of the figure, which in perfect specimens I have since seen is a little longer, abruptly narrowed, and marked with angulated obscure sulci of growth.

Position and Locality. - Not uncommon in the carboniferous limestone of Armagh.

Explanation of Figures.-PI. 3. I. fig. 7. Anterior right tooth, natural size, the upper end when perfect is a little longer and narrower; fig. 7 a, profile of ditto partially shewing the inrollment of the outer margin, apex imperfect; fig. 8, same tooth of left side; fig. $S a$, fore-shortened end vierv of last specimen; fig. 9 , posterior terminal tooth, left side.

\section{Genus. POLYRHIZODUS $\left(I^{\circ} \mathrm{Coy}\right)$.}

Ref.-McCoy, Ann. Nat. Hist. 2nd Series, Vol. II, p. 125.

Gen. Char.-Tooth thick, crown but slightly elevated, forming a transversely oval crushing surface, narrowing towards the extremities; anterior and posterior ridges separating the crown from the root, ohtuse, without imbricating folds, the posterior ridge much lower than the anterior; root very large, deeply divided into several distinct, root-like lobes, or fangs.

This is perhaps the most remarkable genus of ichthyolites yet made known, as it presents the only instance in the entire class of a fish-tooth divided into several distinct fangs; the imperfectly double, divaricating base of certain sharlis' teeth, or the prolonged external plicte of certain sauroids (IIuloptychius, Rhizodus, sc.) not deserving to be viewed in the light of really divided or fanged roots, as in the mammals and the present genus of fish. The group is most allied to L'etaluclus $(O w e n)$, with which Agassiz seems to have confounded one of the species; but instead of the thin, seale-like or petal-like character of the Petalodi. with their highly elevated, compressed, sharp-edged crown, we have a tooth of remarkably thick and clumsy form, with the crown but little raised and all the parts obtuse; the crown in Petalodus is covered with a thick coat of smooth, highly polisherl, cnamel-like substance or ganoine, and separated on each side from the root by several imbricating folds, while the crown in the present genus is nearly as dull as the root, and in one species coarsely punctured as in $P$ sammodus, and the characteristic basal imbrications are replaced by a simple, obtuse ridge; finally, in Petaloclus, the root forms a large, simple, compressed, truncated base, while in Polyrhizodus it is divided into from five to eight fangs.

\section{Polyrimzodus magnus $\left(M^{c}\right.$ Coy $)$. Pl. 3. K. figs. $6,7,8$.}

Ref.-M'Coy, Ann. Nat. Hist. 2nd Series, Vol. II. p. 126. = Petalodus radicans (Ag. MSS. names in collections).

Desc.-Tooth from one-half to two inches wide, and about one inch in depth; crown from three to four lines wide, nearly flat, inclining at an angle of about $70^{\circ}$ from the slightly raised posterior edge, smooth, or with minute branching strix on the upper edge; anterior and upper margins nearly parallel for the middle half of the width, while they rapidly converge in the two outer fourths, so that the extremities are narrowed to a point at each end, and considerably bent downwards; root very thick and deeply divided into six or eight long, ovate, fang-like lobes, roughened by the passage of the nutrient vessels; inferior posterior ridge is (like the anterior margin of the crown) simply rounded, without imbricating folds, and about one-third more than the width of the crown below the cutting edge.

Position and Locality.-This fine species is not uncommon in the lower carboniferous limestone of Armagh. $4 \times 2$ 
Explanation of Figures.-Pl. 3. K. fig. 6, average sized tooth, front view, natural size; fig. 7, ditto, section and perspective end view, natural size, shewing the much lower level of the ridge defining the base of the crown on the posterior than on the anterior base; fig. 8 , ditto, portion of entire width of crown, from cutting edge to base, magnified three diameters.

\section{Polyritzodus pusillus $\left(M^{c} \mathrm{Coy}\right)$. Pl. 3. K. fig. 2.}

Ref.-Mc Coy, Ann. Nat. Hist. 2nd Series, Vol. II. p. 127.

Desc.-Crown compressed, raised into a rounded obtuse lobe, less than half the width of the base in height; base of the crown forming a very prominent obtusely-rounded ridge; root divided into about ten small rounded fangs; surface of the erown coarsely punctured, a few of the punctures near the apex longitudinally confluent, so as to give it a slightly pectinated appearance; width of crown two and a half lines.

Easily distinguished by its small size, coarsely punctured surface, and the raised lobe of the margin of the crown. There is a more distinct specimen than that in the University collection in the cabinet of Capt. Jones R. N., M.P.

Position and Locality.-Rare in the carboniferous limestone of Armagh.

Explanation of Figures.-PI. 3. K. fig. 2, natural size, front view; fig. $2 \alpha$, ditto, magnified two diameters; fig. $2 b$, ditto, section and end view magnified two diameters.

\section{Genus. PRISTICLADODUS $\left(M^{c} \mathrm{Coy}\right)$.}

Gen. Char.-Base of tooth expanded at right angles to the crown, large, sub-semicircular, thick, coarsely osseous; from the truncated straight edge of the base in front the crown rises as one large thick, sharplypointed, compressed cone, with two denticulated cutting edges; lateral cones very ferv (? one on each side or none); surface of crown highly polished, and marked with fine longitudinal ridges, or smooth.

These teeth agree with Cladodus in general character of crown, and the remarkable, large, horizontal, sub-semicircular base, but differ in the greater robustness of the principal cone, and most remarkably in the denticulation of the elges. The first specimen which I saw of this genus I supposed might have been the Carcharopsis prototypus of Agassiz' lists, but subsequently finding a second species, which was still more nearly like Carcharodon, to which he likens his species, I hesitated to identify an undescribed fossil which I had never seen, more especially as neither of my specimens shewed any trace of the ridges at the base of the crown, alluded to by Agassiz; and the horizontally-dilated base was so remarkable a character, totally separating them from Carcharodon, and nearly allying them to Cladodus, that I could not suppose that the true Carcharopsis prototypus was identical with my fossils, or the one resemblance would not have been stated, and the other affinity overlooked.

\section{Pristicladodus dentatus ( $M{ }^{c}$ Coy). Pl. 3. G. fig. 2.}

Desc.-Medial cone large, triangular, rather flattened on the outer side, and with a deep triangular, hollow, the base of which is parallel with, and a little above, the base of the tooth, which is narrow, arched upwards in the middle, and not prominent; the sides of the hollow are parallel with the sides of the tooth; back of the crown rounded, strongly convex; cutting edges set with a row of strong, equal, sharply defined, sub-cylindrical, obtusely pointed teeth, set at right angles to the edge (about three in the space of one line), about half their diameter apart, and rather longer than wide; base on inner side horizontally extended, thick, fibrous, almost semicircularly rounded; surface of large cone smooth on the outside, faintly striated longitudinally on the inner side. Lateral cones unknown. Length of base about one inch; horizontal extension at right angles thereto five lines; depth of root one and half lines; height of cone about nine lines (tip imperfect); width about six lines 
The strong, close, regular dentation of the edges easily separates this species from the $P$. Goughi; the deep triangular hollow in the anterior face, and the smoother surface, are also distinctive.

Position and Locality.-Rare in the black upper carboniferous limestone of Derbyshire.

Explanation of Figures.-PI. 3. G. fig. 2, tooth natural size, outer surface; $2 a$, base of ditto, on the inner side, seen from above; fig. 3 , profile of another specimen.

\section{Pristicladodus Goughi $\left(M^{\circ} \mathrm{Coy}\right)$. Pl. 3. K. fig. 11.}

Desc.-Crown compressed, triangular, moderately convex, marked with close, sharp, irregular, longitudinal strix, averaging five in one line, becoming obsolete at the apex, and close to the base of the crown; cutting edges sharp, marked with broad, slightly-marked, tooth-like undulations, nearly their width apart, and gradually blending at their base into the edge, being obsolete in the upper third of the cone; lateral cones two. robust, subcylindrical, striated like the principal one. Height of principal cone, one inch two lines; width at base eight lines; height of side cone five lines; width at base three and half lines; width of whole tooth one inch three lines; lateral breadth of base six lines; lateral breadth or thickness of principal cone four lines.

Position and Locality.-Very rare in the sandy lower carboniferous schists of Kettlewell, Kendal. perfect).

Explanation of Figures.-Pl. 3. K. fig. 11, front view, natural size, (apices of the cusps slightly im-

\section{Genus. PSAMLIODUS $(A g$.}

Gen. Char.--Tecth oblong, wide, thick, flat above, without cones or keels; surface porous or minutely rugose; base of the same form as the crown, very thick, coarse, osseous.

The punctures of the surface are of the same size and distance apart as the vertical medullary tubes, and I have repeatedly traced their identity; (Prof. Owen having thought differently in his Odontography). I have however clearly scen on occasional spots of the surface that they were originally covered with $a$ thin impervious layer of ganoine, as I have stated when describing the allied genus Cochliodus.

\section{Psammodus canaliculatus ( $M^{c}$ Coy). Pl. 3. G. fig. 12. \\ Ref.-M $\mathbf{I}^{\mathrm{C}} \mathrm{Coy}$, Ann. Nat. Hist. 2nd Series, Vol. II. p. 122.}

Desc.-Tooth oblong, generally about twice as long as wide, the two long sides straight and parallel; one of the short sides or ends very convex, the other equally concave (for articulation); the crown of the tooth concave along the middle, the two long margins being prominent and rounded; there is generally a considerable hump-like elevation near the convex end; surface roughly wrinkled transversely, the ends generally more or less rudely plicated longitudinally.

This remarkable tooth is much allied to the $P$. rugosus (Ag.), but is strongly distinguished by its ends being formed for articulation, one convex, the other concave, instead of being straight, as in that species; also by the strong longitudinal plication of the surface near the ends, and the peculiar curved swelling near the convex extremity. When the ends are wanting, it is distinguished by its mesial concavity (the other being convex), and by the minute rugre of the surface running across instead of in the direction of the length. When much worn the surface becomes polished and porous, as in the P.porosus (Ag.), and as we constantly see on the prominent parts of the $P$. rugosus (Ag.) Length generally about two inches.

Position and Locality.--Rare in the carboniferous limestone of Armagh.

Explanation of Figures.-Pl. 3. G. fig. 12, tooth, natural size.

\section{Psamiodus connutus (Ag.)}

Ref.-Portk. Geol. Rep. t. 14a, fig. 3.

Desc.-Trapezoidal; lateral sides long, straight, equal, posterior side usually shorter than the lateral ones, and concave, the latero-posterior angles being often a little produced in the line of the sides; anterior 
side shortest, slightly convex; crown flattened, slightly convex, or slightly concave in the middle; the lateral sides most prominent, often somewhat reflected, rounded; surface granulo-punctate by the ends of the medullary canals, averaging eleven punctures in one line, as in $P$. porosus. Average length seven lines; width of posterior end six and half lines; width of anterior end five lines.

It is possible that this may be the median row of teeth of Psammodus porosus, with which it agrees in surface, differing principally in its smaller size, symmetrical sides, and regular trapezoidal form. I have, however, seen one large tooth of $P$. porosus (in the University collection) having a close approximation to the characteristic shape of the $P$. cormutus. Specimens have been found by Captain Jones arranged in lines, the convex edge of one fitting into the concave one of the other.

Position and Locality.-Not uncommon in the carboniferous limestone of Armagh; rare in the dark lower limestone of Lowick, Northumberland.

\section{Psammodus rugosus ( $A g$. )}

Ref. and Syn:=P. rugosus Ag. P. F. t. 14. fig. 17 and 14; t. 19. f. 14; + P. porosus id. ib. t. 13 .

Desc. Tar. mugusus.-Oblong, nearly square or irregularly trapezoidal in form; the square, or those having the length and breadtl equal, rarest; most specimens about one-fourth wider than long, the long sides being either parallel, or one slightly concave and the other convex, in the latter case, the convex long side is shorter than the concave one; these long sides are usually bevelled obliquely on the under side for articulation, the short straight lateral sides are always rudely vertical; the surface is nearly level in the middle, but generally raised towards the short sides, which are usually the most prominent parts of the tooth, one being usually more prominent than the other, and frequently exhibiting a boss-like protuberance near one of its corners. Entire surface covered with close, small, rugged, flexuous ridges, averaging three to four in two lines, but varying from three to eight in the same space, and on specimens of the same size; the wrinkles run parallel to the long bevelled sides of the oblong teeth from one of the short sides to the other; the wrinkles have sometimes only one row of pores opening on them, and sometimes as much as three or four rows; in many of the specimens, but not all, there is a very much larger, rude, irregular plication of the bevelled, articular sides, which extends at variable distances across the tooth. Length varying from two inches to three and half: the width varying from one inch to upwards of two; the depth of root and crown together of average specimens being nine lines.

Var. porosus.-General size and shape the same as in the Var. mugosus, but the surface generally rather more even (though not universally so), and entirely or nearly destitute of the wrinkles of the surface of that variety, being regularly and uniformly covered with a coarse granulo-punctation, formed by the openings of the medullary tubes.

I have little doubt that Captain Jones is right in suggesting the identity of the species $P$. mogosus and $P$. porosus of Agassiz, and I here describe them only as recognisable varieties; the var. rugosus seems the true type, but to lose the minute wrinkling of the surface by wear; some of the most rugged specimens having all the prominent parts worn smooth, and presenting the regularly punctate appearance of the $P$. porosus. Specimens illustrating this fact unusually well are in the Collection. On the other hand, large uniformly porous specimens of the $P$. prorosus shew in occasional hollow places the characteristic rugation of the rar. munosus; and a remarkable intermediate specimen of this kind is also in the Collection.

Position and Locality.-Var. rugosus, very common in the red lower carboniferous limestone of Armagh; rare in the dark lower carboniferous limestone of Arnside, Kendal.

Var. porosus.-Rare in the lower carboniferous limestone of Lowick, Northumberland; common in the carboniferous limestone of Armagh; not uncommon in the carboniferous limestone of Arnside, Kendal. 
I N D E X. 



\section{N D EX \\ OF THE FOSSILS DESCRIBED IN THIS WORK; COMPILED BY}

JAMES CARTER, M.R.C.S., \&c., CAMBRIDGE SECRETARY OF THE PALEONTOGRAPICAL SOCIETY.

ABRANCHIA, 128

Acanthocladia, 45

ACANTHODIDE, 579

ACANTHOPYGE, 150 Anglica, 151

Acervularia, 35

ananas, 35

Baltica, 38

pentagona, 71

Achelois, 312

Acidaspis, 152

Brightii, 152

Acroculia, 290

Acrolepis, 609

Hopkinsi, 609

Actinaria, 13

Actinoceras, 312

giganteum, 571

Hocktreense, 315

Simmsi, 571

Actinoconchus paradoxus, 436

ACtinocrinus, 55

Atlas, 120

Gilbertsoni, 120

moniliformis, 56

olla, 121

polydactylus, 121

pulcher, 55

tesselatus, 121

triaconta-dactylus, 121

Actinocyathus, 34

Actinodonta, 272

Actinophyllum, 42

Eonia, 173

AgantDes, 401

Barbotanus, 563

carbonarius, 563

diadema, 563

Gilbertsoni, 564

Henslowi, 564

implicatus, 565

Listeri, 565

reticulatus, 566

sphrericus, 566

spirorbis, 567

vinctus, 401

var. crenistria, 567

AGNOSTIN E, 141

Agnostus pisiformis, 142

trinodus, 141, 142

Aleyonaria, 9

[FASC. III.]
The names printed in Italics are Synonyms.

ALCYONID $\mathbb{E}, 9$

Alcyoniens, 9

Allorisma, 276

elegans, 505

regularis, 507

ALVeolites, 68

fibrosa, 25

vermicularis, 69

AмmoNychi, 264

? acuticostata, 264

striata, 264

vetusta, 482

Ammonites carbonarius, 565

diadema, 563

Henslowi, 564

Listeri, 565

sacer, 565

Amphidesma depressa, 495

pristina, 494

AMPHITRIT E, 132

Amphoracrinus Atlas, 120 ?olla, 121

Amplexus, 70

coralloides, 92

Sowerbyi, 92

spinosus, 91

tortuosus, 70

Ampullaria helicoides, 534

Aмprx, 147

latus, 147

nudus, 148

Amosiun, 478

? deornatum, 478

Sowerbyi, 478

Annellida, 127

ANNULATA, 127

ANonontopsis, 270

angustifrons, 271

bulla, 271

deltoideus, 396

lovis, 271

?pristina, 494

quadratus, 272

securiformis, 272

Anomia acuminata, 380

angulata, 439

biloba, 213

crispa, 192

pecten, 245

pugnus, 380

reticularis, 198
Anomites aculeatus, 458

cuspidatus, 426

giganteus, 463

glaber, 428

lineatus, 429

productus, 467

punctatus, 469

resupinatus, 449

sacculus, 411

scabriculus, 470

semireticulatus, 471

striatus, 422

thecarius, 469

trigonalis, 423

Anthozoa, 1

AN'TIPATHACE $\mathrm{E}, 13$

Apioceras, 321

(Aploceras), 312

ARACHNOPIILLUA, 37

Hennahi, 72

typus, 38

ArCA, 282

antiqua, 511

costata, 497

Edmondiiformis, 283

Kingiana, 511

Loftusiana, 511

primitiva, 283

striata, 511

subæqualis, 283

subantiqua, 284

subovata, 284

tumida, 511

ARCIIEOCIDARTS, 125

vetusta, 125

ARCID $\mathrm{E}, 282$

Arges Anglicus, 151

Arthrorachis, 141

tarda, 142

ARTICULATA, 127

classes of, 127

ASAPHIN $\mathbb{E}, 159$

AsAPIIUS, 169

Buchii, 148

caudatus, 160

elevatus, 170 gemmuliferns, 183

laticostahus, 170

longicaudatus, 161

macrophthalmus, 163

Powisii, 164, 170 
AsapHuS

seminiferus, 183

seticornis, 147

Stokesii, $17 \pm$

tyrannus, 171

Aspidostraca, 134

ASTERLA, 58

Asterias primceva, 60

Asterolepis, 597

AsteroptycInUs, 615 ornatus, 615 semiornatus, 616

Astræa ananas, 35 carbonaria, 111

Hennahi, 72

intercellulosa, 72

pentagona, 71

porosa, 67

ASTR 玉ID E, 36

Astroeopora grandis, 18 Lonsdalei, 18

ATITrRIS, 196 ambigua, 432 concentrica, 378 depressa, 433 de Roissyi, 433 expansa, 433 glabristria, 434 globularis, 434 gregaria, 435 var, trapezoidalis, 435 paradoxa, 436 pectinifera, 436 squamigera, 437 tumida, 196

Atractopyge, 156 verrucosa, 156

Airypa aspera, 198 crassa, 194 cuboides, 381 decussata, 378 depressa, 201 desquamata, 378 expansa, 433, 436 fallax, 382 fimbriata, 433 galeata, 208 gibbera, 447 globosus, 208 gregaria, 435 hemisphorica, 201 hispida, $37 \mathrm{~s}$

isorhyncha, 444

juvenis, 410

laticliva, 444

lens, 209

oblonga, 378 orbicularis, 198 pectinifera, 436
Atmpa protracta, 382 rotunda, 205 semisulcata, 204 squamosa, 379 striatula, 384 subdentata, 382 sublobata, 432 tenuistriata, 196 triangularis, 380 tumida, 196

undatus, 211

unguiculus, 377 virgoides, 413

(Atutia), 556

AUCELLA, 481 speluncaria, 481

Aulosteges, 387

AVICULA, 257 ampliata, 260, 262 antiqua, 490

Binneyi, 491

Boydi, 259 ceratophaga, 490

Damnoniensis, 394

Danbyi, 258

demissa, 260, 262

discors, 491

erecta, 262

granulosa, 486

gryphceoides, 481

inflata, 491

informis, 479

levvigata, 479

naviformis, 262

? orbicularis, var, 258

pectinoides, 393

pleuroptera, 261

reticulata, 263

retroflexa, 262

subfulcata, 263

subvetroflexa, 262

sub-radiata, 392

texturata, 391

A VICULID A, 257

AviculorecteN, 392

cælatus, 483

cancellatulus, 483

concavus, 484

concentrico-striatus, 484

conoideus, 485

docens, 485

granosus, 392,486

illegalis, 486

incrassatus, 487

interstitialis, 487

mactatus, 487

papyraceus, 488

pectinoides, 393

pera, 488
Aviculopecten

plano-radiatus, 489

Ruthreni, 489

segregatus, 489

transversus, 393

Axinus, 494

lunulata, 505

obliquns, 496

obscurus, 496

parves, 496

pusillus, 497

rotundatus, 497

undatus, 496

BAFEWELLIA, 490

antiqua, 491

bicarinata, 490

ceratophaga, 490

var. antiqua, 490

var. bicarinata, 490

inflata, 491

tumida, 491

Barrandia, 149

Cordai, 149

(Basilicus), 169

8 laticostatus, 170

Powisii, 170

tyrannus, 171

Battus tardus, 142

BELLEROPIION, 308

acutus, 309

atlantoides, 555

bicarenus, 553

bilobatus, 308

bisulcatus, 400

Blainvillei, 55

carinatus, 309

clathratus, 552

cornu-arietis, 551

costatus, 551

decussatus, 552

dilatatus, 309

Duchastelli, 553

Dumonti, 553

elegans, 552

elongatus, $30 \mathrm{~s}$

expansus, 309

gibbus, 308

globates, 309, 400

hiulcus, 553

Larcomi, 554

loevigatus, 542

Murchisoni, 310

ornatus, 310

Phillipsii, 554

recticostatus, 551

reticulatus, 552

striatus, 400

striatus, 310 
INDEX.

\section{BELLEROPHON}

subdecussatus, 311

subglobatus, 400

tangentialis, 554

tenuifascia, 555

trilobatus, 311

Urei, 555

Wenlockensis, 311

BELLEROPHONTL A, 307

BrRENTCEA, 44 heterogyra, 45

BETRICHLA, 135 complicata, 136

gibba, 135

Klödeni, 135

strangulata, 136

tuberculata, 135

BLASTOIDEA, 122

Bolboceras, 321

BRACHIOPODA, 186

BRACHYTIITIS, 192

Branchiopoda, 134

Bronteds, 179

alutaceus, 179

fabellifer, 179

Bryozoa, 44

Bucania, 307

Buccinum acutum, 399, 547, 549

curvilineum, 548

imbricatum, 547

parallele, 530

rectilineum, 547

sigmilineum, 549

(Brssoarca), 282

striata, 511

suboequalis, 283

Calamopora, 19

Gothlandica, 20

inflata, 82

tumida, 82

Calceula heteroclita, 377

Calophrluas, 91 spinosum, 91

CAITMENE, 164 accipitrina, $17 \%$

Baylei, 165

Blumenbachii, 165

Blumenbachii, 165

brevicapitata, 165

clavifions, 154

Downingice, 160

diademata, 166

granulata, 177

lavis, 178

latifrons, 177

Latreillii, 177

macrophthalmus, 163

Odini, 164

\section{Caltarene}

parvifrons, 167

subdiademata, 166

tuberculosa, 167

variolaris \& 157

CAMerophotia, 443

globulina, 443

isorhyncha, 444

laticliva, 444

multiplicata, 445

Schlotheimi, 445

sulcirostris, 446

(CA3IPUlites, 322

Campyloceras Gesneri, 570

Caxtnta, 25

cornu-bovis, 90

cornu-copice, 90

gigantea, 89

lata, 28

putula, 91

sub-ibicina, 89

turbinata, 28

CApulus, 290

auricularis, 523

? euomphaloides, 290

? Haliotis, 290

Cartontcola, 514

acuta, 514

subconstricta, 515 var. robusta, 515

turgida, 516

Candrola, 28I

fibrosa, 282

interrupta, 282

CARDIONORPIA, 509

? modioliformis, 509

oblonga, 510

orbicularis, 510

Cardium aliforme, 516

cormucopice, 282

elongatum, 517

Ouralicum, 517

striatum, 264

Carfoctstites, 61

Darisi, 61

granatum, 62

Caryophyllia truncata, 35

Catenipora, 26

approximata, 26

distans, 26

escharoides, 26

exilis, 26

labyrinthica, 20

reticulata, 26

(CAunopora), 66

placenta, 66

ramosa, 67

verticillata, 67

Centrocrinus, 118
Centrodos, 610

striatulus, 611

CEPHALOPODA, 306

Ceratiocaris, 136

ellipticus, 137

inornatus, 137

solenoides, 138

? umbonatus, 138

Ceraurus, 153

clavifrons, 154

octolobatus, 154

Williamsi, 155

Ceriopora granulosa, 26 oculata, 21

Cחeteres, 81 capillaris, 82

septosus, 82

CHATETINAE, 24

Chassiops, 163

Odini ? $16 \pm$

Chemnitzia scalaroidea, 546

(Cheiracanthus), 582

(Cheirolepis), 580

CimracaxtmUs, 582

grandispinus, 582

lateralis, 582

microlepidotus, 583

minor, 583

MIurchisoni, 583

pulverulentus, 583

CHIrodos, 616 pes-ranæ, 616

Cimrolisis, 580

curtus, 580

macrocephalus, 580

Traillii, 581

uragus, 581

velox, 581

Chirurus, 153, 155 globosus, 154

Chomatodos, 617

cinctus, 617

clavatus, 617

denticulatus, 618

linearis, 618

obliquus, 618

truncatus, 618

Chondrites acutangulus, Plate $1, \mathrm{~A}$. informis, Plate I, A.

Chondropterygicn, 575

(Chonetrs,) 249

comata, 455

crassistria, 454

Hardrensis, 454

lata, 259

papilionacea, 455

polita, 456

subminima, 456

Choristites, 191

402 
Cidaris vetusta, 125

Cirrus, $\mathbf{5 3 6}$

acutus, 537

rotundatus, 539

tabulatus, 537, 541

Cuadochones, 84

bacillarius, 84

brevicollis, 85

crassus, 85

Cladocrinus, 53

Chanodus, 619

læris, 619

marginatus, 619

mirabilis, 619

striatus, 620

Clidoprorus, 273

costatus, 497

ovalis, 273

planulatus, 273

Clumaxodus, 620 imbricatus, 620

Cliothyris pectinifera, 436

Clisiopirtuluas, 33

bipartitum, 39

Keyserlingi, 94

multiplex, 95

prolapsum, 95

turbinatum, 96

vortex, 33

Crymenta, 401

bisulcata, 401

inequistriata, 404

lavigata, 402

linearis, 404

Muensteri, 402

Pattisoni, 403

quadrifera, 403

subloevis, 404

sublinearis, 404

undulata, $40 \frac{1}{4}$

Coccosteus, 601

decipiens, 602

latus, 602

microspondylus, 602

oblongus, 603

pusillus, 603

? trigonaspis, 603

CocmLIODUs, 621

acutus, 621

contortus, 622

magnus, 622

oblongus, 623

striatus, 624

Codaster, 122

acutus, 123

trilobatus, 123

Coelacanthi, 589

CELONOTID X, $275^{2}$

Coenites, 21

\section{Conites}

intertextus, 22

strigatus, 22

Coldmiraria, 92 laxa, 92

Concuodes, 593 ostreiformis, 593

CoNocardiUM, 516 aliforme, 516 rostratum, 517

ConUtaria, 287 cancellata, 287 quadrisulcata, 287,520 quadrisulcata, 520 subtilis, 288 tubericost $a, 520$

Corallium Gothlandicum, 20

Cornutites, 63 serpularius, 63

Corydocephalus, 151

Coscinopora placenta, 66

CRANIAD AE, 187

CREPHDULID $\approx, 289$

Creseis primoeva, 316 Sedgwickii, 317 ventricosus, 318

CRINOIDEA, 52

Crossopodia, 130 lata, 130 Scotica, 130

Crotalocrivus, 54 rugosus, 55

CRUSTACEA, 133

Cryphoeus, 155 Sedgwicki, 155

(Cryptoceras), 556

Cryptolithus, 144

Cryptonomus Rosenbergi, 172

Ctenacantius, 624 crenatus, 624 denticulatus, 625 distans, 625 heterogyrus, 625

Ctenontychius, 626 apicalis, 626 macrodus, 626 serratus, 626

Cuculloca cemygdalina, 395 angresta, 393 antiquo, 284 depressa, 394 IIardingi, 395 ovata, 284 sulcata, 511 trapezium, 395 unilateralis, 395

Cucullella, 283 antiqua, 284 coarctata, 284
Cucullella ovata, 284

Cupressocrines, 117 calyx, 117 impressus, 117

Cyatuatonia, 36 cornu, 109 costata, 109 Siluriensis, 36

Cratmocrinus, 76 geometricus, 77 pyriformis, 54 megosus, 55 tuberculatus, 53

CYATHOPHYLLID $\mathrm{E}, 27$ CYATHOPHYLLIN E, 27

Cyathophillum, 69 basaltiformis, 107 crespitosum, 69 ceratites, 70 dianthoides, 85 fungites, 91 helianthoides, 73 multiplex, 95 paracida, $\$ 6$ pentagonum, $7 \mathrm{I}$ pseudo-vermiculare, 86 subturbinatum, 28 turbinatum, 28 vermiculare, 73 vesiculosum, 71

Cratmopsis, 8 ? cornu-bovis, 90 cornu-copia, 90 ? eruca, 90 fungites, 91

Cybele, 156 sexcostatus, 157 verrucosa, 156

(Crcloceras,) 318 annulatum, 319 arcuoliratum, 319 bilineatum, 319 Flemingi, 569

Ibex, 319

rugosum, 573 striatulum? 406 subannulatum, 320 tenuiannulatum, 320 tracheale, 321 tubicinella, 406 undatum, 574

Cypricardia amygdalina, 278 cymbaformis, 275 deltoidea, 396 I impressa, 279 Murchisoni, 497 ?retusa, 278 solenoides, 269 
Cypricardia striato-lamellosus, 506

2. tricostata, 507

undata, 279

Cypricardites, 265,276

angustifrons, 267

modiolaris, 267

nasutus, 275

ovatus, 267

Cyprina Egertoni, 500

(Crrtia), 191

cuspidata, 426

heteroclita, 377

laminosa, 426

trapezoidalis, 196

Critoceias, 312

?bdellalites, 404

Gesneri, 570

multicameratum, 312

reticulatum, 405

subornatum, 405

tuberculatum, 570

Cyrtolites omatus, 310

CYSTIDEA, 61

CYSTIPHYLLIN E, 29

Cystipuyllum, 32

brevilamellatum, 32

Damnoniense, 71

vesiculosum, 71

Cythere? umbonata, 138

Cytheropsis Aldensis, Plate I. L.

Dalmannia, 160 affinis, 162

obtusi-caudatus, 161

Delthyris, 190 cardiospermiformis, 213 cyrtcena, 193

Dendrodes, 597 latus, $59 \mathrm{~s}$

Dendropora megastoma, 79

Dentaliug, 550 dentaloideum, 550

ingens, 550

ornatum, 550

DIPIYPTIXLLM, 87 gracile, 88 lateseptatum, 88

Dirlacantues, 584 crassispinus, 584 gibbus, 584 longispinus, 584 perarmatus, 585 striatus, 585

Dipleura, 167

Drplograrses, 7 . foliaceus, 7 folium, 7 mucronatus, 7 pristis, 8
Diplograpsts ramosus, 8 rectangularis, 8 ? sextans, 9

Duplopterax, 586 affinis, 586 Agassizii, 586 gracilis, 586 macrolepidotus, 587

Diplopterus, 586 macrocephalus, 587

Diplonthri, 142 triplicata, 142

Dipriacantros, 627 Stokesii, 627

Dipterus, 590 brachypygopterus, 592 macrolepidotus, 587 macropygopterus, 592 Valenciennesii, 592

DIscina, 190

bulla, 407

Morrisi, 190

nitida, 407

rugata, 190

? striata, 191

(Discites), 556

complanatus, 557

discus, 558

pusillus, 477

quadratus, 560

sulcatus, 561

trochlea, 561

Discophyllum, 42

Dithrrocaris, 181

Dolabra, 269

angusta, 393

Damnoniensis, 394

depressa, 394

elliptica, 269

Hardingi, 395

obtusa, 270

unilateralis, 395

Donax sulcatus, 495

DORSIBRANCHIATA, 128

Dysplanus centrotus, 173

EсCортоCIILE, 155

Sedgwickii, 155

(ECCYLIOMPHALUS, 301)

ECHINODERMATA, 51

EDMONDL, 499

compressa, 500

Egertoni, 500

Josepha, 500

Murchisoniana, 501

oblonga, 501

phascolina, 502

rudis, 502
EDsrondia

scalaris, 502

sulcata, 503

unioniformis, 503

Elasmobranchii, 575

Elasmopora, 48

Excrivurus, 158 punctatus, $15 \mathrm{~S}$

Excrutompiralus, 301 æqualis, $5+2$ cristatus, 542 Scoticus, 301

Endosiphonites, 401 carinatus, $40 \pm$ minutus, 404 $s p .402$

ENTOMOSTRACA, 134

Entomostracites punctatus, 158 Stokesii, 158

Epithyris, 408 elongata, 409 sufflata, 412

Erismacantilos, 628 Jonesii, 628

ESCHARID AE, 44

Edcaltptocrinus, 57 decorus, 58 polydactylus, 58

Euomphalus, 536

EuompHaLes, 297 bifrons, 541

Bronni, $5+1$

caly $x, 537$

carbonarius, 537

catillus, $53 \mathrm{~s}$

centrifugus, 297

clausus, $5 \pm 0$

cristatus, $5 \pm 2$

crotalostomus, 539

discors, 298

funatus, 298

lyratus, 298

nodosus, 540

pentangulatus, 540

pileopsideus, 540

pugilis, $5 \pm 1$

quadratus, 537

rugosus, 298

sculptus, 299

substriatus, 297

tricinctus, 299

triporcatus, 299

Euphemus, 30 s

EUPSAMMID E, 18

EURTterUs, 175

cephalaspis, 175

EUSMILIN ג, 36

Fafosites, 19 
Fatosites

alveolaris, 19

alveolaris, 20

aspera, 20

capillaris, 82

crassa, 20

fibrosa, 24

Gothlandica, 20, 80

Lycupodites, 24

multipora, 19

? oculata, 21

polymorpha, 68

ramosa, 67

septosus, 82

FAVOSITIN E, 19

Fenestella, 49

antiqua, 50

antiqua, 75

carinata, 113

formosa, 113

membranacea, 113

Milleri, 49

patula, 50

plebeia, 76, 114

polyporata, 114

prisca, 76

retiformis, 114

rigidula, 50

subantiqua, 50

undulata, 114

Fenestrellina, 49

Fistultrora, 11

decipiens, 11

minor, 79

Floscularia, 69

Flustra lanceolata, 47

Forbesid, 173

latifrons, 174

Stokesii, 174

GATTOTDEA, 579

GASTEROPODA, 288

Geocrimes, 56

Geoporites, 14 intermedia, 15

Lonsdalei, 15

Gervillia lumulata, 48

GLAUCONOME, 48 disticha, 49

Globulodus, 614

Globulus helicoides, 531

Glossodus, 629 marginatus, 629

Guyptocrints, 56 basalis; 57

Glyptolepis, 590 leptopterus, 590

Gomploceras, 321

Goniatites, 401
Goniatites Barbotanus, 563

crenistria, 567

diadema, 563

Gilbertsoni, 564

implicatus, 565

insignis, 401

reticulatus, 566

spirorbis, 567

striolatus, 563

vinctus, 401

Gorgonia antiqua, 114 infundibuliformis, 114

GORGONIAD $\mathrm{E}, 9$

Gramiysia, 280

cingulata, 280

var. triangulata, 280

var. obliqua, 280

extrasulcata, 281

rotundata, 281

Graptolites convolutus, 3

foliaceus, 7

latus, 4

lobiferus, 4

Ludensis, 4

millipeda, 5

mucronatus, 7

Murchisoni, 5

ramosus, 8

sagittarius, 5

Sedgwickii, 6

sextans, 9

spiralis, 3

tenuis, 6

GRAPTOLITID E, 3

Griffituides, 182

meso-tuberculatus, 182

Gryphites aculeatus, 465 speluncarius, 481

Grracantitus, 629 obliquus, 629

Grroptromids, 596 angustus, 596

diplopteroides, 597

HALIOTID AE, 290

HaLysites, 26 catenulatus, 26

HALYSITIN IE, 26

Harmodites, 27 parallelus, 84

HARPEDIN E, 143

Harpes megalops, 143

Harpes parvulus, Plate ], L.

HARPIDELIA, 143 megalops, 143

IIelicites catillus, 538

Heliopora pyriformis, 67

Helix cirriformis, 526

striata, 529
HELODUS, 630

cinctus, 617

denticulatus, 617

didymus, 630

lævissimus, 630

linearis, 617

mammillaris, 631

obliquus, 617

planus, 631

rudis, 631

turgidus, 632

HeMtimrRIS, 199

acuminata, 380

var. acuminata, 381, 438

var. mesogona, 381, 439

var. platyloba, 381, 438

var. pugnus, 381, 435

angulata, 439

angustifrons, 199

crispata, 200

cuboides, 381

Davidsoni, 200

depressa, 201

didyma, 201

diodonta, 201

flexistria, 439

hemisphærica 201

var. Scotica, 202

heteroptycha, 40

lacunosa, 202

Lewisii, 203

longa, 440

nasuta, 203

navicula, 204

nucula, 204

pentagona, 205

? pisum, 205

pleurodon, 382, 441

protracta, 382

reniformis, 441

rotunda, 205

sphæroidalis, 206

Stricklandi, 206

subclentata, 383

subundata, 207

upsilon, 207

Wilsoni, 207

Heterogangliata, 185

Heterophylia, 112

grandis, 112

ornata, 112

IIiatella sulcata, 507

Hipponyx, 290

Holopelida, 303

cancellata, 303

conica, 303

gracilior, 303

gregaria, 303

intermedia, 304 
Holorelua

monile, 304

obsoleta, 304

tenuicineta, 304

HoLoptychies, 593

Andersoni, 594

giganteus, 594

Hibberti, 612

Hopkinsi, 609

nobilissimus, 595

Portlocki, 612

princeps, 595

Sedgwickii, 595

Homacantirus, 632

macrodus, 632

microdus, 633

Homaloyotus, 167

bisulcatus, 168

cephalaspis, 175

Knightii, 168

Ludensis, 168

rudis, 168

Homothorax, 598

Hortulus, 324

giganteus, 324

Ibex, 324

Huronia, 312

HYDROIDA, 2

Hydrozoa, 2

Hypanthocrinites decorus, 58 .

Hypanthocrinus, 57

ICHTHYOCRINUS, 54 pyriformis, 54

ILLENLS, 171

Bowmani, 173

centrotus, 173

Darisii, 171

latus, 172

MIurchisoni, 172

Rosenbergi, 172

Inachus sulcatus, 297

Inoceramus vetustus, 482

ISEDROLOTILA, 265

Isocardia oblonga, 510 unioniformis, 503

Isocrinus, 53

Isorluynchus, 212

ISOTELUS, 169

affinis, 169

gigas, 169

laticostatus, 170

planus, 169

Powisii, 169

Powisii, 170

tyrannus, 171

Jania baccillaria, 81 crassa, 85
Keratophytes retiformis, 114

LAMELLIBRANCHJATA, 256

Leda Vinti, 513

LEPIDOIDEA, 605

LEPTACAXTIUU, 633

? junceus, 633

Jenkinsoni, 633

LEPT ENA, 232

alternata, 233

analoga, 389, 453

var. distorta, 453

var. multirugata, 453

anomala, 473

antiquata, 241

arachnoidea, 385

cancrini, 457

caperata, 388

caperata, 388

comata, 455

compressa, 242

corrugata, 233

crassistria, 454

crenistria, 450

cylindrica, 450

deltoidea, 234

var. undata, 234

depressa, 248

depressa, 248

distorta, 389

duplicata, 240

euglypha, 243

excavata, 457

? filosa, 243

fragaria, $3 \mathrm{SS}$

funiculata, 244

gigas, 386

Goldfussi, 458

grandis, 244

Hardrensis, 454

Kellyi, 45I

Irevigata, 235

lata, 249

lata, $2 \pm 9$

lepisma, 235, 240

membranacea, 388

? minima, 235

Morrisiana, 457

nobilis, 386

nodulos $a$, 389

Ouralensis, 236

papilionacea, 455

parva, 458

pecten, 245

pelargonata, 452

polita, 456

prcelonga, 390

quinquecostata, 236

rugosa, 248

\section{LEPT TINA}

semiovalis, 231

senilis, 452

sericea, 237

var. rhombica, 239

var. spinangula, 239

simulans, 246

sinuata, 453

sordida, 386

spiriferoides, 246

sub-aculeata, 388

subminima, 456

tenuicincta, 239

tenuissimestriata, 239

tenuistriata, 248

transversalis, 240

umbraculun, 387

ungula, 249

Leptonalosia, 387

(LePTAGONIA,) 247

analoga, 389, 453

depressa, 248

sinuata, 453

ungula, 249

LEPTODOMUS, 277

amygdalinus, 278

constrictus, 396

costellatus, 508

globulosus, 278

impressus, 279

truncatus, 279

undatus, 279

Licris, 150

(Bucklandi,) 151

nodulosus, 151

\{propinqua? 150

$\{$ sub-propinqua, PI. 1,F.note $\}$

Lima Valdaica, 473

Limaria, 21

clathrata, 22

LINGULA, 250

attenuata, 251

cornea, 251

Credneri, 474

curta, 251

Davisi, 252

elliptica, 475

granulata, 252

lata, 253

Iatior, 475

Lewisii, 253

longissima, 253

minima, 251

obtusa, 251

ovata, 254

squamiformis, 475

tenuigranulata, 254

LINGULID $\approx$ E, 250

Lithodendron fasciculatum, 108 
Lithodendron pauciradialis, 108 sexdecimale, 109

Litnodomus, 493 Jenkinsoni, 493

Lithostrotion, 34 emarciatum, 103 floriforme, 103 Lonsdalei, 35

LrTORINA, 305 biserialis, 535 corallii, 305 octavia, 305 undifera, 306

Lituites, 323 anguiformis, 323 articulatus, 323 cornu-arietis, 323 giganters, 324 Ibex, 321 planorbiformis, 324

LoNSDaleta, 104 crassiconus, 104 duplicatus, 105 rugosa, 105 stylastrxiformis, 106

Loxoceras Breyni, 567 laterale, 572 Sowerbyi, 573

LOTONEMIA, 302, 544 elegans, 302 fasciata, 545 Geinitziana, 545 impendens, 545 loevigata, 546 nexilis, 399 rugiferib, 545 scalaroidea, 546 tenuistria, 546 tumida, 546

Lucina bulla, 271 minima, 497

LYMNIADIAD E, 135

LYRODESMA, 272 planá? 272

Maclureta, 300 macromphala, 300 magna, 300

Macrocinues, 398,547 acutus, 547 brevispiratus, 547 curvilineus, 548 imbricatus, 399 limnxiformis, 548 Michotianus, 548 subimbricatus, 399 sigmilineus, 549 ? spiratus, 549 symmetricus, 549
Macrocimlus ventricosus, 399

Macrodon, 510 striatus, 511

MACROTRACHIA, 518

Mactra? depressa, 495

MADREPHYLLACE. $\mathrm{E}, 18$

Madrepora ananas, 35 organum, 37 turbinata, 28

MADREPORACEA, 13

Madreporites duplicatus, 105 floriforme, 103 interstinctus, 15

Marsupiocrinus, 54 colatus, 54

(MLartinia), 192 decora, 427 elliptica, 427 imbricata, 429

lineata, 429

rhomboidalis, 430

similis, 430 symmetrica, 431

Urei, 377

Megalichthys Hibberti, 610, 612

Melania rugifera, 545 scalaroidea, 546 tumida, 546

Meleagrina leevigata, 482 pulchella, 483 rigida, 393

Metoptoma, 523 elliptica, 523

Michelinea, 80 glomerata, 80 grandis, $8 \mathbf{l}$

Mierodon? 270

Iillepora repens, 21

MILLEPORID E, 19

Modiola, 492

acuminata, 492

antiqua, 266, 267

expansa, 267

Nilsoni, 267

I semisulcata, 275

Modiolopsis, 265

? antiqua? 266

complanata, 266

expansa, 267

inflata, 266

modiolaris, 267

nasuta, 275

Nilsoni, 267

platyphylla, 268

postlineata, 268

solenoides, 269

MOLLUSCA, 185

classes of, 185
Molossus, 312

Monotis speluncarius, 481 sitb-radiata, 392

Murciisonia, 292 angulata, 527,532 angulata, 531 argustata, 292 cancellatula, 292 cingulata, 293 dispar, 531 gyrogonia, 293 Lloydi, 293 pulchra, $29 \pm$ quadricarinata, 531 simplex, 294 sulcata, 532 torquata, 294 Verneuilana, 532 var. Kendalensis, 532

Mya rotundata, 281

Mralina, 491 acuminata, 492 squamosa, 492

MYID E, 518.

Mrophoria, 494 carbonaria, 495 depressa, 495 obliqua, 496 obscura, 496 rotundata, 497

Mrrianites, 129 Macleayi, 129 tenuis, 130

MYRIAPORIDA, 48

MYTILID E, 265

IIytilites retroflexus, 362

Mytilus ceratophagus, 490 gradatus, 267

Hausmanni, 492 platyphyllus, 268 septifer, 492 squamosus, 492 striatus, 473,511 unguiculatus, 265

Natica ampliata, 543 elongata, 543 glaucinoides, 302 MI Coyana, 549 plicistria, 543 variata, 544

NATICID E, 301

Naticodon, 543

NATICOPSIS, 301 ampliata, 543 glaucinoides, 302 plicistria, $5 \pm 3$ spirata, 544 variata, 544 
NAUTILID E, 311

NAUTILT'S, 550

bicarinatus, 560

bilobatus, 556

bistrialis, 558

cariniferus, 557

clitellarius, 556

complanatus, 557

coronatus, 557

costato-coronatus, $55 \mathrm{~s}$

discus, 558

dorsatus, 561

globatus, 558

hiulcus, 553

ingens, 559

Luidi, 559

oxystomus, 560

pentagonus, 559

primcevus, $32 \pm$

quadratus, 560

sphcericus, 566

subsulcatus, 560

sulcatus, 561

sulcifer, 561

trochlea, 561

tuberculatus, 562

tuberosus, 562

Verneuilianus, 560

Wrighti, 558

Nebulipora, 22

explanata, 23

lens, 23

papillata, 24

Nematoneura, 51

NEMATOPHYLLIN E, 33

Neslatophrluum, 97

arachnoideum, 97

clisioides, 98

decipiens, 99

minus, 99

Nesertites, 128

Olivanti, $12 \mathrm{~S}$

Nemoptery $x$ mandibularis, 608

Nereites, 128

Cambrensis, 129

Sedgwickii, 129

Nerita haliotis, 290

spirata, $5 \pm 4$

Nuculd, 285

Anglica, 285

? attenuata, 511

cingulata, 280

clarata, 512

claviformis, 511

coarctata, 284

gibbosa, 512

Krachtæe, 397

levata, 285

luciniformis, 512
Nrote.

ovalis, 285

pullastriformis, 397

speluncaria, 513

tumida, 512

Vinti, 513

NUCULID_E, 285

Nuculites planulatus, 273 scitula, 273

Nuculites post striatus, 286

Nudibrachiata, 2

ODoxtochile, 160

caudata, 160

longicaudata, 161

obtusicaudata, 161

truncatocaudata, 162

Odontopleura, 152

OGrGia, 148

Buchii, 145

radians, 149

OGYGINE, 143

Oxcmos, 577 tenuistriatus, 577

(Ophiura Salteri, 60

OracantiUUs, 634 Milleri, 634

Orbicula, 190 cincta, 407

Morrisi, 190

nitida, 407

rugata, 190

striata, 191

ORBICULID $\mathbb{E}, 185$

ORBICULOIDEA, 189 implicata, 189

Ormoceras, 312

Orthambonites parva, 221

OrTuIs, 212

Actonix, 213

alternata, 217

antiquata, 241

arcuata, 384

avellana, 221

biloba, 213

bilobata, 230

callactis, 214

calligramma, 214

var, calliptycha, 215

canalis, 216

compressa, 242

confinis, 215

connivens, 447

corrugata, 233

crispa, 216

cylindrica, 450

elegantula, 216

excavata, 457

expansa, 217
OrTHIS

filosa, 243

flabellulum, 218

funiculata, 244

gibbera, 447

grandis, 244

Hardrensis, 454

Hirnantensis, 219

Lybrida, 220

inflata, 223

interlineata, 384

Kellyi, 451

lata, 239

lunata, 220

Michelini, 448

orbicularis, 220

parva, 221

pecten, 217,245

persarmentosa, 384

plicata, 222

porcata, 223

proteusa, 224

quinquecostata, 236

resupinata, 449

retrorsistria, 224

reversa, 225

rigida, 226

rustica, 226

sagittifera, 227

sarmentosa, 227

Sharpei, 450

striatula, 447

tenuissimestriata, 239

testudinaria, 228

turgida, 229

undata, 234

Vespertilio, 230

virgata, 214, 222

ORTHISID E, 211

ORTHISINA, 231

ascendens, 231

Scotica, 232

Orthoceras, 312

angulatum, 313

annulatum, 319

annulatum, 574

arcuoliratum, 319

articulatum, 319

baculiforme, 313

hilineatum, 319

Breyni, 567

Brighti, 313

bullatum, 313

calamiteus, 406

? centrale, 314

cordiforme, 568

cornu-raccinum, 568

cylindraceum, 560

dactyliophorum, 574 


\section{ORTHOCERAS}

dentaloideum, 550

dimidiatum, 314

distans, 315

ellipticum, 321

filosum, 314

Flemingi, 569

fusiforme, 569

Gesneri, 570

giganteum, 571

Ibex, 319

Ibex, 406

imbricatum, 315

inequiseptum, 571

laqueatum, 315

laterale, 572

(lineolatum), 574

Ludense, 315

Mocktreense, 315

ovale, 572

paradoxicum, 573

perelegans, 320

politum, 316

primærum, 316

pyriforme, 321

pyriforme, 322

rugosum, 573

semipartitum, 316

Sowerbyi, 573

striatulum? 406

striatulum, 406

striatum, 405

striatum, 313

subannulatum, 320

subdimidiatum, 314

subimbricatum, 572

subundulatum, 317

tenuiannulatum, 320

tenuicinctum, 317

tenuistriatum, 317

tenuistriatum, 405

tracheale, 321

tubicinella, 406

undatum, 574

undulatum, 319, 573

vagans, 318

? ventricosum, 318

virgatum, 313

Orthoceratites striatus, 405

subannulatus, 320

substriatus, 313

Ortionotus, 274

cingulata, 280

cymbrformis, 274

extrasulcata, 281

inornata, 277

nasutus, 275

semisulcatus, 275

triangulata, 280
Orthotrix, 387

excavatus, 457

lamellosus, 457

Osteolepis, 587

arenatus, 587

brevis, 587

macrolepidotus, 588

major, 588

microlepidotus, 588

OSTEOPLAX, 613

erosus, 613

Ostroea \& pusilla, 492

? Tayloriana, 492

Pachyodon agrestis, 515

amygdala, 515

antiques, 514

Embletoni, 515

exoletus, 514

lateralis, 514

levedensis, 514

subtriangularis, 515

transversus, 514

turgidus, 516

Pecrlodus, 638

aliformis, 638

foveolatus, 639

Jonesii, 639

obliquus, 640

parallelus, 640

sublæris, 640

transversus, 639

Paloeadoe, 138

Palsochorda major, Plate 1, A. minor, Plate 1, A.

Paleoniscus, 605 comptus, 606

elegans, 605

Freieslebeni, 606

glaphyrus, 607

macropthalmus, 607

megacephalus, 606

Palieoroma, 14

expatiata, 14

? farosa, 15

interstincta, I5

var. subtubulata, 16

megastoma, 16

potalliformis, 17

pyriformis, 67

subtilis, 17

tubulata, 18

Palceothrissum, 605

elegans, 605

Freieslebeni, 606

macrocephalum, 606

magnum, 606

Palastraea carbonaria, 111

PALLIOBRANCHIATA, 185
PALUDINID 死, 302

Pamphractus, 598

PARADOXINE, 152

Patella elliptica, 523

implicata, 189

Pectex, 476

Bathus, 478

coelatus, 483

cancellatulus, 483

concavus, 481

concentrico-striatus, 484

conoideus, 485

deornatus, 478

elongatus, 477

? fimbriatus, 477

flexrosus, 485

granosus, 392, 486

illegalis, 486

incrassatus, 487

intercostatus, $\mathbf{4 8 7}$

interstitialis, 487

mactatus, 487

papyraceus, 488

pera, 488

plicatus, 486

pusillus, 477

segregatus, 489

Sowerbyi, 478

subelongatus, 477

transversus, 393

Pecten, 478

PECTINIBRANCHIATA, 289

PECTINID无, 476

Penniretepora, 48 Lonsdalei, 49

Pentamerus, 208 Aylesfordi, 211

brevirostris, 384

carbonarius, 442

galeatus, 208

? globosus, 208

Knighti, 209

lævis, 208

lens, 209

microcamerus, 210

oblongus, 211

undatus, 211

Pentremites, 123

campanulatus, 123

Derbiensis, 124

ellipticus, 124

Periechocrinus, 56

costatus, 56

moniliformis, 56

PERISCHOECHINID E, 124

Petalodus, 635

acuminatus, 635

dentatus, 620

Hastingsii, 635 
Petalodus

lovissimus, 635

psittacinus, 636

radicans, $6+1$

rectus, 636

rhombus, 635

sagittatus, 636

truncatus, 618

Petraia, 39

xequisulcata, 39

bina, 40

Celtica, 74

elongata, 40

gigas, 74

rugosa, 40

subduplicata, 40

uniserialis, 41

Petrodus, 637

patelliformis, 637

Pricors, 159

alifrons, 159

apiculatus, 162

Downingixe, 160

felinus, $16 \pm$

truncato-caudatus, 162

Phanerotinus, 301 cristatus, 542

Phasianella ventricosa, 399

PHLLLIPSIA, 183 gemmulifera, 183

Jonesii, 183

seminifera, 183

Pholadomya Visetensis, 507

Phragmoceras, 322

arcuatum, 322

intermedium, 322

ventricosum, 322

PHYLLOPODA, 134

Pitsonenos, 638

arcuatus, 638

subteres, 638

Pileopsis, 290

angustus, 523

neritoides, 523

vetustus ? 523

PInNa, 498

costata, 498

flabelliformis, 498

flexicostata, 499

inflata, 473

spatula, 499

Pinnites flabelliformis, 498 nudus, 498

Pisces, 575

Placoida, 575

Pracoderarata, 598

Plagiostoma, 576

Planorbis cequalis, 542

Plasmopora, 14
Puatrcrinds, 118

antheliontes, 119

coronatus, 119

ellipticus, 119

laevis, 119

megastylus, 119

mucronatus, 118

pileatus, 119

vesiculosus, 119

Platysciisua, 533

glabrata, 533

helicoides, 534

Jamesi, $53 \pm$

oroidea, 535

tiara, 535

Platysomus, 614

parvus, 614

striatus, 614

PLEUROCONCHA, 257

Pleurocrinus, 118

Pleuronectia, 478

Pleurophorus, 273 costatus, 497

Pleurorhynchus elongatus, 517 $\operatorname{minax}, 516$

Pleurotomaria, 290

altavittata ? 524

angulata, 525

antrina, 525

aspera, 398

callosa, 525

canaliculata, 530

catenata, 533

cirriformis, $\mathbf{5 2 6}$

concentrica, 530

conica, 526

consobrina, 527

crenulata, 291

decipiens, 527

decussata, 526

erosa, 528

glabrata, 533

Griffithi, 528

helicinoides, 529

imbricata, 398

interstrialis, 398

lenticularis, 291

Lloydi, 293

monilifera, 530

ovoidea, 535

Permiana, 525

Sedguickiana, 525

striata, 529

sub-monilifera, 530

- Tunstallensis, 525

turrita, 291

undata, 292

undulata, 530

Verneuili, 525
Pleurotomaria

vittata, 526

Yranni, 530

PCECILOPODA, 174

Polycoelia, 91

Polypiaria, 2

Polypora, 115 dendroides, 115 verrucosa, 116

Pouyrhizodus, 611 magnus, $6+1$ pusillus, 642

Polytremania, 533 catenata, 533

POLYZOA, 44

Porambonites, 212 alta, 212

dentatus, 192

elevata, 212

intercedens, 212

lata, 212

latissima, 212

parva, 212

pentagona, 212

plana, 212

rotunda, 212

subrecta, 212

trigona, 212

Porcellia, 555

loevigata 542

Puzosi, 556

Porites expatiata, 14

megustoma, 16

petalliformis, 17

pyriformis, 15, 67

tubulata, 18

Portlockin, 162

? apiculata, 162

granulata, 177

latifrons 177

Stokesii, 163

Posidonia, 521

Becheri, 521

lateralis, 522

tuberculata, 522

Posidonomya, 521

(Poterioceras), 321

cordiforme, 568

\& cornu-vaccinum, $56 \mathrm{~s}$

ellipticum, 321

fusiforme, 569

pyriforme, 322

Poteriocrinus, 116

granulosus, 116

nuciformis, 117

Prionotus convolutus, 3

folium, 7

pristis, 8

sagittarius, 5

4 P 2 
Pristicladodus, 642 dentatus, 642

Goughi, $6 \pm 3$

Prodveta, 390

aculeata, 458

analoga, 389

antiquatus, 471

aurita, $46 \pm$

calva, 465

cancrini, 457

carbonarius, 472

Christiani, 390

concinna, 467

Cora, 459

corrugata, 459

costata, 460

costellata, 461

crassa, 463

depressus, 248

Edelburgensis, 468

elegans, 460

fimbriata, 461

Flemingi, 461

fexistria, 466

gigantea, 463

Goldfussi, 458

granulosa, 472

hemisphærica, 464

Hoppei, 465

horrida, 465

Keyserlingiana, 466

latissim $\alpha, 463$

laxispina, 458

limiformis, 473

lobatus, 461, 462

longispinus, 461, 462

margaritacea, 466

? marginalis, 467

Martini, 467

mesoloba, 468

papillatus, 472

pectinoides, 466

plicatilis, 468

prolonga, 390

pugilis, 461,462

punctata, 469

pustulosa, 469

pyxidiformis, 462

quincuncialis, 470

scabricula, 470

Scotica, 463

semireticulata, 471

setosa, 472

spinulosa, 472

spinulosa, 458

striata, 473

sulcatus, 461, 462

tenuistriatus, 459

tortilis, 474
Producta

tubarius, 461

tubuliferus, 465

undatus, 474

PRODUCTID $\mathbb{E}, 389$

Pronites adscendens, 231

Propora, 14

Protaster, 60 Sedgwickii, 60

Protovirgularia, 10 dichotoma, 10

Psammodus, 643 canaliculatus, 643 cornutus, 643 porosus, $6 \pm 4$ rugosus, 644

Pseddocrania, 187 divaricata, 187

Ptericitrits, 598 cancriformis, 599

latus, 600 oblongus, 600 productus, 600 testudinarius, 600

Pterlatea, 258

?asperula, 259

Boydi, 259

demissa, 260

hians, 260

? informis, 479

lavigata, 479

lineata, 261

lunulata, 480

megaloba, 261

modiolaris, 267

pleuroptera, 261

retroflexa, 262

Sowerbyi, 263

subfalcata, 263

tenuistriata, 263

Pteronites, 391 persulcatus, 480 subradiatus, 392

PTEROPODA, 286

Pterygotus leptodactylus, 175

Ptychomphalus, 291

PTylodictya, 45 acuta, 45 costellata, 46 explanata, 46 fucoides, 47 lanceolata, 47 sublanceolata, 47

Pullastra antiqua, 397 complanata, 266 loevis, 271

Pycnodonti, 614

Pygopterus, 608 mandibularis, $60 \mathrm{~S}$
Pygopteres

Scoticus, 608

sculptus, 608

PYRAMIDELLID E, 302

Pyritonema fasciculus, 10

RADIATA, 1

classes of, 1

Retepora, 48

antiqua, 75

Alustracea, 114

Hisingeri, 48

membranacea, 113

polyporata, 114

prisca, 76

undulata, 114

virgulacea, 115

Reteporina, 49

RnIzoDes, 611 gracilis, 611

Hibberti, 612

RHYNCHONELLID E, 199

Rostellaria angulata, 531

RUDISTES, 186

Sanguinolaria concentrica, 503

? elliptica, 397

oblonga, 501

phascolina, 502

sulcata, 503

Sangulnolites, 276

anguliferus, 276

clava, 504

decipiens, 277

inornatus, 277

Iridinoides, 504

lunulatus, 505

striato-lamellosus, 506

sub-carinatus, 506

sulcatus, 507

tricostatus, 507

variabilis, 508

Sarcinula, 36

organum, 37

Phillipsii, 110

placenta, 110

tuberosa, 110

SAURODIPTERIDA, 585

SAURoldir, 608

Sauropsis Scoticus, 608

Schizodus, $49+$

elliptica, 189

obscurus, 496

Rossicus, 497

rotundatus, 497

Schizotreta, 189

truncatus, 497

SeMinula, 409

elongata, 409 
SEMINULA

ficus, 409

hastata, 409

juvenis, 410

pisum, 412

sacculus, 411

seminula, 412

sufflata, 412

virgoides, 413

? Serpularia, 301

SERPULIN E, 131

SERPUlites, 132

carbonarius, 181

dispar, 132

longissimus, 132

Sertulariens, 2

SipHoNodendroN, 107

aggregatum, 108

fasciculatum, 108

sexdecimale, 109

Siphonophyllia, 28 cylindrica, 89

SipHoNotreTA, 188

Anglica, 188 micula, 188

Solemya, 518

SOLENIMY A, 518

?primera, 519

Puzosiana, 519

Sparsispongia, 66

Sphorexochus clavifrons, 151 juvenis, $15 \pm$

Sphæronites tesselatus, 77 testudinarins, 62

Spirifera, 191

afjinis, 379

alata, 414

ambiguus, 432

arachnoidea, 385

attenuatus, 422

biforata, 192

var. biforata, 192

var. dentata, 192

var. fissicostata, 193

var. Lynx, 192

calcarata, 376

clathrata, 422

connivens, 447

costata, 376

crassa, 415

crenistria, 450

crispa, 193

crispus, 417

cristata, 415

cuspidata, 426

cyrtxna, 193

decora, 427

dentata, 192

disjuncta, 376

\section{SPIRIFERA}

duplicicosta, 415

elliptica, 427

expansa, 433

fasciculata, 416

fasciger, 415

filiaria, 448

fimbriata, 433

Fischerianus, 423

gigantea, 376

glaber, 428

glabra, 428

var. glabra, 428

var. oblata, 428

var, obtusa, 428

glabristria, 434

globularis, 434

grandeva, 375

grandicostata, 417

hemisphorica, 419

heteroclita, 377

imbricata, 429

incrassatus, 423

insculpta, 417

insularis, 194

2 interlineatus, 193

Koninckianus, 417

lsevicosta, 375

loevis, 210

laminosa, 426

lineata, 429

lineata, 429

lineatus (var.) 427

Lynx, 192

minima? 418

nucleolus, 412

oblatus, 428

obtusus, 428

octoplicata, 418

octoplicatus, 195

Ornithorhyncha, 418

ovalis, 419

papilionacea, 455

parcicostata, 420

Pentlandi, 423

percrassa, 194

pinguis, 419

pinguis, 420

$?$ pisum, 205

planicostata, 415

- plebia, 430

plicatus, 195

Q plicatus, 222

porambonites, 212

radiata, 195

recurvata, 421

rhomboidalis, 430

rhomboidea, 423

de Roissyi, 433
SPIRIFERA

rotundatus, 419,423

senilis, 452

sexradialis, 421

similis, 430

sinuatus, 213

speciosa, 376

Stranguaysi, 423

striata, 422

striatus, 423

subconica, 377

subrotundata, 423

sub-spuria, 195

symmetrica, 431

trapezoidalis, 196

trigonalis, $\mathbf{4 2 3}$

var, bisulcata, 424

var. semicircularis, 425

var. trigonalis, 423

undulatus, 414

Urei, 377

Urei, 377

Verneuili, 376

SPIRIFERID E, 191

Spirigera, 196

SPIRIGERINA, 197

? cuneata, 197

desquamata, 378

Mantix, 437

marginalis, 197

? radialis, 438

reticularis, 198, 379

var. aspera, 379

SPIRORBIs, 131

tenuis, 131

Sroxdyloboles, 255

craniolaris, 255

Spondylus Goldfussi, 458

Spongarium, 42

xquistriatum, 42

Edwardsi, 42

interlineatum, 43

interruptum, 43

SQUALID $x, 576$

StaurocepmaLUs, 152

Murchisoni, 153

Steganodyctium Carteri, Plate 2, A.

Cornubicum, PI. 2, A.

Stexorora, 24

fibrosa, 24

?granulosa, 26

inflata, 82

tumida, 82

Stictopora, 45

acuta, 45

costellata, 46

explanata, 46

fucoides, 47

Straparollus, 536 
STrAPAROLLUS

acutus, 537

? calyx, 537

carbonarius, 537

? catillus, $53 \mathrm{~S}$

costellatus, 538

? crotalostomus, 539

Dionysii, 539

nodosus, 540

pentangulatus, 540

pileopsideus, 540

pugilis, 541

tabulatus, 541

Streblopteria, 482

lavigata, 482

pulchella, 483

STrephodes, 29

Craigensis, 30

gracilis, 72

helianthoides, 73

multilamellatum, 93

pseudo-ceratites, 30

trochiformis, 31

vermicularis, 73

vermiculoides, 31

StreptolasMa, 39

Streptorhynchus pelargonatus, 452

Stringoceptialus, 383

brevirostris, 384

giganteus, 383

Stromatopora, 12

concentrica, 12

concentrica, 65

polymorpha, 65

striatella, 12

placenta, 66

ramosa, 67

verticillata, 67

STrombodes, 34

conaxis, 102

emarciatum, 103

floriforme, 103

helianthoides, 73

Wenlockensis, 34

Strombodes, 29

(Strophalosia), 387

cancrini, 457

caperata, 388

excavata, 457

Goldfiussi, 458

Morrisiana, 457

parva, 458

subaculeata, 388

(Strophomena), 241

antiquata, 241

arachnoidea, 385

compressa, 242

crenistria, 450

cylindrica, 450
Strophomera

euglypha, 243

filosa, 243

funiculata, 244

gigas, 386

grandis, 214

Kellyi, 451

nobilis, 386

pecten, 245

pelargonata, 452

senilis, 452

simulans, 246

? sordida, 386

spiriferoides, 246

umbraculum, 387

Strlastrade, 107

basaltiformis, 107

irregularis, 101

STYlatis, 100

Flemingii, 100

irregularis, 101

major, 101

SYNBatmocrinus, 118 conicus, 118

SYMOCLADIA, 114 virgulacea, 115

Syringopora, 27

bifurcata, 27

catenata, 83

geniculata, 83

ramulosa, 83

reticulata, 84

TAXOCRINUs, 53

? Orbignyi, 53

tuberculatus, 53

Tellinites affinis, 286

TelinNomya, 274

lingulicomes, 274

Tentaculifera, 307

Textaculites, 63 annulatus, 63

ornatus, 63

scalaris, 63

tenuis, 64

Terebra arcuata, 399 nexilis, 399

Terebratula affinis, 198 ambigua, 432

aspera, 379

bidentata, 201

borealis, 201

cordiformis, 380

corymbosa, 443

crispata, 200

crineata, 197

decemplicata, 201

de-Roissyi, 436, 443

didyma, 201
Terebratula diodonta, 201

excavata, 439

explanata, 198

flexistria, 439

fusiformis, 413

globulina, 443

hastata, 409

hastiformis, 413

imbricata, 197, 429

insularis, 194

juvenis, 410

lacunosa, 201

locvicosta, 375

Levisii, 202

lineata, 429

Mantioe, 437

marginalis, 197

mesogona, 380

Michelini, 448

navicula, 204

nucula, 204

pectiniferc, 436

pentagona, 205

planosulcata, 436

platyloba, 380

pleurodon, 382

prisca, 198

pulchra, 204

radialis, 438

reniformis, 441

resupinata, 449

sacculus, 411

Schlotheimi, 445

seminula, 412

sinuata, 213

speciosa, 376

sphorrica, 200

squamigera, 437

Stricklandi, 206

sulcirostris, 446

upsilon, 206

ventilabrum, 446

vesicularis, 412

Wilsoni, 207

TEREBRATULID $\mathrm{E}, 40 \mathrm{~S}$

Terebratulites alatus, 414

biforatus, 192

complanatus, 409

cristatus, 415

elongatus, 409

lacunosus, 445

latus, 409

ostiolatus, 375

pelargonatus, 452

Qualeni, 400

suflatus, 412

umbraculum, 387

TETRABRANCHIATA, 307

Tetragonis, 62 
Tetragonis

Danbyi, 62

Tetraspis, 146

fimbriatus, 146

seticornis, 147

TIIECA, 287

Forbesii, 287

Tuecia, 14

Thelodus parridens, 576

Trachyderma, 132

? lævis, 133

squamosa, 133

Trigonoceras paradoxicum, 573

Trigonotreta, 414

cristata, 414

speciosa, 376

undulata, 414

TRILOBITAD E, 138

Trimerocepilalus, 178 lævis, 178

Trimerus, 167

Trinodus, 141 agnostiformis, 141 tardus? 142

Trinccleus, 144 Caractaci, 144 fimbriatus, 146 gibbifrons, 145 latus, 145 loevis, 178 nudus, 148 ? radiatus, 146

TrLPLOPTERUS, 589 Pollexfeni, 589

Tripterus, 589 Pollexfeni, 589

Trocholites, 323 anguiformis, 323 antrinus, 525 helicinus, 536 planorbiformis, 324

Trocirunts, 151, 152
Trochuros nodulosus, 151

Trocucs, 296 acutus, 525 crelatulus, 296 constrictus, 296 belicites, 297 lenticularis, 291 Moorei, 297 sub-helicinoides, 529 Yvanni, 530

TUBICOLA, 131

Tubipora catenulatus, 26 TUBIPORID无, 9

Tubiporites catenatus, 83,84 Tubuliclida, 24

TUNICATA, 185

Turbinites centrifugus, 297

Turbinolia Celtica, 74 fungites, 91 turbinata, 28

TURBINOLID E, 38

Turbinolopsis bina, 40 Celtica, 74

elongata, 40 pauciradialis, 74 regosa, 40

Tеrbo, 295

? biserialis, 535 carinatus, 305 corallii, 305 crebristria, 295 ? helicinus, 536 Mancuniensis, 530 Meyeri, 536 minutus, 536 octavia, 305 semisulcatus, 535 spiratus, 549 Taylorianus, 536 Thompsonianus, 536 tiara, 535
Turbo

Tunstallensis, 536

? Williamsi, 296

Turritella cancellata, 303 conica, 303

gregaria, 303

obsoleta, 304

? tenuistria, 546

Ulima Phillipsiana, 546

UNCITES, 380

læris, 380

UNCITID E, 380

Unio acutus, 514 aquilinus, 514

robusta, 515

sub-constricta, 515

UNIONID $\approx, 513$

URASTER, 59

? hirudo, 59

primævus, 60

Ruthreni, 59

Uropteryx striatus, 614

Venerupis scalaris, 502

Venus carbonaria, 495

VERTEBRATA, 575

Vioa prisca, 260

ZETHUS, 156 atractopyge, 156 sexcostatus, 157 rariolaris, 157

ZOANTHARIA, 13

Zoantharia aporosa, 18 migosa, 18 tabulata, 18

Zoocorallia-octactinia. 9 ZOOPHYTA, 1

Zoophyta helianthoidea, 13 ZOOPHY'TARIA, 9 
CAMBRIDGE:

PRINTED AT THE UNIVERSITY PRESS. 


\title{
APPENDIX A.
}

\author{
Descriptions of a few species from Wales and Westmoreland, referred to in the foregoing Work, \\ by John William Salter, F.G.S., A.L.S.
}

IT requires some apology on my part for introducing these few notes into the large work on which my friend Professor MeCoy has expended so much time and labour, and in which I have been unwillingly prevented taking the share I originally intended, both with regard to figures and descriptions.

The fruits of Professor Sedgwick's labours in Westmoreland, together with the contributions of his friends from the same quarter, added to his own Collections in North Wales, were examined and their localities catalogued in 1843 and 1844 , and the summer-months of those years were most pleasantly spent with him in Wales, adding to his collections, and recording the localities, on the spot, of all the Silurian species we met with in that country.

But sulssequent engagements prevented me from working out the materials thus brought together, further than as regards the Crustacea and a few of the Mollusca; and as Professor $\mathbf{M}^{\circ}$ Coy has fully described all the species, old as well as new, it is only necessary for me to give the characters on which I rely for the establishment of the few species to which my name is attached.

February, 1852.

\section{RADIATA.}

Áttnocrinus pulcher, Sp. Nov. Ref. Plate 1. D. fig. 3.

Stems very long: below smooth and cylindrical, witl 1 a single row of about six tubercles round each joint,-near the pelvis without tubercles, but annulated, with a few rings; prominent, the intermediate ones being narrow. Pelvis small, the plates with six large deep pits round each; arms ten, each twice branched, about twice and a half the length of the pelvis.

The great length of the stems, which are frequently fifteen or sixteen inches long, and beautifully tuberculate, characterise this species; the stem is even and cylindrical in the lower part, with but few tubercles on each ring; the tubercles become more numerous as the stem is followed upwards; but for some inches below the pelvis the rings become alternately more prominent than the others, and the tubercles are quite lost. The arms are close jointed, and clothed with tentacles from their first bifurcation.

So perfectly are the casts made in the flagstone, that it lias been rendered possible to figure the specimens as if in relief; and the deposition of the mud has been so tranquil, that the arms have not been disturbed in position, each branch lying at an equal distance from its fellow on either side.

Loc.-Wenlock shale of Nant-gwrhwyd-uchaf, S. of Llangollen.

Encrinite fragments were found throughout the whole of the N. Welch strata by Prof. Sedgwick and myself, forming a large part of the Bala limestone in certain localities. In the Caradoc sandstone and Upper Silurians of Denbighshire they are common where the strata are sandy, but rare where composed, as in the above instance, of fine shales.

\section{ARTICULATA.}

Serpulites dispar, $S p . N^{\top}$ ov. Pl. 1. D. fig. 11, 12.

Sp. Ch.-Flat, membraneous, rapidly tapering, curved, finely corrugated obliquely or transversely; the edges thick, rounded.

This species shews a great disparity between the edges and the surface; such a difference could not be accounted for by pressure, for the calcareous or rather corneous matter seems all collected on the thick edge, leaving the rest but thin membrane.

S. longissimus is distinguished by the uniform shelly texture of its laminated tube; the laminæ are so much thickened on the two lateral edges as to form solid bars of shell along them; it is always compressed, and there is every reason to believe this is the natural state, not the result of pressure. It often attains the length of eighteen or twenty-four inches, and, con- trary to the usual habit of mud-burrowing Annelides, often assumes a subspiral form.

Loc,-Ludlow rock, Kendal; in several places.

Cornulites, Schlotheim.

I only mention this genus, because it, as well as Tentaculites, has been referred to various families. Dr Volborth has supposed Cornulites to belong to the Cystidea, as the stems of Echino. encrinites. It is true they much resemble them, and to heighten this resemblance, the conical stems of Ech. striatus are striated lengthwise, and have their lower edges imbricated downwards. But then these rings are moveable one on the other, while the joints of Cornulites are continuous in substance, forming a single rigid tube. Both genera are evidently tubular and cellular shells, - the cellular structure at the varices being clearly shewn in the figures in the "Silurian System." In the British 
Association Reports for 1845, I have endeavoured to shew that they are Serpulina. And Prof. Forbes has since kindly pointed out to me, that a corneous Annelide, of similar form but thin texture, occurring in very deep water in the Egean, seems to confirm my opinion.

When the exterior coat of a Cornulites is stripped, the celIular structure at the varices appears about half-way down each cup; the tube is narrower at the mouth than at the back of each joint-in all probability this is due to the inversely conical shape of the head, and this character is more strongly marked in the full grown animal.

The internal cast of Tentaculites also is different from the external form, just as in Cornulites; - the thick varices of each ring presenting on the cast a step-like form; this is well shewn in the common Silurian species T. annulutus, Schlotheim, which when the shelly tube has disappeared in the matrix, always appears as the T. scalaris of Schlotheim, but when the exterior is preserved, or what is more frequent, when the impression of the outer surface remains, the surface is regularly covered by longitudinal strix exactly resembling those of Cornulites; I believe this has not before been observed.

Cythere? umbonata, Sp. Nov. Ref. Pl. 1. E. fig. 6, (as Cera tiocaris?) natural size and magnified.

$S p$. Ch.-Smooth, broad-oval, oblique, margined round the anterior end, or that side where the general convexity rises to an umbo. Length nearly a quarter of an inch.

A common species, varying from nearly round to oval : the convexity sometimes diagonal.

Loc.-N. Wales, in Cambrian rocks.

\section{Beyriciita, $\boldsymbol{M} I^{\circ}$ Coy.}

A genus easily recognized, now that its characters have been described by Prof. $\mathbf{M}^{\circ} \mathrm{Coy}$. Formerly it was associated with Agnostus, a true trilobite, from which the separated valves are at once distinguished, by their unequal division into lobes. The genus now contains four or five species.

The valves are oblong and convex, their dorsal margin slightly concave or straight, the ends nearly equal : the surface deeply grooved, dividing them into two or more ridges-a raised rim, separated by a deep concentric furrow, runs round the ends and ventral margin (in our three British species).

\section{Beyricha conplicata. $P l .1$. E. fig. 3.}

Srw.Agnostus pisiformis, Salter, in Quart. Geola Journ. Vol. I. p. 20 a, \&c. B. complic. id. in Memoirs Geol. Survey, Fol. II. Pt. 1. Pl. 8. fig. 16.

Sp. Ch. -Smooth, compressed, oblong, the ends rounded; three transverse tubercles, or ridges, united towards the ventral edge, and separated by a deep concentric furrow from a thick rim which runs round the ends and front; the caudal tubercle deeply bifurcate.

Internal casts frequently lose the thick marginal rim. The caudal tubercle varies in shape, and sometimes, instead of being bifurcate, is divided into two, which lie nearly parallel. The species can hardly be mistaken, and is very plentiful in the Cambrian rocks.

$$
\text { Loc.-N. Wales. }
$$

Beyrichla strangulata, Sp. Nov, Pl. 1. E. fig. 1. Srv._Cytherina levigata, Salter, in Quart. Geol. Journal, Vol. I. 445.

Sp. Ch.-Granulose, ovate-reniform; a raised marginal rim, separated by a deep furrow, round the anterior half of the ventral edge; a transverse deep sulcus runs obliquely from the dorsal edge nearer the smaller (anterior) end.

Our figure represents the ventral rim as probably produced round both ends; we do not feel sure of it -and the specimens seem rather to indicate that it is confined to the anterior half or two-thirds. The fossil has much the aspect of a Cypridina, when the rim is lost, as it frequently is-but the short furrow, bounded anteriorly by a swelling, runs from the dorsal, not the ventral edge.

$$
\begin{aligned}
& \text { Loc.-Coniston, Lancashire, Cambrian. } \\
& \text { Pracops, Emmerich. }
\end{aligned}
$$

Including under this genus all the forms (or subgenera) which have been described as Crypheeus, Odontochile, Phacops, and Portlockia, we have an extensive and natural genus, beginning in nearly the lowest part of the Cambrian rocks, and extending upwards to the Devonian-probably even to the best of the Carboniferous system.

P. (Ovont.) ogtusicaudatus, Sp. Nov. Ref. Pl. 1. G. figs. $15,16$. Syn.-Asaph, caudatus, Salter, Quart.Geol. Journ. Vol. I. p. 446.

P. obtusicaudatus, id. Mem. Geol. Surv. Decade II. Pl. 1. p. 7, note.

Sp. Ch. - Head broad and short; glabella with very distinct furrows, the uppermost lobe not much larger than the rest; cheeks wide, with a short and narrow posterior spine; tail short, broad, subtriangular, obtusely angulate at the end; axis broad, convex, 11-12 ringed, obtuse; lateral ribs, about nine, nearly straight, distinctly interlined, abruptly terminated against the narrow equal margin.

It is the tail which differs so much from the other British species of the genus as to render it necessary to give a new name; the head, though wider and with much smaller headspines than $P$. caudatus ", is yet very like it in general contour; it also resembles $P h$. rotundifrons, Burm. The neck-furrow on the cheek, which in $P$. caudatus is broad and turns upward, is in this narrow, and runs close along the straighter posterior margin. We have not the eyes preserved.

Loc,-Coldwell, Westmoreland, Upper Cambrian.

P. (Puac.) alifrons, Sp. Nov. Ref. Pl. 1. G.fig. 12 (and tait, 13, 14).

Sp. Ch.-Cephalic shield very convex, tuberculate, semicircular, truncate and with two projecting angles in front; glabella subtriangular, wide above, the forehead lobe wide

* Phacops caudatus has been referred to as occurring in two or three localities in the Lower Silurian rocks of $N$. TIales. ( $Q$ uart. Geol. Journ. Vol, 1. p. 20, 21). There is no good evidence of this. It occurs there plentifully in the upper Silurian; and in S. Wales has been found in Lower Silurian. 
and confluent with the thickened front margin; lateral lobes of the glabella short and indistinctly marked, the upper lobe but little larger than the rest; eyes rather small, cheeks prominent along their inner edge, posterior angles rounded?

The peculiar character of this species, and to which the name applies, consists in the absence of any separating furrow between the upper lobe of the glabella and the outer margin of the cheek ; the glabella thus seems to be drawn out into it on either side.

['Tail convex, truly semicircular, the axis obtuse, reaching fully four-fifths the length of the tail, and with eiglt strong rings ; the lateral portions with seven distinct furrows, directed outwards, and but very little arched, they terminate abruptly, and leave a very narrow margin.

We can only suppose this tail to belong to the large head which occurs with it in tolerable plenty; and as the tail is quite that of the genus, we have but little doubt of it.]

The tail of $\boldsymbol{P}$. sclerops, as figured by Dalman, is considerably like that we have associated with this species, and the head also a good deal resembles Swedish specimens which we have seen labelled as $\boldsymbol{P}$. sclerops, - they do not however appear identical.

From $P$. Odini, our species is easily distinguished by the more equal lobes of the glabella, the lower lobes also being quite distinct. $\boldsymbol{P}$. Jamesii, Portlock, appears also to be an allied species.

Loc.-Capel Garmon, Llanrwst, N. Wales, in Cambrian rocks.

\section{P. (Phac.) apiculatus, Sp. Nov。 Ref. Pl. 1. G. fig. 17-19.}

$S p$. Ch. - Head longer than a semicircle. Glabella elongate, with nearly parallel sides, and small circumscribed basal lobes; the middle pair of furrows faintly marked, the upper ones distant, and very oblique; the eye narrow, gently curved, and extending along the two upper glabella lobes; angle of cheeks nearly square. Caudal shield triangular, nearly equilateral, marginate, with a recurved mucro at the apex; axis narrow, prominent, with six or seven ribs distinct, lateral furrows four, besides the uppermost one, interlined. Thorax........?

In many respects like $\boldsymbol{P}$. Downingice; but the long glabella, with its very oblique upper furrows and the circumscribed basal lobes (like those of the subgenus Portlockia), distinguish the head, while the pointed and recurved tip of the longer tail well distinguishes that part. There are no other species that we think can be confounded with it. This species appears to be strictly a lower Silurian one, and is common in the slaty rocks of the Bala series, often much squeezed in the direction of the cleavage.

Loc.-Bala; Pwllheli ; Berwyns, \&c. N. Wales; Cambrian rocks.

Calyuene parvifrons, Sp. Nov. Ref. Pl. 1. F. fig. 7.

$S p$. C $\%$ - Cephalic shield much depressed, semicircular, Alattish; glabella narrow, short, subconical, with two lateral lobes directed forwards, terminal one small, and not prominent; front margin as long as the glabella, exclusive of the neck-segment; the eye distant from the glabella, and placed very forwards, just in advance of it. Cheeks a little more prominent than the glabella.

Distinct from $C$. duplicata, the tail of which is figured in the "Silurian System" as an Asaphus, by the great projection forwards of the front margin beyond the glabella. To that species, however, and to Calym. Baylei, Barrande, it is most closely allied.

Loc.-Tai-hirion, near Arenig Fawr, N. Wales, in Lower Cambrian.

Cneirurus clavifrons, Dalm. Ref. Pl. 1. G. fig. 9.

Srn,-Cal. clavifrons, Dalm. Palead. pp. 58,59. Lovën. Ofv. Vetenskaps. Acad. 1844. Spharexochus juvenis, Salter, Mem. Geol. Surv. Vol. II. Pt. 1. Pl. 7. figs. 1 to 3 (exclude 36.) and description of tail, ibid. Errata, p. viii.

The small specimens on our plate shew only the young state, when the glabella is more globular than in advanced age. In the Memoirs Geol. Surv. quoted above, it is described as having no head-spines. We bave since seen them in specimens which retain the crust:-internal casts frequently mislead in this respect, as Burmeister has shewn.

The full description by Lovën of this species leaves no room to doubt that it was a Cheirurus with the ordinary nodular pleuræ of that genus. The tail too, as described by him, agrees well with the fragment mentioned in the Errata to the "Survey Memoirs," Vol. II. Prof. $\mathbf{I}^{\circ}$ Coy has very properly separated the tail there figured (fig. 3 b.), and also in our Pl. 1. F. fig. 10, as distinct; we had overlooked it in describing the species.

Loc-Bala, \&c. see p. 154, Cambrian rocks.

\section{Crbele, Lovën.}

The species of this genus were referred by Dalman to Calymene, but have since been distinguished by the above-mentioned naturalist. Dr Bœek, in the "Gra Norvegica," had indicated the group, but not characterized it. It is very remarkable for the long pedunculate eyes, twelve rounded thorax segments, most of which extend into long points directed back, and for the tail, the lateral ribs of which are few and turned backward, while the axis is cut up into a great number of segments. Dr Volborth of St Petersburg has given excellent figures, which shew that the facial sutures are much like those of Calymene, a small rostral shield being inserted in front. He proposes to restore the name Zethus to the genus, because Pander had so named one species; and I see that Professor $\mathbf{M}^{\mathrm{c}} \mathrm{Coy}$ follows him. But Pander had a mere fragment, and evidently intended a species of Cheirurus for the type of his genus; his description and figures, moreover, are so very uncertain, that his name cannot be accepted for either group without creating confusion.

\section{Rugosa, Portl. Ref. Pl.1.G. fig. 8 (magnified).}

Sxn.-Ogygia rugosa, Portlock, Geol. Rep. 302. t. 5. fig. 10.

Caudal shield long, triangular, axis equal to the deflected side lobes, with about twenty-eight rings effaced down the middle, which is occupied by a broad smooth band; in the upper three-fourths these rings at intervals become stronger and more prominent, but there are no tubercles down the central line; side lobes more prominent at first than the axis, but towards the end of the tail strongly bent down: lateral ribs five, directed longitudinally, each with three or four tubercles; an intermediate rib and rugose surface between the upper ones; the last two or three from each side uniting beyond the axis in a 4-5 spined point. 
This pretty species agrees exactly with Portlock's original specimen, which is far larger, but less perfect-the only difference in ours being the presence in the upper part of intermediate ribs between the larger ones. The lower part of the axis, where it is most prominent, has a few tubercular longitudinal ribs: all the lateral ribs have terminal spines, but the four last ones are much longer; they are united for some distance, and then diverge to form the serrate tip of the tail.

Loc.-Coniston limestone : the specimen has been presented by J. Marshall, Esq., of Leeds.

\section{Encrinurus, Emmerich.}

This includes those species of Cybele which have none of the thorax segments produced into spines, but all of equal length; and a further difference has been shewn by Dr Kutörga, viz. that there is no rostral shield, but a vertical suture separating the cheeks in front. E. punctatus forms the type of the genus, which is further distinguished from Cybele by having but eleven thorax rings.

E. sexcostatus. $\%$. 1. G. fig. 6, 7 .

Sxn.-Cybele sexcostata, Salter, MIem. Geol. Survey, Vol. II. Pt. 1. Pl. 8. fig. 10 (not fig. 9).

Perfect specimens of this species are now in the collections of the Geological Survey, and will be figured very shortly in one of the Decades. They shew that the head provisionally associated with this peculiar and characteristic tail, in the work above quoted, was erroneously attributed to it; the glabella of the true head is nuch more clavate, and like other species of Encrinurus.

Loc.-Bala, N. Wales, Cambrian rocks.

Licras nontrosus, Sp Nov. Ref. Pl. 1. F. fig. 16.

This caudal shield appears to differ from any previously published, and though not perfect it seems necessary to give it a name. I see that my friend Professor $\mathbf{M}^{\mathrm{C}} \mathrm{Coy}$ refers it to the genus Trochurus of Beyrich: but I regard that as only a section of Lichas, and M. de Burrande agrees with me.

Caudal shield granulose, rudely triangular, with two lateral serratures and a terminal pair; axis half the length of the tail, convex, with four rings and a terminal prominence from which a narrow ridge runs to the end of the tail; the two upper laternl ribs are prominent and nodulose at their ends; they reach the base of the serratures, the lower ones are short and almost round: the interstices are nodular.

The species is allied to L. laxatus, but the nodular character of the ribs and interstices will distinguish it readily. I think the artist has not represented the terminal pair of serratures as sufficiently projecting; but I hope the species will be recognized by the characters mentioned above.

Loc.-Pont-y-Glyn, Diffivys, W. of Corwen, Cambrian rocks.

Ilumenus Davisir. Ref。 Pl. 1. G. fig. 36.

Syr.-I. Davisii, Salter, Mem. Geol Survey, Decade II. Pl. 2.

To the description given in the above reference we have at present nothing to add, except to say that the name is given in recognition of our friend J. E. Davis, Esq. of Lim Court, Temple, a. gentleman who has taken mucl pains to illustrate the geology of Wales. Our figured specimen is presented by him.
Ildanus Murcuisoni, Salter. Ref. Pl. 1. G. fig. 33, 34, 35. Syn.-I. Rosenbergii, Salter, Mem. Geol. Surv. Vol. II. Pt.1. Pl.5.f. 6-8. I. Murchisoni, id. Decade II. (1849) Pl.2, page 4.

We at first thought this species identical with the I. Rosenbergii, described by Eich wald in his account of a journey through the Baltic provinces. But a subsequent consideration has induced us to separate them. Eichwald's figure is very incomplete, though he had apparently seen better specimens. The eyes are figured as at some distance from the axal furrows, and described as close to the neck margin, (margini postico proxime sitis) while in ours they are near the furrows, and fully their own diameter from the posterior margin. This character is one of considerable importance in the genus.

There are certainly some points of resemblance, especially in the thorax, but in the absence of better evidence, we think it is safer to distinguish by a separate name a fine and wellmarked species, distinct from any yet described, unless it may be the above doubtful figure.

Illanus giganteus, Burmeister, is like our species, but we cannot identify it; the axis appears to be not nearly so wide in proportion to the pleure.

Our specimens are much narrowed by pressure in the direction of the cleavage:-and this makes the really broad axis of the tail, f. 35 , appear much too narrow:-it is from a much younger specimen than the head and thorax. The surface is remarkably covered with short lines and puncta.

Loc.-Black shaly limestone, Coniston Water, in Cambrian rocks.

Illanus Bowmanni, Salter: Ref. Pl. 1. E, f, 19.

Srv.-I. centrotus, Portlock, Geol. Rep. Tyrone, Pl. 10. f. 3-6.

I. Boumanni, Sulter, Mrem. Geol. Surv. Vol. II. Part 1.

Pl. 8.f. 1, 2. Decade II. Pl. 2, page 3.

This is readily distinguished from all the other British species by having only nine rings; but this peculiarity is also

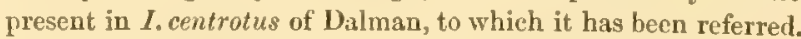

We have fortunately of late examined a specimen of $I$. centrotus from Christiania, in Sir R. I. Murchison's cabinet, and find it well distinguished by several characters. The eyes are as backward, but not so far outward as in 1. Bowmanni, the axal furrows of the head do not converge, and are in this specimen considerally longer. The head angles of our species, too, appear even in Captain Portlock's examples to have been quite destitute of a point, while in others from Kildare which agree well with them, the corner of the head was evidently rounded. These Kildare specimens agree so closely with those which were described by Portlock, that we cannot doubt their identity, more especially as the species is a common one in the Lower Silurian rocks, and we have recognized it from several localities with the same cliaracters, both in young and old specimens.

The tail in this specimen of 1 . centrotus, still further differs by being flatter, wider, the fulcral point much further out to correspond with its place in the pleuræ, and the axis, instead of being scarcely marked as in our species, is distinct half-way down the tail, and beneath the crust it is marked by two or three rudimentary upper rings. In this particular the difference is 
perhaps more marked than in any other, for the tail of the British species is regularly convex, and the axis is scarcely marked even by an indentation on the upper edge.

The position of the eye at once separates this species from I. Davisii, though they occur together in the Bala limestone; I. Bowmanni is by far the more common species.

Loc.-Llanwddyo, Montgomeryshire, Cambrian rocks. The late Mr Bowman found the specimens figured, and his son, J. E. Bowman, Esq., of King's College, kindly presented them to the Woodwardian Museum.

I had not intended, in so short an Appendix, to introduce any species on which I differed from the author of this work, as to the nomenclature. In. the present genus, however, the differences between the species are so little apparent, consisting chiefly in differences of proportion and position of the organs, that I depart from my rule, having carefully re-examined the species.

Homalonotus bistlcatus, Sp. Nov. Ref. Pl. 1. G. fig. 24 to 28 (and var. $\beta$. minor, figs. 29-31).

$S p . C h$ - Unarmed; eyes behind the middle of the head; thorax not at all trilobed,-the fulcrum close to the broad axal lobe; tail parabolic, rounded, the axal furrows very faintly marked, with about eight lateral furrows, the two upper ones on each side strong, the rest faint.

The head found everywhere with this species is but moderately convex; the glabella, considerably narrower than the cheeks, is bounded by very indistinct furrows on the upper surface of the crust, but beneath it both the axal and neckfurrows present strong ridges, which therefore cause deep sulcations on the cast. The front margin is a little recurved; the facial suture nearly vertical above the eye, which is not very close to the glabella, but placed more than half-way down the cheek. The body with regularly arched (not trilobate) broad smooth segments, the axis of each wider than the pleuræ, and only separated from them by a depression with an angular convexity in front of it, this angular point forming the fulcrum. From this part the pleure are arched forward (those behind most so), and at their broad round ends bent sharply down. Tail convex, with about seven or eight lateral furrows, the two uppermost on each side very deep, the third less so, and the rest faint; the axal lobe not equal in width to the sides, from which it is divided by very slight axal furrows; it is broadly conical, and terminates without any abruptness at three-fourths the length of the tail; the margin is narrow and flat. Trimerus platypleurus, and $T$. Jacksoni of Green, are nearly allied to this, but are distinguished by the proportions of the tail, which are all shorter than in our species.

Loc.-Figs. 24, 26, 27, from the Caradoc sandstone, Wittingslow, near Acton Scott, Shropshire (collection of the Geol. Soc.) Figs. 25, 28, Cambrian, Tremadoc, N. Wales.
Var. p. minor. Pl. 1. G. 29-31.

We hardly think this deserves the name of a variety, but it is smaller than the typical form, the furrows which surround the glabella are stronger, and the two upper ones of the tail not so distinctly marked; the eyes, too, seem placed a little more forward, and the front margin more turned up. It is possible, but not very likely, that these may be characters of the younger individual.

Loc,-Lower Silurian. Fig. 29, 30, Bala. Fig. 31, Westmoreland.

Howalonotus rudis, Sp. Nov. Ref. Pl. 1. E. figs. 20, 20 a.

$S p . C h$ - Thorax strongly trilobate; tail with a rather narrow and prominent axis, with six or seven distinct ribs, its apex prominent, indistinctly ribbed; axal furrows strong; sides with six or seven ribs, tubercular at their origin.

We have but imperfect specimens of this, and as in the former species, only describe internal easts; and we refer fig. $20 a$ with some doubt to the species, as it has a broader axis, and the ribs are fewer and larger; but it is probably the older state.

'The tail is distinguished easily from that of $H$. bisulcatus, by the tubercular strong ribs, and the distinctness of the axis from the sides; the anterior edge is much curred, while that of $H$. bisulcatus is but little so. Nearly perfect specimens in the collection of the Geol. Survey confirm the distinctness of the species.

Loc.-Capel Garmon, Denbighshire, Cambrian.

Homalonotus - Sp. Ref. Pl. 1. G. fig. 32.

Caudal shield very convex, with eight interlined lateral furrows, and about eight on the short broad axis.

It appears to differ from both the above species, but is not perfect enough to deserve a name.

Loc - - Bryn Eithin, Caernarvonshire, Cambrian rocks.

Euryfterus cepralaspis, $S p$. Nov. Ref. Pl. 1. E. fig. 21.

This curious head was at first supposed to belong to a flattened species of Trilobite, but the absence of all facial sutures, or of any distinct glabella, and the general correspondence in form with other species of Eurypterus, enable us to refer it to that genus-of which it appears to be the only example yet descrihed from the Silurian rocks-those from America and Russia being from strata of Devonian age, and that in Britain from the carboniferous rocks.

The head is half elliptical, three fourths as long as broad, undivided, regularly and very gently convex; the eyes placed behind the anterior third, and as far from each other as from the front margin. A faint ridge, forked upwards from the region of the cyes, runs down the middle, and a distinct and flattened but narrow border surrounds the front and sides, of about equal width throughout.

The specimen has lost all traces of the crust, as indeed is the case with all the fossils in the compact sandstone in which it occurs.

Loc.-Kirkby Moor, Kendal, in Ludlow rocks.

\section{MOLLUSCA.}

Conularia, Miller.

This genus of Pteropods varies much in shape, and especially in the transverse view; for while $C$. quadrisulcata has a nearly square section, the $C$. Sowerbyi is greatly compressed.
If we consider, as it appears to me we ought to do, that in this compressed species the two opposite angles of the flatter sides are the dorsal and ventral ones, we shall then, I think, have a character by which we may be able to trace these parts in the 
squarer species, and in some which are probably compressed laterally; for I find that the line where the usual transwerse ribs are bent or broken at about the middle of each lobe, is not really in the middle in all cases, but is nearer the dorsal and ventral angles than the lateral ones; and again, the two lobes which form the dorsal side are sometimes wider than those two which form the rentral face. Of course this will only apply to the symmetrical species, and not to those which have been described and figured as rhomboidal, with the opposite sides only equal. And there are several other forms of this remarkable genus.

\section{Sowerbyt, Defrance.}

Srv.-C. quadrisulcata, Sowerby, Sil. Syst. t. 12. fig. 22. C. Sowerbyi, Defrance, Dict. Sc. Nat. and De Blainv. Malacologie, 377, Pl. 14. fig. 2. De Vern, and Keyserl. Geol. Russ. $t 24 . f .5$.

Variety? C. gerolsteinensis, De Vern. and $d^{*}$ Arch. Geol. Trans. 2nd Series, Vol. $1 V$. / l.31. fig. 5.

$S p$. Ch. -Rather quickly tapering, depressed dorsally, surface of the lobes gently and regularly convex, with sharp transverse ribs continuous and angularly bent (not arched) over the submedian line, and ending on a higher level at the dorsal than at the lateral furrows; longitudinal striæ regular between the ribs, which they render granular in parts. [Septum finely striated in the longer diameter, and with a central compressed umbo].

After examination of numerous specimens, $\mathrm{I}$ can find but little characteristic differences in the variable strix between this and C. 4 sulcata. In the latter the transverse ribs are fine or coarse, and either angularly bent or arched continuously over the submedian line, or broken at this point and inserted one above the other; but the general form is more elongate than in C. Sowerbyi,-the section too, is square; in our species it is an acute rhomb, and this is not the result of pressure, for it is observable in every specimen. The shell figured in the Silurian System is terminated abruptly at the smaller end by a septum, which has been particularly described by Mr Sowerby, and is a very curious thing. De Koninck says that sections have been repeatedly made, and no septa found in true Conularia. Yet this is certainly a continuation of the general surface, and has a central umbo, which might have been pierced by a siphon. I beg to offer as an explanation of it, that the apex of the shell had been broken off, and the septum was the animal's attempt to fill up the hole as in Cuvieria; this may account for the ornamented surface, and perhaps for the acuminate central point. But Hall speaks positively of septum and an excentric siphuncle in this species, so that the matter is still open to observation. Conularia teres Sow., which has real septa, is by common consent allowed to be a Cephalopod.

Loc-Upper Silurian, Westmoreland; Cambrian, Bala, N. Wales. The variety with fine strix, which we have referred to C. gerolsteinensis, De V., occurs in the Upper Ludlow, Kendal.

$$
\text { C. subtilis, Sp. Nov. Ref. Pl. 1.L. fig. 24。' }
$$

Syn.-C. Gervillei, De Vern. and d'Arch. Geol. Tr. l.c.t. 29.

$$
\text { fig. } 3 \text { (not fig. 4)? }
$$

Sp. Ch.-Moderately conical, compressed a little laterally, ventral lobes smaller than the dorsal; lobes flat, crossed by very fine close ribs, continuously arched over the submedian line, which is nearer the dorsal and ventral than the lateral furrows; longitudinal strix very faint.

The extreme fineness of the ribs distinguish this species from all yet described, except, perhaps, Eichwald's C. Buchii, and De Verneuil's C. Gervillei, from the Rhenish strata. Unfortunately, of the latter we have" not "specimens of similar age for comparison, and that species is not described as inæquilateral, nor does it taper nearly so much as ours. Nor can we identify Eichwald's imperfectly described C. Buchii, Sil. Syst. of Esthonia, p. 111, since that species is said to be more rapidly conical than $C$. quadrisulcata in the young part,-ours is less conical.

The chief peculiarity of our shell is the inequality of the lobes, and the lateral, not dorsal, compression of the form. Agreeably with this, the submedian line is considerably nearer those furrows which mark back and front; attention to this character will probably enable us in all cases to ascertain which portion of the body we observe.

Loc.-Collinfield; Brigsteer; and Benson Knot, Kendal, in Ludlow Rocks.

Onthoceras Vagans, Salter. Ref. Pl. 1. L. fig. 28 and 29. SYN.-O. vagans, id. Geol. Quart. Journ. Vol. V. Pl.6.fig. 6.

$S p$. Ch._Smooth, long-tapering when young, more conical when old; septa broad elliptical, oblique on the longer axis, moderately distant in the young shell, distant more than the diameter in middle age, and by less than one-fourth of it when old ; deep, cup-shaped; siphuncle prominent, central.

Var. $\alpha_{0}$ - Septa in middle and old age much closer.

Var. $\beta, \ldots$ Conical in the young state.

This common species differs from $O$. distans, Sil. Syst., in the less size and in the position of the siphon. A large series of specimens shews how much care is necessary in establishing species on the distance of septa and general conic form, unless the species distinguished are known in similar ages. In its youngest state, when the growth was comparatively feeble, the septa, which may be considered as varices of growth, are not far apart; in middle-age vigour, if it be not checked by untoward causes, the growth is quicker, and in full age it is proportionally slower, while the diameter expands as the shell attains its full size, and when probably the ova are developed. This sudden increase of diameter is sometimes very marked in Orthoceras and the allied genera, and we think may be attributed to the cause above mentioned, viz. the enlargement of the reproductive organs.

Loc.-Bala limestone, N. Wales; Coniston, Westmoreland ; Cambrian.

O. Bactliforme, Sp. Nov. Ref. fig. 27. Pl. 1. $L$.

SrN.-O. linearis, Munst. Beitr. Heft. 3. t. 19. fig. 1 ?

Sp. Ch.-Long, linear, smooth, with a deep sinus in the lines of growth on one of the flatter sides; section long-oval; septa flattish, a little oblique, about one-fourth their diameter apart; siphuncle central.

The portion figured hardly tapers at all, but we cannot estimate the length from this circumstance; and as it is an interior cast, there may be fine transverse strix on the outside; if so, it would be very difficult to separate it from $O$. linearis, the 
septa and form of which it imitates. The sinus of the mouth occurs on the higher side of the oblique septa.

Loc.-Brigsteer, Westmoreland, in Ludlow rocks.

Orthoceras mimiditum, Sor.

Srr.-O. dimidiatum, Sow。 in Sil. Syst. t. 8. fig. 18. Munster, Beitr. 1840, t. 19. fig. 2.

Sp. Ch._-"Slender, surface transversely undulated; waves reaching but half across ; septa moderately distant." Sow.

The section appears to be oval, the ridges of growth (they are hardly undulations) are sometimes on the dorsal and sometimes on the ventral side of the shell, and, as they are oblique, in one case they point backwards,-in the other, rise forwards from the margin.

There are specimens of both in Mr Sharpe's cabinet from Radnorshire.

Loc.-Brigsteer; and Derby Arms, near Kendal, in Ludlow rock.

O. TORQUatur, Mrunst.

$$
\text { Srw.-O.torquatus, Munst. Beitr. 1840, p. } 101 .
$$

Sp. Ch.-Cylindric, linear; crossed obliquely by close strong strix, which are distant, oblique, and lost on the ventral side in the young shell, but less oblique and continuous across as it grows older; near the mouth the shell is crossed only by fine strix, some more prominent than the rest.

Munster gives no specific claracters to his species, and I have tried to supply one from tolerable specimens sent by him to Cambridge. The siphon is not visible, but he says it is central, and the septa close.

I believe I cannot be wrong in referring a fragment found in the Ludlow rock of Kendal to this strongly-marked species; the specimen is of larger diameter than Munster's before the change of striation takes place.

Loc.-Helme Foot, Kendal, in Ludlow rock.

\section{O. primever, Forbes $S p$.}

Srwi_Creseis mimceva, Forbes, Geol. Journ. Vol. I. p. 146. Sharpe, ib. Vol. II. Pl.13. fig. 2.

Sp.Ch.-Very long, linear, dilated toward the mouth, smooth; septa (in the linear portion) very convex, more than their diameter apart.

This very abundant species, first described by Prof. Forbes, seems to be distinct from any previously published; the expansion near the mouth is very decided. Total length 7 or 8 inches. Mr Sharpe has fine specimens of this, and there are very good ones in the collection of the Geological Survey. The reference of these thin shelled species to Pteropod Mollusea, which they much resemble, is rendered unnecessary by the occurrence of septa, frequently crushed flat, but sometimes distinctly visible, in the smaller part of the tubes. The dislocated septa are frequently found imbedded by the side of the shells in the fine mud; they are extremely convex, and therefore, as Mr J. Sowerby suggests to me, the more easily crushed flat within the shell :-septa placed more at right angles to the tube would be more visible, because they would better resist pressure.

Loc.-Quite abundant in the Wenlock shales of Denbighshire, and also of Montgomeryshire.

\section{O. ventricosus, Sharpe Sp. \\ Srr.-Creseis ventricosa, Sharpe, Geol. Journ. Vol. II. $t .13$. fig. 3 .}

$S p . C h$ - Subcarinate on the back? conical, lines of growth very oblique, rather prominent.

A common species, not above 2 or 3 inches long, found with the preceding, in the lower parts of the shales of Denbighshire.

$$
\text { O. InEx, Sow. }
$$

SrN._O. annulatus, His. Leth. Suec. Pl. 9. fig. 8? O. Ibex, Siw. Sil. Syst t. 5. fig. 30. O. articulatus, ib. fig. 31. 0 . Ibex, Salter, Mem. Geol. Surv. Vol. II. Pt. 1.p. 355.

$S p . C h$.-Very gradually and irregularly tapering, covered with close elevated longitudinal threads, and with oblique straight rings, one-fourth or one-fifth the diameter distant in the old portion, one-third or half in the young; section elliptical; septa oblique in the direction of the rings (distant the space of two?); siphuncle a little excentric, nearer to the upper edge of the septum.

This elegant species wants fresh illustration, as the figure given by Mr Sowerby, in the Silurian System, is very imperfect, and does not shew the close longitudinal striæ. Fine specimens in the Cambridge Museum shew a sudden expansion of the older part, which then continues parallel, and the rings are not more distant in the old than in the younger portions. Specimens which we believe to be of this species shew a septum between each two rings; but we cannot insist on this character. It is permanently distinguished from $O$. perelegans, Salt, by the longitudinal, not transverse striæ.

Portlock's $O$. perannulatum differs in having the ribs much closer, and with a strong sigmoid curve, the shell, too, tapers much more rapidly (these comparisons being of course made between similar ages of the two). De Verneuil and d'Archiac seem to be quite in error about the relation of this species to O. annulatum, Sow. See Geol. Trans. 2nd Series, Vol. VI.

Loc. - Many localities round Kendal in Ludlow rock; Dinas Bran, Llangollen, in Wenlock shale.

\section{Lituites PLANoRiformis, Conrad $S p$.?}

Srn.-Trocholites planorbiformis, Conrad, in Hall's Paleont. New Fork, Pl. 84. fig. 3. Nautilus primavus, Salter, Quart. Geol. Journ. Vol. I. p. 20.

Descr.-Volutions covering about half the preceding whorl ; the back rounded; the sides gibbous, rounded, and sloping inwards toward the umbilicus; sections of whorl reniform, twice as wide as deep; septa gently concave, siphuncle large and prominent, a little way from the inner edge ; aperture twice as broad as long. Surface with fine lines of growth, which bend backwards over the dorsal margin, and crossed (in the young shell at least) by faint irregular concentric lines: the aperture was occasionally thickened, as indicated by indentations on the cast.

It seems hardly right to give a new name to this very interesting shell, which if it be not identical with Hall's figured species, is yet a near representative of this American form of Lituites, in which the whorls are closely appressed and indenting each other. Hall describes Conrad's species as having 
strong concentric strix, as well as transverse ones; in ours we have only seen them on the young part of the shell, and there they are but faint. It is to be regretted that we cannot see the outer edge of the septum in our specimen; it is most probably a little curved back, as in both the American species of 'Trocholites.

Loc.-The Cymmerig brook, Bala; Bryn Eithin, Caernarvonshire ; in Cambrian rocks.

L, CORNU-ARIETIS, Sow.

Sys, - L. perfectus, Wahl, Act, Soc, Reg. Upsal. Vol. VIII.p. 83

L. lituus, His. Leth. Suec. t. 8. fig. 5? L. cornu-arietis, Sowerby, in Sil. Syst. Pl. 20. fig. 20 (not fig. 18).

$S p . C h .-D i s c o i d$, whorls three or four, close at first, but not indented by each other: afterwards produced and straight; crossed by numerous slightly-raised costre, with close wavy lines of growth between them and parallel to their direction, which is backward, in a curved line.

I have not referred to Lituites cornu-arietis, var. $\beta$. Sil. Syst. Pl. 22. fig. 18; for there is much doubt whether that regularly ribbed shell be at all the same; it seems much nearer to $L$. giganteus. I cannot help believing our fossil to be identical with Wahlenberg's, especially as $L$. cornu-arietis does occur in Norway. There are specimens of it in Sir R. I. Murchison's cabinet.

Loc.-Coniston, in Cambrian rocks.

L. A NGUiformis, Sp. Nov. Pl. 1. L. fig. 26.

Sp. Ch.-Smooth, with obscure lines of growth; whorls not indenting each other, elliptical, the shorter diameter in the thickness; each whorl about twice the width of the preceding; septa concave, close, their lateral edge curved deeply back, across the whorl, then passing straight across the periphery, so as to truncate the concave cup formed by cach septum; they are directed obliquely back, so that the inner margin of the septum is more forward than the outward one; siphuncle moderately large, close to the inner margin.

The very faint strix on the shell are somewhat distant, and are-curved backward, as in $L$. cornu-arietis, but they do not interrup the smoothness of the surface.

The Clymenia lavigata, Münst., from the limestone of Schubelhammer much resembles our fossil, although quite distinct from it in the form of the septum. In that specics, as in ours, the septa curve simply back;-but instead of passing straight across the dorsal margin they curve slightly forwards. C. lavigata and its allies from the same locality differ widely too from other Clymenix, by wanting the lateral notch or sinus in the septum. And our shell and the Lituites Odini, De Vern., seem only a step removed from these forms, by having the septum edge straight across the back. L. undosus (Nautilus, Sow.) goes a step farther, and has this line again curved back a little, so that the meeting of the lateral curve with the dorsal one leaves a projecting angle on each side the outer edge of the septum. Then in Trocholites, the American involute form of Lituites, this'backward curve is enlarged, and becomes almost a dorsal sinus. And lastly, in an unpublished form of this kind in the Cambrian rocks of Ireland, the dorsal sinus is complete, and a decided approach made to such palrozoic forms of $\mathrm{Nau}$ tilus as $N$. clitellarius of the coal strata.

Loc-Limestone of Mynydd Fron-frys, in the Glyn Ceiriog, S. of Llangollen, Cambrian rocks. 
. 


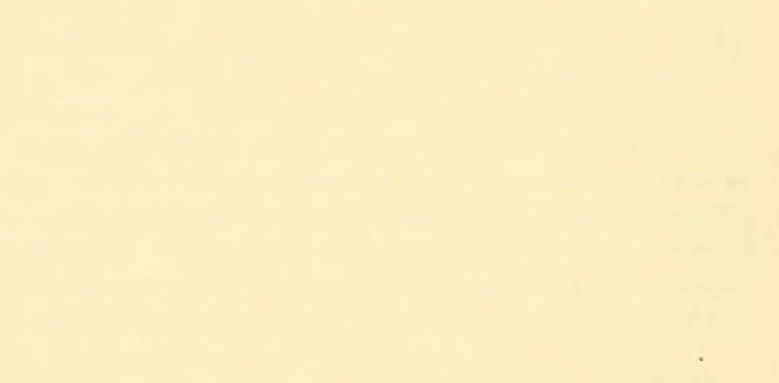


